\title{
The Operations of the Navy in the Dutch East Indies and the Bay of Bengal
}

Compiled by

The War History Office of the National Defense College of Japan

Edited and translated by Willem Remmelink 
The Operations of the Navy in the Dutch East Indies and the Bay of Bengal 

War History Series, Volume 26

\title{
The Operations of the Navy in the Dutch East Indies and the Bay of Bengal
}

\author{
Compiled by
}

The War History Office of the National Defense College of Japan

Edited and translated by

Willem Remmelink

Leiden University Press 


\title{
Advisory Board
}

Prof. Dr. Ken'ichi Gotō (Professor Emeritus, Waseda University)

Prof. Dr. Hisashi Takahashi (Professor Emeritus, Sophia University)

Prof. Dr. Ryōichi Tobe (Teikyo University)

Prof. Dr. Jirō Mizushima (Chiba University)

Dr. Petra Groen (Netherlands Institute for Military History)

Dr. Anita van Dissel (Leiden University)

Lt. Gen. (ret.) Ad Herweijer (Royal Netherlands Army) (†)

Lt. Gen. (ret.) Jan Folmer (Royal Netherlands Army)

V. Adm. (ret.) Egmond van Rijn (Royal Netherlands Navy) (†)

V. Adm. (ret.) Matthieu Borsboom (Royal Netherlands Navy)

This publication is part of a project of the Corts Foundation (www.cortsfoundation.org) that aims to translate into English several volumes of the Senshi Sōsho series concerning the former Dutch East Indies.

The publication of this volume was made possible by grants from the Isaac Alfred Ailion Foundation, the Suntory Foundation, the Samenwerkende Maritieme Fondsen (i.e. Vaderlandsch Fonds ter Aanmoediging van 's-Lands Zeedienst, Directie der Oostersche Handel en Reederijen, Vereeniging de Prins Hendrik Stichting), M.A.O.C. Gravin van Bylandt Stichting, and the Netherlands Institute of Military History (NIMH). Their logos may be found at the back of this volume.

Original title: 蘭印・ベンガル湾方面海軍進攻作戦 [Ran-In Bengaru-wan Hōmen Kaigun Shinko Sakusen], published by Asagumo Shimbunsha [Asagumo Newspaper Inc.], Tokyo 1969

(C) National Defense College of Japan [National Institute for Defense Studies], Japan 1969

English translation title: The Operations of the Navy in the Dutch East Indies and the Bay of Bengal (C) The Corts Foundation/Leiden University Press, 2018

\author{
Cover design: Geert de Koning \\ ISBN 9789087282806 \\ e-ISBN 9789400602939 (e-pdf) \\ NUR 686
}

All rights reserved. Without limiting the rights under copyright reserved above, no part of this book may be reproduced, stored in or introduced into a retrieval system, or transmitted, in any form or by any means (electronic, mechanical, photocopying, recording or otherwise) without the written permission of the publisher and the Corts Foundation, Secretariat, Mozartweg 3, 1323 AV Almere, The Netherlands.

This book is distributed in North America by the University of Chicago Press (www.press.uchicago.edu). 


\section{Contents}

Editor's Note

xvii

About the Senshi Sōsho (War History Series)

Foreword

xxxi

Preface, Explanatory Notes

xxxiii

Chapter I The Circumstances Leading to Japan's Invasion of the Dutch East Indies

1. The Prewar Operational Policy of the Navy and the Supply and Demand of Oil

2. Changes in the International Situation and the Import of Essential Materials

3. The International Situation and the Changes in the Policy for Coping with the Current Situation

4. The Supply and Demand of Essential Materials and the Appropriate Moment to Open Hostilities

5. Changes in the Measures to Cope with the Fuel [Problem] 10

6. The Breakdown in the Japan-U.S. Negotiations

Chapter II The Military Topography of the Southwestern Region

1. General Topography $\quad 15$

$\begin{array}{ll}\text { The Philippines } & 15\end{array}$

$\begin{array}{ll}\text { Thailand } & 15\end{array}$

Burma $\quad 16$

British Malaya $\quad 16$

British Borneo $\quad 16$

The East Indian Islands $\quad 16$

2. Summary of Meteorological Conditions $\quad 18$

3. Summary of Air Bases 18

The Philippines $\quad 18$

$\begin{array}{ll}\text { Malaya Area } & 18\end{array}$

$\begin{array}{ll}\text { British Borneo } & 19\end{array}$

$\begin{array}{ll}\text { The East Indian Islands } & 19\end{array}$ 
4. Summary of Major Ports, Waterways, etc. 19

$\begin{array}{ll}\text { The Waters of the Philippines } & 19\end{array}$

$\begin{array}{ll}\text { South China Sea } & 20\end{array}$

$\begin{array}{ll}\text { The Malaya Waters } & 20\end{array}$

The Waters of the Dutch East Indies $\quad 20$

5. The Military Situation in the Southwestern Region $\quad 22$

Distribution of Forces $\quad 22$

Strategic Assessment Based on the Location of the Air Bases 24

\section{Chapter III The Drafting of a Plan of Operations for the} Southern Advance $\quad 26$

1. Fixing the Outline of the Plan of Operations 26

2. IGHQ's [Navy Department's] Mission Directives and the Army-Navy Central Agreement 34

3. The Plan of Operations of the Combined Fleet $\quad 42$

4. Conclusion of the Tokyo Agreement 62

Agreement Between the Commanders in Chief of the Combined Fleet and the Southern Army $\quad 62$

Agreement Between the Commander in Chief of the Southern Army and the Commander of the Navy Southern Task Force 62

5. Conclusion of the Iwakuni Agreement and the Saigon Agreement 69

6. Issue of Orders by Each Navy Unit $\quad 70$

$\begin{array}{ll}\text { The Southern Task Force } & 70\end{array}$

$\begin{array}{ll}\text { The Philippines Unit } & 75\end{array}$

$\begin{array}{ll}\text { The Malaya Unit } & 75\end{array}$

7. The Southern Army Issues the Order to Launch the Invasion 75

8. Remaining Problems in the Southern Operation 76

\section{Chapter IV Progress in the Preparations for the Invasion of the} Dutch East Indies

1. Smooth Progress in the Stage-One, Phase-One Operations 79

Success in the Leadoff Operations on the First Day of the Opening of Hostilities 79

Satisfactory Progress Seen also in the Operations in Malaya and Northern Borneo $\quad 81$

Gaining Command of the Air in the Philippines Area and the Rapid Advance

of the Ground Units

2. The Bulk of the [Navy] Philippines Unit is Shifted to the Dutch East Indies Unit $\quad 83$

The Shift to the Phase-Two Disposition of Forces $\quad 83$

The Situation of the Navy Southern Task Force $\quad 84$

The Situation of the Army Units $\quad 87$

3. Assessment of the Enemy Situation in the Dutch East Indies Area at the Launch of Phase-Two Operations $\quad 87$

4. Conclusion of the Army-Navy Agreement for the Java Invasion [Operation] 89

The First [Scheduled] Army-Navy Meeting is Moved up 
Conclusion of the Cam Ranh Agreement and the Shortening of the Invasion Schedule

5. Issuing the Phase-Two Plan of Operations, etc.

The Southern Task Force

The [Navy] Dutch East Indies [Operation] Unit $\quad 94$

$\begin{array}{ll}\text { The Air Unit } & 100\end{array}$

The Submarine Unit $\quad 101$

The Army Units $\quad 103$

6. The Preparations of All Units Move Ahead 104

The Operational Directives of the Southern Task Force Commander and the Situation of the Main Body of the Southern Task Force 104

The Operational Directives of the Dutch East Indies Unit Commander and the Movements of the Units of the Dutch East Indies Unit

The Operational Directives of the [Southern Task Force] Air Unit Commander and the Actions of Each Component of the Air Unit

The Situation of the Carrier-Based Air Units 116

The Situation of the Army Units 116

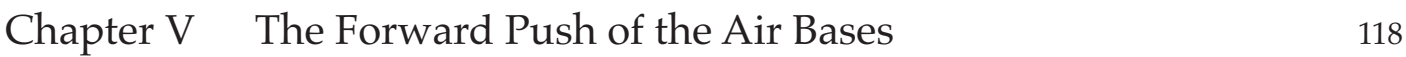

1. Outline of the Progress of the Operation 118

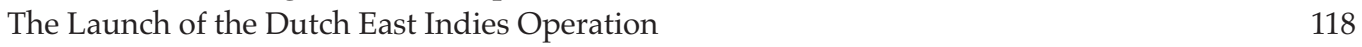

The Invasion of Malaya Makes Progress $\quad 119$

$\begin{array}{ll}\text { Capture of Ledo and Southern Malaya } & 120\end{array}$

The Engagements of the Submarine Units $\quad 121$

$\begin{array}{ll}\text { The Manila Conference } & 122\end{array}$

Completion of the Forward Push of the Bases in the Direction of Eastern Java 123

Completion of the Forward Push of the [Air] Bases in the Malaya Area 124

Capture of Southern Sumatra; the Preparations to Invade Western Java More or Less

$\begin{array}{ll}\text { Completed } & 125\end{array}$

2. The Capture of Tarakan $\quad 126$

$\begin{array}{ll}\text { Plan of Operations, etc. } & 127\end{array}$

The Arrangements Between the 1st Escort Unit and the [Army] Sakaguchi
Detachment

The Plan of Operations of the 1st Escort Unit $\quad 127$

The Plan of Operations of the Sakaguchi Detachment 129

The Plan of Operations of the Air Unit of the Southern Task Force 130

The Plan of Operations of the 2d Base Unit 131

The Plan of Operations of the 1st Air Unit 131

Assessment of the Enemy Situation Centering on Tarakan 133

The Launch of the Invasion Operation $\quad 133$

Preliminary Neutralization of the Enemy Air Power Completed 133

$\begin{array}{ll}\text { The Sailing of the Convoy } & 135\end{array}$

$\begin{array}{ll}\text { The Landings and the Land Combat } & 135\end{array}$

The Engagement of Minesweepers No. 13 and No. $14 \quad 137$

The Sinking of an Enemy Minelayer 143

The Guarding Against [Enemy] Submarines and Aircraft, and the Search for

$\begin{array}{ll}\text { the Enemy } & 143\end{array}$

The Launch of Preparations for the Coming Operations $\quad 145$

$\begin{array}{ll}\text { Taking over the Guarding from the Army } & 145\end{array}$ 
The Minesweeping of the Inner Port Delayed $\quad 145$

Little Progress in Conditioning the Airfield 146

The Swift Restoration of the Oil Fields 147

The Air Operations 149

3. The Capture of Menado 149

The Plan of Operations $\quad 150$

The 2d Escort Unit $\quad 150$

The Sasebo Combined Special Landing Force $\quad 152$

The 1st Base Unit $\quad 153$

The 2d Air Unit $\quad 153$

The 1st Air Raid Unit 154

The 1st Yokosuka Special Landing Force $\quad 154$

The Launch of the Invasion Operation $\quad 158$

Prior Neutralization of the Enemy Air Power $\quad 158$

The Sailing of the Convoy 158

The Engagements of the Sasebo Combined Special Landing Force and the Paratroop $\begin{array}{ll}\text { Unit } & 159\end{array}$

$\begin{array}{ll}\text { The Engagements of the Seaplane Unit } & 161\end{array}$

The Land-Based Air Units Scarcely Spotted the Enemy 164

The Operations from the 12th till the 20th [of January] 165

Lessons from the Operation and Observations 170

The Operations of the Main Body and the Base Unit $\quad 171$

Sweeping the Molucca Sea of Whales 172

The Operations of the Support Unit and the Dutch East Indies Unit 172

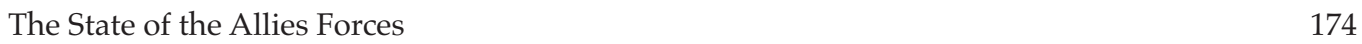

4. The Capture of Balikpapan 177

Postponement of the Invasion Schedule 177

Plan of Operations, etc. $\quad 177$

The Arrangements Between the 1st Escort Unit and the Sakaguchi Detachment 178

The Plan of Operations of the [Army] Sakaguchi Detachment 178

$\begin{array}{ll}\text { The Covert Operation of the Sakaguchi Detachment } & 179\end{array}$

The Plan of Operations of the Detached Force of the Sakaguchi Detachment 179

The Plan of Operations of the 1st Escort Unit 179

The Plan of Operations of the 2d Base Unit 181

The Plan of Operations of the 1st Air Unit 181

The Plan of Operations of the Air Unit of the Southern Task Force 182

Assessment of the Enemy Movements in the Balikpapan Area $\quad 183$

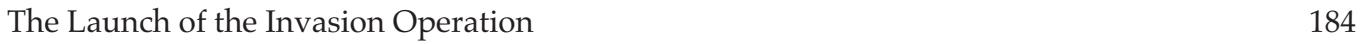

Prior Neutralization of [Enemy] Air Power Completed $\quad 184$

The Sailing of the Convoy 184

Surprise Attack of an Enemy Surface Unit on the Japanese Anchorage 188

The Situation of the Allied Navy 192

The Situation After the Landing 194

The Situation from the 25th Onwards 195

The Air Campaigns After the Departure of the Convoy 198

5. The Seizure of Kendari 200

6. The Manila Agreement and the Operational Policy for Phase-Three 205

Request for a Two-Week Postponement of the Operation Schedule 205

$\begin{array}{ll}\text { The Difficult Conclusion of the Manila Agreement } & 208\end{array}$ 
Issue of the Order to Commit the Main Force of the Carrier Task Force to the Southern Theater 211

The Operational Policy of Phase-Three Operations of the Southern Task Force 212

7. The Capture of Ambon $\quad 213$

$\begin{array}{ll}\text { Plan of Operations, etc. } & 213\end{array}$

The Arrangement Between the 2d Escort Unit and the Itō Detachment 214

$\begin{array}{ll}\text { The Plan of Operations of the 2d Escort Unit } & 215\end{array}$

The Plan of Operations of the Itō Detachment 216

The Plan of Operations of the 1st Kure Special Landing Force 217

The Plan of Operations of the 2d Air Unit 218

The Plan of Operations of the Air Unit of the Southern Task Force 218

$\begin{array}{ll}\text { The Launch of the Operation } & 218\end{array}$

Signs of the Enemy Hardly Seen 218

The Enemy Movements in the Ambon Area at the Time of the Launch of

The Sailing of the Invasion Convoy 221

The Launch of the Landing Operation and the General Completion of
the Capture

Minesweeping Delayed $\quad 227$

The Operations of the 2d Air Unit 229

The Engagements of the Land-Based Air Units 231

The Formation of the 24th Special Base Force and the Preparations for

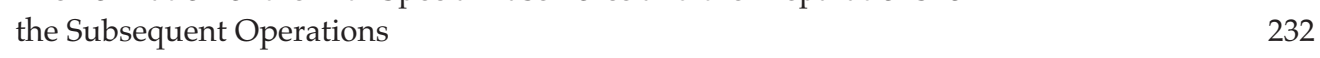

8. Operation Z of the Air Units and a Sea Engagement off Java 233

The Launch of the Operations $\quad 233$

$\begin{array}{ll}\text { Operation Orders } & 233\end{array}$

Reconnaissance $\quad 234$

Bombing the Airfields in the Surabaya Area $\quad 235$

Destroying the Enemy Fighter Plane Units $\quad 235$

Destroying an Enemy Fleet off Java $\quad 237$

The Second Attack of [Operation] Z 241

Letting the Remnant of the Enemy Fleet Slip by $\quad 242$

A Review of the Course of the Engagement 243

Related Operations $\quad 244$

A Change in Deployment $\quad 245$

9. The Capture of Makassar 246

$\begin{array}{ll}\text { Preparations for the Operation } & 246\end{array}$

Plan of Operations, etc. $\quad 248$

Assessment of the Enemy Movements Centering on Makassar $\quad 248$

$\begin{array}{ll}\text { The Plan of Operations of the 1st Base Unit } & 248\end{array}$

The Plan of Operations of the Sasebo Combined Special Landing Force 249

The Plan of Operations of the 2d Air Unit 249

The Plan of Operations of the Land-Based Air Units 250

$\begin{array}{ll}\text { The Launch of the Operation } & 250\end{array}$

Neutralization of the Enemy Air Power and the Sailing of the Convoy 250

The Natsushio Torpedoed; the Landing $\quad 251$

The Redeployment of the [Makassar] Invasion Units 253

The Operations of the Air Units 256

10. The Seizure of Banjarmasin 256 
11. The Invasion of Southern Sumatra 258

Arrangement on the Air [Operations] in Operation L 258

Arrangement on Operation L $\quad 260$

The Plans of Operation, etc. $\quad 261$

The Plan of Operations of the [Navy] Malaya Unit $\quad 261$

Outline of the Plan of Operations of the Army Units
(Excluding the [Army] Air Units)

Detailed Arrangements Between the 38th Division Commander and

The Plan of Operations of the Escort Unit $\quad 267$

$\begin{array}{ll}\text { The Plan of Operations of the Base Units } & 270\end{array}$

$\begin{array}{ll}\text { The Plan of Operations of the 1st Air Unit } & 270\end{array}$

The Plan of Operations of the 2d Air Unit $\quad 271$

The Plan of Operations of the 3d Air Unit $\quad 272$

The Plan of Operations of the Submarine Unit $\quad 272$

The Plan of Operations of the Army Air Units $\quad 273$

$\begin{array}{ll}\text { The Launch of the Operation } & 274\end{array}$

$\begin{array}{ll}\text { Postponement of the Operation Schedule } & 274\end{array}$

Little Progress in the Prior Neutralization of the [Enemy] Air Power 279

The Sailing of the Convoy $\quad 282$

Missing an Opportunity to Destroy the Enemy Fleet 287

The Lack of Military Gains Produced by the Air Units 290

Success of the Upriver Sail to Palembang 295

The Operations of the Surface Units from the 16th Onwards 296

The Operations of the Air Units from the 16th Onwards 299

The Operations of the Submarine Units $\quad 299$

The Engagements of the Army Air Units $\quad 300$

The Operations of the Army Units $\quad 302$

The Failed Counterattacks by the Allied Forces $\quad 304$

12. The Capture by Surprise of Bali $\quad 305$

The Air Unit's Insistence on the Capture of Bali 305

$\begin{array}{ll}\text { The Plan of Operations } & 308\end{array}$

$\begin{array}{ll}\text { The 1st Base Unit } & 308\end{array}$

$\begin{array}{ll}\text { The Army Units } & 310\end{array}$

The [Navy] Air Units 310

Assessment of the Enemy Movements Centered on Bali 310

The Launch of the Operation 311

The Prior Neutralization of the [Enemy] Air Power Made Little Progress 311

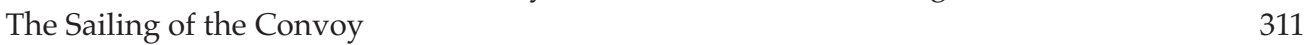

The First Phase of the Sea Engagement off Bali

(From 2353 on 19 February till 0110 on 20 February) 314

The Second Phase of the Sea Engagement off Bali

$\begin{array}{ll}\text { (From } 0310 \text { till 0323) } & 317\end{array}$

The Third Phase of the Sea Engagement off Bali
(From 0341 till 0346)

The Fourth Phase of the Sea Engagement off Bali

(From 0347 till 0354) 317

The Withdrawal of the 1st [Phase Operation] Raiding Unit 319

$\begin{array}{ll}\text { The Communiqué by IGHQ } & 320\end{array}$

$\begin{array}{ll}\text { The Operations of the Air Unit } & 321\end{array}$ 
The Engagements of the Army Units 322

The Second [Phase]: The Bali Transport Operation $\quad 322$

A Review of the Sea Engagement off Bali $\quad 324$

$\begin{array}{ll}\text { The First Phase } & 324\end{array}$

$\begin{array}{ll}\text { The Second, Third, and Fourth Phases } & 326\end{array}$

13. The Surprise Attack Operation Against Port Darwin 330

The Plan of Operations for a Surprise Attack on Port Darwin 330

The Launch of the Operation $\quad 334$

Reconnaissance and Sailing $\quad 334$

The Destruction of Port Darwin $\quad 337$

14. The Capture of Timor $\quad 342$

The State of Affairs up to the Capture [Operation] 342

The Invasion Schedule and the Units Involved $\quad 342$

$\begin{array}{ll}\text { The Issue of Invading Portuguese Timor } & 342\end{array}$

The Issue of Which Forces to Assign to the Invasion of Timor 345

The Plan of Operations $\quad 346$

Plan of Operations of the Eastern Attack Unit 346

The Arrangements Between the 2d Escort Unit and the [Army] Itō Detachment 347

$\begin{array}{ll}\text { The Plan of Operations of the Other Units } & 348\end{array}$

$\begin{array}{ll}\text { The Launch of the Operation } & 349\end{array}$

Prior Neutralization of the [Enemy] Air Power $\quad 349$

The Sailing of the Invasion Units 351

The Landing in Kupang and the Uphill Battle of the Airborne Unit 351

The Landing at Dili $\quad 355$

\section{Chapter VI The Drafting of the Java Invasion Operation Plan 358}

1. The Circumstances Until the Launch of the Operation 358

[The Circumstances] up to the Manila Conference 358

[The Circumstances] After the Manila Conference Until the Launch of the Operation 360

The Situation of the Units to Be Involved [in the Operation] 360

The Outline of the Arrangements Between the Commanders of the Army and
the Navy

The Operational Policy of the Southern Task Force Commander 362

The Operational Policy of the Dutch East Indies Unit Commander 362

The Problems in the Java Invasion [Operation] in Terms of Strength 363

The Preparations of Each Unit $\quad 364$

Partial Changes in the Disposition of Forces of the Dutch East Indies Unit 365

The Postponement of the Landing Date [on Java] Until 26 February 366

The Assembling of the Invasion Convoys Completed 366

Insufficient Results of the Air Campaign to Destroy the Enemy Air Power 367

The Malaya Unit's Cooperation in the Western Java Operation 368

The Participation of the Sakaguchi Detachment in the Eastern Java Invasion
Operation

$\begin{array}{ll}\text { The Situation Right Before the Invasion [Operation] } & 371\end{array}$

2. The Army-Navy Arrangement and the Plan of Operations of Each Unit 374

The Army-Navy Arrangement for the Java Invasion Operation ([at] Manila) 374

The Plan of Operations of the Dutch East Indies Unit 379

The Units Involved in the Western Java Invasion [Operation] 383 
The Army-Navy Arrangements Between the Sixteenth Army and

the 5th Destroyer Squadron 383

The Plan of Operations of the 3d Escort Unit $\quad 384$

The Plan of Operations of the 1st Air Unit 387

The Units Involved in the Eastern Java Invasion [Operation] 391

The Arrangements Between the 4th Destroyer Squadron and the [Army] 48th

Division 391

The Plan of Operations of the 1st Escort Unit $\quad 392$

The Plan of Operations of the 2d Base Unit 393

The Plan of Operations of the 2d Air Unit and Its Circumstances 395

The Plan of Operations of the Land-Based Air Unit 395

The Plan of Operations of the Army Units 397

\section{Chapter VII The Implementation of the Java Invasion Operation $\quad 400$}

1. Outline of the Progress of the Operation 400

2. From the Launch of the Operation Until the Landings 402

Further Postponement of the Landing Dates 402

The Conduct of the Operation by the Commanders of the Southern Task Force and

The Unsatisfactory Prior Neutralization of the Enemy Air Power Both in Eastern and

Western [Java]

The Operations of the Surface Unit in the Western Java Area 410

$\begin{array}{ll}\text { The Sailing of the Convoy } & 410\end{array}$

The Appearance of a Powerful Enemy Surface Unit $\quad 412$

The 7th Cruiser Division's Avoidance of a Decisive Battle $\quad 414$

Heading for the Landing Points $\quad 418$

The Engagements of the 1st Air Unit $\quad 420$

The Operations of the 3d Air Raid Unit Fell Short of Expectations 421

The Mihoro Air Group of the Malaya Unit Failed to Provide Effective Support 423

The Belated Advance of the 4th Carrier Division $\quad 423$

The Engagements of the Army Air Units 424

The Sailing of the Convoy for the Eastern Java Invasion [Operation] 424

The Operations of the 2d Air Unit $\quad 427$

The 2d Air Raid Unit Largely Neutralized Eastern Java $\quad 429$

3. The Sea Engagement off Surabaya 431

The Appearance of a Powerful Enemy Surface Unit (27 February) 431

The First Phase of the Daytime Engagement (from 1725 until 1850) 435

The Second Phase of the Daytime Engagement (from 1850 until 1950) 437

The First Phase of the Night Engagement (from 2050 until 2110) 439

The Second Phase of the Night Engagement (from 0030 until 0100) 440

The Main Unit of the Dutch East Indies Unit Came to Assist But Too Late to Participate

in the Engagement $\quad 442$

The Transport Convoy's Entry into [the Anchorage off] Kragan 443

Destroying the Remnants of the Enemy Fleet $\quad 444$

Lessons Learned and Reviews After the Sea Engagements 446

The Engagements of the 2d Air Unit $\quad 458$

The Engagements of the 2d Air Unit $\quad 458$

The Land-Based Air Unit Sinks the Tender USS Langley $\quad 459$ 
The Engagements of the 4th Carrier Division $\quad 461$

The Situation of the Allied Forces 461

4. The Sea Engagement off Batavia (28 February - 1 March) 465

The First Phase of the Engagement (from 0009 until 0100) 465

The Second Phase of the Engagement (from 0100 until 0116) 467

The Third Phase of the Engagement (from 0116 until 0132) 468

The Fourth Phase of the Engagement (from 0138 until 0206) 469

The Damage Sustained by the Army Transport Ships and Minesweeper No. $2 \quad 472$

Lessons of War and Observations After this Sea Engagement 472

5. The Main Body of the Southern Task Force Advances to the South of Java 475

6. The Operations of the Carrier Task Force (Until 1 March) 476

7. The Operations of the Submarine Units 481

Submarine Unit A, Guarding Java and [the Area] to the East 482

Submarine Unit C, Guarding [the Area] South of Java 485

8. The Army Units Sweep Across Java 488

9. The [Naval] Operations Around Java After the Landing of the Army Units 491

The Devastation of Cilacap by the Carrier Task Force 491

The Main Body of the Southern Task Force Destroys Enemy Vessels [on the Waters]

South of Java 493

The Actions of the [Land-Based] Air Unit $\quad 495$

The Engagements of the Army Air Units $\quad 500$

The Eastern Java Units Clear [the Sea of] the Enemy 501

The Western Java Units Clear [the Sea of] the Enemy 508

The Formation of Special Base Forces $\quad 510$

Revision of the Disposition of Forces of the Dutch East Indies Unit 512

10. The Lessons of War in the Air Campaign in the Dutch East Indies [Operation] 513

Lessons of War; General [Issues]

The Lessons of War [Drawn] by the Commander of the Genzan Air Group 518

11. The Conclusion of the Java Invasion Operaton 524

Military Gains and Losses $\quad 524$

An Assessment of the Enemy Movements in the Southwestern Theater 534

Evaluation of the World Situation and the Fundamental Principles in Conducting
the War

Evaluation of the Achievements of the Initial Operations 538

A Critical Review [of the Operation] 541

\section{Chapter VIII The State of the Allied Forces Before the} Java Operation

1. The State of the Allied Forces Before the Outbreak of the Second European War

The United States $\quad 554$

Britain $\quad 556$

$\begin{array}{ll}\text { The Netherlands } & 559\end{array}$

2. The Situation of the Allied Forces Right Before the Opening of Hostilities 560

$\begin{array}{ll}\text { Britain } & 560\end{array}$

The United States $\quad 562$

$\begin{array}{ll}\text { The Netherlands } & 562\end{array}$ 
3. The Situation of the Allied Forces at the Time of [Japan's] Launch of the Dutch East Indies Operation

1. Outline of the Course of the Operation 565

The Circumstances Leading to the Capture of Burma and Neighboring Strategic Areas $\quad 565$

Burma

Northern Sumatra

566

The Andaman Islands $\quad 567$

$\begin{array}{ll}\text { Christmas Island } & 567\end{array}$

The Arrangements Between the Army and the Navy, etc. 568

The Course Leading to the Implementation of a Carrier Operation in the Indian Ocean $\quad 569$

$\begin{array}{ll}\text { The Surprise Attack Operation on Ceylon } & 569\end{array}$

$\begin{array}{ll}\text { The Striking Operation in the Bay of Bengal } & 569\end{array}$

[The Operation to] Capture Burma and Key Areas Nearby Is Put in Motion 570

The Carrier Operation in the Indian Ocean Is Put in Motion 571

2. Clearing the Waterways in the Malacca Strait 571

$\begin{array}{ll}\text { Plan of Operations and Preparations } & 571\end{array}$

Clearing of the Waterways Completed 573

3. The Northern Sumatra Invasion Operation 576

The Plan of Operations $\quad 576$

$\begin{array}{ll}\text { The Malaya Unit } & 576\end{array}$

The 1st Escort Unit $\quad 577$

$\begin{array}{ll}\text { The 2d Escort Unit } & 578\end{array}$

$\begin{array}{ll}\text { Preparation for the Operations } & 579\end{array}$

Landings Made Without Bloodshed 579

4. The Capture of the Andaman Islands $\quad 581$

The Plan of Operations $\quad 582$

$\begin{array}{ll}\text { The Malaya Unit } & 582\end{array}$

The Air Unit of the Southern Task Force $\quad 583$

The Shift of the Air Units $\quad 584$

The Enemy Garrison Unconditionally Surrenders $\quad 585$

5. The Burma Transport Operation $\quad 588$

The Position of the Units Right Before the Launch of the Operation 588

The Transport of More Than Two [Army] Divisions 590

6. The Capture of Christmas Island $\quad 592$

The Plan of Operations $\quad 593$

The Naka Torpedoed $\quad 594$

7. The Carrier Operations in the Indian Ocean 601

$\begin{array}{ll}\text { Return of the 5th Carrier Division Delayed } & 601\end{array}$

The Enemy Movements in the Indian Ocean $\quad 603$

$\begin{array}{ll}\text { The Plan of Operations } & 604\end{array}$

$\begin{array}{ll}\text { The Southern Task Force } & 604\end{array}$

The Carrier Task Force of the Southern Task Force $\quad 605$

The Air Unit of the Southern Task Force 612 
The Malaya Unit

The Submarine Unit

The Launch of the Operation

The Movements of the Air Unit of the Southern Task Force

The Movements of Units Other Than the Carrier Task Force as of 31 March

The Advance of the Carrier Task Force of the Southern Task Force

The Air Raid on Colombo; the Sinking of Two [Enemy] Heavy Cruisers

The Air Strike on Trincomalee; the Sinking of One Small Aircraft Carrier

The Lessons of War Drawn from the [Operation of the] Carrier Task Force in Operation C

The Cooperation of the Air Unit of the Southern Task Force

The Malaya Unit Striking Force Neutralizes the Bay of Bengal

The Reconnaissance of Key [Enemy] Places by the Submarines Proved Difficult

646

The Distress of Britain

649

8. The Shift to Stage-Two Operations

653

The Grand Plan of Operations of IGHQ [Navy Department]

653

The Revision of the Wartime Formation

655

The Main Points of the Outline of the Stage-Two Operations of the Combined Fleet

656

Plan for the Stage-Two, Phase-One Operations of the Southwest Area Fleet

658

Conclusion

660

List of Abbreviations and Symbols Used in the Imperial Japanese Navy

Glossary

Attached Table No. 1: List of the Main [Naval] Personnel Involved in the Southern Operation

Attached Table No. 2: Characteristics of the Vessels and Aircraft of the Southern Task Force

Attached Illustration No. 5: The Sea Engagement off Surabaya [Battle of the Java Sea], Part I 
Attached Illustration No. 6: The Sea Engagement off Surabaya [Battle of the Java Sea], Part II

Attached Illustration No. 7: The Sea Engagement off Batavia [Battle of Sunda Strait]

List of Organizations That Supported this Publication 


\section{Editor's Note}

$\mathrm{T}$

he history of Japan's involvement in the Second World War is still a matter of great controversy, not least in Japan itself. There, scholars, the public and politicians cannot even agree on what to call the war, the Pacific War, the Greater East Asia War, the Fifteen Years War, the Asia-Pacific War, to name just a few examples, each with its dedicated partisan following. Successive Japanese governments have avoided the use of any of these names out of context, and the war is usually referred to as "The Late War" (Saki/Konji no Sensō/Taisen). Even though the Imperial Household Agency denies any specific intent, in practice the late Emperor, too, only referred to the war as "the late war," or used expressions such as "that unfortunate war" and "that unfortunate period," unless he was speaking in an international context about the "Second World War."1

Not surprisingly, the same controversy affected the 102-volume War History Series (Senshi Sōsho), of which The Operations of the Navy in the Dutch East Indies and the Bay of Bengal constitutes Volume 26, and the previously published The Invasion of the Dutch East Indies Volume 3. Here, a compromise was finally found by allowing the use of the term "Greater East Asia War" in the main text, but avoiding it in titles, forewords and explanatory notes, although this did not prevent the publisher, Asagumo Newspaper Inc., from prominently putting the term on its flyers. ${ }^{2}$ The foreign reader, who is mostly unaware of the enormous controversy still surrounding Japan's involvement in the Second World War and the vigorous, if not acrimonious, debate within Japan, is often left nonplussed by the vague official expressions used in Japan to refer to the war to paper over fundamental differences that all sides seem unable or unwilling to resolve. Moreover, to foreign readers, used to official war histories, as for example in the case of Britain and Australia, that are commissioned and endorsed by the government, or at least commissioned, even if the contents are left to the responsibility of the author, as in the case of the Netherlands, the Japanese example of a war history that is neither commissioned nor endorsed, but nevertheless compiled by a government agency, seems an anomaly and raises the question of whose view it represents.

The foreword to the present book is clear about it: the contents are the sole responsibility of the author and the head of the War History Office. But, as Professor Tobe shows in his introduction, it is not that simple. The text went through a great many study sessions and numerous revisions, and although great care was taken to present the facts and the oral testimonies as objectively as possible, the resulting text does to a large extent represent a view shared by Imperial Army and Navy veterans. But even here we should be careful. In the flyer supplied by the publisher for Volume 3, Major Okamura, a former staff officer of Imperial General Headquarters sent out to Singapore to join the invasion of the Dutch East

\footnotetext{
${ }^{1}$ Shōji Jun'ichiro, 'What Should the 'Pacific War' be Named? A Study of the Debate in Japan,' NIDS Security Studies, Vol. 13, No. 3, Mar. 2011, pp. 70-72.

${ }^{2}$ Idem, pp. 75-76.
} 
Indies, explicitly denies the claim made in both volumes that the war was all about oil. For such a vulgar materialistic matter, the Imperial Army did not go to war. It went to war with the idealistic idea of establishing a new order in Asia and freeing the Western colonies of the Western colonizers. This, incidentally, is an argument often heard in Japan to justify Japan's entry into the war. In its most minimal form, it asserts that something good came out of something bad, after all.

When even the name of your subject is a matter of controversy, it becomes very hard to write an authoritative, let alone academically sound, historical narrative. Not being academically trained historians, the authors of the Senshi Sōsho may not be expected to handle their material with all the conventions of the historian's craft regarding primary sources, secondary sources, the literature, references, etc. But in these respects, the Senshi Sōsho do not differ much from most of the older Western military histories. In the official histories compiled by the Allied powers after the war almost simultaneously with the compilation of the Senshi Sosho, the role of the home side is typically emphasized, and they serve to give an account of, if not to account for, the actions of their own forces. A certain bias and one-sidedness is inherent; the Senshi Sōsho are no exception. ${ }^{3}$ The professionalization of the field of military history is a comparatively recent phenomenon. Also the Dutch counterpart, Nederlands-Indië contra Japan, ${ }^{4}$ compiled by the War History Section of the Royal Netherlands Indies Army (KNIL) and completed by the Military History Section of the Royal Netherlands Army, is a case in point. However, there is a difference. The Dutch narrative spends no less than two of its seven volumes on the events leading up to the war. The authors of The Invasion of the Dutch East Indies and The Operations of the Navy in the Dutch East Indies and the Bay of Bengal only need a few pages to hop, step and jump to the opening of hostilities. This seems to be a deliberate choice. Other volumes in the series - eventually no less than seven - would be dedicated to the circumstances that led to the opening of hostilities. Moreover, the authors' primary task was to provide educational and research material for the Japanese Self-Defense Forces, so not surprisingly they opted for the simplest explanation of the war, the quest for oil, and jumped as quickly as possible into the nitty-gritty details of the planning and execution of the operations.

It has been remarked that the Senshi Sōsho "... provide a great treasure of data and fact. Yet they often omit discussion of questions of primary interest to the Western historian." 5 That the Senshi Sōsho and many other Japanese sources are often "maddeningly silent" ${ }^{6}$ on such matters, however, does not take away their immense value as a treasure trove of data and fact. As Professor Tobe remarks in his introduction: "It is virtually impossible to examine how Japanese forces fought in the Pacific War without referring to the Senshi Sōsho series."

For the student of the Japanese invasion of the Dutch East Indies, the present translations will fill a large gap in his knowledge, even though he may not find answers to some of his most fundamental questions. There is another limitation. Despite its title, The Invasion of the Dutch East Indies deals mainly with the operations of the Japanese Sixteenth Army until the

\footnotetext{
${ }^{3}$ See also: P. J. Dennis, 'Military History in Australia,' Mededelingen Sectie Militaire Geschiedenis (Vol. 14, 1991) 9-18, pp. 9-10; A. R. Millett, 'The Study of Military History in the United States Since World War II', Idem, 109129, pp. 122-123.

${ }^{4}$ Sectie Krijgsgeschiedenis, Nederlands-Indië contra Japan, 7 Vols., 's-Gravenhage, Staatsdrukkerij, 1949-1961.

${ }^{5}$ David C. Evans, Mark R. Peattie, Kaigun: Strategy, Tactics, and Technology in the Imperial Japanese Navy, 18871941, Annapolis, Naval Institute Press, 1997, p. xxiii.

${ }^{6}$ Idem, p. xxiv.
} 
beginning of March 1942 when the Royal Netherlands Indies Army surrendered. This means that the events in central and northern Sumatra are not dealt with at all, for they mainly took place after that date and, moreover, fell under the responsibility of the Japanese Twenty-fifth Army; and events in other areas that fell under the responsibility of the Japanese Navy, e.g. Celebes, are dealt with only very summarily. In Volume 26, the latter limitation has been largely lifted, because it describes in reasonable detail the events in Menado, Makassar and even the Navy's involvement in the northern Sumatra campaign. A fuller treatment of the latter will have to wait for the planned publication of a third volume dealing with northern Sumatra and a more detailed treatment of the Japanese Army air force in the Dutch East Indies campaign, both extracted from Volume 5 and 34 of the Senshi Sōsho series. Despite all limitations, Volume 3 and Volume 26 provide an unparalleled insight into the Japanese military campaign and the men who executed it. Moreover, we hope it will answer some of the questions of those who still wonder how it all could have happened, and who often still bear the scars of defeat and the subsequent years in prison or internment camps. A look over the hill, or the horizon, to see what was done and thought on the side of the former enemy, may not excuse anything, but it may explain many things.

The translation of military terms: Although the organization of the Imperial Japanese Army (IJA) and the Imperial Japanese Navy (IJN) was similar to those of Western armies and navies, there is often no one-to-one correspondence in the names and functions of their constituent parts. Some translators have chosen to emphasize the differences by not translating specific military terms, while others prefer literal translations in some form or another. For example, we might find hiko sentai (飛行戦隊) simply as “sentai" or translated more literally as “air regiment." Others again try to find designations in Western armies and navies that most closely resemble their Japanese counterpart in function, resulting in translations such as "group," "air group," "air combat group," or even "wing." In this book, we have generally followed the third option without being too dogmatic. “Gun" (軍) as in “daijūroku gun" (第 十六軍 [Sixteenth Army]) remains “army," even though "army corps" would be more correct in terms of size and function. At the same time, we have tried to avoid British or Commonwealth terminology and generally followed American usage common in the U.S. Army and Navy during World War II. This limitation precludes the use of terms such as "wing" in the example above because a comparable "wing" did not come into existence in the U.S. (Army) Air Force until after the war. The same applies to the terms "sentai" (戦隊) and "kōku sentai" (航空戦隊) in the IJN. Since American World War II usage reserves "squadron" for destroyer and submarine squadrons, we turned the other fleet "sentai" / "kōku sentai" into "divisions," and the IJN land-based air "sentai" into air "flotillas." However, we did not try to reinvent the wheel and based our translations mainly on the 1944 U.S. Army manual "A Handbook on Japanese Military Forces" [https://archive.org/details/TME30-480] for the IJA, and Japanese Monograph No. 116 for the IJN [http://www.ibiblio.org/hyperwar/Japan/ Monos/JM-116/index.html]. As not everyone may agree with our choices, we have made them explicit in the glossary at the end of the book.

Japanese names: The characters used in Japanese names can often be read in more than one way. In the text we have used the readings from the name lists of the IJA and IJN, if given and unless pointed out otherwise by later research. If no reading is given in these lists, we 
have used readings found in bibliographical dictionaries and other sources. In all other cases, we have adopted the most common reading. In the Index of Personal Names, we have added a question mark behind the family and/or personal name whenever the reading remains open to interpretation. In the translated text, Japanese names are given in Japanese order, i.e. the family name first, followed by the personal name without a comma in between.

Place names: In the Japanese text, foreign place names are either written in characters, as in the case of Chinese place names, or in the Japanese phonetic katakana script. Especially in the latter case, this has led to a great number of hard to identify place names. We think that we managed to identify most of them. With the exception of Hong Kong and Saigon, all place names are given in their modern, local readings, e.g. Guangdong instead of Canton, and Gaoxiong instead of Takao. An exception has been made for the names of Japanese naval air groups that take their name from their home bases outside Japan proper. These are given with their Japanese names, for example, Takao Air Group from Gaoxiong (Taiwan), Genzan Air Group from Wǒnsan (North Korea), and Tōkō Air Group from Donggang (Taiwan). In the case of the Dutch East Indies, colonial era names such as Batavia and Buitenzorg have been preserved, but their modern names, Jakarta and Bogor, have been added in the Index of Place Names. The spelling of Indonesian place names is rather inconsistent and differs from atlas to atlas. We have followed what seems to be the most commonly accepted spelling.

The Tohoku University Gaihozu Digital Archive (http: / / chiri.es.tohoku.ac.jp / gaihozu / index.php) provided by the Tohoku University Library, Institute of Geography, Graduate School of Science, was a great source for hard to find maps and charts.

Ship names: We have checked most of the requisitioned ship names against the List of Japanese Ship Names (日本汽船名簿 [Nihon Kisen Meibo]), the Imperial Maritime Association Register (帝国海事協会レジスター [Teikoku Kaiji Kyōkai Rejisutā]), and especially for smaller vessels, such as fishing boats, the Japanese Ship Names' Record (日本船名録 [Nihon Senmeiroku]). Unfortunately, the latter source does not give the readings of the names. In such cases, we have adopted the most common reading.

Maps: We have reproduced all the maps inside the book and provided them with English legends. A list of the symbols and abbreviations used in the maps may be found on page 664 . The ten separately attached maps of the original Japanese edition, however, proved too large for the confines of the English edition. Moreover, they did not add much to the understanding. We have made an exception for attached maps 5, 6, and 7. Fortunately, these maps could be scaled down to a still readable size. They depict a Japanese reconstruction of the course of the Battle of the Java Sea and the Battle of Sunda Strait, and are of intrinsic interest to the naval historian.

Names of engagements: In the translation, we have kept to the Japanese names. This means that, for example, the "Strike in Badung Strait" becomes the "Sea Engagement off Bali," the "Battle of the Java Sea" the "Sea Engagement off Surabaya," and the "Battle of Sunda Strait" the "Sea Engagement off Batavia." 
Editorial notes and emendations: Respecting the wishes of the copyright holder, the National Institute for Defense Studies of Japan (NIDS), the translation is full and unabridged. ${ }^{7}$ Although the text invites comparison with foreign sources, we have generally refrained from adding external material. The editorial emendations and notes within brackets or in the form of footnotes are only meant to make the text more readable, to indicate misprints, contradictory descriptions within the text itself, or occasionally differences with the descriptions in other volumes of the Senshi Sōsho series. Obvious misprints and errata pointed out in the list of errata compiled by NIDS in 2005 have been silently corrected. Parentheses are as used in the Japanese text.

The translation: The present translation is the joint effort of Willem Remmelink and Yumi Miyazaki. The latter also conducted almost all the background research in Japanese sources. We wish that more time could have been given to the solution of remaining problems. However, in the interest of making this translation quickly available to the public, we had to limit ourselves to the most obvious problems. We hope that other researchers will pick up the threads where we left off.

Acknowledgements: I would like to thank the National Institute for Defense Studies for granting us the copyright to publish this translation. Many other institutions and persons helped us with the background research. I would especially like to thank the Military Archives of the National Institute for Defense Studies. The expanding website of JACAR [Japan Center for Asian Historical Records: https: / / www. jacar.archives.go.jp] was of great help in quickly checking many of the underlying sources.

The advisory board read and commented upon the translation. I am grateful to the members of the board for their many helpful comments and suggestions. I would also like to thank Lt. Cdr. (ret.) Jeroen Mohrmann, Royal Netherlands Navy, and my fellow members of the Lochem Club “De Eendracht," Maj. Gen. (ret.) Egbert Klop, Royal Netherlands Marine Corps, and Capt. (ret.) Donald Weekenstroo, Royal Netherlands Navy, for their help. Especially the latter freely shared his extensive knowledge of naval tactics, ships and weapon systems. The final responsibility for the translation, however, rests solely with the editor.

March 2018

Willem G. J. Remmelink

\footnotetext{
${ }^{7}$ I am not aware of any other translations of Volume 26, full or partial, in any language, except for a series of summaries made by R. Adm. J. F. W. Nuboer (RNN) in Dutch and published in the Dutch Marineblad [Naval Journal], Volume 84-87 (1974-1977). These summaries were based on a partial translation of Vol. 26 that was prepared within the Royal Netherlands Navy. The present whereabouts of this translation are unknown.
} 



\section{About the Senshi Sōsho (War History Series)}

7 he Senshi Sōsho is a series of 102 volumes (to which two supplementary volumes were later added) on the military history of the Pacific War (including the Sino-Japanese War). These volumes contain the results of research conducted at the then War History Office (renamed the Military History Department, and later reorganized into the Center for Military History) of the National Defense College (later renamed the National Institute for Defense Studies) of the Defense Agency, or the Ministry of Defense as we know it today. The series was published by Asagumo Shimbunsha [Asagumo Newspaper Inc.] between 1966 and 1980. Although the series is usually called an "official" war history, the fact that it was published by a private publisher and not the government shows the official stance of the government that, although the series contains the results of research conducted by a branch of a governmental institution (i.e. the War History Office of the National Defense College), it does not express the official view of the Japanese government on the Pacific War. As mentioned in the foreword, "the main purpose of the publication of this series is to serve as educational and research material for the Self-Defense Forces," but that "its public use has been taken into consideration as well."

A study of the history of the Pacific War and a compilation of the results by a Japanese governmental institution had been planned since the days of the occupation right after the defeat. However, it was not until 1955, after the end of the occupation, when the War History Office was established within the Defense Agency, that the plan was put into effect in earnest. At the War History Office, dozens of veterans were appointed to compile the materials. They held meeting after meeting to write materials for educational and research purposes, revised these materials based on the discussions in these study meetings, and prepared manuscripts. For the research, the War History Office gathered about 70,000 documents, which were scattered and lost after the defeat, interviewed about 15,000 veterans, and collected about 10,000 documents transferred from the Ministry of Health and Welfare, which had taken over the demobilization of the Army and the Navy, and about 30,000 documents that had been collected by the occupation forces and were subsequently returned from the United States.

In 1965, the Defense Agency set forth a plan to publish the research results of the War History Office as the Senshi Sōsho series. Publication was started the next year; the study meetings at the War History Office, as many as 3,500 in ten years, and the results of some 240,000 pages of prepared manuscripts provided the basis for the series. The number of authors and researchers who participated in the compilation was 134. The entire 102-volume series can be subdivided in various ways. In one way, they can be divided into seven volumes on the circumstances which led to the opening of hostilities, ten volumes on the Army Department of IGHQ, seven volumes on the Navy Department of IGHQ and the Combined 
Fleet, ten volumes on the military preparations, nine volumes on the invasion operations, ten volumes on the operations in the Solomon Islands and New Guinea, five volumes on the operations in the central Pacific theater, three volumes on the defensive operations in the southwestern theater, four volumes on the operations in Burma, three volumes on the operations in the northeastern theater, three volumes on the operations in Manchuria, fifteen volumes on the operations in China, five volumes on the decisive battles in the Philippines, three volumes on the decisive battles on Okinawa, four volumes on the operations in the homeland, three volumes on the history of special operations (vessel escorting, submarine warfare, etc.) and one volume with a chronological table and a glossary of technical terms. The series can also be subdivided in a different way, e.g. twenty-four volumes on the general conduct of the war, ten volumes on military preparations, sixty-seven volumes on the operations themselves, and one volume on other matters. Finally, the series could be divided into sixty-nine volumes on the Army and thirty-two volumes on the Navy, and one volume common to both (the chronological table). The present book, Volume 26: The Operations of the Navy in the Dutch East Indies and the Bay of Bengal, would then fall into the category of invasion operations conducted by the Navy, whereas the previously published Volume 3, The Invasion of the Dutch East Indies, would belong to the category of invasion operations conducted by the Army.

The published Senshi Sōsho series was on the whole favorably received by historians of modern and contemporary Japan. It was because the series filled a gap at a time when objective data on the history of the Pacific War were scarce. Also, the attitude of the authors who strove to be objective and ideologically unbiased was well thought of.

Needless to say, there was harsh criticism as well. For example, from a historiographical point of view, the series was criticized that its academic level was not necessarily high, which was only natural, for it was written not by academically trained researchers but by veterans. However, I doubt whether there were more suitable persons at that point to write the war history series than these veterans. Even if it had been possible to commission university-level professional researchers to do the writing, without sufficient military knowledge they would not have had the competence to do the work. I should also add that even though there were more than 120,000 historical documents available at the time of publication, their number was limited compared to the current number of available documents.

The authors of the Senshi Sōsho series were consistent in their attitude that they should just convey as faithfully as possible the facts based on the documents and the oral evidence from the interviews, and leave analyses and interpretation to the reader or the specialist, rather than on the basis of their research results publish their own analyses or interpretations. This is even reflected in the title of the series. By choosing the title "War History Series," they consciously tried to steer clear of the political and ideological controversies that surrounded such titles as "History of the Greater East Asia War," or "History of the Pacific War." As a result, many researchers regarded the series as a kind of primary historical source and tried to utilize the information extracted from the series in their own research. In that sense, even if indices and notes were insufficient, it can be said that the authors successfully achieved in their own way their intention to just convey the facts and the evidence. Moreover, not all of the 102 volumes did necessarily fall short of the required academic level. Of the 102 volumes, quite a few did attain a considerably high research level. 
Another criticism was that the authors, as veterans, might be biased towards the organization to which they once belonged and in their evaluation of the record might have become lenient with it or its members. As I mentioned above, the texts of each author were discussed at study meetings, attended by the whole group, and revised. We cannot tell whether in the reviews at the study meetings, any criticism of their fellow soldiers was toned down or actually reinforced. But at least it is clear that the reviews at the study meetings must have put as much restraint as possible on prejudices or feelings of favor or disapproval. In that sense, we may say that objectivity and impartiality were to a large extent guaranteed in the series.

The criticism that the series was written by a group of insiders was also leveled at the fact that the inter-service rivalry between the Army and the Navy sometimes resurfaced in this series. A typical example is the fact that different Army and Navy versions were written, with considerable differences in interpretation, about the circumstances that led to the opening of hostilities. The Senshi Sōsho series can be divided into those volumes of which the Army was in charge and those of which the Navy was in charge. In other words, the parallel tracks that the Army and the Navy had pursued from the time of their foundation in the early Meiji period onwards extended to the issue of who would take charge of certain volumes. However, the difference in interpretation and views between the Army and the Navy mainly occurred in the descriptions of the general conduct of the war; only a few cases show traces of this rivalry in the description of operations. Whereas Volume 3, of which the Army was in charge, mainly deals with the history of operations and engagements with a focus on land engagements, Volume 26, of which the Navy was in charge, describes the history of operations and engagements with a focus on naval and aerial engagements. We may say that in both volumes the influence of a Army-Navy rivalry is hardly seen.

Another criticism of the Senshi Sōsho series was that it focused on operations, and that the analysis and description of subjects such as the line of communication (logistics), intelligence, and medical matters were extremely few. Other criticism was that the descriptions were too flat and often offered nothing but a list of facts. Many parts of Volume 3 and 26 may fall under the latter criticism in particular. However, as I mentioned, this could be the result of the efforts of the authors to just convey the facts or the oral evidence, obtained in the process of their research and writing, while leaving out their subjective judgments as much as possible.

After publication, a considerable number of misprints and factual mistakes were found. Apart from the misprints, factual misunderstandings have been clarified by newly found material and through progress in research. The Military History Department (or the Center for Military History) is said to be working on an updated list of errata. However, at this stage much work still needs to be done.

Despite the above criticisms and shortcomings, there is no doubt that the Senshi Sōsho series is the first basic reference work to turn to when studying the history of the Pacific War; it is a rich and indispensible source for all future research. It is virtually impossible to examine how Japanese forces fought in the Pacific War without referring to the Senshi Sōsho series.

March 2018 


\section{References}

Hara Takeshi, 'Senshi Sōsho no Raireki oyobi Gaiyō’ （原剛「『戦史叢書』の来歴および概要」『防 衛研究所戦史部年報』第1号（1998年3月） [Takeshi, Hara, 'History and outline of the Senshi Sōsho series,' NIDS Military History Department Annual Report No. 1, Mar. 1998]).

Shōji Jun'ichirō, 'Senshibu Ryaku-shi' （庄司潤一郎「戦史部略史」『防衛研究所戦史部年報』第1号 （1998年3月） [Jun'ichirō, Shōji, ‘A brief history of the Military History Department,' NIDS Military History Department Annual Report No. 1, Mar. 1998]).

Id., 'Senshi Sōsho ni okeru Riku-Kaigun Tairitsu ni kansuru Ichi-Kōsatsu — Kaisen Keii o Chūshin to shite' (同「「戦史叢書」における陸海軍対立に関する一考察—「開戦経緯」を中心として—」 『戦史研究年報』第12号（2009年3月） [Id., 'A study on the rivalry between the Army and the Navy in the Senshi Sōsho series, with a focus on the circumstances which led to the opening of hostilities,' NIDS Military History Studies Annual Report No. 12, Mar. 2009]).

Id., 'Nihon ni okeru Sensō Koshō ni kansuru Mondai no Ichi-Kōsatsu' (同「日本における戦争呼称に 関する問題の一考察」『防衛研究所紀要』第13巻第3号（2011年3月）[Id., 'What Should the 'Pacific War' be Named? A Study of the Debate in Japan,' NIDS Security Studies, Vol.13, No.3, Mar. 2011])

Id., 'Shiryō o Yomitoku: Taiheiyō Sensō Senshi Kenkyū no Kihon Bunken Senshi Sōsho,' Shūkan Asahi Hyakka vol. 43, 'Shin-Hakken! Nippon no Rekishi-Gendai 3,' (同「史料を読み解く 太平洋戦争 戦史研究の基本文献「戦史叢書」」『週刊朝日百科43 新発見！日本の歴史 現代3』2014年5月 4日 $/ 11$ 日合併号 [Id., 'Interpreting historical materials: Fundamental literature on the military history of the Pacific War, the Senshi Sōsho series,' 'Newly discovered! History of Japan: Contemporary History No. 3,' Weekly Asahi Encyclopedia vol. 43, 4/11 May 2014 issue]).

Senshi Kenkyū Zadankai, 'Senshi-bu ni okeru Senshi Kenkyū no Arikata' （戦史研究座談会「戦史部 における戦史研究のあり方」『戦史研究年報』第12号（2009年3月） ['A round-table discussion on the study of military history, 'The way military history studies should be at the Military History Department,' NIDS Military History Studies Annual Report No. 12, Mar. 2009].

Kagatani Tadashi, ‘Senshi Sōsho Kankō 30 Shūnen ni yosete' （加賀谷貞司「「戦史叢書」刊行30周 年に寄せて」『戦史研究年報』第13号（2010年3月） [Tadashi Kagatani, ‘[Commemorating] the 30th anniversary of the publication of the Senshi Sōsho series,' NIDS Military History Studies Annual Report No. 13, Mar. 2010]).

Fukushige Hiroshi, 'Senshi Sōsho Hensan Tōji no Omoide' （福重博「「戦史叢書」編さん当時の思 い出」『戦史研究年報』第13号（2010年3月） [Fukushige Hiroshi, 'Memories of the time of compiling the Senshi Sōsho series,' NIDS Military History Studies Annual Report No. 13, Mar. 2010]).

Kondō Shinji, 'Senshi-bu no Kaisō' （近藤新治「戦史部の回想」『戦史研究年報』第13号（2010年3 月) [Kondō Shinji, 'Recollections of the Military History Department,' NIDS Military History Studies Annual Report No. 13, Mar. 2010]).

Ichiki Toshio, 'Senshi Hensankan no Omoide' （市来俊男「戦史編さん官の思い出」『戦史研究年報』 第13号（2010年3月） [Ichiki Toshio, 'Memories of a war historiographer,' NIDS Military History Studies Annual Report No. 13, Mar. 2010]).

Hatano Sumio, 'Ichigayadai no Senshi-bu to Senshi Sōsho' （波多野澄雄「市ヶ谷台の戦史部と戦史叢 書」『戦史研究年報』第13号（2010年3月） [Hatano Sumio, “The Military History Department at Ichigaya-dai and the Senshi Sōsho series' NIDS Military History Studies Annual Report No. 13, Mar. 2010]).

Takahashi Hisashi, 'Senshi-bu Kimmu Jidai o kaerimite' （高橋久志「戦史部勤務時代を顧みて」『 戦史研究年報』第13号（2010年3月）[Takahashi Hisashi, 'Looking back my time at the Military History Department,' NIDS Military History Studies Annual Report No. 13, Mar. 2010]). 


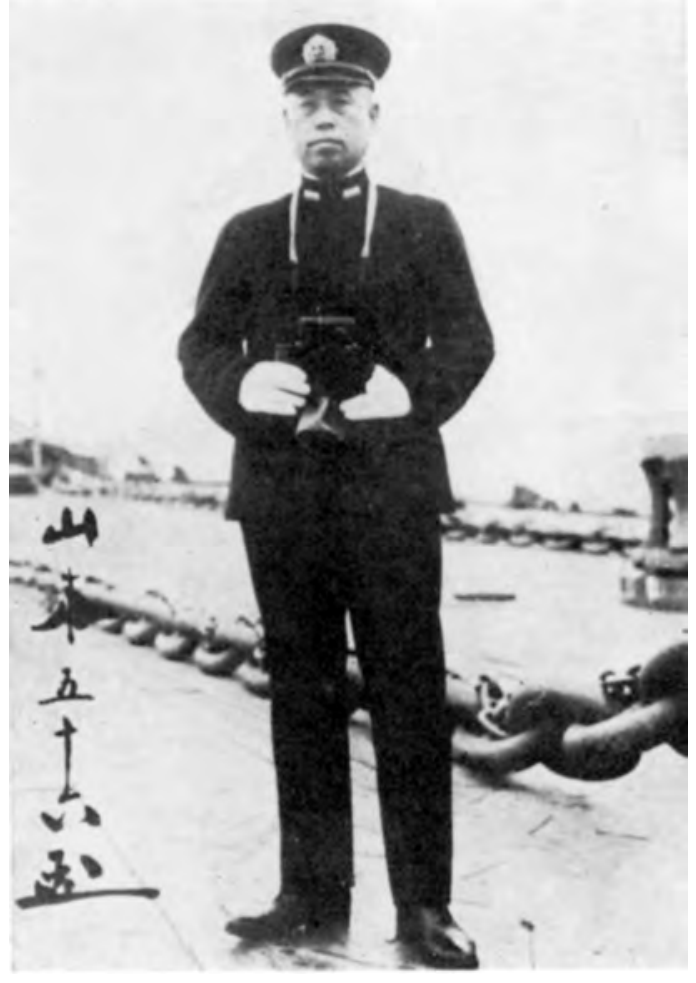

Commander in Chief, Combined Fleet Admiral Yamamoto Isoroku

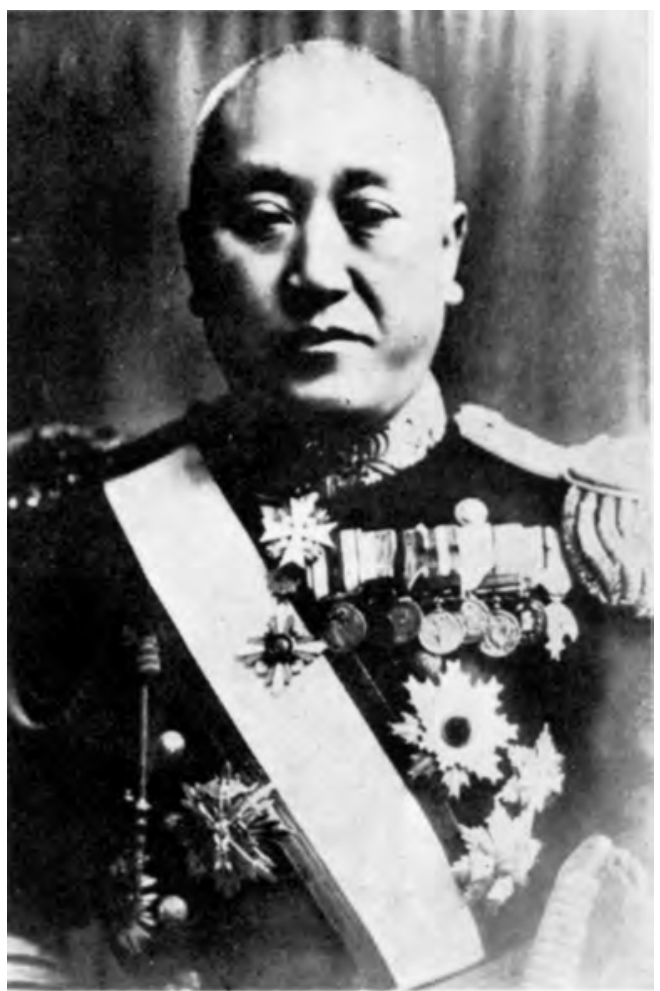

Commander in Chief, Second Fleet V. Adm. Kondō Nobutake

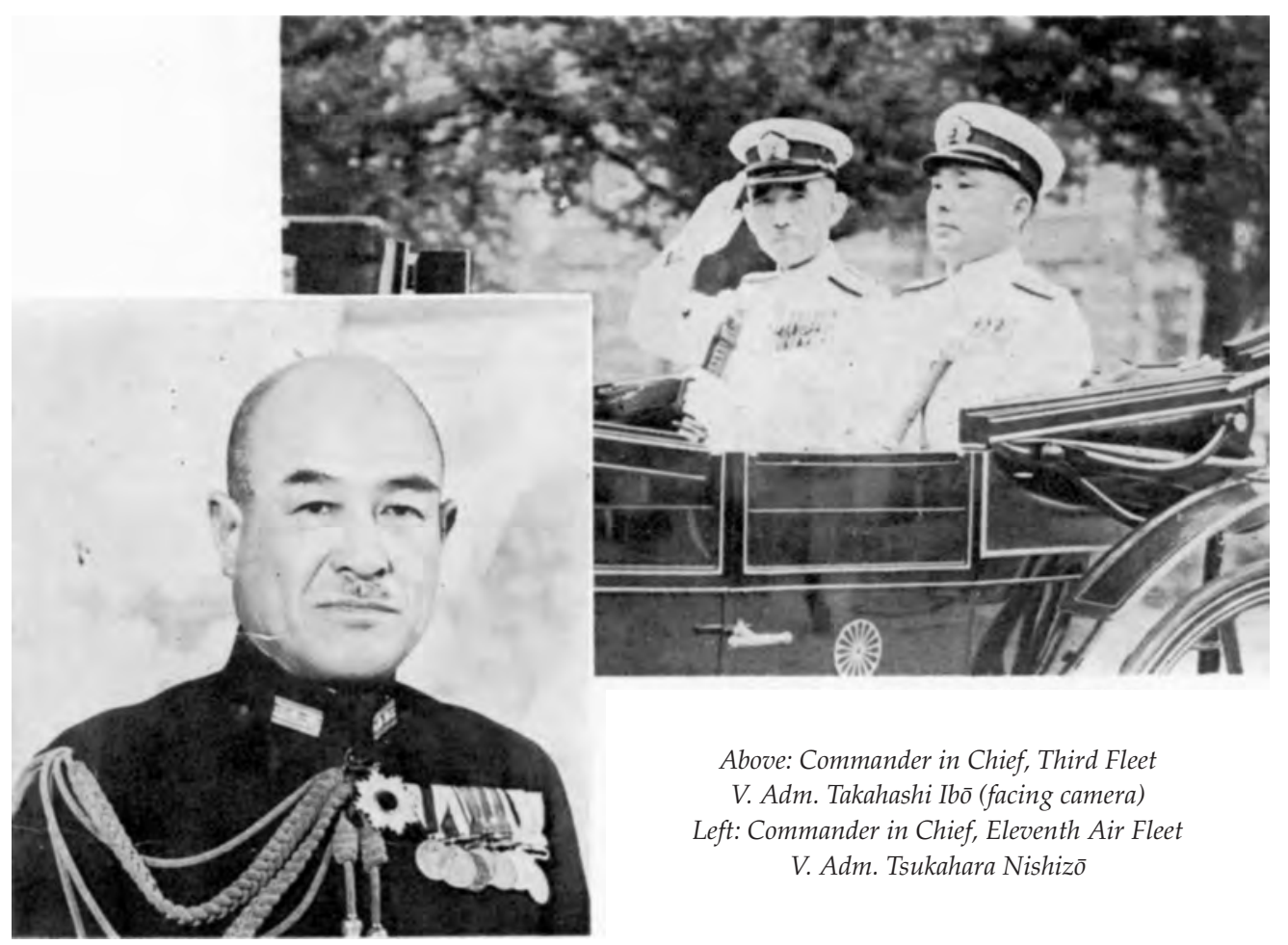




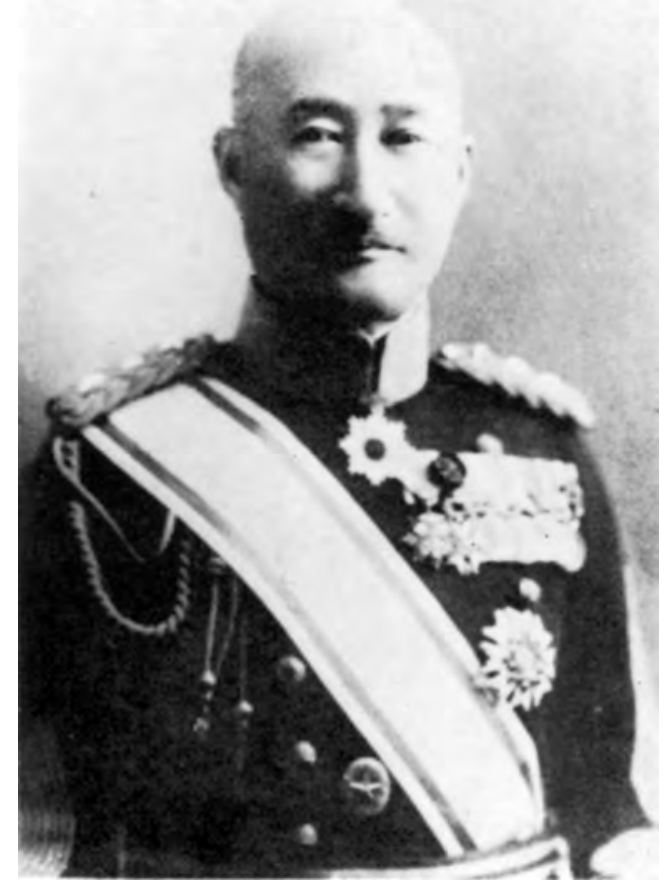

Commander in Chief, Southern Army General Terauchi Hisaichi

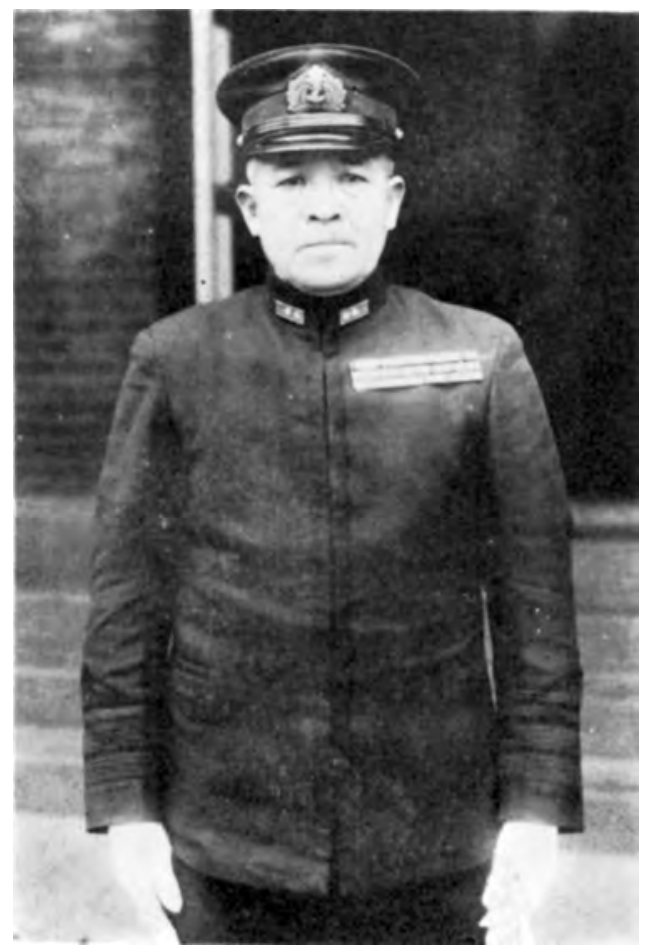

Commander in Chief, First Air Fleet V. Adm. Nagumo Chüichi

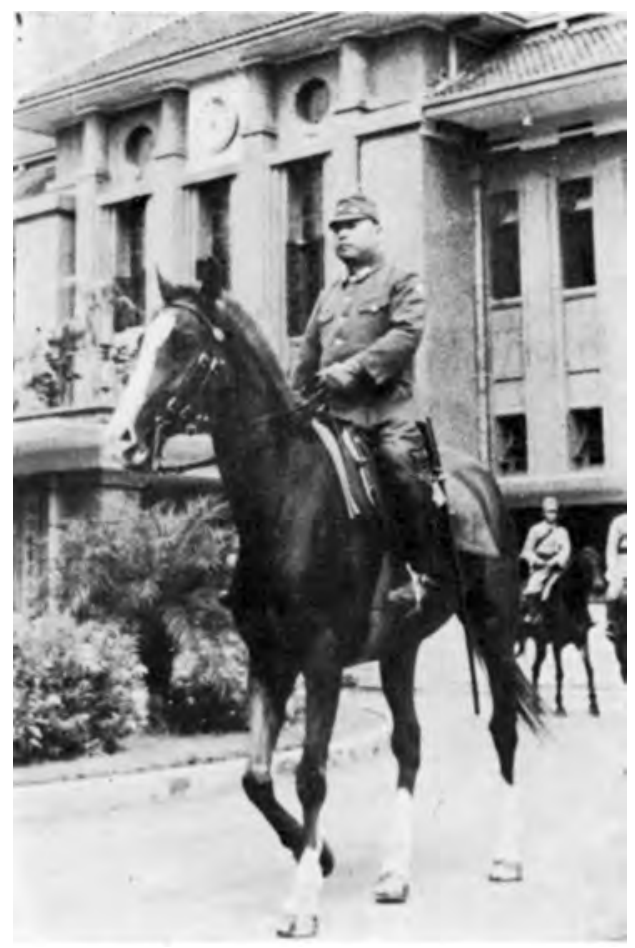

Commander, Sixteenth Army Lt. Gen. Imamura Hitoshi

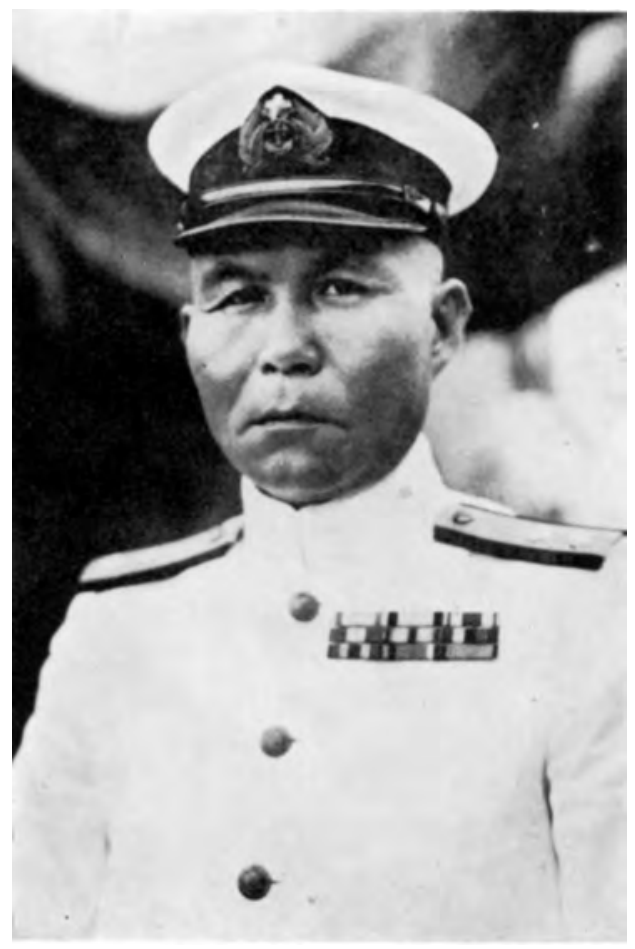

Commander in Chief, Southern Expeditionary Fleet V. Adm. Ozawa Jisaburō 


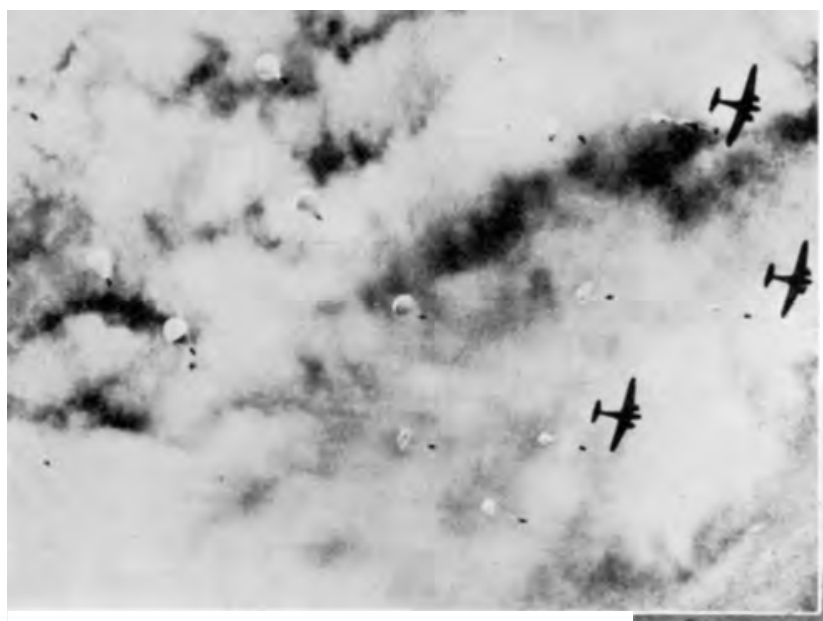

Naval Paratroop Unit's Drop on Menado

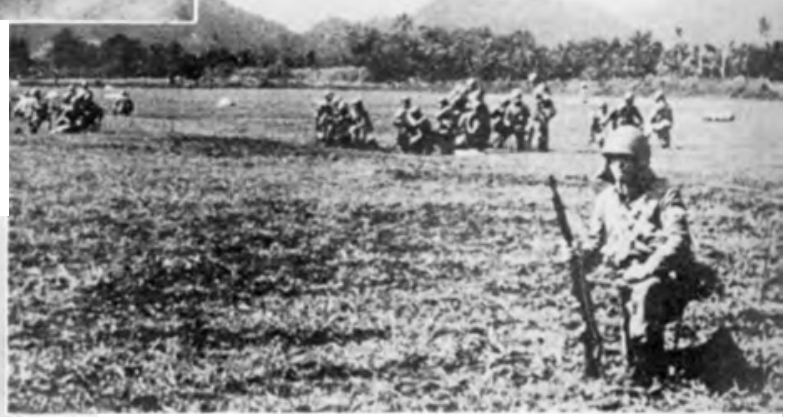

The [Naval] Paratroop Unit Ready to Go into Action Right After the Drop on Menado
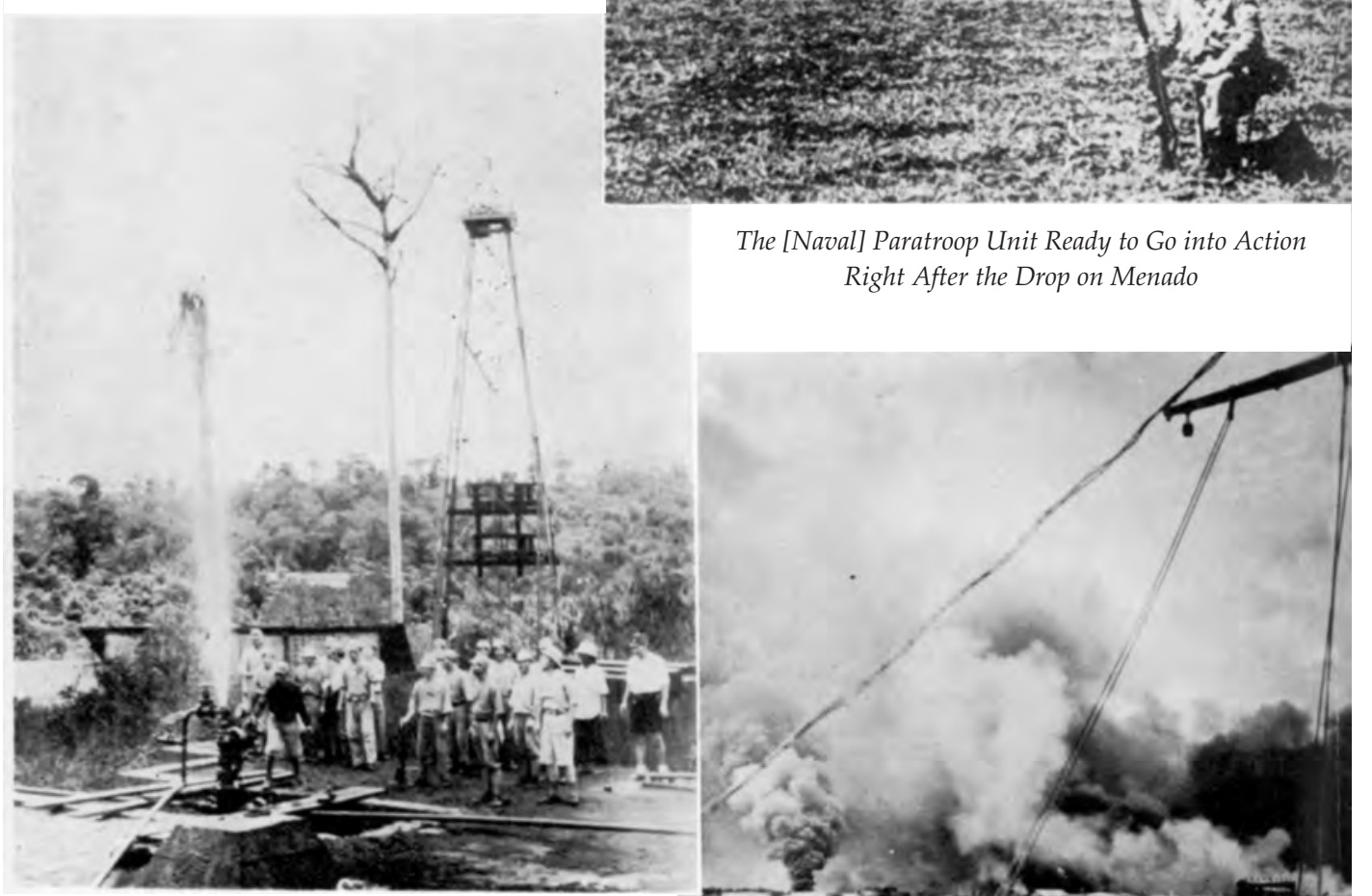

Making Haste with the Restoration Work of the Oil Fields in Balikpapan

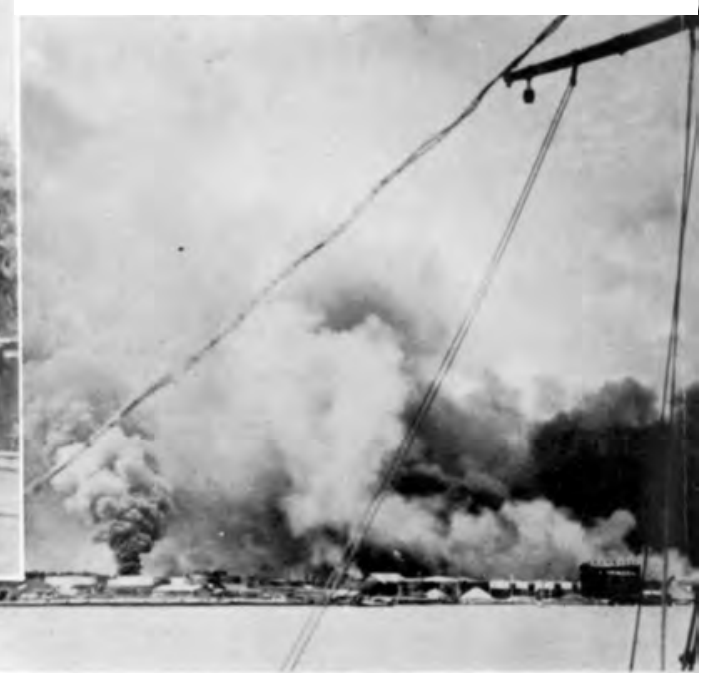

Palembang Ablaze As Seen from the Musi River 


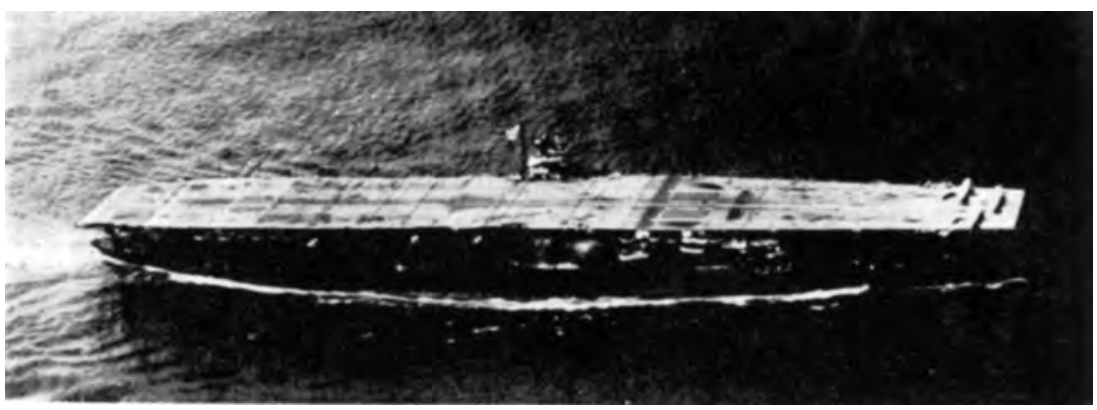

The Carrier Akagi

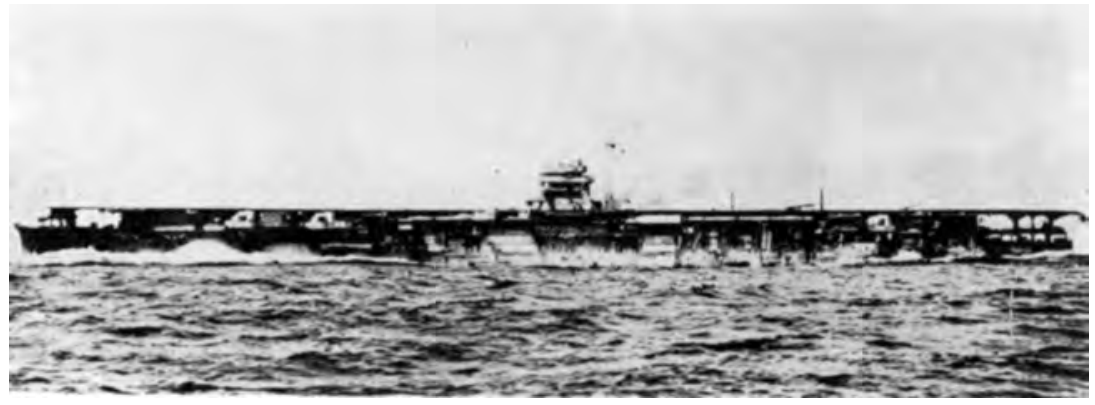

The Carrier Hiryū (the Same Class As Sōryū)

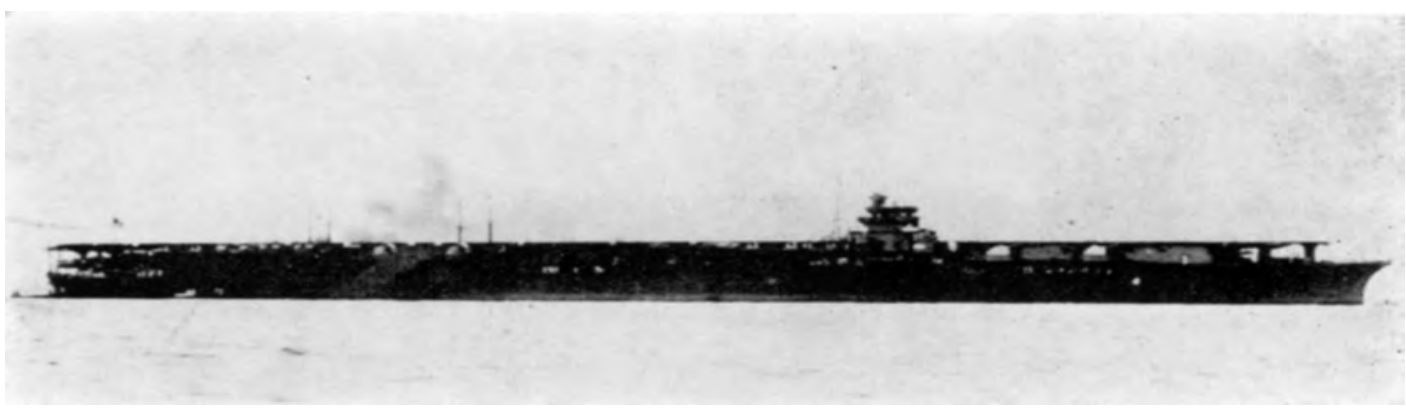

The Carrier Shōkaku (Zuikaku Is of the Same Class)

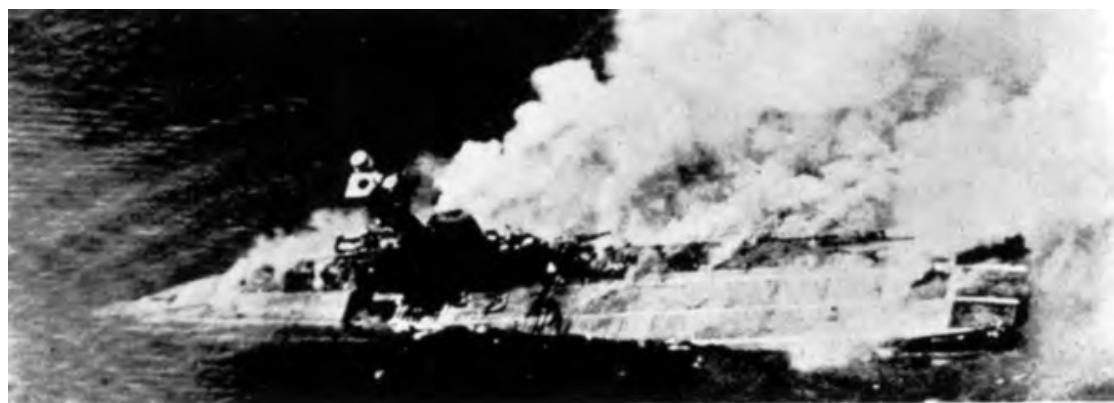

The British Carrier HMS Hermes About to Sink 


\section{Foreword}

$\mathrm{M}$

ore than a decade after the establishment of the War History Office, we are finally ready to publish some of the results of our research one after another, and as the twenty-sixth volume [of the series], we now publish The Operation of the Navy in the Dutch East Indies and the Bay of Bengal. Although the main purpose of the publication [of this series] is to serve as educational and research material for the Self-Defense Forces, its public use has been taken into consideration as well.

As enormous quantities of documents were destroyed, scattered or lost at the end of the war and, moreover, there was a gap of ten years before the establishment of the War History Office, the difficulties of compiling a history of the war were, compared to past war history compilations in Japan as well as overseas, beyond description. Yet fortunately, the understanding of all concerned and the enthusiastic support by a great many veterans helped realize the publication of this work. Here, once again, we would like to express our deep gratitude.

Due to space limitations, not a few parts have been omitted in the account. It is also expected that some parts will need further revision in the future because of newly added collections of historical materials. We earnestly solicit the cooperation and comments of all of you, in or outside the War History Office.

The research on the materials for this volume was firstly shared among the war historiographers Tanaka Ken'ichi, Iki Haruki and Nambu Nobukiyo of our office, and on the basis of their results, further research was conducted by war historiographer Sasaki Masao to write this volume.

Further, we would especially like to add that the head of the War History Office and the author are solely responsible for the contents of this volume.

May 1969

National Defense College

Head of the War History Office

Nishiura Susumu 



\section{Preface}

$\mathrm{B}$ eing poor in natural resources, Japan depended on foreign countries for most of the materials it needed. Particularly, oil products, which may be called the root of military strength, were for a large part imported from the United States.

However, due to the escalation of the China Incident and the rising tensions in the political situation in Europe, the United States gave notice in July 1939 that it would abrogate the U.S.Japan Treaty of Commerce and Navigation, as it tried to constrain Japan's movements in the Far East by controlling the export of essential materials to Japan. At this point, Japan had no choice but to aim at quickly becoming self-supporting by adding the areas to its south to [the bloc of] Japan, Manchuria and China, and end its dependence on the United States and Britain for essential materials. In the southern areas, the focus of interest was particularly upon getting hold of the oil in the Dutch East Indies.

Although the Dutch East Indies produced an amount of oil that surpassed the amount needed by Japan, most of the petroleum companies there were operated by U.S. and British capital, and hence the amount that Japan had requested to buy was never permitted by the Dutch East Indies government. Therefore, availing itself of the golden opportunity of Germany's sweep across Europe in the summer of 1940, Japan arrived at the idea to aggressively solve the southern question. In the fall of that year, the Tripartite Pact between Japan, Germany and Italy was concluded, and troops were advanced and stationed in the northern part of French Indochina, against which, the United States and Britain further intensified their economic and military encirclement policy against Japan. Although Japan had started negotiations with the United States from the spring of 1941 onwards, it resolutely decided to station troops in southern French Indochina in July of that year from the standpoint of stepping up its preparations for self-sufficiency and self-defense, and also partly due to the deadlock in the negotiations with the Dutch East Indies. Against this move, the United States, Britain and the Netherlands took strong retaliatory measures such as freezing Japanese overseas assets and putting a total embargo on oil exports to Japan, which completely stopped the import of oil. At that time, the amount of oil Japan had stored was not sufficient to prosecute a war; Japan had no other choice than either make great concessions to its claims in the JapanU.S. negotiations in order to settle the negotiations, or use armed force in the southern regions in order to get hold of the main areas with resources, fully aware of [the possibility of] a war against the United States. Thus, while making every possible effort to bring about a breakthrough in the Japanese-U.S. negotiations on the one hand, Japan started full-scale war preparations in case the worst came to the worst. However, despite Japan's efforts, Japanese-U.S. relations came to the worst, and on 8 December, Japan opened hostilities.

The operation to invade the main areas of the south was conducted with the aim to advance as far as to the line of Java, quickly get hold of the resources necessary to nurture and maintain Japan's national power, while creating political stability in the Far East by estab- 
lishing a Greater East Asia Co-prosperity Sphere. Although Burma was listed as a key point of military, political and economic importance in establishing the Greater East Asia Co-prosperity Sphere, due to the military strength necessary for the [whole southern] operation, a full-scale invasion of the country was not considered at the time of the opening of hostilities. However, after the more-than-expected progress in the southern operation, it was decided to conduct a full-scale invasion [of Burma], and in order to support it, the Navy carried out an operation in the Indian Ocean. This operation concluded the offensive operations of the Navy [in the theater] to the southwest [of Japan]; the major operations of the Navy thereafter came to be directed to the east and southeast of Japan.

This volume deals with the Navy invasion operations in the Dutch East Indies as well as its operations in the Indian Ocean, which followed the operations in the Philippines and Malaya areas. It was an undeniable fact that in these operations, some engagements were [rather] passively conducted, which was not the Navy's preferred way in view of its annihilate-the-enemy-on-sight tradition. It seems that this was caused by the fact that the Japanese Navy regarded itself inferior to its principal enemy, the U.S. Navy, and had to be very careful not to lose vessels, particularly cruisers and larger vessels, and by the fact that due to the remarkable results achieved by our aircraft after the opening of hostilities, the Navy became unconsciously too impressed by the power of air forces.

\section{Explanatory Notes}

1. In general, date and time are indicated in Japan Standard Time [JST] unless otherwise specified.

2. Time of day, such as 2.30 p.m. is expressed as 1430 .

3. 'Meter,' 'centimeter,' 'millimeter,' and 'nautical mile (1,852 meters)' are used to express length [and distance].

4. 'Knot' (nautical miles per hour) is used for the speed of ships.

5. [Concerns the original Japanese text. Not relevant to the translation. Omitted by the editor.]

6. [Concerns the original Japanese text. Not relevant to the translation. Omitted by the editor.]

7. The numbers within parentheses refer to the historical source materials. These are shown together at the end of this volume.

8. [Concerns the original Japanese text. Not relevant to the translation. Omitted by the editor.]

9. The names of units are expressed with their proper names or abbreviated names; their symbols and abbreviations, a list of which is attached at the end of the volume, are only used in the attached maps and illustrations.

10. [Concerns the original Japanese text. Not relevant to the translation. Omitted by the editor.] 


\section{Chapter I The Circumstances Leading to Japan's Invasion of the Dutch East Indies}

\section{The Prewar Operational Policy of the Navy and the Supply and Demand of Oil}

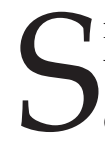

ince Japan's victory in the Russo-Japanese War, the interests of Japan and those of the United States gradually started to clash over policies in the Far East, and they came to consider each other as potential enemies. Consequently, Japan established an Imperial Defense Policy for the first time in 1907, and singled out the United States, Russia and France as its hypothetical enemies. However, in view of the difference in national power between Japan and these countries, the policy was adopted that a war against two or more countries at the same time should be avoided; that by political means Japan should be steered to a war against one country [only]; and that if war should be waged, it should be conducted quickly and decisively. In this plan, the strategy against the United States, where the Navy would play the leading role, was, in view of [the differences in] national power and military strength, to take advantage of the different strategic positions of both countries and intercept the U.S. Fleet at sea close to Japan. The reason [for this strategy] was that, gathering from the operational thinking of the U.S. Navy and American Far Eastern policy, it was considered inevitable that the U.S. Fleet would attack at an early stage after the opening of hostilities. Later on, due to changes in the international situation, France was removed from [the list of] hypothetical enemies and China and Britain were added instead. Further in 1918, the plan to capture the Philippines at the opening of hostilities was added to the operational outline against the United States. Although Britain was added to [the list of] hypothetical enemies in 1936, hardly any concrete operation plans were studied. It goes without saying that no operation plans at all were considered against the Dutch East Indies.

As is generally known, Japan was lacking in natural resources and its industrial technology lagged far behind the United States and Britain, which rendered it dependent on other countries for most resources as well as technology. On top of that, for a large proportion [of its needs] it depended on its hypothetical enemies, the United States and Britain, as well as on other countries that were under their strong influence. Japan's domestic production of oil, for which demand had sharply increased among others because of the switch of the Navy to heavy oil as fuel, the growing industrialization of Japan, and the rapid increase in the number of cars and aircraft, covered merely about 10 percent of the demand. For the rest, it had to rely on imports. Ironically, 70 percent of the total imports came from the United States, its hypothetical enemy. Moreover, it relied on the United States for its entire oil refinery technology (according to the statistics of 1936). In those years, as the largest consumer of oil, the 


\section{Dutch East Indies}

Navy took the lead in improving the oil policy and although it tried hard to solve the problems, it still could not come up with proper solutions.

The annual production of oil in the southern region from 1936 to 1939 was about 7.95 million tons in the Dutch East Indies, about 0.93 million tons in British Borneo, and about 1.27 million tons in Burma, while the annual demand in Japan in this period was between about 4.40 million and about 5.70 million tons. ${ }^{(1)}$ The oil production in the southern region well surpassed the demand in Japan, while the oil fields in these areas were not yet much developed. Therefore, Japan planned to shift from its hypothetical enemy, the United States, to the southern region for its import source of oil. However, the plan was not successful, and it remained dependent on [oil imported from] the United States.

\section{Changes in the International Situation and the Import of Essential Materials}

In 1933 in the wake of the Manchurian Incident (1931), Japan walked out of the League of Nations (due to the latter's adoption of a resolution that Manchuria should be made a demilitarized zone under international control). Following that, Japan concluded in November 1936 the Anti-Comintern Pact with Germany, which Italy also joined. After that, relations between Japan and the United States briefly relaxed, but in 1937 the China Incident occurred, and despite the policy of the [Japanese] government to contain it, the incident continued to expand. The United States, leading the countries concerned, resumed and continued its protest against Japan. Moreover, the United States took the proclamation of the "Establishment of a New Order in East Asia," which Japan had announced in November 1938, as an open challenge to the principles of its foreign policy. Meanwhile in Europe, the radical policies of the Nazi government increased tensions in the international situation surrounding Germany, and the political situation worldwide, in the West as well as in the East, turned turbulent.

In May 1939, the Soviet Union carried out a large operation in Nomonhan, and Japan was exposed to a serious threat from the north, too (the Nomonhan Incident). Meanwhile, the United States took the opportunity of Japan's blockade of the British concession in Tianjin to give on 28 July 1939 Japan notice of the abrogation of the U.S.-Japan Treaty of Commerce and Navigation (with an advance notice of six months). The aim [of the United States] was to contain Japan's actions in the Far East by [showing] its readiness to control at any time the export of materials that were essential to Japan. This measure caused much concern in Japan, which was hurriedly building up its military preparedness against interference by third countries, while prosecuting the China Incident at the same time. Particularly from the perspective of the situation in those days, it was considered highly likely that should Japan be involved in another war it would likely be a protracted war. In order to endure such a protracted war, it was absolutely essential for Japan to obtain the raw materials indispensable for maintaining and nurturing its national power. Consequently, Japan had no other choice but to urgently obtain them in areas closer at hand, i.e. the Far East.

In Europe, the Second European War [the Second World War] began with the German invasion of Poland in September 1939. At the end of the year, the United States condemned the Soviet Union's indiscriminate bombing of Finnish citizens and banned the export of refinery technology and equipment to produce high-grade gasoline [to the Soviet Union]. As this 


\section{Dutch East Indies}

measure was also applied to Japan, which was prosecuting the China Incident, Japan was no longer able to import the technology and was seriously affected by it.

Although the abrogation of the U.S.-Japan Treaty of Commerce and Navigation came into effect in January 1940, the U.S. government did not immediately start imposing restrictions on exports to Japan. However, the strain on the Japanese economy was not eased at all, and Japan desperately tried every means to meet the situation.

As mentioned previously, Germany had all of a sudden invaded Poland on 1 September 1939, and partitioned the country with the Soviet Union, but it showed little noteworthy activity after that. However, from April 1940 onwards the German Army became active [again], occupied Denmark and Norway at a stroke, drove the allied forces from the European Continent (the so-called "Dunkirk Tragedy") and finally occupied Paris on 14 June. Belgium, the Netherlands and France were overwhelmed in the German blitzkrieg, and a German landing on the British mainland seemed highly likely. This meant that the British, Dutch and French colonies in the Far East had lost or were about to lose their mother countries. [Meanwhile,] still maintaining its neutrality, the United States stayed focused on supporting the allied countries in Europe, while in the Far East urgently containing the offensive actions of Japan, which was taking advantage of the situation. For that purpose, the United States took the following measures against Japan:

[1940]

May: Announced the permanent stationing of its Pacific Fleet in Hawaii in order to contain Japan's southward advance.

June: Imposed an embargo on the export of machine tools.

July: Enacted the "Act to Expedite the Strengthening of National Defense," [i.e. Export Control Act of 1940] with which the United States applied a license system to the export of materials essential to its defense, and granted the President the authority [to decide the licensing]. However, petroleum products and scrap iron were excluded from the items subject to an export license.

[July]: Enacted the "Two-Ocean Navy Act," (an armaments expansion plan to expand the number of warships by 70 percent as well as the number of aircraft to 15,000).

End [of July]: Added particular petroleum products and scrap iron to the items subject to export licensing.

Note:

1. Japan was rapidly expanding its industrial power and was very much short of machine tools. Moreover, due to its [poor level of] technology, most precision machines were imported.

2. Scrap iron was essential as a material for steelmaking, and most of it was imported from the United States at that time.

However, as the U.S. government permitted the export of petroleum products and scrap iron to Japan even after the enactment of the "Act to Expedite the Strengthening of National Defense," Japan made every possible effort to import and store them. 


\section{The International Situation and the Changes in the Policy for Coping with the Current Situation}

When Japan was in such a predicament, the war situation in Europe was rapidly developing to the advantage of Japan. It led Japan to decide in July 1940 on an ambitious national policy to set its course to "Establishing a Greater East Asia New Order," which, with Japan, Manchuria and China as the basis, would include the southern region. In line with this, Japan decided on the Outline of the Main Principles for Coping with the Changing World Situation, in order to solve existing problems at a stroke. The main points of the outline are as follows:(2)

1. Efforts shall be made to promptly settle the China Incident.

2. Political ties with Germany and Italy shall be promptly strengthened.

3. Military forces of one element strong shall be advanced into French Indochina to work out [and take] measures to stop the support for the Chiang Kai-shek [Jiang Jieshi] regime from northern French Indochina as well as to obtain resources.

4. As for the Dutch East Indies, [Japan] shall seek to obtain resources for the time being by diplomatic means. If the situation permits, the aim shall be accomplished even by resorting to force of arms. Even in such a case, friction with the United States shall be avoided as much as possible, though preparations for a war against the United States shall be duly made.

In accordance with this outline, Japan advanced [its forces] into northern French Indochina and also concluded the Tripartite Pact in September of the same year [1940]. [Previously] on 1 August, the United States had already banned the export of aircraft fuel to areas outside the western hemisphere, and it further added scrap iron and steel to the export embargo except for the western hemisphere and Britain. Also, Britain notified the re-opening of the supply route [to the Chiang regime] via Burma. Around this time, the [Japanese] Army and Navy started their study of the Dutch East Indies invasion operation for the first time as a contingency plan. Although the Navy had been making war preparations so as to be ready for an intervention by a third power in the wake of the China Incident, it could simply not catch up with the developments in the current situation. The Navy even considered to issue the order to put a preparatory fleet mobilization into motion, which was supposed to be passed down only when an opening of hostilities was expected (a preparatory action required to shift the Naval forces and institutions to their wartime footing). In the meantime in September 1940, the [Japanese] government dispatched Minister of Commerce and Industry Kobayashi Ichizō to the Dutch East Indies as special envoy to start negotiations for an increase in the imports of oil and other resources. At that time in the United States, President Roosevelt was expected to be reelected for a third term, which, in Japan's view, would result in a much more uncompromising policy toward Japan.

On 12 September 1940, while Japan worried about a U.S. oil embargo after the expected third-term reelection of Roosevelt, Special Envoy Kobayashi arrived in Java. Special Envoy Kobayashi negotiated to the best of his ability with the aim of importing 3.15 million tons, or if possible, 3.80 million tons of oil. However, on 17 October, before achieving his aim, he received the order recalling him home. At that time, the Dutch East Indies was heavily dependent on the United States and Britain, and the relations [between them] were so close that a meeting between the United States, Britain and the Netherlands on the defense of the region was held in Singapore in October 1940. Replacing Special Envoy Kobayashi, Ambassador 


\section{Dutch East Indies}

Yoshizawa Kenkichi arrived in Java on 28 December, and resumed the negotiations. But the negotiations were not substantially different from those with the Americans and the British. On 14 June 1941, with almost no progress made, he was instructed to discontinue the negotiations and received an order recalling him home.

Prior to this, the Army and the Navy had differed in their judgment of the international situation. The difference was whether the United States would immediately stand up for Britain and wage war against Japan should Japan strike Britain (which meant that they should be regarded as inseparable), or not (which meant they could be considered as separable). The Outline of the Main Principles for Coping with the Changing World Situation of July 1940 had been decided upon the assumption that the United States and Britain were separable, in view of the world situation at that time (i.e. [the battle of] Dunkirk in May, Italy's opening of hostilities against Britain and France in June, and the surrender of France of the same month). However, in the course of a study conform to the Outline of the Main Principles for Coping with the Changing World Situation, the Navy became skeptical about the judgment that the United States and Britain were separable, and returned to its former judgment that they should be considered inseparable. In the meantime, as the likelihood of a German landing on the mainland of Britain and the latter's collapse, which Japan had expected, diminished, the Army was also becoming cautious about the use of force in the southern region. As a result, in April 1941, the Outline of Policy toward the South was agreed upon between the Army and the Navy Departments of IGHQ. This outline took a step back from the active advance into the south policy of the previous year and contained the following major points: $(3,4)$

1. The objective of the present policy toward the south is to promptly expand the overall national defense strength for the sake of the Empire's self-preservation and self-defense. To this end:

(1) The military, political and economic ties between the Empire, French Indochina, and Thailand shall be made closer.

(2) Close economic relations shall be established between the Empire and the Dutch East Indies.

(3) Normal commercial relations shall be maintained between the Empire and the other southern nations.

2. The above shall be achieved through diplomatic means. In particular, military ties shall be urgently established with French Indochina and Thailand.

3. In case the following situations should occur and no solutions should be found, force of arms shall be employed for the sake of self-preservation and self-defense:

(1) In case where the self-preservation of the Empire should be threatened by the embargoes imposed by Britain, the United States and the Netherlands.

(2) In case the encirclement by the United States, Britain, the Netherlands, China, etc. were stepped up to the degree that it is no longer tolerable from the standpoint of national defense.

4. If the collapse of Britain may be taken for certain, the purpose of this policy shall be achieved, particularly by intensifying diplomatic actions toward the Dutch East Indies.

In the meantime, Japan succeeded in mediating the border dispute between Thailand and French Indochina in November 1940, and in March 1941, it also concluded agreements [with French Indochina and Thailand] that neither of them should have political or military cooperative relations with third countries. 


\section{Dutch East Indies}

In those days, the United States government increased the economic pressure with the following measures:

December 1940: Added aviation lubricant manufacturing equipment to the items subject to an
export license.
February 1941:
Added well-drilling rigs, oil tanks, oil drums and others to the items subject
to an export license.
April 1941:
(1) The decision as to the additional inclusion of derivatives and materials
transformed from the items subject to an export license into items to be con-
Control.
(2) The leaking of information to other countries on the production and pro-
cessing of items currently subject to an export license should be controlled.

Furthermore, on 21 June 1941, right after the discontinuation of the negotiations between Japan and the Netherlands, the United States included all petroleum products in the items subject to export licensing.

The next day, 22 June 1941, the German army all of a sudden invaded the Soviet Union, and the German-Soviet War started. After that, the support for Chongqing [government] by the United States and Britain was strengthened more than ever. [Also], the so-called ABCD encirclement ([by] America, Britain, China, and the Dutch) was formed, and machinations in French Indochina and Thailand to alienate them from Japan were intensified, which made it difficult for Japan to obtain rice, rubber, and tin. The Dutch East Indies was also getting tougher in its attitude. On 25 June 1941, the Measures for Advancing the Southern Policy, which included [the idea to] advance into southern French Indochina, was decided upon; it was aimed to cut off the connections between the United States, Britain and the Chongqing government, to confront the United States, Britain, and the Netherlands, which had placed political, economic and military pressure [on Japan] in the southern region, and also to contain the machinations [of these countries] in French Indochina and Thailand to alienate them from Japan. Furthermore, on 2 July, the Outline of National Policies in View of the Changing Situation was decided upon, in which three policies were laid down: that [Japan] should firmly hold the course to establish the Greater East Asia Co-prosperity Sphere, that it should accelerate the preparations for a southward advance, and that it should solve the northern problems depending on the situation. ${ }^{(2)}$

Note: In order to solve the northern problems [mentioned] here, the Army mobilized an unprecedented number of troops and reinforced the Kwangtung Army and the Korean Army (the Special Grand Maneuvers of the Kwantung Army, a.k.a. "KANTOKUEN"). However, due to subsequent changes in the situation, the lull in tension at the border between Manchuria and the Soviet Union lasted until right before the end of the war.

On 28 July 1941, in accordance with these policies, the Japanese Army advanced into southern French Indochina in a peaceful way. Prior to this, on 25 July, the [Japanese] government had Nomura Kichisaburō, Japanese ambassador to the United States, directly explain to President Roosevelt the intentions and the reasons of the advance [of the Army] into southern French Indochina. In the wake of this, on 26 July, the U.S. government announced a freeze on Japanese assets, which was followed by Britain and the Netherlands. Then on 1 August 1941, the United States put a total embargo on the export of oil [to Japan]. Until that time the U.S. gov- 


\section{Dutch East Indies}

ernment had not put an embargo on oil because it judged that Japan would certainly start its southward advance to seek oil by force of arms if the oil supply [to Japan] was stopped. Therefore, Roosevelt's intention to totally stop the oil supply to Japan was of extremely great significance.

\section{The Supply and Demand of Essential Materials and the Appropriate Moment to Open Hostilities}

It was obvious that Japan, having been prohibited from importing oil, would not be able to survive an anticipated, protracted war against two or more countries with its current stock and [small] domestic production [of oil]. Cornered into such a situation, [Japan] had no other way but to make large concessions in an attempt to break the deadlock in the Japan-U.S. negotiations, or to swiftly obtain oil in the Dutch East Indies even by force of arms.

As of 1 August 1941, an investigation by the Naval Affairs Bureau of the Navy Ministry of the supply and demand of oil in case of war yielded the following results. In this study, it was assumed that the key areas in the south including the Dutch East Indies were captured and the oil produced in those areas could be sent back [to Japan]. ${ }^{(5)}$

1. Estimated Supply and Demand (kilo tons)

War

A. Amount of Stock at the Beginning of the Year

B. Acquirable Amount per year

Domestic Production

Synthetic Oil

Oil Sent from the South

C. Total $(\mathrm{A}+\mathrm{B})$

D. Annual Consumption

E. Amount of Stock at the End of the Year (C-D) 1st year

9,400

200

300

300

10,200

5,400

4,800

800

1,000

500

2,300

F. Minimum Reserve

$\begin{array}{lr}\text { Fixed reserve in tanks } & 800 \\ \text { Reserve mainland Japan } & 1,000 \\ \text { Reserve for decisive battles } & 500 \\ \text { Total } & 2,300\end{array}$

Amount usable by the End of the Year (E-F)

2,500

440

1,710

2. Presuppositions of this study

(1) All oil facilities [in the areas to be occupied] are destroyed by the time of occupation.

(2) Drilling rigs

The current number of rigs: 200. Under construction: 40 rigs ([ordered by] the Navy; to be completed in December 1941), and 40 rigs ([ordered by] civilians, to be completed in March 


\section{Dutch East Indies}

1942); the number of rigs [under control of or ordered by] the Army is unknown. Estimated annual turnout of rigs: 100 (amount of steel necessary [for constructing] one unit: 200 tons).

(3) Workers

Current [oil] workers at home: 7,800. On-site workers required: 3,200 in Borneo, 1,500 in Sumatra, totaling 4,700.

(4) Steel pipes stored or in production at home shall be used when they are ready. (The domestic annual production capacity: 250,000 tons, which allows the construction of 2,000 wells of 700 meters deep).

(5) The drillings shall be primarily wartime makeshift drillings.

(6) The rate of loss of crude oil by enemy attacks shall be set at $10 \%$.

(7) Transport capacity

The current number of tankers is 47 with a [total] capacity of 440,000 tons, and the amount [of oil] to be transported from the Dutch East Indies to the mainland is about 5 million tons. The number of tankers to be built in the next three years (as of 1 August [1941]) is 10 tankers of the 10,000-ton class and about 20 of the 5,000-ton class, with [a capacity of] 200,000 tons in total. (This plan works [only] when the rate of wartime transport loss is calculated at $10 \%$. The shipbuilding costs have to be increased if necessary in the light of actual performance.)

3. Negative factors in this study

(1) Loss of domestic oil reserve by possible enemy air strikes is not included in the calculation.

(2) Although loss [of oil] on site by possible enemy air strikes is, combined with transport loss, calculated at $10 \%$ of the production, the loss rate may be larger.

(3) No drilling mishaps were taken into consideration.

(4) [In the light of] considerable difficulties to transport the oil produced in Seria and Sumatra [to ports], six months was allotted for fixing the pipelines from Seria and seven months for those from Palembang. However, it may take many more days to fix them depending on the degree of damage.

4. Positive factors in this study

(1) The production from the northern Sakhalin oil field is not included in the calculation. (The amount could be 50,000, 200,000, and 1,200,000 tons respectively for the first, the second and the third year, if all of its production will be available.)

(2) [The production from] the oil field in western New Guinea is not taken into consideration. According to fairly reliable information, the quantity of oil in that area is no less than that in Borneo. After the test drillings, deadlight-lids were reportedly put over the wellheads. If this is true, it will be quite easy to obtain the oil after occupation.

(3) [The production of] the domestic oil fields for the first and the second year is calculated at half the amount produced in peacetime. If production work is concentrated on the main oil fields as a stopgap measure, it is possible to obtain the same production amount as in peacetime from the first year on ([which means] an increase in the domestic oil production for both the first and the second year by 200,000 tons.)

(4) As for the [average] monthly production of oil per well, Engineer Ōmura of Nippon Oil estimates that the current average production can be [increased] by [at least] three times for sure by drilling new wells as a wartime stopgap measure, while abandoning the wells, whose production has sharply dropped. However, to make this study more reliable, [the average monthly production per well] was calculated at two times or less [the current average production]. If the estimate by Engineer Ōmura is correct, the production can be further increased by fifty percent.

(5) The oil fields in central and northern Sumatra are not included in [this] calculation. It is possible to double the amount of oil production in southern Sumatra if drilling rigs are ordered 


\section{Dutch East Indies}

simultaneously with the opening of hostilities (oil drilling rigs ordered by the Army are excluded from the calculation).

(6) [The situation will be] all the more favorable if fires of gushing oil wells are extinguished or current facilities [assumed to be destroyed] are fixed and used, and extremely favorable, particularly if the fires are successfully extinguished because such wells will be available as they are.

(7) Some further increase in the production of synthetic oil is likely.

5. Conclusions of this study

(1) Due to the oil embargo imposed by the United States, Britain and the Netherlands, the stock of oil [in Japan] will decrease from August onwards by 400,000 tons every month. Unless war is waged by the end of October [1941], fuel [shortage] is feared at the end of the second year of the war.

(2) It is necessary to make as much effort as possible to increase the production of synthetic oil, but not much can be expected unless drastic measures would be taken.

(3) When conducting the Dutch East Indies invasion, it is necessary to come up with good ideas when planning and carrying out the operation in order to minimize damage to the oil fields.

(4) It is necessary to give oil field workers to be dispatched to the occupied areas a training to extinguish fires set at [naturally] flowing oil wells. (Note: For this purpose, a system of defense details was employed later, and two defense details were formed.)

As seen in this study, it was feared that the war potential [of Japan] would sharply drop and finally be lost if the embargo on the import of oil should continue and the moment to wage war should be delayed. Meanwhile, the Cabinet Planning Board made the following estimates at the end of October [1941]. ${ }^{(2)}$

War

A. Amount of Stock at the Beginning of the Year

B. Annual Production

Domestic Production

Synthetic Oil

C. Total $(\mathrm{A}+\mathrm{B})$

D. Annual Consumption

E. Amount of Stock at the End of the Year (C-D)

F. Minimum Reserve

Amount usable by the End of the Year (E-F)

1 st year
8,400

360
300
9,060
4,400
4,660
1,500
3,160

$2 \mathrm{~d}$ year

4,660

400

500

5,560

4,000

1,560

1,500

60
$3 d$ year

1,560

440

700

2,700

3,950

$-1,250$

1,500

$-2,750$

[kilo tons]

Therefore, if Japan had no choice but to wage war, it needed to decide as soon as possible in view of the oil [stocks].

Furthermore, apart from oil, Japan's stockpiles of other materials for which it depended on imports were also extremely small. The stockpiles of materials kept by the Navy as of August 1940 were as follows. The stockpiles were at such a [low] level that they would barely last for about one year if imports of the materials should stop. ${ }^{(6)}$

$\begin{array}{lr}\text { Items } & \text { Period (months) [the item will last] } \\ \text { Nickel } & 10.5 \\ \text { Copper } & 11.0 \\ \text { Asbestos } & 13.0\end{array}$




\section{Dutch East Indies}

$\begin{array}{lr}\text { Aluminum } & 9.5 \\ \text { Items Period (months) [the item will last] } \\ \text { Crystal } & 13.0 \\ \text { Tungsten } & 19.5 \\ \text { Lead } & 15.0 \\ \text { Items } & \text { Period (months) [the item will last] } \\ \text { Cobalt } & 7.5 \\ \text { Mica } & 4.0 \\ \text { Chromium } & 15.5 \\ \text { Mercury } & 10.0 \\ \text { Items Period (months) [the item will last] } \\ \text { Molybdenum } & 22.0 \\ \text { Zinc } & 10.0 \\ \text { Crude Rubber } & 3.5\end{array}$

According to the study of the Cabinet Planning Board as of the end of October 1941, the procurement of tungsten ore, tin ore, crude rubber, rice, corn, rock phosphate, pine resin, raw lacquer, cowhide, vegetable fats and oils and the like had [already] become difficult, while in the southern region, large amounts of crude rubber, sugar, timber, Manila hemp, cinchona, iron, copper, chromium, tin, zinc, nickel, bauxite, and coal for iron-manufacturing were produced. Consequently, from the standpoint of Japan it was desirable to try to get hold of the region as soon as possible.

Also from a military point of view, it was preferable that if worst came to worst and there was no choice but to wage war, it should be done the sooner the better in view of the fact that with the passage of time the ratio in military strength between Japan and the United States would worsen [for Japan] and the encirclement by the ABCD countries could be expected to become stronger; furthermore, that it was necessary to finish the southern operation before a northern operation became feasible because of a thaw in the weather in the north in order to avoid simultaneous operations in both the north and the south, and that it was also necessary to launch the operation before the northeastern monsoon started in the South China Sea which would make the landing operations on the east coast of the Malay Peninsula difficult.

So, the Army and the Navy pressed the government to not lose the right moment in deciding to wage war should the emergency arise. At the same time, the Navy started full-scale war preparations as a precaution and, on 1 September 1941, announced the all-out wartime formation. At that time, the Japan-U.S. negotiations were hardly making any progress. On 6 September, the Main Points for the Implementation of Imperial National Policy was decided at the request of the Army and the Navy. ${ }^{(2)}$ The gist was that [Japan] should complete the preparations for war by the end of October, while taking all possible diplomatic steps to break the deadlock in the Japan-U.S. negotiations and try to attain its minimum demands, but that it would nevertheless decide to wage war in the beginning of October if it had no prospect of attaining its demands.

\section{Changes in the Measures to Cope with the Fuel [Problem]}

As seen above, Japan was heavily dependent on its hypothetical enemy, the United States, for the supply of oil as the energy source of all of Japan's activities, so the [U.S.] export con- 


\section{Dutch East Indies}

trols against Japan posed a great threat to the latter. To put it forcibly, it may even be said that [the controls] forced the latter into war. In view of the importance of oil, let us try to summarize the changes in the policy adopted by the Navy, which had a leading role in [Japanese] oil policy, as well as the changes in the national oil policy.

\section{The Navy's countermeasures [against oil shortage]}

At the end of the Meiji Period when heavy oil came into use as fuel for naval vessels, it was expected that [the demand] could be covered by domestic production. However, heavy oil became the only fuel for the engines of naval vessels; then it was also adopted as fuel for civilian factories and the like, and the relation between supply and demand became, contrary to expectations, rather precarious. The Navy, considering it urgent to quickly stockpile oil, purchased 3,700 tons by the end of 1909. Afterwards, the Navy aggressively purchased and stored oil, and by the end of 1926, the [oil storage] tank capacity reached 1.59 million tons, and the heavy oil storage 1.54 million tons. ${ }^{(7)}$

In 1920, the Imperial Diet approved the "Eight-Eight Fleet Plan" ([aiming to build] a large fleet of eight battleships and eight [armored] battle cruisers as the core), which were within the first period of a warship's life, i.e. eight years from the start of construction, which made the current level of stored oil totally inadequate. On the completion of this plan, the annual amount of heavy oil required in the first year of a war would jump to about 3.6 million tons, and that in the second year and onwards to about 2.6 million tons. ${ }^{(7)}$ Accordingly, the Navy had to urgently push forward comprehensive countermeasures against a fuel [shortage]. The principal measures taken were the following: ${ }^{(7,8,9)}$

(1) Promotion of import of overseas oil: The first contract was made in 1917, and imports from Borneo, the United States and others got on track.

(2) Development Assistance to the north Sakhalin oil fields: Owing to this measure, the annual production [of the oil fields] reached about 200,000 tons around 1932 and 1933.

(3) Development Promotion of oil field(s) in Taiwan: Although the field(s) did not yield satisfactory amount(s), this measure greatly raised awareness regarding oil [shortage] issues in Taiwan, and had a great effect [on promoting alternative fuel plans such as] the use of natural gas.

(4) Research on low-temperature carbonization: Although it did not reach [the level of] practical use, the research formed a basis for the coal liquefaction industry.

(5) Stimulation of the shale oil industry: Shale oil, when blended with oil from Tarakan at a ratio of three or less to seven, was fit for use by the Navy as heavy oil. It was said that shale oil from the Fushun Mines in Manchuria would reach 5 billion tons, and that that amount was located above the coal bed alone. Shale oil had much potential as alternative liquid fuel and the annual production of unrefined oil reached 370,000 tons from 1939 to 1940.

(6) Promotion of the coal liquefaction industry: Although coal liquefaction was by and large successful as an experiment in 1935, due to the high temperature and the high pressure required, there were technical difficulties in its industrial production. [As the industrialization] was also hampered by the difficulty in obtaining materials from 1937 and onwards, the actual production only reached about $10 \%$ of the plan.

(7) [Increase in] oil storage: Although the target amount of the crude oil storage of the year 1936 was 10 million tons, [only] half of the target was actually stored.

(8) Subsidizing the building of tankers.

(9) Promotion of countermeasures against [shortage of] aviation fuel: Research on a practical application of tetraethyl lead (an antiknock substance to prevent early ignition and improve power output) as well as research on a method to produce high-octane cracked gasoline by hydrogenation was conducted.

(10) Introduction of [foreign] technologies to produce isooctane and aviation lubricant. 


\section{Dutch East Indies}

(11) Promotion of an industry to synthesize isooctane.

(12) Development of the domestic production of high-grade aviation lubricant: The production succeeded at last in 1943 and 1944.

(13) Construction of oil storage tanks: The [total] capacity reached 6,914,000 tons in 1942.

(14) Facilitating the supply and demand of fuel by streamlining the departments managing it.

2. The transition of the national oil policy

Until about 1930 - 1931, fuel policy was [mainly a subject of] research and discussion. However, in the wake of the Manchurian Incident in 1931, [the Japanese government] shifted to the implementation of a fuel policy, and with the Petroleum Industry Law, which became effective in July 1934, oil came under strict control of the government. The main measures of the national oil policy were as follows. ${ }^{(10)}$ First of all, with the Petroleum Industry Law:

(1) A license system was introduced to control the oil business.

(2) The duty of storing oil was imposed on oil companies: Each company was required to store at all times half the amount of its total imports of crude oil, heavy oil and gasoline of the previous year.

(3) According to the policy [to promote] domestic refining, protection was given to domestic companies by giving an advantage to domestic products over the imported products in the allotment of sales.

Soon after that, due to the outbreak of the China Incident in July 1937, oil consumption had to be brought under control.

(1) The First [Oil] Consumption Controls (November 1937)

\{1\} Ban on cruising taxis.

$\{2\}$ Ten percent reduction in gasoline consumption of buses and gasoline-fueled cars in both public and private use.

\{3\} Saving gasoline consumption of trucks by improving efficiency of business operations.

\{4\} Voluntary restrictions on the use of gasoline for private cars.

\{5\} Creating substitute fuel for official cars by blending 5\% alcohol with the gasoline.

\{6\} Propagating equipment for gasoline-substitute fuel such as charcoal and firewood, and promptly employ wood gas generators for buses, trucks and gasoline-fueled cars in governmental use.

\{7\} Ten percent reduction in the consumption of heavy oil in the mining and manufacturing industries by increasing the efficiency of its use and by improving facilities.

(2) The Second [Oil] Consumption Controls (May 1938)

About the same time as the enactment of the National Mobilization Law, the regulations for the control of gasoline and heavy oil sales were promulgated, and a coupon sales system was adopted.

(3) The Third [Oil] Consumption Controls (September 1941)

All private vehicles were completely prohibited from using gasoline, and made to run on substitute fuel (wood gas).

Apart from the above, such measures as the implementation of an overall fuel administration by a newly established Fuel Agency, the stockpiling of fuel and the promotion of the substitute fuel industry were taken, but the outlook for the supply and demand of fuel remained bleak. 


\section{Dutch East Indies}

In conformity with the consumption controls imposed on civilians, the Navy, too, placed a rigid limit on the fuel used in fleet training, the bulk consumer. From 1935 onwards, the Navy earnestly made efforts to conserve oil by only [allowing its fleet training] an annual allotment [of fuel] that would merely cover thirty to forty-five around the clock sailings at cruising speed (about twelve knots), with a separate amount set aside for eight around the clock tactical exercises. As for naval vessels not included in the fleet, it further reduced the allotment of fuel, limiting the allotment to an amount that would cover twenty-five around the clock sailings.

\section{The Breakdown in the Japan-U.S. Negotiations}

As mentioned previously, Japan decided on the Main Points for the Implementation of Imperial National Policy on 6 September 1941, and in the negotiations with the United States tried to attain its minimum demands, but even in mid-October nothing concrete had materialized. The Konoe Cabinet, however, could not make up its mind about war or peace, and finally resigned en bloc. On 18 October the Tōjō Cabinet was formed and, in accordance with the personal instruction of the Emperor, started all over again with the decision of 6 September, and reexamined the whole situation from scratch. Nonetheless, on 5 November, as a result of the reexamination, it was decided "to suspend the initiation of military action should the negotiations with the United States prove successful by 0000 on 1 December." Pending that, it was decided "to remain resolved to wage war against the United States, Britain and the Netherlands, to set the time for the launch of military action at the beginning of December and to have the Army and the Navy complete their operational preparations, while at the same time making efforts to come to an agreement in the negotiations with the United States." (2) Following this, the high command set the tentative date for the opening of hostilities on 8 December. Judging from the situation of that time, the outlook for an agreement in the Japan-U.S. negotiations was bleak.

Prior to this, the Navy launched a full-scale war preparation from August 1941 onwards, and on 15 August, the Combined Fleet issued an order to complete the war preparations by the beginning of October (anticipating the opening of hostilities in mid-November). However, partly due to the massive personnel shifts, which followed the announcement of the all-out wartime formation, the war potential [of the Navy] sharply dropped and it had to postpone the tentative date for the opening of hostilities previously fixed on the middle of November. The Army could not complete its preparations in time either, and consequently the [new tentative] date for the opening of hostilities was fixed on 8 December. In the meantime, the work to draw up an operation plan went on, and the plan was for the most part completed by the end of October. Although there were complicated developments in the course of the planning, the surprise attack on Hawaii right at the outset of the war with a unit consisting of the full strength of the main carriers (six carriers) as its core, was adopted in the operational policy of the Navy Department of IGHQ at the strong request of Commander in Chief of the Combined Fleet Admiral Yamamoto Isoroku.

The Navy Department of IGHQ put forth the "Operational policy to be carried out by the Combined Fleet" as of 5 November, and the latter issued its operation orders in conformity to this policy. The Combined Fleet shifted its forces to the dispositions at the time of the opening of hostilities ([by] disposing its forces so as to suit the planned operations), and each unit 


\section{Dutch East Indies}

started its deployment to the standby positions before the opening of hostilities. Then on 21 November, the Navy Department of IGHQ told the Combined Fleet to advance its units to the operational waters, and all units started to advance to their respective stations for the time of launching operations.

Meanwhile, concerning the rough going Japan-U.S. negotiations, the government furthermore urgently dispatched Ambassador Kurusu Saburō [to the United States] to present a new proposal and to seek progress in the negotiations. However, the reply from the U.S. Government, the so-called "Hull Note," was unbending. It plainly demanded the following points:

1. Withdrawal of all military, naval, air and police forces from China and from Indochina.

2. Repudiation of any government or regime in China other than the regime [of Chiang Kai-shek] with its capital at Chongqing.

3. Renunciation of special close relations between Japan and China.

4. Declaring the Tripartite Pact a dead letter.

On 28 November 1941, having received the full text of the "Hull Note," the [Japanese] government and the high command examined the contents in a liaison conference and came to the unanimous conclusion that this could not be regarded as anything but an ultimatum [to Japan], and that no way was left now for Japan other than to wage war for its self-preservation and self-defense. As a consequence, at 1610, 1st December, 1941, the following decision was given by the Emperor:

The negotiations with the United States in accordance with the Main Points for the Implementation of Imperial National Policy decided on 5 November were unsuccessful. The Empire [of Japan] shall wage war against the United States, Britain and the Netherlands.

On the next day, the 2d, both chiefs of the Army and the Navy General Staffs reported to the Emperor side by side and asked for the approval of the Emperor to exercise military force against the United States, Britain and the Netherlands from 0000, 8 December, 1941 onwards. As a result, at 1730 on that day, the Combined Fleet transmitted the secret code telegram "Niitaka-yama Nobore 1208" [Climb Mount Niitaka on 1208] (Fix 8 December as Day X), and plunged headlong into the Greater East Asia War. 


\section{Chapter II The Military Topography of the South- western Region}

(See Attached Illustrations No. 1, No. 2 and No. 3) [Omitted]

$\mathrm{B}$ efore the opening of hostilities, both the Army and the Navy tried hard to gather military information about the southwestern region [southeast Asia], but except for the Philippines the information collected was utterly insufficient. As a result, the reality was that except for the Philippines [both] knew almost nothing about the details of the military topography [of the region] required for actual operations, and that they pushed forward with the operations while proceeding with the research. ${ }^{(11)}$

It is said that volumes one and two of [a compiled set of] military data kept at the Navy General Staff Office before the opening of hostilities partly contained rather detailed data. However, as they are no longer extant and other materials referred to at that time, ${ }^{(12,13)}$ such as, "Aviation handbook of the southern countries," "Military sketches," "Airport chart(s) of the Dutch East Indies," "Air base plans of the southern countries," "Meteorological charts of the southern countries," and "Wind volumes and directions chart," are virtually no longer extant either, the details [of what was known or not] are unclear.

The following is an outline of the military topography of the southwestern region obtained by the Navy by the end of 1941 .

\section{General Topography}

\section{The Philippines ${ }^{(14)}$}

The Philippines is a U.S.-ruled territory south of Taiwan. It consists of about 7,100 large and small islands that stretch for about 1,700 kilometers from south to north between latitude $5^{\circ}$ to $21^{\circ}$ north and for about 1,100 kilometers from east to west, of which Luzon is located in the north, the Visayan Islands in the center, Mindanao in the south, and Palawan Island and the Sulu Archipelago to the west of Mindanao. It was a strategic area that [Japan] had to secure at any cost for the advance on Java.

Air transportation in the Philippines is relatively developed. As for ground transportation, railroads are only available on Luzon, Panay, and Cebu, but they are in poor condition. However, on the flat country of the main islands motorways are well developed, and there are also many cars. Major ports are those of Manila and Cebu, and other ports such as those of Iloilo, Davao, and Legaspi serve for exporting local specialties.

\section{Thailand ${ }^{(15)}$}

Thailand lies in the middle of the Indochina Peninsula; it shares its eastern border with French Indochina and its western border with Burma. In the south it faces the Gulf of Thai- 
land. With its capital in Bangkok, it is the only independent nation in the Indochina Peninsula. Southern Thailand is also called Thai Malaya and borders on British Malaya. At that time, it was totally under the influence of Britain.

\section{Burma $^{(15)}$}

In Burma, the Arakan mountain range lies in the northwest, where the country borders on India, and in the east the Shan Plateau extends to where it shares borders with Yunnan and Thailand. The Irrawaddy River flows more or less southward through the central lowlands into the Bay of Bengal. Along with the seaport of Rangoon, this country came to attract the attention of the world as the so-called supply route to the Chiang Kai-shek regime.

\section{British Malaya $^{(15)}$}

British Malaya is a peninsula that further juts out from the Indochina Peninsula and faces the South China Sea in the east and the Bay of Bengal in the west. At the tip of the peninsula lies the island of Singapore, which serves as Britain's political, economic and military center in Asia. In British Malaya, rubber is commercially produced on an extensive scale, and mineral products are also abundant. The export hub [of these products] is Singapore. British Malaya produced respectively $40 \%$ and $30 \%$ of the total world production of rubber and tin respectively (in 1938).

\section{British Borneo $^{(15)}$}

British Borneo consists of the Principality of Sarawak and British Northern Borneo and borders on Dutch Borneo in the south. It faces the South China Sea in the north and also borders on the Philippines across the Balabac Strait. Oil is produced near Miri. Kuching, the capital of the Principality of Sarawak, has an airfield, which is located about 420 nautical miles from Singapore, about 420 nautical miles from Palembang, and about 510 nautical miles from Batavia; it is very important as an air base for the air campaign in the Java invasion operation.

\section{The East Indian Islands $\mathbf{s}^{(16,17,18)}$}

The Dutch East Indies consist of numerous islands situated close to each other in an area stretching from latitude $6^{\circ}$ north to $11^{\circ}$ south and from longitude $95^{\circ}$ to $141^{\circ}$ east with the equator more or less in the middle. The area can roughly be divided into the Sunda Islands, Borneo, Celebes, the Moluccas and New Guinea. The total area is 1.90 million square kilometers and the total population is over 60 million.

The Sunda Islands consist of the Greater Sunda Islands (with Sumatra and Java as the main components) and the Lesser Sunda Islands (with Bali, Lombok, Sumbawa, Sumba, Flores and Timor as the main components). The Moluccas consist of Halmahera, Buru, Ceram, and other islands, and are also known as the Spice Islands. The major waters between these archipelagos are the Celebes Sea, the Molucca Sea, the Banda Sea, the Flores Sea and the Java Sea, etc.; the Indian Ocean, the Timor Sea and the Arafura Sea are on the periphery of the southern region. 
The Dutch East Indies is situated in a location that more or less forms a bridge connecting the Asian continent and Australia; furthermore its southern part faces the Indian Ocean. It forms the outermost part of the area [Japan] plans to occupy. Of this area, Sumatra and Java are the most important.

Sumatra and Java: Sumatra, from where the Malay Peninsula can be seen across the Malacca Strait, has oil fields near Palembang, Medan, etc. Those in the sector of Palembang and vicinity (with an annual oil production of three million tons) and those of northern Aceh (one million tons) were eagerly coveted by Japan.

Java is the most developed island in the East Indies. Batavia in the west, the seat of the government-general of the Dutch East Indies, has a population of about 600,000 , and Surabaya in the east about 400,000. In Java, the mountain areas are [also] well developed, and so is the transportation system. Along with Cilacap on the south coast, Batavia and Surabaya constitute important ports not only as commercial but also as military (strategic) ports.

Celebes: Celebes is located midway between New Guinea and Borneo. Makassar at the southern tip of the island, located at a distance of about 430 nautical miles from Surabaya and about 400 nautical miles from Kupang, was very important as a base for the air campaign during the attack on eastern Java. With an area of about 190,000 km², Celebes has many mountain ranges and gorges. The island produces nickel, which was also exported to Japan, and it is further said to have large iron ore reserves.

Borneo: Borneo is the third largest island in the world with an area of 750,000 km², of which about $540,000 \mathrm{~km}^{2}$ is Dutch-ruled; however, the population is remarkably sparse. Balikpapan and Banjarmasin on the southern coast, respectively located at a distance of about 450 nautical miles and 260 nautical miles from Surabaya, were important as air bases for the campaign to destroy the enemy air power in eastern Java. The annual oil production of the Sanga Sanga sector in Borneo (with a refinery [in Balikpapan]) was one million tons, and that of the Tarakan sector 700,000 tons. The Japanese Navy had been importing heavy oil from Tarakan for many years.

New Guinea: New Guinea is the world second largest island with an area of a little over $800,000 \mathrm{~km}^{2}$, of which the Dutch-ruled territory stretches westward from longitude $141^{\circ}$ east, occupying an area of a little over $390,000 \mathrm{~km}^{2}$. As situated in between the United States and Australia, this island holds an extremely important position for Japan to conduct operations to cut off communications between the United States and the Australia. A central mountain range like a spinal column links a series of mountains of 4,000 meters or higher and is covered with snow through all seasons. The island has many areas untrodden by man, and as situated in the tropics, it consists of many vast wetlands and dense jungles.

Timor Island: Situated between Java and Australia, the island of Timor serves as a key location for supporting Java from Australia. While the western part of the island is Dutch-ruled, the eastern part is ruled by Portugal, a neutral country. Dutch Timor is about the same size 
as Kyūshū, while Portuguese Timor is about the same size as Shikoku. * The latter has a colonial government and is administered by a civilian governor general. The city of Dili is administered separately. Although no demographic statistics are available, the population on the basis of tax collection is 477,000 . Since the end of October 1941, a permission of the governor general is required to go outside the Dili city district.

\section{Summary of Meteorological Conditions ${ }^{(19)}$}

The seasonal and trade winds together form a unique wind system over the whole southwestern region. As the wind direction reverses about every half year, it is generally called the monsoon wind.

As the northeastern wind is dominant around January from the Philippines to northern Borneo, French Indochina, Thailand and the Malay Peninsula, it causes [much] rainfall on the eastern side of the [southwestern] region, while resulting in very little rainfall on the western side of the region.

In the south from the Sunda Islands to the Moluccas, the dry northwestern wind creates a dry season in January, while the wet southeastern wind creates a rainy season in July. Although the seasonal wind [generally] dictates the climate in this area, different [local] winds blow along the coastal and mountain areas, which bring about some variation in the climate.

Typhoons often cross the Philippines, its northern part in particular, the east coast of French Indochina, the South China Sea, the waters east of the Philippines, the northeastern and northwestern coasts of Australia, etc., and sometimes cause serious damage. Typhoons are mostly formed in the area between latitude $3^{\circ}$ to $12^{\circ}$ north and longitude $130^{\circ}$ to $135^{\circ}$ east; two thirds of the typhoons appear between July and October.

\section{Summary of Air Bases}

\section{The Philippines}

For inter-island transportation, the Philippines is very much dependent on air transport. Although it has as many as one hundred or more airports, they are generally small and many of them are quite inadequate as air bases for operations. The main bases in the southern Philippines used by its air force as operational bases are as follows: ${ }^{(20)}$

Mindanao: Davao, Zamboanga, Delmonte, Cagayan, Cotabato, etc.

Other [islands]: Jolo, Iloilo, Cebu, etc.

\section{Malaya Area}

Air transportation in Malaya is relatively well developed. There are more airfields on the west coast, and military air bases are located in the Kota Bharu sector, Kwantan, Singapore (Seletar, Sembawang, Tengah, Kallang are for civilian use and also available for seaplanes), Alor Setar, Sungai Petani, Penang, etc.

\footnotetext{
* Actually, the whole of Timor island is slightly smaller than Kyūshū.
} 


\section{British Borneo}

British Borneo has only two airfields, Kuching and Miri. It is presumed that in case of a Japanese attack, Miri will be destroyed and that Kuching and Jesselton (the latter is located on the west coast close to the northern tip of the island; its airfield of 600 meters by 800 meters with a diagonally running 1,500 meter [runway] is still under construction by converting and expanding a racetrack) will be made ready for use.

The Kuching airfield is situated about 13 kilometers from [the city of] Kuching. It is an Lshaped airfield with runways of 800 meters by 300 meters and of 600 meters by 300 meters. The ground is solid, and it is [even] accessible in the rainy season. [Moreover,] as no hangars stand nearby, it is extensible. The Miri airfield is about 7 kilometers north of the city. It has a runway of 900 meters by 300 meters, and is extensible to the size of 1,200 meters by 300 meters.

\section{The East Indian Islands}

Regular air services are provided between Java, Sumatra, Borneo, Celebes, Timor and others. Particularly Java has many airfields. However, there are no aircraft building facilities in the Dutch East Indies, only aircraft repair facilities located in Bandung and Surabaya. ${ }^{(12,13)}$

The major airfields are as follows:

Sumatra: Sabang (700 [meters] by 200 [meters]), Medan (1,000 by 1000), Belawan (Seaplane Base), Pekanbaru ( 800 by 800$)$, Jambi (700 by 200$)$, Palembang $(1,000$ by 1,000$)$, and Mentok $(1,000$ by 200)

Java: Batavia (west: 1,000 by 1,000; south: 1,200 by 1,200), Buitenzorg (for bombers), Bandung $(1,200$ by 1,000$)$, and Surabaya $(1,000$ by 820$)$

Menado: Kakas (presumably 1,000 by 1,000), and Kakas (Seaplane Base)

Ambon: Army Base (1,200 by 400), Naval Base (unknown)

Borneo: Tarakan ( 900 by 800$)$, Balikpapan ( 800 by 800 ), Bengkayang (700 by 150 ), and Pontianak (Seaplane Base)

Others: Bali ( 800 by 800$)$, Kupang ( 800 by 800$)$, Dili ( 800 by 500$)$, Kendari (1,000 by 600$)$, and Makassar ( 800 by 700$)$

\section{Summary of Major Ports, Waterways, etc.}

\section{The Waters of the Philippines ${ }^{(22)}$}

Numerous large and small islands lie scattered around and the waters enclosed by these islands make up many good harbors that give shelter against the northeastern monsoon. However, few ports meet both conditions of port facilities and anchorage, except for Manila. Davao Gulf is the largest bay in the southern Philippines; however, it is unsuitable for anchoring because its mouth is wide open to the south and it is too deep. However, the port of Davao, located furthest in the bay, is equipped with some port facilities, and good areas very much suitable for anchoring are located in its neighborhood and in Malalag Bay, which will make the port a possible operational base next to Manila Bay.

In the Sulu Archipelago (which consists of more than 300 islands between Mindanao and Borneo), there are good anchorages near Tawi-Tawi and Jolo. 


\section{South China Sea ${ }^{(23)}$}

The South China Sea is a vast oblong sea enclosed by Taiwan and continental China in the north, the Philippines in the east, Indochina and the Malay Peninsula in the west, and Borneo in the south; it stretches for about 1,800 nautical miles from north to south with a width of about 500 nautical miles from east to west. The islets and cays of the Paracel Islands, the Spratly Islands and others stud the waters; the islands belonging to the Natuna Islands, the Anambas Islands and others are located in the southern part. There are no good ports or bays on the western side of this sea (i.e. Malaya and Indochina), except for Cam Ranh Bay in French Indochina; repair and replenishment facilities are available only at [the ports of] Saigon and Bangkok, and [not] in Malaya or Borneo where there are no suitable ports.

In northern Borneo, only Brunei Bay is suitable for anchoring and replenishing. Kuching, the center of the Sarawak district, and Miri, the port [to ship] the oil produced [nearby], have port facilities built on the banks at the mouth of the rivers.

On [the side of] the Malay Peninsula [which faces the South China Sea], only the port of Singora in southern Thailand is [considered available], but the port is small and its facilities are poor.

\section{The Malaya Waters ${ }^{(24,25)}$}

The Malaya waters are the ocean area [enclosed by] Malaya and northern and central Sumatra with the Malacca Strait in the center. The major ports [in these waters] include Singapore, Malacca, Penang, and Sabang. Singapore is a small island situated the south end of the Malay Peninsula and a strategic location for maritime traffic connecting the Pacific Ocean and the Indian Ocean, which made the city Britain's largest military foothold in the East. Malacca is another key location for [maritime] traffic on the west coast of the Malay Peninsula in the southern part of the Malacca Strait. Although it has port facilities built on both banks of the mouth of the river, it cannot be used for large naval vessels. Penang is an island adjacent to the west coast of the Malay Peninsula in the northern part of Malacca Strait. It has port facilities on the side facing the west coast of the peninsula as well as an anchorage, which not only provides shelter against the northern wind but also enables repair works.

The Malacca Strait is the only strait which connects the Indian Ocean to the South China Sea and Java. On the whole it is deep and easy to sail; even at the narrowest part it has a depth of eighteen meters or more and a width of three nautical miles.

On the west coast of Sumatra, high mountains come close down to the coast. Flat lands are scarce and neither are there good ports along the coast. One of them is the port of Padang, but the port can only be used for some replenishing and loading and unloading. Sabang is an island adjacent to the north end of Sumatra with a good bay. The port is relatively well equipped with facilities, including those for replenishing and repair. It is a strategic point on the [sea] route from Singapore to the Indian Ocean.

\section{The Waters of the Dutch East Indies ${ }^{(26)}$}

The ocean areas [meant here] are the waters of the Dutch East Indies (including Portuguese Timor) except for northern Sumatra. These areas border on the Indian Ocean and the Arafura Sea in the south with Sumatra and the [other] Sunda Islands in between, and face the Philippines in the north and New Guinea in the east. Numerous large and small islands, including 
Borneo, Celebes and Java, lie scattered in the vast waters of an area of about 2,000 nautical miles from east to west and about 600 nautical miles from south to north, which includes the Java Sea, the Banda Sea, the Molucca Sea, the Makassar Strait and others.

Although the seasonal wind blows from the northwest in winter and from the southeast in summer in these waters, the impact of the wind is weaker than in the South China Sea. It is warm but rainy all through the year; particularly the rainfall is heavier in spring and autumn when the seasonal wind changes [direction]. Although in these waters many locations constitute good harbors, most of them are still undeveloped.

The Java Sea is enclosed by southern Sumatra, southern Borneo, southern Celebes, Java and the Lesser Sunda Islands; submerged rocks and islets lie scattered around while the sea is shallow with a depth of no more than seventy meters at the deepest, which allows ordinary ships to drop anchor anywhere. [The port of] Surabaya is the best port in the area; as the base of the Dutch East Indies Navy it is fully equipped with an arsenal and replenishing facilities, and it also has a dock with a capacity of accommodating heavy-cruiser-class ships.

Batavia (i.e. its outer port Tanjung Priok), which is enclosed by breakwaters, is fully equipped with replenishing and repair facilities. The port has a dock with a capacity of accommodating light-cruiser-class ships, too.

Cilacap is the only port on the southern coast of Java and is equipped with facilities to supply coal and oil.

Makassar is located at the southwestern tip of Celebes and dominates the entrance of the Makassar Strait. It has a small bay open to the high seas and is equipped with facilities for replenishing and minor repairs.

Palembang, the center of the oil production region on the east coast of southern Sumatra, is situated on the banks of a river about fifty nautical miles upriver from the sea; ships with a draft of less than six or seven meters can easily sail the river. [The port of] Palembang is fully equipped with replenishing facilities. The Celebes Sea faces the east coast of Borneo and the northwestern coast of Celebes. The Makassar Strait, the strait between Borneo and Celebes, is an important route to reach Java from the Philippines. The strait is shallow in the western half and many islets lie scattered around its southern exit. The strait has much rainfall in winter. The wind there is weaker than in the Java Sea, and the tide and ocean currents are also weak on the whole. Whereas the terrain is gently sloped and [several] ports and anchorages are found on the coast of Borneo, on the Celebes side, mountains come right down to the coast and no suitable ports or anchorages are found.

Tarakan is a small island adjacent to the east coast of northern Borneo, which produces oil. As for its port facilities, it has all the facilities necessary for replenishing oil, but its capacity to replenish other materials is poor.

Samarinda is located about twenty kilometers upstream of the Kutei River [from] the east coast of central Borneo, which faces the Makassar Strait; it has a copious production of oil and coal. It has substantial port facilities with replenishing facilities.

Balikpapan is situated south of Samarinda; it has port facilities and an oil refinery at the mouth of its river.

Menado and the Bangka anchorage are located at the northeastern tip of Celebes. As the port of Menado is exposed to the high sea and is only equipped with a few mooring facilities, it cannot be called a good port. The Bangka anchorage to the east of this port is suitable for anchoring fleets and convoys. 
The area of the Banda Sea, with the Banda Sea as the center and [adjacent to] the Flores Sea, the Ceram Sea, etc, faces the Banda Islands, the eastern side of Celebes, and the eastern part of the [Lesser] Sunda Islands. This area in general has much rainfall and is hot and humid throughout the year.

Ambon is situated at the center of this ocean area and is a traffic hub. The harbor in an inward curving bay is deep and few locations are suitable for anchoring. With poor port facilities, it has little capacity for replenishing.

\section{The Military Situation in the Southwestern $\operatorname{Region}^{(13,27)}$}

From the "Notes of Lt. Cdr. Matsumoto Makoto" and the "Documents kept by Lt. Cdr. Yonehara Tsunaki," the military information and the assessment of the military situation regarding the southwestern region which the Japanese Navy had obtained until right before the war can by and large be summarized as follows: ${ }^{(13,27)}$

Oil Production of $1940^{(13)}$

Place

Java

Central Area

Annual Production

Eastern Area

$800,000 \mathrm{t}$

$160,000 \mathrm{t}$

Sumatra

Palembang

$2,800,000 \mathrm{t}$

Jambi

Northern Area

$900,000 \mathrm{t}$

Tarakan

$820,000 \mathrm{t}$

Borneo

Sanga Sanga (Balikpapan)

$720,000 \mathrm{t}$

Greater East

Ceram

$1,000,000 \mathrm{t}$

$80,000 \mathrm{t}$

Miri (British [Borneo])

$900,000 \mathrm{t}$

Yenangyaung (Burma)

$1,000,000 \mathrm{t}$

Total

$9,180,000 \mathrm{t}$

Note: Production varies from year to year. ${ }^{(13)}$

\section{Distribution of Forces}

1. The Philippines

Navy

Heavy Cruisers
Light Cruisers
Destroyers

Flying Boat Tenders 4

Torpedo Boats

Total
Army

U.S. Garrison

(Caucasians 6,500)

14

17

The Philippines Army

Other than the above

Reserve

125,000
Air Force

Bombers $\quad 15$

Recon. Planes 15

Fighter Planes 100

Flying Boats $\quad 36$ 
1. The strength of the Army Air Force

Most of [the army air force, consisting of] five squadrons of attack planes, one squadron each of bombers and reconnaissance planes, seven squadrons in total, are stationed in Luzon and are mainly deployed at Nichols Field, Clark Field, and Camp Murphy.

2. Navy

Two squadrons of flying boats are conducting training patrols from the bases Cavite, Olongapo and Tawi-Tawi, etc. They patrol areas [with a radius] of about 300-400 nautical miles with their bases as the center and usually start patrolling around 0900, but sometimes they conduct dawn and night patrols.

2. British Malaya

\begin{tabular}{lrlrlr} 
Navy & \multicolumn{3}{l}{ Army } & & Air Force \\
Light Cruisers & $4-5$ & $\begin{array}{l}\text { Regular Army } \\
\text { around Singapore }\end{array}$ & 12,000 & Bombers & \\
Destroyers & $6-8$ & NE Malaya & 18,000 & Torpedo Bombers & 32 \\
Submarines & 1 & E Coast of Malaya & 8,000 & LB Recon. planes & 120 \\
River Gunboats & 8 & NW Malaya & 20,000 & Fighter planes & 64 \\
Torpedo Boats & 50 & W Coast of Malaya & 10,000 & Flying boats & 11 \\
Spec. Dispatched & $1-2$ & Volunteer Army & 20,000 & Total & 317 \\
& & & $(6,000)$ & & About 550 planes in \\
Total & $70-74$ & Police Force & 15,000 & total incl. reserve and \\
& & & $(1,500)$ & training planes
\end{tabular}

In order to secure the shipping lanes, Britain's policy is to defend Malaya, the Dutch East Indies and Australia mainly with its air force and army.

1. Distribution of the air force

Singapore: Torpedo bombers, fighter planes, reconnaissance planes [to keep guard over] the east coast, and flying boats

Calcutta, Ceylon, and Penang: Land-based reconnaissance planes

Andaman: Flying boats

British Borneo: Bombers and reconnaissance planes

Although it boasts that it shall increase the number of aircraft to 800-1,000, the number of aircraft as of the end of 1941 is 338. Reinforcement will be sent from Australia, the United States (fighter planes and flying boats), the Near East, India and the [British] mainland. Although the number of air bases, which used to be seventeen, was increased to twenty-two, only four bases are equipped with direction finders. Crew members are also brought from New Zealand and Australia. Although trainings are usually conducted in a formation of two or three aircraft, a formation consisting of twelve aircraft has been observed once. Aircraft are gathering in Kota Bharu.

2. Outline of the patrols in British Malaya

(1) Interdiction of vessels entering or leaving territorial waters at night.

(2) Patrolling of the east coast by cruisers or auxiliary vessels.

(3) Conducting air patrols over the east and the south. 


\section{British Borneo}

(1) Army: About 10,000 regular army men; further reinforcement is expected.

(2) Police Force: About 24,000 men.

\section{Burma}

(1) Navy: Two patrol boats and fifteen other small vessels

(2) Army: About 35,000 men (of which about 13,000 men are stationed in the Tennasserim area.)

(3) Air Force: Twenty bombers, ten reconnaissance planes, some fighter planes, and twenty amphibians, about sixty planes in total.

\section{Dutch East Indies}

(1) Navy

Five cruisers (including one assumed), eight destroyers, nineteen submarines (including four assumed), one coastal defense ship, two gunboats, six minelayers, eight minesweepers, ten high-speed torpedo boats, and thirty-two torpedo boats, aggregating to ninety-one.

(2) Army

\{1\} Regular Army (80\% consisting of indigenous people): 54,500 men in Java, 9,000 men in Sumatra, 6,500 men in Borneo and 6,200 men in the Greater East, aggregating to 76,200 men.

\{2\} Volunteer Army: 15,000 men (mostly Caucasians), the indigenous units: 3,000 men, (95\% consisting of indigenous people), the field police units: 7,000 men (90\% consisting of indigenous people), aggregating to 25,000 men.

\{3\} The total number to be mobilized: about 120,000 men.

(3) Air Force

$\{1\}$ Navy Air Force

Forty flying boats, thirty-five seaplanes (including carrier-based planes), and twentyfive reconnaissance planes: one hundred planes in total.

$\{2\}$ Army Air Force

One hundred bombers, one hundred fighter planes, twenty-five reconnaissance bombers, eighty reconnaissance planes: 305 planes in total.

(4) Outline of security precautions

$\{1\}$ They are patrolling with flying boats and patrol boats all over the Dutch East Indies waters. Particularly, they are on high alert at the Bali, Lombok, Alas and Sape straits, and the strait between Timor and Flores.

$\{2\}$ They are watching the Moluccas Strait with (a) destroyer(s) and (a) guard ship(s).

\{3\} They are on high alert at the Makassar Strait employing ships as well as aircraft.

\section{Strategic Assessment of Deployment Based on the Location of the Air Bases ${ }^{(27)}$}

1. Although there is no great difference in total strength between the enemy and us, [the strength of] the enemy is roughly divided into three, that is, the southern central part of Luzon for the Philippines, the British Strait Settlements for Malaya, and mainly Java for the Dutch East Indies. The distances between them are more than one thousand and several hundred nautical miles, which makes it relatively difficult for them to support each other.

2. The southern central part of Luzon is roughly within a range of 550 nautical miles from southern Taiwan, and the southern Philippines are roughly within a range of 600 nautical miles from Palau, which means they are within attacking range by Type- 0 fighter planes and land-based attack planes. 
British Malaya lies roughly within a range of 600 nautical miles from the bases in southern Indochina, which means northern Malaya is within attacking range by Type- 0 fighter planes and southern Malaya by land-based attack planes.

It will be most advantageous for Japan to concentrate its strength against them and destroy them one by one.

3. As the enemy has many bases and is likely to disperse when escaping, it is necessary to conduct air raids on their permanent bases with as much strength as possible in the first strike, and catch and destroy them.

4. When the enemy aircraft disperses in escaping, it is necessary to advance Type- 0 fighter planes to the bases in northern and southern Luzon and northern Malaya (such as Aparri, Vigan, Laoag, Legaspi, and Kota Bharu) and have the planes wipe out [the enemy aircraft].

5. It is necessary to seize as quickly as possible relay air bases (such as Legaspi, Davao, Jolo, Miri, Kuching, Kota Bharu), so that the enemy will not escape [across the seas] between the Philippines, Malaya, and the Dutch East Indies.

6. As enemy air strikes on [Japanese] convoys are expected, it is necessary to be on strict alert [for such strikes]. It is [also] necessary for the convoys to timely conduct evasive maneuvers and take measures to control damage.

7. Finally, it is necessary to prepare a plan to destroy the enemy air power gathering into Java with a combined force of fighter planes and bombers, by conducting concentrated attacks [on them, departing] from the [already] occupied bases both in the east and the west (such as Kendari, Makassar, Balikpapan, Banjarmasin, Kuching and Palembang).

8. In order to check reinforcements from Australia, it is necessary to conduct offensive air operations towards northern Australia (such as Port Darwin and Broome) from bases on the island of Timor (Kupang and Dili) to destroy [the enemy] air power.

9. The enemy's capacity to repair aircraft (repair depot and personnel) is quite poor. 


\section{Chapter III The Drafting of a Plan of Operations for the Southern Advance}

\section{Fixing the Outline of the Plan of Operations}

lthough the plan of operations for the [administrative] year 1941 of the Navy General
Staff was completed in March of that year, the plan [only] covered operations against
one single country [at a time] of each of the hypothetical enemies. Since the summer of 1940, a joint study of the Army and the Navy General Staff Offices had been conducted on simultaneous operations against all four hypothetical enemies (the United States, Britain, the Netherlands and China), but it did not reach the stage of examining concrete details due to a lack of material for [planning] operations at that time. It was in April 1941 and onwards that the Navy General Staff seriously set about studying a plan of simultaneously executing operations against all four countries, assuming that the United States and Britain were inseparable. ${ }^{(28)}$

By June, the working plan for the operations showed considerable progress, and by the beginning of July the outline was informally and tentatively agreed upon between the persons in charge at the General Staff Offices of both the Army and the Navy; by mid-August they also won an unofficial agreement from [both] the Chief of the Navy General Staff, Admiral Nagano Osami, and the Chief of the Army General Staff, General Sugiyama Gen. ${ }^{(28)}$

In the meantime, Germany's opening of hostilities against the Soviet Union at the end of June, Japan's advance into southern French Indochina, the [subsequent] break-off of economic relations with Japan by the United States and Britain at the end of July, and [Japan's] informal decision in the beginning of August to not take the offensive against the Soviet Union before the end of the year, had rapidly altered the situation. The outline of the plan to simultaneously execute operations against four countries, agreed upon by the Army and the Navy around mid-August, when the Navy General Staff showed a firm determination to "complete war preparations by the end of October," was in summary as follows:(28)

1. Tentatively setting the opening of hostilities at the beginning of November, [the Navy] shall, concurrently with the opening of hostilities, launch simultaneous operations against both the Philippines and Malaya in conjunction with the Army and complete the invasion of the necessary key areas in the south in roughly five months.

2. The naval strength to be employed for the southern operation shall consist of the bulk of the surface units of the Combined Fleet and the land-based air units, while the carrier-based air units shall be employed in the air campaign at the beginning of the opening of hostilities.

3. The Army strength to be employed for the southern operation shall consist of about seven divisions of ground [units] and two numbered air forces. 


\section{Advance}

4. In the operation against the United States, the submarine unit shall keep watch on [the U.S. fleet in] Hawaii, and the Fourth and the Fifth Fleets shall be on alert [for the U.S. fleet] in the area east of Japanese territory, while the battleship unit shall stay in the homeland [waters], ready to intercept [the U.S. fleet]. In case the U.S. fleet comes to the attack in the western Pacific, the main force of the southern operation task force shall be extracted, be combined with the battleship unit and together with strength rallied from everywhere, they are expected to destroy the U.S. fleet.

As seen in the above outline of the plan of operations, the Navy General Staff Office at that time still set the U.S. Navy as the main enemy even in the [simultaneous] operations against multiple countries. It drew up a [new] operational policy on the basis of the former plan of operations against the United States by [only and newly] adding to this plan an operation to capture key areas in the south right at the opening of hostilities.

The Navy General Staff Office, which unofficially had decided on a plan to speedily complete war preparations, gave instructions to the Combined Fleet around the middle of August to break off its ongoing trainings and operations by the end of August and complete a rapid war preparation roughly in one month starting from the beginning of September. Following this instruction and keeping only a part of the strength in reserve, almost the full strength of the Combined Fleet began to take positions in the homeland [waters] in the beginning of September to speed up the war preparations. Also, on 15 August, a part of the second stage of the preparatory fleet mobilization order was put into motion. ${ }^{(29)}$ (The first stage of the preparatory fleet mobilization order had [already] been put into motion in November 1940. The first stage preparation was supposed to require about half a year and be completed by the issuing of the order of the war formation. The second stage was to be executed following it.)

Meanwhile, the Combined Fleet headquarters pressed the Navy General Staff Office to adopt [the idea of an] operation to conduct a surprise attack on Hawaii by aircraft carriers right at the outset of the war. In mid September, after getting the approval of the Navy General Staff Office, the Combined Fleet headquarters conducted a map exercise at the Naval College in Meguro, Tokyo, and examined [the feasibility of] this plan, taking the previous roughly fixed outline as a start and further based it on a concrete draft plan of operations that included the surprise attack on Hawaii, on which the headquarters had firmly insisted. This is the so-called "Map Exercise at the Naval College," although the exercises of the operation to control the western Pacific and the operation of a surprise attack on Hawaii were conducted separately. ${ }^{(28)}$

The general outline of the map exercise at the Naval College was as follows (parts concerning the Philippines and Malaya have been omitted by the author):

1. Assuming the hostilities to be opened on 16 November, the operations against the Philippines and Malaya shall be launched almost simultaneously, and the strategic areas of the Philippines,

Malaya and the Dutch East Indies shall be captured in roughly 150 days. ${ }^{(30)}$

2. The strength to be employed in the southern operation ${ }^{(11,31,32,33)}$

(1) Navy

One element of the First Fleet (one destroyer squadron and carrier division each)

The bulk of the Second Fleet

The full strength of the Third Fleet, the Eleventh Air Fleet, and the Southern Expeditionary Fleet 


\section{Advance}

One element of the First Air Fleet (small aircraft carrier(s))

The bulk of the force attached to the Combined Fleet (a seaplane tender division, submarine squadrons, landing force(s), supply vessels, etc.)

(2) Army

About 300,000 troops consisting of about 10 divisions as the core

An air unit of about 600 aircraft in about two numbered air forces

3. Assessment of the enemy situation in the southern region at the time of the map exercise ${ }^{(34)}$

(1) The Philippines area (the U.S.-Filipino Army)

Naval vessels: About 60 ships, consisting of 2 cruisers, 14 destroyers, 17 submarines, 4 seaplane tenders as the core

Air force: About 160 aircraft (of the Army and the Navy in total)

Ground troops: About 40,000 regular troops ([and possible] mobilization of about 160,000 troops of the Filipino Army)

(2) Malaya area (British armed forces, including [those from] Hong Kong)

Naval vessels: About 90 ships, consisting of 5 cruisers and 10 destroyers as the core (A powerful unit including battleships and aircraft carriers is deployed in the Indian Ocean)

Air force: About 200 aircraft (A reinforcement of 300 aircraft or more is anticipated by the end of year)

Ground troops: About 60,000 - 70,000 regular troops (Apart from these, a voluntary army of about 20,000 men)

(3) The Dutch East Indies area (the Dutch East Indies armed forces)

Naval vessels: About 90 ships, consisting of 5 cruisers, 8 destroyers, 19 submarines as the core Air force: About 300 aircraft ([of] front line aircraft; apart from these, about 200 reserve aircraft)

Ground troops: About 70,000 troops

4. General Plan of Operations ${ }^{(11,34,35)}$

(1) An air force of about two to three times as strong as that of the enemy directly in front shall be employed.

(2) In the Malaya area, an army unit shall be disembarked in the southern Thai area and sent southward along the Malay Peninsula, to capture Singapore. This operation is supposed to be accomplished in about 100 days from the opening of hostilities.

(3) The operation against the Philippines shall be launched from Taiwan, and pushed ahead first to Luzon, then to the central and southern Philippines. The capture of Manila is supposed to be accomplished in about 45 days from the opening of hostilities.

(4) In the Dutch East Indies, the lines of operation shall be pushed forward to Celebes and Borneo in the east with the southern Philippines as the basis, and to Sumatra in the west, setting the capture of Java as the final target. This operation is supposed to be accomplished in about 150 days from the opening of hostilities.

(5) The area to be captured is roughly set as the Philippines, British Malaya, British Borneo and the Dutch East Indies. [An attack on] Burma shall be conducted for the purpose of eliminating interference with the Malaya operation, and [only] to the degree of capturing a part of southern Burma and conducting air campaigns.

5. The disposition of forces of the Navy $\mathrm{y}^{(12,33,36,37,38)}$

(1) The Philippines and the Dutch East Indies

Commander: Commander in Chief of the Second Fleet

Forces: The bulk of the Second Fleet

The full strength of the Third Fleet

The bulk of the Eleventh Air Fleet

The bulk of the units attached to the Combined Fleet

Three small aircraft carriers of the First Fleet and the First Air Fleet 


\section{Advance}

Outline of the Disposition:

Capture of strategic areas: a force [consisting of] the Third Fleet as the core

Air campaign: a force [consisting of] the Eleventh Air Fleet as the core

Destruction of the enemy surface forces: a force [consisting of] the Second Fleet as the core

Submarine operation: submarine squadrons

(2) Malaya area

Commander: Commander in Chief of the Southern Expeditionary Fleet

Forces: $\quad$ The full strength of the Southern Expeditionary Fleet

One element of the Eleventh Air Fleet (About one air unit each of land-based

attack planes and fighter planes)

One cruiser division and destroyer squadron each from [both] the First and

the Second Fleets

One small aircraft carrier of the First Fleet

One element of the 6th Submarine Squadron

Outline of the Disposition:

Surface escort: a force [consisting of] cruiser divisions, destroyer squadrons and a small aircraft carrier as the core

Destruction of the enemy surface forces: a force [consisting of] cruiser divisions, destroyer divisions and the Eleventh Air Fleet

6. Outline of the Philippines operation ${ }^{(12,33,34,39)}$

(1) Right at the outset of the war, about 200 Navy aircraft and about 450 Army aircraft shall launch an air campaign from southern Taiwan to destroy the enemy air power on its air bases on Luzon. Prior to this, Type-0 fighter planes of the land-based air unit shall be advanced on the waters at a short distance from Manila on three small aircraft carriers on the first day of hostilities to support the strikes of the land-based attack units from Taiwan.

(2) On the day of the opening of hostilities, the advance unit shall make surprise landings at Aparri and Vigan, swiftly seize the air bases and make them ready for use, and let the fighter plane unit(s) advance from Taiwan, so as to thoroughly carry out the operation to destroy the enemy air power from that time on.

(3) Making use of the results of the campaign to destroy the enemy air power right at the opening of hostilities, the main force of the Army unit to capture Luzon shall be disembarked at Luzon in about ten to fifteen days after the opening of hostilities and seize the capital Manila at a stroke. The strength of the Army ground forces is supposed to be about two divisions.

(4) When the air campaign against Luzon is for the greater part completed, the frontline of the operation shall gradually be extended southward towards the central and southern Philippines, so as to seize Davao and Jolo roughly in twenty to thirty days after the opening of hostilities, and secure footholds for the Dutch East Indies invasion operation.

7. Outline of the Malaya operation ${ }^{(30,33,34,35,39,40)}$

(1) Right at the outset of the war, the air units of both the Army and the Navy (about 450 aircraft) shall conduct preemptive air strikes against northern Malaya and Singapore from southern French Indochina. Simultaneously, small advance units of the Army shall conduct surprise landings (under the escort of a small number of Navy war vessels) at the strategic locations north of and including Singora, or north of and including Nakhon in southern Thailand, swiftly seize the airfields and make them ready for use, so as to advance the Army air units one by one.

(2) After that, when the [air] campaign of the Army air unit as the main strength to destroy the enemy air power has achieved results, the main force of the Army Malaya invasion unit shall go ashore, advance overland through the Malay Peninsula southward to capture Singapore. The Army ground forces to be employed in this area are supposed to be about five divisions. 
(3) In the early period after the opening of hostilities (roughly between Day X and about Day X +5), a Navy unit shall make a surprise landing at Miri and Kuching in northern Borneo, secure the oil fields in Miri and quickly ready the airfield in Kuching, so as to advance the Navy air unit [there] and put them in charge of air campaigns against Singapore and the Java Sea.

8. Outline of the Dutch East Indies operation (summary)

(1) After the air unit has been advanced to Davao and Jolo in the southern Philippines, invasion operations against Borneo and Celebes shall be launched from about Day $X+50$ onwards.

(2) In the eastern part [of the Dutch East Indies], operations shall proceed along two lines of operation, that is, the line Tarakan - Balikpapan - Banjarmasin and the line Menado Kendari - Makassar. The capture [of those areas] and the advance of the air units [there] shall be conducted [simultaneously] in parallel. [Then, the air units] shall conduct the air campaign to destroy the enemy air power in Java from Makassar and Banjarmasin in concert with [the campaigns conducted] from the direction of Malaya and Sumatra.

(3) When the air campaign to destroy the enemy air power has achieved results, the Army units shall be disembarked on Java and capture the entire island. This operation is supposed to be completed in about five months from the opening of hostilities.

(4) The forces to be employed for the Dutch East Indies [Operation]

$\{1\}$ Navy: the force of the Second and Third Fleets, and the Eleventh Air Fleet, after participating in the Philippines operation.

\{2\} Army: The ground forces of three divisions, and one numbered air force to be transferred from the Malaya Invasion Operation.

Note by the author: No specific materials are extant concerning the advance of the lines of operation in the western part.

According to the above plan, the map exercise was carried out; the findings concerning the Dutch East Indies Operation were in outline as follows: ${ }^{(11,12,33,36)}$

1. It should be expected that while advancing the air bases [of the air units] from the Philippines one after another, as many as ten bases have to be made ready in three months before reaching eastern Borneo. As it is also quite difficult to carry out operations in which air units would shift their positions one after another, it may be a [better] idea to focus all the strength on the Malaya area and advance southward toward Java from the west, avoiding the southern advance in the east. (Eleventh Air Fleet)

2. Concerning the above opinion, [the Combined Fleet] cannot agree to the idea to put priority on the advance from the west because on an operational level it is an essential condition that the Combined Fleet first copes with the Philippines. (Combined Fleet)

3. Concerning the above, it is necessary to study a case in which the share of responsibility is clearly defined in such a way that the Army air unit shall take charge of the operation in Malaya and the Navy air unit of that in the Philippines and the Dutch East Indies.

4. The Navy has no units specialized in the speedy preparation of airfields after seizing them, and no such trainings were ever conducted. [The Navy] should swiftly form [such] construction units, conduct trainings, and draw up concrete plans of how to condition bases.

5. In this map exercise, the loss of Type-0 fighter planes and the land-based attack planes respectively reached $160 \%$ and $40 \%$. We have to be prepared for the possibility that no aircrew leaving from Taiwan will make it to Java. It is necessary to give due consideration to the training and the replenishment of personnel and draw up an adequate plan, let alone [a plan for] the replenishment of aircraft. (Eleventh Air Fleet)

6. The Philippines invasion plan of operations of the Second Fleet is too careful. As the research by the Navy General Staff Office judges that the defense of the Philippines is not so much to be 


\section{Advance}

worried about, it should be captured in a shorter period. (And [the invasion unit] shall [more] quickly advance to the line of Davao and Jolo) to swiftly set about the Dutch East Indies [operation]. (Navy General Staff Office [Note by the author:] it seems that along with the interception of the U.S. fleet, the biggest matter of concern of the Navy in those days was to swiftly seize the oil fields in eastern Borneo.)

7. It is necessary to attach [more] importance to Miri and Kuching. Agreements between the Army and the Navy have to be arranged concerning the preparation of these air bases. (Navy General Staff Office)

8. During this operation, the [enemy sea] transport around Burma and in the Indian Ocean has to be destroyed with land-based attack planes from the airfields in Thailand or Malaya, so as to cut off the enemy from its rear. (Eleventh Air Fleet)

9. It is necessary to employ more careful measures in the campaign to destroy the enemy air power in Java. (Eleventh Air Fleet [Note by the author:] this meant that such campaigns should be launched after the lines [of operation] to southern Sumatra, Banjarmasin and Makassar had been duly established.)

10. As the military information on the southern region is inadequate, a further study should be made especially on the air bases to be seized and used, so that the plan of operations will not be frustrated. [Particularly,] further photoreconnaissance of Menado, Kendari, Miri, Kuching, Ambon, etc. needs to be conducted immediately. Also, it is necessary to obtain as much as possible metereological information on this region because it is seriously lacking. (Eleventh Air Fleet)

11. The Third Fleet, which shall execute the invasion operations, has a severe lack of small craft. It is necessary to quickly increase the number [of such craft]. (Third Fleet)

12. As operations are carried out at sea, it is impossible to specify the invasion schedule in the form of detailed operation timetables. The plan must be given elasticity by dividing the schedule into rough periods and allotting areas of operations to the participating units.

These problems were solved one by one, except for a few (such as those of the invasion schedule, the units to condition air bases, and the measures to be taken against attrition in the air campaigns, which shall be explained later). That is, measures were taken to split the responsibility for the air operation in such a way that the responsibility for Malaya would fall on the Army and that for the Philippines and the Dutch East Indies on the Navy, that base construction units would be promptly formed, and that in the early period after the opening of hostilities sudden landings would also be conducted on the central and the southern Philippines simultaneously with those on the northern Philippines.

The map exercise at the Naval College marked a major advance in the process of formulating the Navy plan of operations. Meanwhile, the Army had also started studying the details of the [draft] southern plan of operations and was hurriedly completing a concrete version.

After going through [further] study on the Army side and passing through the "Kanoya Map Exercise" on the Navy side in the beginning of October 1941 (a map exercise conducted by the Eleventh Air Fleet headquarters at the Kanoya Air Group's [base] in Kagoshima), the [draft] plan of operations of the General Staff Offices [of the Army and the Navy] was for the most part completed and had reached a stage where the views of the Army and the Navy on the whole could find mutual agreement. In mid-October, the Combined Fleet headquarters conducted a map exercise based on the roughly completed final draft of the plan of operations on its flagship Nagato and saw to it that the plan was fully understood by the commanders at every level as well as their staff officers. This is the so-called "Nagato Map Exercise." From the viewpoint of swiftly obtaining oil resources to build up a self-supporting position and doing it before U.S. and British forces in the Far East were reinforced, it would 
be better to wage war as soon as possible. However, the massive personnel shifts due to the Combined Fleet's shift to a wartime formation caused the readiness level to drop and preparations could not be managed in time. The supposed date [of the opening of hostilities] in the Kanoya map exercise was [delayed until] 7 December 1941, and in the Nagato map exercise, it was [further] put off until 8 December. Also, the number of the regular aircraft carriers to be employed in the air strike on Hawaii, which might have quite a large impact on the southern operation, underwent the following changes. In the map exercise at the Naval College, the number of carriers allotted to the southern operation and the operation against Hawaii were nil and four respectively. After the completion of the large aircraft carrier Zuikaku on 25 September 1941 and due to the postponement of the assumed date of the opening of hostilities, the number of carriers allotted to the southern operation and Hawaii were changed to two and four respectively. ${ }^{(28)}$ Then in the Kanoya map exercise in the beginning of October, a [new] idea of employing three carriers (with shorter cruising ranges, the Akagi, the $\operatorname{sor} r \bar{u}$, and the Hiry $\bar{u}$ ) for the southern operation and the other three (with longer cruising ranges, the Kaga, the Shōkaku, and the Zuikaku) for Hawaii was adopted. ${ }^{\left({ }^{35}\right)}$ After all these changes, a strong request by Commander in Chief of the Combined Fleet Yamamoto Isoroku and his confidence [in his proposal] finally won the agreement of the Navy General Staff Office, so on 19 October the number of carriers to be allotted to the southern operation and Hawaii was decided upon as nil and six respectively (so as to ensure the success of the [Hawaii] operation and have sweeping military gains).

In this way, the final decision was made to execute the air strike on Hawaii with the full strength of the main aircraft carriers. With the other problems mostly solved, [the draft of] the central agreement between the Army and the Navy concerning the southern operation was for the most part informally decided by 26 October. The main persons of the Army and the Navy in charge added necessary modifications to this draft and obtained the approval of the chief of the Navy General Staff by 29 October. ${ }^{(40)}$ Although some pending issues remained at that time, most of them were solved one after another by the time of the conclusion of the agreement between the Army and the Navy on 10 November 1941.

During this period, the [Japanese] government was trying hard to reach an agreement in the U.S.-Japanese negotiations, but the negotiations made no progress. Finally, at the Imperial Conference on 5 November 1941, the Main Points for the Implementation of Imperial National Policy was decided upon with the following contents (excerpted by the author):(41)

1. In order to resolve the present crisis, to assure its self-preservation and self-defense, and to establish a New Order in Greater East Asia, the Empire [of Japan] is now determined to wage war against the United States, Britain and the Netherlands. The following measures are to be taken:

(1) The time to initiate military action shall be set at the beginning of December, and both the Army and the Navy shall complete operational preparations accordingly.

(2) The main points of the negotiations with the United States (omitted by the author).

(3) Cooperation with Germany and Italy shall be strengthened.

(4) Close military relations with Thailand shall be established (omitted by the author).

2. If the negotiations with the United States are successful by 0000 on 1 December, the initiation of military action shall be suspended.

By IGHQ Navy Department Order No. $1^{(42)}$ and IGHQ Navy Department Instruction No. $1^{(43)}$ of the same date [5 November 1941], the Navy issued to the Commander in Chief of the Com- 


\section{Advance}

bined Fleet the Imperial command "to complete operational preparations by early December, expecting to wage war against the United States, Britain and the Netherlands," and also announced the "Operational Policy of the Imperial Japanese Navy" and the "the Army-Navy Central Agreement," based upon which this operation should be executed. The chiefs of the Navy and the Army General Staffs [also] informed the Combined Fleet that the tentative date to wage war was set on 8 December 1941.

In the meantime, on 6 November, the Army issued the order of battle ${ }^{(44)}$ of the forces to be involved in the southern operation, and gave new assignments [to its personnel] accordingly. And while conveying to the commander in chief of the Southern Army the Imperial command "to prepare for the invasion of the strategic areas in the south," it also announced the "General Plan of Operations of the Imperial Japanese Army" as well as the "Army-Navy Central Agreement."

The southern operation, the Dutch East Indies invasion operation in particular, had the following characteristics:

1. It is required to complete the operation in as short a period as possible.

(1) It is required to secure the strategic materials, which are absolutely indispensable for Japan to fight a protracted war, oil in particular, as soon as possible before the enemy destroys them.

(2) As the preparations for a joint defense between the United States, Britain and the Netherlands are rapidly progressing, it is required to invade [the area] before the preparations of the enemy are [further] strengthened.

(3) It is desirable to carry out the invasion of the area before the U.S. Fleet is fully prepared to come for an attack, so as to establish a strategically unbeatable position.

(4) Considering a worst-case scenario where [Japan] would have to conduct operations in both the northern and southern theaters, the Dutch East Indies operation shall be completed by spring when it becomes feasible to conduct operations against the north.

2. Characteristics of the execution of the operation

(1) The operation is [characterized by] a repeated process of gaining control of the air, invading, capturing and preparing bases, and advancing [the Army and Navy] air forces over a wide area. For this reason,

(i) It is required to draw up a detailed plan for the operation of transport ships and their escort vessels.

(ii) A close cooperation between ground, sea and air forces is particularly required.

(2) Due to the shallowness of the waters, large-scale mine warfare is expected.

(3) It is necessary to prepare for the employment of paratroopers to occupy the oil fields in sudden attacks, and also for their quick reopening and resumption of production, etc.

3. [The operation] will be greatly affected by other operations.

(1) The operation depends on the success or failure of the Carrier Task Force's surprise attack on Hawaii. That is, whereas the Malaya invasion operation and the Philippines invasion operation shall be pushed through regardless of the success or failure of the surprise attack on Hawaii, the execution of the Dutch East Indies operation shall be affected by the success or failure of the surprise attack on Hawaii.

(2) As the operation is carried out by advancing air bases while using the Philippines, Malaya and British Borneo as stepping-stones, it is affected by the progress of these [local] operations. As the main strength of the enemy in the southern [region] is situated in the Philippines and Malaya areas, the operation will turn into a pursuit battle once the main strength of the enemy has been overcome. 


\section{IGHQ's [Navy Department's] Mission Directives and the Army-Navy Central Agreement}

On 5 November, IGHQ [Navy Department] issued the following order and instructions to the Combined Fleet: ${ }^{(42,43)}$

\section{IGHQ Navy Department Order No. 1}

5 November 1941

By Imperial Order, Chief of Navy General Staff Nagano Osami directs Commander in Chief of the Combined Fleet Yamamoto as follows:

1. The Empire [of Japan], for the sake of its self-preservation and self-defense, expects to wage war against the United States, Britain and then the Netherlands in early December and has decided to complete all operational preparations.

2. The commander in chief of the Combined Fleet shall implement the necessary operational preparations.

3. Regarding details, the chief of the Navy General Staff shall give instructions.

\section{IGHQ Navy Department Instruction No. 1}

5 November 1941

Chief of Navy General Staff Nagano Osami directs Commander in Chief of the Combined Fleet Yamamoto in conformity with IGHQ Navy Department Order No.1 as follows:

1. In anticipation of waging war against the United States, Britain and later the Netherlands in early December, the commander in chief of the Combined Fleet shall timely advance the necessary units to their standby points before the launch of operations.

2. The commander in chief of the Combined Fleet shall be on strict alert against unforeseen attacks delivered by the United States, Britain and the Dutch [East Indies] forces.

3. The commander in chief of the Combined Fleet may secretly conduct reconnaissance when it is specifically required for executing operations.

4. The commander in chief of the Combined Fleet shall have the Fourth Fleet timely lay mines in the [waters] of the equatorial Pacific Islands in conformity with its defense plan.

5. The mission directives and the Army-Navy Central Agreement, in conformity with which the operations are to be conducted, are given in the supplement.

6. The commander in chief of the Combined Fleet shall make agreements with the commanders concerned of the Army on joint operations between the Army and the Navy.

7. The bases of operations right at the launch of the operations are generally determined as follows: Yokosuka: The Fourth, the Fifth and the Sixth Fleets

Kure: $\quad$ The First and the Second Fleets, the First Air Fleet and the units under direct control of the Combined Fleet

Sasebo: $\quad$ The Third Fleet, the Southern Expeditionary Fleet and the Eleventh Air Fleet

\section{IGHQ Navy Department Instruction No.1, Supplement}

Mission of the Imperial [Japanese] Navy for War against the United States, Britain and the Netherlands (Excerpted by the author)

Part 1.

Mission in Case War against the United States, Britain and the Netherlands Breaks Out

During the Operation Against China 


\section{Advance}

\section{Chapter 1. Summary}

1. The outline of the mission of the Imperial [Japanese] Navy is, while continuing [operations] to take control of the Chinese coast and the lower reaches of the Yangzi basin, to promptly destroy the enemy fleet and air power in the East, to occupy and secure key areas in the south, to build up a sustainable and unbeatable position, and [eventually] to destroy [more of] the enemy's fleet and in the end deprive the enemy of his will to fight.

\section{Chapter 2. Mission of the Combined Fleet Section 1. Stage-One Operations}

2. The unit, consisting of the Second Fleet, the Third Fleet, the Southern Expeditionary Fleet, and the Eleventh Air Fleet as its core, shall clear [the sea] in the Philippines, British Malaya, and the Dutch East Indies of the enemy fleet, destroy them, and in conjunction with the Army, carry out the following operations:

(1) [The unit] shall launch operations against British Malaya and the Philippines simultaneously, conduct preemptive air strikes on the air power and on the naval forces of the enemy in these areas and [at the same time] put ashore the Army's advance corps in the key locations in Malaya and the Philippines as quickly as possible in order to push ahead the air units and intensify the air operations.

(2) After the above operations [in 2.(1)] produce results, the main force of the invasion corps of the Army shall be put ashore in the Philippines and then in Malaya to promptly capture the Philippines and British Malaya.

(3) In the early stages of the operations, strategic places in British Borneo shall be occupied, followed by those in Dutch Borneo, Celebes, and southern Sumatra at the earliest opportunity. Key places in the Moluccas and Timor shall [also] be occupied at favorable opportunities and the necessary air bases [at each place] shall be made ready for use.

(4) As soon as the air bases mentioned in the above [2.(3)] are made ready for use, air units shall be advanced one after another to suppress the air power of the enemy in the Java area. After [the operation] produces results, the main force of the invasion corps of the Army shall be put ashore on Java to capture it.

(5) After capturing Singapore, strategic areas in northern Sumatra shall be occupied, and the operations against Burma shall timely be conducted in order to block the enemy's supply route to China.

3. -5. (Omitted by the author - [concerning] the operations in the equatorial Pacific Islands as well as the sea to the east of Japan, and the operation by submarines against Hawaii.)

6. The unit consisting of the First Air Fleet as its core shall conduct a surprise attack on the enemy fleet in Hawaii right at the outset of the war and strive to degrade its power. After that, it shall mainly be assigned to support the operations of the Fourth Fleet and the southern invasion operation.

7. The main force of the Combined Fleet shall be assigned to support operations as a whole and take action at the right moment according to the movements of the enemy fleet.

8. An element of the Combined Fleet shall be assigned to disrupt the shipping lanes of the enemy in the Pacific and Indian Ocean areas at the right moment.

9. As for Thailand and French Indochina, while doing our best not to provoke their hostility, efforts shall be made to make [both countries] follow our operations. However, if any hostile behavior is observed, armed force shall be employed without hesitation so as not to let it hinder our operations.

\section{Section 2. Stage-Two Operations}

10. While continuing the task of reconnoitering, observing and conducting surprise attacks against the main force of enemy fleets, the unit consisting of the Sixth Fleet as its core, shall, along with 
an element of the Combined Fleet, intensify [operations to] disrupt the shipping lanes of the enemy, and when required, destroy enemy advance bases in surprise attacks.

11. The unit consisting of the First Air Fleet and the Eleventh Air Fleet as its core shall take charge of searching for and attacking enemy forces. Also, it shall at an opportune moment attack and destroy enemy advance bases.

12. The Third Fleet, the Southern Expeditionary Fleet and [other] necessary units shall take charge of defending and patrolling the occupied [sea] areas in the south as well as protecting the shipping lanes in these areas. They shall [also] strive to search for enemy naval vessels appearing in these areas as well as to attack and destroy enemy advance bases in the outer areas [of the south].

13. The unit consisting of the Fourth Fleet as its core shall take charge of seizing the equatorial Pacific Islands as well as the Bismarck Islands, defending and patrolling strategic locations, protecting the shipping lanes in these areas, and searching for and attacking enemy naval vessels [there]. At the same time, it shall strive to surprise the enemy advance bases in the outer areas.

14. The unit consisting of the Fifth Fleet as its core shall take charge of defending the Ogasawara [Bonin] Islands, and patrolling and protecting the shipping lanes in the waters north of and including the islands and to the east of Japan. At the same time, the unit shall search for and attack enemy fleets appearing in the waters and, at a favorable opportunity, strive to surprise the enemy advance bases in the Aleutians.

15. One element of the Combined Fleet shall timely be sent to the Pacific Ocean and the Indian Ocean, where it shall make utmost efforts to disrupt enemy shipping lanes.

16. The main force of the Combined Fleet shall take charge of timely acting in response to movements of the enemy fleets and supporting the entire operation.

17. In case the U.S. main fleet comes [for an attack], the unit consisting of the Sixth Fleet as its core shall take charge of reconnoitering the enemy at close range, so that while the air units and the submarine units strive to weaken the enemy power, the major part of the Combined Fleet, which shall timely be concentrated, shall intercept them and destroy them.

18. In case a powerful British fleet comes [for an attack], the Third Fleet, the Fourth Fleet, the Southern Expeditionary Fleet, air units and submarine units, etc. shall timely be moved and concentrated, and try to scout, reconnoiter at close range, and weaken the power of the enemy. In the meantime, while responding to the movements of the U.S. fleet, the main force of the Combined Fleet shall search for the British Fleet and destroy it.

19. Among the areas to be occupied, defense shall be provided for the following strategic locations: Manila, Hong Kong, Davao, Singapore, Batavia, Surabaya, Tarakan, Balikpapan, Menado, Makassar, Ambon, Penang and Rabaul.

20. Advance bases [to be set up] in the occupied areas shall be as follows: Manila, Singapore and Surabaya.

Chapter 3. Mission of the China Area Fleet (Omitted by the author)

\section{IGHQ Navy Department Instruction No. 1 Supplement}

\section{The Army - Navy Central Agreement for the Southern Operation (Summary)}

1. The areas to be occupied in the south are as follows:

The Philippines, British Malaya, Burma, Java, Sumatra, Borneo, Celebes, Timor, etc.

2. Forces to be employed for the operation

(1) The Army (as in the following table) 
Chapter III / The Drafting of a Plan of Operations for the Southern

\section{Advance}

\begin{tabular}{|c|c|c|c|}
\hline Army & \multicolumn{2}{|c|}{ Forces } & Deployment Area \\
\hline \multirow{5}{*}{ Southern Army } & 14th Army & $\begin{array}{l}\text { 16th Div, } 48 \text { th Div, } 2 \\
\text { tank rgts, } 44 \text { antiair- } \\
\text { craft guns, } 6 \text { artillery } \\
\text { bns under direct con- } \\
\text { trol of the army (Note: } \\
65 \text { th Bde shall not be } \\
\text { employed in the inva- } \\
\text { sion operation.) }\end{array}$ & The Philippines \\
\hline & 15th Army & $\begin{array}{l}\text { 33d Div, 55th Div } \\
\text { (minus one element) }\end{array}$ & Thailand, Burma \\
\hline & 16th Army & $\begin{array}{l}\text { 2d Div, 38th Div (to be } \\
\text { transferred after com- } \\
\text { pleting the Hong Kong } \\
\text { operation), } 3 \text { tank rgts, } \\
\text { 48th Div (to be trans- } \\
\text { ferred after completing } \\
\text { the Philippines opera- } \\
\text { tion), 56th Mixed Inf } \\
\text { Gp (Sakaguchi Det), } 5 \\
\text { artillery bns under di- } \\
\text { rect control of the } \\
\text { army, } 88 \text { antiaircraft } \\
\text { guns }\end{array}$ & The Dutch East Indies \\
\hline & 25th Army & $\begin{array}{l}\text { Imperial Guard Div, } \\
\text { 5th Div, 18th Div, 56th } \\
\text { Div (to be afterwards } \\
\text { transferred to Burma), } \\
4 \text { tank rgts, } 11 \text { artillery } \\
\text { bns under direct con- } \\
\text { trol of the army, } 60 \text { an- } \\
\text { tiaircraft guns }\end{array}$ & Malaya \\
\hline & $\begin{array}{l}\text { Units under direct con- } \\
\text { trol of the Southern } \\
\text { Army }\end{array}$ & $\begin{array}{l}\text { 21st Div, 21st Inde- } \\
\text { pendent Mixed Bde, } 48 \\
\text { antiaircraft guns, 3d } \\
\text { Air Force, 5th Air } \\
\text { Force, 21st Independ- } \\
\text { ent Air Unit }\end{array}$ & \\
\hline 23d Army & \multicolumn{2}{|c|}{ 38th Div, 1 light bomber air gp } & Hong Kong \\
\hline South Seas Detachment & \multicolumn{2}{|l|}{ 55th Mixed Inf Gp } & Pacific [Islands] \\
\hline
\end{tabular}




\section{Advance}

(2) The Navy

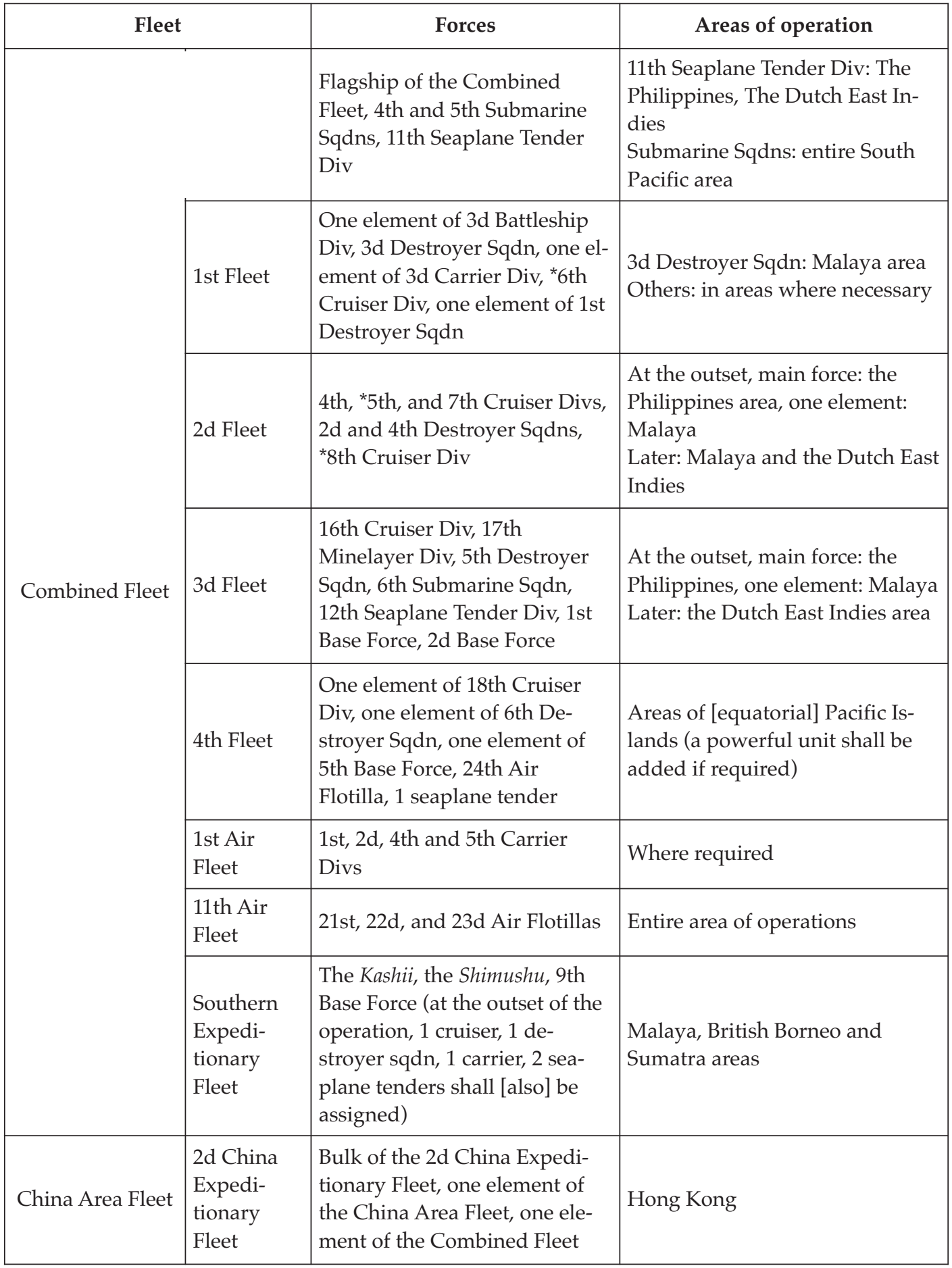

Notes:

(1) Part of the strength shall be increased or reduced depending on the situation.

(2) * Indicates forces whose strength may be partly employed depending on the situation. 


\section{Advance}

3. Outline of the launch of the operation (Omitted by the author)

4. Outline of the Philippines operation

(1) Right at the outset of the war, while preemptive air strikes shall be carried out on the enemy air power, naval vessels, etc. in the Philippines, the Navy unit shall simultaneously make a sudden attack on Batan Island to quickly prepare an emergency landing field.

(2) Advance units shall, with the cooperation of the Army and the Navy, land in Aparri, Vigan (followed by Laoag), Legaspi and Davao and their vicinities, first seize air bases and make them ready for use. Then, they shall capture Jolo Island and make the air base ready for use as quickly as possible. After that, air units of both the Army and the Navy shall advance their air bases to continue their air operations.

(3) Making most of the results of the above air campaigns, by the fifteenth day of the operation at the latest, the main force of the Fourteenth Army shall be put ashore at Lingayen Gulf, and one element at Lamon Bay, to promptly capture Manila, and subsequently occupy [other] key locations in the Philippines.

(4) When the [Philippines] invasion operation is for the most part completed, the 48th Division shall be assembled near Manila to be transferred to the Dutch East Indies invasion corps.

5. Outline of the British Malaya operation

(1) The unit consisting of the Twenty-fifth Army, the Third Air Force and the Southern Expeditionary Fleet as its core shall launch the operation in the following manner:

\{1\} Plan A (in case execution of a sudden landing is likely in view of the situation in Britain and in Thailand)

The advance corps shall enter into the anchorage at 0000 on Day X and onwards, conduct a sudden landing at Ban Don, Nahkon, Singora and Pattani and their vicinities, to swiftly seize air bases and make them ready for use. Air units of both the Army and the Navy shall launch air strikes at 0000 on Day $X$ and onwards from southern Indochina, and mainly carry out preemptive air strikes on the enemy air power and naval vessels in British Malaya.

$\{2\}-\{4\}$ (Plan B and others; omitted by the author)

(2) Outline of the invasion of Singapore (Omitted by the author)

6. Outline of the British Borneo operation

(1) Right at the opening of hostilities, one element of the force under the direct control of the Southern Army shall seize Miri in a sudden attack, and secure the important resource areas and the air base.

(2) After the seizure of Miri, it shall proceed to capture Kuching, seize the air base, make it ready for use, and advance the Navy air unit.

7. Outline of the Dutch East Indies operation

(1) During the Philippines operation, the Army and the Navy in conjunction shall, with one element of the Sixteenth Army, capture Tarakan as swiftly as possible, then Balikpapan and Banjarmasin one after another, depending on the situation of the Philippines and the Malaya operations. During or after this operation, Ambon and Kupang shall be seized at an opportune moment, where necessary air bases shall be seized and made ready for use, and key resource areas shall be secured.

(2) Roughly at the same time with the capture of Tarakan, the Navy shall seize Menado, then Kendari and Makassar without assistance [of the Army] during the latter's operations in the previous item.

(3) Apart [from the above], when the operation against British Malaya has made progress, one element of the Sixteenth Army shall at an opportune moment seize the key locations on Bangka Island as well as Palembang, ready the air base and secure the important resource areas. 
(4) After the necessary air bases [seized] in the above (1), (2), (3) [operations] have been readied and the enemy air power in Java has been brought under control, the main force of the Sixteenth Army shall land in western Java and one corps diverted [from the Philippines] in eastern Java, and promptly capture Batavia, Bandung and Surabaya. After that, they shall mop up the key areas in Java.

(5) When the Malacca Strait has been brought under control after the capture of Singapore, one element of the Twenty-fifth Army shall timely be disembarked in the vicinity of Medan from the west coast of the Malay Peninsula to seize the key areas in Aceh and, at an opportune moment, Sabang Island.

\section{Command}

The operations shall be carried out by the Army and the Navy in conjunction. However, when the Army unit and the Navy special landing force shall conduct operations in the same area in a local landing operation, a unified command may be instated depending on the situation.

9. Transport and escort

(1) The Navy shall provide escort to the landing units in all operational areas. However, escort to be provided for transport units after the landing of the main force [in charge] of the area shall be provided within the limit of the strength available under the circumstances of that time.

(2) Generally, no particular direct escort shall be provided to empty return ships and to general shipping north of Taiwan. [However,] depending on the circumstances, escort for general shipping north of Taiwan may be provided by one element of the forces of the China Area Fleet.

(3) Necessary escorts shall be provided to ships replenishing and transporting the Army or evacuating its casualties. These transports, which should be carried out in groups as much as possible, shall be determined in view of the timing of the transport and the situation of the operations, taking the availability of escort forces into consideration.

10. Assembly points of the invasion units (Omitted by the author)

11. Agreements and arrangements to be made between the commanders of the Army and the Navy If the opening of hostilities should be decided on, [agreements and arrangements] shall be concluded at an earliest opportunity between the commanders of the following units:

(1) The Southern Army, the Combined Fleet, and the Second Fleet (Note: concerning southern operations in general)

(2) The Southern Army and the Southern Expeditionary Fleet (Note: concerning the British Borneo operation)

(3) The Fourteenth Army, the Sixteenth Army and the Third Fleet (Note: concerning the Philippines and the Dutch East Indies operations)

(4) The Fifteenth Army, the Twenty-fifth Army and the Southern Expeditionary Fleet (Note: concerning the Malaya operation)

(5) The Third Air Force, the Fifth Air Force and the Eleventh Air Fleet (Note: concerning the southern air operation)

(6) The Third Air Force and the Southern Expeditionary Fleet and the 22d Air Flotilla (Note: concerning the Malaya air operation)

12. Code names

The Philippines operation: Operation M; The British Borneo operation: Operation B; The Malaya operation: Operation E; the entire southern operation: Operation "A-Gö"; The Dutch East Indies operation: Operation $\mathrm{H}$ 


\section{Advance}

\section{Attachment to the Army-Navy Central Agreement for the Southern Operation}

The Army-Navy Central Agreement on the Air [Operation] for the Southern Operation (Summary)

1. The forces to be employed (as in the following table)

\begin{tabular}{|c|c|c|c|c|c|c|}
\hline \multirow{2}{*}{ Areas } & \multicolumn{3}{|c|}{ Navy } & \multicolumn{3}{|c|}{ Army } \\
\hline & Commander & \multicolumn{2}{|l|}{ Forces } & Commander & \multicolumn{2}{|l|}{ Forces } \\
\hline \multirow[t]{2}{*}{ The Philippines } & $\begin{array}{l}\text { Commander } \\
\text { in Chief, } \\
\text { 11th Air } \\
\text { Fleet }\end{array}$ & $\begin{array}{l}9 \text { land-based re- } \\
\text { connaissance } \\
\text { planes, } 108 \text { land- } \\
\text { based fighter } \\
\text { planes, } 144 \text { land- } \\
\text { based attack } \\
\text { planes, } 18 \text { flying } \\
\text { boats (reinforce- } \\
\text { ments shall be } \\
\text { brought from } \\
\text { other areas, if sit- } \\
\text { uation requires) }\end{array}$ & 279 & \multirow[t]{2}{*}{$\begin{array}{l}\text { 5th Air Force } \\
\text { Commander }\end{array}$} & \multirow[t]{2}{*}{$\begin{array}{l}36 \text { reconnaissance } \\
\text { planes, } 36 \text { fighter } \\
\text { planes, } 54 \text { light } \\
\text { bombers, } 18 \text { heavy } \\
\text { bombers (apart } \\
\text { from these, about } \\
30 \text { fighter planes } \\
\text { shall be employed } \\
\text { for the air defense } \\
\text { of Taiwan) }\end{array}$} & \multirow[t]{2}{*}{144} \\
\hline & $\begin{array}{l}\text { Commander } \\
\text { in Chief, 3d } \\
\text { Fleet }\end{array}$ & $\begin{array}{l}\text { About } 60 \text { recon- } \\
\text { naissance sea- } \\
\text { planes ( } 40 \text { right } \\
\text { [at the opening of } \\
\text { hostilities]) }\end{array}$ & $\begin{array}{c}60 \\
(40)\end{array}$ & & & \\
\hline \multirow{2}{*}{$\begin{array}{c}\text { Malaya } \\
\text { Burma } \\
\text { British Borneo }\end{array}$} & $\begin{array}{l}\text { Com- } \\
\text { mander, 22d } \\
\text { Air Flotilla }\end{array}$ & $\begin{array}{l}9 \text { land-based re- } \\
\text { connaissance } \\
\text { planes, } 36 \text { land- } \\
\text { based fighter } \\
\text { planes, } 72 \text { land- } \\
\text { based attack } \\
\text { planes }\end{array}$ & $117^{*}$ & \multirow{2}{*}{$\begin{array}{l}\text { 3d Air Force } \\
\text { Commander }\end{array}$} & \multirow{2}{*}{$\begin{array}{l}72 \text { reconnaissance } \\
\text { planes, } 168 \text { fighter } \\
\text { planes, } 108 \text { light } \\
\text { bombers, } 99 \text { heavy } \\
\text { bombers (after the } \\
\text { completion of the } \\
\text { Philippines opera- } \\
\text { tions, main force of } \\
\text { the } 5 \text { th Air Force } \\
\text { shall be diverted) }\end{array}$} & \multirow[t]{2}{*}{447} \\
\hline & $\begin{array}{l}\text { Commander } \\
\text { in Chief, } \\
\text { Southern Ex- } \\
\text { peditionary } \\
\text { Fleet }\end{array}$ & $\begin{array}{l}7 \text { reconnaissance } \\
\text { seaplanes (about } \\
20 \text { right [at the } \\
\text { opening of hostil- } \\
\text { ities]) }\end{array}$ & $\begin{array}{c}7 \\
(20)\end{array}$ & & & \\
\hline $\begin{array}{l}\text { The Dutch East } \\
\text { Indies }\end{array}$ & \multicolumn{3}{|c|}{$\begin{array}{l}\text { Most of the forces assigned to the } \\
\text { Philippines and Malaya operations } \\
\text { shall be diverted, and one element of } \\
\text { the 1st Air Fleet shall be added, de- } \\
\text { pending on the situation. }\end{array}$} & \multicolumn{3}{|c|}{$\begin{array}{l}\text { As much force as possible shall be di- } \\
\text { verted from Malaya areas after the } \\
\text { Malaya operation is for the most part } \\
\text { completed or the fate of Singapore is } \\
\text { sealed, though depending on the situa- } \\
\text { tion. }\end{array}$} \\
\hline
\end{tabular}

* The text mistakenly has 177. 


\section{Advance}

2. Outline of the Philippines operation

(1-4) (Omitted by the author)

(5) When the air campaign to destroy the enemy air power in the Philippines is completed, the Navy air units shall be diverted to the Dutch East Indies operation.

3. Outline of Malaya, Burma, and British Borneo operations

(1-4) (Omitted by the author)

(5) While the Army shall be in charge of the preparation of the air bases in Malaya, Thailand and Burma, the Navy shall be in charge of those in British Borneo and of the seaplane bases.

(6) When the air bases on the east coast of the Malay Peninsula are made ready for use, the Army shall successively advance [its forces], while the Navy shall appropriately use these bases with one element to intensify its air campaigns.

4. Outline of the Dutch East Indies operation

(1) Although the Navy shall take the major part in this operation, the operation in northern Sumatra shall be mainly conducted by the Army, whereas those in southern Sumatra and western Java shall be carried out by the Army and the Navy in conjunction.

(2) The Navy shall allocate the air units to be diverted from the Philippines to the main force and, according to the war situation, also divert necessary strength from the units conducting the Malaya and British Borneo operations.

(3) The Army shall cooperate in this operation with the units to be diverted from the Malaya area. The air campaign against northern Sumatra shall be carried out at appropriate moments even while the Malaya operation is in progress.

\section{The Plan of Operations of the Combined Fleet}

In conformity with the mission directives and the central agreement given by central command, the Combined Fleet disclosed its plan of operations against the United States, Britain and the Netherlands to all its units by Combined Fleet Operation Order Classified No. 1 of 5 November, an excerpt of which is as follows (some parts are summarized):(45)

\section{Supplement to Combined Fleet Operation Order Classified No. 1}

Operations of the Combined Fleet in a War against the United States, Britain and the Netherlands (Excerpted by the author)

Part 1.

Mission of the Combined Fleet in Case War against the United States, Britain and the Netherlands Breaks Out During the Operation Against China

Chapter 1.

Summary of the operation

1. In the east, the U.S. fleet shall be destroyed and the lines of operation and the supply lines of the United States to [their forces and allies in] the east shall be disrupted.

2. In the west, the British Malaya area shall be captured, and the lines of operation and the supply lines of Britain to [its forces and allies in] the east, as well as the supply route in Burma [to China] shall be cut off.

3. The enemy power in the east shall be destroyed, their operational bases seized and resource areas captured.

4. By seizing key locations, expanding [the seized areas], and strengthening defenses a position shall be secured from where a protracted war can be conducted.

5. The enemy power shall be intercepted and destroyed. 


\title{
Advance
}

6. By expanding the military gains, the morale of the enemy shall be undermined.

\section{Chapter 2}

Preparations for the opening of hostilities and the [actual] opening of hostilities

Section 1

Preparations for the opening of hostilities

1. In case the Empire [of Japan] anticipates a war against the United States, Britain and the Netherlands and determines to complete various operational preparations, the "first [phase] of preparations for the opening of hostilities" order shall be passed down, along with a tentative date for the opening of hostilities (Day Y). Each unit shall act as follows:

(a) Each fleet and unit shall, without particular separate orders, shift its formation according to the phase-one operational disposition of the stage-one operations, complete war preparations and timely advance to the standby point before the launch of the operation designated by the commander of each unit, and stand by.

(b) Each unit shall stay on strict alert against unexpected attacks delivered by U.S., British, and Dutch forces.

(c) Each commander may secretly conduct reconnaissance when it is specifically required for executing operations.

(d) (The laying of mines in the [Japanese administered] equatorial Pacific Islands: omitted by the author.)

2. When advance units required for executing the operation are sent to the operational waters, the "second [phase] of preparations for the opening of hostilities" order shall be issued.

Each unit shall act as follows:

(a) The advance units, the Carrier Task Force, the units to disrupt [the enemy] shipping lanes, the submarine units belonging to the Southern Task Force and the South Seas Unit shall timely start for their respective operational waters designated by the commander of each unit.

(b) The remaining units shall act as designated by the commander of each unit in conformity to their dispositions right at the opening of hostilities.

3. Depending on circumstances, [it is possible that] some units shall be designated to make [specific] necessary preparations for the opening of hostilities. It is [also] possible that the "second [phase] of preparations for the opening of hostilities" shall be reversed to the "first [phase] of preparations for the opening of hostilities," if huge changes should occur in the circumstances.

\section{Section 2}

The opening of hostilities and the use of arms before the opening of hostilities

(Omitted by the author)

\author{
Chapter 3 \\ Stage-one operations
}

\section{Section 1}

Mission

1. The advance units, the Carrier Task Force, the South Seas Unit, the Northern Task Force and the main unit [the Combined Fleet] shall conduct operations against the U.S. Fleet.

Right at the outset of the war, the advance unit and the Carrier Task Force shall destroy [the U.S. Fleet] in a surprise attack and block its offensive operations. The units shall strive to capture and destroy the U.S. Fleet if the latter should go into action (the rest omitted by the author). 
2. While holding the upper hand in the area, the Southern Task Force shall clear and destroy the enemy fleets in the waters of the Philippines, British Malaya, and Dutch East Indies; at the same time it shall conduct the following operations in conjunction with the Army:

(a) [The unit] shall launch operations against British Malaya and the Philippines simultaneously, conduct preemptive air strikes on the air power and on the naval forces of the enemy in these areas and repeatedly attack them. [At the same time] it shall put ashore the Army's advance corps in the key locations in Malaya, the Philippines and then British Borneo as quickly as possible in order to push ahead the air units and intensify their air operations.

(b) After the above operations [2(a)] produce results, the main force of the invasion corps of the Army shall be put ashore in the Philippines and then in Malaya to promptly capture the Philippines and British Malaya.

(c) In the early stages of the operation, strategic places in Celebes shall be occupied, followed by those in Dutch Borneo and southern Sumatra. Key places in the Moluccas and Timor shall [also] be occupied at favorable opportunities and the necessary air bases [at each place] shall be made ready for use.

(d) As soon as the air bases mentioned in the above [2(c)] are made ready for use, air units shall be advanced one after another to suppress the air power of the enemy in the Java area. After [the operation] produces results, the main force of the invasion corps of the Army shall be put ashore in Java to capture it.

(e) After capturing Singapore, strategic areas in northern Sumatra shall be occupied, and the operations against Burma shall timely be conducted in order to block the enemy's supply route to China.

3. In case the U.S. Fleet should come for an attack, the Third Fleet, the Southern Expeditionary Fleet, and others shall carry out the southern operation for the time being, while the bulk of the decisive force shall take charge of implementing the operation to intercept the U.S. Fleet.

4. -5 . (The operation to disrupt the [enemy] shipping lanes, and the items concerning Thailand and French Indochina [operations]: Omitted by the author.)

\section{Section 2}

Outline of the operation against the U.S. Fleet

(Omitted by the author)

Section 3

Outline of the southern operation

The southern operation shall be conducted by the commander of the Southern Task Force, except for mission directives and orders particularly given in conformity with the agreements between the commanders in chief of the Combined Fleet and the Southern Army.

Section 4

Periodization of the operation

Stage-one operations shall be divided into the following phases, and particular orders shall be given for shifts [from one phase to another].

1. Phase-one operations: The operations [cover the period] from the opening of hostilities roughly until the completion of the landing of the main force of the Army Philippines invasion [unit]

2. Phase-two operations: The operations [cover the period] after phase-one operations roughly until the completion of the landing of the main force of the Army British Malaya invasion [unit]

3. Phase-three operations: The operations [cover the period] after phase-two operations until the Dutch East Indies operation is for the most part completed. 


\title{
Advance
}

Section 5

Disposition of forces

The disposition of forces during stage-one operations shall be designated as follows:

1. Phase-one disposition: Separate Table No. 1

2. Phase-two disposition: Separate Table No. 2

3. Phase-three disposition: Separate Table No. 3

4. Disposition for the interception operation: Separate Table No. 4 (Omitted by the author.)

\author{
Chapter 4 \\ Stage-two operations
}

Section 1

Mission

1. The advance units shall continuously watch and surprise the U.S and British fleets and, at favorable opportunities, land-based air units and carrier-based air units shall [also] carry out raids.

2. The lines of operation and the supply lines of the United States and Britain to [their units and the allies in] the East shall be securely cut off, and the defense of key locations shall be strengthened.

3. Enemy forces in the waters under [Japanese] control as well as enemy remnants in the seized key locations shall be cleared and destroyed, resources shall be secured, and the shipping lanes shall be protected.

4. By taking advantage of [our] inner [defense] lines, the U.S. and British fleets coming for an attack shall be destroyed one by one.

5. The operation to disrupt the U.S. and Britain's shipping lanes shall be intensified.

\section{Section 2}

Strategic locations and advance bases in the occupied areas to be defended

1. In the occupied areas, the strategic locations to be defended shall be planned as follows:

Manila, Davao, Singapore, Batavia, Surabaya, Tarakan, Balikpapan, Menado, Makassar, Ambon, Penang, and Rabaul

2 In the occupied areas, the advance bases shall be planned as follows:

Manila, Singapore, and Surabaya

\section{Section 3}

The areas planned to be occupied or destroyed

The areas to be occupied or destroyed as swiftly as the operational situation permits are as follows:

1. Eastern New Guinea, New Britain, Fiji, and Samoa area

2. Aleutians, and Midway area

3. Andaman Islands

4. Key locations in Australia

Section 4

Disposition of forces

(Omitted by the author)

\section{Chapter 5}

Protection of shipping lanes and disruption of those of the enemy and mining operations 
Section 1

Protection of shipping lanes

In addition to the following table, the protection of the shipping lanes shall be implemented as designated by the commander of each unit in accordance with the Wartime Commerce Protection Plan of [administrative] year 1941.

\begin{tabular}{|c|c|c|}
\hline Unit & Assigned Areas & Main Assignments \\
\hline $\begin{array}{l}\text { The Philippines } \\
\text { Dutch East Indies } \\
\text { Unit }\end{array}$ & $\begin{array}{l}\text { West of } 136.2^{\circ} \mathrm{E} \text { (excluding the wa- } \\
\text { ters guarded by the } 3 \mathrm{~d} \text { Base Force) } \\
\text { South of } 20^{\circ} \mathrm{N} \\
\text { East of the } 315^{\circ} \text { line with the north } \\
\text { end of British Borneo as the center } \\
\text { (excluding the areas of the } 2 \mathrm{~d} \\
\text { China Expeditionary Fleet) }\end{array}$ & \multirow{4}{*}{$\begin{array}{l}\text { - Controlling the movements of ships in } \\
\text { the assigned areas } \\
\text { - Matters concerning the escort of } \\
\text { [friendly] ships in the assigned areas } \\
\text { - Collecting information and its communi- } \\
\text { cation } \\
\text { - Controlling ship signals in the assigned } \\
\text { areas } \\
\text { - Issuing warnings and all-clear signals in } \\
\text { the assigned area }\end{array}$} \\
\hline Malaya Unit & $\begin{array}{l}\text { South of the } 315^{\circ} \text { line with the } \\
\text { north end of British Borneo as the } \\
\text { center }\end{array}$ & \\
\hline South Seas Unit & $\begin{array}{l}\text { East of } 136.2^{\circ} \mathrm{E} \text { (also includes the } \\
\text { waters guarded by the } 3 \mathrm{~d} \text { Base } \\
\text { Force) } \\
\text { Waters south of } 24^{\circ} \mathrm{N}\end{array}$ & \\
\hline $\begin{array}{l}\text { [Assigned to the } \\
\text { Northern Task } \\
\text { Force:] }\end{array}$ & $\begin{array}{l}\text { Waters north of } 24^{\circ} \mathrm{N} \\
\text { Waters south of } 29^{\circ} \mathrm{N}\end{array}$ & \\
\hline $\begin{array}{l}\text { Other operational } \\
\text { units }\end{array}$ & Each operational area & $\begin{array}{l}\text { Shall cooperate in the following way: } \\
\text { 1. Destroying the enemy power in each op- } \\
\text { erational area } \\
\text { 2. Cooperation in the escort (by mainly } \\
\text { providing indirect escort; direct escort } \\
\text { depending on the circumstances) } \\
\text { 3. Support of signal communications }\end{array}$ \\
\hline
\end{tabular}

Section 2

1. Mission

The operation to disrupt the [enemy] shipping lanes

The operation to disrupt the [enemy] shipping lanes shall swiftly be conducted against the most important areas for the shipping of the United States, Britain and the Netherlands, while at the same time containing the enemy forces in order to support the main operations.

Later, the operations shall be increasingly intensified and carried out for a longer period, so as to undermine the morale of the enemy.

2. Outline of the implementation

(a) - (c) ([Areas] other than the southwestern region: Omitted by the author.) 


\section{Advance}

(d) After stage-one, phase-one operations, the 4th, the 5th, and the 6th Submarine Squadrons shall take charge of disrupting the [enemy] shipping lanes partly at the south coast of Java or near the west exit of the Malacca Strait, as designated by the commander of the Southern Task Force. When the southern operation is for the most part completed, they shall further actively engage in the disruption of [enemy] shipping lanes in the Indian Ocean and [the waters near] Australia.

(e) When stage-one operations are for the most part completed or when favorable opportunities are found during the operations, the force engaging in the disruption of [enemy] shipping lanes shall further be strengthened, and [the operation] shall be vigorously carried out with naval vessels and aircraft.

\section{Section 3}

Mining operations

Apart from the below, the mining operations of the Combined Fleet shall be [carried out] as designated by the commander of each unit.

1. The southern operation area

(a) The standard implementation of offensive mining operations: As in Attached Table No. 1

(b) The table of the bases to be defended with mines and antisubmarine nets (standard): As in Attached Table No. 2

(Followed by "A table of mines and antisubmarine nets to be replenished" and "Mining operations in the equatorial Pacific Islands," etc., which are omitted by the author.)

\section{Attached Table No. 1}

The standard implementation of offensive mining operations in the southern operation area

(1) Stage-one, phase-one operations (The Philippines and Malaya areas: Omitted by the author)

(2) Stage-one, phase-two operations (Note by the author: As in the following table)

\begin{tabular}{|c|c|c|c|c|c|}
\hline Areas & $\begin{array}{c}\text { Waters to be } \\
\text { mined }\end{array}$ & $\begin{array}{c}\text { Moment [to } \\
\text { lay mines] }\end{array}$ & $\begin{array}{c}\text { Forces to be } \\
\text { employed }\end{array}$ & $\begin{array}{c}\text { Number of } \\
\text { mines }\end{array}$ & Remarks \\
\hline $\begin{array}{c}\text { The Dutch } \\
\text { East Indies }\end{array}$ & $\begin{array}{c}\text { North exit of } \\
\text { Surabaya }\end{array}$ & $\begin{array}{c}\text { Around Day } \\
\mathrm{X}+25\end{array}$ & $\begin{array}{c}\text { Submarines of } \\
\text { 6th Submarine } \\
\text { Sqdn }\end{array}$ & About 40 & $\begin{array}{l}\text { Light cruisers } \\
\text { and other war } \\
\text { vessels with } \\
\text { shallow draft } \\
\text { are set as tar- } \\
\text { gets }\end{array}$ \\
\hline Malaya & $\begin{array}{c}\text { Entrance of } \\
\text { Singapore } \\
\text { trait or south } \\
\text { of Malaya }\end{array}$ & $\begin{array}{c}\text { At appropriate } \\
\text { moments }\end{array}$ & $\begin{array}{c}\text { Force and 3 } \\
\text { [minelayers] of } \\
\text { the 17th } \\
\text { the 9th Base }\end{array}$ & About 500 & $\begin{array}{l}\text { Minelayer Div } \\
\text { 1. To block the } \\
\text { enemy's } \\
\text { passage } \\
\text { the mining } \\
\text { operations } \\
\text { in phase-one } \\
\text { operations }\end{array}$ \\
\hline
\end{tabular}

(3) Stage-one, phase-three operations and thereafter 


\section{Advance}

\begin{tabular}{|c|c|c|c|c|c|}
\hline Areas & $\begin{array}{l}\text { Waters to be } \\
\text { mined }\end{array}$ & $\begin{array}{l}\text { Moment [to } \\
\text { lay mines] }\end{array}$ & $\begin{array}{l}\text { Forces to be } \\
\text { employed }\end{array}$ & $\begin{array}{l}\text { Number of } \\
\text { mines }\end{array}$ & Remarks \\
\hline \multirow[b]{2}{*}{$\begin{array}{l}\text { Waters off } \\
\text { Australia }\end{array}$} & Port Darwin & $\begin{array}{l}\text { At the earliest } \\
\text { opportunity }\end{array}$ & $\begin{array}{c}\text { Minelayers of } \\
\text { the 17th } \\
\text { Minelayer Div }\end{array}$ & 300 & $\begin{array}{l}\text { To block the } \\
\text { enemy's pas- } \\
\text { sage }\end{array}$ \\
\hline & $\begin{array}{c}\text { Key locations } \\
\text { of Australia }\end{array}$ & $\begin{array}{l}\text { Advance at the } \\
\text { first opportu- } \\
\text { nity }\end{array}$ & $\begin{array}{c}1 \text { or } 2 \text { subma- } \\
\text { rine (s) of the } \\
6 \text { th Submarine } \\
\text { Sqdn } \\
1 \text { minelayer* } \\
\text { of the } 17 \text { th } \\
\text { Minelayer Div }\end{array}$ & $\begin{array}{l}\text { Appropriately } \\
\text { [as needed] }\end{array}$ & $\begin{array}{l}\text { 1. To block the } \\
\text { enemy's } \\
\text { passage } \\
\text { 2. Mines shall } \\
\text { be laid when } \\
\text { Type } 88 \\
\text { mines are } \\
\text { supplied }\end{array}$ \\
\hline Indian Ocean & $\begin{array}{l}\text { Rangoon } \\
\text { Colombo } \\
\text { Bombay }\end{array}$ & $\begin{array}{l}\text { At the earliest } \\
\text { opportunity } \\
\text { after the } \\
\text { seizure of Sin- } \\
\text { gapore }\end{array}$ & $\begin{array}{c}1 \text { or } 2 \text { subma- } \\
\text { rine (s) of the } \\
\text { 6th Submarine } \\
\text { Sqdn }\end{array}$ & $\begin{array}{l}\text { Appropriately } \\
\text { [as needed] }\end{array}$ & Ditto \\
\hline
\end{tabular}

\section{Attached Table No. 2}

The table of the bases to be defended with mines and antisubmarine nets

(1) The Philippines area (Omitted by the author)

(2) The French Indochina area (Omitted by the author)

(3) The Dutch East Indies area:

Tarakan, Balikpapan, Makassar, Surabaya, Ambon or Kupang, Batavia, and the Sunda Strait.

(4) The Malaya area:

Outer area of the port of Singapore, and the Malacca Strait.

\section{Chapter 6}

Signal Communications

(Omitted by the author)

\section{Chapter 7}

Replenishment

(Omitted by the author)

\section{Chapter 8}

Operations [to be conducted] by others than the Combined Fleet

(Omitted by the author)

Part 2

Operations of the Combined Fleet in Case War against Russia Breaks Out While the War Against the United States, Britain, the Netherlands and China Is Underway

(Omitted by the author)

\footnotetext{
* The text mistakenly has submarine.
} 


\section{Advance}

Part 3

Miscellaneous Rules

(Omitted by the author)

Separate table No. 1

Stage-One, Phase-One Disposition of Forces (Note by the author: As in the following table*)

(From the first [phase] of preparation for the opening of hostilities until about Day $X+20$, when the landing of the main force of the Army Philippines invasion unit is completed.)

\begin{tabular}{|c|c|c|c|c|c|c|c|}
\hline Unit & \multicolumn{2}{|c|}{$\begin{array}{l}\text { Com- } \\
\text { mander }\end{array}$} & $\begin{array}{l}\text { Force to be } \\
\text { employed }\end{array}$ & $\begin{array}{c}\text { Main } \\
\text { assignment }\end{array}$ & Outline of operation & $\begin{array}{l}\text { Standby } \\
\text { position }\end{array}$ & Notes \\
\hline 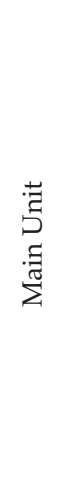 & \multirow[b]{2}{*}{ 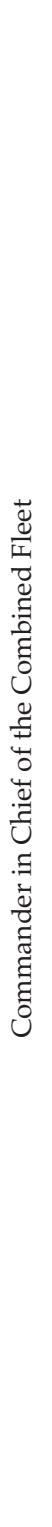 } & & $\begin{array}{l}\text { 1st Battleship Div, } \\
\text { 1st Fleet (minus 3d } \\
\text { Battleship Div, 6th } \\
\text { Cruiser Div, 1st De- } \\
\text { stroyer Sqdn } \\
\text { (minus } 2 \text { destroyer } \\
\text { divs), and minus } \\
\text { 3d Destroyer } \\
\text { Sqdn), and 1 de- } \\
\text { stroyer of 7th De- } \\
\text { stroyer Div }\end{array}$ & $\begin{array}{l}\text { Support for the } \\
\text { entire operation }\end{array}$ & $\begin{array}{l}\text { 1. The unit stays on alert } \\
\text { at anchor in the west- } \\
\text { ern part of the Inland } \\
\text { Sea and makes a sor- } \\
\text { tie for support when } \\
\text { necessary. } \\
\text { 2. Based on Operation } \\
\text { Tactics } 1 \text { against the } \\
\text { U.S. Fleet, it shall } \\
\text { cover the return of } \\
\text { the Carrier Task Force } \\
\text { after the attack by de- } \\
\text { parting on Day X. }\end{array}$ & $\begin{array}{l}\text { Western part } \\
\text { of the Inland } \\
\text { Sea of Japan }\end{array}$ & \\
\hline 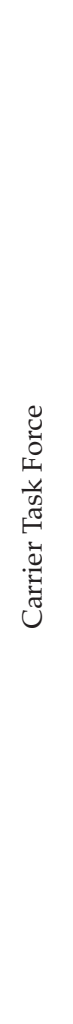 & & 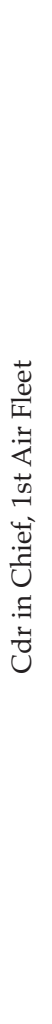 & $\begin{array}{l}\text { 1st Air Fleet (minus } \\
\text { 4th Carrier Div and } \\
\text { destroyer div), 1st } \\
\text { Destroyer Sqdn } \\
\text { (minus } 3 \text { destroyer } \\
\text { divs), } 1 \text { destroyer } \\
\text { div of 2d Destroyer } \\
\text { Sqdn, the Akigumo, } \\
\text { 3d Battleship Div } \\
\text { (minus 2d Section), } \\
\text { 8th Cruiser Div, 7th } \\
\text { Destroyer Div } \\
\text { (minus 1 de- } \\
\text { stroyer), and } 1 \\
\text { transport ship }\end{array}$ & $\begin{array}{l}\text { 1. [To conduct] } \\
\text { Operation Tac- } \\
\text { tics } 1 \text { against } \\
\text { the U.S. [Fleet]. } \\
\text { (a) To destroy the } \\
\text { enemy fleet in } \\
\text { Hawaii in a } \\
\text { surprise at- } \\
\text { tack. } \\
\text { (b) To support } \\
\text { the opera- } \\
\text { tions of the } \\
\text { South Seas } \\
\text { Unit and the } \\
\text { Northern } \\
\text { Task Force. } \\
\text { 2. [To conduct] } \\
\text { Operation Tac- } \\
\text { tics } 2 \text { and } 3 \\
\text { against the } \\
\text { U.S. Fleet. } \\
\text { (a) To support } \\
\text { the operations } \\
\text { of the South } \\
\text { Seas Unit and } \\
\text { the Northern } \\
\text { Task Force. }\end{array}$ & $\begin{array}{l}\text { 1. Operation Tactics } 1 \\
\text { against the U.S. } \\
\text { [Fleet]. } \\
\text { (a) On Day X, it shall } \\
\text { destroy the enemy } \\
\text { warships in Hawaii } \\
\text { in a surprise attack } \\
\text { with all its air } \\
\text { strength. } \\
\text { (b) It shall attack the } \\
\text { Midway Islands } \\
\text { with one element to } \\
\text { destroy the [enemy] } \\
\text { base facilities there. } \\
\text { (c) After the air strikes, } \\
\text { it shall return to the } \\
\text { mainland [of Japan] } \\
\text { for maintenance and } \\
\text { replenishment. } \\
\text { 2. Operation Tactics } 2 \\
\text { and } 3 \text { against the U.S. } \\
\text { Fleet. } \\
\text { (a) It shall take action, } \\
\text { responding to the } \\
\text { enemy situation; } \\
\text { while staying on } \\
\text { alert against U.S. } \\
\text { Fleet, it shall cooper- }\end{array}$ & $\begin{array}{l}\text { Hitokappu } \\
\text { Bay }\end{array}$ & \\
\hline
\end{tabular}

* Separate tables No. 1-3 contain a number of small mistakes. We have revised these tables on the basis of the original archival document cited in note 45 . 


\section{Advance}

\begin{tabular}{|c|c|c|c|c|c|c|c|}
\hline 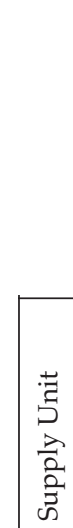 & & 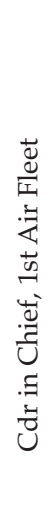 & 11 transport ships & $\begin{array}{l}\text { (b) To cooperate } \\
\text { with the } \\
\text { South Seas } \\
\text { Unit in its op- } \\
\text { eration to } \\
\text { seize key lo- } \\
\text { cations. } \\
\text { (c) To support } \\
\text { the operation } \\
\text { of the South- } \\
\text { ern Task Force } \\
\text { if required. }\end{array}$ & $\begin{array}{l}\text { ate in the South Seas } \\
\text { Unit's operation to } \\
\text { seize key locations if } \\
\text { required. } \\
\text { (b) One element shall } \\
\text { participate in the op- } \\
\text { erations of the } \\
\text { Southern Task Force } \\
\text { by separate orders. }\end{array}$ & & \\
\hline 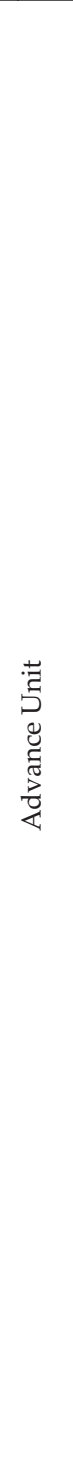 & 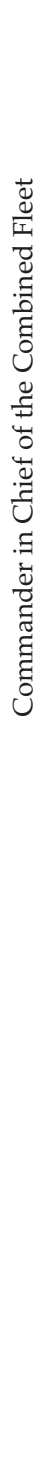 & 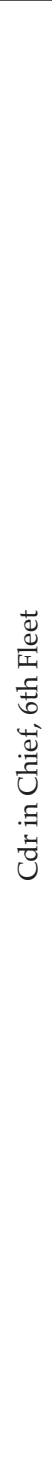 & 6th Fleet & $\begin{array}{l}\text { 1. To reconnoiter, } \\
\text { observe and } \\
\text { attack the U.S. } \\
\text { Fleet in the } \\
\text { Hawaii area. } \\
\text { 2. To cooperate } \\
\text { with the Car- } \\
\text { rier Task Force } \\
\text { in its opera- } \\
\text { tion. } \\
\text { 3. To attack [the } \\
\text { enemy] air } \\
\text { bases between } \\
\text { Hawaii and } \\
\text { Samoa. }\end{array}$ & $\begin{array}{l}\text { 1. It shall observe and } \\
\text { attack the U.S. Fleet } \\
\text { in the area of Hawaii. } \\
\text { It shall intercept [the } \\
\text { enemy] at the water- } \\
\text { way of Pearl Harbor } \\
\text { and strive to block the } \\
\text { waterway. If the } \\
\text { enemy makes a sortie, } \\
\text { follow him and attack } \\
\text { him. } \\
\text { 2. In the Operation Tac- } \\
\text { tics } 1 \text { against the U.S. } \\
\text { Fleet, it shall operate } \\
\text { roughly as follows: } \\
\text { (a) The key locations in } \\
\text { the Aleutians as well } \\
\text { as those in the areas } \\
\text { of Samoa, Fiji and } \\
\text { Tutuila shall be re- } \\
\text { connoitered by Day } \\
\text { X-3 with one sub- } \\
\text { marine each for both } \\
\text { areas. } \\
\text { Should any powerful } \\
\text { enemy units, which } \\
\text { may cause damage } \\
\text { to the Carrier Task } \\
\text { Force, be found, they } \\
\text { shall be watched and } \\
\text { reported. } \\
\text { (b) An element shall sail } \\
\text { and sweep in front } \\
\text { of the Carrier Task } \\
\text { Force; Others shall } \\
\text { secretly conduct re- } \\
\text { connaissance, encir- } \\
\text { cling Hawaii at a } \\
\text { distance by Day X- } \\
\text {, wile approaching }\end{array}$ & $\begin{array}{l}\text { Designated } \\
\text { by the Ad- } \\
\text { vance Unit } \\
\text { commander }\end{array}$ & $\begin{array}{l}\text { The Ad- } \\
\text { vance Unit } \\
\text { shall re- } \\
\text { main } \\
\text { under } \\
\text { command } \\
\text { of the Car- } \\
\text { rier Task } \\
\text { Force com- } \\
\text { mander } \\
\text { after the } \\
\text { completion } \\
\text { of the sur- } \\
\text { prise attack } \\
\text { on Hawaii } \\
\text { until Day } \\
\text { X + 3. }\end{array}$ \\
\hline
\end{tabular}




\section{Advance}

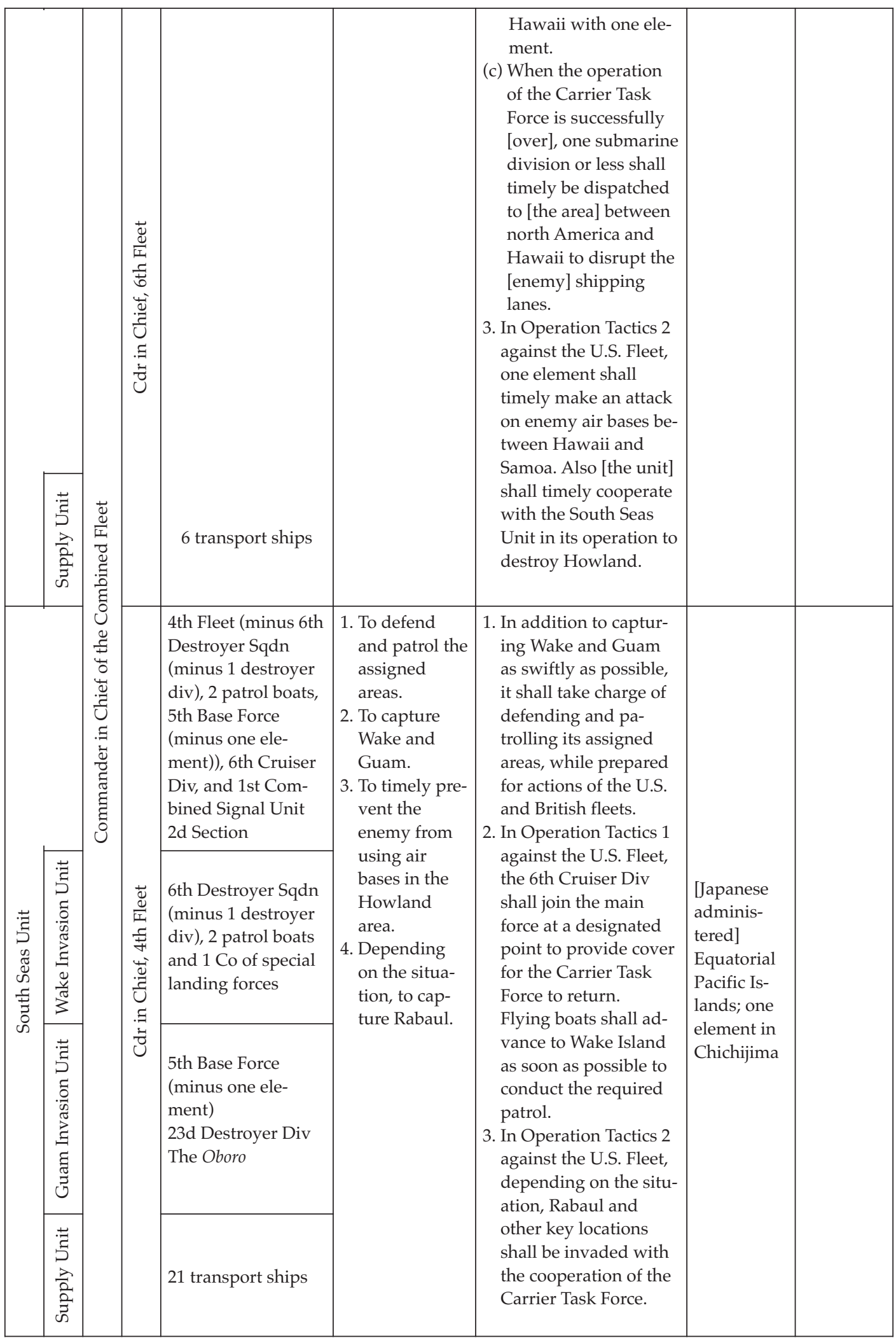




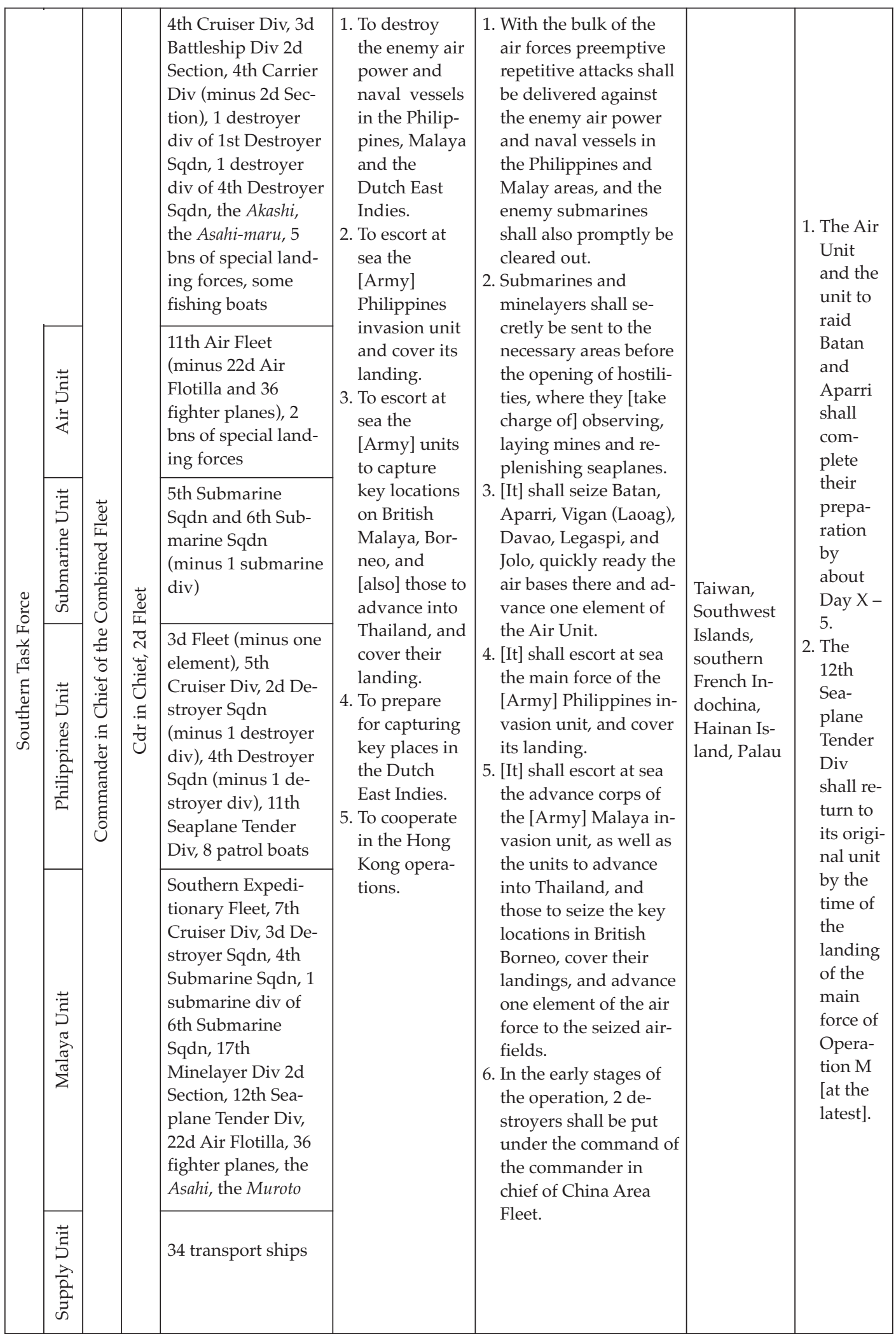




\section{Advance}

\begin{tabular}{|c|c|c|c|c|c|c|}
\hline 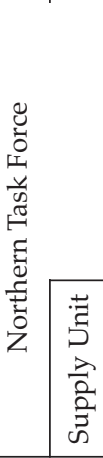 & & 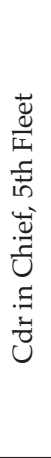 & $\begin{array}{l}\text { 5th Fleet, (Kisarazu } \\
\text { Air Gp), Chichijima } \\
\text { Signal unit, } \\
9 \text { land-based attack } \\
\text { planes of Yokosuka } \\
\text { Air Gp } \\
3 \text { transport ships }\end{array}$ & \begin{tabular}{|l|} 
1. To patrol and \\
defend the as- \\
signed areas. \\
2. To guard the \\
sailing route \\
of the Carrier \\
Task Force \\
and cover its \\
return. \\
3. To guard \\
against the \\
Soviet Union.
\end{tabular} & Omitted by the author & $\begin{array}{l}\text { [Location] } \\
\text { designated } \\
\text { by the com- } \\
\text { mander }\end{array}$ \\
\hline 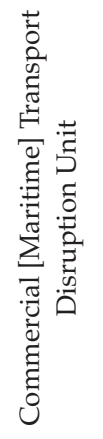 & 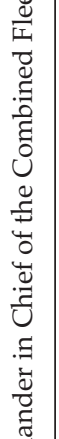 & 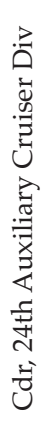 & $\begin{array}{l}\text { 24th Auxiliary } \\
\text { Cruiser Div } \\
1 \text { transport ship }\end{array}$ & $\begin{array}{l}\text { To disrupt [the } \\
\text { enemy] ship- } \\
\text { ping lanes. }\end{array}$ & Omitted by the author & $\begin{array}{l}\text { [Japanese } \\
\text { adminis- } \\
\text { tered Equa- } \\
\text { torial] } \\
\text { Pacific Is- } \\
\text { lands }\end{array}$ \\
\hline 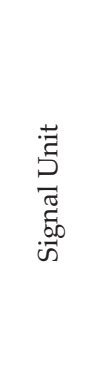 & $\begin{array}{l}\text { हूँ } \\
\text { ठ }\end{array}$ & 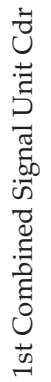 & $\begin{array}{l}\text { 1st Combined Sig- } \\
\text { nal Unit first sec- } \\
\text { tion (minus } \\
\text { Chichijima Signal } \\
\text { Unit) }\end{array}$ & \begin{tabular}{|l|} 
To [maintain] \\
operational \\
communica- \\
tions and con- \\
duct espionage \\
through signals.
\end{tabular} & Omitted by the author & $\begin{array}{l}\text { Each loca- } \\
\text { tion }\end{array}$ \\
\hline 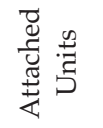 & & & \multicolumn{4}{|c|}{ Omitted by the author } \\
\hline 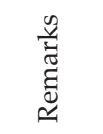 & \multicolumn{6}{|c|}{ Omitted by the author } \\
\hline
\end{tabular}

\section{Separate table No. 2}

\section{Stage-One, Phase-Two Disposition of Forces}

(Until about Day X +40 , when the landing of the main force of the Army Malaya invasion unit is completed.) 


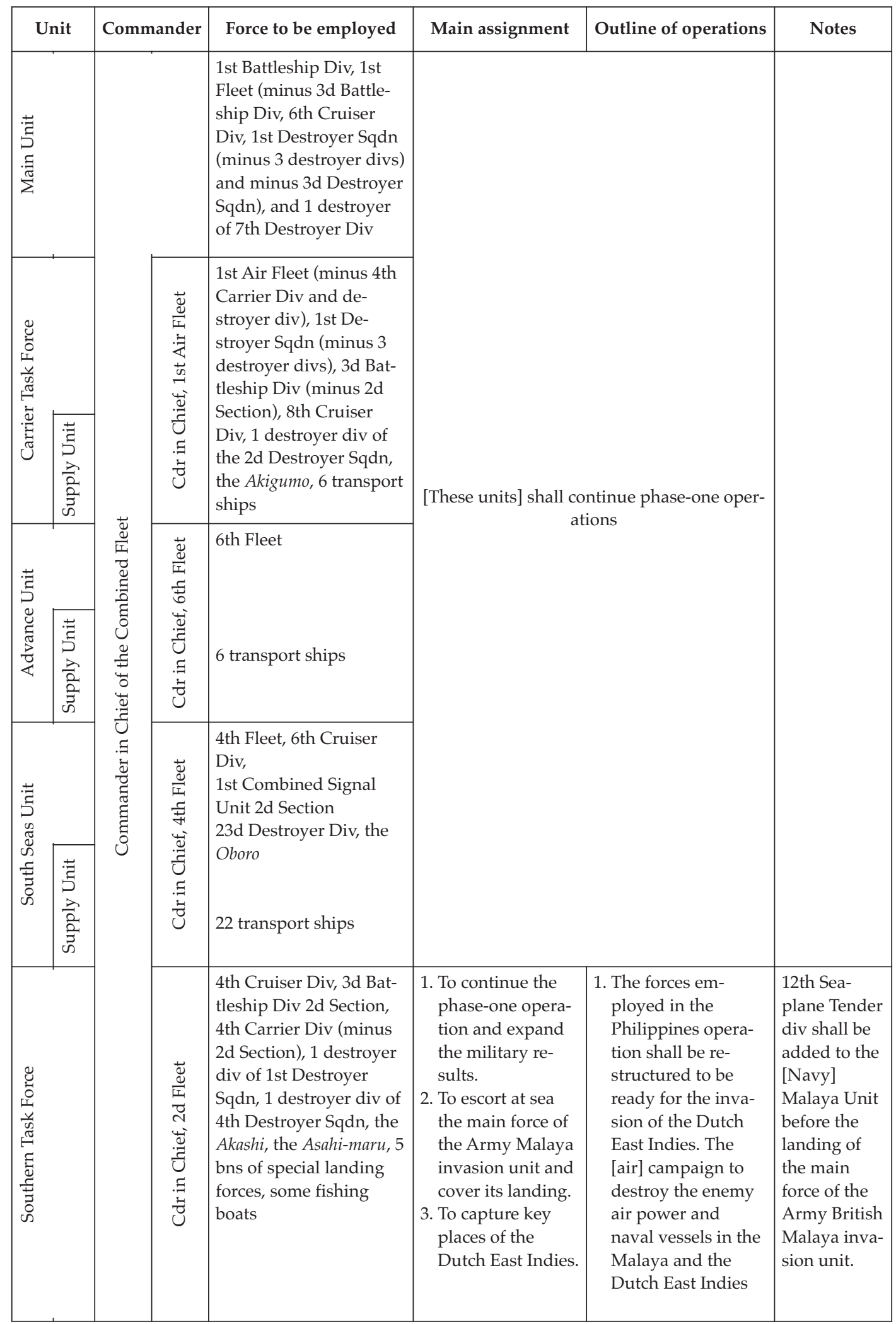




\section{Advance}

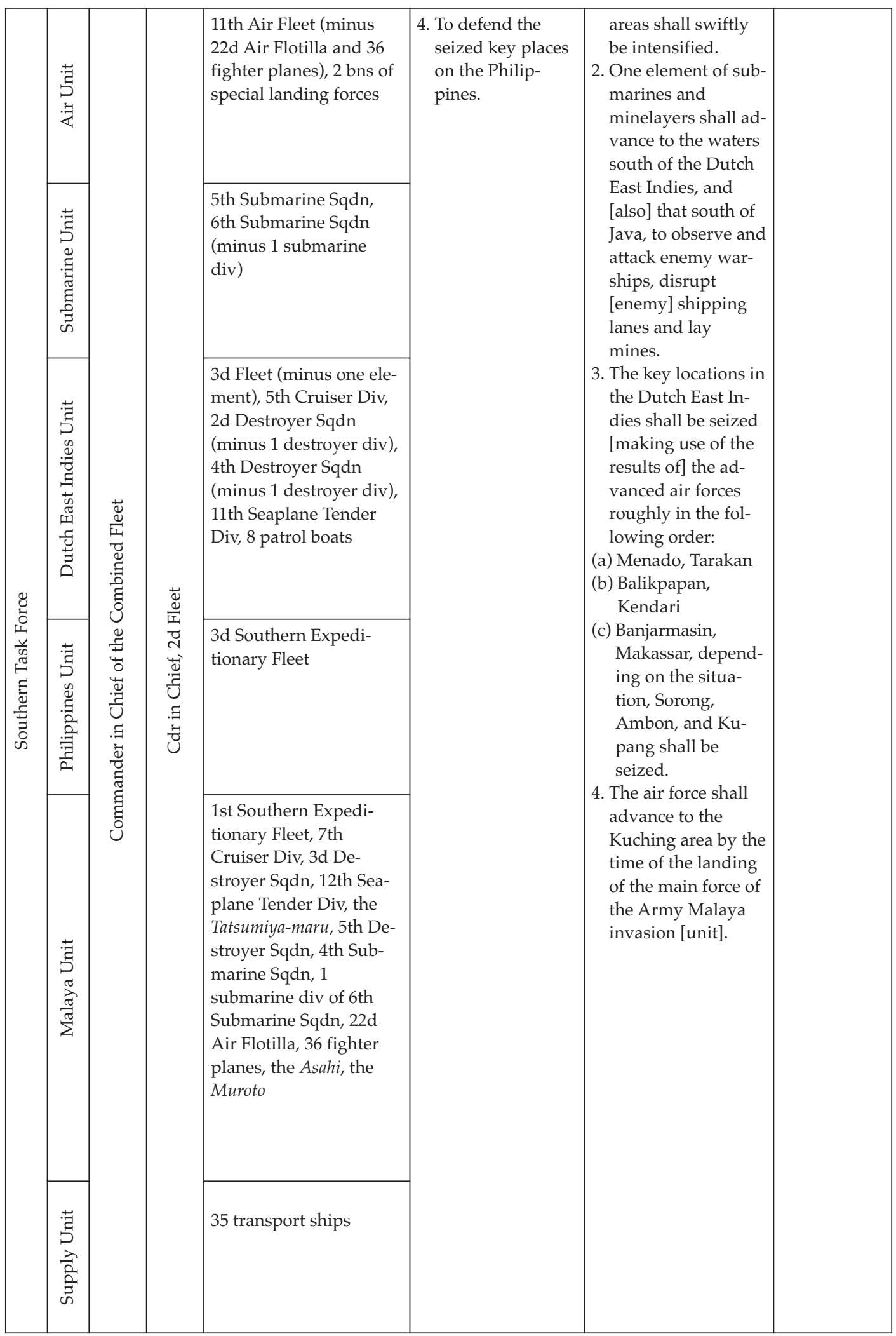




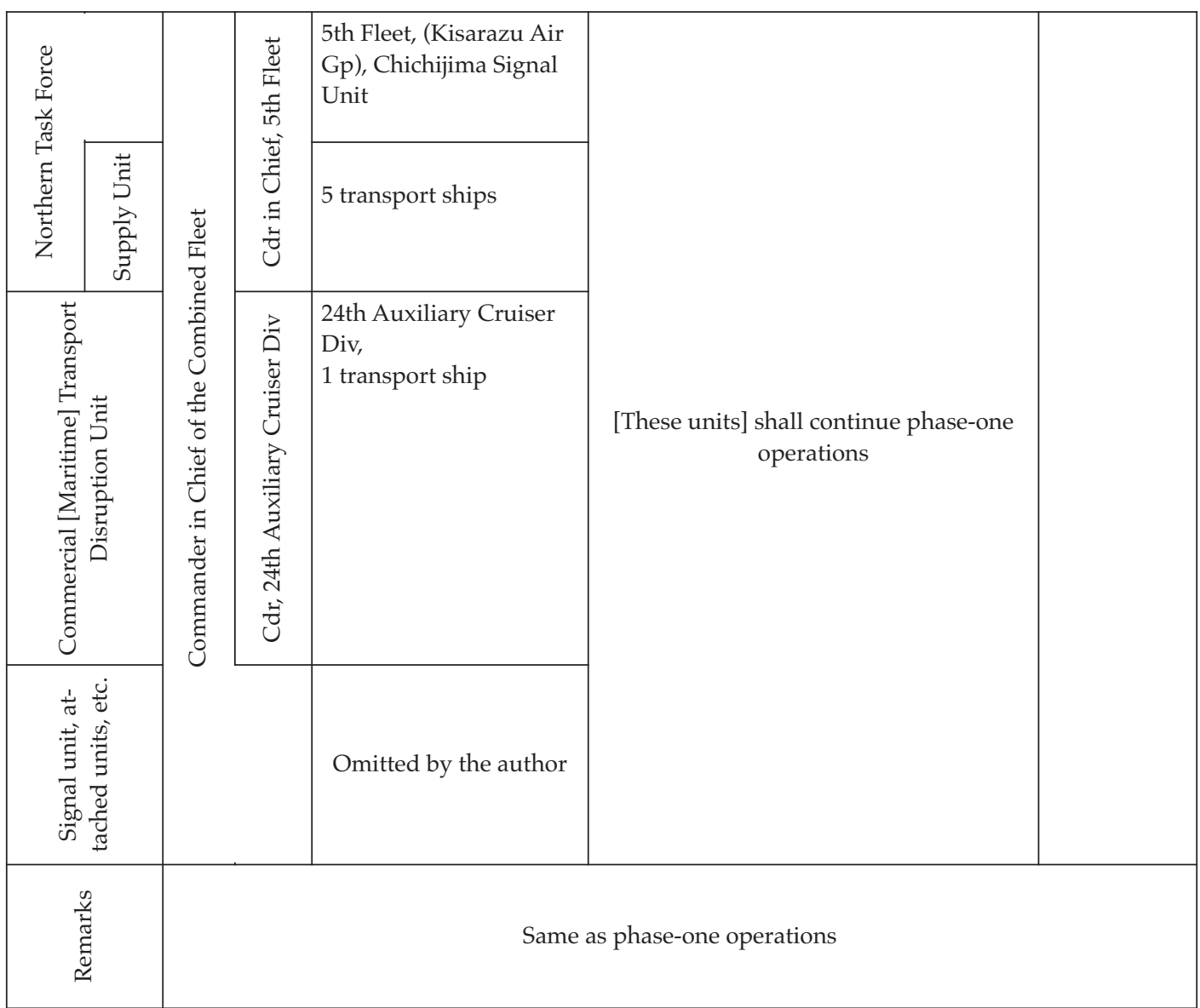

\section{Separate table No. 3}

\section{Stage-One, Phase-Three Disposition of Forces}

(Until the southern operation is for the most part completed.)

\begin{tabular}{|c|c|c|c|c|c|c|}
\hline Unit & \multicolumn{2}{|c|}{ Commander } & Force to be employed & Main assignment & Outline of operations & Notes \\
\hline 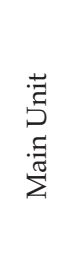 & \multirow{2}{*}{ 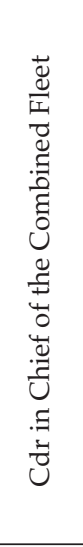 } & & $\begin{array}{l}\text { 1st Battleship Div, 1st } \\
\text { Fleet (minus 3d Battle- } \\
\text { ship Div, 6th Cruiser } \\
\text { Div, 1st Destroyer } \\
\text { Sqdn (minus } 2 \text { de- } \\
\text { stroyer divs), and 3d } \\
\text { Destroyer Sqdn) }\end{array}$ & \multirow{2}{*}{\multicolumn{2}{|c|}{$\begin{array}{l}\text { [The units] shall continue phase-two opera- } \\
\text { tions. }\end{array}$}} & \\
\hline 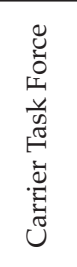 & & 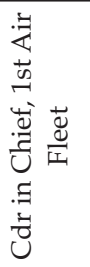 & $\begin{array}{l}\text { 1st Air Fleet (minus } \\
\text { 4th Carrier Div), 3d } \\
\text { Battleship Div (minus } \\
\text { 2d Section), 8th } \\
\text { Cruiser Div, and 1st } \\
\text { Destroyer Sqdn }\end{array}$ & & & \\
\hline
\end{tabular}




\section{Advance}

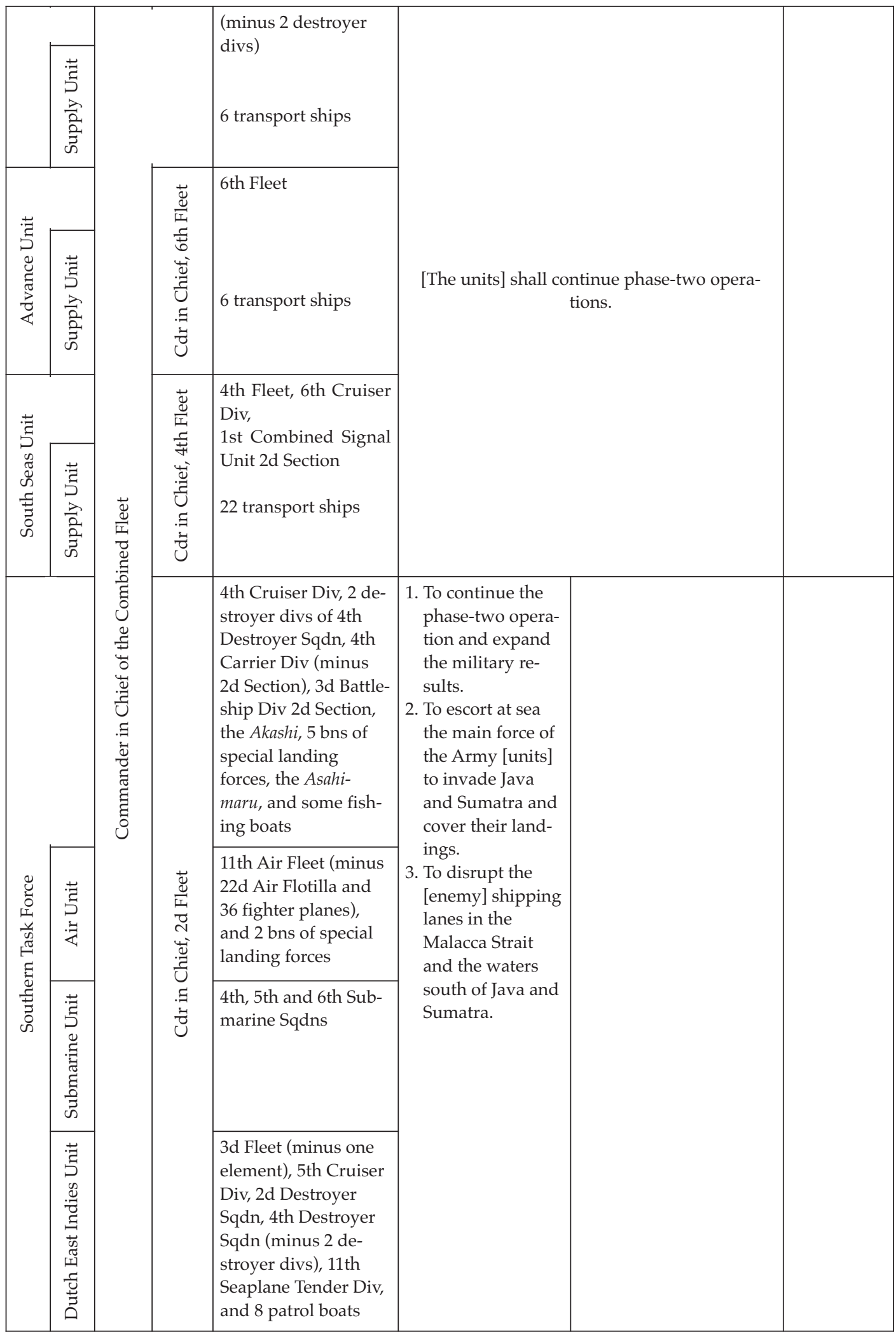




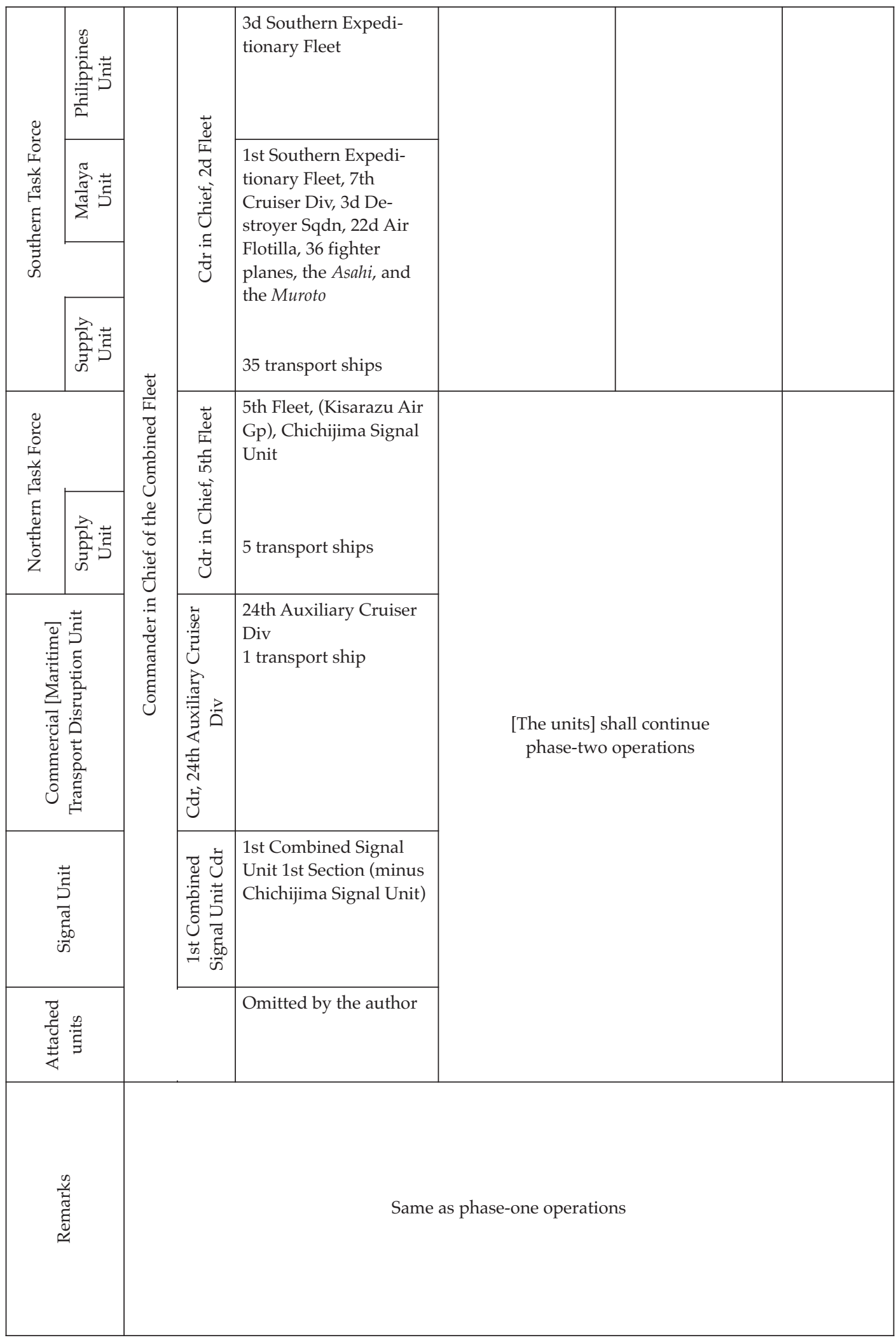




\section{Advance}

By means of the above [plan of operations], the commander in chief of the Combined Fleet gave detailed instructions concerning the operational outline of the stage-one operations to all units under his control and also disclosed the plan for the stage-two operations. Following this, on 7 November, he gave the order of the first [phase] of preparations for the opening of hostilities and indicated the scheduled date to open the hostilities. ${ }^{(46)}$

The Combined Fleet Operation Order Classified No. 2

7 November 1941

[Start] the first [phase] of preparations for the opening of hostilities; Day Y [is] 8 December.

By this order, each unit shifted to the phase-one disposition of forces and started its advance toward the standby point before the launch of operations.

In the wartime organization of the Imperial [Japanese] Navy, the composition of the main force of the Combined Fleet was as follows:

\begin{tabular}{|c|c|c|c|c|c|}
\hline \multicolumn{3}{|c|}{ Disposition } & Units o & ps and Auxiliary Warships & Notes \\
\hline \multirow{12}{*}{ 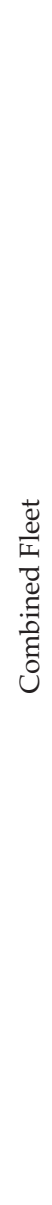 } & & 1st Battleship Div & Nagato, $N$ & & 2 battleships \\
\hline & \multirow{7}{*}{ 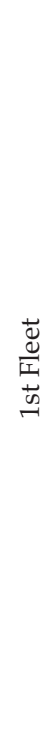 } & 2d Battleship Div & Ise, $H y \bar{u} g$ & mashiro & 4 battleships \\
\hline & & 3d Battleship Div & Kongō, $\mathrm{He}$ & ishima, Hiei & 4 battleships \\
\hline & & 6th Cruiser Div & Aoba, Kin & ko, Furutaka & 4 heavy cruisers \\
\hline & & 9th Cruiser Div & Kitakami, & & 2 light cruisers \\
\hline & & 1st Destroyer Sqdn & Abukuma & $\begin{array}{l}\text { 6th Destroyer Div } \\
\text { 17th Destroyer Div } \\
\text { 21st Destroyer Div } \\
\text { 27th Destroyer Div }\end{array}$ & $\begin{array}{l}1 \text { light cruiser } \\
16 \text { destroyers }\end{array}$ \\
\hline & & 3d Destroyer Sqdn & Sendai & $\begin{array}{l}\text { 11th Destroyer Div } \\
\text { 12th Destroyer Div } \\
\text { 19th Destroyer Div } \\
\text { 20th Destroyer Div }\end{array}$ & $\begin{array}{l}1 \text { light cruiser } \\
14 \text { destroyers }\end{array}$ \\
\hline & & 3d Carrier Div & $H \overline{o s h} \bar{o}, \mathrm{Zu}$ & zuki, Yūkaze & $\begin{array}{l}2 \text { small carriers } \\
2 \text { destroyers }\end{array}$ \\
\hline & \multirow{4}{*}{$\begin{array}{l}\frac{\vec{d}}{\mathbb{I}} \\
\vec{N}\end{array}$} & 4th Cruiser Div & Takao, Ata & i, Maya & 4 heavy cruisers \\
\hline & & 5th Cruiser Div & Nachi, $\mathrm{Ha}$ & & 3 heavy cruisers \\
\hline & & 7th Cruiser Div & Mogami, 1 & uzuya, Kumano & 4 heavy cruisers \\
\hline & & 8th Cruiser Div & Toné, Chik & & 2 heavy cruisers \\
\hline
\end{tabular}




\section{Advance}

\begin{tabular}{|c|c|c|c|c|c|}
\hline & \multirow{2}{*}{$\begin{array}{l}\vec{d} \\
\frac{\mathbb{U}}{\mathbb{I}} \\
\vec{d}\end{array}$} & 2d Destroyer Sqdn & Jints $\bar{u}$ & $\begin{array}{l}\text { 8th Destroyer Div } \\
\text { 15th Destroyer Div } \\
\text { 16th Destroyer Div } \\
\text { 18th Destroyer Div }\end{array}$ & $\begin{array}{l}1 \text { light cruiser } \\
16 \text { destroyers }\end{array}$ \\
\hline & & 4th Destroyer Sqdn & Naka & $\begin{array}{l}\text { 2d Destroyer Div } \\
\text { 4th Destroyer Div } \\
\text { 9th Destroyer Div } \\
\text { 24th Destroyer Div }\end{array}$ & $\begin{array}{l}1 \text { light cruiser } \\
16 \text { destroyers }\end{array}$ \\
\hline & & 16th Cruiser Div & Ashigara, Naga & uma & $\begin{array}{l}1 \text { heavy cruiser } \\
2 \text { light cruisers }\end{array}$ \\
\hline & & 17th Minelayer Div & Itsukushima, $Y_{a}$ & a, Tatsumiya-maru & 3 minelayers \\
\hline & $\frac{\bar{Q}}{\bar{D}}$ & 5th Destroyer Sqdn & Natori & $\begin{array}{l}\text { 5th Destroyer Div } \\
\text { 22d Destroyer Div }\end{array}$ & $\begin{array}{l}1 \text { light cruiser } \\
8 \text { destroyers }\end{array}$ \\
\hline & & 6th Submarine Sqdn & Chōgei & $\begin{array}{l}\text { 9th Submarine Div } \\
\text { 13th Submarine Div }\end{array}$ & $\begin{array}{l}1 \text { submarine tender } \\
4 \text { submarines }\end{array}$ \\
\hline & & $\begin{array}{l}\text { 12th Seaplane Tender } \\
\text { Div }\end{array}$ & Kamikawa-mart & ''yō-maru & 2 seaplane tenders \\
\hline & & & Kashima [Flags & f the 4 th Fleet]* & 1 light cruiser* \\
\hline & & 18th Cruiser Div & Tenryū, Tatsuta & & 2 light cruisers \\
\hline ت्ञ & & 19th Minelayer Div & Okinoshima, To & Tsugaru, Ten'yō-maru & $\begin{array}{l}3 \text { minelayers } \\
1 \text { auxiliary minelayer }\end{array}$ \\
\hline है & $\begin{array}{l}\frac{0}{I} \\
\frac{\text { If }}{f}\end{array}$ & 6th Destroyer Sqdn & Yūbari & $\begin{array}{l}\text { 29th Destroyer Div } \\
\text { 30th Destroyer Div }\end{array}$ & $\begin{array}{l}1 \text { light cruiser } \\
8 \text { destroyers }\end{array}$ \\
\hline & & 7th Submarine Sqdn & Jingei & $\begin{array}{l}\text { 26th Submarine Div } \\
\text { 27th Submarine Div } \\
\text { 33d Submarine Div }\end{array}$ & $\begin{array}{l}1 \text { submarine tender } \\
9 \text { submarines }\end{array}$ \\
\hline & & 24th Air Flotilla & $\begin{array}{l}\text { Chitose Air Gr } \\
\text { Yokohama Air }\end{array}$ & & 2 air groups \\
\hline & $\frac{\vec{Q}}{\square}$ & 21st Cruiser Div & Tama, Kiso, Kin & a-maru & $\begin{array}{l}2 \text { light cruisers } \\
1 \text { seaplane tender }\end{array}$ \\
\hline & 落 & 22d Aux Cruiser Div & Awata-maru, $A$ & maru & 2 auxiliary cruisers \\
\hline & & 1st Submarine Sqdn & Yasukuni-maru & $\begin{array}{l}\text { 1st Submarine Div } \\
\text { 2d Submarine Div } \\
\text { 3d Submarine Div } \\
\text { 4th Submarine Div } \\
\text { Submarine I-9 }\end{array}$ & $\begin{array}{l}1 \text { submarine tender } \\
13 \text { submarines }\end{array}$ \\
\hline & 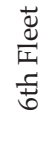 & 2d Submarine Sqdn & Santos-maru & $\begin{array}{l}\text { 7th Submarine Div } \\
\text { 8th Submarine Div } \\
\text { Submarine } I-7 \\
\text { Submarine } I-10\end{array}$ & $\begin{array}{l}1 \text { submarine tender } \\
8 \text { submarines }\end{array}$ \\
\hline & & 3d Submarine Sqdn & Taigei & $\begin{array}{l}\text { 11th Submarine Div } \\
\text { 12th Submarine Div } \\
\text { 20th Submarine Div } \\
\text { Submarine I-8 }\end{array}$ & $\begin{array}{l}1 \text { submarine tender } \\
9 \text { submarines }\end{array}$ \\
\hline
\end{tabular}

\footnotetext{
* Table rearranged by the editor.
} 


\section{Advance}

\begin{tabular}{|c|c|c|c|c|c|}
\hline \multirow{4}{*}{\multicolumn{2}{|c|}{ 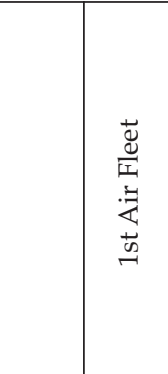 }} & 1st Carrier Div & \multicolumn{2}{|c|}{ Akagi, Kaga, 7th Destroyer Div } & $\begin{array}{l}2 \text { aircraft carriers } \\
3 \text { destroyers }\end{array}$ \\
\hline & & 2d Carrier Div & \multicolumn{2}{|c|}{ Sōryū, Hiryū, 23d Destroyer Div } & $\begin{array}{l}2 \text { aircraft carriers } \\
3 \text { destroyers }\end{array}$ \\
\hline & & 4th Carrier Div & \multicolumn{2}{|c|}{ Rȳ̄jō, Kasuga-maru, 3d Destroyer Div } & $\begin{array}{l}2 \text { aircraft carriers } \\
2 \text { destroyers }\end{array}$ \\
\hline & & 5th Carrier Div & \multicolumn{2}{|c|}{ Shōkaku, Zuikaku, Oboro, Akigumo } & $\begin{array}{l}2 \text { aircraft carriers } \\
2 \text { destroyers }\end{array}$ \\
\hline \multirow{9}{*}{ 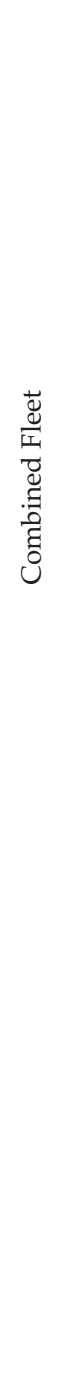 } & \multirow{3}{*}{ 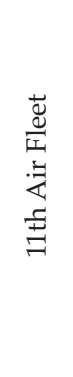 } & 21st Air Flotilla & \multicolumn{2}{|c|}{$\begin{array}{l}\text { Kanoya Air Group } \\
\text { Tōkō Air Group } \\
\text { 1st Air Group }\end{array}$} & 3 air groups \\
\hline & & 22d Air Flotilla & \multicolumn{2}{|c|}{$\begin{array}{l}\text { Mihoro Air Group } \\
\text { Genzan Air Group }\end{array}$} & 2 air groups \\
\hline & & 23d Air Flotilla & \multicolumn{2}{|c|}{$\begin{array}{l}\text { Takao Air Group } \\
\text { Tainan Air Group } \\
\text { 3d Air Group }\end{array}$} & 3 air groups \\
\hline & 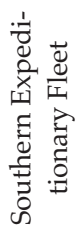 & & \multicolumn{2}{|c|}{ Kashii, Shimushu } & $\begin{array}{l}1 \text { light cruiser } \\
1 \text { coastal defense ship }\end{array}$ \\
\hline & & 24th Aux Cruiser Div & \multicolumn{2}{|c|}{ Hōkoku-maru, Aikoku-maru, Kiyosumi-maru } & 3 auxiliary cruisers \\
\hline & & $\begin{array}{l}\text { 11th Seaplane Tender } \\
\text { Div }\end{array}$ & \multicolumn{2}{|c|}{ Mizuho, Chitose } & 2 seaplane tenders \\
\hline & & 4th Submarine Sqdn & Kinu & $\begin{array}{l}\text { 18th Submarine Div } \\
\text { 19th Submarine Div } \\
\text { 21st Submarine Div }\end{array}$ & $\begin{array}{l}1 \text { light cruiser } \\
8 \text { submarines }\end{array}$ \\
\hline & & 5th Submarine Sqdn & Yura & $\begin{array}{l}\text { 28th Submarine Div } \\
\text { 29th Submarine Div } \\
\text { 30th Submarine Div }\end{array}$ & $\begin{array}{l}1 \text { light cruiser } \\
6 \text { submarines }\end{array}$ \\
\hline & & $\begin{array}{l}\text { 1st Combined Signal } \\
\text { Unit }\end{array}$ & $\begin{array}{l}\text { Toky } \\
\text { Takac } \\
\text { Chich } \\
\text { Okin } \\
\text { 3d Si } \\
\text { 4th S } \\
\text { 5th S } \\
\text { 6th S }\end{array}$ & $\begin{array}{l}\text { Jnit } \\
\text { iit } \\
\end{array}$ & 8 signal units \\
\hline
\end{tabular}




\section{Conclusion of the Tokyo Agreement}

In conformity with the Army-Navy Central Agreement that was issued on 5 November, [a conference to conclude] operational agreements between the top commanders of the Army and the Navy of the southern operation (i.e. the commanders in chief of the Combined fleet and the Second Fleet and the commander in chief of the Southern Army) was held at the War College from 8 to 10 November, and on the 10th of the same month [the agreements] were sealed.

The persons concerned at the high command of the Army and the Navy were present as well, and also the staff officers of each army and fleet involved in the southern operation participated in the meeting. This is the so-called "Tokyo Agreement," which consisted of the following two agreements.

\section{Agreement Between the Commanders in Chief of the Combined Fleet and the Southern Army}

This agreement was signed on 10 November, 1941 between Admiral Yamamoto Isoroku, commander in chief of the Combined Fleet, and General Terauchi Hisaichi, commander in chief of the Southern Army. It was in summary as follows: ${ }^{(34)}$

1. The operation shall be launched in the following manner:

(1) At the moment of the launch of Operation A-Go (Note: a code name for the southern operation) [i.e.] ([on] Day X), the Combined Fleet shall conduct preemptive air strikes against the enemy fleet in another area. (Note: another area means Hawaii.)

(2) If after the Emperor's order to launch operations is given, we come under a serious preemptive attack from the enemy prior to Day X, the Navy shall immediately go into the state of war and launch its operations.

2. The agreements concerning plans for Operation A-Go other than this (except for the operations against Guam, Hong Kong, and the Bismarck Islands), and those during the implementation of the operation shall be made between the commanders in chief of the Southern Army and the Second Fleet. However, if the commander in chief of the Second Fleet is engaged in an operation to intercept the U.S. Fleet, the commander in chief of the Third Fleet shall take charge of concluding agreements concerning implementation of the operation instead.

\section{Agreement Between the Commander in Chief of the Southern Army and the Commander of the Navy Southern Task Force}

This agreement was concluded between Commander in Chief of the Southern Army, General Terauchi Hisaichi and Commander in Chief of the Second Fleet V. Adm. Kondō Nobutake. It was in outline as follows: ${ }^{(34)}$

\section{Policy of the joint operations}

In conformity with the "Army-Navy Central Agreement for the Southern Operation" of 6 November 1941 (hereinafter referred to as the "Central Agreement"), the Navy Southern Task Force and the Southern Army shall accomplish the objective of the southern operation within a short period of time in an atmosphere of close and proper cooperation.

II. [Editor's note: omitted by the author.]

III. Standard dates [to implement] the invasion [operations] 


\section{Advance}

The key areas where the Army and the Navy shall in cooperation with each other launch invasions as well as the starting dates of the landings (along with assembly points and the key areas which the Navy shall capture unassisted as well as the starting dates of the landings)

\begin{tabular}{|c|c|c|c|c|c|}
\hline \multirow{2}{*}{$\begin{array}{l}\text { Date of the } \\
\text { start of the } \\
\text { landings }\end{array}$} & \multicolumn{4}{|c|}{$\begin{array}{l}\text { Key areas to capture } \\
\text { (*stands for the areas which the Navy will capture unassisted) }\end{array}$} & \multirow{2}{*}{ Assembly points } \\
\hline & Operation M & Operation E & Operation B & Operation $\mathrm{H}$ & \\
\hline Day X & *Batan Isl & $\begin{array}{l}\text { Vicinities of Ban } \\
\text { Don, Nakhon, } \\
\text { Singora, Pattani }\end{array}$ & & & $\begin{array}{l}\text { M: Magong, } \\
\text { E: Sanya }\end{array}$ \\
\hline Day X + 1 & $\begin{array}{l}\text { Vicinity of Vigan } \\
\text { or vicinity of } \\
\text { Laoag, and vicin- } \\
\text { ity of Aparri }\end{array}$ & & & & Magong \\
\hline $\begin{array}{l}\text { Depending } \\
\text { on the pro- } \\
\text { viso of 5.2.a)* }\end{array}$ & & $\begin{array}{l}\text { Vicinity of Kota } \\
\text { Bharu }\end{array}$ & & & Sanya \\
\hline By Day X + 4 & $\begin{array}{l}\text { Vicinity of } \\
\text { Legaspi }\end{array}$ & & & & Palau \\
\hline By Day X + 6 & Vicinity of Davao & & & & Palau \\
\hline $\begin{array}{l}\text { Around Day } \\
\mathrm{X}+8\end{array}$ & & $\begin{array}{l}\text { Vicinities of Sin- } \\
\text { gora and Pattani }\end{array}$ & & & Cam Ranh Bay \\
\hline $\begin{array}{l}\text { Around Day } \\
X+8\end{array}$ & & & Vicinity of Miri & & Cam Ranh Bay \\
\hline $\begin{array}{l}\text { Around Day } \\
X+13\end{array}$ & & & $\begin{array}{l}\text { Vicinity of Kuch- } \\
\text { ing }\end{array}$ & & Miri \\
\hline $\begin{array}{l}\text { Around Day } \\
X+13\end{array}$ & Jolo & & & & Davao \\
\hline $\begin{array}{l}\text { By around }{ }^{* *} \\
\text { Day } X+14\end{array}$ & $\begin{array}{l}\text { Lingayen Gulf, } \\
\text { Vicinity of } \\
\text { Lamon Bay }\end{array}$ & & & & $\begin{array}{l}\text { Penghu Islands } \\
\text { [for the unit] for } \\
\text { Lingayen Gulf; } \\
\text { Amami Ōshima } \\
\text { [for the unit] for } \\
\text { Lamon Bay }\end{array}$ \\
\hline $\begin{array}{l}\text { Around Day } \\
X+23\end{array}$ & & & & $\begin{array}{l}\text { *Vicinity of } \\
\text { Menado }\end{array}$ & Palau \\
\hline $\begin{array}{l}\text { By around } \\
\text { Day } X+25\end{array}$ & & $\begin{array}{l}\text { Southern Thai- } \\
\text { land or east coast } \\
\text { of Malaya (for } \\
\text { the first [landing] } \\
\text { of the main force) }\end{array}$ & & $\begin{array}{l}\text { Vicinity of } \\
\text { Tarakan }\end{array}$ & $\begin{array}{l}\text { E:Penghu Islands } \\
\text { (Guangdong) } \\
\text { H: Palau }\end{array}$ \\
\hline $\begin{array}{l}\text { Around Day } \\
X+35\end{array}$ & & & & $\begin{array}{l}\text { *Vicinity of } \\
\text { Kendari }\end{array}$ & Menado \\
\hline
\end{tabular}

* The text has 5.2.1. We have followed the numbering in Vol. 3.

** The text has no around. We have followed Vol. 3. 


\section{Advance}

\begin{tabular}{|c|c|c|c|}
\hline $\begin{array}{l}\text { Around Day } \\
X+35\end{array}$ & & $\begin{array}{l}\text { Vicinity of Balik- } \\
\text { papan }\end{array}$ & Tarakan \\
\hline $\begin{array}{l}\text { Around Day } \\
X+45\end{array}$ & & $\begin{array}{l}\text { *Vicinity of } \\
\text { Makassar }\end{array}$ & Kendari \\
\hline $\begin{array}{l}\text { By and large } \\
\text { around Day } \\
X+50\end{array}$ & & $\begin{array}{l}\text { Vicinity of Ban- } \\
\text { jarmasin }\end{array}$ & Balikpapan \\
\hline $\begin{array}{l}\text { Around Day } \\
X+60\end{array}$ & $\begin{array}{l}\text { Southern Thai- } \\
\text { land or east coast } \\
\text { of Malaya (for } \\
\text { the second [land- } \\
\text { ing] of the main } \\
\text { force) }\end{array}$ & & $\begin{array}{l}\text { Cam Ranh Bay } \\
\text { (Sanya) }\end{array}$ \\
\hline $\begin{array}{l}\text { By around } \\
\text { Day } X+60\end{array}$ & & $\begin{array}{l}\text { Ambon and Ku- } \\
\text { pang (as far as } \\
\text { possible) }\end{array}$ & Palau \\
\hline $\begin{array}{l}\text { By and large } \\
\text { around Day } \\
X+80\end{array}$ & & Java, Sumatra & $\begin{array}{l}\text { Hong Kong for } \\
\text { [the units to cap- } \\
\text { ture] Sumatra; } \\
\text { Manila for [the } \\
\text { units to capture] } \\
\text { eastern Java; Tai- } \\
\text { wan and Hong } \\
\text { Kong for [the } \\
\text { units to capture] } \\
\text { western Java }\end{array}$ \\
\hline [Particulars & be decided on & $\mathrm{n}$ the highest co & nanders of the \\
\hline
\end{tabular}

IV. Disposition of Forces

1. Southern Army

\begin{tabular}{|c|c|c|c|c|c|}
\hline 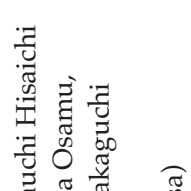 & Areas & Corps & $\begin{array}{l}\text { Commander } \\
\text { (Chief of Staff) }\end{array}$ & $\begin{array}{l}\text { Forces (assem- } \\
\text { bly point or the } \\
\text { position at the } \\
\text { opening of hos- } \\
\text { tilities) }\end{array}$ & $\begin{array}{l}\text { Outline of mis- } \\
\text { sion in the early } \\
\text { stages of opera- } \\
\text { tion }\end{array}$ \\
\hline 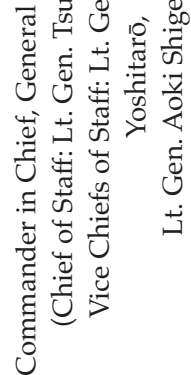 & M & 14th Army & 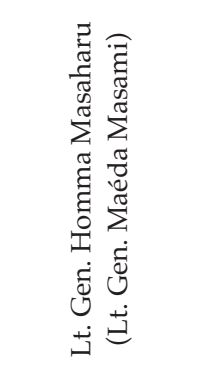 & $\begin{array}{l}\text { 16th Div (South- } \\
\text { west Islands**) } \\
\text { and } 48 \text { th Div } \\
\text { (with main force } \\
\text { in Taiwan) as the } \\
\text { core; } \\
\text { 5th Air Force } \\
\text { (Taiwan) shall be } \\
\text { attached }\end{array}$ & $\begin{array}{l}\text { Air campaigns } \\
\text { and seizure of } \\
\text { airfields in the } \\
\text { Philippines, and } \\
\text { the capture of } \\
\text { Manila }\end{array}$ \\
\hline
\end{tabular}

* Following Vol. 3, we have added around.

** Following Vol. 34, we have added Islands. 


\section{Advance}

\begin{tabular}{|c|c|c|c|c|c|}
\hline \multirow{6}{*}{ 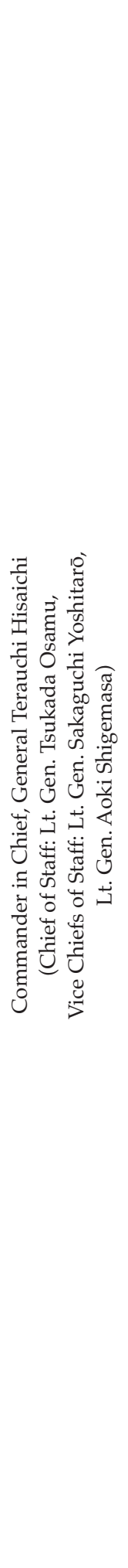 } & \multirow{3}{*}{ 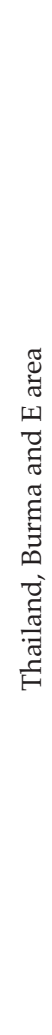 } & 15th Army & 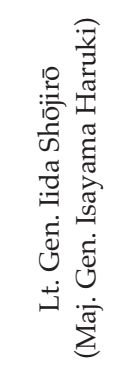 & $\begin{array}{l}\text { 55th Div (French } \\
\text { Indochina) and } \\
\text { 33d Div (north- } \\
\text { ern China) as the } \\
\text { core; } \\
\text { Main force of the } \\
\text { Imperial Guard } \\
\text { Div (French In- } \\
\text { dochina) shall be } \\
\text { attached at first }\end{array}$ & $\begin{array}{l}\text { Advance into } \\
\text { central Thailand, } \\
\text { preparation for } \\
\text { the Burma oper- } \\
\text { ation }\end{array}$ \\
\hline & & 25th Army & 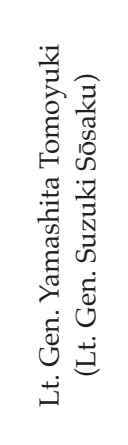 & $\begin{array}{l}\text { Imperial Guard } \\
\text { Div (French In- } \\
\text { dochina), 5th } \\
\text { Div (advance } \\
\text { unit* in Sanya; } \\
\text { the rest in Tai- } \\
\text { wan), and 18th } \\
\text { Div (advance } \\
\text { unit* in Sanya; } \\
\text { main force in } \\
\text { Guangdong) as } \\
\text { the core }\end{array}$ & $\begin{array}{l}\text { Sudden landings } \\
\text { in southern } \\
\text { Thailand, launch } \\
\text { of Singapore in- } \\
\text { vasion operation }\end{array}$ \\
\hline & & 3d Air Force & 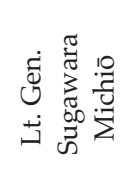 & $\begin{array}{l}\text { 3d, 7th, 10th and } \\
\text { 12th Air Divs (all } \\
\text { in French In- } \\
\text { dochina) as the } \\
\text { core }\end{array}$ & $\begin{array}{l}\text { Support for the } \\
\text { operations of the } \\
\text { 25th Army and } \\
\text { the 15th Army; } \\
\text { air campaigns }\end{array}$ \\
\hline & B & Kawaguchi Det & 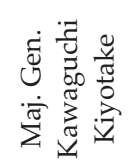 & $\begin{array}{l}\text { One inf rgt of the } \\
\text { 18th Div (French } \\
\text { Indochina) as } \\
\text { the core }\end{array}$ & $\begin{array}{l}\text { Capture of key } \\
\text { locations in } \\
\text { British Borneo }\end{array}$ \\
\hline & $\mathrm{H}$ & 16th Army & 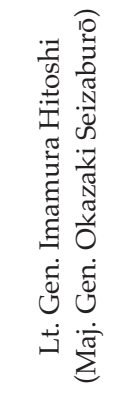 & $\begin{array}{l}\text { 2d Div (home- } \\
\text { land Japan), 38th } \\
\text { Div (Op C at } \\
\text { first), 48th Div } \\
\text { (Op M at first), } \\
\text { 56th Mixed Inf } \\
\text { Gp (Palau), and } \\
\text { South Seas Det } \\
\text { (Ops G and R at } \\
\text { first) as the core }\end{array}$ & $\begin{array}{l}\text { Capture of Jolo, } \\
\text { Tarakan, Balik- } \\
\text { papan and Ban- } \\
\text { jarmasin }\end{array}$ \\
\hline & 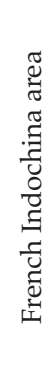 & $\begin{array}{l}\text { 25th Army at } \\
\text { first; later 21st } \\
\text { Div }\end{array}$ & 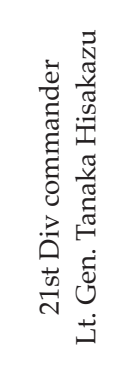 & $\begin{array}{l}\text { 21st Div (north- } \\
\text { ern China), 21st } \\
\text { Mixed Bde } \\
\text { (French In- } \\
\text { dochina) and 4th } \\
\text { Independent } \\
\text { Mixed Rgt } \\
\text { (French In- } \\
\text { dochina) as the } \\
\text { core }\end{array}$ & $\begin{array}{l}\text { Securing stabil- } \\
\text { ity in French In- } \\
\text { dochina }\end{array}$ \\
\hline
\end{tabular}

* We have followed the term used in Vol. 34. 


\section{Advance}

Remarks:

1 The outline of the distribution of the first transport for the landing operations and the landing schedule is as shown in Attached Table No. 1 (omitted by the author).

2 The units other than those in the above table, which are standing by for embarkation at the time of the opening of hostilities, and the ships they shall embark are in outline as shown in Attached Table No. 2 (omitted by the author).

\section{Navy Southern Task Force}

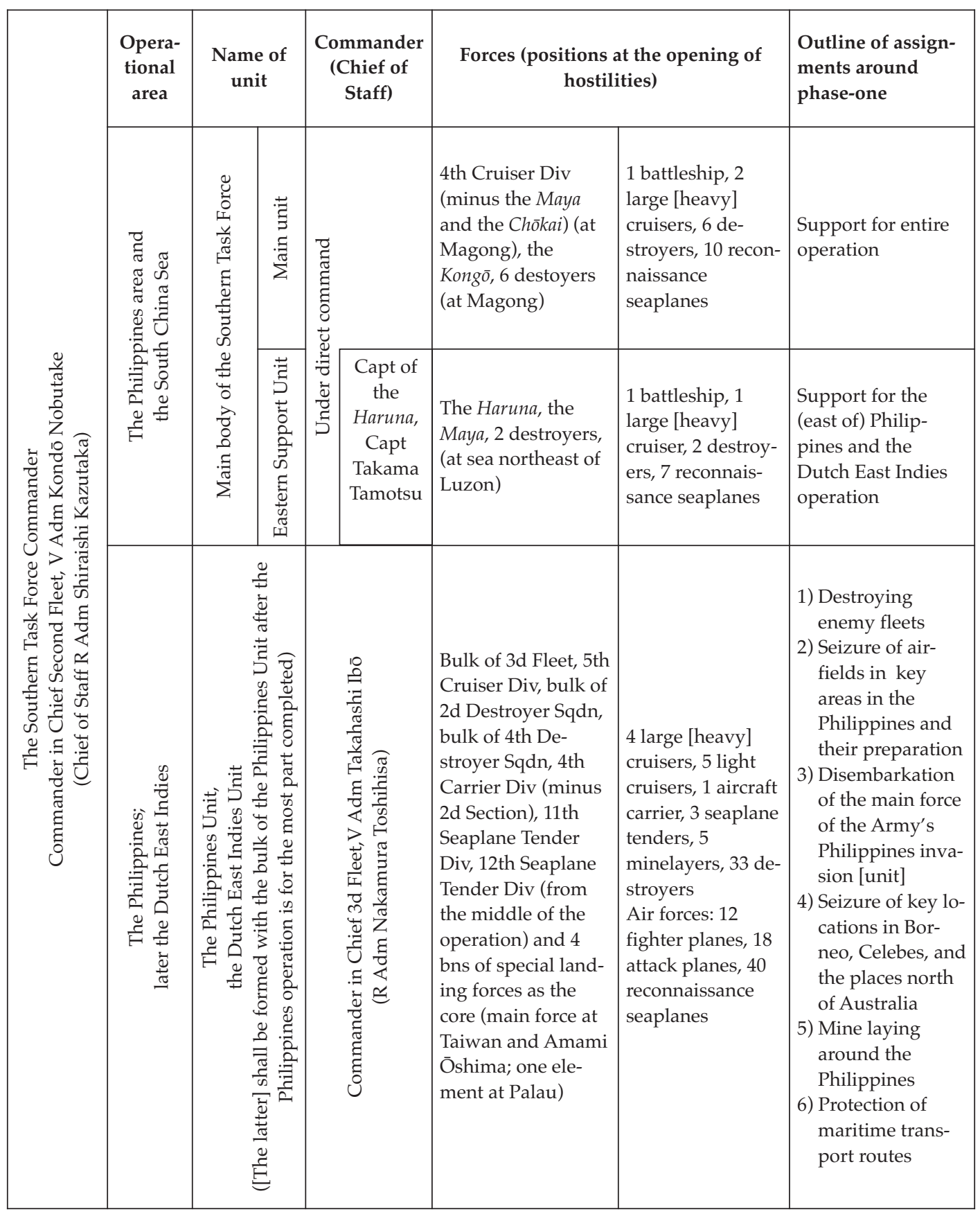




\section{Advance}

\begin{tabular}{|c|c|c|c|c|c|c|}
\hline \multirow{4}{*}{ 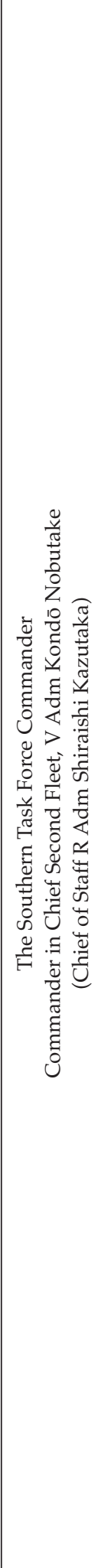 } & 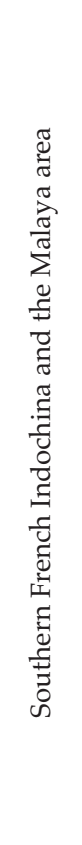 & 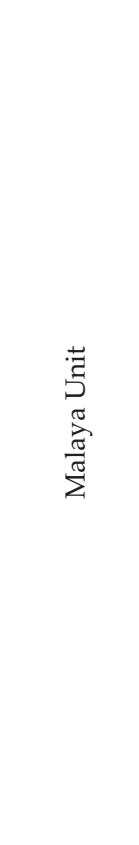 & 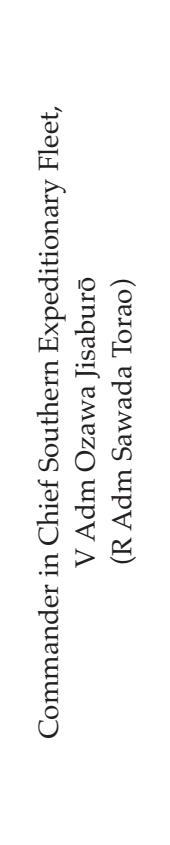 & $\begin{array}{l}\text { Southern Expedi- } \\
\text { tionary Fleet, the } \\
\text { Chōkai, 7th Cruiser } \\
\text { Div, 3d Destroyer } \\
\text { Sqdn, 4th Subma- } \\
\text { rine Sqdn, one ele- } \\
\text { ment of 6th } \\
\text { Submarine Sqdn, } \\
\text { 17th Minelayer Div } \\
\text { 2d Section, 12th } \\
\text { Seaplane Tender } \\
\text { Div ([shall] return } \\
\text { to the Philippines } \\
\text { [unit] in the middle } \\
\text { of the operation), } \\
\text { 22d Air Flotilla, as } \\
\text { the core (the bulk of } \\
\text { the surface vessels } \\
\text { at Sanya, sub- } \\
\text { marines at Singa- } \\
\text { pore, air forces in } \\
\text { southern French In- } \\
\text { dochina) }\end{array}$ & $\begin{array}{l}5 \text { large [heavy] } \\
\text { cruisers, } 2 \text { light } \\
\text { cruisers, } 16 \text { de- } \\
\text { stroyers, } 8 \text { sub- } \\
\text { marines, } 3 \\
\text { seaplane tenders } \\
\text { Air forces: } 36 \\
\text { fighter planes, } 72 \\
\text { land-based attack } \\
\text { planes, } 6 \text { land- } \\
\text { based reconnais- } \\
\text { sance planes, } 24 \\
\text { reconnaissance } \\
\text { seaplanes }\end{array}$ & $\begin{array}{l}\text { 1) Destroying } \\
\text { enemy naval ves- } \\
\text { sels } \\
\text { 2) Disembarkation } \\
\text { of the Army } \\
\text { units in southern } \\
\text { Thailand } \\
\text { 3) Seizure of north- } \\
\text { ern Borneo } \\
\text { 4) Air campaigns } \\
\text { against Malaya } \\
\text { 5) Mine laying and } \\
\text { submarine oper- } \\
\text { ations }\end{array}$ \\
\hline & 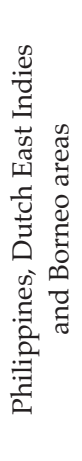 & 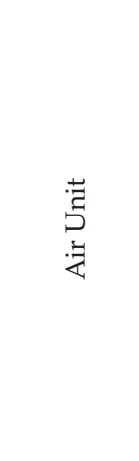 & 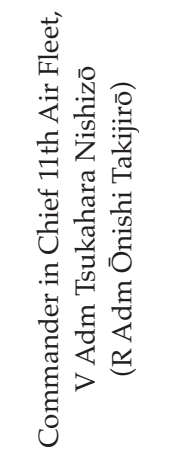 & $\begin{array}{l}\text { The bulk of 11th } \\
\text { Air Fleet as the core } \\
\text { (main force in Tai- } \\
\text { wan; one element } \\
\text { in Palau) }\end{array}$ & $\begin{array}{l}\text { Air Force: } 72 \\
\text { fighter planes, } 114 \\
\text { land-based attack } \\
\text { planes, } 18 \text { flying } \\
\text { boats, } 12 \text { land- } \\
\text { based reconnais- } \\
\text { sance planes }\end{array}$ & $\begin{array}{l}\text { 1) Destroying the } \\
\text { [enemy] air } \\
\text { power in the } \\
\text { Philippines and } \\
\text { the Dutch East } \\
\text { Indies } \\
\text { 2) Searching for the } \\
\text { enemy at sea and } \\
\text { attacking it } \\
\text { 3) [With one ele- } \\
\text { ment] advancing } \\
\text { into Borneo }\end{array}$ \\
\hline & 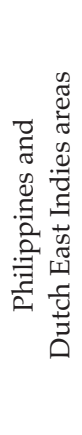 & 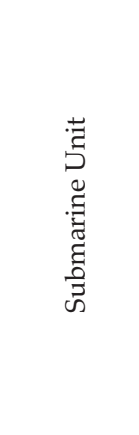 & 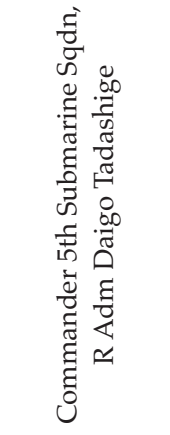 & $\begin{array}{l}\text { 5th Submarine } \\
\text { Sqdn, one element } \\
\text { of the 6th Subma- } \\
\text { rine Sqdn (the } \\
\text { Philippines) }\end{array}$ & $\begin{array}{l}1 \text { light cruiser, } 1 \\
\text { submarine tender, } \\
8 \text { submarines }\end{array}$ & $\begin{array}{l}\text { In the Philippines } \\
\text { and the Dutch East } \\
\text { Indies areas } \\
\text { 1) Patrolling and } \\
\text { observing } \\
\text { 2) Surprise attack } \\
\text { on enemy naval } \\
\text { vessels } \\
\text { 3) Mine laying and } \\
\text { severing [enemy] } \\
\text { electric cables }\end{array}$ \\
\hline & & $\begin{array}{l}\text { Unit at- } \\
\text { tached [to } \\
\text { the South- } \\
\text { ern Task } \\
\text { Force] }\end{array}$ & $\begin{array}{l}\text { Under direct } \\
\text { command }\end{array}$ & $\begin{array}{l}\text { Special service ves- } \\
\text { sels and about } 30 \\
\text { transport vessels in } \\
\text { total ([at] replenish- } \\
\text { ment bases) }\end{array}$ & $\begin{array}{l}1 \text { repair vessel, } 1 \\
\text { hospital ship, } 30 \\
\text { transport vessels }\end{array}$ & $\begin{array}{l}\text { Replenishment, } \\
\text { transport, repair, } \\
\text { rescue and [med- } \\
\text { ical] treatment, etc. }\end{array}$ \\
\hline
\end{tabular}


V. Outline of the operation

1. Measures to be taken against the enemy [if it comes for an attack] before the opening of hostilities (omitted)

2. The general operational outline

(1) The operation to capture key areas shall be carried out in conformity with [item] III. Standard dates [to implement] the invasion [operations] (omitted).

(2) Escort at sea

$\{1\}$ When required, restrictions may be placed on the sea routes and the movements of empty homeward-bound ships and of ships transporting army supplies, sick and wounded being sent back, or transporting diverted forces, etc. by the commander of the Navy (commander in chief of the Navy in the Southern Area, or the commander of the Philippines (the Dutch East Indies) Unit). However, when it is recognized that such restrictions may seriously affect subsequent operations, [further] agreements or arrangements shall be made between the commander in chief of the Navy in the Southern Area and the commander of the Southern Army, or the commanders of the Army and the Navy on site.

\{2\} An escort for the transfer of Army forces shall be provided according to item (3) [below].

\{3\} Other particulars shall be arranged between the commanders of each landing corps and the escort fleet.

(3) Transfer of Army forces and replacement of Army forces by Naval forces

$\{1\}$ The replacement of the forces guarding Jolo shall be arranged between commanders of the Navy Philippines unit and the Sixteenth Army.

$\{2\}$ The replacement of the forces guarding Tarakan and Ambon The replacement of the forces defending these areas after they are seized and secured shall be arranged between the commanders of the Navy Dutch East Indies Unit and the Sixteenth Army.

\{3\} The transfer of the 48th Division (the Dutch East Indies invasion corps)

The completion of the corps' assembly near Manila shall be scheduled roughly on Day $X+55$, and its departure from the assembly point on around Day $X+70$. The Navy Philippines (Dutch East Indies) Unit commander shall provide escort for the above transfer with the necessary forces.

$\{4\}$ The escort for the transfer of the corps that is to capture Bangka and southern Sumatra (one element of the Sixteenth Army) shall be provided by the Navy Malaya Unit commander with the necessary forces.

$\{5\}$ The transfer of one element of the 38th Division (a unit to invade the Dutch East Indies)

The escort for the transfer of this corps (from Hong Kong to western Java), along with [the escort of] the main force of the Sixteenth Army (from Taiwan to southern French Indochina and further to western Java), shall be provided by the Navy Dutch East Indies Unit commander with the necessary forces.

\{6\} The transfer and redeployment of the units to capture Ambon and Kupang (one element of the Sixteenth Army)

The escort for the transfer and redeployment (between Palau and Hong Kong, and the departure from Palau or Hong Kong) of the units shall be arranged between the commanders of the Navy Dutch East Indies Unit and the Sixteenth Army.

\{7\} The escort to be provided for the transfer and redeployment of other smaller units shall be arranged between the commanders of the Army and the Navy concerned.

3. Outline of the air operation (Omitted)

VI. Signal communications (Omitted) 


\section{Advance}

VII. Setting up of supply bases (Omitted)

VIII. Exchanges of information (Omitted)

IX. Exchanges of agreements and arrangements

1. Further detailed communication of the Central Agreement shall be made as follows:

[Between] the commander in chief of the Southern Expeditionary Fleet and Major General Kawaguchi ([at] Saigon)

The commanders in chief of the Third Fleet and the Eleventh Air Fleet, and the commanders of the Fourteenth Army and the Fifth Air Force shall conclude joint arrangements ([at] Iwakuni).

The commander in chief of the Southern Expeditionary Fleet, the commanders of the Fifteenth Army, the Twenty-fifth Army, the Third Air Force and the [Navy] 22d Air Flotilla shall conclude joint arrangements ([at] Saigon).

2. Conferences to be held between the commanders concerned of the Army and the Navy shall be scheduled as follows:

(1) Around the 40th day of the operation

(2) Around the 120th day of the operation

(3) Conferences shall be added if necessary.

3. For the duration of this operation and in order to communicate all particulars resulting from the Central Agreement as well as this agreement, the Navy shall dispatch one staff officer to each army headquarters [concerned] and the Third Air Force [headquarters]. Other than the above, if the situation permits, the Army and the Navy shall dispatch staff officers to each other at every important moment, promote their mutual understandings and communicate information so as to attain a smooth and swift implementation of the joint operations.

4. The responsibility [to provide] support and provisions for the dispatched staff officers, as mentioned in the previous item, which may be necessary to accomplish their tasks, shall fall on each receiving unit.

\section{Conclusion of the Iwakuni Agreement and the Saigon Agreement}

After concluding the Tokyo Agreement on 10 November, the main persons in charge of the Army and the Navy units involved in the Philippines and the Dutch East Indies operations gathered at [the base of] the Navy Iwakuni Air Group in Yamaguchi Prefecture from 14 to 16 November and made the necessary arrangements stipulated in the Tokyo Agreement. This is the "Iwakuni Agreement." In the Iwakuni Agreement, the arrangements concerning the Philippines and those concerning the Dutch East Indies were separately dealt with. In the following outline, only the points that differed from those in the Tokyo Agreement are given:(34)

1. [Operations in] the Philippines ([arranged] between the Third Fleet and the Eleventh Air Fleet of the Navy, and the Fourteenth Army and the Fifth Air Force of the Army)

[The scheduled dates for] the sudden attacks on the key locations in northern Luzon and the disembarkation of the main force of the Army Luzon invasion unit shall be postponed for two days.

2. [Operations in] the Dutch East Indies ([arranged] between the Navy Third Fleet and the Sixteenth Army)

Other than deciding on the postponement of the landing on Tarakan for five days and that of the seizure of Banjarmasin for six days, the capture of Bali, which was not included in the Tokyo 


\section{Advance}

Agreement, was scheduled for Day X +70 . A proposal of adding the Sakaguchi Detachment of the Sixteenth Army to [the forces to] capture Davao was made, but it was left pending (On 24 November [the proposal] was adopted as it was).

In the meantime, the Army and the Navy units involved in [the operations in] the Malaya area held a meeting in Saigon on 18 November, and made arrangements between the commanders on site. This was the "Saigon Agreement," which was in summary as follows:

1. [Operations in] British Malaya and Thailand ([arranged] between the Southern Expeditionary Fleet and the 22d Air Flotilla of the Navy, and the Twenty-fifth Army, the Fifteenth Army and the Third Air Force of the Army)

The details of the action of the advance corps, a simultaneous landing [also] to be conducted on Kota Bharu in British [Malaya], the share of responsibility concerning the air campaign and others were decided on.

2. [Operations in] British Borneo ([arranged] between the Navy Southern Expeditionary Fleet and the Army Kawaguchi Detachment)

Arrangements for the capture of Miri and Kuching, etc. were made.

\section{Issue of Orders by Each Navy Unit}

\section{The Southern Task Force}

On 15 November, when the Iwakuni Agreement was essentially ready, Southern Task Force Commander Vice Admiral Kondō issued Southern Task Force Order Classified No. 1, which read in summary as follows: ${ }^{(47)}$

I. The Southern Task Force shall, in conjunction with the Army, completely destroy the U.S., British and Dutch naval vessels and air power in the Far East, demolish all bases in the Philippines, British Malaya, Burma and the Dutch East Indies, and capture key areas in these territories, while making preparations to intercept attacks by the U.S. mainland fleets and others.

\section{Mission}

1. In conjunction with the Southern Army, it shall first destroy the enemy power in the Philippines, British Malaya and British Borneo, invade the Dutch East Indies from both the southern Philippines and Malaya, and mop up [the enemy] there.

2. The execution of the operations shall roughly be divided in the following three periods. (Omitted)

3. The launch of the southern operation (Omitted by the author)

III. Outline of the operation

1. The Philippines operation (Omitted by the author)

2. The British Malaya and British Borneo operations

(1) - (4) (Omitted by the author)

(5) At the earliest opportunity after the opening of hostilities, the British Borneo invasion unit shall be escorted to capture first Miri, and then Kuching, and quickly make air bases [there] ready for use, so as to advance one element of the Navy air units and intensify the air campaigns against Malaya and the Dutch East Indies.

3. The Dutch East Indies operation 


\section{Advance}

(1) When the air bases in Davao and Jolo are ready, forces of the Eleventh Air Fleet shall successively be advanced [there] to completely destroy the remnants of the enemy in the Philippines, as well as to launch the air campaign to destroy the enemy air power in the Dutch East Indies.

(2) Once operations at sea around Malaya are for the most part completed, the Navy air units in the area shall also be diverted to the bases in Miri, Kuching and others to participate in the air campaign against the Dutch East Indies.

(3) After the Philippines invasion operation has made progress, submarines shall gradually be advanced to the waterways south of the Celebes Sea. The surface units shall [also] be advanced and act in concert with the air campaign, and Menado shall be seized with a Naval landing force. After that, they shall advance to Kendari and Makassar one after another. Apart from [the above], in conjunction with the Army, invasion operations shall be carried forward largely in parallel with the above against Tarakan, Balikpapan and Banjarmasin, while at an opportune moment Ambon and Kupang shall be captured.

(4) Necessary bases in the above captured areas shall be quickly prepared, and the air forces shall be advanced one after another, in order to secure footholds (Kupang, etc.) for operations against Australia, as well as to further intensify air campaigns against Java from the east and to destroy the enemy air power and naval vessels. Also, one element of the submarine [units] shall be advanced to the Indian Ocean to disrupt the supply lanes to British Malaya through the Malacca Strait and those to the Dutch East Indies from the south.

(5) When the operation in the Malaya area has made progress, strategic locations on Bangka Island (Note: [near] Sumatra) and Palembang shall be seized at an opportune moment, and air bases [there] shall be made ready for use, so that [the Japanese forces can] close in on western Java. Concerted air campaigns from the east and the west shall be intensified, so as to suppress the enemy air power, and gradually tighten the encirclement. [Meanwhile,] the main force of the Sixteenth Army shall be disembarked near Batavia, and another corps near Surabaya. They shall swiftly seize Batavia, Bandung and Surabaya and then mop up the enemy in the key areas on Java.

(6) When the Malacca Strait is brought under control after the capture of Singapore, one element of the Twenty-fifth Army shall timely be put ashore near Medan from the west coast of the Malay Peninsula to capture the strategic areas in northern Sumatra and then at an opportune moment the island of Sabang.

(7) In this operation, depending on the nature of the terrain, etc., the 1001 Unit (Note: paratrooper unit) and maneuvers and supply by fishing boats and other small vessels shall be employed.

4. [Later] when the situation permits, submarine cables from Java to Malaya, Australia and the Cocos Island (Note: [in] the Indian Ocean) shall be severed with submarines. [However,] those between the islands of the Dutch East Indies shall not be cut with the aim of using them after the Dutch East Indies has been occupied.

5. The areas to be invaded in the final stage of the southern operation and the operations afterwards

[The areas to be invaded] shall be the U.S., British and Dutch territories, enveloped by western New Guinea and the eastern islands of the Dutch East Indies in the east, and Burma, the Andaman Islands, the Nicobar Islands and the line [streching to] the western peripheral islands of the Dutch East Indies in the west. Advance bases shall be set up along the lines connecting the outer border islands, and mine barriers shall be set up in the waters adjacent to Australia such as the Arafura Sea, the areas around the Malacca Strait, and a part of waterways south of the Dutch East Indies. At the same time, one element of the submarine units shall reconnoiter the movements of the enemy forces in Australia and India, attack 


\section{Advance}

them and disrupt the [enemy] shipping lanes. Also, an air raid shall timely be carried out on Port Darwin for the purpose of defending the occupied areas.

IV. Deployment of forces

Main body of the Southern Task Force:

departure from the Inland Sea on Day X - 9 arrival in Magong on Day X -6

Submarine Unit/ 6th Submarine Sqdn: departure from the Inland Sea on Day $X-17$ arrival in Sanya on Day X - 9

5th Submarine Sqdn: departure from the Inland Sea on Day $X-13$ arrival in Palau on Day X -7

V. Disposition of forces

1. Phase-one (as in the following table)

\begin{tabular}{|c|c|c|c|c|}
\hline \multicolumn{2}{|c|}{ Name of unit } & \multicolumn{2}{|r|}{ Commander } & Forces \\
\hline \multirow{2}{*}{ Main Body } & Main unit & \multirow{6}{*}{ 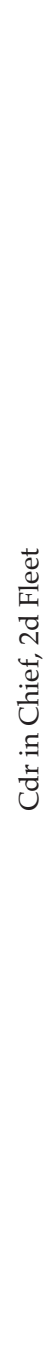 } & & $\begin{array}{l}\text { 4th Cruiser Div (minus 2d Section), 3d Battleship } \\
\text { Div 4th Ship (the Kongō), 4th Destroyer Div, 6th } \\
\text { Destroyer Div 2d Section; Support for entire opera- } \\
\text { tion ([also] cooperation in the Hong Kong invasion } \\
\text { operation) }\end{array}$ \\
\hline & $\begin{array}{l}\text { Eastern Sup- } \\
\text { port Unit }\end{array}$ & & Senior Captain & $\begin{array}{l}\text { 3d Battleship Div 3d ship (the Haruna), 4th Cruiser } \\
\text { Div 3d ship (the Maya), 6th Destroyer Div (minus } \\
\text { 2d section); Support for the operation in the area } \\
\text { east of the Philippines }\end{array}$ \\
\hline \multicolumn{2}{|c|}{ The Philippines Unit } & & $\begin{array}{l}\text { Cdr in Chief, } \\
\text { 3d Fleet }\end{array}$ & $\begin{array}{l}\text { 3d Fleet (minus one element), 5th Cruiser Div, } 4 \text { th } \\
\text { Carrier Div (minus } 2 \text { d Section), } 2 \text { d Destroyer Sqdn } \\
\text { (minus } 1 \text { destroyer div), } 4 \text { th Destroyer Sqdn } \\
\text { (minus } 1 \text { destroyer div), 11th Seaplane Tender Div, } \\
4 \text { bns of special landing forces, } 8 \text { patrol boats, etc. }\end{array}$ \\
\hline Malay & Unit & & $\begin{array}{l}\text { Cdr in Chief, } \\
\text { Southern Expedi- } \\
\text { tionary Fleet }\end{array}$ & $\begin{array}{l}\text { Southern Expeditionary Fleet, } 4 \text { th Cruiser Div 4th } \\
\text { Ship (the Chōkai), 7th Cruiser Div, 3d Destroyer } \\
\text { Sqdn, 4th Submarine Sqdn, } 1 \text { submarine div of 6th } \\
\text { Submarine Sqdn, 17th Minelayer Div 2d Section, } \\
\text { 12th Seaplane Tender Div, 22d Air Flotilla, one ele- } \\
\text { ment of 23d Air Flotilla (36 fighter planes and } 6 \\
\text { land-based reconnaissance planes), } 1 \text { bn of special } \\
\text { landing forces, etc. }\end{array}$ \\
\hline \multicolumn{2}{|c|}{ Air Unit } & & $\begin{array}{l}\text { Cdr in Chief, } \\
\text { 11th Air Fleet }\end{array}$ & $\begin{array}{l}\text { 11th Air Fleet (minus 22d Air Flotilla and one ele- } \\
\text { ment of 23d Air Flotilla), } 1001 \text { Unit }\end{array}$ \\
\hline \multicolumn{2}{|c|}{ Submarine Unit } & & $\begin{array}{l}\text { Cdr, 5th Subma- } \\
\quad \text { rine Sqdn }\end{array}$ & $\begin{array}{l}\text { 5th Submarine Sqdn, 6th Submarine Sqdn (minus } \\
\text { one submarine div) }\end{array}$ \\
\hline
\end{tabular}




\section{Advance}

Note: The 1st Secton of the 4th Carrier Division consisted of the aircraft carrier Ryujjo and the destroyer Shiokaze.

2. Phase-two (as in the following table)

\begin{tabular}{|c|c|c|c|}
\hline Main Body & \multirow{6}{*}{ 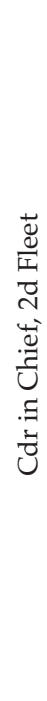 } & & Same as phase-one \\
\hline The Philippines Unit & & \multirow[b]{2}{*}{$\begin{array}{l}\text { Cdr in Chief, } \\
\text { 3d Fleet }\end{array}$} & One element of $3 \mathrm{~d}$ Fleet \\
\hline The Dutch East Indies Unit & & & $\begin{array}{l}\text { Bulk of } 3 \text { d Fleet, } 5 \text { th Cruiser Div, } 2 \text { d Destroyer } \\
\text { Sqdn (minus } 1 \text { destroyer div), } 4 \text { th Destroyer Sqdn } \\
\text { (minus } 1 \text { destroyer div), 11th Seaplane Tender Div, } \\
8 \text { patrol boats, } 4 \text { bns of special landing forces, etc. }\end{array}$ \\
\hline Malaya Unit & & $\begin{array}{l}\text { Cdr in Chief, } \\
\text { Southern Expedi- } \\
\text { tionary Fleet }\end{array}$ & $\begin{array}{l}\text { 5th Destroyer Sqdn and } 4 \text { th Carrier Div (minus } 2 d \\
\text { Section) shall be added to the force deployed for } \\
\text { phase-one. }\end{array}$ \\
\hline Air Unit & & $\begin{array}{l}\text { Cdr in Chief, } \\
\text { 11th Air Fleet }\end{array}$ & Same as phase-one \\
\hline Submarine Unit & & $\begin{array}{l}\text { Cdr, 5th Subma- } \\
\text { rine Sqdn }\end{array}$ & Same as phase-one \\
\hline
\end{tabular}

3. Phase-three

\begin{tabular}{|c|c|c|c|}
\hline Main Body & \multirow{6}{*}{ 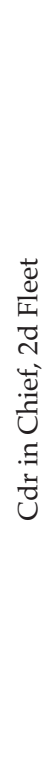 } & & $\begin{array}{l}\text { 4th Cruiser Div (minus the Chōkai), 3d Battleship } \\
\text { Div 2d Section, 4th Carrier Div (minus 2d Section), } \\
\text { 4th and 24th Destroyer Divs }\end{array}$ \\
\hline The Philippines Unit & & & One element of $3 \mathrm{~d}$ Fleet \\
\hline The Dutch East Indies Unit & & $\begin{array}{l}\text { Cdr in Chief, } \\
\text { 3d Fleet }\end{array}$ & $\begin{array}{l}\text { Bulk of 3d Fleet, } 5 \text { th Cruiser Div, } 2 d \text { Destroyer } \\
\text { Sqdn, } 4 \text { th Destroyer Sqdn (minus } 2 \text { destroyer divs), } \\
\text { 11th Seaplane Tender Div, } 8 \text { patrol boats, } 4 \text { bns of } \\
\text { special landing forces, etc. }\end{array}$ \\
\hline Malaya Unit & & $\begin{array}{l}\text { Cdr in Chief, } \\
\text { Southern Expedi- } \\
\text { tionary Fleet }\end{array}$ & $\begin{array}{l}\text { Southern Expeditionary Fleet, 4th Cruiser div 4th } \\
\text { Ship (the Chōkai), 7th Cruiser Div, 3d Destroyer } \\
\text { Sqdn, 22d Air Flotilla, one element of the 23d Air } \\
\text { Flotilla, } 1 \text { bn of special landing forces }\end{array}$ \\
\hline Air Unit & & $\begin{array}{l}\text { Cdr in Chief, } \\
\text { 11th Air Fleet }\end{array}$ & Same as phase-one \\
\hline Submarine Unit & & $\begin{array}{l}\text { Cdr, } 4 \text { th Subma- } \\
\quad \text { rine Sqdn }\end{array}$ & 4th, 5th and 6th Submarine Sqdns \\
\hline
\end{tabular}

Then, the commander of the Southern Task Force dealt with [the units] to cooperate in the Hong Kong operation, along with the necessary measures for the ground units, such as special landing forces, construction squads and defense details, as follows: 


\section{Advance}

1. In order to cooperate in the Hong Kong operation, the 2d Section of the 6th Destroyer Division (assigned to the main body of the Southern Task Force) was temporarily put under the command of the Second China Expeditionary Fleet.

2. Distribution of the special landing forces and others

As the units in the following table were incorporated into the Southern Task Force as of 20 November, the commander ordered the distribution of each unit [as follows].

\begin{tabular}{|c|c|c|c|}
\hline Type & Name of unit & Disposition & Notes \\
\hline \multirow{6}{*}{ 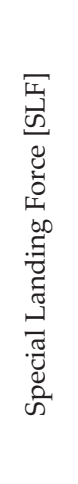 } & 1st Yokosuka SLF & Air Unit & Paratrooper unit \\
\hline & 2d Yokosuka SLF & Malaya Unit & $\begin{array}{l}\text { Order was given to advance to Sanya by Day } X-6 \text {; to } \\
\text { be employed for the British Borneo operations }\end{array}$ \\
\hline & 3d Yokosuka SLF & Air Unit & Paratrooper unit \\
\hline & 1st Kure SLF & $\begin{array}{l}\text { The Philippines } \\
\text { Unit }\end{array}$ & $\begin{array}{l}\text { Planned to be employed for the Legaspi and Jolo op- } \\
\text { erations }\end{array}$ \\
\hline & 2d Kure SLF & Ditto & $\begin{array}{l}\text { Planned to be employed for [the operation in] the } \\
\text { Dutch Borneo area }\end{array}$ \\
\hline & Sasebo Combined SLF & Ditto & Planned to be employed for [the operation in] Celebes \\
\hline \multirow{6}{*}{ 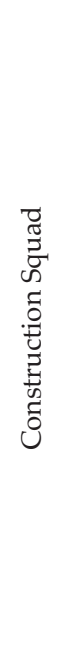 } & 1st Construction Squad & Ditto & $\begin{array}{l}\text { Planned to be employed for [the operation in] } \\
\text { Legaspi; attached to the 1st Kure SLF }\end{array}$ \\
\hline & $2 \mathrm{~d}$ Construction Squad & Ditto & Planned to be employed for [the operation in] Davao \\
\hline & 3d Construction Squad & Ditto & $\begin{array}{l}\text { Planned to be employed for [the operation in] } \\
\text { Celebes; attached to the Sasebo Combined SLF }\end{array}$ \\
\hline & 4th Construction Squad & Malaya Unit & $\begin{array}{l}\text { Planned to be employed for [the operation in] British } \\
\text { Borneo; attached to the } 2 \mathrm{~d} \text { Yokosuka SLF }\end{array}$ \\
\hline & 5th Construction Squad & $\begin{array}{l}\text { The Philippines } \\
\text { Unit }\end{array}$ & $\begin{array}{l}\text { Planned to be employed for [the operation in] Dutch } \\
\text { Borneo; attached to the } 2 \mathrm{~d} \text { Kure SLF }\end{array}$ \\
\hline & 6th Construction Squad & Ditto & $\begin{array}{l}\text { Planned to be employed for [the operation in] } \\
\text { Celebes; attached to Sasebo Combined SLF }\end{array}$ \\
\hline \multirow{2}{*}{ 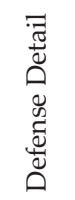 } & 1st Defense Detail & Ditto & $\begin{array}{l}\text { Planned to be employed for [the operation in] Dutch } \\
\text { Borneo; attached to the } 2 \mathrm{~d} \text { Kure SLF }\end{array}$ \\
\hline & 2d Defense Detail & Ditto & Ditto \\
\hline
\end{tabular}

Note: The defense details are units for preventing fire and destruction, and providing emergency repairs of oil fields and other important facilities. 


\section{Advance}

\section{The Philippines Unit}

The order of the Philippines Unit was issued on 20 November 1941 [actually 23 November]. It started with an assessment of the enemy situation in the Philippines area, gave an outline of the situation of friendly forces (the operations of the Air Unit and the Submarine Unit as well as the Malaya and Hong Kong operations), and explained in detail the operational directives, the disposition of forces, and actions of each unit in the Philippines area; furthermore it gave the general idea of the Dutch East Indies operation. ${ }^{(47)}$

\section{The Malaya Unit}

The order of the Malaya Unit was issued on 20 November 1941. It roughly explained the enemy situation in the Malaya area, the mission [of the unit], the employment of force before and after the opening of hostilities, the disposition of forces, and the outline of the operational directives. ${ }^{(47)}$

\section{The Southern Army Issues the Order to Launch the Invasion}

Dated 6 November, the Army Department of IGHQ disclosed its concept of the operation. On the same day, General Terauchi Hisaichi was personally appointed commander in chief of the Southern Army by the Emperor. He was given by [the Army Department of] IGHQ the Order to Prepare for the Seizure of Strategic Areas in the South, along with the Summary of the Operations of the Southern Army, and the Army-Navy Central Agreement for the Southern Operation." On 10 November, Commander in Chief Terauchi, along with his staff officers, concluded agreements for the southern operation with the commanders in chief of the Combined Fleet and the Second Fleet, and simultaneously issued to his subordinate units the orders concerning the operational preparations. On 15 November, based on the order of battle of the Southern Army his high command came into effect, and the Southern Army issued the Plan of Operations for the South. ${ }^{(34)}$

Then on 16 November, the armies [under] the Southern Army concluded the necessary arrangements with the Navy units concerned (the Iwakuni Agreement), after which on 20 November he [Terauchi] issued the order to invade the southern key areas, the excerpt and summary of which are as follows: ${ }^{(34)}$

1. - 10. (Concerning the Philippines, Malaya, Thailand, and Burma: Omitted by the author.)

11. The commander of the Sixteenth Army shall swiftly occupy Davao, Jolo, Tarakan and then Balikpapan, Banjarmasin with an element of his force and secure the necessary air bases as well as vital resource areas. (The rest omitted by the author)

12. Commander Kawaguchi of the Kawaguchi Detachment shall depart from the assembly point after the opening of hostilities, occupy Miri and Seria first in a sudden attack, secure vital resource areas as well as air bases and, immediately after that, occupy the air base near Kuching as quickly as possible.

13. - 14. (Omitted by the author)

15. In order to restore order, obtain resources crucial to national defense and secure the means for the armies to maintain themselves on their own account in the occupied territories, each army commander and Commander Kawaguchi shall take charge of establishing a military administration in each area. Separate orders shall be issued concerning the details of the establishment of a military administration (summarized by the author). 
With this, [the Southern Army] had issued the orders to control the operations of the armies under its command for the next forty to fifty days.

\section{Remaining Problems in the Southern Operation}

Among the problems concerning the southern operation that became clear after the map exercise at the Naval College, the following three major problems remained unsolved until the last minute:

1. The problem of the invasion schedule ${ }^{(11)}$

The Army was eager to shorten the [invasion] schedule from the strategic point of view that it wanted to be ready for a [possible] northern operation sooner, that it wanted to seize the oil before it was destroyed by the enemy, and that it wanted to quickly [complete the invasion] before the enemy strengthened its defenses. However, this was difficult to realize due to the problems in the shipping operation, etc. Meanwhile, the Navy shared the same view about the shortening of the schedule from the point of view that it wanted to be ready for the operation against the United States, and that it wanted to quickly seize oil. However, it had to be cautious by all means due to the required thorough air campaigns to safely transport the convoy carrying the invasion [corps], the preparation of bases, the operation of its vessels for escort, and others. That is to say, both the Army and the Navy had a strong ambition to shorten the schedule but it was difficult to form a clear view of the schedule. Moreover, both had concerns about whether they [even] could conduct the operations as scheduled.

2. The problem of the construction units to set up air bases

The operational outline against the United States that the Japanese Navy had adopted for years was based on the idea to intercept the main force of the enemy by making use of the [Japanese administered equatorial] Pacific Islands and destroy the enemy at a stroke in a decisive battle. Therefore, it had almost never considered an operation [to be conducted while] advancing its bases.

However, the main part of the present southern operation was an operation [conducted while] advancing bases. As a quick preparation of advance bases was required, operational units assigned to [setting up] facilities became necessary. (In peacetime, the Navy Facility Department was in charge of the construction of naval air bases.)

Therefore, on 12 September 1941, the formation of construction squads was stipulated in an amendment to Navy order No. 105, the Auxiliary War Vessels Unit Order. At that time, the regular personnel of a construction squad consisted of engineers, assistant engineers and civil officers totaling 10 officers, about 20 clerks, employees, etc., and up to 3,000 military laborers as needed. However, they were not equipped with modern construction machines. For this reason, the construction capacity of the squads was too low to meet the needs of the operational units.

\section{Measures against attrition in the air campaigns}

(1) Shortage of aircraft

The map exercise at the Naval College had shown that 160\% of the fighter planes and $40 \%$ of the land-based attack planes of the land-based air units would be lost in fighting before advancing to the line of Java, so the replenishment [of the loss] became an issue. After further examination, it was found that whereas the $40 \%$ loss of land-based attack planes could somehow be replenished, it was totally impossible to replenish the $160 \%$ loss of fighter planes. Although [a total of] 150 Type-0 fighter planes were built by April of 1941, the production capacity around October of the same year was merely about 50 aircraft per month. ${ }^{(49)}$ For 


\section{Advance}

reference, the following table shows the actual numbers of aircraft built in April 1941 (monthly production) and the planned numbers of aircraft to be built in April 1942 estimated as of July 1941. ${ }^{(50)}$

\begin{tabular}{|l|r|r|}
\hline \multicolumn{1}{|c|}{ Classification } & $\begin{array}{c}\text { 1 Apr., 1941 } \\
\text { (actual } \\
\text { numbers) }\end{array}$ & $\begin{array}{c}\text { 1 Apr., 1942 } \\
\text { (planned } \\
\text { numbers) }\end{array}$ \\
\hline Carrier-based fighter planes & 32 & 58 \\
\hline Medium-sized land-based attack planes & 15 & 23 \\
\hline Large-sized land-based attack planes & 1 & $5^{*}$ \\
\hline Carrier-based attack planes & 28 & 0 \\
\hline Carrier-based bombers & 13 & 17 \\
\hline Three-seater reconnaissance seaplanes & 6 & 23 \\
\hline Observation planes & 9 & 15 \\
\hline Large-sized flying boats & 4 & 9 \\
\hline Medium-sized flying boats & & 162 \\
\hline Transport planes & & 196 \\
\hline Training planes & 77 \\
\hline In total & & 31 \\
\hline
\end{tabular}

At the study meeting of the map exercise at the Naval College, Commander in Chief of the Combined Fleet Admiral Yamamoto strongly demanded that 150 more Type-0 fighter planes should be built by January 1942 on top of the current production plan. However, it was totally impossible to meet his demand. ${ }^{(49)}$ As a countermeasure, the [Navy] Aeronautical Department drew up a plan to increase the production of Type-0 fighter planes and land-based attack planes by decreasing the production of land-based transport planes and observation planes until March 1942, while increasing the production of 20-mm machine guns to be mounted on aircraft by also making use of the production capacity of 25-mm machine guns at the Toyokawa Naval Arsenal, which was under control of the Navy Technical Department. But these measures were only able to slightly increase production. ${ }^{(51)}$

(2) Shortage of flight crew

The Navy, which had envisioned the scenario of an intercepting operation, had planned for a short decisive battle. Therefore, in training its flight crew, it had set the target of [just] filling the full regular number of personnel for its units. The regular number of personnel was one and a half times the number of flight crew for the regular number of aircraft. Even the report of the Aviation System Study Committee of the [administrative] year 1939 stated that the targeted [full regular number of] flight crew in peacetime should be set at three times as many as the number of flight crew for the regular aircraft. ${ }^{(52)}$ ([Note by the author:] As the military capacity [the number of aircraft] is to be doubled in wartime, the number of flight crew, [three times as many as the number of flight crew for the regular aircraft at peacetime,] will make half as many again as the [increased] military capacity.)

* The text mistakenly has 15. 
In the meantime, every time a [new] naval armaments supplement program was approved, the plans to increase the power of air units had been significantly stepped up. As a result, despite the desperate efforts of the persons concerned, the number of trained flight crew could not even reach [the targeted number] as in the above, which was half as many again [as the number of flight crew for the regular aircraft]. For that reason, the naval armaments supplement program (five-year plan) of the [administrative] year 1939 went so far as to stipulate the increase of air training units by as many as forty units all at once.

Due to the [difficulty of] the tasks, flight crew were given piloting (reconnaissance) training for about one year on top of a [just] sufficient fundamental training, after which they were further given in-service training for about one year before somehow becoming fullfledged crew members. [Moreover,] in order to become a cadre flight crew member of aircraft carriers or of the front line base units, a further training of one to two years was required, which meant that the training of flight crew had to be started at least three years prior to an increase in the armaments supplement programs. It was impossible to increase [flight crew numbers] just like that.

Although adequate documents about the actual situation of the training of flight crew are not extant, the rates of filled vacancy of flight crew as of the end of March 1941 were respectively $80 \%$ and $70 \%$ for pilots and reconnaissance staff. These numbers included a large number of fledgling crew, who had just finished [flying training]. ${ }^{(51)}$ The rate of filled vacancy of specially-trained mechanics was 74\% until the end of March 1941.(51)

Although the rates of filled vacancy were improved in the autumn of 1941, there was a great shortage in personnel skilled enough to be assigned to the immediate operations, especially to aircraft carriers, due to the [particular] increase in the number of younger crew [on one hand] and the rapid increase in the number of aircraft carriers [on the other].

Such being the case, the meeting of the Navy General Staff and the Combined Fleet decided the following: ${ }^{(35)}$

1. Skilled members among the flight crew of the $3 \mathrm{~d}$ and the 4th Carrier Divisions shall [be removed to] replenish the 1st and the $2 \mathrm{~d}$ Carrier Divisions (main aircraft carrier unit), so as to prevent a deterioration in skills which may be caused by the increase in the regular number [of crew] due to the wartime shift.

2. [The flight crew of] each ship of the 5th Carrier Division ([consisting of] newly built vessels) shall be replenished with teachers, instructors and the cadre crew of air training units and homeland units. For that purpose,

(1) The number of students and trainees assigned to a teacher or an instructor shall be increased.

(2) Training of unskilled flight crew shall be conducted in the units engaged in battles outside [Japan].

3. It cannot be helped to reduce the rate of [flight] crew assigned to the fleets. ([In such a case,] the reserve flight crew shall [first] be reduced.)

4. No replenishment may be required for the $3 \mathrm{~d}$ and the 4 th Carrier Divisions (small aircraft carriers).

5. No reinforcement shall be made to the Eleventh Air Fleet. Consequently, a large number of unskilled flight crew was assigned to the Eleventh Air Fleet, [consisting of] land-based air units, which also incurred the responsibility for their training. 


\section{Chapter IV Progress in the Preparations for the Invasion of the Dutch East Indies}

(See Attached Illustration No.1) [Omitted]

\section{Smooth Progress in the Stage-One, Phase-One Operations}

\section{Success in the Leadoff Operations on the First Day of the Opening of Hostilities}

7 he first action in the Greater East Asia War was initiated in Kota Bharu in the Malaya area. Right before 0000 on 8 December, the main force of the 1st Escort Unit of the Malaya Unit ([consisting of] one light cruiser and four destroyers of the 3d Destroyer Squadron as the core) escorted three transport ships of the Army Takumi Detachment and entered the roadstead off Kota Bharu at the northern end of the British part of the Malay Peninsula, from where the Army unit started landing from 0215 onwards. From the land fierce counterattacks were immediately made against these landings. These were the first hostilities in the Greater East Asia War. The Kota Bharu unit, while continuing its landing operation, [also] came under repeated attacks of several enemy aircraft from around 0330 onwards.

Meanwhile, the Navy's Carrier Task Force ([consisting of] six aircraft carriers as the core) reached the waters about 200 nautical miles north of Hawaii at 0100 on that day and launched the first attack unit consisting of 180 carrier-based aircraft. These rushed into the skies over Pearl Harbor at 0320, carrying out strikes on the main force of the U.S. Pacific Fleet anchored there. It was a perfectly successful surprise attack.

At 0600 on the same day, IGHQ announced: "Today, the 8th, before dawn, the Imperial [Japanese] Army and Navy entered a state of war with U.S. and British forces in the western Pacific."

The other engagements on 8 December are in outline as follows:

1. The 5th Division that was to land in the Singora and Pattani areas in Malaya entered the anchorage at 0035 and successfully landed in Singora and Pattani respectively at 0410 and 0430.

2. At 0515 the Navy dispatched a bearer of a flag of truce to the U.S. and British gunboats in Shanghai to demand their surrender. Whereas USS Wake surrendered, HMS Peterel opened fire at 0530. The Navy unit sank the latter at 0605.

3. Thirty-two land-based attack planes of the Navy Mihoro Air Group of the 22d Air Flotilla departed from Thủ Dâu Một in French Indochina at 0015 and carried out air strikes on airfields and military facilities in Singapore from 0530 to 0545.

4. The special landing force of the $2 \mathrm{~d}$ Base Force came ashore on Batan Island in the Philippines at 0730 and seized the airfield. 


\section{Dutch East Indies}

5. A combined force of about 160 fighter planes and bombers of the Army Third Air Force departed from air bases in southern French Indochina around 0630 and carried out air strikes on the Kota Bharu sector in full force (and the Kedah sector with one element) around 0800.

6. Twenty-two carrier aircraft of the 4th Carrier Division departed at 0545 and carried out air strikes on the airfield in Davao and the auxiliary seaplane tender USS William B. Preston between 0746 and 0843 .

7. Five reconnaissance seaplanes of the 18th Air Group of the Fourth Fleet departed from Saipan at 0645 and carried out air strikes on Guam.

8. The $2 \mathrm{~d}$ Escort Unit, which escorted the Uno Detachment of the Fifteenth Army, put the latter ashore north of Nakhon (included) on the Malay Peninsula at 1000.

9. Thirty-four land-based attack planes of the Chitose Air Group of the Fourth Fleet departed from Roi (note: [in the] northern part of the Marshall Islands) at 0510, and bombed Wake Island at 1010.

10. Eighteen heavy bombers and twenty-five light bombers of the Army Fifth Air Force departed from southern Taiwan between 0620 and 0730, and conducted a bombing raid on Tuguegarao and Baguio in the northern Philippines around 0930.

11. The Navy Special Landing Force at Shanghai started the seizure of the International Settlement ([particularly] the U.S. and British [concessions]) at 1100.

12. 106 Land-based attack planes and 85 fighter planes of the Eleventh Air Fleet departed from southern Taiwan between 0920 and 1030, and conducted an attack on the Clarke and Iba [airfields] on the Philippines respectively at 1332 and 1345.

All of these leadoff strikes were a big success. Particularly, the air strikes on Hawaii, on which the Navy had staked the success or failure of the first engagements, achieved a tremendous success. In two [waves of] strikes, [the Navy] dealt a devastating blow to the main force of the U.S. Pacific Fleet only at the cost of twenty-nine aircraft. However, as none of the U.S. carriers were in port in Pearl Harbor [at that time], the Navy missed the opportunity of destroying them. Also, in the Malaya area, Japanese forces were able to secure a beachhead in Kota Bharu, which had been regarded as extremely difficult, and completed the landing operations in the Pattani and the Singora sectors in southern Thailand, meeting almost no resistance. In the Philippines area, naval air groups reported military gains of bringing down or destroying ninety or more [enemy] aircraft with the attack on the Clarke and Iba airfields. Also, Army air units reported military gains of bringing down or destroying about fifty enemy aircraft in the attack on British air force bases in the Kota Bharu sector (and partly in the Kedah sector) in the Malaya area.

In the Thailand area, the Imperial Guard Division, which had been standing by at the border between Thailand and French Indochina, departed from the border at 0700 on the 8th to launch its advance into Thailand. The Yoshida Detachment of the Fifteenth Army, which had been standing by on Phú Quốc Island, also reached [the waters] south of Bangkok before dawn of the 8 th, and started landing. The negotiations concerning the stationing of Japanese forces in Thailand had been delayed due to the absence of Prime Minister [Luang] Pibulsonggram, and the advance was made before the negotiations had reached an agreement, which led to conflicts with the Royal Thai Army at a few places. However, Thailand soon took steps to stop the resistance, and after the negotiations reached an agreement at 1200, the advance was implemented without problems. 


\section{Dutch East Indies}

\section{Satisfactory Progress Seen also in the Operations in Malaya and Northern Borneo}

The surprise landings on Malaya on the first day of the opening of hostilities had been successful, and it was [also] judged that the air campaign of the Army air units against the enemy air power in northern Malaya had destroyed on the whole the greater part of the British air forces in the space of two days, the 8 th and the 9 th. During this period, other than a few attacks by [enemy] aircraft and several counterattacks by [enemy] submarines, there was no noteworthy resistance, and the operations progressed satisfactorily.

On the afternoon of 9 December, submarine(s) deployed at sea on the east coast of the Malay Peninsula noticed two [enemy] battleships and some destroyers sailing north, but due to bad weather, it was impossible to attack them on that day. On the afternoon of the next day, the 10th, about eighty Navy land-based attack planes attacked them, and sank the battleships HMS Prince of Wales and HMS Repulse, the main force of the British Fleet in the East (the sea battle off Malaya).

On 10 December, the head unit of the 5th Division, which had landed in the vicinity of Singora, destroyed the British army [there], broke through the border between Thailand and Malaya, continued its bold charge, and as early as on 26 December, seized Ipoh, a strategic location in central Malaya. Meanwhile, after breaking through Terengganu on the 23d, the Takumi Detachment in the Kota Bharu sector closed in on Kwantan. In the meantime, on 26 December, the 1st Escort Unit of the Malaya Unit escorted the army units of the second [wave of] landings and put them ashore at Singora and other areas. The units of the second wave, following after the units of the first wave, advanced southward.

While carrying out air campaigns and providing support for the ground operations in northern and central Malaya, the Army Third Air Force advanced its main force to Sungai Petani in northern Malaya around the 20th.

Meanwhile in the Burma region, one element of the Army Third Air Force advanced to Bangkok on the 10th, and launched air strikes against southern Burma, such as Victoria Point [Kawthaung], etc. In the meantime, the Uno Detachment, which had landed in southern Thailand, captured Victoria Point on the 14th, while the air units carried out air raids on Rangoon with a massive strength both on 23 and 25 December.

In the northern Borneo region, in parallel with the second landings in the Malaya area, the Kawaguchi Detachment of the Army, a naval special landing force and a construction squad landed in Miri on the 16th and in Kuching on the 24th of December under the escort of the $2 \mathrm{~d}$ Escort Unit of the Malaya Unit. In this operation, three destroyers were sunk and several transport ships were damaged by air raids of the enemy and torpedo attacks by enemy submarines. The landing units captured Kuching on the 25th, and started preparations to advance the main force of the naval land-based air units, while one element of the air units, which had advanced to Miri on the 22d, carried out an air strike on Tarakan on the 26th for the first time. 


\section{Gaining Command of the Air in the Philippines Area and the Rapid Advance of the Ground Units}

The air campaign to destroy the enemy air power in Luzon [conducted by] the naval landbased air units as the main force had been continued since 8 December, employing a massive strength, and as early as on the 13th, they had already destroyed the greater part of the U.S. air units.

In parallel with this air campaign, the Army advance units and the naval special landing forces seized key locations such as Batan Island on the 8th, and Aparri and Vigan on the 10th under the escort of the surface vessels of the Navy Philippines Unit and with the support of the air units of the Army and the Navy, which [enabled] the advance of the Army Fifth Air Force [to the area]. On the 12th, Legaspi at the southeastern tip of Luzon was seized in a sudden attack, which enabled an element of the Navy land-based air units to advance and launch their air campaign against the enemy air power in central Luzon. On the 20th, the [Navy] Philippines Unit captured Davao, a strategic location in the southern Philippines. (Although the landing in Davao was at first scheduled for 14 December, it was postponed until the 22d, due to the appearance of the British state-of-the-art battleships, which led the Southern Task Force on 28 November to concentrate its air and naval forces on that sector. However, because of the sinking of [both battleships] in the sea battle off Malaya, as well as the military gains in the air campaign to destroy the enemy air power in the Philippines right at the outset of the war, and the less-than-expected resistance of the enemy, it was judged advantageous to move up the date of the landing. On 15 December, in an arrangement between the Army and the Navy on site, it was moved up by two days to 20 December.)

Following [the above], the main force of the Fourteenth Army was put ashore at Lingayen Gulf and at Lamon Bay respectively on the 22d and the 24th. On the 25th, the [Navy] Philippines Unit captured Jolo, (which was [originally] scheduled for the 21st but postponed in line with the postponement of the capture of Davao). With the capture of Davao and Jolo, the footholds were secured, from where the subsequent Dutch East Indies operation should be launched. The main force of the Fourteenth Army, which had landed at Lingayen Gulf and Lamon Bay, made a pincer attack on the U.S.-Filipino Army from the north and the east, and charged toward Manila (which was seized on 2 January).

Against these multiple landing operations, no surface war vessels of the U.S. Asiatic Fleet showed up, apart from some active counterattacks conducted by submarines. The fleet was considered to have escaped to the Dutch East Indies and northern Australia.

In the meantime, the Navy land-based air units with their bases in Taiwan, which had continued air raids on the Manila Bay areas as well as on the central Philippines, started advancing their forces to Davao and Jolo respectively on 22 and 26 December to launch reconnaissance and air strikes on Tarakan and Menado. 


\section{Dutch East Indies}

\section{The Bulk of the [Navy] Philippines Unit is Shifted to the Dutch East Indies Unit}

\section{The Shift to the Phase-Two Disposition of Forces}

Combined Fleet Commander in Chief Admiral Yamamoto, who judged that the landings of the main force of the Army unit for capturing the Philippines were completed, issued an order to shift to phase-two operations at 1200 on 26 December. ${ }^{(53)}$ The [new] distribution of forces of the Southern Task Force in this order was roughly as in the following table. Except for an element of the Third Fleet, the bulk of the [Navy] Philippines Unit was shifted to the Dutch East Indies Unit. ${ }^{(47)}$

\begin{tabular}{|c|c|c|c|}
\hline Name of Unit & \multicolumn{2}{|c|}{ Commander } & Forces \\
\hline $\begin{array}{l}\text { Main Body of the } \\
\text { Southern Task Force }\end{array}$ & \multirow{6}{*}{ 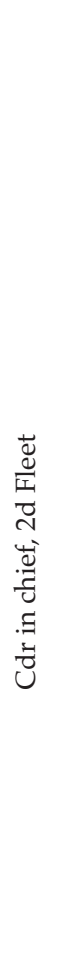 } & & $\begin{array}{l}\text { 4th Cruiser Div (minus the Chōkai), 3d Battleship Div 2d } \\
\text { Section, 4th Carrier Div (minus 2d Section), 4th De- } \\
\text { stroyer Div and 6th Destroyer Div 1st Section }\end{array}$ \\
\hline The Philippines Unit & & & One element of the $3 \mathrm{~d}$ Fleet \\
\hline The Dutch East Indies Unit & & $\begin{array}{l}\text { Cdr in chief, } \\
\text { 3d Fleet }\end{array}$ & $\begin{array}{l}\text { Bulk of 3d Fleet, 5th Cruiser Div, 2d Destroyer Sqdn } \\
\text { (minus 8th and 18th Destroyer Divs), 4th Destroyer Sqdn } \\
\text { (minus 4th Destroyer Div), 11th Seaplane Tender Div, 1st } \\
\text { Patrol Boat Div (minus } 2 \text { patrol boats), } 3 \text { SLFs, } 5 \text { con- } \\
\text { struction squads }\end{array}$ \\
\hline Malaya Unit & & $\begin{array}{l}\text { Cdr in chief, } \\
\text { Southern Ex- } \\
\text { peditionary } \\
\text { Fleet }\end{array}$ & $\begin{array}{l}\text { Southern Expeditionary Fleet, the Chōkai, 7th Cruiser } \\
\text { Div, 3d and 5th Destroyer Sqdns, 8th Destroyer Div, 4th } \\
\text { Submarine Sqdn, 17th Minelayer Div 2d Section, 22d Air } \\
\text { Flotilla, main body of Kanoya Air Gp, Yamada Unit, 12th } \\
\text { Seaplane Tender Div (minus the San'yō-maru), 2d Yoko- } \\
\text { suka SLF, 4th Construction Squad, 11th* Submarine Base } \\
\text { Unit }\end{array}$ \\
\hline Air Unit & & $\begin{array}{l}\text { Cdr in chief, } \\
\text { 11th Air Fleet }\end{array}$ & $\begin{array}{l}\text { 11th Air Fleet (minus 22d Air Flotilla, main body of } \\
\text { Kanoya Air Gp, } 36 \text { carrier-based fighter planes and } 6 \\
\text { land-based reconnaissance planes), } 2 \text { SLFs }\end{array}$ \\
\hline Submarine Unit & & $\begin{array}{l}\text { Cdr, 5th Sub- } \\
\text { marine Sqdn }\end{array}$ & 5th and 6th Submarine Sqdns \\
\hline
\end{tabular}

The main force of the Southern Task Force was further divided into the following units:

\begin{tabular}{|l|l|l|}
\hline \multicolumn{1}{|c|}{ Name of Unit } & \multicolumn{1}{|c|}{ Commander } & \multicolumn{1}{c|}{ Forces } \\
\hline Main Unit & $\begin{array}{l}\text { Under direct command of cdr in } \\
\text { chief, 2d Fleet }\end{array}$ & $\begin{array}{l}\text { 4th Cruiser Div 1st Section, the Kongō, 4th } \\
\text { Destroyer Div }\end{array}$ \\
\hline Eastern Support Unit & Capt of the Haruna & $\begin{array}{l}\text { The Haruna, the Maya, 6th Destroyer Div 1st } \\
\text { Section }\end{array}$ \\
\hline
\end{tabular}

* The text mistakenly has 111th. 


\section{Dutch East Indies}

Notes:

1. The 4th Carrier Division was temporarily put under the command [of the main body of the Southern Task Force] to be [further] transferred to the Malaya Unit, and therefore not included in this distribution of forces.

2. [Concerns abbreviations in Japanese, irrelevant to the translation: Omitted by the editor.]

\section{The Situation of the Navy Southern Task Force}

The movements of each unit around 26 December were as follows:

\section{The Dutch East Indies Unit (as in the following table)}

\begin{tabular}{|c|c|c|c|}
\hline \multicolumn{2}{|c|}{ Name of Unit } & Whereabouts & Movements \\
\hline \multicolumn{2}{|c|}{ 3d Fleet HQ; 16th Cruiser Div } & Magong & $\begin{array}{l}\text { Returned to Magong on 23d December after support- } \\
\text { ing the Luzon invasion operations; is preparing for the } \\
\text { next operations }\end{array}$ \\
\hline \multicolumn{2}{|c|}{ 17th Minelayer Div 1st Section } & Palau & $\begin{array}{l}\text { Returned to Palau on } 11 \text { December after implementing } \\
\text { offensive mining operations in the waterways east of } \\
\text { the Philippines; is protecting maritime transport routes } \\
\text { between Davao, Legaspi and Palau }\end{array}$ \\
\hline \multicolumn{2}{|l|}{ San'yō-maru } & Gaoxiong & $\begin{array}{l}\text { Aircraft unit returned to Donggang on } 25 \text { December } \\
\text { after participating in the Lingayen landing operations }\end{array}$ \\
\hline \multicolumn{2}{|l|}{ 5th Cruiser Div } & Palau & $\begin{array}{l}\text { Due to arrive in Palau between } 27-28 \text { December after } \\
\text { supporting the operations to capture Davao and Jolo }\end{array}$ \\
\hline \multirow{3}{*}{ 2d Destroyer Sqdn } & $\begin{array}{l}\text { Jintsū and 15th } \\
\text { Destroyer Div }\end{array}$ & Jolo & $\begin{array}{l}\text { Are guarding Jolo after engaging in the operation to } \\
\text { capture Jolo }\end{array}$ \\
\hline & $\begin{array}{l}\text { 16th Destroyer } \\
\text { Div 2d Section }\end{array}$ & Davao & $\begin{array}{l}\text { Is guarding Davao after engaging in the operation to } \\
\text { capture Davao }\end{array}$ \\
\hline & $\begin{array}{l}\text { 16th Destroyer } \\
\text { Div 1st Section }\end{array}$ & $\begin{array}{l}\text { Heading for } \\
\text { Palau from } \\
\text { Lamon Bay }\end{array}$ & $\begin{array}{l}\text { Left Lamon Bay on } 26 \text { December for Palau after com- } \\
\text { pleting the operation in Lamon Bay }\end{array}$ \\
\hline \multirow{2}{*}{$\begin{array}{l}\text { 4th Destroyer } \\
\text { Sqdn }\end{array}$} & $\begin{array}{l}\text { Naka, 2d and } \\
\text { 9th Destroyer } \\
\text { Divs }\end{array}$ & Gaoxiong & $\begin{array}{l}\text { Arrived in Gaoxiong on } 26 \text { December via Magong after } \\
\text { the Lingayen landing operation }\end{array}$ \\
\hline & $\begin{array}{l}\text { 24th Destroyer } \\
\text { Div }\end{array}$ & $\begin{array}{l}\text { Heading for } \\
\text { Palau from } \\
\text { Lamon Bay }\end{array}$ & $\begin{array}{l}\text { Left Lamon Bay on } 26 \text { December for Palau after com- } \\
\text { pleting the operation in Lamon Bay }\end{array}$ \\
\hline \multirow{2}{*}{$\begin{array}{l}\text { 11th Seaplane } \\
\text { Tender Div }\end{array}$} & Chitose & $\begin{array}{l}\text { Heading for } \\
\text { Davao from } \\
\text { Jolo }\end{array}$ & $\begin{array}{l}\text { Due to arrive in Davao on } 27 \text { December, leaving Jolo } \\
\text { on } 26 \text { th, after providing guard for the landing [opera- } \\
\text { tion] of the Jolo operation unit }\end{array}$ \\
\hline & Mizuho & $\begin{array}{l}\text { Heading for } \\
\text { Palau from } \\
\text { Lamon Bay }\end{array}$ & $\begin{array}{l}\text { Left Lamon Bay on } 26 \text { December for Palau after com- } \\
\text { pleting the operation in Lamon Bay }\end{array}$ \\
\hline
\end{tabular}




\section{Dutch East Indies}

\begin{tabular}{|c|c|c|c|}
\hline \multicolumn{2}{|l|}{ 1st Base Force } & $\begin{array}{l}\text { Main force in } \\
\text { Lamon Bay; } \\
\text { one element in } \\
\text { Davao }\end{array}$ & $\begin{array}{l}\text { Is guarding the anchorage in Lamon Bay with the main } \\
\text { force, while setting up defense facilities at Davao with } \\
\text { one element }\end{array}$ \\
\hline \multirow{2}{*}{ 2d Base Force } & Main Force & Lingayen Gulf & Is guarding the anchorage in Lingayen Gulf \\
\hline & Sanuki-maru & Gaoxiong & $\begin{array}{l}\text { Aircraft units returned to Donggang from Vigan on the } \\
\text { 25th }\end{array}$ \\
\hline \multicolumn{2}{|c|}{ 1st Patrol Boat Div } & Palau, etc. & $\begin{array}{l}\text { Is guarding anchorage(s) or [returned] to Palau, after } \\
\text { engaging in operations in Lamon Bay, Legaspi and } \\
\text { Jolo; one element is guarding the Chitose and the } \\
\text { Mizuho }\end{array}$ \\
\hline \multicolumn{2}{|c|}{ Special Landing Force [SLF] } & $\begin{array}{l}\text { Main force in } \\
\text { Palau; one ele- } \\
\text { ment in other } \\
\text { places }\end{array}$ & $\begin{array}{l}\text { The main force is standing by in Palau; one element is } \\
\text { guarding Legaspi, Lamon Bay and Jolo }\end{array}$ \\
\hline \multirow{5}{*}{$\begin{array}{l}\text { Construction } \\
\text { Squad }\end{array}$} & $\begin{array}{l}\text { 1st Construc- } \\
\text { tion Squad }\end{array}$ & Legaspi & $\begin{array}{l}\text { Landed in Legaspi on } 12 \text { December; is setting up air } \\
\text { field(s) }\end{array}$ \\
\hline & $\begin{array}{l}\text { 2d Construction } \\
\text { Squad }\end{array}$ & Davao & $\begin{array}{l}\text { Landed in Davao on } 20 \text { December; is setting up air } \\
\text { field(s) }\end{array}$ \\
\hline & $\begin{array}{l}\text { 3d Construction } \\
\text { Squad }\end{array}$ & Palau & Is standing by \\
\hline & $\begin{array}{l}\text { 5th Construc- } \\
\text { tion Squad }\end{array}$ & $\begin{array}{l}\text { Heading for } \\
\text { Palau from } \\
\text { Kure }\end{array}$ & Due to arrive in Palau on 27 December \\
\hline & $\begin{array}{l}\text { 6th Construc- } \\
\text { tion Squad }\end{array}$ & $\begin{array}{l}\text { Heading for } \\
\text { Palau from } \\
\text { Sasebo }\end{array}$ & Due to arrive in Palau on 28 December \\
\hline
\end{tabular}

\section{The Air Unit}

\begin{tabular}{|l|l|l|l|}
\hline \multicolumn{2}{|c|}{ Name of Unit } & Whereabouts & \multicolumn{1}{c|}{ Movements } \\
\hline \multicolumn{1}{|c|}{ 11th Air Fleet HQ } & Gaoxiong & Is directing the operations \\
\hline \multirow{2}{*}{ 21st Air Flotilla } & HQ & $\begin{array}{l}\text { Palau ([shift- } \\
\text { ing] to Davao) }\end{array}$ & $\begin{array}{l}\text { [Shifted] from Tainan to Palau on 19 December, and } \\
\text { will further [shift] to Davao on 27 December }\end{array}$ \\
\cline { 2 - 5 } & Ket & $\begin{array}{l}\text { Peleliu (One el- } \\
\text { ement [shift- } \\
\text { ing] to Davao) }\end{array}$ & $\begin{array}{l}\text { 25* Type-1 land-based attack planes [flew] from } \\
\text { Taizhong to Peleliu on 18 December, 10 [of which] will } \\
\text { [shift] to Davao on 28 December }\end{array}$ \\
\cline { 2 - 4 } & 1st Air Gp & Tainan & $\begin{array}{l}\text { Cancelled its advance of 39 Type-96 land-based attack } \\
\text { planes to Jolo; leaves it with no immediate advance } \\
\text { scheduled }\end{array}$ \\
\cline { 2 - 4 } & 1001 Unit & Jiayi & 28 Type-96 transport planes \\
\hline
\end{tabular}

* The number given in Illustration No. 1, p. 102, is 27. 


\section{Dutch East Indies}

\begin{tabular}{|c|c|c|c|}
\hline \multirow{3}{*}{$\begin{array}{l}\text { 21st Air Flotilla } \\
\text { [cont.] }\end{array}$} & $\begin{array}{l}\text { 1st Yokosuka } \\
\text { SLF }\end{array}$ & $\begin{array}{l}\text { Heading for } \\
\text { Davao from } \\
\text { Gaoxiong }\end{array}$ & Left Gaoxiong for Davao on 26 December \\
\hline & $\begin{array}{l}\text { 3d Yokosuka } \\
\text { SLF }\end{array}$ & Jiayi & Is standing by \\
\hline & Tōkō Air Gp & $\begin{array}{l}\text { Main force in } \\
\text { Davao; one ele- } \\
\text { ment in Palau } \\
\text { and Donggang }\end{array}$ & $\begin{array}{l}18 \text { flying boats [shifted] from Palau to Davao between } \\
22-25 \text { December }\end{array}$ \\
\hline \multirow{4}{*}{ 23d Air Flotilla } & HQ & Gaoxiong & Is directing operations \\
\hline & Takao Air Gp & Gaoxiong & 61 Type-1 land-based attack planes \\
\hline & Tainan Air Gp & Tainan & $\begin{array}{l}\text { Of } 25 \text { Type- } 0 \text { fighter planes, } 2 \text { land-based reconnais- } \\
\text { sance planes and a few Type- } 96 \text { fighter planes about } \\
\text { half were advanced to Legaspi on } 14 \text { December, [the } \\
\text { other] half were advanced to Jolo on } 25 \text { December }\end{array}$ \\
\hline & 3d Air Gp & Gaoxiong & $\begin{array}{l}\text { Of } 31 \text { Type- } 0 \text { fighter planes, } 4 \text { land-based reconnais- } \\
\text { sance planes and a few Type- } 96 \text { fighter planes about } \\
\text { two-thirds were [advanced] to Davao between } 23-25 \\
\text { December }\end{array}$ \\
\hline
\end{tabular}

\section{The Philippines Unit}

\begin{tabular}{|l|l|l|}
\hline 32d Special Base Force & Davao & $\begin{array}{l}\text { Landed in Davao on 20 December; is guarding the } \\
\text { place }\end{array}$ \\
\hline One element of 1st Base Force & $\begin{array}{l}\text { Lamon Bay } \\
\text { (One element } \\
\text { for Palau })\end{array}$ & $\begin{array}{l}\text { 1st Gunboat Div left Lamon Bay for Palau on 26 De- } \\
\text { cember; the rest is guarding Lamon Bay }\end{array}$ \\
\hline One element of 2d Base Force & Lingayen Gulf & Is guarding Lingayen Gulf \\
\hline
\end{tabular}

\section{The Submarine Unit}

\begin{tabular}{|l|l|l|l|}
\hline \multirow{2}{*}{ Submarine Unit A } & Chōgei & $\begin{array}{l}\text { Heading for } \\
\text { Davao from } \\
\text { Magong }\end{array}$ & Left Magong on 26 December for Davao \\
\cline { 2 - 5 } & $\begin{array}{l}\text { Main force of } \\
\text { 6th Submarine } \\
\text { Sqdn }\end{array}$ & $\begin{array}{l}\text { Assembling in } \\
\text { Davao }\end{array}$ & $\begin{array}{l}\text { 3 submarines are assembling in Davao; 1 submarine } \\
\text { off Manila }\end{array}$ \\
\hline Submarine Unit B & $\begin{array}{l}\text { Yura force of } \\
\text { Mth Submarine } \\
\text { Sqdn }\end{array}$ & $\begin{array}{l}\text { Assembling in } \\
\text { Cam Ranh Bay } \\
\text { Cam Ranh Bay }\end{array}$ & $\begin{array}{l}\text { Left waters off Kuching on 25 December for Cam Ranh } \\
\text { Bay }\end{array}$ \\
\hline
\end{tabular}




\section{Dutch East Indies}

5. The Main Body of the Southern Task Force

\begin{tabular}{|l|l|l|}
\hline Main Unit & Cam Ranh Bay & $\begin{array}{l}\text { Arrived in Cam Ranh Bay on 24 December, after sup- } \\
\text { porting the Lingayen Gulf landing operation }\end{array}$ \\
\hline Eastern Support Unit & Magong & $\begin{array}{l}\text { Arrived in Magong on 23 December, after supporting } \\
\text { the Lingayen Gulf landing operation }\end{array}$ \\
\hline 4th Carrier Div & Palau & $\begin{array}{l}\text { Arrived in Palau on 26 December, after supporting the } \\
\text { operation in Jolo }\end{array}$ \\
\hline 8th Destroyer Div & Magong & Temporarily transferred to the Malaya Unit \\
\hline
\end{tabular}

\section{The Situation of the Army Units}

\begin{tabular}{|l|l|l|}
\hline 16th Army HQ & Tokyo & $\begin{array}{l}\text { Is engaged in gathering information, studying the op- } \\
\text { eration plan and taking command of its [subordinate] } \\
\text { units }\end{array}$ \\
\hline 2d Div & Central Japan & $\begin{array}{l}\text { Shifted to the maneuvering grounds in central Japan; is } \\
\text { conducting training }\end{array}$ \\
\hline Sakaguchi Det & $\begin{array}{l}\text { Main force in } \\
\text { Davao; one ele- } \\
\text { ment in Jolo } \\
\text { and Palau }\end{array}$ & $\begin{array}{l}\text { Landed in Davao with its main force on 20 December; } \\
\text { [the unit] is mopping up the enemy in the vicinity }\end{array}$ \\
\hline 38th Div & Hong Kong & $\begin{array}{l}\text { Is engaged in the Hong Kong operation; it captured the } \\
\text { city on 25 December }\end{array}$ \\
\hline 48th Div & Luzon & $\begin{array}{l}\text { Landed at Lingayen Gulf on 22 December; is advanc- } \\
\text { ing to Manila }\end{array}$ \\
\hline
\end{tabular}

\section{Assessment of the Enemy Situation in the Dutch East Indies Area at the Launch of Phase-Two Operations}

On 26 December, the shift to phase-two dispositions was put into effect. V. Adm. Takahashi Ibō, commander of the [Navy] Philippines Unit until that time, became the Dutch East Indies Unit commander, while the bulk of the Philippines Unit was shifted to the Dutch East Indies Unit. In the meantime, the Air Unit had also advanced its forces to the Davao - Jolo line in the southern Philippines and was making preparations to launch the Dutch East Indies operation, while clearing remnants of the enemy in the Philippines. On 29 December, Southern Task Force Commander V. Adm. Kondō Nobutake held a meeting with Commander in Chief of the Southern Army General Terauchi Hisaichi at Cam Ranh Bay and agreed upon a major moving-up of the schedule of the coming operations (which will be explained later in detail), while dated on the same day, the Dutch East Indies Unit issued Operation Order No. 1* concerning the invasion of the Dutch East Indies. In this period, Dutch East Indies Commander Vice Admiral Takahashi's assessment of the enemy situation was in outline as follows: ${ }^{(47)}$

\footnotetext{
* Apparently a mistake for Dutch East Indies (Philippines) Unit Order Classified No. 3. See p. 94.
} 


\section{Air power}

1. It seems that although most of the U.S. air power in the Philippines was destroyed, an element escaped to the Dutch East Indies and is planning a counterattack along with British and Dutch air forces.

2. The Dutch East Indies air force is estimated roughly as follows. The force seems to conduct air campaigns using Ambon, Kendari, Balikpapan and Sorong as first line concentration bases, and Menado, Gorontalo, Ternate and Tarakan as the relay bases.

(1) Army aircraft

Bombers: Glenn L. Martin, Lockheed, etc.

Fighter planes: Curtiss Hawk, etc.

Patrol bombers: Douglas, etc.

Training aircraft

In total:

$$
\begin{aligned}
90-100 & \text { aircraft } \\
90-100 & \text { aircraft } \\
20-25 & \text { aircraft } \\
70-80 & \text { aircraft } \\
270-305 & \text { aircraft } \\
& \\
40-60 & \text { aircraft } \\
25-50 & \text { aircraft } \\
20-25 & \text { aircraft } \\
85-135 & \text { aircraft } \\
355-440 & \text { aircraft } \\
265-335 & \text { aircraft }
\end{aligned}
$$

(2) Navy aircraft

Flying boats: PBY, Dornier, etc.

Reconnaissance seaplanes and attack planes: Dornier, Fokker

Training aircraft

In total:

Grand total:

First line aircraft in the above:

3. It seems that about 100 aircraft of the Australian air force have advanced to Ambon and Kupang.

\section{Naval forces}

1. Almost all of the U.S. Pacific Fleet was destroyed in the strike against Hawaii at the beginning of the hostilities, and it is for the time being unlikely that the fleet will carry out a transoceanic attack with its main force.

2. Although the situation of the U.S. Asiatic Fleet from the time of the opening of hostilities is unclear, it is more or less certain that it has already escaped to Celebes and further south.

3. Although the situation of the British fleet in the East after the complete destruction of its main force is also unclear, it is highly likely that in the days ahead the U.S. and British fleets in the East will put up defensive battles mainly in the waters of the Dutch East Indies and Australia, in league with the Dutch East Indies fleet.

4. The strength of the Dutch East Indies fleet is estimated as follows: 2 light cruisers, 8 destroyers, 15-19 submarines, 3 gunboats or coastal defense ships, 6 minelayers, 8 minesweepers, 7 torpedo boats and 32 other ships

5. Surface war vessels of the enemy sometimes appear at Tarakan, Menado, Sorong and other places.

6. Although some of the U.S., British and Dutch submarines have already been lost, a major part of the strength still infests all areas. It is anticipated that in the days ahead more and more will go into action particularly in the Dutch East Indies waters. It seems that the enemy submarines are concentrated outside Davao Gulf and in the southern part of the Celebes Sea, which led to frequent alarms given against them.

7. In view of the geographical features and the armaments of the Dutch East Indies, it is required to be on the alert against enemy mines [particularly] in the Java Sea as well as in the southern part of the South China Sea. 


\section{Dutch East Indies}

\section{Ground forces}

1. The Dutch East Indies Army is [estimated at] about 100,000 men in total, consisting of about 75,000 men of the regular army and 25,000 men of the voluntary army and the police force; the total mobilizable force is assumed to be 120,000 men.

2. It appears that of the ground forces the main force (about 60,000 men) is stationed in Java, while the forces, which we face at each of the key locations in the eastern part of the Dutch East Indies, are deployed in the following way:

$\begin{array}{lrlr}\text { Tarakan } & 3,000 & \text { Menado } & 2,500 \\ \text { Ternate } & 200 & \text { Balikpapan } & 1,500 \\ \text { Kendari } & 150 & \text { Makassar } & 1,500 \\ \text { Banjarmasin } & 1,000 & \text { Ambon } & 1,200 \\ \text { Kupang } & 350 & & \end{array}$

3. There are about 900 Australian troops in Ambon.

\section{Conclusion of the Army-Navy Agreement for the Java Invasion [Operation]}

\section{The First [Scheduled] Army-Navy Meeting is Moved up}

None of the documents regarding the Central Agreement of 5 November that specified the details of the operation schedule are extant. However, according to documents related to the agreement, ${ }^{(54)}$ it seems that IGHQ planned to aim at landing on the island of Java roughly around Day X +100 (18 March) and completing the southern operation by Day X +120 , that is, in about four months from the launch of operations. As a matter of fact, it would have suited both the Army and the Navy if [the operation] were completed sooner. However, in view of the [available] shipping tonnage of the transport ships carrying the invasion units, the shipping operations, the tempo of advancing the air bases, and the distribution of vessels for escorting, etc., [both the Army and the Navy] for the moment set the target [date] at four months [from the launch of the operations].

However, Southern Army headquarters, which was most keen on shortening the schedule of the southern operation, strongly insisted at the Tokyo Agreement [conference] on an agreement to complete the operations in about three months, shortening the period in the plan drawn up by IGHQ by about one month. ${ }^{(34)}$ The Navy, being in charge of implementing the air operations as well as the escort operations, was of the opinion that that plan was not feasible, and that an allowance of at least one month should absolutely be taken into account. ${ }^{(11)}$ Also, the Army Department of IGHQ did not entirely agree to the [Southern Army's] plan [to complete the operation] in three months, mainly in terms of the [available] shipping tonnage of transport ships. However, in the end, owing to the strong insistence of the Southern Army headquarters, it was agreed to set [the scheduled date of] the landing on Java on "by and large around Day X +80 " (26 February) in the Tokyo Agreement, and to strive to realize this as the target date. That line was taken in the Iwakuni Agreement as well and agreed to in the same way. ${ }^{(34)}$

However, as the progress in the initial stages of the war was better than expected, the Southern Army headquarters judged it advantageous to make use of the war momentum 
and direct the operations on the concept of a strategic pursuit. Accordingly, at its staff meeting on 20 December, it decided on a plan to advance [the starting date of] the Java landing [operation] by ten days to Day X + 70 (16 February; and set the [date of] completion of the operation on Day X +90). It wired this proposal to [the Army Department of] IGHQ and also informed the Navy side of its intentions. ${ }^{(30)}$

Just then on the next day, 21 December, Hattori Takushirō, chief of the Operations Section of the Office of Army General Staff [who also belonged to the Army Department of IGHQ], and his party arrived on site [Saigon]. The Southern Army headquarters explained the plan to shorten the schedule with the proviso that in order to execute it a further increase in the allotment of ships to the Southern Army by about 150,000 tons was required. Agreeing to the plan, Section Chief Hattori personally sent a telegram to [the Army Department of] IGHQ. Based on the proposal of the Southern Army, [the Army Department of] IGHQ held meetings with the Navy and also examined [the possibility of] increasing the shipping tonnage. However in the end, on 27 December, it replied to the Southern Army that an increase in tonnage was simply impossible. ${ }^{(40)}$ Having no other choice, the Southern Army headquarters studied the means to shorten the [invasion] schedule by using [just] the ships it had under its control at that time (though loss would be replenished). After changing parts of the plan in such a way that the forces taking part in the Sixteenth Army be reduced to some extent and that the shift and transfer of [other] forces be avoided as much as possible, [the Southern Army] tentatively drew up a final draft. ${ }^{(30)}$

In the meantime, problems that needed to be discussed by the Army and Navy commanders were piling up also on the Navy side, including the situation of recent enemy reinforcements brought up from Australia (mainly by way of Port Darwin), [which led the Navy to think that] it was urgently necessary to swiftly seize the Ambon - Kupang line. Consequently, without waiting until the scheduled date of the first [Army-Navy] meeting which was set on Day X + 40 (17 January) in the Tokyo Agreement, the Southern Army and the Navy Southern Task Force summoned the staff officers of the relevant units under their command to Cam Ranh Bay on 29 December, to discuss matters on the flagship of the Second Fleet Atago, which had anchored in the bay. This was the Cam Ranh Agreement [conference].

\section{Conclusion of the Cam Ranh Agreement and the Shortening of the Invasion Schedule}

The Cam Ranh Agreement [conference] was held on the Atago on 29 December, and on 1 January 1942, the agreement was signed. Firstly, prior to the conclusion of the agreement, the operational directives for the southern operation from that time onwards were discussed and decided upon as follows: ${ }^{(30,33,34,40,62)}$

1. [The schedule of] the Dutch East Indies operation shall further be advanced from that in the former plan, and [the operation] shall be completed in three months from the opening of hostilities. That is, the Java landing [operation] shall be launched on Day $X+70$ (16 February).

2. [The schedule of] the capture of Singapore shall [also] be moved up by about one month from the anticipated date in the former plan, which was about the 100th day from the opening of hostilities. [In the new plan], the fall [of the city] is expected in the beginning of February.

3. Prior to the landing on Java, Bangka and Palembang shall be seized after bypassing Singapore as swiftly as possible. 


\section{Dutch East Indies}

4. The time to capture Ambon and Kupang shall be fixed and moved up; it shall be carried out in parallel with the capture of Celebes.

5. Taking advantage of the current war situation, the Burma operation shall be pushed forward and intensified; the northern Sumatra invasion operation shall be implemented after the fall of Singapore.

6. The starting point of the operations to seize Tarakan, Menado and Ambon shall be changed from Palau to Davao.

7. The Army's plan for operating its units

(1) Although at first the plan was to allot four divisions to the Malay Peninsula and Singapore operations, three divisions are sufficient [to do the job]. So, the diversion of the 56th Division to the Burma theater must be considered.

(2) The capture of Ambon and Kupang shall be assigned to Detachment B ([consisting of] three battalions of the 38th Division), which shall be extracted from [the unit in] Hong Kong. The South Seas Detachment (which was scheduled to join the Dutch East Indies operation after capturing Guam and Rabaul) shall henceforth not be employed for the southwestern theater.

(3) At the request of the Navy, the Kawaguchi Detachment shall carry out the [operation to] capture Ledo (which shall be explained later).

(4) Due to the [shortage of] shipping tonnage, the force of the Sixteenth Army for the Java invasion [operation] shall be slightly reduced.

8. The Navy's plan for operating its units concerned

(1) The $2 \mathrm{~d}$ Carrier Division ([consisting of] two aircraft carriers as the core) shall be employed from the time of the Ambon operation; the redeployment of the main force of the Carrier Task Force to the southern theater shall be considered at the time of invasion of Java.

(2) As the Ledo airfield, which was lately spotted, is essential for the operation against the Dutch East Indies, it is hoped that an Army unit shall swiftly seize it.

(3) A submarine base shall be set up at Penang ([off] the northwestern coast of Malaya) for operations in the Indian Ocean.

(4) In order to bring the Malacca Strait under control, one element of the land-based air units shall be advanced to the Malay Peninsula.

(5) After the capture of southern Sumatra, naval air units shall advance there in order to conduct the air campaign against Java and to cut off Malaya from its rear.

In accordance with the above general operational directives, the agreement was concluded in outline as follows: ${ }^{(34,62)}$

1. Standard dates [to implement] the invasion [operations]

\begin{tabular}{|c|c|c|c|}
\hline $\begin{array}{c}\text { Date of the start of } \\
\text { the landings }\end{array}$ & $\begin{array}{c}\text { Key areas to capture } \\
\text { (*stands for the areas } \\
\text { which the Navy will cap- } \\
\text { ture unassisted) }\end{array}$ & Assembly Point & $\begin{array}{l}\text { Commanders to conclude the arrange- } \\
\text { ments }\end{array}$ \\
\hline Day X + 33 (10 Jan) & $\begin{array}{l}\text { *Menado and Tarakan, } \\
\text { and vicinities }\end{array}$ & Davao or Jolo & \multirow{3}{*}{ Cdr in chief $3 \mathrm{~d}$ Fleet and 16th Army Cdr } \\
\hline Day $X+43$ (20 Jan) & $\begin{array}{l}\text { *Kendari and Balikpapan, } \\
\text { and vicinities }\end{array}$ & $\begin{array}{l}\text { Menado and } \\
\text { Tarakan }\end{array}$ & \\
\hline Day X + 48 (25 Jan) & Ambon & Davao & \\
\hline
\end{tabular}




\section{Dutch East Indies}

\begin{tabular}{|c|c|c|c|}
\hline Day X + 53 (30 Jan) & $\begin{array}{l}\text { *Makassar and Banjar- } \\
\text { masin, and vicinities }\end{array}$ & $\begin{array}{l}\text { Kendari and } \\
\text { Balikpapan }\end{array}$ & \\
\hline $\begin{array}{l}\text { Roughly Day X }+60 \\
(6 \mathrm{Feb})\end{array}$ & $\begin{array}{l}\text { Bangka and Palembang } \\
\text { [and vicinities] }\end{array}$ & Cam Ranh & $\begin{array}{l}\text { Cdr in chief Southern Expeditionary Fleet } \\
\text { and 16th Army Cdr }\end{array}$ \\
\hline $\begin{array}{l}\text { Roughly Day X + } 65 \\
\text { (11 Feb) }\end{array}$ & Kupang & Ambon & Cdr in chief $3 \mathrm{~d}$ Fleet and 16th Army Cdr \\
\hline $\begin{array}{l}\text { Roughly Day X + } 70 \\
\text { (16 Feb) }\end{array}$ & Java & $\begin{array}{l}\text { At Luzon for } \\
\text { eastern Java } \\
\text { At Gaoxiong for } \\
\text { western Java }\end{array}$ & Ditto \\
\hline $\begin{array}{l}\text { Roughly Day X }+80 \\
(26 \text { Feb) }\end{array}$ & Northern Sumatra & Penang & $\begin{array}{l}\text { Cdr in chief Southern Expeditionary Fleet } \\
\text { and 25th Army Cdr }\end{array}$ \\
\hline
\end{tabular}

[Particulars for] other [targets] shall be decided on in arrangements [between] the highest commanders of the Army and the Navy of each area.

2. The Army convoys to be directly escorted by the Navy
Sakaguchi Det (about 10 ships)
Davao-Tarakan-Balikpapan-Banjarmasin
Det B (about 7 ships)
Hong Kong-Davao-Ambon-Kupang
Main force of the 38th Div (about 18 ships)
Hong Kong-Cam Ranh Bay-Bangka
Main force of the 16th Army (about 50 ships) Gaoxiong-Cam Ranh Bay-western Java
48th Div (about 50 ships)
Manila-Menado-eastern Java

The characteristics of this agreement were as follows:

1. Comparison of the dates [to implement] the invasion [operations] (as in the following table):

\begin{tabular}{|c|c|c|c|c|}
\hline \multirow{2}{*}{$\begin{array}{l}\text { Key Areas } \\
\text { to capture }\end{array}$} & \multicolumn{3}{|c|}{ Comparison of Schedules } & \multirow[b]{2}{*}{ Notes } \\
\hline & $\begin{array}{c}\text { Tokyo } \\
\text { Agreement }\end{array}$ & $\begin{array}{c}\text { Iwakuni } \\
\text { Agreement }\end{array}$ & $\begin{array}{l}\text { Cam Ranh } \\
\text { Agreement }\end{array}$ & \\
\hline Menado & $\begin{array}{l}\text { Around } \\
\text { Day } X+23\end{array}$ & $\begin{array}{l}\text { Roughly at } \\
\text { the same } \\
\text { time with } \\
\text { the capture } \\
\text { of Tarakan }\end{array}$ & Day X + 33 & \multirow{3}{*}{$\begin{array}{l}\text { 1. As Davao and Jolo were captured behind schedule, } \\
\text { the launch of the Tarakan and the Menado opera- } \\
\text { tions were put off for some days so as to be } \\
\text { launched on the same day. After that, the operations } \\
\text { in eastern Borneo and eastern Celebes shall be car- } \\
\text { ried out in parallel, and the simultaneous advance } \\
\text { on the line connecting Banjarmasin and Makassar } \\
\text { shall be made } 17 \text { days before the landing on Java. } \\
\text { 2. The Army was not so willing to advance [the date } \\
\text { of] the Ambon invasion [operation], and had in } \\
\text { mind that it should be launched around Day X + 60, } \\
\text { as in the Iwakuni Agreement. However, [the Army] } \\
\text { was persuaded by the Navy, [which insisted on] }\end{array}$} \\
\hline Tarakan & $\begin{array}{l}{[\text { By] around }} \\
\text { Day X + } 25\end{array}$ & Day $X+30$ & Day X + 33 & \\
\hline Kendari & $\begin{array}{l}\text { Around } \\
\text { Day X + } 35\end{array}$ & & Day X + 43 & \\
\hline
\end{tabular}




\section{Dutch East Indies}

\begin{tabular}{|c|c|c|c|c|}
\hline Balikpapan & $\begin{array}{l}\text { Around } \\
\text { Day X }+35\end{array}$ & Day X + 35 & Day $X+43$ & \multirow{9}{*}{$\begin{array}{l}\text { moving up [the schedule], and the date was set on } \\
\text { Day X }+488^{(30)} \\
\text { 3. Because of the advance of [the operation to] capture } \\
\text { Java, [the need of] the operation to capture Bali } \\
\text { [first] automatically disappeared. } \\
\text { 4. The Army insisted that the capture of Bangka and } \\
\text { Palembang [should be scheduled] } 20 \text { days before } \\
\text { the Java operation (i.e. Day } X+50 \text { ), as an important } \\
\text { stepping stone before the landing [operation] in } \\
\text { western* Java, without waiting for the capture of } \\
\text { Singapore. However, due to the availability of es- } \\
\text { cort forces and the preparation of air bases of the } \\
\text { Navy, it was set on Day X }+60 \text {. }\end{array}$} \\
\hline Makassar & $\begin{array}{l}\text { Around } \\
\text { Day X }+45\end{array}$ & Day X + 54 & Day X + 53 & \\
\hline $\begin{array}{l}\text { Banjar- } \\
\text { masin }\end{array}$ & $\begin{array}{l}\text { By and large } \\
\text { around Day } \\
X+50\end{array}$ & Day X + 54 & Day $X+53$ & \\
\hline Ambon & $\begin{array}{l}\text { By around } \\
\text { Day } X+60\end{array}$ & Day X +60 & Day $X+48$ & \\
\hline Kupang & $\begin{array}{l}\text { By around } \\
\text { Day } X+60\end{array}$ & & $\begin{array}{l}\text { Roughly } \\
\text { Day X+65 }\end{array}$ & \\
\hline Bali & & Day $X+70$ & & \\
\hline $\begin{array}{l}\text { Bangka/ } \\
\text { Palembang }\end{array}$ & $\begin{array}{l}\text { By and large } \\
\text { around Day } \\
X+80\end{array}$ & & $\begin{array}{l}\text { Roughly } \\
\text { Day X+ } 60\end{array}$ & \\
\hline Java & $\begin{array}{l}\text { By and large } \\
\text { around Day } \\
X+80\end{array}$ & & $\begin{array}{l}\text { Roughly } \\
\text { Day X+70 }\end{array}$ & \\
\hline $\begin{array}{l}\text { Northern } \\
\text { Sumatra }\end{array}$ & & & $\begin{array}{l}\text { Roughly } \\
\text { Day X+ } 80\end{array}$ & \\
\hline
\end{tabular}

2. Employment of the units

(1) It seems that the employment of the Navy 1001 Unit (a paratrooper unit) was not yet decided. $^{(47)}$

(2) The plan was that the capture of Ambon and Kupang should be carried out with Detachment B for the Army, while [the Navy] would redeploy the 1st Kure Special Landing Force, which was then in Legaspi (in the Philippines). Although the strength of the Detachment B was decided on as two battalions as the core in the Iwakuni Agreement, it was further increased by one battalion in view of the latest enemy movements. ${ }^{(30,34)}$

(3) Although the employment of the aircraft carrier unit was not yet decided except for the $2 \mathrm{~d}$ Carrier Division's participation in [the operation to] capture Ambon, it seems to have been under consideration to employ [the aircraft carrier unit] at the time of the Java invasion operation. ${ }^{(30,40)}$

3. Changes in the assembly points

Although the assembly points of the units to capture Tarakan, Menado and Ambon were all designated as Palau in the Tokyo Agreement and the Iwakuni Agreement, they were changed to Davao in this agreement. It was because Davao was more advantageous in terms of geography and the capacity of its base..$^{(11,34)}$

* The text mistakenly has eastern Java. 


\section{Issuing the Phase-Two Plan of Operations, etc.}

\section{The Southern Task Force}

On the verge of phase-two operations, Southern Task Force Commander Vice Admiral Kondō transmitted by telegram the mission of the Dutch East Indies operation and the immediate operational directives, which were in summary as follows: ${ }^{(62)}$

1. The order to [shift to] the phase-two disposition of forces and the operational directives At 1200 on 26 December, the Southern Task Force issued the order to put in motion [the shift to] the phase-two disposition of forces by Telegraphic Order No. 35. It gave official notice of the [new] disposition of forces and disclosed the tasks of each unit.

2. The orders for the mission of the submarine operations and the setting-up of a submarine base The order was issued to incorporate the 11th Submarine Base Unit, which had been transferred to the Southern Task Force on 27 December, into the Malaya Unit, to set up a submarine base at Penang ([by] Telegraphic Order No. 39), and to designate the subsequent operational areas of the three submarine units belonging to the Southern Task Force ([also by] Telegraphic Order No. 39).

3. Present operational directives for the main body of the Southern Task Force

On 28 December, the Southern Task Force commander issued the order by Telegraphic Order No. 40, which was in summary as follows: ${ }^{(63)}$

(1) The Malaya Unit shall leave Magong on 31 December and take charge of escorting the transport of the main force of the Twenty-fifth Army and others scheduled to land in the Singora and Saigon areas in the beginning of January. The Dutch East Indies Unit shall launch the scheduled invasion [operations] of the Tarakan and Menado areas around 10 January.

(2-4) Support for the Malaya operations (Omitted by the author)

(5) The Eastern Support Unit shall leave Magong [at a time] designated by its commander, advance to [the waters] in between Palau and Mindanao around dawn of 10 January and, after supporting the operations of Unit H (the unit to conduct the Dutch East Indies operation), drop anchor at Palau.

(6) The main unit is scheduled to leave Cam Ranh Bay on 9 January and, after replenishing at Magong, depart on the 14th to advance to Palau.

[With these orders] Vice Admiral Kondō, commander of the Southern Task Force, judging that the end of the operation in the Malaya area, which he had primarily supported so far, was now in sight, showed that he meant to shift his position to the support of [the operation in] the area of the main force of the Dutch East Indies Unit, which was finally about to be launched.

\section{The [Navy] Dutch East Indies [Operation] Unit}

On 28 December, Dutch East Indies Unit Commander Vice Admiral Takahashi issued the immediate outline of the disposition of forces and the schedule. Following the 29 December agreement with the Army at Cam Ranh Bay, he issued the operation plan by way of Dutch East Indies (Philippines) Unit Order Classified No. 3 of the same date. According to the "Matsudaira documents," ${ }^{(47)}$ the main points were as follows:

Note:

1. It seems that some elements in the last part of this plan are missing [in this document]. 


\section{Dutch East Indies}

2. It would seem that this document was taken down from a copy of the operation plan of 29 December that included revisions that had been made by 5 or 6 January. (This is assumed from the scheduled date to capture Kupang, which was advanced to 5 February from 11 February, as well as from the allotment of tasks to the $2 \mathrm{~d}$ Destroyer Squadron and the 1st Base Force.)

1. The situation of enemy and friendly forces

(1) Almost all of the U.S. Pacific Fleet was destroyed in the strike at the beginning of the hostilities, and it is for the time being unlikely that the fleet will carry out a transoceanic attack with its main force.

(2) It is very likely that in the days ahead the remnants of the U.S. Asiatic Fleet and the British fleet in the East will put up defensive battles mainly in the waters of the Dutch East Indies and Australia, in league with the Dutch East Indies fleet.

(3) Although some of the U.S., British and Dutch submarines have already been lost, a major part [of the strength] still infests all areas. It is anticipated that in the days ahead more and more will go into action particularly in the Dutch East Indies waters.

(4) It seems that although most of the U.S. air units in the Philippines were destroyed, an element escaped to the Dutch East Indies and is planning a counterattack along with British and Dutch air forces.

(5) In view of the geographical features and the armaments of the Dutch East Indies, it is required to be on the alert against enemy mines [particularly] in the Java Sea as well as in the southern part of the South China Sea.

(6) The Air Unit of the Southern Task Force has already advanced a part of its force to Davao and Jolo, and is conducting operations against Area H (the Dutch East Indies). The deployment is expected to be completed by around 5 January.

(7) The $2 \mathrm{~d}$ Carrier Division (consisting of the Sōryū and the Hiryū as its core) is scheduled to be incorporated into the Air Unit of the Southern Task Force around 16 January.

(8) The 6th Submarine Squadron is conducting operations in Area H, as shown in Separate Illustration No. 2. (No separate illustrations are attached.)

(9) Our army units invading the Philippines and Malaya are steadily enlarging their military gains and charging toward Manila and Singapore respectively.

2. Mission

In accordance with the mission [stated] in Philippines Unit Operation Order Classified No. 1, the Dutch East Indies Unit shall, on the one hand, in conjunction with the Air Unit of the Southern Task Force as well as the Sixteenth Army, first seize Tarakan and Menado, and then strategic locations on the Makassar Strait, the Moluccas Sea, and the Banda Sea one after another, and push forward its attack, while on the other hand, in cooperation and in concert with the Southern Expeditionary Fleet and the Malaya Invasion Army, advance the preparations to encircle Java to swiftly attack Java at the core.

3. Outline of the operation

(1) Especially by maintaining close cooperation and coordination with the friendly air units, the attack shall be pushed forward after having as far as possible established command of the air.

(2) Powerful direct escort forces shall be deployed against the enemy's submarine warfare and mine warfare, and through a close cooperation of these [escort forces], base units and air units, it shall be made doubly sure that the surface escort and landing cover will be flawless.

(3) [Sufficient] escort forces shall be deployed so that those on site will be able to defeat the enemy surface forces. [They] shall make efforts to catch and destroy the latter in concert with powerful support units and friendly air units, which will [also] search for the enemy and attack them. 


\section{Dutch East Indies}

(4) The main purpose of the capture of strategic locations in the Dutch East Indies is to neutralize and seize important enemy air bases with the aim to advance in parallel in the east and the west roughly according to the following order and schedule:

$\{1\}$ Eastern side of Celebes and the Banda Sea

[Conducted] by the Navy [unassisted]: Menado (around 10 January) $\longrightarrow$ Kendari (around 20 January) $\longrightarrow$ Makassar (shall be seized at a favorable opportunity between 25 January and 14 February)

[Conducted] independently by the Army: Ambon (around 25 January) $\longrightarrow$ Kupang (around 5 February)

$\{2\}$ The Makassar Strait area and eastern Java

In conjunction with the Army: Tarakan (around 10 January) $\longrightarrow$ Balikpapan (around 20 January) $\longrightarrow$ Banjarmasin (around 30 January) $\longrightarrow$ Surabaya (around 16 February)

Depending on the situation, Makassar shall be seized around 5 February, and Bali shall be captured almost simultaneously with the capture of Surabaya in conjunction with the Army.

\{3\} Western Java

In conjunction with the Army: Batavia area (around 16 February)

4. The distribution of forces (as shown in the following table)

\begin{tabular}{|c|c|c|c|c|}
\hline \multicolumn{2}{|r|}{ Unit } & & Commander & Forces \\
\hline \multicolumn{2}{|c|}{ Main Unit } & \multirow{12}{*}{ 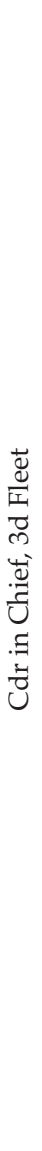 } & & 16th Cruiser Div (minus 2d Section) \\
\hline \multirow{4}{*}{ 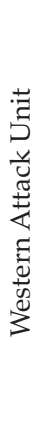 } & $\begin{array}{l}\text { 1st Escort } \\
\text { Unit }\end{array}$ & & $\begin{array}{l}\text { 4th Destroyer Sqdn } \\
\text { Cdr }\end{array}$ & $\begin{array}{l}\text { 4th Destroyer Sqdn (minus 4th Destroyer Div), one element of } \\
2 \mathrm{~d} \text { Base Force, } 2 \mathrm{~d} \text { Kure SLF (minus } 1 \text { plt), Patrol Boats Nos. } \\
36^{*}, 37 \text {, and } 38\end{array}$ \\
\hline & $\begin{array}{c}\text { 2d Base } \\
\text { Unit }\end{array}$ & & 2d Base Force Cdr & Major part of $2 \mathrm{~d}$ Base Force and the Itsukushima \\
\hline & 1st Air Unit & & $\begin{array}{l}\text { Capt of the } \\
\text { San'yo-maru }\end{array}$ & $\begin{array}{l}\text { The San'yo-maru, the Sanuki-maru, Patrol Boat No. 39, } 1 \text { plt of } \\
\text { 2d Kure SLF, the Kureha-maru, No. 3, and } 4 \text { fishing boats }\end{array}$ \\
\hline & $\begin{array}{l}\text { 3d Escort } \\
\text { Unit }\end{array}$ & & $\begin{array}{l}\text { 5th Destroyer Sqdn } \\
\qquad \text { Cdr }\end{array}$ & $\begin{array}{l}\text { 5th Destroyer Sqdn, one element of 1st Base Force, one ele- } \\
\text { ment of } 2 d \text { Base Force (after the 5th Destroyer Sqdn is re- } \\
\text { turned from the Malaya Unit) }\end{array}$ \\
\hline \multirow{4}{*}{ 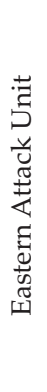 } & $\begin{array}{c}\text { Support } \\
\text { Unit }\end{array}$ & & 5th Cruiser Div Cdr & 5th Cruiser Div, 6th Destroyer Div 2d Section \\
\hline & $\begin{array}{l}\text { 2d Escort } \\
\text { Unit }\end{array}$ & & $\begin{array}{l}\text { 2d Destroyer Sqdn } \\
\text { Cdr }\end{array}$ & $\begin{array}{l}\text { 2d Destroyer Sqdn (minus } 4 \mathrm{th}^{* *} \text { and } 18 \text { th Destroyer Divs), 1st } \\
\text { Kure SLF (minus one element), Sasebo Combined SLF (minus } \\
2 \text { plts), Patrol Boats Nos. 1, 2, and } 34\end{array}$ \\
\hline & $\begin{array}{c}\text { 1st Base } \\
\text { Unit }\end{array}$ & & 1st Base Force Cdr & One element of 1st Base Force and the Nagara \\
\hline & 2d Air Unit & & $\begin{array}{l}\text { 11th Seaplane Tender } \\
\text { Div Cdr }\end{array}$ & $\begin{array}{l}\text { 11th Seaplane Tender Div, the Kiku-maru, Patrol Boat, No. 35, } 2 \\
\text { plts of Sasebo Combined SLF, some fishing boats }\end{array}$ \\
\hline \multicolumn{2}{|c|}{$\begin{array}{l}\text { Eastern } \\
\text { Philippines Unit }\end{array}$} & & $\begin{array}{l}\text { 32d Special Base } \\
\text { Force Cdr }\end{array}$ & $\begin{array}{l}\text { 32d Special Base Force, 1st Gunboat Div, 51st Subchaser Div, } 6 \\
\text { reconnaissance seaplanes, one element of 1st Kure SLF }\end{array}$ \\
\hline \multicolumn{2}{|c|}{$\begin{array}{l}\text { Western } \\
\text { Philippines Unit }\end{array}$} & & $\begin{array}{l}\text { 17th Minelayer Div } \\
\text { Cdr }\end{array}$ & $\begin{array}{l}\text { 17th Minelayer Div (minus the Itsukushima, and the Tatsumiya- } \\
\text { maru), 3d Gunboat Div, 53d Subchaser Div, the Kuma }\end{array}$ \\
\hline \multicolumn{2}{|c|}{ Attached Units } & & & 1st, 2d, 3d, 5th and 6th Construction Squads, and others \\
\hline
\end{tabular}

* The text mistakenly has 3, 16 .

** Probably a mistake, since a 4 th Destroyer Div is also mentioned in the second row, third column. 


\section{Dutch East Indies}

\section{Tasks of each unit}

(1) Main Unit

Staying on alert in Malalag Bay, it shall make a sortie, depending on the enemy situation, to Celebes and the Makassar Strait area to mainly cover the Western Attack Unit.

(2) Western Attack Unit

\{1\} 1st Escort Unit

Escorting the Sakaguchi Detachment, it shall leave Davao around 7 January, cast anchor [off] Tarakan at the waters east of Cape Batu, put ashore the detachment and capture [the place] in conjunction, secure the air base and advance the air force of the Eleventh Air Fleet.

[Then] it shall have the 2d Kure Special Landing Force replace the Army Sakaguchi Detachment and leave Tarakan around 18 January, escorting the detachment. Having suppressed the [enemy] air power, it shall put the detachment ashore in the Balikpapan area before dawn around 20 January and in conjunction seize the air base and resource locations, and then advance the air force of the Eleventh Air Fleet.

After that, having gained command of the air, it shall leave Balikpapan around 28 January, escorting one element of the Sakaguchi Detachment, enter into Banjarmasin before dawn around 30 January and seize the enemy air base. During this period, it shall keep close communication with the 1st Air Unit (seaplane tender unit), clear enemy submarines and prepare against enemy surface forces.

Separate orders shall be given when the cooperation of the 1001 Unit (a paratrooper unit) is available.

\{2\} 2d Base Unit

After making arrangements with the 1st Escort Unit commander, it shall incorporate primarily its minesweeper divisions and subchaser* divisions into the 1st Escort Unit for the period required. The remaining unit shall defend the key locations of Tarakan, Balikpapan and others, while protecting the shipping lanes, as well as escorting and covering empty Army ships.

\{3\} 1st Air Unit (a seaplane tender unit)

It shall advance its bases to places where necessary, and cooperate with the 1st Escort Unit by guarding against [enemy] submarines as well as by supporting the landing attacks.

\{4\} 3d Escort Unit

After returning to the Dutch East Indies Unit, it shall sail to Gaoxiong, from where it shall escort the main force of the Sixteenth Army, leaving Gaoxiong (Magong for one element) on 30 January to head for Cam Ranh Bay. It shall leave the bay on 11 February and put [the Army unit] ashore in Batavia and vicinity on 16 February. Cooperation by the force of the Southern Expeditionary Fleet shall be provided for one part [of the operation].

(It may [also] escort with one element the ship(s) carrying the 101st Fuel Depot.)

(3) Eastern Attack Unit

\{1\} Support Unit

While covering and supporting the [operation to] seize Menado, Kendari, Ambon, Makassar, Kupang, etc. conducted by the Eastern Attack Unit, it shall prepare against the maneuvers of enemy surface forces from the direction of Australia.

\{2\} 2d Escort Unit

Leaving Davao on 8 January, it shall seize Menado in a sudden attack before dawn on 10 January, secure and ready the air base to advance the forces of the Eleventh Air Fleet. Next, it shall have one element participate in a sudden attack on Kendari to be conducted

* The text mistakenly has destroyer. 
before dawn around 20 January under the command of the 1st Base Force commander, while covering [the operation] with the bulk of its force. After that, the unit shall escort Army Detachment B to Ambon from Menado (it is supposed to have escorted [the detachment] from Davao to Menado with one element of the 2d Escort Unit [beforehand] after the seizure of Menado), seize Ambon around 25 January and secure the airfield [there]. Then, [the unit] shall further escort Detachment B (one element of which shall be left in Ambon, depending on the situation) and make preparations to seize Kupang roughly on 5 February in conjunction with the detachment.

While keeping in contact with the $2 \mathrm{~d}$ Air Unit (seaplane tender unit), the unit shall clear enemy submarines and prepare against enemy surface forces.

Separate order(s) shall be given when the 1001 Unit is to be employed [in the relevant operations].

\{3\} 1st Base Unit

After making arrangements with the $2 \mathrm{~d}$ Escort Unit commander, it shall incorporate one element of its minesweeper divisions and subchaser divisions into the $2 \mathrm{~d}$ Escort Unit for the period required, while guarding the Bangka anchorage after the capture of Menado. Then, with the major part of the unit, and also taking command of one element of the $2 \mathrm{~d}$ Escort Unit, it shall make a sudden attack on Kendari before dawn on around 20 January under the cover of the $2 \mathrm{~d}$ Escort Unit, secure the air base [there] to advance the air forces of the Eleventh Air Fleet.

After that, it shall take charge of defending key locations and protecting the shipping lanes, mainly those to Menado.

Depending on the circumstances, it shall seize Makassar.

The incorporation of the minesweeper divisions and subchaser divisions into the $3 \mathrm{~d}$ Escort Unit at the time of the landing of the main force of the Sixteenth Army shall be arranged with the 5th Destroyer Squadron commander.

\{4\} 2d Air Unit (a seaplane tender unit)

It shall advance its bases to the points required and cooperate with the $2 \mathrm{~d}$ Escort Unit by guarding against [enemy] submarines and supporting the landing operations.

(4) Eastern Philippines Unit

It shall take charge of guarding key locations such as Davao, Legaspi, Jolo and Malalag, etc., protecting the shipping lanes in the east of the Philippines, and replenishing the naval units operating in the vicinity.

(5) Western Philippines Unit

While guarding Lingayen Gulf to secure the line of communications of the main force of the Fourteenth Army to its rear, the unit shall, depending on the situation, advance to Manila Bay to take charge of clearing and defending the bay as well as protecting the shipping lanes to the west of the Philippines.

This order differed from the outline of the disposition of forces on 28 December and from the Cam Ranh Agreement on the following points: ${ }^{(47,53,62)}$

1. The differences from the outline of the disposition of forces

Because at the end of December there was advance information that a Third Southern Expeditionary Fleet would be formed in the beginning of January to take charge of the Philippines area, the disposition of forces was altered in the following way:

(1) The 17th Minelayer Division commander shall be appointed commander of the Western Philippines Unit. The 17th Minelayer Division (minus the Itsukushima and the Tatsumiyamaru) shall be added to the unit, and 2d Base Force and one element of the 2d Signal Unit shall be removed. 


\section{Dutch East Indies}

(2) The Itsukushima shall be added to the $2 \mathrm{~d}$ Base Force, from which the mine-laying unit shall be removed.

(3) The Kuma shall be removed from the 2d Base Force, and added to the Western Philippines Unit.

[The change] that the Third Southern Expeditionary Fleet would take over the operations in the Philippines areas from the Third Fleet was meant to have the latter concentrate on its operations in the Dutch East Indies. The formation [of the new fleet] was planned as follows: The Kuma (planned as the flagship), the Yaeyama, the 31st Special Base Force, the 32d Special Base Force, the 3d Gunboat Division, the 2d Survey Unit, the Kyōdo-maru No. 36. *

For this purpose, the 17th Minelayer Division was disbanded; the commander R. Adm. Kobayashi Tetsuri and the staff of the division were transferred to the newly formed 31st Special Base Force and advanced to the Manila area. The Itsukushima and the Tatsumiya-maru of the 17th Minelayer Division were attached to the Third Fleet, while the Yaeyama was to be incorporated into the Third Southern Expeditionary Fleet.

2. The differences from the Cam Ranh Agreement

(1) Whereas in the [Cam Ranh] Agreement, the seizure of Makassar was scheduled for around 30 January with no provisos attached, in this order it was mentioned in one part that "[Makassar] shall be seized at a favorable opportunity between 25 January and 14 February by the Navy [unassisted]," and in other parts that "Depending on the situation, Makassar shall be seized around 5 February, ... in conjunction with the Army," "Depending on the circumstances, the 1st Base Force shall seize Makassar." [Consequently, the schedule of] the seizure [of Makassar] was not clearly designated as 30 January.

This was because the operations of the Eastern Attack Unit had become very tight due to the increase of lines of operations from the two that were in the initial plan of the Dutch East Indies Unit (Tarakan - Balikapan - Banjarmasin, and Menado - Kendari - Makassar) to three (the Ambon - Kupang line was added). That is to say, the destroyers of the $2 \mathrm{~d}$ Destroyer Squadron had to be transferred back and forth between the Squadron and the 1st Base Force every five days, so as to realize the two lines of attack in the east (Menado on the 10th of January, Kendari on the 20th, Ambon on the 25th, Makassar on the 30th, and Kupang on the 5th of February), which made it totally impossible to schedule [the operation to seize] Makassar on the 30th. ${ }^{(11)}$

On top of that, there were two other problems about [the operation to] seize Makassar:

$\{1\}$ It was quite dangerous to advance from Kendari to Makassar by sailing around the south of Celebes, because it meant that on their way [the ships] would expose their flank to Kupang, one of the leading air bases of the enemy at a distance of merely 300 nautical miles.

\{2\} Because Makassar was a strategic outpost of Java, it was assumed that the enemy had also deployed considerably powerful ground forces there. Although it had been decided to seize this place only with the naval landing forces, there was some concern about the strength of these landing units, if part of this force was also employed in the Ambon theater.

For these reasons the Dutch East Indies Unit seemed more strongly inclined to seize Kupang first, rather than Makassar, so that it could go to Makassar after having eliminated the concern [of being attacked] on its flank. This [feeling] was reflected in the phrase "... at a favorable opportunity between 25 January and 14 February...;" while the concern about the shortage of ground forces was expressed in the part "Depending on the situation, ... in conjunction with the Army."

In any case, the Dutch East Indies Unit was not sure that it would be able to implement [the operation to] seize Makassar precisely on 30 January. This was probably why the unit, because

* The text mistakenly has No. 3. 
of the great many uncertain elements, used rather evasive expressions, even though the schedule of the seizure was decided on in the agreements.

(2) Whereas [the operation to] capture Bali had automatically disappeared in the Cam Ranh Agreement, this order stated that "Depending on the situation, ... Bali shall be captured almost simultaneously with the capture of Surabaya" ([the capture of Bali had been scheduled] ten days prior to the capture of Java in the Iwakuni Agreement).

This reflected the demand of the Eleventh Air Fleet, which wanted to cut off Java from its rear in a most effective way by capturing Bali with a small unit (of course, solely by the Navy) simultaneously with [the capture of] Surabaya. Needless to say, since it was a landing simultaneous with the landing in the Surabaya area, it did not mean that [the Eleventh Air Fleet] intended to conduct an air campaign to destroy the enemy air power on the main island of Java from Bali. ${ }^{(20,64)}$

Although the Dutch East Indies Unit showed little enthusiasm for making a landing just like that right under the nose of Surabaya, it seems that due to the strong demand of the Eleventh Air Fleet, it tentatively expressed in the order the possibility of capturing [Bali].(11)

(3) Whereas the capture of Kupang was scheduled for Day X + 65 (11 February) in the Cam Ranh Agreement, it was [moved up to] 5 February in this order. The reason may be attributed to the strong desire of the Navy to capture Kupang as soon as possible in order to [safely] advance to Makassar as well as to neutralize [the threat from] Australia. It seems that because the Eleventh Air Fleet was particularly adamant about capturing the Ambon - Kupang line, the Third Fleet as well moved up the date, following the demand [of the Eleventh Air Fleet]. ${ }^{(20)}$ (The change [of schedule] was made around 5-6 January.)

\section{The Air Unit (See Illustration No. 1)}

When [the order to shift to] phase-two dispositions was put into effect on 26 December, the Air Unit of the Southern Task Force, with some elements advancing to Davao and Jolo, were shifting to their positions for the launch of the Dutch East Indies operation. However, the condition of the airfields in Davao and Jolo was unexpectedly bad (the ground of [the airfield in] Davao was soft, and frequent squalls hindered the progress of the rolling of the apron, while [the airfield in] Jolo had a large inclination and the field undulated), ${ }^{(54)}$ which meant that the immediate deployment of all forces was impossible. On the other hand, the air operations in the Malaya area had progressed smoothly, and it became unnecessary to conduct operations from Miri and Kuching ([in] British Borneo) to Malaya. Therefore, on the grounds that the operation plan needed to be reexamined and the like, the unit obtained the prior approval of the Combined Fleet and the Second Fleet headquarters and postponed putting in motion its shift to phase-two dispositions until 2 January. ${ }^{(12)}$

In the meantime, V. Adm. Tsukahara Nishizō, commander of the Air Unit, had not only launched the Dutch East Indies operation with the part of the forces that had been advanced to the southern Philippines, but also accelerated the construction work at the Davao and Jolo bases and the deployment of his forces, while at the same time striving to clear the remnants of the enemy forces in the Philippines with his main force. Meanwhile, the deployment of forces for the operations in the Malaya area from British Borneo had become unnecessary, and no reinforcements needed to be brought to Kuching and Miri from the east. Therefore, he made changes in the operational plan and offered his opinion to step up [the operation to] seize Ambon, which he had put on hold due to a lack of strength; it was decided to seize the place in late January. ${ }^{(58)}$ 


\section{Dutch East Indies}

On 2 January, Air Unit Commander Vice Admiral Tsukahara transmitted [the order to] put in motion the shift to phase-two dispositions by way of Telegraphic Operation Order No. 19. The outline of the Air Unit's operation plan at that moment was as follows: ${ }^{(54)}$

1. Each air raid unit commander shall engage in the assigned operations in conformity with the phase-two disposition of forces, unless otherwise ordered by separate orders.

2. Support for the invasion operation in the Dutch East Indies areas shall be implemented according to [the directives of] the operational area of each air raid unit as shown separately.

3. The operational border of the 1 st and the $2 \mathrm{~d}$ Air Raid Units has been tentatively decided on as the line of $122^{\circ} \mathrm{E}$.

4. Phase-two disposition of forces (inferred) (as shown in the following table)

\begin{tabular}{|c|c|c|c|c|c|}
\hline \multicolumn{2}{|r|}{ Unit } & \multicolumn{2}{|r|}{ Commander } & Force & Main Tasks \\
\hline \multirow{3}{*}{ 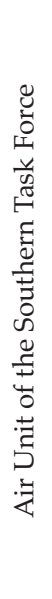 } & 1st Air Raid Unit & \multirow{3}{*}{ 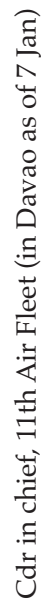 } & $\begin{array}{l}\text { Cdr, 21st Air Flotilla } \\
\text { (in Davao as of } 27 \mathrm{Dec} \text { ) }\end{array}$ & $\begin{array}{l}\text { Kanoya Air Gp Det, } \\
\text { Tōkō Air Gp, 1st and } \\
\text { 3d Air Gps, 1st Yoko- } \\
\text { suka SLF }\end{array}$ & $\begin{array}{l}\text { Support for the East- } \\
\text { ern Attack Unit (to } \\
\text { seize Menado, } \\
\text { Kendari, Ambon, } \\
\text { Makassar, Kupang, } \\
\text { and Bali) }\end{array}$ \\
\hline & 2d Air Raid Unit & & $\begin{array}{l}\text { Cdr, 23d Air Flotilla } \\
\text { (in Jolo as of } 3 \text { Jan) }\end{array}$ & $\begin{array}{l}\text { Takao Air Gp, Tainan } \\
\text { Air Gp, 3d Yokosuka } \\
\text { SLF }\end{array}$ & $\begin{array}{l}\text { Support for the West- } \\
\text { ern Attack Unit (to } \\
\text { seize Tarakan, Balikpa- } \\
\text { pan and Banjarmasin) }\end{array}$ \\
\hline & $\begin{array}{c}\text { Carrier-based } \\
\text { Air Unit }\end{array}$ & & Cdr, 2d Carrier Div & $\begin{array}{l}\text { The Sōry } \bar{u} \text {, the Hiry } \bar{u} \text {, } \\
\text { 7th Destroyer Div, 27th } \\
\text { Destroyer Div 2d Sec- } \\
\text { tion }\end{array}$ & $\begin{array}{l}\text { Support for [the opera- } \\
\text { tion to] capture } \\
\text { Ambon }\end{array}$ \\
\hline
\end{tabular}

Note: The 2d Carrier Division was supposed to advance to Davao on 17 January

5. The invasion [operation] shall be scheduled as follows:

Menado on 10 January, Kendari on 20 January, Ambon on 25 January, Makassar on 30 January (on the 28th, depending on the situation), Kupang on 5 February, Bali on 11 February, Tarakan on 10 January (on the 11th, depending on the situation), Balikpapan on 20 January, Banjarmasin on 30 January, Palembang during 1 to 6 February, Surabaya and Batavia on 16 February.

6. When the operations in the Malaya area are largely completed and the Dutch East Indies operation is about to be launched, the forces under the command of the 22d Air Flotilla (which had been transferred to the Malaya Unit) shall return to the Air Unit except for one element, and participate in the air campaign against the Dutch East Indies from Ledo and Palembang as the 3d Air Raid Unit.

The situation of the Air Unit's shift of its bases is as shown in Illustration No. 1.

\section{The Submarine Unit}

At the time of the shift to phase-two disposition of forces put into effect on 26 December, Southern Task Force Commander Vice Admiral Kondō removed the 5th Submarine Squadron from the Malaya Unit to form Submarine Unit B as the submarine unit under the direct com- 


\section{Dutch East Indies}

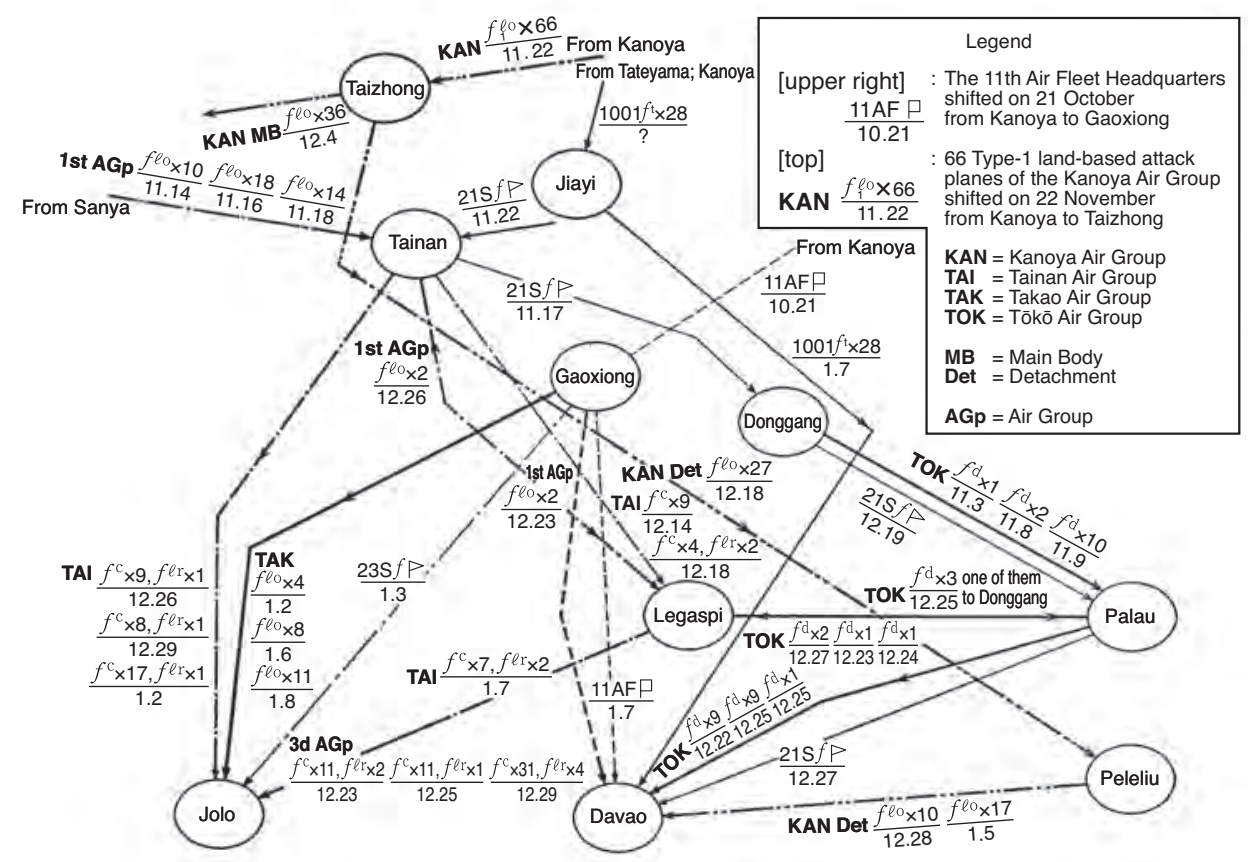

Illustration No. 1 - The Shift of the Bases of the Air Units

mand of the Southern Task Force, and also formed Submarine Unit A with the 6th Submarine Squadron. ${ }^{(65)}$

On the same day, Southern Task Force Commander Vice Admiral Kondō transmitted the tasks of phase-two operations to each unit by Telegraphic Order No. 35. Although the contents of the telegraphic order are unclear, they are roughly assumed to have been as follows: ${ }^{(60)}$

Submarine Unit A (6th Submarine Squadron)

1. To search for and attack enemy war vessels and disrupt [enemy] shipping lanes in the Banda

Sea, the Flores Sea and the waters north of Australia, in concert with the operations of the Dutch

East Indies Unit

2. To observe the strategic locations of the enemy and lay mines

Submarine Unit B (5th Submarine Squadron)

1. To advance into the Indian Ocean and disrupt [enemy] shipping lanes

2. To sever the [enemy] submarine cables between the Dutch East Indies and Australia

Following this, on 28 December, the operational areas and the immediate operational directives of each submarine unit were transmitted by Telegraphic Order No. 39, a summary of which was as follows: ${ }^{(63)}$

1. The operational areas of the submarine units shall roughly be divided as follows: 


\section{Dutch East Indies}

(1) Submarine Unit A (6th Submarine Squadron)

The waters of the Dutch East Indies, Australia and the Indian Ocean east of $117^{\circ} \mathrm{E}$

(2) Submarine Unit of the Malaya Unit (4th Submarine Squadron)

The South China Sea, the Java Sea and the Indian Ocean west of $117^{\circ} \mathrm{E}$ and east of $106^{\circ} \mathrm{E}$

(3) Submarine Unit B (5th Submarine Squadron)

The Indian Ocean west of $106^{\circ} \mathrm{E}$

2. The submarines of the Submarine Unit B shall advance into the Indian Ocean as soon as replenishment and repair at Cam Ranh Bay is completed and engage in the tasks assigned in Southern Task Force Telegraphic Operation Order No. 30 when the submarine base at Penang is ready.

3. The submarines of the Submarine Unit A shall advance to the assigned waters as soon as replenishment at Davao is completed and engage in the tasks assigned in Telegraphic Operation Order No. 30. However, they shall be careful to carry out mine warfare [only] in the waters of Australia.

\section{The Army Units}

After concluding the Iwakuni Agreement, the Sixteenth Army worked out its plan of operations in Tokyo. The initial employment plan of its forces was roughly as follows: ${ }^{(66)}$

1. The Sakaguchi Detachment ([consisting of] three battalions as the core)

For Tarakan, [and later] Balikpapan and Samarinda

One battalion for Banjarmasin and half a battalion for Bali

2. The 38th Division

Main force for Southern Sumatra; one element for western Java

Detachment B ([consisting of] two battalions as the core) for Ambon and Kupang

3. The $2 \mathrm{~d}$ Division and a major part of the units under the direct control of the army

For western Java

4. The 48th Division

For eastern Java

5. The South Seas Detachment

For western Java; depending on the situation, for Ambon and Kupang instead of Detachment

B

After intercommunication with the Southern Army in late December and the [conclusion of the] Cam Ranh Agreement, the [above] plan was modified in the following way:

1. The South Seas Detachment shall not be employed in the operations in the southwestern theater.

2. The force to be employed in the capture of Ambon and Kupang shall be increased.

3. The force to be employed in the capture of Java shall be slightly reduced.

This modification changed the operational concept of the Sixteenth Army as of the end of December in the following way:

1. The Sakaguchi Detachment shall capture Tarakan, Balikpapan and Samarinda as [previously] planned, and [also] capture Banjarmasin with the strength of one battalion as its core.

2. The 38th Division shall be divided into the following three units:

(1) Main force ([consisting of] four battalions as the core) for the occupation of the oil [producing] areas in Palembang and the preparation of the air base(s). 


\section{Dutch East Indies}

(2) Detachment B ([consisting of] three battalions as the core) for capturing Ambon and Kupang.

(3) One element ([consisting of] two battalions as the core) for the landing in western Java along with the main force of the army.

3. The main force of the army that is to land in western Java ([i.e.] the $2 \mathrm{~d}$ Division, one element of the 38th Division and a major part of the units under the direct control of the army) shall assemble in Gaoxiong, while the 48th Division that is to land in eastern Java shall assemble in Manila after capturing the place.

4. In [the operation to] capture Java, landings in eastern and western [Java] shall generally be carried out in concert. Batavia and Surabaya shall swiftly be seized, after which Bandung, the base of operations of the Dutch East Indies Army, shall be seized.

On 25 December, the Sixteenth Army commander decided to advance the command post of the army to Saigon, leaving Tokyo on the 29th of the month. Then on the 27th, he instructed the $2 \mathrm{~d}$ Division and the units under the direct control of the army to assemble in Gaoxiong and prepare for the coming operations.

\section{The Preparations of All Units Move Ahead}

The situation of each unit from the time of the shift to phase-two dispositions of 26 December to the launch of the Dutch East Indies operation developed as follows: ${ }^{(53,57,62,63)}$

\section{The Operational Directives of the Southern Task Force Commander and the Situation of the Main Body of the Southern Task Force}

26 December: [The Southern Task Force commander] issued the order to shift to phase-two dispositions and assigned the tasks of phase-two operations to each unit (Telegraphic Order No. 35)

27 December: Based on reports from the air units that had been searching for the enemy for days in succession, the Southern Task Force commander made the personal judgment that a large scale escape of U.S.-Filipino units was imminent. He disposed the forces so as to catch and destroy them. (Telegraphic order No. 37; there was actually no evacuation of large units.)

[He also] issued an order to the Malaya Unit to set up a submarine base in Penang and incorporated the 11th Submarine Base Unit into the Malaya Unit as of the 28th. (Telegraphic Order No. 38)

28 December: [The Southern Task Force commander] decided on the operational areas of the 4 th, the 5th and the 6th Submarine Squadrons, and gave immediate operational directives to the 5th and the 6th Submarine Squadrons, which were under his direct command. (Telegraphic Order No. 39)

[He also] informed the Malaya Unit and the Dutch East Indies Unit of the outline of their phase-two operations and gave directions to the main body of the Southern Task Force as to the schedule of its advance to Palau. (Telegraphic Order No. 40)

29 December: The Cam Ranh Agreement [conference] was held.

30 December: [The Southern Task Force commander] gave directions to remove the 8th Destroyer Division (minus the $2 \mathrm{~d}$ Section) from the Malaya Unit and incorporate it into the Dutch East Indies Unit as of 3 January, and to have it escort the seven ships carrying the Ambon invasion unit of the 38th Division due to leave Hong Kong on 8 January for Davao. [He also] issued an order to remove the $2 \mathrm{~d}$ Section of the 8th Destroyer Division from the 


\section{Dutch East Indies}

Malaya Unit as of 6 January to return to the main body [of the Southern Task Force]. (Telegraphic order No. 41)

31 December: Upon the request of the 2d Destroyer Squadron commander (in Davao), [the Southern Task Force commander] ordered the repair vessel Akashi, which had advanced to Palau from the time of the opening of hostilities to primarily take charge of repairing vessels of the Philippines Unit, to [further] advance to Davao. (Telegraphic order No. 43)

1 January 1942: The Cam Ranh Agreement was officially concluded.

Upon the request of the Malaya Unit commander, [the Southern Task Force commander] removed the 4th Carrier Division (minus the $2 \mathrm{~d}$ Section) from the main body [of the Southern Task Force] and attached it to the Malaya Unit as of 3 January.

[He] also decided to remove the auxiliary torpedo boat tender Kamikaze-maru from the main body as of the same day, 3 January, to incorporate it into the Dutch East Indies Unit and assign it a supply mission between homeland Japan and Davao.

4 January: Along with the formation of the Third Southern Expeditionary Fleet, [the Southern Task Force commander] issued the change(s) in the disposition of forces as of 3 January. (Telegraphic order No. 48)

[He] decided on the areas where the Dutch East Indies Unit and the Philippines Unit were respectively responsible for protecting the shipping lanes. (Telegraphic order No. 49; contents omitted [by the author].)

[He also] issued an order to Submarine Unit A to lay mines around Port Darwin (the operational base of the United States and Australia for sending reinforcements to the Dutch East Indies theater). (Telegraphic order No. 50)

[He also] disclosed the schedule of the movements of the main unit of the main body of the Southern Task Force (to leave Cam Ranh Bay on 8 January to sail to Magong, and leave Magong on the 14th to advance to Palau). Along with the above, [he] also issued an order to add the $2 \mathrm{~d}$ Section of the 8 th Destroyer Division to the escort [forces] of the Ambon invasion unit of the 38th Division, and to remove the 5th Destroyer Squadron from the Malaya Unit between 9 and 12 January, so as to incorporate it into the Dutch East Indies unit. (Telegraphic order No. 51)

8 January: [The Southern Task Force commander] issued an order to form a carrier-based air unit with the 2d Carrier Division (minus the 23d Destroyer Division), the 7th Destroyer Division and the $2 \mathrm{~d}$ Section of the 27th Destroyer Division. As its main task, he assigned it the destruction of the enemy air power and naval vessels in the eastern part of the Dutch East Indies and the support of the Ambon invasion operation; their operational directives he assigned to the air unit commander. (Telegraphic order No. 55)

\section{The Operational Directives of the Dutch East Indies Unit Commander and the Movements of the Units of the Dutch East Indies Unit}

Prior to this, on 19 December, the Philippines (Dutch East Indies) Unit Commander Vice Admiral Takahashi had directed all units to advance to Davao, the assembly point for launching the Dutch East Indies operation. As Davao was captured behind schedule, the Dutch East Indies operation was expected to be launched roughly around 10 January. Accordingly, as the [Army] invasion units were scheduled to leave Davao on 7 to 8 January, the units [of the Dutch East Indies Unit] were scheduled to assemble in Davao by 4 to 5 January. The Dutch East Indies Unit commander was also scheduled to advance to Davao on 2 January on the Ashigara. ${ }^{(53,62)}$ 
27 - 28 December: Although he was in the middle of [working out] an agreement with the Southern Army at that moment, Dutch East Indies Unit Commander Vice Admiral Takahashi issued the outline of the disposition of forces to the units under his command so as to get across the concept of the immediate operations. He also informed them that the Dutch East Indies operation would be launched around 10 January, that he would leave Gaoxiong on 2 January and advance to Davao on the 6th. (Although the advance to Davao had been scheduled for the $2 \mathrm{~d}$, it was delayed due to the huge backlog of matters to be discussed with the Sixteenth Army headquarters.)

29 December - 2 January: [The unit] provided escort at sea centering on Davao, the main tasks of which were as follows.

1. Escort for transport ships carrying invasion units and others, advancing from Palau to Davao.

2. Escort for transport ships returning from Davao to Taiwan.

3. Escort for transport ships sailing from Taiwan to Davao.

27 December - 7 January: As the senior commander on site in Davao, 2d Destroyer Squadron Commander R. Adm. Tanaka Raizō was in charge of designating the anchorages for the advancing units as well as guarding Davao Gulf until 30 December. On the 27th, he offered his opinion to the chief of staff of the Third Fleet that the anchorages were limited in area and in many ways difficult to defend against air raids, and that [the location] had to be reconsidered because of the recently frequent air raids.

Note: Davao Gulf was impossible [to guard] by setting antisubmarine nets or laying mines due to its depth. [Moreover,] as the anchorage did not have the capacity for large units and the wide mouth of the bay allowed [enemy] submarines to easily enter the bay, it was not particularly suitable for a base. Malalag Bay had a narrow entrance and was safer against [enemy] submarines, but raised concerns in terms of antiaircraft [defense]. Other than these bays, there were places with a suitable depth for anchorage in the waters west of Samal Island and in Magnaga Bay, but because they were exposed to the open sea, they raised concerns in terms of antisubmarine [defense].

On 30 December, the 5th Cruiser Division arrived in Davao, and Division Commander R. Adm. Takagi Takeo became the senior commander on site. On 31 December, the commander gave instructions on the main points of guarding the bay to the units there, the contents of which were roughly as follows:

1. Two destroyers of the $2 \mathrm{~d}$ Destroyer Squadron shall patrol the entrance of Davao Gulf at night. When the 4th Destroyer Squadron arrives on 2 January, the former and two destroyers of the latter shall take turns to continuously patrol the entrance of the bay.

2. One each of the reconnaissance seaplanes of the [cruisers of] the 5th Cruiser Division and of the Jintsu $\bar{u}$ and the Naka shall take turns to continuously carry out antisubmarine patrols at the entrance of the bay during daytime. (The reconnaissance seaplane unit of the $32 \mathrm{~d}$ Special

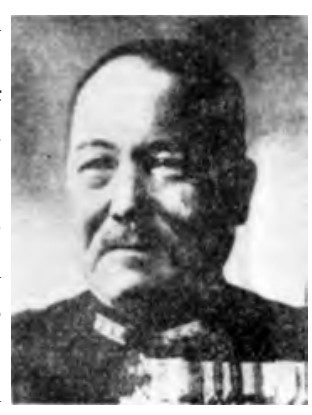

5th Cruiser Division Commander R. Adm. Takagi Takeo Base Force shall cooperate in the [patrols].)

3. The 11th Seaplane Tender Division shall keep guard in the air above the anchorage during daytime with its observation seaplanes, as designated by the 11th Seaplane Tender Division commander. (The fighter planes of the Eleventh Air Fleet, which have already advanced to Davao, shall cooperate in this [guarding].)

4. When the strength of the 1st Base Force arrives in Davao on 2 January, it shall patrol the waters south of Samal Island with a minesweeper or a submarine chaser around the clock and provide guard for the anchorages of Davao and Samal Island. The outline of these protective measures is as shown in Illustration No. 2. 


\section{Dutch East Indies}

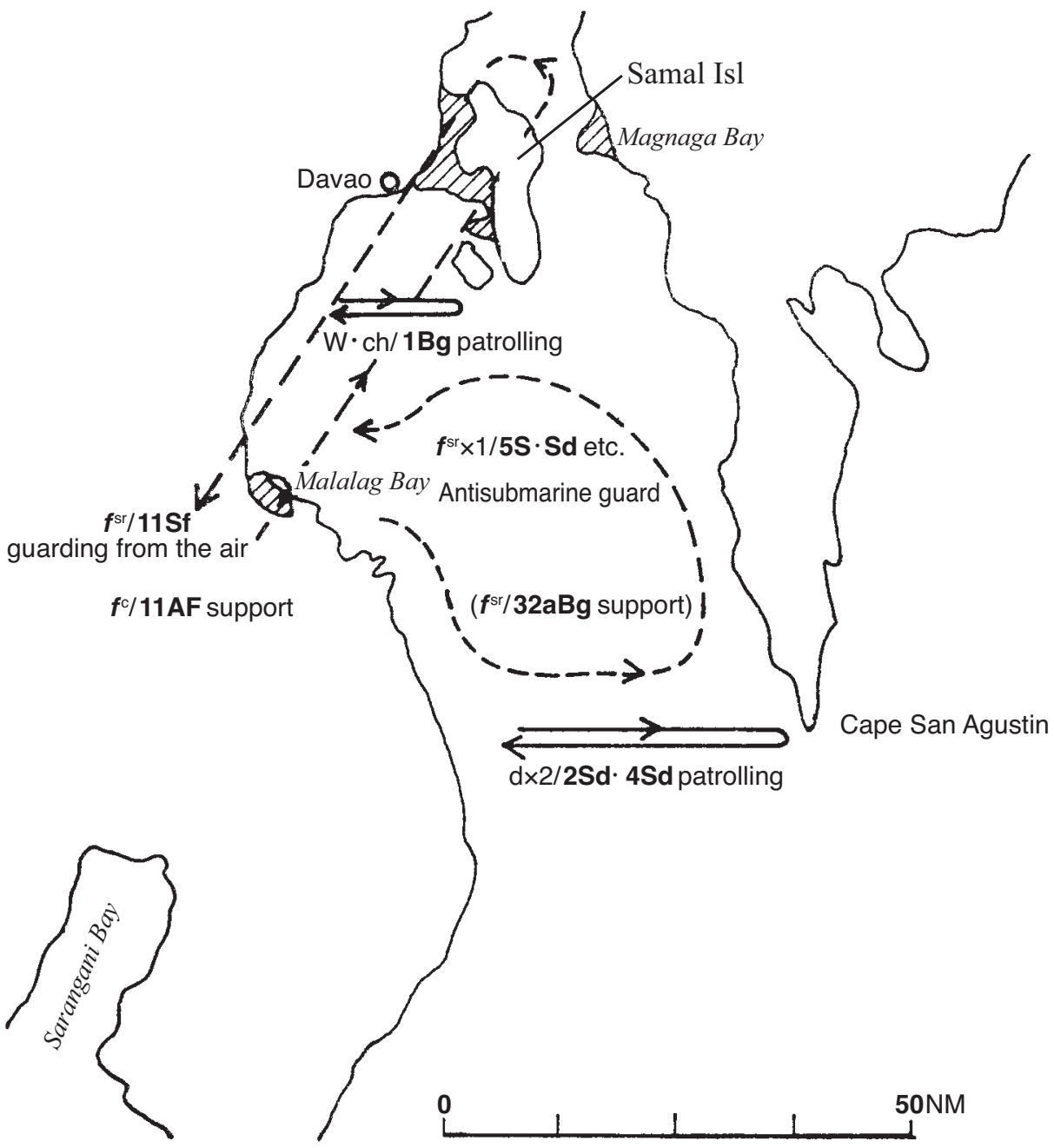

Illustration No. 2 - Outline of the Guarding of the Anchorages in Davao Gulf

30 December -8 January: The employment plan of the special landing forces of the Dutch East Indies Unit was as follows: ${ }^{(47,53,67,68)}$

[For] Tarakan and Balikpapan: the 2d Kure Special Landing Force

[For] the Menado, Kendari and Makassar areas: the Combined Special Landing Force of the Sasebo Naval Station (consisting of the 1st and the $2 \mathrm{~d}$ Sasebo Special Landing Force)

[For] the Ambon and Kupang areas: the main force of the 1st Kure Special Landing Force (one element of it was to be left in the Philippines) and one element of the Sasebo Combined Special Landing Force

When phase-two operations were put in motion, the Sasebo Combined Special Landing Force and the $2 \mathrm{~d}$ Kure Special Landing Force had already advanced as far as to Palau and they only needed to advance to Davao, which was no problem. However, the main force of the 1st Kure Special Landing Force was still in Legaspi, engaging in the operation to clear [the enemy] in the vicinity, while one element of its strength was clearing [the enemy] in Jolo. Dutch East Indies Commander Vice Admiral Takahashi gave instructions to the 1st 


\section{Dutch East Indies}

Kure Special Landing Force regarding its operational schedule in order to arrange its deployment so that it would be able to advance to Davao for the Ambon invasion [operation]. The advance of the 1st Kure Special Landing Force was [further] delayed due to the allocation of ships [for the transfer of the force], and the Dutch East Indies Unit commander exerted pressure to allocate ships. In the end, the force left Legaspi on 14 January and advanced to Menado, while the other special landing forces left Palau on 1 January and advanced to Davao on the 4 th.

30 December -6 January: The employment plan of the construction squads of the Dutch East Indies Unit was as follows. ${ }^{(53)}$

1st Construction Squad: Legaspi $\longrightarrow$ Kendari

2d Construction Squad: Davao $\longrightarrow$ Balikpapan

3d Construction Squad: Jolo $\longrightarrow$ Makassar

5th Construction Squad: Tarakan

6th Construction Squad: Menado

Although [squads to be employed for the invasion of] Ambon and Kupang were not yet decided, it seems that the plan was to employ the 5th and/or the 6th Construction Squads. However, because it was decided in the Cam Ranh Agreement that the Ambon - Kupang line should also be captured in tandem, the employment plan was changed so as to make full use of the construction squads on hand, by moving them at an interval of about twenty to thirty days.

1st Construction Squad: Legaspi at that time $\longrightarrow$ Ambon [from] 25 January

2d Construction Squad: Davao at that time $\longrightarrow$ Balikpapan [from] 20 January

3d Construction Squad: Jolo at that time $\longrightarrow$ Makassar [from] 30 January

5th Construction Squad: Palau at that time $\longrightarrow$ Tarakan [from] 10 January $\longrightarrow$ Kupang [from] 30 January

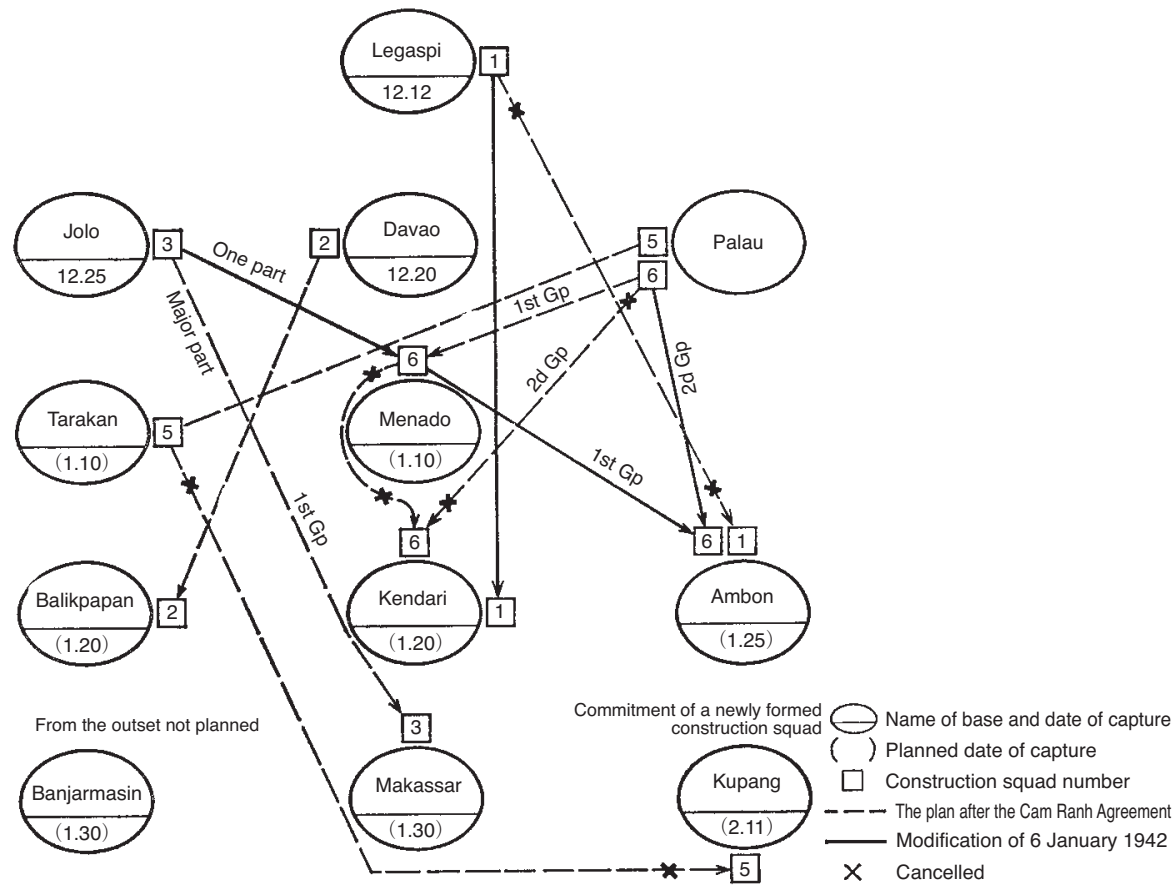

Illustration No. 3 - The Employment Plan of the Construction Squads After the Cam Ranh Agreement 


\section{Dutch East Indies}

6th Construction Squad: Palau at that time $\longrightarrow$ Menado [from] 10 January for the 1st group and Kendari [from] 20 January for the $2 \mathrm{~d}$ group

While the preparations for the Dutch East Indies operation progressed, it became clear that the conditions at the Legaspi, Davao and Jolo bases, which had been seized and were being prepared, were worse than expected, and that the preparation would require more days than planned. Moreover, the vessels for redeploying the construction squad(s) were delayed in reaching their actual locations. Therefore, on 6 January, the Dutch East Indies Unit commander once again changed the employment plan of the construction squads as follows, and requested central command to form another construction squad and assign it to him. 1st Construction Squad: [deployment to] Ambon cancelled; to Kendari [instead]

$2 \mathrm{~d}$ Construction Squad: [to be deployed to] Balikpapan as in the former plan

$3 \mathrm{~d}$ Construction Squad: [to be deployed] as in the former plan for the main force; one element

[to be deployed] to Menado

5th Construction Squad: [deployment to] Kupang cancelled

6th Construction Squad 1st group: [to be deployed to] Menado as in the former plan

6th Construction Squad 2d group: [deployment] changed from Kendari to Ambon

New Construction Squad: [to be deployed] to Kupang

These changes can be illustrated as in the diagram above. [Illustration No. 3]

On 9 January, a reply with the following gist came from the chief of the Naval Affairs Bureau; the result was that the request to form a new construction squad and assign it to the unit was realized.

1. For the present, the Kupang base shall be quickly made ready for use with the aim to accommodate 27 fighter planes.

(1) The 9th Construction Squad ([consisting of] about 1,000 men including engineers) shall be formed in the homeland [Japan] as of 15 January and attached to the Third Fleet.

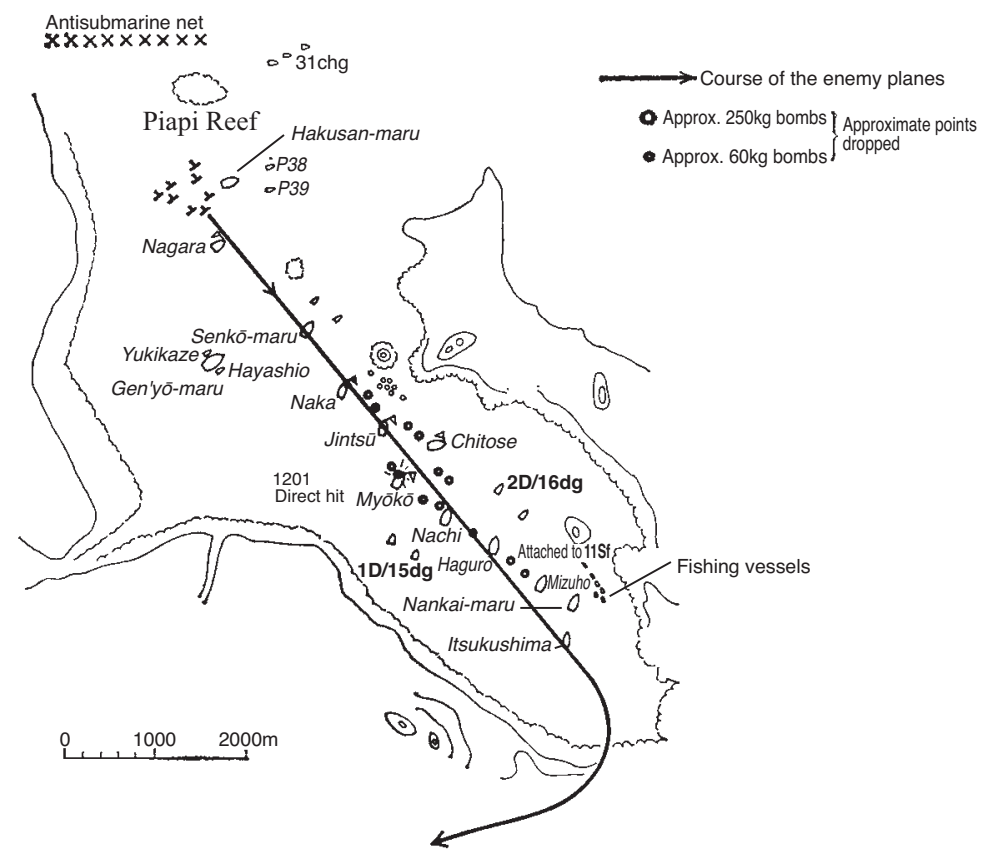

Illustration No. 4 - Outline of the [Enemy] Air Strikes [on the Anchorage] at Malalag Bay

(at 1200, 4 January 1942) 


\section{Dutch East Indies}

(2) It shall advance to Davao by 20 January carrying a minimum load of matériel with it.

2. Then the base shall be made ready step by step so that it can accommodate large units of land-based attack planes.

(1) The personnel shall be successively increased from other squads on site.

The required amount of matériel is in preparation.

25 December - 6 January: Phase-one of the Philippines operation ended with the capture of Jolo on 25 December, and the bulk of the Philippines Unit was shifted to the Dutch East Indies Unit. From the next day, the 26th, onwards, the unit shifted its position so as to advance to Davao. On 6 January, the Ashigara, with the Dutch East Indies Unit commander on board, also advanced to Davao, completing the advance of almost all of its forces to Davao.

4 January: At 1155, the warships and other vessels at anchor in Malalag Bay came under attack of eight B-17s of the enemy. A bomb hit the port side of the front deck of the Myōko (the flagship of the 5th Cruiser Division) with the senior commander on site on board. The ship sustained the loss of twenty men and more than forty men injured, as well as considerable damage on her hull. Rear Admiral Takagi, commander of the 5th Cruiser Division, was also knocked down on the front deck by the bomb blast and suffered minor injuries. ${ }^{(57,69)}$ (See Illustration No. 4)

At that time, the Davao airfield was swamped by heavy rain day after day, and no patrols by fighter planes around the bay were carried out. Moreover, because concern about [enemy] air raids conducted from the Philippines had almost gone, which had lessened the attention to antiaircraft [precautions], the enemy aircraft was spotted too late. On the Myōkō, the bomb hit the front deck packed with gunners of the main gun, who were trying to get into the turret in order to take up their positions, and caused many casualties. The fact that the ship with the senior commander on site on board was damaged and had to leave the line of battle when the Dutch East Indies operation was about to be launched, and that it had even failed to mount an effective counterattack, was a great shock to the Dutch East Indies Unit.

Commander Takagi of the 5th Cruiser Division changed his flagship to the Nachi and sent the Myōkō to Magong (later it was changed to Sasebo) for repair, while requesting a tightening of the guard by the fighter planes of the 21st Air Flotilla. Also, it was decided that from the 5th onwards, each unit should move around in the bay by day, and break up [in small groups] and ride at anchor at different anchorages by night.

5 January: A strategy meeting of the Dutch East Indies Unit was held in Davao, and the following was decided upon: ${ }^{(53,70)}$

1. The schedule of the Dutch East Indies invasion operation shall be postponed by one day, and [in line with the postponement] arrangements shall be made with the Sixteenth Army. The reasons for the postponement were as follows:

(1) The delay in the preparation of air bases hindered the progress in gaining command of the air.

(2) The allotted transport ships for redeploying the special landing forces and the construction squads (the 6th Construction Squad in particular) had been operating behind schedule.

(3) The advance of one element of the $2 \mathrm{~d}$ Base Force to Davao, which would be employed for the capture of Tarakan, had been delayed.

2. The 1st Yokosuka Special Landing Force (a paratrooper unit) shall be employed in the capture of Menado. Particulars need to be arranged concerning its drop at the airfield in concert with the Sasebo Combined Special Landing Force of the 2d Escort Unit.

3. The employment plan of the construction squads shall be finalized, and an opinion shall be offered to central command that the newly formed construction squad be allotted to Kupang (as described previously). 


\section{Dutch East Indies}

4. In view of the two lines of attack in the east, it was decided that the responsibility of capturing [the following locations] should fall on the following [units]:

Menado: the 2d Destroyer Squadron, one element of the 1st Base Force, the Sasebo Combined Special Landing Force, and the 1st Yokosuka Special Landing Force

Kendari: the 1st Base Force, one element of the 2d Destroyer Squadron, the major part of the Sasebo Combined Special Landing Force

Ambon: the $2 \mathrm{~d}$ Destroyer Squadron, one element of the 1st Base Force, the major part of the 1st Kure Special Landing Force

The 1st Base Force and the 2d Destroyer Squadron shall respectively take charge of the capture of Makassar and Kupang.

29 December - 6 January: In conformity with the Cam Ranh Agreement [draft] of 29 December, the Third Fleet and the Sixteenth Army had made a preliminary arrangement at Gaoxiong, and the arrangement was officially concluded on 6 January. It was called the 1st Takao [Gaoxiong] Arrangement, the main points of which were as follows. ${ }^{(53)}$

1. Army Detachment B ([i.e.] the Itō Detachment in four transport ships; note: [in] seven [transport ships] in the Cam Ranh Agreement) shall leave Hong Kong on 12 January under the escort of the 1st Section of the 8th Destroyer Division and reach Davao on 18 January. From there, escorted by a force [consisting of] the $2 \mathrm{~d}$ Destroyer Squadron as the core, it shall capture Ambon and Kupang respectively on 25 January and 5 February.

2. The Sakaguchi Detachment shall be escorted by a force [consisting of] the 4th Destroyer Squadron as the core and seize Tarakan, Balikpapan and Banjarmasin, which are respectively scheduled for 11, 21 and 31 January.

3. The main force of the Sixteenth Army shall assemble in Gaoxiong between 29 January and 5 February, and land in Batavia and vicinity around 16 February, escorted by a force [consisting of] the 5th Destroyer Squadron as the core. The detailed arrangements concerning the landings shall be made between the 5th Destroyer Squadron commander and the Sixteenth Army commander on 26 January at Gaoxiong.

4. The 48th Division shall be escorted by a force [consisting of] the 4th Destroyer Squadron as the core. It shall leave Manila on 7 February and land in Surabaya and vicinity around 16 February. The detailed arrangements shall be made between the 4th Destroyer Squadron commander and the 48th Division commander in Manila on 4 February.

If the above arrangements as well as the results of the strategy meeting are put together, the outline of the operation plan of the Dutch East Indies Unit commander before the Dutch East Indies operation was [actually] put in motion (on 7 January 1942) was as shown in Illustration No. 5.

6- 7 January: The Dutch East Indies Unit commander assigned the following tasks to the units concerned: ${ }^{(53)}$

1. He ordered the $2 \mathrm{~d}$ Gunboat Division to guard Jolo and the Itsukushima to lay a mine barrier at the eastern entrance of the Bangka anchorage (north of Menado) after capturing Menado.

2. He ordered the 8th Destroyer Division (with its 2d Section added) to escort the Army Itō Detachment's transfer from Hong Kong to Davao.

3. He arranged the deployment for a rescue operation at the time of the attack on Ambon from the 6th to the 7th by large flying boat units and land-based attack plane units. 


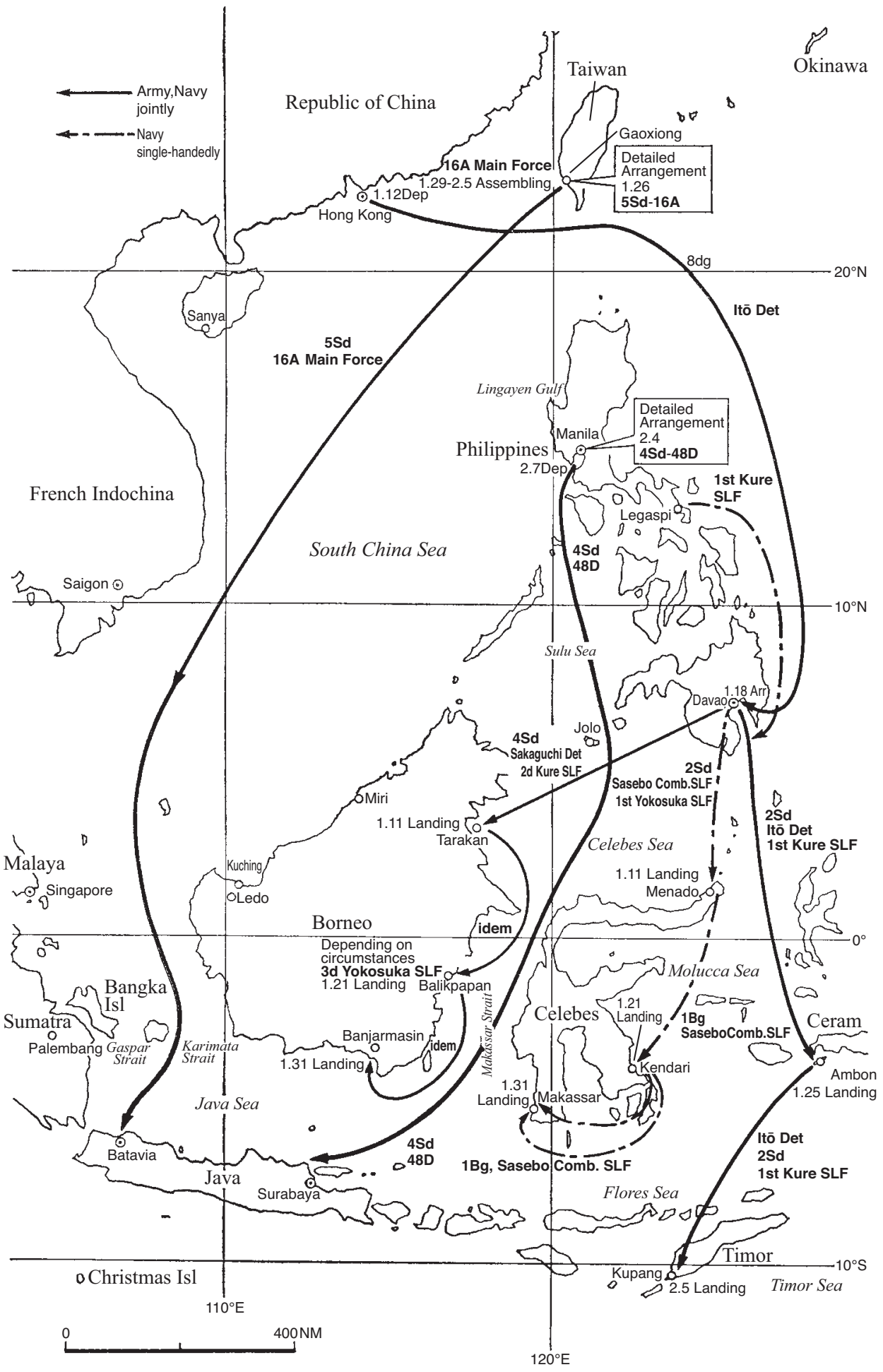

Illustration No. 5 - Plan of the Dutch East Indies Operation Right Before the Launch of the Operation ([As of] 7 January, 1942) 


\section{Dutch East Indies}

\section{The Operational Directives of the [Southern Task Force] Air Unit Com- mander and the Actions of Each Component of the Air Unit}

By 20 December it was concluded that the enemy air power in the Philippines area was mostly destroyed and that the [enemy] surface forces in the Malaya and the Philippines areas had already pulled back to the Java area as well. The Army air campaign to destroy the enemy air power in the Malay Peninsula also progressed for the most part smoothly. Vice Admiral Tsukahara, commander of the Air Unit, launched the Dutch East Indies operation with the forces that had been advanced to the southern Philippines and was gradually intensifying the operation by accelerating the construction of bases as well as the shift of his air forces to the southern regions. Yet, he conducted the operation in such a way that the units in Taiwan and those deployed in Legaspi, Davao and Jolo should according to the circumstances continue the Philippines operation and wipe out the remnants of the [enemy] forces there. The total military gains and losses of the Eleventh Air Fleet up until 31 December were reported as follows: ${ }^{(54)}$

\section{The total military gains up until 31 December}

1. [Enemy aircraft] that were brought down or caught fire with certainty (those brought down are shown in parentheses)

(68) Fighter planes, 28 (0) middle-sized planes, 39 (5) large-sized planes, 24 (6) flying boats, 17 (0) training aircraft, totaling 251 (79) aircraft

2. [Enemy aircraft] that were wrecked on the ground by strafing or bombing or which may have been brought down but not with certainty

72 Small planes, 4 middle-sized planes, 15 large-sized planes, 3 flying boats, 15 training planes, totaling 109 aircraft

3. [Enemy] war vessels sunk or badly damaged

4 Destroyers, 4 submarines, 24 merchantmen of 1,000 tons or more, 2 vessels of less than 1,000 tons

4. [Enemy war vessels] considerably damaged by direct or near hits of bombs 1 Light cruiser, 1 destroyer, 1 submarine, and 21 merchantmen

Losses up until 31 December (Except for losses incurred in other situations than aerial combats)

1. Flight crew: 4 land-based attack plane teams, 1 transport plane team, 14 Type- 0 fighter plane crew, and 2 flying boat teams

2. Equipment: 10 land-based attack planes (4 Type-1s, 6 Type-96s), 24 Type- 0 fighter planes, 1 transport plane and 2 flying boats

\section{The condition of the seized air bases}

1. Legaspi: A runway of 50 meters wide and 1,000 meters long is to be ready by 5 January. It can accommodate 18 fighter planes, 2 land-based reconnaissance planes, and about 3 landbased attack planes.

2. Jolo: Although a runway of 140 meters wide and 1,100 meters long is to be ready by 5 January, it is not available until 8 January because it has not only a large inclination but also undulates. (The rest is unclear because the next part in the original document is missing.)

3. Davao land base: A runway of 1,200 meters long is to be ready [at] 1030 on 6 January. However, due to the soft ground and frequent squalls, the rolling of the apron has not made much progress, and the accommodation available as of 8 January is [limited to] 54 fighter planes, 


\section{Dutch East Indies}

8 land-based reconnaissance planes and 40 land-based attack planes. The Eleventh Air Fleet headquarters is due to advance [there] on 7 January.

The scheduled deployment of forces as of 8 January and the current deployment as of 31 December (Note: the latter is shown in parentheses)

1. Tainan: the 1st Air Group (about one half of the Tainan Air Group and the 1st Air Group)

2. Gaoxiong: About one half of the Takao Air Group (the Eleventh Air Fleet headquarters, the 23d Air Flotilla headquarters, and the Takao Air Group)

3. Davao: the Eleventh Air Fleet headquarters, the 21st Air Flotilla headquarters, about one half of the Kanoya Air Group, the Tōkō Air Group, the transport plane unit of the 1st Air Group (the 21st Air Flotilla headquarters, the 3d Air Group, the Tōkō Air Group, and one element of the Kanoya Air Group)

4. Jolo: About one half of the 23d Air Flotilla, the Tainan Air Group (one element of the Tainan Air Group)

5. Legaspi: (One element of the Tainan Air Group)

On 2 January, the Air Unit commander ordered [the shift to] the phase-two disposition of forces, generally set the operational border of the 1st and the $2 \mathrm{~d}$ Air Raid Units at the line of $122^{\circ} \mathrm{E}$, and entrusted each air raid unit commander with [the arrangement of] the particulars for implementing the operation. He also put the 1st and the 3d Yokosuka Special Landing Forces (both paratrooper units) respectively under the command of the 1st Air Raid Unit and of the $2 \mathrm{~d}$ Air Raid Unit from 2 January onwards, to have them prepare for the operations respectively against Menado and Balikpapan. Along with that, he temporarily put the transport plane unit of the 1001 Unit under the command of the 1st Air Raid Unit, so as to have it participate in the 1st Yokosuka Special Landing Force's operation to capture Menado.

Following this [order], the 1st Air Raid Unit, which had [already] launched the operation in the Dutch East Indies area with as preliminary actions the search for the enemy in the Celebes Sea on the 23d of December and the reconnaissance attack on Menado on the 24th, advanced its headquarters to Davao on 27 December. Following the above [order], it mainly carried out attacks on the northern part of the island of Celebes. Moreover, on 7 January, prior to [the operation to] capture Menado, flying boats of the Tōkō Air Group and landbased attack planes of the Kanoya Air Group carried out a night raid on Ambon. Meanwhile, the 1st Yokosuka Special Landing Force left the port of Gaoxiong on the 26th of December, entered the port of Davao on the 31st, and set about preparing for the paradrop operation on Menado scheduled for the 11th and the 12th of January.

In the meantime on 30 December, the $2 d$ Air Raid Unit launched the Dutch East Indies operation with, as the first attack, the attack on Tarakan by the Tainan Air Group from the Jolo base. ${ }^{(71)}$ The 23d Air Flotilla headquarters also advanced to Jolo on 3 January.

Note: The air raid on Tarakan was also carried out from the Miri base by Type- 0 fighter planes and land-based attack planes of the Mihoro Air Group of the Malaya Unit on 26 and 28 December, as well as by Type- 0 fighter planes and land-based reconnaissance planes of the $3 \mathrm{~d}$ Air Group of the 1st Raid Unit also on the 28th ([the latter] will be described later).

From that time on, the $2 \mathrm{~d}$ Air Raid Unit carried out patrols over the northern half of the Makassar Strait and reconnaissance attacks over the Tarakan and Balikpapan areas, while continuing the Philippines operation. Meanwhile, the 3d Yokosuka Special Landing Force left Gaoxiong on the 5th of January and arrived in Davao on the 12th (due to the operation 


\section{Dutch East Indies}

of the available ship, it called at Jolo on the way) and set about preparing for the paradrop operation in Balikpapan. ${ }^{(71)}$

The major engagements of the Air Unit during the preparation for the Dutch East Indies operation are as follows: ${ }^{(71)}$

28 December: The 3d Air Group ([of] the 1st Air Raid Unit) conducted an attack on Tarakan with seven Type-0 fighter planes and one land-based reconnaissance plane from Davao and fought against nine enemy fighter planes. It pursued the enemy who lacked fighting spirit and escaped into the clouds; all aircraft [of the group] safely returned, reporting that [the group] brought down four [enemy] Buffalo's for sure, more or less certainly brought down two old-model Boeing's, and was not sure about the results of the other two to three planes. Only one aircraft [of the group] was hit. At that time, due to the [thick] clouds, it was impossible to reconnoiter Tarakan and the air raid [on the aircraft] on the ground was called off. As this attack was conducted outside the operational area of the 1st Air Raid Unit (the area was the responsibility of the $2 \mathrm{~d}$ Air Raid Unit) and moreover, it was a long-distance attack almost reaching the limit of the cruising range of the Type- 0 fighter planes, the unit was severely admonished by the Eleventh Air Fleet headquarters. ${ }^{(12)}$

31 December: Six flying boats of the Tōkō Air Group ([consisting of] three equipped with bombs and three with torpedoes) and five land-based attack planes of the Kanoya Air Group carried out a bomb and torpedo attack from 1655 to 1730 against a Canopus-class cruiser (Note: it was the Dutch seaplane tender Heron; [editor's note: in fact it was the USS Heron]), which was sailing southward on the waters west of the island of Kasiruta (southwest of Halmahera). However, due to the high-speed evasive movements of the enemy ship, only two 60kilogram conventional bombs of the land-based attack plane unit (led by Lt. Cdr. Irisa Toshiié) hit the ship, which caused fires but failed to sink the ship. The defensive fire of the enemy ship in this attack was fierce and precise. It [hit] the flying boat of the torpedo unit commander (Lt. Ōta Jusō) and made him to ditch it. Four other aircraft were also hit, and the second and the third flying boats of the torpedo unit were beached when they returned.

5-6 January: After the [enemy] air strikes over Malalag Bay, the search for and the attacks on the enemy in the Philippines from the air were intensified and so was the direct air defense above Davao and Jolo, but almost no enemy aircraft were spotted. The enemy aircraft that had conducted the air strike over Malalag Bay were eight B-17s of the U.S. 5th Bomber Command. Having departed from Malang on Java, they had carried out the attack using Samarinda on Borneo as a staging base and already returned to Malang on the 5th.

6-7 January: Six flying boats of the Tōkō Air Group ([consisting of] two torpedo bombers, one illumination aircraft, and three bombers, led by Cdr. Aizawa Tatsuo) and twenty-one landbased attack planes of the Kanoya Air Group Detachment (led by Lt. Cdr. Irisa Toshiié) were going to conduct a night attack on Ambon (a torpedo attack [with flying boats that would release their torpedoes] after landing [and while running on the water]). However, due to engine trouble right after taking off from the water, the flying boat with Commander Aizawa on board hit the foremast of the transport ship Kirishima-maru at anchor in Davao Gulf; it crashed killing all the crew (eight personnel including Commander Aizawa). Due to this accident, the attack by the torpedo unit ([consisting of] two torpedo-equipped flying boats and one with illumination flares) was called off. Meanwhile, seven of the land-based attack planes also returned [to base] due to trouble of the plane that had the commander on board. Eventually, three flying boats and fourteen land-based attack planes attacked the Ambon airfield from 0348 till 0447, and all aircraft returned safely. It was concluded that this attack had sealed the enemy's use [of the Ambon airfield] during the operation against Menado. 


\section{The Situation of the Carrier-Based Air Units}

The main force of the First Air Fleet had completed the Hawaii operation and returned to the Inland Sea of Japan on 23 December. As a result of a meeting on the 24th, it was decided that the 1st and the 5th Carrier Divisions should cooperate in the Rabaul invasion operation, after which they should get ready for [an attack from] the east, and that the $2 \mathrm{~d}$ Carrier Division should be incorporated in the Southern Task Force. ${ }^{(46)}$ The $2 \mathrm{~d}$ Carrier Division ([consisting of] the Sōry $\bar{u}$ and the Hiry $\bar{u}$ as the core) participated in the operation to capture Wake Island between 21 and 23 December on their way back from the attack on Hawaii and entered the port of Kure on 29 December. After entering the port of Kure, the division replenished its personnel along with conducting repair and maintenance of the ships and armaments, while striving to complete the preparations for the coming operations. ${ }^{(72)}$

\section{The Situation of the Army Units}

The situation of the Army units during the preparatory period of the Dutch East Indies operation was as follows:

Sixteenth Army headquarters: The army headquarters was [still] situated in the premises of the War College in Tokyo, but was scheduled to advance to the field in January 1942. However, as the Dutch East Indies operation was substantially moved up and, in line with this, considerable changes had to be made in the deployment plan of units, Army Commander Lt. Gen. Imamura Hitoshi decided to quickly advance the headquarters to the field on 25 December, moving up the original schedule by half a month. On 27 December, he also issued an order to the $2 \mathrm{~d}$ Division and the units under the direct control of the army to assemble in Gaoxiong.

The army commander left Tokyo on 30 December, advanced to Saigon on the 3d of January, and received the order to capture Bangka, Palembang, Ambon and Kupang from Commander in Chief of the Southern Army General Terauchi on the 4th. From that time on, the commander directed the operations at the command post in Saigon.

2d Division: [Having received] the army order on 27 December to assemble in Gaoxiong, the $2 \mathrm{~d}$ Division, which had conducted training at maneuvering grounds in central Japan, left the maneuvering grounds one after another, and was assembling at Ujina to embark from there. The advance unit was expected to leave Ujina around 15 January.

48th Division: Having landed along Lingayen Gulf on 22 December, the division had charged southward with unstoppable force, captured Manila on 2 January, and moved its main force toward the Bataan Peninsula in pursuit of the defeated enemy. On 5 January, the division had received an unofficial order to redeploy its force to the Dutch East Indies theater. Thus, relieved on the front line by the 65th Brigade on 8 January, it was gradually assembling in the Manila area. The division was incorporated in the order of battle of the Sixteenth Army on 14 January.

38th Division: The 38th Division had captured Hong Kong on 25 December. Shortly after that, on 30 December, it received an order from the Twenty-third Army to form a detachment suitable for operations against different islands with [a unit consisting of] one infantry regiment and one artillery battalion led by the infantry group commander as the core, and have the detachment prepared so that it would be able to embark on the 6th of January at Hong Kong to leave port on the 9th. This was the Itō Detachment, led by Maj. Gen. Itō Takeo, which was the Detachment B (scheduled for the capture of Ambon) that had been decided on in the Cam Ranh Agreement. The Itō Detachment, whose preparation for the departure had 


\section{Dutch East Indies}

slightly fallen behind schedule, left Hong Kong for Davao on 12 January in five transport ships (note: seven ships in the Cam Ranh Agreement and four in the 1st Takao Agreement). In the meantime, the 38th Division was incorporated in the order of battle of the Sixteenth Army on 4 January, received an unofficial order to capture Bangka and Palembang, and started its operational preparations.

Sakaguchi Detachment: The Sakaguchi Detachment had roughly completed the mopping-up [operation] around Davao by the end of December, handed over the task of maintaining security of the area to the Miura Detachment ([of] the 16th Division of the Fourteenth Army) and assembled its units in the Talomo and Daliao sectors to make operational preparations for the coming Tarakan operation. On 4 January, its rear units advanced from Palau. The detachment embarked its entire force on nine ships that then assembled in the anchorages of Davao and Daliao, thereby completing its operational preparations on 6 January.

Fifth Air Force: The Fifth Air Force had deployed its main force in various areas of the northern Philippines and primarily supported the ground operations of the main force of the Fourteenth Army, while assigning one element to the air campaign to destroy the enemy air power as well as to the cover of the anchorages. On 5 January, the force was given an unofficial notification of redeployment to the Burma area; it set about the preparation from that day onwards and gradually began its redeployment to central Thailand by air and sea transport from the 14th onwards. Thereafter, the [Army] air operations in the Philippines were carried out by a small force of air units attached to the army.

Third Air Force: The Third Air Force had been stationed in French Indochina, Thailand and the Malay Peninsula at the time of opening of hostilities and supported the Army ground operations in the Malaya area. The force advanced to the Malay Peninsula one after another by around the end of December and was in charge of the support for the ground operations as well as of the air campaign to destroy the enemy air power in the Malaya and Burma areas. 


\title{
Chapter V The Forward Push of the Air Bases
}

\author{
(See Attached Illustrations No. 1, No. 2 and No. 3) [Omitted]
}

\section{Outline of the Progress of the Operation}

\section{The Launch of the Dutch East Indies Operation}

$\mathrm{H}$ aving concluded that with the successful landing of the main force of the Army in the Philippines and the capture of key locations in the southern Philippines the stage-one, phase-one operations were more or less completed, Combined Fleet Commander in Chief Admiral Yamamoto Isoroku issued an order to shift to the phase-two disposition of forces at 1200 on 26 December.

The land-based air unit advanced its force to Davao and Jolo from late December till early January and launched its air campaign against eastern Borneo and Celebes. However, contrary to expectations, the condition of the Davao and Jolo airfields was bad, and since only a part of the force could be advanced, [the operation to] gain command of the air did not progress as scheduled. In the meantime, the surface unit had assembled in Davao from the end of December till early January and was making preparations for the operation. Because of his concern about gaining command of the air, Dutch East Indies Unit Commander V. Adm. Takahashi Ibō decided on 7 January, after consulting all sections, to conduct the attack on Menado and Tarakan on 11 January, one day later than the date stipulated in the Cam Ranh Agreement. Meanwhile, as described previously, the Myōko, the flagship of the 5th Cruiser Division, having sustained damage in the air raid by enemy heavy bombers on 4 January, had left the line of battle.

On 7 January the Dutch East Indies Unit launched the operation against the Dutch East Indies with the sailing of the Tarakan invasion unit from Davao. On 11 January, the landings on both Menado and Tarakan were launched, and after quite fierce fighting, the airfields [in both places] were seized. In the attack on Menado, the 1st Yokosuka Special Landing Force carried out a paradrop operation for the first time in Japanese [military history] and achieved great success. However, in Tarakan, two minesweepers were sunk, and this, as well as the fact that the sweeping of the sea for mines required an enormous amount of time, pointed to the many difficulties in the way of the invasion operations.

Although the advance of the Air Unit was behind schedule due to the delay in the minesweeping and the inadequate condition of the seized airfields, by 15 and 16 January it had pushed forward its bases to Menado and Tarakan and expanded its air campaign to Samarinda, Balikpapan, Kendari, Makassar and Ambon. Furthermore, on 23 January, in parallel with the Kendari and the Balikpapan invasion operations, the carrier-based air unit ([consisting of] two aircraft carriers, one heavy cruiser and six destroyers) with the $2 \mathrm{~d}$ Carrier 
Division as its core, which had been incorporated to the Southern Task Force on 8 January, attacked Ambon, a place of strategic importance north of Australia, scarcely meeting with any counterattacks worth mentioning.

Although the launch of the operations to seize Kendari and Balikpapan was slightly delayed, the respective invasion units, which had started from Menado and Tarakan, seized Kendari and Balikpapan on 24 January. While the resistance on land at these [locations] was not very serious, at Balikpapan, the unit came under quite a fierce counterattack that included raids by enemy aircraft, a night raid on the anchorage by enemy destroyers and torpedo attacks by [enemy] submarines, and it sustained the loss of some transport ships that were sunk or caught fire and of one patrol boat that was badly damaged. Nonetheless, the counterattack did not greatly affect the progress of the operation. Whereas the airfields that had been seized until then were poor, the Kendari [airfield] was a remarkably excellent and large airfield that could be used without hardly any improvements and that was suitable for use by large units.

As of early January, the main body of the Southern Task Force wound up its support for the operations in the Malaya area, left Cam Ranh Bay and advanced via Magong to Palau on 18 January, shifting to a position of support for the operation of the main force of the Dutch East Indies Unit.

\section{The Invasion of Malaya Makes Progress}

From the very opening of hostilities, the Southern Army had nurtured a plan to swiftly disembark one unit on the east coast of Malaya to accelerate the operation to neutralize Singapore. So, in concert with the rapid advance of the units [charging southward] along the west coast of Malaya, the army decided to put this plan into action in late December as Operation $\mathrm{Q}$ (Kuantan landing [operation]) and discussed arrangements with the [Navy] Malaya Unit. The Malaya Unit at first did not agree to the plan, saying that the plan was a dangerous operation [because it meant] rushing into an area where the enemy had command of the air, but in the end, [it agreed on the condition that] the implementation would be somewhat delayed, and it was decided that an operation unit, which would standby in Singora, should land in Kuantan at a favorable opportunity after 31 December. However, because in late December the Takumi Detachment, which was heading south from Kota Bharu, got close to a point north and within a short distance of Kuantan, operation [Q] was called off. The Operation $Q$ unit, which had advanced to Singora on the 27th under the escort of one half of the 3d Destroyer Squadron, was put ashore in Kota Bharu, and the escort unit returned to Cam Ranh Bay on 31 December. [Meanwhile,] on 26 December, about one half of the air unit of the Malaya Unit had advanced to Kota Bharu.

Then the Malaya Unit had a unit, consisting of the 5th Destroyer Squadron and one half of the 3d Destroyer Squadron as the core, escort the convoy of more than fifty ships in total of the main force of the Twenty-fifth Army and one element of the Fifteenth Army. They left Magong on 31 December; on 8 January the major part was put ashore in Singora and one element in Bangkok. On completing this operation, the 5th Destroyer Squadron was immediately transferred to the Dutch East Indies Unit. In the meantime, the other half of the 3d Destroyer Squadron, which had returned from [the cancelled] Operation Q, sailed to Guangdong, from where it escorted the main force of the 18th Division, which was to participate in 
the Malaya operation; it arrived in Cam Ranh Bay on 10 January. The next operations of the Malaya Unit were those to disembark the 18th Division on the east coast of the Malaya and to capture the Anambas Islands. That is to say, the Southern Army had a plan, called Operation S, which was to disembark the main force of the 18th Division in Endau and vicinity on the east coast of Malaya to envelop and destroy the enemy forces in the Malay Peninsula, while swiftly advancing air bases to southern Malaya in preparation for the coming Sumatra operation. The [Navy] Malaya Unit currently used Cam Ranh Bay as its [main] supply base and Cap Saint Jacques and Puolo Condore as advance supply bases for its rapid units, but as the war situation developed smoothly, it was decided to move forward the advance supply base to the Anambas Islands in order take an even more active part in the operations. Although Operation S was clearly defined in the Cam Ranh Agreement and particulars had been arranged between the [Navy] Malaya Unit and the [Army] 18th Division on 11 January, the operation became unnecessary because on 18 January the Army Koba Detachment had already closed in on Endau while the 5th Division was charging [southwards] through Gemas west [of Endau], so in the end it was cancelled. Accordingly, [the plan] was changed in such a way that the 18th Division should be disembarked at Singora. The 3d Destroyer Squadron escorted the division, leaving Cam Ranh Bay on the 20th of January, and arrived in Singora on the $22 \mathrm{~d}$. However, a prompt disembarkation of aviation fuel and ammunition at Endau [became] necessary for the conduct of the subsequent air operations, and it was decided to send two transport ships there. The 3d Destroyer Squadron, escorting these ships, left Singora, entered the anchorage [at Endau] on the afternoon of the 26th and began the disembarkation. During this period, they came under attack of as many as several dozen enemy aircraft, but the counterattacks by army fighter plane units drove back every wave of attack, and the [disembarkation] work was continued without incurring much damage. Around 0430 on the 27 th, two enemy destroyers raided the anchorage, one of which was sunk in the counterattack of the 3d Destroyer Squadron and another sustained damage and escaped. In the meantime, [the operation to] seize the Anambas [islands] was carried out by the 9th Base Force; it seized the islands on the morning of 26 January, meeting no resistance at all.

\section{Capture of Ledo and Southern Malaya}

Earlier, the preparation of the Kuching airfield in northern Borneo, which was seized on 25 December, had contrary to the huge expectations of the Navy made no progress [at all] because of such unfavorable conditions as the wet ground of the airfield and the rainy season [which made it worse]; the plans for conducting the air campaign after advancing to the Kuching airfield seemed to become thoroughly upset. Therefore, the Navy greatly placed its hopes on the newly spotted large airfield in Ledo about fifty nautical miles southwest of Kuching and changed its plans so as to make to the fullest extent use of this airfield.

Since the Navy had expressed at the Cam Ranh Agreement [conference] its hope that Ledo be seized, General Terauchi Hisaichi, commander in chief of the Southern Army, issued an order to the Kawaguchi Detachment on 6 January to seize the Bengkayang area in western Borneo. The detachment was somewhat tardy in its preparations, but it launched the action from Kuching in late January, and seized Ledo and Pontianak respectively on 27 and 29 January. 
As for the overland [advance] in the Malaya area, the leading unit of the 5th Division, which had reached Ipoh on 26 December, continued its southward advance, completely destroyed a large enemy unit near Slim on 7 January, and captured Kuala Lumpur, a place of strategic importance, on 11 January. By around that time, the Imperial Guard Division, which had entered into Thailand from French Indochina at the time of the opening of hostilities, was catching up [with the units ahead] by land, started charging [southward] along the west coast of Malaya in parallel with the 5th Division, and partly by maneuvering in small craft along the shore. This shifted the battlefront to southern Malaya; Malacca was seized on the 14th of January, Gemas and Batu Pahat on the 16th, and Kluang on the 25th. On 31 January, the leading units of both divisions charged into Johor Bahru, [from where] Singapore was visible within hailing distance.

The Koba Detachment, which was heading southward along the east coast of the Malay Peninsula, broke through Endau and Mersing respectively on the 20th and the 26th of January, and rendezvoused with one unit of the 5th Division, which was heading eastward from Kluang on the 28th. [With this], communication between [the units heading southward along the] east and west [coasts] was [finally] established.

\section{The Engagements of the Submarine Units}

During phase-one operations, the submarine units [in the southwestern region] were mostly concentrated in the Malaya area to attend to the British Fleet in the East. However, in phasetwo operations, only the 4th Submarine Squadron remained in the Malaya area to participate in the operations around Java, whereas the 5th Submarine Squadron and the 6th Submarine Squadron respectively took charge of [the operations in] the Indian Ocean, and [those in] the Celebes area and the area north of Australia, as the submarine unit of the Southern Task Force.

The 4th Submarine Squadron, which remained in the Malaya area, engaged with Cam Ranh Bay as its base in the attack on enemy naval vessels as well as in the disruption of [enemy] shipping lanes in the waters south of Singapore, the east coast of Sumatra and around Java from late December through mid and late January, and sank five or six [enemy] merchantmen.

Having returned to Cam Ranh Bay after completing its support of the northern Borneo operation in late December, the 5th Submarine Squadron carried out the operations in the Indian Ocean by shifting its base to Penang after the seizure of the location in late December and after the 11th Submarine Base Unit had been assigned [to the base]. The submarines of the squadron departed from Cam Ranh Bay in early and mid January (one element joined from the mainland of Japan via Davao), and engaged in the disruption of [enemy] shipping lanes around Java. After carrying out operations as far as around the island of Ceylon with one element, it advanced [its base] to Penang from late January to early February. During these operations, the squadron sank more than a dozen enemy ships, but it [also] lost one of its submarines (the I-60). The 6th Submarine Squadron, which had laid mines in the Philippines area at the opening of hostilities and returned to Cam Ranh Bay, [again] left the bay in the middle of December for surveilling and patrolling [around] the Philippines and with one element the strategic area of Surabaya; it returned to Davao at the end of December. [Then] in early January, all submarines [of the 6th Submarine Squadron] left Davao for northern 
Australia to take on a mission of laying mines in [the waters of] Port Darwin and the Torres Strait and keeping a watch on the enemy fleet in the Arafura Sea; it returned to Davao in late January. During these operations, the squadron spotted the U.S. heavy cruiser USS. Houston in the Banda Sea on 14 January and chased her, but they let her slip away. The squadron lost one submarine (the I-24 [I-124]) outside the port of Port Darwin.

\section{The Manila Conference}

Although at the Cam Ranh Agreement [conference] on 29 December it was decided, as described previously, to drastically move up the operation schedule, not a few in the Navy units on site from that moment onwards commented that on the operational level the [new] schedule was impossible. After the launch of the Dutch East Indies operation, unfavorable conditions had developed one after another just as had been feared, and the opinion that the operation schedule should be postponed grew stronger. The grounds [for the opinion] included the poor condition of the seized airfields, the counterattacks by enemy aircraft, the delay in the minesweeping operations, the fatigue of the crews of the escort ships, and the issue of the maintenance of the ships. Because the Army stubbornly opposed the Navy's opinion to postpone [the operation], the staff personnel concerned gathered in Manila on 21 January and discussed the matter, which resulted in the following changes in the contents of the Cam Ranh Agreement.

1. Invasion schedule: To be postponed for four to nine days.

2. The air operation to destroy the enemy air power on Java shall be carried out from Balikpapan and Makassar, and Banjarmasin will not be used. Instead, if possible, Bali should be seized right before the landing on Java, and air units should be advanced [there], so as to have a hold upon Java.

3. One requirement for the operations against southern Sumatra and western Java was the availability of the airfields in Western Borneo for the Navy, such as those in Kuching or Ledo. However, if they could not be readied in time, the Navy should use the airfields on the Malay Peninsula.

Having concluded that the disembarkation of the main force of the Army units for the Malaya region had been completed, Commander in Chief of the Combined Fleet Admiral Yamamoto issued on 24 January the order to shift to the phase-three disposition of forces. The aim of the Southern Task Force in phase-three [operations] was the invasion of Java, for which the forces of the Southern Task Force were roughly disposed as follows:

1. The Dutch East Indies Unit shall continue [its operation] to seize key areas in the eastern part of the Dutch East Indies, such as Makassar, Ambon, and Timor.

2. As a preparatory operation for the invasion of Java, air operations to destroy the enemy air power in eastern Java shall be carried out by land-based air units from Balikpapan and Kendari.

3. The Malaya Unit shall seize key areas in southern Sumatra, [from where] land-based air units shall conduct air operations to destroy the enemy air power in western Java.

4. Before the landing on Java, Bali shall be seized, and air units shall be advanced [there].

5. The Dutch East Indies Unit shall put ashore the main force of the Sixteenth Army simultaneously in eastern and western Java.

6. The Submarine Unit shall be deployed around Java to support the operations. 
7. Almost simultaneously with the landing [operation] on Java, mobile operations shall be conducted on the waters south of Java with the main body of the Southern Task Force as well as the newly added $2 \mathrm{~d}$ Carrier Division and $2 \mathrm{~d}$ Submarine Squadron, in order to attack Java from all sides as well as to cut off the escape routes of the enemy.

8. The [newly] attached 2d Carrier Division shall in the first place make an attack on Port Darwin, a strategic location in northern Australia, in concert with [the operation to] seize Timor.

9. The Malay Unit shall prepare for the operations in northern Sumatra, the Andaman Islands, the Nicobar Islands, and the Burma area, so that it will be able to start [those operations] after the seizure of Singapore.

\section{Completion of the Forward Push of the Bases in the Direction of Eastern Java}

In the eastern part of the Dutch East Indies, conform to the [above] plan, the Ambon invasion unit, which had left Davao on 27 January and had been joined on the way by naval escort vessels from Menado and Kendari, started the landing [operation] on Ambon on 31 January. The unit captured the place on 3 February, which led to the advance of Navy fighter planes to the Ambon airfield as early as on the 5th. Then, [another] unit, which had left Kendari on 6 February, seized Makassar on 9 February. In this operation [against Makassar], one destroyer was sunk by an enemy torpedo attack.

In the meantime, on 31 January, the Sakaguchi Detachment of the Army in Balikpapan launched the Banjarmasin operation, starting its advance toward Banjarmasin by land (and for one element by maneuvering small craft along the shore) and seized it on 10 February.

The main force of the land-based air unit advanced to Kendari and Balikpapan in late January and carried out an air operation from 3 to 5 February to destroy the enemy air power in eastern Java. On the 4 th, it spotted a powerful enemy fleet on the sea east of Java and attacked it with its full force. The result was seen as having utterly destroyed the main force of the enemy. When it was further reported that more than one hundred enemy aircraft had been destroyed, it was judged that the major part of the enemy air force in the area had been destroyed. It was followed by the first air raid on Kupang from Kendari on 6 February.

On 8 February, the main force of the Carrier Task Force (minus the 5th Carrier Division and the $2 \mathrm{~d}$ Section of the 18th Destroyer Division) was newly incorporated into the Southern Task Force and advanced from the mainland of Japan [on p. 212: from the Marshall Islands] to Palau. After joining there the 2d Carrier Division, which had completed the attack on Ambon, they left Palau on the 15th of February and attacked Port Darwin on the 19th. In concert with this [operation], the land-based air unit also made a sortie from Ambon and Kendari, attacked Port Darwin and caused serious damage to enemy aircraft, numerous naval vessels and facilities on land.

The unit to capture Bali left Makassar on 18 February, landed on Bali on 19 February, and seized the airfield [there]. However, that night a powerful enemy fleet attacked the anchorage. The 8th Destroyer Division (four destroyers) on site engaged it in a fierce night engagement, and reported the military gain of sinking several enemy warships, while sustaining some damage to two destroyers.

Earlier, at the Manila Conference on 21 January, the invasion of [Dutch] Timor had been fixed on 20 February. Almost concurrently, an invasion against Portuguese Timor (Portugal being a neutral state) was discussed at IGHQ, and it was decided to invade [the territory] on the grounds that allied forces had after all been deployed in Portuguese territory and because 
of the importance of an air base in Dili. The invasion unit left Ambon on 17 and 18 February, conducted a simultaneous landing in Kupang and Dili on 20 February, drove back the enemy there and seized the airfield on the 21st. The 3d Yokosuka Special Landing Force carried out a paradrop operation on Kupang. The land-based air unit advanced to Bali on the 20th of February and Kupang on the 24th, from where it immediately launched a search and attack [operation] for the enemy in eastern Java and northern Australia from the air; the preparations for the invasion of eastern Java were [now] for the most part completed.

\section{Completion of the Forward Push of the [Air] Bases in the Malaya Area}

With the operation at Endau in late January, the Malaya Unit finished for the time being its task of putting Army units ashore in Malaya and was subsequently supposed to engage upon the southern Sumatra operation.

The plan for the southern Sumatra invasion operation was to advance land-based air units to western Borneo, conduct an air campaign against southern Sumatra and western Java that also served to cut off the escape routes from Singapore and to neutralize the enemy [there], and after extending the search range for the enemy as far as the Java Sea, capture those areas in conjunction with the Army. In order to realize that, the Navy put all its energy into accelerating the preparation of the Kuching airfield, while at the same time trying to rapidly transport air base matériel to the seized Ledo airfield. However, the Ledo airfield was situated far inland, and moreover, the roads and bridges [to the airfield] had been thoroughly destroyed, which made it difficult to transport the fuel and ammunition. On top of that, it was learned that airfield itself was not very good, which meant that it could not be ready in time for the southern Sumatra operation.

Having no other choice, Malaya Unit Commander V. Adm. Ozawa Jisaburō decided to advance one half of the force of the land-based air unit to Kuantan and the other half to Kuching, and proposed to the Southern Army a two-day postponement of the operation, which was supposed to be implemented on 4 February.

On 5 February, [part of] the air force was advanced to the Kuching base at last, which enabled [the unit] to launch the air operation against Bangka [Island] and western Java. However, due to the poor condition of the airfield, aircraft were allowed to load only half of the loading capacity of ammunition and fuel, and [the operation] to gain command of the air did not make as much progress as one had wished. Meanwhile, when an advance unit went to the Kuantan airfield, to where it had been hastily decided to advance [part of the unit], it found that [the airfield] was not suitable for immediate use by land-based attack plane units, because giant trees obstructed the extension of the runway. It was estimated that felling these trees would take several days. The Navy had not made a survey of the Kuantan [airfield] until that time. On 6 February, Malaya Unit Commander Vice Admiral Ozawa proposed to the Southern Army a further four-day postponement of [the launch of] the operation. As the Southern Army headquarters was in favor of invading [area after area] in one go on the concept of a strategic pursuit, they were extremely displeased with the postponement of the operations and the Navy's lack of preparation. However, as long as the Navy did not put the operations in motion, the Army could not launch them [on its own], and the Army impatiently passed the days. In the end, on 9 February, the prospect became clear that the [Kuantan] airfield would be ready for use (though [limiting] the fuel and ammunition [for the 
aircraft] to half), and the southern Sumatra invasion unit left Cam Ranh Bay on the evening of the 9th, in order to definitely carry out [the operation] on 15 February (five days later than planned in the Manila Agreement).*

The Navy land-based air unit advanced to the Kuantan airfield on 11 February and launched the attack on the Bangka [island] area, while the Army Third Air Force launched air raids on the Palembang area on consecutive days from 6 February onwards. In the meantime, the main force of the Twenty-fifth Army, which had reached the southern tip of the Malay Peninsula on 31 January, launched the operation to land in the face of the enemy on the island of Singapore on 9 February.

\section{Capture of Southern Sumatra; the Preparations to Invade Western Java More or Less Completed}

Before dawn on 15 February, [one of] the advance units of the southern Sumatra invasion unit landed in Mentok on Bangka Island, while the other units started sailing upriver toward Palembang by operating [landing] craft. That morning, reconnaissance seaplane(s) searching for the enemy spotted a large enemy unit sailing northward through the Gasper Strait. [At that time] Malaya Unit Commander Vice Admiral Ozawa was on the waters north of Bangka Island, leading the main force of the surface unit in order to cover the main convoy of the [southern Sumatra] invasion unit (with the 38th Division on board). He judged that the enemy force was a powerful unit including one battleship, and decided to destroy [the enemy] with the surface unit, after first attacking them with the air unit. Although the air attack was carried out for as much as six hours by the force of the land-based unit, which flew from Saigon, Kuching and Kuantan, etc., as well as by aircraft of the carrier $(R y \bar{u} j \bar{o})$ of the surface unit, the enemy reversed course and [the unit] let the latter escape before dealing it a major blow.

On 14 February, the Army paratrooper unit was dropped on the airfield and the oil refineries of Palembang and seized them, while the unit that had sailed upstream the Musi River in [landing] craft also reached Palembang on the evening of the 15th. After the river was cleared of mines, the main force of the Army southern Sumatra invasion corps also sailed upstream the Musi River and reached Palembang on the 17th.

Two days earlier, on 15 February, Singapore surrendered. The surface unit of the Malaya Unit caught up with the naval vessels escaping from Singapore, and caught or sank more than a dozen small ones.

Malaya Unit Commander Ozawa concluded that the southern Sumatra invasion operation was more or less completed as of 18 February, pulled the major part of the surface unit back to the Anambas Islands in order to shift to the preparations for the coming operations ([that is] the clearing [of mines in] the waterways of Singapore and the Malacca Strait).

As the operations in the Malaya area were largely completed, Southern Task Force Commander V. Adm. Kondō Nobutake as of 21 February removed one element of the 3d Destroyer Squadron and some other forces from the Malaya Unit and incorporated them into the Dutch East Indies Unit for the operation against western Java. The main force of the 22d Air Flotilla was also removed from the Malaya Unit and incorporated into the land-based

* According to Vol. 3, pp. 302, 310, only the amount of fuel was halved and the planes made a stopover at Kahang to top up their fuel tanks. 
air unit of the Southern Task Force to conduct operations under the command of Eleventh Air Fleet Commander V. Adm. Tsukahara Nishizō. With these [redeployments], the preparations for the invasion of western Java were also by and large completed.

\section{The Capture of Tarakan (See Illustration No. 7)}

The capture of Tarakan was carried out by the Western Attack Unit with the support of the Air Unit of the Southern Task Force. The disposition of forces of the Western Attack Unit was as shown in the following table. ${ }^{(47)}$

\begin{tabular}{|c|c|c|c|c|c|}
\hline \multicolumn{2}{|c|}{ Disposition } & \multicolumn{2}{|c|}{ Commander } & Forces & Assignments \\
\hline \multirow{3}{*}{ 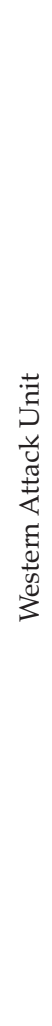 } & 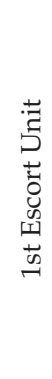 & \multirow{3}{*}{ 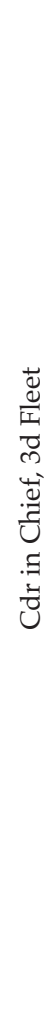 } & 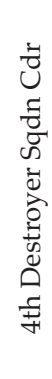 & $\begin{array}{l}\text { The Naka, 24th Destroyer Div, } \\
\text { 9th Destroyer Div (minus the } \\
\text { Yamagumo), 2d Destroyer Div } \\
\text { (minus the Murasame), 11th } \\
\text { and 30th Minesweeper Divs, } \\
\text { 31st Subchaser Div, Patrol } \\
\text { Boats Nos. 36, 37, and 38, 2d } \\
\text { Kure SLF (minus 1 plt), 5th } \\
\text { Construction Squad, and 2d } \\
\text { Defense Detail }\end{array}$ & $\begin{array}{l}\text { 1. To provide direct escort for } \\
\text { the convoy of the Army } \\
\text { Sakaguchi Det and the } 2 \mathrm{~d} \\
\text { Kure SLF } \\
\text { 2. In conjunction with the } \\
\text { Army, to seize Tarakan and } \\
\text { secure its air base }\end{array}$ \\
\hline & 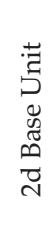 & & 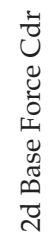 & $\begin{array}{l}\text { 2d Base Force (minus 11th and } \\
\text { 30th Minesweeper Divs, 31st } \\
\text { Subchaser Div, Minesweeper } \\
\text { No. 20, and the Sanuki-maru), } \\
\text { and the Itsukushima }\end{array}$ & $\begin{array}{l}\text { 1. To cooperate with the 1st Es- } \\
\text { cort Unit (by providing } \\
\text { forces) } \\
\text { 2. To defend key locations and } \\
\text { provide protection for ship- } \\
\text { ping lanes }\end{array}$ \\
\hline & 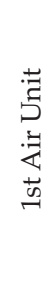 & & 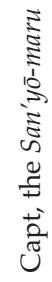 & $\begin{array}{l}\text { The San'yō-maru, the Sanuki- } \\
\text { maru, Patrol Boat No. } 39 \text {, } \\
\text { Kureha-maru No. 3, 2d Kure } \\
\text { SLF 1st Plt, and fishing boats }\end{array}$ & $\begin{array}{l}\text { To provide the 1st Escort Unit } \\
\text { with guard against sub- } \\
\text { marines, as well as to support } \\
\text { the landings }\end{array}$ \\
\hline
\end{tabular}

\section{Notes:}

1. Although the commander in chief of the Third Fleet commanded the Western Attack Unit, the invasion operation was virtually directed by 1st Escort Unit Commander and 4th Destroyer Squadron Commander R. Adm. Nishimura Shōji.

2. 24th Destroyer Division:

2d Destroyer Division:

9th Destroyer Division:

31st Subchaser Division:

11th Minesweeper Division:

30th Minesweeper Division: the Umikaze, the Kawakaze, the Yamakaze, and the Suzukaze the Yüdachi, the Samidare, the Harusame, and the Murasame the Asagumo, the Minegumo, the Natsugumo and the Yamagumo three submarine chasers

four minesweepers two minesweepers 
Plan of Operations, etc.

\section{The Arrangements Between the 1st Escort Unit and the [Army] Sakaguchi Detachment}

On 5 January, 1st Escort Unit Commander R. Adm. Nishimura Shōji and Maj. Gen. Sakaguchi Shizuo concluded the arrangements concerning capture of Tarakan, which were in outline as follows:

1. Disposition of Forces for the Landing Operation

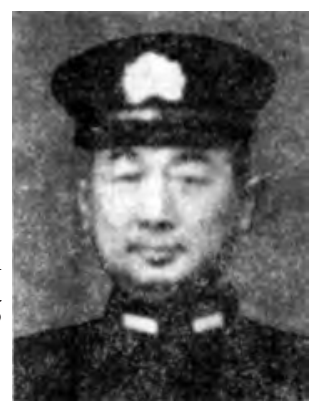

4th Destroyer Squadron Commander R. Adm. Nishimura Shōji

\begin{tabular}{|l|l|l|}
\hline \multicolumn{1}{|c|}{ Force } & \multicolumn{1}{|c|}{ Coast to land on } & \multicolumn{1}{c|}{ Tasks } \\
\hline $\begin{array}{l}\text { Main force of the Sakaguchi Det } \\
\left(1 \frac{1}{2} \text { bns }\right)\end{array}$ & Central part, east coast of Tarakan & To seize the oil fields and Lingkas \\
\hline $\begin{array}{l}\text { One element of the Sakaguchi Det } \\
(1 \mathrm{bn})\end{array}$ & Southeastern end of Tarakan & To seize the Mengacu Battery \\
\hline $2 \mathrm{~d}$ Kure SLF $(1 \mathrm{bn})$ & Central part, east coast of Tarakan & To seize the airfield \\
\hline
\end{tabular}

Note: It had been specified in the Iwakuni Agreement that the $2 \mathrm{~d}$ Kure Special Landing Force should come under the command of Detachment Commander Sakaguchi from the time of landing on Tarakan till the conclusion of operations in the most important areas.

\section{Landing Actions and Disembarkation Operations}

(1) It is principally intended to conduct surprise landings.

(2) Gunfire by Naval vessels to cover the landings shall be provided at the request of Detachment Commander Sakaguchi.

(3) Transport ships shall change anchorage to the Lingkas anchorage one after another when ordered. At that time, depending on the circumstances, naval vessels shall guide them along the waterway.

(4) The preparations for the subsequent operations shall be made at the Lingkas anchorage.

\section{The Plan of Operations of the 1st Escort Unit}

On 4 January, 1st Escort Unit Commander Rear Admiral Nishimura issued 1st Escort Unit Order No. 1 in Malalag Bay, and disclosed the outline of the operation to capture Tarakan, the main points of which were as follows: ${ }^{(56)}$

\section{Distribution of transport ships}

1st Section: 1) the Tsuruga-maru, 2) the Liverpool-maru, 3) the Hiteru-maru, 4) the Hankow-maru, 5) the Ehime-maru, 6) the Kunikawa-maru, and 7) the Kano-maru (with the right wing unit of the Sakaguchi Detachment and the 2d Kure Special Landing Force on board) 

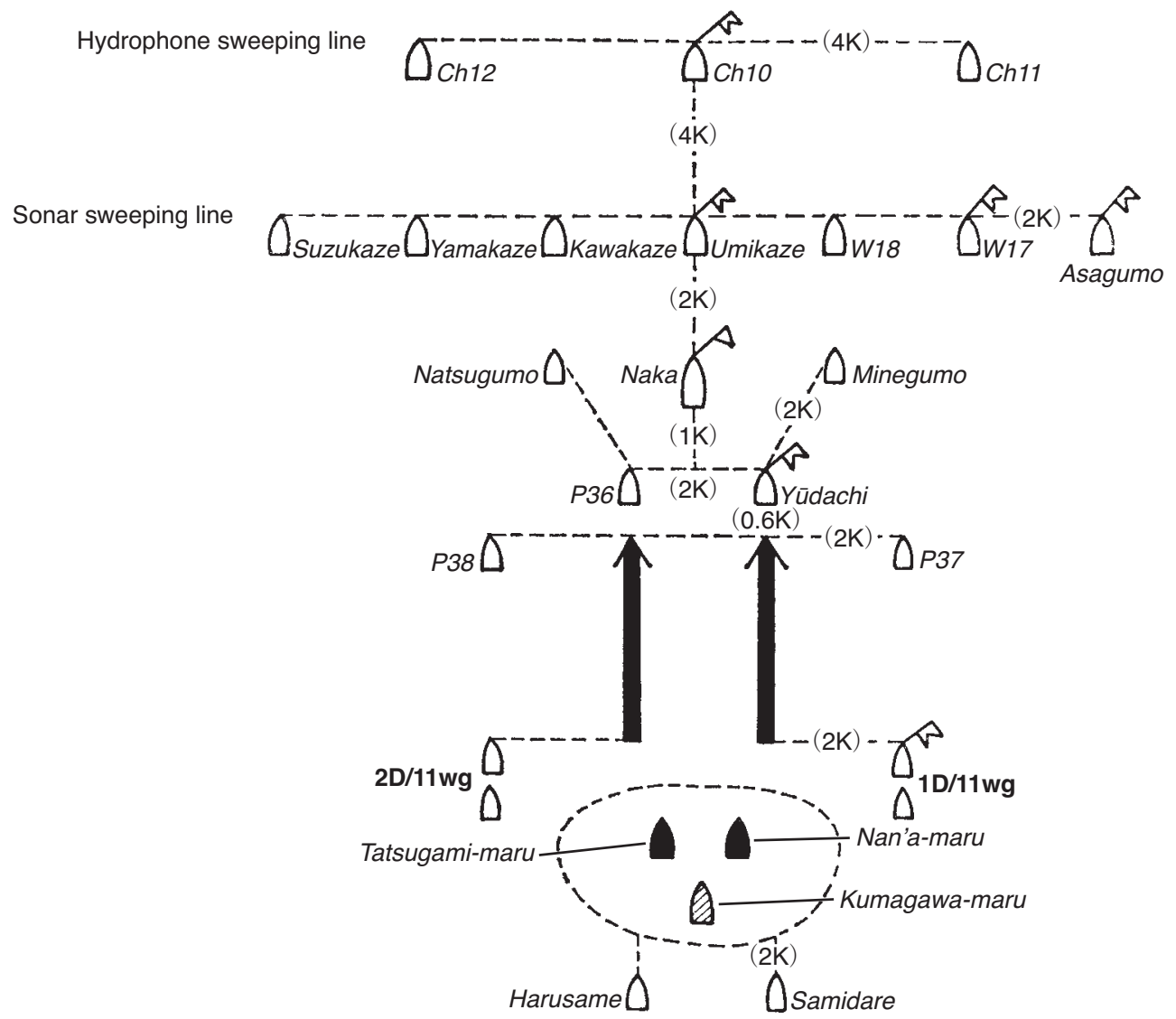

Illustration No. 6 - The Sailing Formation of the 1st Escort Unit on First Alert

2d Section: 1) the Havana-maru, 2) the Teiryū-maru, 3) the Kuretake-maru, 4) the Nichiai-maru, 5) the Kagu-maru, 6) the Kunitsu-maru, and 7) the Rakuto-maru (with the left wing unit of the Sakaguchi Detachment, the [Navy] 5th Construction Squad and the 2d Defense Detail on board)

2. Outline of the sortie from Davao

(1) The 24th Destroyer Division and the 9th Destroyer Division (minus the Yamagumo) shall leave Malalag Bay at 0800 on 7 January as the clearing unit, and clear enemy submarines ahead of the sailing route of the transport fleet, after which they shall join the transport fleet on the evening of that day.

(2) The 2d Destroyer Division (minus the Murasame), Patrol Boats Nos. 36, 37 and 38 shall sail to the sea off Davao, leaving Malalag Bay on the morning of 7 January. [Then] they shall depart from [Davao] at 1100, guiding and escorting the transport fleet.

3. Escort during sail

(1) Planned sailing route: as shown in the Separate Illustration No. 11 (Omitted by the author)

(2) Sailing speed: 8 knots at normal speed, 6 knots at slow speed

(3) Protective sailing formation: as shown in the Separate Illustration No. 10 (Illustration No. 6) 
4. Entering into the anchorage areas

At 0700 on 10 January, the 9th Destroyer Division, 31st Subchaser Division and the 11th and the 30th Minesweeper Divisions shall leave the line without [separate] orders to form a security unit (commander: 9th Destroyer Division commander), sail to the anchorage areas ahead [of the fleet] and sweep for mines at the 1st anchorage as shown in the Separate Illustration No. 12 (Illustration No. 7). After sunset, the unit shall search [for mines] and clear them at the $2 \mathrm{~d}$ anchorage, while trying to detect enemy submarines in the waters nearby. Also, [the unit] shall have two submarine chasers take up the positions shown in the Separate Illustration No. 12 (Illustration No. 7) to act as markers.

The times for anchoring the transport ships and launching the landing [operations] shall be set as follows:

1st anchorage: anchoring at 1930 on the 10th; launch of the landing [operation] at 2130.

$2 \mathrm{~d}$ anchorage: anchoring at 0000 on the 11th; launch of the landing [operation] at 0200.

5. Guarding of the anchorages (one light cruiser, ten destroyers, one submarine chaser, three patrol boats, and six minesweepers)

The 24th Destroyer Division and the 31st Subchaser Division (minus the marker vessels):

Direct guarding around the 1st anchorage

The $2 \mathrm{~d}$ Destroyer Division (minus the Murasame) and Patrol Boat No. 36:

Direct guarding around the $2 \mathrm{~d}$ anchorage

The Naka, the 9th Destroyer Division (minus the Yamagumo and the Natsugumo), the 11th and the 30th Minesweeper Divisions and Patrol Boats Nos. 37 and 38:

Guarding of outer [areas] of the anchorages

The Natsugumo (leaving the line at 0700 on the 11th):

Guarding of the waterway north of Tarakan

6. Sweeping the Lingkas anchorage for mines

The 11th and the 30th Minesweeper Divisions (led by the 11th Minesweeper Division commander) shall sweep the areas A and B in the Separate Illustration No. 12 (Illustration No. 7) for mines by separate orders.

7. Special Landing Forces and others

The $2 \mathrm{~d}$ Kure Special Landing Force, the 5th Construction Squad and the $2 \mathrm{~d}$ Defense Detail shall, in cooperation with the Sakaguchi Detachment, land on the island of Tarakan, seize, ready and secure the air base and [also] secure important resource areas.

\section{The Plan of Operations of the Sakaguchi Detachment ${ }^{(56)}$}

1. Mission

[The detachment] shall land on the east coast of Tarakan Island, cut through the jungle area and seize the Tarakan oil fields in one go, while attacking the enemy strongholds from their rear and destroying them. Following that, it shall seize the airfield and the oil fields in the north. Once the operations on the island are concluded, it shall hand over the guarding [duties] to the Naval unit, assemble the main force around the town [of Tarakan], embark on the ship(s) in succession and make preparation for the subsequent operations.

2. Disposition of forces

Right Wing Unit

Commander: 146th Infantry Regiment Commander Col. Yamamoto Kyōhei

(1) Forces: the 146th Infantry Regiment (minus 2 battalions), one battery, one engineer company, and one battalion of the $2 \mathrm{~d}$ Kure Special Landing Force

(2) Action: As the main force, the Yamamoto Regiment shall make a forced landing at the mouth of the Amal River, and after clearing the enemy around the place, swiftly cut through the jungle, seize the Pamusian oil field area north of the town of Tarakan, and advance to Lingkas 
before sunrise. The $2 \mathrm{~d}$ Kure Special Landing Force shall go ashore about thirty minutes after [the landing of] the main force, charging at the rear of the latter. While the main force is seizing the town of Tarakan], it shall overtake the main force and seize the airfield.

Left Wing Unit

Commander: 146th Infantry Regiment 2d Battalion Commander Maj. Kanauji Ken'ichi

(1) Forces: the 2d Battalion of the 146th Infantry Regiment and one engineer platoon

(2) Action: The unit shall go ashore in a southeastern part of Tarakan Island almost simultaneously with [the landing of] the right wing unit, charge through the jungle, attack and seize the batteries of Mengacu and Karungan from the rear. [After that,] by way of Lingkas, and also passing by the $2 \mathrm{~d}$ Kure Special Landing Force at the airfield, it shall attack and seize the Gunung Cangkol and Juwata oil fields and the Juwata battery.

The unit under the direct control of the detachment

(1) Forces: the 3d Battalion of the 146th Infantry Regiment, armored vehicle unit, one artillery battalion, antiaircraft artillery battalion, independent engineer company, etc.

(2) Action: Following the landing of the right wing unit, the unit shall advance in the rear of the former, and reach the town of Tarakan.

\section{The Plan of Operations of the Air Unit of the Southern Task Force}

As of 7 January, the Air Unit of the Southern Task Force was deployed

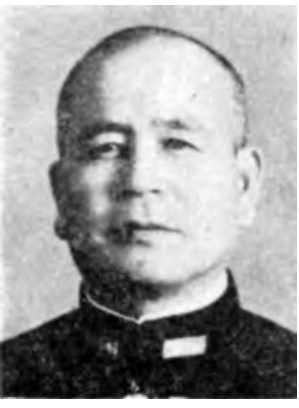

23d Air Flotilla Commander R. Adm. Takenaka Ryōzō

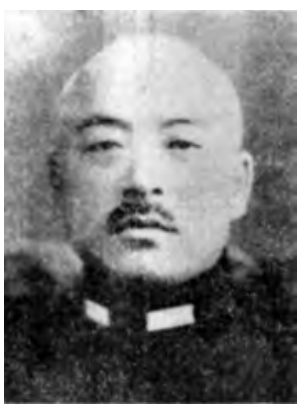

2d Base Force Commander R. Adm. Hirose Suéto in the following way:

Davao base: Eleventh Air Fleet headquarters, 21st Air Flotilla headquarters, 27 Type-1 landbased attack planes of the Kanoya Air Group Detachment, 28 transport planes of the 1st Air Group, 54 Type- 0 fighter planes of the $3 \mathrm{~d}$ Air Group, 7 land-based reconnaissance planes, 20 Type-97 flying boats of the Tōkō Air Group

Jolo base: 23d Air Flotilla headquarters, 12 Type-1 land-based attack planes of the Takao Air Group, 41 Type-0 fighter planes of the Tainan Air Group, 5 land-based reconnaissance planes

On 2 January, Air Unit Commander Vice Admiral Tsukahara disclosed the outline of the support [the unit was to provide] for the invasion operation by Telegraphic Operation Order No. 19, the main contents of which were as follows: ${ }^{(54)}$

\section{Antiaircraft guarding}

(1) [Guarding against enemy aircraft] shall be provided for all invasion units continuously during daylight hours, except for the period from the entering of the units into the anchorages at Menado, Kendari and Ambon until the advance of fighter planes to the seized bases [there].

(2) The 1st Air Raid Unit shall be in charge of guarding for the Tarakan invasion unit against enemy aircraft in [the zone] east of $123^{\circ} 30^{\prime} \mathrm{E}$.

2. As for the reconnaissance of the landing points, photoreconnaissance of each landing point shall be conducted as quickly as possible and sent to the units concerned. 
On 7 January, in conformity with the above Telegraphic Operation Order No. 19, 2d Air Raid Unit Commander R. Adm. Takenaka Ryōzō decided on the following outline of support for the 1st Escort Unit: ${ }^{(62)}$

1. Antiaircraft guarding: 3 Type-0 fighter planes and 1 land-based reconnaissance planes per shift

8 January: 1400-1600

9 January: 0800-1800

10 January: 0800-1630

2. Search for enemy surface vessels and guarding against them

Shall be carried out, leaving the base at 0800 on 9 and 10 January, [in an area] within a radius of 300 nautical miles of the range between $135^{\circ}$ and $220^{\circ}$ with the Jolo airfield as its center, ([to be conducted with] 6 landbased attack planes).

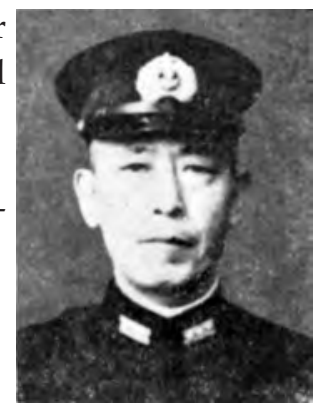

12th Seaplane Tender Division Commander R. Adm. Imamura Osamu

As mentioned previously, since gaining command of the air [in the areas to capture] was delayed, Dutch East Indies Unit Commander Vice Admiral Takahashi on the 7th changed the date to launch [the operation to] seize Tarakan and Menado from the 10th to the 11th. Accordingly, the operation schedule of all units was postponed by one day. ${ }^{(62)}$

\section{The Plan of Operations of the 2d Base Unit ${ }^{(68,72)}$}

1. The commander, on board of the Wakataka, shall leave Davao on 9 January, leading the main force of the $2 \mathrm{~d}$ Base Force, follow in the rear of the 1st Escort Unit and reach Tarakan on 11 January.

2. After the main force reaches Tarakan, the 11th and the 30th Minesweeper Divisions and the Kumagawa-maru shall be returned to the command [of the $2 \mathrm{~d}$ Base Unit] and charged with sweeping for mines inside the port of Tarakan.

3. After sweeping for mines in the port of Tarakan and seizing [areas] around the port, the unit shall take charge of preparing, operating and administering the facilities of the port, while [also] carrying out the guarding and defense of the anchorages, relieving the 1st Escort Unit.

\section{The Plan of Operations of the 1st Air Unit}

R. Adm. Imamura Osamu, commander of the 1st Air Unit (a seaplane unit), by order No. 1 of the unit, assigned [his unit] to support the 1st Escort Unit and escort the Sakaguchi Detachment under sail. He [also] disclosed the outline of the support [the unit was to provide] during the landing operations on Tarakan. The outline of the actions of the ships and the allotment of the air operation were as follows: ${ }^{(76)}$

The outline of the actions of each ship

\begin{tabular}{|c|c|l|}
\hline Ship & Date & \multicolumn{1}{c|}{ Action } \\
\hline San'yō-maru & 9 January & $\begin{array}{l}\text { [The unit shall] conduct flying missions around the anchorages. } \\
\text { At 1700, it shall depart from Davao. } \\
\text { Around 0800, [it shall be] [on the waters] southwest of Tawi-tawi (or the } \\
\text { waters near the convoy when required), and carry out its duties. } \\
\text { [It shall] join the Sanuki-maru at the point } 119^{\circ} \mathrm{E} \text { and } 4^{\circ} \mathrm{N} \text { at } 0700 ; \text { after that } \\
\text { [it shall] act appropriately on the waters north of the convoy; and ad- } \\
\text { vance toward Tarakan while carrying out the air operation. } \\
\text { [It is] scheduled to enter the port of Tarakan in the afternoon. }\end{array}$ \\
\hline
\end{tabular}




\begin{tabular}{|c|c|l|}
\hline Sanuki-maru & 8 January & $\begin{array}{l}\text { [The unit shall] conduct flying missions around the anchorages. } \\
\text { At } 1830 \text { it shall depart from Davao. } \\
\text { [It shall] act appropriately in Sarangani Bay or in the near waters and } \\
\text { carry out air operations. } \\
\text { After that, by 0700, [it shall] join the San'y } \overline{0}-m a r u \text { at the point } 119^{\circ} E^{*} \text { and } \\
4^{\circ} \mathrm{N} ; \text { afterwards [it shall] act appropriately near the San' } y \overline{0}-m a r u ; \text { ad- } \\
\text { vance toward Tarakan while conducting air operations. }\end{array}$ \\
\hline $\begin{array}{c}\text { Patrol Boat } \\
\text { No. } 35^{* *}\end{array}$ & 7 January & $\begin{array}{l}\text { [The unit shall] replenish and prepare for a sortie in the morning; leave } \\
\text { Davao at 1700, after which [it shall] advance toward Tarakan, while } \\
\text { guarding the 1st Air Unit against [enemy] submarines. }\end{array}$ \\
\hline
\end{tabular}

\section{The allotment for the air campaign}

\begin{tabular}{|c|c|c|c|c|}
\hline Date & Tasks & $\begin{array}{c}\text { Time of } \\
\text { Departure } \\
\text { (and Return) }\end{array}$ & $\begin{array}{c}\text { Type, number of aircraft to } \\
\text { be employed per } \\
\text { shift/launching ship }\end{array}$ & Outline of Action \\
\hline \multirow{2}{*}{7 January } & $\begin{array}{l}\text { Direct defense of the trans- } \\
\text { port convoy against } \\
\text { [enemy] aircraft }\end{array}$ & $1100(1800)$ & $\begin{array}{l}2 \text { Type- } 0 \text { observation sea- } \\
\text { planes / Sanuki-maru }\end{array}$ & $\begin{array}{l}\text { As designated by the } \\
\text { captain of the ship. }\end{array}$ \\
\hline & $\begin{array}{l}\text { Guarding of the anchorage } \\
\text { ([of] Davao) against } \\
\text { [enemy] aircraft }\end{array}$ & $1100(1500)$ & $\begin{array}{l}3 \text { Type- } 0 \text { observation sea- } \\
\text { planes / San'yo-maru }\end{array}$ & $\begin{array}{l}\text { 1st shift } 1100(1300) \\
\text { 2d shift } 1300(1500)\end{array}$ \\
\hline 8 January & $\begin{array}{l}\text { Direct defense of the trans- } \\
\text { port convoy against } \\
\text { [enemy] submarines }\end{array}$ & $0630(1830)$ & $\begin{array}{l}2 \text { Type- } 0 \text { observation sea- } \\
\text { planes / Sanuki-maru }\end{array}$ & $\begin{array}{l}\text { As designated by the } \\
\text { captain of the ship. }\end{array}$ \\
\hline \multirow[t]{2}{*}{9 January } & Ditto & $0650(1900)$ & $\begin{array}{l}2 \text { Type- } 0 \text { observation sea- } \\
\text { planes / San'yo-maru }\end{array}$ & $\begin{array}{l}\text { 1st shift } 0650(0900) \\
\text { 2d shift } 0845(1100) \\
\text { 3d shift } 1045(1300) \\
\text { 4th shift } 1245(1500) \\
\text { 5th shift } 1445(1700) \\
\text { 6th shift } 1645(1900)\end{array}$ \\
\hline & Search for the enemy & $1400(1700)$ & $\begin{array}{l}1 \text { Type- } 0 \text { [reconnaissance] } \\
\text { seaplane/San'yō-maru }\end{array}$ & $\begin{array}{l}\text { Around the Sibutu } \\
\text { Passage }\end{array}$ \\
\hline \multirow[t]{2}{*}{10 January } & $\begin{array}{l}\text { Direct defense of the trans- } \\
\text { port convoy against } \\
\text { [enemy] submarines }\end{array}$ & $\begin{array}{l}0650(0930) \\
0900(1230) \\
1200(1430) \\
1400(1630) \\
1600(1910)\end{array}$ & $\begin{array}{l}2 \text { Type- } 0 \text { observation sea- } \\
\text { planes / San'yo-maru } \\
2 \text { Type- } 0 \text { observation sea- } \\
\text { planes / Sanuki-maru } \\
2 \text { Type- } 0 \text { observation sea- } \\
\text { planes / San'yo-maru } \\
2 \text { Type- }-0 \text { observation sea- } \\
\text { planes / Sanuki-maru } \\
2 \text { Type- }-0 \text { observation sea- } \\
\text { planes / San'yō-maru }\end{array}$ & $\begin{array}{l}\text { Each ship can increase } \\
\text { the number of aircraft, } \\
\text { depending on the sit- } \\
\text { uation. }\end{array}$ \\
\hline & Search for the enemy & $0700(1000)$ & $\begin{array}{l}2 \text { Type-0 [reconnaissance] } \\
\text { seaplanes / San'yō-maru }\end{array}$ & $\begin{array}{l}\text { Search area: around } \\
\text { the Sibutu Passage, } \\
\text { southwestern part of } \\
\text { the Sulu Sea. }\end{array}$ \\
\hline
\end{tabular}

* The text mistakenly has $111^{\circ}$

** In the tables on pp. 96 and 126: Patrol Boat No. 39. She was in January replaced by Patrol Boat No. 35. 


\begin{tabular}{|c|c|c|c|c|}
\hline 11 January & $\begin{array}{l}\text { Support for the ground op- } \\
\text { eration } \\
\text { Guarding of the anchorage } \\
\text { against [enemy] sub- } \\
\text { marines }\end{array}$ & $\begin{array}{l}0630(0830) \\
0730(1000) \\
0730(1000) \\
0900(1130)\end{array}$ & 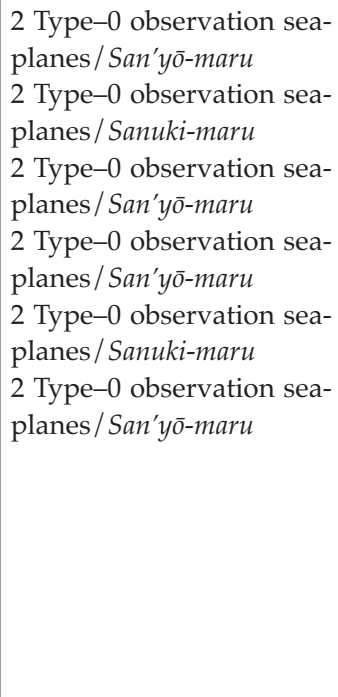 & $\begin{array}{l}\text { 1. Support for the } \\
\text { ground operations } \\
\text { shall be carried out } \\
\text { in close communi- } \\
\text { cation with the } \\
\text { ground units } \\
\text { 2. Attack targets: } \\
\text { (1) [Enemy] posi- } \\
\text { tions and batteries } \\
\text { that are resisting } \\
\text { (2) Enemy troops } \\
\text { and vessels escap- } \\
\text { ing from Tarakan } \\
\text { (3) Targets desig- } \\
\text { nated by ground } \\
\text { units } \\
\text { (4) Enemy forces in } \\
\text { the outer areas of } \\
\text { Tarakan Island }\end{array}$ \\
\hline
\end{tabular}

The execution of subsequent air operations shall be ordered depending on the war situation by separate orders.

Note by the editor: According to note 76, the above table is based on the records of the Sanukimaru. These records could not be traced in the archives. The records of the Sanyō-maru could be traced, but they differ in several places from the table above.

\section{Assessment of the Enemy Situation Centering on Tarakan}

First Escort Unit Commander Rear Admiral Nishimura's judgment about the enemy situation in the Tarakan area right before the sortie from Davao was in outline as follows: ${ }^{(56)}$

1. No enemy aircraft were spotted on the Tarakan airfield.

2. It seems that one or two submarines are staying in the port of Tarakan; it is also reported that a naval vessel that looked like a submarine tender was [also] there.

3. Enemy naval surface vessels are not likely to appear on the waters between Davao and Tarakan.

4. It seems that there are a few enemy naval surface vessels in the Balikpapan area.

5. Although [Japanese] air operations are to be carried out with Jolo as the base, the tardiness in the improvement of the base caused a delay in the advance of land-based attack planes. [Because of this], attacks on Tarakan were conducted only about two times by fighter planes, and these have not yet produced adequate results.

6. As we are advancing toward the Borneo area from now on, the appearance of many enemy aircraft is expected.

7. Enemy submarines are gradually assembling at the mouth of Davao Gulf and in the Celebes Sea; this situation requires the highest state of alert.

\section{The Launch of the Invasion Operation}

\section{Preliminary Neutralization of the Enemy Air Power Completed}

The air attack on Tarakan was launched first of all by the Mihoro Air Group of the Malaya Unit. That is to say, in view of enemy aircraft coming toward Miri and Kuching, the Malaya Unit was keenly aware of the necessity to neutralize Tarakan, and attacked Tarakan on the 
26th of December with seven land-based attack planes, and again on the 28th with seven land-based attack planes and four fighter planes of the Mihoro Air Group. ${ }^{(71)}$ However, each time only one aircraft was spotted on the ground in these attacks, and they were destroyed. As described previously, on the same day, the 28th, the 3d Air Group of the 1st Air Raid Unit attacked Tarakan with seven Type- 0 fighter planes and one land-based reconnaissance plane, and reported that the unit had caught up with nine enemy fighter planes and had brought down four planes for sure, almost certainly brought down two, but was not sure about the results of the other two or three. ${ }^{(71)}$

It was not until 30 December when the 2d Air Raid Unit, which was [supposed to be] mainly in charge of the attack [on the areas including Tarakan], made its first attack on Tarakan. ${ }^{(71)}$ From that time on, the unit conducted reconnaissance attacks over the area of Tarakan with fighter planes and land-based reconnaissance planes on 31 [December] and 3, 4 , and 5 January, but no enemy was spotted other than one auxiliary aircraft carrier, which was seen at Balikpapan on the 31st by a land-based reconnaissance plane. ${ }^{(7)}$ Meanwhile, by the 7th [of January] the long-awaited advance of twelve land-based attack planes of the Takao Air Group from Gaoxiong to the Jolo base was [finally] effected. ${ }^{(62)}$

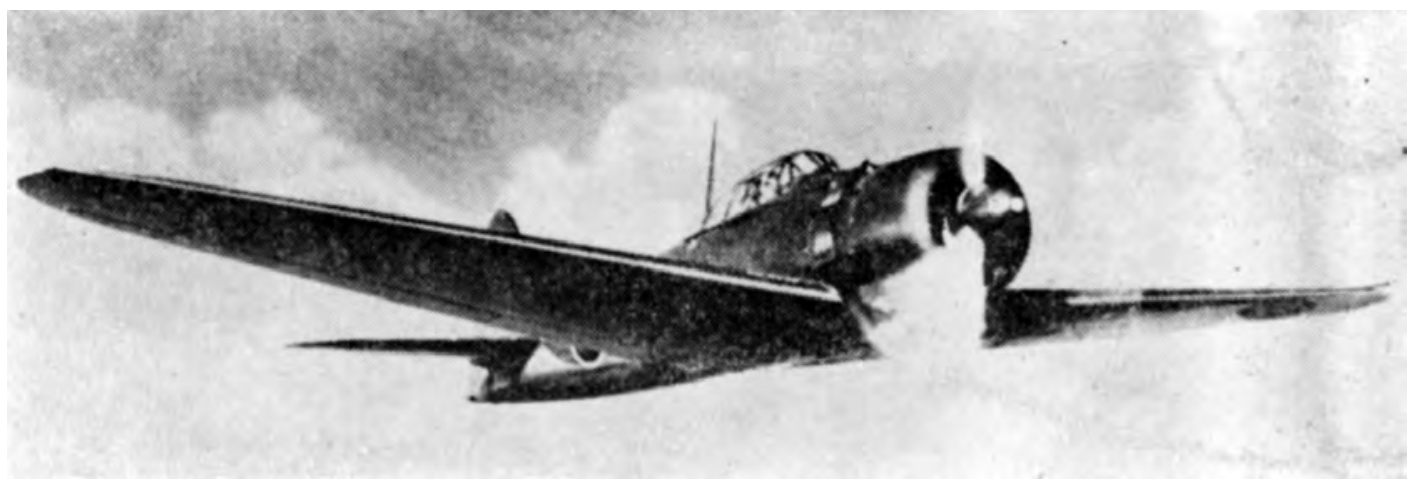

Type-0 Fighter Plane

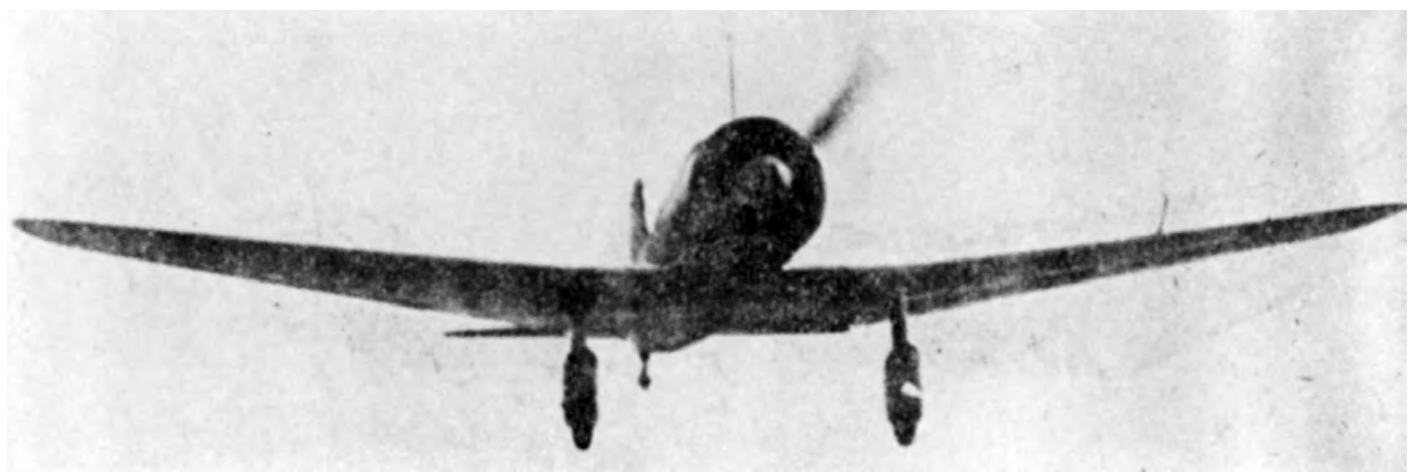

Type-98 Land-based Reconnaissance Plane 


\section{The Sailing of the Convoy}

At 0800 on 7 January, the convoy of about forty ships left Davao as scheduled. Receiving a report that a reconnaissance seaplane of the San'yo-maru had spotted two objects at about $4^{\circ} 55^{\prime} \mathrm{N} 124^{\circ} \mathrm{E}$, which looked like enemy submarines, but that it had lost sight of them in a short while, the convoy [once] altered course to avoid [enemy submarines]. However, other than that, the convoy calmly approached the anchorage. ${ }^{(56)}$ During the sailing, reconnaissance seaplanes of the 1st Air Unit and fighter planes of the 1st and the $2 \mathrm{~d}$ Air Raid Units provided direct defense above the convoy, while the land-based attack planes of the units made a reconnaissance attack on Tarakan as well as searched for the enemy in the Makassar Strait. The outline of the results of the air reconnaissance reported by the $2 \mathrm{~d}$ Air Raid Unit as of the afternoon of the 9 th was as follows: ${ }^{(71)}$

1. On the 9th, [the unit] attacked one merchantman and one gunboat ([of] 200 tons), which were moored alongside the pier at the port of Lingkas. Two bombs directly hit them, and [the ships] are expected to catch flames and sink.

2. It seems that the enemy does not expect that they will come under attack of the Japanese forces soon.

3. Although there is considerably fierce antiaircraft fire, no enemy aircraft were spotted.

The destroyer division and the minesweeper divisions, which had sailed ahead as planned from 0000 on the 10th onward, reached the lightship outside the port of Tarakan around 1000 of the same day, seized a 1,000t-class Dutch merchantman loaded with one aircraft, which had set out from the port just then, led it to the area near the 1st anchorage and had it drop anchor. In the meantime, around 1130, the Natsugumo reached the lightship and seized it. Around that time, the Sanuki-maru, ([which sailed] in the rear out of sight of the transport fleet) was bombed by large enemy planes, but sustained no damage. By 1500 the convoy was approached for about thirty minutes by two large enemy aircraft, and it was considered that the full picture of the Tarakan invasion unit was more or less known [to the enemy].

Around 1600, the security unit, which had sailed ahead, completed the clearing [of mines] of the 1st anchorage and reported no mines [left]. At 1750 when the convoy reached right in front of the anchorage, three twin-engine bombers, and two fighter planes of the enemy came for an attack, dropped bombs near the convoy and immediately escaped. Again at 1818 two twin-engine planes came for an attack and dropped bombs, but fortunately the Japanese forces sustained no damage. At 1900, separating into the 1st and the $2 \mathrm{~d}$ Sections, the convoy dropped anchor at the 1st anchorage thirty minutes earlier than scheduled. Earlier at 1805, a reconnaissance seaplane of the $S a n^{\prime} y \bar{o}$-maru had spotted an enemy submarine afloat one nautical mile off Tarakan, but let her slip away. The security unit cleared the sea of mines at the 2d anchorage between 1935 and 2115, and reported that no mines were snagged.(56)

\section{The Landings and the Land Combat (See Illustration No. 7)}

The 1st Section, i.e. the right wing unit of the Sakaguchi Detachment and the 2d Kure Special Landing Force ([the latter] under the command of Cdr. Makiuchi Tadao), dropped anchor at the 1st anchorage at 1900 and immediately started their preparations for the landings. At 2130, the first landing unit of the right wing unit of the Sakaguchi Detachment left the anchorage, which was followed by the $2 \mathrm{~d}$ Kure Special Landing Force, leaving the anchorage 
thirty minutes later at 2200. Around 2100, flames from fires that had apparently been set were observed from the sea rising up at two locations on Tarakan. At 2215, the 2d Section set sail and headed for the $2 \mathrm{~d}$ anchorage. At 2325, the Yamakaze, which was patrolling the southern side of the 1st anchorage, spotted an enemy submarine that had surfaced, but lost sight of her because she had dived immediately. Four ships of the $2 \mathrm{~d}$ Section dropped anchor at the $2 \mathrm{~d}$ anchorage between 0100 and 0120 on the 11th, and the first landing unit of the left wing unit of the Sakaguchi Detachment left the $2 \mathrm{~d}$ anchorage at 0220 . From 0330 onwards, the [ships of the] 1st Section also moved to the $2 \mathrm{~d}$ anchorage one after another. Around 0700, 1st Escort Unit Commander Rear Admiral Nishimura received a report from Detachment Commander Sakaguchi that "the first landing unit had successfully landed at 0000 on the 11th and the second landing unit at 0400." [Meanwhile] on the island of Tarakan, where fires had been burning from the previous night onwards, [further] explosions occurred at the oil fields and large fires broke out in the area of Lingkas around 0300, creating a ghastly sight in the dim light of dawn with black smoke covering the entire sky. ${ }^{(56)}$

Around 0940, the 1st Escort Unit commander received from the Sakaguchi Detachment the first report on the land combat, which was in summary as follows: "(1) The right wing unit mistook [the location of] the Amal [river] and landed on the northeastern end of Tarakan Island; at present it is preparing to transfer to the mouth of the Amal river. (2) The left wing unit is advancing as scheduled. [Reported at] 0900." Although the seizure of Lingkas and the Mengacu battery was a matter of the utmost urgency, [enemy] machinegun fire from the ground at friendly aircraft flying over these areas indicated that the left wing unit had not yet seized them. [The Navy] had not the slightest idea what had happened to this unit. [Meanwhile,] two enemy four-engine bombers raided the anchorage twice between 1300 and 1340; they dropped bombs around the anchorage, but no damage was sustained. At 1400, the $2 \mathrm{~d}$ Base Unit, which followed [the 1st Escort Unit], [also] arrived at the anchorage, and the 1st Escort Unit commander returned the minesweeping force to the $2 \mathrm{~d}$ Base Unit. Finally at 1700, he received from the Sakaguchi Detachment the second report on the land combat, which was in outline as follows:

1. The right wing unit and the [naval] special landing force have advanced to the highlands east of [the town of] Tarakan, but blocked by a powerful enemy artillery position, their advance has been delayed. They plan to break through the position tonight by means of a night attack.

2. The situation of the left wing unit is unknown.

3. [We] request bombing of the battery position to the east of the foreign residential area in the town of Tarakan, the Juwata Battery at the northern end of Tarakan, and the antiaircraft battery position on the islet of Sadau west [of Tarakan].

Thus, on 11 January, with sunset at 1916, the second night [on Tarakan] came around while the situation of the land combat failed to work out as expected. About one day had passed since the launch of the Tarakan operation, but the advance of the right wing unit had got stuck whereas the situation of the left wing unit was totally unknown. Moreover, the enemy at the Mengacu Battery was [still] very active, while right in front essential resource materials were being consumed by fire. [The Japanese forces] impatiently greeted sunrise on the 12th. In the meantime, in the middle of night of the 11th, having heard nothing at all from the left wing unit since its landing, Detachment Commander Sakaguchi deployed one infantry company, which was under the direct control of the detachment and led by Lt. Col. Namekata 
Shōichi, to land at Cape Batu and advance along the coast to seize the Mengacu Battery. The Namekata Detachment landed on the coast southeast of the battery at 0430 on the 12th, and advanced in front of the battery around dawn. Detachment Commander Sakaguchi was advancing at the rear of the right wing unit after its landing. [According to Vol. 3, The Invasion of the Dutch East Indies, p. 179, Detachment Commander Sakaguchi landed at Amal sometime during the day on the 12th, after it had become clear that his landing at the Lingkas pier was impossible.]

The right wing unit, i.e. the Yamamoto Regiment, which had planned to break through the strong enemy position in a night attack, handed over the task of securing the highlands northeast of the town of Tarakan to the [naval] special landing force and carried out the night attack on the enemy position at 2300. However, meeting with extremely fierce resistance of the enemy, the Yamamoto Regiment, which at one time managed to seize part of the enemy barracks, failed to succeed in seizing the entire position and had no choice but to go back to its original position by dawn. At 0820, when the regiment was making preparations to resume the attack, the bearer of a flag of truce of the enemy sent by the enemy garrison commander came to offer a general surrender. Receiving the offer, Regimental Commander Yamamoto wired Detachment Commander Sakaguchi his request that [the detachment commander] swiftly land at the Lingkas pier. Also, while starting disarming the enemy, he strictly instructed them to forbid any resistance by the batteries at the mouth of the port. The special landing force seized the airfield at 1500, but the left wing unit lost its bearings in the dense forest and only reached the rear of the Karungan Battery around noon on the 12th. However, unable to find the battery and due to communication troubles, the unit was not able to seize the said battery on that day. Detachment Commander Sakaguchi learned of the surrender of the enemy at 0900, and advanced into the town of Tarakan [according to Vol. 3, p. 179, at 1930]. (56)

\section{The Engagement of Minesweepers No. 13 and No. 14}

Having received the report of the surrender of the enemy at 0930, 1st Escort Unit Commander Rear Admiral Nishimura, leading the Naka, shifted to [the area] near the $2 \mathrm{~d}$ anchorage from the outer area of the anchorages, so as to take general command of the clearing of the waterways to the mouth of the port of Tarakan as well as the disembarkation of units and matériel at the port of Tarakan. He took a position from where he could observe the mouth of the port of Tarakan and issued an order to start clearing the waters [of mines] at 1100. According to the "Action Report of the 4th Destroyer Squadron, No. 3," the details of the engagement of the minesweeper divisions were as follows.

\section{The Engagement of the Minesweeper Divisions at the Mengacu Waterway on 12 January}

1. The situation before the engagement

(a) The general situation

(1) Although the situation of the land combat was not clear, its progress seemed quite different from what had been expected. The enemy battery at Mengacu was still intact; two large-sized motorized [landing] craft, which operated near the mouth of the port on the afternoon of the 11th, came under fierce fire from the enemy battery. Although [the craft] managed to return safely, the power [of the battery] should not be underestimated. 


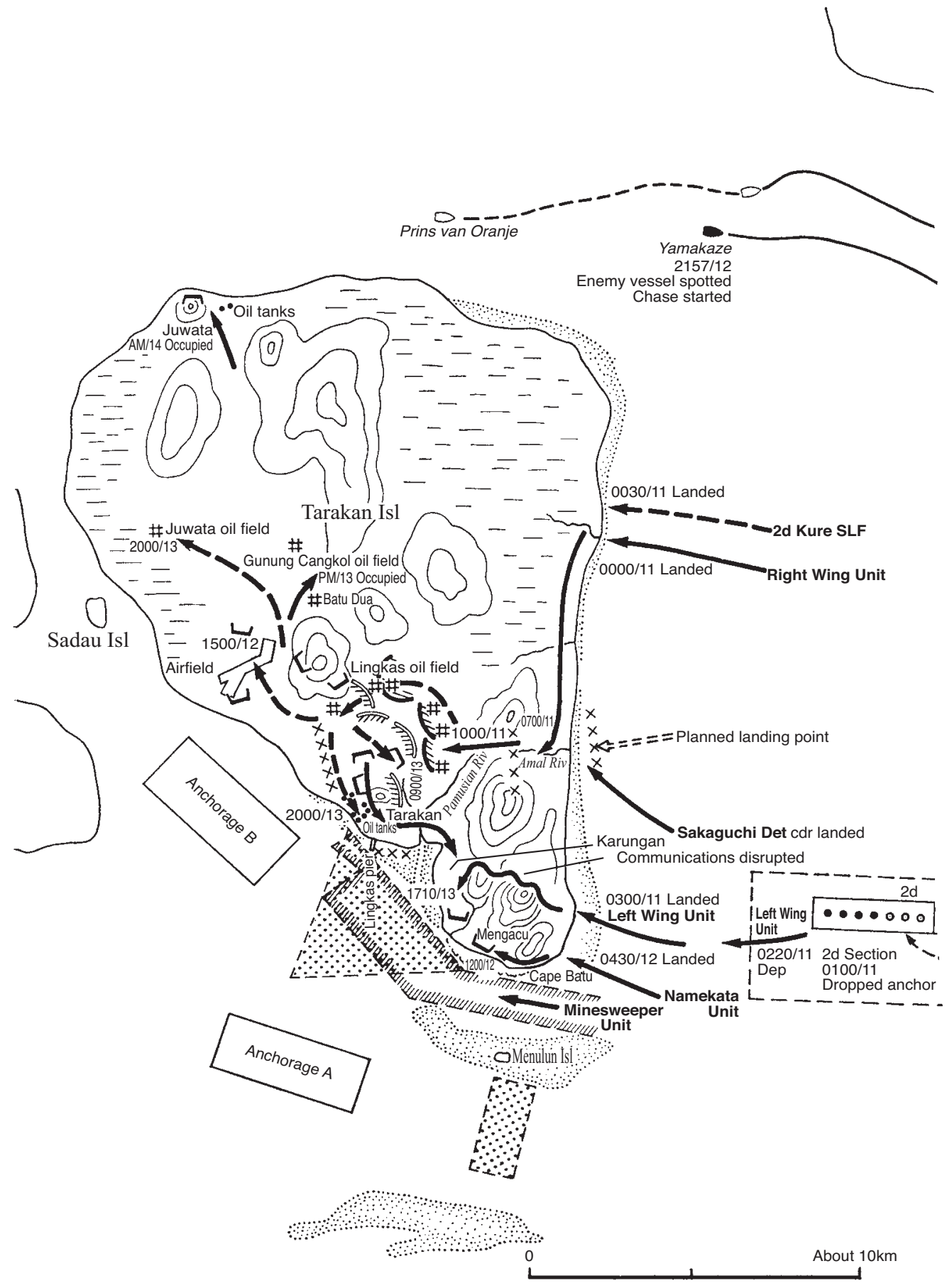

Illustration No. 7 - The Outline of the Capture of Tarakan (10-20 January, 1942) 

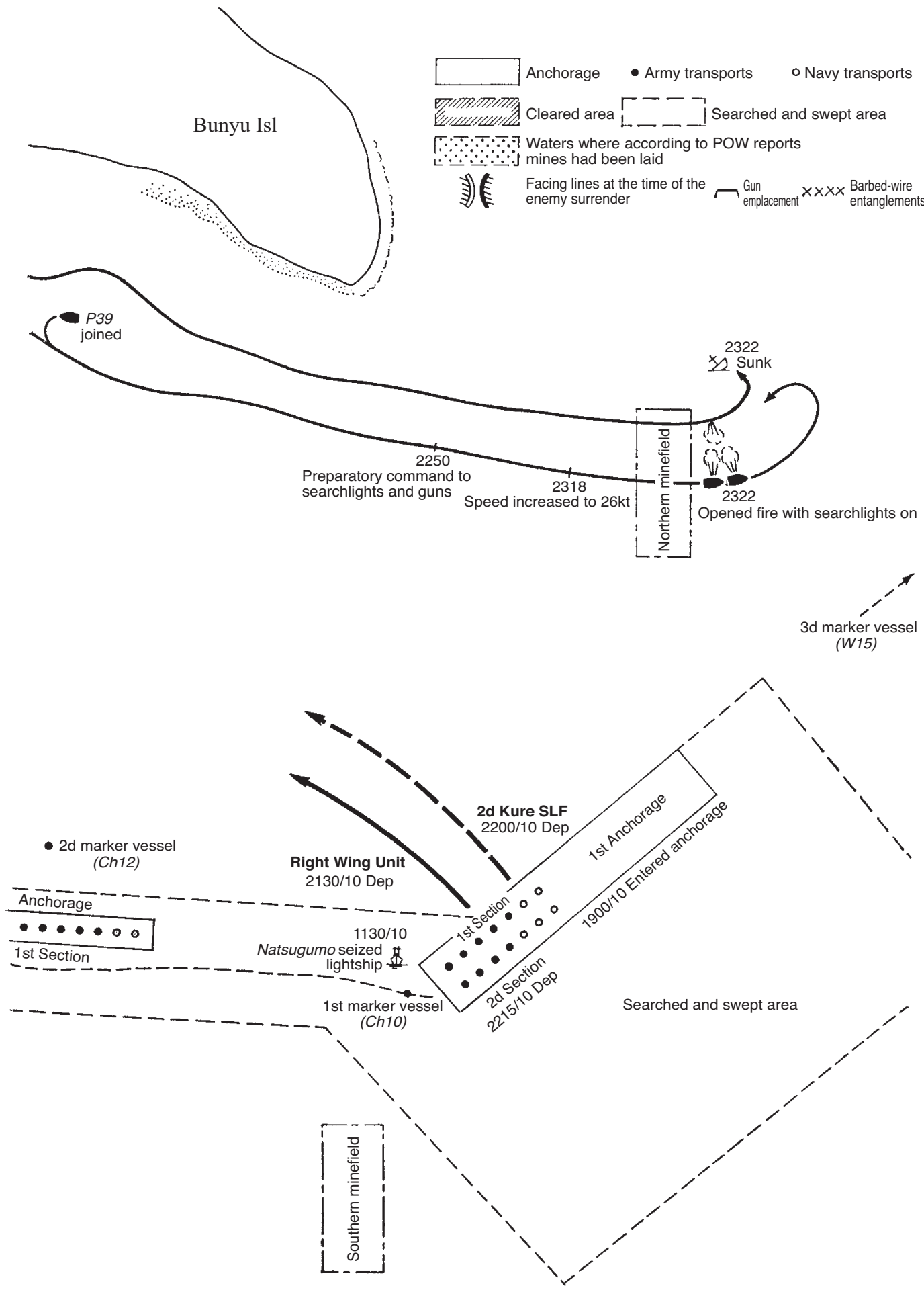
(2) The fires at the oil wells and tanks were burning so furiously that a thick black smoke completely covered the sky in the west, consuming the heavy oil resources, about which we could do nothing but watch them [burn] in front of us.

(3) Because the friendly fighter planes were based on Jolo, which is far away, it was impossible for them to ensure a flawless cover against enemy air raids, due to the time [required to get here] and for meteorological reasons. On the contrary, enemy planes frequently came in for a raid; they sometimes came around sunset after the friendly fighter planes had returned [to their bases].

(4) In view of the coming operations, the rapid preparation of the airfield [on Tarakan] was one of our greatest concerns.

In these circumstances, wishing to clear the waterway [of mines] as soon as possible following a rapid progress in the land combat, in order to disembark the required personnel and matériel, to ready the airfield (so that friendly aircraft could be deployed), and to secure the heavy oil resources, all of [the units] had been making preparations while awaiting the report of victory in the land combat.

(b) The launch of the minesweeper divisions

Around 0930 on the 12th, a report came from the army that the enemy garrison commander and his men had offered to surrender. Then, as soon as the order to clear the waters [of mines] was issued at 1100, the minesweeper divisions got ready to go into action. It was with such swiftness that it struck one by a "are they going already?" feeling of surprise.

The commander of the 11th Minesweeper Division went into action leading the 11th and the 30th Minesweeper Divisions and already reached the mouth of the port around 1200. The 11th and the 30th Minesweeper Divisions got into formation ready for minesweeping and were followed by several large-sized motorized [landing] craft belonging to the Special Minesweeping Service Unit of the Kumagawa-maru. They grandly entered the waterway of Mengacu.

2. The Progress of the Action [Illustration No. 8]

(Although the action report of the minesweeper divisions should [ideally] be referred to for the details, [here] the course of events based on the progress of the action as witnessed from the bridge of the Naka is described because it was difficult to learn the details [from the minesweeper division report] due to the loss of those directly involved in the action, i.e. the 11th Minesweeper Division commander, Minesweepers Nos. 13 and 14, and the majority of the crew. However, from the Naka, the action was almost throughout observed from distance of twelve to thirteen kilometers.)

The Minesweeper divisions got into formation ready for minesweeping, keeping a strict alert against the Mengacu battery as well as against mines. With all the crew having taken up their positions and geared up, they headed for the port with Minesweeper No. 13 at the head. Around 1200, as soon as [Minesweeper No. 13] changed course north of Menulun Island and headed toward the port, a hidden battery at Karungan (situated at the foot of a mountain and so well camouflaged that it was not easy to spot [even] when after the seizure [of Tarakan] viewed from the pier) and located at a distance of about two kilometers [from the ships], abruptly opened fire, at

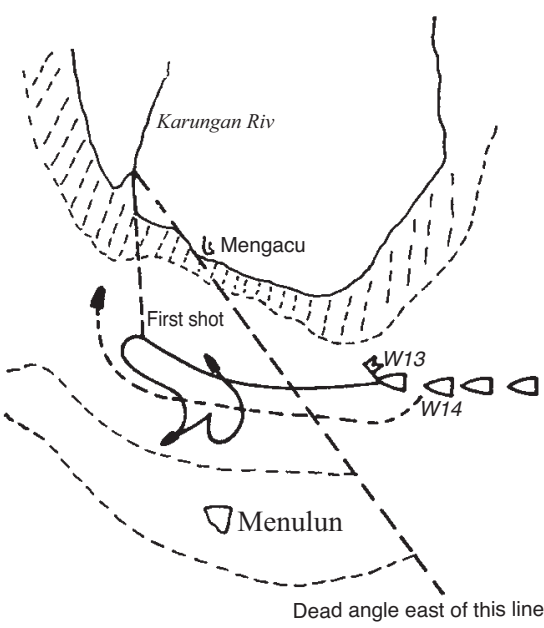

Illustration No. 8 - The Engagement of the Minesweeper Divisions 
first at Minesweeper No. 13. Minesweeper No. 13 immediately fired back, but the enemy fire became suddenly accurate from about the third salvo. [Minesweeper No. 13] first of all received a direct hit midships near the waterline. Following Minesweeper No. 13, Minesweeper No. 14 [also] began firing back.

The enemy markedly stepped up its rate of fire, and the artillery duel became extremely fierce. Although hit by enemy shells, Minesweepers Nos. 13 and 14 still continued firing and kept their course toward the port (seemingly gaining speed). [Meanwhile,] Minesweepers Nos. 15 and 16 and other ships, which had followed [them], slowed down and changed course, steering clear of the enemy's firing range.

Following [the first hit], Minesweeper No. 13 received a second hit near the bridge. Despite the blaze and the black smoke furiously rising from the violent explosion, all guns [of the ship] (the gun on the fore in particular) still kept on firing furiously. After a while, [the ship] gradually turned to port. Although hit by some more enemy shells near the stern, catching fires at places, and with steam violently shooting out, she [once] seemed to have successfully taken an evasive course. However, her speed suddenly slowed down, and she stopped for a moment. Then she [tried to] start an evasive action by moving backward, but she seemed unable to control [her movements]. After a while, as she started moving forward again, she [also] started turning to port. That time, for a moment, it looked as if she succeeded in taking evasive action, which made us feel a little relieved. However, the ship kept turning to port and again turned her bow toward the port [of Tarakan]; her rudder seemed out of order. Earlier, Minesweeper No. 14 had followed in the wake of Minesweeper No. 13. But when the latter slowed down and gradually turned port due to a hit [by the enemy], Minesweeper No. 14 came a little ahead of the latter. From around the time when Minesweeper No. 13 [tried to] start evasive action, enemy fire, which until then had been concentrated on Minesweeper No. 13, was [now] directed at Minesweeper No. 14. Almost all enemy shells scored direct hits causing fires at parts of the bridge, midships and stern, and steam shot from the ship. Particularly, the shell that hit her at the stern seemed to have caused an explosion of antisubmarine depth charges; black smoke from the explosions billowed high up into the sky, and the ship looked as if torn near the mizzenmast. Another shell, which hit near the first gun in the fore part, seemed to have blown off the gun, which was absolutely horrifying. Nevertheless, the ship suddenly changed course in such a way that she was heading toward the enemy battery. Also, she must have been set to full speed; suddenly she seemed to gain speed, wildly shooting steam from her side. With the first gun still firing, she was rushing toward the enemy battery. When the ship was finally about to go behind Cape Mengacu [and out of sight] from the bridge of the Naka, another large column of water was thrown up from around the waterline. The ship slowed down as if she had struck a mine, and was sinking from the bow, [still] closing in to the shore. After a while and about the time the first gun stopped firing, the ship sank behind Cape Mengacu. It was precisely at 1205.

During this period, Minesweeper No. 13 acted as previously described, temporarily evading enemy fire. However, the moment Minesweeper No. 14 sank, Minesweeper No. 13, which had been trying to retreat by slightly moving backward, [began] moving forward, as if already resolved, ([still] turning to port) and with the rudder out of order, she turned her bow again toward the port [of Tarakan], which caused enemy fire to be again concentrated on her. While the ship gradually slowed down, the enemy fire on the contrary became more and more accurate, and almost all shells scored direct hits and caused fires. Particularly, a hit near the bridge was terribly disastrous. A hit near the gun on the fore part looked as if it had totally destroyed the first gun, but the gun reopened fire after a while. And thus, due to a hit near the waterline, the ship, almost standing still, listed to port, and started gradually sinking from the bow. In a short while, raising her stern, the ship bravely met her end. It was 1215 . In the meantime, the other four minesweepers were soon after ordered to retreat. The desperate and courageous fight of Minesweepers Nos. 13 and 14 was so truly heroic that it would have made even a demon weep. 


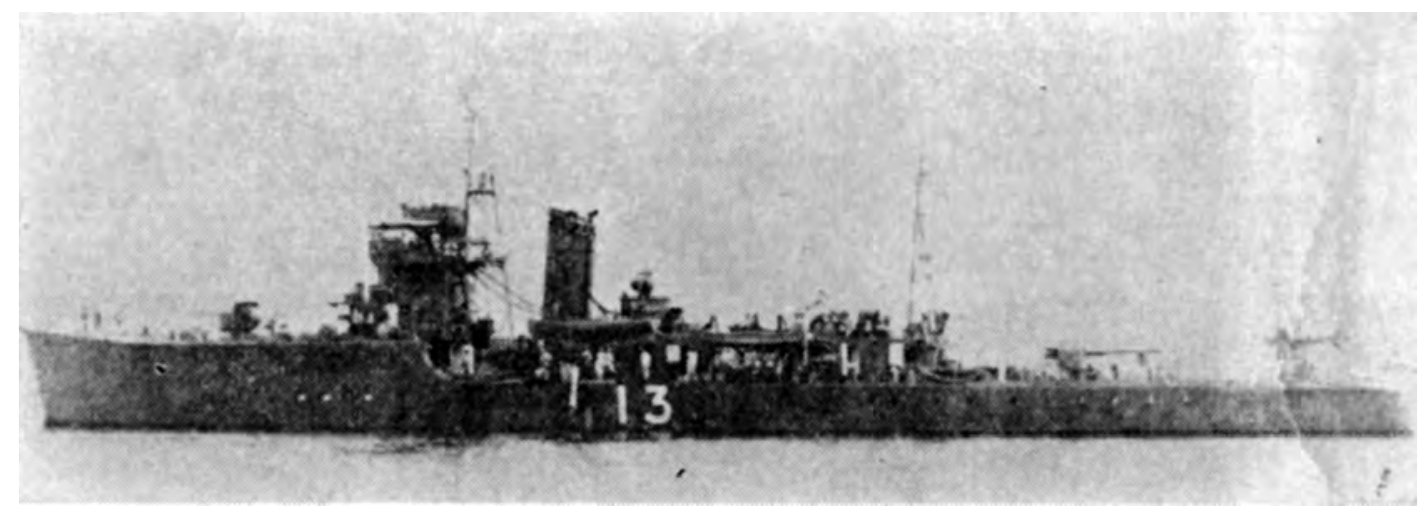

Minesweeper No. 13, Which Engaged with the Enemy Battery and Sank

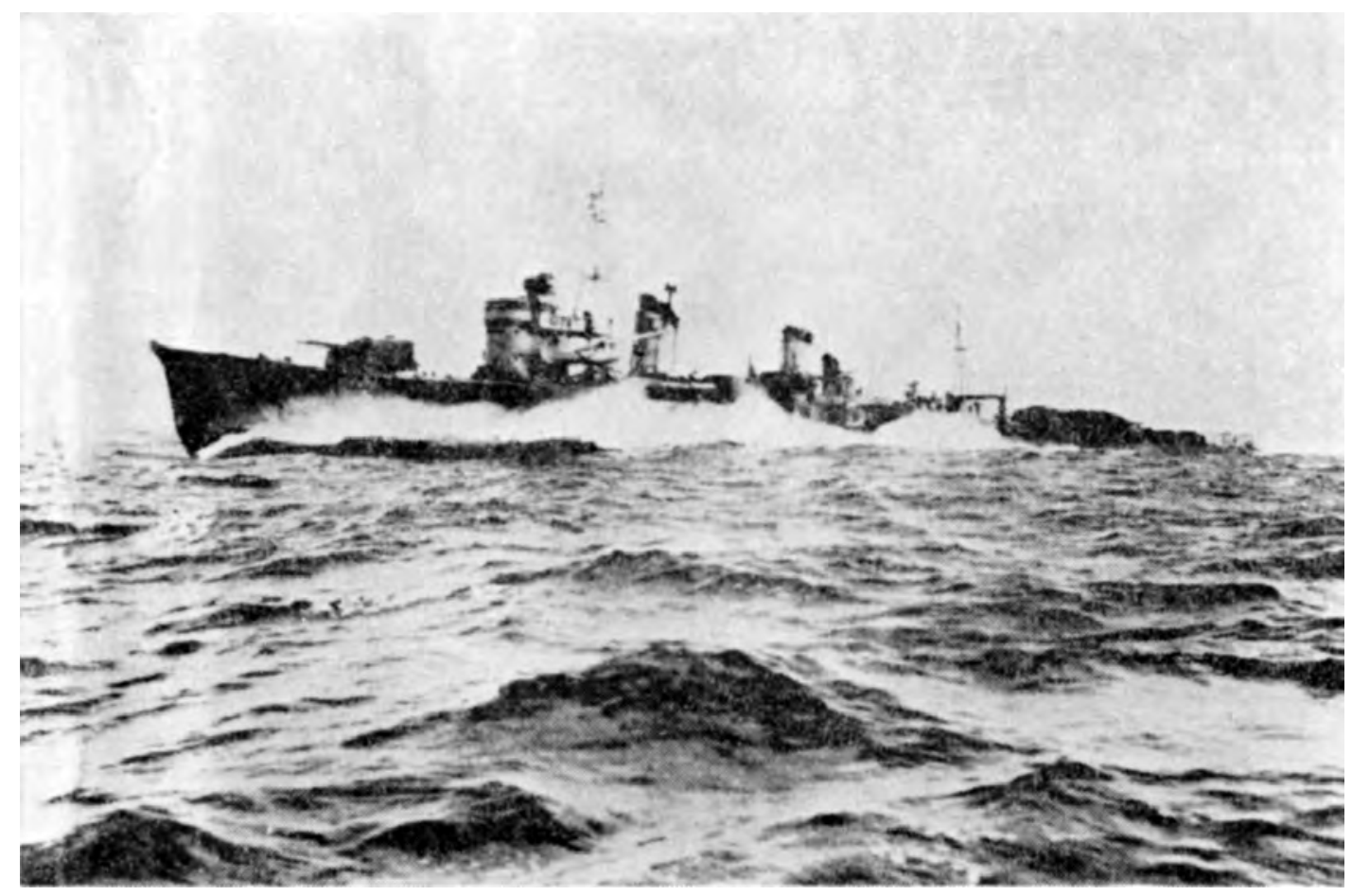

A Yamakaze-class Destroyer

It was an unexpected engagement that happened in only five or ten minutes, and [believing] that the enemy had surrendered, the Naka and the $2 \mathrm{~d}$ Destroyer Division, which witnessed the engagement from beginning till end, were off guard. Moreover, mines had been laid in the very narrow waters of the engagement, which made it impossible for them to rush to the rescue, leaving them helpless while the two minesweepers were lost. In this engagement, the 11th Minesweeper Division sustained a great loss of 156 men killed, including the commander of the division, Cdr. Yamakuma Wakito (graduate of the 48th class of the Imperial Japanese Naval Academy); (there were [only] 53 survivors). ${ }^{(56)}$ 


\title{
The Sinking of an Enemy Minelayer
}

On the night of the 12th, after the tragic engagement of the minesweeper divisions, the Destroyer Yamakaze (Capt.: Cdr. Hamanaka Shūichi; graduate of the 51st class), which had been deployed at the northern waterway, spotted an enemy naval vessel trying to escape [from Tarakan] and sank the latter. According to the "Action report No. 3 of the 4th Destroyer Squadron," the course of the engagement was as follows:

\begin{abstract}
At 2157, the Yamakaze, keeping guard on the waterway between the islands of Tarakan and Bunyu, spotted the silhouette of a ship, which looked like an enemy naval vessel. She gradually and secretly followed the latter up to the wider waters near the eastern exit of the waterway and maintained surveillance, while deliberately making such preparations as previously announcing all the [relevant] units the scheduled time of turning on the searchlights. At 2318, increasing her speed to 26 knots, she closed in on the [enemy] ship. At 2322, both ships almost simultaneously started firing, turning searchlights on each other at a distance of about 2 kilometers; the Yamakaze, along with Patrol Boat No. 38, which followed the former, sank the [enemy] ship at 2332.

Every salvo of the main gun of the Yamakaze scored a direct hit on the ship from the beginning, whereas many of the enemy shells flew over, mostly passing above our heads. And the power of their searchlight was very small; [the enemy] was not a match for us at all. The engagement was one-sided to the end, and the enemy [ship], which tried to escape, sank in the end. The average firing distance was about 1,800 meters. At 2355, we lowered two cutters on the waters near the location of the sinking and rescued five men (including one engineer lieutenant junior grade), after which we immediately continued our patrol. The enemy ship was the HNLMS Prins van Oranje.
\end{abstract}

The enemy ship, which [the Yamakaze] sank, was a Dutch minelayer (1,291 ton, with two 3inch guns and two 40-millimeter machineguns, 15 knots at top speed; built in 1931). This military gain by the Yamakaze was enough to lift the morale of all the personnel at the anchorage, who had felt somewhat frustrated because of the sinking of the minesweepers in the afternoon. ${ }^{(56)}$ This was the first engagement between naval surface vessels in the Philippines and the Dutch East Indies areas.

\section{The Guarding Against [Enemy] Submarines and Aircraft, and the Search for the Enemy [Illustration No. 9]}

The 1st Air Unit and the Air Unit of the Southern Task Force had day after day carried out the guarding of the invasion units against [enemy] submarines and aircraft, while searching for the enemy in the Makassar Strait and conducting attacks on Tarakan. By the 12th, they reported that they had sank or destroyed several [enemy] merchantmen, caused some damage to a submarine that had surfaced and a gunboat; [further] they had brought down one heavy bomber and destroyed another. During these operations, the only loss sustained [by Japanese forces] was one land-based attack plane, which had crashed itself, and one Type-0 fighter plane, which had made an emergency landing (with no loss of crew). 
144 Chapter V / The Forward Push of the Air Bases

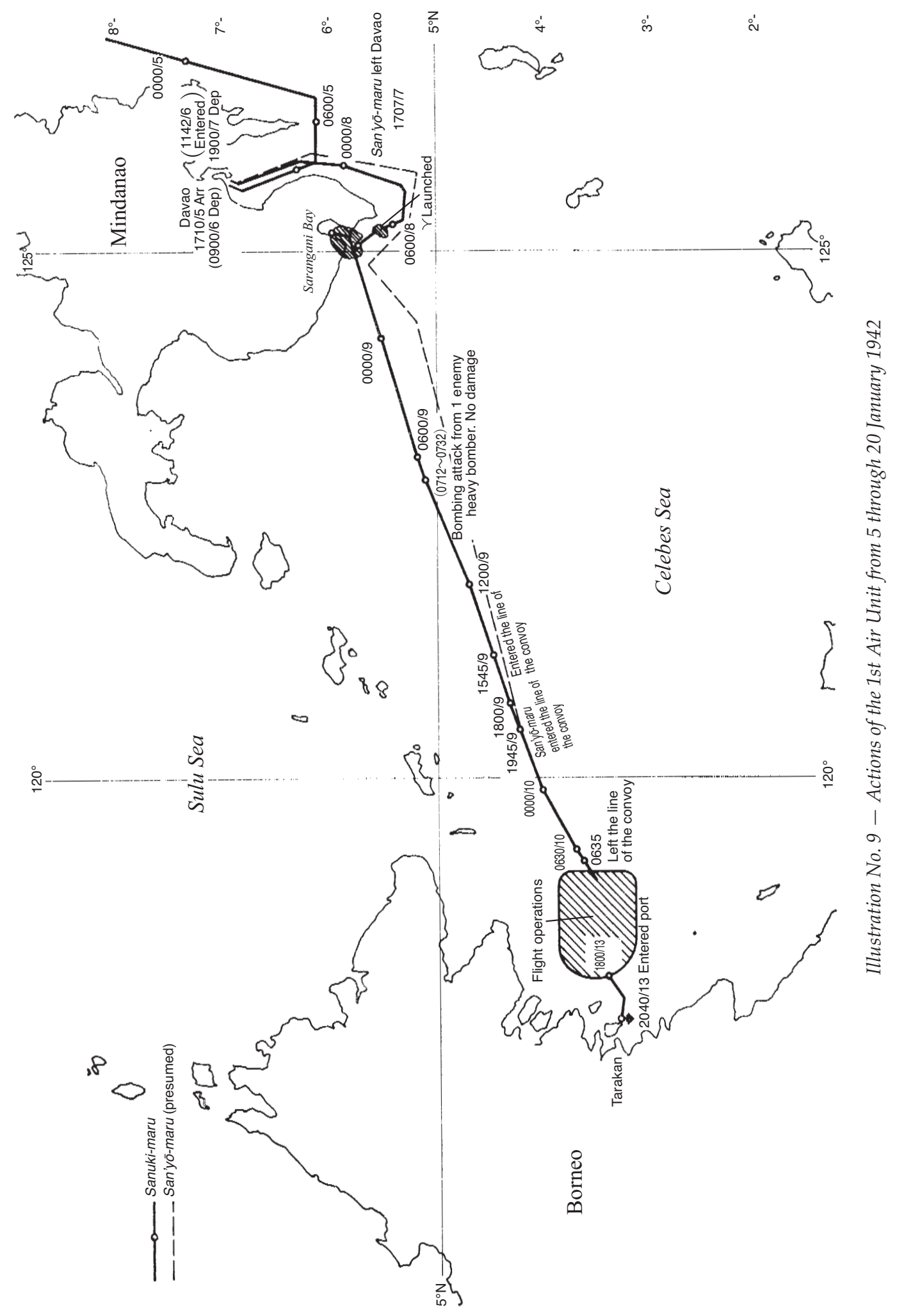




\section{The Launch of Preparations for the Coming Operations}

\section{Taking over the Guarding from the Army}

After the garrison commander had offered surrender at 0820 on the 12 th, the Army units disarmed the garrison one by one, seized the Karungan battery at 1710 on the 13th, and more or less completed the capture of the entire island with the disarmament of the Juwata battery on the morning of the 14th. At 1500 on the 14th, the [Naval] Special Landing Force relieved the Army from the guarding and took charge of the guarding of the entire island. The respective numbers of abandoned enemy bodies as well as those interned with injury and those taken prisoners, known by the 19 th, were about 300 , about 40 , and 871 . The major weapons that the 2d Kure Special Landing Force had seized were 40 heavy machineguns, 322 rifles, 24 pistols, $38500-\mathrm{kg}$ bombs and 48 1000-kg bombs (note by the author: the judgment of the size of the bombs was wrong; they are considered to have been far smaller.) The loss sustained by the Japanese forces in the land combat were 7 killed and about 35 injured of the Sakaguchi Detachment and 3 injured of the $2 \mathrm{~d}$ Kure Special Landing Force. ${ }^{(56)}$

The inhabitants generally disliked the Dutch, but were quite obedient to the Japanese Army, warmly welcoming them. ${ }^{(56)}$

\section{The Minesweeping of the Inner Port Delayed}

Although minesweeping the port was a matter of the utmost urgency for the subsequent operations, it was not an easy matter at all. The Dutch minelayer HNLMS Prins van Oranje, which had earlier been sunk by the destroyer Yamakaze, had laid all the mines she carried

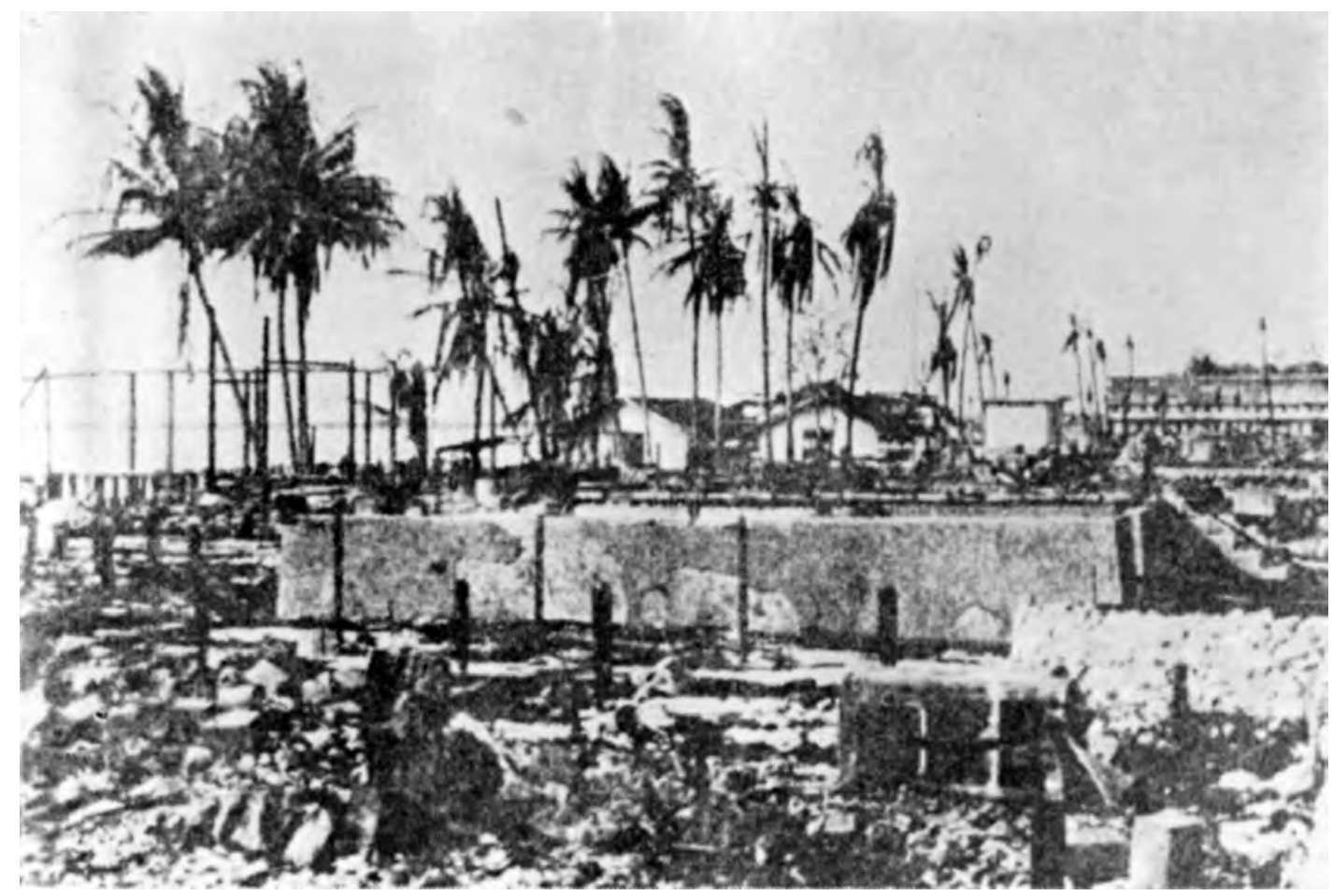

A Battle Site on Tarakan 


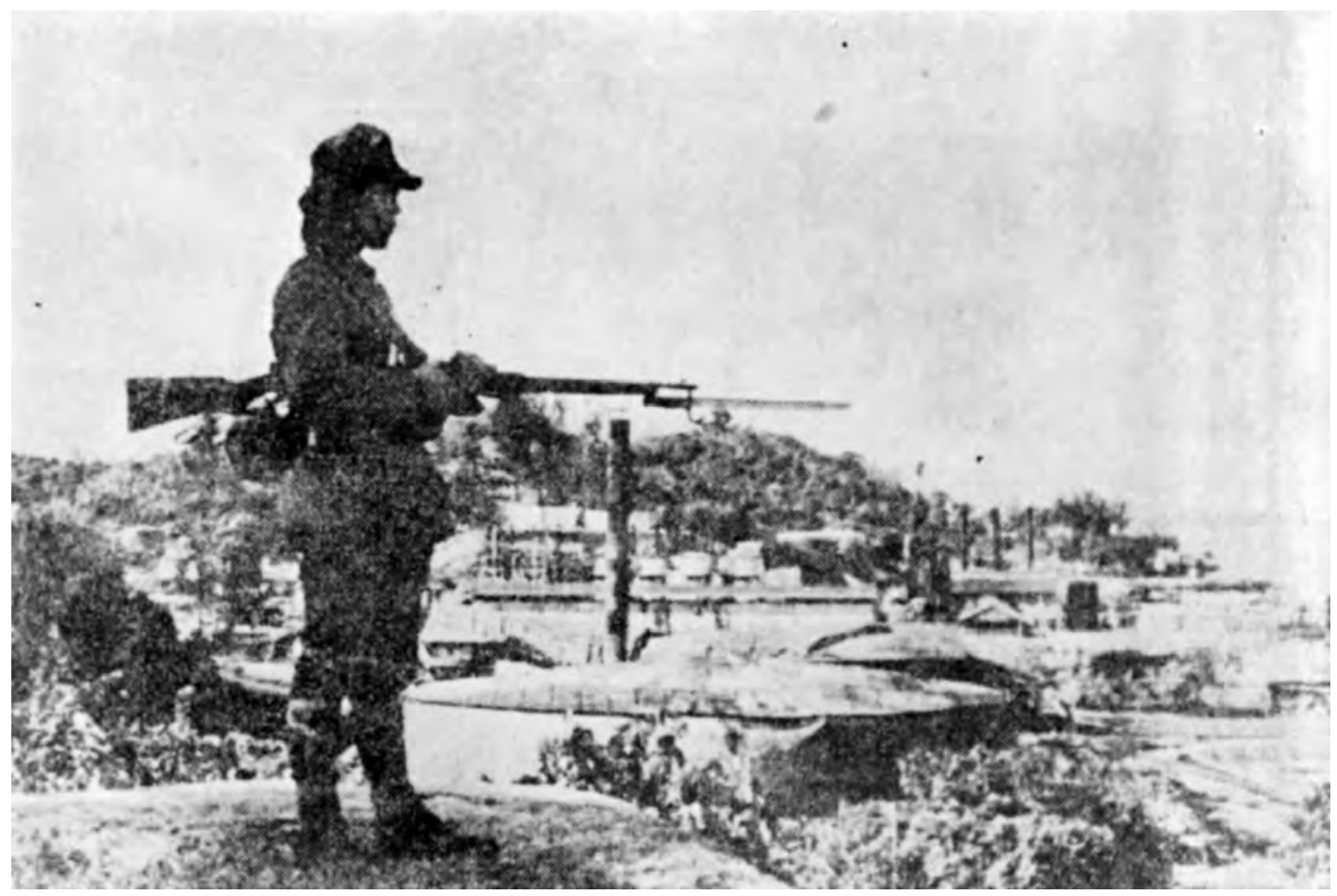

A Member of the Special Landing Force Guarding the Island of Tarakan

(110 mines) all over the port before her escape. Arial reconnaissance by a reconnaissance seaplane of the Naka with a staff officer of the $2 \mathrm{~d}$ Base Force and the commander of the Special Minesweeping Service Unit on board revealed that the port was almost totally covered with mines. After the Army had dealt with the Karungan battery at 1710 on the 13th, the Special Minesweeping Service Unit got to work on minesweeping [the port] with large-sized motorized [landing] craft and boats from 0700 on the 14th onwards, and finally by 1330 managed to clear a waterway wide enough (700 meters) for large-sized motorized [landing] craft to reach the Naval wharf. After that and until the 17th, the unit continued sweeping with largesized motorized [landing] craft and boats, disposed of 77 mines, and cleared a waterway of 1,500 meters wide. It was not until the 18 th that the unit for the first time started minesweeping with the minesweepers ([of] the 11th and the 30th Minesweeper Divisions, four ships in total). The unit disposed of 173 mines in total by the 24th. Nevertheless, no transport ships were able to reach the anchorage inside the port before the launch of the operation to seize Balikpapan. ${ }^{(56)}$

\section{Little Progress in Conditioning the Airfield}

The minesweeping of the anchorage became such a serious hindrance that it was impossible to promptly send in the construction force to condition the airfield. Therefore, 1st Escort Unit Commander Rear Admiral Nishimura decided to put ashore on the 13th in the afternoon for the time being a small number of staff officers of the construction [squad] at the mouth of Amal River, dispatch them to the airfield, and ready the airfield as much as possible with the force of the $2 \mathrm{~d}$ Kure Special Landing Force. However, at 1620 on the same day, three twin- 
engine enemy bombers raided [the airfield] and caused a major loss of fifteen men killed and twenty-seven injured of the special landing force, who were preparing it. This [further] held up the preparation of the airfield. ${ }^{(62)}$ At 1100 on the 14 th, a report came from the $23 \mathrm{~d}$ Air Flotilla headquarters, which was in outline as follows: ${ }^{(62)}$ "Today at 0830 we had a land-based reconnaissance plane conduct a low-altitude reconnaissance [of the airfield]. [According to its report], the airfield is dotted with obstacles, and even a runway [as narrow and short as] 20 meters wide and 700 meters long has not yet been cleared, [which means] it is impossible for Type- 0 fighter planes to take off or land. Moreover, no personnel were spotted working on the airfield at all. If the situation remains as it is, it is impossible [for us] to provide guard [against enemy planes] at dawn and dusk, when they are most likely to come for a raid. Therefore, we would like you to attend to the situation as quickly as possible and clear and ready [a runway] of [more than] 100 meters wide and more than 1,000 meters long (which should be able to support a weight of about three tons)." Meanwhile, as soon as a waterway [wide enough for] large-sized motorized [landing] craft was cleared on the afternoon on the 14th, the 1st Escort Unit commander put ashore the members of the construction squad in quick succession to make together with locals pressed into service a start with the expansion of the runway for fighter planes; on the 16th, a minimum runway for fighter planes to land on was mostly completed. Because of this, nine fighter planes and two land-based reconnaissance planes of the Tainan Air Group of the 23d Air Flotilla advanced to the Tarakan [airfield] on the same day. ${ }^{(62)}$ However, the airfield at Tarakan was unexpectedly small, and a hill to the east ([of] the runway that stretched from east to west) allowed planes to take off and land only from the west. Moreover, the soil was bad and without improvement, [the airfield] was unsuitable for use by land-based attack planes. Because of this, it was expected that another considerable number of days would be required before [the airfield] would allow the landing of land-based attack plane units. Although at that time bulldozers had also been captured, [the Japanese forces] were not able to handle them. ${ }^{(20)}$

\section{The Swift Restoration of the Oil Fields}

According to the report of the head of the $2 \mathrm{~d}$ Defense Detail, the condition of the oil fields after the occupation was as follows: ${ }^{(56)}$

\section{2d Defense Detail Classified Telegram No. 26 (2210 on the 15th)}

A considerable amount of heavy oil is stored, which can be transported in drums. Since it is impossible to examine [the situation] at night, the [amount of] storage and the capacity of transporting it in drums shall be reported as soon as [the results of] the examination become clear tomorrow.

A plan [to install] temporary [oil-] bunkering equipment by using pipelines is under consideration.

2d Defense Detail Classified Telegram No. 9 (1900 on the 16th)

Results of the examination concerning the capacity to supply the remaining oil as well as those concerning the facilities were as follows:

1. The remaining heavy oil in tanks: 12,300 tons (gravity 35 degrees Baumé; the other qualities of the oil are yet unknown) for the tanks in Lingkas only.

2. [There are] 120 drums of heavy oil. 
3. [There are] 1,900 empty drums, which are expected to be filled from the heavy oil tanks and transported by naval vessels.

4. Although one of the three oil pipelines between the Lingkas tanks and the new pier was burned and damaged, the other two are usable. All the pipelines at the pier end are not usable for 500 meters. Due to a lack of machine tools and motor power at present, it is considered extremely difficult to temporarily repair [the pipelines], however, we are planning to make temporary repairs using the equipment left.

5. We have removed all seven explosive devices left set at the heavy oil tanks in the Juwata oilfield area.

2d Defense Detail Classified Telegram No. 13 (1446 on the 17th)

The condition of the oil fields is as follows:

1. The heavy oil storage tanks in the Pamusian area with a capacity of 100 to 1,000 tons are all destroyed with no oil remaining. One of the eight [tanks] in the Juwata area with the capacity of about 1,000 tons was blown up but our detail removed the explosive devices left set on the remaining seven tanks. The amount of heavy oil remaining intact is about 3,000 tons, which can be transported in drums.

2. All power-driven pumps of the oil wells ([in] the Pamusian and Juwata areas) were destroyed, and most of the nodding donkey-type pumps were made unusable by dropping the sucker rods into the wells, [only] very few of them were blown up. All rigs were intact. No [naturally] flowing wells were seen.

3. Oil conveying pumps are all destroyed, and most parts of the oil pipelines are unusable; pipes for bunkering are badly damaged and unusable.

4. All generators are destroyed and impossible to repair.

5. Most of the oil fields are supplied with water.

6. Most of the important plans and part of the important documents have been seized and put in safekeeping.

2d Defense Detail Classified Telegram No. 14 (1620 on the 17th)

Observations and matters investigated about the heavy oil of Tarakan:

1. It is judged that the remaining oil may be used in diesel engines as "L 1 [grade oil]."

2. Compared to "L 0" [boiler fuel], this heavy oil is judged to be lower in specific gravity and viscosity, and its flash point is lower [as well]. Therefore, one needs to particularly keep this in mind in handling the oil when using it as boiler fuel. As it is also considered that the [optimal] angle to spray [this oil] must be different from that when using "L 0 ", it is appropriate to first test the oil before putting it to use.

3. Although ships such as small heavy oil supply ships were not found, one lighter was spotted near the new pier. As our detail was not allotted boats for transportation, the equipment on the ship is unknown. We request to have an appropriate naval vessel examine the ship.

4. As the oil tanks in Lingkas are located upland at a height of about fifty meters and it is difficult to fill drums near the tanks, we are constructing another oil pipeline so that the drums can be filled near the coastal road. The construction will be completed by tonight.

At 1930 on the 18th, 1st Escort Unit Commander Rear Admiral Nishimura reported to his superiors about the condition of the oil fields after the capture of Tarakan as follows: ${ }^{(56)}$

Although there are about 430 oil wells (about 380 in the Pamusian area and about 50 in the Juwata area), most of the sucker rods were dropped. Also, all power engines are completely de- 
stroyed and impossible to repair, but it seems that the oil fields themselves are not destroyed. It is judged that it should not be difficult to restore [them]. The condition of the heavy oil tanks is as already reported.

When finished checking on the damage, the defense detail repaired the wells with incredible speed and started operations from June 1942 onwards, along with the oil fields in Sanga Sanga (located about seventy kilometers northeast of Balikpapan) and the Balikpapan oil refineries. The oil production continued without a hitch until mid-August 1943, when the first air raids started. ${ }^{(77)}$

\section{The Air Operations}

Also from the 13th onwards, the Air Unit continued guarding Tarakan against [enemy] aircraft and submarines as well as searching for the enemy day after day. On the 13th, Type-0 fighter planes brought down in the air above the friendly units two out of three enemy aircraft that had come for a raid, lifting the morale of the entire force [there]. ${ }^{(62)}$ On the 18th, [the air unit] conducted air strikes on Balikpapan, the next target to capture, with Type-0 fighter planes and land-based reconnaissance planes from the Tarakan base, but no enemy was spotted on the ground as well as in the air. On the 20th, [the unit] conducted an attack on Banjarmasin from the same base with four Type-0 fighter planes and one land-based reconnaissance plane, they spotted one PBY-4 flying boat on the river to the west [of Banjarmasin] and strafed it, setting it ablaze and sinking it. The unit additionally conducted a photoreconnaissance of Balikpapan, Banjarmasin and Makassar by land-based reconnaissance planes. ${ }^{(71)}$

Thus, the operation to capture Tarakan was completed, and all units went on to prepare for the operation to seize Balikpapan. On the 17th, 1st Escort Unit Commander Rear Admiral Nishimura gave the following report on the enemy forces and defense of Tarakan. ${ }^{(56)}$

1. Army: 400 artillery men, 800 infantry men, 70 engineers, and about 100 others, in total 1,400 men.

Weapons (known so far): 3 12-cm guns, 12 field guns, many 12-mm to 20-mm machineguns, and a few armored cars, etc.

The defense facing the sea was really strong, for example the Lingkas front, which almost looked like a [true] fortress. (Note by the author: Staff Officer Yano Tsuneo of the Sakaguchi Detachment reported that the [Japanese] landing forces would have been totally destroyed if they had landed from that direction as arranged [between the Sixteenth Army and the Navy Dutch East Indies Unit]).

2. Navy: Apart from the HNLMS Prins van Oranje, there seems to have been one submarine, but it is thought to have escaped before [we] entered the anchorages.

\section{The Capture of Menado (See Illustration No. 11)}

The capture of Menado was conducted by the Eastern Attack Unit with the support of the 1st Air Raid Unit. The disposition of forces of the Eastern Attack Unit [participating in the Menado operation] was as shown in the following table. ${ }^{(78)}$ 


\begin{tabular}{|c|c|c|c|c|c|}
\hline \multicolumn{2}{|r|}{ Disposition } & \multicolumn{2}{|r|}{ Commander } & Forces & Tasks \\
\hline \multirow{4}{*}{ 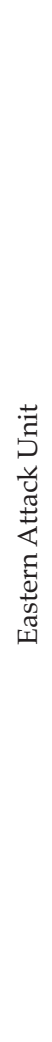 } & Support Unit & \multirow{4}{*}{ 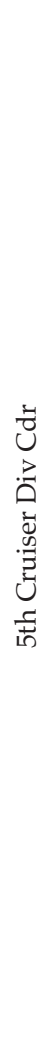 } & & $\begin{array}{l}\text { 5th Cruiser Div (minus } \\
\text { the Myōkō), and 2d Sec- } \\
\text { tion of 6th Destroyer } \\
\text { Div }\end{array}$ & $\begin{array}{l}\text { Support for all opera- } \\
\text { tions }\end{array}$ \\
\hline & 2d Escort Unit & & 2d Destroyer Sqdn Cdr & $\begin{array}{l}\text { The Jintsü (flagship), } \\
\text { 15th and 16th Destroyer } \\
\text { Divs, 21st Minesweeper } \\
\text { Div, 5th [actually: 1st] } \\
\text { Subchaser Div, Patrol } \\
\text { Boats Nos. 1, 2, and 34, } \\
\text { Sasebo Combined SLF } \\
\text { (minus } 2 \text { plts), and 6th } \\
\text { Construction Squad }\end{array}$ & $\begin{array}{l}\text { 1. To provide direct es- } \\
\text { cort for the convoy } \\
\text { [of the units to] cap- } \\
\text { ture Menado and to } \\
\text { capture Menado } \\
\text { 2. To secure the Menado } \\
\text { airfield, and make it } \\
\text { ready for use }\end{array}$ \\
\hline & 1st Base Unit & & 1st Base Force Cdr & $\begin{array}{l}\text { The Nagara (flagship), } \\
\text { 1st Base Force (minus } \\
\text { 21st Minesweeper Div, } \\
\text { and 1st Subchaser Div) }\end{array}$ & $\begin{array}{l}\text { 1. To cooperate with the } \\
\text { 2d Escort Unit } \\
\text { 2. To defend the Bangka } \\
\text { anchorage and pro- } \\
\text { vide protection for } \\
\text { [friendly] shipping } \\
\text { lanes }\end{array}$ \\
\hline & 2d Air Unit & & $\begin{array}{c}\text { 11th Seaplane Tender } \\
\text { Div Cdr }\end{array}$ & $\begin{array}{l}\text { 11th Seaplane Tender } \\
\text { Div, Patrol Boat No. } 39 \text {, } \\
2 \text { plts of Sasebo Com- } \\
\text { bined SLF, and fishing } \\
\text { boats }\end{array}$ & $\begin{array}{l}\text { To guard the } 2 \mathrm{~d} \text { Escort } \\
\text { Unit against [enemy] } \\
\text { submarines, and sup- } \\
\text { port the landing opera- } \\
\text { tion }\end{array}$ \\
\hline
\end{tabular}

Notes:

1. The $2 \mathrm{~d}$ Section of the 6th Destroyer Division: the Ikazuchi, the Inazuma

The 15th Destroyer Division: the Kuroshio, the Oyashio, the Hayashio, the Natsushio

The 16th Destroyer Division: the Hatsukaze, the Yukikaze, the Amatsukaze, the Tokitsukaze

The 21st Minesweeper Division: five minesweepers

The 1st Subchaser Division: three submarine chasers

2. The commander of the Eastern Attack Unit was the commander of the 5th Cruiser Division, Rear Admiral Takagi, but he left the details of the capture operation almost completely to the $2 \mathrm{~d}$ Escort Unit commander, R. Adm. Tanaka Raizō.

\section{The Plan of Operations}

\section{The 2d Escort Unit}

On 5 January, 2d Escort Unit Commander Rear Admiral Tanaka issued 2d Escort Unit Order No. 1 at Magnaga Bay and disclosed the outline of the operation to capture Menado, while at the same time issuing orders to make preparations for the capture of Ambon. The outline was as follows: ${ }^{(54)}$

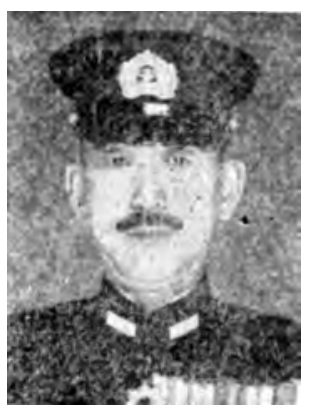

2d Destroyer Squadron Commander R. Adm. Tanaka Raizō 
1. Mission

(1) The enemy garrison is expected to have deployed its main force in the area of the town of Menado. Therefore, [the unit shall] contain the enemy there, rapidly cut off the communication routes between the town and the airfield from the rear, and mutually act in concert with the paradrop operation of the 1st Yokosuka Special Landing Force. The main force of the Sasebo Combined Special Landing Force shall go ashore near Menado city and put one element ashore in the Kema area on the east coast, so as to make a pincer attack on the enemy.

(2) The convoy shall be divided into two echelons of faster ships and slower ships, which shall leave Davao at different times so as to enter into the anchorage at the same time.

(3) The landing shall be made following a two-stage anchoring system; the first landing [unit] shall be launched as far as possible off the coast.

(4) On completion of unloading, the ships shall evacuate to the defended area of the Bangka anchorage (north end of Celebes) one after another.

2. The distribution of the transport ships, the landing points, the escort and the leading naval ships

(1) Distribution according to echelons

\begin{tabular}{|c|c|c|l|}
\hline Echelon & \multicolumn{1}{|c|}{ Escort vessels } & Leading vessel & \multicolumn{1}{c|}{ Transport ships } \\
\hline 1st echelon & $\begin{array}{c}\text { 1st Section of 15th Destroyer } \\
\text { Div and 1st Subchaser Div }\end{array}$ & Hayashio & $\begin{array}{l}\text { The Shōka-maru, the Kōshin- } \\
\text { maru, the Chōwa-maru (all } \\
\text { carrying the 6th Construc- } \\
\text { tion Squad) }\end{array}$ \\
\hline 2d echelon & $\begin{array}{c}\text { 21st Minesweeper Div, Patrol } \\
\text { Boats Nos. 1 and 2 }\end{array}$ & Oyashio & $\begin{array}{l}\text { The Nankai-maru (Sasebo } \\
\text { Combined SLF), the Kinai- } \\
\text { maru (1st Sasebo SLF), the } \\
\text { Hokuriku-maru (2d Sasebo } \\
\text { SLF), the Amagisan-maru, and } \\
\text { the Katsuragi-maru (11th Air } \\
\text { Fleet) }\end{array}$ \\
\hline Outside the line of sailing & $\begin{array}{l}\text { The Oha-maru, and the } \\
\text { Shinkō-maru [B] (both carry- } \\
\text { ing the 6th Construction } \\
\text { Squad) }\end{array}$ \\
\hline
\end{tabular}

(2) Distribution according to landing points

\begin{tabular}{|c|l|l|}
\hline Landing Area & \multicolumn{1}{|c|}{ Escort vessels } & \multicolumn{1}{c|}{ Transport ships } \\
\hline Menado & $\begin{array}{l}\text { 15th Destroyer Div, 3 minesweepers } \\
\text { of 21st Minesweeper Div, 1st Sub- } \\
\text { chaser Div }\end{array}$ & $\begin{array}{l}\text { The Nankai-maru, the Kinai-maru, } \\
\text { the Shōka-maru, the Kōshin-maru, the } \\
\text { Chōwa-maru, and the Amagisan- } \\
\text { maru }\end{array}$ \\
\hline Kema & $\begin{array}{l}\text { 1st Section of 16th Destroyer Div, 2 } \\
\text { minesweepers of 21st Minesweeper } \\
\text { Div, Patrol Boats Nos. 1 and 2 }\end{array}$ & $\begin{array}{l}\text { The Hokuriku-maru, and the Kat- } \\
\text { suragi-maru (disembarkation at } \\
\text { Girian) }\end{array}$ \\
\hline
\end{tabular}

(3) Actions of each unit

$\{1\}$ The 1st Echelon Unit and the 2d Echelon Unit shall respectively leave Davao at 0100 and at 1000 on 9 January, sail at standard speeds of respectively 9 knots and 12 knots along 
the planned sailing route shown on Separate Map No. 14 (omitted), so as to reach the 5th turning point at 1400 on 10 January.*

$\{2\}$ From the 5th turning point onwards, the echelons shall be divided up and sail on [in echelons] distributed according to the landing points. From that time on, the standard speed shall be set at 9 knots.

\{3\} The Jints $\bar{u}$ and the 16th Destroyer Division shall leave Davao at 0600 on 9 January as the main body, catch up with the 1st Echelon while clearing the sailing route ahead of the $2 \mathrm{~d}$ Echelon, and directly support them.

(4) Entering into the anchorage(s) and the launch of the landing operations

$\{1\}$ The following schedule shall apply to both Menado and Kema:

$\begin{array}{lll}\text { Entering into anchorage: } & 0200 & \text { 11 January } \\ \text { Launch of [landing] craft: } & 0300 & \text { ditto } \\ \text { Reaching coast } & 0400 & \text { ditto }\end{array}$

\{2\} The transport ships with the special landing forces on board (the Nankai-maru, the Kinaimaru, and the Hokuriku-maru) shall launch the first landing unit at the first launching point, after which they shall move on to the second launching point, launch the second landing unit, and then move on to the third launching point.

\{3\} The transport ships other than the above (i.e. [those of] the 6th Construction Squad and the 11th Air Fleet) shall advance [to the anchorages] little by little after sunrise of 11 January and moor to buoys or cast anchor after Menado is captured.

\{4\} The landing points at Menado and Kema shall be the coasts south and north of the town of Menado and the front of Kema.

$\{5\}$ The clearing [of mines in] the routes ahead at the time of entering into the Kema anchorage shall be designated by the 16 th Destroyer Division commander.

(5) The guarding and defense of the anchorages

The deployment of the naval vessels to guard around the anchorage of Menado shall be designated by the 15th Destroyer Division commander, and that of Kema by the 16th Destroyer Division commander. The minesweeper division shall sweep the Bangka anchorage from around 1000 on 11 January onwards, and engage in the task of the 1st Base Force to defend [the anchorage].

\section{The Sasebo Combined Special Landing Force}

The plan of the landing operation of the Sasebo Combined Special Landing Force was in outline as follows: ${ }^{(68)}$

1. The Sasebo Combined Special Landing Force headquarters, the units under the direct command of the headquarters and the 1st Sasebo Special Landing Force shall go ashore at both coasts north and south of the town of Menado, envelop the enemy in the town of Menado and destroy them, after which they shall leave Menado and charge toward the Kakas airfield via Tomohon.

2. The $2 \mathrm{~d}$ Sasebo Special Landing Force shall land at Kema and charge toward the Tondano lake and the Kakas airfield via Airmadidi.

3. In concert with the 1st Yokosuka Special Landing Force, which shall drop on the airfield, they shall make a pincer attack on the enemy in the area of the airfield from the east and the west.

4. After destroying the enemy in these areas, they shall assemble in Menado city, and prepare for the coming operation to seize Kendari.

\footnotetext{
* In this plan of 5 January, the departure date from Davao should have been cited as 8 January, because only on 6 January the operation was postponed by one day to 9 January (See p. 158).
} 


\section{The 1st Base Unit}

The outline of the plan of operation of the 1st Base Unit was as follows: ${ }^{(68)}$

1. The main unit (the Nagara and the Chikushi) shall leave Davao on the morning of 9 January, and reach the Bangka anchorage after taking charge of the direct support of the $2 \mathrm{~d}$ Echelon of the 2d Escort Unit.

2. The 1st Defense Unit (the Shirataka, the Aotaka, the Kimishima-maru, one half of the 1st Base Force and the 1st Survey Unit) shall leave Davao at 0800 on 10 January and reach the Bangka anchorage early morning on 12 January to take charge of the defense and guarding of the anchorage.

3. The 2d Defense Unit shall remain in Davao Gulf, in charge of the defense of the gulf, while the units attached to it shall take charge of the supply as well as the guarding of the anchorage.

\section{The 2d Air Unit}

The plan of operation of the $2 \mathrm{~d}$ Air Unit was in outline as follows: ${ }^{(79)}$ the $2 \mathrm{~d}$ Air Unit shall, in support of the $2 \mathrm{~d}$ Escort Unit, temporarily anchor at a point west of the Sangihe Islands (islands about 120 nautical miles north of Menado) and provide cover for the $2 \mathrm{~d}$ Escort Unit with its aircraft. Then, on the 11th, the tender ships shall enter the Bangka anchorage, guard Menado, Kema and the Bangka anchorage against enemy aircraft as well as submarines, and also support the land combat with their aircraft.

\begin{tabular}{|c|c|c|c|c|c|}
\hline & Disposition & & Commander & Forces & Main tasks \\
\hline \multirow{4}{*}{ 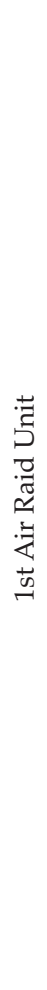 } & Kanoya Air Gp Det & \multirow{4}{*}{ 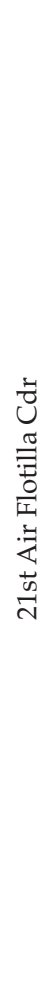 } & Lt Cdr Irisa Toshiié & $\begin{array}{l}\text { One half of the } \\
\text { strength of the } \\
\text { Kanoya Air Gp } \\
27 \text { Type-1 land-based } \\
\text { attack planes }\end{array}$ & $\begin{array}{l}\text { 1. To destroy the } \\
\text { enemy naval ves- } \\
\text { sels and air power } \\
\text { 2. To search for the } \\
\text { enemy and conduct } \\
\text { patrols }\end{array}$ \\
\hline & 1001 Unit & & Cdr Hamada Takeo & $\begin{array}{l}28 \text { Transport planes of } \\
\text { 1st Air Gp } \\
\text { 1st Yokosuka SLF }\end{array}$ & $\begin{array}{l}\text { 1. Menado paradrop } \\
\text { operation } \\
\text { 2. Guarding of the air } \\
\text { base }\end{array}$ \\
\hline & 3d Air Gp & & Cdr of 3d Air Group & $\begin{array}{l}54 \text { Type-0 fighter } \\
\text { planes } \\
7 \text { Land-based recon- } \\
\text { naissance planes }\end{array}$ & $\begin{array}{l}\text { 1.To destroy the } \\
\text { enemy air power } \\
\text { 2. To conduct recon- } \\
\text { naissance }\end{array}$ \\
\hline & Tōkō Air Gp & & Cdr of Tōkō Air Gp & $\begin{array}{l}20 \text { Type- } 97 \text { flying } \\
\text { boats }\end{array}$ & $\begin{array}{l}\text { 1. To search for the } \\
\text { enemy and conduct } \\
\text { patrols } \\
\text { 2. To attack enemy } \\
\text { naval vessels }\end{array}$ \\
\hline
\end{tabular}




\section{The 1st Air Raid Unit}

The disposition of forces and the actions of each unit of the 1st Air Raid Unit in the operation to capture Menado are on the basis of various documents assumed to have been as follows: ${ }^{(12,}$ $71,75)$

1. The disposition of forces (as shown in the table below)

2. The Actions of each unit

(1) The Kanoya Air Group Detachment shall, in cooperation with the Tōkō Air Group, carry out a night attack on Ambon beforehand, so that actions of enemy naval vessels and air power shall be contained during the [Menado] operation, while at the same time preparing against attacks by enemy naval vessels and air power.

(2) The Tōkō Air Group shall take charge of patrol and reconnaissance (attack) over the Celebes Sea, the Gulf of Tomini, the Molucca Sea, the Makassar Strait and the Sulu Sea. It shall also destroy enemy naval vessels and air power by a night attack on Ambon in cooperation with the Kanoya Air Group Detachment.

(3) The 3d Air Group shall conduct a local reconnaissance on Menado with its land-based reconnaissance plane(s) beforehand and send the report and the reconnaissance data to the units concerned. Also, it shall totally destroy the enemy air power with Type-0 fighter planes, while guarding the air above bases, anchorages and the convoys.

(4) The 1001 Unit shall transport the paradrop units of the 1st Yokosuka Special Landing Force with transport planes from Davao to the Menado land air base (Langoan), where the paradrop units shall swiftly secure the air base and facilitate the operation of the Sasebo Combined Special Landing Force by cutting off the escape routes of the enemy from Menado (a sometimes very rugged road) and Kema.

(5) Once the capture of Menado is completed and both the seaplane and land air bases are secured, the Tōkō Air Group, the 3d Air Group, the Kanoya Air Group Detachment and others shall successively be pushed forward in preparation of the coming operations.

\section{The 1st Yokosuka Special Landing Force}

The plan of operation of the 1st Yokosuka Special Landing Force, which for the first time in Japanese [military history] was to conduct a paradrop operation, was in outline as follows: ${ }^{(80)}$

1. The Special Landing Force shall take charge of part of the operation to capture Menado by carrying out a paradrop operation on the enemy airfield at 0930 on 11 January with the support of the fighter plane unit of the 1st Air Raid Unit. They shall attack and drive off the enemy around there and secure the airfield as well as the Kakas seaplane base, so as to facilitate the subsequent air operations.

2. The distribution of tasks and actions of each unit (as shown in the table below)

\begin{tabular}{|c|c|c|}
\hline Distribution & Number of personnel & Tasks and actions \\
\hline First Drop Unit & $\begin{array}{l}\text { Bn HQ: } \\
\text { Signal Unit: } \\
\text { 1st Co: } \\
\text { 2d Co: } \\
\text { Total }\end{array}$ & $\begin{array}{l}\text { [The unit] shall carry out a paradrop on the enemy air- } \\
\text { field in Langoan on } 11 \text { January, attack the enemy it faces } \\
\text { and drive them off. Then, the unit shall act in the follow- } \\
\text { ing way: } \\
\text { 1. 1st Company shall seize Langoan. } \\
\text { 2. The remaining force shall seize the Kakas seaplane base } \\
\text { under the direct command of the commander. }\end{array}$ \\
\hline
\end{tabular}




\begin{tabular}{|c|c|c|c|}
\hline Second Drop Unit & 3d Co: & $173^{*}$ & $\begin{array}{l}\text { [The unit] shall carry out a paradrop on the enemy airfield } \\
\text { in Langoan on } 12 \text { January; the subsequent actions shall be } \\
\text { separately ordered. }\end{array}$ \\
\hline $\begin{array}{l}\text { Unit to advance to } \\
\text { Kema }\end{array}$ & $\begin{array}{l}\text { 1st Co: } \\
\text { 2d Co: } \\
\text { Transport Unit: } \\
\text { Medical Unit: } \\
\text { Paymaster: } \\
\text { Total }\end{array}$ & $\begin{array}{r}74 \\
66 \\
13 \\
1 \\
15 \\
169\end{array}$ & $\begin{array}{l}\text { [The unit] shall leave Davao on the Katsuragi-maru on } 6 \\
\text { January, land in Kema and take charge of transporting } \\
\text { war supplies. Then, it shall join the main body. }\end{array}$ \\
\hline $\begin{array}{l}\text { Unit to advance to } \\
\text { Tondano Lake }\end{array}$ & $\begin{array}{l}\text { Paymaster: } \\
\text { Medical Unit: } \\
\text { Antitank Gun Unit: } \\
\text { Total }\end{array}$ & $\begin{array}{r}1 \\
11 \\
10 \\
22\end{array}$ & $\begin{array}{l}\text { [The unit] shall leave Davao on } 11 \text { January in flying boats. } \\
\text { On landing on the water of Lake Tondano, [the unit] shall } \\
\text { quickly join the main body and receive orders. }\end{array}$ \\
\hline $\begin{array}{l}\text { Unit to advance to } \\
\text { Menado }\end{array}$ & $\begin{array}{l}\text { 1st Co: } \\
\text { 2d Co: } \\
\text { 3d Co: } \\
\text { Paymaster } \\
\text { Engineer Unit: } \\
\text { Transport Unit } \\
\text { Medical Unit: } \\
\text { Total }\end{array}$ & $\begin{array}{r}2 \\
6 \\
5 \\
21 \\
12 \\
16 \\
2 \\
64\end{array}$ & $\begin{array}{l}\text { [The unit] shall leave Davao as separately designated, } \\
\text { and transport war supplies. Then, [the unit] shall join the } \\
\text { main body and receive orders. }\end{array}$ \\
\hline
\end{tabular}

3. The paradrop plan of the First Drop Unit

(1) The formation of the plane units and the paradrop formation

$$
\text { 1st Squadron } \quad\left\{\begin{array}{l}
f^{\mathrm{t}} \times 5 \\
f^{\mathrm{t}} \times 5
\end{array}\right.
$$

2d Squadron

$$
\left\{\begin{array}{l}
f^{t} \times 5 \\
f^{t} \times 5
\end{array}\right.
$$

3d Squadron

$$
\left\{\begin{array}{l}
f^{t} \times 4 \\
f^{t} \times 4
\end{array}\right.
$$

The intervals between the squadrons: 1,500 meters

Note by the author: $f^{\mathrm{t}}$ indicates transport planes.

(2) The number of personnel and weapon packages to be dropped

Number of personnel to be dropped per plane: 12 men

Number of packages hanging from [each] dropping plane: 5

Number of packages loaded on [each] plane: 2 (of which, one is a package of provisions)

(3) The outline of the drop

In one flyover weapons and personnel shall be dropped in that order.

The speed of the plane at the time of drop: 100 knots

The altitude at the time of drop: 150 meters

(4) The dispersion plan of the drop (for each group)

* The text mistakenly has 74 . 


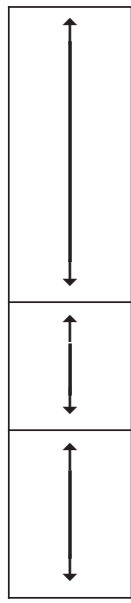

Personnel 800m

$150 \mathrm{~m}$

Weapon [packages] 250m

A three-second interval shall be set between the drop of personnel and the weapon [packages] so as to avoid tangles in the air.

4. Communication, etc. (omitted by the author)

5. Weapons and ammunition

(1) Weapons to be carried along right after the drop

Warrant officers and officers of higher rank

Military sword, pistol, binoculars, steel helmet, canteen, provisions, sword belt, flashlight, map case, semaphore flags, small shovel, national flag, mosquito mask, mosquito gloves, first aid package No. 2

Non-commissioned officers and privates (regular infantry)

Rifle (regular infantry), pistol, bayonet, steel helmet, hand grenade, canteen, provision case, semaphore flags, small shovel, national flag, mosquito mask, mosquito gloves, first aid package No. 2

Heavy machine gun, light machine gun, grenade launcher, Type97 portable wireless phone set (for those assigned)

(2) Number of packages

\begin{tabular}{|l|c|c|c|c|}
\hline \multicolumn{1}{|c|}{ Type of packages } & Bn HQ & 1st Com & 2d Com & Signal Unit \\
\hline No. 1 packages (Rifles) & 4 & 41 & 38 & 7 \\
\hline No. 2 packages (Light machine guns) & 1 & 13 & 13 & 0 \\
\hline Ditto (Generator fuel) & 0 & 0 & 0 & 2 \\
\hline No. 3 packages (Heavy machine guns) & 0 & 2 & $2 *$ & 0 \\
\hline Ditto (Communication Equipment) & 0 & 0 & 0 & 6 \\
\hline No. 4 packages (Ammunition for heavy machine guns) & 0 & 6 & 6 & 0 \\
\hline Special package (Generators) & 0 & 0 & 0 & 1 \\
\hline Miscellaneous packages (Provisions) & 4 & 12 & 11 & 1 \\
\hline
\end{tabular}

* The text mistakenly has 0 . 
(3) Number of main weapons and ammunition of the paradrop unit

\begin{tabular}{|c|c|c|c|c|}
\hline Item & Bn HQ & 1st Com & 2d Com & Signal Unit \\
\hline Browning Pistols & 36 & 109 & 114 & 3 \\
\hline Type38 Carbines & 36 & 109 & 114 & 3 \\
\hline Ammunition for the above & 4,320 & 11,690 & 17,690 & 480 \\
\hline Type96 Light Machineguns & 1 & 13 & 13 & 0 \\
\hline Ammunition for the above & 2,100 & 25,235 & 15,720 & 0 \\
\hline Type89 Grenade Discharger & 0 & 7 & 6 & 0 \\
\hline Grenades for the above & 0 & 194 & 123 & 0 \\
\hline Type92 Heavy Machineguns & 0 & 2 & 2 & 0 \\
\hline Ammunition for the above & 0 & 5,640 & 5,400 & 0 \\
\hline 37mm Antitank Guns & 0 & 0 & 1 & 0 \\
\hline High explosive shells for the above & 0 & 0 & 60 & 0 \\
\hline Fuses for the above shells & 0 & 0 & 60 & 0 \\
\hline Armor-piercing shells for the above guns & 10 & 0 & 40 & 0 \\
\hline Type89 Hand Grenades & 150 & 278 & 274 & 25 \\
\hline Model TM Handy Radio Set & 0 & 0 & 0 & 2 \\
\hline Model TM Handy Radio Set with accessories & 0 & 0 & 0 & 1 \\
\hline “Kū" Mark 2 Radio Set & 0 & 0 & 0 & 1 \\
\hline "Kū" Mark 2 Radio Set with accessories & 0 & 0 & 0 & 1 \\
\hline Spare parts for "Kū" Mark 2 Radio Set & 0 & 0 & 0 & 1 \\
\hline Type97 Portable Telephone Set & 20 & 0 & 2 & 0 \\
\hline Batteries & 0 & 0 & 0 & $(12 V) 4$ \\
\hline Generators & 0 & 0 & 0 & 1 \\
\hline
\end{tabular}

Note: The antitank guns and the weapons and ammunition for them containing high explosives in this table shall be airlifted to Lake Tondano by flying boats. 


\section{The Launch of the Invasion Operation}

\section{Prior Neutralization of the Enemy Air Power}

The preliminary reconnaissance attack on the Menado area started with a photoreconnaissance by a land-based reconnaissance plane of the 3d Air Group conducted over the area on 24 December. After that, combinations of land-based reconnaissance planes and several Type0 fighter planes carried out reconnaissance [missions] over the Menado and Gorontalo areas (west of Menado) day after day. But apart from reporting that they had spotted five flying boats at the Menado seaplane base on 26 December, which they had attacked, strafed and set ablaze, they did not sight the enemy. ${ }^{(71)}$

In the meantime, the Tōkō Air Group carried out reconnaissance (attacks) with flying boats over the Celebes Sea, the Molucca Sea, the Gulf of Tomini, the Makassar Strait, and the Sulu Sea from the 23d onwards, but the group spotted no enemy aircraft or naval vessels, other than one enemy cruiser, one destroyer and one merchantman. On the 5th [of January], [another] seventeen land-based attack planes of the Kanoya Air Group advanced to Davao and, along with the flying boats of the Tōkō Air Group, carried out a night raid on Ambon ([with] fourteen land-based attack planes and three flying boats). The raid caused heavy damage to the enemy, and hindered the latter from using [the airfield] during the [Japanese] operation against Menado (as described previously [p. 117]). ${ }^{(71,81)}$ In the wake of the [enemy] air raid on Malalag Bay on the 4th, the patrol in the sky over Davao with Type-0 fighter planes had been intensified, but almost no enemy had been spotted since then, which by the time of the sailing of the invasion convoy led [the Navy on site] to conclude that the neutralization of the enemy air power was on the whole more or less completed.

\section{The Sailing of the Convoy}

On the morning of 6 January, the 2d Escort Unit and the convoy of the invasion units completed assembling in Magnaga Bay. On the afternoon of the same day, the Ashigara (with the Dutch East Indies Unit commander on board) entered port, and the commanders of the units of the Dutch East Indies Unit assembled on the ship for a last strategy meeting. As the result, the launch of the Dutch East Indies operation was postponed by one day, which changed the sortie of the $2 \mathrm{~d}$ Escort Unit to the 9th. ${ }^{(54)}$ [See editor's note p. 152.]

On 9 January, all units left Magnaga Bay as scheduled. On that day, the weather was fine, and the sea was very calm. Around 0730, the Nagara, (the flagship of the 1st Base Force) in Malalag Bay reported that three enemy planes had come for a raid and dropped bombs. Following that, the Murasame, which was heading for Jolo escorting the Asama-maru reported: “0730: One enemy plane closely [flying by] and reconnoitering [us]." The location was about 100 nautical miles west of the Sarangani islands (about 250 nautical miles from Menado). It was fine and quiet that whole day with no enemy air raid until the evening. Around 1830, when the Kema landing unit reached the area north of Bangka Island, three [enemy] PBYtype flying boats came for an attack and dropped bombs, but no damage was sustained. ${ }^{(54)}$

At 0110 on 11 January, the Menado landing unit reached the first launching point and lowered the [landing] craft. At 0315, the first landing unit left and successfully landed at 0400 . On learning the landing of the Japanese forces, the enemy immediately set fire to the heavy oil tanks with the flames and smoke rising high into the sky. In the meantime, the Kema landing unit also reached its first launching point at 0130, departed from the point at 0345 , and 
successfully landed on the coast of Kema at 0420. Also at Kema the enemy seemed to have set fire to important facilities, and at several places flames were observed rising into the sky. At 0500, the Menado landing unit of the 1st Sasebo Special Landing Force reported that it had [finished] clearing the enemy near the landing point and seized the neighborhood, and that it was going to take up positions to envelop Menado.

On the 11th, the sun rose at 0640 . From around that time onward, enemy aircraft came for raids by turns as described below, which kept the anchorage busy dealing with them. ${ }^{(54)}$

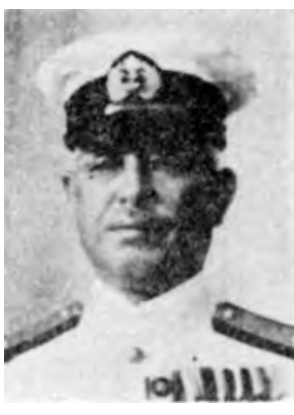

1st Base Force Commander, R. Adm. Kubo Kyūji

0620 Four enemy twin-engine bombers came for a raid and dropped bombs on the Kema anchorage; no loss sustained.

0635 Six enemy heavy bombers came for a raid on the Menado [anchorage]; two of them bombed the Oha-maru sailing at the rear; no loss sustained.

0650 Six enemy twin-engine Lockheed bombers bombed the Jints $\bar{u}$ off Menado for one hour. Although the Jintsū sustained no damage, taking every time evasive actions, the bombardment caused the ship to evacuate as far as 100 nautical miles to the north of Menado.

0700 Three enemy PBY-type flying boats raided Kema, strafing and bombing for one hour and a half; no loss sustained.

1430 Five enemy Lockheed bombers raided Kema, strafing and bombing for about forty-five minutes; no loss sustained.

1540 Three enemy bombers raided the Menado [anchorage]; the Amagisan-maru sustained damage to the hull by a near hit.

1628 Four enemy Lockheed bombers raided Kema; no loss sustained.

On that day, the 21st Minesweeper Division started clearing the Bangka anchorage [of mines] and completed clearing of anchorage A (location unknown) by evening, but no mines were snagged.

Meanwhile, 1st Base Unit Commander R. Adm. Kubo Kyūji headed for Menado leading the Nagara, leaving Malalag Bay on the 9th. The Nagara spotted what seemed to be an enemy periscope at the mouth of Malalag Bay and had the $2 \mathrm{~d}$ Subchaser Division search [for the enemy], but it could not locate the enemy. Afterwards, the Nagara headed southward, mostly sailing along with the $2 \mathrm{~d}$ Echelon of the $2 \mathrm{~d}$ Escort Unit. On the 10th, the Shirataka, the Aotaka and the Kimishima-maru, which were to take charge of the defense and guarding of the Bangka anchorage, left Malalag Bay for the anchorage. Also on that day, the Itsukushima of the $2 \mathrm{~d}$ Base Unit* left Davao as well for the Bangka anchorage to build a mine barrier at the east entrance of the anchorage. At 2115 on the 10th, the Nagara spotted an enemy submarine afloat at a point about forty nautical miles northwest of Menado and attacked her, but with unknown results. The Nagara arrived off Menado on 11 January and took the lead of the base unit. ${ }^{(72)}$

\section{The Engagements of the Sasebo Combined Special Landing Force and the Paratroop Unit}

(See Illustration No. 10)

The main force of the Sasebo Combined Special Landing Force (i.e. the Sasebo Combined SLF headquarters, the units under its direct command and the 1st Sasebo Special Landing

* The text mistakenly has 1st Base Unit (See p. 99). 
Force) landed on the coast north and south of Menado at 0400 on 11 January; their strength consisted of about 1,800 men (led by Capt. Mori Kunizō). After engaging with about 400 enemy troops right after the landing, the unit seized Menado City at 0830. At 0945, the main force headed for Tomohon, leaving one element in Menado City, and advanced southward, while on the way eliminating resistance put up by the enemy, who made use of natural defensive positions as well as [manmade] obstructions. [The main force] seized Tomohon at 1930 and halted there [for the night] on full alert.

In the meantime, about 1,400 men of the $2 \mathrm{~d}$ Sasebo Special Landing Force (led by Cdr. Hashimoto Uroku) successfully landed at Kema at 0420, engaged with about 70 enemy troops, drove them off, and started to advance toward the mountains in the direction of Airmadidi. At 1300, the unit drove off about 300 enemy troops near Airmadidi and seized the location at 1400 . One element of the leading party reached the Tondano front at 2200, and halted there [for the night]. ${ }^{(53,54)}$

At 0630 on 11 January, 324 men of the first drop of the 1st Yokosuka Special Landing Force (commander: Cdr. Horiuchi Toyoaki) took off from the Davao airfield in 27 transport planes and flew toward the Langoan airfield south of Menado, escorted by the fighter plane unit of the 1st Air Raid Unit. * En route, at the north tip of Celebes, the 5th plane of the 4 th team (with 12 paratroopers and 5 crew on board) crashed, having been mistakenly shot down by friendly fire from a reconnaissance seaplane. At 0952, the teams flew into [the airfield area] from the north (the airfield had a runway from north to south). With the support of friendly fighter planes, [the paratroopers] started their drop at the planned drop

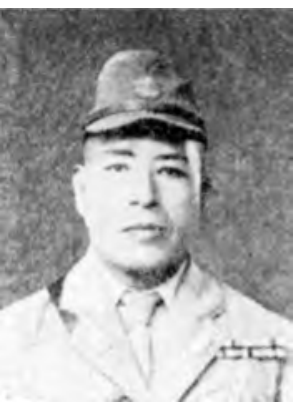

Sasebo Combined Special Landing Force Commander Capt. Mori Kunizō

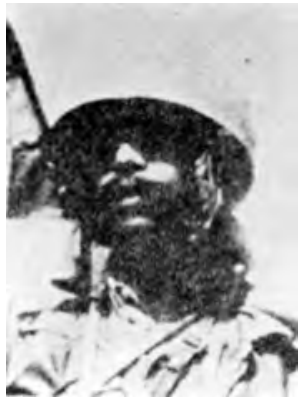

Paratroop Unit Commander Cdr. Horiuchi Toyoaki point and completed the drop at 1020. Simultaneously with the start of the drop, the paratroopers came under fierce machinegun fire from enemy positions on the western side of the airfield, which caused the paratroopers to suffer casualties one after another. On landing, the paratroopers quickly armed themselves and engaged the enemy in a fierce fight, directing their focus of attack to the left wing position of the enemy ([on] the northern side of the airfield) while gradually enveloping the position at 1050 . However, at 1055, an enemy armored car rushed in from the northeastern part of the airfield and machine-gunned the [Japanese] right wing company (the 1st Company) from the rear. Undaunted by this, the company first charged into the enemy left wing position and seized it, opening the way for victory. Following this, [the paratroopers also] charged into the [enemy] positions from the front, seized all of them, and captured the entire area of the airfield at 1125. The unit started on clearing [the enemy] from the airfield and vicinity, while sending (one squad of) a reconnaissance team led by an officer to the Kakas area at 1300 to reconnoiter the movements of the enemy. At 1300, the reconnaissance team encountered one [enemy] armored car at the western end of Kakas and seized it. They further [continued] their advance, engaged with another enemy light-armored car in the town of Kakas and put it to flight. The main force, which had completed clearing [the enemy from] around the airfield at 1300, headed toward Kakas, leaving

* The difference between these numbers and those in the table on p. 157 is seemingly caused by the return of one plane to Davao because of engine trouble; those on board seem to have joined the drop on the next day. 


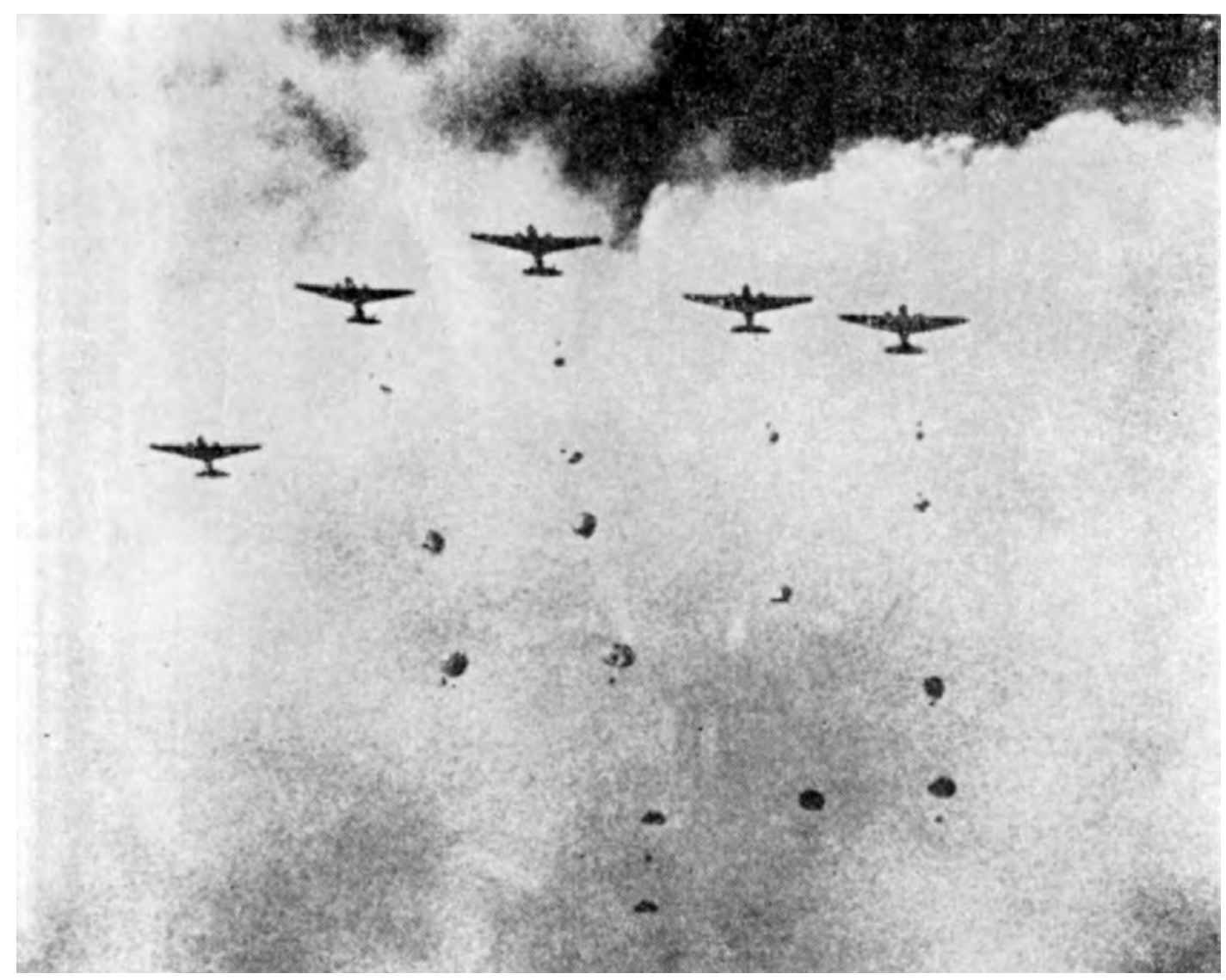

The Drop of the Paratrooper Unit

two squads and the signal unit for the defense of the airfield; they engaged with 150 enemy troops with one light-armored car [on the way]. At 1450, [the main force] completely seized the town, after which they launched an attack on the seaplane base there from 1550 onwards and completely seized the base at 1800. After that, the main force returned to the Langoan airfield, leaving the $2 \mathrm{~d}$ Company to secure Kakas. [The main force] halted [for the night] at the airfield, while making preparations for the attack on the town of Langoan and taking precautions against a counterattack by the enemy. ${ }^{(54,71,80)}$

\section{The Engagements of the Seaplane Unit}

On the morning of the 9th, the Chitose and the Mizuho of the 2d Air Unit (led by R. Adm. Fujita Ruitarō) respectively left Malalag Bay and Pakiputan Strait for the operation to capture Menado. On that day, [the unit] provided guard on the sailing route ahead of the convoy and conducted searches for the enemy and reconnaissance over the waters south of Mindanao with a total of five Type-94 reconnaissance seaplanes; furthermore, it directly guarded the convoy against [enemy] submarines with a total of sixteen Type- 0 observation seaplanes, but no enemy was spotted. At 0900 on the 10th, [the tender ships of] the $2 \mathrm{~d}$ Air Unit temporarily anchored at a point west off the Sangihe Islands and carried out the following air operations: With one Type-94 reconnaissance seaplane and a total of twenty-six Type-0 ob- 


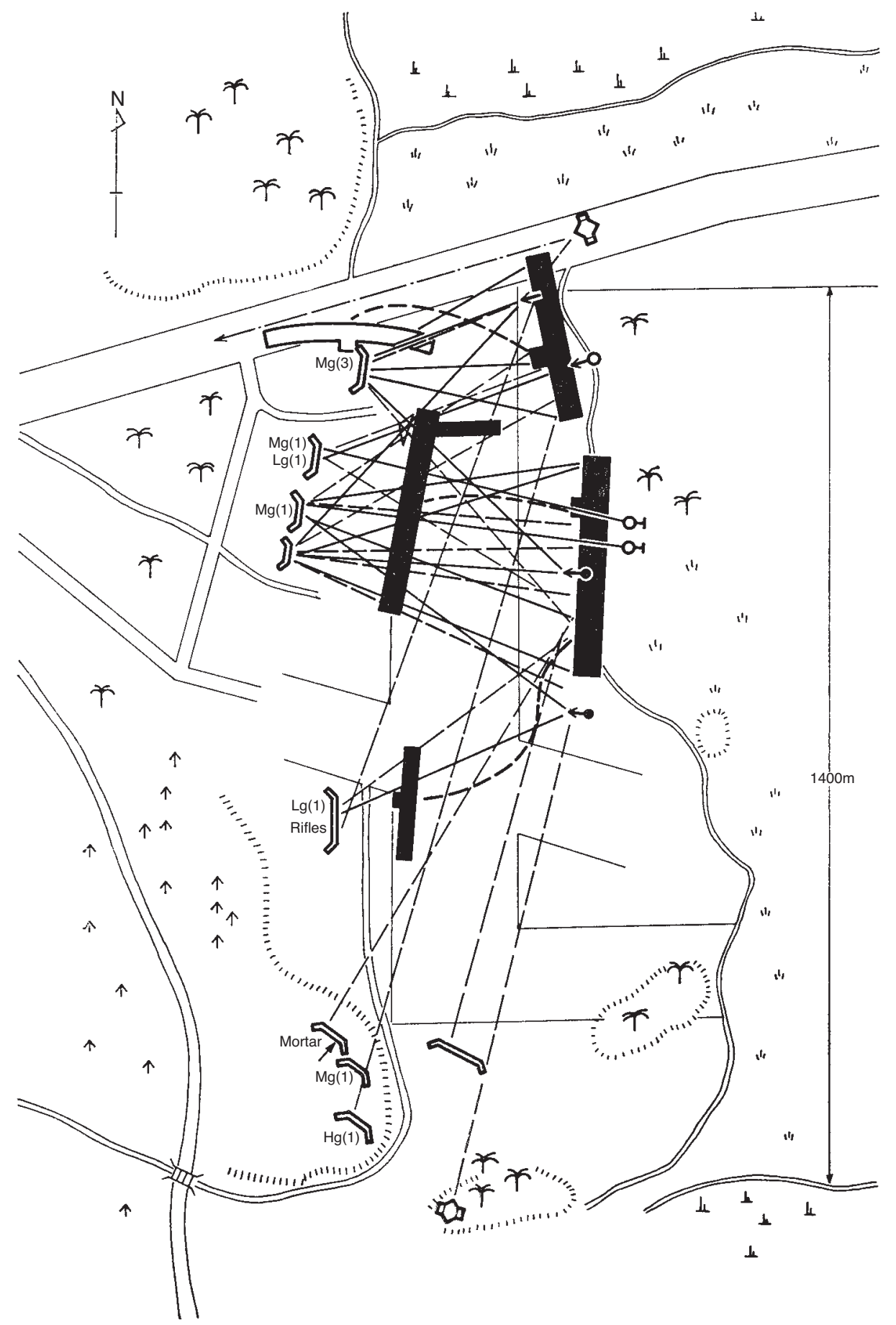

Illustration No. 10 - The Engagement at the Langoan Airfield 
servation seaplanes it provided direct escort for the convoy against [enemy] submarines, guarded its own unit against [enemy] submarines, reconnoitered the Sangihe Islands and bombed the [enemy] radiotelegraph station. With three Type-94 reconnaissance seaplanes it provided guard on the sailing route ahead of the convoy and conducted reconnaissance of the area north of Celebes. After the sunset on that day, the 11th Seaplane Tender Division left the anchorage west of the Sangihe Islands and sailed southward toward Menado. At 0540 on the 11th, the division entered the Bangka anchorage and carried out the following air operations from 0630 till 1900: With a total of forty-nine Type-0 observation seaplanes it provided direct escort and guard for the convoy and the Bangka anchorage against [enemy] submarines and aircraft, and supported the land combat, while with a total of four Type-94 reconnais-

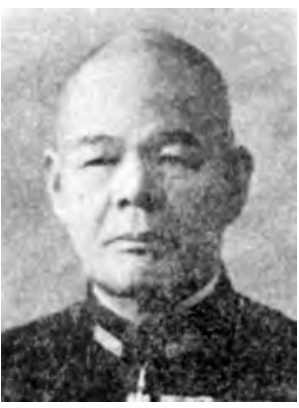

11th Seaplane Tender Division Commander R. Adm. Fujita Ruitarō sance seaplanes it searched for the enemy in the vicinity. During this period, [the division] engaged nine large enemy flying boats and four bombers, and reported that it brought down two flying boats. The Japanese losses were one Type-0 observation seaplane, which crashed (but the pilot bailed out unhurt), two Type-0 observation seaplanes, which made emergency landings (one of them sank but its crew was rescued), and several seaplanes, which got hit.

The aircraft that shot down one of the transport planes of the 1001 Unit was [part of] the $2 \mathrm{~d}$ shift of the Type- 0 observation seaplanes of the Mizuho, which was in the course of directly guarding the Bangka anchorage. ${ }^{\left({ }^{2}\right)}$ Concerning this friendly fire incident, the 11 th Seaplane Tender Division insisted that the action of the 1001 Unit had not been known and that the latter had not performed a friendly identification maneuver [either], ${ }^{(83)}$ while the 1st Air Group retorted that their action had been [shared] at the strategy meeting on 5 January on the flagship of the Third Fleet and [therefore] should have been known; moreover, that right in front of the enemy it is impossible to perform friendly identification maneuvers such as putting down landing gear and lowering altitude. ${ }^{(84)}$ Concerning this incident, the chief of staff of the Dutch East Indies Unit wired on the 13th the following to [all units of] the Dutch East Indies Unit: ${ }^{(53)}$

On 11 January during the operation to seize Menado, an incident has occurred, in which our reconnaissance seaplane(s) shot down one of the transport planes ([of] the 1001 Unit) of the Eleventh Air Fleet. When aircraft units are executing their mission in a combat zone, it may often be difficult for units to apply the currently designated friendly identification methods. Therefore, since it is risky [to identify friends] only by relying on the above friendly identification method, it is requested to strictly keep the following points in mind and be determined to never cause such accidents anymore:

1. To closely communicate with friendly forces and make due arrangements with them prior to the launch of operations, and also to make subordinates thoroughly understand the friendly missions.

2. To communicate well in advance with the units concerned [about the circumstances], particularly those where it is expected that it will be difficult to perform the designated [friendly identification] signals due to the execution of special missions or other reasons.

3. To teach crews in advance how to make proper judgments of situations where a risk of [mistakenly] shooting friendly forces is feared.

4. To make [crews] thoroughly familiar with the models and types of friendly aircraft, and have them [first] identify the model marks as much as possible when carrying out attacks. 


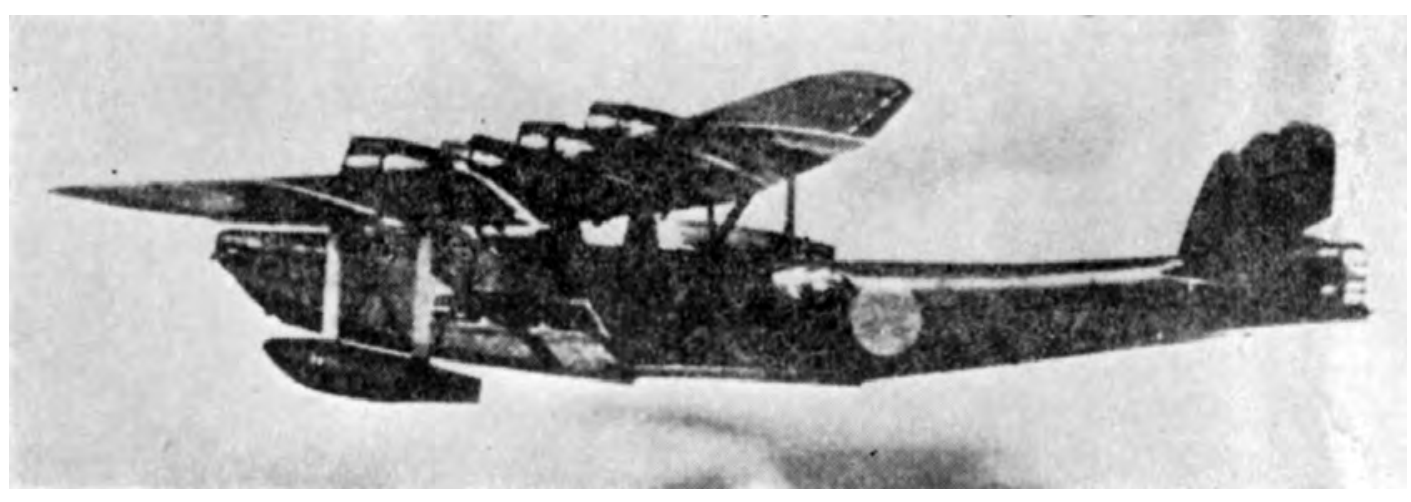

A Type-97 Flying Boat, Which Played an Active Role in Patrol and Reconnaissance

5. To pay special attention when giving instructions to crews who easily get agitated in engagements.

6. Converted Type-96 land-based attack planes are used for the transportation of the 1001 Unit, and the standard altitude at the time of the drop is 150 meters above the ground.

\section{The Land-Based Air Units Scarcely Spotted the Enemy}

On 9 January, the 1st Air Raid Unit had four flying boats of the Tōkō Air Group search for the enemy; [further] it had the land-based attack plane unit stand by for attacks, twelve transport planes in total of the 1st Air Group patrol the sailing route ahead of the convoy, and two transport planes of the group reconnoiter the Menado airfield (the Langoan airfield) and vicinity, while having eighteen Type-0 fighter planes and two land-based reconnaissance planes of the 3d Air Group provide direct escort in the air above the $2 \mathrm{~d}$ Escort Unit. However, no enemy was spotted other than two submerged submarines, of which it was unclear whether they were friend or foe, spotted by the flying boats of the Tōkō Air Group. [Meanwhile, the unit] spotted numerous cheveaux-de-frise (obstructions to prevent aircraft from landing) on the Menado airfield. On the 10th, four flying boats of the Tōkō Air Group searched for the enemy over the Celebes Sea, the Gulf of Tomini and the Molucca Sea, but spotted no enemy other than two [enemy] merchantmen [on the waters] north of Tarakan and three British[-made?] twin-engine two-seater monoplanes to the east of Menado. The 3d Air Group, which provided direct guard over the Davao base as well as direct escort in the air above the convoy, spotted no enemy either, and neither did the Kanoya Air Group Detachment, which carried out patrol over the sailing routes ahead of the convoy with its sixteen land-based attack planes in total. On the 11th, the plan for the day was that the flying boats of the Tōkō Air Group were to search for the enemy, that the land-based attack planes of the Kanoya Air Group Detachment were to stand by for attacks on [enemy] naval vessels, that the transport planes of the 1st Air Group were to transport the paratrooper unit, and that the fighter planes of the 3d Air Group were to advance to Menado, guided by land-based reconnaissance planes or by land-based attack planes, to provide direct guard in the air from 0700 through 1630. However, due to the bad weather around the base, the fighter planes were only able to directly guard it from 0900 through 1415, so they could not catch enemy aircraft that might come in for a raid in the early morning or evening. No other enemy vessels or aircraft were spotted, and no attacks were carried out. The twenty-seven transport planes of 
the 1st Air Group successfully transported the paratrooper unit, but one of them was, as previously told, shot down en route by friendly reconnaissance seaplane(s). Meanwhile, two flying boats (one of which was a transport aircraft) carried the paymaster unit, the medical unit and the antitank gun unit of the paratrooper unit to Lake Tondano and landed on the lake at 1450. At 1750, they successfully established contact with the 1st Yokosuka Special Landing Force, which had seized Kakas, and stayed at anchor on the lake that night. ${ }^{(12,81)}$

\section{The Operations from the 12th till the 20th [of January]}

The second airdrop unit of the 1st Yokosuka Special Landing Force took off from Davao in eighteen transport planes at 0630 on the 12th, parachuted down on the Langoan airfield and joined the unit of the first airdrop. The 1st Yokosuka Special Landing Force immediately launched an attack with its main force on Langoan City and the whole neighborhood of Tompaso. With no real will to fight, the enemy retreated, abandoning a large amount of weapons and ammunition. The 1st Yokosuka Special Landing Force seized the urban area of Langoan at 1125 and Tompaso at 1230, while one element advanced to Paso and completely seized the place at $1035 .{ }^{(71,81)}$

In the meantime, the Sasebo Combined Special Landing Force, which [had halted for the night] around Tomohon and Tondano, went into action from the early morning onwards; it rushed into Tondano at 0810, after which the 1st and the 2d Sasebo Special Landing Forces charged toward the airfield area, the former along the road from Tomohon to Kawangkoan, and the latter via the roads along [both] the east and west shores of Tondano Lake. First of all, at 1100 the $2 \mathrm{~d}$ Sasebo Special Landing Force established contact with the paratrooper unit of the 1st Yokosuka Special Landing Force near Paso and then the 1st Sasebo Special Landing Force established contact near Tompaso at 1230. Both [the 1st and the 2d Sasebo SLFs] arrived at the Langoan and Kakas sector by 1400 . The enemy, which seemed to have escaped toward the direction of Amurang in the west, retreated while blowing up bridges and warehouses and made no real attempt to counterattack. The general populace cheered and warmly welcomed the Japanese forces. After the engagements on the 11th and the 12th, 140 abandoned enemy bodies and 48 prisoners were counted; seized weapons amounted to ten 8-mm field guns and a great number of machineguns, rifles, and war supplies. Japanese losses consisted of 12 men killed and 154 men injured of the Sasebo Combined Special Landing Force, and 32 men killed (of whom, 12 killed in the plane crash) and 32 men injured of the 1st Yokosuka Special landing Force. ${ }^{(80)}$ From the 13th onwards, the Sasebo Combined Special Landing Force switched to a mopping-up operation of the vicinity, completed the operation by the 16th, and assembled in Menado to start preparations for the coming Kendari operation. On 20 January, it again embarked on the transport ships and assembled at the Bangka anchorage. ${ }^{54,57)}$

Day after day the $2 \mathrm{~d}$ Air Unit (the Chitose and the Mizuho of the 11th Seaplane Tender Division) guarded Menado, Kema and the Bangka anchorage against enemy aircraft and submarines; it [also] conducted searches for the enemy as well as reconnaissance [missions] over the Celebes Sea and the Molucca Sea, but it spotted almost no enemies other than the two aircraft coming for a raid on the 12th, which it reported as having brought down. Moreover, since the resistance of the enemy ground forces was not fierce, no support for the land combat was provided. Meanwhile on the 14th, based on a report of a land-based reconnaissance plane of the $3 \mathrm{~d}$ Air Group of having spotted thirty enemy submarines (which will be explained later), the unit carried out an operation to clear the enemy submarines from the 


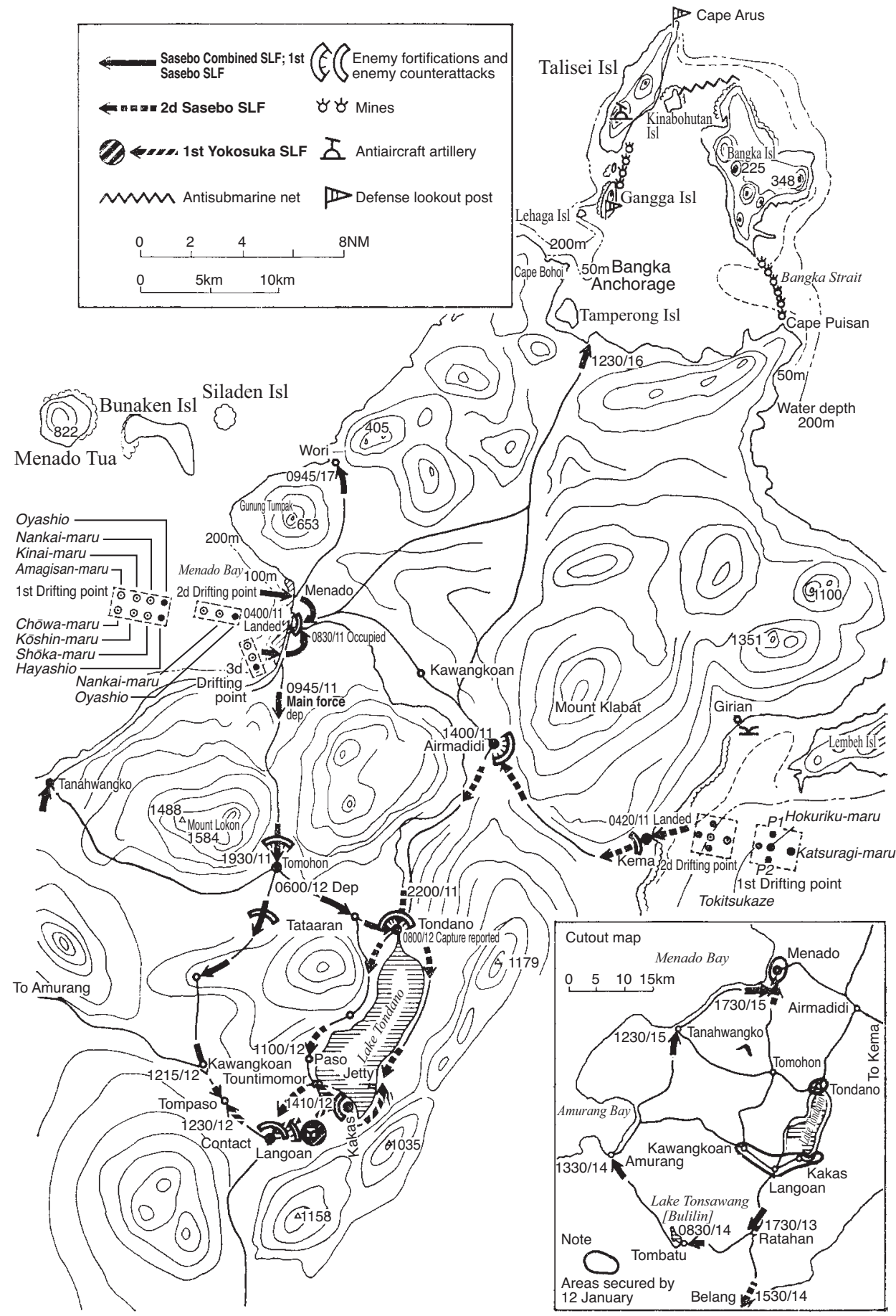

Illustration No. 11 - The Invasion of Menado and the Defense of the Bangka Anchorage 


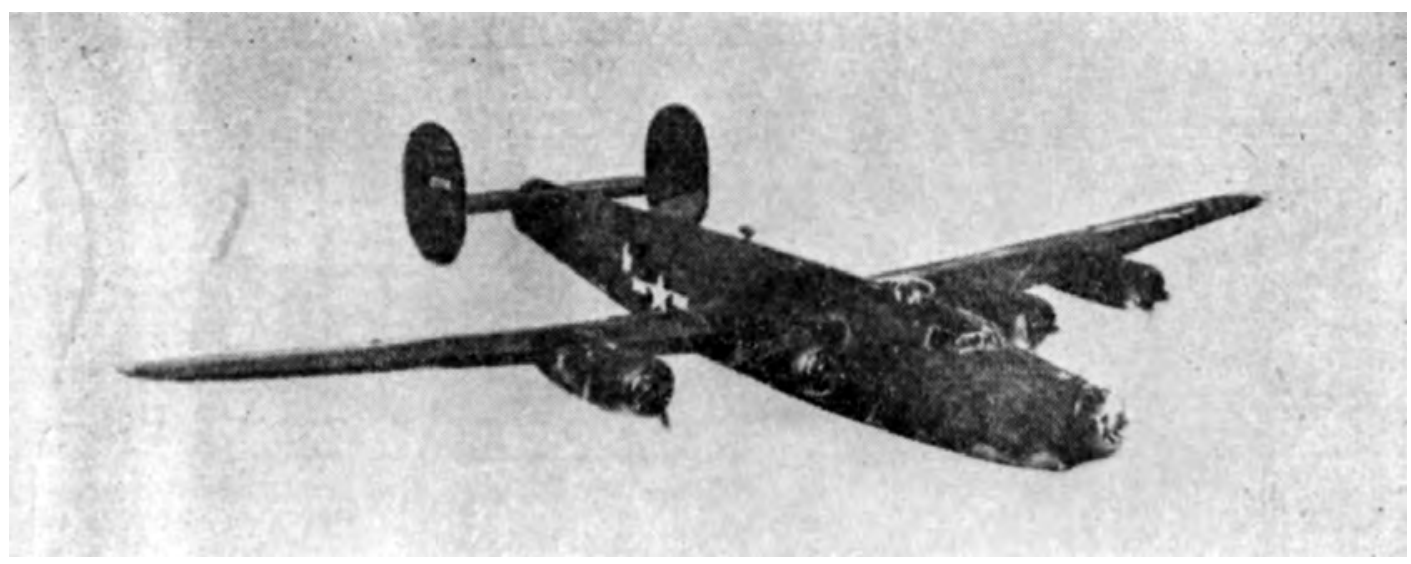

Consolidated B-24

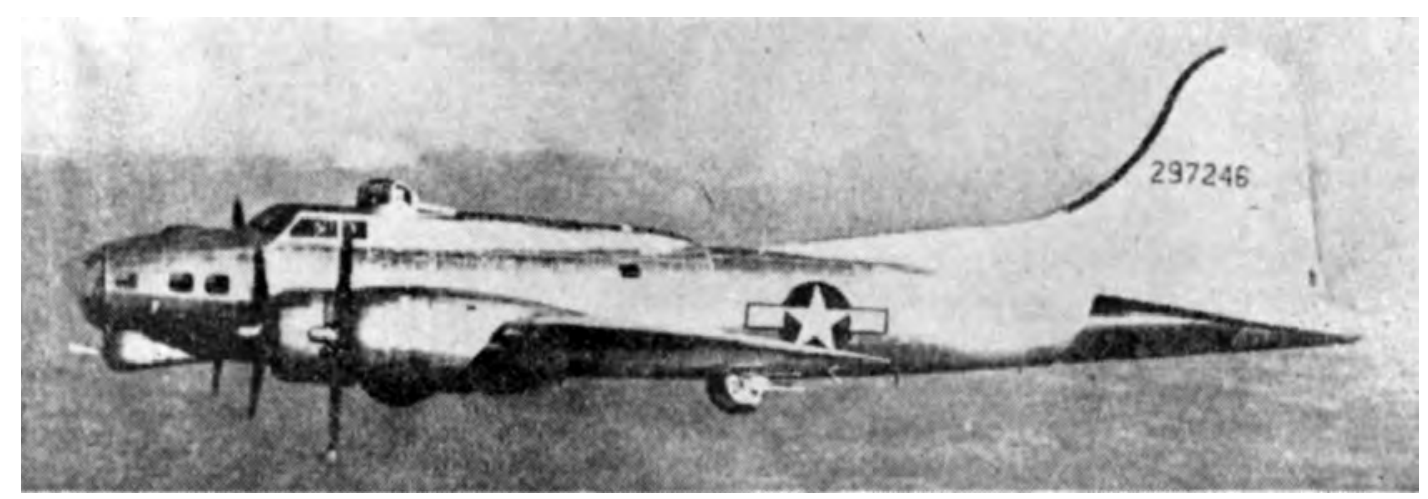

Boeing B-17

Celebes Sea from the 15th through the 19th in support of the 2d Escort Unit, but no enemy was spotted. ${ }^{(71)}$

The 1st Air Raid Unit also provided day after day direct guard in the air over Menado and carried out reconnaissance attacks on Ambon and Kendari, while reconnoitering enemy air bases on the west coast of New Guinea, Halmahera and Celebes, searching for the enemy in the Molucca Strait and the Ceram Sea, as well as searching for and attacking the enemy in the Philippines area. During this period, the following military gains were reported: On the 12th, [the unit] brought down three out of four [enemy] Lockheed Hudson-type bombers that raided Menado, and again one out of two on the 20th. On the 17th, [the unit] attacked three B-24 bombers and two B-17D bombers [of the enemy] that had come for a raid, and caused damage to one of the B-17Ds and two of the B-24s; the former spilling gasoline, and three of the engines of one of the B-24s stalling (it later made an emergency landing), and one engine of another [B-24] stalling, but none of the attacks was effectual enough to bring them down. In the attack on Ambon on the 15th, [the unit] brought down two [enemy] fighter planes right after their takeoff, set ablaze one Douglas bomber on the ground and one twinengine flying boat about to take off and caused serious damage to one twin-engine flying boat as well as to one four-engine flying boat. Also [in the attack] on Ambon on the 16th, [the unit] strafed and sank one twin-engine flying boat, which had just returned [there]. On the 
17th, Type-0 fighter planes attacked Kendari and caused serious damage to one [enemy] heavy bomber, which had taken off to escape, but they were not able to bring it down. ${ }^{(81)}$

According to the Summary Report of the Actions of the 1st Air Raid Unit, the state of affairs [on the 17th] in the attacks on the large [enemy] planes had been as follows:

1. Around 0730, two B-17Ds and three B-24s flew into the skies of the airfield ([at] an altitude of 5,000 meters) from the direction of Tondano. Three B-24s dropped about ten bombs at the southern part of the airfield, [but] we sustained no damage.

(1) Two Type-0 fighter planes patrolling the sky pursued the B-17s in formation, engaged them in air combat for about twenty minutes and fired

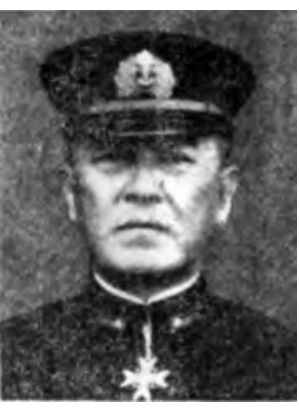

21st Air Flotilla Commander

R. Adm. Tada Takeo all their bullets, many of which hit [the enemy aircraft]. [The hits] caused the second enemy plane to spill [gasoline] from its tank, but it was not [effective enough to] bring it down, letting [both] escape on an $180^{\circ}$ course.

(2) Two Type-0 fighter planes, which, on spotting the enemy, immediately took off, caught up with the B-24s in formation and carried out repeated attacks, firing all their bullets. [The hits] caused one of the engines of the second enemy plane to stall while leaking gasoline. They [also] caused the third plane to descend from an altitude of 4,000 meters to 800 meters while giving off black smoke from three of its engines, forcing an emergency landing (note by the author: [at] Kendari), but the other two planes escaped on a $210^{\circ}$ course.

2. (Omitted by the author)

3. At 0920, one land-based reconnaissance plane and three Type-0 fighter planes made a sortie to attack "LK" (note by the author: Kendari), where the [enemy] plane coming for a raid [earlier] this morning had most likely made an emergency landing. At 1415, all [planes] returned.

(1) The first and the second planes strafed a twin-engine bomber on the airfield and totally destroyed it.

(2) The third plane pursued one B-17D, which had just taken off, and blew off its gun turret after about eight attacks. [The enemy plane] was seen giving off white smoke from a wing, but it was not [so damaged that it was] brought down. [The third plane] returned after using up all its bullets.

4. (Omitted by the author)

5. Damage: four Type-0 fighter planes holed by bullets.

Concerning the large enemy planes, 1st Air Raid Unit Commander R. Adm. Tada Takeo gave his views, which were in summary as follows: ${ }^{(12,81)}$

1. The B-24 and B-17 models that have newly appeared are both very strong in their armored protection. Each Type-0 fighter plane fired all the bullets it had at close range, but failed to bring them down. It is necessary to increase as quickly as possible the power of our fighter planes' armor-piercing ammunition and also to increase the amount of $20-\mathrm{mm}$ bullets loaded [on each aircraft] ( 60 bullets per gun at that time).

2. It is conceivable that from now on the enemy will fly these models to Australia to reinforce their strength. It is necessary to intensify our operations to cut off [the route].

3 The Type-0 fighter planes pursued for 200 nautical miles the large [enemy] planes that had raided Menado; three B-24s escaped on a course of $240^{\circ}$ (to the southwestern part of the Gulf of Tomini) (note: [written as] " $210^{\circ}$ " in the Summary Report of the Actions), and two B-17Ds on a course of $180^{\circ}$. Judging from the reconnoitered condition of the Makassar [airfield] (note: small 
with soft ground, and unfit for use by large planes) and the fact that one made an emergency landing in Kendari, it is concluded that the enemy must have used bases near Kupang and on Java.

4 In order to avoid "out-[of]-range" (the situation that one side is able to attack, but the other side is not, due to the attacking distance), it is necessary for us to have large attack planes ready.

The 3d Air Group completed its advance to Menado by advancing ten fighter planes on the 12th (along with one land-based reconnaissance plane; at that time the Langoan airfield was half completed, and the western half remained unavailable), advancing a total of twentyseven planes on the 14th (along with four land-based reconnaissance planes), and a total of fifty-one planes on the 19th (of which forty-one planes could be put to use in combat). As for the Tōkō Air Group, about half of its flying boats had advanced to Menado on the 17th and all of them on the 18th. The 21st Air Flotilla headquarters [also] advanced to Menado on the 16th. ${ }^{(71,75)}$ In the meantime, twenty of the Type-96 transport planes of the 1st Air Group, which had been engaged in the Menado paradrop operation, had been pulled back to Gaoxiong on the 13th. On the 14th, through a reconnaissance over Ambon conducted by a land-based reconnaissance plane of the 3d Air Group, twenty-five enemy planes (six large planes and eighteen small ones [on the ground] and one fighter plane in the air) were spotted. [Also] spotted were one ship, which looked like a mid-sized cruiser (note: from the photo reconnaissance on the 15th, it was judged to be more like a minelayer), and two merchantmen, all anchored in the port. Judging that the enemy was gearing up for an all-out counterattack, 1st Air Raid Unit Commander Rear Admiral Tada concentrated all his forces on the attack on Ambon on the 15th and the 16th, and destroyed the enemy. ${ }^{(81)}$ (The reported military gain was six [enemy] planes, which were brought down or set ablaze, and the destruction of the airfield facilities.) In the meantime, at 1620 on the 14th when returning from the reconnaissance of Ambon, the land-based reconnaissance plane of the 3d Air Group spotted one [enemy] submarine at a point about 120 nautical miles, $200^{\circ}$ [SW] from Ternate (in the western part of Halmahera) and [also], at 1650, spotted about thirty enemy submarines cruising submerged in loose formation (sometimes showing then hiding their periscopes) along the line connecting the Sula Islands and Labuha (on Halmahera). The 1st Air Raid commander doubted the report, but taking the report as well as the Ambon reconnaissance report into consideration, he had to deal with it just to make sure, and he sent a telegraph, which was in summary as follows:(81)

According to a reconnaissance by our land-based reconnaissance plane today, the 14th, about thirty enemy submarines were cruising submerged in loose formation between Labuha and the western tip of the Sula islands around 1650 and may reach the vicinity of Menado tomorrow morning. Since on Ambon about twenty-five enemy planes were concentrated and also an [enemy] mid-sized cruiser was spotted [in the harbor], our unit shall attack Ambon tomorrow, the 15th, with its full force of land-based mid-sized attack planes as well as fighter planes and [also] carry out attacks on the enemy submarines with its full force of flying boats (of which not more than ten are available).

On the 16th, 1st Air Raid Commander Rear Admiral Tada wired the following about the [enemy] submarines spotted by the land-based reconnaissance plane:(57) 
The state of affairs at the time when the enemy submarines were spotted by the land-based reconnaissance plane on the 14th and my views on it are as follows:

1. From 1620 through 1650, [in an area] about 50 nautical miles $250^{\circ}$ [WSW] from the town of Labuha [and stretching] for about 30 to 50 nautical miles along the $250^{\circ}$ line, 15 pairs of something that looked like submarines (each pair keeping a distance of 2 to 3 nautical miles from one another, and each member of the pair a distance of about 500 to 1,000 meters between one another), 30 in total, were spotted cruising submerged. The course of the enemy was more or less $160^{\circ}$ [SSE].

2. The first one spotted looked very much like a submarine by its periscope and underwater appearance, whereas the others were oval, black and (illegible characters), which made us have some doubts. However, it was [also] said that the one spotted first looked the same after [the plane] circled to take a [closer] look, and that even then (two characters illegible) high, that it raised its periscope at times, and that it submerged, discharging oil and bubbles, when the plane approached. However, what it really was, was not determined. The reconnaissance was made from an altitude of 300 meters, and the skills of crew were excellent.

3. In the state of affairs of the reconnaissance described above, there are several points that leave much room for doubt, such as the fact that many submarines were cruising submerged in an area of merely 40 nautical miles wide, that they looked oval and black, and that they took a southward course. However, a case where they may have dived at the sight of [our] plane when they were about to turn back is imaginable.

4. As stated in the above, there are still some doubts and it is difficult to conclude that there really were about thirty submarines. However, taking into consideration the steps the enemy might take in the current war situation, along with the information [collected] from the wireless, we concluded that it was necessary [to conduct an operation] to thoroughly neutralize [enemy] traffic in the area for another several days.

From the 15th onwards, the Navy conducted a sweeping [operation] of the Molucca Sea against this pack of [enemy] submarines with a total of forty-one flying boats as well as destroyer divisions and minesweeper divisions (which will be described later), but they found no clues at all. From a case on the 18th, when a large flying boat of the Tōkō Air Group had mistaken whales for [enemy] submarines and other such situations, [the Navy] concluded that the major part of the [enemy] submarines spotted by the land-based reconnaissance plane were whales and called off the search on the 19th. ${ }^{(12)}$

\section{Lessons from the Operation and Observations}

According to the Action Report of the 2d Destroyer Squadron, the lessons and observations drawn from the Menado operation were as follows:

1. It is necessary to execute the invasion operations [only] after the air operations to destroy the enemy air power have been almost completed. Since this [Menado] operation was carried out when our air operations to destroy the enemy air power had not yet produced sufficient results, we suffered fierce counterattacks by enemy aircraft. It was fortunate that [the enemy] caused no [major] damage to us because their attacks were carried out by single planes, and, moreover, their skill was not very great. We observe that our losses must have been disastrous should we have been attacked by a considerable number of [enemy planes] in formation.

2. The enemy aircraft attacked, choosing an appropriate moment when our fighter planes were not in the air. Moreover, they easily carried out their bombings because the speed of our observation planes was slow and inferior. 
We observe that it is difficult to stop and destroy the [enemy] high-speed bombers during an antiaircraft guard with observation planes [alone], unless the latter were to be deployed in considerably large numbers.

3. Air defense communications with the land-based air units went not smoothly, and generally took two hours [to be transmitted]. The reason is that these communications depend on the general fleet radio wave, even though insufficient [numbers of] personnel are assigned to this radio wave at advance bases, and this wave gets congested. Quick communications by using this radio wave cannot be expected. The need for a [separate] air defense communications system was keenly felt.

4. The formation of base construction squads is essential in operations to seize [enemy] air bases, therefore their formation and equipment as well as the embarkation and disembarkation [process] on and from transport ships needs to be studied and prepared well ahead. We observe that it is quite inconvenient to send forward temporarily formed [squads of] noncombatants along with front line units and, on top of that, as usual to load equipment and personnel in such a way that it takes as much as one week to unload them.

5. It is also vital to have ready small naval vessels with great mobility, like the ones the U.S. Navy possesses, for the purpose of supplying flying boats, reconnaissance seaplanes and others as well as for use in the construction of bases.

6. From an escort point of view, the requisitioned ships need to be arranged and allotted in advance, so that convoys heading to a same area should be formed with the ships of a similar type with similar speeds. The ships allotted as transport ships for the Sasebo Combined Special Landing Forces for the last Menado operation were ideal indeed.

7. If diesel-powered ships and only coal-burning ships (the next part is partly unclear) are used in the same convoy, it may be difficult to set the speed of the convoy due to the critical speed of the diesel-powered ships.

\section{The Operations of the Main Body and the Base Unit}

On 12 January, the main body of the $2 d$ Escort Unit was sailing about 100 nautical miles northwest of Menado. Rear Admiral Tanaka, commander of the 2d Escort Unit, concluded that the operation to capture Menado was for the most part completed by that day and issued one order after another about replenishment, preparations for the next operations, the outline of the subsequent actions and about the guarding of the anchorage. The main orders concerned the preparations for the Kendari and the Ambon operations. Concerning the preparations for the Kendari operation, he designated the forces participating in the operation and those covering the former. He [also] announced that the Jintsu (the flagship of the $2 \mathrm{~d}$ Escort Unit) would head for Davao (the assembly place for the Ambon invasion units), leaving Menado on the 15th, and that the guarding of the sea in the Menado area would be conducted under the command of the 15th Destroyer Division commander until the unit to seize Kendari was formed. ${ }^{(54)}$ Concerning the preparations for the seizure of Ambon, he announced that the Jintsū would arrive in Davao on the 18th, that the Itō Detachment (the Army unit for seizing Ambon) would arrive in Davao on the 19th, that the 1st Kure Special Landing Force and the 6th Construction Squad would arrive at the Bangka anchorage by the 12th, and that the units in Menado should join the main body later en route (time and place to be ordered later), etc. In the meantime, 1st Base Unit Commander Rear Admiral Kubo on board the Nagara was operating off Menado, commanding the base unit. The base unit, which had started working on the defense of the Bangka anchorage from the early morning of the 12th, closed the east entrance with mines laid by the Itsukushima, set antisubmarine nets at the north en- 
trance with the Shirataka and the Aotaka, while closing the north entrance on the western side with mines as well (See Illustration No. 11). The defense work at the Bangka anchorage was completed by the evening of the 12th, and the ships that had completed disembarkation, supply ships, the units for the next operations, and others assembled in succession at the Bangka anchorage. On the 13th, 1st Base Force Commander Rear Admiral Kubo notified the units that were to participate in the seizure of Kendari to assemble in the Bangka anchorage by the 17 th and leave the anchorage on the 18 th.

\section{Sweeping the Molucca Sea of Whales (See Illustration No. 12)}

On 15 January, 2d Escort Unit Commander Rear Admiral Tanaka was on his way back to Davao from Menado in order to make preparations for the coming Ambon operation. However, because the land-based reconnaissance plane of the 3d Air Group, as previously told, had spotted thirty submerged [enemy] submarines in the Molucca Sea the day before, he ended up taking care of sweeping the sea by order of the Dutch East Indies Unit commander. In this sweeping operation, the 21st Minesweeper Division of the 1st Base Force also participated. The outline of the sweeping operation is as shown in Illustration No. 12. ${ }^{(54)}$ The sweeping operation was led by the commander of the 15th Destroyer Division. [First of all], on the 15th from 2200 onwards, the 15th and the 16th Destroyer Divisions in a row and keeping a distance of nine nautical miles between each ship, sailed southward from the north at a speed of thirteen knots. Then, on the 16th from 0300 onwards, [following the former] the 21st Minesweeper Division repeated the sweeping operation from the north. On the 16th at 0600, the 15th and the 16th Destroyer Divisions reversed course to sail northwards. At 1030, joined by the 21st Minesweeper Division, they [changed course and] swept the sea northeastward in a row while keeping a distance of five nautical miles between each ship. In the meantime, from 0215 to 0220 on the same day, the Takao Signal Unit had detected two [enemy] submarines with their radio direction finding system as shown in the illustration. The 15th and the 16th Destroyer Divisions and the 21st Minesweeper Division headed to the waters where the enemy submarines were supposed to be hiding. However, apart from two enemy heavy bombers, which passed flying over the sweeping unit at 1150, no enemy movements were detected even by 1800 on the 16th, and the operation was called off by the previously given orders. The 15th Destroyer Division headed for the Menado anchorage, while the 16th Destroyer Division and the 21st Minesweeper Division sailed to the Bangka anchorage. Also the Jintsu, which had been supporting the operation as shown in the illustration, broke off the operation and headed for Davao. And also the Nagara, which was on the waters east of Menado to support the operation, broke off the operation and entered into the Bangka anchorage on the evening of the 16th. ${ }^{(54)}$

Most of the [enemy] submarines in this operation, which had been spotted by the landbased reconnaissance plane of the $3 \mathrm{~d}$ Air Group, were judged to have been whales.

\section{The Operations of the Support Unit and the Dutch East Indies Unit}

The Support Unit, i.e. the 5th Cruiser Division left Davao at 1500 on 9 January, and supported the invasion operation by timely deploying in an area about 150 nautical miles northwest of Menado. At 1100 on the 13th, Support Unit Commander Rear Admiral Takagi concluded that the Menado operation was largely completed and left the site at 0000 on the 14 th to enter the 


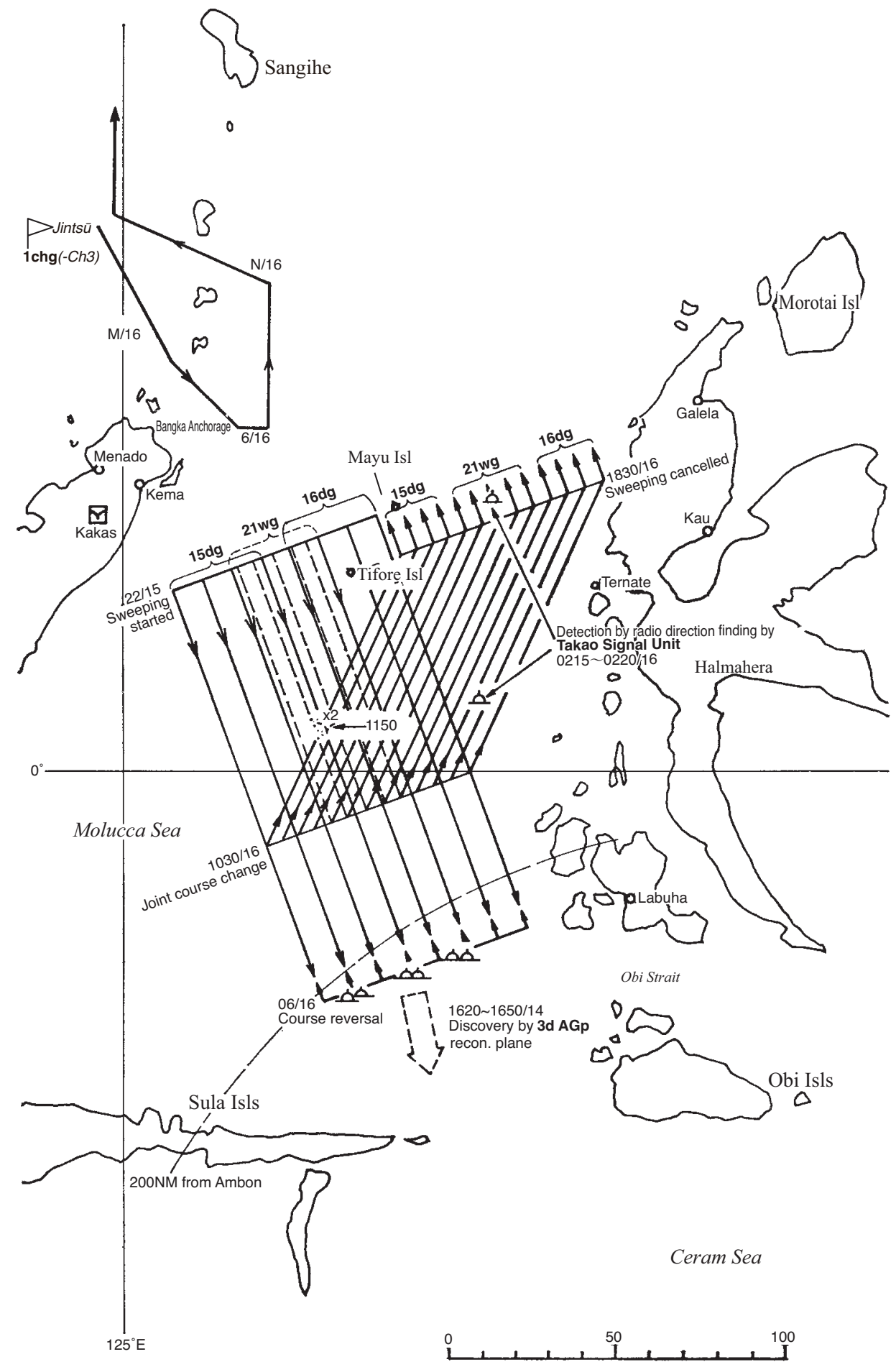

Illustration No. 12 - The Sweeping Operation for Enemy Submarines in the Molucca Sea (15-16 January, 1942) 
anchorage north of Pakiputan Strait in Davao Gulf at $1630 .{ }^{(78)}$ In the meantime, Dutch East Indies Unit Commander Vice Admiral Takahashi was still in charge of directing the entire operation on board the Ashigara in Davao Gulf. After the operations against Tarakan and Menado were largely completed, the commander issued orders on the 15th to postpone the schedule of the [operation] to seize Kendari from the 21st of January to the 24th, and that of capturing Ambon from the 25th of January to the 29th, due to the delay in the advance of the construction squad as well as due to the operation to clear the Molucca Sea of enemy submarines. On the 16th, he further issued orders to postpone [the operation against] Balikpapan from the 21st of January to the 24th. ${ }^{(56)}$

\section{The State of the Allied Forces}

\section{Air forces}

At the time of Japanese invasion of Menado, the allied air forces were deployed in the following way, but no effectual counterattacks were carried out. ${ }^{(85,86)}$

\section{Ambon}

Bombers (Martin; Australian Air Force and Dutch Army)

Fighter planes (Curtis; Dutch Army)

25-30 aircraft

Flying Boats (Catalina and Dornier; U.S. and Dutch Navy)

\section{Kendari}

Flying Boats (Catalina and Dornier; U.S. and Dutch Navy)

about 5 aircraft

about 15 aircraft

Malang (Eastern Java)

Bombers (B-17; U.S. Army)

Bombers (LB-30; U.S. Army)

10 aircraft, increased by 6 on the 15th

unknown, increased by 4 on the 15th

Note: The aircraft, which raided Menado on 17 January and which the Japanese Navy took for B-24s, were in reality LB-30.*

\section{Surface Forces}

Admiral Hart, commander in chief of the U.S. Asiatic Fleet in Surabaya, decided to immediately attack the Japanese convoy in Kema and issued an order that the unit at Port Darwin (the heavy cruiser USS Houston, the destroyers USS Alden, USS Edsall, and USS Whipple, the light cruisers USS Boise and USS Marblehead, the destroyers USS Stewart, USS Bulmer, USS Pope, USS Parrott, and USS Barker, of which the USS Boise and the rest had been escorting a transport ship [the Bloemfontein] to Surabaya from Darwin) should make a sortie in full force. On 12 January, the USS Houston and the unit in Darwin left the port and sailed northward so as to join the unit escorting the transport ship in the Banda Sea. However, it became known from the intelligence provided by the submarines USS Pike and USS Permit, which had been stationed off Kema on the 17th, that the Japanese forces were not in Kema, and the operation was cancelled. ${ }^{(87)}$

\section{Ground Forces}

Although 1,500 men of a Dutch [East Indies] garrison unit were stationed in Menado, the first-ever paratroop operation of Japanese forces caused confusion among the unit, of which the coastal defense unit was contained. As a result, the garrison abandoned Menado by the evening of the 12 th. ${ }^{(85)}$

* These are actually the same planes. B-24 being the U.S. Army Air Force designation; LB-30 being the factory designation. 
According to the Action Report of the 1st Yokosuka Special Landing Force, the state of the enemy, which the 1st Yokosuka Special Landing Force had learned through the interrogation of prisoners, etc. was as follows:

(1) The enemy in the entire Minahasa province had stationed its headquarters in Tomohon and built strong pillbox positions along the strategic roads that led to the direction of the airfield from the landing points of Menado, Belang, Amurang, and Kema, and drastically increased its strength at the Langoan airfield.

Due to our drop on the Langoan airfield, the enemy, being attacked from the rear, had its plans completely shattered and fled into the mountains. The paradrop had an enormous effect on the Menado invasion operation.

(2) Deployment [of the enemy] at the Langoan [airfield] and surrounding areas

\begin{tabular}{|c|c|c|c|c|}
\hline Date & Position & Number of troops & Main armaments & Notes \\
\hline 11 January & Langoan Airfield & 400 & $\begin{array}{l}2 \text { Armored cars } \\
8 \text { Machineguns }\end{array}$ & $\begin{array}{l}\text { More than } 300 \text { che- } \\
\text { veaux-de-frise and } \\
\text { countless bamboo } \\
\text { stakes }\end{array}$ \\
\hline Ditto & Kakas & 150 & $\begin{array}{l}1 \text { Converted } \\
\text { armored car } \\
1 \text { Antitank gun }\end{array}$ & $\begin{array}{l}\text { There were gasoline } \\
\text { tanks, barracks, } \\
\text { powder magazines, } \\
\text { etc. }\end{array}$ \\
\hline 12 January & $\begin{array}{l}\text { Urban area of } \\
\text { Langoan }\end{array}$ & 120 & Machinegun(s) & $\begin{array}{l}\text { Looks like they were } \\
\text { the troops who had } \\
\text { retreated from the } \\
\text { Langoan airfield. } \\
\text { There were barracks, } \\
\text { powder magazines } \\
\text { and arsenals of vari- } \\
\text { ous weapons }\end{array}$ \\
\hline Ditto & Paso & 23 & Ditto & \\
\hline Ditto & Tompaso & 41 & Ditto & \\
\hline
\end{tabular}

(3) On the 11th, as if the enemy already knew the Japanese plans, they had strengthened their defenses by placing cheveaux-de-frise and constructing trenches at strategic places in every town.

Moreover, the enemy had handed out leaflets against [Japanese] paratrooper units and [also] posted them, so as to give an even stronger warning to watch out for them.

In particular, very tight defenses had been put up at the dropping area, the Langoan airfield, where more than three hundred cheveaux-de-frise (of 5 meters long and 1.5 meters wide) had been put all over the place, countless bamboo stakes had been planted and eight pillbox positions and trenches had been constructed in three directions, adjacent to which eight machineguns and two armed cars had been placed at both sides, to make an extremely strong defense system.

Simultaneously with the start of the drop and along with the fire from the armored cars at the rear, the enemy started to rake [our troops] with a fierce fire and tenaciously resisted. 


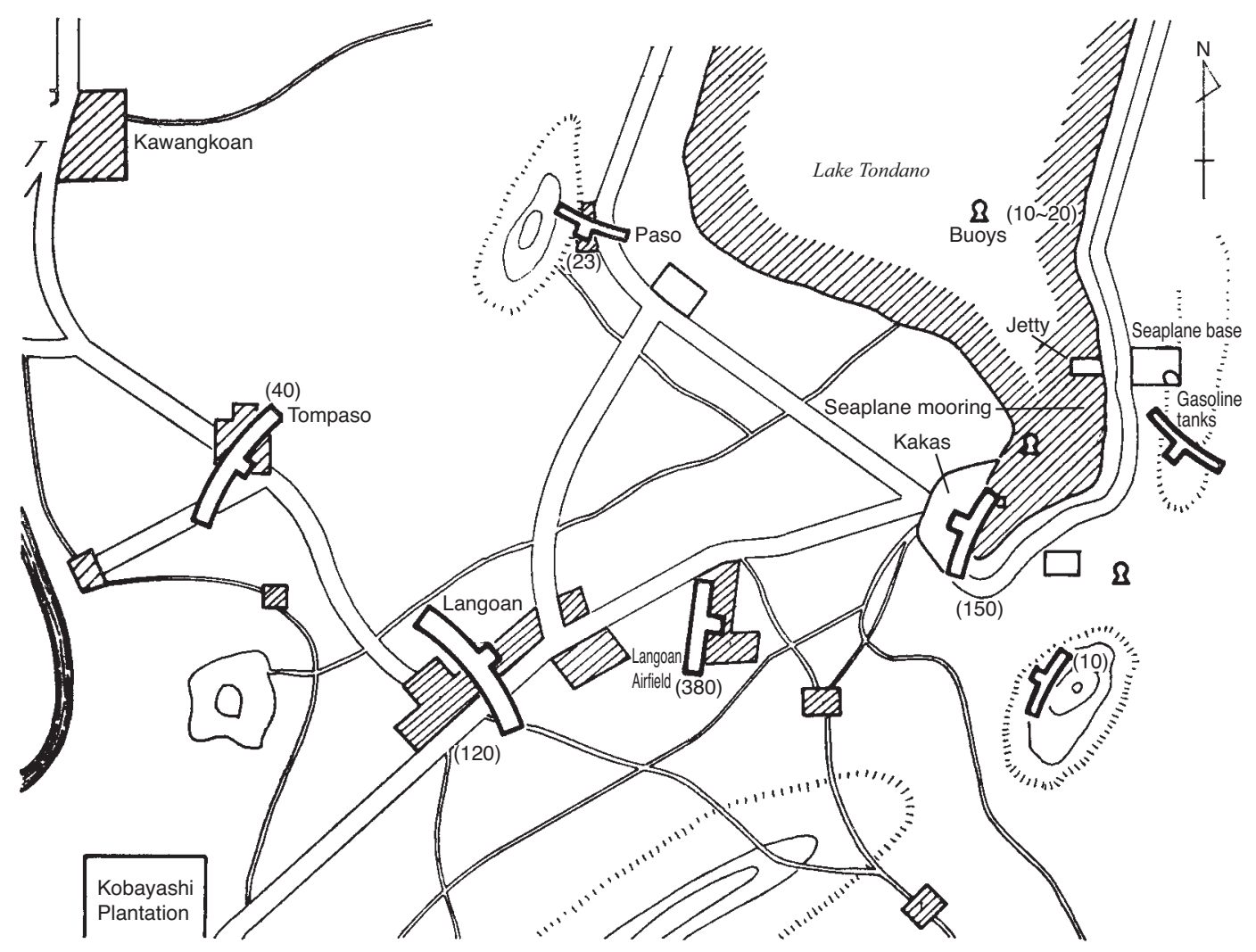

Illustration No. 13 - Enemy Positions in Langoan and the Whole Surrounding Area (The numbers in parentheses indicate the number of troops)

However, at [our] brave charge at their left wing position, the enemy gradually retreated toward Langoan City. In Kakas, with about fifteen men [150 according to the table above] and one antitank gun and one converted armored car deployed, [the enemy] defended [the city] by putting up cheveaux-de-frise and constructing trenches at strategic locations in the urban areas. As the main [Japanese] force advanced, the enemy fought back against our advance guard, but gradually retreated. After that, although the enemy tried to put up some resistance at strategic locations in the urban area as well as in the neighborhood, they fled into mountains, abandoning quite a lot of weapons and ammunition.

(4) On the 12th, the enemy who was deployed in the urban area of Langoan as well as all around Paso and Tompaso, had already lost their will to fight. While putting up some resistance against our attacks by using strategic locations, the enemy fled into mountains, abandoning various facilities, weapons and ammunition.

(5) Sketch of the enemy positions in Langoan and the whole surrounding area

(Separate Illustration No. 1 - Note by the author: Illustration No. 13)

Map of the defensive positions at the Langoan airfield (dropping point)

(Separate Illustration No. 2 - Omitted by the author) 


\section{The Capture of Balikpapan (See Illustrations No. 14 and No. 17)}

\section{Postponement of the Invasion Schedule}

The date of [the operation to] seize Balikpapan had been set for Day X + 43 (20 January) in the Cam Ranh Agreement. However, because the Air Unit's shift to the operation against the Dutch East Indies was delayed due to the delay in the capture of Davao and Jolo and the bad condition of the airfields, it was decided at the meeting on 6 January to postpone the seizure [of Balikpapan] by one day until 21 January. But the sweeping of the Lingkas anchorage after the capture of Tarakan was held up, and the debarkation of matériel and personnel for the construction of the airfield made little progress, delaying the preparation of the Tarakan airfield. On top of that, the condition of the airfield was worse than expected, which lead to a further delay in the advance of air forces. ${ }^{(56)}$ That is, there was only a dim prospect for the advance of nine fighter planes and two land-based reconnaissance planes of the Tainan Air Group on the 16th, but the advance of the land-based attack planes was expected to require a considerable further number of days. ${ }^{(62)}$ Moreover, because it was difficult for land-based attack planes to take off fully loaded from the rear base of Jolo, things came to such a pass that both the air campaign against [enemy bases] south of Balikpapan by land-based attack planes as well as the surprise attack on Balikpapan by the paratrooper unit could no longer be counted on. ${ }^{(12)}$

In the meantime, in view of the example of Tarakan, there were great hopes for taking the oil facilities intact. For that purpose, it was decided to carry out a surprise attack and occupy [Balikpapan] not by means of a frontal attack but by catching the Dutch East Indies garrison off guard through a covert operation by the Army and prevent them from destroying and burning the facilities. On 15 January, 1st Escort Unit Commander Rear Admiral Nishimura conferred with Detachment Commander Sakaguchi and they came to the conclusion that the landing in Balikpapan should be [further] postponed from the 21st until the 24th, and reported the matter to the Dutch East Indies Unit Commander Vice Admiral Takahashi, who approved it on the next day, the 16th. ${ }^{(56)}$

On the same day, the 16th, the Asama-maru with the Navy 1001 Unit (the 3d Yokosuka Special Landing Force, i.e. [another] paratrooper unit) on board entered the port of Tarakan. However, the postponement of only three days was not enough to get the Tarakan base ready for the required transport unit (twenty-eight to thirty-nine aircraft) to land on and take off from [the airfield], and the employment of the paratrooper unit for the Balikpapan [operation] was cancelled. It was decided to employ the unit [instead] in the subsequent operation to seize Banjarmasin, and [for that purpose] the unit was kept on standby in Tarakan. ${ }^{(12)}$

\section{Plan of Operations, etc.}

On the 17th, the units concerned made detailed arrangements in line with the postponed schedule, and the departure from Tarakan of the units to seize Balikpapan was changed to 1700 on 21 January. The outline of the arrangements, plans of operations, etc. were as follows. ${ }^{(56)}$ 


\section{The Arrangements Between the 1st Escort Unit and the Sakaguchi Detachment}

On 17 January, in line with the [new] postponed schedule, the detailed arrangements between the Army and the Navy concerning the operation to seize Balikpapan were changed as follows: ${ }^{(56)}$

\section{Landing points}

Main force: Near the Balikpapan airfield

Detached force: Near the reservoir 10 nautical miles north of Balikpapan, by sailing up the Wain River

2. Landing strength

Main force: two infantry battalions and [a] field artillery battalion as the core

Detached force: one infantry battalion as the core

3. Distribution, movements and sailing routes of the transport ships

Same as those in the plan of the 1st Escort Unit

4. Others

[The arrangements] at the time of the Tarakan invasion operation shall apply.

\section{The Plan of Operations of the [Army] Sakaguchi Detachment}

The main force, consisting of the 146th Infantry Regiment (minus the 2d Battalion), an armored car unit, a field artillery battalion, and an engineer company (minus one platoon), shall land near the airfield. After seizing the airfield, one element shall immediately be dispatched to the Samboja oilfields to the north and occupy them, while [at the same time] being assigned the task of covering the rear of the main force. [Meanwhile,] the main force shall advance westward along the coastal road and storm the Balikpapan stronghold. When carrying out the assault, the main force shall act in concert with the detached force, make use of the military gains [of the latter] and not rush into the assault.

The detached force, consisting of one infantry battalion, one engineer platoon, one independent engineer platoon and one radio section, shall sail up the Wain River, land near the reservoir, and dispatch one element to the water-pumping station, so as to prevent various facilities from being destroyed. The main force [of the detached force] shall swiftly advance to the hamlet of Batu Ampar. While cutting off the escape routes of the enemy, [the force] shall charge into the urban area as unexpectedly as possible and throw the enemy's organized resistance into disorder, so as to facilitate the assault of the main force of the Detachment on the stronghold.

The Resources Salvage Unit under the direct control [of the Detachment], consisting of two infantry companies, [one] antiaircraft artillery battalion, one independent engineer company (minus one platoon), one transport company, two radio platoons, [one] medical unit, and one platoon of the 1st Kure Special Landing Force, shall go ashore in the wake of the main force and enter Balikpapan City along with the main force. The Resources Salvage Unit shall split in two groups, each of which shall respectively accompany the main force and the detached force, and [be in charge of] preventing facilities from being destroyed and resources from being dispersed and lost.

After the occupation of the Balikpapan sector, one detachment consisting of one infantry battalion as the core shall be formed as swiftly as possible to take charge of seizing and securing the Sanga Sanga oilfields in conjunction with the naval special landing force. 
By one unit after another, [the detachment] shall make preparations for the next [operation] to seize Banjarmasin. ${ }^{(88)}$

\section{The Covert Operation of the Sakaguchi Detachment}

[The detachment] shall dispatch Captain Colijn, currently adjutant of the Tarakan garrison, who is the [eldest] son of a former governor-general of the Dutch East Indies [actually: former Dutch prime minister] and who is a manager of BPM (Bataafse Petroleum Maatschappij) and on friendly terms with the Balikpapan garrison commander, to the headquarters of the Balikpapan garrison, having Captain Reinderhoff, a staff officer of Tarakan garrison accompany him, to convey that the garrison "not put up useless resistance or destroy resources and materials." For this purpose, [the detachment] shall put them on board of a seized steam launch and send them ahead to Balikpapan along the coast, flying the Dutch flag. ${ }^{\left({ }^{(9)}\right.}$

\section{The Plan of Operations of the Detached Force of the Sakaguchi Detachment}

From among the prisoners, [the detached force] shall have one native, who worked as a patrol officer in Balikpapan until about ten days ago, [also] board the launch of the unit for the covert operation and have him infiltrate into Balikpapan to light a leading light on the waterway to the Wain River (which flows into the bay of Balikpapan) and to guide the detached force (two companies led by a battalion commander). The detached force shall sail upriver in [landing] craft and land near the reservoir about ten nautical miles north of Balikpapan. In concert with the landing operation of the main force, the [detached] force shall envelop from the rear of Balikpapan the shelters of Dutch noncombatants, thereby advising them to surrender and prevent the resource facilities from being destroyed. Depending on the situation, [the detached force] shall attack the enemy lines at a stroke and occupy Balikpapan. The detached force shall separate from the main force the day before the landing, shift to [landing] craft at the $2 \mathrm{~d}$ anchorage [near] the south coast of Balikpapan Bay, camouflage the craft with mangrove branches and sail upriver along the west coast of the bay. ${ }^{\left({ }^{(9)}\right.}$

\section{The Plan of Operations of the 1st Escort Unit}

On 18 January, the 1st Escort Unit announced its plan of operations for the capture of Balikpapan; it was in outline as follows: ${ }^{(56)}$

\section{Distribution of the Transport Convoy}

(1) 1st Section

The Tsuruga-maru, the Liverpool-maru, the Hiteru-maru, and the Ehime-maru (carrying the Sakaguchi Detachment), the Asahisan-maru and the Nittei-maru (carrying the $2 \mathrm{~d}$ Construction Squad), the Kumagawa-maru (the auxiliary personnel transport ship of the 1st Base Force) and the Sumanoura-maru (the auxiliary net-layer of the 1st Base Force)

(2) 2 d Section

The Havana-maru, the Hankow-maru, the Teiryu-maru, and the Kuretake-maru (carrying the Sakaguchi Detachment), the Kanayama[san]-maru [Kayamasan-maru] (carrying the 2d Construction Squad), the Tóei-maru [B] (carrying the 1st Defense Detail), the Nan'a-maru (the transport ship of the 11th Air Fleet)

(3) The detached force 
The 1 st and the $2 \mathrm{~d}$ ships of the $2 \mathrm{~d}$ Section shall leave the line by separate order and form the detached force.

2. Departure from Tarakan

(1) First of all, at 1700 on 21 January, the 1st Section of the 24th Destroyer Division, the 2d Destroyer Division and the 31st Subchaser Division shall leave [Tarakan] and form a clearing unit; sailing at slow speed ahead of the route of the convoy, they shall [search for the enemy] by using sound and signal detection until ordered otherwise by separate orders.

(2) After that, the Naka, the transport convoy (led or escorted by the 9th Destroyer Division, the 11th and the 30th Minesweeper Divisions, and Patrol Boats Nos. 36, 37 and 38) shall leave [Tarakan] in that order and form a protective sailing formation.

3. Escort during the sailing

(1) Scheduled route: As shown in the Separate Illustration No. 25 (omitted)

(2) Sailing speed: 9 knots at normal speed; 6 knots at slow speed

(3) The protective sailing formation

By day, the 31st Subchaser Division ([with] three submarine chasers) shall sweep the waters by using sound detection, sailing in a row seven kilometers ahead of the convoy. The 1st Section of the 24th Destroyer Division and the 2d Destroyer Division [shall clear the sailing route] by using signal detection, sailing in a row three kilometers ahead of the convoy. The Asagumo shall lead the 1st Section of the convoy and Patrol Boat No. 36 the 2d Section, while the 9th Destroyer Division (minus the Yamagumo), the 30th and the 11th Minesweeper Divisions, three patrol boats and the Naka shall provide direct escort. By night, the formation shall be contracted: the rows to clear the waters ahead shall be removed, and the destroyers shall be deployed at the front [of the convoy] to form a protective screen.

4. Entering into the anchorage

(1) Around 1800 on 22 January, by separate order, the 1st Section of the 24th Destroyer Division, the Havana-maru and the Hankow-maru (note: the ships with the detached force on board) shall leave the line and sail ahead.

(2) On the afternoon of 23 January, by separate order, the Natsugumo shall leave the line and sail ahead to take charge of guarding the waters around the 1st anchorage as the marker vessel east of the anchorage.

(3) At 1800 on the $23 \mathrm{~d}$, the main body shall start shifting to the preparatory formation to enter into the anchorage.

(4) The detached force shall sail ahead [of the main body] along the sailing route shown in the Separate Illustration No. 25 (omitted), and cast anchor at the $2 \mathrm{~d}$ anchorage at 2100 on the 23d. After launching the landing units, the ships shall return to the 1st anchorage.

(5) The main body shall shift to the formation to enter into the anchorage by separate order and enter into the anchorage following the route cleared in a two-tier clearing system, consisting of [a first] clearing [of the waters] along the route ahead by the 31st Subchaser Division and [a second] sweeping of waters by the 30th and the 11th Minesweeper Divisions and the $2 \mathrm{~d}$ Destroyer Division. The main body shall cast anchor at the 1st anchorage around 0100 on the 24th. The 1st and the $2 \mathrm{~d}$ anchorages are as shown in Separate Illustration No. 29 (Illustration No. 14).

(6) The 30th and the 11th Minesweeper Divisions and the Special [Minesweeping] Service Unit (on board the Kumagawa-maru) of the $2 \mathrm{~d}$ Base Force shall by separate order sweep the shallow waterways leading to the inside of the port of Balikpapan from the 1st anchorage.

5. Guarding the anchorage

After [the convoys] have entered into the anchorage, the areas around the anchorage of the convoy shall be guarded by the minesweepers, submarine chasers, and patrol boats. The 9th Destroyer Division shall guard the whole area southeast [of the anchorage], and 24th Destroyer 
Division the area northeast [of the anchorage]. The Naka and the 2d Destroyer Division shall further guard the area outside that under the guard of the 9th Destroyer Division.

6. Communications, etc. (omitted)

\section{The Plan of Operations of the $2 \mathrm{~d}$ Base Unit}

The commander on board of the Itsukushima shall leave Tarakan on 24 January, leading the Wakataka, the Imizu-maru, and the 21st Subchaser Division, to advance to Balikpapan on the 26th. He shall have the 30th and the 11th Minesweeper Divisions, the 31st Subchaser Division, the Kumagawa-maru and the Sumanoura-maru incorporated into the 1st Escort Unit and let them sail ahead. After his advance to Balikpapan, the commander shall have the forces, which had been incorporated into the 1st Escort Unit, rejoin his unit, putting them under his command and take charge of the minesweeping at the anchorage as well as along the waterways inside the port. He shall also take charge of the defense of the anchorage and the management of the port, while supporting the operation of the 1st Escort Unit. The rest of his unit shall remain mostly in Tarakan and take charge of escorting reinforcements and other units. ${ }^{(68)}$

\section{The Plan of Operations of the 1st Air Unit}

The 1st Air Unit was scheduled to escort the Sakaguchi Detachment from Tarakan to Balikpapan, supporting the 1st Escort Unit and, depending on the situation, to support the landing operation in Balikpapan. The aircraft units were supposed to mainly conduct operations from the Tarakan base and the Sangkulirang base (note: about halfway between Tarakan and Balikpapan).

The main scheduled operations were as follows: ${ }^{(90)}$

\section{Division of the operations}

(1) San'yō-maru

She shall dismantle her base at Tarakan on the 23d, collect the base supporting personnel and matériel, and sail at 1600 on the $23 \mathrm{~d}$ along with the $2 \mathrm{~d}$ Base Force vessels to set up a base [at] the coast south of the Balikpapan airfield on the 26th. After that, she shall at an appropriate moment enter the port of Balikpapan.

(2) Sanuki-maru

She shall leave Tarakan on the evening of the 24th, arrive at Sangkulirang Bay on the early morning of the 26th, dismantle the base, collect the base supporting personnel and assist in embarking the large-sized motorized [landing] craft used as patrol boats. She shall enter [the port of] Balikpapan around the 27th and support [the setting up of] a base [there].

2. Aircraft employment division

(1) [On] the 21st

Between 0645 - 0900: sweeping the waters of [enemy] submarines [to be conducted as shown in] Separate Illustration No. 1 (omitted by the author). Between 1000 - 1300: patrol against [enemy] submarines and direct guarding against [enemy] submarines [to be conducted with] one Type- 0 observation seaplane of each ship. Between 1245 - 1900: direct escort of the transport convoy against [enemy] submarines [to be conducted by] two shifts of two observation seaplanes for each shift.

(2) [From] the 22d through the 23d

Direct escort of the convoy against [enemy] submarines shall be conducted almost in the same manner [as the day before].

(3) From the 24th Onwards 
From early morning until about sunset, observation seaplanes shall guard the periphery of the anchorage against [enemy] submarines and reconnoiter the waters where mines were laid, while three-seater reconnaissance seaplanes shall search for the enemy in the area between $205^{\circ}$ [SSW] and $180^{\circ}$ [S] within a radius of 240 nautical miles from the base.

\section{The Plan of Operations of the Air Unit of the Southern Task Force}

The land-based air unit to support [the operation to] seize Balikpapan was the $2 \mathrm{~d}$ Air Raid Unit. The deployment of the unit as of 20 January was as follows:

Tarakan: the 23d Air Flotilla headquarters, 20 Type-0 fighter planes of the Tainan Air Group, 4 land-based reconnaissance planes, and the $3 \mathrm{~d}$ Yokosuka Special Landing Force

Jolo: 45 Type- 1 land-based attack planes of the Takao Air Group and 10 Type-0 fighter planes of the Tainan Air Group

Gaoxiong: 20 Type-1 land-based attack planes of the Takao Air Group and 27 transport planes of the 1001 Unit

Although no documents are extant concerning the plan of operations of the $2 \mathrm{~d}$ Air Raid Unit, the operation schedule of each unit is assumed to have been as in the following table. ${ }^{(71,75)}$

\begin{tabular}{|c|c|c|}
\hline Unit & \multicolumn{1}{c|}{ Actions } \\
\hline 23d Air Flotilla & $\begin{array}{l}\text { 1. To direct the operation of the 2d Air Raid Unit at the Jolo base. } \\
\text { 2. To advance to the Tarakan base when the base is ready. }\end{array}$ \\
\hline Takao Air Group & $\begin{array}{l}\text { 1. To push forward its forces to the Jolo base from Gaoxiong one after another when the Jolo } \\
\text { base is ready. } \\
\text { 2. To patrol the northern half of the Makassar Strait from the Jolo base and attack enemy } \\
\text { naval vesseconnaissance attacks and provide cover for [friendly] convoys as well as } \\
\text { combat support for the landing units upon their request in the area of Balikpapan in Bor- } \\
\text { neo from the Jolo base. } \\
\text { 4. [The group] may advance one element of its force from the Jolo base to the Tarakan base } \\
\text { when the latter is ready. }\end{array}$ \\
\hline Tainan Air & $\begin{array}{l}\text { 1. To conduct a photoreconnaissance of the landing points of Balikpapan and [also] recon- } \\
\text { noiter Banjarmasin and Makassar with land-based reconnaissance planes from the Jolo } \\
\text { base. } \\
\text { To provide direct guard in the air above Jolo and Tarakan and mop up the enemy air } \\
\text { power in the Borneo area with the Type-0 fighter planes (land-based reconnaissance } \\
\text { planes). } \\
\text { 2. To advance from the Jolo base to the Tarakan base when the latter is ready, and mop up } \\
\text { the enemy air power in the areas of Balikpapan and Banjarmasin with land-based recon- } \\
\text { naissance planes from the [Tarakan] base. } \\
\text { To provide direct guard in the air above Tarakan with Type-0 fighter planes. } \\
\text { 3. To provide direct escort in the air above the 1st Escort Unit and the transport convoys } \\
\text { with Type-0 fighter planes (land-based reconnaissance planes). }\end{array}$ \\
\hline
\end{tabular}


1. The 3d Yokosuka Special Landing Force shall leave Gaoxiong on the Asama-maru on the 5 th of January, arrive in Davao on the 12th via Jolo, leave Davao for Tarakan when the Tarakan base is seized, and provide guard for the latter.

1001 Unit 2. To join the operation to seize Balikpapan from the Tarakan base.

3. The transport unit of the 1001 Unit shall advance to the Tarakan base from Gaoxong, and cooperate in the paradrop operation of the $3 \mathrm{~d}$ Yokosuka Special Landing Force participating in the operation to seize Balikpapan.

\section{Remarks}

1. The participation of the 1001 Unit in the operation to seize Balikpapan was cancelled (as already described).

2. Since the Tarakan [airfield] was not anytime soon ready for use by land-based attack planes, and it was also impossible for the planes to take off from the Jolo airfield fully loaded, the search for the enemy and the patrol over the Makassar Strait south of Balikpapan was assigned to the 1st Air Raid Unit until the advance of the land-based attack planes of the $2 \mathrm{~d}$ Air Raid Unit to Balikpapan. Rear Admiral Tada, commander of the 1st Air Raid Unit, carried out the search for the enemy and the patrols over the southern part of the Makassar Strait from Menado with flying boats. ${ }^{(71,75)}$

3. When the Balikpapan airfield was ready for use, the Tainan Air Group and the $2 \mathrm{~d}$ Air Raid Unit headquarters were supposed to advance to the base from Tarakan to prepare for the subsequent operations.

\section{Assessment of the Enemy Movements in the Balikpapan Area ${ }^{(68)}$}

1. As the [Japanese] operations progressed, the allied surface forces moved southward outside the reach of our air forces. They are in the Java Sea area and show little enthusiasm to make a sortie, while a part of the defending forces seems to be operating in the Makassar Strait area.

2. It is necessary to be on alert against [enemy] submarines, because not only do they regularly appear off Tarakan, but also two or three of them have been detected with direction finders in the strait leading toward Balikpapan.

3. According to intelligence and air reconnaissance reports, [the enemy] has deployed to Balikpapan some destroyers, patrol vessels, mine-laying vessels and torpedo boats; they seem to busy themselves putting up a defense.

4. Dutch aircraft have been carrying out considerably aggressive counterattacks using airfields at various places, in particular hidden airfields, unknown to us. We need to be very much on our guard against their four-engine heavy bombers because they carry a large load and are very accurate in their bombing, and also because it is difficult for friendly fighter planes to bring them down.

5. In view of the experience in [the invasion of] Tarakan, it is certain that mines have been laid in the port of Balikpapan. Moreover, due to the shallowness of the waters, we need to be on our guard against mines at the whole planned anchorage.

6. According to air reconnaissance [reports], fires and explosions were spotted in the urban area of Balikpapan and at many places in the oilfields of Samarinda ([as of $] 20$ January); it appears that the enemy is adopting drastic scorched-earth tactics. 


\section{The Launch of the Invasion Operation}

\section{Prior Neutralization of [Enemy] Air Power Completed}

From 30 December [1941] onwards, the Tainan Air Group of the 2d Air Raid Unit had launched reconnaissance [missions] over the Tarakan, Samarinda and Balikpapan areas by its land-based reconnaissance planes with the Jolo airfield as its base. After the capture of Tarakan, the air group advanced nine fighter planes and two land-based reconnaissance planes on the 16th [of January], and launched attacks on Balikpapan with these fighter planes from the 18th onwards. Along with this, it carried out reconnaissance [missions] over Banjarmasin with its land-based reconnaissance planes, but almost no planes or surface vessels of the enemy were spotted. [In the meantime,] the Tōkō Air Group had carried out searches for the enemy in the Makassar Strait almost every day since 7 January with its large flying boats using Davao as its base, but it did not spot the enemy, either. Also, the Takao Air Group, which had launched search (reconnaissance) attacks on the enemy in the Makassar Strait as well as on the Balikpapan airfield from 11 January onwards with its land-based attack planes using Jolo as its base, barely spotted the enemy, other than four enemy fighter planes, which they encountered (one shot down, unconfirmed) and several [enemy] merchantmen which they attacked (no direct hits). ${ }^{(71)}$ In the meantime, the 1st Air Unit (the seaplane unit) started to carry out reconnaissance [missions] over the east coast of Borneo on 17 January and started the construction of the Sangkulirang base on the 20th. ${ }^{(76,90)}$

\section{The Sailing of the Convoy}

At 1535 on 18 January, the steam launch with those assigned to the covert operation on board left [Tarakan] port, heading for Samboja; the Samidare observed and escorted the launch until she was out of the harbor. Then, on the 19th from around 2000, an experiment was conducted on the waters east of Cape Batu [to test whether it was possible to] make out a large-sized motorized [landing] craft of the detached force camouflaged with mangrove branches in the search lights of a destroyer. The experiment confirmed the belief that [landing] craft could successfully sail upstream in disguise even when illuminated by search lights from Balikpapan. ${ }^{(89)}$ At 1200 on the 21st, 1st Escort Unit Commander Rear Admiral Nishimura moved up the time of the main body's anchoring at the 1st anchorage by two hours to 2300 on the $23 \mathrm{~d}$. The reason for this [change] is unknown.

At 1700 on the 21st of January, the 1st Escort Unit and the transport ships left [Tarakan] as scheduled. The total strength consisted of one light cruiser, nine destroyers, four minesweepers, three submarine chasers, three patrol boats and sixteen transport ships, aggregating to thirty-six ships. With frequent squalls the weather was so bad that almost no air operations could be carried out, but [the sea] was relatively calm. ${ }^{(56)}$

On the $22 \mathrm{~d}$, the bad weather from the previous day continued and was such that it was impossible to determine the position of the ships by celestial observation.

Friendly aircraft, which were supposed to directly escort the convoy from the air, did not appear at all, except for two land-based attack planes, which provided guard on the sailing route ahead of the convoy for about one hour in the morning only. Around 1200, when sailing southward at a point northeast of Cape Mangkalihat, [the convoy] spotted the steam launch, which had left [earlier] for the covert operation, coming back. The Kawakaze approached to 


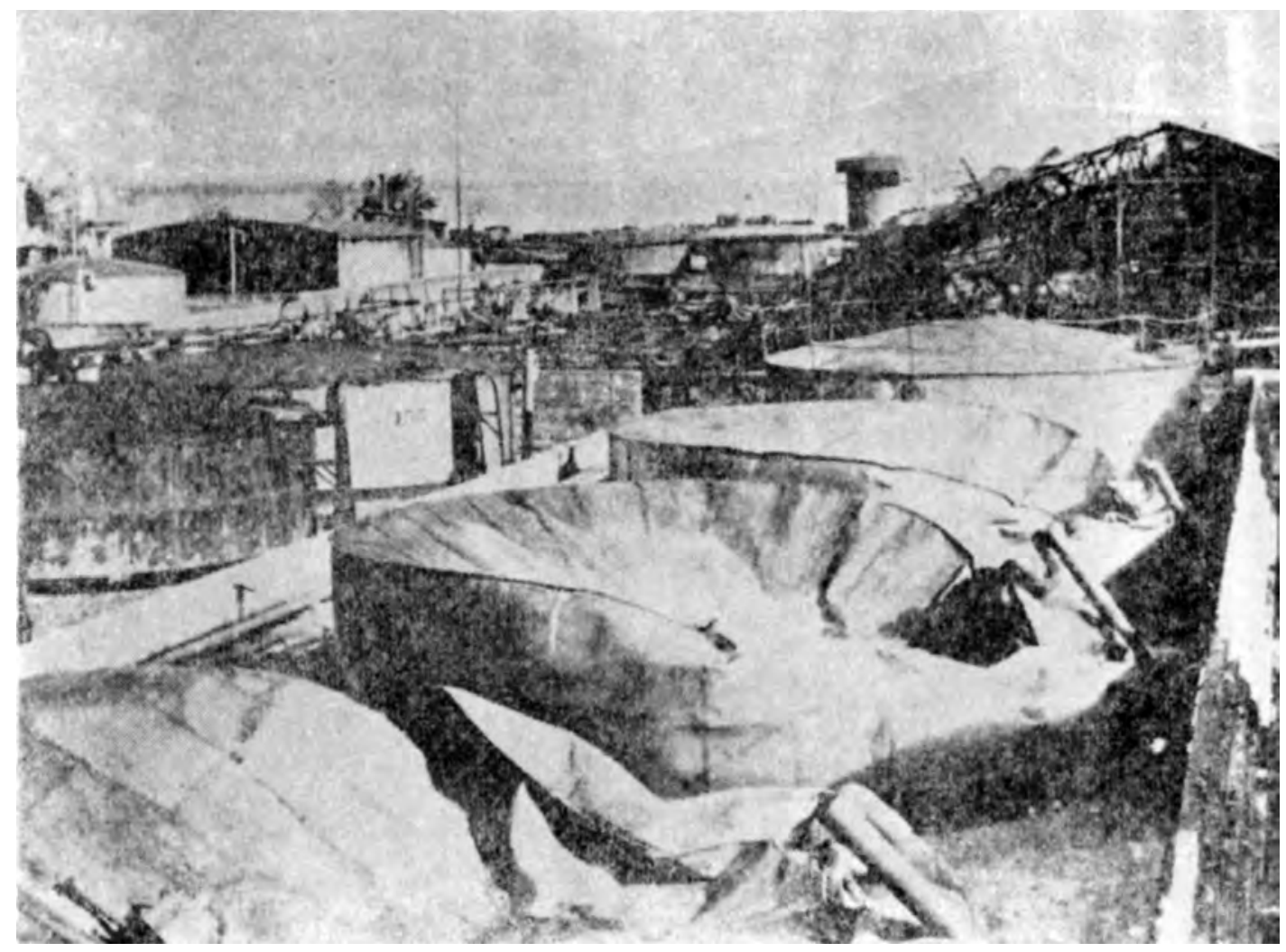

Destroyed Refinery at Balikpapan

investigate, only to find that the covert operation had failed. [The Kawakaze] took the interpreters on board and let the launch return to Tarakan. ${ }^{(56)}$

The above-mentioned party for the covert operation had encountered a Dutch flying boat off Samarinda at 0700 on the 20th; it had landed on the water and taken the two* Dutchmen away. The steam launch had arrived at Samboja around 1600 on the 20th, and temporarily anchored there to wait for the reply from the [garrison] commander of Balikpapan. Around 1800, a military messenger bearing of a flag of truce and carrying the enemy commander's letter had come to the launch. The letter contained a reply to the effect that "the main facilities had been burned before the reception of the message from the Japanese Army;" the [covert] operation to prevent [the facilities] from being destroyed prior [to the invasion] was considered to have come too late and have met with failure. After putting ashore the personnel [assigned] to the marking of the landing point at 0200 on the 21 st, the steam launch had left Samboja at 0300 to head back [toward Tarakan] and come across the convoy around noon on the $22 \mathrm{~d}$. After communicating the situation, the steam launch safely returned to Tarakan on the evening of the $23 \mathrm{~d}$. $^{(89)}$

In the meantime on the $22 \mathrm{~d}$, the convoy continued sailing on as scheduled. It entered the Makassar Strait around 1600 and sent the detached force ahead at 1800. At night, a message came from the 23d Air Flotilla headquarters in Tarakan, which read, "It rained all day long. Because the airfield was unfit for use, the tasks of the fighter planes were not carried out. It

* The text mistakenly has three. See also Vol. 3, p. 355. 


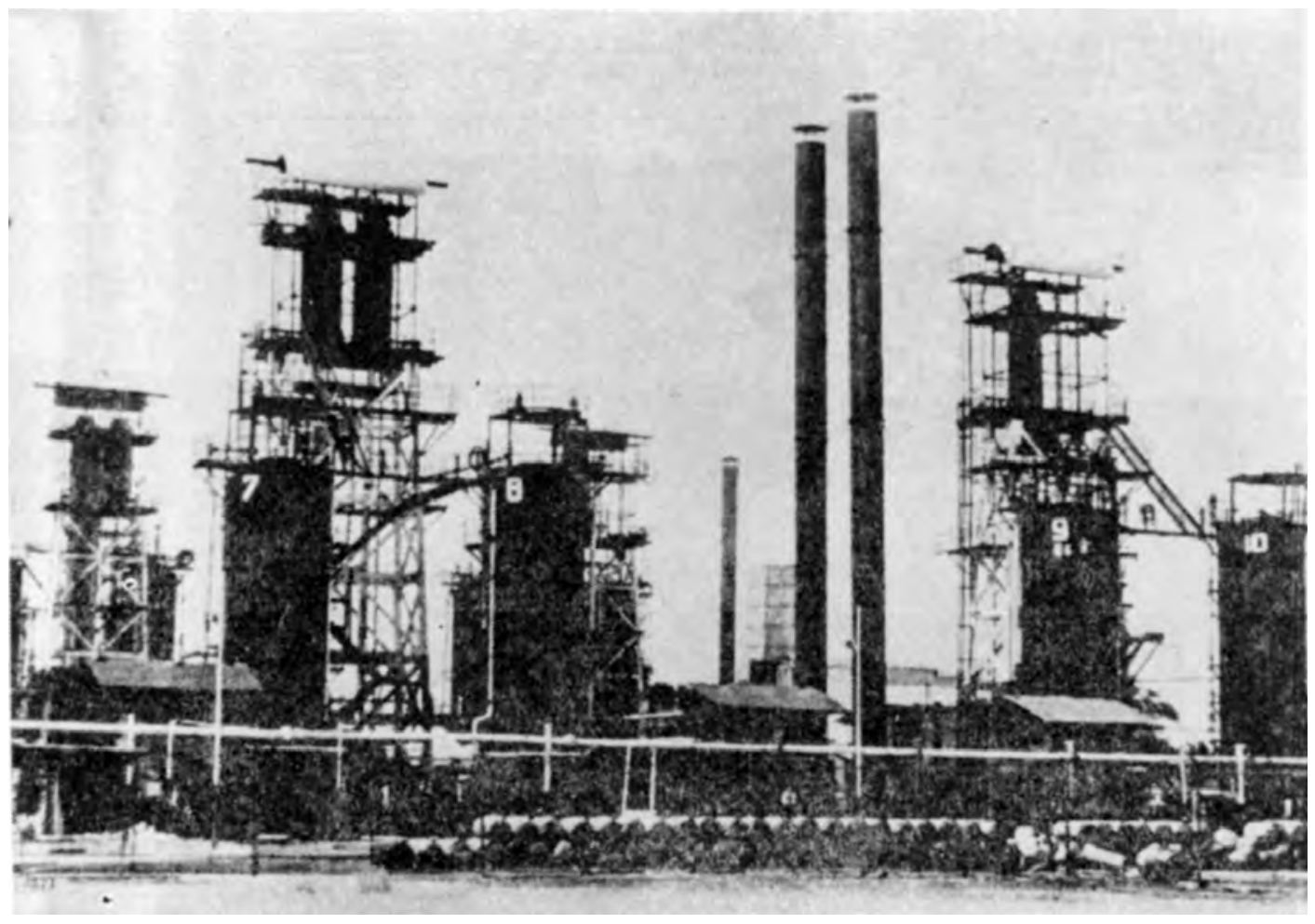

Restored Oilfields of Balikpapan

is expected that [the airfield] will remain unusable tomorrow."(56) Meanwhile on the 22d, the Tōkō Air Group carried out a search for the enemy in the southeastern part of the Makassar Strait from the Menado base with seven flying boats, but spotted no enemy in that area.

At 0005 on the 23d, the Umikaze, [escorting] the detached force, suddenly came under torpedo attacks of enemy submarine(s) at close range. Noticing three torpedoes passing by the bottom of the ship and another ahead of the ship, she immediately moved to detect and attack the enemy. At 0040, she detected an enemy submarine, [closed in] while keeping tracking the latter until the distance between them became 600 meters, and released six [antisubmarine] depth charges, but the results were unconfirmed. ${ }^{(56)}$

Around sunrise on the $23 \mathrm{~d}$, the detached force reached a point about eighty nautical miles east of Balikpapan, while the ships of the main force were following about thirty nautical miles behind. At 1050, three enemy twin-engine bombers appeared in the sky above the ships of the main force, but they passed over in the direction of Samarinda without dropping bombs. Around 1130, the ships of the main force changed their course to $270^{\circ}$ [W], and headed toward the anchorage of Balikpapan. From 1220 through 1305, one enemy twin-engine flying boat reconnoitered the ships of the main force from the south from a great distance. Again on that day, due to the bad weather in Tarakan, no friendly fighter planes showed up. The land-based attack planes just conducted search and attack [missions] against the enemy in the northern part of the Makassar Strait from the Jolo base, while the Tōkō Air Group also conducted no search and attack [missions] against the enemy in the southern part of the Makassar Strait. On top of that, due to the bad condition of the Sangkulirang base, the seaplane unit was unable to provide close support for the escort unit, either. What was more, 


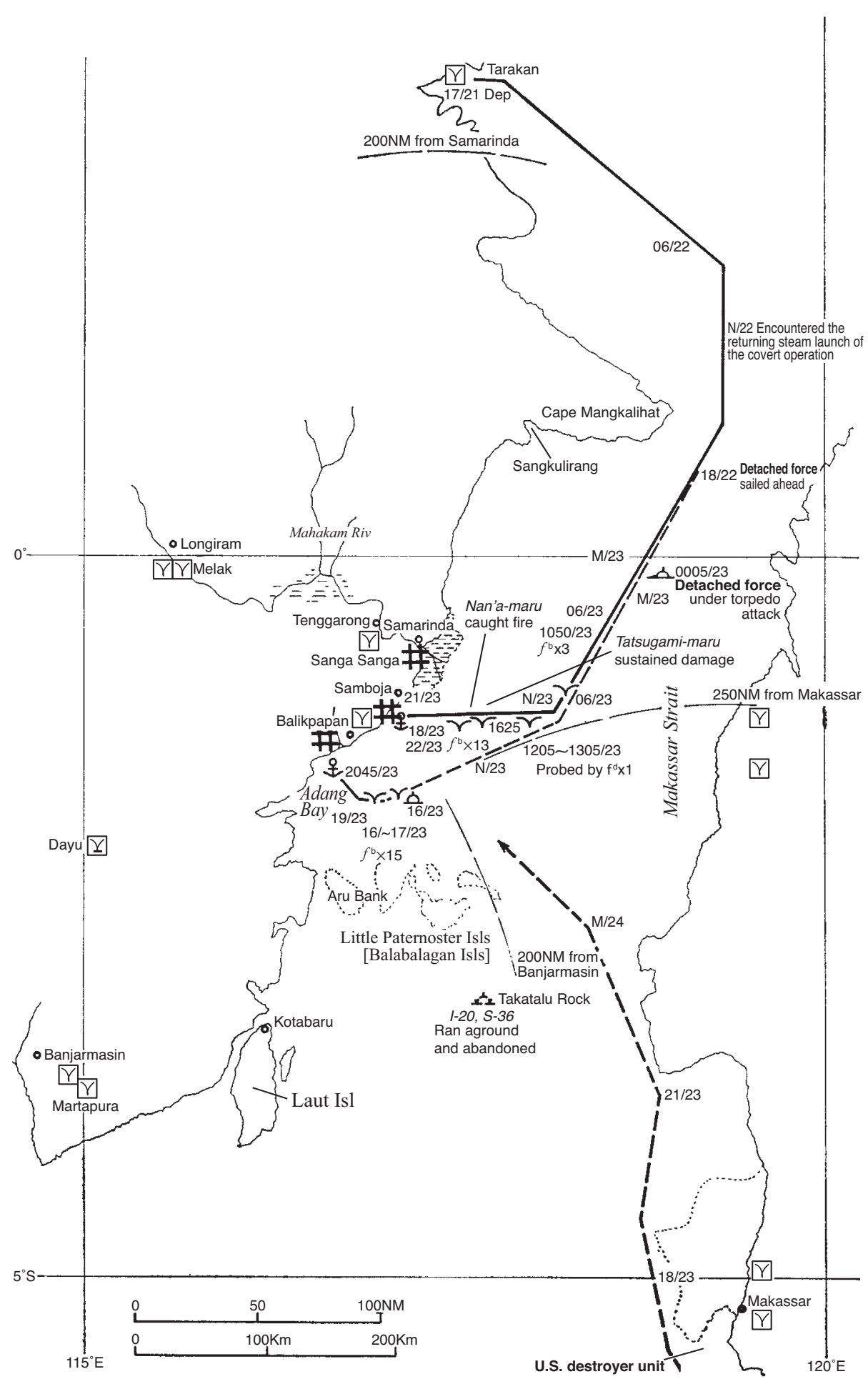

Illustration No. 14 - Summary of the Actions of the Units to Seize Balikpapan (21-24 January, 1942) 
the weather at sea around the convoy was steadily improving, making the conditions more advantageous for enemy aircraft to attack. ${ }^{(56)}$

Sure enough, at 1625 first of all nine twin-engine bombers and four light bombers [dive bombers] of the enemy raided the ships of the main force. In this attack, a small bomb hit the Tatsugami-maru (note: a Navy transport ship accompanying the convoy) sailing at the rear of [the convoy]. Although [the bomb] caused injuries, she fortunately did not sustain major damage. ${ }^{(91)}$ Meanwhile at 1602 on the part of the detached force, the Kawakaze, which had detected enemy submarine(s) and was attacking them with antisubmarine depth charges, was persistently strafed and bombed for about one hour by the enemy aircraft that had completed the attack on the [convoy of the] main force and who were later joined by two light bombers [dive bombers]. However, [the Kawakaze] narrowly avoided damage. Then at 1930 [1730?], when the minesweeping unit of the ships of the main unit started leaving [the line] to sail ahead, one enemy twin-engine bomber unexpectedly attacked from the scattered clouds the Nan'a-maru (note: a transport ship of the Eleventh Air Fleet), which was sailing at the rear of the [ships of the] main force. The [enemy] bomb hit near the mizzenmast of the ship, causing a huge fire and finally the inevitable abandonment of the ship. ${ }^{(56)}$

At 2230, the detached force launched the landing unit and immediately raised anchor to head for the 1st anchorage, reporting that it would join [the main force] around 0900 on the next day. In the meantime, from around 1830 onwards, the main force began sweeping the sailing route ahead, and at 2100 set course towards the port [of Balikpapan]. During this period, at 2030, Patrol Boat No. 36, which was guiding the 2d Section, reported "two trails of [enemy] torpedoes on the starboard side of the ship heading in the opposite direction of the ship," and it was judged that enemy submarine(s) were still continuing their pursuit. However, there were no mines in the vicinity of the anchorage as had been dreaded, and the ships completed their anchoring between 2310 and 2330. ${ }^{(56)}$

\section{Surprise Attack of an Enemy Surface Unit on the Japanese Anchorage}

(See Illustration No. 15)

As the [transport] ships had finished anchoring, all ships of the 1st Escort Unit were about to shift to [the task of] guarding the anchorage. However, the 2d Destroyer Division, which had been in charge of sweeping the anchorage of mines, was still retrieving its minesweeping cables at a point several nautical miles to the south of the anchorage. Just about that time, a submarine chaser, which was positioned to the southwest of the convoy, spotted a suspicious small vessel, but soon lost sight of it. At 0030, the Naka, which had temporarily anchored at a point about one kilometer to the southwest of the Tsuruga-maru, the 1st ship of the 1st Section, spotted a vessel, which looked like an [enemy] torpedo boat, at a distance of about three kilometers, $280^{\circ}[\mathrm{W}]$, and immediately started raising anchor, while giving an order to Submarine chaser No. 12 nearby to look into the matter. Following that, at 0040, [the Naka] spotted the trail of a torpedo heading for her port bow, evaded it, and gave order(s) to submarine chaser(s) to attack [the enemy], while evacuating to the east. The [spotted] ship was considered to be a torpedo boat or a surfaced submarine. Soon around 0045, torpedo(es) hit the Tsuruga-maru, and she sent out a signal that all hands were evacuating. First Escort Unit Commander Rear Admiral Nishimura ordered the 30th Minesweeper Division (Minesweepers Nos. 17 and 18) to go to the rescue. He also decided to newly divide the guarding tasks of the anchorage: he ordered the 9th Destroyer Division to guard an area about three kilo- 
meters east of the convoy, the 31st Subchaser Division the area west of the convoy, the patrol boats the area south of the convoy, and the 11th Minesweeper Division the area north of the convoy. ${ }^{(56)}$

The Naka continued sailing eastward and directed the subsequent operations while operating in an area five kilometers east of the anchorage. At 0140, the 1st Escort Unit commander ordered the 9th Destroyer Division to continue [its current task]. Around that time, the 2d Destroyer Division was patrolling the periphery [of the area covered by the 9 th Destroyer Division].

At 0140, the first landing unit departed, and the second landing unit was preparing for departure. Around 0400, the Naka shifted its position from the patrol area of the 9th Destroyer Division to the peripheral area covered by the $2 \mathrm{~d}$ Destroyer Division but reversed course around 0430 . Just about that time, Minesweeper No. 15, sailing at slow speed on a southeastern course while patrolling the area to the northeast of the convoy, suddenly spotted a suspicious silhouette on her starboard bow. The silhouette approached in no time. Visibly confirming four funnels, the minesweeper at first thought that it could be the Naka, but after spotting more than one vessel, she judged that they were enemy [vessels]. But it was too late. At 0425 , the enemy passed her at high speed and disappeared astern. Three minutes later, she spotted the trails of torpedoes on her port quarter and evaded them. At 0432, the minesweeper spotted a huge explosion in the northern part of the convoy; from the circumstances of the explosion, it was judged that the Sumanoura-maru, which carried antisubmarine depth charges as well as mines, had been instantly sunk. When Minesweeper No. 16, which was positioned to the north of the convoy, was changing course to rush to the rescue of the Sumanoura-maru, she spotted to her north one enemy vessel heading southwestward at high speed, but promptly lost sight of her. At 0437 the minesweeper reached the site where the Sumanoura-maru had sunk, but not an object was spotted on the waters around. ${ }^{*(56)}$

The Kumagawa-maru (an auxiliary personnel transport ship), which was anchored next to the Sumanoura-maru, had raised anchor at the report of the enemy's appearance and headed for shallow waters near the coast. After a while, when changing course southwestward, she spotted an enemy vessel closing in on her at high speed on starboard quarter. The enemy vessel fired at her at close range, and about ten shells hit her. [Then the enemy] crossed her bow 200 meters ahead, switched to her port side and was gone in an instant. The Kumagawamaru also made a counterattack and one of her shells hit the stern of the enemy vessel. The enemy vessel threaded between [the ships of] the convoy at high speed, fired at the Asahi[san?]-maru and the Tóei-maru [B], cut through the line to the eastern side of the convoy and lastly launched a torpedo at the Kuretake-maru (which hit at 0445); after strafing her stern, she disappeared southwestward. ${ }^{(56)}$

In the meantime, the two [enemy] vessels, which had sunk the Sumanoura-maru, disappeared southward, after launching torpedoes at the Tatsugami-maru at the rear of the $2 \mathrm{~d}$ Section [of the convoy] at 0435. At 0440, Patrol Boat No. 38, which was patrolling the area south of the convoy at slow speed, spotted two enemy destroyers to her north. The enemy shortly launched torpedoes at her, but she evaded them, and [the enemy vessels] passed westward at high speed. Then, Patrol Boat No. 37, which was to the west of Patrol Boat No. 36, spotted the same enemy vessels. Patrol Boat No. 37 [also] thought it was the Naka, but when she identified them as enemy [vessels] after having closed in, it was too late. One of three enemy tor-

\footnotetext{
* Actually, she headed for the Sumanoura-maru at 0437 and arrived at 0500.
} 
pedoes hit her at the stern. Despite the immediate order to fire, her guns did not move due to a power supply failure. Before she could turn a searchlight [on the enemy], the latter crossed her bow and switched to her port side again launching torpedoes, one of which hit her at her port bow and another at her stern at 0445. ${ }^{(56)}$

At 0450, Patrol Boat No. 36, which was to the south of Patrol Boats Nos. 37 and 38, spotted a silhouette, which bore a close resemblance to the Naka, at about two kilometers northwest of her. In the time that she identified the silhouette as an enemy [vessel], the enemy sailed past her southeastward launching an illumination flare, and disappeared from sight. The patrol boat mistook both the enemy vessels and the friendly patrol boats behind them for enemy cruisers, and reported that she had spotted four enemy cruisers to the south of the convoy at 0500. The [whole] engagement lasted only thirty minutes, between 0420 when Minesweeper No. 15 first spotted the enemy and 0450 when Patrol Boat No. 36 lost sight of them. ${ }^{(56)}$

The first report that the enemy had been spotted that reached 1st Escort Unit Commander Rear Admiral Nishimura was the report from Minesweeper No. 15 at 0440, which meant that Rear Admiral Nishimura should have seen the explosion of the Sumanoura-maru ([at] 0432) by that time. However, he was on board of the Naka, which was in the patrol area of the $2 \mathrm{~d}$ Destroyer Division about thirteen kilometers away from the anchorage, and he did not confirm the detailed situation. Moreover, when the report that the enemy had been spotted reached him, he was in the course of moving from the patrol area of the $2 \mathrm{~d}$ Destroyer Division to that of the 9th Destroyer Division, and was still as much as ten kilometers away from the convoy. Even after receiving the report of Minesweeper No. $15,{ }^{*}$ the commander did not believe that a number of enemy destroyers were raiding the anchorage. At 0458, he issued an order to "Heighten the alert against enemy submarines and torpedo boats."(56)

[Even] at the report from Patrol Boat No. 36 at 0500 in the patrol area south of the anchorage that she had spotted four enemy cruisers, 1st Escort Unit Commander Rear Admiral Nishimura was still skeptical about a raid by enemy surface vessels. At 0508, the commander inquired of the patrol boat: "Is it not possible that the [enemy] cruisers in the earlier [report] could [actually] have been the 2d Destroyer Division?" At 0512, he received a reply from the patrol boat: "The [enemy] cruisers in the earlier report were a mistake for destroyers with four funnels." ${ }^{* *}$ Around 0520, while still operating in an area six to seven kilometers east of the convoy, he issued an order to the 9th Destroyer Division to attack the enemy to the north of the convoy, and he himself headed northward leading the Naka, but without knowledge about the enemy movements. However, because the 9th Destroyer Division, too, had no inkling about the enemy movements and was getting disorganized, the 1st Escort Unit commander ordered it at 0548 to resume [its previous task]. The commander [then] sailed toward the anchorage to ascertain the state of the convoy, but [in doing so] he got separated from the 9th Destroyer Division. ${ }^{(56)}$

In the meantime at 0515, 1st Escort Unit Commander Rear Admiral Nishimura had wired the Teiryu-maru (note: with Detachment Commander Sakaguchi on board) to have the transport ships timely evacuate eastward. At 0553, he also wired the detached force, which was coming to join [the main force], to suspend the action until dawn. Around dawn at 0652, Submarine chaser No. 12 patrolling the area west of the convoy spotted [enemy] torpedoes passing under the ship. She immediately caught up with the enemy, sailed over the periscope,

* The text mistakenly has Patrol Boat No. 15.

** The allied destroyers involved in the raid were American four stackers; the Japanese destroyers of the $2 \mathrm{~d}$ Destroyer Division were Shiratsuyu-class two stackers; the light cruiser Naka was a four stacker. 


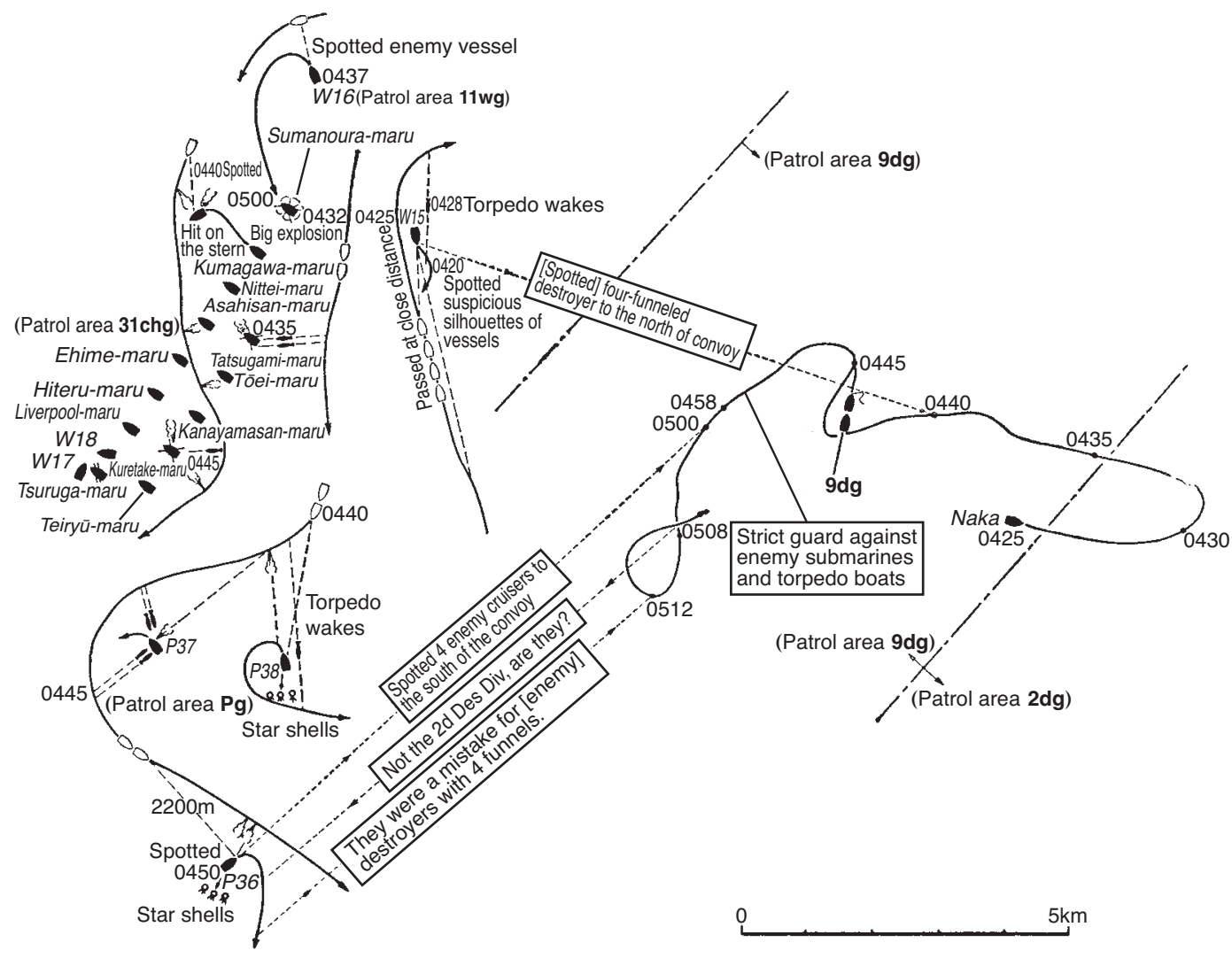

Illustration No. 15 - The Sea Engagement at Balikpapan (24 January, 0420 - 0515)

launched depth charge(s), and witnessed the enemy submarine sinking with its bow standing upright out of the water. ${ }^{(56)}$

Around 0700, finally it became light at the anchorage. The situation at the anchorage was devastating, and it became clear that the following loss was sustained:(56)

Army transport ships: The Tsuruga-maru and the Kuretake-maru, sunk by torpedoes (causing a loss of about thirty men in total)

Naval vessels: Patrol Boat No. 37, hit by three torpedoes at the bow and the stern, and too seriously damaged to sail (causing about thirty-five casualties); the Sumanoura-maru, hit by torpedoes and instantly sunk, leaving nine survivors; the Tatsugami-maru, hit by torpedoes and sunk thirty minutes later; the Kumagawa-maru, hit by about ten enemy shells (causing six casualties and minor damage to the hull); the Asahisan-maru, hit at the stern by several enemy shells (causing about fifty casualties)

Among the sunken Army transport ships, the Tsuruga-maru was hit by a torpedo around 0045 when the first landing unit was just about to depart and part of the unit had already shifted to the [landing] craft. Also, when the Kuretake-maru was hit by a torpedo around 0445, the first landing unit had already departed. It was fortunate that both ships sustained [only] a small loss of personnel. It was very much after the fact that 1st Escort Unit Commander Rear 
Admiral Nishimura confirmed that it had been a night raid by three or four enemy destroyers. ${ }^{(56)}$

The circumstances on that night were as shown in Illustration No. 15.

\section{The Situation of the Allied Navy ${ }^{(87,92)}$ (See Illustration No. 16)}

Anticipating that Japan's next target after the landing on Tarakan would be Balikpapan, the allied headquarters deployed six U.S. and two Dutch submarines in the sea off Tarakan through the southern part of the Makassar Strait. On 20 January, judging that a sortie of the Japanese forces was drawing close, the ABDA naval forces commander issued an order to the main force of Task Force 5 led by U.S. Navy Rear Admiral Glassford, which had been replenishing at Kupang, Timor, to make a sortie. Although the force originally consisted of a strength of two light cruisers and four destroyers, the flagship USS Boise ran aground on an uncharted shoal while sailing through the Sape Strait on the evening of 21 January and sustained damage, which made the light cruiser USS Marblehead the flagship. However, due to engine trouble, she [also] became unable to participate in the attack, which left only four destroyers to take part [in the attack] in the end. The four destroyers, USS John D. Ford, USS Pope, USS Parrott and USS Paul Jones, led by Commander Talbot, commander of the [U.S.] 59th Destroyer Division, rushed into the anchorage at a high speed of 27 knots, dealt a blow against the Japanese convoy, which was highly visible as if silhouetted against the backdrop of Balikpapan in flames, and were gone like the wind. At that time, the United States extensively advertised this engagement as the "Battle of Makassar Strait."

Further, it was the Dutch submarine K-XVIII that tried to torpedo the Naka and sank the Tsuruga-maru right after the unit to seize [Balikpapan] had entered into the anchorage. The submarine sustained serious damage by Japanese [antisubmarine] depth charge(s), and barely managed to return to Surabaya, escorted by three B-17s. The Dutch submarine K-XIV returned also with damage sustained in air raids, but no [allied] vessels were [reportedly] sunk.

The movements of both forces in this sea engagement off Balikpapan may be reconstructed as in Illustration No. 16, based on the "Action Report of the 4th Destroyer Squadron," The Rising Sun in the Pacific [(History of the United States Naval Operation in WWII)] by [Samuel] Morison, and Australia in the War of 1939-1945 Series [2] Navy Vol. 1 Royal Australian Navy [1939-1942] [by G. Hermon Gill], etc..

Concerning the engagement of that night, 4th Destroyer Squadron Commander Rear Admiral Nishimura stated his views in the "Action Report" as follows:

In that engagement, when the enemy destroyers entered into the anchorage of the convoy, they used illumination flares and flash-suppressing gunpowder, deftly threaded their way through the transport ships, thus hiding their whereabouts and actions, accomplished their goals of attack and fled away.

Although their illumination flares were seen, the ignition flashes were not seen. (They might have been seen at a closer distance, but they were at least not seen at [a distance of] 2,000 meters or more.) In the end, it was impossible to catch up with them and we let them escape.

I believe that the performance of the enemy's flash-suppressing gunpowder is well worth studying. 


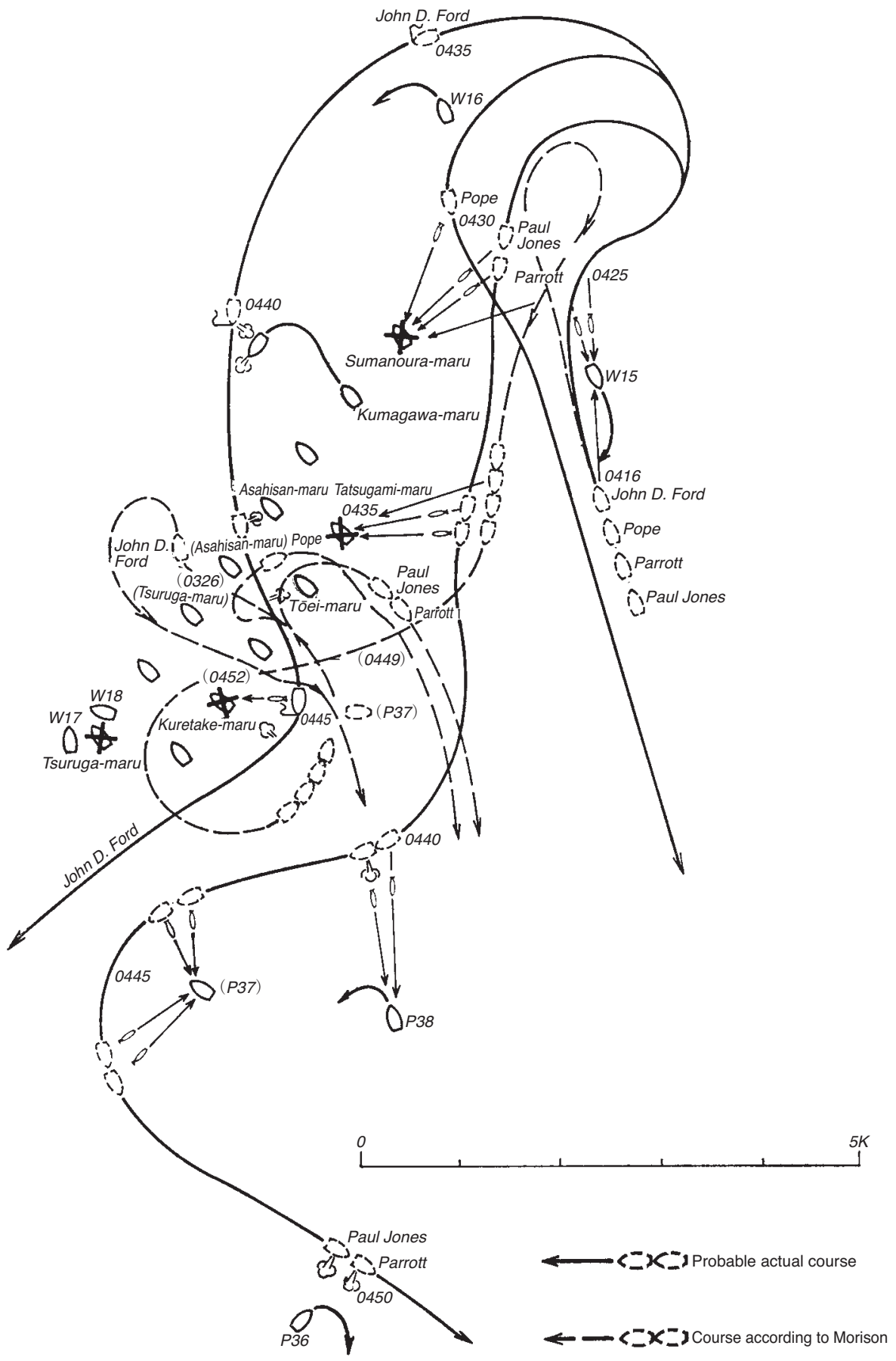

Illustration No. 16 - The Engagement with the U.S. Destroyers in the Sea Battle off Balikpapan (0416 - 0450, 24 January) 


\section{The Situation After the Landing [Illustration No. 17]}

Despite the major loss sustained by the transport convoy, the front line units of the Sakaguchi Detachment successfully landed by and large as scheduled, with the first landing unit at 0240 and the second landing unit at 0640 . Around sunrise, [the convoy of] the detached force was seen joining the 1 st anchorage. [Prior to that] at 0545 while [sailing to] join the main force, the detached force had spotted an enemy surfaced submarine at a point about thirty nautical miles south of the anchorage. It attacked the submarine, which then submerged, the result of the attack remaining unknown. Meanwhile, the Nan'a-maru continued drifting, with the fires far from dying down. ${ }^{(56)}$

On the 24th, as the weather improved, the Japanese fighter plane units, land-based attack plane units, flying boat units, and seaplane units resumed direct guarding and escorting, while attacking and searching for the enemy as scheduled. However, the anchorage continuously came under fierce raids by the enemy from morning onward. ${ }^{(56)}$

At 0812, one enemy four-engine heavy bomber came for a raid, which was followed by one twin-engine flying boat, which came for reconnaissance at 0925. [Then,] five twin-engine bombers with five dive bombers, and seven four-engine heavy bombers came for a raid respectively at 0950 and at 1040 . All of them bombed the convoy while threading through the desperate antiaircraft fire from the escort vessels as well as eluding interception by Japanese fighter planes. Fortunately, there was no damage, and [Japanese] fighter planes shot down some of the enemy aircraft. However, as observed from the naval vessels, the [enemy] fourengine heavy bombers, no matter how persistently attacked by Japanese fighter planes, were not brought down. ${ }^{(91)}$ At 1205, one [enemy] flying boat was seen reconnoitering from a distance, and an [enemy] raid in the afternoon was anticipated. In the meantime, the Sakaguchi Detachment reported that it had secured the airfield and the entire area around the bridge. Also around 0930, the 1st Escort Unit commander received a telegram from the [Navy] Dutch East Indies Unit commander saying: "the main unit is hurrying toward Balikpapan and is due to arrive on the evening of the 24th."

From around 1240 onwards, the 30th Minesweeper Division started clearing the waterway between the anchorage and the mouth of the river [near] the airfield for large-sized motorized [landing] craft. Meanwhile from 1230 through 1420, a total of more than thirty land-based attack planes of the $2 \mathrm{~d}$ Air Raid Unit carried out bombings on batteries and positions to the east of Balikpapan. ${ }^{(71)}$ At 1710, eight enemy twin-engine bombers and three dive bombers raided [the anchorage] and dropped bombs, but no loss was sustained. The raiding enemy aircraft on that day aggregated to thirty-one aircraft.

Taking a lesson from the experience that morning, 1st Escort Unit Commander Rear Admiral Nishimura decided to have the ships leave the anchorage at night. At 1900, the Naka, the 9 th and the $2 \mathrm{~d}$ Destroyer Divisions, the 1st Section of the 24th Destroyer Division, the 30th and the 11th Minesweeper Divisions left the 1st anchorage, escorting eleven transport ships and appropriately moved around the waters to the east. Only the 31st Subchaser Division and three patrol boats remained in the anchorage to guard the area. At 2030 while escorting the ships, the Umikaze spotted probable torpedo trails, and almost simultaneously, also the Samidare and the Asagumo spotted trails of torpedoes; they attacked [the enemy] with [antisubmarine] depth charges, but with unknown results. Around 2100, during these actions, the Nan'a-maru was seen sinking after a huge explosion. ${ }^{(56)}$ 


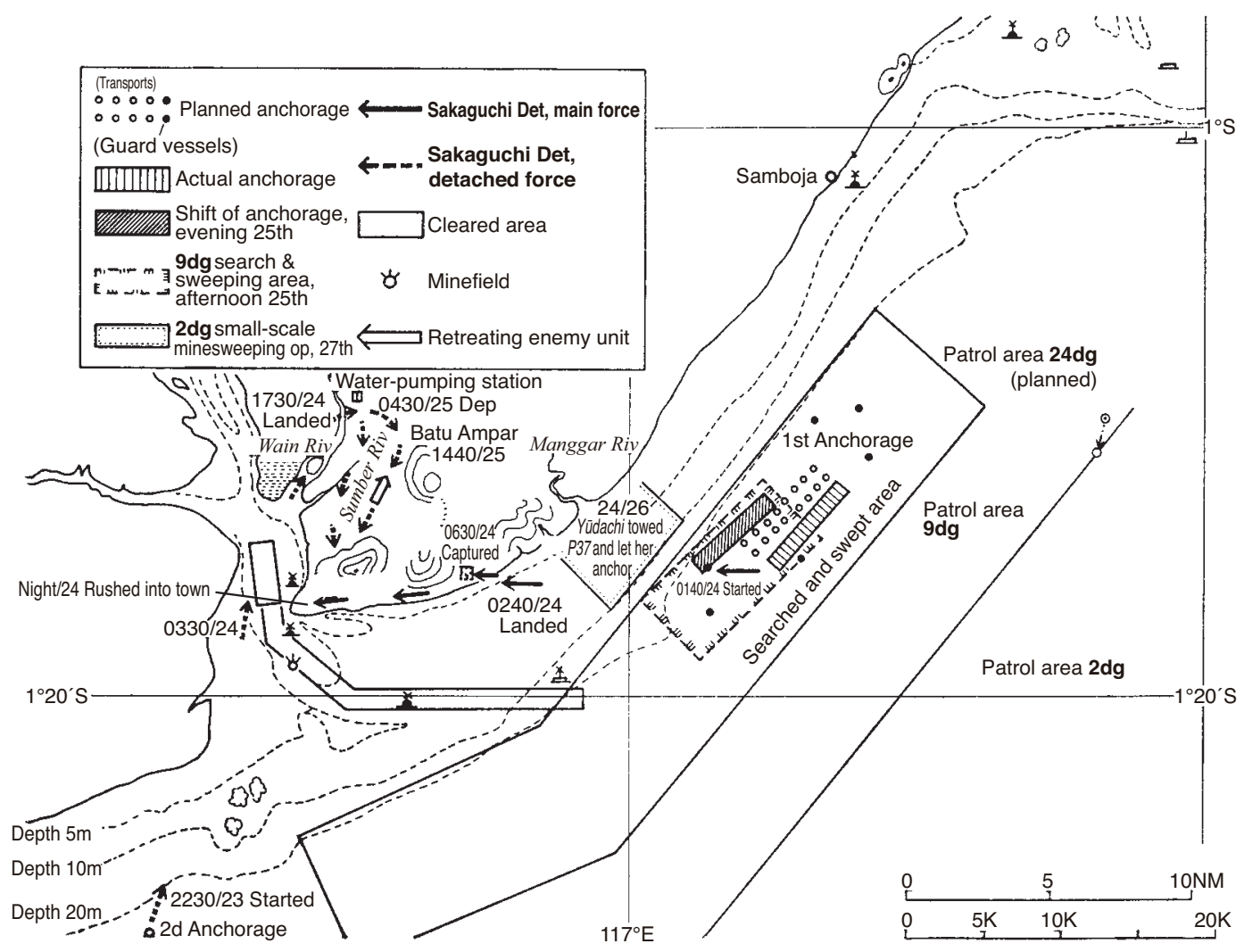

Illustration No. 17 - The Capture of Balikpapan (24-30 January, 1942)

\section{The Situation from the 25th Onwards}

At 0113 on the 25th, the $Y \bar{u}$ dachi detected and attacked a submarine; the attack was believed to have been largely effective. Early in the morning, the Sakaguchi Detachment stormed into the city of Balikpapan. Although the attack did not meet any enemy resistance, it was delayed because the bridges were completely destroyed. At 0740, the transport ships returned to the anchorage and dropped anchor. At 1000, ten [enemy] twin-engine bombers came for a raid. However, no damage was sustained, and friendly fighter planes shot down one of them. ${ }^{56}$, 71) [Meanwhile] at 1045, the San'yō-maru and the Sanuki-maru entered the port of Sangkulirang and dismantled the seaplane base. ${ }^{(76)}$ Although seven [enemy] four-engine heavy bombers came for an attack [on the Balikpapan anchorage] at 1305, no damage was sustained. When the detached force, which had left the water-pumping station on that day early in the morning, was about to advance southward from Batu Ampar at 1440, it encountered the Dutch East Indies garrison commander and his party in about 100 vehicles including armored cars and defeated them. ${ }^{(89)}$

At 1930, the convoy shifted to a new anchorage closer to the coast and dropped anchor. After nightfall, the detached force advanced into the urban area of Balikpapan and established contact with the main force. By the end of the day, the city was completely cleared [of the enemy]. [In the meantime,] the main unit of the [Navy] Dutch East Indies Unit had ad- 


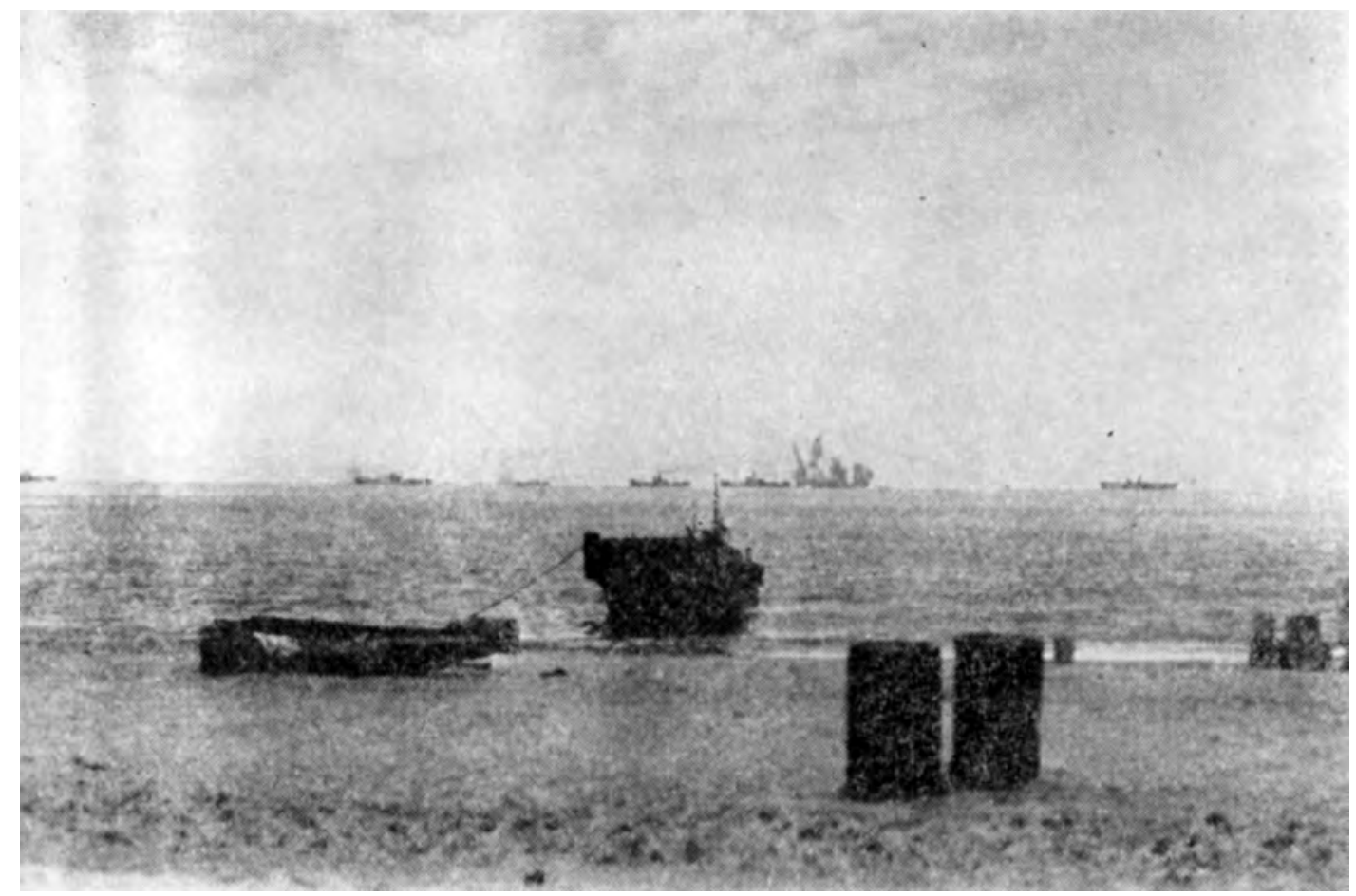

The Enemy's Bombing of [the Anchorage off] Balikpapan

vanced to about 200 nautical miles northeast of Balikpapan so as to support the units to capture the city, but judging that the operation [to] capture [Balikpapan] was for the most part completed, it began to reverse course toward Davao. ${ }^{(56)}$

At 0800 on the 26th, the San'yō-maru and Sanuki-maru entered the port of Balikpapan and launched their support [operations]. ${ }^{(76)}$ At 1030, the $2 d$ Base Unit [also] entered the port and took over the task of directing the minesweeping [operations] from the 1st Escort Unit. The 2d Base Unit from then on until 5 February disposed of 57 mines [in total] and finished clearing the waters inside the port. ${ }^{(56)}$ On that day [the 26th], no enemy air raid was conducted. With the completion of mopping up [the enemy] in the Samarinda and the Sanga Sanga areas, the Sakaguchi Detachment started to prepare for the seizure of Banjarmasin, the next target. $^{(89)}$

On the 27th, at 1300, five [enemy] four-engine heavy bombers again came for a raid. The Sanuki-maru sustained some damage from near hits, which also caused some damage to one of the Type- 0 observation seaplanes that was in the process of being taken on board and slightly damaged another. ${ }^{(76)}$ At 1940, the 2d Destroyer Division (minus the Harusame) made a sortie to clear out five enemy submarines, which, according to signal information of the Takao Signal Unit, [had been detected] in the central area of the Makassar Strait. However, unable to locate the enemy, the division returned [to Balikpapan] early in the morning on the 28th. On that day, nine carrier-based bombers of the $2 \mathrm{~d}$ Carrier Division advanced to Balikpapan. They were brought under the command of $2 \mathrm{~d}$ Air Raid Unit Commander Rear Admiral Takenaka and assigned to guard the area against submarines. Meanwhile, it was decided that the Sanuki-maru, which had sustained damage from the [enemy] bombing, 


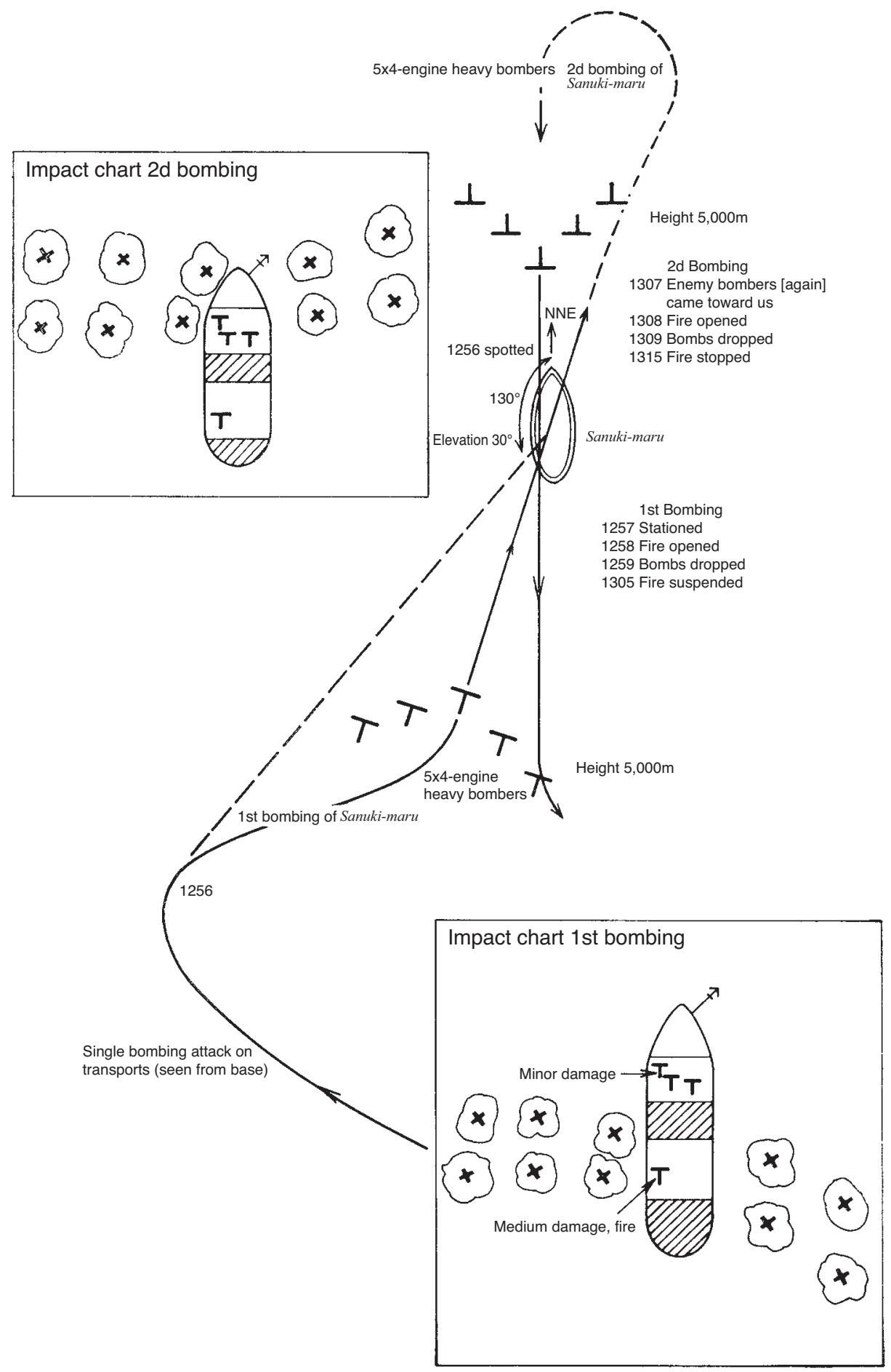

Illustration No. 18 - The Sanuki-maru's Engagement with [Enemy] Aircraft 
would be brought under the command of the $2 \mathrm{~d}$ Base Unit Commander R. Adm. Hirose Suéto, to be assigned to attacking and neutralizing enemy submarines in the Makassar Strait, and that she was due to be transferred to the 1st Base Unit from 7 February onwards. ${ }^{(76)}$ (See Illustration No. 18)

On the afternoon of the 28th, nine Type-0 fighter planes advanced to Balikpapan. At 1630, 1st Escort Unit Commander Rear Admiral Nishimura was notified by the [Navy] Dutch East Indies Unit that Banjarmasin would be seized overland, and that the escort by the 1st Escort Unit was cancelled. ${ }^{(76)}$ The $2 \mathrm{~d}$ Base Unit started to prepare for the seizure of Banjarmasin. On the 29th, twelve Type-0 fighter planes and two land-based reconnaissance planes advanced to Balikpapan. ${ }^{(71)}$ On the next day, the 30th, 1st Escort Unit Commander Rear Admiral Nishimura headed for Lingayen Gulf, leading the main force, in order to make preparations for the next operation (the Java invasion operation); thereafter the defense of Balikpapan and the guarding of the anchorage was left to $2 \mathrm{~d}$ Base Unit Commander Rear Admiral Hirose. On the same day, after dismantling its base, the San'yo-maru, too, left for Cam Ranh Bay in order to be engaged in the operations in the Malaya area. ${ }^{(90)}$ Meanwhile, the $23 \mathrm{~d}$ Air Flotilla headquarters and the entire fighter plane unit completed their advance to Balikpapan. ${ }^{(75)}$

\section{The Air Campaigns After the Departure of the Convoy}

As previously told, from 11 January onwards, the 2d Air Raid Unit day after day carried out search (reconnaissance) attacks on the enemy in Balikpapan and Banjarmasin ([the latter only] from the 18 January onwards) as well as in the Makassar Strait. As a result, by the 20th, enemy aircraft and naval vessels came hardly to be seen [any longer] in those areas. However, from the time of the departure of the convoy to seize [Balikpapan] [from Tarakan] on the 21st through the $23 \mathrm{~d}$, the weather north of Balikpapan including Tarakan was bad, while south [of Balikpapan] it was fine, which created circumstances extremely disadvantageous to the [Japanese] air campaign. On top of this, also the seaplane unit was prevented from executing its [scheduled] flights on the 23d because of the bad condition of the Sangkulirang [sea] base, which the Navy had set up midway between Tarakan and Balikpapan ([that is,] shoals stretching to a good distance from the pebble-covered shore, marshy land, and trees growing even in the sea, which made the base unusable unless [the seaplanes] were moored to buoys). ${ }^{(76,90)}$ Because of the above, both the land-based unit and the seaplane unit were not able to provide effective support for the convoy at the most critical moment, leaving the latter to experience the enemy air raid head-on.

From the 24th onwards, as the weather conditions improved, the air units resumed their search and attack missions against the enemy and also repeatedly attacked the [enemy] secret base in Melak (west of Samarinda), which had newly been spotted; by around the 28th they had on the whole suppressed the enemy movements in that area. ${ }^{(71)}$

However, the preparation of the airfield was delayed again this time (the [Balikpapan] airfield was 900 meters long from north to south: although runway was not paved, its ground condition was better than at Tarakan, and it was extendable). ${ }^{(56)}$ Finally, nine carrier-based bombers of the $2 \mathrm{~d}$ Carrier Division advanced [there] on the $27 \mathrm{th},{ }^{(75)}$ and nine Type- 0 fighter planes of the Tainan Air Group on the 28th. ${ }^{(75)}$ They were followed by the 23d Air Flotilla headquarters, which also advanced [there] on the 30th (as previously told), but it was quite late and not until 3 February that (one element of) the land-based attack planes were advanced [there]. ${ }^{(75)}$ This was because the sinking of the Nan'a-maru and the Tatsugami-maru 
had led to a shortage in the number of large-sized motorized [landing] craft, and the disembarkation of airfield construction matériel did not make the expected progress even after the arrival of the Kamogawa-maru and the Okitsu-maru.

In the meantime, from around that time, air raids by four-engine enemy B-17 heavy bombers had increased, and they were difficult to deal with. The circumstances were as follows: ${ }^{(71)}$

24th [of January 1942]: Seven [enemy] aircraft came for a raid; it was reported that three of them were shot down and another shot down but unconfirmed. Due to hits sustained in the air engagement, two Type- 0 fighter planes were seriously damaged at the time of landing.

25th: Seven [enemy] aircraft came for a raid; the result [of the counterattack] unclear. Shot by [the enemy], one Type- 0 fighter plane fell apart in midair. Another went missing.

27th: Five [enemy] aircraft came for a raid; none of them was brought down.

29th: Four [enemy] aircraft came for a raid; none of them was brought down. One Type-0 fighter plane crashed itself, while another was hit, leaving its crew seriously injured.

31st: Five [enemy] aircraft came for a raid; none of them was brought down.

Thus, the Balikpapan operation was completed. The loss sustained by the Japanese forces was the heaviest thus far in the landing operations in the Dutch East Indies area: The Sumanoura-maru, the Tatsugami-maru and the Kuretake-maru were sunk, Patrol Boat No. 37 and the Asahisan-maru badly damaged, the seaplane tender Sanuki-maru half damaged, and the Kumagawa-maru slightly damaged. However, despite these losses, the number of casualties was small. Also, the resistance put up by the enemy ground forces was extremely limited in this operation, [which led to a result that] only eight men of the Sakaguchi Detachment were killed on the ground. The Navy requisitioned the Sanga Sanga oil fields as well as the BPM oil refineries situated in Balikpapan and operated them. Although the enemy had thoroughly destroyed these facilities before retreating, the Japanese defense detail [1st Defense Detail] repaired the oil wells at an amazing speed and smoothly kept them in operation during the period from June 1942 until August 1943 (as mentioned previously). The crude oil from the Sanga Sanga oil fields was light in quality and could for $34 \%$ turned into petroleum. With a high octane rating, [the oil] refined at Balikpapan was of great use in the [Japanese] operations in the southwestern Pacific. ${ }^{(77)}$

Just for reference, the loss of munitions sustained in the sinking of the transport ships is as shown in the following [tables] (the tables partly include losses in [later] naval engagements): ${ }^{(75)}$

The Depletion of Ammunition Stocks (from 2 January 1942 until 9 April 1942, [of] the Air Unit of the Southern Task Force)

1. Ordnance

\begin{tabular}{|l|l|rc|}
\hline \multicolumn{2}{|l|}{ Torpedoes } & \multicolumn{2}{|c|}{6} \\
\hline \multirow{2}{*}{ No. 80 bombs } & Regular bombs & 18 & $(160)$ \\
\cline { 2 - 4 } & Land bombs & 28 & $(332)$ \\
\hline \multirow{2}{*}{ No. 25 bombs } & Regular bombs & 475 & $(750)$ \\
\cline { 2 - 4 } & Land bombs & 2,635 & $(700)$ \\
\hline
\end{tabular}




\begin{tabular}{|c|c|c|c|}
\hline \multirow{2}{*}{ No. 6 bombs } & Regular bombs & 2,908 & $(2,500)$ \\
\hline & Land bombs & 2,043 & $(2,450)$ \\
\hline \multicolumn{2}{|l|}{ No. 7 Mark-6 bombs } & \multicolumn{2}{|l|}{75} \\
\hline \multirow{2}{*}{ Machinegun bullets } & 7.7-mm & 434,134 & $(212,000)$ \\
\hline & 20-mm & 42,800 & $(24,900)$ \\
\hline \multicolumn{2}{|l|}{ Tubular clips [???] } & 190,654 & $(137,900)$ \\
\hline \multirow{2}{*}{ Drop tanks } & For Type-0 fighter planes & 626 & \\
\hline & For Type-96 fighter planes & 124 & \\
\hline Remarks & \multicolumn{3}{|c|}{$\begin{array}{l}\text { 1. [The numbers] in parentheses were the loss incurred by the sinking of } \\
\text { the Tatsugami-maru and the Yübari-maru [Editor's note: the Yübari-maru } \\
\text { was sunk in Kupang on } 27 \text { March 1942.] } \\
\text { 2. No. 80: 800-kg; No. 25: } 250-\mathrm{kg} \text {; No. } 7: 70-\mathrm{kg} \text {; No. } 6: 60-\mathrm{kg} \\
\text { 3. [Omitted: remarks on Japanese abbreviations] }\end{array}$} \\
\hline
\end{tabular}

2. Aviation fuels

\begin{tabular}{|c|c|c|c|}
\hline \multirow{4}{*}{ Aviation Fuel } & Special 92 Octane Gasoline & \multicolumn{2}{|l|}{412.1} \\
\hline & 92 Octane Gasoline & $7,062.7$ & $(4,040)$ \\
\hline & 91 Octane Gasoline & \multicolumn{2}{|l|}{4452.1} \\
\hline & 87 Octane Gasoline & 5430.3 & $(1,139)$ \\
\hline \multicolumn{2}{|c|}{ Aviation Mineral Oil (kiloliter) } & 675.7 & $(280)$ \\
\hline Remarks & \multicolumn{3}{|c|}{$\begin{array}{l}1 \text { [The numbers] in parentheses were the loss incurred by the sinking of } \\
\text { the Nan'a-maru, the Kamogawa-maru and the Yübari-maru } \\
2 \text { [Omitted: remarks on Japanese abbreviations] }\end{array}$} \\
\hline
\end{tabular}

\section{The Seizure of Kendari (See Illustration No. 19)}

On 24 January, the same day as the capture of Balikpapan, the [operation to] seize Kendari was carried out single-handedly by the Navy. The seizure [operation] was executed by the Eastern Attack Unit (commander: 5th Cruiser Division Commander R. Adm. Takagi Takeo) with almost the same forces as employed in the [operation to] seize Menado (except for the paratrooper unit). However, the unit to seize Kendari was supposed to be directly commanded by 1st Base Unit Commander Rear Admiral Kubo, and 2d Escort Unit Commander Rear Admiral Tanaka was supposed to support it while making preparations for the [operation] to capture Ambon. In conducting the [Kendari] operation, the 15th and the 16th Destroyer Divisions and others of the $2 \mathrm{~d}$ Escort Unit were incorporated into the 1st Base Unit, and the 21st Minesweeper Division and the 1st Subchaser Division were also returned to the 1st Base Force. ${ }^{(78)}$

The [operation to] seize Kendari had been scheduled for 21 January at the time of the launch of the Dutch East Indies operation. However, [having found that] the transfer of the 
1st Construction Squad could not be made in time, the staff of the 1st Base Force wired on the 14th [of January] that the next operation was expected be postponed for several days. ${ }^{(54)}$ Further, after [receiving] on the night on 14 January the telegram reporting that the landbased reconnaissance plane of the 3d Air Group had "spotted thirty [enemy] submarines" (as previously told), Dutch East Indies Commander V. Adm. Takahashi Ibō decided, on 15 January, that [the operation to] seize Kendari should be postponed for three days till 24 January. ${ }^{(54)}$ Without having detected after all [particular] enemy movements in the operation to clear the Molucca Sea of enemy submarines, the Nagara, the 15th and the 16th Destroyer Divisions and the 21st Minesweeper Division returned to the Bangka anchorage on the morning of the 17th. Earlier, the Air Unit had with Davao as its base launched its air campaign to destroy the enemy air power, as described previously. That is, starting with the night raid on Ambon on the 7th, the unit carried out search missions for the enemy in the Gulf of Tomini, the Molucca Sea, and the Ceram Sea as well as reconnaissance attack missions on Menado, Kendari and Ambon almost every day. Other than the twenty-five large and small aircraft, which [the unit] had spotted on the Ambon [airfield] on the 14th and destroyed in the raid on the 15th and the 16th, as previously told, it spotted no enemy worth attacking during the campaign. Signs of the enemy were no longer seen at Kendari around the 15th, and on the 18th, no enemy aircraft was spotted even in Ambon, either. Also, no enemy naval vessels were spotted even in the first reconnaissance of Makassar on the 17th, and it was concluded that [the campaign to] neutralize the enemy from the air was more or less completed by the time of departure of the unit to seize [Kendari]. On 24 January, the day when [the operation to] seize Kendari was conducted, carrier-based air units ([consisting of] the Sōry $\bar{u}$ and the Hiry $\bar{u}$ of the $2 \mathrm{~d}$ Carrier Division as the core) carried out an air strike on Ambon (which shall be described later), but no enemy vessels or aircraft were spotted. ${ }^{(71,75,81)}$

The unit to seize [Kendari] left the Bangka anchorage on 21 January. While the $2 \mathrm{~d}$ Air Unit ([consisting of] the Chitose and Mizuho) provided direct escort against enemy aircraft and submarines and patrolled the sailing route ahead, it reached Kendari on the morning of the 24th and successfully landed at 0428. ${ }^{(54)}$ Although several times during that period objects that seemed to be submarines had been detected, there was no counterattack from the allied forces, so the support unit, after merely cruising in the area to the north of Celebes, simply returned to Davao on the 26th. During this operation, the surface unit and the air unit pursued one enemy light cruiser, the only allied naval vessel that had come in the area (landbased reconnaissance planes had spotted the cruiser at a point south of Kendari on the 24th; according to The Rising Sun in the Pacific [History of the United States Naval Operations by Samuel] Morison, it was the U.S. seaplane tender USS Childs). However, due to the delay in the start of the pursuit and hindered by bad weather, they lost sight of the ship. ${ }^{(54,93)}$

Meeting with little resistance on land, Capt. Mori Kunizō, commander of the Sasebo Combined Special Landing Force, who had made the landing, reported at 0305 on the 25th that [his force] had occupied the airfield at 1700 on the 24 th. The condition of the airfield was quite good, and the commander reported: "[the airfield is] right away available for 30 fighter planes. [The condition of] the airfield is quite good and it can be used even by medium-sized land-based attack planes without problem."(53) The main force of the fighter plane unit of the 1st Air Raid Unit ([consisting of] twenty-five fighter planes and five land-based reconnaissance planes) advanced to the Kendari airfield as early as on the afternoon of the 25 January. Apart from just one disadvantage that it was far from the coast, for the Japanese [forces] the 


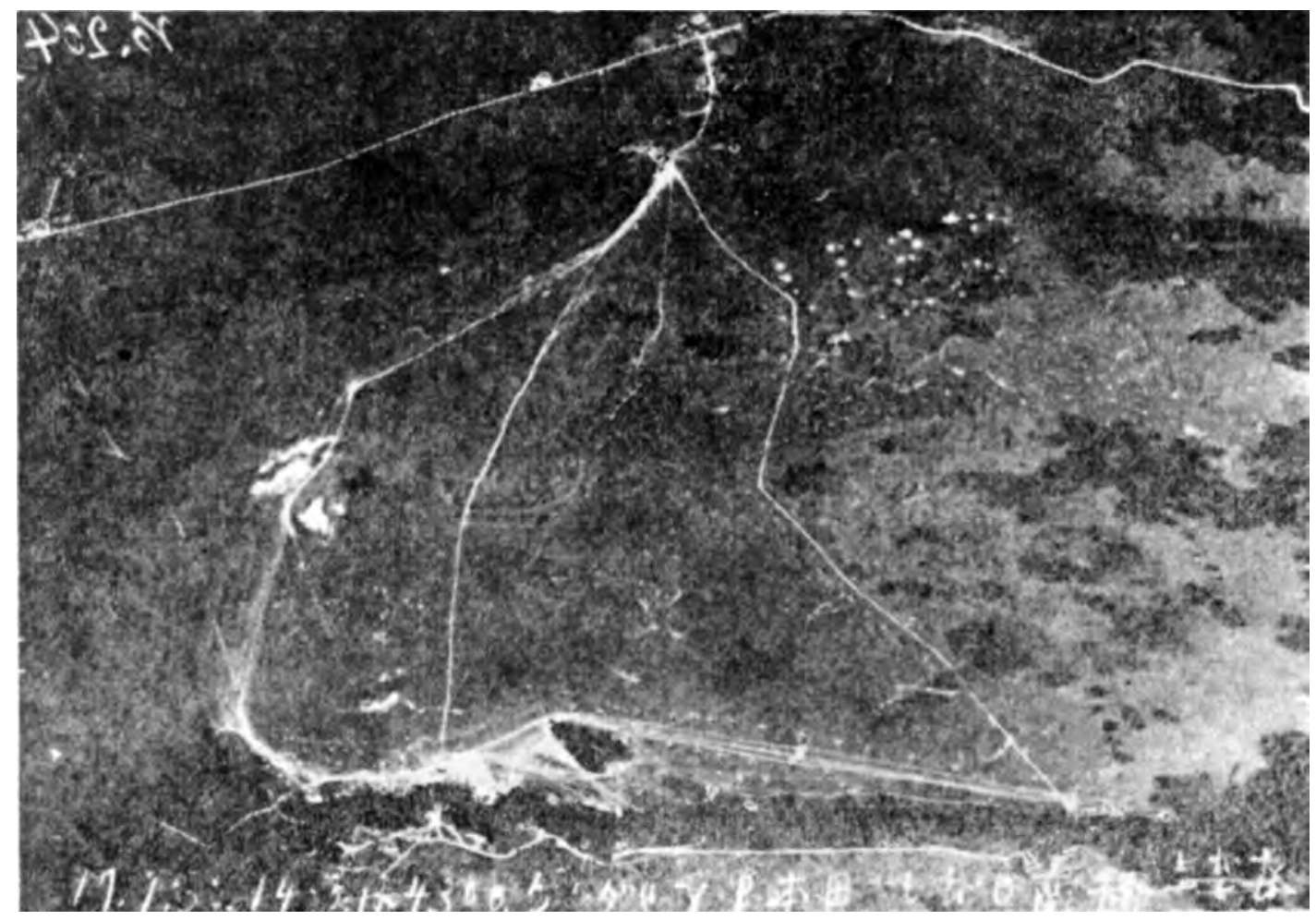

The Kendari Airfield

airfield very fortunately met the conditions for a base in that it required almost no construction work and was immediately usable for land-based attack planes. ${ }^{(12)}$ As early as the 27 th, the 21st Air Flotilla headquarters and twenty-seven land-based attack planes of the Kanoya Air Group Detachment advanced to Kendari. ${ }^{(53)}$

It seemed that the Kendari operation would be successfully completed with only two men of the special landing force injured, but an unexpected accident happened early in the morning on the 25th. It was the collision between the Hatsuharu of the 21st Destroyer Division, which had been incorporated into the 1st Base Unit from the support unit for reinforcement and was rushing toward Kendari, and the Nagara with the 1st Base Force commander on board. At that time, it was raining and visibility was limited. The Hatsuharu collided into the Nagara near starboard midship at a high speed of 21 knots. The collision crushed the former's bow up to the turret of the fore gun, and left the Nagara with some damage to its starboard and to some of its upper structures. ${ }^{(94)}$ It was fortunate that the only personnel damages were serious injuries to two men on board of the Nagara. Due to this [collision], 1st Base Force Commander Rear Admiral Kubo [had to] change ships from the Nagara to the Hatsushimo (the fourth ship of the 21st Destroyer Division). The Nagara [had to] be brought to Davao on its own [for repair], while the Hatsuharu [had to] be brought to Davao [as well], escorted by the Nenohi (the third ship) and the Wakaba (the first ship); the reinforcement of the Kendari operation unit [instead] ended up in a reduction of its strength. ${ }^{(87)}$ Responding to this, the Eastern Attack Unit commander adopted such measures as to delay for one day the return of the 16th Destroyer Division, which had been due to leave [Kendari] on the 25th for the Bangka anchorage to prepare for the subsequent Ambon operation. ${ }^{(78)}$ However, this accident 


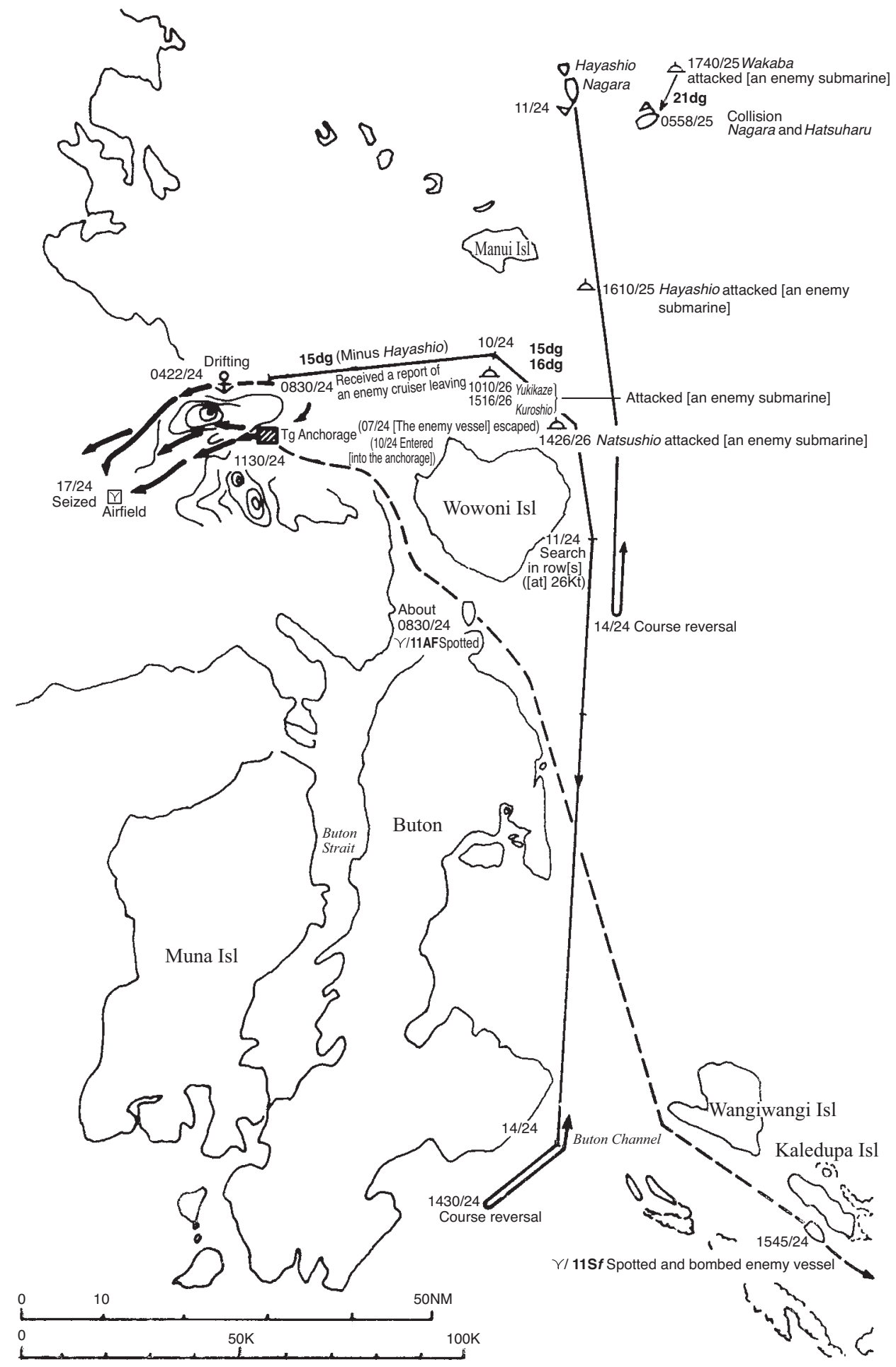

Illustration No. 19 - The Seizure of Kendari 
struck a hard blow to the Eastern Attack Unit, which [already] suffered from a shortage of smaller vessels.

Apart from the unexpected accident of the collision between the Nagara and the Hatsuharu, the Kendari operation made smooth progress. The Chitose and the 16th Destroyer Division left Kendari on the 26th, the Sasebo Combined Special Landing Force on the 27th, the 15th Destroyer Division on the 27th and the 29th, the 21st Minesweeper Division on the 29th, and the rest on the 30th, which completed the withdrawal of all [invasion] units from the town, and they started preparations for the subsequent Makassar and Ambon operations. Meanwhile on the afternoon of the 26th, it was decided that the Mizuho should leave Kendari on the 29th to participate in the Ambon operation straight [from there]. ${ }^{(54,59,78)}$

The Japanese seized Kendari by catching the allied forces totally off guard. Until the invasion units entered into the anchorage, the allied forces were totally unaware of them. ${ }^{(92)}$ This presumably had several causes: the allied air unit in Ambon had sustained loss after loss caused by the Japanese air campaigns, which had day by day been getting increasingly fierce from 7 January onwards, and its capacity to conduct patrols had markedly declined; in preparation against the Japanese [operation to] capture Balikpapan, allied submarines were concentrated in the Makassar Strait, which led to the deployment of fewer submarines in the Molucca Sea and the Banda Sea; and during [the Japanese approach to Kendari], the weather was calm but visibility was low.

After the landing of the [Japanese] invasion unit [at Kendari], too, half of the [U.S.] 19th Bombardment Group at Malang in eastern Java was engaged in operations from Palembang to Malaya, while the other half was attacking [Japanese forces] in Balikpapan and had no strength to spare for Kendari. ${ }^{(86)}$ Although an Australian bomber squadron was stationed in Kupang, Kendari was beyond its range of action. And since no air unit was stationed in Makassar, no counterattack [on Kendari] was conducted from the air. ${ }^{(95)}$ As for the [allied] surface units, though U.S. Task Force (TF) 5 was [covering the area], the unit with the USS Houston was out to the Torres Strait to escort transport ships carrying reinforcements from the United States, while the unit with the USS Boise was moving to attack [Japanese forces] in Balikpapan, leaving no strength to spare for the [Kendari] area. ${ }^{(87)}$

On the day when the landing on Kendari was carried out, Commander in Chief of the Combined Fleet Admiral Yamamoto issued an order to shift to the phase-three disposition of forces. Having concluded that the landing of the main force of the Army Malaya invasion unit was completed with the landing of the main force of the 18th Division at Singora on 22 January, the commander in chief of the Combined Fleet issued an order by Telegraphic Operation Order No. 50 ([at] 1200 on 24 January), which read: "[The units shall] shift the disposition of forces to that of phase-three operations. However, the destroyer divisions (destroyers) shall remain in the same disposition as of 1200 on the 24th." ${ }^{\prime(62)}$ At that moment, the Endau and the Anambas operations were about to be launched in the Malaya area, while on the same day the units to capture Balikpapan and Kendari landed in these places in the Dutch East Indies, which made it impossible for the Southern Task Force to immediately shift the disposition of forces. Thus, [the commander in chief of the Combined Fleet] issued the order in such a way that [these units could] shift to the phase-three operations with their current disposition of forces. ${ }^{(62)}$ 


\section{The Manila Agreement and the Operational Policy for Phase-Three}

\section{Request for a Two-Week Postponement of the Operation Schedule}

On 18 January, Southern Task Force Commander Vice Admiral Kondō advanced to Palau, leading the main body of the Southern Task Force. ${ }^{(61)}$ On the next day the 19th, he summoned the senior staff officers of the Third Fleet and the Eleventh Air Fleet, Capt. Yamaki Akira and Capt. Takahashi Chihaya, to discuss the subsequent Dutch East Indies operation. At this meeting, Captain Yamaki of the Third Fleet strongly demanded a two-week postponement of the operation schedule of the subsequent Dutch East Indies operation, ${ }^{(11)}$ giving the following reasons:

1. The seized airfields in Davao and Jolo in the southern Philippines, and Tarakan and Menado in the Dutch East Indies are all in such an unexpectedly bad condition that [several] days will be required to extend and make them ready for use, and that two weeks from the moment of seizure would be required before land-based attack plane units could use them.

2. It is impossible to arrange the escort ships, if the invasion [were to be conducted] according to the schedule specified in the Cam Ranh Agreement.

3. The current schedule has put us in a situation where the Air Unit's [operations to] neutralize the [enemy] air power are started almost simultaneously with the departure of the invasion units from their bases. [Consequently,] the latter will [have to] rush headlong into the points to be seized before [the air operations] have brought about sufficient results, which we greatly fear may increase the damage to the invasion units.

4. In Tarakan, the mines laid by the enemy gave us a lot of trouble and much time was spent on minesweeping, which, as a result, became a major cause of the delay in the operation schedule. It may be expected that the farther we go southward from now on, the more minefields [will be encountered], which means that it is necessary to allow more time for sweeping mines.

5. In the current schedule, escort ships cannot afford to take time off for maintenance; their engines cannot be maintained because they have to be ready all the time for sailing at high speed, which is causing steam leakage and other troubles one after another. [Moreover,] the officers and crew are extremely exhausted due to patrol [duties], which do not allow them to rest even for a moment. It makes us worry about the prospect [for the coming operations] if the operations continue [in this way].

Remarks:

(1) For example, the operations of the destroyers ${ }^{(72)}$ (as shown in the following table)

(2) The duty hours of the ships' captains

While the crews were exhausted, the overwork of the captains was an even bigger problem. That is, the captain was by far senior to his second-in-rank senior staff officer in terms of graduation classes at the Naval Academy. To the captain it was out of the question to regard his senior staff officer as his substitute. So, after leaving the port of Palau, the captain left the bridge only when he had a call of nature and even seldom slept in bed, which made the captain's work the toughest among the crew. [Examples of the differences in] graduation classes of the captain and the senior staff officer [of some destroyers] were as follows:

Natsushio (50th class - 65th class), Kuroshio (50th - 62d), Oyashio (50th - 63d), Hayashio (50th -61st), Yukikaze (50th - 61st), Tokitsukaze (48th - 64th), Amatsukaze (49th - 61st), Hatsukaze (49th - 63d)

6. In the current circumstances, it is impossible to spare escort forces at the time of [the operation to] seize Banjarmasin. Moreover, the operation is tactically unfavorable because the operation 


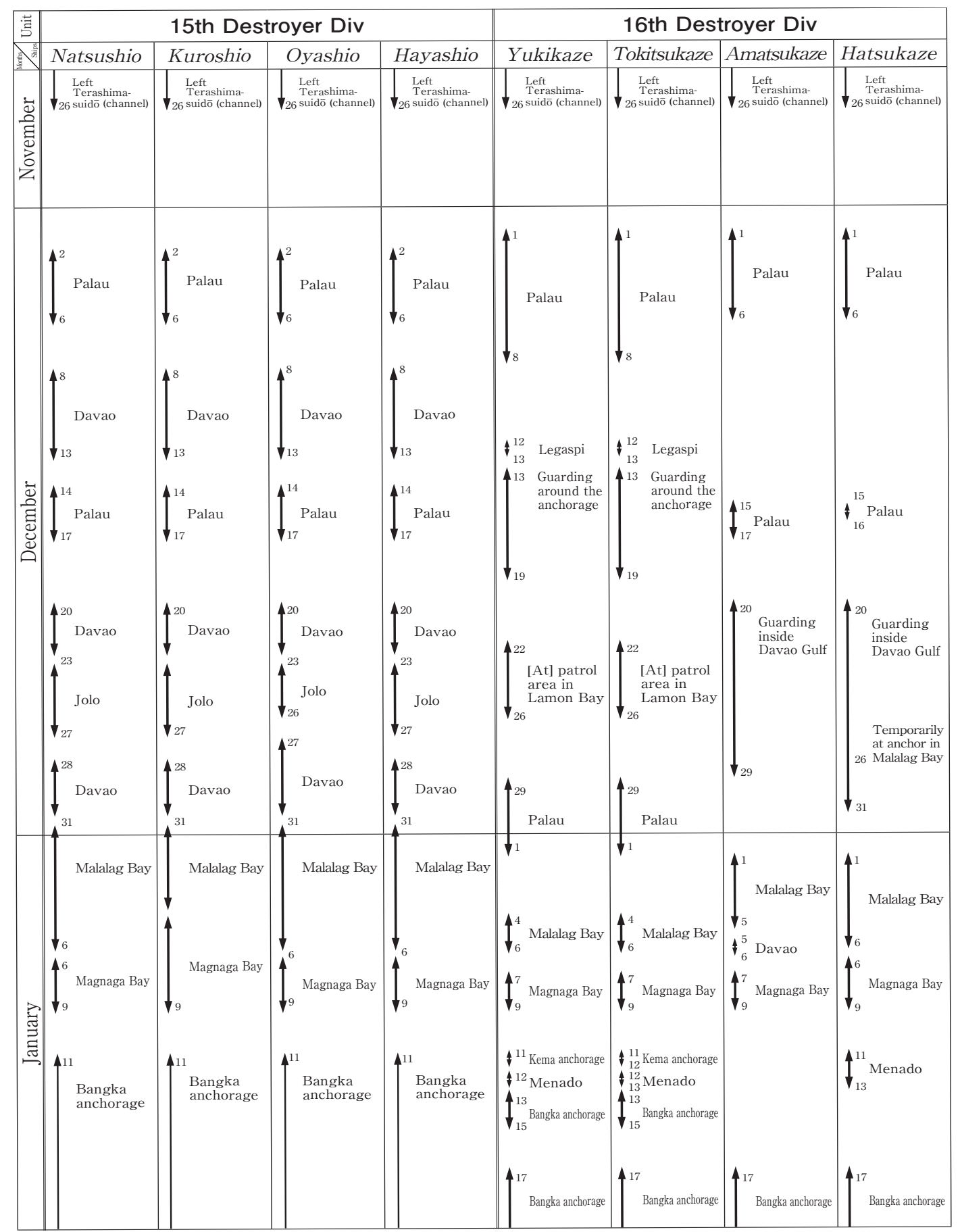

The Operations of the 15th and the 16th Destroyer Divisions

(from 26 November 1941 through 18 January 1942)

Note: In the above table, Palau was the only safe port where it was not necessary to keep the engines on standby. 
to seize [Banjarmasin] would be made by a sea route that exposed the flank [of the seizing unit] to Java. So, we would like to omit the escort on sea in this operation.

Also, Eleventh Air Fleet [Senior] Staff Officer Captain Takahashi requested a postponement on the following [grounds]: ${ }^{(34)}$

1. It has taken more days than expected to make airfields ready for use, which has resulted in successive delays in the forward deployment of the Air Unit. I am of the same opinion as the Third Fleet on the postponement of the schedule.

2. The air campaign against eastern Java prior to the invasion of Java shall be conducted from Balikpapan and from Makassar. [That from] Banjarmasin shall be called off.

3. As a result of finding detailed documents on the airfield on Bali among the recently seized enemy objects at Tarakan, it became clear that the airfield has better facilities than expected. Therefore, we want our forces to capture this place, advance one element of the Air Unit there prior to the invasion of Java and use the facility as an air base for the invasion operation.

Remarks:

The view that [the operation to seize] Banjarmasin should be cancelled and [that an operation to seize] Bali should be added [instead] presumably came from the [following] judgment: the condition of the Banjarmasin airfield was not yet known and it was expected to take considerable time to ready the Banjarmasin airfield even if it were captured; [moreover,] supplying the airfield would involve serious risks; however, the airfield on Bali was better than expected; if [the Japanese forces] had to take risks in either case, occupying Bali and using it for the air campaign to destroy the enemy air power would be far more effective, because it would also enable [the Japanese forces] to cut off the enemy supply route from Australia. It was a strong request from the $23 \mathrm{~d}$ Air Flotilla headquarters.

Though sympathetic to the predicament of the units on site, the Second Fleet headquarters, in response to these views, demanded [more] effort not to postpone the invasion schedule for reasons that a postponement of the schedule would have quite an impact on the entire conduct of the operation as well as on the [Navy's] good faith with the Army. However, persuaded by the insistence of the units on site that they could not give what they did not have, the Second Fleet decided to urgently confer with the Southern Army and propose as a compromise plan a postponement of ten days. For this purpose, it was decided to hold a conference at Manila from the 21st through the $23 \mathrm{~d}$ of January. The telegram sent from the chief of staff of the Second Fleet to the chief of staff of the Southern Army read as follows: ${ }^{(34)}$

The actual situation of the schedule for the invasion of the Dutch East Indies is that the advance and deployment of the air forces is experiencing one delay after another because the condition of the occupied bases in the eastern part of the Dutch East Indies is unexpectedly bad, despite all efforts to expand and ready those bases. Meanwhile, the enemy is mounting counterattacks using a great many bases. Moreover, from the situation at Tarakan, we may infer that mines have been laid across many stretches of water. In order to advance the subsequent invasion operations without major problems, it is inevitable to postpone the landing dates for Banjarmasin, Makassar, Timor and Java by more or less ten days. Therefore, in order to discuss the details, we will send the senior staff officer of our fleet to a conference to be held in Manila from 21 to 23 January in order to make arrangements between the Sixteenth Army, the Third Fleet and the Eleventh Air Fleet. We would appreciate it if you would arrange the dispatch of staff officers from your headquarters. 
Southern Army headquarters was dead against the request by the Second Fleet to postpone the schedule. It insisted [in outline] that: ${ }^{(34)}$

1. A postponement of the schedule would, if anything, give the enemy [an opportunity to] strengthen (in particular its naval and air) defense, which would all the more delay our invasion [schedule]. At this juncture, [we maintain that the invasion schedule] should be carried out on the basis of the schedule stipulated in the Cam Ranh Agreement at any cost.

2. The Army shall provide more than enough support for the Navy air units by such things as getting hold of and preparing airfields and by supplying the necessary fuel.

Not only the central command of the Army but also the upper echelon of the Navy, namely, the Navy General Staff and the Combined Fleet headquarters were against a postponement. ${ }^{(40)}$ In particular, the Combined Fleet headquarters was extremely frustrated: it had ordered the Second Fleet headquarters to study the possibility of conducting [the operation to] capture Ambon around the 10th of January in tandem with [the operation against] Menado, but the latter had postponed it, replying that it was not feasible. Adding to the frustration was the fact that the Combined Fleet headquarters had taken the extraordinary step of transferring the $2 \mathrm{~d}$ Carrier Division, which had returned from Hawaii, to the Southern Task Force in order to speed up the capture of Ambon, but nevertheless the Second Fleet headquarters had postponed the schedule from the 25th till the 29th [See p. 177], and then again postponed it till the 31st. Stating that the request for such a significant postponement for whatever reason was extremely inimical to the entire conduct of the operation, the Combined Fleet headquarters sent telegrams to the Second and the Third Fleets to demand explanations from them. The Navy General Staff also sent to the Combined Fleet as well as the Second and the Third Fleets a telegram demanding them to take appropriate steps, bearing in mind that a postponement of the operation schedule would have a large impact on all quarters. ${ }^{(34)}$

In the meantime, the First Southern Expeditionary Fleet [too] had made a request to postpone Operation L (Bangka and Palembang) for two weeks on the grounds that the condition of the Kuching airfield on Borneo was bad and that it had had no prospects of occupying and preparing the Ledo airfield [yet]. This request was also added to the agenda at Manila. ${ }^{(34)}$

\section{The Difficult Conclusion of the Manila Agreement}

The Manila Conference, held from 21 January, had four objectives: the schedule of the entire [southern] operation, Operation L, the operations in the eastern part of the Dutch East Indies, and the operations in western Java. ${ }^{(34,97)}$ The meeting was held from the evening of the 21st of January until deep into the night. To begin with, the Navy made the following proposals. ${ }^{(34)}$

1. The operation schedule after [the operations against] Makassar and Kupang until the landing in Java shall be postponed for about ten days from those stipulated in the Cam Ranh Agreement. That is, [the date of the operation against] Makassar shall be set on Day X + 69 (15 February), that against Kupang on Day X +74 (20 February), and that against eastern Java on Day X +80 (26 February). As for the date of [the operation to capture] Ambon, the Third Fleet and the Sixteenth Army have already agreed to postpone it till Day X + 54 (31 January).

2. The operation [to seize] Banjarmasin shall be cancelled and the air campaign to destroy the enemy air power in Java shall be conducted from Makassar and Balikpapan. 
3. Instead of Banjarmasin, Bali shall be captured right before the invasion of Java so as to use it as a support air base at the time of the [Java] landings.

4. If the 48th Division is to depart from Lingayen Gulf on 8 February ([the place of departure was] changed because the delay in occupying Bataan Peninsula made it impossible for the division to depart from Manila Bay) and sail at an average speed of eight knots, it cannot arrive in eastern Java earlier than 19 February. It is impossible to conduct a landing [operation] on Java on Day $\mathrm{X}+70$ (16 February).

As previously told, the Army side fiercely objected to this proposal, saying that, in view of reports that the enemy's air and naval forces were being reinforced, a postponement of a few days at this moment would give the enemy time to reinforce its forces and eventually result in a delay of ten to twenty days; that by omitting [the operation against] Banjarmasin, Japan would also give up a perfect strategic point for the air operations against Java, which meant that sufficient results could not be expected unless reinforcements were to be provided by the aircraft carriers; that, for these reasons, the invasion operations had to be carried out as stipulated in the Cam Ranh Agreement at any cost. With neither side giving in, the conference continued well into the dead of the night and was then suspended for the time being.

The next day the $22 \mathrm{~d}$ started early in the morning with the conference on Operation L between the staff of the First Southern Expeditionary Fleet and the staff of the Southern Army. The Navy side proposed a two-week postponement, as previously mentioned. ${ }^{(34)}$ The Southern Army fiercely objected to a postponement of the dates, arguing that: ${ }^{(38,98)}$

1. If the Ledo airfield cannot be made ready in time, [the Navy] shall use the bases on the Malay Peninsula, because [the Army] has previously said that [the Navy] could make use of them. The airfields in the southern part of the Malay Peninsula will [soon] be seized by the ground units and made available by the time of Operation L.

2. We will see to it that the Ledo airfield shall be seized as soon as possible and we will have the Kawaguchi Detachment fully cooperate in the transportation of fuel and the preparation of the base, so as to have the airfield as ready as possible for Operation L.

These differences between the Army and the Navy stemmed from a fundamental difference in their way of thinking. That is to say, the Army thought it best to rush and seize strategic points of the enemy with the idea of a pursuit battle and without giving the latter time to put up a defense. The Navy on the other hand took the view that the invasion of strategic points should throughout adopt a standard method of attack, in which, prior to the launch of the invasion operation, preliminary air campaigns to destroy the enemy air power at air bases in the rear as well as at the invasion points should be carried out and once the air power of the enemy was neutralized, the invasion units should be pushed forward. If not, there would only be a useless increase in losses.

The Southern Army considered that some concession to the Third Fleet's request for a postponement was unavoidable, but it was absolutely against a postponement of Operation L by the First Southern Expeditionary Fleet. However, the Sixteenth Army, the Army unit that was to carry out the invasion operation, expressed approval of the Navy, taking the view that if there was no absolute certainty about the escort, the [invasion] date should be postponed. ${ }^{(34)}$ Neither the Southern Army on the Army side nor the Third Fleet and the First Southern Expeditionary Fleet on the Navy side would budge until finally Capt. Yanagisawa 
Kuranosuke, senior staff officer of the Second Fleet, proposed a compromise that at last managed to bring them together. The contents of the proposal were [in outline] as follows: ${ }^{(34)}$

1. Operation $L$ shall be postponed for four days from the date stipulated in the Cam Ranh Agreement, till Day X + 64 (10 February).

2. [The operation against] Makassar shall be postponed for four days from the date stipulated in the Cam Ranh Agreement till Day X + 63 (9 February), and [that against] Kupang for nine days till Day X + 74 (20 February).

3. After the capture of Makassar in the east and Palembang in the west on 9 and 10 February, air units shall be pushed forward there so as to substantially complete the air campaigns to destroy the enemy air power by and large by 20 February. The landing on western Java shall be carried out on Day X + 75 (21 February) and that on eastern Java on Day X + 77 (23 February).

4. While Banjarmasin shall be seized overland single-handedly by the Sakaguchi Detachment, the Navy shall as far as is practical provide forces to help with the maneuvering of craft along the coast and other operations.

5. Bali shall be captured around Day X +75 (21 February), and the Navy air units shall be pushed forward there so as to use it as an air operation base at the time of the landing [operation] on eastern Java.

In accordance with the [principles of] the draft agreement above, a draft arrangement for the Java invasion was concluded between the Third Fleet, the Eleventh Air Fleet, the Sixteenth Army and the [Army] Third Air Force on the 23d. It was agreed to arrange it in such a way that after this draft arrangement had been brought back to each headquarters by its staff officers, the Second Fleet would first send a consultative telegram to the Southern Army while also informing the Combined Fleet and central command in order to make sure of their intentions, and that the agreement would formally come into effect after the reception of a telegram of approval from the Southern Army. On the next day, the 24th, all staff officers left Manila for their respective headquarters. ${ }^{(34)}$

Then, on the 25th, in accordance with the arrangement of staff officers at Manila, Second Fleet Commander in Chief Vice Admiral Kondō sent Southern Army Commander in Chief General Terauchi the following consultative telegram: ${ }^{(62)}$

\section{Second Fleet Classified Telegram No. 750, 2100, 25 January}

We would like to make the following additions and revisions to the agreement of 1 January, 1942, between the commander in chief of the Southern Army and the commander in chief of the Navy in the South, and [would like to] discuss these [with you].

1. Standard dates [to implement operations] of capturing (areas to be seized, the dates to start landing [operations])

(a) Makassar, around Day X + 63; (b) Bangka and Palembang, around Day X + 64; (c) Kupang, around Day X + 74; (d) Western Java, around Day X + 75; (e) Eastern Java, around Day X + 77

2. The seizure of Banjarmasin shall be conducted overland from Balikpapan as quickly as possible. However, depending upon the circumstances, the operation may be launched after consultations between the commander of the Sixteenth Army and the commander in chief of the Third Fleet.

3. The air base on Bali shall be seized in conjunction by the Army and the Navy around Day X+ 75 , so that [it can be used] as an air base at the time of [the operations to] capture eastern Java. The details of the implementation of the above operation shall be arranged between the commander of the Sixteenth Army, [the commander in chief of the Third Fleet], the commander of the Third Air Force and the commander in chief of the Eleventh Air Fleet. 
4. The commander of the Third Air Force and the commander in chief of the Eleventh Air Fleet shall be included in the [number of] commanders with whom the arrangements for the operations to capture Java shall be made.

Looking at this consultative telegram and finding the word "around" before every invasion date, the discussion became heated again at the Southern Army headquarters. ${ }^{(34)}$ It was settled by agreeing that regardless of the word "around," [both sides] should do their very best and commit themselves to execute [the invasion operation] in accordance with this invasion schedule as the standard schedule. In the meantime, since the high command of the Army had not yet been informed of the plan to capture Banjarmasin overland, a telegram had come inquiring whether it was [still possible to capture the town] by means of [advancing] overland or by maneuvering craft along the coast, while advising that it would be better to seize the town in order to make sure of [the success of] the subsequent operations even if it was not in time for the capture of Java. ${ }^{(99)}$ Then on the 28th, the high command of the Army, finally coming to understand that the Southern Army had a plan to capture the town overland in early February, approved the draft, and the draft arrangement made at Manila was formally concluded on 28 January.* The arrangement was called the Manila Agreement. ${ }^{(65)}$

\section{Issue of the Order to Commit the Main Force of the Carrier Task Force to the Southern Theater}

In late December, when the Carrier Task Force returned to mainland Japan from the air strike on Hawaii, it was decided that for the subsequent operations the main force, that is, the 1st and the 5th Carrier Divisions, should support the operation to capture Rabaul, and that the $2 \mathrm{~d}$ Carrier Division should be committed to the southern operation. Due to a lack of [relevant] materials, the detailed plans at that time of how these forces should subsequently be employed are unclear, but by putting all [available] documents together, various patterns of employment as shown below seem to have been considered by central command:

1. To commit one element of the Carrier Task Force to the [southern] theater at the time of the invasion of Java by the Southern Task Force, and have it act in concert with the invasion operation.

2. To carry out offensive operations with the Carrier Task Force to cut off Australia from the United States in tandem with the invasion of Java.

3. To have the 1st and the 5th Carrier Divisions advance [off] the east coast of Australia in early February after the operation to capture Rabaul, and carry out attacks in that area, after which they shall prepare against [an attack from] the east.

The $2 \mathrm{~d}$ Carrier Division shall be engaged in the southern operation. ${ }^{(40)}$

In the end, the third plan was adopted as [operational] policy. However, on 24 January a detailed report from Submarine I-8 on the sinking of the USS Lexington (on 12 January) came in, and its instant sinking was regarded as certain. ${ }^{* *}$ This led the Combined Fleet to conclude that it no longer needed to worry about [an attack from] the east, and that it would be more

* A more extensive version of the proceedings at Manila may be found in Vol. 3, pp. 209-22.

** The torpedo attack and the report were in fact made by $I-6$ (Vol. 98, pp. 112, 118). The target was actually the Lexington-class USS Saratoga, who was severely damaged and had to be withdrawn for repairs (https://en. wikipedia.org/wiki/USS Saratoga_(CV-3)). 
effective to employ the main strength of the Carrier Task Force in the south at the time of Java invasion operation. So, on 31 January, by means of telegraphic order No. 54, it ordered the incorporation of the Carrier Task Force into the Southern Task Force. ${ }^{(100)}$

However, on the next day, 1 February, a U.S. Task Force conducted a raid on the Marshall Islands. The main force of the Carrier Task Force, which just at that time had returned to Truk after completing the Rabaul operation, headed for the Marshall Islands to attack them. At 1100 on 1 February, Combined Fleet Commander in Chief Admiral Yamamoto issued an order that the time of incorporation of the Carrier Task Force into the Southern Task Force in accordance with telegraphic operation order No. 54 would be given later. However, with no [updated] infor-

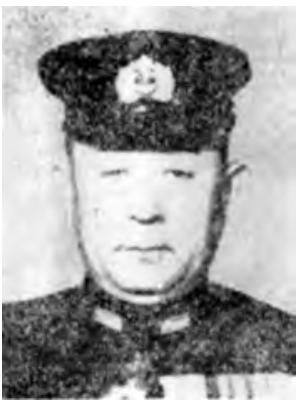

2d Carrier Division Commander R. Adm. Yamaguchi Tamon mation about the movements of the enemy in the Marshall [Islands] after that, he issued an order to the Carrier Task Force late at night on 2 February to cancel the advance to the Marshall Islands and prepare for joining the Southern Task Force. However, it was decided that the 5th Carrier Division and three destroyers [of the Carrier Task Force] should return to the mainland for training and guarding against [possible attacks by] U.S. Task Forces. By this order, the main force of the Carrier Task Force ([consisting of] the 1st Carrier Division as the core) sailed straight from the Marshall Islands to Palau. At 0000 on 8 February, the Combined Fleet formally issued an order to incorporate the Carrier Task Force (minus the 5th Carrier Division and three destroyers) into the Southern Task Force. ${ }^{(100)}$

Prior to this, the 2d Carrier Division, which had been incorporated into the Southern Task Force on 7 January, carried out an air raid on Ambon (which will be described later) in concert with the Kendari operation on 24 January, and achieved considerable success. As a result of this [raid], 2d Carrier Division Commander R. Adm. Yamaguchi Tamon proposed to the Second Fleet and the Combined Fleet a plan to attack Port Darwin with the 2d Carrier Division, stating that, rather than attacking the important invasion points prior to the invasions, the best employment of the aircraft carrier unit in support of the southern operation would be to attack Port Darwin, the point where the enemy concentrated its reinforcements, and that this operation [to attack Port Darwin] would be highly promising, judging from the current situation. ${ }^{(101)}$

Incorporating 2d Carrier Division Commander Rear Admiral Yamaguchi's plan for an air strike on Port Darwin as well, Southern Task Force Commander Vice Admiral Kondō issued on 9 February by Telegraphic Order No. 92 orders for the Carrier Task Force's mobile operation I (air strikes on Port Darwin) and mobile operation II (mobile operations to the south of Java), as well as orders for the operations of the submarine units (the details of which will be described later [p. 331]). ${ }^{(53)}$

\section{The Operational Policy of Phase-Three Operations of the Southern Task Force}

Around 30 January, when it was informally decided to commit the Carrier Task Force to the southern theater, the Southern Task Force's phase-three operations in the Dutch East Indies theater were guided by the following operational policy: ${ }^{(53)}$

1. In late February, the Java invasion operation shall be carried out to completely destroy the last bases of the allied forces in the southern theater. 
2. In early February, the air campaign to destroy the enemy air power in eastern Java shall be launched with the air units from Balikpapan and Kendari.

3. In the western [part] of the Dutch East Indies, Bangka and Palembang shall be captured by the [Navy] Malaya Unit and the Sixteenth Army around 10 February; the Air Unit of the Malaya Unit shall swiftly be deployed at the [earliest] possible opportunity in western Borneo, southern Malaya and the Palembang area to launch its air campaign to destroy the enemy air power in western Java in tandem with the Army air units.

4. Makassar shall be captured by the Dutch East Indies Unit around 9 February; air units shall be advanced there in order to intensify the air operation against Java.

5. Ambon shall be captured on 31 January and Timor around 20 February by the Dutch East Indies Unit and one element of the Sixteenth Army; air units shall be advanced there in order to cut off the enemy route of supply and reinforcements from Australia to Java as well as to launch air strikes on northern Australia.

6. Almost simultaneously with the capture of Timor by the Dutch East Indies Unit, a surprise attack on Port Darwin shall be conducted with the newly to be deployed main force of the Carrier Task Force. The land-based air units shall also carry out simultaneous attacks.

7. Around 20 February, Bali shall be captured by the Dutch East Indies Unit in order to push forward there one element of the Air Unit.

8. From 21 to 23 February, the main force of the Dutch East Indies Unit shall escort the main force of the Sixteenth Army and put them ashore on both eastern and western Java.

9. In concert with the landing [operation] against Java, the main body of the Carrier Task Force, the main body of the Southern Task Force and the [later] to be added Submarine Unit C (2d Submarine Squadron) shall advance to the waters south of Java and carry out the operation to cut off the escape routes of the enemy, etc. The Air Unit shall act in concert with this operation.

10. Submarine Unit A (the 4th and the 6th Submarine Squadrons) shall act in concert with the Java invasion operation, watch and patrol the southern coast of Java, Port Darwin, the Torres Strait, etc.

\section{The Capture of Ambon (See Illustrations No. 20 and No. 21)}

\section{Plan of Operations, etc.}

[The operation to] capture Ambon was carried out by the Eastern Attack Unit with the support of the Air Unit of the Southern Task Force; this time, 2d Escort Unit Commander and 2d Destroyer Squadron Commander Rear Admiral Tanaka directly took command of the capture [operation]. The main force of the escorting force, i.e. the 15th and the 16th Destroyer Divisions and the 21st Minesweeper Division, which had been put in the 1st Base Unit in [the previous operation to] seize Kendari, were this time incorporated in the $2 \mathrm{~d}$ Escort Unit. In the meantime, the 1st Base Unit was assigned to the defense of the Bangka anchorage and the protection of the sea lanes, while preparing for the coming operation against Makassar. ${ }^{(78)}$ The following units were supposed to cooperate with the Eastern Attack Unit: ${ }^{(78)}$

1. Army unit: the Itō Detachment (Commander: 38th Infantry Group Commander Maj. Gen. Itō Takeo)

Strength: three infantry battalions, one mountain gun battalion, one antitank gun battery and one field antiaircraft artillery battery, one engineer company, and one independent engineer company as the core ([with] about 5,300 men, 110 automobiles, etc.)

2. Land-based air unit: the 1st Air Raid Unit of the Southern Task Force's Air Unit ([consisting of] the 21st Air Flotilla and the $3 \mathrm{~d}$ Air Group as the core) 
3. Carrier-based air unit: the unit consisting of the $2 \mathrm{~d}$ Carrier Division, which had been incorporated into the Air Unit of the Southern Task Force, as the core ([i.e.] The 2d Carrier Division, the Maya, the 7th Destroyer Division, the 2d Section of the 27th Destroyer Division)

\section{The Arrangement Between the 2d Escort Unit and the Itō Detachment}

On 18 January, escorted by the 8th Destroyer Division, the Itō Detachment had advanced from Hong Kong to Davao, where it made a [draft] arrangement on [the operation to] capture Ambon with 2d Escort Unit Commander Rear Admiral Tanaka on the 20th, and signed the arrangement on the next day the 21st. The outline of the arrangement was as follows. ${ }^{(54)}$ Due to the delay in the shift from the Philippines operation to the Dutch East Indies operation, the search for enemy submarines in the Molucca Sea and the diversion of forces from Kendari, the schedule for [the operation to] capture Ambon had been changed again and again (25th $\rightarrow$ 26th $\rightarrow$ 29th). On the 19th, the day of signing of the arrangement, it was set on 31 January.*

1. Disposition of forces at the time of landing (as shown in the table below)

\begin{tabular}{|c|c|c|}
\hline Distribution of Units & Main force of the Army Itō Det & $\begin{array}{l}\text { The Navy 1st Kure SLF and the } \\
\text { Army Wakabayashi Com }\end{array}$ \\
\hline $\begin{array}{l}\text { Time [to start] drifting near } \\
\text { the anchorage }\end{array}$ & 0100, 31 January & 0000, 31 January \\
\hline $\begin{array}{l}\text { Time to launch the landings } \\
\text { (time to leave the [mother] ships) }\end{array}$ & 0400, ditto & 0300, ditto \\
\hline Landing points & Coast east of Rutung & Coast west of Hitulama \\
\hline Disembarkation operations & \multicolumn{2}{|c|}{$\begin{array}{l}\text { First of all, the matériel and personnel required to carry out the immedi- } \\
\text { ate combat shall be disembarked; the rest shall be disembarked at Ambon } \\
\text { Bay. }\end{array}$} \\
\hline
\end{tabular}

(1) The Army Itō Detachment and the Navy 1st Kure Special Landing Force shall act in conjunction with each other.

(2) One company led by 1st Lt. Wakabayashi Tōichi shall be dispatched from the Itō Detachment to the 1st Kure Special Landing Force, and brought under the command of the latter.

2. Landing combat and cover for the landing [operation]

(1) Although [the unit] is primarily supposed to make a surprise landing, [it shall] determinedly carry out an assault landing if the situation is unavoidable.

(2) Covering fire for the landing operations shall be provided at the request of Detachment Commander Itō.

(3) If requested by the Army, the naval vessels near the anchorages of the [Army] transport ships shall provide temporary repairs for [Army] craft, when the war situation permits.

3. The movement of the transport ships after the landing (omitted by the author)

4. Others (omitted by the author)

* There seems to be some confusion about when the agreement was signed and when the date of the Ambon invasion was decided. See also Vol. 3, pp. 362 and 366. 


\section{The Plan of Operations of the 2d Escort Unit}

On 25 January at Davao, 2d Escort Unit Commander Rear Admiral Tanaka issued an order concerning the main points of [the operation to] capture Ambon by 2d Escort Unit Order No. $4 . .^{(54)}$

1. Distribution of the transport ships

1st Echelon: Yamaura-maru, Africa-maru, Zen'yō-maru, Miike-maru (all with the Army Itō Detachment on board)

2d Echelon: Kirishima-maru (1st Kure SLF), Yamafuku-maru (3d Construction Squad), Yamagirimaru (3d Construction Squad), Lyons-maru, Hino-maru No. 5, Katsuragi-maru (the last three belonging to the Eleventh Air Fleet)

Out of the line: Ryōyo-maru (will leave port along with the 1st Echelon)

2. Disposition of forces (as in the table below)

\begin{tabular}{|c|c|c|c|c|}
\hline Unit & & Commander & Forces & Outline of the tasks \\
\hline Main Body & \multirow{4}{*}{ 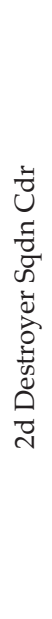 } & & $\begin{array}{l}\text { Jints } \bar{u}, 1 \text { st Section of the } \\
\text { 16th Destroyer Div }\end{array}$ & $\begin{array}{l}\text { [In charge of] the entire } \\
\text { [operation] }\end{array}$ \\
\hline Covering Unit & & 15th Destroyer Div Cdr & 15th Destroyer Div & $\begin{array}{l}\text { To watch and guard the } \\
\text { entrance of the bay and to } \\
\text { cover both detachments }\end{array}$ \\
\hline 1st Detachment & & 8th Destroyer Div Cdr & $\begin{array}{l}\text { 8th Destroyer Div, 1st } \\
\text { Subchaser Div (minus } 3 \\
\text { submarine chasers), 21st } \\
\text { Minesweeper Div (minus } \\
\text { Minesweepers Nos. } 9 \text { and } \\
\text { 11) }\end{array}$ & $\begin{array}{l}\text { To escort 1st Echelon and } \\
\text { cover its disembarkation }\end{array}$ \\
\hline 2d Detachment & & Capt of the Amatsukaze & $\begin{array}{l}\text { 2d Section of the 16th De- } \\
\text { stroyer Div, Minesweep- } \\
\text { ers Nos. } 9 \text { and } 11\end{array}$ & $\begin{array}{l}\text { To escort } 2 \mathrm{~d} \text { Echelon and } \\
\text { cover its disembarkation }\end{array}$ \\
\hline
\end{tabular}

(1) This disposition of forces shall take effect from 0000 on 26 January onwards.

(2) Incorporation of units currently engaged in other operations in progress shall be ordered by separate orders.

(3) The 1st Kure Special Landing Force (minus one element) shall be assigned to landing operation in conjunction with the Army units.

3. Tasks and operations of each unit

(1) The main body (the Jintsu and the 1st Section of the 16th Destroyer Division) The Jintsu shall leave Davao at 1300 on 26 January, and sail to the Bangka anchorage. Then she shall generally operate near the $2 \mathrm{~d}$ Detachment. After the arrival of all units in Ambon, she shall timely operate around the Ceram Sea and the Molucca Sea. The 1st Section of the 16th Destroyer Division shall operate along with the $2 \mathrm{~d}$ Detachment until ordered otherwise by separate orders.

(2) The covering unit (The 15th Destroyer Division)

On the morning of 30 January, it shall join the 1st Detachment on the waters northeast of Buru ([by] sailing straight from Kendari), take charge of the direct cover of the detachment until 1800 on that day. After that, it shall be assigned to watch the entrance of Ambon Bay 
while directly supporting the minesweeping inside the bay, as designated by the commander.

(3) The 1st Detachment (The 8th Destroyer Division, the 1st Subchaser Division, and the main force of the 21st Minesweeper Division)

Escorting the 1st Echelon, it shall leave Davao at 1600 on 27 January, and have the former disembark at Ambon (on the coast east of Rutung). The scheduled time to enter into the anchorage ([staying] adrift) shall be at 0100 on 31 January. Submarine chaser No. 2 shall escort the Ryoyo-maru and catch up with the detachment. The 21st Minesweeper Division (minus Minesweepers Nos. 9 and 11) shall join the detachment on the morning of the 30th (by sailing straight from Kendari).

(4) The 2d Detachment (the 2d Section of the 16th Destroyer Division, and Minesweepers [No. 9] and No. 11)

Escorting the 2d Echelon, it shall leave the Bangka anchorage at 0000 on 29 January, and have the former disembark at Ambon (on the coast west of Hitulama). The scheduled time to enter into the anchorage ([staying] adrift) shall be at 0000 on 31 January. Minesweepers Nos. 9 and 11 shall join the detachment on 30 January (by sailing straight from Kendari).

4. Outline of the escort

(1) Sailing speed: 10 knots at normal speed; 11 knots at fast speed

(2) Sailing route and sailing formation (omitted by the author)

5. Outline of the entry into the anchorages (omitted by the author)

6. Outline of the guarding after shifting to the anchorage inside Ambon Bay (omitted by the author)

7. Main points of the plan

(1) The landing operation is meant to be carried out after the 1st Air Raid Unit has thoroughly neutralized the enemy air power in Ambon and vicinity.

(2) Since the enemy's defense of the front of Ambon Bay is extremely strong and the entire area has practically been turned into a stronghold, the landing points are set at Rutung and Hitulama in order to seize the area from the rear.

(3) In view of the situation at the time of the capture of Tarakan, minesweeping inside the bay shall not be launched until the batteries at the entrance of the bay surrender. Disembarkation shall proceed at the landing points as much as possible until it becomes feasible to [safely] anchor inside the bay.

(4) When it is not necessary to worry about counterattacks by enemy surface vessels, the main body shall hide its whereabouts as much as possible from enemy aircraft.

(5) Due to [the schedule of] the units diverting from the Menado and Kendari operations (i.e. the 15th and the 16th Destroyer Divisions and the 21st Minesweeper Division), the operational preparations of the 1st Detachment (the Army unit) and the 2d Detachment (the Navy unit) shall be made respectively at Davao and at the Bangka anchorage.

(6) In the event of major counterattacks by enemy aircraft, the transport ships shall be evacuated to the Bangka anchorage after having disembarked the minimum [amount of men and matériel] required.

\section{The Plan of Operations of the Itō Detachment ${ }^{(102)}$}

1. Operational policy

[The unit] shall land in Rutung, swiftly cut through the mountains and charge into the urban area of Ambon from the east. Then it shall seize the battery on the southwestern peninsula.

2. Disposition of forces

(1) Left Attack Unit (the main force of the 228th Infantry Regiment) 
After the landing in Rutung, [the unit shall] split into two units; the main force shall head straight for Ambon through the mountains from Rutung, while the detached force shall head for Ambon along the southern road through Hatalai.

(2) Right Attack Unit (the 2d Battalion of the 228th Infantry Regiment)

[The unit shall] advance eastward from Rutung along the coastal road to Paso and seize such strategic points as Paso and Halong.

(3) The Wakabayashi Company

[The company shall] come under the command of the 1st Kure Special Landing Force and land in Hitulama along with that force.

\section{The Plan of Operations of the 1st Kure Special Landing Force}

On 28 January at the Bangka anchorage, the 1st Kure Special Landing Force announced the outline of the operation to capture Ambon by Operation Order No. 10. ${ }^{(103)}$ Now, Cdr. Fujimura Masasuke, the commander of the 1st Kure Special Landing Force, had fallen ill after the capture of Legaspi (the Philippines) and Cdr. Hayashi Shōjirō had been ordered to replace him as of 21 January, but Commander Hayashi could not be in time to assume his new post, so until that time it fell to senior officer Lt. Hatakeyama Kunito as acting commander to draw up the plan.

\section{Operational Policy}

Before daybreak on 31 January, [the force shall] determinedly carry out the landing at the coast of Hitulama and swiftly seize the Laha airfield as well as the Alang battery.

2. Disposition [of forces] at the time of landing

(1) First Landing Unit ([at] the coast of Hitulama)

First landing: Special Landing Force headquarters, 2d Company, one element of the artillery unit and the main force of the attached units

Second landing: The [Army] Wakabayashi Company, the main force of the artillery unit, the paymaster unit, ammunition and provisions

Third landing: ammunition, provisions, base construction matériel, and supplies for the Wakabayashi Company

(2) Second Landing Unit ([at] the coast of Hitulama) and the Third Landing Unit ([at] the coast of Laha)

Base construction personnel and matériel; depending on the situation, the landing of the second landing unit shall be called off and immediately [combined] with the landing of the third landing unit.

3. Operations after landing (omitted by the author)

4. The forces under the command of the 1st Kure Special Landing Force (750 men in total; components omitted by the author)

In order to make up for the understaffing at the 1st Kure Special Landing Force caused by the absence of its commander, Dutch East Indies Unit Commander Vice Admiral Takahashi ordered that R. Adm. Hatakeyama Kōichirō, prospective commander of the 24th Special Base Unit, which was due to be set up at Ambon after the capture of the island, should take command of the 1st Kure Special Landing Force after its landing. Also, Cdr. Ieki Kōnosuke, prospective senior staff officer, and two other officers were assigned for the staff work. ${ }^{(103)}$ 


\section{The Plan of Operations of the 2d Air Unit}

Also accepting the opinion offered by 11th Seaplane Tender Division Commander R. Adm. Fujita Ruitarō (that the Ambon operation should be carried out with the whole force), 5th Cruiser Division Commander Rear Admiral Takagi decided on 26 January to have the full strength of the $2 \mathrm{~d}$ Air Unit participate in the operation to capture Ambon; he issued orders that the Mizuho, and Patrol Boats Nos. 34 and 39 should leave Kendari on the 29th in order to participate in the Ambon operation straight [from there]. ${ }^{(53)}$ The flagship Chitose, which was scheduled to participate in the invasion of Ambon from the start [of the planning], left Salabangka Channel on the 26th, arrived at the Bangka anchorage at 1500 on the 27th, where 2d Air Unit Commander Rear Admiral Fujita met with 2d Escort Unit Commander Rear Admiral Tanaka to discuss the Ambon operation. As a result [of this meeting], it was decided that in [the operation to] capture Ambon, the $2 \mathrm{~d}$ Air Unit should carry out such tasks as patrolling the route ahead of the convoy, providing direct escort against [enemy] aircraft and submarines, providing direct protection around the anchorages as well as protecting the unit itself against enemy aircraft and submarines, and searching for the enemy in the Banda Sea. ${ }^{(54)}$

\section{The Plan of Operations of the Air Unit of the Southern Task Force}

\section{1st Air Raid Unit}

It was decided that the 1st Air Raid Unit should provide guard for the invasion unit against enemy aircraft and reconnoiter the landing points, as well as such tasks as destroying enemy naval vessels and air power, searching for the enemy and patrolling [against them], and supporting the ground combat. ${ }^{(53)}$

2. Carrier-based Air Unit

In order to destroy the enemy surface and air power in Ambon in concert with the [operation to] seize Kendari on 24 January, the carrier-based air unit ([consisting of] the 2d Carrier Division as the core) was scheduled to leave Palau on the $22 \mathrm{~d}$ of January to carry out air strikes on Ambon on the $23 \mathrm{~d} .{ }^{(71)}$

\section{The Launch of the Operation}

\section{Signs of the Enemy Hardly Seen}

As previously told [p. 117], 1st Air Raid Unit Commander Rear Admiral Tada carried out a (night) attack on the Ambon [airfield] for the first time on 7 January with the forces of the Kanoya Air Group Detachment and the Tōkō Air Group. After that, he gradually intensified the attacks and reconnaissance in the following way: ${ }^{(71)}$

14 January: One land-based reconnaissance plane of the 3d Air Group conducted a reconnaissance on Ambon from Menado.

15 January: Twenty-six land-based attack planes of the Kanoya Air Group Detachment and eighteen Type-0 fighter planes and one land-based reconnaissance plane of the $3 \mathrm{~d}$ Air Group carried out an attack on Ambon (the former from the Davao base and the latter from Menado) and reported a military gain of destroying seven enemy aircraft.

16 January: Sixteen land-based attack planes of the Kanoya Air Group Detachment, four Type0 fighter planes and one reconnaissance plane of the $3 \mathrm{~d}$ Air Group, and one large flying boat of the Tōkō Air Group carried out an attack on Ambon.

18 January: One land-based reconnaissance plane of the 3d Air Group reconnoitered Ambon. 
19 January: Four large flying boats of the Tōkō Air Group reconnoitered the area of Ambon.

21 January: Three Type- 0 fighter planes and two land-based reconnaissance planes of the $3 \mathrm{~d}$ Air Group attacked and reconnoitered Ambon, while conducting a photoreconnaissance of the landing points.

On 22 January, 1st Air Raid Unit Commander Rear Admiral Tada sent Rear Admiral Yamaguchi, commander of the $2 \mathrm{~d}$ Carrier Division (carrier-based air unit) the following telegram concerning the situation of Ambon. ${ }^{(53)}$

The situation of Ambon is as follows:

1. In January, our unit has carried out attacks and reconnaissance (at night) on the 7th as well as (in the daytime) on the 14th, the 15th, the 16th, the 18th, and the 21st. After it destroyed seven aircraft in total (all aircraft [spotted there]) on the 15th and the 16th, no enemy aircraft has been seen since then. However, [this is to be expected because] the military airfield located at Laha [on Ambon] seems to have been used only occasionally as a staging base.

2. Although several fast enemy naval ships and merchantmen were seen at anchor [at Ambon] until around the 16th, no enemy vessels have been spotted recently.

Yesterday, the 21st, two mid-sized [enemy] merchantmen entered the port.

3. Apart from the military airfield and the flying boat base, another airfield is under construction at the eastern point of Ambon Island, but it is not yet fit for use.

4. In view of [our] use [of the existing facilities] after the capture of Ambon, we consider it better to choose the following attack targets in case no enemy naval vessels or aircraft are spotted:

(a) The batteries on both sides of the entrance of Ambon Bay in the west

(b) The battery southwest of the city of Ambon

5. For reference:

(a) The enemy air force has its main bases on Timor and Java, and uses Ambon, Kendari, and Banjarmasin as advance bases, but it lacks fighting spirit.

(b) U.S. naval vessels sometimes appear in the Banda Sea; at present the USS Houston is in Darwin.

(c) There are oil fields as well as large-scale port facilities in Bula at the east point of Ceram; it is better to seize and make use of them. There is no airfield on Groot-Banda (note by the author: an islet located about sixty nautical miles south of Ceram).

(d) [We have] roughly bombed and destroyed [enemy facilities in] Sorong and Babo (in western New Guinea) and Ternate (note by the author: on Halmahera Island). [The enemy has] formerly made counterattacks in these areas, but we have met with no counterattacks these days.

Today, the $22 \mathrm{~d}$, the search for the enemy in these areas was carried out by one large flying boat.

On 23 January, under the command of Lt. Cdr. Kusumi Masashi, the Hiryū Air Unit commander, the carrier-based air unit headed for Ambon for an attack with nine Type-0 fighter planes, nine Type-99 carrier-based bombers and nine Type-97 carrier-based attack planes of the Hiry $\bar{u}$ and nine Type-0 fighter planes, nine Type-99 carrier-based bombers and nine Type97 carrier-based attack planes of the Sōryū, fifty-four planes in total. However, due to bad weather, the unit was unable to carry out the attack and changed its target to Ternate, where it found no suitable targets. The unit ended up cancelling the attack and all aircraft returned safely. ${ }^{(71)}$ On the next day the 24th, the unit [again] reached the sky above Ambon with the same strength. But having spotted no enemy naval vessels or aircraft, the unit bombed the 
barracks and the battery southwest of the city [instead], and all returned safely, [after which] the carrier-based air unit headed back to Davao ${ }^{(71)}$ (arriving in Davao on the 25th). Furthermore on 27 January, in accordance with the Air Unit's Telegraphic Operation Order No. 36, eighteen Type- 0 fighter planes and nine carrier-based bombers of the carrier-based unit were advanced to Kendari from Davao [in Vol. 3, the date and number of planes differs] and put under the command of 1st Air Raid Unit Commander Rear Admiral Tada, in order to take charge of destroying the enemy naval vessels and air power until the completion of the Ambon operation. ${ }^{(81)}$

\section{The Enemy Movements in the Ambon Area at the Time of the Launch of the Invasion Operation}

As of 28 and 29 January, the intelligence that the unit to capture Ambon had obtained on the enemy movements was by and large as follows:

1. The situation of [enemy] air units ${ }^{(54)}$

(1) Because Kendari has fallen into Japanese hands, which brought Timor as well as Ambon within the action range of Type-0 fighter planes, large-scale enemy counterattacks are not expected, [although there may be] counterattacks by a small number of mid- and small-sized aircraft using [airfields in] western New Guinea as their staging base, or from Port Darwin by a few large aircraft or flying boats.

(2) However, there are still traces of use at the Ambon airfield even now; [the airfield] seems to be still in use as a staging base from the Port Darwin area. Also, Namlea on Buru (west of Ceram) is being used as an air base; we must be on alert against other hidden enemy bases as well.

2. The movements of [enemy] surface units ${ }^{(54)}$

(1) Although the enemy surface forces seem to have evacuated to the areas south of Timor and west of Makassar, it is likely that they will make a surprise counterattack.

(2) While it seems that enemy submarines have [mainly] been deployed in the area south of the Molucca Sea, some of them are also active near the Bangka anchorage.

(3) Although it seems that the U.S. and Dutch naval units are by and large stationed at Port Darwin and Surabaya, one element of them appears in the Banda Sea at times.

3. The situation on Ambon and the surrounding waters ${ }^{(103)}$

(1) As the central military and economic base of the eastern part of the Dutch East Indies, Ambon has recently been provided with strong defenses; it seems that almost the entire island has been fortified.

(2) Although the strength of the Dutch East Indies garrison stationed in Ambon is said to have consisted of about 1,000 men, it seems to have been reinforced with about 2,000 men of the Australian army.

(3) Reconnaissance by our naval air units from the end of December [1941] onwards has delivered the following [picture]:

$\{1\}$ From the end of December onwards, [enemy] naval vessels have frequently sailed in and out of Ambon; they seem to have been assigned [the task] of troop reinforcements as well as the transport of evacuees.

$\{2\}$ Mines seem to have been laid over strategic areas such as the entrance of Ambon Bay as well as Baguala Bay; before 16 January, several minelayers as well as light and fast ships were seen at anchor. 
\{3\} Antisurface vessel [coastal] batteries seem to be located both at the south and the north entrance of Ambon Bay, and it is certain that the Halong seaplane base as well as the Laha airfield have antiaircraft battery positions.

(4) Putting all the above together, it seems that for Ambon the Ambon Bay area serves as its front defense and the Baguala Bay as its rear defense, while there are strong defensive positions around the city of Ambon as well on the western part of the Laha airfield.

\section{The Sailing of the Invasion Convoy}

At 1530 on 27 January, the 1st Echelon left Davao and started sailing southward toward Ambon. At 0200 on 28 January, the Asashio and Submarine chaser No. 1 left the Bangka anchorage in order to join the 1st Echelon; they joined it around 1400. In the meantime, the 1st Section of the 15th Destroyer Division and the 21st Minesweeper Division, which were at Kendari, discontinued the Kendari operation and left Kendari at 0700 on the 28th for the Ceram Sea to join the $2 \mathrm{~d}$ Escort Unit. ${ }^{(54)}$

At 0000 on 29 January, the 16th Destroyer Division and the 2d Echelon left the Bangka anchorage. They met up with the Jintsu around 0915, after which they sailed southward in the Molucca Sea, following the 1st Echelon at a distance of about twenty-five nautical miles. During the sailing, first at 1426 the Arashio, which escorted the 1st Echelon, then at 1623 the Amatsukaze, which escorted the 2d Echelon, and then at 1703 the Hayashio, which guarded the 1st Echelon, detected a little north of the equator enemy submarine(s). Each of them made an attack with antisubmarine depth charges but with unconfirmed results. ${ }^{(54)}$ Although a little choppy, the weather was fine that day. With fighter planes of the 1st Air Raid Unit and seaplanes of the $2 \mathrm{~d}$ Air Unit flying over the convoys the whole day to guard against enemy aircraft and submarines, no enemy aircraft came to attack. ${ }^{(94)}$ In the meantime, the support unit left Davao at 1700 as scheduled and headed for the Bangka anchorage to support the invasion unit. ${ }^{(78)}$ On that day, flying boat[s] of the Tōkō Air Group reconnoitered Ambon and sent the following report: ${ }^{(81)}$

1. One flying boat was moored (in the north corner) inside the inner harbor.

Two reconnaissance seaplanes were taking off from the water, while two twin-engine aircraft were spotted on the airfield.

2. As for the ships at anchor, in addition to two 200t-class ships, there were many small boats. Also, two fast ships were spotted near Cape Nusanive.

3. The defense gunfire near the seaplane base and near the airfield was fierce and relatively accurate.

4. Reconnaissance altitude: $3,000 \mathrm{~m}$

In the early morning on 30 January, the convoy sailed into the Ceram Sea, passing between the Sula Islands and the island of Obi Mayor. At 0715, the 1st Section of the 15th Destroyer Division and the 21st Minesweeper Division, both of which had sailed straight from Kendari, joined the convoy, and sailed southward at seven to ten nautical miles ahead of the latter by way of precaution.

At 0745, one enemy Lockheed bomber was spotted reconnoitering [the convoy], but it soon disappeared into the clouds. It was judged that with this reconnaissance the enemy must have gotten the full picture of the Japanese invasion unit. At 1200, the main body (the Jints $\bar{u}$ and the 1st Section of the 16th Destroyer Division) separated from the $2 \mathrm{~d}$ Detachment 

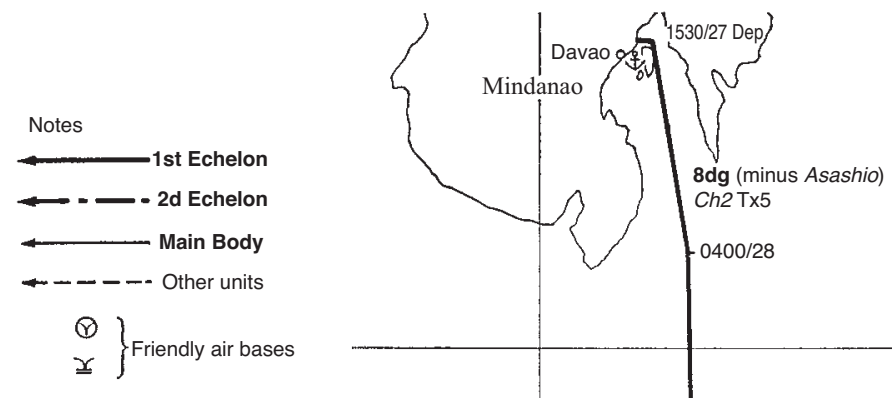

Main enemy air bases

Celebes Sea
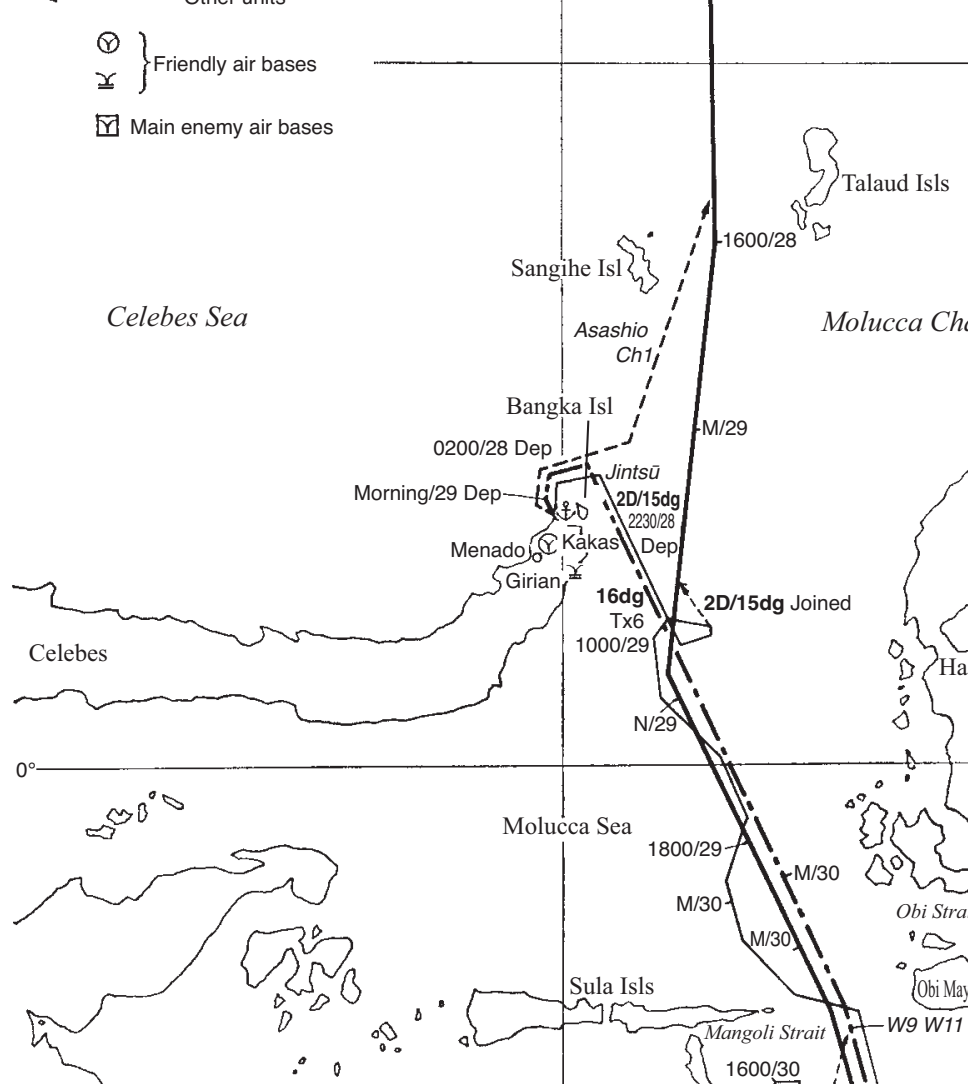

Pacific Ocean $-5^{\circ} \mathrm{N}$

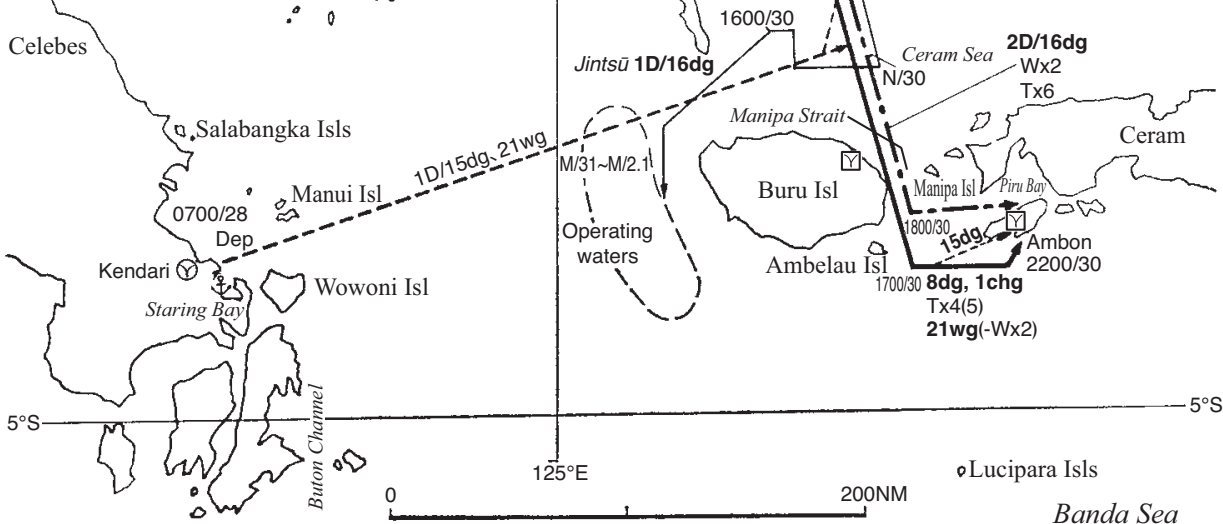

Illustration No. 20 - Outline of the Operations of the Ambon Invasion Units (27-31 January, 1942) 
and sailed westward to be on guard to the west of Buru. At 1320, one Lockheed bomber once again approached the main body and the $2 \mathrm{~d}$ Echelon; three observation planes in the sky attacked it, but it disappeared into the clouds. However, with friendly fighter planes, reconnaissance seaplanes and observation planes providing also on that day guard in the sky above, the escort unit basically did not need to worry about [enemy] air attacks. ${ }^{(70)}$

About sunset on the 30th, the 15th Destroyer Division, which sailed ahead, was approaching a point about twenty nautical miles from the entrance of Ambon Bay, the 1st Echelon a point about forty-five nautical miles from Rutung, and the $2 \mathrm{~d}$ Echelon only thirty-five nautical miles from the Hitulama anchorage. At 1950, the 15th Destroyer Division reached the entrance of Ambon Bay and reported: "The heavy oil tanks near the urban area of Ambon as well as near the Laha airfield are in flames." ${ }^{(94)}$ The weather conditions at that time showed occasional sudden showers with the wind from a $0^{\circ}$ direction and a velocity of 6 meters [per second]. At 2216, the Hino-maru No. 5, the fifth ship of the 2d Echelon was torpedoed by [an] enemy submarine (with three torpedoes that passed by her bow), but she sustained no damage. The Amatsukaze and Minesweeper No. 11 immediately attacked to neutralize the enemy, while Minesweeper No. 9 reversed course to pin down the enemy submarine astern. At 2218, the Amatsukaze spotted a surfaced enemy submarine at a distance of about 6,000 meters and approached it for an attack but lost the opportunity to attack it because it submerged. At 2300, the 2d Echelon entered the Hitulama anchorage about one hour earlier than planned, while at 0020, the 1st Echelon entered the Rutung anchorage forty minutes earlier than planned without encountering the enemy. ${ }^{(54)}$ Meanwhile, 2d Escort Unit Commander Rear Admiral Tanaka, leading the Jintsu $\bar{u}$ and the 1st Section of the 16th Destroyer Division, directed the operation while appropriately operating from a position about ten nautical miles west of Buru. At 1420 on that day, the Support Unit (the 5th Cruiser division and the Ikazuchi) advanced to the Bangka anchorage. ${ }^{(78)}$

\section{The Launch of the Landing Operation and the General Completion of the Capture}

Having entered the Hitulama anchorage at 2300 on the previous night, the $2 \mathrm{~d}$ Echelon immediately launched the landing operations, and at 0100 on 31 January, two hours earlier than planned, its landing craft departed from the anchorage of the convoy. However, because the enemy had placed wooden stakes, barbed wire entanglement and underwater obstacles along the coast and put up stiff resistance from pillbox positions with trench mortars and machineguns, the landing operation got momentarily bogged down. The $2 \mathrm{~d}$ Detachment commander reported the situation in quick succession: "0120: Departed;" “0200: Having difficulty in landing;" "0210: Meeting with resistance." The 1st Kure Special Landing Force forced a landing, eliminating stiff enemy resistance and finally succeeded in landing at 0320, occupying Hitulama, the landing point. ${ }^{(54)}$

In the meantime, the 1st Echelon had entered the anchorage at Rutung, [and its landing craft] departed from the anchorage of the convoy at 0220, about one hour earlier than planned. After [the Army unit] had successfully landed at 0245 without meeting any resistance, Second Escort Unit Commander Rear Admiral Tanaka reported the success of the landings at both Rutung and Hitulama. ${ }^{(54)}$ From about 0700 or 0800 on that day, the weather on Ambon and its surroundings rapidly worsened; it rained torrentially with a west wind blowing as strongly as twenty meters [per second]. The $2 \mathrm{~d}$ Air Unit wired that it would suspend its air campaign until the weather improved. The rainstorm weakened from around 1100 on- 
wards, and by around 1200 it completely cleared up; the 2d Air Unit reported that it would resume its air campaign. Despite the return of the good weather, the enemy fortunately did not carry out any air raids in the afternoon. ${ }^{(54)}$

During that period, whereas the ground operations of the Army went smoothly, the advance of the 1st Kure Special Landing Force seemed to experience extreme difficulties. That is, from 1100 onwards, the headquarters of the 1st Kure Special Landing Force, which had headed for the Laha airfield from Hitulama, lost contact with the force remaining at the Hitulama landing point, leaving the Landing Force totally clueless as to the situation at its front. In the evening, the 15th Destroyer Division in charge of watching the entrance of Ambon Bay reported that the batteries to the southwest of [the city of] Ambon were volleying toward the Laha and Lata areas, so it was assumed that the front of the 1st Kure Special Landing Force had advanced more or less to that neighborhood.

Meanwhile, the Rutung anchorage was calm, with no enemy raids other than that the Asashio, which was guarding the anchorage, detected at 1715 [an] enemy submarine and attacked her, with unconfirmed results. The debarkation of personnel and matériel from the Miike-maru and the other ships at the Rutung anchorage was largely completed by the evening. After that, in order to avoid attacks by enemy submarines, excepting the Miike-maru, the other three ships left the anchorage at 2000 escorted by the 8th Destroyer Division and timely sailed to an area within thirty nautical miles southeast of the anchorage. During that action, at 2035, the Asashio again detected [an] enemy submarine and attacked her almost at the same point as she had done in the evening, [again] with unconfirmed results. At the Hitulama anchorage [the ships] kept drifting there on the alert, but there were no enemy attacks.

Whereas at 2400 the Army unit reported to have charged into Ambon city before sunset, the 1st Kure Special Landing Force remained out of contact with its headquarters until the morning of 1 February. In order to establish contact with the front as well as to supply ammunition and provisions, the commander of the 16th Destroyer Division guarding the Hitulama [anchorage] formed a landing party of one platoon with the approval of $2 \mathrm{~d}$ Escort Unit Commander Rear Admiral Tanaka and dispatched it to the coast of Hitulama at 0700 (it returned to the ship(s) at 1900 on the same day). Right after the dispatch of the landing party, contact with the headquarters of the 1st Kure Special Landing Force was restored, and their situation from the afternoon of the 31st onwards became clear. According to the report, the front line unit had reached Hunut at 1000 and [further] advanced westward along the coast. While from that moment on fierce torrential downpours and bad roads had troubled them, they continued marching on while on the alert. However, because of the rain they actually avoided being spotted from the enemy positions on the opposite shore [of the bay]. The unit passed through Waiame at 1430 without meeting with any resistance and reached Suakodo by 1530 . However, because of the heavy rain the wireless radio set[s] had broken down, and it became impossible to establish contact. Also, the unit following [the front line unit] became unable to move forward due to fierce shelling from the opposite shore [of the bay] at the bridge near Waiame and [also] lost contact with the front line unit. ${ }^{(103)}$ At 1600 on the 31st, the front line unit reached the line of the Weti River and advanced to the attack, intending to break through the enemy position at a stroke with the Wakabayashi Company on the right and the $2 \mathrm{~d}$ Company on the left front. However, fierce enemy counterattacks from positions at the airfield as well as from the batteries near Ambon city on the opposite shore with weapons such as trench mortars and machineguns made it difficult to break through. There- 
fore, at 1850 the unit suspended the attack and momentarily retreated as far as Suakodo to halt there for the night while on the alert and make preparations for the next day. ${ }^{(103)}$

On the morning of 1 February, contact with the friendly units was restored, but as a result of a thorough reconnaissance of the enemy positions, it was judged impossible to carry out a daylight assault with the present strength. So, it was decided to request a bombardment by friendly aircraft on the enemy positions during the day, and [then] break through the enemy positions in a night attack on the 1st. While stationed between Suakodo and the Weti River, the unit made efforts to reconnoiter and learn the movements of the enemy, while trying to make contact with [its fellow units in] the Hitulama area. At 1430 the bulk of the rear unit as well as a considerable amount of ammunition and provisions arrived. For the disposition of forces for the night attack it was decided that the Wakabayashi Company should leave at 2100 and make a detour through the mountains to the north and charge into the enemy [position] from behind from the highland to the north, while the $2 \mathrm{~d}$ Company should launch an attack on the enemy position at 2200. The Wakabayashi Company, which was dispatched to the north at 2100 in accordance with this disposition, was [also] ordered that if the company did not reach the enemy position by midnight, it should make a further detour in a northwestern direction, refrain from making an assault by daylight on the $2 \mathrm{~d}$, and charge into the enemy position exactly at 0300 on the $3 \mathrm{~d}$ of February. ${ }^{(103)}$

The $2 \mathrm{~d}$ Company organized a suicide squad to destroy the barbed wire entanglements [of the enemy positions] under the command of Lieutenant Hatakeyama [Kunito], advanced to the attack at 2200 on the 1st, breached the enemy position north of Tawiri at 0400 on the $2 \mathrm{~d}$, and penetrated into a corner of the position. However, after that, fiercely concentrated enemy fire made it difficult for the company to advance, and the sun rose. The company remained pinned down there until the sunset on the $2 \mathrm{~d}$, unable to move either forward or backward. The rear unit (accompanied by Rear Admiral Hatakeyama [Kōichirō]) also [tried] to advance toward the breach before sunrise in order to cover the $2 \mathrm{~d}$ Company, but fierce [enemy] gunfire totally cut it off from the latter. In the meantime, Rear Admiral Hatakeyama dispatched Commander Ieki and tried to have him inspect the front, but an enemy trench mortar shell killed the commander around 0800. Rear Admiral Hatakeyama, after requesting the air units as well as the $2 \mathrm{~d}$ Escort Unit to bomb and shell the enemy positions to the north of the airfield, decided to suspend the attack at 1200 to rearrange his force. On that day, from around 0800 till around 1630, friendly attack planes and reconnaissance seaplanes continuously bombed the enemy positions, and naval gunfire from the sea was added to it in the afternoon. Although considerable confusion was seen at the enemy positions and white flags were spotted at places on the Laha airfield, the main force of the enemy still had a strong will to fight and kept fiercely firing at the Japanese forces. From the night of the 1st till the morning of the $2 \mathrm{~d}$, the Wakabayashi Company did so far not show up at the rear of the enemy position, and no contact was established with the company either. ${ }^{(103)}$

The rear unit, which had been prevented from advancing, retreated to the neighborhood of Suakodo at 2200 on the night of the $2 \mathrm{~d}$, after sustaining a loss of about twenty men including Commander Ieki killed and about forty men injured. In the meantime, the assault unit, led by Lieutenant Hatakeyama [Kunito], which had penetrated a corner of the enemy position, also succeeded in extricating themselves at 2300. Although having sustained a loss of more than a dozen men killed and about twenty men injured, they managed to join the rear unit, and tried to reorganize. Despite doubts about [the readiness for] an attack on the morn- 


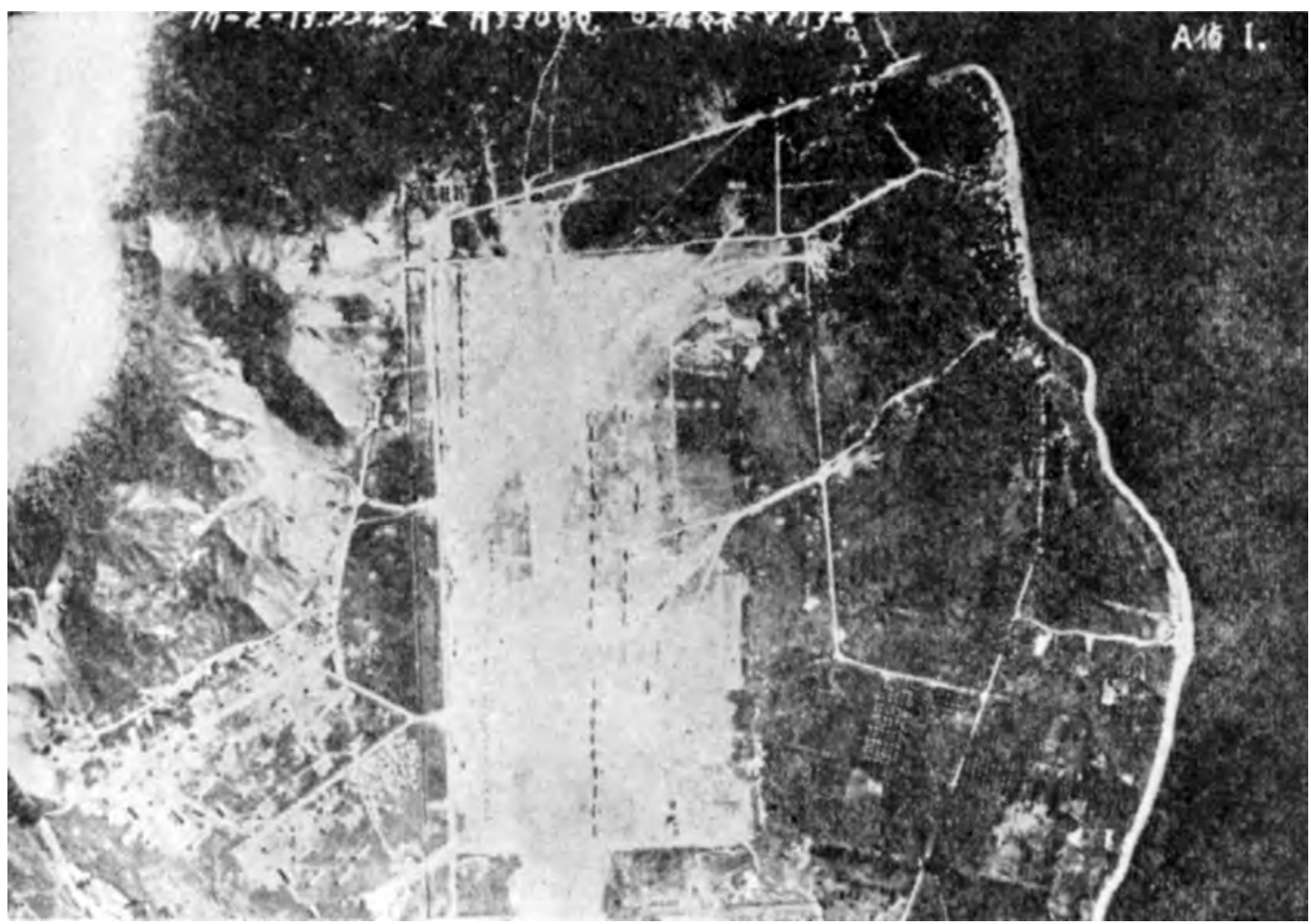

The Ambon Airfield

ing of the 3d, the 1st Kure Special Landing Force decided to once again carry out a night attack in concert with the Wakabayashi Company, because that company was supposed to storm [the airfield] at 0300. It was [also] decided that the 1st Kure Special Landing Force would leave one platoon to guard the injured and advance to the attack at 0115 on the $3 \mathrm{~d}$ under the command of Lieutenant Hatakeyama [Kunito] with all the rest of the force. ${ }^{(103)}$

At 0215 on the $3 d$, the point of the advance guard reached the enemy position in Tawiri, and the engagement was reopened. At 0500, the enemy fire slackened off markedly, and [the 1st Kure Special Landing Force,] without missing an opportunity, carried out an all-out attack and broke through the Tawiri position at a blow, and charged into the area around the Laha pier by 0530 . This brought about that the enemy troops soon raised white flags and offered a general surrender. At 0615, the 1st Kure Special Landing Force raised a naval flag at a northern part of the airfield and completely seized the airfield at 0630; Rear Admiral Hatakeyama [Kōichirō] then also entered the airfield. Meanwhile, the Wakabayashi Company, whose advance had experienced immense difficulties because its detour had taken it through a large and densely forested region that had consumed more time than expected, charged into the airfield from the rear of the enemy at 0600 on the 3d. Another company of the Army that had been dispatched overland from the Paso area for support reached Laha on the evening of the 3d. ${ }^{(54)}$

The operations of the Itō Detachment that had landed in Rutung had gone smoothly after the landing. That is, at 2030 on the 31st, the detachment had forced 800 enemy troops in Paso to surrender, had occupied Halong at 0500 on the 1st, and Detachment Commander Itō had 
entered into the urban area of Ambon at 1000 on the 1st. After that, the detachment had attacked the enemy in the hilly areas southwest [of the city], seized Amahusu and Mt. Nona by the early morning of the $2 \mathrm{~d}$, and had forced the surrender of the whole enemy army in the area of Eri by 0630 on the next day, the 3d. The loss sustained by the Itō Detachment in that area was 55 men killed and 135 men injured. ${ }^{(104)}$ On the other hand, the loss sustained by the 1st Kure Special Landing Force was 40 men killed (including Commander Ieki and three platoon commanders) and 50 men seriously injured; the casualties with serious injuries or more amounted to $12 \%$ of its total strength of 750 men. ${ }^{(103)}$

Having seized the airfield (about 1,300 meters long and 100 meters wide), the 1st Kure Special Landing Force with one element of its force immediately started clearing the obstacles and repairing the destroyed parts and together with the advance base personnel of the Eleventh Air Fleet, which had advanced in its wake, worked hard to put it back into service. As a result, it was expected that the airfield would be available for a few fighter planes from the next day, the 4th, onwards (two planes advanced on the 4th). From the afternoon on the $3 \mathrm{~d}$ onwards, the 1st Kure Special Landing Force started mopping up the enemy in the area of Cape Alang with its main force, and completed the cleanup operation after having all the remnants of the enemy surrender by around 7 February. ${ }^{(103)}$

\section{Minesweeping Delayed}

In the meantime at sea, Minesweepers Nos. 7, 8 and 12 from Rutung, and Minesweepers Nos. 9 and 11 from Hitulama had assembled at the entrance of Ambon Bay by 0700 on the 1st, completing preparations for clearing [the bay] of mines. However, the Laha airfield and the batteries on the southern coast had not yet been seized, which prevented the minesweepers from entering into the bay and kept them there on standby. During that period, the Army unit requested the rapid sweeping of Ambon Bay in order to speed up the disembarkation of its matériel in the area of Paso (it was difficult to enter into Baguala Bay due to the risk of mines). Furthermore, the special landing forces were in a situation that needed strong support from sea. At 0800 on the 2d, 2d Escort Unit Commander Rear Admiral Tanaka ordered the 21st Minesweeper Division and the 15th Destroyer Division to launch the scheduled minesweeping, while watching out for gunfire from land. The 21st Minesweeper Division immediately entered the bay and started a single-ship minesweeping maneuver ([i.e.] sweeping mines by extending sweeping wires from both sides of a ship) while the 15th Destroyer Division followed in its wake and covered it with gunfire and machinegun fire against enemy coastal positions. At 1030, the minesweeper division advanced as far as the line connecting Amahusu and Laha, where it snagged a mine for the first time, after which the division cut and disposed of fifteen mines by 1200 . However, when the division was about to further advance into the area off Ambon [city], mines successively touched the paravanes of Minesweepers No. 11 and No. 12 and exploded. The explosions caused a leak at the stern of Minesweeper No. 12 and engine trouble to Minesweeper No. 11. Then at 1400, Minesweeper No. 9 hit a mine and sank. When this was reported to $2 \mathrm{~d}$ Escort Unit Commander Rear Admiral Tanaka, he immediately called off the sweeping operation by the minesweepers and switched to a small-scale minesweeping operation by large motorized [landing] craft (an operation where small shallow-draft boats or small motorized vessels would tug compact and simple minesweeping devices to snag mines and blow them up). 


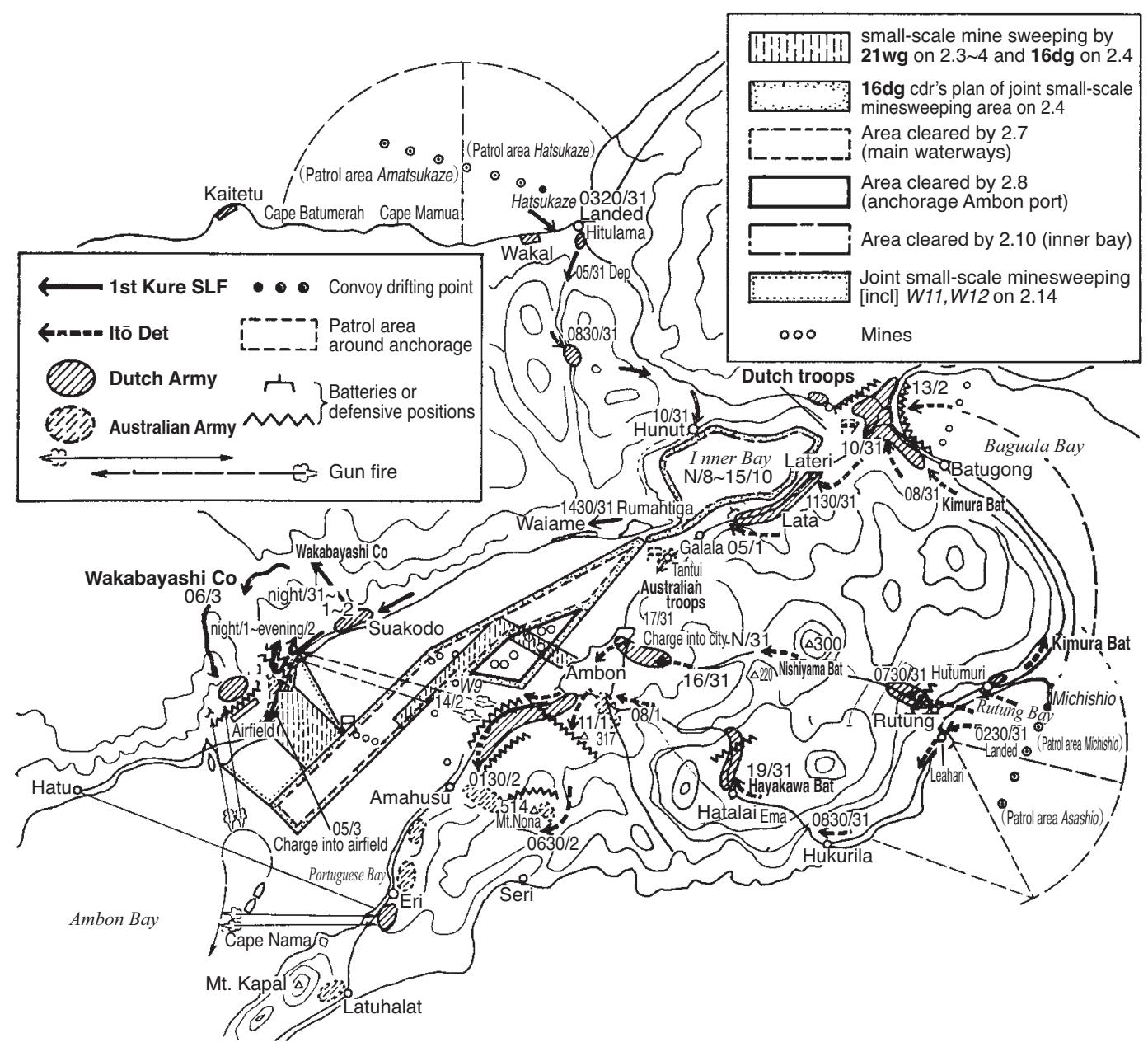

Illustration No. 21 - The Invasion of Ambon and the Minesweeping

Meanwhile, the 8th Destroyer Division had been discussing the disembarkation [of personnel and matériel] of the Army at Paso. In the end, a minesweeping operation was launched by means of a small minesweeping unit consisting of a motor launch and four small motorized [landing] craft from 1020 on the $2 \mathrm{~d}$ onwards. It reached Paso at 1215 and successfully established a communication route for small boats. The unit swept the waters down to five meters deep, but snagged no mines. On that day, there were no enemy attacks from the air or appearances of [enemy] submarines, except for one enemy flying boat that was spotted in the southern part of Ambon Bay around 1440.

On 3 February, the 21st Minesweeper Division off Ambon city carried out a small-scale minesweeping operation on the waters in front of the urban area using its motor launch with the support of [a] large motorized [landing] craft and disposed of three mines. However, because they only performed a few sweeps, the sweeping was far from thorough. To make matters worse, the damage survey of Minesweepers Nos. 11 and 12 resulted in the conclusion 
that both were crippled beyond an emergency repair of the engines. Meanwhile, at 1500 on the 3d, the 8th Destroyer Division reached the entrance of Ambon Bay, escorting the 1st Echelon [of the transport convoy]. However, because the anchorage in front of the urban area of Ambon was not yet completely swept, [the echelon] could not enter into the anchorage and perforce started the disembarkation by shipping the freight in landing craft from the vicinity of Portuguese Bay in the outer bay area to the urban area of Ambon.

From 1000 on 4 February onwards, the warships launched a small-scale minesweeping operation with boats and completed clearing the anchorage south of Laha at 1500, with no tethered mines found. It was concluded that no mines had been laid, so the Navy transport ships entered the anchorage one after another and started disembarkation right in front of the airfield. [However, ] because the anchorage in front of the urban area of Ambon (hereafter called Ambon port) had a wide waterway leading to it with many tethered mines, it would take [the Navy] much time to clear it of mines, which kept the Army transport ships still standing by near Portuguese Bay.

From 5 February onwards, under the command of the captain of the destroyer Sazanami, [the naval vessels] jointly formed a number of small-scale minesweeping units and went on with the minesweeping of Ambon port. After snagging five mines on that day, fourteen mines on the 6th, and nine mines on the 7th, they completed clearing Ambon port on the morning of the 8th. After this operation, five Army transport ships and the Katsuragi-maru (with the base matériel of Tōkō Air Group on board) were finally allowed to enter the port at 1430 . Afterwards, the operation of the joint small-scale minesweeping units continued until 10 February, and was finally completed after disposing of forty-two mines in total. During that period, on the 9th, one requisitioned merchantman struck a mine and sank in the yet-to-beswept waters south of the swept waterways.

\section{The Operations of the 2d Air Unit (See Illustration No. 22)}

As previously told [p. 221], at 1130 on 26 January, the flagship Chitose departed from the Salabangka Channel (north of Kendari). At 1500 on the next day the 27th, the ship arrived at the Bangka anchorage ${ }^{(68)}$ where she provided direct escort in the air above the convoy and patrol against submarines until 1900 on the 29th; thereafter she headed for Sula Mangoli Strait. ${ }^{(71,}$ ${ }^{72)}$ Meanwhile, the Mizuho provided guard on the sailing route ahead of the 1st Section of the 15th Destroyer Division, the 21st Minesweeper Division and the 1st Subchaser Division, which left Kendari at 0730 on the 29th, while [also] providing them with patrol against submarines. Then at 0940, the ship departed from the Salabankga anchorage for Sula Mangoli Strait along with Patrol Boats Nos. 34 and 39 and six fishing boats, and joined the Chitose south of Sula Mangoli Island at 1000 on the 30th. ${ }^{(68)}$

On the 30th, the $2 \mathrm{~d}$ Air Unit provided direct escort in the air above the convoy sailing southward at a point southeast of Sula Mangoli [Island], while escorting it against enemy submarines, guarding its sailing route ahead, and conducting a reconnaissance attack on Namlea. During these operations, the unit strafed and seriously damaged one Lockheed Hudson and one PBY flying boat at Namlea, and further drove away mid-sized enemy attack plane[s], which came for reconnoitering the echelon at $1320 .{ }^{(68,71)}$

On the evening of that day, the ships left Sula Mangoli for Kelang Bay (to the west of Ceram) and arrived there at 0550 on the next day the 31 st. ${ }^{(68)}$ 


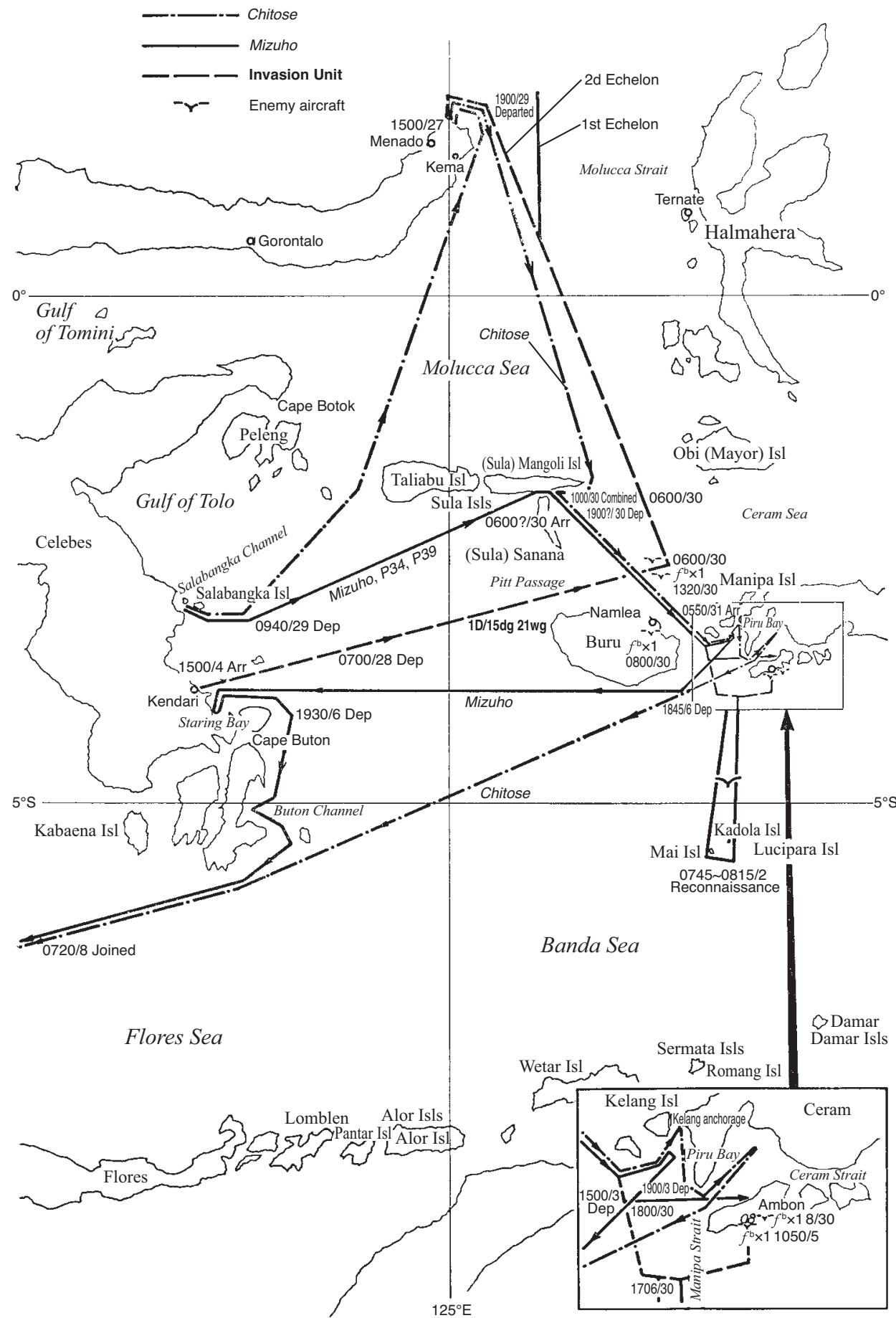

Illustration No. 22 - The Outline of the Operations of the $2 d$ Air Unit in the Ambon Operation 
On the 31st (the day of the landing operation [on Ambon]), the unit provided direct escort against [enemy] submarines as well as direct escort in the air above the convoy, while searching for the enemy in the Banda Sea ([the aircraft assigned to the latter] turned back due to bad weather). During these operations, no enemy was spotted other than one plane, which the aircraft assigned to the 1st shift of the direct escort in the air above [the convoy spotted,] pursued without knowing whether it was friend or foe and lost sight of. On the morning of that day, as previously told [p. 226], the weather was quite bad on Ambon and the surrounding waters, and it was not possible to carry out air operations.

On the 1st and the $2 \mathrm{~d}$ of February, the unit carried out a search for the enemy in the Banda Sea, provided the convoy with guard against enemy submarines as well as in the air above, while supporting the land combat with its full force. The unit dropped $13760-\mathrm{kg}$ bombs using a total of about 70 aircraft on the 1st, and on the $2 \mathrm{~d} 25160-\mathrm{kg}$ bombs, using a total of about 70 aircraft on the enemy positions near the Laha airfield as well as on the batteries [near the city of] Ambon, and neutralized the enemy. ${ }^{(68,71)}$ Also from the $3 \mathrm{~d}$ of February until the 6th, the unit searched for the enemy on the Banda Sea, while providing guard against enemy submarines as well as enemy aircraft day after day. During this period, no enemy was spotted other than one PBY flying boat, which had come for a raid on the 5th, but was shot down by friendly aircraft. ${ }^{(71)}$ At 1500 on the 3d, the Mizuho, Patrol Boat No. 39 as well as three guard ships left the Kelang anchorage, headed for Kendari to participate in the Makassar operation. ${ }^{(68)}$ Meanwhile, the Chitose left the Kelang anchorage at 1900 on the 3d, headed for Piru Bay (to the north of Ambon). After carrying out operations [while stationed] at Piru Bay, she discontinued the Ambon operation at 1730 on the 6th, left the bay at 1845 along with Patrol Boats Nos. 34 and 38 and headed for a point southeast of Selayar Island (to the south of Celebes) in order to participate in the Makassar operation.

\section{The Engagements of the Land-Based Air Units ${ }^{(68,71,81)}$}

From 24 January onwards, the land-based air units continued their operation to search for the enemy in the Banda Sea and conduct reconnaissance attacks on the airfields on Ambon and Namlea [Buru], while directly escorting the convoy from the air after its sortie, with large flying boats of the Tōkō Air Group, land-based attack planes of the Kanoya Air Group Detachment and the 1st Air Group, Type-0 fighter planes and land-based reconnaissance planes of the $3 \mathrm{~d}$ Air Group, along with the carrier-based bombers and Type- 0 fighter planes of the force dispatched from the $2 \mathrm{~d}$ Carrier Division. By the 30th, the unit had destroyed most of the enemy military facilities in that area and also virtually driven off all existing enemy aircraft. During that period, no enemy naval vessels appeared at all. Meanwhile on 27 January, the 21st Air Flotilla headquarters and the Kanoya Air Group Detachment advanced from Menado to the Kendari base. ${ }^{(71,81)}$

On the 31st (the day of the landing operations), no air campaign was executed due to bad weather. After the weather improved from the 1st onwards, [the unit] carried out a search for the enemy operation in the Banda Sea and provided patrol in the air above Ambon. On the $2 \mathrm{~d}$, [the unit] totally destroyed enemy positions in support of the ground combat with its land-based attack planes. As early as the 4 th, two fighter planes advanced to the Laha airfield, which was followed by one reconnaissance plane and seven fighter planes on the 5th. From the 7th onwards, the land-based air unit began its reconnaissance over the vicinity with its land-based reconnaissance planes, while starting preparations for the subsequent opera- 
tions. Meanwhile, the Tōkō Air Group pushed forward three of its flying boats to Ambon. It was followed by the 1st Air Group, which pushed forward its land-based attack planes to the Laha airfield, attaining the expected goal of the Ambon operation. ${ }^{(71,81)}$

\section{The Formation of the 24th Special Base Force and the Preparations for the Subsequent Operations}

As mentioned previously, the prospective staff members of the 24th Special Base Force headquarters had landed along with the 1st Kure Special Landing Force and advanced to the Laha airfield led by Rear Admiral Hatakeyama [Kōichirō]. On 5 February, the 24th Special Base Force was [officially] formed and assigned to guard Ambon Island and the surrounding waters with a strength of about 490 men of the 1st Kure Special Landing Force, the $3 \mathrm{~d}$ Military Supplies Department and about 2,000 men of the 3d Construction Squad. From the 10th onwards, the force successively took over the guard from the Army Itō Detachment and completed the takeover on the 16th. It was [also] decided to assign the crippled Minesweepers Nos. 11 and 12 to the guarding of Ambon and cooperate with the 24th Special Base Force until ordered otherwise by special order. ${ }^{(107)}$

In the meantime, the Support Unit, which had stayed at the Bangka anchorage from the 30th onwards, left the anchorage and sailed northward at 1100 on 5 February to return to Davao for the preparations of the Makassar operation (arriving there at 0800 on the 6th). ${ }^{(78)}$ Meanwhile, 2d Escort Unit Commander Rear Admiral Tanaka, who had been on the waters southwest of Buru during the Ambon operation, arrived in the port of Ambon at 1030 on 10 February, leading the Jints $\bar{u}$. Thereafter, the $2 \mathrm{~d}$ Escort Unit started on the preparations for the operation against Kupang, while its escort forces, the 8th and the 15th Destroyer Divisions and others began the preparations for the operations against Makassar. ${ }^{(54)}$

The Ambon operation was thus completed: During the operation, the $2 \mathrm{~d}$ Escort Unit sustained a loss of one minesweeper sunk and two half-damaged at sea, while forty men of the 1st Kure Special Landing Force were killed and fifty men seriously injured on land. As for the 1st Kure Special Landing Force, it reported military gains of 150 enemy abandoned bodies, 250 prisoners, 5 seized tanks, 12 firearms, etc. ${ }^{(54)}$ According to the documents of the allied forces, ${ }^{(95)}$ the strength of the garrison at that time consisted of about 2,600 men of the Dutch East Indies army and about 1,100 men of Australian army, about 3,700 men in total.

The action report of the $2 \mathrm{~d}$ Destroyer Squadron describes its observations and lessons learned in the operations as follows:

1. Since in this operation the friendly air units gave quite close and well-timed support and the air campaign to destroy the air power of the enemy had produced sufficient results, the operation progressed without enemy counterattacks.

2. Although providing [friendly forces] with fire and bombing cover in their ground combat is difficult because of the risk of friendly fire [accidents], it inflicts an enormous mental blow to the enemy. Therefore, against a tough enemy, it is necessary to do this vigorously while leaving enough margin [to avoid mistakes] and specifying the [bombing] zones, thus eliminating the possibility of friendly fire [accidents].

3. In conducting minesweeping operations in hostile territory, it is required to conduct them in such a way as to first sweep the sea with special craft (of 0.5-meter draft or lighter), and then clear the waters with minesweepers. 
For that purpose, it is urgently necessary to build powerful high-speed special minesweepers as well as to develop [new] minesweeping equipment (both of the cutting mine cables type and the pair-ship minesweeping type).

4. In guarding against enemy aircraft, close cooperation between fighter planes assigned to the direct escort and naval vessels is most required. Since the observation ability of fighter planes in direct escort is generally quite poor, it is most essential to swiftly inform the aircraft in charge of the direct escort about enemy planes spotted by the superior observation [ability] from the vessels. And the best and most certain way [to provide the directly escorting aircraft with information about the enemy aircraft] is gunfire from general naval ships. This was keenly felt both in the Jolo operation as well as in the Ambon operation.

Therefore, when there is [support from] friendly fighter planes, it is necessary to show the position and direction of the enemy aircraft by swiftly firing some salvos regardless of the firing range.

\section{Operation $\mathrm{Z}$ of the Air Units and a Sea Engagement off Java}

\section{The Launch of the Operations (See Illustrations No. 23 and No. 24)}

It was decided that the air units, which had deployed in Kendari and Balikpapan, should immediately launch an air campaign to destroy the enemy air power in the Surabaya area. The strength of the [Japanese] air units deployed in that area as of the end of January was as follows: (75, 81$)^{2}$

Eleventh Air Fleet headquarters
1st Air Raid Unit (21st Air Flotilla) headquarters
Kanoya Air Group Detachment
1st Air Group
Tōkō Air Group

3d Air Group

Unit dispatched from the 2d Carrier Division

2d Air Raid Unit (23d Air Flotilla) headquarters Tainan Air Group

Unit dispatched from the 2d Carrier Division

$\begin{array}{cl} & \text { Davao } \\ & \text { Kendari } \\ \text { 34 land-based attack planes } & \text { Kendari } \\ \text { 27 land-based attack planes } & \text { Kendari } \\ 4 \text { large flying boats } & \text { Kendari } \\ \text { 17 large flying boats } & \text { Menado } \\ 41 \text { Type-0 fighter planes } & \text { Kendari } \\ 6 \text { land-based recon. planes } & \text { Kendari } \\ \text { 18 carrier-based fighter planes } & \text { Kendari } \\ 8 \text { carrier-based bombers } & \text { Kendari } \\ & \text { Balikpapan } \\ 30 \text { Type-0 fighter planes } & \text { Balikpapan } \\ 3 \text { land-based recon. planes } & \text { Balikpapan } \\ 9 \text { carrier-based bombers } & \text { Balikpapan }\end{array}$

At that time, the condition of the Kendari airfield was such that it could immediately be used by a large number of aircraft. However, it took a considerable number of days to ready the base in Balikpapan. Finally at the end of January, it was ready for a concentrated use by fighter planes, but land-based attack planes could only use it in small numbers and lightly loaded.

\section{Operation Orders}

At 1650 on 30 January, Southern Task Force Air Unit Commander Vice Admiral Tsukahara issued his orders, which were in summary as follows:(75) 
1. On the $3 \mathrm{~d}$ and 4 th (with the 5th as an alternative date) of February, the unit shall [conduct an operation to] destroy the enemy air power in eastern Java with its whole force.

2. Deployment of forces

The bulk of the fighter planes shall assemble in Balikpapan and shall be led by the $2 \mathrm{~d}$ Air Raid Unit commander. The entire force of the land-based attack planes shall assemble in Kendari and shall be led by the 1st Air Raid Unit commander.

3. Disposition of forces in the attack

$\left.\begin{array}{ll}\text { 1st Attack Unit } & \text { Full force of the Takao Air Gp } \\ \text { 1st Fighter Plane Unit } & \text { Full force of the main unit of the 3d Air Gp }\end{array}\right\} \begin{aligned} & \text { Surabaya and } \\ & \text { vicinity }\end{aligned}$

2d Attack Unit Full force of the Kanoya Air Gp Det

2d Fighter Plane Unit Half of the Tainan Air Gp

\} Madiun (about $80 \mathrm{NM}$

3d Attack Unit Full force of the 1st Air Gp

3d Fighter Plane Unit Half of the Tainan Air Gp west of Surabaya)

The 1st weather reconnaissance plane ([of] the 1st Air Raid Unit) shall reconnoiter the Sunda Sea, the eastern part of the Java Sea, and at 0700 [the waters] north of Madura.

The $2 \mathrm{~d}$ weather reconnaissance plane ([of] the $2 \mathrm{~d}$ Air Raid Unit) shall reconnoiter the eastern part of the Java Sea, and [the waters] north of Surabaya at the earliest possible hour.

The 1st reconnaissance plane ([of] the 1st Air Raid Unit) shall observe the military gains.

Rescue unit: 2 large flying boats of the Tōkō Air Gp; each aircraft shall take positions near Laut Island and the Kangean Islands.

4. The time to launch the attack
Day 1:
1200
Day 2:
$1100-1330$

5. Shifting [of bases] and the command system

The Takao Air Gp (note: [currently] at Jolo) shall shift to Kendari by 2 February, to come under the command of the 1st Air Raid Unit commander. Also, the main body of the 3d Air Group shall shift to Balikpapan by 2 February, to come under the command of the $2 \mathrm{~d}$ Air Raid Unit commander.

6. Related operations

The 1st Air Raid Unit shall destroy the enemy air power in Timor, the Banda Sea and the Arafura Sea area with the $2 \mathrm{~d}$ Carrier Division Unit dispatched to Kendari and 3d Air Group Detachment, and clear the area of the enemy.

7. This operation shall be called Operation $\mathrm{Z}$ only within our unit.

The outline of cooperation between the fighter planes and bombers in this operation was discussed [and decided] in such a way that [both] should go into action at a fixed time without assembling [beforehand]. ${ }^{(12)}$

Note: The time of sunrise and sunset was at 0730 and around 2000 respectively.

\section{Reconnaissance}

On 1 February, the 2d Air Raid Unit Commander Rear Admiral Takenaka conducted a reconnaissance over eastern Java (Surabaya, Malang, and Madiun) with three land-based reconnaissance planes of the Tainan Air Group. Although the first reconnaissance plane, which had headed for Surabaya, went missing without [prior] communication, the second recon- 
naissance plane successfully reconnoitered the Malang area, spotted three B-17s and two small planes on the airfield as well as in the Madura Strait one vessel, which looked like a tender ship, and returned. The third reconnaissance plane, which reconnoitered Madiun, spotted nine large planes and three mid-sized planes on the airfield. ${ }^{(71)}$ In the meantime, the 1st Air Raid Unit searched for the enemy in the Banda Sea and the Sunda Sea with three landbased attack planes, but spotted no enemy except for five large enemy flying boats, which were flying toward Surabaya. On the $2 \mathrm{~d}$, the unit spotted eighteen flying boats on the Surabaya seaplane base. ${ }^{(71)}$

\section{Bombing the Airfields in the Surabaya Area}

At 0757 on 3 February, twenty-six land-based attack planes of the Takao Air Group of the 1st Attack Unit under the command of Lt. Cdr. Nonaka Tarō took off from the Kendari base and headed for the Surabaya airfield for an attack. At 1220, the unit carried out a bombing of the airfield as well as the port facilities and reported that all bombs had hit their targets and that one out of four moored flying boats had been sunk. Although the unit engaged with four enemy fighter planes in the air from [the beginning of] the bombing till 1230, there were no military gains or losses [in the air combat]. After the attack, the 1st and the $2 \mathrm{~d}$ Squadrons returned to Balikpapan (as had been specified in the plan of operations), and the $3 \mathrm{~d}$ Squadron to Kendari, all without damage. Twenty-seven land-based attack planes of the Kanoya Air Group of the 2d Attack Unit under the command of Lt. Cdr. Irisa Toshiié took off from Kendari at 0710 for Madiun. At 1225, the unit carried out a bombing of the airfield and the area of the hangars and barracks, reporting a military gain of [damaging] two [buildings] and one large plane, [both of] which had been set ablaze, and seriously damaging two midsized planes (the unit spotted ten large planes and two mid-sized planes on the ground and two small planes in the course of taking off). The unit also engaged with five enemy fighter planes in the air, which came for an attack after the bombing, and reported shooting down two of them (one of which was unconfirmed). All aircraft returned to the Kendari airfield (five of them marked by bullets). Also, nineteen land-based attack planes of the 1st Air Group of the 3d Attack Unit, led by Lt. Cdr. Ozaki Takeo, took off from Kendari at 0630. The unit bombed Malang at 1210 and reported seriously damaging one large plane (out of six planes it spotted on the ground) and scoring direct hits on two warehouses as well as an antiaircraft artillery position, after which all aircraft returned to Kendari without damage. The unit further reported around 1350 on its way back [to Kendari] having spotted at Madura two battleships, one Class-A cruiser and two Class-B cruisers and nine destroyers at anchor.

\section{Destroying the Enemy Fighter Plane Units ${ }^{(71)}$}

At 0930, twenty-seven Type-0 fighter planes and two land-based reconnaissance planes of the $3 \mathrm{~d}$ Air Group of the 1st Fighter Plane Unit took off from Balikpapan led by Lt. Yokoyama Tamotsu. [The unit] rushed into [the air over] Surabaya, and reported military gains of shooting down fifteen Curtis-Wright fighter planes, three P-36 fighter planes (one of which with unconfirmed results), four $\mathrm{P}-40$ fighter planes (one of which [also] with unconfirmed results), four flying boats, nine Buffalo fighter planes, and four Hawker Hurricane fighter planes, totaling thirty-nine planes, as well as seriously damaging one B-17 and four flying boats, and [also damaging] fourteen flying boats, which had caught fire. Although three Type-0 fighter 


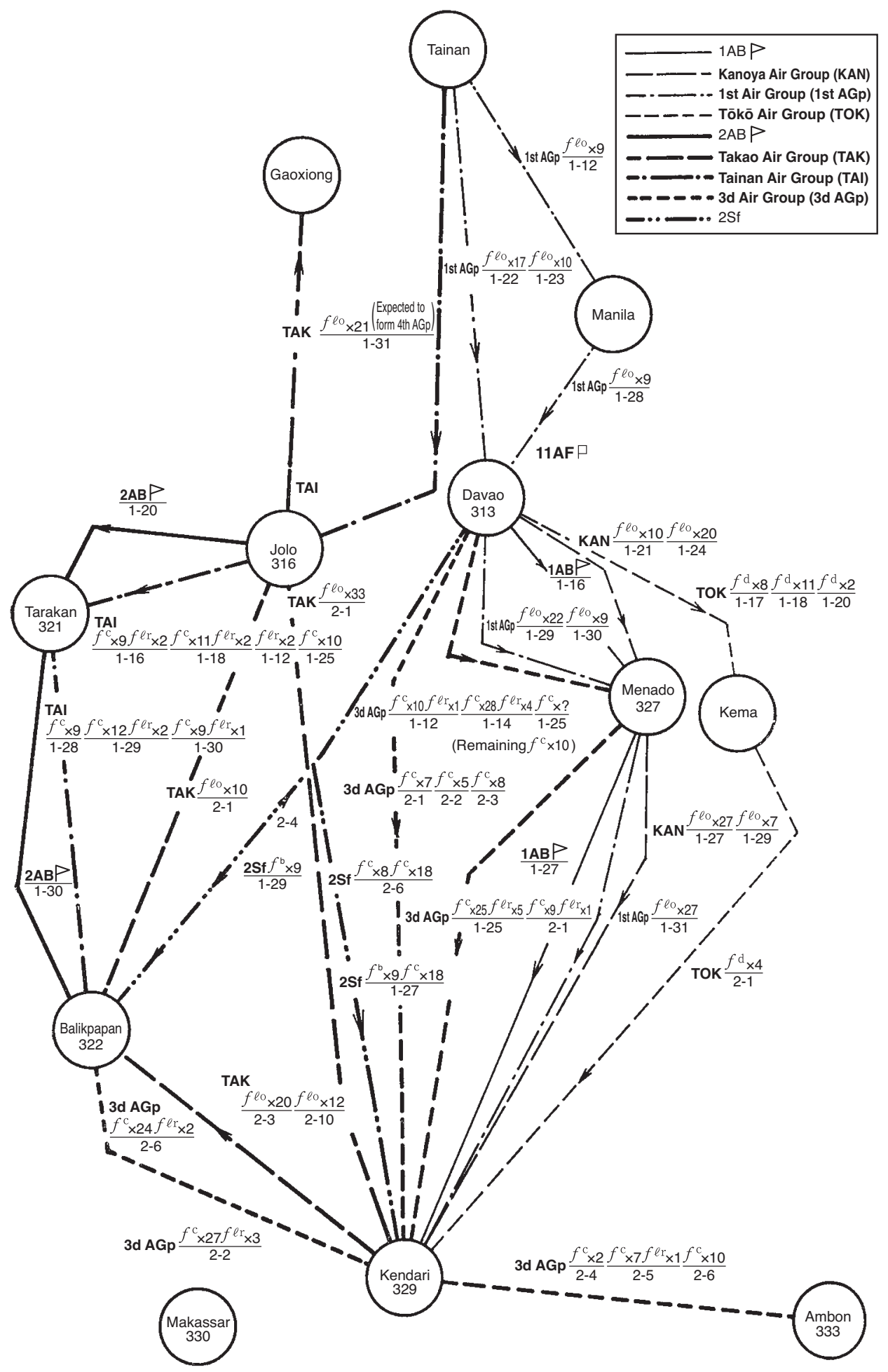

Illustration No. 23 - The Shift of the Bases of the Air Units (11 January - 6 February, 1942) 
planes and one land-based reconnaissance plane went missing, all other Japanese planes returned to Balikpapan without problems (of the latter, three Type-0 fighter planes were marked by bullets). [Also,] seventeen Type-0 fighter planes and one land-based reconnaissance plane of the Tainan Air Group of the 2d Fighter Plane Unit, led by Lt. Asai Masao, took off from Balikpapan at 0900. [The unit] rushed into [the air over] Madiun at 1230. Reporting military gains of shooting down two and destroying four [enemy planes], all planes returned to Balikpapan without damage. [Meanwhile,] fourteen Type-0 fighter planes and one landbased reconnaissance plane of the Tainan Air Group of the 3d Fighter Plane Unit, led by Lt. Shingō Hideki, took off from Balikpapan at 0915, rushed into [the air over] Malang, and reported military gains of damaging one B-17, one twin-engine flying boat, five four-engine planes, one twin-engine plane and one small plane, which were destroyed or had been set ablaze, by strafing [those on the ground] or in air combat. Other than one Type- 0 fighter plane, which crashed itself, the unit returned to Balikpapan (seven of which were marked by bullets).

At 2350 on the 3d, Eleventh Air Fleet Commander in Chief Vice Admiral Tsukahara reported the military gains of that day as sixty-two planes being confirmed results (shot down or set ablaze), and twenty-three or twenty-four planes being unconfirmed results (heavily damaged by strafing or shot down but unconfirmed), totaling eighty-five aircraft. ${ }^{(54)}$ The loss sustained on the Japanese side was one Type-0 fighter plane, which crashed itself, and three Type- -0 fighter planes and one land-based reconnaissance plane, which did not return, totaling five aircraft. This attack surprised the enemy to such a degree that, having no idea of where the Japanese fighter planes had flown from, they [even] assumed that the Japanese had conducted the raid from the south, using aircraft carriers. ${ }^{(108)}$ Air Unit Commander Vice Admiral Tsukahara [then] issued an order concerning the attacks on the following day, the 4th, ordering that the Kendari Unit should attack the enemy fleet (which had been spotted by the attack [plane] unit of the 1st Air Group), while the Balikpapan Unit should continue Operation Z. ${ }^{(75)}$

\section{Destroying an Enemy Fleet off Java}

As previously told, on 3 February on its way back from the attack on Malang the land-based attack plane unit of the 1st Air Group had spotted two enemy battleships, one Class-A cruiser, two Class-B cruisers and nine destroyers at anchor off Madura Island around 1350. (As a result of a review after its return [to base], the "battleships" in that report were amended to "Class-A cruisers.") Air Unit Commander Vice Admiral Tsukahara decided to immediately conduct a probe and an early morning search for the enemy, and to attack the enemy fleet with the full force of the land-based attack planes on the following day, the 4 th. ${ }^{(12)}$ However, with regard to the attacks by the land-based attack planes on the 4th, the Air Unit commander issued an order at 2330 [on the 3d] that eighteen land-based attack planes of the Takao Air Group at Balikpapan should continue Operation Z. ${ }^{(75)}$

At 1900 on the 3d, one land-based attack plane of the 1st Air Group took off to probe the enemy, but [shortly] returned due to trouble with its telegraph. Then it was decided that two large flying boats of the Tōkō Air Group at Kendari should take off, but this was delayed due to bad weather; one took off at 2245 and the other at 2315. One of them spotted three large enemy cruisers and two destroyers at 0410 (the report of the sighting did not reach [the base] before 0530) and continued tailing them until 0600, returning [to base] at 0945 . The 


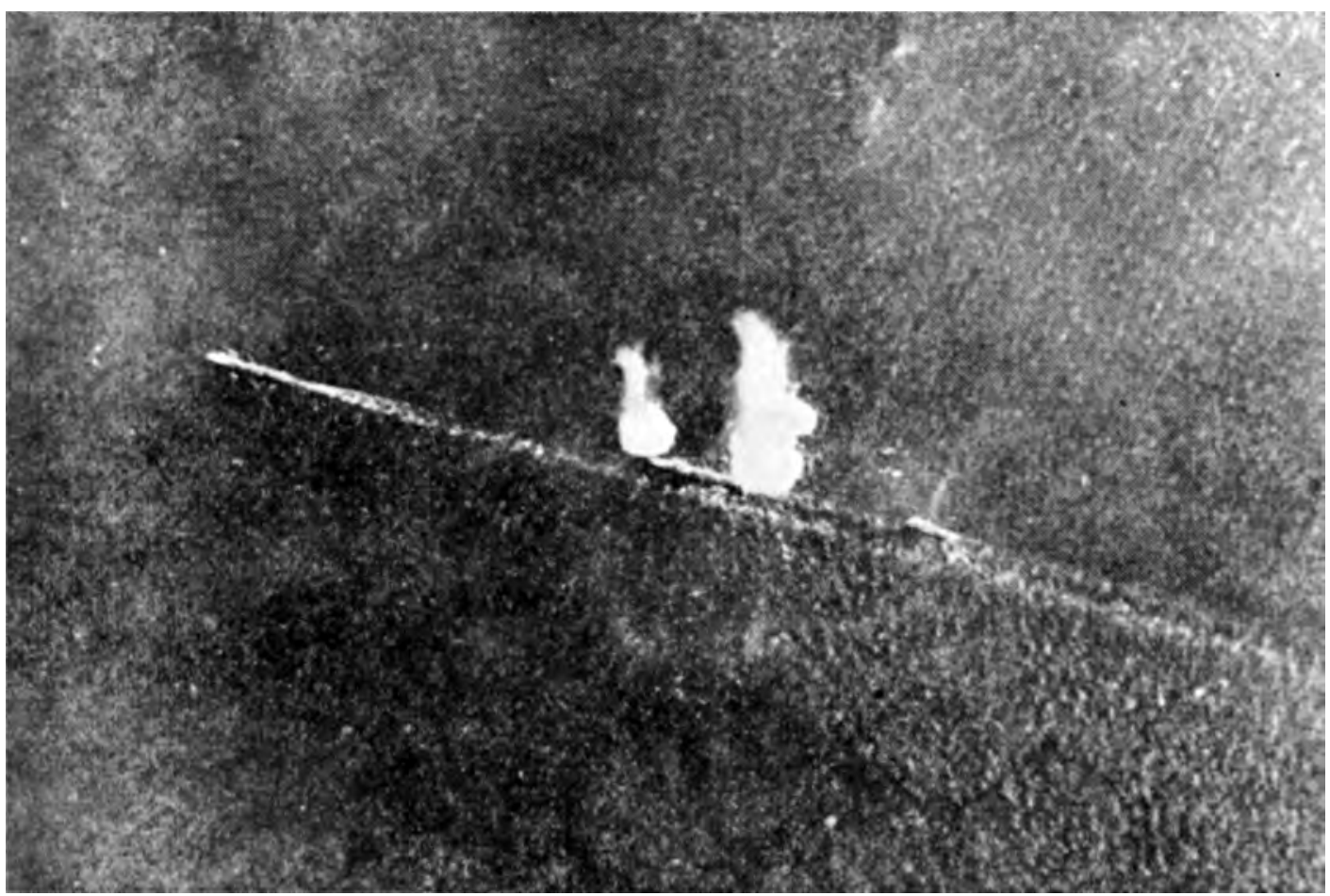

The Enemy Fleet Under Fierce Bombing from Japanese [Air Units]

other plane spotted one large enemy cruiser and four destroyers at 0537 , tailed them until 0630 and returned [to base] at 1055..$^{(71)}$

In line with the plan that the land-based attack planes should [start] searching for the enemy if no report on the enemy movements from the flying boats had been received by 0530 on 4 February, four land-based attack planes of the Takao Air Group at Balikpapan and one land-based attack plane of the Kanoya Air Group at Kendari were deployed to search for the enemy and took off from their respective airfields at 0735 and 0600. ${ }^{(81)}$ The plane of the Kanoya Air Group returned to Kendari at 1345 without spotting the enemy, while three out of four land-based attack planes of the Takao Air Group returned [to Balikpapan] due to bad weather. However at 1005, the last aircraft spotted one cruiser, one destroyer and two armed merchantmen at a point 80 nautical miles 93 ${ }^{\circ}$ [E] from Surabaya. After tailing them and reporting on them until 1130, the aircraft further searched for the enemy and in the end spotted another enemy fleet ([consisting of] five cruisers and five destroyers) at 1305. It tailed them and reported on them until 1317 before returning to base at $1530 .{ }^{(71)}$ Meanwhile, on the basis of the report that the enemy had been spotted, twenty-seven land-based attack planes of the Kanoya Air Group (led by Lieutenant Commander Irisa), nine land-based attack planes of the Takao Air Group (led by Lt. Yokomizo Kōshirō) and twenty-four land-based attack planes of the 1st Air Group (led by Lieutenant Commander Ozaki), which had already taken off from the Kendari base around 0800 and were heading toward Surabaya, immediately rushed toward the enemy fleet.

At 1115, the land-based attack plane unit of the Kanoya Air Group spotted an [enemy] fleet consisting of two Java-class cruisers, one De Ruyter-class cruiser, one Marblehead-class 


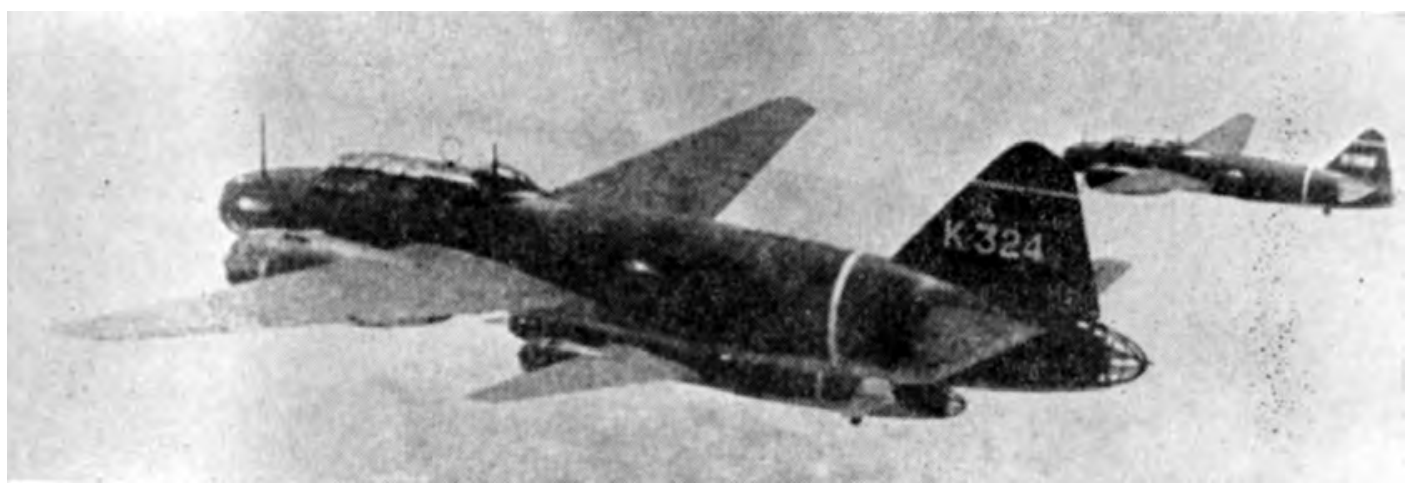

Type-1 Land-based Attack Plane

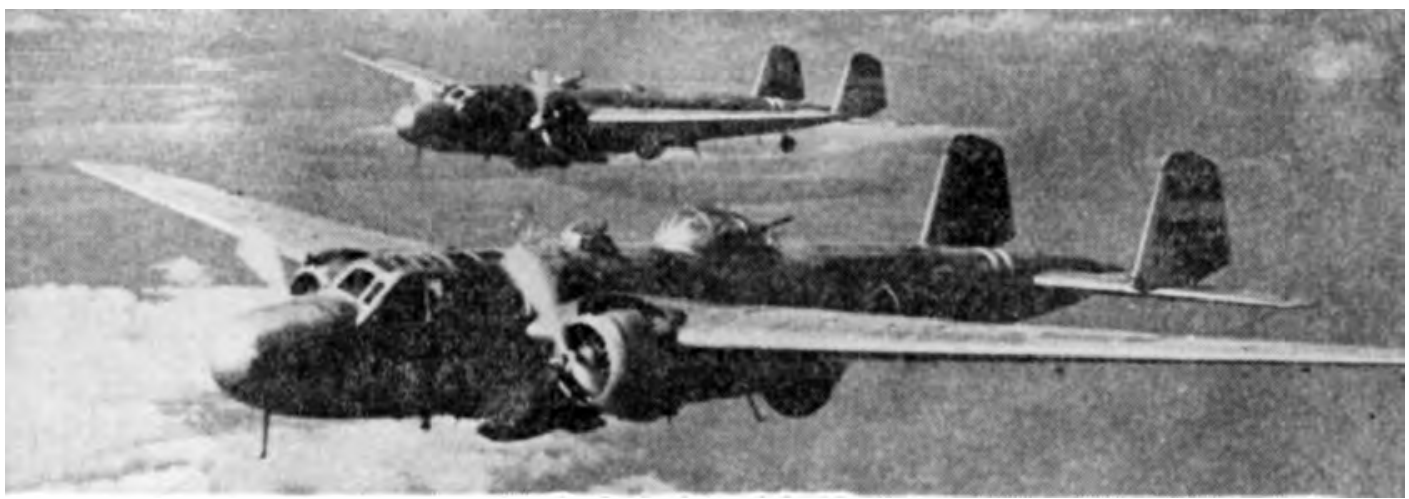

Type-96 Land-based Attack Plane

cruiser, and five destroyers (two of the latter being Tromp-class) [sailing] (at a speed of twenty-four knots on a southeastern course) at a point thirty nautical miles south of the Kangean Islands and attacked it. [The unit] reported the following military gains: The 1st Squadron ([led by] Lieutenant Commander Irisa) bombed the 1st ship at 1140, which was half damaged by two near hits at the stern, while the $2 \mathrm{~d}$ Squadron ([led by] Lt. Morita Rinji) dropped bombs at the $2 \mathrm{~d}$ ship at 1129 , two of which hit the ship at the fore and at midship, causing an explosion near the engine around 1132. [The second] bombing at the 1st ship had no results, while the $2 \mathrm{~d}$ ship sank at 1153 . The $3 \mathrm{~d}$ Squadron ([led by] Lt. Tanaka Takekatsu) dropped bombs at the $3 \mathrm{~d}$ ship at 1138, [one of] which fell at 100 meters from the side; the ship was half damaged by two bombs which fell close to the stern. At 1157, the bombing of the 1st ship scored one direct hit at the fore, another at the aft, and four nearby hits, [which caused] damage to the rudder. [After] one explosion near the fore turret around 1200, the flagship USS Houston sank at 1215. Then, all aircraft (of which thirteen planes were marked by bullets) returned to Kendari between 1425 and 1500. ${ }^{(71,81)}$

Nine land-based attack planes of the Takao Air Group spotted a combined fleet of U.S. and Dutch naval forces at 1135, and carried out a bombing at 1141 for the first time and at 1149 for the second time. However, because the enemy took large evasive actions at high speed, the unit scored no direct hits. During [the engagement], at 1152 the $3 \mathrm{~d}$ plane of the $3 \mathrm{~d}$ Flight crashed itself after being hit by enemy antiaircraft fire; the others returned to Kendari at 1416 without damage. . $^{(1)}$ 


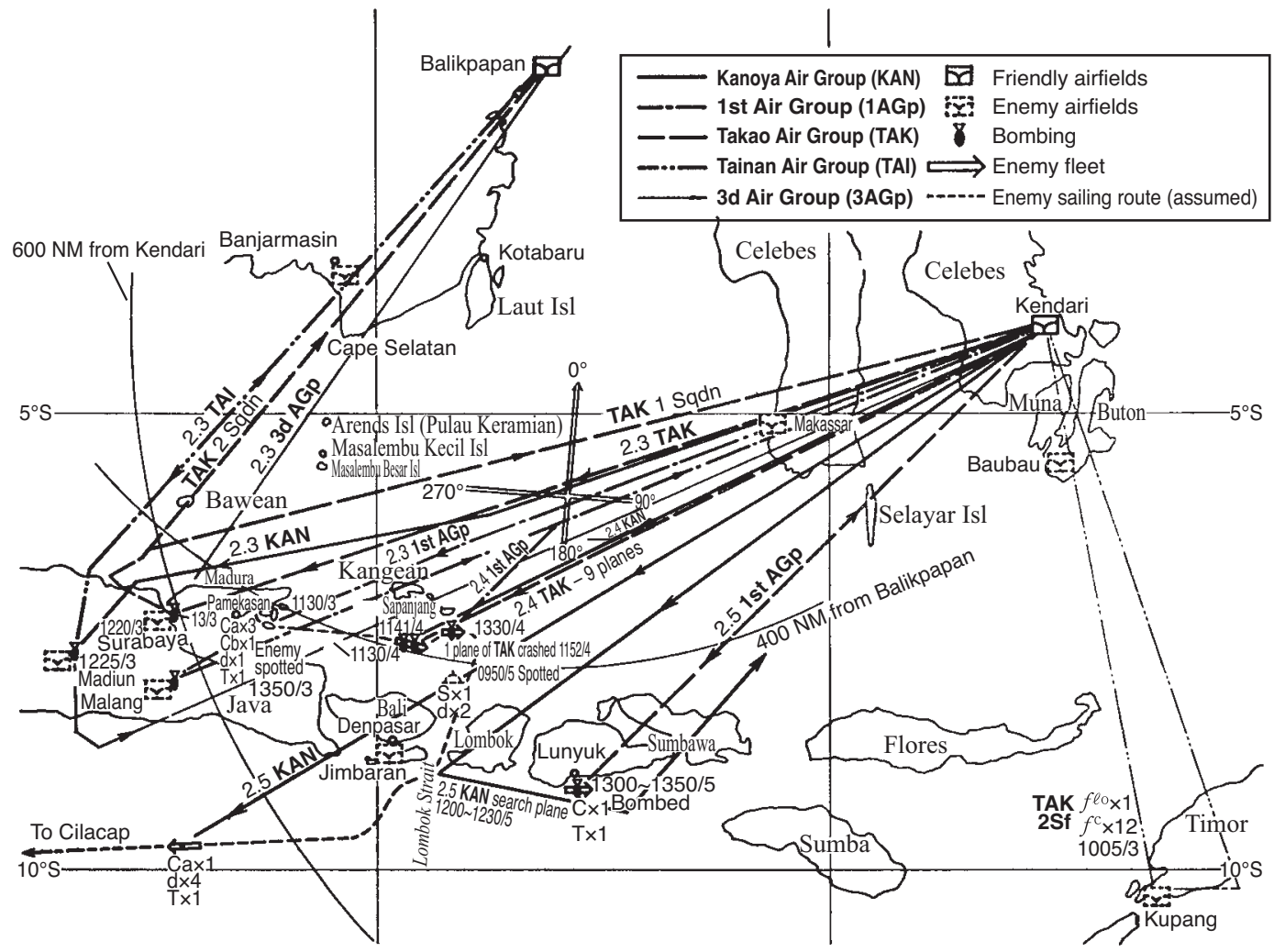

Illustration No. 24 - Operation Z and the Sea Engagement off Java

Twenty-four land-based attack planes of the 1st Air Group spotted a 5,000t-class transport ship escorted by two destroyers on the waters off Makassar and reported it at 1110 (they were later attacked by carrier-based bombers of the $2 d$ Carrier Division). Then at 1240, [the unit] spotted two heavy cruisers, two light cruisers and seven destroyers sailing in a disorderly formation about ten nautical miles south of Sepanjang Island. Launching an attack on the fleet from 1330 onwards, the unit reported having sunk one De Ruyter-class cruiser and having caused considerable damage to one Marblehead-class cruiser and one Java-class cruiser. The unit returned to Kendari between 1630 and 1730. Three planes of the unit were marked by bullets. ${ }^{(71)}$

First Air Raid Unit Commander Rear Admiral Tada reported the military gains in these attacks in his preliminary operation report as follows: ${ }^{(81)}$

The results of the attacks on the enemy fleet today, the 4th, are as follows:

Of the enemy fleet consisting of two Java-class [cruisers], one De Ruyter-class [cruiser], one Marblehead-class [cruiser], and seven destroyers (two of the latter were assumed to be Tromp-class), one Java-class [cruiser] was instantly sunk ([by] two direct hits of regular No. 25 bombs), and one De Ruyter-class [cruiser] was seriously damaged by two direct hits of regular No. 25 bombs and a number of near hits. She caught fire, and stopped for a while. [However,] after [successfully] putting out the flames one hour later, she sailed without sinking, trailing a large amount of spilt heavy oil. 
One Sumatra-class [destroyer] was directly hit by a No. 6 regular bomb and nearly hit by two No. 25 bombs and for a while belched out black-brown smoke. Though the fire was put out, she was heavily damaged. One (Marblehead-class) light cruiser was directly hit by a No. 25 bomb at [one of] its turrets and nearly hit by another No. 25 bomb, [both of] which caused considerable damage.

Meanwhile, one transport ship ([of] about 5,000 tons) heading for Makassar escorted by two gunboats was set ablaze and destroyed by carrier-based bombers of the $2 \mathrm{~d}$ Carrier Division.

The 1st Air Raid Unit commander decided to have [some] large flying boats of the Tōkō Air Group try as hard as possible to tail the enemy fleet on the night of the 4 th, in order to resume the attack on the next day, the 5th, and completely destroy the enemy. ${ }^{(81)}$ Accordingly, one large flying boat took off from Kendari at 1533 on the 4th, but did see no enemy fleet other than spotting one merchantman in flames (accompanied by two destroyers; the one attacked by the carrier-based bombers of the $2 \mathrm{~d}$ Carrier Division) to the south of Makassar at 1730 . Another flying boat took off at 1820 and searched for the enemy around the Lombok Strait at 2345 , but returned due to bad weather without finding the enemy. ${ }^{(71)}$ Thereafter, [all] sorties were suspended due to bad weather, and the chance to tail the enemy fleet was completely lost. Also, the attack of [Operation] Z by the Balikpapan Unit on the 4th was not carried out due to bad weather and was postponed to the 5th. ${ }^{(75)}$

\section{The Second Attack of [Operation] Z}

On 5 February, the unit at the Balikpapan [base] carried out the second attack of [Operation] Z. ${ }^{(71)}$ On that day, because it was expected that enemy fighter planes would be advanced to Bali in connection with an evacuation of the enemy fleet, one element of the attack was directed to the Bali airfield.

At 0820, twenty-seven Type-0 fighter planes ([led by] Lieutenant. Shingō) and one landbased reconnaissance plane of the Tainan Air Group took off from Balikpapan, dashed [into the air over] Surabaya at 1115; the reconnaissance plane immediately headed back. The Type0 fighter plane unit was engaged in air combat and strafing until 1150. After reporting military gains of shooting down four [enemy] fighter planes and one flying boat, damaging one flying boat that was set ablaze, destroying one reconnaissance seaplane, and damaging two large four-engine planes that had belched out black smoke, all returned [to base] (four of them marked by bullets).

Eleven Type-0 fighter planes ([led by] Sublt. Yamaguchi Sadao) and a land-based reconnaissance plane of the 3d Air Group took off from Balikpapan at 0915, and entered [into the air over] Surabaya at 1145 . After reporting [military gains of] shooting down one flying boat and two P-36s, and damaging two flying boats, which had been set ablaze, between 1200 and 1300, all returned [to base].

Eighteen land-based attack planes of the Takao Air Group ([led by] Lt. Adachi Jirō; after the attack on the $3 \mathrm{~d}$ the unit had moved to Balikpapan) attacked the Surabaya airfield, having left Balikpapan at 0820. Having dropped their full load of bombs ([totaling] 108 60-kg bombs) at 1120, hitting the facilities of the airfield, all [aircraft] returned to Balikpapan without damage.

Ten Type-0 fighter planes ([led by] Lt. Hasuo Ryūichi) and one land-based reconnaissance plane of the 3d Air Group left Balikpapan at 0835 and entered into the air over Denpasar 
([on] Bali Island) at 1125. After reporting having shot down in air combat until 1200 eleven P-14s (two of them unconfirmed), all returned [to base]. Only one aircraft had bullet marks. It was concluded that in the first and the second attacks of Operation Z, almost all of the enemy aircraft stationed in the Surabaya area had been destroyed..$^{(81)}$

\section{Letting the Remnant of the Enemy Fleet Slip by}

At 0700 on the 5 th, three land-based attack planes took off from Kendari and searched for the enemy on the waters south of Lombok Strait. ${ }^{(81)}$ After spotting one surfaced [enemy] submarine at 0950, the 1st search plane spotted one badly damaged Class-A cruiser, four destroyers and one transport ship at a point 150 nautical miles $243^{\circ}$ [WSW] from Bali. The plane tailed them until 1300 and returned to base at $1650 .{ }^{(71)}$ However, the transmission of this sighting of the enemy did not reach the attack units of the Kanoya Air Group or the Takao Air Group. ${ }^{(75)}$ Meanwhile, at 1200, the $2 \mathrm{~d}$ search plane had spotted one Marblehead-class cruiser and one 5,000t-class transport ship sailing eastward at 10 nautical miles south of Sumbawa. The plane tailed them until 1230 and returned to the base at 1410 . However, the transmission of this sighting of the enemy did not reach the attack units, either. ${ }^{(75)}$

Twenty-three land-based attack planes of the Kanoya Air Group ([led by] Lieutenant Commander Irisa) took off from Kendari at 0815 along with the eight land-based attack planes of the Takao Air Group ([led by] Lieutenant Yokomizo) and in concert with the search unit headed for an attack on the enemy fleet. However, unable to detect enemy movements, [both] units reversed course at 1200 and headed for the Jimbaran airfield on Bali. After bombing the airfield from 1228 till 1249 (there were one large, seven mid-sized and ten small aircraft on the ground) and reporting having damaged three mid-sized aircraft, which had been set ablaze, and destroying three mid-sized and four small aircraft, all returned to the Kendari airfield without damage. ${ }^{(71)}$ Meanwhile, twenty-three land-based attack planes of the 1st Air Group ([led by] Lieutenant Commander Ozaki) took off from Kendari at 0835 and spotted one Marblehead-class [cruiser] and one transport ship sailing eastward at a point ten nautical miles south of Sumbawa at 1220. From 1300 through 1350, the unit bombed the enemy at a low altitude (900 - 1,500 meters) despite fierce enemy defensive fire, bad weather and treacherous air currents. However in the end, due to the treacherous air currents, the unit could not score direct hits on the enemy. In this attack, the right engine of the plane of the commander stalled due to enemy hits, and he had to fly back to base on only one engine. Although seven other planes were [also] hit, all aircraft returned to Kendari by 1845.(71)

On the 6th, a search and attack mission was conducted with as many as fifty-three landbased attack planes, but in the end they failed to spot the enemy fleet. On that day at 1600, [the Navy Department of] IGHQ made the following announcement:(109)

During [the mission to] search for the enemy fleet on 4 February, following the air operation to destroy the air forces of the Dutch East Indies on the previous day, the air unit of the Imperial Japanese Navy spotted the main force of the enemy fleet accompanied by several destroyers on the waters thirty nautical miles south of the Kangean Islands in the Java Sea. Without missing an opportunity, the unit fiercely attacked [the enemy fleet], and during an engagement of several hours, it instantly sank one enemy cruiser of the Dutch Java-class and seriously damaged the Dutch cruiser De Ruyter, which sank before long; it [also] caused some damage to one Dutch Java-class cruiser as well as one U.S. Marblehead-class cruiser, and sank one enemy 5,000t-class ship. In this sea engagement, the enemy fleet, which had been operating in the western Pacific 
from the opening of hostilities, the main force of the Dutch East Indies fleet in particular, has in effect been virtually destroyed. In this sea engagement, we lost one aircraft.

(NB: This sea engagement shall be called the Sea Engagement off Java.)

\section{A Review of the Course of the Engagement}

By comparing the Japanese materials ${ }^{(71,81)}$ with The Rising Sun in the Pacific [(History of the United States Naval Operation in WWII), pp. 298-303] by [Samuel] Morison, the course of events in the engagement may be reconstructed as follows:*

On 3 February, the enemy fleet had assembled in the Banda** anchorage at Madura Island. The forces consisted of the Dutch light cruiser HNLMS De Ruyter, the U.S. heavy cruiser USS Houston, the U.S. light cruiser USS Marblehead, the Dutch light cruiser HNLMS Tromp, the U.S. destroyer USS Stewart, the U.S. destroyer USS [John D.] Edwards, the U.S. destroyer USS Barker, the U.S. destroyer USS Bulmer, the U.S. destroyer USS Paul Jones, the U.S. destroyer USS Pillsbury, the U.S. destroyer USS Whipple, the U.S. Oiler USS Pecos, and a Dutch destroyer unit. [Editor's note: According to Dutch sources, the last four mentioned ships were not present. The Dutch destroyers were HNLMS Banckert, HNLMS Piet Hein, and HNLMS Van Ghent.]

At 0130 on 4 February, the Dutch commander, Rear Admiral Doorman, left the Bundan anchorage, leading a combined striking force in order to intercept the Japanese units that were about to advance into the Makassar Strait to seize either Makassar or Banjarmasin (they were then assembling at Kendari). The force headed for the Makassar Strait with the flagship HNLMS De Ruyter in the lead, followed by the USS Houston, the USS Marblehead, the HNLMS Tromp in that order, and guarded by four U.S. destroyers on the flanks, as well as by four [three] Dutch destroyers at the rear.

Since Rear Admiral Doorman had sent out a warning at 1105 that thirty-seven [Japanese] land-based attack planes were heading for Surabaya, the USS Marblehead dumped more than 4,000 gallons of aviation gasoline that was stacked on the deck into the sea. At 1115, the landbased attack plane unit of the Kanoya Air Group and the Takao Air Group spotted the U.S.Dutch fleet at thirty nautical miles south of the Kangean Islands. At 1120, Lieutenant Commander Irisa, commander of the attack unit gave the order to attack, and the attack planes in formations of nine planes each and at an altitude of 4,000 meters and a speed of 150 knots entered upon a bombing course aimed at HNLMS De Ruyter and USS Houston. At the first try, they lost the opportunity to drop bombs due to the high-speed evasive movements [of the enemy ships] and they flew over the ships. On the second try they again flew over. Then, on the third try, they attacked from 1129 till 1149, but [still] could not damage the fleet. (Note: Although the Morita Squadron reported sinking USS Houston, and the Tanaka Squadron half-damaging USS Marblehead, and the Irisa Squadron half-damaging HNLMS De Ruyter, Morison's The Rising Sun in the Pacific has no record of any bomb damage.) During that attack, one of the land-based attack planes of the Takao Air Group was hit by antiaircraft fire from the USS Marblehead and crashed itself.

\footnotetext{
* The author does not make a clear distinction between the passages from Morison which he summarizes and those which he quotes directly. Here the directly quoted passages are given as in the original and put within quotation marks.

** Morison has Bunda. Dutch sources only mention that the fleet was assembled at the Gili Islands off the southeast coast of Madura. Bunda should probably read as Bundan, a place on the island of Giligentis.
} 
At 1157 in the second attack, the Tanaka Squadron bombed the USS Marblehead from the [port] quarter. Fourteen 250-kg bombs were dropped over the target scoring two direct and four near hits. One of the direct hits "crashed through the starboard motor launch, pierced the deck, and exploded below, wiping out the sick bay, demolishing the wardroom and nearby cabins, and blowing a 6-foot hole in the deck. Fires broke out all over the stricken section." Another direct hit at the stern pierced "the main deck and exploded in the hand-steering compartment." With this [explosion], "all living quarters in that part of the ship were gutted and leaks started." Although the fires in the after part were extinguished soon, "the rudder jammed hard left and the ship started steaming in circles with a 10-degree list to starboard." The attack caused a loss of "15 killed or mortally wounded, and 34, including the executive officer" injured. Furthermore, the bow was also damaged by a near hit.

At 1240, the 1st Air Group unit attacked HNLMS De Ruyter (reporting a military gain of sinking the ship). [According to Morison, only] "her antiaircraft fire control [was] knocked out" and disabled in this attack. In the last of four attacks, the 1st Air Group unit scored a direct hit on the USS Houston. The 250-kg bomb "exploded on her main deck, [and] killed some fifty men." The shrapnel of the bomb which "knocked out the after gun turret," "pierced the turret in a hundred places and set fire to the powder" and blew up the turret. The crew of the turret and "turret 3, except for two men, were all burned to death." [The author seems to think that the "after gun turret" and "turret 3" were different turrets. In fact, they are the same turret.] The damage sustained in this engagement by both sides was as follows:

$\begin{array}{ll}\text { HNLMS De Ruyter: } & \begin{array}{l}\text { Serious damage to her antiaircraft fire control system (attacked by the } \\ \text { 1st Air Gp) }\end{array} \\ \text { USS Houston: } & \begin{array}{l}\text { Serious damage to her after gun turret (attacked by the 1st Air Gp) } \\ \text { USS Marblehead: }\end{array} \\ \text { Fires at the fore part; damage to the bow; rudder trouble (attacked by } \\ \text { Kanoya Air Gp) }\end{array}$

In this sea engagement, no torpedo attacks were conducted due to various reasons; in reality the Navy was not able to sink even a single ship. The allied fleet repaired to Cilacap on 8 February. Since her after gun turret was destroyed, USS Houston was assigned for the time being to escort important convoys between Port Darwin and Timor. Meanwhile, after having her bottom temporarily repaired at Cilacap and after a further temporary repair at Ceylon, USS Marblehead sailed westward to enter on 5 April the U.S. Naval dockyard in Brooklyn (southeast of New York).

\section{Related Operations}

The major related operations conducted from 1 February onwards from the Kendari and the Balikpapan bases were [in summary] as follows. ${ }^{(71)}$ (The Ambon operation has been previously described.) 


\begin{tabular}{|c|c|c|}
\hline & Kendari Base & Balikpapan Base \\
\hline 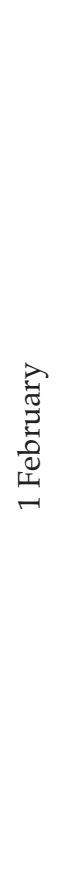 & $\begin{array}{l}\text { - Eight land-based attack planes of the } \\
\text { Kanoya Air Gp and one Type-0 fighter } \\
\text { plane of the 2d Carrier Div carried out an } \\
\text { attack on Kupang, destroying one [enemy] } \\
\text { 10,000t-class merchantman; no enemy air- } \\
\text { craft was spotted either in the air or on the } \\
\text { ground. } \\
\text { - Nine land-based attack planes of the } \\
\text { Kanoya Air Gp and six Type-0 fighter } \\
\text { planes of the 2d Carrier Div carried out an } \\
\text { attack on Waingapu (Sumba Island); no } \\
\text { enemy [aircraft] was spotted either in the } \\
\text { air or on the ground. The unit bombed one } \\
\text { warehouse, which caught flames, but there } \\
\text { were no signs of use [by the enemy] at the } \\
\text { airfields in Waingapu, Seba (Savu Island), } \\
\text { and Reo (Flores Island). } \\
\text { - Two carrier-based bombers of the 2d Car- } \\
\text { rier Div carried out a reconnaissance } \\
\text { around the Makassar area, but no enemy } \\
\text { aircraft or naval vessels were seen. }\end{array}$ & $\begin{array}{l}\text { - Three carrier-based bombers of the } 2 \mathrm{~d} \text { Car- } \\
\text { rier Div searched for enemy naval vessels. } \\
\text { They spotted two submarines afloat, and re- } \\
\text { ported sinking one of them. } \\
\text { - Nine carrier-based bombers of the division } \\
\text { carried out an attack on [enemy] sub- } \\
\text { marines, and reported sinking one [enemy] } \\
\text { submarine sailing with its conning tower } \\
\text { above the water. }\end{array}$ \\
\hline $\begin{array}{l}\hat{0} \\
\overrightarrow{0} \\
0 \\
0 \\
0 \\
+\end{array}$ & $\begin{array}{l}\text { - Seven carrier-based bombers and one Type- } \\
0 \text { fighter plane of the } 2 \mathrm{~d} \text { Carrier Div and } \\
\text { one land-based attack plane of the Takao } \\
\text { Air Gp carried out an attack on a transport } \\
\text { ship (accompanied by two gunboats, which } \\
\text { were spotted by the attack unit of the } 1 \mathrm{st} \\
\text { Air Gp; two direct hits of (60kg) bombs on } \\
\text { the ship set her ablaze, while one near hit } \\
\text { on each of the two gunboats were deliv- } \\
\text { ered. }\end{array}$ & \\
\hline
\end{tabular}

\section{A Change in Deployment}

Having destroyed the bulk of the enemy aircraft in the Surabaya area with the first and second attacks of Operation $\mathrm{Z}$ and having destroyed the main force of the allied surface units in the Java area in the sea engagement off Java, the air units continued their reconnaissance and search for the enemy in the Surabaya area, but because few enemy aircraft or naval vessels were spotted, they returned to phase-two dispositions from the 6th onwards. ${ }^{(75)}$ However, since it was necessary that the $2 \mathrm{~d}$ Air Raid Unit, whose current number of fighter planes was inadequate, should from then on for a long period continue [the operation] to neutralize the enemy air forces in the Java area, nine fighter planes of the 3d Air Group of the 1st Air Raid Unit were incorporated in the $2 d$ Air Raid Unit, while, due to the capacity of the Balikpapan base, one element of the land-based attack planes of the Takao Air Group was kept in Kendari 
to be brought under the command of the 1st Air Raid Unit commander. ${ }^{(81)}$ Also on 4 February, seventeen carrier-based bombers and eighteen Type- 0 fighter planes of the unit dispatched by the $2 \mathrm{~d}$ Carrier Division, which had been incorporated to the 1st and the $2 \mathrm{~d}$ Air Raid Units to carry out operations until the end of the Ambon operation, were withdrawn from Kendari and Balikpapan to Davao. ${ }^{(75)}$

\section{The Capture of Makassar (See Illustrations No. 25 and No. 26)}

As previously told, the following had been decided at the Manila Conference:(54)

1. [The operation to] seize Banjarmasin by sea shall be cancelled; the city shall be seized overland by the Army Sakaguchi Detachment as quickly as possible. As for the air base to be used for the air campaign against eastern Java, the air base on Bali Island shall be captured by the Army and the Navy in conjunction around 21 February (two days before the landing on eastern Java).

2. Makassar shall be seized single-handedly by the Navy on 9 February (Day X +63 ).

This [agreement] meant that the plan conceived by the Navy would be implemented, i.e. that the air campaign to destroy the enemy air power in eastern Java before the Java landing operation should be conducted with Balikpapan and Makassar as the front line bases on the north and the east, and that after seizing Bali right before the landing in eastern Java, one element of the air unit should be pushed forward to the island to provide cover for the Java landing [operation] as well as to cut off the enemy from the rear.

\section{Preparations for the Operation}

On 24 January, Dutch East Indies Unit Commander Vice Admiral Takahashi announced the main points of the implementation of the operation to seize Makassar by Dutch East Indies Unit Order No. 9, the outline of which is as follows. ${ }^{(54,68,72,78)}$ This operation was planned to be carried out after the enemy air power in the Java area had been neutralized.

1. Forces employed for the invasion (Commander: 1st Base Force Commander Rear Admiral Kubo) Bulk of the 1st Base Force, the 21st Destroyer Division, one destroyer division of the $2 \mathrm{~d}$ Destroyer Squadron, bulk of the Sasebo Combined Special Landing Force, 3d Construction Squad*

2. Support Units

The $2 \mathrm{~d}$ Air Unit (the 11th Seaplane Tender Division as the core)

3. Outline of the operation

(1) The units of the 1st Base Force, which are engaged in [the operation to] seize Kendari, shall successively return to the Bangka anchorage after the completion of the operation.

(2) One destroyer division of the 2d Destroyer Squadron, the 21st Minesweeper Division and the 1st Subchaser Division shall return to the Bangka anchorage when the Ambon operation is for the most part completed.

(3) After assembling at the Bangka anchorage, the unit to seize Makassar shall depart on 5 February, sail westward on the Celebes Sea, turn southward into the Makassar Strait, and seize Makassar on 9 February.

(4) When the Ambon operation is for the most part completed, the $2 \mathrm{~d}$ Air Unit shall return to the Bangka anchorage and support the Makassar operation.

* According to pp. 249, 381, 5th and 6th Construction Squads. 


\section{Others}

Among the forces of the 1st Base Force, two minesweepers of the 21st Minesweeper Division and the Myōko-maru shall return to Cam Ranh Bay by 10 February to be incorporated into the $3 \mathrm{~d}$ Escort Unit to participate in the Batavia landing operation.

Then on 28 January, the 7th Destroyer Division (which had accompanied the 2d Carrier Division) was added to reinforce the Dutch East Indies Unit. The Dutch East Indies Unit Commander Vice Admiral Takahashi decided to assign this division to [the forces] for the Ambon area and reassign another destroyer division currently assigned for the Ambon [operation] to [the operation to] seize Makassar, making the destroyer divisions [for the Makassar operation] two in total. On the 29th, he notified the 2d Destroyer Squadron commander that after the seizure of Ambon, the 8th and the 15th Destroyer Divisions, the 21st Minesweeper Division and the 1st Subchaser Division should come under the command of the 1st Base Force commander and participate in [the operation to] seize Makassar. ${ }^{(54)}$

Originally, [the operation to] seize Makassar had been planned in such a way that [the ships] would sail from the Bangka [anchorage] around the west of Celebes to attack the city. However, the movements of the enemy since the time of the launch of [the operations to] seize Balikpapan and Kendari on 21 January had created a situation where compared to the Balikpapan area where the counterattacks were intense, from counterattacks by submarines to night attacks by surface vessels as well as air raids, there were almost no counterattacks in the Kendari area. Therefore, on 28 January, Dutch East Indies Unit Commander Vice Admiral Takahashi decided to conduct [the operation to] seize Makassar by sailing around the east and south of Celebes, ${ }^{(78)}$ which also made it easier to divert forces from the Ambon operation [to the Makassar operation].

Judging that the diversion of forces [from the Ambon operation] would become easier [by sailing around the south of Celebes], Dutch East Indies Unit Commander Vice Admiral Takahashi contacted, after receiving the report of the success of the Ambon landing operation on 31 January, Eastern Attack Unit Commander Rear Admiral Takagi about advancing [the operation to] seize Makassar by one or two days. ${ }^{(78)}$ The Eastern Attack Unit commander replied that it was feasible to move up the operation by one day and started to move up the operation from the $2 \mathrm{~d}$ onwards, setting the date of the landing on Makassar on 8 February. ${ }^{(54)}$ However, after that and contrary to their expectations, the ground operations as well as the minesweeping operations in the Ambon area got delayed and it was getting impossible to divert the forces one day earlier. On 2 February, the Dutch East Indies Unit Commander changed the date of the Makassar operation [again] to the 9th as originally scheduled. ${ }^{(78)}$ Also, in view of the hard fight experienced by the 1st Kure Special Landing Force on Ambon, the Dutch East Indies Unit commander gave up [the idea to] have the Chitose participate in the Makassar operation and decided to deploy only the Mizuho in that operation. Following this decision and in order to make up for the shortage of reconnaissance seaplanes, it was decided to have the reconnaissance seaplane unit of the Sanuki-maru, which was then in Balikpapan (due to the damage she had sustained in the [enemy] air strike on 27 January), support the [Makassar operation]. ${ }^{(54)}$

Then, as a result of the (previously mentioned) sinking of Minesweeper No. 9 and the accidents, which crippled Minesweepers Nos. 11 and 12 on the afternoon of 2 February in the bay of Ambon, Dutch East Indies Unit Commander Vice Admiral Takahashi judged it impossible to dispatch one element of the 21st Minesweeper Division to Cam Ranh Bay (i.e. he 
had planned to have two of the minesweepers participate in the operation to invade western Java). On the 3d, he decided to incorporate two torpedo boats of the 21st Torpedo Boat Division of the $2 \mathrm{~d}$ Base Force into the $3 \mathrm{~d}$ Escort Unit (the western Java invasion unit) to replace those minesweepers. ${ }^{(54)}$ On 4 February, the Dutch East Indies commander also decided to bring in the minesweeper division of the $2 \mathrm{~d}$ Base Force and the destroyers of the 4 th Destroyer Squadron, which had been [temporarily] brought under the command of the 2d Base Force and stationed in Balikpapan, in order to make up for the shortage of minesweepers and also to support the Makassar operation unit. This unit had been scheduled to arrive in Jolo around the 13th or the 14th to provide escort for the eastern Java landing unit. ${ }^{(56)}$ (Fourth Destroyer Squadron Commander Rear Admiral Nishimura had already left Balikpapan on 30 January, leading the Naka and the $2 \mathrm{~d}$ Destroyer Division, heading for Lingayen Gulf to prepare for the Java invasion operation.)

\section{Plan of Operations, etc.}

\section{Assessment of the Enemy Movements Centering on Makassar}

The assessment of the enemy movements by the Makassar invasion unit around 5 February when the unit had assembled in Kendari was by and large as follows: ${ }^{(54,78)}$

1. The [enemy] air power in eastern Java has suffered a major loss through the air campaign of our land-based air units from Kendari and Balikpapan in early February.

2. The enemy air power in the Kupang area has been pushed toward western Java and Port Darwin because of our daily air attacks conducted from the bases in Ambon and Kendari; [the enemy power in] the Dutch East Indies is being divided by our air campaign to neutralize their power.

3. Since our land-based air units' attack on the main force of the enemy combined fleet to the east of the Madura Strait on 4 February, we have not seen powerful enemy surface naval vessels operate on the Java Sea east of Surabaya.

4. Enemy submarines frequently appear in the Makassar Strait area. Despite the clearing operations, which were carried out several times, they are still rampant; it is quite dangerous for lowspeed convoys to sail the strait.

5. It seems that one or two enemy submarines are constantly deployed in the Kendari area as well as at the entrance of Staring Bay to keep an eye on our units coming and going, while seeking an opportunity to make a surprise attack.

6. Before the opening of hostilities, the [enemy] strength on the ground around Makassar was reported to be about 1,500 men, but thereafter it is unclear.

\section{The Plan of Operations of the 1st Base Unit}

On 1 February, 1st Base Unit Commander Rear Admiral Kubo announced the plan of operations of the unit by Signal Order No. $6{ }^{(110)}$ a summary of which is as follows:

1. Outline of the advance toward Kendari

(1) Distribution of units

$\{1\}$ Main unit (directly led by the 1st Base Force commander): the Nagara

\{2\} 1st Echelon (led by the 21st Destroyer Division commander): the 21st Destroyer Division (minus the Hatsuharu), the Hokuriku-maru, the Nankai-maru, the Kinai-maru (the above [three] carrying the main force of the Sasebo Combined Special Landing Force) 
\{3\} 2d Echelon (led by the captain of the Tsukushi): the Tsukushi, the Aotaka, the Ikushimamaru, Submarine Chasers No. 3 and No. 14, Patrol Boats No. 1 and No. 2, the Matsuémaru, the Montevideo-maru, the Yamashimo-maru, (the above [three] carrying the 5th and the 6th Construction Squads), the San Clemente-maru (supply ship for the operation unit)

(2) Main points of the operation

$\{1\}$ The 1 st and the $2 \mathrm{~d}$ Echelons shall depart [from the Bangka anchorage] at 0800 on 2 February, and pass the Greyhound Strait (west of the Sula Islands) with each echelon in a group. They shall advance to Kendari on the morning of 4 February.

\{2\} The main unit (the Nagara) shall leave the Bangka [anchorage] at 1600 on 2 February and arrive at Kendari early in the morning on 4 February.

2. Distribution of forces (omitted by the author)

3. Actions of the units

(1) Transport Convoy

It shall leave Kendari (Staring Bay) around 2100 on the 6th of February, and enter the anchorage of Makassar around 0000 on the 9th, via Buton Channel and the channel to the south of Selayar Island.

(2) Main Unit

It shall depart from Kendari almost at the same time as the transport convoy and take charge of clearing the route ahead of the convoy while supporting it.

(3) Supply unit (omitted)

(4) The entry into the anchorage and the guarding (omitted)

4. Others (omitted)

\section{The Plan of Operations of the Sasebo Combined Special Landing Force ${ }^{(68)}$}

1. Assault Unit ([consisting of] about two and a half companies of the $2 \mathrm{~d}$ Sasebo Special Landing Force)

The unit shall embark in Patrol Boats Nos. 1 and 2, go ashore at the coast of Aeng Batu Batu ahead of the main force, rapidly advance and promptly secure the bridge over the [Jene]berang River, a strategic point, which leads to the airfield as well as to the urban area of Makassar. After that, as the advance guard of the main force, it shall advance toward the Maros airfield and seize it.

2. Main Unit ([consisting of] the Sasebo Combined Special Landing Force headquarters unit, the $2 \mathrm{~d}$ Sasebo Special Landing Force (minus three companies), one company of the 1st Sasebo Special Landing Force)

The unit shall land at the coast of Aeng Batu Batu in the wake of the assault unit; while covering the advance of the assault unit, it shall seize the Maros airfield.

3. Detached Unit ([consisting of] the 1st Sasebo Special Landing Force (minus one and a half company))

The unit shall land along with the main unit. After crossing the [Jene]berang River, it shall head for the Sungguminasa area. [From there,] it shall charge into the urban area of Makassar, seize it and clear it of the enemy.

4. Afterwards, the force shall be assigned to mop up the enemy in Makassar and vicinity and guard the area.

\section{The Plan of Operations of the 2d Air Unit}

Only the Mizuho had been scheduled to participate in the Makassar operation. However, after the occupation of the Laha airfield by the 1st Kure Special Landing force at 0630 on 3 February, it became no longer necessary to keep the Chitose, the flagship of the 11th Seaplane 
Tender Division, at Ambon until the 9th. Thus, the plan was changed so that the 11th Seaplane Tender Division should participate in the Makassar operation with its entire force. The plan after the change was as follows:

The Mizuho, Patrol Boat No. 39 and three cutters shall head for Kendari, leaving the Kelang anchorage at 1500 on the $3 \mathrm{~d}$, while the flagship Chitose, Patrol Boats No. 34 and No. 38 shall stay engaged in the Ambon operation until the 6th of February. They shall leave Piru Bay and reach a point south of Selayar Island around the sunset of the 6th. At 0700 on the 8 th, they shall join the Mizuho at a point southeast of Selayar Island, to be in charge of the direct escort of the convoy, the guarding against enemy submarines and aircraft as well as the guarding of the anchorage.

\section{The Plan of Operations of the Land-Based Air Units}

First Air Raid Unit Commander Rear Admiral Tada's plan to support the Makassar operations was in outline as follows: ${ }^{(81)}$

1. During the advance from the Bangka anchorage to Kendari (2-4 February), the patrol for the Makassar invasion unit against enemy submarines shall be carried out from the Kema base (Menado) as designated by the Tōkō Air Group commander.

2. The guard against enemy aircraft and submarines at Kendari (Staring Bay) shall be provided during the 4 th and the 6 th of February by Type-0 fighter planes of the $3 \mathrm{~d}$ Air Group and Type0 fighter planes and carrier-based bombers of the unit dispatched from the $2 \mathrm{~d}$ Carrier Division, as designated by the $3 \mathrm{~d}$ Air Group commander.

3. Orders for the subsequent operations shall be given later.

\section{The Launch of the Operation}

\section{Neutralization of the Enemy Air Power and the Sailing of the Convoy}

On 17 January, the 1st Air Raid Unit had launched a covert reconnaissance of Makassar from Menado with one land-based reconnaissance plane of the 3d Air Group, while on 20 January the $2 \mathrm{~d}$ Air Raid Unit had launched its reconnaissance of Makassar from Tarakan with one land-based reconnaissance plane of the Tainan Air Group. ${ }^{(71)}$ After that, land-based reconnaissance planes and Type-0 fighter planes of the Tainan Air Group and the $3 \mathrm{~d}$ Air Group as well as carrier-based bombers of the $2 \mathrm{~d}$ Carrier Division carried out reconnaissance attacks on Makassar, while flying boats of the Tōkō Air Group provided guard against enemy submarines for the convoy heading for Kendari, and the $2 \mathrm{~d}$ Carrier Division and Type-0 fighter planes of the $3 \mathrm{~d}$ Air Group patrolled the air above the Kendari anchorage. The enemy was hardly seen during this period, and along with the results of Operation Z, it was concluded that the Japanese forces had largely secured command of the air in that area.

The damage to the flagship of the 1st Base Unit Nagara, caused by the previously mentioned collision with the Hatsuharu off Kendari* [p. 202], was being repaired by the repair ship Akashi at Davao from 27 January onwards and was completed on 1 February. The Nagara immediately left Davao and arrived at the Bangka anchorage at 1600 on 2 [February]. ${ }^{(59)}$ In the meantime, the 21st Destroyer Division (Wakaba and Nenohi), which had escorted the damaged Hatsuharu to Davao [and arrived there] on the 29th of January, departed from Davao on the next day, the 30th, leaving the Hatsuharu in Davao for repair, and arrived in the Bangka

* The text mistakenly has Balikpapan. 
anchorage on the 31st. ${ }^{(59)}$ As for the unit that had seized Kendari, the first batch of units withdrawn [from Kendari] and the Hatsushimo ([of] the 21st Destroyer Division) with 1st Base Force Commander Rear Admiral Kubo on board had returned to the Bangka anchorage on the 29th, which was followed by the second batch on the 1st of February. ${ }^{(59)}$

At 0800 on 2 February, the Makassar invasion unit left the Bangka anchorage and headed for Kendari, scheduled to sortie from Kendari on the 5th and land in Makassar on the 8th. ${ }^{(110)}$ As previously told, after its departure from the anchorage, the operation to seize Makassar was postponed for one day, and [accordingly] the departure from Kendari was changed to 6 February. The 1st Echelon arrived at Staring Bay (a bay to the east of Kendari) around 2230 on the $3 \mathrm{~d}$, the Nagara at 0330 on the 4 th, and the $2 \mathrm{~d}$ Echelon around 0600 on the same day. ${ }^{(59,110)}$ As for the units diverted from Ambon, the Mizuho and Patrol Boat No. 39 arrived in Staring Bay on the evening of the 4th, the 15th Destroyer Division at 2030 on the 4th, the 21st Minesweeper Division and the 1st Subchaser Division early in the morning on the 5th, and the 8th Destroyer Division on the morning of the 5th. Also, Submarine chaser No. 14, which had left the Bangka [anchorage] on 3 February, arrived at the bay on the afternoon of the 5th. This completed the advance to Kendari of the whole force of the Makassar invasion unit. ${ }^{(59,68)}$

From the 4th onwards, while replenishing supplies at Staring Bay by mooring one ship after another alongside the San Clemente-maru, the unit had ample discussions about the operation until the sortie on the 6th. ${ }^{(93)}$ During that time, at 1830 on the evening of the 4 th, the Suzukaze ([of] the 24th Destroyer Division [of] the main unit), came under a torpedo attack by an enemy submarine while patrolling outside Staring Bay. Hit by one enemy torpedo at her starboard bow, she sustained leaks in the fore boiler room and returned to the bay to have emergency repairs. ${ }^{(68)}$

On the evening of 6 February, the Makassar invasion unit sailed from Staring Bay. ${ }^{(68,93)}$ At 0140 on the 7th, the 15th and the 8th Destroyer Divisions, which sailed ahead, spotted a surfaced [enemy] submarine, but let her slip when she submerged. ${ }^{(93)}$ At 0845, the Michishio ([of] the 8th Destroyer Division), while clearing the route ahead, detected an enemy submarine, carried out an attack with antisubmarine depth charges and reported the result as confirmed. ${ }^{(68)}$

\section{The Natsushio Torpedoed; the Landing}

The convoy passed south of Selayar Island around noon on 8 February, changed course to the northwest to head toward the southwest of Celebes. ${ }^{(68)}$ Although it was partly sunny with a slight breeze from the northwest and a calm sea in the morning, the weather got worse as the convoy approached Makassar in the afternoon while visibility became poor. ${ }^{(93)}$ Around 1630 , out of concern about sailing with poor visibility as well as the guarding against the enemy whose movements were unknown, 1st Base Unit Commander Rear Admiral Kubo gave the following instructions to the units under his command [summary]:(110)

1. In order to confirm the position of the ships, commanders shall take such appropriate measures as detaching certain ships, etc.

2. Due to the poor visibility, some ships shall be sent ahead to guide the echelons. However, if visibility worsens, the measures to be taken are in outline as follows. 
(1) [The ships] shall enter [into the anchorage at Makassar] as far as is navigable, [temporarily] drop anchor and launch large-sized motorized [landing] craft, which shall further advance, guided by submarine chaser(s). The echelons shall follow the craft.

(2) Depending on the situation and if unavoidable, the landing point shall be changed to [a point further] south.

(3) When the circumstances make it inevitable, the landing shall be postponed for one day.

Troubled by poor visibility, the transport echelons managed toward sunset to reach the waters about fifteen nautical miles south of Tanakeke Island and changed formation to enter into the anchorage. At 2030, the echelons entered the depth zone of 200 meters or less, about ten nautical miles southwest of Tanakeke Island, and the 21st Minesweeper Division started sweeping mines on the route ahead. ${ }^{(68)}$ At 2210, the 1st Patrol Boat Division, which had sailed ahead, entered the planned anchorage, and the following convoy [also] changed course to the northeast and headed toward the port of Makassar under poor visibility and a drizzle that blanketed the surface of the sea. The ships kept exchanging signals and put on identification lights in order to maintain formation. During these moments, it seemed as if there was a total absence of alertness against the enemy. ${ }^{(93)}$ At 2215, the Natsushio, the 1st ship of the 15th Destroyer Division, which was following the echelon in its wake, was hit by a torpedo on her starboard quarter, flooding her engine room and crippling her. While she worked on stopping the flooding on the spot, the fellow destroyers Oyashio and Kuroshio provided guard on the waters nearby, but no enemy submarines were detected. ${ }^{(111)}$ Meanwhile, the first landing unit of the commando unit of the Sasebo Combined Special Landing Force, which had entered into the $2 \mathrm{~d}$ anchorage, made a successful landing on the coast of Aeng Batu Batu at $2340 .^{(110)}$

At 0800 on that day [8 February], the element of the 2d Base Unit stationed in Balikpapan but assigned to support the Makassar operation ([i.e.] the 1st Section of the 24th Destroyer Division, the 9th Destroyer Division (minus the Yamagumo), the 30th and the 11th Minesweeper Divisions and Patrol Boat No. 36) departed from the port of Balikpapan under the command of 2d Base Force Commander Rear Admiral Hirose (on board of the Natsugumo). It crossed the Makassar Strait, reached the waters off Cape William [Tanjung Rangas] on the west coast of Celebes around 2100, and headed for [the waters] off Makassar. At 2130, the Minegumo ([of] the 9th Destroyer Division) spotted a surfaced enemy submarine and attacked her with antisubmarine depth charges after illuminating and shelling her, results unconfirmed. ${ }^{(112)}$

On 9 February, the second landing unit of the commando unit of the Sasebo Combined Special Landing Force landed on [the coast] of Aeng Batu Batu around 0050, which was followed by the main unit of the Sasebo Combined Special Landing Force around 0340. ${ }^{(110)}$ The landing units reached the [Jene]berang River at 0400 and the Telo River at 0810, charged into the urban area of Makassar at 1130, completely seized the area at 1230, and seized the Maros airfield at $1900 .{ }^{(67,68)}$ The military gains of this land combat were seventy-seven abandoned bodies and eighty-five men taken prisoners, while the loss sustained [by the special landing force] was four killed and five injured. ${ }^{(67,68)}$

In the meantime, based on the judgment that the torpedoed Natsushio was not likely to sink, it was decided that the Kuroshio should tow the Natsushio to Kendari. ${ }^{(93)}$ From 0330 on the 9th, the Kuroshio began towing [the Natsushio] and started sailing, escorted by the Oyashio. However, after three hours of towing, the wind direction suddenly changed south of 


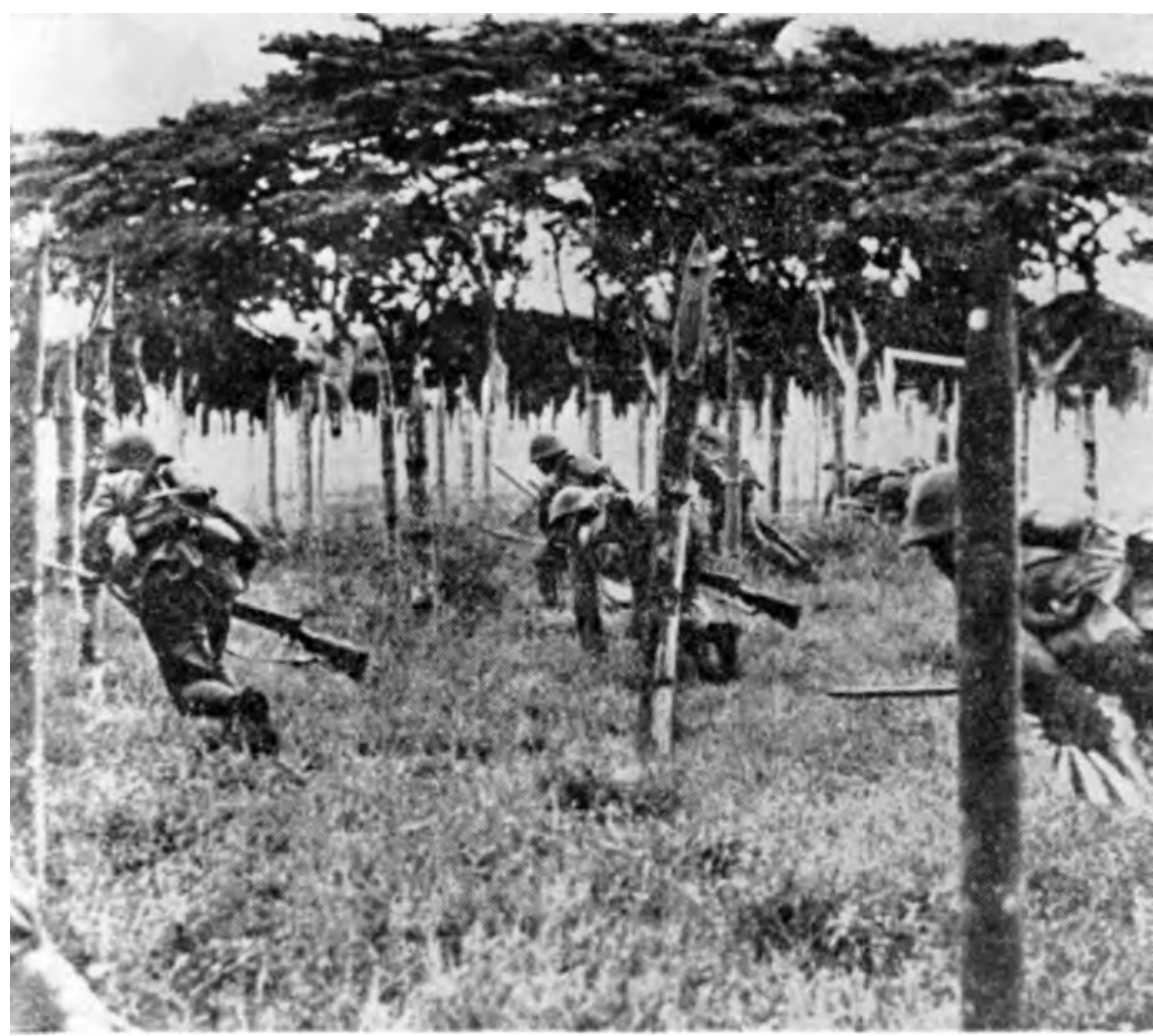

Japanese Special Landing Forces Rushing Forward, Picking Their Way Through the Bamboo Spears Set Up Against Paratroopers

Tanakeke Island, and at 0840 the Natsushio ended up sinking (with five men killed and six seriously injured). Cdr. (later Capt.) Nagai Sumitaka, [then] captain of the destroyer Natsushio, recalled that the failure of the towing was due to an overoptimistic judgment of the damage.

After rescuing the crew of the Natsushio, the 15th Destroyer Division (the Oyashio and the Kuroshio) reached their designated patrol area, while the 8th Destroyer Division departed for Jolo to provide escort for the Bali invasion unit, departing at 0600 on the 9 th as scheduled. Just after its departure, the 1st Section of the 24th Destroyer Division and the 9th Destroyer Divison (minus the Yamagumo) from the Balikpapan unit arrived and started to patrol the area. ${ }^{(68)}$ With no enemy attack on the anchorage, the disembarkation made smooth progress on the 9th. ${ }^{(68)}$

The Support Unit (the Nachi and the Haguro), which had left Davao at 1800 on 6 February, entered the Banda Sea via the Ceram Sea on the 8th and took charge of the support for the Makassar operation at 150 nautical miles southwest of Ambon. It discontinued the support operation on the evening of that day, judging that the operation was more or less completed, and entered Staring Bay at 1030 on 10 February.

\section{The Redeployment of the [Makassar] Invasion Units}

Judging that that operation was more or less completed after the seizure of the Maros airfield on the evening of the 9th, 1st Base Unit Commander Rear Admiral Kubo had the 15th De- 


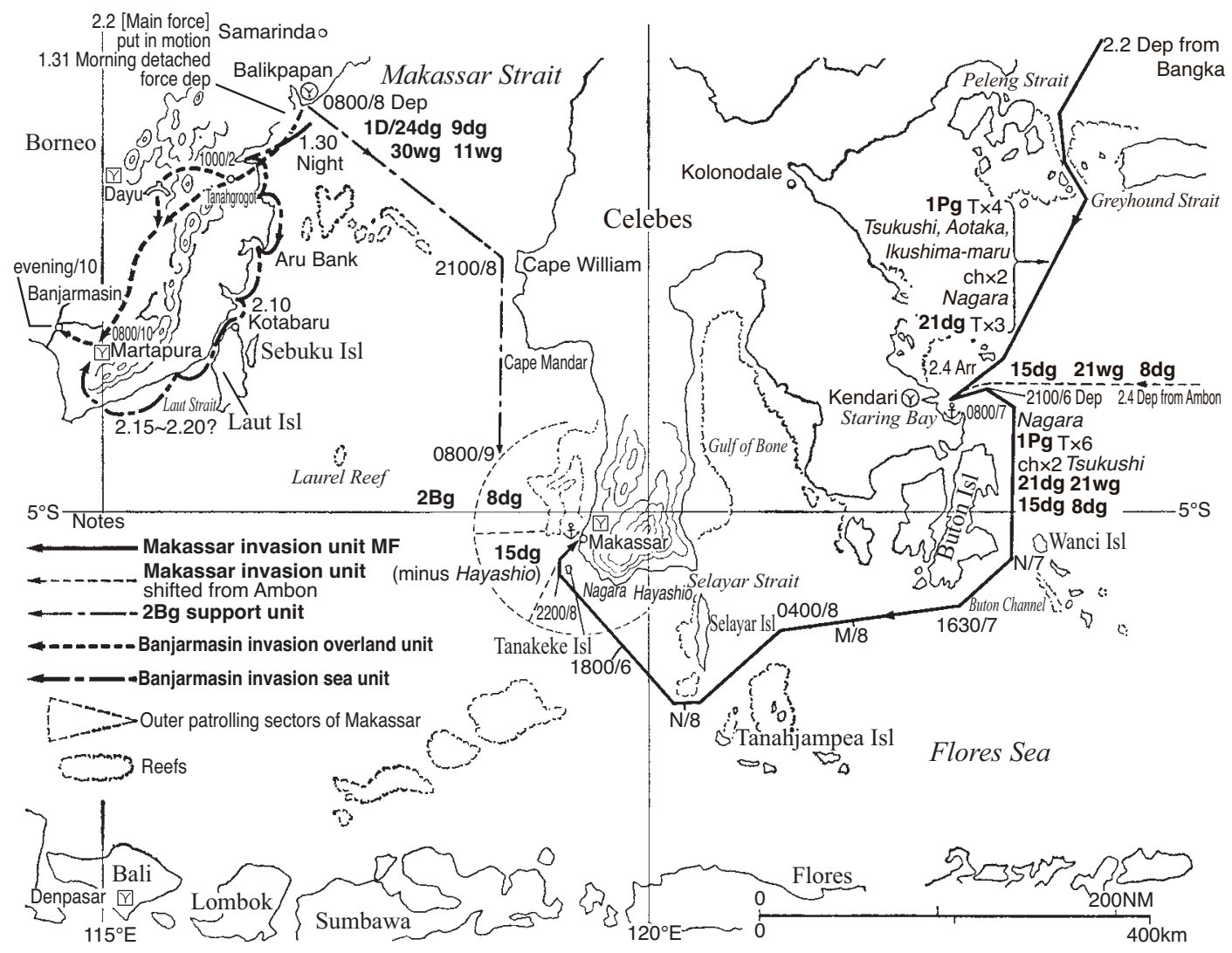

Illustration No. 25 - The Movements of the Units to Seize Makassar and Banjarmasin

stroyer Division (minus the Natsushio and the Hayashio) depart for Kendari at 0800 on the 10th in order to participate in the Kupang operation. ${ }^{(68)}$ The minesweeping of the anchorage [at Makassar] was carried out by the 21st, the 11th and the 30th Minesweeper Divisions, the 1st Patrol Boat Division, and the motor launches as well as the large-sized motorized [landing] craft of the [1st Base] Unit. However, no mines were snagged, and the transport ships shifted from the $2 \mathrm{~d}$ anchorage to that inside the port around $1600 .{ }^{(110)}$ After the minesweeping mission was completed, the 30th and the 11th Minesweeper Divisions returned to their original unit, while the destroyers of the $2 \mathrm{~d}$ Base Unit also discontinued their support and headed for Jolo one after another to cooperate in escorting the eastern Java invasion units. ${ }^{(112)}$

Although on 11 February the Sasebo Combined Special Landing Force was still mopping up the enemy in the neighborhood, it was decided that two platoons of the force should participate in the Kupang operation. They embarked on the ships of the 21st Minesweeper Division and the 1st Patrol Boat Division, both of which were also supposed to take part in the Kupang operation, and left Makassar at 0700 for Kendari. ${ }^{(59,}{ }^{110)}$ The Hayashio of the 15th Destroyer Division also left her patrol area at 1500 for Kendari to take part in the Kupang operation. At 1600, 1st Base Unit Commander Rear Admiral Kubo entered into the port of Makassar, leading the Nagara, and gave the necessary instructions and notifications. ${ }^{(68,78)}$

At 0600 on the 12th of February, the commander left Makassar on the Nagara, and returned to Staring Bay at 1700 on the 13th. ${ }^{(59)}$ In the meantime, the 21st Minesweeper Division, the 


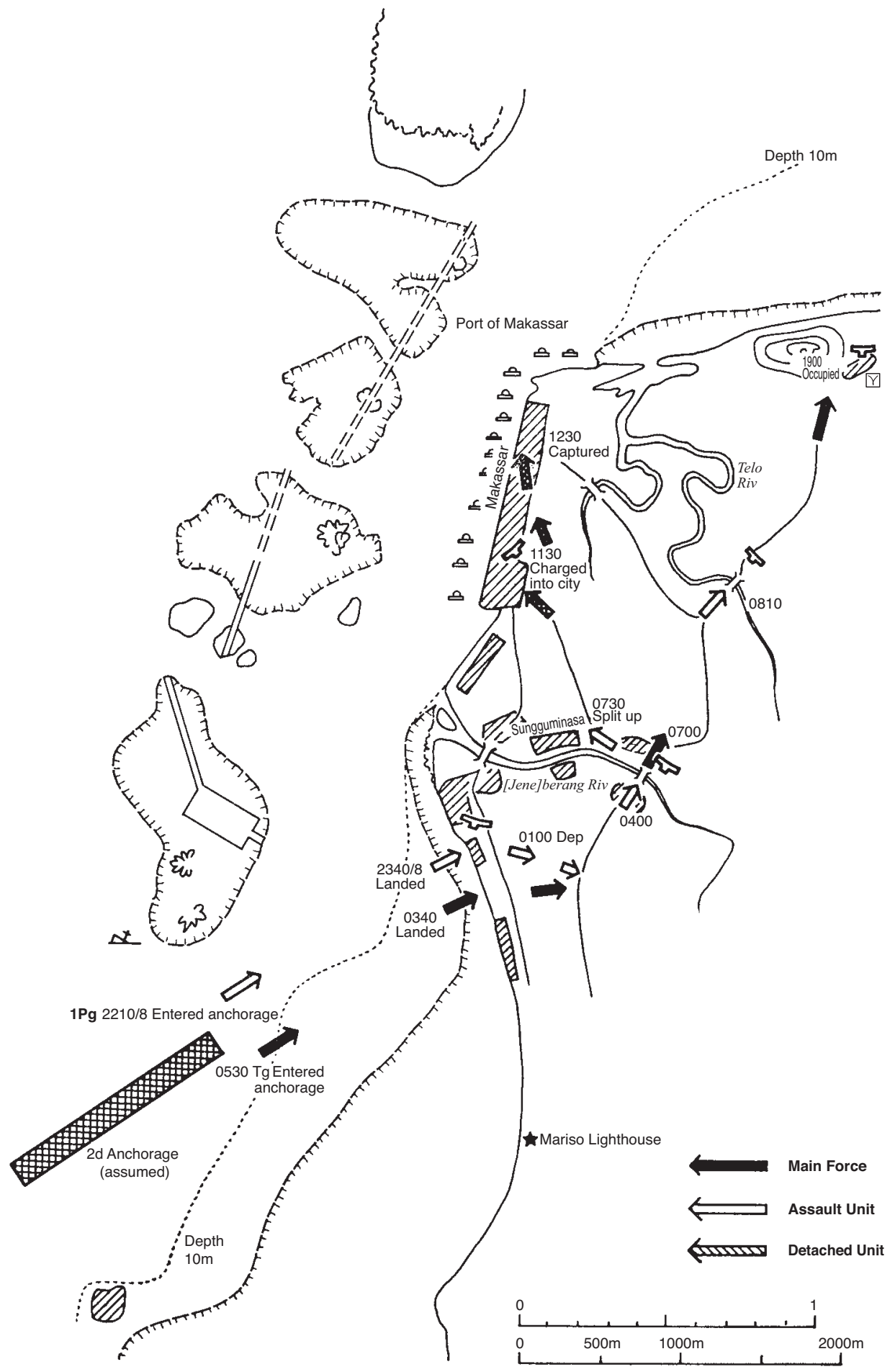

Illustration No. 26-The Operations of the Sasebo CombinedSpecial Landing Force in the Attack on Makassar 
1st Patrol Boat Division and the Hayashio, which had left Makassar earlier, returned to Staring Bay on the evening of the 12th, ${ }^{(59)}$ where the 1st Base Unit started on the preparations to capture Bali, while the others began their preparations to seize Kupang. ${ }^{(59)}$ Makassar was located at a distance of about 450 nautical miles from eastern Java, about 400 nautical miles from Kupang, and about 330 nautical miles from Bali, and [the seizure of] this [place] completed the network of air bases enveloping eastern Java.

\section{The Operations of the Air Units}

From the departure of the convoy until the completion of the capture operation, the 1st Air Raid Unit, the $2 \mathrm{~d}$ Air Unit and the Sanuki-maru were engaged in patrolling against enemy aircraft and submarines as well as patrolling the route ahead and the flanks of the sailing route, while searching for enemy in the vicinity and clearing the Makassar Strait of enemy submarines as well as supporting the land combat. [However,] except for a raid by enemy aircraft at 0340 on 10 February (causing no damage) on the tender ships of the $2 \mathrm{~d}$ Air Unit, which were conducting operations at anchor to the southwest of Bulunrue Island, no enemy was seen at all. ${ }^{(71,81)}$ At 1920 on the 10th, the Chitose, Patrol Boats No. 34 and No. 38 discontinued the operation and headed for Jolo to prepare for the subsequent eastern Java landing operation, ${ }^{(68)}$ while the Mizuho [also] left at 1900 on the 11th for Kendari along with Patrol Boat No. 39 and Submarine chaser No. 2, to prepare for the operation to capture Bali. ${ }^{(68)}$ Meanwhile on the 10th, the reconnaissance seaplane units of the Sanuki-maru advanced to the coast of Parepare ([near] Makassar) to be engaged in operations there. ${ }^{(76)}$ On the 15th, two Type-0 fighter planes of the 3d Air Group advanced to Makassar from Kendari for the first time, which was followed by seven on the 17th ([no advance was made] on the 16th due to bad weather.) $)^{(71)}$

Conversely, the allied forces were thrown in total confusion by the Japanese air attacks (Operation Z) from 3 to 5 February. Although U.S. submarine S-37, being deployed outside the port of Makassar, retaliated by sinking the Natsushio, no other air or naval counterattacks were made. Even on land, after some resistance put up by a garrison consisting of merely two companies, the strategic point Makassar was given up. ${ }^{(85,86,113)}$

\section{The Seizure of Banjarmasin (See Illustration No. 25)}

[See also Vol. 3, pp. 391-394]

On 25 January, after having returned to Gaoxiong from the Manila Conference, Sixteenth Army Commander Lieutenant General Imamura, conform to the arrangements made at the conference, issued the order to seize Banjarmasin overland. In line with this order, Detachment Commander Sakaguchi drew up the following outline of the operation to seize Banjarmasin: ${ }^{(88,99)}$ (Summary)

\section{Forces employed for the invasion operation}

Commander: 146th Infantry Regiment Commander Col. Yamamoto Kyōhei

Strength of the overland task force: one infantry battalion, one artillery battery, and one engineer company as the core

Strength of the seaborne task force: one infantry company, one engineer platoon and one independent engineer platoon as the core 


\section{Outline of the operation}

(1) Overland operation

[The unit shall] leave Balikpapan in the evening of 30 January, go ashore near Tanahgrogot at dawn on the 31st, and push through the jungle-covered Meratus mountains into the plain of Banjarmasin, from where the unit shall rapidly advance and seize the Martapura airfield as well as the urban area of Banjarmasin.

(2) Seaborne operation

The unit shall leave Balikpapan at night on 30 January in large- and small-sized motorized [landing] craft. By day it shall hide in inlets along the coast under the dense forest to conceal its movements. Only at night it shall maneuver ahead and via Tanahgrogot, Pamukan, Kotabaru, and Laut Strait, land on the coast southeast of Martapura to seize the airfield there. On its way, it shall conduct a night raid on Kotabaru [on Laut Island] to obtain military supplies and gather information.

(3) Cooperation by the Naval units

\{1\} The Navy 2d Base Unit shall dispatch one pilot officer to the seaborne task force.

$\{2\}$ Aviation fuel and ammunition as well as a skeleton crew for preparing the airfield shall be dispatched by the Eleventh Air Fleet and transported to Banjarmasin by sea in fishing boats. One element of the fishing boats shall accompany the seaborne task force.

On 30 January, the [Army] seaborne task force left Balikpapan in four large- and two smallsized motorized [landing] craft as well as well as in fishing boats (the number of the latter is unknown) along with one element of the naval units. The force reached Adang Bay at dawn on the 31st. Then via Apar Besar Bay, Pamukan Bay and Klumpang Bay, it seized Kotabaru at the northern tip of Laut Island on 10 February. ${ }^{(89,114)}$ Meanwhile, the advance unit of the overland task force left Balikpapan on the morning of 31 January, seized Tanahgrogot on the morning of 1 February, while its main force left Balikpapan on the next day the $2 \mathrm{~d}$ and arrived in Tanahgrogot on the 3d. After that, the overland task force entered the mountains covered with rain forest. While being attacked by swarms of mosquitoes, land leeches and other insects, they clambered up steep mountains, threw temporary log bridges over deep gorges and pushed their way through the mountains for about 100 kilometers. After having driven off a small enemy unit, which the force had encountered on its way, it rushed into the plain of Banjarmasin. At 0900 on 10 February, the vanguard of the overland task force finally reached the Martapura airfield and seized it. ${ }^{(89)}$

[Then,] taking command of the units of the overland task force, which arrived one after another at Martapura, Regimental Commander Yamamoto completely seized the urban area of Banjarmasin on the evening of that day. The officers and men of the overland task force had marched about some 400 kilometers over bad tracks (of which 100 kilometers had consisted of jungle). As many as about $80 \%$ of them developed malaria, which at one point even made it difficult for the force to operate, but they attained their goal in the end. ${ }^{(86)}$

The seaborne task force reached Banjarmasin around 15 - 20 February; the naval base unit reinforcements around the 20th. ${ }^{(115)}$ After that, the conditioning of the airfield was started, but the Navy air units did not immediately advance to the base; only one element of the 23d Air Flotilla advanced there on 25 February. Thereafter the base was used as a staging base for the advance to Bali. ${ }^{(71)}$

Prior to this, and after having launched a reconnaissance of Banjarmasin with one landbased reconnaissance plane of the Tainan Air Group on 18 January, the 2d Air Raid Unit had attacked Banjarmasin with Type-0 fighter plane[s] and land-based reconnaissance plane[s] 
on the 20th, the 25th, and the 27th and reported having set four PBY flying boats and four B17 heavy bombers ablaze. However, no more enemy planes had been spotted since then. After the departure of the Army units, [the 2d Air Raid Unit] had reconnoitered the Army front lines day after day and completed the operations as of 15 February. ${ }^{(71)}$

\section{The Invasion of Southern Sumatra}

(See Attached Illustrations No. 1 and No. 2 [omitted], and Illustration No. 28)

On 31 January, the Army units in the Malay theater rushed into Johor Bahru on the bank opposite of Singapore. In the meantime, the southern Sumatra invasion [operation] (to capture Bangka and Palembang; Operation L), which had been set on 6 February (Day X +60$)^{*}$ in the Cam Ranh meeting on 29 December, was postponed for four days till 10 February (Day X + 64) as a result of the Manila Conference ([held] between 21 and 23 January), as previously told. ${ }^{(34)}$

In accordance with this result, on 31 January, ${ }^{* *}$ the Arrangement on the Air [Operations] in Operation L was concluded between the commander in chief of the First Southern Expeditionary Fleet, the Sixteenth Army commander, and the [Army] Third Air Force commander. Furthermore, an Arrangement for Operation L was concluded between the commander in chief of the First Southern Expeditionary Fleet and the [Army] 38th Division commander, ${ }^{(116)}$ both of which were [in outline] as follows:(117)

\section{Arrangement on the Air [Operations] in Operation L}

\section{Arrangement on the Air [Operations] in Operation L between the First Southern Expeditionary Fleet Commander in Chief, the Sixteenth Army Commander and the Third Air Force Commander}

First Southern Expeditionary Fleet Commander in Chief, V. Adm. Ozawa Jisaburō

Sixteenth Army Commander, Lt. Gen. Imamura Hitoshi

Third Air Force Commander, Lt. Gen. Sugawara Michiō

I. Name of Operation and Basic Dates

1. The operations against Bangka Island and Palembang shall be called Operation L.

2. The day when the advance party of the 38th Division lands in Mentok shall be indicated as Day $\mathrm{L}$, and is scheduled for 10 February. In case a change of date for Day $\mathrm{L}$ is required due to the progress of the air operations, weather conditions or enemy movements, a decision shall be made by 1200 on Day L - 6 upon deliberation between the First Southern Expeditionary Fleet commander in chief and the Sixteenth Army commander.

However, regarding [matters involving] air operations, the Sixteenth Army commander shall consult the Third Air Force commander.

II. Forces to be employed

1. Navy

1st Air Unit: About 100 land-based attack planes, about 30 fighter planes, and 6 land-based reconnaissance planes.

Malaya Unit: About 40 seaplanes.

2. Army

About 9 command reconnaissance planes, ${ }^{+}$about 40 Type- 1 fighter planes, ${ }^{+}$about 30 Type97 fighter planes, ${ }^{+}$about 9 assault planes, ${ }^{+}$about 20 twin-engine light [bombers] ${ }^{+}$and about

* The text mistakenly has Day X+10.

** On pp. 274, 278, and Vol. 3, p. 265: 28 January. However, Vol. 3, p. 272 also 31 January. 
30 heavy bombers.

${ }^{+}$Indicates aircraft to be advanced to the airfield[s] in southern Sumatra. Depending on the condition of the airfields, the above number of aircraft shall be slightly changed.

III. [Air] bases to be used and distribution of forces

1. Navy

(a) When the Ledo [airfield] is fit for use:

Ledo and Kuching [airfields]: 2 air groups of land-based attack planes, about 30 fighter planes and 6 command reconnaissance planes.

Kuantan: about 30 land-based attack planes.

Sungai Petani: about 10 planes.

(b) When [the airfields in] Ledo and Kuching are unusable, [aircraft] shall be advanced in the following way:

Kuantan: about 60 land-based attack planes and one element of the fighter planes.

Kahang: about 30 fighter planes.

About 30 land-based attack planes may use [the airfield] as an advance base for refueling. If the XX Unit (note by the author: the [paratroop] raiding unit) should use [the airfield], [the use by the land-based attack planes] shall be only until and including Day $\mathrm{L}-3$ or on Day $\mathrm{L}+1^{*}$ and onwards.

Sungai Petani: about 10 land-based attack planes.

Kota Bharu: about 40 land-based attack planes.

\section{Army}

Kahang: about 25 Type- 1 fighter planes and about 45 transport planes.

The remaining units to be employed for Operation L shall use the Kluang, Batu Pahat, Kuala Lumpur, Ipoh, Ketil and other airfields. Depending on the readiness and other circumstances of the airfields, the above disposition and the forces to be deployed will be changed.

3. The Army shall be charged with readying the Mentok and Palembang [air] bases. In the preparation of Mentok, the Navy shall cooperate with the Army. In the initial days after the seizure of the Mentok and Palembang [air] bases, Mentok shall be shared [by the Army and the Navy] in the following way, whereas Palembang shall be used by the Army:

Navy fighter planes and others: about 30 planes.

Army fighter planes: about 30 planes.

When possible, the Army shall assist the Navy in the transport of its aviation fuel. The later use of this [air] base shall be newly arranged between the Army and the Navy commanders concerned.

IV. Outline of the operation

1. We shall be determined to swiftly destroy the enemy air power in Sumatra as well as neutralize the enemy air power in Java. The areas assigned to [the Army and the Navy] are roughly decided as follows. However, [both] shall attack the enemy in the other's area as occasion may require.

Navy: [the area] east of the line connecting Mentok and Palembang ([the line] included).

Army: [the area] west of the above-mentioned line ([the line] included).

2. The Navy shall be in charge of attacking enemy naval ships.

3. Covering of the transport convoy

(1) Under sail

(a) Direct cover on Day L - 1 by [both] Army and Navy fighter planes in conjunction shall be provided as follows:

Until 1400: the Navy.

From 1400 onwards: the Army. In case XX Unit (note by the author: the [paratroop] raiding group) is used, the cover [will be started] roughly from 1700 onwards.

* The text mistakenly has Day $L-7$. 
In case XX Unit (note by the author: the [paratroop] raiding group) is used, the Navy fighter planes shall provide cover [for the convoy] on its own as much as possible.

(b) The guarding under sail other than the above shall be charged to the Navy.

(2) At the Mentok and Palembang anchorages and while sailing upstream

The guarding against enemy aircraft after both the Army and the Navy fighter planes are advanced in the area shall be provided by both forces in conjunction; the guarding other than the above shall be assigned to the Navy.

(3) Support for ground [operations] and for the operations to sail upstream

Support for the operations to sail upstream to Palembang shall mainly be assigned to the Navy. Support for ground operations after that shall be assigned to the Army. However, the Navy shall assume this [task] until the Army aircraft are advanced to the area.

V. Exchange of Information

The Army shall make efforts to reconnoiter the movements of the enemy air forces in the Batavia area and provide the Navy with the information.

\section{Arrangement on Operation L ${ }^{(118)}$}

The arrangement on Operation L was in outline as follows:

\section{Forces}

(1) Army: 38th Division

(a) Advance party: two infantry battalions and two artillery batteries as the core, [in] eight ships.

Mentok landing unit: half an infantry battalion as the core.

River-ascending Unit [up to] Palembang: one and a half infantry battalion and two artillery batteries as the core.

(b) Main force: two infantry battalions and one artillery battalion as the core, [in] fourteen ships.

(2) Navy

(a) Forces to escort the advance party: the main force of the 3d Destroyer Squadron ([consisting of] the (light cruiser) Sendai and four destroyers), a few minesweepers and submarine chasers.

(b) Forces to escort the main force: the (light cruiser) Yura, the (coastal defense ship) Shimushu, four destroyers of the $3 \mathrm{~d}$ Destroyer Squadron and other small naval vessels.

(c) Supporting surface forces: the main force of the surface unit of the Malaya Unit ([consisting of] five heavy cruisers (the flagship Chōkai, and the Kumano, the Suzuya, the Mikuma and the Mogami of the 7th Cruiser Division), one aircraft carrier (the Ryūjō), two auxiliary seaplane tenders (the Kamikawa-maru and the Sagara-maru), six destroyers, etc.).

(d) Air force: the 22d Air Flotilla in full force.

(e) River-ascending Unit for Palembang: the main force of the 9th Base Force ([consisting of] auxiliary minesweeper[s], cutter[s], fishing boat[s], etc.).

2. Schedule for the departure of the transport ships from the assembly point and the start of the landing ([and] going upstream)

Advance party:

- Mentok Landing Unit ([in] two ships): shall depart from the assembly point on the evening of Day L-6, arrive at the Mentok [anchorage] before daybreak, and swiftly go ashore at Mentok.

- River-ascending Unit [up to] Palembang ([in] six ships): shall depart from the assembly point on the evening of Day $\mathrm{L}-6$, arrive at the Mentok [anchorage] before daybreak and 
after shifting to [landing] craft and reaching the mouths of the Musi, the Telang and the

Saleh rivers, start going upstream early in the morning.

Main force ([in] fourteen ships): shall depart from the assembly point on the evening of Day $\mathrm{L}-4$, and reach the mouth of the Musi River before daybreak on Day $\mathrm{L}+2$. Landing and debarkation is expected [to be completed] in about ten days for the Mentok landing unit, and about two weeks for the River-ascending Unit [up to] Palembang and the main force of the division.

3. Support for the landing and disembarkation, and cooperation concerning the waterway of the Musi River

(1) Small Navy vessel[s] shall lead the way when the [Army] advance party maneuvers craft from the Mentok anchorage to the mouth of [each] river to go upstream.

(2) Members of the Navy Special Minesweeping Unit shall borrow fifteen large- and small-sized motorized [landing] craft from the Army at the Mentok anchorage, in which they shall clear the waterway of the Musi River and sweep the river sailing upstream from the river mouth up to Palembang.

\section{Others}

Details of escort at sea, entry into the anchorage[s], guarding at the anchorage[s] and the waterway shall be arranged between the 38th Division commander, the 3d Destroyer Squadron commander and the 9th Base Force commander.

\section{The Plans of Operation, etc.}

\section{The Plan of Operations of the [Navy] Malaya Unit}

On 1 February, in accordance with the previously mentioned arrangements, the [Navy] Malaya Unit Commander Vice Admiral Ozawa announced the plan of operations for Operation L at Cam Ranh Bay by Malaya Unit Operation Order No. 17, which was in outline as follows: $:^{(119)}$

\section{Operational aim}

To swiftly put ashore the 38th Division at Bangka and near Palembang and seize the strategic places in the neighborhood

2. Operational policy

(1) This operation shall be immediately launched when the enemy air power in the Malaya area, southern Sumatra, western Borneo and western Java has been more or less neutralized.

(2) The transport ships shall stand by at Cam Ranh Bay and depart under the escort of the escort unit at an opportune time.

3. Disposition of Forces

(As shown in the following table)

\begin{tabular}{|c|c|c|c|c|c|}
\hline \multicolumn{2}{|c|}{ Disposition } & \multicolumn{2}{|r|}{ Commander } & Forces & Main Tasks \\
\hline \multicolumn{2}{|c|}{ Main Unit } & \multirow{2}{*}{ 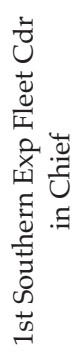 } & & $\begin{array}{l}\text { Chōkai, 7th Cruiser } \\
\text { Div, } 5 \text { destroyers of }\end{array}$ & $\begin{array}{l}\text { Support for the op- } \\
\text { eration on the whole }\end{array}$ \\
\hline Escort Units & 1st Escort Unit & & 3d Des Sqdn Cdr & $\begin{array}{l}\text { 3d Destroyer Sqdn } \\
\text { (minus } 8 \text { destroyers), } \\
\text { 1st Minesweeper Div, } \\
\text { 11th Subchaser Div } \\
\text { (minus } 1 \text { submarine } \\
\text { chaser) }\end{array}$ & $\begin{array}{l}\text { Direct escort for the } \\
\text { advance party }\end{array}$ \\
\hline
\end{tabular}




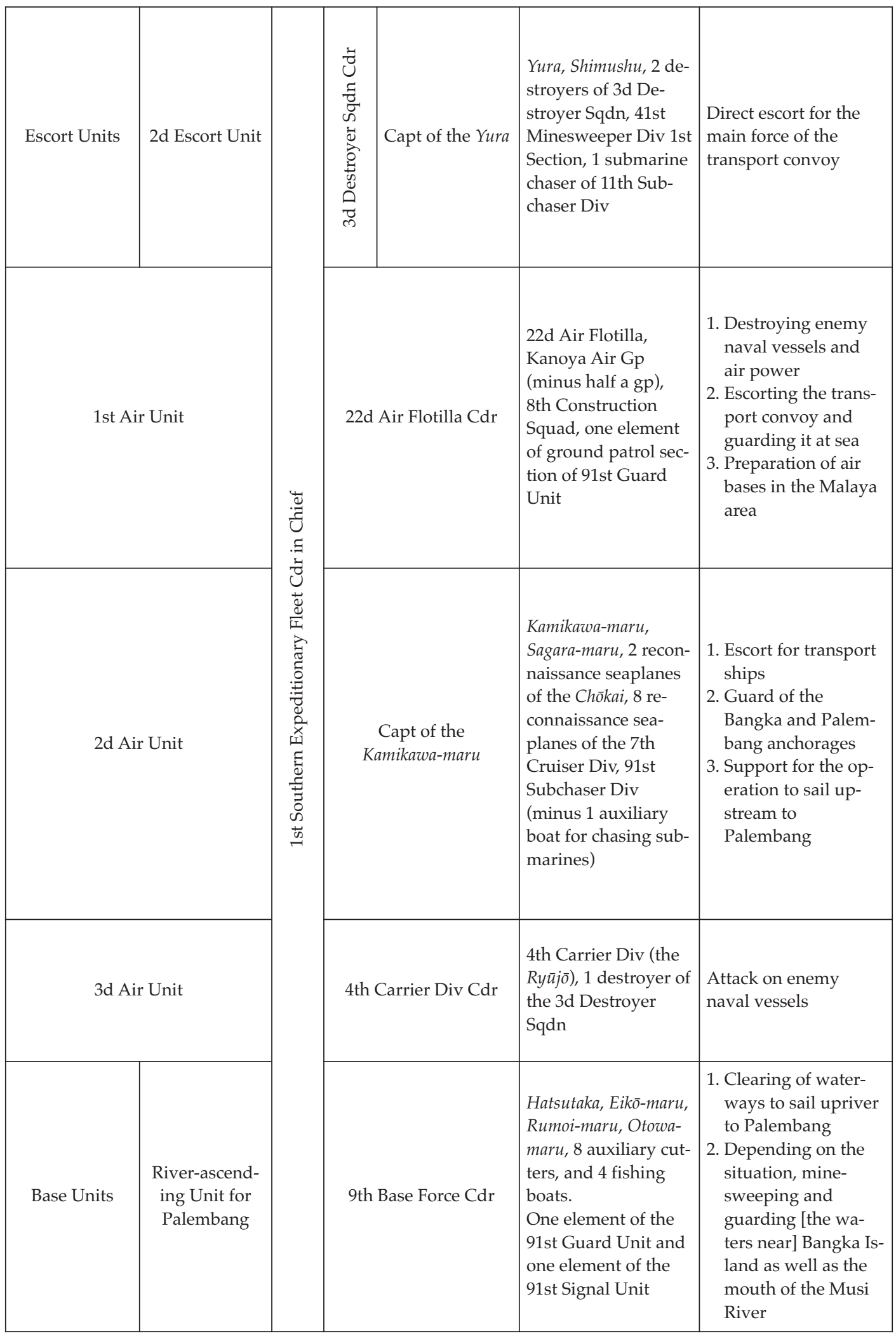




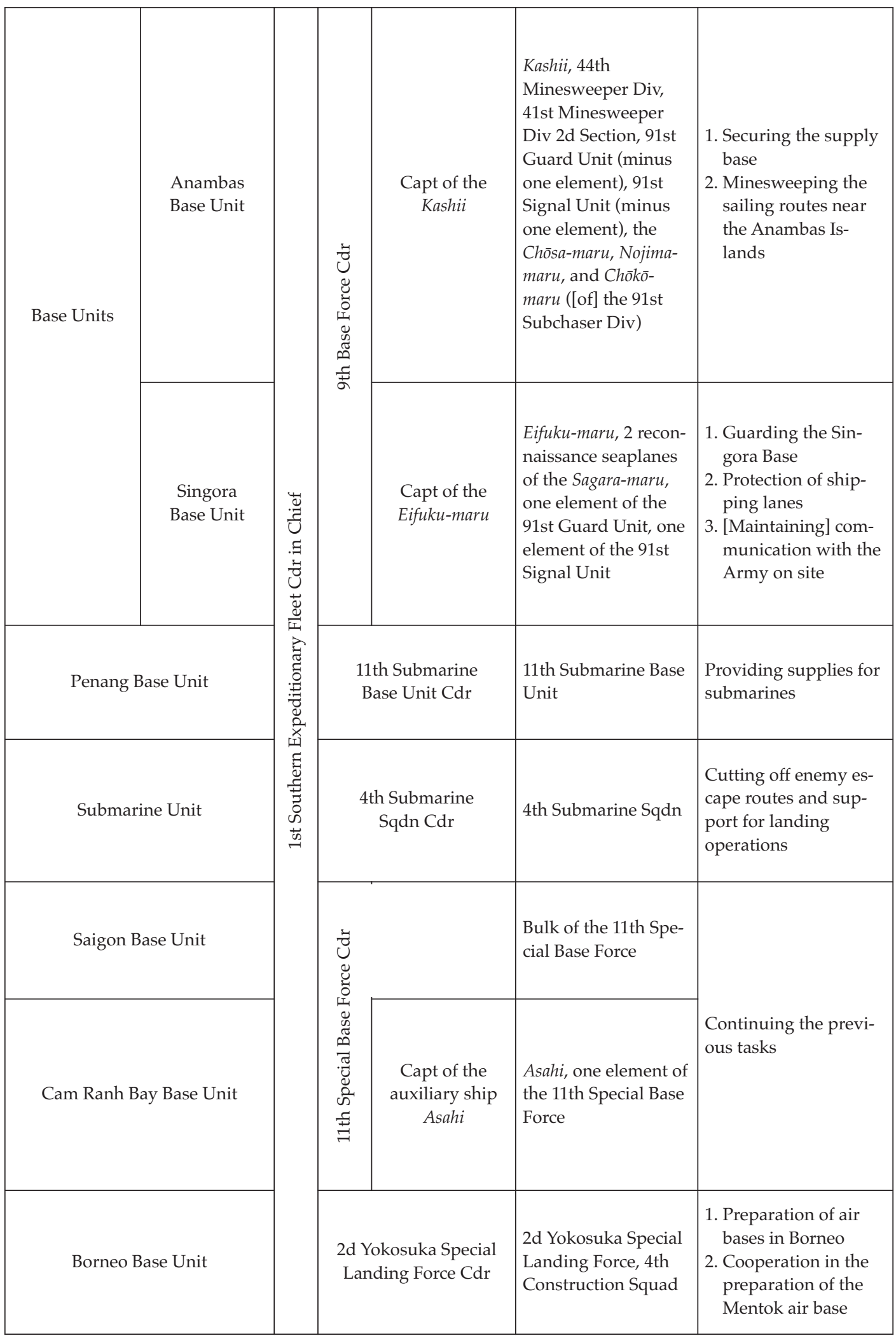




\begin{tabular}{|c|c|c|c|}
\hline \multirow{4}{*}{ Attached Units } & \multirow{4}{*}{$\begin{array}{l}\text { 1st Southern Expeditionary } \\
\text { Fleet Cdr in Chief }\end{array}$} & $\begin{array}{l}\text { 10th Special Base } \\
\text { Force, 101st Navy } \\
\text { Arsenal }\end{array}$ & $\begin{array}{l}\text { Preparation to ad- } \\
\text { vance into Singapore }\end{array}$ \\
\hline & & $\begin{array}{l}\text { 1st Southern Expedi- } \\
\text { tionary Fleet Special } \\
\text { Meteorological De- } \\
\text { tail }\end{array}$ & $\begin{array}{l}\text { Meteorological obser- } \\
\text { vations }\end{array}$ \\
\hline & & $\begin{array}{l}\text { Erimo, Nichiei-maru, } \\
\text { Tsurumi, Kōryū-maru, } \\
\text { Kisogawa-maru, and } \\
\text { Kasuga-maru No. } 2\end{array}$ & Supply \\
\hline & & $\begin{array}{l}\text { Seiha-maru, Muroto, } \\
\text { and Tatsumiya-maru }\end{array}$ & $\begin{array}{l}\text { [Providing] repair, } \\
\text { medical treatment and } \\
\text { transport }\end{array}$ \\
\hline
\end{tabular}

4. Outline of the tasks of each unit

\begin{tabular}{|c|c|}
\hline Unit & Outline of tasks \\
\hline Main Unit & $\begin{array}{l}\text { It shall leave Cam Ranh Bay at an appropriate moment and timely act depending on the } \\
\text { enemy movements; [assigned to] support operations on the whole. }\end{array}$ \\
\hline 1st Escort Unit & $\begin{array}{l}\text { 1. Escorting the advance party, it shall leave Cam Ranh Bay on Day L- } 6 \text { (the 1st } \\
\text { Minesweeper Div and the 11th Subchaser Div (minus } 1 \text { submarine chaser) shall join } \\
\text { the 1st Escort Unit from [the waters] near the Anambas Islands), and act in line with } \\
\text { the Army-Navy agreement. } \\
\text { 2. After [the party] enters into the anchorage, it shall take charge of guarding the anchor- } \\
\text { age as well as the north and the south entrances of the Bangka Strait. }\end{array}$ \\
\hline 2d Escort Unit & $\begin{array}{l}\text { 1. Escorting the transport convoy, it shall leave Cam Ranh Bay on Day L - } 4 \text { (the } 41 \text { st } \\
\text { Minesweeper Div 1st Section shall join the } 2 \mathrm{~d} \text { Escort Unit from [the waters] near the } \\
\text { Anambas Islands), and act in line with the Army-Navy agreement. } \\
\text { 2. After the convoy enters into the anchorage, the Shimushu shall act as designated by the } \\
\text { 9th Base Force Cdr, while the rest shall take charge of guarding the area surrounding } \\
\text { the anchorage. }\end{array}$ \\
\hline 1st Air Unit & $\begin{array}{l}\text { 1. By making use of air bases in the Malay Peninsula as well as in the western part of } \\
\text { Borneo, it shall conduct search and attack on enemy naval vessels in the Malacca } \\
\text { Strait, on the waters southeast of Singapore and on the western part of the Java Sea. } \\
\text { 2. It shall be assigned to destroy the enemy air power in the western part of Borneo and } \\
\text { the Bangka and Palembang areas, while neutralizing the enemy air power in western } \\
\text { Java. } \\
\text { 3. On Day L - } 1 \text { (until 1400, or the whole day if [Army] paratrooper units shall be em- } \\
\text { ployed), it shall take charge of guarding the advance party against enemy aircraft with } \\
\text { fighter planes. } \\
\text { 4. The Type-0 fighter plane unit(s) shall advance to the Mentok land base when the base } \\
\text { is ready for use. }\end{array}$ \\
\hline
\end{tabular}




\begin{tabular}{|c|c|}
\hline 2d Air Unit & $\begin{array}{l}\text { 1. It shall escort the transport convoy; [first] it shall guard the advance party against } \\
\text { enemy submarines and aircraft on Day } L-2 \text { and against enemy submarines on Day } L \\
-1 \text {; then it shall guard the main force of the transport ships against enemy submarines } \\
\text { on Days } L \text { and } L+1 \text {. } \\
\text { 2. It shall be assigned to guard the anchorage near Mentok against [enemy] aircraft. } \\
\text { 3. It shall cooperate in the operation to sail upriver to Palembang, while supporting the } \\
\text { land combat. }\end{array}$ \\
\hline 3d Air Unit & $\begin{array}{l}\text { 1. The unit shall by and large operate along with the main unit, while taking charge of } \\
\text { attacking enemy naval vessels as well as attacking and driving off enemy aircraft. } \\
\text { 2. It may be assigned to guard the advance party against enemy aircraft on Day L - } 1 \\
\text { and the morning of Day L by separate orders. }\end{array}$ \\
\hline Base Forces & $\begin{array}{l}\text { 1. The unit to sail upstream to Palembang shall be on standby at the Anambas [base], } \\
\text { and by and large follow in the wake of the 1st Escort Unit (while timely capturing the } \\
\text { light ships at the mouth of the Musi River, and obtaining the documents concerning } \\
\text { the waterways). [Then] it shall launch the operation to sail upstream to Palembang in } \\
\text { line with the Army-Navy agreement. The Eikō-maru shall cooperate in transporting } \\
\text { base personnel and matériel of the 2d Air Unit on her sail from the Anambas Islands } \\
\text { to Mentok. [She shall also cooperate] in setting up the base. } \\
\text { 2. The Anambas Base Unit shall be in charge of securing the Anambas base, while } \\
\text { searching for and clearing mines on the sailing routes in the Anambas areas. The } \\
\text { Anambas Base Commander shall take command of the 1st Minesweeper Division, the } \\
\text { 41st Minesweeper Division 1st Section, the 11th and the 91st Subchaser Divisions } \\
\text { while they are at anchor [at the Anambas Islands]. } \\
\text { 3. The Singora Base Unit shall continue its previous tasks. }\end{array}$ \\
\hline Penang Base Unit & [It shall] continue its previous tasks. \\
\hline Submarine Unit & $\begin{array}{l}\text { 1. One submarine each shall be deployed at the north and the south entrances of the } \\
\text { Sunda Strait as well as [the waters] near the southern entrance of the Lombok Strait. } \\
\text { 2. The remaining [submarines] shall make preparations for the subsequent operations as } \\
\text { designated by the } 4 \text { th Submarine Squadron commander. }\end{array}$ \\
\hline Others & Units other than those assigned with particular tasks shall continue their previous tasks. \\
\hline
\end{tabular}

\section{Communications (omitted)}

6. Replenishments (omitted)

\section{Outline of the Plan of Operations of the Army Units (Excluding the [Army] Air Units)}

On 5 January at Saigon, Sixteenth Army Commander Lieutenant General Imamura received [Southern Army] Operation Order Classified No. 32 from Southern Army Commander in Chief General Terauchi. On 15 January, in accordance with the order, he concluded an arrangement on Operation L with First Southern Expeditionary Fleet Commander in Chief Vice Admiral Ozawa at Cam Ranh Bay (it was a general agreement with no details provided). ${ }^{(20)}$ Then on 17 January at Hongkong, he issued an order to the 38th Division (minus the Itō and the Shōji Detachments) to capture Mentok and Palembang. ${ }^{(121)}$ 
In accordance with this order, 38th Division Commander Lt. Gen. Sano Tadayoshi drew up a plan of operations, which was in summary as follows*:(117)

1. Disposition of forces

(1) Advance party ([in] 8 transport ships)

Commander: 229th Infantry Regiment commander (Col. Tanaka Ryōsaburō)

Mentok Landing Unit

Commander: 229th Infantry Regiment 1st Battalion commander (Capt.

Orita Masaru); [consisting of] half an infantry battalion as its core.

Musi River Ascending Unit

Commander: 229th Infantry Regiment commander; [consisting of] one infantry battalion and one artillery battery as its core.

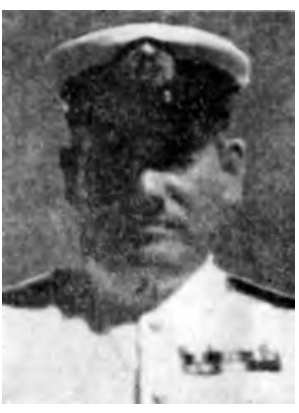

3d Destroyer

Squadron

Commander R. Adm.

Hashimoto Shintarō

Saleh River Ascending Unit

Commander: 38th Engineer Regiment commander (Lt. Col. Iwabuchi Tsuneo); [consisting of] one infantry company, one artillery battery and one engineer company as its core.

Telang River Ascending Unit

Commander: 229th Regiment 2d Battalion commander (Maj. Miyazawa Shigezō); [consisting of] half an infantry battalion and one artillery section as its core.

(2) Main force of the [38th] division ([in] 14 transport ships)

[Consisting of] two infantry battalions, one artillery battalion and one engineer company as its core.

2. Outline of the conduct of the operation

(1) The Mentok landing unit

[The unit shall] carry out a surprise landing on the shore south of the Mentok airfield around $0300^{* *}$ on Day L. After seizing the airfield [first], it shall seize strategic points on Bangka Island.

(2) The river-ascending units [up to] Palembang

After shifting to [landing] craft at the Mentok anchorage, the main force of the advance party shall start sailing upstream from the mouth of the rivers around 0700 on Day L. In cooperation with the paratrooper unit, which [will land in Palembang] ahead of them, it shall first seize the airfield, resources and facilities in Palembang and its vicinity. After that, while swiftly seizing the Martapura and the Tanjungkarang airfields as well as the oil producing regions around [Talang] Abab and Limau, it shall prepare for [the operations] to destroy and clear the enemy naval bases in the Lampung and Semangka Bays. The seizures of Martapura and Tanjungkarang are scheduled for Day $L+6$ and Day $L+9$ respectively.

(3) The main force of the division shall reach the mouth of the Musi River on Day L +2 , ascend the river in its [transport] ships [without changing ships], land at Palembang and extend the military gains of the advance party.

\section{Detailed Arrangements Between the 38th Division Commander and the 9th Base Force Commander}

On 1 February, both commanders concluded detailed arrangements on Operation L at Cam Ranh Bay in accordance with the afore-mentioned arrangement between the First Southern Expeditionary Fleet commander in chief and the Sixteenth Army commander, and that be-

* See also Vol. 3, pp. 270-71.

** The text has 0200 . 
tween the First Southern Expeditionary Fleet commander in chief and the 38th Division commander as well as the operation orders of the senior commanders. ${ }^{(118)}$ The contents of the arrangements are omitted [here] because they overlap the plans of operation of the units.

\section{The Plan of Operations of the Escort Unit}

In line with the plan of operations of the Malaya Unit, 3d Destroyer Squadron Commander R. Adm. Hashimoto Shintarō announced on 1 February at Cam Ranh Bay by means of 1st Escort Unit Operation Order No. 3 the main points of Operation L to be implemented by the 1st and the 2d Escort Units. ${ }^{(118)}$

\section{Malaya Unit 1st Escort Unit Order}

1. In conformity with Malaya Unit Operation Order Classified No. 17, the 1st and the $2 \mathrm{~d}$ Escort Units of the Malaya Unit shall strive to accomplish the following tasks:

(a) 1st Escort Unit

[The unit shall] escort the transport ships of the Army advance party for Operation L from Cam Ranh Bay to a point off Mentok, and put ashore [one element of] the party at Mentok, while guiding and escorting the [landing] craft and boats [of the main force of the advance party] to the mouths of the Musi and the Saleh rivers.

(b) 2d Escort Unit

[The unit shall] escort the transport ships of the Army main force for Operation L from Cam Ranh Bay to the mouth of the Musi River.

2. Distribution of Forces (Note by the author: [as shown in] the table below)

\begin{tabular}{|c|c|c|c|c|c|}
\hline \multicolumn{2}{|c|}{ Unit } & \multicolumn{2}{|c|}{ Commander } & Forces & Main Tasks \\
\hline \multirow{2}{*}{ 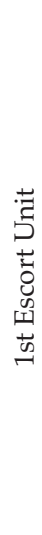 } & 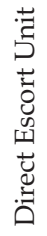 & \multirow{2}{*}{ 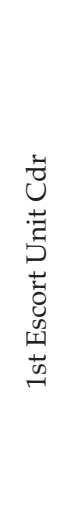 } & \multirow[b]{2}{*}{ 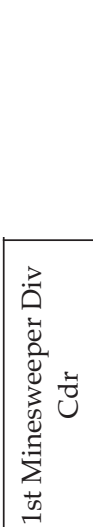 } & $\begin{array}{l}\text { Sendai, 11th Destroyer Div, Asagiri, } \\
\text { 11th Subchaser Div (minus Subma- } \\
\text { rine Chaser No. 9) }\end{array}$ & $\begin{array}{l}\text { 1. To escort the transport ships of the ad- } \\
\text { vance party of the [Army] 38th Div (from } \\
\text { Cam Ranh Bay to Mentok and the mouth } \\
\text { of the Musi River) } \\
\text { 2. Guarding of the anchorage and its vicinity }\end{array}$ \\
\hline & 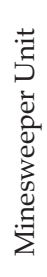 & & & 1st Minesweeper Div & $\begin{array}{l}\text { Guiding and escorting the units maneuver- } \\
\text { ing in [landing] craft } \\
\text { a) Minesweeping on the sailing route ahead } \\
\text { of the transport ships as well as at the an- } \\
\text { chorage } \\
\text { b) Searching for and clearing of mines in the } \\
\text { northern part of the Bangka Strait }\end{array}$ \\
\hline \multicolumn{2}{|c|}{ 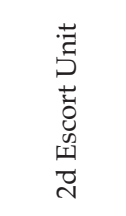 } & \multicolumn{2}{|c|}{ 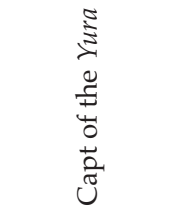 } & $\begin{array}{l}\text { Yura, Shimushu, 20th Destroyer Div } \\
\text { (minus Asagiri), 41st Minesweeper } \\
\text { Div 1st Section, Submarine Chaser } \\
\text { No. } 9\end{array}$ & $\begin{array}{l}\text { 1. Escorting the transport ships of the main } \\
\text { force of the 38th Div (from Cam Ranh Bay } \\
\text { to the mouth of the Musi River) } \\
\text { 2. Guarding of the anchorage and its vicinity }\end{array}$ \\
\hline
\end{tabular}

3. The outline of operations of each unit

(a) The 1st Escort Unit 


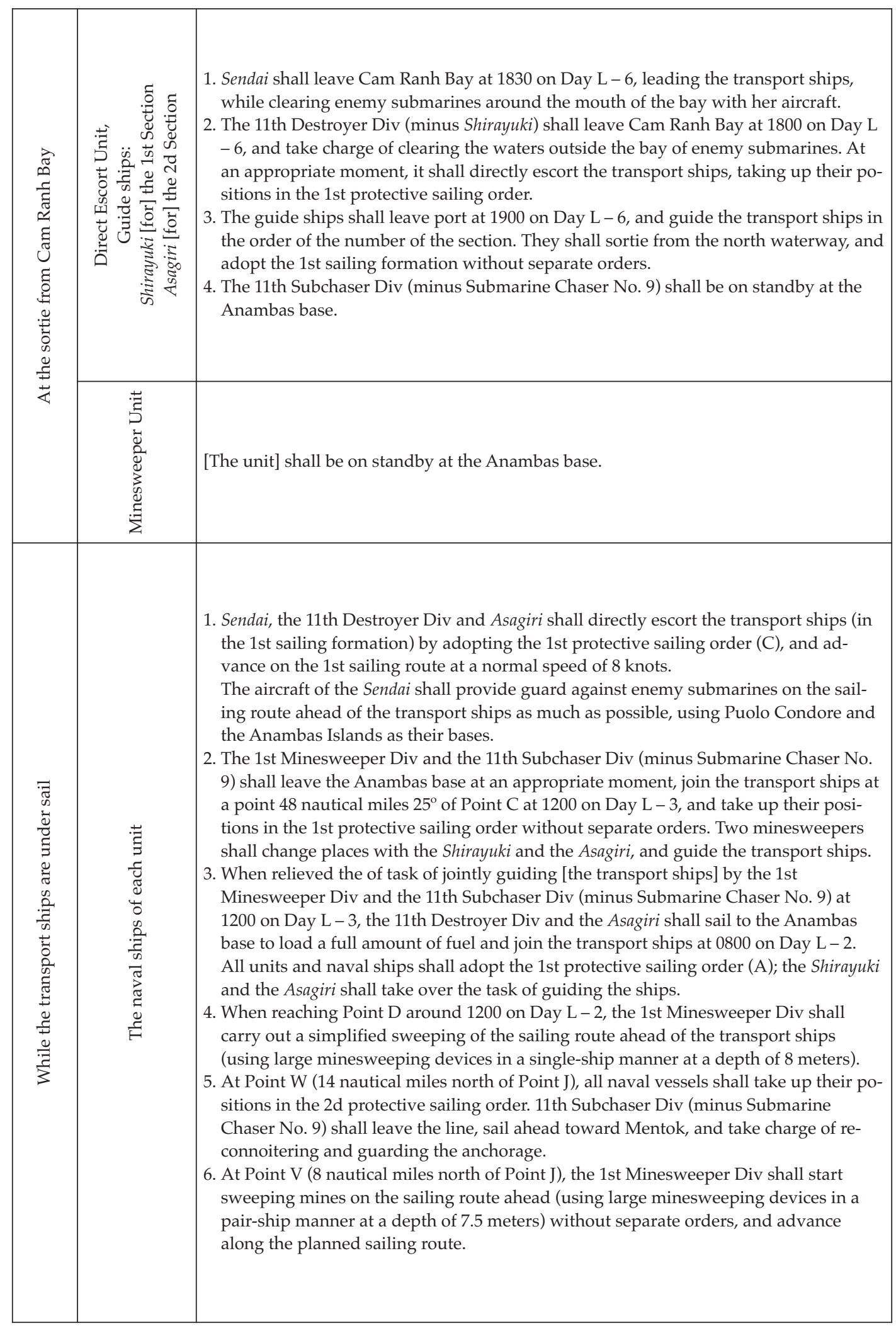




\begin{tabular}{|c|c|c|}
\hline 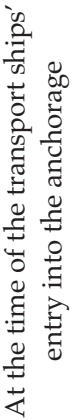 & 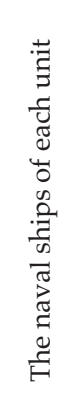 & $\begin{array}{l}\text { 1. [Each naval ship] shall operate according to "the main points regarding entry into the } \\
\text { anchorages" stated in the memoranda attached to the Army-Navy agreement. The } \\
\text { time to drop anchor at the Mentok anchorage is } 0000 \text { on Day L. } \\
\text { 2. Patrol areas of each naval ship (omitted by the author) } \\
\text { 3. Submarine chasers shall take charge of relief operations at sea as well. }\end{array}$ \\
\hline \multirow{3}{*}{ 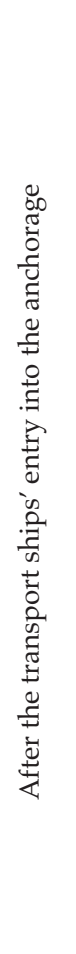 } & 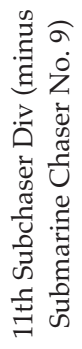 & $\begin{array}{l}\text { 1. While on guard, the submarine chasers shall take up position near the Tajima-maru } \\
\text { and the Kinugawa-maru. When the [landing] craft of the river-ascending unit [up to] } \\
\text { Palembang are ready (around } 0300 \text { on Day L), they shall guide and escort the latter } \\
\text { respectively to the mouths of the Saleh and the Musi rivers. After that, they shall } \\
\text { guard the Mentok anchorage (Sector M). } \\
\text { 2. From the time when the transport ships (minus the An'yo-maru and the Alaska-maru) } \\
\text { shift to the anchorage at the mouth of the Musi River on the evening of Day L until } \\
\text { the time [they start] sailing upriver on the early morning of Day L+1, one submarine } \\
\text { chaser shall be dispatched to the anchorage to guard there. }\end{array}$ \\
\hline & 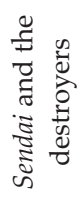 & $\begin{array}{l}\text { 1. [The unit] shall be in the patrol areas and keep guard according to the outline on the } \\
\text { attached sheet[s]. } \\
\text { 2. The aircraft of the Sendai shall timely advance to the Mentok seaplane base when the } \\
\text { latter has been made ready (on the morning of Day L), and guard the anchorage and } \\
\text { surrounding areas. }\end{array}$ \\
\hline & 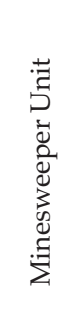 & $\begin{array}{l}\text { 1. The unit shall sweep for mines at the northern part of the Bangka Strait, [the waters] } \\
\text { off the Mentok pier, and the anchorage at the mouth of the Musi River, in accordance } \\
\text { with the outline given on the attached sheets. } \\
\text { 2. When the minesweeping at the anchorage at the mouth of the Musi River is com- } \\
\text { pleted on Day L, one of the minesweepers shall guide the transport ships (minus the } \\
\text { An'yo-maru and the Alaska-maru) and have them shift to the [new] anchorage by the } \\
\text { sunset of the day. } \\
\text { 3. When the tasks in the above items are completed, [the minesweepers] shall go to their } \\
\text { patrol areas and keep guard according to the outline on the attached sheets. }\end{array}$ \\
\hline
\end{tabular}

(b) The 2d Escort Unit

(1) [The unit] shall depart from Cam Ranh Bay at 1800 on Day L - 4, escort the transport ships carrying the main force of the 38th Division in conformity with the arrangements between the Army and the Navy, and have them enter into the anchorage at the mouth of the Musi River around 0000 on Day L +2 .

(2) After the above transport ships have arrived at the anchorage at the mouth of the Musi River, [the unit shall] keep guard in the Bangka Strait according to the outline given on the attached sheet[s].

(3) At the time of the departure of the transport ships carrying the advance party of the 38th Division from Cam Ranh Bay on Day L - 6, two destroyers [of the unit] shall cover the departure of these ships.

4. The Army-Navy arrangements (omitted by the author)

5. Communications (omitted by the author)

6. Replenishment (omitted by the author) 


\section{The Plan of Operations of the Base Units ${ }^{(68)}$}

1. The River-Ascending Unit for Palembang

[The unit], which consisted of the main unit, the minesweeping unit and the supply unit, was supposed to carry out the following tasks under the command of the 9th Base Force Commander R. Adm. Hiraoka Kumeichi.

(1) Replenishment support for the minesweeping units

(2) Clearing the enemy on the land

(3) Setting buoys to show the sailing route

(4) Minesweeping and disposal of controlled mines and booms [at harbor entrances and in the rivers]

(5) The transport and supply of matériel for the Mentok seaplane base

2. The Anambas Base Unit and the Singora Base Unit

[The units] shall carry out the tasks designated by the commander in line with Malaya Unit Operation Order Classified No. 17 (the abovementioned plan of operations of the Malaya Unit).

\section{The Plan of Operations of the 1st Air Unit}

On 31 January, Malaya Unit Commander Vice Admiral Ozawa issued the order concerning the deployment [of air units to the newly-acquired] bases by Malaya Unit Telegraphic Operation Order No. 108, which was in outline as follows: ${ }^{(118)}$

1. The Genzan Air Group and the Yamada Type-0 Fighter Plane Unit shall advance to the Kuching base on 3 and 5 February respectively; [both] shall advance to the Ledo base when the latter has been made ready for use.

2. The Mihoro Air Group shall advance to the Kuantan base on 6 February.

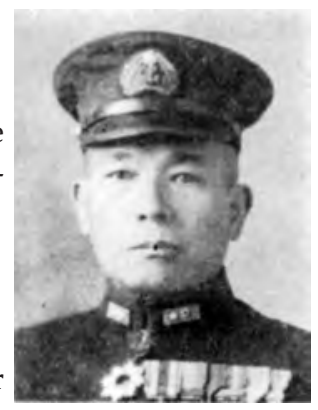

9th Base Force Commander R. Adm.

Hiraoka Kumeichi

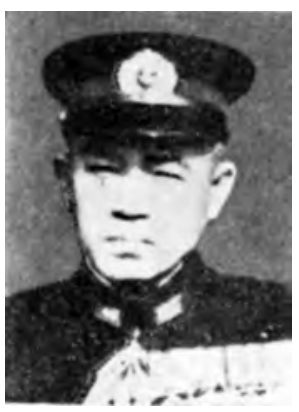

22d Air Flotilla Commander R. Adm. Matsunaga Sadaichi

3. The Kanoya Air Group shall promptly advance to the Kuantan base, and [further] advance to the Ledo base when the latter has been made ready for use.

In accordance with this [order], 1st Air Unit Commander R. Adm. Matsunaga Sadaichi gave orders for the [air unit's] plan of operations for Operation L, which was in outline as follows. (Since the relevant materials are [no longer] extant, the author has reconstructed the plan from action records, action reports and other documents.)

1. Disposition of Forces (as shown in the following table)

\begin{tabular}{|c|c|c|c|c|c|c|c|}
\hline \multicolumn{3}{|c|}{ Unit } & \multicolumn{3}{|c|}{ Commander } & Forces & Tasks \\
\hline 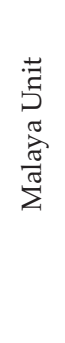 & 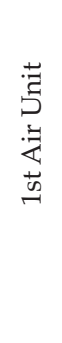 & 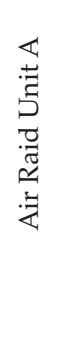 & 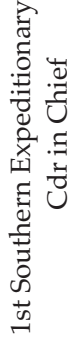 & 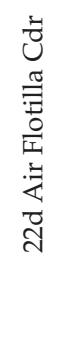 & 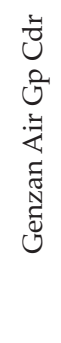 & $\begin{array}{l}36 \text { Type-96 land-based attack planes } \\
\text { and } 3 \text { Type-96 fighter planes of the } \\
\text { Genzan Air Gp }\end{array}$ & A, B, C, D \\
\hline
\end{tabular}




\begin{tabular}{|c|c|c|c|c|c|c|c|}
\hline \multirow{3}{*}{ 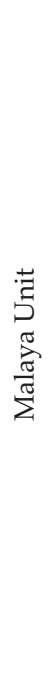 } & \multirow{3}{*}{ 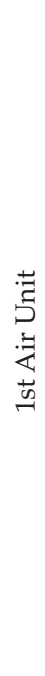 } & 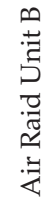 & \multirow{3}{*}{ 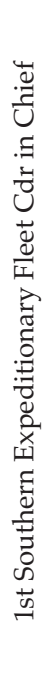 } & \multirow{3}{*}{ 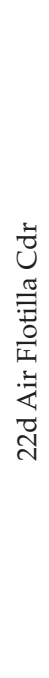 } & 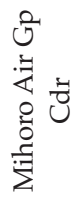 & $\begin{array}{l}36 \text { Type-96 land-based attack planes } \\
\text { and } 9 \text { Type-96 fighter planes of the } \\
\text { Mihoro Air Gp }\end{array}$ & $\mathrm{A}, \mathrm{B}, \mathrm{C}, \mathrm{D}, \mathrm{E}$ \\
\hline & & 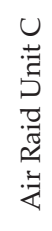 & & & 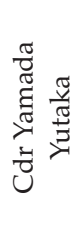 & $\begin{array}{l}\text { A Type- } 0 \text { fighter plane unit led by } \\
\text { Commander Yamada, [consisting of] } 30 \\
\text { Type-0 fighter planes, one element of } \\
\text { the ground patrol section of the 9th } \\
\text { Base Force (about } 30 \text { men), 8th Con- } \\
\text { struction Squad }\end{array}$ & B, C, D \\
\hline & & 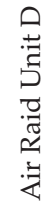 & & & 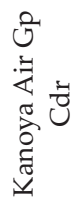 & $\begin{array}{l}27 \text { Type- } 1 \text { land-based attack planes of } \\
\text { the Kanoya Air Gp }\end{array}$ & A, B, D \\
\hline
\end{tabular}

Note by the author:

$\mathrm{A}=$ Destroying [enemy] naval vessels

$\mathrm{B}=$ Destroying the enemy air power in the area east of Bangka and Palembang as well as

in the western part of Borneo while neutralizing the enemy air power in western Java

$\mathrm{C}=$ Providing escort for transport ships

$\mathrm{D}=$ Patrolling

$\mathrm{E}=$ Preparing air bases in Malaya

2. Deployment [of air units to the newly-acquired] bases

(1) [Deployment of air units to the newly-acquired air bases shall be carried out] in accordance with Malaya Unit Telegraphic Operation Order No. 108, (as previously told.)

(2) When the air base in Mentok has been seized and readied, Air Raid Unit C shall advance to the base.

(3) The subsequent deployment [of air units] shall be ordered later.

\section{The Plan of Operations of the 2d Air Unit}

On 31 January, 2d Air Unit Commander Rear Admiral Imamura* issued the following order by 2d Air Unit Operation Order No. 1 (summary):(122)

1. The outline of tasks and actions of each naval ship (as shown in the following table)

\begin{tabular}{|c|l|l|}
\hline Name of the ships & \multicolumn{1}{|c|}{ Main tasks } & \multicolumn{1}{c|}{ Actions } \\
\hline Kamikawa-maru & $\begin{array}{l}\text { Preparations for the subsequent operations } \\
\text { Support for the [set-up] work of the Anam- } \\
\text { bas base and the guarding of the base }\end{array}$ & $\begin{array}{l}\text { At anchor near Cam Ranh Bay base } \\
\text { by the 13th; then, she shall leave Cam } \\
\text { Ranh Bay on the afternoon of the 14th } \\
\text { to advance to the Anambas [base] on } \\
\text { the afternoon of the 16th. }\end{array}$ \\
\hline
\end{tabular}

\footnotetext{
* In the table on p. 262, the captain of the Kamikawa-maru (Capt. Shinoda Tarohachi) is listed as the commander
} of the $2 \mathrm{~d}$ Air Unit of the Malaya Unit. He replaced Rear Admiral Imamura as of 1 February. 


\begin{tabular}{|c|l|l|}
\hline Sagara-maru & $\begin{array}{l}\text { Support for the [set-up] work of the Anam- } \\
\text { bas base and the guarding of the base }\end{array}$ & At anchor near the Anambas [base]. \\
\hline $\begin{array}{c}\text { One auxiliary submarine } \\
\text { chaser (designated by the } \\
\text { commander) }\end{array}$ & $\begin{array}{l}\text { Transport of the base personnel and the } \\
\text { guarding of the Mentok base }\end{array}$ & $\begin{array}{l}\text { After the departure of the aircraft } \\
\text { units on Day L, she shall leave Anam- } \\
\text { bas for Mentok. }\end{array}$ \\
\hline Ditto & Guarding of the Anambas base & $\begin{array}{l}\text { She shall appropriately operate on the } \\
\text { waters surrounding the Anambas } \\
\text { base. }\end{array}$ \\
\hline
\end{tabular}

\section{Actions of the aircraft units}

On Day L - 2, [the units shall] provide the advance party with direct escort against enemy submarines and aircraft, while guarding the sailing route ahead of it as well as the sailing route ahead of the main unit. On Day L - 1, [the unit shall] guard the sailing routes ahead of the advance party as well as of the main unit. On Day L, [the unit shall] provide the main unit with guard against enemy submarines, while shifting their base from Anambas to Mentok.

After having advanced to the Mentok base, the unit was supposed to take upon itself the task of guarding the area around the anchorage against enemy aircraft and submarines, while supporting the river-ascending and landing operation to Palembang.

\section{The Plan of Operations of the 3d Air Unit}

After having completed Operation S (the operation to put the 18th Division ashore on Endau), the 4th Carrier Division (minus the 2d Section, i.e. the Ryūjō and the Shiokaze; led by R. Adm. Kakuta Kakuji) had entered into the port of Cam Ranh Bay at 1130 on 30 January and was engaged in training, maintenance and replenishment for the subsequent operations. ${ }^{(71)}$ By Malaya Unit Operation Order Classified No. 17 on 1 February, the unit was ordered to [also] participate in Operation $\mathrm{L}_{r}^{(122)}$ and undertake the task of attacking enemy naval vessels and of attacking and driving off enemy aircraft while operating by and large along with the main unit. The unit was also charged with the task of guarding the advance party against enemy aircraft on Day L - 1 and on the morning of Day L by separate orders. Furthermore, it was decided that the one destroyer of the $3 \mathrm{~d}$ Destroyer Squadron that was to form the $3 \mathrm{~d}$ Air Unit along with the 4 th Carrier Division would be the Shikinami. ${ }^{(120)}$

\section{The Plan of Operations of the Submarine Unit}

Having been informally informed on 24 January of the Malaya Unit's plan of operations for Operation L, and learning that the intended support and strength for that operation would consist of three submarines (one at the south entrance of the Sunda Strait and one each at the north and the south entrance of the Lombok Strait), the Submarine Unit commander (4th Submarine Squadron Commander R. Adm. Yoshitomi Setsuzō) announced his plan of operations on 26 January, which was in outline as follows: ${ }^{(123)}$

\section{The outline of the operation}

[The unit] shall support Operation L by deploying three submarines at strategic points in the rear of the enemy in order to destroy fleeing [enemy] units, while at the same time making preparations for the coming Java operation with the other five submarines.

2. The outline of operations of the unit supporting Operation $\mathrm{L}$ 
[The unit shall] depart from Cam Ranh Bay in order to be deployed at the following points by Day L -2 .

I-55 ([of] the 18th Submarine Division): at the south entrance of the Lombok Strait

I-56 ([of] the 19th Submarine Division): at the south entrance of the Sunda Strait via the Lombok Strait

Ro-34 ([of] the 21st Submarine Division): at the north entrance of the Lombok Strait

However, 4th Submarine Squadron Commander Rear Admiral Yoshitomi had on 27 January been ordered by Malaya Unit Telegraphic Operation Order No. 103* to lead [among others] the Kinu, the Fujigawa-maru, the Tatsumiya-maru and two destroyers of the 3d Destroyer Squadron

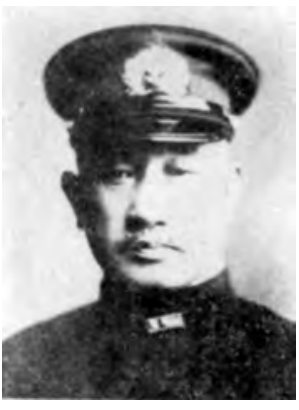

4th Carrier Division Commander R. Adm. Kakuta Kakuji and advance to the Ledo area to carry out the operation to transport personnel and matériel for the base there, and on 1 February he was still engaged in that operation (the details of which will be described later [p. 274]). ${ }^{(123)}$ Therefore, because it was impossible to hand him Malaya Unit Operation Order No. 17 concerning Operation L in person, the assignment of the submarine units was announced by Malaya Unit Telegraphic Order No. 113 on 2 February. ${ }^{(123)}$ [However,] in this order, the previously decided deployment of two submarines at the Lombok Strait and one at the Sunda Strait was changed in such a way that two submarines should be deployed at the Sunda Strait and one at the Lombok Strait. In accordance with this order, the submarine unit commander left the deployment of I-55 and I-56 as he had planned, and changed the deployment of Ro-34 from the north entrance of the Lombok Strait to the north entrance of the Sunda Strait.

\section{The Plan of Operations of the Army Air Units ${ }^{(117)}$}

By the end of January, the Army Third Air Force had already deployed its forces to the bases in Sungai Petani, Ipoh, Alor Setar, and Ketil on the Malay Peninsula, and was preparing for the operation against Sumatra by searching out the enemy air power as well as by attacking enemy airfields from time to time. On 30 January, the Southern Army decided to employ the 1st [Paratroop] Raiding Group (a paratrooper unit) and give priority to [the seizure of] the Palembang airfield, putting the unit under the command of Third Air Force Commander Lt. Gen. Sugawara Michiō. The unit was supposed to be employed in the following way:

1. The unit shall seize the Palembang airfield to facilitate Operations $\mathrm{L}$ and $\mathrm{H}$ (the operation against western Java) and, if possible, seize and secure the Palembang oil refineries before the enemy destroys them.

2. The first drop or landing shall be carried out on the morning of Day L - 1; the operation shall be aborted if the weather does not permit it.

3. The dropped or landed unit shall be put under the command of the Sixteenth Army commander after the arrival of the main force of the 38th Division at Palembang.

* The text mistakenly has 10 . 


\section{The Launch of the Operation}

\section{Postponement of the Operation Schedule (See Illustration No. 27)}

As previously told, at the Manila Conference the Navy had made a draft arrangement [with the Army] on 22 January that in principle it would chiefly use the Ledo airfield, which was [still] an unknown quantity, and that it would use the Kuantan and the Kahang airfields for the time being if the Kuching and the Ledo airfields were unusable; also Day L was set on 10 February (Day X +64 , which meant a four-day postponement [from the schedule decided on in the Cam Ranh Agreement]). Then on 28 January, the (previously described) Arrangement on the Air [Operations] in Operation L was concluded. Meanwhile, the Kawaguchi Detachment had seized the Ledo airfield at 1000 on 27 January. The seaplane(s) of the Kamikawa-maru sent the following report after reconnoitering the Ledo airfield. ${ }^{(122)}$

1. The [main] Ledo airfield is located about five kilometers east of Ledo, with three runways; one which runs from north to south is about 2,500 meters long, another which runs from east to west is about 1,200 meters long, and the other which runs in between is about 1,200 meters long. There are about seventy-nine large and small holes blasted by landmines, which are currently being repaired by army units. The soil [appears] to be red clay, with some patches of grass; the ground appears to be in comparatively good condition. No obstacles were found in the perimeter.

2. A dozen or more bridges on the road[s] from Singkawang to Ledo have been destroyed. Also a dozen or more holes probably blasted by landmines were spotted on the road.

3. No Japanese forces were spotted other than large-sized motorized [landing] craft in Pemangkat and the army in Ledo.

As previously told, by means of Malaya Unit Telegraphic Order No. 103 on 27 January, the 4th Submarine Squadron commander had been given the task to transport the personnel and matériel to be advanced to the Ledo air base. ${ }^{(123)}$ In accordance with this order, 4 th Submarine Squadron Commander Rear Admiral Yoshitomi launched the Ledo transportation operation, departing from Saigon at 1400 on 30 January with [among others] the Fujigawa-maru (carrying the personnel and matériel of the Genzan Air Group) and the Tatsumiya-maru (carrying the advance personnel and matériel of the Kanoya Air Group for the Ledo base). On the early morning of 2 February, escorted by the Kinu, the 44th Minesweeper Division and the Murakumo, the transport ships entered the port of Pemangkat, but it was decided to redirect them to Pontianak because the conditions for the overland transport [from Pemangkat] were bad. However, as a result of an investigation on the $3 \mathrm{~d}$ of the actual conditions [for an overland transport from] Pontianak, it became clear that the transport conditions from Pemangkat were better, so the transport ships sailed back again to Pemangkat on the 4th. ${ }^{(123)}$

However, the main roads to Ledo and the bridges on them were thoroughly destroyed, and moreover the roads were dangerously steep; it was extremely difficult to repair them for motorized traffic. In the end, among the several roads leading to Ledo, two routes, one which connected Singkawang, Montrado, Bengkayang, and Ledo, and another which connected [the sea and] Ledo via the Sambas river ([using] the waterway up to Sanggau) were selected. However, on 1 and 2 February it was expected that the repair of the former route would take two weeks and the latter one week. ${ }^{(123)}$ Although the Kawaguchi Detachment cooperated in the repair of the roads as well as in the disembarkation and transportation of 


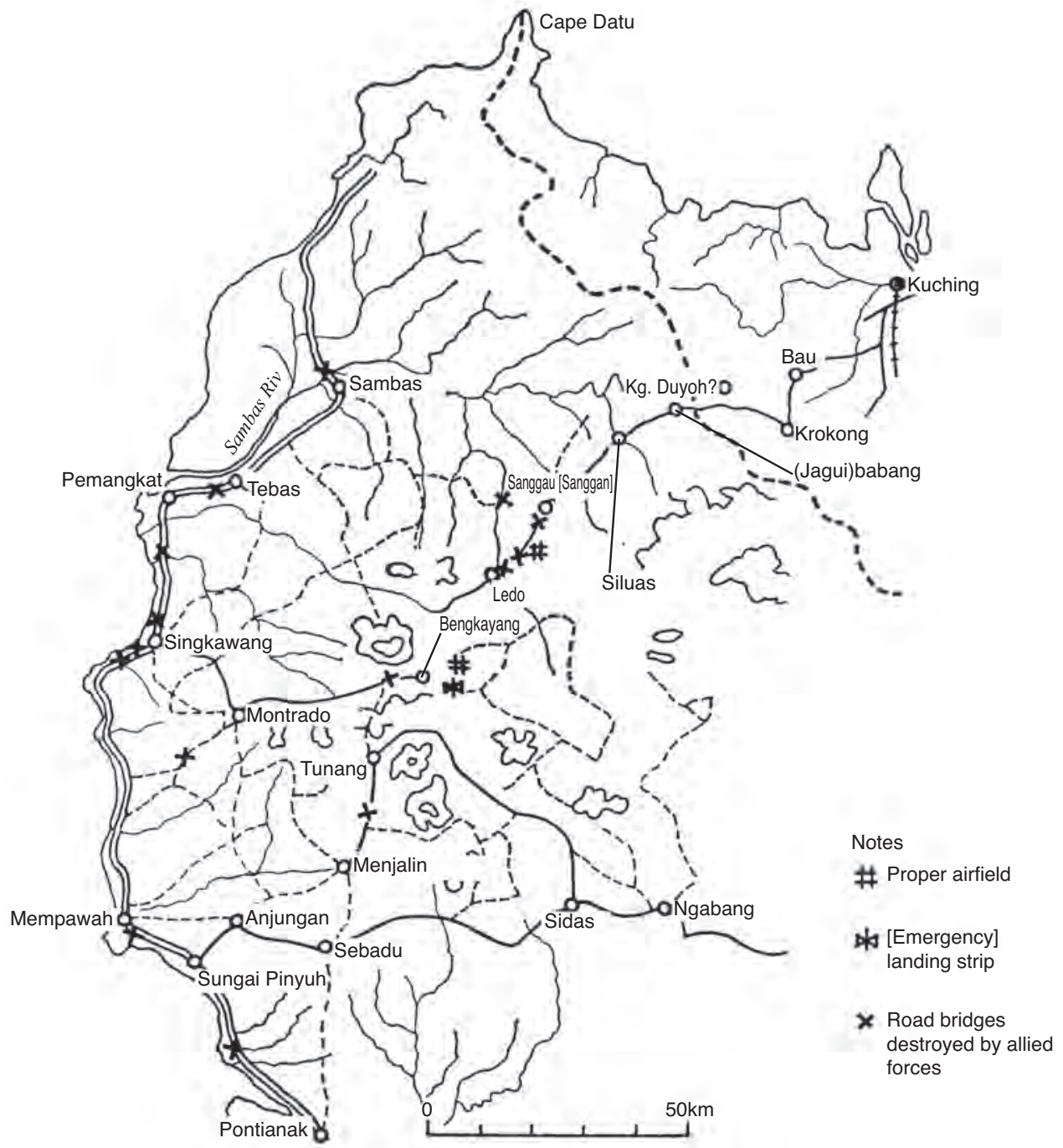

Illustration No. 27 - A Sketch Map of Western Borneo

fuel and ammunition with all its might, the fuel accumulated by 4 February was a mere 200 drums. ${ }^{(34)}$ As for the airfield, the Kawaguchi Detachment reported on the same day that [a runway of] 100 meters wide and 1,000 meters long had been completed. ${ }^{(34)}$

On 4 February, Malaya Unit Commander Vice Admiral Ozawa finally gave up the idea to use the Ledo airfield and decided to conduct the operations by using the Kuantan and the Kuching [airfields] (an assumption by the author based on the movements of the aircraft units and other factors). At 1900 on that day, the invasion unit [of Operation L] was supposed to leave Cam Ranh Bay. However, the Mihoro Air Group had not advanced to the Kuantan [airfield] yet (the advance was scheduled for 6 February). As for the Genzan Air Group, only twelve Type-96 land-based attack planes had advanced to the Kuching [airfield] (the advance had been scheduled for 3 February) and, moreover, the airfield's condition was bad. Having no other choice and running out of time, the Malaya Unit commander decided on his own 
responsibility to postpone day L by two days and ordered the postponement to his subordinate units by telegram. ${ }^{(122)}$

Without delay, Malaya Unit Commander Vice Admiral Ozawa conferred about the matter with the Army side through Cdr. Wakatsuki Ryōzō (a gunnery staff officer of the Third Fleet) who was seconded to the Sixteenth Army. On the afternoon of the 4th, Cdr. Wakatsuki visited the staff section of the Southern Army headquarters along with the Sixteenth Army staff officers and held talks on a two-day postponement of Operation L. ${ }^{(34)}$ The Southern Army headquarters insisted that at the Manila Conference it had been mutually agreed to carry out the air campaigns by using airfields in the Malaya area in case the Ledo airfield was unusable, and that it was now too late to use the impracticability of the Ledo airfield as an excuse for a postponement of Operation L. The army sent the following telegram to the Navy Southern Task Force commander: ${ }^{(34)}$

1. At the talks, which the OsAmu-SHŨDAN (note by the author: the Sixteenth Army) had with the First Southern Expeditionary Fleet at Cam Ranh Bay today, a request for a two-day postponement of the launch of Operation L was made by the First Southern Expeditionary Fleet because the airfields had not yet been made ready for use.

2. Presently, we have completed all our preparations and scheduled the start of our ground attacks against Singapore from the 7th onwards. As the surrender [of Singapore] is imminent, we would like to seize an opportune moment ahead [of the fall of Singapore] to carry out [Operation] L. We would like your consideration for the realization of the above.

In reply, Southern Task Force Commander Vice Admiral Kondo wired that "[We] would like a one- or two-day postponement be [decided] in talks between the Sixteenth Army and the First Southern Expeditionary Fleet." ${ }^{(34)}$ Having no other choice, the Southern Army obtained approval from the IGHQ Army Department and issued on the 5th an order to postpone [Operation] L for two days until 12 February. ${ }^{(34)}$

During these negotiations [with the Army], another problem had arisen, which further worsened the worries of Malaya Unit Commander Ozawa. Namely, when in accordance with Malaya Unit Telegraphic Operation Order No. 108 of 31 January the advance team of the Mihoro Air Group arrived at Kuantan (assumed to have been on 2 or 3 February; the advance of the Kanoya Air Group to the airfield seemed to have been postponed), it turned out that the trees of the forest in front of the runway were so tall that the land-based attack planes could not take off from the airfield with a regular load of bombs unless the trees in zone of 200 meters wide and 300 meters long were cleared. Although the advance team hurriedly started cutting down the trees, it only managed in two days to fell the trees in a stretch of a mere twenty meters, because many of them were giant hardwood trees. ${ }^{(34)}$ On the other hand, the Kuching airfield was located on a hill and difficult to enlarge, moreover its soil was bad. ${ }^{(124)}$ Among the aircraft of the Yamada Unit (twenty-one Type-0 fighter planes and four land-based reconnaissance planes), which had advanced there on 5 February, two Type-0 fighter planes, two land-based reconnaissance planes, and one land-based attack plane (the latter was an aircraft of the Mihoro Air Group which had given assistance in the air transport) were badly damaged at the time of landing, causing slight injuries to four crew members. It was reported that due to these incidents, the repair of the airfield would not be completed before the 7 th. ${ }^{(118)}$ 


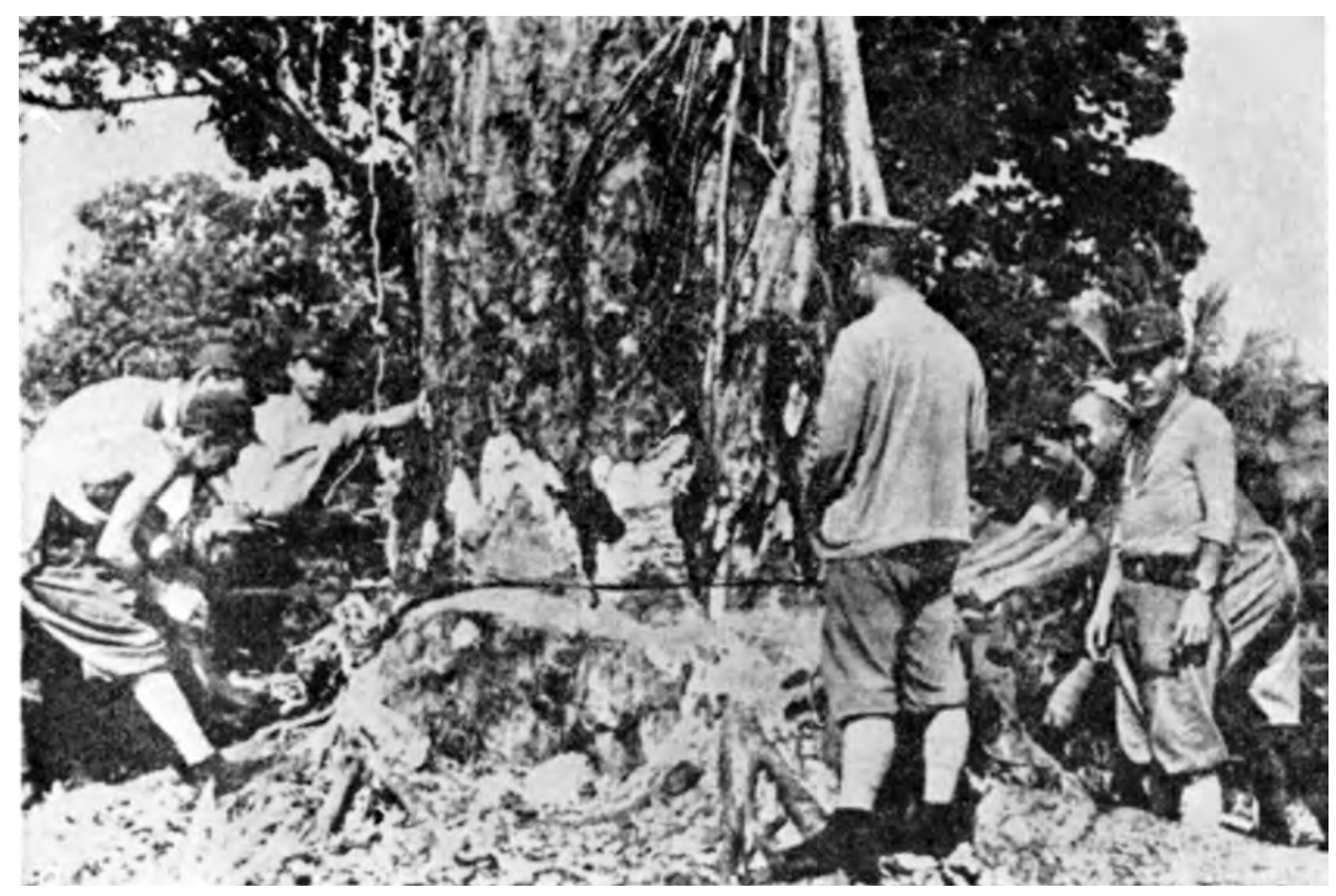

The Felling of the Giant Trees Surrounding the Kuantan Airfield

Realizing that the use of the Ledo airfield was beyond hope, that the felling of the trees at the Kuantan airfield would require more time, and that, moreover, the condition of the Kuching airfield was bad, the Malaya Unit commander judged that it would take another four or five days before the land-based attack planes could be deployed. On the 5th, he made a decision to postpone Operation $L$ for another four days (the departure of the invasion units was scheduled on the evening of the 6th); (a reconstruction by the author based on the Sagaramaru Action Report and the Ishii documents). Consequently, the commander sent a telegram to the Southern Army, which read: "We will dispatch our Chief of Staff R. Adm. Sawada Torao (accompanied by Senior Staff Officer Captain Tomari) to Saigon on 6 February to discuss Operation L." [See also Vol. 3, p. 300.] This telegram reached the Southern Army headquarters just after it had issued the order for a two-day postponement of Operation L. ${ }^{(34)}$

At 0800 on the 6th, Malaya Unit Commander Vice Admiral Ozawa wired the Malaya Unit by means of Classified Telegram No. 628: "Day L shall be postponed until specifically ordered otherwise." (125) [See also Vol. 3, p. 304.] On that afternoon, First Southern Expeditionary Fleet Chief of Staff Sawada and Staff Officer Tomari sought an approval for the postponement of Operation L at the Southern Army headquarters in Saigon in the following way: (34) "Yesterday on the 5th when [land-based] attack planes and fighter planes landed on [the] Kuching [airfield], four aircraft were damaged because of bomb craters. We were informed that the repair [of the airfield] should be completed on the 7th, which we consider very doubtful. As for the Ledo airfield, on the other hand, the transport routes are long and poor, and the accumulation of fuel and ammunition has yet to be completed. Furthermore, the Kuantan airfield in Malaya, to which the [Navy land-based] medium-sized attack planes have advanced (note: thirty-six land-based attack planes and nine Type-96 fighter planes of the Mihoro Air Group 
had advanced to the airfield on 5 February) is surrounded by a tall forest, and the trees in a zone of two hundred meters wide and three hundred meters deep need to be cut down. However, we have managed to clear only twenty meters in two days, as many of the trees are enormous. We fear that it will further take as much as ten days [if we continue] at this pace. As the Navy [has decided to] have aircraft maintenance personnel as well engage in the work of felling the trees, we would like you to approve at least another four days, that is, in total a postponement of six-days."*

Responding to this request, the Southern Army mainly accused the Navy of having made insufficient preparations. ${ }^{(34)}$ "In the arrangements for the air [operation] on 28 January concluded after the Manila Conference, the Navy was supposed to advance to both the Kuantan and the Kahang airfields for Operation L if the Ledo airfield was not fit for use. The Navy should have thoroughly examined [the practicality of] the airfields. It is a terrible lack of preparation [to say] at this time that the trees are an obstruction." It was certainly a fault of the Navy. Since the Kuantan airfield was supposed to be used [anyway] even when the Ledo airfield was put to use, the Navy certainly should have surveyed it without delay. However, the Navy had been confident [that the airfield could be used] because Army aircraft could use it without problems. ${ }^{(124)}$ (Note: That Army aircraft could use it was caused by a difference in performance between the Army and the Navy aircraft.)

Although they did not come to an understanding after all, it was decided that the Southern Army would for the time being postpone the departure of the convoy of the 38th Division scheduled for the evening of that day till the evening of the 7 th, and check up on the situation at Ledo. Meanwhile, considering that those trees had to be cut down the sooner the better, it was [also] decided to dispatch about fifty men, mainly consisting of the cadre of a company of the 20th Independent Engineer Regiment, which had been assigned to the Third Air force and was fortunately assembling near Kahang, and have them cooperate in the felling of the trees. In the meantime, the Navy arranged to immediately send about three tons of dynamite from Saigon to Kuantan. ${ }^{(34)}$

On the 6th, the Combined Fleet headquarters stationed on Hashira-jima in the Inland Sea learned that the Malaya Unit headquarters and the Second Fleet headquarters were confronting each other [about the Sumatra operation], with the former insisting that Sumatra landing operation should be [postponed and] carried out around the 16th due to the delay in the preparation of the bases in Kuantan, Kuching, Ledo, etc., while the latter was pressing the former to carry out the operation [as scheduled] from the point of view of the entire operation and without worrying about the damage. After having communicated with central command regarding the matter, the chief of staff of the Combined Fleet sent [his opinion] to the chief of staff of the Second Fleet that it should not be [carried out] in such a rush. ${ }^{(46)}$

On the night of the 6th, the Southern Army headquarters sent the following telegram to the IGHQ Army Department. **(34)

1. Today, we received another request for a further postponement of four days from the First Southern Expeditionary Fleet. The main reason for this was that trees in (some) place(s) around the Kuantan airfield needed to be cut down, and even though the work had been started two days ago, the amount of work was too much to tell when it would be finished.

* See also Vol. 3, p. 301.

** See also Vol. 3, p. 302. 
2. Although we were frustrated by this request, as it was made after such a long time since the conclusion of the arrangements for Operation L, we immediately arranged the assistance of [Army] engineers, and [at the same time] based on the concluded arrangements, urged [the Navy] to use the Kahang airfield and took measures to let [the Navy aircraft] use army fuel, etc. However, it was decided to determine a new date for Day L by tomorrow, the 7th, upon careful examination of all the factors that the Navy said were still unclear.

Because of troubles with telegrams, etc., only fifteen engineers were transported on the 7th, and it was decided that the remainder would be transported on the 8th. On that day [the 7th], the Malaya Unit commander officially proposed to the Southern Army commander in chief that "We would like to postpone [Operation] L for another four days. However, we would like to have [the convoy] depart as soon as the preparations for the air operation have been completed."*(34) From the point of view that the strength of the allied forces was being increased day by day and that it was considered advantageous to conduct Operation L before the completion of the capture of Singapore, the Southern Army headquarters were against a postponement of Operation L, but reluctantly approved the request. ${ }^{(127)}$ At 1925 on that day, Malaya Unit Commander Vice Admiral Ozawa wired the following order. ${ }^{(126)}$ "On the 7th, the following arrangement was made with the [Southern] Army: Day L will be postponed for another four days. However, [the operation shall be] launched as soon as the preparations for the air operations are complete."**

On the 8th, the Southern Task Force headquarters sent the Southern Army headquarters a telegram to request a change in the invasion schedule as follows: ${ }^{(34)}$ "L: on Day $\mathrm{X}+70 ; \mathrm{H}$ (note by the author: eastern Java): on Day X + 81; I (note by the author: western Java): no later than Day X +81 (to be arranged between the Third Fleet and the Sixteenth Army)." Having no choice, the Southern Army headquarters approved it, too. ${ }^{(34)}$

On 8 February, [Army] engineers and [Navy] maintenance personnel started blowing up the trees in front of the runway of the Kuantan airfield. ${ }^{(128)}$ On that afternoon, 1st Air Unit Commander Rear Admiral Matsunaga ordered the land-based attack plane unit of the Mihoro Air Group to advance from the Kuantan airfield to the Kahang airfield and attack $\mathrm{Java}^{(122)}$ (which was called off later). Meanwhile the preparations of the land-based attack plane units and Type-0 fighter plane units at the Kuching airfield was completed, and it was decided that the Naval air units should launch the air operation to destroy the enemy air power in the Batavia area from the 9th onwards. ${ }^{(129)}$ Accordingly, it became possible to move up the departure of the invasion unit scheduled for the 10 th by one day. ${ }^{(30)}$ At 1400 on the 9th, Malaya Unit Commander Vice Admiral Ozawa issued the following order. ${ }^{* * *(122)}$

1. The date of L is set for 15 February.

2. Each unit shall operate as planned.

\section{Little Progress in the Prior Neutralization of the [Enemy] Air Power}

Having advanced in succession from Saigon to Kuching with its first nine planes on 30 January, the land-based attack planes of the Genzan Air Group launched a search and attack on the enemy in the Karimata Strait from 1 February onwards. ${ }^{(71)}$ Meanwhile, the Mihoro Air

\footnotetext{
* See also Vol. 3, p. 304.

** See also Vol. 3, p. 304.

*** See also Vol. 3, p. 305.
} 
Group stationed in Kota Bharu ([on] the Malay Peninsula), having advanced one element to Sungai Petani ([on] the Malay Peninsula) on 17 January, also started its search and attack on the enemy in the Karimata Strait on 1 [February]. However, due to the bad condition of both airfields, the aircraft were only allowed to load one fourth (i.e. one $250 \mathrm{~kg}$ bomb or four $60 \mathrm{~kg}$ bombs) of their regular load of bombs, while the Type-1 land-based attack planes of the Kanoya Air Group were unable to advance [their bases] from Thủ Dâu Một (an [air] base north of Saigon). The general situation of [the progress of] the neutralization of the enemy air power from the 1st until the departure of the invasion unit was as follows. ${ }^{(71)}$

1 [February]: Five land-based attack planes each of the Genzan and the Mihoro Air Groups bombed the industrial zone on Belitung Island as well as Mentok, setting ablaze warehouses and powder magazines. They also reported having spotted one [enemy] destroyer, one gunboat and six merchantmen at Mentok as well as on the waters near the Bangka Strait and sunk a 6,000t-class merchantman. All of the aircraft returned to base.

2 [February]: Nine land-based attack planes of the Genzan Air Group and ten land-based attack planes of the Mihoro Air Group carried out a search and attack mission on the enemy in the Bangka Strait and on the west coast of Sumatra. They reported having spotted two [enemy] destroyers and six merchantmen and inflicted serious damage to one 4,000t-class merchantman and also some damage to one 2,500t-class merchantman. All of the aircraft returned to base.

3 [February]: Eight land-based attack planes of the Genzan Air Group and nineteen land-based attack planes of the Mihoro Air Group carried out a search and attack mission on the enemy in the areas of the Bangka Strait and Mentok. They reported having spotted eight [enemy] light cruisers, six destroyers, twenty-four merchantmen and one auxiliary ship ([note by the author] a considerable number of ships were counted twice) and sunk a 10,000t-class merchantman, a 7,000t-class armed merchantman, and a 6,000t-class merchantman. All of the aircraft returned to base.

[Meanwhile,] nine land-based attack planes of the Mihoro Air Group (of which one returned to base due to a breakdown) carried out an attack on Singapore and bombed its commercial port. They reported having scored a large number of direct hits on three 10,000t-class merchantmen and the military facilities on the wharf. Seven planes were marked with bullets, one made an emergency landing on the Kluang airfield used by the Army, but the others returned to base.

4 [February]: Nine land-based attack planes of the Genzan Air Group and six land-based attack planes of the Mihoro Air Group carried out a search and attack mission on the enemy in the Bangka Strait. They reported having spotted one [enemy] heavy cruiser, one light cruiser, four destroyers, one escort naval ship, one small naval vessel and six merchantmen, and sunk two 20,000t-class merchantmen and the escort ship. Two of the planes sustained hits and made an emergency landing on Ledo, while others returned to base.

5 [February]: Five land-based attack planes each of the Genzan and the Mihoro Air Groups carried out a search and attack mission on the enemy in the Bangka area. They reported having spotted two [enemy] cruisers, two destroyers, two auxiliary gunboats, one fishing boat (500 ton class), and one sailboat (200 ton class), and scored near hits on one auxiliary gunboat, the fishing boat and the sailboat. All of the aircraft returned to base.

Four land-based attack planes of the Mihoro Air Group attacked the coastal areas of northern Sumatra. They reported having spotted one [enemy] destroyer and two merchantmen and scored near hits on the merchantmen. All of the aircraft returned to base.

Twenty-one Type-0 fighter planes and four land-based reconnaissance planes of the Yamada Unit advanced from Kota Bharu to Kuching. However, due to the bad condition of 
the airfield, two Type-0 fighter planes, one land-based reconnaissance plane and one landbased attack plane, which had assisted with the transport, were seriously damaged (as previously told) in this advance. Meanwhile, the aircraft that had advanced to the Kuching airfield were three Type-96 fighter planes, four land-based reconnaissance planes, twentyone Type-0 fighter planes and eighteen Type-96 land-based attack planes.

The Army air units in the Malaya area had completed their deployment for the air campaign to destroy the [enemy] air power in the Palembang area. ${ }^{(117)}$

6 [February]: Thirty-six land-based attack planes of the Mihoro Air Group (full force) advanced from Kota Bharu and Sungai Petani to the Kuantan base. Also, nine Type-96 fighter planes of the group advanced to Kuantan from Kota Bharu.

The Army air units launched their air campaign to completely destroy the [enemy] air power in the Palembang area. ${ }^{(117)}$

7 [February]: No operations were conducted.

8 [February]: The 22d Air Flotilla headquarters advanced to Kuching from Saigon. ${ }^{(75)}$

Six land-based attack planes of the Genzan Air Group carried out a search and attack mission on the enemy [on the waters surrounding] Bangka Island. They reported having spotted two destroyers and two merchantmen and sunk one 10,000t-class merchantman out of them. All of the aircraft returned to base.

The Mihoro Air Group did not conduct operations due to the felling of the trees in the extension zone of the runway.

One land-based reconnaissance plane of the Yamada Unit carried out a reconnaissance of the Batavia area. After spotting two battleships (which were later amended to 'not battleships'), twenty large merchantmen in the port and six large and twenty-seven small aircraft on the airfield, as well as one Buffalo, one Spitfire and others in the air, it returned to base. ${ }^{(129)}$

Army aircraft spotted one [enemy] cruiser, two destroyers and twenty transport ships, which had sortied from Batavia and were sailing northward, as well as one [enemy] destroyer and seven transport ships, which were sailing southward on the waters north of Java. From the 6th onwards, the Army air units reported having brought down or damaged around 100 aircraft of the enemy air forces in the three-day air campaign to destroy the enemy air power. ${ }^{(117)}$

On this day, the Navy air units (the Genzan, the Mihoro Air Groups and the Yamada Unit) finally completed preparations to conduct attacks from the advance bases, and it was decided to launch the air campaign to destroy the enemy air power in the Batavia area from the 9th onwards.

9 [February]: One land-based reconnaissance plane and fifteen Type-0 fighter planes of the Yamada Unit carried out an attack on Batavia. All of the aircraft returned after reporting having shot down twelve enemy aircraft and strafed eight, which were set ablaze. However, one Type- 0 fighter plane was seriously damaged when landing. The [enemy] movements reconnoitered at Batavia were as follows: ${ }^{(129)}$

1. Naval ships at anchor in Batavia

One Renown-class battleship, about twenty large merchantmen, and about twenty small merchantmen.

2. Kemajoran airfield

Two large and seventeen small aircraft

3. Cililitan airfield

Four Blenheim bombers and ten small aircraft

One land-based attack plane of the Kanoya Air Group conducted a survey of the Kuantan base from Thủ Dâu Một and concluded that it was unusable as an operation base for Type1 land-based attack planes. ${ }^{(117)}$ On that day, the invasion unit left Cam Ranh Bay. 


\section{The Sailing of the Convoy}

At 1900 on the 9th, the 1st Escort Unit and the convoy carrying the Army advance party left Cam Ranh Bay. ${ }^{(118)}$ Earlier, in view of the movements of enemy surface units in the Bangka area for the past several days, Malaya Unit Commander Vice Admiral Ozawa had judged that it was highly likely that his units would encounter powerful enemy surface units in the coming Operation L. Therefore, in order to reinforce the support surface force, he had decided to put the Yura of the $2 \mathrm{~d}$ Escort Unit into the main unit and the Kashii into the $2 \mathrm{~d}$ Escort Unit instead of the Yura, and on 8 February he had changed the disposition of his forces in the following way. ${ }^{(118)}$

1. The Yura shall be removed from the $2 \mathrm{~d}$ Escort Unit and added to the main unit.

2. The Kashii shall be removed from the Anambas Base Unit and added to the 2d Escort Unit; accordingly the captain of the Kashii shall become the 2d Escort Unit commander.

3. The 91st Guard Unit commander shall become commander of the Anambas Base Unit.

The force, which left Cam Ranh Bay on the 9th, consisted of the following [ships]. ${ }^{(118)}$

The Sendai (the flagship of the 3d Destroyer Squadron), the 11th Destroyer Division (the Hatsuyuki, the Shirayuki, and the Fubuki), the Asagiri, and eight Army transport ships

At 1920 when departing from Cam Ranh Bay, the Fubuki detected and attacked [an] enemy submarine, with unknown results. ${ }^{(118)}$ After that, the ships smoothly continued their sailing southward. On that evening, the Uranami and the Murakumo, which had been engaged in the Ledo operation, broke off the operation and left Pamangkat for the Anambas Islands. The 1st Section of the 41st Minesweeping Division also returned to the Anambas Islands. In the meantime, on the early morning of the 9th, the Army units had successfully landed on Singapore Island and launched an all-out attack.

Around 1000 on the 10 th, the 1 st Escort Unit crossed the $10^{\circ} \mathrm{N}$ line and changed course south southwestward toward the Anambas Islands. At 1800 on that day, the main unit and the 3d Air Unit left Cam Ranh Bay as scheduled. This force consisted of the following [ships]:(68)

Main unit: The Chōkai (the flagship of the First Southern Expeditionary Fleet), the 7th Cruiser Division (the Kumano, the Suzuya, the Mikuma, and the Mogami), the Yura, the 1st Section of the 19th Destroyer Division (the Ayanami and the Isonami), and the 12th Destroyer Division (the Shirakumo)

The 3d Air Unit: The 4th Carrier Division (the Ryūjō) and the Shikinami

On the 11th, the 1st Escort Unit still continued sailing south and by the evening reached a point as close as about two hundred nautical miles north of the Anambas Islands. ${ }^{(118)}$ The main unit and the $3 \mathrm{~d}$ Air Unit sailed after the 1st Escort Unit, closing in on it at sunset at a distance of about seventy nautical miles behind. At sunset, the main unit spotted two torpedo trails. Carrier-based attack planes of the 4th Carrier Division, the Yura and the Shirakumo carried out an attack, but with unknown results. ${ }^{(119)}$ At 1800, the 2d Escort Unit left Cam Ranh Bay as scheduled, escorting the main force of the Army, ${ }^{(68)}$ which consisted of the following [ships]: 
The Kashii, the Shimushu, the 20th Destroyer Division (the Yügiri and the Amagiri), Submarine Chaser No. 9 and fourteen Army transport ships

On that day, the Kinu returned to Cam Ranh Bay from the Ledo operation in order to prepare for the subsequent operations. ${ }^{(123)}$

On the early morning of the 12th, the Main unit and the 3d Air Unit caught up with the 1st Escort Unit at a point about 150 nautical miles north northeast of the Anambas Islands. ${ }^{(118)}$ At that point, one element of the escort unit changed places with the unit that had sailed north from the Anambas Islands, and the former sailed to the Anambas Islands for refueling. ${ }^{(68)}$ According to a subsequent air reconnaissance, one [enemy] cruiser, one gunboat and some vessels that looked like transport ships were spotted sailing south on the waters north of the Bangka Strait, and Malaya Unit Commander Vice Admiral Ozawa judged that the enemy was still in a full-fledged escape from the Singapore area. ${ }^{(119)}$ The commander decided to advance with a force consisting of the main unit, the $3 \mathrm{~d}$ Air Unit and the $3 \mathrm{~d}$ Destroyer Squadron to the waters of Bangka and catch and destroy the escaping enemy units before the invasion units would reach the area. ${ }^{(118)}$ From around 2000 or 2030, the units started sailing southward, increasing their speed to 18 knots; the Chōkai, the $2 \mathrm{~d}$ Section of the 7 th Cruiser Division, the Ryuj $\bar{j}$, and the 19th Destroyer Division headed for a point about 130 nautical miles east of Singkep, while the Sendai, the Yura, the 11th Destroyer Division, the 1st Section of the 7th Cruiser Division and the 12th Destroyer Division headed for a point about 60 nautical miles east of Singkep. ${ }^{(119)}$ Around that time, the 1st Escort Unit was sailing southeast of the Anambas Islands, while the $2 \mathrm{~d}$ Escort Unit was sailing south on the waters east of the island of Puolo Condore. In the meantime, the low speed unit of the Base Unit, [i.e.] the Otowamaru, the Rumoi-maru, eight auxiliary cutters and four fishing boats, had left the Anambas Islands at 1500, and was sailing southward toward the Bangka area, intending to reach the mouth of the Musi River on the early morning of the 15th. ${ }^{(68)}$

Around 0800 on the 13th, the units, which had advanced to catch the escaping enemy units, reached their respective positions, ready to meet the fleeing enemy vessels. ${ }^{(130)}$ By the end of that day, the 3d Destroyer Squadron unit ([consisting of] the Sendai, the Yura, the 11th Destroyer Division and the Asagiri) reported the following military gains: ${ }^{(118)}$

1403: The Hatsuyuki and the Shirayuki sank one British 4,000t-class merchantman.

1404: The Fubuki and the Asagiri sank a ship, which looked like a British 2,000t-class auxiliary minelayer.

2245: The Sendai and the Yura sank a ship, which looked like a 3,000t-class auxiliary cruiser.

In the meantime, at 1845 one enemy aircraft came probing, which was followed by a raid of five aircraft at 1940; they strafed and bombed the Fubuki and the Asagiri, but no damage was sustained. ${ }^{(118)}$ The 7th Cruiser Division unit did not spot any enemy other than an enemy merchantman on fire, and at 1700, by an order of the Malaya Unit commander, [started] sailing north toward the waters east of Cape Jang to be ready against the enemy [in the zone] south of Singapore and north of Bangka Island. On that evening, the 1st Escort Unit and the 2d Escort Unit were sailing south, respectively at a point about forty nautical miles northwest of Tambelan Island and about a hundred nautical miles north of Great Natuna Island. 
At 0045 on the 14th, the Fubuki and the Asagiri sank one British merchantman at thirty nautical miles east of Cape Jabung. At 0800, 1st Escort Unit Commander Rear Admiral Hashimoto decided the subsequent disposition of forces as follows: ${ }^{(118)}$

1. The Sendai and the 1st Section of the 11th Destroyer Division shall join the transport ships.

2. The Yura, the Asagiri and the Fubuki shall appropriately operate on these waters and attack enemy naval vessels under the command of the captain of the Yura, and operate in such a manner as to guard the area north of the transport ships as they sail south.

3. The Fubuki shall join the transport ships at 1800 (supposed to cover the transport ships sailing into the Bangka Channel).

At 0600, the transport convoy of the advance party reached a point about forty-six nautical miles east of Cape Jang and kept sailing southward. At 0800, three enemy aircraft came for a raid and dropped bombs but caused no damage. Between 0910 and 0950 in the course of joining the convoy, the Sendai and the 1st Section of the 11th Destroyer Division spotted three floating mines about ten nautical miles south of Saya Island and got rid of them. Also, the convoy [itself] spotted three floating mines and got rid of them between 1115 and 1230. The friendly fighter planes started the direct escort in the air [over the convoy] from around 1000 onwards. Although six enemy aircraft came for a raid in the air above the convoy around 1230, which was followed by four aircraft around 1450, friendly fighter planes and antiaircraft fire drove them off, and they caused no damage. The friendly fighter planes shot down some of the enemy aircraft. The friendly fighter planes withdrew their direct escort at 1545 and returned to base. ${ }^{(118)}$

At 1400, the transport convoy reached [the waters] about twenty nautical miles $200^{\circ}$ [SSW] off Saya Island, set its course at $170^{\circ}$ [SSE] and headed for the Bangka Strait. At 1600, 1st Escort Unit Commander Rear Admiral Hashimoto issued the following order:(118) "When tonight entering into Mentok [anchorage], enemy merchantmen must not be attacked unless they do harm to us. [Also,] when attacking enemy merchantmen, you have to focus on crippling them and try as much as possible not to sink them." The order was issued in view of the experience that since the 13th, [the attack units], full of fighting spirit and too anxious to attack, had wasted ammunition against an enemy that had almost no pluck to fight back, and that, moreover, the penetrating power of the shells was so great that they just went right through the ships' sides without readily sinking them. ${ }^{(131)}$

Around 1815, the Army's small cargo ship unit sailing in the wake of the 1st Escort Unit at a distance of about twenty nautical miles encountered a 1000t-class British auxiliary gunboat and was coming under fire from the latter. However, the Yura, the Fubuki and the Asagiri, which were covering the rear, soon came in for support and sank the gunboat. One of the small cargo ships caught fire and was abandoned because there was no chance of extinguishing it. ${ }^{(118)}$ Around 1920, the convoy was strafed and bombed by eleven enemy bombers at a point about seventy nautical miles north of Palembang, and the 9th Base Unit sustained some damage. ${ }^{(68)}$ The convoy reached Point J at 2100 and shifted to the formation for entering into the Mentok anchorage. While the Hatsuyuki and the Fubuki, which had sailed ahead, provided guard on the surrounding waters, it entered into the anchorage, guided by the Shirayuki. The Hatsutaka of the 9th Base Force separated [from the convoy] at some point near Point J to head for the mouth of the Musi River. ${ }^{(118)}$ In the meantime, when on that day [the 14th] the 1st Section of the 7th Cruiser Division was operating on the waters east of Cape Jang, it re- 
ceived around 1430 a report from [an] aircraft of the Ryūjō [about spotting] one mid-sized [enemy] merchantman at ten nautical miles east of Cape Jang and headed for the target. Around 1620, the section spotted a ship, which looked like a British auxiliary minelayer, and fired at her, but let her get away because she escaped into shallow waters, which appeared to be a minefield. Meanwhile at 1120, a [scout] plane of the Suzuya reported having spotted [an enemy] submarine on the waters west of Lingga Island and having attacked and sunk her. ${ }^{(114)}$ The main unit and the $3 \mathrm{~d}$ Air Unit operated on almost the same waters as they had on the previous day. Although they came under a surprise attack by nine heavy bombers in the afternoon, they sustained no damage. ${ }^{(130)}$ In the evening, a report came in: "The Army [paratroop] raiding unit has successfully landed at Palembang at 1125 today, the 14th."(114)

Between 0010 and 0100 on the 15th, the convoy entered into the Mentok anchorage as scheduled. Around 0020, the Hatsutaka, which had headed for the mouth of the Musi River [ahead], wired: "Spotted [a vessel], which looks like [an] enemy destroyer to the south of the light ship at the mouth of the Musi River. Request to drive her off." First Escort Unit Commander Rear Admiral Hashimoto ordered the 11th Destroyer Division to attack her, and the Fubuki headed for the mouth of the Musi River at 0055. Meanwhile, after guiding the transport convoy into the anchorage, the Shirayuki seized [an enemy] 1,500t-class armed merchantman and [a] 200t-class small merchantman to the south of the anchorage, led them to Mentok to hand them over to Submarine chaser No. 7, which seized from the ships nautical charts of the waters around Singapore. ${ }^{(118)}$

After entering into the anchorage, the transport convoy immediately launched the operation to land in Mentok as well as prepare for the operation to maneuver [landing] craft to the mouth of the Musi River. The Mentok landing unit and the [Musi River] landing craft task force respectively left the anchorage at 0205 and around 0300. ${ }^{(132)}$ The [Army's] Saleh River-ascending Unit and the Musi River-ascending Unit (including the Telang River Unit) respectively reached the mouth of each river at 0545 and 0615. ${ }^{(133)}$ In the meantime, the Fubuki searched for the enemy naval vessel at the mouth of the Musi River along with the Hatsutaka. However, unable to spot the vessel, she broke off the search at 0500 and returned to her patrol area ${ }^{(68)}$ Meanwhile, finally at 0450 , the 1 st Escort Unit commander received a report from the 11th Subchaser Division commander that the landing had been successfully carried out at 0220. At 0545, the [Navy] Base Unit's River-ascending Unit for Palembang (the unit to clear the waterways [to Palembang]) arrived at the mouth of the Musi River. ${ }^{(118)}$

The deployment of forces around the sunrise on 15 February was as follows:

The north entrance of the Bangka Strait: the Sendai, the Hatsuyuki and the Fubuki

[The area] to the south of Saya Island and the east entrance of the Berhara Strait: the Yura and the Asagiri

The Mentok anchorage:

The anchorage of the convoy: eight Army transport ships, the Eikō-maru, the Kōryū-maru, Submarine Chasers Nos. 7 and 8

The waters [requiring] minesweeping: 1st Minesweeper Division (in the course of sweeping mines)

The area south of the anchorage: the Shirayuki

The mouth of the Musi River: the Hatsuyuki, the Otowa-maru, the Rumoi-maru, eight auxiliary cutters, four fishing boats and the Army task force in their landing craft

At the mouth of the Saleh River: the Army task force in their landing craft 


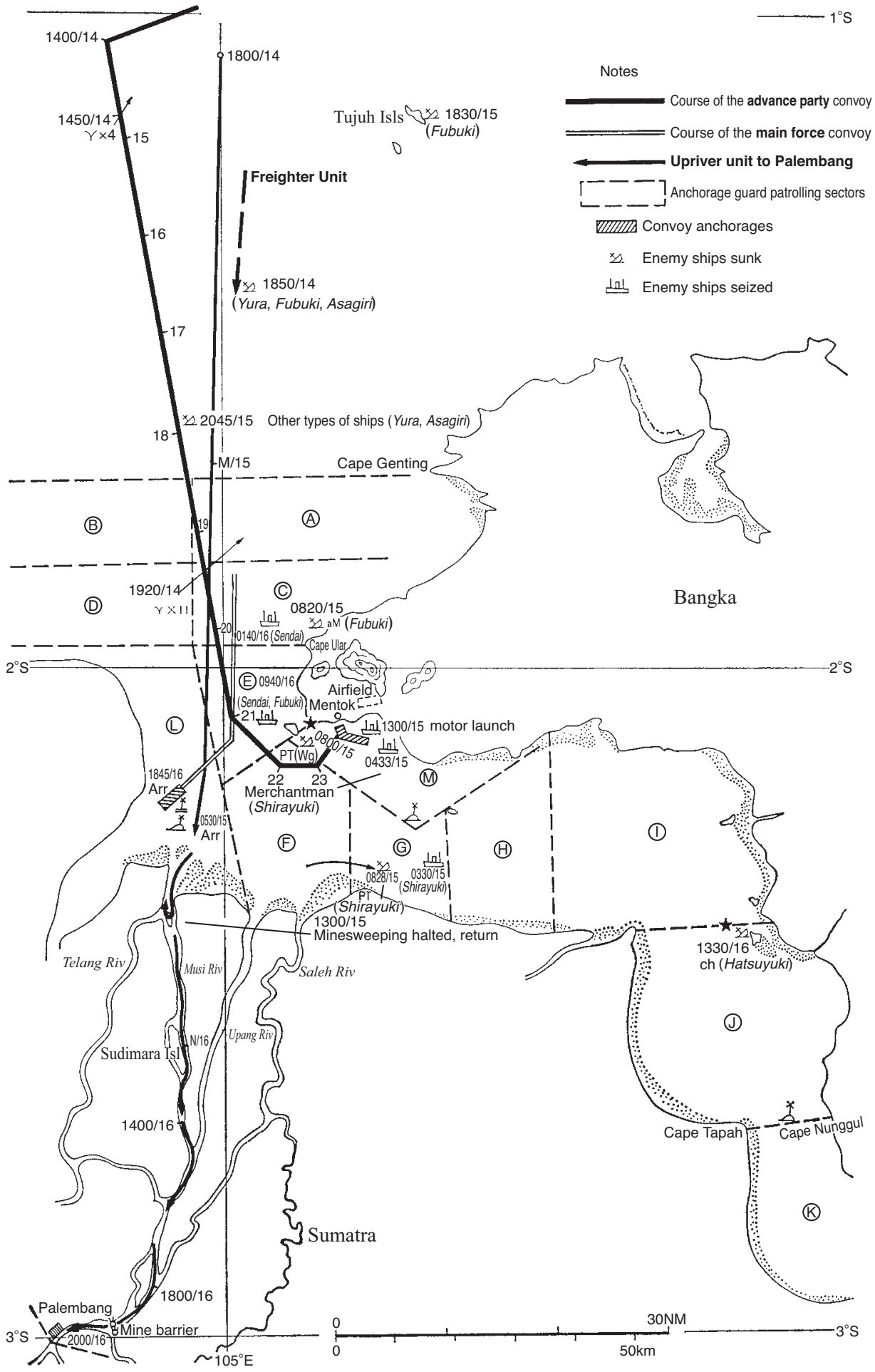

Illustration No. 28 - The Guarding at the Bangka Strait Anchorage and the Outline of the Operation to Sail Upstream to Palembang 
At 0800, the 1st Minesweeper Division encountered one British torpedo boat off Cape Kelian and sank her. At 0830, the Shirayuki [also] sank [one] British torpedo boat in the area south of the Mentok anchorage. Around that time the Fubuki pursued a ship, which looked like a British minelayer, and ran her aground to the north of Cape Ular. At 0930, the 1st Minesweeper Division completed clearing the surrounding waters of mines (no tethered mines [found]). In the meantime at 0830, the Army river-ascending units (consisting of small shallow-draft [landing] craft, which did not need to worry about mines) started sailing upstream. Following that, the Navy River-ascending Unit for Palembang (for clearing waterways) started sailing upstream. ${ }^{(118)}$ At 1400 on 15 February, Singapore finally fell.

\section{Missing an Opportunity to Destroy the Enemy Fleet (See Attached Illustration No. 4 [omitted])}

On the morning of 15 February, the main unit ([consisting of] the Chōkai, the $2 \mathrm{~d}$ Section of the 7th Cruiser Division, the 4th Carrier Division and the 19th Destroyer Division) and the 1st Section of the 7th Cruiser Division were operating on the waters about a hundred nautical miles east northeast of Mentok. At 1000, the following report from a scout seaplane of the Chōkai was sent: ${ }^{(134)}$ "0938: Three enemy cruisers and five destroyers are sailing north in the Gaspar Strait." “0950: The enemy seems to be directly escorted by six destroyers and accompanied by one battleship." It was followed by a report, which came from the 4th Carrier Division:(119) "1005: The [current] enemy position is thirty-five nautical miles $340^{\circ}$ [NNW] of Liat Island and on a course of $0^{\circ}[\mathrm{N}]$ at a speed of 12 knots." (The position was actually a mistake for twenty-five nautical miles $40^{\circ}$ [NE of the island].) "No enemy aircraft carriers were seen at the rear of the enemy cruisers." The enemy position as of 1000 was about 160 nautical miles $145^{\circ}$ [SSE] of the main unit. It was partly sunny with a wind of ten meters [per second] from the north and a visibility of fifty kilometers, creating perfect weather conditions for an attack.

Malaya Unit Commander Vice Admiral Ozawa made roughly the following judgments and decisions: ${ }^{(119)}$

1. The enemy seems to have rallied a powerful unit and is heading northward in order to attack our Operation L units.

2. [Judging from] the reconnaissance reports of the Batavia area before the launch of Operation L as well as from the reports delivered by the aircraft of the Chōkai, it is certain that a battleship is among the enemy unit.

3. We shall pick up the enemy movements by keeping on probing the enemy as much as possible with our air force, and first of all attack them with our air units. Then, taking a favorable opportunity, our surface units shall rush at the enemy and destroy them.

At 1035, the Malaya Unit commander reversed course to head southeastward and issued the following orders, while beginning to assemble his main unit in line for approaching the enemy. ${ }^{(134)}$ [First, he issued the following order] to the 22d Air Flotilla: "1035: Get ready for an attack with the full force of the land-based attack planes." [Also,] to the main unit: "From 1200 onwards, stand by and be ready for immediate sailing at a speed of 28 knots and for the maximum battle speed in fifteen minutes." Then at 1045, he ordered the 1st and the $3 \mathrm{~d}$ Air Units to carry out repeated attacks on the enemy, while ordering the $2 \mathrm{~d}$ Air Unit to probe the enemy fleet. ${ }^{(118)}$ 
The main unit did fourteen knots, taking by and large a southeastern course. ${ }^{(134)} \mathrm{A}$ little after 1100, a [scout] plane of the Chōkai reported as follows: "1108: The position of the enemy main force is at twenty-five nautical miles $50^{\circ}$ [NE] of Cape Berikat." [That is to say,] the enemy position as of 1100 was 115 nautical miles $140^{\circ}$ [SE] of the main unit. Around that time, the following report of the $2 \mathrm{~d}$ Escort Unit Commander Capt. Kojima Hideo came in:(118) “The position of the $2 \mathrm{~d}$ Escort Unit as of 1000 is $0^{\circ} 37^{\prime} \mathrm{N}, 106^{\circ} 16^{\prime} \mathrm{E}$. If things carry on like this, it shall reach the mouth of the Musi River around 1100 on the 16th." The 2d Escort Unit's scheduled entry into the anchorage had been around 0000 on the 17th. However, its current position was forty-five nautical miles northeast of the main unit. Judging that it was dangerous to let the unit continue its course when a decisive battle with the enemy fleet was about to be launched, Malaya Unit Commander Vice Admiral Ozawa ordered at 1125: "The 2d Escort Unit shall temporarily evacuate to the north." ${ }^{(119)}$ At 1135, the $2 \mathrm{~d}$ Escort Unit reversed course and started to evacuate, setting its course at $0^{\circ}[\mathrm{N}]$.

At 1130, [an] aircraft of the 22d Air Flotilla sent in the following report:(134) "1100: The enemy main force consists of a battleship and three cruisers as its core and sails at a speed of 18 knots on a course of $300^{\circ}$ [WNW], accompanied by eight destroyers." It was followed by a report from [an] aircraft of the 4th Carrier Division: "1120: One battleship is among the main force of the enemy." At 1155, 22d Air Flotilla Commander Rear Admiral Matsunaga reported: "1130: The attack [plane] unit has been launched." After that, reports on the state of the enemy poured in one after another from friendly aircraft. ${ }^{(134)}$ From a scout seaplane of the Chōkai: "1137: The enemy sails counting from the north in a line of five destroyers and three cruisers. All turned $270^{\circ}$ [W] together, [sailing] at a speed of 20 knots." From [an] aircraft of the 22d Air Flotilla: "1145: The position of the enemy main force is 50 nautical miles $0^{\circ}$ [N] of Gaspar Island [and they are sailing] at a speed of 20 knots." From [an] aircraft of the 4th Carrier Division: "1155: Spotted two enemy cruisers and one destroyer at 58 nautical miles $90^{\circ}$ [E] of Cape Tuing. They are [sailing] on a course of $0^{\circ}[\mathrm{N}]$ at a speed of 14 knots." It was followed by "1215: Correction: the enemy position is 22 nautical miles $2^{\circ}[\mathrm{N}]$ of Gaspar Island."

The main unit was still approaching [the enemy fleet] at a speed of fourteen knots. Malaya Unit Commander Vice Admiral Ozawa informed his subordinate units of his overall judgment of the enemy situation as of 1240 as follows: (134) "The enemy main force consists of one battleship, three cruisers and eight destroyers. Its position is at $2^{\circ} \mathrm{N} 106^{\circ} 7^{\prime} \mathrm{E}$ and it is [sailing] on a course of $350^{\circ}$ [NNW]." Again, the following reports came in: From a [scout] seaplane of the Chōkai: "1250: The position of the enemy main force is 55 nautical miles $105^{\circ}$ [E] of Cape Tuing. [The enemy is] sailing on the course of $310^{\circ}$ [NW] at a speed of 14 knots." "1315: Add further two battleships to the force." From the 4th Carrier Division commander: "1300: The enemy strength consists of five large cruisers and eight destroyers. They are [sailing] on a course of $310^{\circ}$ [NW] at a speed of 14 knots." From a scout seaplane of the Kumano: "1300: [The position of] the enemy main force is 45 nautical miles $0^{\circ}[\mathrm{N}$ ] of Cape Berikat. It is [sailing] on a course of $310^{\circ}$ [NW] at a speed of 18 knots."

Although more than three hours had passed since the enemy was [first] spotted, friendly air units had not yet conducted any attacks. Malaya Unit Commander Vice Admiral Ozawa judged that if his unit would continue sailing southeastward, it was likely to meet head-on with an enemy fleet that was superior to his unit and included a battleship. At 1328, the commander changed his course northeastward at a right angle to the course of the enemy and [also] issued the following orders: 
1. The Sendai, the Yura, the 11th Destroyer Division and the Asagiri shall join the main unit.

2. The main unit shall operate on the waters northeast of Cape Jang.

3. [The ships of] the 1st Escort Unit other than those above shall enter [and stay in] the mouth of the Musi River.

While assembling around 1500, the Sendai, the Yura and the other ships that were ordered to join [the main unit] started sailing north from the north entrance of the Bangka Strait. The convoy also raised anchor at 1500 to head for the mouth of the Musi River. ${ }^{(118)}$

Setting its course virtually to the north at 1350, the main unit sailed as if it was backing away from the enemy. ${ }^{(134)}$ Then, it received the following reports: From a scout seaplane of the Mikuma: "By the bombing attacks of our forces at 1335 [1325?], one large cruiser is sending up black smoke. The formation of the enemy has lost coherence." It was the first bombing attack conducted on the enemy fleet by seven carrier-based attack planes of the 4th Carrier Division. At 1406, [by ordering the main unit] "Stand by and get ready for immediate sailing at 24 knots and at maximum battle speed in thirty minutes," the Malaya Unit commander eased the standby level of the engines. At 1430, he changed his course north northwestward and kept this course so that he would maintain a distance of more or less 65 nautical miles from the enemy. Right after that, friendly aircraft reported the enemy's course reversal as follows: From a scout seaplane of the Suzuya: "1417: The enemy reversed course." From [an] aircraft of the 4th Carrier Division: "1420: The enemy main force has reversed course. It is [sailing] on a course of $120^{\circ}$ [ESE] at a speed of 24 knots." From a [scout] plane of the Mogami: "1430: The enemy changed course to starboard." From [an] aircraft of the 22d Air Flotilla: "1430: At 1405 [we] bombed the main force of the enemy but did not score direct hits."

Before the attacks of friendly air units had produced considerable military gains, the enemy started reversing course to withdraw. At 1450, the [Japanese] main unit set its course at $0^{\circ}[\mathrm{N}]$. At 1500 , it changed course again to the northeast, and then headed southeastward at 1513, but it still kept sailing at a low speed. Then, the following reports were received:(134) From a scout seaplane of the Kumano: "1515: The enemy has reversed course, [and sails] on a course of $145^{\circ}$ [SE]. There are no battleships. A Hawkins-class cruiser was wrongly taken for a battleship. This is certain." From the 4th Carrier Division commander: "1550: A Hawkinsclass cruiser was mistaken for a battleship." From the 4th Carrier Division commander: "1600: Based on the confirmed report from the aircraft that probed [the enemy], [I] partly revise the report on the enemy strength as follows: [the enemy consists of] seven cruisers (three Emerald-class, two Danae-class, and two Hawkins-class), and five destroyers. [There are] no battleships." Despite this report, Malaya Unit Commander Vice Admiral Ozawa did not yet abandon his judgment that [a] battleship was among the enemy [fleet]. ${ }^{(134)}$

Around 1600, there followed reports about the friendly land-based attack planes' bombing attacks, but the enemy still seemed to be evacuating on a course of $120^{\circ}$ [SE] without having sustained fatal damage. From this situation, the Malaya Unit commander judged that the enemy had given up its plans due to the attack of our air units. Accordingly at 1620, the commander issued an order to the $2 \mathrm{~d}$ Escort Unit, which was evacuating to the north: "The $2 \mathrm{~d}$ Escort Unit shall operate as planned. Report your [current] position." (118) In accordance with this order, the $2 \mathrm{~d}$ Escort Unit reversed course: its position [at that time] was 102 nautical miles $39^{\circ}$ [NE] of Cape Jang. [Meanwhile,] aircraft continually reported on the enemy movements. ${ }^{(134)}$ Gathering from the reports, the distance to the enemy was expected to be 130 nautical miles or more by 1700. Judging that an engagement was hardly likely on that day, the 
Malaya Unit commander ordered the 1st Escort Unit at 1700: "The 1st Escort Unit commander shall return to his original tasks at an appropriate moment."(118) In accordance with the order, the 3d Destroyer Squadron unit returned to its deployment in the Bangka Strait area at midnight. At 1810, the aircraft reconnoitering [the enemy] reported that the enemy was still sailing south. After ordering the air unit at 1810 to have "all aircraft stop the reconnaissance," the Malaya Unit commander decided to have the main unit guard the present waters by appropriately operating there. ${ }^{(134)}$

Although the enemy had sustained some damage by the attacks of the Japanese air units, which had caused two of the ships to send out black smoke, they sailed through the Gaspar Strait at 1900 to the Java Sea. The attacks of the air units on that day had scarcely been able to cause any serious damage, and the surface unit also missed an opportunity to have an engagement. ${ }^{(134)}$ Capt. Tanaka Kikumatsu, then captain of the Kumano of the 7th Cruiser Division, criticized the conduct of the operation in his post-war memoir as follows:

If he [Vice Admiral Ozawa] had the intention to carry out a decisive battle with his main unit, he should at least have kept the enemy in sight. I understand that he attached greater importance to the air attacks, but by having the few bombers of the 4 th Carrier Division carry out repetitive attacks the whole day, I wonder whether he did not depend too much on aircraft [attacks]. And it is regrettable that he ignored the positive statements by the aircraft of the Kumano (confirmed by Aviation Officer Lt. Itō Motoé himself) as well as by 4th Carrier Division Commander Rear Admiral Kakuta that there was no battleship among the enemy [fleet].

On the other hand, Malaya Unit Commander Vice Admiral Ozawa stated in his post-war memoir the following:(38)

After this operation, 4th Carrier Division Commander Kakuta once asked me whether the surface unit should not have hotly pursued and closed in on the enemy when the enemy had been spotted. To that question, I answered in the following way:

1. The fleet should not distance itself too far from the transport convoy it was supposed to escort. In addition, it was supposed to continue its task to catch and destroy as much as possible enemy vessels escaping from Singapore.

2. I judged that the enemy fleet had come out to conduct a rescue operation and had anticipated our air raid to some degree. I never expected that at our first air raid the enemy would flee in total confusion.

As for the enemy battleship, it was concluded afterward that a battleship had not been included after putting together the reconnaissance reports and photos.

\section{The Lack of Military Gains Produced by the Air Units}

On 10 February, twenty-seven land-based attack planes of the Mihoro Air Group advanced from the Kuantan base to the Kahang base to prepare for the attack on Batavia. On the 11th, the land-based attack planes of the Mihoro Air Group headed for the attack on Batavia, each aircraft carrying seven $60 \mathrm{~kg}$ bombs for use on land (about half [of the regular full load]) and fuel loaded to capacity. However, because the fighter planes to cover the attack could not take off due to bad weather at Kuching, the attack planes called off the [scheduled] attack and conducted a search and attack on enemy naval vessels in the Bangka Strait [instead]. ${ }^{(128)}$ The unit spotted three [enemy] cruisers, one destroyer and two merchantmen near Bangka 
Island and carried out a bomb attack, but the attack produced very few results, because the evasive actions of the enemy were very skillful and because the unit had to use bombs for use on land (with impact fuses; the fuses for attacks on naval vessels had not yet arrived). ${ }^{(71}$, 128) (It was reported that one cruiser and two merchantmen had been destroyed.)

On the 12th, seventeen land-based attack planes of the Genzan Air Group, twenty-six land-based attack planes of the Mihoro Air Group, and twenty-seven land-based attack planes of the Kanoya Air Group, seventy aircraft in total, carried out a search and attack on enemy naval vessels in the Bangka Strait. They spotted three merchantmen, one cruiser, three destroyers and two auxiliary vessels, and reported having destroyed one merchantman, one cruiser, and one auxiliary vessel. ${ }^{(71,81)}$ On that day, eleven land-based attack planes of the Genzan Air Group advanced to Kuching, by which the total number of the aircraft advanced there became thirty-one. ${ }^{(135)}$

On the 13th, twenty-seven land-based attack planes of the Genzan Air Group, twentyeight land-based attack planes of the Mihoro Air Group and twenty-seven land-based attack planes of the Kanoya Air Group, eighty-two aircraft in total, carried out a search and attack on enemy naval vessels in the Bangka and Singapore Straits. They spotted some dozen merchantmen, one destroyer and one auxiliary vessel and carried out attacks on them, but only to report that they had only sunk one merchantman and seriously damaged another. ${ }^{(71,81)}$ The poor bombing scores of the land-based air units were a big problem.

Note: "Yamada Takeo Hisōchō Nisshi" [The Journal of Chief Flight Warrant Officer Yamada Takeo] put it in the following way: "Today, all squadrons had poor scores. Because all bombs blanketed the [enemy] ships, at least one should have hit. But [the enemy] really must have had all the devil's luck that not a single bomb did hit them. Tomorrow, we are again scheduled to attack [enemy] naval vessels. We must score direct hits, for the honor of the Navy air units as well. The squadron commander is also racking his brains over how to correct the bomb run. He even said that he would award a prize to anyone who would offer him a good idea. All of us feel really exasperated." Furthermore, the entry on 14 February in the "Sanagi Chūsa Nikki" [Diary of Commander Sanagi] relates: "The Malaya Unit was trying hard to attack enemy naval vessels in the Singapore and Bangka Island areas with the entire force of its air units and surface vessels. However, it is deplorable when, like on yesterday the 13th, the mid-sized [land-based] attack plane units of the 22d Air Flotilla attacked an enemy transport convoy with seventy-one aircraft in total only to sink no more than a single ship. That should be called a worse than bad result."

On the same day, seventeen Type-0 fighter planes and one land-based reconnaissance plane of the Yamada Unit headed for an attack on Batavia but returned due to bad weather. ${ }^{(129)}$

On the 14th, twenty-seven land-based attack planes of the Genzan Air Group, twentynine land-based attack planes of the Mihoro Air Group and twenty-seven land-based attack planes of the Kanoya Air Group carried out a search and attack on enemy naval vessels in the Bangka and the Singapore Straits. They spotted one [enemy] destroyer, four minelayers, three auxiliary vessels and eight merchantmen, and reported having sunk one minelayer and two merchantmen, run one minelayer aground and inflicted some damage to another, while having inflicted serious damage to two merchantmen, some damage to one and minor damage to another, and also run two merchantmen aground. ${ }^{(71,81)}$ Meanwhile, the Yamada Unit provided direct escort in the air over the convoy for Operation $\mathrm{L}$ and reported that the unit had shot down ten enemy Lockheed bombers (almost all) that had come for a raid between 
1235 and 1400 before they could bomb [the convoy]. Five Japanese aircraft were marked by bullets, but all returned. ${ }^{(129)}$

[Concerning the operation for] the 15th, 1st Air Unit Commander Rear Admiral Matsunaga had issued orders that six land-based attack planes of the Genzan Air Group should take off at dawn and search for the enemy in the Bangka area, while the other aircraft should be on standby, primarily to be serviced. At 1000, a [scout] plane of the Chōkai, which had been searching for the enemy, reported having spotted an enemy fleet, ${ }^{(134)}$ which was followed by orders of the Malaya Unit commander to prepare for an attack at 1035 and to implement the attack. ${ }^{(122)}$ At 1040, the 1st Air Unit commander ordered all air raid units to attack the enemy with their full force. ${ }^{(122)}$ All units hurriedly prepared for the attack. [However,] some units were unable to gather their full regular crew and [had to] conduct the mission with mixed crews. ${ }^{(128)}$ Twenty-three land-based attack planes of the Genzan Air Group took off from Kuching at 1130, carried out bombings on the enemy fleet, whose formation had been broken by the bombings of the carrier-based attack-plane unit of the Ryūjō at 1335 [1325?]. However, without scoring direct hits, all returned with eight of them marked by bullets. ${ }^{(71)}$ However, this attack made the enemy fleet reverse course at 1417. ${ }^{(134)}$ Twenty-seven land-based attack planes of the Mihoro Air Group took off from the Kuantan base at 1235 to attack the enemy fleet and carried out attacks from 1545 till 1634. They scored no direct hits either and all returned to Kuantan with twelve of them marked by bullets. ${ }^{(71)}$ The Kanoya Air Group also hurriedly prepared for attack. At 1230, the first team of nine aircraft departed from the Thu Dâu Một base, which was followed by seventeen aircraft at 1342; they headed for an attack on the enemy fleet. The land-based attack planes of the Kanoya Air Group had been scheduled to land on the Kahang base after the attack. Having received a telegram from the 22d Air Flotilla Commander Rear Admiral Matsunaga, "1640: If it is not possible to return to base before sunset, the unit shall suspend the attack and return. Sunset: 2021," the 1st Squadron reversed course and returned to base. ${ }^{(134)}$ However, the $2 \mathrm{~d}$ and the $3 \mathrm{~d}$ Squadrons continued their attack missions. Around 1842, they attacked the enemy fleet but none scored any direct hits and almost all aircraft were marked by bullets. While the commander plane returned to Thủ Dâu Một, six planes flew to Ledo, and ten to Kahang. Among the planes that had headed for Ledo, one made an emergency landing in a dense forest area near the Ledo [airfield] and caught fire, which killed all eight crewmembers. ${ }^{(71)}$ One of the aircraft which had landed on the Kahang [airfield] fell into a ditch on the left side of the runway and was seriously damaged. ${ }^{(128)}$ In the meantime, the Yamada Unit conducted patrols over Kuching with Type-96 fighter planes, while supporting the attack on the enemy fleet with one land-based reconnaissance plane and six Type-0 fighter planes, but without spotting enemy aircraft, all returned. ${ }^{(129)}$

The $2 \mathrm{~d}$ Air Unit (seaplane unit) had carried out patrols over the anchorage as well as the convoy (after its departure from the port) against enemy submarines and also patrols [against enemy aircraft] day after day. However, no enemy was spotted other than some aircraft, which had come to raid the Anambas area. From the 12th onwards, the unit searched for the enemy [on the waters] south of the Anambas Islands and reported having spotted small enemy naval vessels and a large number of merchantmen. Then on the 15th, after the scout plane of the Chokkai had spotted the enemy, the unit reconnoitered the enemy fleet with its full force and reported useful information on the enemy movements. ${ }^{(122)}$ In the meantime, the advance base personnel of the $2 \mathrm{~d}$ Air Unit carried out a landing in front of the enemy at 


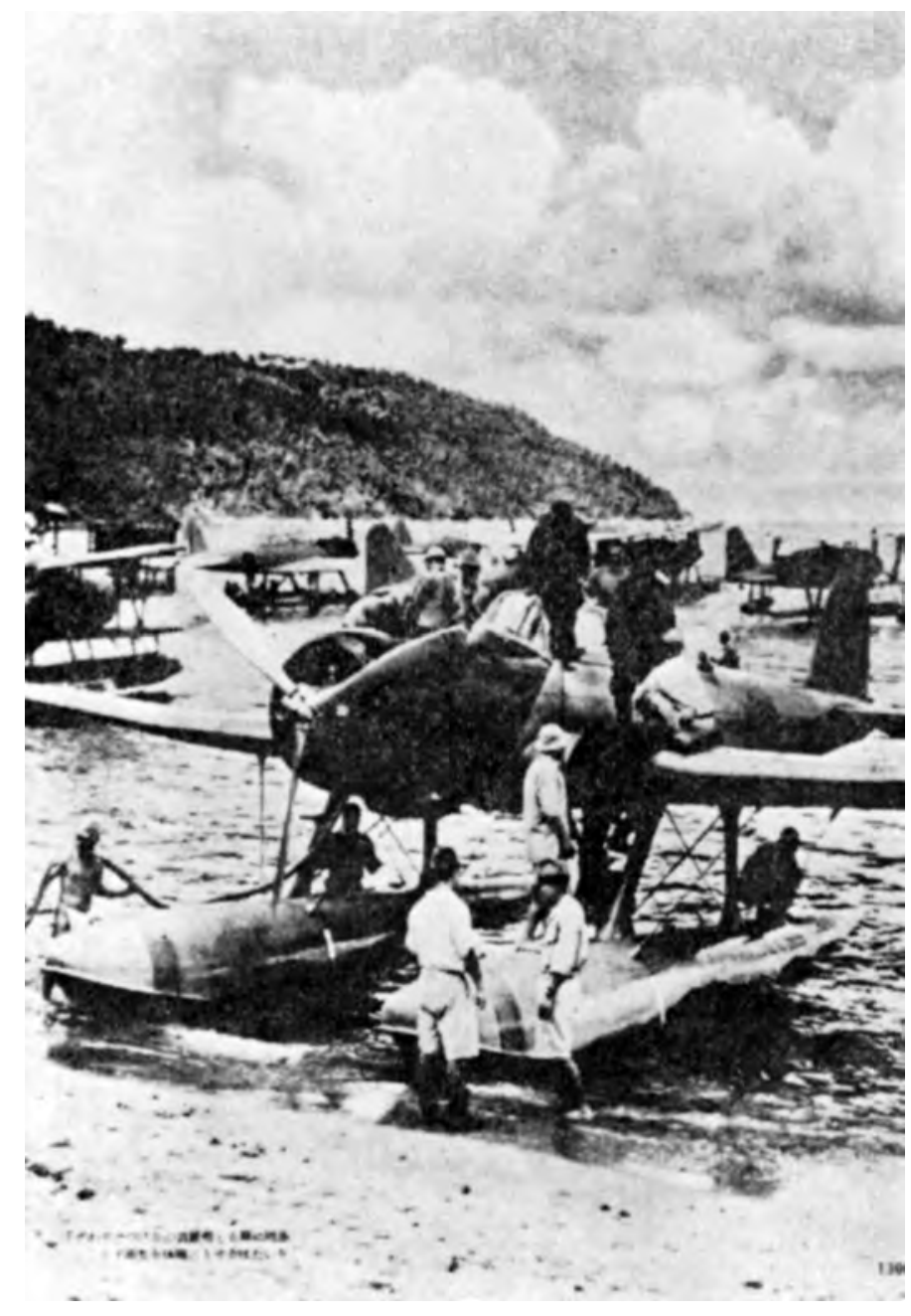

A Seaplane Base

Mentok along with the army unit and set up a seaplane base there. ${ }^{(125)}$ At 1300, one element of the reconnaissance seaplane unit advanced to the Mentok [base] and carried out patrols over the anchorage against enemy submarines and aircraft, while supporting the river-ascending units to seize Palembang. ${ }^{(125)}$ During this period, on the 14th, the unit reported having sunk an enemy submarine, inflicted minor damage to a gunboat and serious damage to a torpedo boat, setting the latter ablaze, and also destroyed one merchantman. It also produced a military gain of inflicting minor damage to an [enemy] merchantman and leading [a] friendly destroyer to her to sink her. Also on the 15th, the unit reported military gains of sinking an [enemy] auxiliary gunboat, inflicting some damage to one gunboat and minor damage to another, and setting a merchantman ablaze. ${ }^{(119,122,125)}$

At 1800 on the 10 th, the $3 \mathrm{~d}$ Air Unit ([consisting of] the Ryūjō, the Shiokaze, and the Shikinami) had left Cam Ranh Bay following the main unit of the Malaya Unit. At 0800 on the 13th, the unit advanced to [the waters] about 130 nautical miles $85^{\circ}$ [E] of Singkep Island. Afterwards, the unit appropriately operated on the waters north of Bangka Island to be ready against the enemy in the Gaspar and Karimata Straits. ${ }^{(71)}$ The unit guarded the air over the main unit and the carrier with the carrier-based fighter planes, while patrolling against enemy submarines with carrier-based attack planes. Also, it carried out a search and attack mission on the enemy in the Bangka Strait with carrier-based attack planes; on the 13th, it reported military gains of having sunk one merchantman, setting two ablaze, inflicting serious damage to one, some damage to another, and minor damage to two, while having run another aground; ${ }^{(71)}$ on the 14 th, it reported military gains of having sunk one torpedo boat tender in cooperation with a scout seaplane of the Mogami, and also having sunk an auxiliary vessel and a gunboat, destroyed one minelayer, while having sunk one merchantman and run another aground. There were no attacks by enemy aircraft or submarines. ${ }^{(68)}$ 


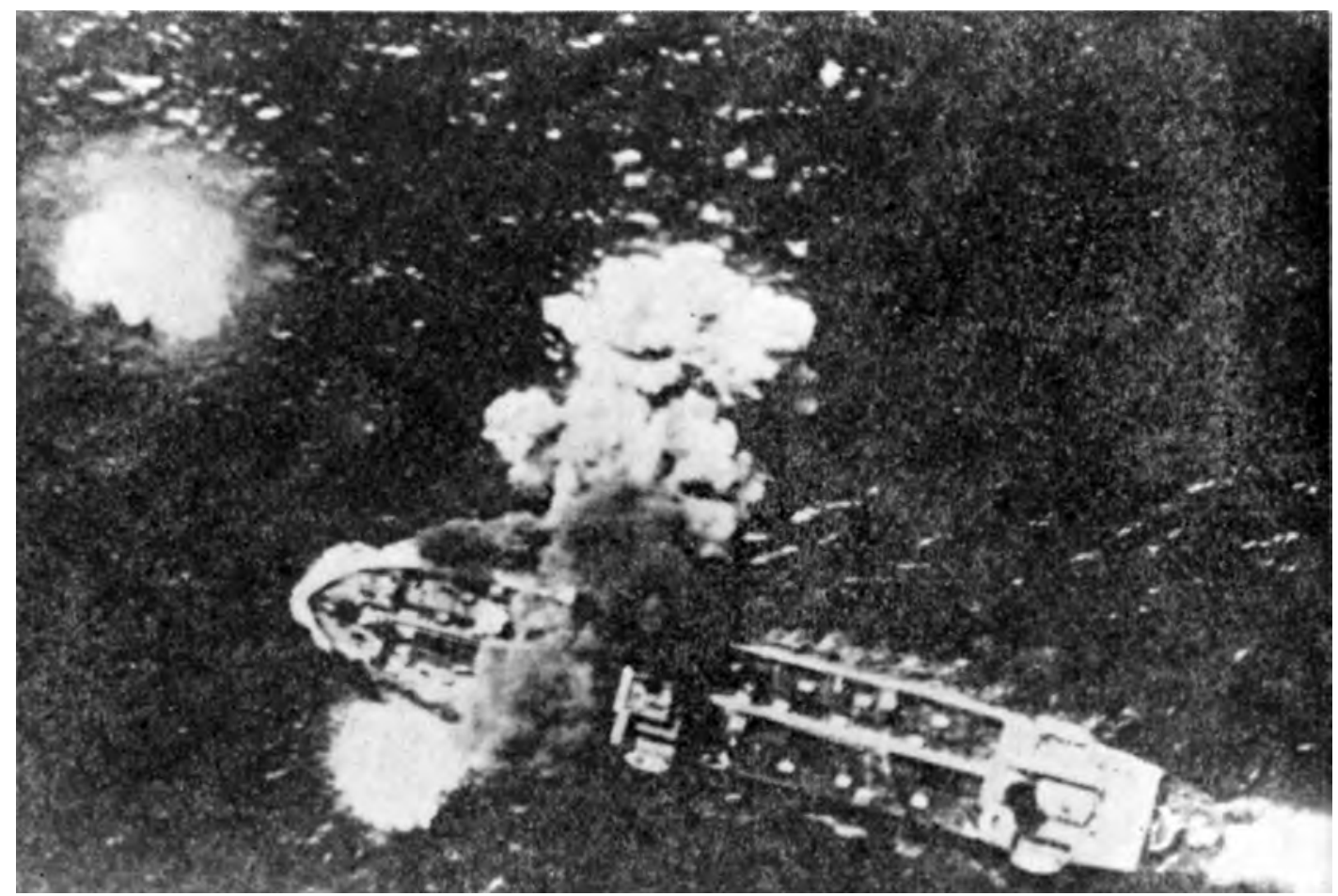

The Sinking of a Large Oiler in the Bangka Strait at 1600 on 13 February

On the 15th, the $3 \mathrm{~d}$ Air Unit was following in the wake of the main unit of the Malaya Unit. At 0848, Type-96 carrier-based fighter planes on guard in the air drove off an enemy flying boat, which had probed the main unit. The [air] unit was in the course of carrying out a search and attack on the enemy in the Riouw and the Berhara Straits, while attacking enemy gunboat[s] in the Palembang area. Learning that a [scout] plane of the Chōkai had spotted an enemy fleet at 1000, the $3 \mathrm{~d}$ Air Unit immediately separated from the main unit and started advancing toward the enemy. ${ }^{(37)}$ At that time, it was partly sunny with a wind of ten meters [per second] from the north and a visibility of fifty kilometers, creating a perfect opportunity for an air attack.

Note: The topnotch crews had been culled from the 3d Air Unit for the attack on Hawaii and the unit was made up of scratch crews right before the opening of hostilities, so in fact they had barely had time for practice and their bombing or torpedo attack skills were far from polished. That is why Commander Kakuta left the cover provided by the main unit and boldly advanced toward the enemy alone, so it would be easier to conduct repeated attacks (by making it possible to conduct attacks from a close distance). ${ }^{(37)}$

At 1105, the first attack unit of seven carrier-based attack planes of the 3d Air Unit took off. At 1325, the first attack unit bombed an Exeter-class cruiser, set her ablaze, and reported having sunk or seriously damaged the ship. ${ }^{(71)}$ At 1430 [1540?], the second attack unit of six carrier-based attack planes bombed the enemy fleet, but with no results. At 1630, the third attack unit (the second attack by the first attack [unit]) carried out a bombing, but with no results. At 1735, the fourth attack unit (the second attack by the second attack [unit]) took off. At 
1900, the attack unit bombed a Leander-class cruiser and scored one to three near hits near the stern. All aircraft returned including two that had been marked by bullets. At 2120, 4th Carrier Division Commander Rear Admiral Kakuta reported the following: ${ }^{(134)}$ "2120: The reconnaissance report by the fourth attack unit. As of 1703 the enemy fleet was heading south in the Gaspar Strait with thirteen ships sailing in a single line ahead, stretching for about twenty nautical miles, largely at a speed of twenty knots or more. The head is reaching a point twelve nautical miles $80^{\circ}$ [E] of Liat Island. The two cruisers in the rear are sailing southward while [still] on fire."

Note: Cdr. Yoshitomi Shigema, the aviation staff officer [of the 4th Carrier Div], recollected the following reasons why the carrier-based attack planes had not carried out torpedo attacks:

1. The crews had not been given enough training.

2. The torpedoes had not been satisfactorily maintained or adjusted. For those reasons, he was even less confident in torpedo attacks than in bombing attacks. The reason why the land-based attack planes had not carried out torpedo attacks was because the condition of the airfields was so bad that they were not able to take off with a torpedo load.

\section{Success of the Upriver Sail to Palembang}

At 0530 on the 15th, the Otowa-maru and the rest of the Navy River-ascending Unit for Palembang (the Otowa-maru, the Rumoi-maru, eight auxiliary cutters and four fishing boats) arrived in the mouth of the Musi River and joined the Hatsutaka (carrying the Base Unit commander), which had sailed ahead. At 1000, the unit completed the preparation for the upriver minesweeping operation and started sailing upstream at 1030. ${ }^{(118)}$ (Note: The Army units going upriver to Palembang in [landing] craft had already started sailing upstream at 0830.) However, for about two hours right from the start of the upriver sail, a total of thirty-nine enemy aircraft came attacking [the Navy units] in twelve raids, and bombed and strafed the minesweeping unit in rapid succession. The unit was kept busy returning fire, and on top of that, many obstacles on the river bottom near the mouth of the river frequently severed the minesweeping cables, which only allowed the unit to completely sweep mines in a stretch of about ten nautical miles in the morning. At 1300, Base Unit Commander Rear Admiral Hiraoka called off the minesweeping for that day and ordered the [sub-]units to return to the mouth of the river. By 1500, the units returned to the mouth of the river and evaded the enemy air raids, which still went on persistently until the evening even after the units had taken cover. Although no damage of the ships was sustained in this antiaircraft engagement, it caused a few casualties. ${ }^{(68)}$ At nightfall, Malaya Unit Commander Vice Admiral Ozawa incorporated three minesweepers of the 1st Minesweeper Division into the River-ascending Unit. ${ }^{(118)}$ At 1900 on that day, the Musi River Ascending Unit of the Army advance party reached Palembang and started landing. ${ }^{(133)}$

On the 16th, with the support of three minesweepers incorporated as reinforcements and the seaplane units, which had advanced to the Mentok base, the River-ascending Unit changed the disposition of forces and restarted the minesweeping operation, sailing upriver at 0800. ${ }^{(68)}$ Around 0900, Minesweeper No. 5 spotted vessels, which looked like enemy gunboats, immediately reversed course, engaged them and sank one and crippled another. On that day, fewer enemy aircraft interfered, and the minesweeping operation by and large made 


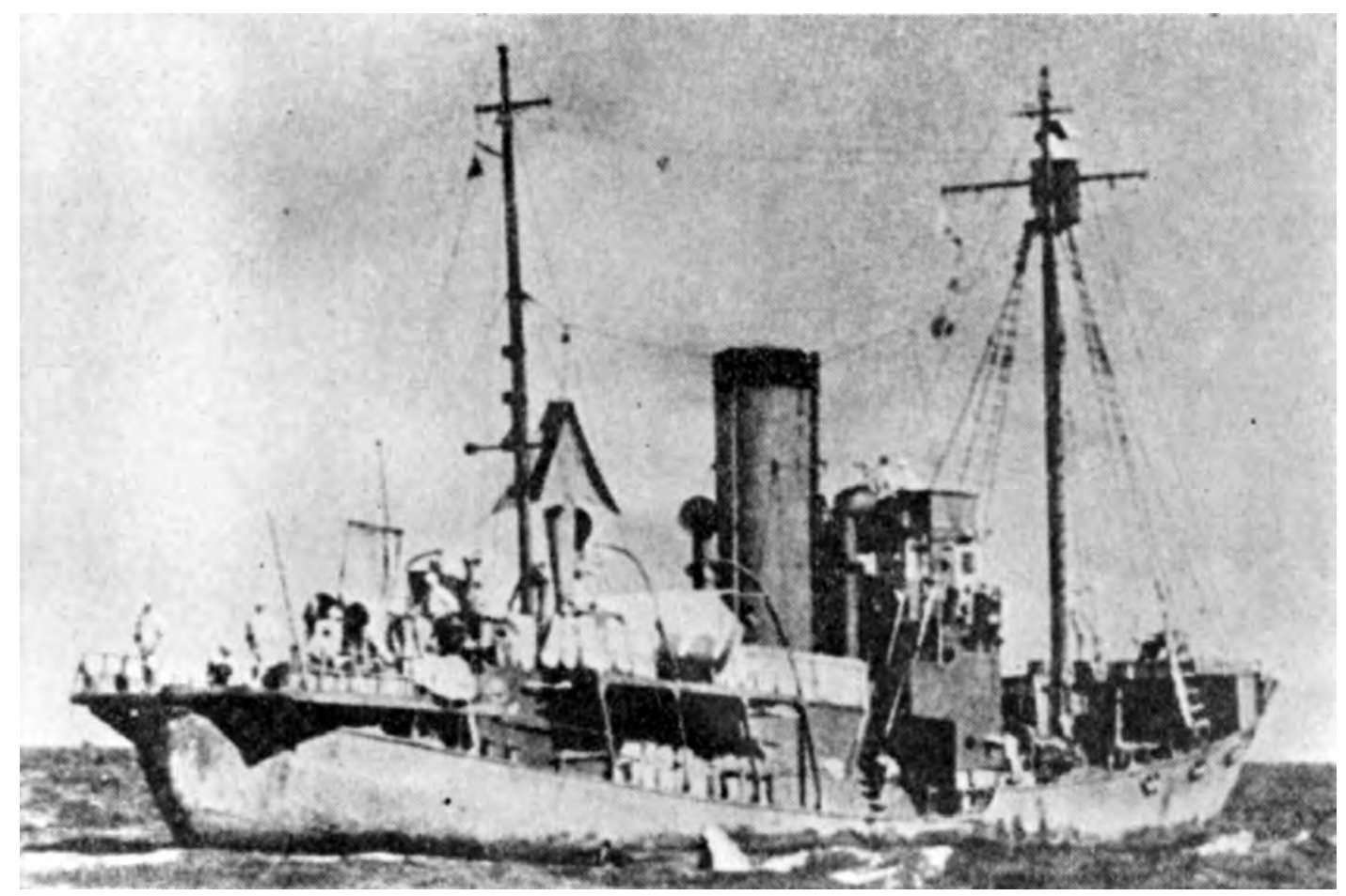

Minesweeping on the Musi River (1)

smooth progress. That is, around 1430, the unit reached the confluence of the Upang River [with the Musi River], by and large the midpoint [between the mouth of the river] and Palembang. At 2030 the unit reached Palembang and for the most part completed the scheduled minesweeping operation. ${ }^{(118)}$ Meanwhile at 1845, the convoy of the Army main force in fourteen ships had reached the mouth of the Musi River, escorted by the 2d Escort Unit. ${ }^{(68)}$

On the morning of the 17th, the Shimushu, to which the [Army] 38th Division headquarters had been transferred from the transport ship Gin'yo-maru, started sailing upriver, guiding nineteen Army transport ships. However, at a point around three nautical miles upstream of Borang Island, they encountered a yet-to-be-swept mine barrier, which made it impossible for the transport ships to sail upriver. Consequently, after having the transport ships temporarily drop anchor [there], the Shimushu [continued to] sail upriver alone; she reached Palembang at 1435 and disembarked the divisional headquarters. The minesweeping of that [barrier] was finally completed on the 19th (having disposed of twenty-eight mines), and the Army convoy at long last reached Palembang at 1500 on the $22 \mathrm{~d} .{ }^{(68)}$ In the meantime, because at 1030 on the 17th, by means of Malaya Unit Telegraphic Operation Order No. 136, orders concerning the operation to clear the waterways in the Malacca Strait and the Singapore area had been issued, 9th Base Force Commander Rear Admiral Hiraoka in charge of the operation began preparations (i.e. by sending the minesweeping force to the Singapore area). ${ }^{(118)}$

\section{The Operations of the Surface Units from the 16th Onwards}

As of the early morning on the 16th, [the surface unit] was deployed as follows:(118) 


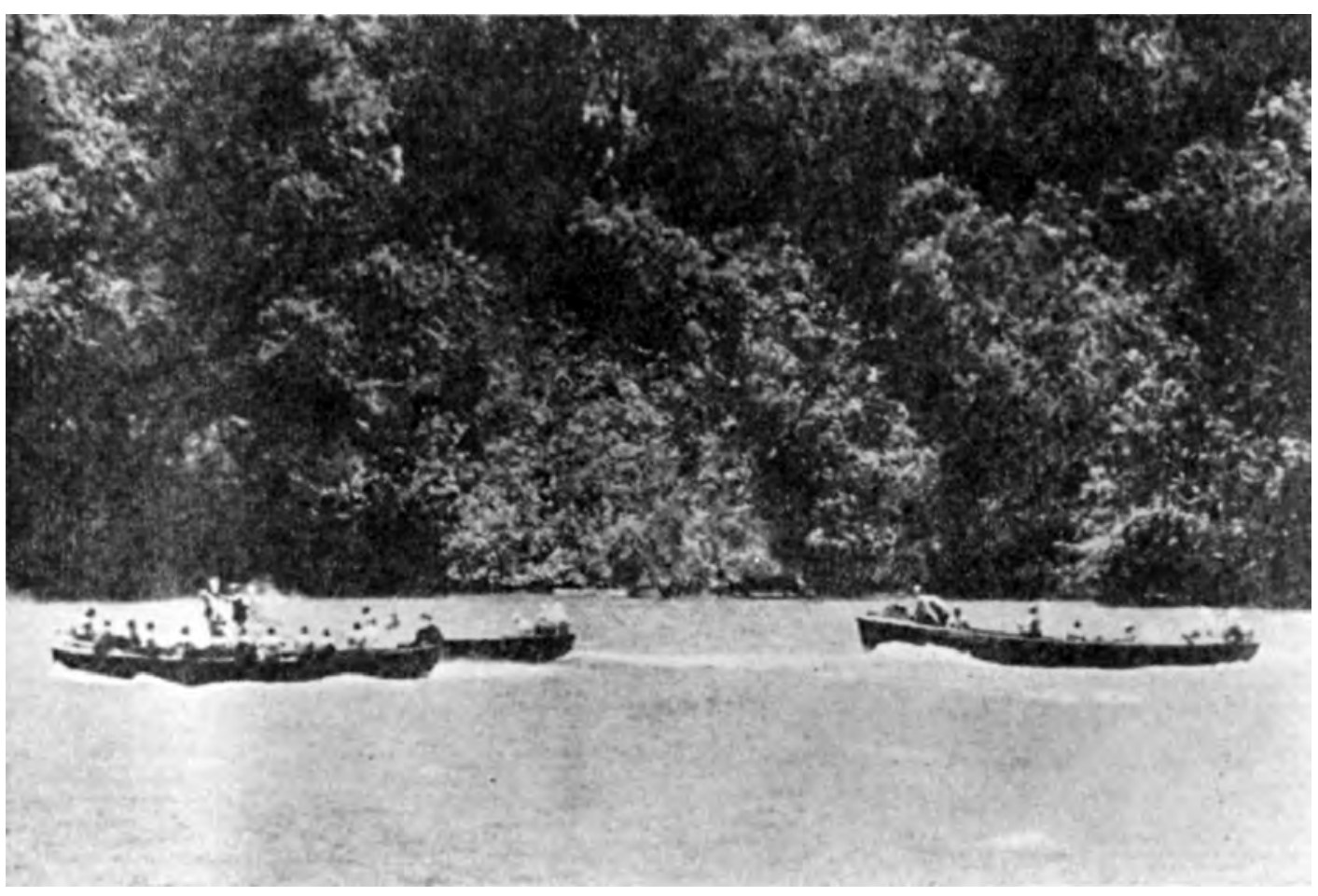

Minesweeping on the Musi River (2)

[From the] Northeast of Cape Genting [to] the Berhara Strait: the Yura and the Asagiri Off Cape Ular (the north entrance of the Bangka Strait): the Sendai and the Fubuki The Mentok anchorage: Submarine Chasers Nos. 7 and 8, the Eikō-maru, the Kōryū-maru, and three Army transport ships

The center of the [Bangka] Channel: the Hatsuyuki, the Shirayuki and Minesweepers Nos. 2 and 3 The mouth of the Musi River: the Base Unit, Minesweepers Nos. 1, 4 and 5, and five Army transport ships

On that day, the 1st Escort Unit seized or destroyed the following enemy naval vessels:(118)

0140: The Sendai attacked [a] British patrol boat off Cape Ular and destroyed her. 0825: The Sendai inspected a British cutter, disarmed her and led her to Mentok. 0900: Minesweeper No. 5 sank [an] enemy torpedo boat and disarmed [a] patrol boat. 0940: The Fubuki seized two British speed boats.

0945: The Sendai and the Fubuki seized a British tanker off the lighthouse of Cape Kelian. 1300: The 11th Subchaser Division seized [a] British cutter off Mentok.

1330: The Hatsuyuki destroyed a British submarine chaser at a point southeast of Nangka [Besar] Island.

1630: The Yura and the Asagiri seized a small British gunboat and led her to Mentok.

At 1430, four enemy bombers bombed the Mentok anchorage and caused some damage to the Tajima-maru. Another raid by six enemy bombers followed at 1645, but no damage was sustained. ${ }^{(118)}$ 
At 1800, Malaya Unit Commander Vice Admiral Ozawa issued an order to the 7th Cruiser Division and the 19th Destroyer Division (minus the Isonami) to sail to the Anambas [base] to replenish and stand by [there] for the coming Java operation. He also ordered the Kashii to sail to the Anambas [base] when the transport convoy had entered the anchorage at the Musi River. He further ordered Escort Unit Commander Rear Admiral Hashimoto to send the Yura, the 11th Destroyer Division and the 1st Minesweeper Division to the Anambas [base] by the 19th at the latest. At 1845 on that day, the 2d Escort Unit, which had escorted the Army main force, entered the anchorage at the mouth of the Musi River as much as five hours earlier than scheduled (as previously told). ${ }^{(118)}$

On the 17th, just as on the previous day, the escort unit [again] took charge of guarding the area surrounding the anchorage. They seized the following enemy [vessels] in the Bangka channel on that day: ${ }^{(118)}$

0730: The 1st Section of the 41st Minesweeper Division seized a British motor launch.

0830: Submarine Chaser No. 8 seized two British cutters.

1710: Patrol Boat No. 3 [actually Minesweeper No. 3] seized a British steam launch.

At 1140 on that day, the Southern Task Force issued telegraphic order No. 103, concerning changes of the disposition of forces (in accordance with the completion of the Malaya operation). Its contents were as follows: ${ }^{(118)}$

1. As of 21 February, the disposition of forces shall be changed as follows:

(a) [To be transferred] from the Malaya Unit to the Dutch East Indies Unit: The Yura, the 11th and the 12th Destroyer Divisions, the 1st Minesweeper Division, the Kamikawa-maru, two auxiliary submarine chasers, two fishing boats, and the Tsurumi.

(b) [To be transferred] from the Malaya Unit to the air unit: The 22d Air Flotilla (minus the Mihoro Air Group), a detachment from the 21st Air Flotilla and a detachment (minus Type-96 carrier-based fighter planes) from the 23d Air Flotilla.

2. The Malaya Unit shall cooperate in the western Java invasion operation, while staying engaged in its own mission.

Also on the 18th, the [surface unit] seized three small enemy boats in the Mentok area. In the meantime, the 11th Destroyer Division and the Yura withdrew from their patrol areas respectively at 0700 and at 1000, to head for the Anambas [base] to prepare for the Java operation. Also the main unit and the $3 \mathrm{~d}$ Air Unit, concluding at 0600 that Operation L was largely finished, left the waters north of Bangka Island where they had conducted support operations, and headed for Cap Saint Jacques. Meanwhile, the Ayanami had its propeller damaged by an uncharted reef on the 17th. Judging that the she would not be able to participate in the Java operation, Malaya Unit Commander Vice Admiral Ozawa decided to keep the Ayanami in the main unit and have the Isonami participate in the Dutch East Indies operation instead (and transferred the latter to the Dutch East Indies Unit as of the 27th). ${ }^{(118)}$

From the 19th onwards, the units to participate in the subsequent Java operation left their patrol areas one after another, and by the 25th, only the Shimushu, two auxiliary cutters and two Army transport ships were left in Mentok. During this period, a small number of enemy planes sporadically raided [the anchorage], but no damage was sustained. On the 21st, the 
shift in the disposition of forces was implemented as scheduled, and the units went into a major shift for the preparation of the subsequent operations. ${ }^{(68,118,139)}$

\section{The Operations of the Air Units from the 16th Onwards}

On the 16th, all units of the 1st Air Unit performed maintenance. ${ }^{(128)}$ A little after noontime on the 17th, a scout seaplane of the Mogami, which had been dispatched to the Mentok seaplane base, spotted a large enemy merchantman and a destroyer to the south of the Gaspar Strait. The air units carried out attacks on them; at 1615, fifteen land-based attack planes of the Genzan Air Group sank the merchantman, and ten carrier-based attack planes of the Ryūjō sank the destroyer at 1657. ${ }^{(71)}$ The enemy ships were [the destroyer] HNLMS Van Nes and [the transport ship] Sloet van de Beele, which were evacuating the personnel of the Bangka [and Belitung] Garrison Army to Java. ${ }^{(136)}$

From the 16th through the 18th, the weather conditions around the Batavia area were bad, and did not allow land-based reconnaissance planes to reconnoiter [the area]. On the 18th, all units performed maintenance. ${ }^{(129)}$ On the 21st, ${ }^{*}$ the 1st Air Unit was transferred to the Dutch East Indies Unit, except for the Mihoro Air Group, and started on the preparations for the coming Java operations. ${ }^{(122)}$ The $2 \mathrm{~d}$ Air Unit continued its search for the enemy on the surrounding waters and the guarding of the anchorage against enemy aircraft and submarines also from the 16th onwards while supporting land combats; it attained considerable military gains. The aircraft units withdrew from the Mentok base on the 19th and the 20th to return to their [mother] ships in the Anambas base. ${ }^{(119,122,125)}$ As mentioned previously, the $3 \mathrm{~d}$ Air Unit, which had been on the waters north of Bangka Island along with the main unit, concluded that the operation was largely finished and started sailing north toward Cap Saint Jacques. ${ }^{(119)}$ In the few days before its departure, the unit had reported to have sunk one [enemy] destroyer (as previously told), run one merchantman aground and seriously damaged another, while having shot down one PBY flying boat which had come for a raid. ${ }^{(71)}$

As for the 1st Air Unit, on the 21st, a Type-1 land-based attack plane of the Kanoya Air Group conducted a survey of the Palembang and Gelumbang [airfields] (the latter had been newly spotted about thirty-seven kilometers southwest of Palembang). Then on the 22d, a Type-96 transport plane of the Genzan Air Group also conducted a survey of the Gelumbang base. As a result, it was decided that the Navy should make use of the Gelumbang base because the Palembang base was small [and already full] by just accommodating the Army aircraft. From the 24th onwards, the 22d Air Flotilla advanced to Gelumbang and launched the Java operation in earnest from the 25 th onwards, making use of this base. ${ }^{(135)}$ In the meantime on the $23 \mathrm{~d}$, three land-based reconnaissance planes and fifteen Type-0 fighter planes of the Yamada Type- 0 fighter plane unit advanced to the Mentok base and launched the operation against the Java area from the 24th onwards, thus completing the preparations for the invasion of western Java.

\section{The Operations of the Submarine Units ${ }^{(60,123)}$}

Submarines I-55, I-56 and Ro-34, which had left Cam Ranh Bay for Operation L on 31 January and replenished at the Anambas [base] on 2 February, reached their respective patrol areas at the north entrance of the Lombok Strait, and the south and north entrances of the Sunda

\footnotetext{
* Actually the 19th. See p. 421.
} 


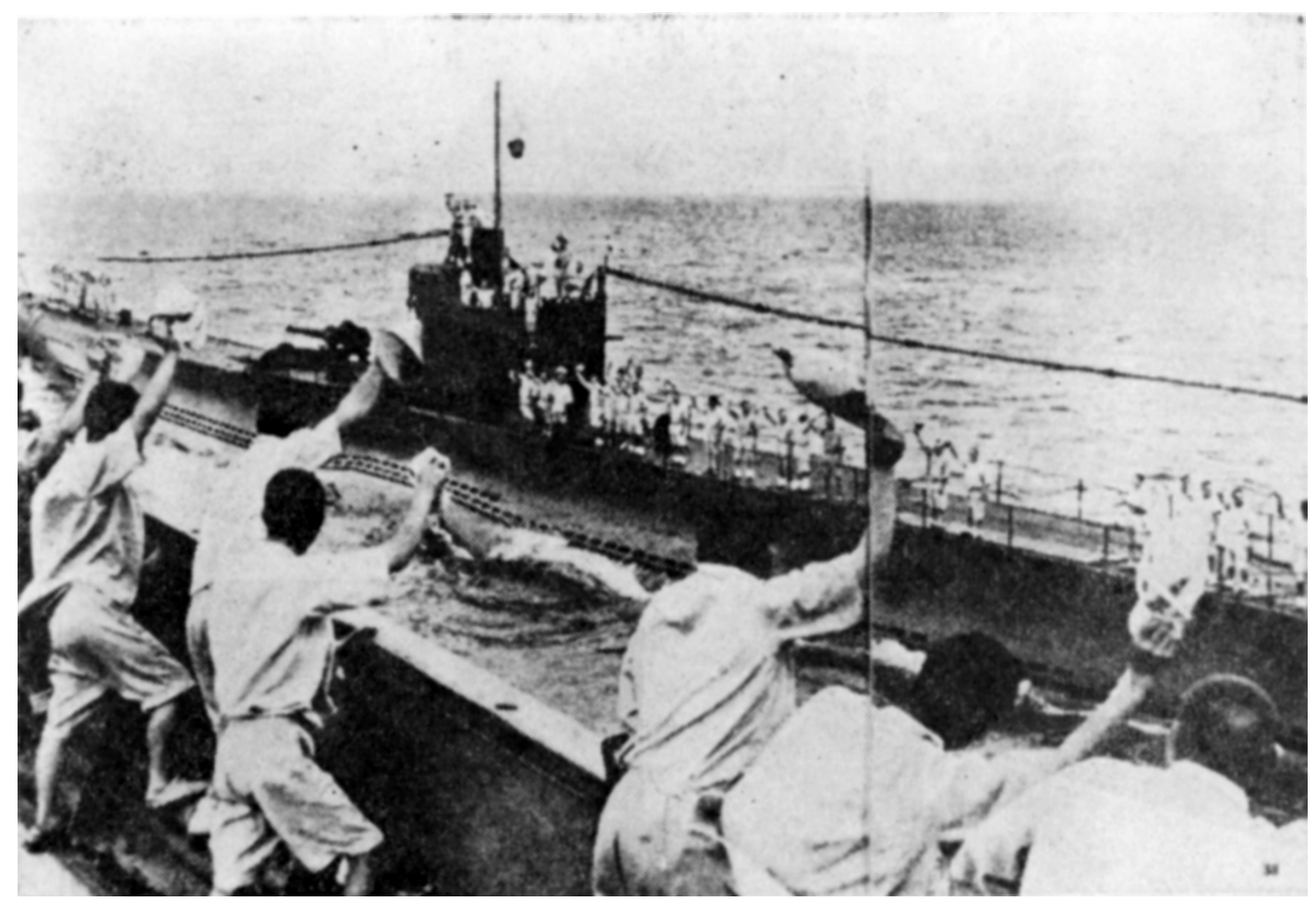

The Sortie of a Submarine

Strait. Submarine Ro-34 arrived in its patrol area at the north entrance of the Sunda Strait on 5 February. That evening, she spotted and attacked [an enemy] transport convoy and sank one escorting destroyer. As she reported having used up her torpedoes, Submarine Unit Commander Rear Admiral Yoshitomi [Setsuzō] ordered Submarine Ro-34 to return to Cam Ranh Bay, while having Submarine I-55 shift to the north entrance of the Sunda Strait. On the 15th, receiving the report on the spotting of the enemy fleet, the submarine unit commander decided to block off the escape routes of this fleet at the north entrance of the Sunda Strait. Accordingly, the commander ordered Submarine I-55 as well as Submarines I-53 and Ro-33, which were operating in areas nearby to take up positions for the coming Java operation, to take up positions in a skirmish line at the north entrance of the Sunda Strait. However, unable to detect the enemy fleet, the commander gave orders to call off the skirmish line at 1600 on the 16th. On 17 February, Submarines I-55 and I-56 left their patrol areas to return to Cam Ranh Bay [Staring Bay, pp. 332, 482]. During this period, the three submarines reported military gains of having sunk three merchant ships and sunk another with unconfirmed results apart from the previously mentioned [sinking of] a British destroyer.

\section{The Engagements of the Army Air Units}

The [Army] Third Air Force had been preparing for Operation L, while providing support for the Malaya operation of the Twenty-fifth Army. That is, the force [started] keeping an eye on the Medan airfield from 11 December onwards, and the airfields in Pekanbaru, Palembang and Mentok from the 17th onwards, while carrying out attacks on 28 December, 16, 17 and 23 January. On 4 February, the Third Air Force headquarters advanced to Kluang, and from 


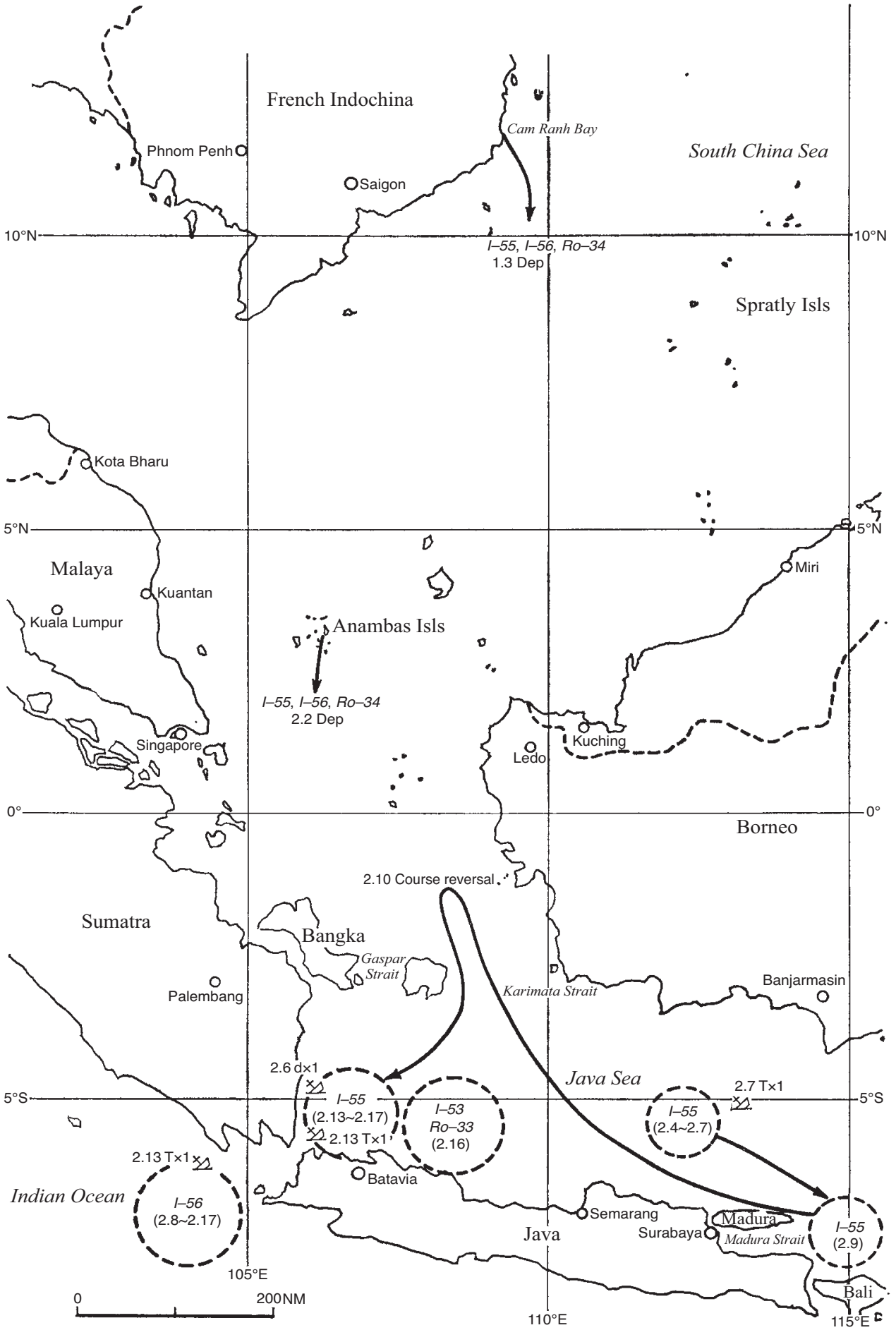

Illustration No. 29 - The Outline of the Operations of the Submarine Unit of the Malaya Unit During Operation L (30 January - 17 February, 1942) 
the 6th onwards launched the air campaign to destroy the enemy air power mainly with its fighter planes. The military gains of the force were reported as follows: On the 6th, [the force] shot down fifteen [enemy] aircraft and destroyed eleven, on the 7th it shot down more than a dozen and destroyed twenty, on the 8th, it shot down two and destroyed nine, and on the 13th it shot down five and destroyed four. In these operations, five aircraft of the force did not return. ${ }^{(117)}$

At 1500 on the 13th, the first airdrop unit (commander: Maj. Kōmura Takeo) of the 1st Raiding Group (the parachute unit) had completed its deployment at the Kahang and Kluang airfields, while the second airdrop unit (commander: 1st Lieutenant Morisawa) was standing by at Sungai Petani. At 0830 on the 14th, the first airdrop unit took off from both airfields, and the airfield raiding unit and the oil refineries raiding unit completed their drops at 1126 and 1130 respectively. Whereas the airfield raiding unit seized the airfield by that evening, the oil refineries raiding unit [finally] seized all the distillation towers at 0100 on the 15th after fierce engagements. [Meanwhile] at 1130 on the 15th, ${ }^{*}$ Raiding Group Commander Col. Kume Seiichi carried out a forced landing at about ten kilometers south of the airfield, advanced to the airfield the next morning, and took charge of the overall command after that. At 1300 on the 15 th, the second airdrop unit also landed on the airfield without problems. ${ }^{* *(117)}$

At 1930, Raiding Group Commander Colonel Kume advanced into the city of Palembang. In cooperation with the advance party of the 38th Division, which had arrived in succession from around 2100 [1900], the [paratroop] raiding unit secured the airfield as well as the city of Palembang. Although the attack unit at the oil refineries area had suffered persistent counterattacks by the enemy all through the night, the enemy counterattacks tapered off after daybreak on the 15th, and the unit completed clearing the vicinity of the enemy by noon on the 15th. On the 16th, the Third Air Force pushed forward its command post to Palembang, and the fighter plane unit advanced twenty of its aircraft on the 16th and twenty-seven on the 17th [to the airfield]. Also, two command reconnaissance planes advanced there on the 17th, and on the 18th, practically the entire fighter plane unit (about forty aircraft [in total]) advanced to Palembang. After that, no large enemy [air units] were spotted in southern Sumatra except for sporadic air raids by small numbers of aircraft, and the Third Air Force mainly took on the task of communicating orders for the 38th Division while reconnoitering the routes ahead. ${ }^{(117)}$

\section{The Operations of the Army Units (See Illustration No. 30)}

\section{The Mentok Unit}

The first landing unit left the anchorage at 0205 on the 15th, and successfully landed around 0220 to 0230 . There were no obstacles in the waterways or counterattacks with firearms from the shore in the area where they landed. Although many British soldiers, who had escaped from Singapore, were scattered over the area, none put up resistance. The main force seized the airfield at 0640 and the urban area of Mentok at 0830. ${ }^{(132)}$ The lighthouse was also seized at 0730 without meeting with enemy resistance. After that, the main force was stationed near Mentok; they engaged in securing and readying the airfield as well as debarkation while clearing the island of the enemy with one element. The force completed mopping up the whole island by the 19th. ${ }^{(121)}$

* Actually the 14th. See Vol 3, p. 331.

** Vol. 3, pp. 316-333 gives a detailed description of the airdrop operation. In several places, dates and times differ. This also applies to the following summary of the operations of the 38th Division. See Vol. 3, pp. 333-345. 


\section{The [Army] River-Ascending Unit for Palembang}

At 0830 [0800?] on the 15th, the [Army] river-ascending units all together started sailing upstream the Telang, the Musi and the Saleh Rivers, ahead of the naval vessels. ${ }^{(133)}$ Despite the three [enemy] air raids en route, the Musi River Ascending Unit, directly led by the advance party commander Tanaka, reached Palembang at 1900 on the same day and started landing. On that day, no contact was established with the paratrooper units. ${ }^{*}$ It was not until around 1100 on the next day, the 16th that contact with the paratrooper unit at the BPM oil refinery was finally established. As soon as having secured the urban area of Palembang and successfully made contact with the paratrooper units, advance party commander Tanaka immediately started marching southward. That is, he formed and sent off one company [Vol. 3, p. 337: platoon] on bicycles toward Tanjungkarang at 1200 on the 15 th, ${ }^{* *}$ which was followed by one motor car company. ${ }^{(133)}$ On the evening of the 16th, this advance party of the 38th Division spotted about thirty-seven kilometers west of Palembang a large secret airfield of the enemy (the Gelumbang base). [Meanwhile,] the Telang River Ascending Unit (the Miyazawa Battalion) had reached the northern side of Palembang on the evening of the 15th, come ashore, advanced to the Palembang airfield by the end of the day and made contact with the paratrooper unit. On the next day, the 16th, the unit reached the city of Palembang and joined the Musi River Ascending Unit.

The Saleh River Ascending Unit (the Iwabuchi Batallion) had sailed upriver, turned left from the midstream of the Musi River, and advanced to the vicinity of the Martapura airfield around 0400 on the 19th, seizing it after a minor engagement. ${ }^{* *(133)}$

\section{The Main Force of the Division}

The 38th Division headquarters had embarked on the Shimushu, and reached Palembang around 1500 on the 17th. ${ }^{(68)}$ After his arrival at Palembang, Divisional Commander Lieutenant General Sano took command of the Tanaka advance party as well as the paratrooper unit, putting the latter newly under his command, and told off the advance party to seize Tanjungkarang. While the vanguard unit of the party had already started heading south at 1200, the Miyazawa Battalion [also] left Palembang on the afternoon of the 17th. Advance party commander Tanaka left Palembang at 1200 on the 18th and arrived at the Martapura airfield at 0500 on the 19th, where he took command of the Iwabuchi and the Miyazawa Battalions. At 0200 on the 20th, the Tanaka advance party left Martapura, and its vanguard reached Tanjungkarang by daybreak on that day. At 1200 on that day, the rearmost unit of the enemy left the pier in two gunboats. Because his artillery had not yet arrived, the Tanaka advance party stood by idly and let them escape. ${ }^{(133,}$ 137)

On the next day, the 21st, Sixteenth Army staff officer Itoda Isamu located the Tanjungkarang airfield after great effort, but the airfield was still unfinished. ${ }^{(138)}$ The Tanaka advance party promptly set to preparing the airfield and completed a runway of 800 meters by the 25 th; on that afternoon, Type-97 fighter planes of the 12th Air Division advanced there. ${ }^{(117)}$

On the 20th, after the main force had reached Palembang, Divisional Commander Lieutenant General Sano told off forces to seize Bengkulu (the Kanki Detachment), while ordering the Orita Detachment on Bangka Island to shift to Palembang, leaving one element behind. ${ }^{(132)}$

The Kanki Detachment ([consisting of] the 38th Mountain Artillery Regiment headquarters, one mountains artillery battery, one infantry battalion, and one tank company as its core) left

* According to Vol. 3, p. 337, they established contact with the airfield unit and Colonel Kume.

** According to Vol. 3, p. 337, the 16th.

*** The route taken by the Iwabuchi Batallion is unclear. The route given here implies that they went up the Saleh River, then turned right via the Kumbang River to the Musi River and just before Palembang turned left into the Kommering River to Martapura. The map and description in Vol. 3, pp. 336, 339 implies that they went all the way up the Saleh River and then made a right and left turn into the Kommering River. 


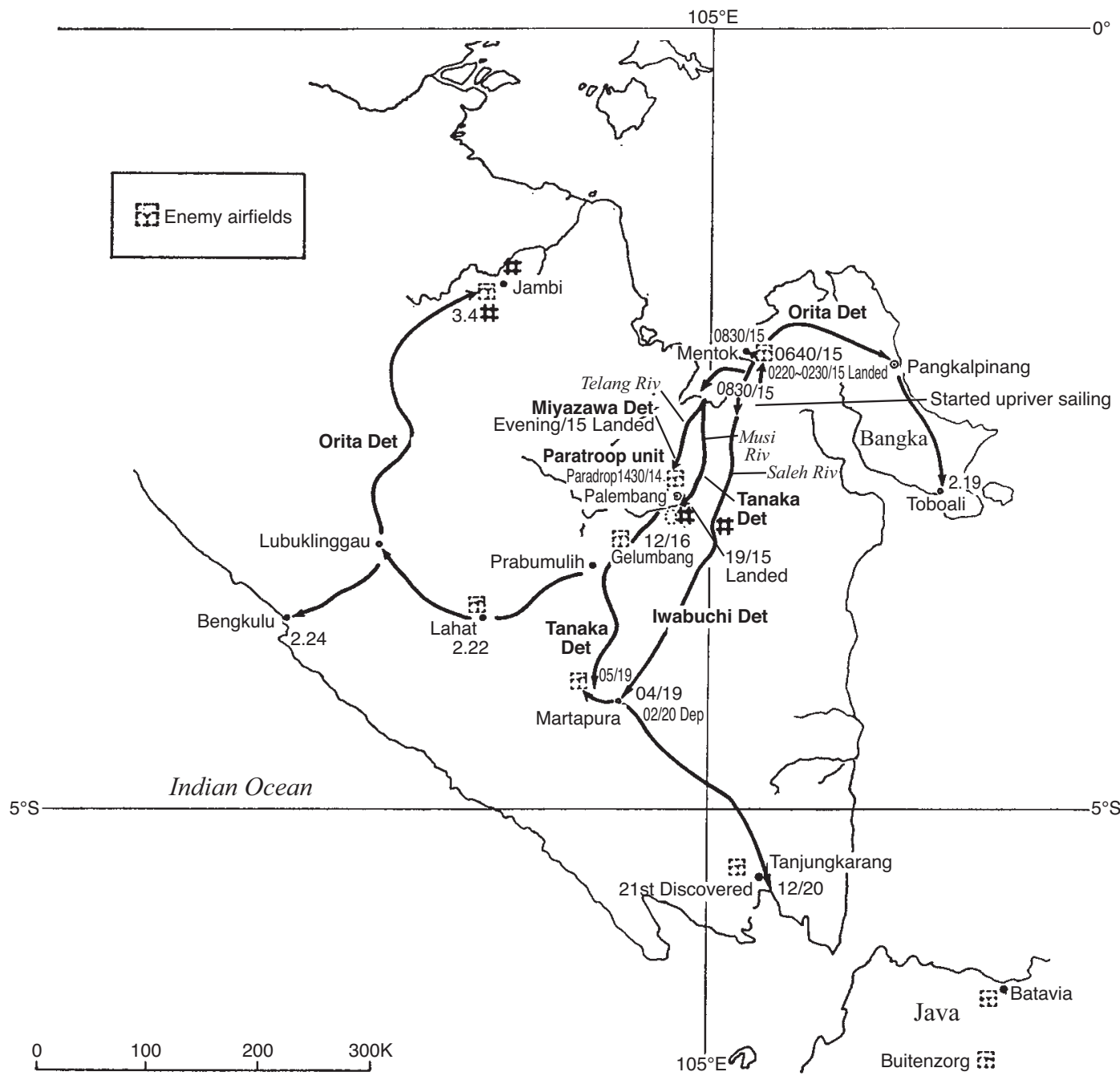

Illustration No. 30 - Outline of the Operations of the Army Units (38th Division)

Palembang on the 21st and seized Lahat and Bengkulu on the $22 \mathrm{~d}$ and the 24th respectively. The Orita Detachment, which had shifted to Palembang, was ordered to seize the Jambi oilfields. On 4 March, the detachment seized Jambi; with this the main part of the Sumatra operation of the 38th Division was completed. ${ }^{(121)}$

\section{The Failed Counterattacks by the Allied Forces}

As of 1 February, the allied air strength in this area had consisted of about fifty bombers and about fifty fighter planes. However, due to the Japanese air attacks, which had started from the 6th onwards, their strength had been worn down day by day. Because powerful [Japanese] fighter plane [units] provided cover for the convoy, the [allied] bombers, which had headed to attack the convoy, were shot down before being able to do anything, not standing the slightest chance. The desperate attacks against the [Japanese Army] Musi River-ascending Unit on the 15th were also fruitless; that evening, as the Japanese ground units advanced, [the allied air 
forces] eventually had to abandon the Palembang area, and by the 18th they had completely retreated to Java. The remaining strength that had managed to make it to Java consisted of only twenty-five fighter planes and eighteen bombers, forty-three aircraft in total. ${ }^{(85,139)}$

As for the [allied] surface unit, on the basis of information that the Japanese forces were on the verge of advancing to Bangka, the following strength had been assembled at Batavia by 13 February (under the command of Rear Admiral Doorman): the Dutch cruisers HNLMS De Ruyter, HNLMS Java and HNLMS Tromp, the British cruiser HMS Exeter, the Australian cruiser HMAS Hobart, the U.S. Destroyers USS Bulmer, USS Barker, USS Whipple, USS Alden, USS [John D.] Edwards and USS Edsall, the Dutch Destroyers HNLMS Banckert, HNLMS Van Ghent, HNLMS Kortenaer, and HNLMS Van Nes. On the early morning of the 14th, the allied task force departed from Batavia northward under the command of Rear Admiral Doorman of the Dutch Navy. However, since HNLMS Van Ghent ran aground and sank en route, which kept HNLMS Banckert behind to rescue her $\mathrm{crew}^{\left({ }^{(92)}\right.}$ the force that sailed through the Gaspar Strait northward on the early morning of the 15th consisted of five cruisers and eight destroyers. Although from around noon until sunset on the 15th, the unit had come under persistent air attacks from the Japanese forces, the only damage sustained was some slight damage to the U.S. destroyers USS Bulmer and USS Barker by near hits. Commander Doorman gave up the attack halfway, reversed course and returned to Batavia on the next day the 16th. ${ }^{(92)}$ This to the enormous disappointment and frustration of the allied headquarters. ${ }^{(85)}$

Along with the landing of the Japanese forces on Bangka Island, the garrison army on the island had retreated to its southern coast. The unit had embarked on the Dutch destroyer HNLMS Van Nes and the transport ship Sloet van de Beele on the 17th to evacuate to the south. However, both ships were sunk on their way by an attack of Japanese aircraft, and only some survivors were rescued by Dutch flying boats. ${ }^{(58)}$ The garrison army at Palembang had consisted of about 530 British, Dutch and Australian troops under the command of a Dutch colonel and been equipped with trucks, a large number of light-armored cars, thirteen antiaircraft guns, and five antiaircraft machineguns. The garrison stationed at the oil refineries had consisted of about 530 men under the command of a captain and been equipped with ten antiaircraft guns and five antiaircraft machineguns. These units of about a thousand men [in total] were neutralized by a far inferior Japanese paratrooper unit of about 300 men and retreated..$^{(117)}$

\section{The Capture by Surprise of Bali (See Illustration No. 31)}

\section{The Air Unit's Insistence on the Capture of Bali}

The (previously related) decisions made at the Manila Conference on 22 January were as follows: ${ }^{(53)}$

The seaborne capture [operation] on Banjarmasin shall be called off; Banjarmasin shall be seized overland solely by the Army. [Instead] around Day X +75 (two days before the landing on eastern Java), Bali shall be seized [to be used] as an air base from which to launch air operations at the time of invasion of eastern Java.

The grounds for the Navy's claims at the Manila Conference were as follows: ${ }^{(11,34)}$

1. If the landing of Java is supposed to be conducted around 20 February as the Army insists upon, we cannot provide an escort force for the unit to seize Banjarmasin.

2. It is possible to adequately carry out the air campaign to destroy the enemy air power before the invasion of eastern Java from the line [connecting] Balikpapan and Makassar, ([which is at a distance of] about 450 nautical miles [from eastern Java]). 
3. A comparison of the pluses and minuses of the capture of Banjarmasin against that of Bali prior to the invasion of eastern Java gives the following results:

\begin{tabular}{|c|c|c|c|}
\hline \multicolumn{2}{|c|}{ Items compared } & Bali & Banjarmasin \\
\hline \multicolumn{2}{|c|}{ Condition of the airfield } & $\begin{array}{l}\oplus \text { Enemy documents about the } \\
\text { airfield obtained in Tarakan con- } \\
\text { firm that the airfield is in good } \\
\text { condition. }\end{array}$ & $\begin{array}{l}\ominus \text { Since no documents have } \\
\text { been obtained concerning the } \\
\text { airfield, it is difficult to judge [its } \\
\text { condition]. }\end{array}$ \\
\hline \multicolumn{2}{|c|}{$\begin{array}{l}\text { Distance of the invasion unit from } \\
\text { Surabaya at sunset on the day before the } \\
\text { invasion operation }\end{array}$} & $\begin{array}{l}\oplus \text { It is possible to keep a dis- } \\
\text { tance of about } 270 \text { nautical miles } \\
\text { [from Surabaya] when faster } \\
\text { ships are used. }\end{array}$ & $\begin{array}{l}\ominus \text { Even with faster ships, the } \\
\text { unit will come as close as about } \\
250 \text { nautical miles [to Surabaya]. }\end{array}$ \\
\hline \multicolumn{2}{|c|}{$\begin{array}{l}\text { The distance of the anchorage of the inva- } \\
\text { sion convoy from Surabaya }\end{array}$} & $\begin{array}{l}\ominus \text { Since the distance is about } \\
170 \text { nautical miles, repetitive at- } \\
\text { tacks by enemy air power are } \\
\text { likely. }\end{array}$ & $\begin{array}{l}\oplus \text { Since [the anchorage will be] } \\
\text { about } 290 \text { nautical miles away } \\
\text { [from Surabaya], counterattacks } \\
\text { by enemy air power are rela- } \\
\text { tively less likely. }\end{array}$ \\
\hline \multirow{2}{*}{ 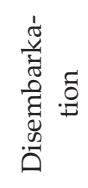 } & Condition of the anchorage & $\ominus$ Deep sea with fast currents & $\begin{array}{l}\oplus \text { Shallow sea, good [for an- } \\
\text { choring] }\end{array}$ \\
\hline & Difficulty of the disembarkation & $\oplus$ Close to the airfield & $\begin{array}{l}\ominus 30 \text { kilometers or more to the } \\
\text { airfield }\end{array}$ \\
\hline \multicolumn{2}{|c|}{ Neutralization of the enemy air power } & $\begin{array}{l}\oplus \text { It is easy to neutralize the } \\
\text { enemy air power in eastern Java } \\
\text { with fighter planes [from the air- } \\
\text { field]. }\end{array}$ & $\begin{array}{l}\ominus \text { Since it is rather distant, it } \\
\text { will be difficult to constantly } \\
\text { conduct operations to neutralize } \\
\text { [the enemy air power]. }\end{array}$ \\
\hline \multicolumn{2}{|c|}{ Cover of the convoy } & $\begin{array}{l}\ominus \text { The convoy will sail a long } \\
\text { distance. }\end{array}$ & $\begin{array}{l}\oplus \text { The convoy will sail a short } \\
\text { distance. }\end{array}$ \\
\hline \multicolumn{2}{|c|}{$\begin{array}{l}\text { Search of the enemy rear to cut off his es- } \\
\text { cape routes }\end{array}$} & $\begin{array}{l}\oplus \text { [The airfield can] effectively } \\
\text { [be used] to search for the } \\
\text { enemy to the south of Java and } \\
\text { cut off his escape routes. }\end{array}$ & $\begin{array}{l}\ominus \text { It will be difficult to search } \\
\text { the enemy rear and cut off his } \\
\text { escape routes. }\end{array}$ \\
\hline \multicolumn{2}{|c|}{ Forces for escorting [the invasion unit] } & $\begin{array}{l}\oplus \text { It is possible to employ one } \\
\text { element of the Makassar inva- } \\
\text { sion unit. }\end{array}$ & $\begin{array}{l}\ominus \text { If the invasion of eastern Java } \\
\text { has to be carried out sooner, } \\
\text { there will be no strength to spare } \\
\text { [for the escort]. }\end{array}$ \\
\hline
\end{tabular}

4. The above comparison shows that the risks of both invasions are pretty much the same. However, Bali is by far more advantageous, not only because of the certainty that the airfield is good, but also because its location is strategically superior.

[At the Manila Conference] this claim was most strongly asserted by the Eleventh Air Fleet headquarters in terms of the implementation of the air operation. Although the Dutch East Indies Unit headquarters had considerable concerns about the risks of the capture [operation], it approved its implementation considering the effectiveness of the airfield and its tactical value. ${ }^{(11)}$ The Southern Army headquarters also approved of the Navy's proposal and decided to seize Banjarmasin overland, while specifically allocating fast ships for the Bali invasion. ${ }^{(34)}$ 
The arrangements for the capture operation of Bali between the Third Fleet Commander in Chief Vice Admiral Takahashi and the Sixteenth Army Commander Lieutenant General Imamura were discussed in Manila on 23 January, following the Manila Conference. The [concluded] arrangements may be reconstructed as follows: ${ }^{(53,54,68)}$

1. The date of invasion shall be set on 18 February ([or] Day $\mathrm{X}+72$; five days before the invasion of eastern Java).

Note: At the Manila Conference [the capture of Bali] had been scheduled two days prior to the invasion [of eastern Java], but that would not be early enough to use [the airfield] for the operation to neutralize the enemy air power before the invasion; at the most it would just be used as [a base to] cover the invasion convoy on the day before the landing. Therefore, after examining the details between them, they seemed to have concluded that it was possible to move up the operation by three days. If five days prior [to the invasion of eastern Java], the air units could be smoothly advanced there, the base could not only be used for the neutralization of enemy air bases right before the landing in Java, but also be effectively used for cutting off the enemy escape routes.

2. The Units Participating in the Operation

(1) The Army

One detachment of one infantry battalion as the core shall be extracted from the 48th Division (currently in the Philippines) and employed [in the operation].

Note: Although in the Iwakuni Agreement, [the detachment] had been designated as one element of the Sakaguchi Detachment, it became impossible to employ the [Sakaguchi] Detachment because [the detachment] was already assigned to the overland operation to seize Banjarmasin as well as to the maintenance of public order in the Balikpapan area.

(2) The Navy

The main force of the 1st Base Force and part of the destroyer divisions of the 2d Destroyer Squadron led by the 1st Base Force commander.

3. The Main Points of the Operation

(1) The Army invasion unit shall leave Lingayen Gulf around 5 February, make the necessary Army-Navy arrangements at Jolo, load the necessary naval air base matériel, and advance to Makassar by 15 February.

(2) The Navy shall embark the advance team of the 5th Construction Squad and part of the construction matériel, [currently] located in Tarakan, onto the Army transport ships at Jolo.

(3) On the early morning of 17 February, the invasion unit shall leave Makassar under the escort of the Navy 1st Base Unit, enter into the Sanur anchorage of Bali before dawn on the 18th, and swiftly land to seize the Denpasar airfield and strive to make it ready for use.

(4) The main force of the 5th Construction Squad and the transport ships carrying the base matériel of the Eleventh Air Fleet shall reach Bali by 24 February under the escort of one element of the 1st Base Force, and disembark personnel and matériel.

From late January, the units concerned started preparations for the operation to seize Bali. ${ }^{(53)}$ However, due to the delay in the southern Sumatra operation in early February, the Java landing operation was [re]set on 26 February (postponed for six days), which would expand the interval period between the eastern Java operation and the Bali invasion operation to eight days. On 14 February, Eastern Attack Unit Commander Rear Admiral Takagi offered his opinion concerning the matter, which was in outline as follows: ${ }^{(78)}$

Due to the postponement of the schedule of the invasion of eastern Java, the interval between it and the date of the Bali invasion operation becomes eight days, which means that the second 
operation to transport the base matériel will also be executed ahead of the landing in eastern Java. It also means that the invasion unit shall on its own be exposed to the enemy bases at close distance. Therefore it is necessary to thoroughly carry out search and attack missions with the air units on the enemy air power as well as naval vessels in the area from Surabaya to the Sunda Islands before the unit for the 1st [phase] of the Bali Raiding Operation leaves Makassar.

Dutch East Indies Unit Commander Vice Admiral Takahashi took the advice and requested the air units to intensify their air attacks in the area. ${ }^{(78)}$

\section{The Plan of Operations}

\section{The 1st Base Unit}

The plan of operations of the 1st Base Unit was successively announced in accordance with the telegraphic orders and instructions of the Dutch East Indies Unit. The outline of the plan was in summary as follows: ${ }^{(54,78)}$

1. Disposition of Forces

(1) 1st [phase]: Raiding Operation

\begin{tabular}{|c|c|c|c|c|c|}
\hline \multicolumn{2}{|c|}{ Unit } & \multicolumn{2}{|c|}{ Commander } & Forces & Main Tasks \\
\hline \multicolumn{2}{|c|}{ Support Unit } & \multirow{4}{*}{ 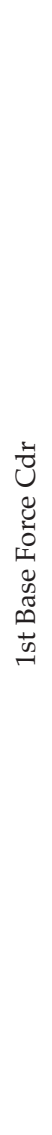 } & & $\begin{array}{l}\text { The Nagara, and the 21st De- } \\
\text { stroyer Div (minus the Hatsu- } \\
\text { haru) }\end{array}$ & Support for the entire operation \\
\hline \multicolumn{2}{|c|}{ Invasion Unit } & & $\begin{array}{c}\text { 8th Destroyer } \\
\text { Div Cdr }\end{array}$ & $\begin{array}{l}\text { The 8th Destroyer Div, 5th Con- } \\
\text { struction Squad, and one ele- } \\
\text { ment of the 3d Military } \\
\text { Supplies Dept ([in] two Army } \\
\text { transport ships) }\end{array}$ & $\begin{array}{l}\text { 1. Direct escort for the Army in- } \\
\text { vasion unit } \\
\text { 2. Guarding of the anchorages } \\
\text { and preparation of airfield. }\end{array}$ \\
\hline \multirow[b]{2}{*}{$\begin{array}{l}\text { 苟 } \\
\text { D } \\
\frac{\lambda}{2} \\
\frac{2}{2} \\
\text { की }\end{array}$} & $\begin{array}{l}\text { Makassar } \\
\text { Strait } \\
\text { Unit }\end{array}$ & & $\begin{array}{c}\text { Capt of the } \\
\text { Tsukushi }\end{array}$ & $\begin{array}{l}\text { The Tsukushi, the Aotaka, 2d } \\
\text { Subchaser Div, Submarine } \\
\text { Chaser No. } 1\end{array}$ & \multirow[b]{2}{*}{$\begin{array}{l}\text { 1. Defense and guarding of the } \\
\text { anchorage } \\
\text { 2. Protection of sea lanes } \\
\text { 3. Replenishment }\end{array}$} \\
\hline & $\begin{array}{c}\text { Kendari } \\
\text { Unit }\end{array}$ & & $\begin{array}{c}\text { Capt of the } \\
\text { Hakusan-maru }\end{array}$ & $\begin{array}{l}\text { The Hakusan-maru, the } \\
\text { Kimishima-maru, the 52d Sub- } \\
\text { chaser Div, the 1st Subchaser } \\
\text { Div (minus Submarine Chaser } \\
\text { No. 1), and the Ikushima-maru }\end{array}$ & \\
\hline
\end{tabular}


(2) $2 d$ [phase]: Transport Operation

\begin{tabular}{|c|c|c|c|c|}
\hline Unit & \multicolumn{2}{|c|}{ Commander } & Forces & Main Tasks \\
\hline Main Unit & \multirow{3}{*}{ 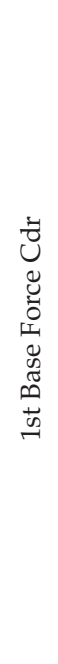 } & & The Nagara & $\begin{array}{l}\text { Support for the entire operation } \\
\text { and destroying enemy naval } \\
\text { vessels }\end{array}$ \\
\hline $\begin{array}{l}\text { Transport } \\
\text { Echelons }\end{array}$ & & $\begin{array}{l}\text { 21st Destroyer } \\
\text { Div Cdr }\end{array}$ & $\begin{array}{l}\text { The 21st Destroyer Div (minus } \\
\text { the Hatsuharu), 2d Subchaser } \\
\text { Div, 5th Construction Squad } \\
\text { (the Toyosaka-maru and the } \\
\text { Hino-maru No. 3), and } 2 \text { trans- } \\
\text { port ships of the Eleventh Air } \\
\text { Fleet }\end{array}$ & $\begin{array}{l}\text { 1. Direct escort for the transport } \\
\text { ships } \\
\text { 2. Destroying enemy naval ves- } \\
\text { sels } \\
\text { 3. Setting up the airfield }\end{array}$ \\
\hline Supply Unit & & & $\begin{array}{l}\text { The Aotaka, the Hakusan-maru, } \\
\text { the Kimishima-maru, the } \\
\text { Ikushima-maru, 1st, 52d, and } \\
\text { 12th Subchaser Divs, and the } \\
\text { Tsukushi }\end{array}$ & $\begin{array}{l}\text { 1. Defense and guard of the an- } \\
\text { chorage } \\
\text { 2. Replenishment and protec- } \\
\text { tion of sea lanes } \\
\text { 3. Cooperation with the 1st Es- } \\
\text { cort Unit }\end{array}$ \\
\hline
\end{tabular}

2. The Operations of Each Unit and the Outline of Operations

(1) First [Phase]: Raiding Operation

$\{1\}$ The transport echelon [of the invasion unit] shall leave Makassar at 0100 on 17 February. From sunset on the 17th, the Arashio shall sail ahead and carry out a simplified clearing of the anchorage, after which [the echelon] shall enter the Sanur anchorage of Bali at 0000 on the 18th, and swiftly put ashore the army units.

\{2\} After [the disembarkation of] the army units, the transport ships shall strive to disembark the base personnel and matériel as much as possible. They shall complete the disembarkation by and large by the evening of the 18th, and return to Makassar under the escort of the 8th Destroyer Division.

$\{3\}$ The main unit shall leave Makassar on the morning of the 17th, and appropriately operate on the waters north of Bali on the evening of that day to support the transport echelon.

\{4\} After the return of the transport echelon to Makassar, the 8th Destroyer Division shall return to its original unit.

\{5\} The supply units shall continue their tasks at each place.

(2) Second [Phase]: Transport Operation

$\{1\}$ The transport ships shall leave Balikpapan on 20 February under the escort of the $2 \mathrm{~d}$ Subchaser Division, reach Makassar on the 22d, where they shall stay on standby.

\{2\} By and large on the evening of the 23d, the main unit, the transport echelon and the support unit shall leave Makassar. The transport echelon shall enter the Sanur anchorage on the early morning of the 25th and carry out the disembarkation.

\{3\} During the disembarkation operation, the main unit and other forces shall guard the area around the anchorage and also catch and destroy escaping enemy naval vessels.

\{4\} The supply unit shall continue its previous tasks. 


\section{The Army Units}

The following [Army] force and commander participated in this operation: ${ }^{(140)}$

Force: The 3d Battalion (minus one company) of the 1st Taiwan Infantry Regiment, one mountain artillery section, one independent engineer platoon and others

Commander: 1st Taiwan Infantry Regiment 3d Battalion Commander Maj. Kanemura Matabē

The Kanemura Detachment was scheduled to embark on the Sagami-maru and the Sasakomaru, leave Lingayen Gulf on 5 February, reach Jolo on the 8th, Makassar on the 15th, and land on Bali on the 18th to swiftly occupy the Denpasar airfield and clear key places on the island of the enemy.

\section{The [Navy] Air Units}

In relation to the change of the outline of the operation to seize Banjarmasin on 29 January, which resulted in a reduction of the [prospective] use of the Bajarmasin base, the $2 \mathrm{~d}$ Air Unit was deployed [also] to Makassar, and the lines of operation were changed as follows: ${ }^{(75)}$

$$
\text { Tarakan-Balikpapan } \quad \backslash \begin{aligned}
& \text { Makassar } \\
& \text { Banjarmasin }
\end{aligned} \backslash \text { Bali }
$$

Eleventh Air Fleet Commander in Chief Vice Admiral Tsukahara decided that at the time of the operation to capture Bali, nine Type-0 fighter planes of the $3 \mathrm{~d}$ Air Group of the 1st Air Raid Unit, then stationed at the Kendari base, should be advanced to Makassar to be incorporated into the 2d Air Raid Unit. Second Air Raid Unit Commander Rear Admiral Takenaka planned to advance nine Type-0 fighter planes and two land-based reconnaissance planes of the Tainan Air Group from the Balikpapan base to the Makassar base and, along with the [above] forces of the 3d Air Group, have them under his command provide guard in the air over the Bali invasion unit from the [Makassar] base. ${ }^{(68,71)}$ The commander also planned to destroy the enemy surface naval vessels as well as air power in Surabaya and the Flores Islands area with the entire force stationed in Balikpapan and the forces in Makassar. ${ }^{(71)}$

The aircraft unit of the Sanuki-maru advanced from Balikpapan on 10 February to set up a base at Ujung Parapa near Makassar under the command of Aviation Officer Lt. Cdr. Kōzai Fusaichi, with five Type-0 observation seaplanes, one Type-95 reconnaissance seaplane, Patrol Boat No. 36 and two fishing boats. The aircraft unit was supposed to provide guard against enemy submarines for the Bali invasion units. ${ }^{(76)}$

\section{Assessment of the Enemy Movements Centered on Bali}

(1) The enemy air power, with its main bases in Java, seems to be trying to get reinforcements from the Port Darwin area by way of Kupang and Bali. Although its main force has suffered substantial losses due to our frequent air attacks, considerable air counterattacks are to be expected because Bali is very close to the enemy air bases. (2) After the devastating damage caused by our air units in the Sea Engagement off Java on 4 February, powerful enemy naval surface units have not been seen. However, since Bali is located close to an enemy fleet base, it is necessary to be on an appropriate alert against surprise attacks by small naval vessels. 
(3) Although the deployment of enemy submarines is unclear, it is necessary to be on alert against them as much as against naval surface vessels. (4) The Denpasar airfield on Bali is suitable for use by land-based attack planes. (5) A garrison army of about one battalion is stationed on Bali; it seems that the main force is stationed in Singaraja on its northern coast and that an infantry guard of about one company or so is guarding the Denpasar airfield. ${ }^{(140)}$

\section{The Launch of the Operation}

\section{The Prior Neutralization of the [Enemy] Air Power Made Little Progress}

[An air campaign] by air units to preliminarily neutralize the [enemy] air power for the Bali invasion operation was conducted in the following way: ${ }^{(71,81)}$

14th [of February]: One land-based attack plane of the Takao Air Group reconnoitered weather conditions but returned due to bad weather.

15th: One land-based attack plane of the Takao Air Group reconnoitered weather conditions but returned due to bad weather.

Two Type-0 fighter planes of the $3 \mathrm{~d}$ Air Group advanced from Kendari to Makassar, but the other seven planes called off the advance due to bad weather.

16th: Two land-based attack planes of the Takao Air Group reconnoitered weather conditions but returned due to bad weather.

As described above, the weather conditions in the Makassar Strait were very bad day in and day out, and from 10 February onwards, hardly any air attacks on eastern Java were carried out. [Even] the advance of fighter plane units to the Makassar [base] was not completed, either. ${ }^{(71)}$ In view of this situation, Dutch East Indies Unit Commander Vice Admiral Takahashi anticipated that the weather would not improve for another few days and on the 16th decided for the moment to postpone the Bali Operation for one day (so that [the invasion units would] enter into the anchorage on the 19th). ${ }^{(78)}$

The weather was still bad on the 17th, and twenty-four land-based attack planes of the Takao Air Group gave up an attack on enemy naval vessels in the Surabaya area and returned. However, the seven Type-0 fighter planes of the $3 \mathrm{~d}$ Air Group managed to advance from Kendari to Makassar.

Judging that any further postponement of the schedule would lead to a loss of opportunity [for making the attack], Base Unit Commander Rear Admiral Kubo decided to launch the invasion operation on the 18 th as scheduled (and enter into the anchorage on the 19th). ${ }^{(78)}$

\section{The Sailing of the Convoy}

At 0100 on the 18th, the invasion unit ([consisting of] the 8th Destroyer Division (the Ōshio, the Asashio and the Michishio), the Sasako-maru and the Sagami-maru) left Makassar as scheduled. After joining around 0400 on the waters southwest of Tanakeke Island the Arashio, which had sailed ahead since the previous evening to clear the route of enemy submarines, the unit sailed on a course of $245^{\circ}$ [WSW] at a speed of 16 knots toward the eastern tip of the Kangean Islands. ${ }^{(68)}$

From a little after sunrise (around 0715) onwards, the invasion unit proceeded under the protection of an antisubmarine patrol provided by the aircraft unit of the Sanuki-maru and 
guarded by a fighter plane unit of the 3d Air Group against enemy aircraft. Around 1000, the convoy entered within the three hundred nautical miles range from Surabaya; it reached the waters near the Kangean Islands around 1530 and changed course toward the Lombok Strait. ${ }^{(68)}$

On that day, other than one enemy flying boat, which came probing the invasion unit, there were no enemy attacks. Around sunset (about 1900), as scheduled, the unit came within the two hundred nautical miles range from Surabaya, where the Arashio sailed ahead in order to sweep the anchorage for mines. At 2300, the invasion unit arrived off Sanur without problems and started entering into the anchorage. ${ }^{(68)}$

Around noon on that day, the 18th, Dutch East Indies Unit Commander Vice Admiral Takahashi advanced to Balikpapan from Jolo, leading the Ashigara and the Yamakaze. ${ }^{(72)}$ Earlier, at 0100 on that day, the commander sent the following telegram to 1st Base Force Commander Rear Admiral Kubo: "[The invasion unit shall] turn back if the 1st Base Force commander judges the weather on the early morning of the 18th to be not suitable [for Navy aircraft] to fly. In such a case, Operation "HA" (note by the author: Bali Invasion Operation) shall be postponed for another day (so that the unit shall enter the anchorage on 20 February)." ${ }^{(78)}$ Having received the telegram, 1st Base Force Commander Rear Admiral Kubo replied at 0800: "The invasion unit for [Operation] "HA" has left Makassar at 0100 on the 18 th, and is scheduled to enter [the anchorage at] Bali at 0000 on the 19th. This invasion [operation] shall be determinedly carried out according to the above schedule unless major hindrances are caused by [severe] weather, etc." On that day [the 18th], the air unit carried out an air raid on Surabaya with twenty-seven land-based attack planes and eight Type-0 fighter planes and reported having destroyed two [enemy] light cruisers and three destroyers and [also] shot down thirteen fighter planes. ${ }^{(108)}$

On 19 February, the Arashio, which had sailed ahead and carried out a simplified minesweeping of the anchorage off Sanur, had found no tethered mines. ${ }^{(68)}$ At 0015, the invasion unit entered the anchorage as scheduled. The first landing unit of the Kanemura Detachment left the anchorage in [landing] craft at 0100 and went ashore on the coast nearby, but met with no enemy resistance. The 8th Destroyer Division commander reported: “0100 on the 19th: Landing successfully made at the scheduled point. Met with no enemy resistance." (54) Following the first landing, the landing units started to quickly disembark personnel and matériel.

After sunrise at 0722, the invasion units came under continual enemy air raids as anticipated. First, around 0800, three enemy aircraft bombed the convoy, but caused no damage. Then around 0830, enemy heavy bombers (the number of aircraft unknown) came for a raid. Bombs directly hit the Sagami-maru amidships, which made her engines inoperable. Around 1000 , four or five enemy heavy bombers raided the convoy, causing no damage, which was followed by another raid by three enemy flying boats and four heavy bombers between 1030 and 1100, but causing no damage either. After that, the enemy constantly kept on probing with one or two flying boats, and carried out repetitive attacks with aircraft in small numbers, only to cause minor damage to the Sasako-maru with near hits. From a later damage survey, it became clear that the Sagami-maru was able to sail using one propeller. ${ }^{(68)}$

At 1630, the Ōshio, which was patrolling the area off the anchorage, spotted an enemy periscope. Then, four torpedoes attacked her; evading them, she carried out an attack with antisubmarine depth charges, but with unknown results. The disembarkation from the trans- 


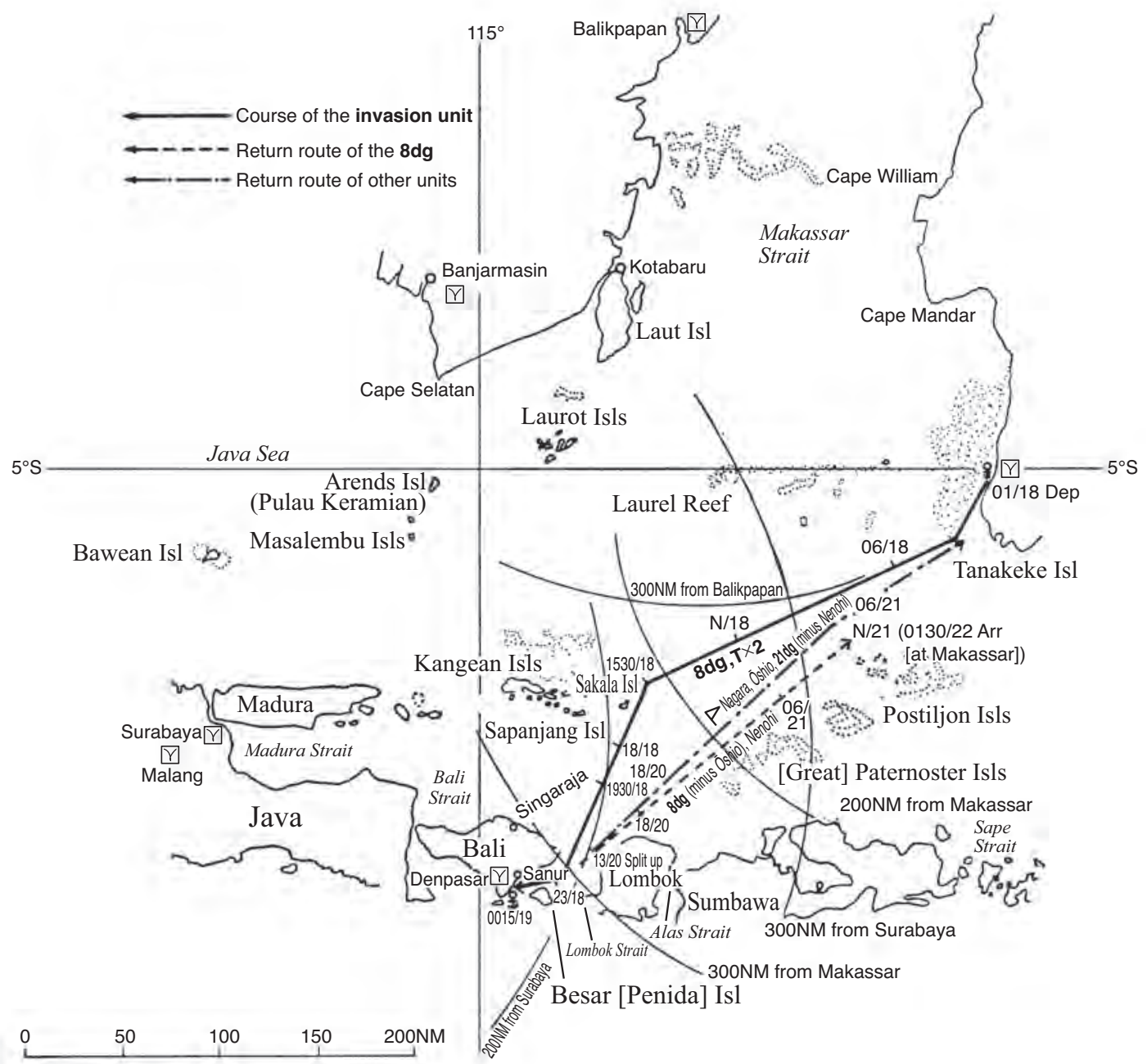

Illustration No. 31 - The Movements of the Invasion Unit and the Support Unit in the First [Phase] of the Bali Raiding Operation

port ships was mostly completed by around 1700. Although the Sasako-maru had not finished retrieving the [landing] craft, both ships raised anchor at 1725 and evacuated to the north of the entrance to the Lombok Strait in order to avoid enemy air raids as well as attacks by submarines. [From there] the Sagami-maru headed for Makassar at an actual speed of seven knots, escorted by the $2 \mathrm{~d}$ Section of the 8 th Destroyer Division. The Sasako-maru reversed course around 1930 and headed back to the Sanur anchorage to retrieve the landing craft. Around 2100 , the ship entered the anchorage under the escort of the 1st Section of the 8th Destroyer Division. ${ }^{(54)}$

On the morning [of the 19th], the Army units seized the Denpasar airfield, and the head of the [Navy] construction squad sent the following report concerning the condition of the airfield: "At the airfield, a runway of seventy meters wide and eight hundred meters long shall be ready by the end of the 19th. From the 20th onwards, it can be used by eighteen fighter planes, three land-based reconnaissance planes and nine land-based attack planes. 
[A runway of] 1200 meters long can be additionally constructed for mid-sized land-based attack planes." (108) In the meantime, [the units for] the air attack against Surabaya turned back due to bad weather again on that day; the land-based attack plane units returned after carrying out bombings on the Bawean Islands (about eighty nautical miles north of Surabaya) on their way back. ${ }^{(71)}$

\section{The First Phase of the Sea Engagement off Bali ${ }^{(54,58,68)}$}

(From 2353 on 19 February till 0110 on 20 February) (See Illustration No. 32)

The 1st Section of the 8th Destroyer Division (the Ōshio and the Asashio) and the Sasako-maru, which had entered in the Sanur anchorage again at 2130 on the 19th and finished retrieving the landing craft around 2350, was about to start sailing. It was a dark cloudy night with the [crescent] moon of the fourth lunar day and visibility was barely eight kilometers. At 2353, the Asashio spotted the silhouettes of naval vessels on the waters about six kilometers to the south and soon spotted two Java-class cruisers sailing northward at high speed. The enemy vessels rapidly approached and at 0000 within a distance of 2,000 meters while launching flares opened up on the Asashio. The Asashio immediately returned fire and started a gun battle on a parallel course [with the enemy ships]. However, since she had just started sailing when she ran into them, the Asashio was unable to gain [sufficient] speed and lost sight of the enemy ships after an artillery duel of [just] two minutes. Assuming that the enemy had reversed course southward, the Asashio [also] turned southward while increasing her speed. In this phase of the battle, no damage was sustained except for a searchlight on the Asashio that was hit by shell fragments at 0001, while the effects of her gunfire remained unknown. The Asashio reported: "Engaging with Java-class enemy [cruisers] [in] the Lombok Strait."

The Óshio, who was two to three kilometers ahead of the Asashio, saw the engagement of the Asashio and started sailing to take part in the artillery duel, but she was too late. However, at that time, at 0005, she spotted at a distance of about 6,000 meters one [enemy] destroyer sailing northward while emerging from a smoke screen that trailed to the south, and she changed course southward to attack her. At 0011, the Asashio, who was sailing closer to the enemy [than the Ōshio], spotted on her starboard bow the [same enemy] destroyer sailing on a parallel course and opened fire at a close range of 1,500 meters. Since the [enemy] destroyer was trying to escape southward while laying a smoke screen, the Asashio fiercely pursued her. During the pursuit, she spotted [another] two [enemy] destroyers appearing in the distance. The Asashio ran the destroyer down and closing in to a distance of 1,000 meters launched torpedoes; at 0016 she confirmed that the torpedoes had hit and sunk the destroyer. While the Asashio was turning her bow to launch the torpedoes, the Ōshio appeared on the port bow of the Asashio. At 0024, the Asashio spotted enemy naval vessels in the smoke screen on her starboard side and fired at them, but she lost sight of them in the smoke screen. Both [the Asashio and the Ōshio] sailed southward in search for the enemy. In a few minutes, they spotted two U.S. destroyers sailing on a parallel course, and immediately opened fire. However, the enemy turned their bows to the far side while firing back at them, and disappeared laying a smoke screen. It seemed that [the Asashio and the Öshio] had inflicted considerable damage to these enemy [destroyers]. Assuming that the enemy had escaped northward, both [the Asashio and the Ōshio] turned right and headed northward. At 0042, the Asashio entered into the wake of the Öshio, and they proceeded in column. 


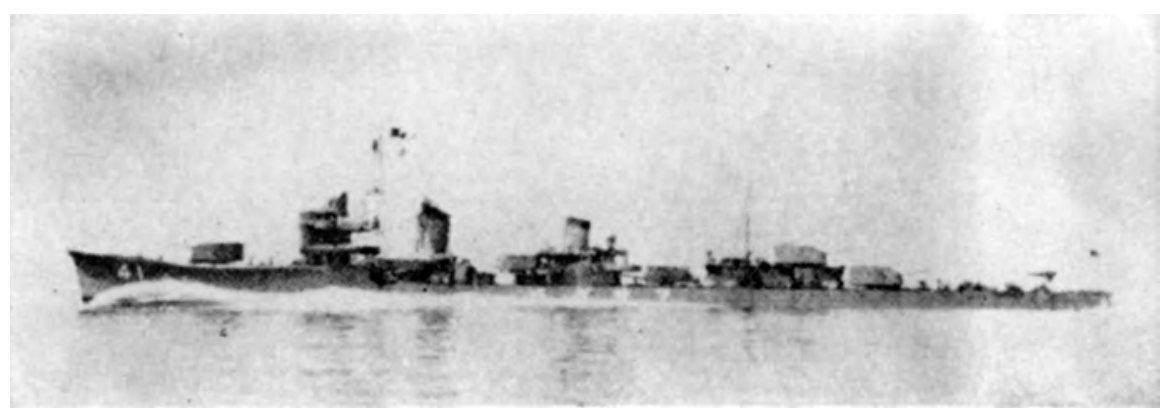

An Asashio-class Destroyer

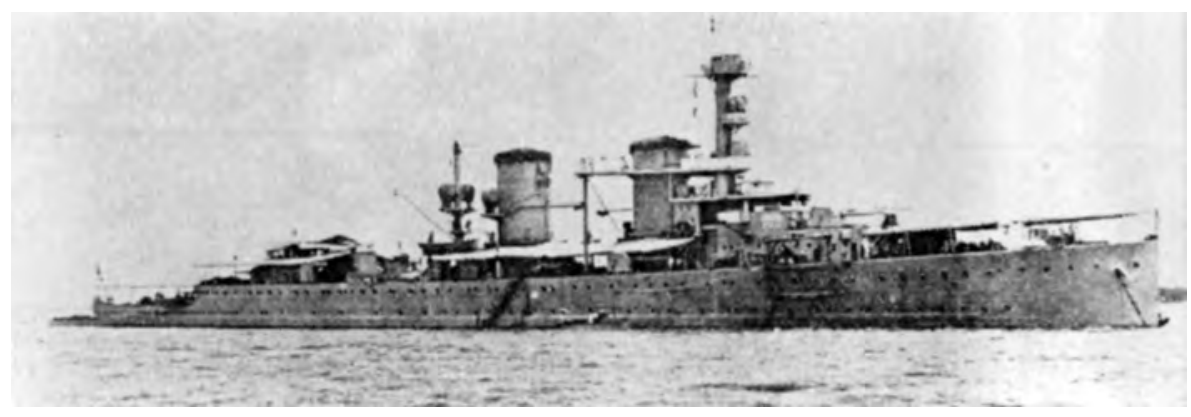

The Dutch Cruiser HNLMS Java

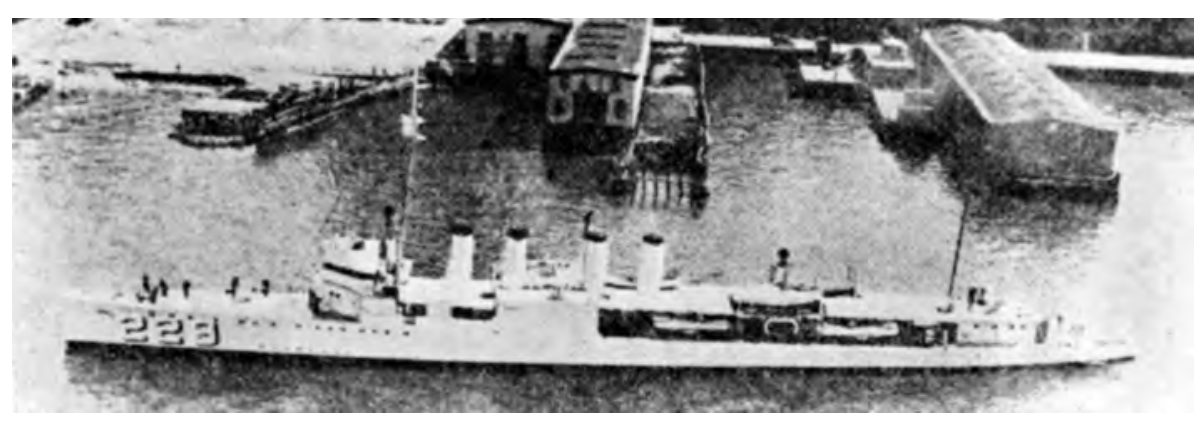

The U.S. Destroyer USS John D. Ford

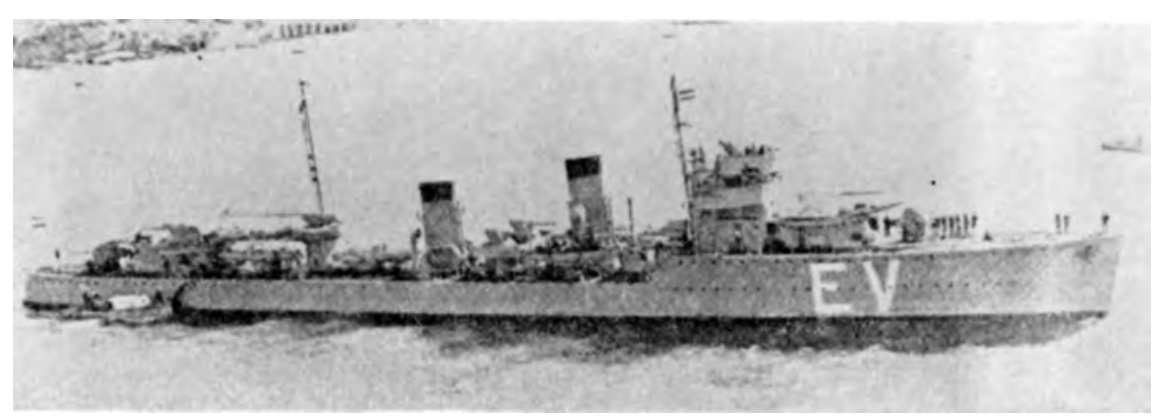

The Dutch Destroyer HNLMS Piet Hein [Actually: HNLMS Evertsen] 


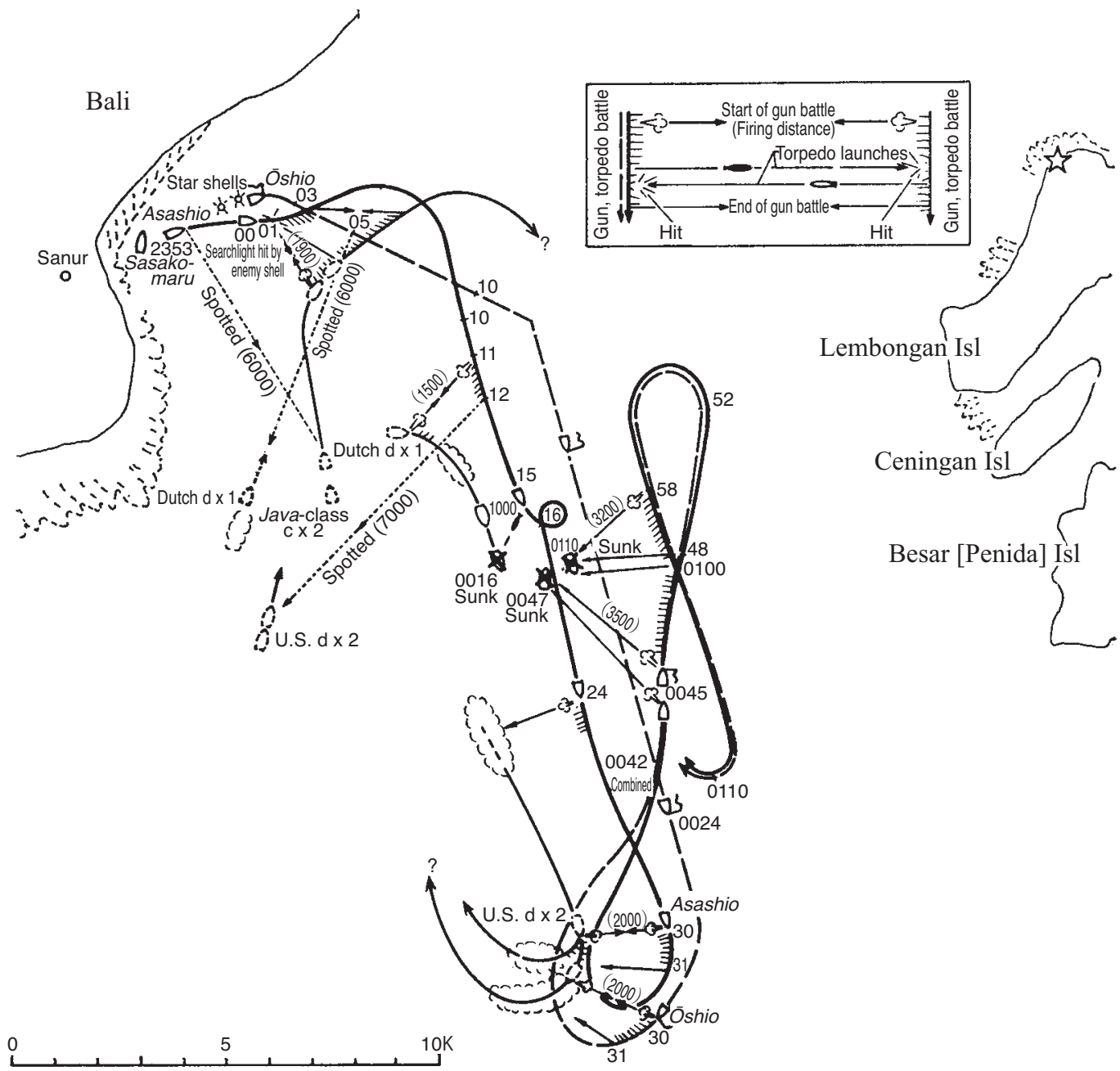

Illustration No. 32 - The First Phase of the Sea Engagement off Bali (2353 on 19 February - 0110 on 20 February)

At 0045, three minutes after they had swung in line, they spotted two [enemy] destroyers sailing at a distance of 3,500 meters on their port bow on a parallel course, and immediately opened up a concentrated fire. At 0047, one of the destroyers caught fire and sank, and the other also caught fire. While keeping firing at the enemy destroyer in flames, both [the Asashio and the Oshio] reversed course southward, and again around 0110 reversed course northward. Around 0110, the enemy vessel in flames disappeared, and they assumed that she had sunk. Both [the Asashio and the Ōshio] sailed northward, keeping a strict guard [against enemy vessels] on the surrounding waters. Around 0140, [both] returned to the waters off Sanur, and continued patrolling, doubling from east to west at the center of the Lombok Strait. The 8th Destroyer Division commander reported: “0140: Two Java-class enemy [cruisers] escaped northward through the Lombok Strait. Among the three remaining destroyers, two were sunk and one was seriously damaged. No damage to us." 
The Support Unit's Nagara had left Makassar at 0800 on the 19th; after having joined up with the 21st Destroyer Division, which had left Balikpapan at 1000, she had reached in the evening a point eighty nautical miles north of the Lombok Strait, from where she was engaged in the support operation. On receiving the report of a sea engagement from the 1st Section of the 8th Destroyer Division, the unit sailed southward at full speed. En route, 1st Base Force Commander Rear Admiral Kubo ordered the 8th Destroyer Division commander to let his $2 \mathrm{~d}$ Section join in as well. By that order, the Sagami-maru [was left] to sail north toward Makassar on her own, while the $2 \mathrm{~d}$ Section of the 8th Destroyer Division reversed course at 0145 and headed toward the Lombok Strait.

\section{The Second Phase of the Sea Engagement off Bali ${ }^{(54,58,68)}$}

(From 0310 till 0323) (See Illustration No. 33)

At 0310 on the 20th, the 1st Section of the 8th Destroyer Division [the Asashio and the Ōshio] again spotted two enemy cruisers and one destroyer sailing northward at high speed from the south. At 0315, they launched an attack with gunfire and torpedoes at a distance of 3,200 meters. At 0323, they detected the sound of an underwater explosion and judged that a torpedo had hit target, but they lost sight of the enemy in the silhouette of the mountains of Bali. The 8th Destroyer Division commander reported: "0315: We are in a fierce fight against two [enemy] Java-class cruisers off Sanur."

\section{The Third Phase of the Sea Engagement off Bali ${ }^{(54,58,68)}$}

(From 0341 till 0346) (See Illustration No. 33)

The 1st Section of the 8th Destroyer Division [the Asashio and the Ōshio] sailed at high speed through the Badung Strait eastward in pursuit of the three enemy vessels that had escaped northward from the waters off Sanur, and reached the waters northwest off Lembongan Island at 0341 on the 20th, where they spotted a Tromp-class cruiser at a distance of 3,200 meters on their port bow sailing on a parallel course. The section immediately launched an attack with gunfire and torpedoes, while sailing on a parallel with the enemy on their port side. The enemy cruiser returned fire, and an artillery duel at a close distance of 3,000 meters continued for a few minutes. Although the result of the torpedo attacks could not be confirmed, many shells from both [the Asashio and the Öshio] hit the enemy vessel. However, at 0346, one enemy shell hit the Ōshio at the powder handling room of Turret No. 2 (near the mizzenmast). Although it was assumed that enemy vessel was seriously damaged in this engagement, she continued sailing eastward and at 0350 disappeared into the gun smoke, while exchanging fire with the $2 \mathrm{~d}$ Section of the 8th Destroyer Division, which had come sailing on the opposite course from the north.

\section{The Fourth Phase of the Sea Engagement off Bali ${ }^{(54,58,68)}$}

(From 0347 till 0354) (See Illustration No. 33)

The $2 \mathrm{~d}$ Section of the 8th Destroyer Division, which had been ordered to reverse course at 0145 on the 20th, had reached the east entrance of the Badung Strait around 0340. Spotting the flashlights of an artillery duel far ahead, the section had sailed westward to take part in the engagement. At 0345, apart from the gun flashes seen on port bow, they spotted two U.S. destroyers suddenly approaching out of the silhouette of Bali Island on starboard bow, sailing 


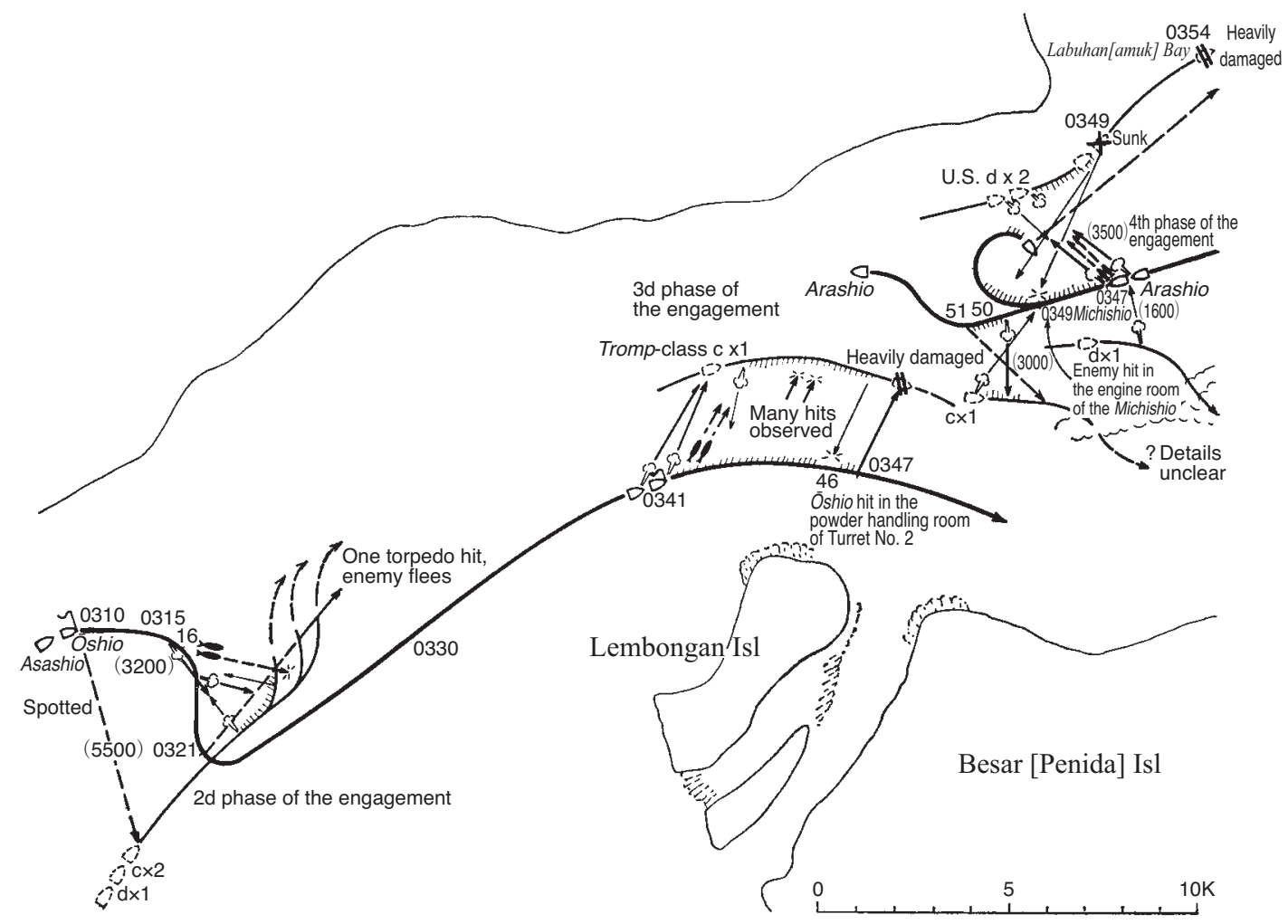

Illustration No. 33 - The Sea Engagement off Bali

The Second Phase (0310-0323, 20 February)

The Third Phase (0341-0346, 20 February)

The Fourth Phase (0347-0354, 20 February)

on an opposite course. At 0347, both sides simultaneously opened fire at each other at a distance of 3,500 meters. In two minutes from the start of the artillery duel, [the section] noticed that the first ship of the enemy had instantly sunk. However, almost at the same time, the Michishio was hit by enemy shell[s] at the engine room. With steam sharply blowing off, she became unable to sail but was still pouring fire on the remaining [enemy] vessel.

Just when both the destroyers [of the $2 \mathrm{~d}$ Section] started exchanging fire with the [enemy] destroyers on starboard side, another [enemy] destroyer suddenly appeared at a close distance of 1,600 meters on portside sailing on an opposite course. Although the [Japanese] destroyers fired at her [too], she disappeared straight into the gun smoke. She was followed by one [enemy] cruiser, which sailed at a distance of 3,000 meters [also] on an opposite course. At 0500, the Arashio opened fire at her; though the engagement lasted only for a short period, the Arashio confirmed hits before the enemy vessel disappeared straight into the gun smoke. It was believed that the remaining [enemy] destroyer sailing on the starboard side on opposite course had been seriously damaged too in this engagement. However, as previously told, the Michishio was crippled due to a hit in her engine room; this and other direct hits caused sixty-four casualties including the chief engineer. Fortunately, there was no flooding, and 
while drifting the crew worked hard to make emergency repairs. The ammunition consumed by each destroyer in these four phases was as follows:

$\begin{array}{llrl}\text { The Öshio } & 12.7-\mathrm{cm} \text { gun } & 217 \text { shells } & \text { about } 36 \text { salvos } \\ \text { The Asashio } & 12.7-\mathrm{cm} \text { gun } & 310 \text { shells } & \text { about } 52 \text { salvos } \\ \text { The Michishio } & 12.7-\mathrm{cm} \text { gun } & 62 \text { shells } & \text { about } 10 \text { salvos } \\ \text { The Arashio } & 12.7-\mathrm{cm} \text { gun } & 73 \text { shells } & \text { about } 12 \text { salvos }\end{array}$

After the engagement, the 8th Destroyer Division picked up one Dutch officer, and nine noncommissioned officers and men drifting on the waters off Sanur. From interrogations it was learned that the enemy strength in the first phase of the engagement had consisted of two Dutch cruisers, two U.S. destroyers, and one Dutch destroyer.

Incidentally, the Support Unit of the Eastern Attack Unit was not able to support this engagement, because it had advanced to the Timor Sea in order to attack an enemy cruiser that had been spotted [on the waters] west of Port Darwin on the 19th. ${ }^{(78)}$

\section{The Withdrawal of the 1st [Phase Operation] Raiding Unit ${ }^{(54,68)}$}

The Nagara and the 21st Destroyer Division, who had hurried to the Lombok Strait from the waters east of the Kangean Islands, finally reached the site around 0600, but they were too late for the battle against the enemy fleet. First Base Force Commander Rear Admiral Kubo had the Nagara and the Hatsushimo guard the north entrance of the Lombok Strait, while having the rest of the 8th Destroyer Division as well as the 21st Destroyer Division rescue the Michishio.

From 1000, the Arashio started towing the Michishio, and started withdrawing at an actual speed of 8 knots. However, right after the start of the towing, some enemy heavy bombers came for a raid and the towing cable was cut due to the evasive actions. The Michishio was flooded because of near hits. The Ōshio was also flooded and became unable to sail at a speed of more than 10 knots. First Base Force commander Rear Admiral Kubo ordered the Wakaba to escort the Ōshio and had them sail ahead. The 8th Destroyer Division commander changed ships from the Ōshio to the Asashio. The unit was divided into the following three groups for withdrawal, and each sailed north in the following three groups.

1st Group: the Asashio, the Arashio towing the Michishio, the Nenohi

2d Group: the Wakaba and the Ōshio

3d Group: the Nagara and the Hatsushimo

The 1st Group again came under a bombing attack by seven [enemy] heavy bombers a little after 1300 and suffered bombings by a total of twenty-six enemy aircraft by that evening. But, fortunately, without sustaining [any more] damage, the group escaped out of the 200 nautical miles range from Surabaya by sunset. The other groups also sailed out of the 200 nautical miles range from Surabaya by sunset. After that, the $2 \mathrm{~d}$ and the $3 \mathrm{~d}$ Groups managed to enter the port of Makassar between 1530 and 1600 on the 21st, and the 1st Group also finally managed to return to Makassar at 0130 on the 22d. Both the Sagami-maru and the Sasakomaru also somehow returned to Makassar. On the afternoon of the 22d [21st, p. 373], Dutch East Indies Unit Commander Vice Admiral Takahashi incorporated the 8th Destroyer Division into the main unit and ordered the division to stay on standby in Makassar. 


\title{
The Communiqué by IGHQ
}

After entering the port of Makassar, the 8th Destroyer Division commander reviewed the military gains of the sea engagement off Bali and reported the following conclusions: ${ }^{(54)}$

\begin{tabular}{|c|c|c|}
\hline Phase & Enemy Forces & Military Gains \\
\hline \multirow{3}{*}{$\begin{array}{l}\text { 1st phase } \\
\text { (by the Ōshio and the Asashio) }\end{array}$} & 2 Java-class cruisers & \\
\hline & 2 U.S. destroyers & $\begin{array}{l}\text { Inflicted considerable damage, but } \\
\text { details are unknown }\end{array}$ \\
\hline & 3 Dutch destroyers & Sank all \\
\hline \multirow{2}{*}{$\begin{array}{l}\text { 2d phase } \\
\text { (by the Öshio and the Asashio) }\end{array}$} & 2 Java-class cruisers & $\begin{array}{l}\text { One slightly damaged (by a tor- } \\
\text { pedo hit) }\end{array}$ \\
\hline & 2 U.S. destroyers & $\begin{array}{l}\text { (Maybe the same ones as in the } 1 \text { st } \\
\text { phase engagement?) }\end{array}$ \\
\hline $\begin{array}{l}\text { 3d phase } \\
\text { (by the Ōshio and the Asashio) }\end{array}$ & 1 Tromp-class cruiser & $\begin{array}{l}\text { Seriously damaged } \\
\text { (One of the cruisers of the } 2 d \text { phase } \\
\text { engagement) }\end{array}$ \\
\hline \multirow{3}{*}{$\begin{array}{l}\text { 4th phase } \\
\text { (by the Michishio and the Arashio) }\end{array}$} & 2 U.S. destroyers & $\begin{array}{l}\text { Sank one and seriously damaged } \\
\text { another }\end{array}$ \\
\hline & 1 De Ruyter-class (?) cruiser & $\begin{array}{l}\text { (Maybe the same one as in the } 3 \mathrm{~d} \\
\text { phase engagement?) }\end{array}$ \\
\hline & 1 Destroyer (class unclear) & \\
\hline
\end{tabular}

Based on this [report], the IGHQ [Navy Department] released the following communiqué:(109)

\begin{abstract}
IGHQ [Navy Department] Communiqué (3.15 p.m., 21 February)
While carrying out an Army-Navy joint operation in the Bali area, two destroyers of the ... Destroyer Division, part of a destroyer squadron of the Imperial Navy, encountered at 0000 on 20 February in the Lombok Strait east of Bali a combined enemy unit of U.S. and Dutch forces, consisting of two cruisers and three destroyers. On encountering the unit, the destroyers immediately went on the offensive. After opening fire at 0040, they sank within ten minutes two enemy destroyers and seriously damaged another. Further, they hotly pursued two enemy cruisers who tried to escape and again engaged with them at 0315 . The other two destroyers of the same division, who had been engaged in a separate operation, hastened south to attack the enemy. However, after sustaining damage by our gunfire and torpedo attacks, the enemy beat a hasty retreat under the cloak of the night and fled from our sight. One of our destroyers sustained damage in the engagement, but it does not prevent her from fighting or sailing.
\end{abstract}

The main officers, who participated in this engagement, were the following: ${ }^{(96)}$

8th Destroyer Division Commander: Capt. Abe Toshio (graduate of the 46th class of the Imperial Japanese Naval Academy)

Captain of the destroyer Ōshio: Cdr. Kikkawa Kiyoshi (graduate of the 50th class)

Captain of the destroyer Asashio: Cdr. Yoshii Gorō (ditto)

Captain of the destroyer Michishio: Cdr. Ogura Masami (graduate of the 51st class)

Captain of the destroyer Arashio: Cdr. Kuboki Hideo (ditto) 


\section{The Operations of the Air Unit}

From 18 February onwards, the weather slightly improved and the air unit launched attacks on [enemy] naval vessels in the Surabaya area. The following air operations were carried out: ${ }^{(71,75)}$

18th [of February]

- Four Type-0 fighter planes of the $3 \mathrm{~d}$ Air Group patrolled in the air over the convoy but spotted no enemy.

- Three Type-0 fighter planes of the group conducted a reconnaissance attack on the Bali airfield but spotted no enemy.

- One land-based reconnaissance plane of the Tainan Air Group conducted a search for the enemy but returned due to bad weather.

- One land-based reconnaissance plane of the group reconnoitered the Bali airfield, but spotted no enemy.

- Fifteen Type-0 fighter planes and one land-based reconnaissance plane of the group attacked Madiun and reported having shot down one [enemy] reconnaissance seaplane and destroyed two fighter planes on the ground.

- Nine Type-0 fighter planes and two land-based reconnaissance planes of the group advanced from Balikpapan to Makassar.

- Eight Type-0 fighter planes of the group attacked Surabaya, engaged with twenty P-40s, reported having shot down nine (of which three with unconfirmed results), all returned.

- One land-based attack plane of the Takao Air Group reconnoitered the weather conditions and [reported] no impediments to an attack. [Accordingly], twenty-two land-based attack planes of the group carried out an attack on the [enemy] naval vessels at Surabaya and reported having scored direct hits on two light cruisers, who caught fire, as well as on two destroyers and [also] near hits on a large merchantman. Nine aircraft were marked by bullets, three crashed themselves, four crew were killed and two injured on board.

19th

- A total of sixteen Type-0 fighter planes directly guarding the anchorage, spotted seven B17s and three B-24s and attacked them but failed to shoot them down.

- One land-based reconnaissance plane and five Type-0 fighter planes searched for the enemy in Surabaya, Bali and the Madura Strait, and spotted eleven [enemy] merchantmen, one minesweeper and one B-17.

- Three land-based attack planes searched for the enemy in the Sunda and the Java Seas, spotted four B-17s, one twin-engine bomber, and one large flying boat. Two of them were attacked by [enemy] fighter planes.

- Although eighteen land-based attack planes and twenty-three Type-0 fighter planes were [scheduled to] conduct attacks on Surabaya, the land-based attack plane unit called off the attack due to bad weather; nine of them carried out bombings on the urban area of Bawean Island [instead]. The Type-0 fighter planes engaged with thirty P-40s in the air and reported having shot down seventeen (of which three with unconfirmed results). One of Japanese aircraft crashed itself.

20th

- Eighteen Type-0 fighter planes advanced to the Bali base, after patrolling in the air over the Bali anchorage. During the patrol, they had an [air] engagement with three [enemy] light bombers and two dozens or more fighter planes, and reported having shot down six. One of Type- 0 fighter plane went missing after having gone to reconnoiter naval vessel[s], of which it was unclear whether they were friend or foe. 
- Thirteen Type-0 fighter planes carried out an attack on Surabaya, but spotted no enemy.

- Nine of the Type- 0 fighter planes that had advanced to the Bali base carried out an attack on Malang, and reported having set ablaze four B-17s and destroyed another B-17 and one twin-engine plane.

- Sixteen land-based attack planes carried out an attack on [an enemy] cruiser, but scored no direct hits.

- Thirteen land-based attack planes went to conduct attacks on enemy naval vessels in the Lombok Strait, but spotted no enemy. They carried out bombings on the urban area of Banyuwangi (on the eastern end of Java) [instead].

Reconnaissance seaplanes of the Sanuki-maru provided the convoy carrying the [Bali] invasion unit with patrols against enemy submarines when the unit left Makassar, but the details are unclear.

\section{The Engagements of the Army Units}

At 0100 on the 19th, the Kanemura Detachment landed on the coast of Sanur without meeting any enemy resistance at all. That night, with dark clouds hanging low and poor visibility, was convenient for a surprise attack. Having carried out a sudden attack on the barracks in Denpasar before dawn and seizing them, the detachment moved south and seized the airfield around 1130. After that, the detachment took charge of securing the route[s] to transport Navy air base matériel as well as guarding the airfield..$^{(140)}$

\section{The Second [Phase]: The Bali Transport Operation}

The unit for the second phase of the transport operation, i.e. the Rakutō-maru, the Okitsu-maru ([of] the Eleventh Air Fleet), the Daito-maru, the Toyosaka-maru, the Hino-maru No. 3 ([of] the 5th Construction Squad) left Balikpapan at 1700 on the 20th under the escort of the 2d Subchaser Division, and reached Makassar at 1130 on the 22d. ${ }^{(59)}$ On the 22d, Dutch East Indies Unit Commander Vice Admiral Takahashi, leading the main unit, advanced from Balikpapan to Staring Bay, where he issued the following orders. ${ }^{(54)}$

1. It seems that there are five to seven enemy cruisers and about ten destroyers in Batavia, and one De Ruyter- and one Java-class [cruiser] and about five destroyers in Surabaya.

2. The Dutch East Indies Unit shall, with the support of the Air Unit ([of] the Southern Task Force) and the Malaya Unit, cover the Sixteenth Army's landings on Java, while catching and destroying enemy naval vessels.

3. Other than the following, all units shall operate in accordance with the outline stipulated in the Dutch East Indies Unit Order Classified No. 9.

(a) The Nagara, the 8th Destroyer Division (minus the Ōshio and the Michishio), the 21st Destroyer Division (minus the Hatsuharu) and the 2d Destroyer Division shall escort the Rakutōmaru, the Okitsu-maru, the Daito-maru, the Toyosaka-maru and the Hino-maru No. 3 under the command of the 1st Base Force commander. They shall leave the roads off Makassar on the evening of 23 February, reach Bali before dawn on the 25th, and cover and guard the disembarkation of matériel, while catching and destroying enemy naval vessels fleeing through the waterways both east and west of Bali.

(b) - (d) (The operations of the 2d Escort Unit and others - Omitted by the author)

(e) The main unit (the Ashigara, the Ikazuchi and the Akebono) shall reach the waters north of Lombok on the night of the 24th. Thereafter, the unit shall take charge of covering and sup- 
porting the units for Operation HA [against Bali], and also take on the task of supporting the whole operation while catching and destroying escaping enemy naval vessels by appropriately operating on the waters north of the Lombok Strait around 28 February.

Although the 8th Destroyer Division, [namely] the Asashio and the Arashio who had not sustained damage in the sea engagement off Bali, had been ordered to join the main unit, by this order they were supposed to take again part in the [Bali] operation. Anticipating counterattacks by enemy naval vessels, Base Unit Commander Rear Admiral Kubo decided to further add to the forces for the second [Bali] operation the Tsukushi and the 1st Subchaser Division, which were then at Makassar, as well as Submarine Chaser No. 21 of the 12th Subchaser Division, which had been newly formed and advanced to Staring Bay from mainland Japan. ${ }^{(68)}$

On 23 February, Base Unit Commander Rear Admiral Kubo issued to the units that had assembled in Makassar for the second [Bali] operation the outline of the second operation, which was in summary as follows: ${ }^{(68)}$

\section{Disposition of forces}

(1) The main unit (directly led [by the commander]: The Nagara, the 8th Destroyer Division (minus the Ōshio and the Michishio)

(2) The Echelon (led by the 21st Destroyer Division commander): The 21st Destroyer Division (minus the Hatsuharu), the 2d Subchaser Division and Submarine Chasers No. 1 and No. 21

(3) The support unit: The Tsukushi

2. Main points of the operation

The units shall leave Makassar at 1800 on the $23 \mathrm{~d}$, pass the point of $6^{\circ} 21^{\prime} \mathrm{S} 118^{\circ} 25^{\prime} \mathrm{E}$ at 0400 on the 24th, the point of $7^{\circ} 40^{\prime} \mathrm{S} 116^{\circ} 9^{\prime} \mathrm{E}$ at 2030 [on that day], and reach the roads off Pantai Timur at 0900 on the 25 th. After that, they shall at that place conduct the disembarkation and the guarding.

The following information on the enemy had by that time been found out from the statements of the prisoners etc. ${ }^{(54)}$

1. The enemy forces which had participated in the sea engagement off Bali

Commander: Rear Admiral Doorman of the Dutch Navy

HNLMS De Ruyter, HNLMS Java and another cruiser as well as five destroyers

2. The base to where the enemy navy escapes is Cilacap (USS Houston stayed there around 5 or 6 February).

3. It seems that ten U.S. cruisers and twenty U.S. destroyers sometimes come to give support, while they patrol the areas [surrounding] Australia as well as the Indian Ocean.

4. The Dutch [Navy] possesses twelve submarines, and if U.S. and British submarines are included, [the allies] have thirty to forty submarines.

5. Military supplies are delivered from the United States every day.

6. Others

(1) Seaplane bases: Surabaya and Cilacap

(2) Land bases: Surabaya, Batavia and many others

(3) Fuel bases: Semarang and Tebakubekun [?]*

* In Dutch sources Semarang is never mentioned as a fuel base. The main fuel depots for the fleet were at Surabaya, Batavia (Tanjung Priok), and Cilacap. Also a few strategically placed oil tankers were used as auxiliary depots. Before the engagement at the Gaspar Strait on 15 February, the Allied Striking Force had partly refueled at Telukbetung, south Sumatra. Maybe Tebakubekun should be read Telukbetung. 
Based on air reconnaissance information gathered until 22 February, it was judged that one A-class cruiser, one De Ruyter-class and one Java-class cruiser as well as five destroyers were at anchor in the Surabaya area. ${ }^{(108)}$ In the meantime on the $22 \mathrm{~d}$, for the first time eleven landbased attack planes advanced to Bali, which increased the [total] strength on Bali to thirtytwo fighter planes, four land-based reconnaissance planes and eleven land-based attack planes. However, the enemy had day after day persistently come to attack [the Bali airfield] although in small numbers. ${ }^{(71)}$

At 1800 on 23 February, the Second [Bali] Transport Operation Unit left Makassar. Although an enemy aircraft came probing around 1000 on the 24th, it did not lead to enemy attacks. When the unit approached the 230 nautical miles range from Surabaya at 1700 that day, a report came from [an] aircraft: "[Spotted] one enemy cruiser and three destroyers at sixty nautical miles north of Surabaya." Base Unit Commander Rear Admiral Kubo assumed that the enemy was likely to be escaping in the direction of Bali or coming to shell the airfield on Bali. Therefore, he advanced to the waters between the Kangean Islands and Bali, leading the Nagara, and the 21st and the 8th Destroyer Divisions to search for the enemy, but did not spot them. ${ }^{(68)}$

At 0800 on the 25th, the transport unit entered the anchorage and by the end of February completed the disembarkation. Although there were a few air raids by enemy aircraft during that period, no damage was sustained. Also, a few enemy naval vessels appeared but they all fled without engaging. The Bali operation of the 1st Base Force was wrapped up as of 5 March. ${ }^{(68)}$ In the meantime, the landings in eastern and western Java had been successfully carried out on 1 March, and during that time the aircraft units, which had advanced to the Denpasar [airfield], carried out a very effective air campaign. ${ }^{(71)}$

\section{A Review of the Sea Engagement off Bali (See Illustrations Nos. 34, 35, and 36.)}

Concerning the circumstances of the engagements in this sea battle, there are on the Japanese side no records of the 8 th Destroyer Division extant. The only available data consist of a fragmentary record of telegrams in the action report of the 2d Destroyer Squadron, some brief accounts in the operation reviews, and the rough artillery records in the lessons of war compiled by the Yokosuka Gunnery School. As for records on the allied side, since there are almost no data available from the Dutch side, we have to chiefly rely on Morison's The Rising Sun in the Pacific. However, we cannot have complete faith in his account. I will try to examine all these data together, although it may be difficult to expect a definite [reconstruction]*.

\section{The First Phase}

The opponent in the first phase of the engagement consisted of five ships: the Dutch cruisers HNLMS De Ruyter and HNLMS Java, the Dutch destroyer HNLMS Piet Hein and the U.S. Destroyers USS [John D.] Ford and USS Pope.

The five ships sailed with HNLMS De Ruyter in the lead, followed by HNLMS Java, while USS [John D.] Ford and USS Pope followed in their wake at a distance of 10,000 meters. The latter two lagged behind because they had lost the wake of HNLMS Piet Hein for a while due to a course change before rushing into the attack. When rushing into the attack, HNLMS De

* After the Japanese publication of the present volume, a Dutch analysis of this battle appeared in Ph. M. Bosscher, De Koninklijke Marine in de Tweede Wereldoorlog [The Royal Netherlands Navy in the Second World War], 1986, Vol. 2, pp. 263-270. With one exception, we have not incorporated his findings in the following description. 


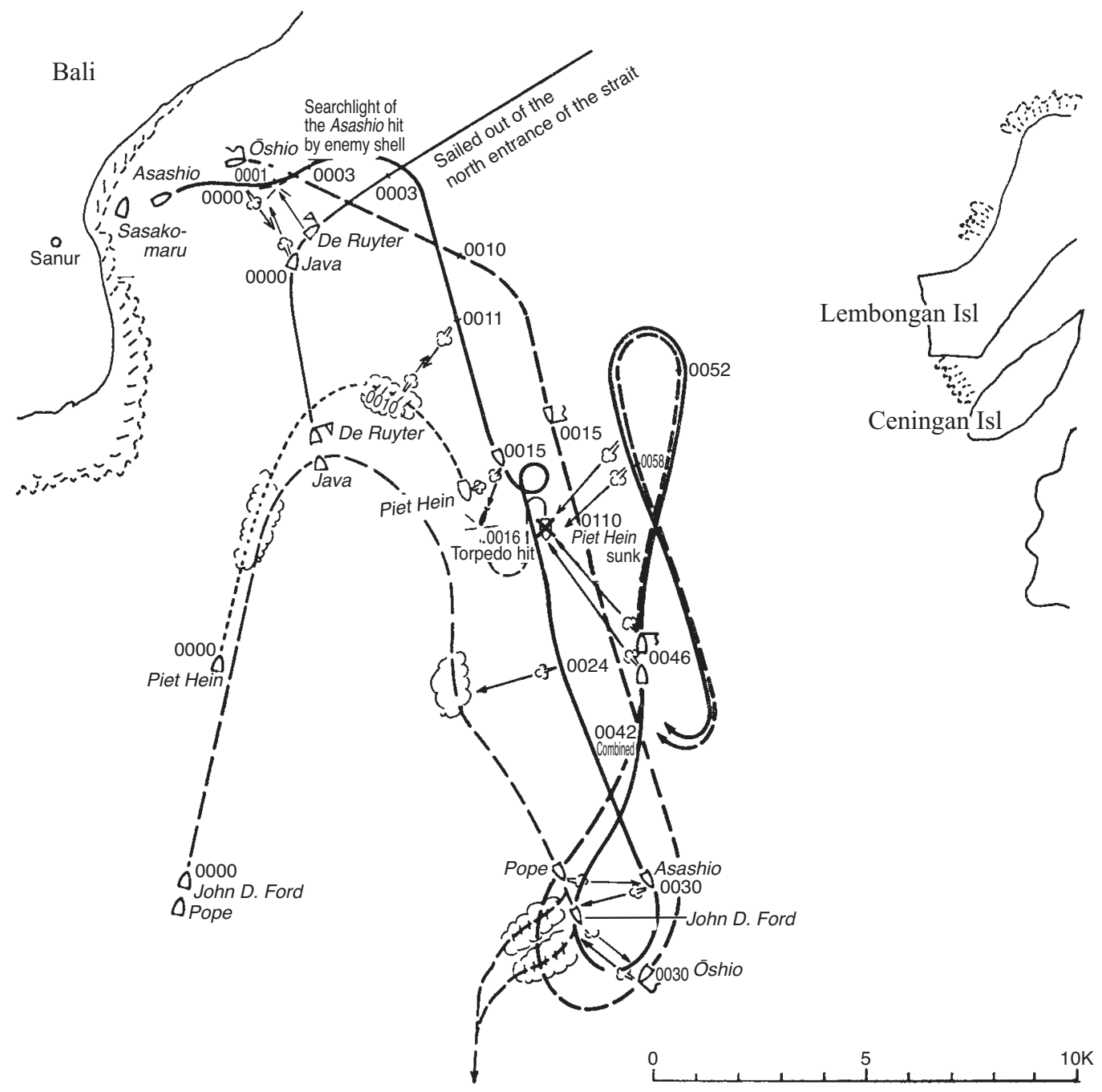

Illustration No. 34 - The Relative Positions of Both Forces during the First Phase of the Sea Engagement off Bali

Ruyter had been prepared for an artillery duel with the enemy on starboard. The "two Javaclass enemy cruisers" that the Asashio had spotted at 2353 were correctly HNLMS De Ruyter and HNLMS Java. Because the Japanese force had the mountains [on Bali] at the back, the allied force spotted them too late. Consequently, both sailed past each other in an instant with no time to spare for a [true] artillery duel. The [allied] cruisers disappeared to the north, without [turning back to] repeat the attack.*

The enemy vessel that the Ōshio had spotted at an end of a smoke screen to the south at 0005 right after the artillery duel was HNLMS Piet Hein. For unknown purposes, HNLMS Piet Hein had laid a smoke screen at the sight of the artillery duel ahead of her. ${ }^{* *} H N L M S$

* The Asashio and the Java did exchange fire.

** According to Bosscher p. 266, by some unknown cause Piet Hein's smoke generator had been activated, thereby betraying her position to the Japanese. 
Piet Hein and the Asashio rapidly closed the distance. Checked by the Asashio, HNLMS Piet Hein turned right, and both came to sail on parallel courses. From 0010 onwards, HNLMS Piet Hein came under fierce fire from the Asashio, which was followed by a direct hit of a torpedo at 0016 . The damage was huge and her speed rapidly decreased. At that time the Asashio assumed that she had sunk her, but in reality [HNLMS Piet Hein] was moving about on the waters nearby at low speed.

The two U.S. destroyers, who had followed in the wake of HNLMS Piet Hein, sailed into the smoke screen the latter had laid and turned right to avoid it, where they came to sail on a parallel course on the starboard side [of the Piet Hein] (i.e. her unengaged side). The two vessels that the Asashio spotted at 0012 were these U.S. destroyers. Both destroyers were about to join the engagement, but seeing the damage sustained by HNLMS Piet Hein, they took evasive actions for some time, but ended up sailing southward on a parallel course with the Asashio. However, when they came under concentrated fire from a Japanese force that had been increased with the Oshio, they hurriedly laid a smoke screen and fled southward. Then, while sailing northward after reversing course, the Öshio and the Asashio newly spotted two destroyers (actually one) on their port side bows at 0045; [in fact] it was HNLMS Piet Hein that the Asashio believed she had sunk. Although HNLMS Piet Hein was set ablaze by the gunfire from the Ōshio and the Asashio directed at her for the second time around, she [in fact] did not sink yet. Still more, what the Oshio and the Asashio fired at from 0058 onwards after [again] reversing course was still HNLMS Piet Hein. It seems that she [finally] sunk around 0110. The Japanese ships assumed that they had sunk or heavily damaged another vessel, but they must have wrongly taken the burning heavy oil spilt over the waters for another vessel. In the final analysis, the conclusion that in the first phase of the battle they had sunk two [enemy] destroyers and inflicted serious damage to a third appears to have been a mistake for having sunk HNLMS Piet Hein [only].*

\section{The Second, Third and Fourth Phases}

The allied naval vessels that appeared in the second phase and after were the Dutch cruiser HNLMS Tromp, the U.S. destroyers USS Stewart, USS Parrott, USS [John D.] Edwards and USS Pillsbury. They sailed in a column with the U.S. destroyers at the head, while HNLMS Tromp followed at a distance of 8,000 meters. While sailing north at a speed of 25 knots, the U.S. destroyers haphazardly fired torpedoes toward the Sanur anchorage around 0306, which naturally hit nothing. During the torpedo launch action, the USS Pillsbury lost the wake of the vessels in front of her, separated from the column and headed north of Lembongan Island on her own. At 0310, the Ōshio and the Asashio spotted the enemy, but they mistook the three U.S. destroyers for two cruisers and one destroyer.

The Oshio and the Asashio opened up with gunfire and torpedo attacks against the superior enemy. After the opening of the battle, the column of the U.S. destroyers got into disarray due to the smoke of the gunfire and also because USS Stewart had been hit in the steeringengine room. [Consequently,] the third ship, USS [John D.] Edwards, became the lead, whom the first ship, USS Stewart, followed, while the second ship, USS Parrott, became unable to control its movements due to trouble with her rudder; she left the line and sailed northward on the waters north of both ships.

* Morison and other allied sources interpret the gunfire heard after USS Ford and Pope had managed to get away as if the Asashio and Oshio had inadvertently fired at each other. 


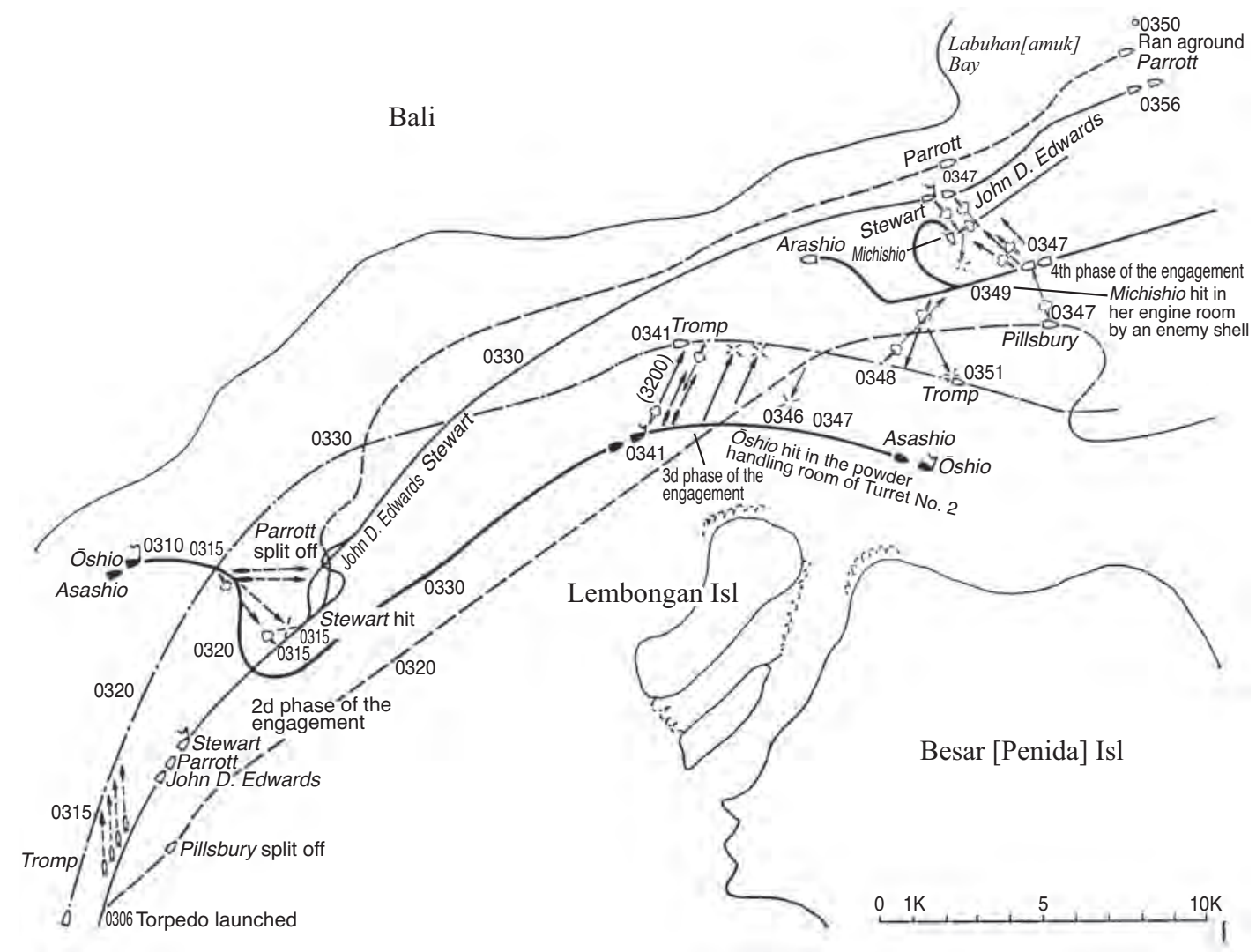

Illustration No. 35 - The Relative Positions of Both Forces from the Second to the Fourth Phase of the Sea Engagement off Bali

When the Ōshio and the Asashio changed course and started sailing eastward in pursuit of the U.S. destroyers, HNLMS Tromp, who had lagged behind, sailed past the Sanur anchorage. [Hidden] in the silhouette of the island, she was not seen by the 8th Destroyer Division, but she could not catch sight of the Japanese forces either because the latter had entered in the blind zone on her starboard quarter. The Öshio and the Asashio [first] spotted HNLMS Tromp [on the waters] northwest of Lembongan, fired at her from her starboard quarter at 0341, and scored a number of direct hits. Although unable to operate her fire control and searchlight, HNLMS Tromp also scored a direct hit on the Ōshio. While firing at [the Japanese on] starboard, HNLMS Tromp also came under attack on her port side, which disabled the port searchlight as well. The ship that was firing at her from the other side was the Arashio, who had come sailing in on an opposite course.

The $2 \mathrm{~d}$ Section of the 8 th Destroyer Division [i.e. the Arashio and the Michishio] had rushed right in between the enemy, who was sailing eastward divided into a northern and southern group. USS Parrott, USS [John D.] Edwards, and USS Stewart, were sailing on their northern side while on their southern side were HNLMS Tromp and USS Pillsbury, who was sailing ahead [of HNLMS Tromp]. At 0347 the $2 \mathrm{~d}$ Section opened up with gunfire and torpedo attacks on USS [John D.] Edwards and USS Stewart while sailing on an opposite course and assumed that they had sunk the first ship in the 7th salvo. However, simultaneously the Michishio re- 
ceived a direct hit in her engine room and became unable to sail. The Michishio continued firing at the U.S. destroyers while turning her bow to the right and believed that she had inflicted serious damage to the second ship. After the Michishio had sustained damage, the Arashio who followed in her wake spotted an enemy cruiser sailing on an opposite course on her port side and fired a few salvos at the latter, but she disappeared on her port side quarter. It was these [salvos] that had destroyed the port searchlight of HNLMS Tromp. Witnessing the artillery duel between the Arashio and the Michishio and the [allied] units to the north of them, USS Pilsbury spotted the Japanese destroyers [as well], but after only firing a couple of salvos she evacuated [from the scene of action]. USS Parrott, who had separated from the column [due to] steering trouble and sailed to the north of USS Stewart since then, sailed east past the waters where the gun battle was going on, without exchanging fire with the Japanese force at all. Although she ran aground off Cape Labuan, she got free on her own and escaped to the north entrance of the Lombok Strait.

The actual forces in the engagement and the damage they sustained were as follows:

\begin{tabular}{|c|c|}
\hline \multicolumn{1}{|c|}{ Japanese Navy } & Allied [Naval] Forces \\
\hline & $\begin{array}{c}\text { HNLMS De Ruyter (cruiser), HNLMS Java } \\
\text { (cruiser) } \\
\text { HNLMS Tromp (cruiser): some damage; hit at }\end{array}$ \\
$\begin{array}{c}\text { The Ōshio (destroyer): minor damage; one hit } 10 \text { shells } \\
\text { in a powder handling room }\end{array}$ & HNLMS Piet Hein (destroyer): sunk \\
The Asashio (destroyer) & USS [John D.] Ford (destroyer), USS Pope (de- \\
The Michishio (destroyer): serious damage; hit & stroyer) \\
by several shells and crippled & USS Stewart (destroyer): minor damage; one \\
The Arashio (destroyer) & direct hit at the steering equipment \\
& USS Parrott (destroyer), USS [John D.] Edwards \\
& (destroyer), USS Pilsbury (destroyer) \\
\hline
\end{tabular}

That is to say, the allied forces had sent out three cruisers and seven destroyers and sustained the loss of having one destroyer sunk, one cruiser half damaged, and one destroyer slightly damaged, while the Japanese only suffered a loss of having one destroyer seriously damaged and another slightly damaged out of four destroyers (two at the initial phase of engagement).

The circumstances of the allied forces were as follows: It was on 17 February that the information came in that Japanese invasion units against Bali were about to leave Makassar. ABDA Naval Forces Commander Vice Admiral Helfrich of the Dutch Navy (who had replaced Admiral Hart of the U.S. Navy on 11 February) issued an order to the Doorman unit to immediately attack the enemy. At that time, the allied striking force under the command of [Rear Admiral] Doorman had just retreated from the attack by Japanese air units in the Gaspar Strait and dispersed to various [naval ports]. Judging that it would be too late to make a sortie after having assembled his [full] strength, Rear Admiral Doorman issued the following outline of attack:

1. Time and point of attack

The night of 19-20 February at the Badung Strait

2. The main points of attack

(1) The first attack unit (consisting of two cruisers and four destroyers currently stationed in Cilacap) shall rush in at 0030 (Japan time) on the 20th. 


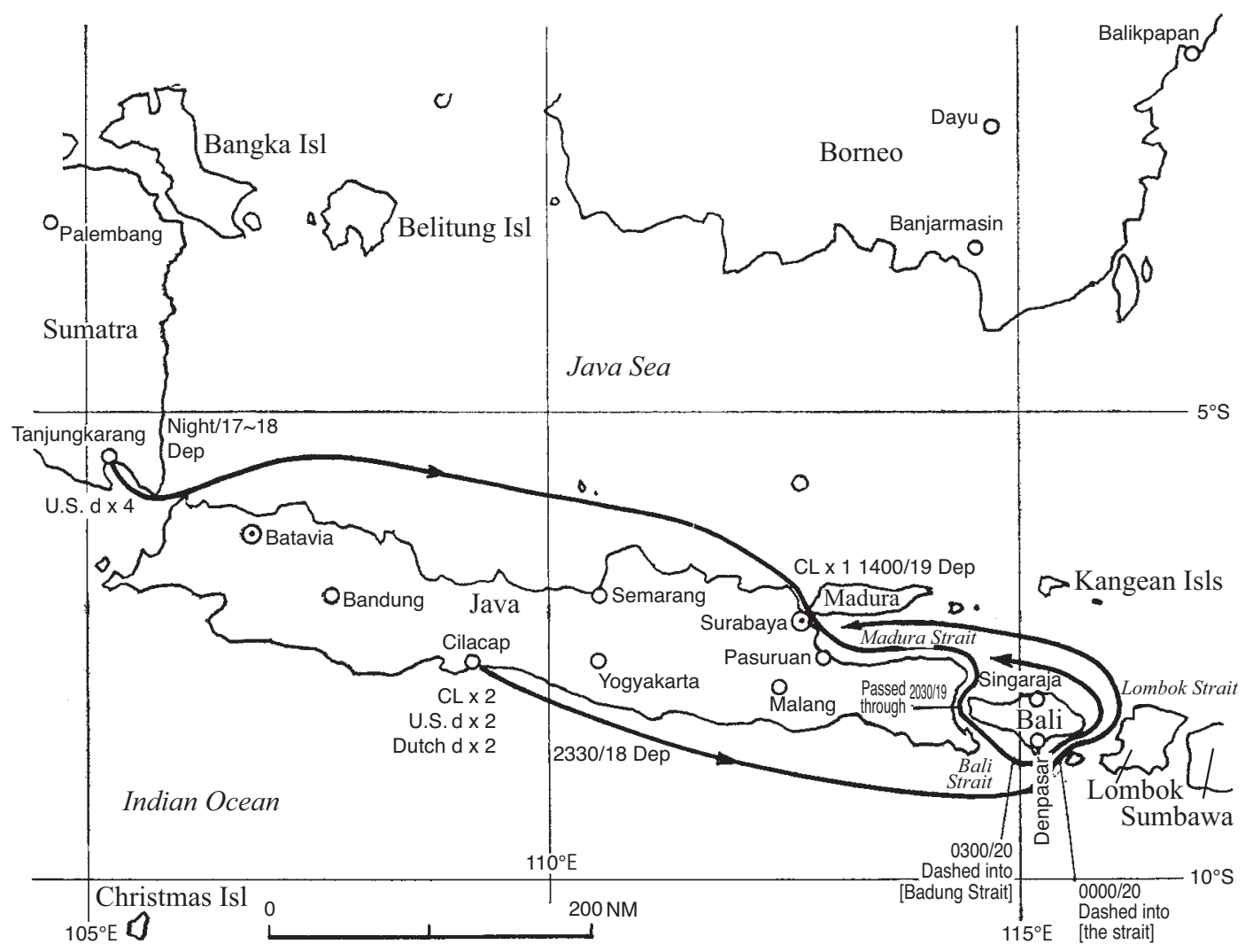

Illustration No. 36 - Outline of the Operations of the Allied Attack Units (17-20 February, 1942)

(2) The second attack unit (consisting of one cruiser currently stationed in Surabaya and four destroyers currently in the Sunda Strait) shall assemble at Surabaya and rush in three hours after the charge of the first attack unit.

(3) The 3d attack unit (consisting of seven torpedo boats currently stationed at the Bali Strait base) shall rush in one hour after the charge of the $2 \mathrm{~d}$ attack unit.)

On the basis of such a plan, the operation was carried out. However, the third attack unit did not even spot the Japanese destroyers and in spite of committing an overwhelmingly superior unit, the allied naval force lost a favorable opportunity to destroy the transport convoy escorted by only two Japanese destroyers (later increased to four) due to the operating units' dubious implementation of the operation. 


\section{The Surprise Attack Operation Against Port Darwin}

(See Illustration No. 37)

\section{The Plan of Operations for a Surprise Attack on Port Darwin}

We have already described the circumstances that led to the commitment of the Carrier Task Force to the Southern Operation [pp. 211-212]. At that time, at 0000 on 31 January, R. Adm. Ugaki Matome, the chief of staff of the Combined Fleet, sent the following telegram to Vice Admiral Kondō, the commander of the Southern Task Force, outlining the intentions behind the employment of the Carrier Task Force. ${ }^{(141)}$

1. With the fall of Singapore and the progress in the operations against Java and Celebes, the enemy will look for paths of retreat from Java and Sumatra to Australia and the Indian Ocean. It is very likely that we will see the British Indian Ocean Fleet and U.S. and Australian surface forces come out to rescue and cover [the retreating forces]. By catching and destroying such forces as well as destroying the fleeing transport convoys and, depending on the circumstances, destroying the enemy forces in the Java area from the rear, the final operation of the southern operation will be wrapped up and won in one stroke. For executing such an operation, the forces [mentioned in] Second Fleet Classified Telegram No. 781 are considered insufficient, and thus the Carrier Task Force and one element of the Sixth Fleet have been added as reinforcements.

2. During the period of employment of the Carrier Task Force, we want you to make absolutely sure that the force shall be perfectly guarded against enemy submarines, so that it can be deployed in attacking the bases of the enemy fleet and its air power as effectively and appropriately as possible and in the shortest period of time. Also, we want you to pay due regard to clearly defining the operations of friendly submarines so they will not be confused with enemy submarines.

In response, Southern Task Force Commander Vice Admiral Kondō drew up around 5 February an internal draft plan of operations outlining a surprise attack on Port Darwin in the rear of Kupang on 17 February, prior to the operation to seize Kupang (whose capture had been postponed till 20 February at the Manila Conference), by a force consisting of the $2 \mathrm{~d}$ Carrier Division as the main body under the command of Eleventh Air Fleet Commander in Chief Vice Admiral Tsukahara.

Note: The suggestion of 2d Carrier Division Commander Rear Admiral Yamaguchi [p. 212] was accepted that, in view of the enemy surface unit's night attack off Balikpapan, the primary bases of the enemy should be attacked [first], because the conventional method of attacking and neutralizing the enemy within 600 nautical miles [from a friendly base] and pushing forward air bases by just 300 nautical miles carried the risk of being attacked by enemy surface vessels at the time of invasion. ${ }^{(101)}$

The second part [of Vice Admiral Kondō's plan of operations] outlined the incorporation of the $2 \mathrm{~d}$ Carrier Division into the First Air Fleet for the second carrier operation (the carrier operation in the Indian Ocean). ${ }^{(141)}$

Then on 8 February, the main force of the Carrier Task Force (minus the 5th Carrier Division (minus the Oboro), and minus the Arare and the Kagerō) and the $2 \mathrm{~d}$ Submarine Squadron were formally incorporated into the Southern Task Force, as previously told. With that and 
with the postponement of the Java operation, [the Southern Task Force] became less pressed for time. Accordingly, at 1500 on 9 February, Southern Task Force Commander Vice Admiral Kondō divulged his immediate plan for the southern operation as a whole, as well as his plans for the first carrier operation (to destroy enemy forces that might come in the way of the capture of strategic places such as Timor) and for the second carrier operation (to completely destroy the enemy by cutting off his paths of retreat at the time of Java operation). These plans were as follows: ${ }^{(53)}$

\section{Southern Task Force Telegraphic Order No. 92}

[at] 1500 on the 9 th

1. Because of our air attacks in early February, the enemy who has made Java his stronghold has lost the best part of his naval and air power. Since it is highly likely that the remnants will attempt to evacuate to Australia, India and South Africa as our invasion operations progress, it is also quite likely that, in order to rescue [the evacuees], British, U.S., Dutch and Australian surface forces will appear in the eastern part of the Indian Ocean. Further, it seems that one element of the enemy forces has already evacuated to Port Darwin and its vicinity. According to intelligence, one element of the U.S. air reinforcements, acting in concert with the British and Australian forces, is using the place as its base.

2. The Malaya Unit is currently carrying out an attack on the port of Singapore, and intends to capture Bangka and Palembang in mid-February. Following the capture of Makassar, the Dutch East Indies Unit and the air unit are going to capture Bali and Timor around 20 February, and launch [the operation to] capture Java from around 25 February onwards.

3. The Southern Task Force shall timely let the Carrier Task Force carry out carrier operations, first in the Arafura Sea and then in the eastern part of the Indian Ocean. In these operations, it shall try to completely destroy the enemy air power in the Port Darwin area as well as catch and destroy enemy fleets and transport convoys, while attacking the enemy forces in the Java area from their rear. While continuing their present tasks, the remaining units shall act in concert with the above carrier operations and try to further expand the military gains, so that the clearing [of the enemy] in the entire Dutch East Indies area will be accelerated.

4. The Carrier Task Force shall conduct the carrier operations in the following way:

(1) First carrier operation (surprise attack on Port Darwin and vicinity)

[The units] shall timely depart from Palau, advance to the Arafura Sea, and carry out a surprise attack on Port Darwin and vicinity (around 19 February) on the day before the launch of the capture [operation] of Timor, after which they shall put in at Staring Bay for replenishment (in case the $3 \mathrm{~d}$ Battleship Division is not going to participate in the operation, the $2 \mathrm{~d}$ Section of the 4 th Destroyer Division shall also remain in Palau as its guard unit).

(2) Second carrier operation (carrier [operations] in the eastern part of the Indian Ocean)

[The units] shall timely leave Staring Bay and advance to the Indian Ocean; they shall conduct carrier operations on the ocean for about five days, and if there is no change in the enemy movements, they shall operate with the aim of reaching the waters south of the Sunda Strait on 1 March. After that, they shall return to Staring Bay.

5. In the first carrier operation, the Air Unit shall with one element carry out joint air strikes on Port Darwin and vicinity. For the second carrier operation, they shall take on search and attack missions over the waters where the Carrier Task Force operates, particularly the wide areas ahead of the sailing route of the latter, using the bases on the southern coast of the Dutch East Indies. At the same time, they shall conduct reconnaissance attacks on the Christmas and Cocos Islands as soon as possible.

6. The Dutch East Indies Unit shall let a force [consisting of] the 5th Cruiser Division as the core operate in the Banda Sea during the first carrier operation and in the area southwest of Timor 
during the second carrier operation. The force shall be assigned to cover and accomodate the Carrier Task Force while guarding its rear during the operation.

7. Submarine Unit A (the 4th and the 6th Submarine Squadrons) shall operate as scheduled; it shall be assigned to watch and patrol the southern coast of the Dutch East Indies east of (and including) Java as well as the Torres Strait and the Port Darwin area.

8. Submarine Unit B (the 5th Submarine Squadron) shall be assigned to watch and patrol the coastal areas of Ceylon and India as well as the north entrance of the Malacca Strait and the southern coast of Sumatra.

9. Submarine Unit C (the $2 \mathrm{~d}$ Submarine Squadron) shall leave Staring Bay around 23 February and advance into the Indian Ocean. The bulk of the unit shall advance while searching for the enemy more or less 400 nautical miles southeast of Java, and swiftly reach the area south of the Cocos Islands. After that and until about $1 \mathrm{March}$, it shall conduct patrols from a position on the waters between about $97^{\circ} \mathrm{E}$ and $100^{\circ} \mathrm{E}$ beyond the 600 nautical miles range from Palembang. One element shall be assigned to covertly patrol the regular sailing routes on the western coast of Australia off Freemantle, after which it shall return to Staring Bay around 6 March.

Also, one designated submarine shall promptly be assigned to reconnoiter and watch the Cocos Islands.

10. The main body of the Southern Task Force shall leave Palau on 18 February and advance to Staring Bay, from where it shall advance into the Indian Ocean in tandem with the Carrier Task Force and appropriately operate to support all operations.

11. In this operation, the forces operating in the Indian Ocean may be unified to carry out [particular] missions. The outlines of these missions shall be issued in separate orders.

On 10 February, Southern Task Force Commander Vice Admiral Kondō ordered the 2d Carrier Division (minus the 23d Destroyer Division) and the 7th Destroyer Division to return to the Carrier Task Force. ${ }^{*(54)}$ (In response, Eastern Attack Unit Commander Rear Admiral Takagi, who experienced a shortage of destroyers, strongly requested that the 7 th Destroyer Division should remain, which was finally approved on the 12th. The details will be described later.) Then, at 0700 on 12 February, Southern Task Force Commander Vice Admiral Kondō announced that during the carrier operations of the Southern Task Force, the units operating in the Indian Ocean would operate under his unified command. Again on the 15th, he issued the following order concerning the operations of the Carrier Task Force (Telegraphic Order No. 53). ${ }^{(141)}$

1. In accordance with Southern Task Force Telegraphic Order No. 92, the Carrier Task Force shall carry out carrier operations in the Port Darwin area as well as in the eastern part of the Indian Ocean, according to the following schedule:

(a) The first [carrier operation]

[The force] shall leave Palau on 15 February, sail by way of the Molucca Strait ([at] 1800 on the 17th), the Manipa Strait ([at] 1200 on the 18th), west of Babar Island ([at] 0300 on the 19th) to a point about 80 nautical miles south of Babar Island around 0600 on the 19th, from where it shall launch the surprise air strike operation against Port Darwin. After that, it shall put in at Staring Bay.

(b) The second [carrier operation]

[The force] shall leave Staring Bay around 25 February and sail by way of the Ombai Strait and along the western side of the Savu Islands so as to reach the eastern part of the Indian Ocean. After operating there, it shall return to Staring Bay.

\footnotetext{
* See p. 345. Actually, this order was issued by the Commander in Chief of the Combined Fleet.
} 
2. The air unit of the Southern Task Force shall, in concert with the above carrier operations, be assigned to catch and destroy enemy forces as well as to search for and attack the enemy on the waters where the Carrier Task Force operates, particularly the wide areas ahead of the sailing route of the latter.

3. Apart from the following operations, the air unit of the Southern Task Force shall operate according to its assigned dispositions.

(a) The 1st Air Raid Unit

(1) From the departure of the Carrier Task Force from Palau till the completion of the operations of the force, the unit shall search for the enemy on the sailing route ahead of the force in the area of the Molucca Strait and to the south, while clearing and neutralizing [the enemy] in the northwestern part of New Guinea, Halmahera, and the Savu Islands.

(2) On 19 February, in concert with the surprise attack of the Carrier Task Force, it shall carry out an air strike on Port Darwin with its land-based attack plane units at 1130 with the facilities of the east airfield as their target.

(3) On the 19th, it shall search for the enemy in the Arafura and the Timor Seas with one element of large flying boats, ready against fleeing enemy vessels.

(4) After that, [the unit] shall search for and attack [the enemy] in the Arafura and the Timor Seas as designated by the commander, while accelerating the advance to the Kupang base. [The unit shall also] continue reconnaissance attacks on key places in northwestern Australia.

(5) During the second operation of the Carrier Task Force, [the unit] shall search for the enemy in as wide an area as possible on the sailing route ahead of the force in order to catch and destroy enemy surface forces.

(6) If the [capacity of the Kupang] base permits, the bulk of the large flying boat units shall be advanced to Kupang during the carrier operations.

(b) The 2d Air Raid Unit

(1) The unit shall accelerate the advance of the land-based attack plane units to the Jimbaran [airfield] (note by the author: Bali). Upon its advance, the unit shall search for and attack enemy naval vessels in the coastal areas of Java as well as in the Christmas Island area.

(2) During the second operation of the Carrier Task Force, the unit shall search for and attack the enemy on the sea in as wide an area as possible west of a line $160^{\circ}$ [SSE] from the Jimbaran base (west of a $120^{\circ}$ [ESE] line until the land-based attack plane units of the 1st Air Raid Unit will have advanced to Kupang).

4. The 3d Air Raid Unit shall be incorporated into the Air Unit of the Southern Task Force and conduct the following search and attack [missions].

(1) After the advance of the land-based attack plane units to Palembang, [the unit] shall search for and attack enemy naval vessels in the Cocos Island, Java and Sumatra areas.

(2) During the second operation of the Carrier Task Force, [the unit shall search for and attack the enemy in the area] west of the Palembang line.

At 2030 on the 16th, 5th Cruiser Division Commander Rear Admiral Takagi sent the units concerned the outline of operations regarding the cover for the units of the first carrier operation by the following telegram: "The Eastern Support Unit (the Nachi, the Haguro, and the Akebono) shall leave Staring Bay at 1500 on the 17th and, after having been joined by the Ikazuchi en route, take charge of covering the units of the first carrier operation, while [also] supporting the $2 \mathrm{~d}$ Escort Unit. The operation schedule is as follows (the rest is omitted by the author; it will be described later on in [the section on] the Timor Invasion Operation.)"(53)

The status of the Carrier Task Force when it left Palau for the first carrier operation was as follows: ${ }^{(141)}$ (as of 15 February [1942]) 
1. The disposition of forces (as shown in the following table)

\begin{tabular}{|c|c|c|c|c|}
\hline Unit & & Commander & Forces & Main Tasks \\
\hline Air Raid Unit & \multirow{3}{*}{ 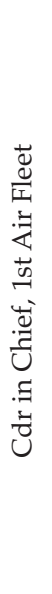 } & & $\begin{array}{l}\text { First Air Fleet (minus } \\
\text { 4th and } 5 \text { th Carrier Divs } \\
\text { and destroyer div[s]) }\end{array}$ & $\begin{array}{l}\text { To attack enemy air } \\
\text { power and naval vessels }\end{array}$ \\
\hline Support Unit & & 8th Cruiser Div Cdr & 8th Cruiser Div & $\begin{array}{l}\text { To cover the main unit } \\
\text { and attack enemy naval } \\
\text { vessels }\end{array}$ \\
\hline Guard Unit & & 1st Destroyer Sqdn Cdr & $\begin{array}{l}\text { 17th Destroyer Div, 18th } \\
\text { Destroyer Div 1st Sec- } \\
\text { tion, 27th Destroyer Div } \\
\text { 2d Section }\end{array}$ & $\begin{array}{l}\text { To provide guard [for } \\
\text { friendly forces], attack } \\
\text { enemy naval vessels } \\
\text { and transport ships, } \\
\text { provide guard along the } \\
\text { sailing route, provide } \\
\text { guard on the flying } \\
\text { routes }\end{array}$ \\
\hline
\end{tabular}

Note: The 1st Carrier Division (the Akagi and the Kaga), the 2d Carrier Division (the Sōryū and the Hiry $\bar{u}$ ), the 8th Cruiser Division (the Toné and the Chikuma) and the 1st Destroyer Squadron (the Abukuma and seven destoyers)

2. The state of aircraft replacements

The 1st and the $2 \mathrm{~d}$ Carrier Divisions have been provided at Truk with ten carrier-based fighter planes, eighteen carrier-based bombers and fourteen carrier-based attack planes from the 5th Carrier Division, which was going to return to mainland Japan. ${ }^{(100)}$

\section{The Launch of the Operation}

\section{Reconnaissance and Sailing}

At 1020 on 10 February, one land-based reconnaissance plane of the 3d Air Group took off from Ambon, carried out a covert photoreconnaissance over Port Darwin and returned at 1720.

The results of the visual reconnaissance were as follows: ${ }^{(81)}$

1. There are two airfields [with a runway] of 1,500 meters to 2,000 meters long in the northern suburbs of the city of Port Darwin. Five large planes and about twenty small planes were spotted on the eastern airfield. Three [enemy] fighter planes were patrolling in the air at an altitude of about 2,000 meters.

2. There is [a] seaplane base at the southeastern end of the city of Port Darwin. Three flying boats were spotted in the neighborhood.

3. One vessel, which looked like a carrier-plane tender, about ten large merchantmen, eleven small merchantmen and about five vessels, which looked like destroyers, were spotted in the bay.

4. No air bases were spotted on the Melville and Bathurst Islands.

5. Although adequate reconnaissance may not have been performed due to clouds, the objective was by and large attained.

6. No damage was sustained. 
In connection with the Carrier Task Force's attack on Port Darwin, the commander of the land based air units, Vice Admiral Tsukahara, refrained from attacking Port Darwin until the very day of the air strike.

At 1400 on 15 February, the Carrier Task Force left Palau for the first carrier operation (the surprise attack on Port Darwin). ${ }^{(141)}$ On that day, the Kanoya Air Group Detachment planned to conduct a reconnaissance attack over the Lesser Sunda Islands with eighteen land-based attack planes, but due to bad weather, attacked only Flores and the Alor islands. ${ }^{(81)}$ [Meanwhile,] three large flying boats of the Tōkō Air Group searched for the enemy in the Banda and the Timor Seas; at 1100, one of them spotted one [enemy] cruiser, three destroyers and four transport ships sailing westward in the Timor Sea and went on probing, but did not return. Two land-based attack planes of the 1st Air Group took off to probe the above convoy and spotted it at 1755, but it was too late to carry out an attack on that day. On that day, nine land-based attack planes of the 1st Air Group carried out an attack on Dobo ([on] the Aru Islands), while another nine on Fak Fak ([on] New Guinea). ${ }^{(81)}$

On the 16th, the Carrier Task Force sailed south, while having carrier-based attack planes guard its sailing route ahead, carrier-based bombers patrol against enemy submarines, and [some] carrier-based fighter planes provide escort [against enemy aircraft] in the air and also [others] on standby on the carriers. ${ }^{(71)}$ Although two Type- 0 fighter planes of the $3 \mathrm{~d}$ Air Group Detachment carried out a search and attack mission on the enemy air power on Halmahera and the surrounding waters, they did not spot the enemy. [Meanwhile,] land-based attack planes of the 1st Air Group and large flying boats of the Tōkō Air Group carried out an attack on the [enemy] convoy they had spotted on the day before in the Timor sea, but could not attain large military gains. ${ }^{(81)}$ Also, twenty-seven aircraft of the Kanoya Air Group Detachment took off for the attack on this convoy, but they could not spot the enemy [convoy] due to bad weather (to be described later.)

On the 17th, the Carrier Task Force [continued] sailing south on strict alert. Since no water depths were provided on the nautical charts of the area, the Carrier Task Force sailed ahead, greatly worried about the sailing route. ${ }^{(142)}$ On that day, the Takao Signal Unit commander reported that communication intelligence had shown that twenty-three U.S. naval vessels, thirteen British naval vessels and two vessels of the Dutch East Indies had appeared in the direction of Darwin and Batavia. [A] carrier-based attack plane of the Kaga, which was guarding the sailing route ahead of the force, spotted one submerged enemy submarine at thirtyfour nautical miles $220^{\circ}$ [SW] of the main unit, and neutralized her. At 2150, the Carrier Task Force crossed the equator. ${ }^{(141)}$ In the meantime, as for the land-based air unit, two large flying boats of the Tōkō Air Group searched for the enemy in the Molucca and the Ceram Seas, but spotted no enemy. Also, in order to attack the convoy spotted on the days before, four large flying boats of the Tōkō Air Group and four land-based attack planes of the Kanoya Air Group took off for the search while twenty-six land-based attack planes of the 1st Air Group and nineteen land-based attack planes of the Kanoya Air Group took off for the attack, but without spotting the enemy convoy, attacked their second target, [a] battery at Kupang. ${ }^{(81)}$

On the 18th, like the day before, the Carrier Task Force went on sailing further south on strict alert. ${ }^{(53)}$ The land-based air unit had six large flying boats of the Tōkō Air Group search for the enemy [within a range of] 550 nautical miles between $120^{\circ}$ [ESE] and $200^{\circ}$ [SSW] from Ambon, while having three land-based attack planes of the Kanoya Air Group search for the enemy [within a range of] 650 nautical miles between $165^{\circ}$ [SSE] and $200^{\circ}$ [SSW] from 
Kendari. However, they spotted nothing more than one armed transport ship (sailing on a $100^{\circ}$ [E] course at a speed of 16 knots) at 320 nautical miles $50^{\circ}$ [NE] from Port Darwin and two transport ships and a destroyer (on a northeastern course at a speed of 12 knots, directly escorted by aircraft) at 90 nautical miles $268^{\circ}$ [W] [from Port Darwin]. ${ }^{(81)}$

On the 18th, the land-based air unit commander, Vice Admiral Tsukahara, reported on the enemy movements: According to air reconnaissance of northwestern Australia, there are one small aircraft carrier, a few destroyers and a few submarines. On 15 February, one classA cruiser, three destroyers and four transport ships were sailing westward in the Timor Sea, but due to serious damage inflicted on three of the transport ships on 16 [February] by our air attack, [the enemy] seems to have escaped to the south, abandoning plans to bring reinforcements to Java or Kupang. There are no other powerful units in western Australia, and it is highly likely that the Australian main fleet and the U.S. Fleet reinforcements are stationed on the east coast. The British Indian Ocean Fleet seems to be operating from its base on Ceylon with one element in the Cocos Islands and / or the Rangoon area. Its strength is estimated to consist of two battleships, two aircraft carriers, two to three class-A cruisers, three to four class-B cruisers and ten to twelve destroyers. ${ }^{(81)}$

Carrier Task Force Commander V. Adm. Nagumo Chūichi's plans till that day [the 18th] for the air strike on Port Darwin can by and large be pieced together as follows: ${ }^{(17,141)}$

1. The enemy movements in the area of Port Darwin

(1) Since aircraft radio communications are sparse, the [enemy] movements are not very active. The number of enemy aircraft on site can by and large be estimated at around 30 aircraft.

(2) The enemy vessels on site are one aircraft carrier-like vessel, one or two cruisers, some destroyers and other [types of] ships, and about ten transport ships.

2. The formation of the attack units

(1) Commander: Cdr. Fuchida Mitsuo

(2) Formation of the aircraft units

\begin{tabular}{|c|c|c|c|c|c|}
\hline Carrier & $\begin{array}{c}\text { Type- } 0 \text { fighter } \\
\text { planes }\end{array}$ & $\begin{array}{l}\text { Type-97 carrier-based } \\
\text { attack planes }\end{array}$ & $\begin{array}{c}\text { Type-99 carrier-based } \\
\text { bombers }\end{array}$ & Total & $\begin{array}{c}\text { Grand } \\
\text { total }\end{array}$ \\
\hline Akagi & 9 & 18 & 18 & 45 & \multirow{4}{*}{188} \\
\hline Kaga & 9 & 27 & 18 & 54 & \\
\hline Sōryū & 9 & 18 & 18 & 45 & \\
\hline Hirȳ̄ & 9 & 18 & 17 & 44 & \\
\hline
\end{tabular}

3. Weather reconnaissance and armament

(1) The scheduled time for the weather reconnaissance plane of the 8th Cruiser Division to reach the foremost [reconnaissance] point shall be set at 0600 .

(2) The carrier-based attack planes shall carry $800-\mathrm{kg}$ bombs.

4. The status of the friendly forces (scheduled for the 19th)

(1) Land-based attack plane units shall carry out air strikes on the Port Darwin airfield at 1130.

(2) Large flying boats shall search for the enemy in the Arafura and the Timor Seas. 
5. The scheduled movements of the carrier group (after the takeoff of the aircraft)

(1) In case of northwesterly winds: set course to $90^{\circ}$ [E] and change course to $300^{\circ}$ [NW]after two hours.

(2) In case of northeasterly winds: set course to $270^{\circ}[\mathrm{W}]$ and change course to $60^{\circ}$ [ENE] after two hours.

(3) In case of southwesterly winds: set course to $60^{\circ}$ [ENE] and change course to $240^{\circ}$ [ESE] after three hours.

(4) In case of southeasterly winds: set course to $330^{\circ}$ [NNW] and change course to $130^{\circ}$ [SE] after two hours.

(5) In whichever case, [the carriers] shall sail at a speed of 20 knots. However, for take off and landing of aircraft, their course may be shifted slightly upwind.

[An antiaircraft] guard in the air over the carriers shall be instituted prior to the take off of the attack units and continued by and large until sunset.

\section{The Destruction of Port Darwin}

On the early morning of the 19th, the scout seaplane of the Toné took off and reached the foremost [reconnaissance] point at 0600 for a weather reconnaissance, but could not make radio contact due to trouble with its radio set. At 0825 after its return, it reported that the weather was suitable. ${ }^{(143)}$ However, before that, Carrier Task Force Commander Vice Admiral Nagumo had already judged the weather to be suitable and issued the order to strike Port Darwin. First of all at 0615, three Type-0 fighter planes of the Akagi to provide an [antiaircraft] guard in the air took off and took up positions. (Although the guard was provided by a total of fifteen aircraft in five shifts until 1735, no enemy was spotted.) ${ }^{(71)}$ At 0622, the Type-97 carrier-based attack plane of the Akagi carrying Commander Fuchida, commander of the attack plane unit, took off. The aircraft units of all carriers took off one after another and formed formations above the Carrier Task Force. At 0700, the aircraft with the commander on board flew over the flagship and headed to attack Port Darwin. ${ }^{(71)}$ At 0745, the aircraft units deployed for the attack over Melville Island and in full force went on to the attack at 0810; they completed the strike a little after 0900, returned and were recovered by the mother ships by 1212. The military gains and losses reported were as follows: ${ }^{(71)}$

1. The carrier-based attack plane units of the Akagi ([led by] Cdr. Fuchida Mitsuo)

First Sqdn (nine carrier-based attack planes): Bombed and seriously damaged the railway pier and two merchantmen on both sides of it; no damage was sustained.

Second Sqdn (nine carrier-based attack planes): Bombed a large merchantman and scored a near hit at the bow; no damage was sustained [by the Japanese side].

2. The carrier-based bomber units of the Akagi ([led by] Lt. Chihaya Takehiko)

First Sqdn (nine carrier-based bombers): Inflicted some damage to a destroyer and minor damage to a merchantman; no damage was sustained.

Second Sqdn (nine carrier-based bombers): Inflicted serious damage to two merchantmen, which were set ablaze, and some damage to another; one aircraft was marked by bullets.

3. The carrier-based fighter plane unit of the Akagi (nine carrier-based fighter planes [led by] Lt. Cdr. Itaya Shigeru)

Shot down four enemy fighter planes in an air engagement and set four [enemy] bombers [on the ground] ablaze and destroyed another four [on the ground] by strafing; three aircraft were marked by bullets.

4. The carrier-based attack plane units of the Kaga ([led by] Lt. Cdr. Hashiguchi Takashi) 
First Sqdn (nine carrier-based attack planes): Scored all direct hits on virtually the whole administrative district; seven aircraft were marked by bullets.

Second Sqdn (nine carrier-based attack planes): Scored all direct hits on the [enemy] Navy headquarters and the southeastern side of the administrative district; no damage was sustained.

Third Sqdn (nine carrier-based attack planes): Scored one hit at the stern of a merchantman and another hit at the railway pier. The direct hits caused serious damage; the squadron [also] sank two small merchantmen by near hits; no damage was sustained.

5. The carrier-based bomber units of the Kaga ([led by] Lt. Ogawa Shōichi)

First Sqdn (nine carrier-based bombers): Bombed the east airfield, blew up two hangars and set them ablaze; bombed the west airfield, blew up the hangar[s] and barrack[s] and set them ablaze; strafed a barrack and [a] radio direction locator station; one aircraft crashed itself and another was marked by bullets.

Second Sqdn (nine carrier-based bombers): Bombed one 5,000t-class merchantman and set her ablaze, sank another, and strafed one armored car and set it ablaze; five aircraft were marked by bullets.

6. The carrier-based fighter plane unit of the Kaga (nine carrier-based fighter planes [led by] Lt. Nikaidō Yasushi)

Shot down four [enemy] fighter planes and one flying boat in an air engagement, strafed one [enemy] flying boat and set it ablaze; four aircraft were marked by bullets.

7. The carrier-based attack plane units of the Sōry $\bar{u}$ ([led by] Lt. Abe Heijirō)

First Sqdn (six carrier-based attack planes): Bombed a large merchantman, with little result; three aircraft were marked by bullets.

Second Sqdn (six carrier-based attack planes): Bombed two large merchantmen, with little result; one aircraft was marked by bullets.

Third Sqdn (six carrier-based attack planes): Bombed barrack[s], with enormous result; no damage was sustained.

8. The carrier-based bomber units of the Sōryū ([led by] Lt. Cdr. Egusa Takashige)

First Sqdn (nine carrier-based bombers): Instantly sank one destroyer, set ablaze another and one mid-sized merchantman as well as heavy oil tank[s]; six aircraft were marked by bullets.

Second Sqdn (nine carrier-based bombers): Set one oiler and one flying boat ablaze; strafed a gunboat, barrack[s] and others; one [Japanese] aircraft sank during an emergency landing on the water (the crew were rescued) and four aircraft were marked by bullets.

9. The carrier-based fighter plane unit of the $S \bar{o} r y \bar{u}$ (nine carrier-based fighter planes [led by] Sublieutenant Fujita Iyozō)

Directly covered the attack units, strafed one auxiliary cruiser and reduced her speed.

10. The carrier-based attack plane units of the Hiry $\bar{u}$ ([led by] Lt. Cdr. Kusumi Masashi)

First Sqdn (nine carrier-based attack planes): Bombed one 10,000t-class cargo ship, set her ablaze; positive to have sunk her.

Second Sqdn (nine carrier-based attack planes): Bombed one 10,000t-class oiler, set her ablaze; positive to have sunk her.

A total of four aircraft of the 1st and the $2 \mathrm{~d}$ Squadrons were marked by bullets.

11. The carrier-based bomber units of the Hiry $\bar{u}$ (eighteen carrier-based bombers [led by] Lt. Kobayashi Michio)

Sank one 10,000t-class and one 7,000t-class merchantman, seriously damaged one class-B cruiser and inflicted considerable damage to one 7,000t-class and one mid-sized merchantman; two aircraft were marked by bullets.

12. The carrier-based fighter plane unit of the Hiryū ([led by] Lt. Nōno Sumio )

Shot down one [enemy] fighter plane in an air engagement, seriously damaged two large and two small aircraft [on the ground] by strafing, set ablaze three large and three small planes and two flying boats; one aircraft crashed itself and seven were marked by bullets. 


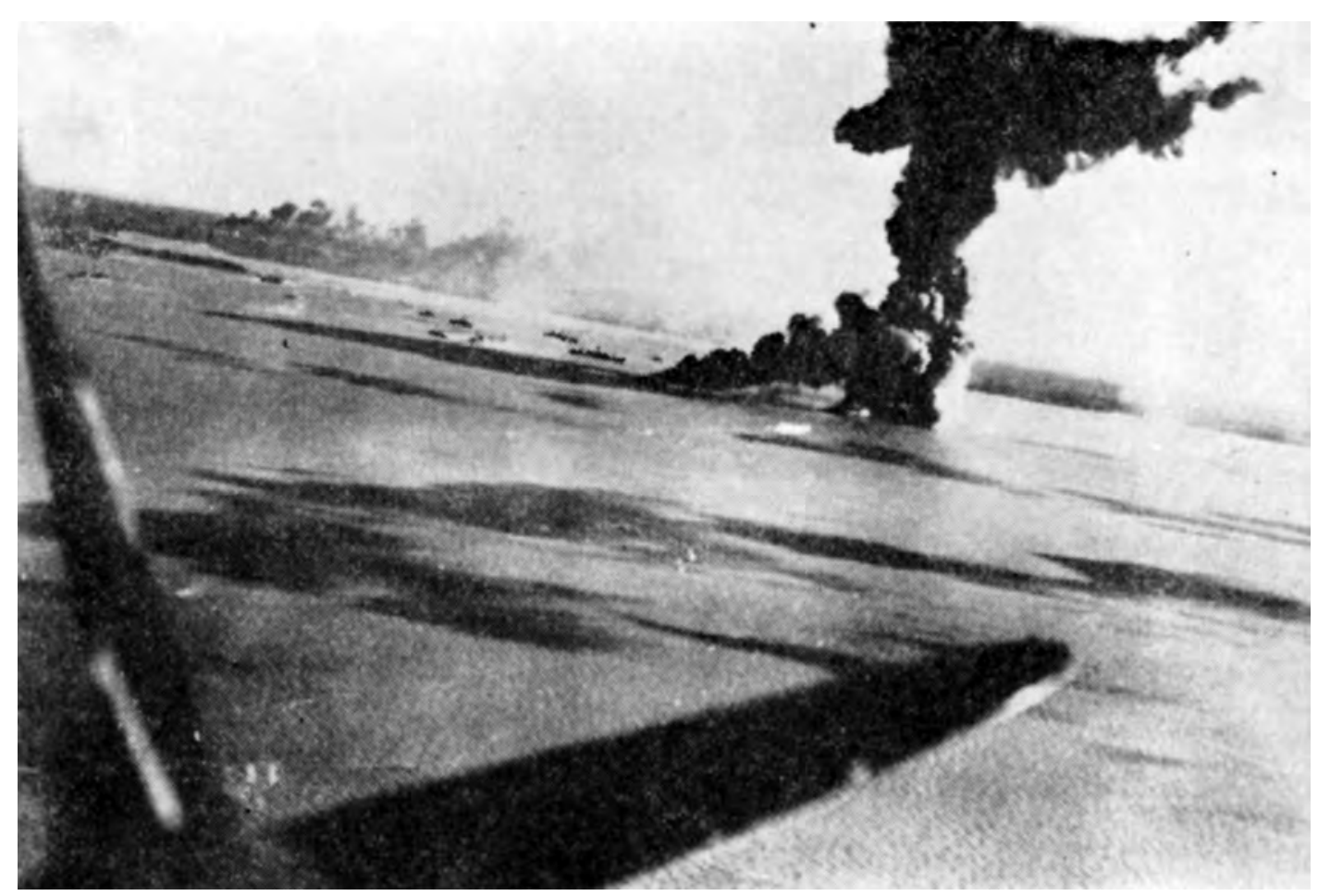

The Bombing of Port Darwin

As for the land-based air units, one land-based reconnaissance plane reconnoitered Port Darwin at 1010, which was followed by twenty-seven land-based attack planes of the Kanoya Air Group and twenty-seven land-based attack planes of the 1st Air Group, which raided Port Darwin and bombed the east airfield at 1037 and 1040. The unit reported as military gains that all bombs had hit the airfield facilities as well as the runways, engulfing one large hangar on the south side, two small hangars and neighboring facilities in a huge fire (the large hangar on the north side was already on fire), while setting two large planes ablaze, and seriously damaging one mid-sized and four small planes. One aircraft was marked by bullets. ${ }^{(81)}$

At 1005, aircraft of the Akagi returning from Port Darwin spotted one 6,000t-class auxiliary cruiser about 100 nautical miles north of Port Darwin. Carrier Task Force Commander Vice Admiral Nagumo immediately ordered the 8th Cruiser Division to probe the enemy, while ordering the $2 \mathrm{~d}$ Carrier Division to attack her. On receiving the [returning] units of the first attack, 2d Carrier Division Commander Rear Admiral Yamaguchi promptly prepared for a second attack, and the second attack units (consisting of nine carrier-based bombers each of the Sōryū and the Hiryū) took off at 1306. At 1406, [a] scout seaplane of the Toné reported that the location of the [enemy] auxiliary cruiser was 30 nautical miles $10^{\circ}[\mathrm{N}]$ of Cape Fourcroy [and that she was sailing] on a $200^{\circ}$ [SSW] course at a speed of 18 knots. From 1456 to 1512, the carrier-based bomber unit of the Sōryu strafed and bombed the enemy about 10 nautical miles $0^{\circ}[\mathrm{N}]$ of [Cape] Fourcroy, scored three direct hits with $250 \mathrm{~kg}$ bombs and rendered her unable to sail, while the carrier-based bomber unit of the Hiry ù spotted one 1,000t-class merchantman at 32 nautical miles $350^{\circ}$ [NNW] of Cape Fourcroy at 1456, attacked and reported 


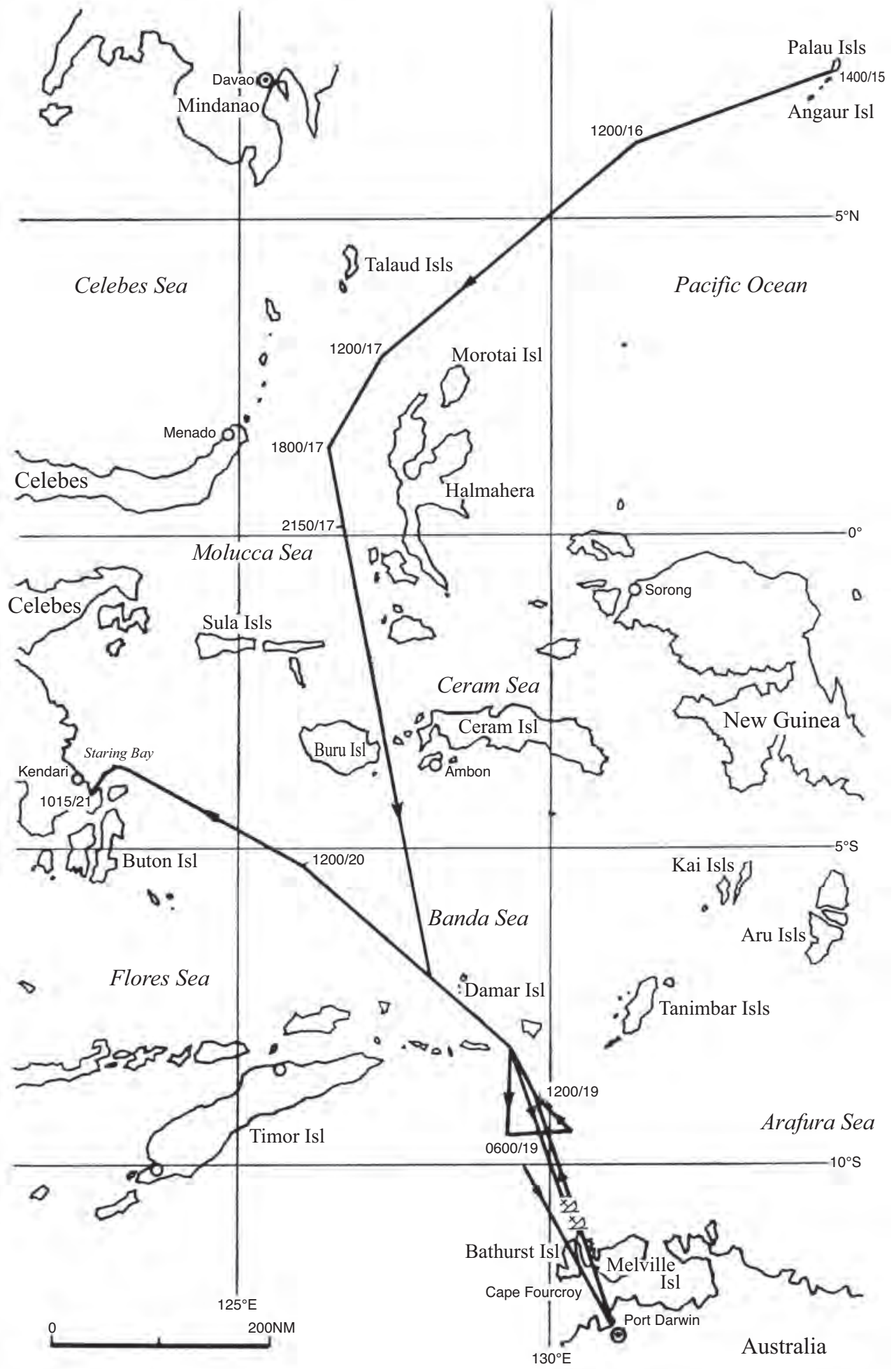

Illustration No. 37 - The Operations of the Carrier Task Force in the Air Strike on Port Darwin (15-21 February, 1942) 
to have sunk her. The loss sustained by Japanese forces was one aircraft that was marked by bullets; all aircraft returned at $1700 .^{(71,141)}$

At 2430 on the 19th, the Carrier Task Force commander reported the military gains in his Summary Report of the Actions No. 5 as follows. ${ }^{(141)}$

1. After having reconnoitered the weather with a scout seaplane of the 8th Cruiser Division, we carried out [the operation] to attack Darwin at 0830 on the 19th as scheduled.

At 0825 , we were spotted by an enemy twin-engine flying boat; we pursued it but let it slip away to the south.

2. The military gains

(a) One large and ten small [enemy] aircraft were shot down, four large and three small planes and three flying boats were strafed and set ablaze, and two large and three small planes were strafed and destroyed, amounting to twenty-six aircraft (all on site)

(b) Eight transport ships, two destroyers, and one submarine chaser were sunk. One destroyer was seriously damaged. Other than the above, one hospital ship and some small boats were spotted but they were not attacked. No aircraft carriers or submarines were spotted inside the bay.

(c) As for ground facilities, all (three) hangars on both the east and west airfields and one barrack were set ablaze. The buildings in the neighborhood of the administrative district and the Navy headquarters as well as the mooring pier were bombed and destroyed. [Also,] barrack[s] at the northeastern end of the urban area were bombed and set ablaze.

(d) The carrier-based bombers of the $2 \mathrm{~d}$ Carrier Division (eighteen bombers) and a scout seaplane of the 8th Cruiser Division carried out the second attack on one 6,000t-class auxiliary cruiser and one 1,000t-class transport ship, which were fleeing on the waters north of Cape Fourcroy at 1500; they sank the transport ship and crippled the auxiliary cruiser. (Since three No. 25 normal bombs directly hit the latter and caused a fire, it was assumed that she must have sunk later.)

3. Losses

One carrier-based bomber of the Kaga and one carrier-based fighter plane of the Hiry $\bar{u}$ crashed themselves and met a heroic end.

4. Remarks

(a) The enemy hardly has a will to fight.

(b) Except for the fire directed at the previously mentioned aircraft that crashed themselves, [the level] of the [enemy] antiaircraft fire cannot be considered particularly superior, [considering that only] a few aircraft were marked by bullets while conducting horizontal bombing runs at an altitude of 3,000 meters.

5. During this operation, at 0930 on the 17 th, one submerged [enemy] submarine was spotted at $2^{\circ} 30^{\prime} \mathrm{N} 127^{\circ} 26^{\prime} \mathrm{E}$ and neutralized.

Note by the author: [S.W.] Roskill states in The War at Sea that "great damage was done to the port and to the shipping in it."

In the meantime on that day [the 19th], large flying boat[s] of the Tōkō Air Group, which were searching for the enemy in the western part of the Arafura Sea and the eastern part of the Timor Sea, spotted one (Canberra-class) cruiser at a point sixty-three nautical miles $247^{\circ}$ [WSW] of Port Darwin. However, this naval vessel was lucky to avoid an attack, because she was a little out of the maximum attack range of the carrier-based planes and because she was spotted after the land-based attack planes' attack on Port Darwin. ${ }^{(141)}$

The Carrier Task Force completed the operation and headed for Staring Bay as scheduled, and at 1015 on 21 February, it safely put in at the bay. ${ }^{(141)}$ 


\section{The Capture of Timor (See Illustrations No. 38 and No. 39)}

\section{The State of Affairs up to the Capture [Operation]}

\section{The Invasion Schedule and the Units Involved}

In the Tokyo Agreement concluded on 10 November 1941, it was stipulated that the [operation to] capture Kupang should be executed by around Day X + 60 (6 February) following the [operation to] capture Ambon. Then, in the conference at Cam Ranh Bay on 29 December [1941], it was decided that the Ambon and Kupang operations should be carried out in parallel with the Makassar Strait and the east of Celebes lines of operation, constituting three lines of operation. Accordingly, the capture [operation] was fixed on Day X+65 (11 February). However (as described previously [p. 99]), partly due to the Navy's wish to capture Kupang before Makassar, in the plan of operations of the Dutch East Indies Unit announced on 29 December ([and] revised by about 5 or 6 January), it was decided that the capture [of Kupang] should be carried out on Day X + 59 (5 February).

As for the units to be employed in the capture, it was decided that the Army should divert the Itō Detachment ([consisting of] three battalions of the 38th Division as the core) from Hong Kong, while the Navy was supposed to add minesweepers and submarine chaser[s] of the 1st Base Force to the main force of the 2d Destroyer Squadron as the escort force. Also, the Eleventh Air Fleet planned to advance to this area the necessary strength of land-based attack planes and fighter planes. Further, it was decided that the 9th Construction Squad, which was to be newly organized on 15 January, should be employed.

After that, in connection with the delay in the Menado and the Kendari operations, the [operation to] capture Ambon was postponed (for six days) to 31 January, and along with that the [operation to] capture Kupang was postponed to Day X +74 (20 February) at the Manila Conference of 22 January. ${ }^{(53)}$ Meanwhile, earlier on 16 January, the $3 \mathrm{~d}$ Yokosuka Special Landing Force (a paratrooper unit) had advanced to Tarakan to be dropped on Balikpapan, but the operation was hindered by the delay in the preparation of the airfield, leaving them on standby in Tarakan. On 27 January, as a result of a discussion between the air unit of the Southern Task Force and the Dutch East Indies Unit, it was decided that the force should be employed for the Kupang operation. ${ }^{(67)}$ Because of this [change], the employment of one element of the 1st Kure Special Landing Force, scheduled to be dispatched from Ambon to capture Kupang, was called off; instead, it was decided that one element of the Sasebo Combined Special Landing Force (two platoons) and another small element of the $3 \mathrm{~d}$ Yokosuka Special Landing Force (which does not conduct paradrop operations) should participate in the [Kupang] operation from Makassar. ${ }^{(53)}$

\section{The Issue of Invading Portuguese Timor}

In relation to the Kupang operation, the decision of how to deal with Portuguese Timor, a third country, was one of the issues in conducting the war. In the beginning of January 1942, intelligence was received that an element of Dutch East Indian and Australian troops had invaded the Dili area of Portuguese Timor, ${ }^{(34)}$ and this became a serious problem for Tokyo as the Kupang operation was drawing near. It was on 20 January that the issue was taken up at the Liaison Conference between IGHQ and the Government for the first time, ${ }^{(41)}$ and at the next conference on the 28th, Prime Minister Tōjō and Chief of Navy General Staff Nagano 
sharply differed in opinion on the issue and could not reach agreement. ${ }^{*}$ Prime Minister Tōjō maintained that as long as the enemy troops are deployed in Dili, it is only natural to mop them up, but that Japanese troops should be promptly withdrawn from the [Portuguese] territory, once they had mopped up the enemy in the city, whereas Chief of Navy General Staff Nagano maintained that the withdrawal of our troops from Portuguese Timor should depend on the attitude of the Portuguese as well as the circumstances at the time. ${ }^{(1,41,144)}$ Taking into account that in a prolonged war in the future, Dili would be an important operational base for neutralizing Australia, the chief of Navy General Staff could not easily approve a withdrawal [of Japanese forces]. In the end, at the liaison conference on 2 February, a compromise plan was agreed on: "After mopping up the British, Dutch and Australian forces on Portuguese territory, the Imperial [Japanese] forces shall withdraw from the area concerned, as long as Portugal ensures the neutrality [of the territory]. However, if it is unavoidable in terms of the attitude of the Portuguese and the other circumstances of the entire operation, the [Japanese forces] can continue to use [the place] as a base for operations."(144)

Earlier on 5 January, at the same time as issuing an order to the Sixteenth Army to capture Ambon and Kupang, the Southern Army headquarters had sent a telegram to [the Army Department of] IGHQ that they would like to receive as soon as possible actual proof that the enemy forces were using Portuguese Timor, ${ }^{(34)}$ but they had been left without a reply. However, all of a sudden on 4 February, the Southern Army headquarters received an advisory telegram from the Navy, which read: "In view of the present situation where both Australian and Dutch East Indies forces have occupied Portuguese Timor, we would like, at the time of [the operation to] capture Timor, to have an element of the Itō Detachment go ashore in Dili (under the escort of the Navy) almost simultaneously with the landing in Kupang and seize the vicinity." The Southern Army promptly wired central [command] requesting directives. ${ }^{(34)}$

On 7 February, both the Navy and the Army Departments of IGHQ issued orders concerning the capture of Kupang and Dili. ${ }^{(42,43,145,146)}$ This order stated that unless Portugal took hostile action, [both forces] were supposed to respect the sovereignty [of Portuguese Timor] as much as possible. On 7 February, having received the Imperial Order concerning the capture of Kupang and Dili, the Southern Army for the first time confirmed the policy of central [command] and, on the same day, wired a reply to the Southern Task Force approving the advisory telegram of 4 February. ${ }^{(34)}$ Accordingly, on 9 February, Southern Task Force Commander Vice Admiral Kondō issued an order to seize Dili. Earlier, from around 5 February, Dutch East Indies Unit Commander Vice Admiral Takahashi had started preliminary negotiations with Sixteenth Army Commander Lieutenant General Imamura. On 7 February, he sent an official advisory telegram and by the [Sixteenth Army's] telegram of approval of 11 February, the arrangement between them was officially concluded. The arrangement read in outline as follows: ${ }^{(24)}$

1. Almost simultaneously with [the operation to] seize Kupang, one element of the Itō Detachment (for which adequate escort shall be provided) shall be put ashore in Dili and vicinity in Portuguese territory in order to seize the city (with seizing the airfield as the main purpose).

2. Depending on the situation after seizing Kupang, the Itō Detachment shall seize the Kolbano airfield overland and make it ready for use.

Details shall be decided after consultation between Detachment Commander Itō and the $2 \mathrm{~d}$ Destroyer Squadron commander.

* See also Vol. 3, p. 381. 
Since the particulars concerning the seizure of Dili as well as the official text of the arrangements with Sixteenth Army Commander Lieutenant General Imamura had been decided, Dutch East Indies Unit Commander Vice Admiral Takahashi sent on the same day, the 11th, the following communication to Rear Admiral Takagi, commander of the Eastern Attack Unit, who was supposed to implement the operation: ${ }^{(54)}$

Third Fleet Classified Telegram No. 271 [at] 1500 on the 11th

Concerning the landing and occupation of Dili, it is requested that arrangements in line with the following main points be made with [Army] Detachment Commander Itō and the 21st Air Flotilla before they are carried out:

1. Summary of the Policy of the Government in [Navy Ministry] Secretariat Classified Telegram No. 146 (brought and explained by Staff Officer Koseki)

(a) In order to secure air base[s] and prospective base[s] of operations, [the invasion] shall be conducted for the purpose of clearing the British, Australian and Dutch forces [from the territory] and shall be carried out, while trying not to make an enemy of the Portuguese forces. Therefore, before entering [Portuguese territory], various parts of the territory shall be reconnoitered, and the use of airfield[s] and the requisitioning of buildings shall take the form of obtaining approval of the Portuguese [authorities] beforehand, unless the Portuguese units become hostile toward us.

(b) At or after 0800 on the 20th, the Government will give the necessary notifications to the Portuguese.

2. The main points of the arrangements

(a) [The invasion unit] shall advance to Dili and vicinity before dawn on the 20th and disembark. The landing points shall be selected in such a way that visual identification of friend or foe from the air will be easy. It will be better to avoid the front of Dili as much as possible and appropriately land at a more distant place.

Metinaro, ten nautical miles west ${ }^{*}$ of Dili or Aipelo to the west of Dili seem to be suitable [landing points].

(b) [The invasion unit] shall advance on Dili by and large after dawn while friendly aircraft keep watch in the air. Simultaneously, handbills (to the effect that the purpose of our forces is to clear the British, Australian and Dutch forces [from the territory], and that the Portuguese forces should avoid hostilities [against us]) shall be dropped from the air.

(c) After that, depending on the enemy movements, reinforcements shall be brought in and the ground units shall be covered and supported from the sea.

(d) Concerning the preliminary air reconnaissance over the landing points, arrangements with the air unit must be made as soon as possible.

(e) The construction squad to be employed for the Dili operation shall be designated later.

At the same time, Dutch East Indies Commander Vice Admiral Takahashi issued the order to seize Kupang and Dili to 2d Escort Unit Commander Rear Admiral Tanaka, which was in outline as follows: ${ }^{(54)}$

1. The schedule of the operation to capture the Dutch East Indies shall be changed as follows:

(1) Batavia and Surabaya: 26 February

(2) Kupang and Dili: 20 February

* Actually east of Dili 
(3) Bali: 18 February (as scheduled)

2. The 2d Escort Unit shall escort one element of the Itō Detachment to Dili by 20 February with one element. It shall also make arrangements with Detachment Commander Itō concerning [the operation to] seize the Kolbano airfield.

At the same time, Dutch East Indies Unit Commander Vice Admiral Takahashi informed Tokyo that no naval special landing forces would be employed in the invasion operation against Dili and that it would be alright if the Government's notification would be given to the Portuguese side at or after 0800 on the 20th. ${ }^{(54)}$ Also, it was decided that one element of the 1st Construction Squad ([currently in] Kendari) would be employed for Dili. ${ }^{(78)}$

\section{The Issue of Which Forces to Assign to the Invasion of Timor}

\section{The Participation of the 1st Patrol Boat Division}

In view of the Ambon operation, the necessity of being able to conduct small-scale minesweeping operations with shallow-draft large-sized motorized [landing] craft was keenly felt, which led to the decision that the small-scale minesweeping unit ([consisting of] four large-sized motorized [landing] craft loaded [on the vessels of] the 1st Patrol Boat Division and specially-assigned minesweeping personnel) that had been organized in the Makassar operation should be brought in. [Accordingly, it was decided to incorporate the 1st Patrol Boat Division into the 2d Escort Unit and put the specially assigned personnel (who belonged to the 1st Base Force) onto the patrol boats. Second Destroyer Squadron Commander Tanaka had also requested an increase in the number of minesweepers, but this was not realized due to a lack of available forces. ${ }^{(54)}$

2. The Assignment of the 7th Destroyer Division (three destroyers)

As of 30 January, the 7th Destroyer Division, which had been assigned to the carrier air unit and advanced to Palau, was transferred to the Eastern Attack Unit, where the 1st Section was incorporated into the $2 \mathrm{~d}$ Escort Unit to engage in the Ambon operation, while the $2 \mathrm{~d}$ Section accompanied the 5th Cruiser Division and became [part of] the Support Unit. However, along with the decision to commit the Carrier Task Force to the southern theater, the Combined Fleet [also] issued an order to the $2 \mathrm{~d}$ Carrier Division and the 7th Destroyer Division to return to the Carrier Task Force as of 10 February. Regarding this [order], Eastern Attack Unit Commander Rear Admiral Takagi and 2d Destroyer Squadron Commander Rear Admiral Tanaka strongly requested that the 7th Destroyer Division should stay, which was finally confirmed on the 12th. ${ }^{(54)}$

3. The Issue of the Participation of the Seaplane Tenders

As of 9 February, the deployment of the seaplane tender force of the Dutch East Indies Unit was envisioned in the following way: ${ }^{(54)}$

The Chitose: Shall directly cover the eastern Java invasion unit from Jolo.

The Mizuho: Shall engage in the service of aircraft at Staring bay; therefore it is all right if she cannot be employed for the invasion operation against eastern Java.

The Sanuki-maru: Crippled and remains at Balikpapan; her aircraft units shall advance to Makassar and support the Bali invasion operation as well as the eastern Java invasion units.

The Kamikawa-maru and the San'yo-maru: Shall directly cover the western Java invasion units from Cam Ranh Bay. 
Therefore, no seaplane tenders were available for the Timor operation. Concerned about this, 21st Air Flotilla Commander Rear Admiral Tada requested the air unit commander that since it would be difficult to securely provide the invasion units with patrols against enemy aircraft or submarines, or with support for the land combats from the Kendari base, which was 385 nautical miles away, the 11th Seaplane Tender Division should cooperate in the operation. The $2 \mathrm{~d}$ Destroyer Squadron commander also strongly requested it of the Dutch East Indies Unit. On 11 February, Dutch East Indies Commander Vice Admiral Takahashi sent a telegram to the 11th Seaplane Tender Division to the effect that there was a possibility that the Mizuho might be made to support the Timor operation for a while prior to the Surabaya operation. ${ }^{\text {(78) }}$ After that, on the 16th, it was decided that the Mizuho and Patrol Boat No. 39 should be incorporated into the $2 \mathrm{~d}$ Escort Unit, while the aircraft unit of the Sanuki-maru, Patrol Boat No. 36 and two fishing boats should be incorporated into the $2 \mathrm{~d}$ Air Unit. ${ }^{(54)}$

\section{The Plan of Operations}

\section{Plan of Operations of the Eastern Attack Unit}

Eastern Attack Unit Commander Rear Admiral Takagi successively issued his orders concerning the operation to capture Timor, which were, as of 16 February (and launched as of the 17th), in summary as follows: ${ }^{(78)}$

1. Forces to be employed and their distribution

\begin{tabular}{|c|c|c|c|c|}
\hline \multicolumn{2}{|r|}{ Unit } & \multicolumn{2}{|r|}{ Commander } & Forces \\
\hline \multirow[b]{2}{*}{ 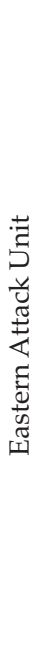 } & Support Unit & \multirow[b]{2}{*}{ 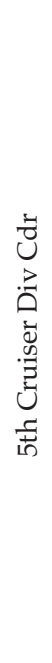 } & & $\begin{array}{l}\text { 5th Cruiser Div (minus the } \\
\text { Myōkō), the Akebono and the } \\
\text { Ikazuchi }\end{array}$ \\
\hline & 2d Escort Unit & & 2d Destroyer Sqdn Cdr & $\begin{array}{l}\text { The Jints } \bar{u} \text {, the 16th Destroyer } \\
\text { Div, the 15th Destroyer Div } \\
\text { (minus the Natsushio), the 7th } \\
\text { Destroyer Div 1st Section, the } \\
\text { 21st Minesweeper Div ([only] } \\
\text { Minesweepers Nos. } 7 \text { and 8), } \\
\text { Patrol Boats Nos. } 1 \text { and 2, two } \\
\text { plts of the Sasebo Combined } \\
\text { SLF, the Mizuho, Patrol Boat } \\
\text { No. 39, } 4 \text { naval transport } \\
\text { ships ([with] the 1st Construc- } \\
\text { tion Squad and one element } \\
\text { of 3d Yokosuka SLF [on } \\
\text { board]) }\end{array}$ \\
\hline
\end{tabular}

2. Supporting friendly forces

(1) The 1001 Unit ([i.e.] the 3d Yokosuka Special Landing Force) of the Eleventh Air Fleet, fighter plane units and land-based attack plane units

(2) The Army Itō Detachment ([consisting of] three infantry battalions as the core) in five transport ships

3. Tasks 
(1) In cooperation with the Army Itō Detachment and the 1001 Unit of the Eleventh Air fleet, the unit shall seize Kupang and the vicinity and secure the Kupang airfield.

(2) In cooperation with the Army Itō Detachment, the unit shall carry out a sudden attack to seize Dili ([in] Portuguese Timor) as well as occupy and secure the airfield there.

(3) On top of the support for the above operations, the support unit shall also provide cover in the first carrier operation to be conducted by the carrier operation unit.

4. Outline of the operation

(1) The Support Unit

$\{1\}$ The 5th Cruiser Division (minus the Myōkō) and the Akebono shall leave Staring Bay at 1500 on 17 February. After approaching the 1st Echelon of the 2d Escort Unit on the morning of the 18th, [the unit] shall change course eastward. At night on the 18th, about 30 nautical miles north of Romang Island, it shall turn northward, and about 110 nautical miles north of the island again change course westward. After approaching the $2 \mathrm{~d}$ Echelon on the morning of the 19th, [the unit] shall [further] sail westward and, at night on the 19th, it shall operate around the area to the north of the Alor Strait. Thereafter, it shall appropriately operate, depending on the enemy movements.

\{2\} The Ikazuchi shall replenish in Staring Bay on the 18th and join [the unit] at 38 nautical miles $145^{\circ}$ [SE] of Maromaho at 1100 on the 19th.

(2) The 2d Escort Unit

On top of [sailing along] the invasion route designated in Third Fleet Classified Telegram No. 199 (note: the route between Kambing and the Alor Islands), [the unit shall operate] as designated by the commander.

5. The operations of the Carrier Task Force and the air unit

On the morning of 19 February, a day prior to the invasion of Timor, our Carrier Task Force shall conduct a surprise attack on enemy air power and naval vessels in Port Darwin as well as on facilities situated there. Also, the air unit shall, in concert with this operation, attack Port Darwin from the Ambon and Kendari bases.

\section{The Arrangements Between the 2d Escort Unit and the [Army] Itō Detachment}

In accordance with the Dutch East Indies Unit Order of 11 February and the instructions from the Third Fleet chief of staff, 2d Escort Unit Commander Rear Admiral Tanaka made arrangements with Detachment Commander Itō on 14 February at Ambon, which were in summary as follows: ${ }^{(54)}$

1. The distribution of the transport convoy

(1) The 1st Echelon: the units [to seize] the Kupang area

(2) The 2d Echelon: the units [to seize] the Dili area

2. The invasion forces

(1) Army

\{1\} The Kupang Area: the Itō Detachment (commander: Major General Itō): the 38th Infantry Group headquarters, two infantry battalions and one mountain artillery battalion as the core

\{2\} The Dili Area: One element of the Itō Detachment, [that is] one infantry battalion as the core

(2) Navy

\{1\} The Kupang Area: One battalion of the 3d Yokosuka Special Landing Force (the main force shall parachute down, while the other element shall make a seaborne landing) and two platoons of the Sasebo Combined Special Landing Force

3. The assembly points, times and dates of departure, landing points, times to start landing, etc. 


\begin{tabular}{|c|c|c|c|c|c|}
\hline Landing areas & $\begin{array}{c}\text { Time to leave } \\
\text { the assembly } \\
\text { points }\end{array}$ & $\begin{array}{l}\text { Time to enter } \\
\text { the anchorages }\end{array}$ & $\begin{array}{l}\text { Time to launch } \\
\text { the landings } \\
\text { (time to leave } \\
\text { the [mother] } \\
\text { ships) }\end{array}$ & Landing points & Remarks \\
\hline $\begin{array}{l}\text { Kupang area } \\
\text { (1st Echelon) }\end{array}$ & $\begin{array}{c}0500 \\
\text { on } 17 \text { February }\end{array}$ & $\begin{array}{c}0100 \\
\text { on } 20 \text { February }\end{array}$ & $\begin{array}{c}0300 \\
\text { on } 20 \text { February }\end{array}$ & $\begin{array}{l}\text { Army forces: } \\
\text { coast east and } \\
\text { west of Cape } \\
\text { Mali } \\
\text { Navy SLFs: } \\
\text { coast east of } \\
\text { Cape Mali }\end{array}$ & $\begin{array}{l}\text { After disem- } \\
\text { barking combat } \\
\text { units, [the trans- } \\
\text { port ships] shall } \\
\text { change anchor- } \\
\text { age to the area } \\
\text { off Oilalus or to } \\
\text { the Semau Strait } \\
\text { to disembark the } \\
\text { remaining units. }\end{array}$ \\
\hline $\begin{array}{c}\text { Dili area } \\
\text { (2d Echelon) }\end{array}$ & $\begin{array}{c}0230 \\
\text { on } 18 \text { February }\end{array}$ & & & $\begin{array}{l}\text { Coast west of } \\
\text { Dili }\end{array}$ & \\
\hline
\end{tabular}

Each echelon shall change anchorage to the anchorage outside the Ambon port by 1700 on the day before the date of departure in the above.

4. The main points of the escort (omitted)

5. The entry into the anchorage and the cover of the landing [operation] etc. (omitted)

6. The movements of the transport ships after the landing (omitted)

\section{The Plan of Operations of the Other Units}

On 14 February at Ambon, 2d Escort Unit Commander Rear Admiral Tanaka disclosed the outline of the operation to seize Timor by means of $2 \mathrm{~d}$ Escort Unit Order No. 5. ${ }^{(54)}$ This order stated that the southern coast, which was considered to be weakly defended, was chosen as the landing point for Kupang, and that in tandem with the operation of the 1001 Unit, which would conduct a paradrop operation on an area near the northern coast, [the invasion unit] should capture Puton [Penfui] airfield as well as Kupang while cutting off the only road leading to the east.

Also, it stated that the units to capture Dili should first of all occupy an area along the coast west of Dili and try as best as they could not to provoke the [authorities of] Portuguese Timor, while appropriately operating in accordance with the course of the diplomatic negotiations. In the meantime, since the Mizuho and Patrol Boat No 39 had been incorporated in the $2 \mathrm{~d}$ Escort Unit as previously told, the commander formed the $2 \mathrm{~d}$ Escort Unit air unit and assigned the unit to guard the sailing route as well as the anchorage of the 1st Echelon against enemy aircraft and submarines, while providing support for the ground combat of the landing units. The captain of the Mizuho reported that his operation plan was to leave Kendari at 1400 on the 17th, [operate] on the waters near Binongko the whole day on the 18th, near the Alor Strait the whole day on the 19th, and near Maikuru [? Nai Kliu? Naibonat?] on the northwest coast of Timor around 0000 on the 20th, and after that operate depending on the weather conditions and the enemy movements. ${ }^{(54)}$

As for the land-based air unit, twenty-two large flying boats of the Tōkō Air Group had been advanced from Kema to Ambon from the 1st through the 10th of February, while nine- 
teen Type-0 fighter planes and two land-based reconnaissance planes of the $3 \mathrm{~d}$ Air Group had been advanced from Kendari to Ambon from the 4th through the 9th of February. ${ }^{(71,81)}$ Also, thirty-eight Type-96 land-based attack planes of the 1st Air Group had been advanced from the 7th through the 11th from Menado and Kendari to Ambon, which was followed by 1st Air Raid Unit Commander Rear Admiral Tada, who advanced to Ambon from Kendari on 12 February to direct the Timor operation. ${ }^{(75)}$

The plan was that the land-based air unit should carry out attacks on enemy air power and military facilities in the area, as well as search for and attack enemy naval vessels in the Arafura and the Timor Seas, while [also] providing support to the Carrier Task Force during the first carrier operation and providing direct escort in the air against enemy aircraft for the [Timor] convoy. The plan also included dropping the paratrooper unit at a point twelve kilometers northeast of the Kupang airfield and, in conjunction with the Army Itō Detachment, having the unit capture Kupang and vicinity and secure the airfield.

\section{The Launch of the Operation}

\section{Prior Neutralization of the [Enemy] Air Power ${ }^{(71,81)}$}

The air unit, which on 25 January had advanced to Kendari (seized on the 24th), launched a strike on Kupang with fighter planes as early as on the 26th and gradually intensified the air strikes, virtually neutralizing the Kupang airfield by the end of January. Thereafter, following the advance of airplane units to Ambon, the search and attack missions in the [Kupang] area were further intensified, but the enemy was barely seen; even in reconnaissance attacks in western New Guinea on 9 February, no enemy aircraft were spotted. In the meantime (as previously told), a large number of [enemy] naval vessels and aircraft were spotted in a reconnaissance over Port Darwin by a land-based reconnaissance plane of the $3 \mathrm{~d}$ Air Group on the 10th. No enemy aircraft was spotted in a reconnaissance over the Dili area on the 11th ([conducted by] one land-based attack plane of the Kanoya Air Group).

Since then, reconnaissance attacks had been carried out day in and day out in the Kupang and Dili areas. However, only several merchantmen but no enemy aircraft were spotted. During this period, as mentioned previously, an enemy convoy ([consisting of] one heavy cruiser, three destroyers, three large and one mid-sized transport ships) was spotted to the west of Port Darwin on the 15th and the 16th, and attacks were carried out with ten large flying boats as well as thirty-five land-based attack planes of the 1st Air Group. However, they reported of having only seriously damaged three large transport ships (one of which had confirmedly sunk). The accurate shooting of the enemy heavy cruiser on the contrary had inflicted damage on twelve aircraft, which were marked by bullets, and seriously injured two men and one slightly.

According to the Dai-ichi Kūshū Butai Sentō Gaihō (Summary Action Report of the 1st Air Raid Unit), the circumstances of this attack were as follows, with special attention paid to the skillful evasive actions and the accurate antiaircraft fire of the enemy: ${ }^{(81)}$

1. At 0400 [on the 16th], four large flying boats of the Tōkō Air Group took off to search for enemy transport convoys and, at 0830, one of them spotted a convoy [consisting of] one U.S. large (Chester-class) cruiser, one large destroyer, two destroyers, three 8,000 ton or larger transport ships and one 6,000t-class transport ship, a total of eight vessels, at 570 nautical miles $193^{\circ}$ [S] 
of Lu (note by the author: Ambon). [The flying boat] appropriately and effectively kept on probing and guided the attack unit.

2. From 0630 onwards, thirty-five middle-sized land-based attack planes of the 1st Air Group and ten large flying boats of the Tōkō Air Group took off one after another and carried out a bombing attack on the enemy vessels from 1045 until about 1150 at an altitude of 3,500 to 4,500 [meters]. Although all four squadrons of the 1st Air Group bombed the enemy large cruiser in their first attack, no effective hit was scored due to her large high-speed (thirty knots) evasive actions. In the second attack, all squadrons carried out attacks on the transport ships; one squadron scored two direct hits with No. $6^{*}$ regular bombs and four effective near hits, which caused one ship to stop and list. (It is certain that she will sink.) Each of the other two squadrons scored two effective near hits with No. 6 bombs (four in total) at the large transport ships.

The Tōkō Air Group completed its bombing by 1150. When it was leaving the battle site after having scored several effective near hits, it spotted nearby one [enemy] large cruiser, which was evacuating at a speed of 30 knots on a $200^{\circ}$ [SSW] course, and two destroyers, which stayed with the transport ships. It also spotted that out of the three transport ships that had stopped, two were in flames and another was seriously damaged. Based on the above, it is certain that at least three transport ships had been seriously damaged. Detailed reports of the military gains will follow after examining the results from the detailed reports and the photos [to be] provided by the Tōkō Air Group.

3. The Kanoya Air Group Detachment had planned to search for the enemy with three aircraft and attack them with twenty-four aircraft, by having them take off after 0500 . However, due to the bad weather at the base and its vicinity, the takeoff [was delayed till] 1100 before the twentyseven aircraft [finally] took off to attack the enemy. Because of the frequent rain showers in the area where the enemy was expected to be at that time, they were in the end unable to spot the enemy.

4. Two Type-0 Fighter Planes of the 3d Air Group Detachment carried out a search and attack [mission] on the enemy air power on Halmahera and the surrounding areas, but did not spot the enemy.

5. Losses: Twelve mid-sized land-based attack planes of the 1st Air Group were marked by bullets, two men were seriously injured and one man slightly injured.

In the attacks today, while taking very skillful evasive actions, the enemy large cruiser delivered a very fierce, accurate and continual antiaircraft barrage as a Houston-class [cruiser] had done the other day.

Tomorrow, we shall further search for and attack this enemy.

Contrary to the accurate antiaircraft fire of the enemy, the bombing accuracy of the Japanese forces was rather poor. This was supposedly caused by a lack of adequate frontline bombing practice and also because of problems with the Japanese bombsights.

Note: Earlier, on 14 February, (a part of?) a Norden bombsight had been seized from a PBY flying boat at the Ambon Seaplane Base. This bombsight used a small gyrocompass to ensure that the bombsight would stay vertical, which enabled such an accurate bombing that effective [results] could be expected even in single aircraft bombings. On the other hand, we Japanese used [level] bubble bombsights that were poor in accuracy, for which we compensated to some extent by training and with formation bombings. Although we had seized the bombsight, we lacked, among others, the production technology for small gyrocompasses and until the end of the war were never able to copy this bombsight. ${ }^{(124)}$

\footnotetext{
* The text has No. 25, which is apparently a misprint because the Action Report also has No. 6.
} 


\section{The Sailing of the Invasion Units}

On the morning of the 17th, the 2d Escort Unit and the 1st Echelon (the Kupang invasion unit) left Ambon, while on the next day, the 18th, the 2d Echelon (the Dili invasion unit) left Ambon. ${ }^{(54)}$ Also, the Mizuho and Patrol Boat No. 39 left Staring Bay on the 17th. ${ }^{(68)}$ On the morning of the 18th, the Mizuho unit reached Binongko Island, where they set up a seaplane base to provide the 1st Echelon with a guard against enemy aircraft and submarines; the unit dismantled the base by the evening and [again] sailed south. At 0420 on the 19th, when the 1st Echelon was sailing southwestward fifty nautical miles off Timor in parallel to the coast, it came under an attack by a torpedo, but it sustained no damage nor had it any clue [from where the torpedo had come].

At 2330 on the 19th, the $2 \mathrm{~d}$ Echelon began the operation to enter into the anchorage, while the minesweeping unit of the 1st Echelon, which had sailed ahead, entered into the 1st anchorage east of Cape Mali around 2000 to start sweeping for mines; it completed the sweeping by 2400 and reported no tethered mines. At 0600, the Mizuho reached off Cape Lewolein on the northern coast of Lomblen Island, set up a seaplane base in the bay and guarded the 1st Echelon against enemy aircraft and submarines. On that day, as previously told, the Carrier Task Force and the air unit attacked Port Darwin in large numbers and inflicted devastating damage on the naval vessels on site as well as the port facilities and the airfield. Meanwhile, the Support Unit was sailing southward and advanced into the Timor Sea on the 20th, to be ready against the [enemy] heavy cruiser, which the aircraft of the Eleventh Air Fleet had attacked on the 16th (the enemy was not spotted in the end). During this period, the air unit carried out reconnaissance attacks on Kupang and the vicinity (its battery in particular) as well as the waters surrounding that area, and also reconnoitered the Port Darwin area. It barely spotted enemy vessels or aircraft other than some merchantmen, except for those in the Port Darwin area. On the 18th, a thorough reconnaissance of the dropping point at Kupang was carried out. ${ }^{(71)}$

\section{The Landing in Kupang and the Uphill Battle of the Airborne Unit}

At 0050 on 20 February, the 1st Echelon entered the 1st Anchorage east of Cape Mali and the unit to land on the coast east of Cape Mali made a successful landing at 0240. At 0410, the second landing unit also came ashore. ${ }^{(54)}$ In the meantime, about 450 men of the unit of the first drop of the $3 \mathrm{~d}$ Yokosuka Special Landing Force were dropped on a pasture to the north of Babau at 1045, without meeting with any enemy resistance. The Army unit seized Highland 385, halfway between the landing point and Kupang by the end of the day, while the 3d Yokosuka Special Landing Force advanced to the east of Babau around 1200, fought a fierce battle against a large enemy unit equipped with tanks and armored cars, and completely seized Babau at 1755. Also after that, the 3d Yokosuka Special Landing Force continued to battle with powerful enemy units, but after having driven off the enemy in front westward at 1926 and getting native people to show them a shortcut to the airfield, the force headed for the airfield. The 3d Yokosuka Special Landing Force had gotten in fierce engagements with the enemy because by advancing along the main road from Kupang to Dili, they [unintentionally] came to cut off the escape route of the enemy. The losses sustained by the force amounted to two platoon commanders and three dozen non-commissioned officers and men killed, and one platoon commander and forty to fifty non-commissioned officers 


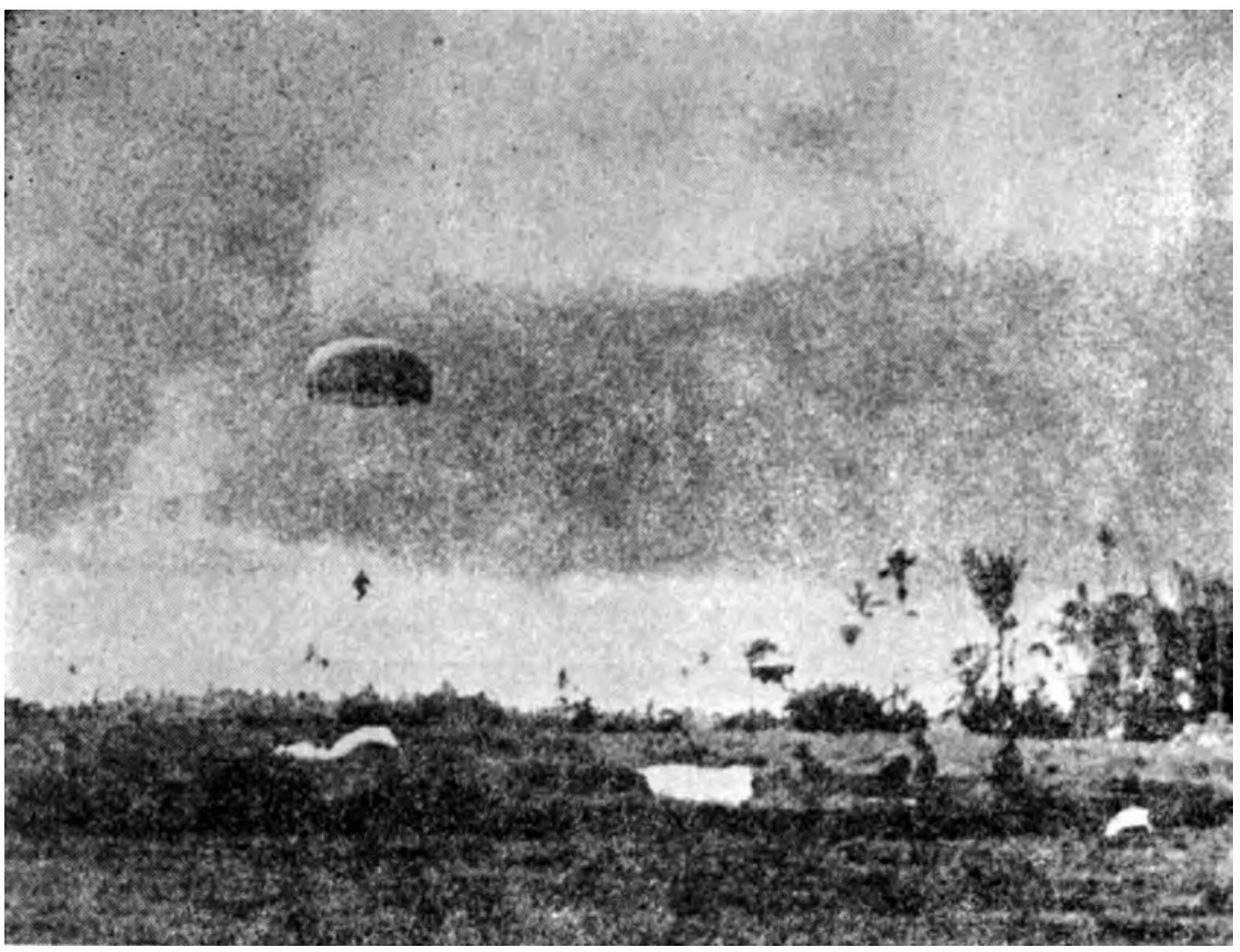

The Navy Paratrooper Unit About to Land

and men injured. ${ }^{(147)}$ In the meantime at sea, the main unit sailed to the north of Kupang, while the Support Unit took up a position to the south of Kupang to support the operation. Also, the Mizuho left Lomblen Island in early morning and provided guard for the anchorages and support for the land combat, while appropriately operating on the waters south of Alor Island.

At 0900 on 21 February, the center attack unit of the Itō Detachment charged into the city of Kupang. At 1024 and in the same way as the day before, about 250 men of the unit of the second drop of the 3d Yokosuka Special Landing Force were dropped on the [above-mentioned] pasture and headed for Babau; from around noon, the unit conducted a fierce twohours battle near Babau against a large enemy unit, equipped with tanks and armored cars, after which the unit drove off the enemy. Then, contact with the first drop unit was established, and [the unit] advanced along the bypath in the mountain forest toward the airfield. At 1200, the Itō Detachment completed clearing [the enemy] from the city of Kupang and also seized the landing point for the 4th anchorage at Tenau to the north [of the other three anchorages]. At 1400, one element of the center attack unit of the Itō Detachment seized the Kupang airfield. After having handed over the guard [of the airfield] to the 1st Sasebo Special Landing Force detached force, which had advanced with them, they joined the main force. In the meantime, the right attack unit of the Itō Detachment had at 1730 advanced to Oesau, a key point on the enemy escape route toward the east. ${ }^{(54)}$ At night, the 1st Sasebo Special 


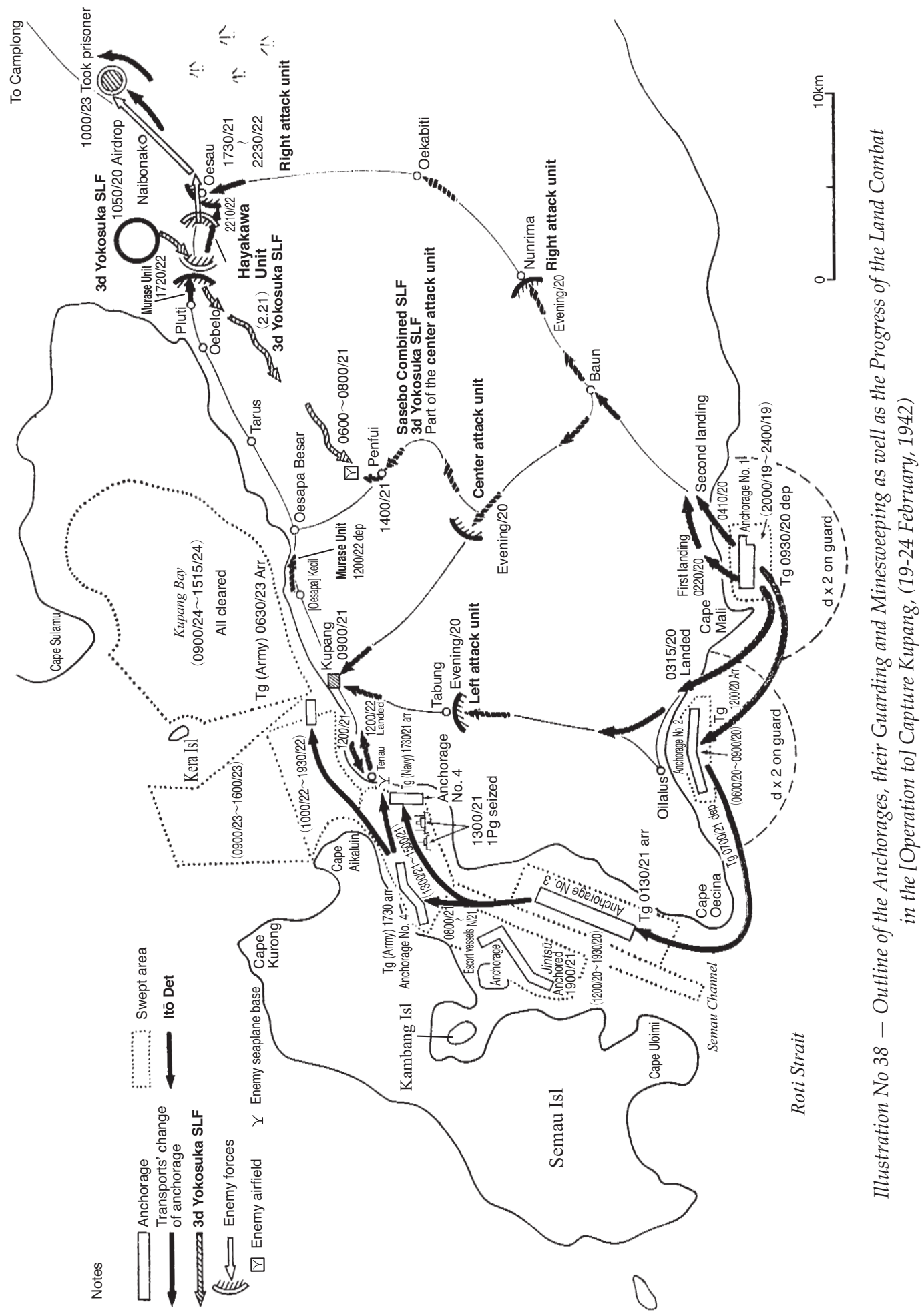


Landing Force detached force commander sent the following report on the condition of the airfield: "2250: The area of the airfield is about 600,000 square meters and there are 220 or more holes blasted in the center. Fighter planes can use [the airfield] from the $23 \mathrm{~d}$ onwards and there will be no hindrances to its use ([by] mid-sized land-based attack planes from the 25th [onwards]). ${ }^{(54)}$

The minesweeper units dealt with the minesweeping at each anchorage and in the waterways, but found no tethered mines. The Support Unit, which had operated on the waters west of Roti Island during the daytime, judged that the objectives of the operation had been more or less attained and started withdrawing toward Staring Bay in order to prepare for the Java operation. ${ }^{(54)}$ On that day, as the Java operation was approaching, Dutch East Indies Unit Commander Vice Admiral Takahashi let the Mizuho unit return to her original unit. After retrieving her aircraft in the afternoon, the Mizuho sailed in the evening northward through the Alor Strait toward the Makassar Strait. ${ }^{(54)}$

At 0600 on the $22 \mathrm{~d}$, the vanguard of the paratrooper unit finally reached the airfield. Meanwhile from the early morning onwards, the Itō Detachment fought a fierce engagement in the Oesau area, the escape route of the enemy, and drove off the enemy (during this engagement, the detachment requested the Navy to bomb the enemy, in which the land-based attack planes cooperated). From around 2210, the detachment turned to the pursuit of the escaping enemy, caught them and made them surrender to the east of Naibonak at 1000 on the $23 \mathrm{~d}$. The enemy consisted of about 1,000 men equipped with about 100 armored cars and other vehicles. $^{(104)}$

At 1600 on the 22d, the Support Unit put in at Staring Bay, where the unit joined the main unit of the Dutch East Indies Unit; the Ikazuchi and the Akebono, which had been in the Support Unit, were incorporated into the main unit, while the Kawakaze and the Yamakaze, which had been in the main unit, were put into the Support Unit instead. At 0000 on the 23d, as previously told, the Dutch East Indies Unit commander issued the outline of the Java Invasion operation, which was [in summary] as follows: ${ }^{(54)}$

1. (The enemy movements in the Batavia and Surabaya areas - Omitted by the author)*

2. (The plan of the Dutch East Indies Unit - Omitted by the author)

3. (a) (Concerning the second [phase] of transport operation in Bali - Omitted by the author)

(b) The $2 \mathrm{~d}$ Escort Unit shall be disbanded at 1800 on 24 February. The vessels of each unit shall operate according to the following outline.

(1) The 2d Destroyer Squadron (minus the 8th, the 15th, and the 18th Destroyer Divisions) shall sail to Makassar and replenish [there], after which it shall get to the waters south of Cape Selatan around 1600 on the 26th. After that, it shall operate on the waters northwest of the 1st Escort Unit to take charge of supporting the latter as well as catching and destroying enemy naval vessels.

(2) The 15th Destroyer Division shall be assigned to guard the Kupang area, after which it shall operate in accordance with Southern Task Force Telegraphic Order No. 106 (i.e. joining the main unit of the Southern Task Force; it shall take charge of towing and replenishing).

(3) The 21st Minesweeper Division (minus Minesweepers Nos. 11 and 12) and Patrol Boats Nos. 1 and 2 shall escort the transport ships ([of] both the Navy and the Army) that are currently in the Timor area to Kendari, as soon as they are empty after disembarkation; after that they shall in consultation with the 21st Air Flotilla commander escort the 21st

* See pp. 322-323 for the items omitted here. 
Air Flotilla transport ships to Kupang.

(4) The 2d Section of the 7th Destroyer Division shall replenish at Makassar, after which it shall operate as designated by the 5th Cruiser Division commander.

(c) The Tomozuru shall escort the Sasako-maru from Makassar to [the waters] off Takisung (eighteen nautical miles north of Cape Selatan) and embark one element of the Army Sakaguchi Detachment [on the latter], after which they shall join the 1st Escort Unit [on the waters] south of Cape Selatan around 1200 on the 26th.

(d) The 5th Cruiser Division (minus the Myōkō), the 1st Section of the 7th Destroyer Division, the Yamakaze and the Kawakaze shall appropriately operate in the rear area of the 1st Escort Unit, taking charge of its support as well as catching and destroying enemy naval vessels.

The 5th Cruiser Division commander may at his discretion arrange the tasks of the 4th and the $2 \mathrm{~d}$ Destroyer Squadron commanders.

(e) The operations of the main unit (as previously told)

By this order, the $2 \mathrm{~d}$ Escort Unit came to be disbanded on the evening of the 24 th and all vessels from destroyers and above were to pull out of Kupang immediately to participate without a moment of respite in the eastern Java invasion operation; the 15th Destroyer Division, [however,] was to join the Southern Task Force to participate in the carrier operation to the south of Java, while the 21st Minesweeper Division (Minesweepers Nos. 7 and 8) and the 1st Patrol Boat Division (Patrol Boats Nos. 1 and 2) were to be kept on site to guard and escort the transport ships. However, the advance of the Support Unit to the southwest of Timor to support the carrier operation to the south of Java and to guard its rear at the time of Java invasion operation was to be called off, and its tasks were to be changed to the support and cover of the eastern Java invasion unit after advancing to the north of Surabaya.

Since the minesweeping in front of the city of Kupang was completed on the $22 \mathrm{~d}$, the transport ships shifted their anchor from the 4th Anchorage in the Semau Strait to the waters in front of Kupang on the 23d to start disembarkation. The minesweeping unit had completed the minesweeping in Kupang Bay by 1600, and because the 1st Minesweeping Division* was ordered to take charge of guarding Dili, it left Kupang for Dili at 1600 on the $23 \mathrm{~d}$. On that day, nine fighter planes and two land-based reconnaissance planes of the $3 \mathrm{~d}$ Air Group of the 1st Air Raid Unit advanced to the Penfui airfield, while the seven flying boats of the Tōkō Air Group advanced to the Tenau seaplane base. ${ }^{(81)}$

At 1200 on the 24th, 2d Escort Unit Commander Rear Admiral Tanaka left Kupang for Makassar, leading the Jintsu $\bar{u}$ and the 16th Destroyer Division. ${ }^{(54)}$ Only the 21st Minesweeper Division and the 15th Destroyer Division, the latter being on standby to join the Southern Task Force, were left in Kupang. While sailing to Makassar, the 2d Escort Unit Commander transmitted an order to his subordinate units that the $2 \mathrm{~d}$ Escort Unit would be disbanded at 1800. In this operation, with no enemy air or submarine attacks, and moreover no mines, which had been anticipated and for which a cautious stage-by-stage minesweeping operation had been conducted, the surface unit had in the end sustained no losses at all. ${ }^{(54)}$

\section{The Landing at Dili}

At 0130 on 20 February, when the $2 \mathrm{~d}$ Echelon started preparing for the landing operation after having entered the 1st Anchorage under the escort of the 7th Destroyer Division, it suddenly came under fire from land. The escorting destroyers immediately returned fire, which

\footnotetext{
* Actually the 1st Patrol Boat Division. See pp. 298, 345.
} 


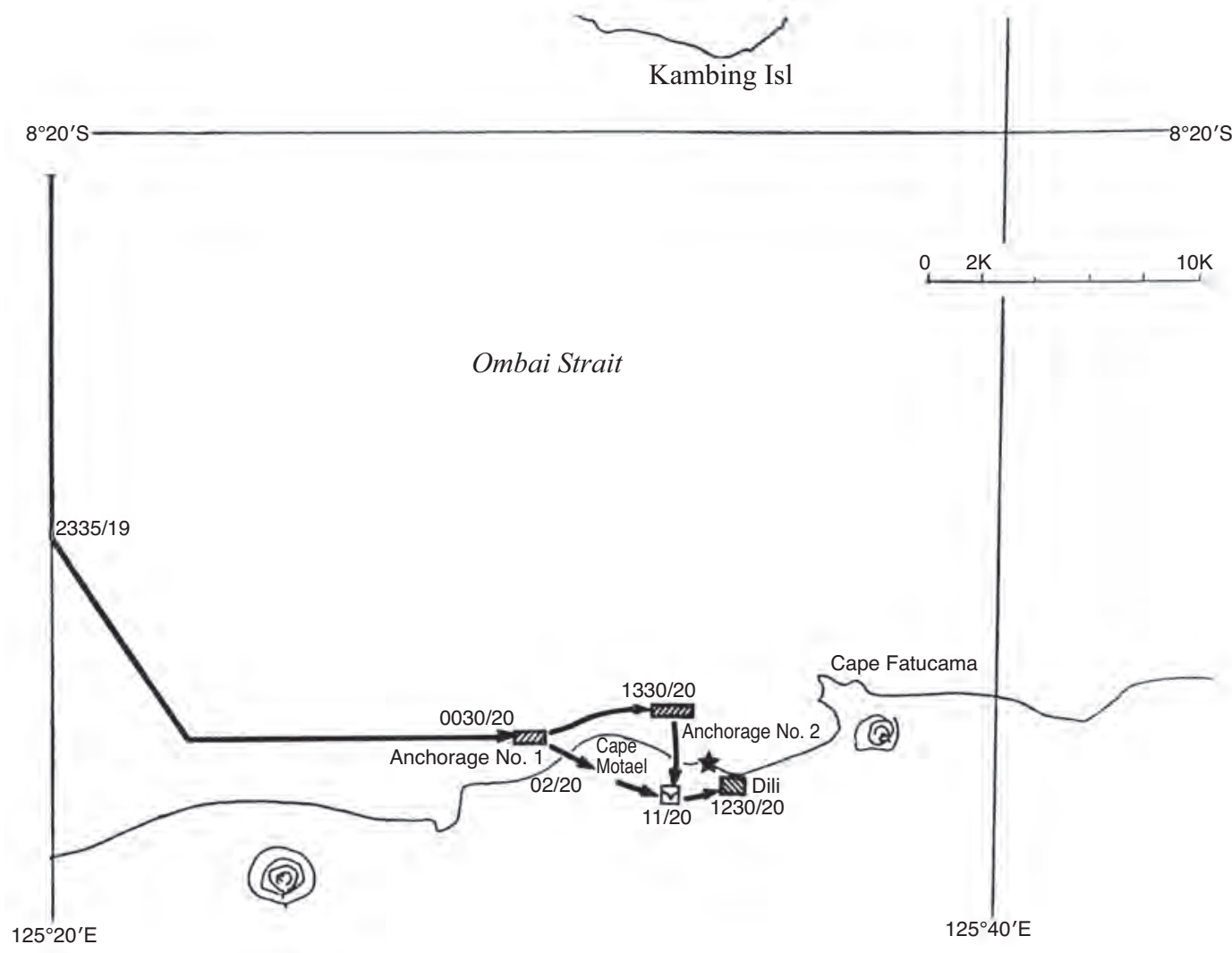

Illustration No. 39 - The Outline of the Invasion of Dili (20 February, 1942)

silenced the enemy fire. At 0220, the first landing unit successfully landed, and the second landing was also carried out successfully around 0530, both with no losses on the Japanese side. ${ }^{(54)}$ At 1100, the army landing unit seized the Dili airfield, eliminating powerful enemy resistance. The airfield had no signs of recent use; since it had no runways and land mines were laid at places, it was judged that it would take seven days before fighter planes could use the airfield. At 1230, the army unit rushed into the urban area of Dili and rescued thirty Japanese who had been put in detention. ${ }^{(54)}$

On the 21st, the 3d Air Group Detachment commander examined the condition of the airfield and wired that with the construction materiel brought to the site or requisitioned on site, it was expected to take ten days before it could accommodate about twenty fighter planes. ${ }^{(45)}$ Worried about this, the 7th Destroyer Division commander dispatched the captain of the destroyer Ushio to the shore to hold talks with the 3d Air Group Detachment commander, the 1st Construction Squad, the Army units, etc. As a result, they [now] forecasted that it would be available for fighter planes in four days, and he reported this to the departments and sections concerned. ${ }^{(54)}$

The disembarkation was continued on the $22 \mathrm{~d}$ and the $23 \mathrm{~d}$; on the 24 th, the 1 st Section of the 7th Destroyer Division handed over the tasks to guard Dili to the 1st Patrol Boat Division and left Dili for Makassar at 0830. ${ }^{(110)}$ At 1500 on that day, the transport ships of the 2d Echelon left Dili for Kupang under the escort of the 1st Patrol Boat Division, which completed the 
withdrawal of the surface unit at Dili, and only the ground units remained. At 0700 on the 25th, the $2 \mathrm{~d}$ Echelon arrived at Kupang. Concerning the attitude of the Portuguese in the Dili operation, the $2 \mathrm{~d}$ Escort Unit commander sent the following report at 0000 on the 25th: ${ }^{(53)}$

According to the report of the 7th Destroyer Division commander, at the time of landing on Dili, only the Australian troops had fought back. The Portuguese forces did not put up resistance and the government officials did not evacuate to the suburbs, either. After having occupied Dili, the army has wholly respected the sovereignty [of the Portuguese] by using the barracks of Australian forces, etc. However, the Portuguese seem to feel offended; in every negotiation with the Japanese, they quibbled that they were not able to provide answers without instructions from the home government, as if they had no intention to cooperate with us.

Because the Allies had no powerful forces stationed in the Timor area and the flames were licking around their feet in the Java and Port Darwin areas, they could not send reinforcements. The Australian ground troops in Timor consisted of about 2,000 men. ${ }^{(95)}$

In this way, Timor, located halfway between Australia and Java and forming a strategic point for supply of forces and materials, was seized, and the eastern Java part of the [Japanese] envelopment of Java was completed. Still more, by the end of January, Rabaul on New Britain, a strategic point of communications between the United States and Australia, had already fallen in the hands of the Japanese forces as well. 


\section{Chapter VI The Drafting of the Java Invasion Operation Plan}

\section{The Circumstances Until the Launch of the Operation}

\section{[The Circumstances] up to the Manila Conference}

A lthough no extant documents concerning the Army-Navy Central Agreement of 5 100 and capture the island within twenty days after the landing. ${ }^{(34)}$

Then in the Tokyo Agreement of 10 November, the outline of the plan became fairly concrete, and the following points were agreed upon: ${ }^{(34)}$

1. The landing on Java shall be scheduled by and large for Day X +80 (26 February). However, the Army Department of IGHQ expressed disapproval of this schedule in terms of the available tonnage and the shipping schedule.

2. The Sixteenth Army ([consisting of] the 2d, the 48th Divisions and one element of the 38th Division as the core) shall be employed for the invasion of Java, and the Navy Dutch East Indies Unit shall provide the escort at sea.

3. The air operation against Java shall be conducted in the following way:

(1) Prior to the landing on Java, air campaigns on eastern and western Java shall be carried out in concert from the following seized bases.

$\{1\}$ Eastern Java: Banjarmasin and Makassar as the frontline [bases], including Balikpapan and Kendari

\{2\} Western Java: Southern Sumatra and Kuching

(2) Responsibility for the air campaigns

\{1\} Eastern Java: the Navy (the Eleventh Air Fleet)

\{2\} Western Java: the Army and the Navy in conjunction (the Third Air Force and the Eleventh Air Fleet)

4. Others

(1) The 48th Division shall be diverted from the operations in the Philippines and be scheduled to leave Manila on Day X + 70 (16 February).

(2) The main force of the Sixteenth Army shall head for western Java from Taiwan and southern Indochina, while the element of the 38th Division shall head there from Hong Kong.

(As previously told), in [Navy] Southern Task Force Order Classified No. 1 issued on 15 November in accordance with these agreements, the Java operation was envisioned roughly as follows: ${ }^{(47)}$ 
1. In concert with the Air Unit, the [naval] special landing forces shall seize Menado, Kendari and Makassar. Apart from this and in parallel with the above, Tarakan, Balikpapan and Banjarmasin shall be captured in conjunction with the Army to advance air bases to each place.

2. As the operations in the Malaya area progress, Bangka and Palembang shall be seized at an appropriate opportunity, and air bases [there] shall be made ready for use.

3. The concerted air campaigns against eastern and western [Java] shall be intensified from the bases in the items above in order to tighten the envelopment and neutralize the enemy air power, after which the Sixteenth Army shall be disembarked near Batavia and Surabaya.

4. One submarine element shall be advanced to the Indian Ocean to cut off the shipping of supplies to the Dutch East Indies from the south.

In Dutch East Indies Unit (Philippines Unit) Operation Order No. 1, which was issued on 23 November in accordance with the above, the following operational outline was indicated:(47)

1. The following three lines of operations shall be [pursued]:

The Makassar Strait area: The line leading to Tarakan, Balikpapan and Banjarmasin

The area east of Celebes: The line leading to Menado, Kendari and Makassar

The Banda Sea area: The line leading to Ambon and Kupang

Note: The Ambon, Kupang line was supposed to be implemented at an appropriate opportunity, depending on the progress of the other two operations.

2. The Air Unit shall be advanced to the Makassar Strait area to intensify the air campaign to destroy the enemy air power in Java. Assisted by this air campaign, the main force of the Sixteenth Army shall be put ashore near Batavia and another corps near Surabaya to swiftly capture Java.

Around that time, the [operation] to capture southern Sumatra had not yet been given shape.

With this operational concept in mind, the plunge was taken and hostilities were opened, but since the operations, including the Hawaii [operation], the sea engagement off Malaya, the Philippines invasion operation and the Malaya invasion operation, had made smooth progress, the Southern Army headquarters judged that it would be advantageous to complete the [entire] operation as soon as possible and planned to move up the schedule of the invasion operations. It led to the conference at Cam Ranh Bay on 29 December, where revisions were made to the Tokyo Agreement of 10 November, and (as previously told) the invasion schedule was changed as in the following table. ${ }^{(62)}$

\begin{tabular}{|c|c|c|c|c|}
\hline Target & $\begin{array}{c}\text { Central Agreement } \\
\text { of } 5 \text { November }\end{array}$ & $\begin{array}{c}\text { Tokyo Agreement } \\
\text { of } 10 \text { November }\end{array}$ & $\begin{array}{c}\text { Iwakuni Agreement } \\
\text { of } 16 \text { November }\end{array}$ & $\begin{array}{l}\text { Cam Ranh Agree- } \\
\text { ment [discussed] on } \\
29 \text { December }\end{array}$ \\
\hline Makassar & & Around Day $X+45^{*}$ & Day X +54 & Day $X+53$ \\
\hline Banjarmasin & & $\begin{array}{c}\text { By and large around } \\
\text { Day } X+50\end{array}$ & Day X + 54 & Day X + 53 \\
\hline $\begin{array}{l}\text { Bangka and } \\
\text { Palembang }\end{array}$ & Day $X+85^{* *}$ & $\begin{array}{c}\text { By and large around } \\
\text { Day } X+80\end{array}$ & & Roughly day X+60 \\
\hline
\end{tabular}

* The text mistakenly has 54 .

** The text mistakenly has 58 . 


\begin{tabular}{|c|c|c|c|}
\hline Java & \multicolumn{1}{|c|}{ Day X+103 } & $\begin{array}{c}\text { By and large around } \\
\text { Day X }+80\end{array}$ & Roughly day X+70 \\
\hline Remarks & $\begin{array}{l}\text { 1. The landings on Java were scheduled for 16 February, ten days earlier than in the } \\
\text { Tokyo Agreement } \\
\text { 2. The capture of Bangka and Palembang was scheduled for 6 February, twenty days ear- } \\
\text { lier than in the Tokyo Agreement } \\
\text { 3. [The capture of] Makassar and Banjarmasin was postponed due to the delay in the } \\
\text { Tarakan and Menado operations }\end{array}$ \\
\hline
\end{tabular}

However, after the launch of the operation to advance the air bases, it was strongly asserted at the operational meeting between the Southern Task Force, the Dutch East Indies Unit and the Air Unit on 18 January at Palau that, taking into consideration the preparation of the seized air bases, the allocation of escort naval vessels and the minesweeping schedule of the anchorages for the invasion [operations], etc., it was not feasible to execute [the operations] exactly according to the schedule specified in the Cam Ranh Agreement. Thus, as described previously, from 21 January onwards a conference to revise the Cam Ranh Agreement was held at Manila (the Manila Conference) and, on 28 January, the invasion [operation] schedule was changed in the following way: ${ }^{(62)}$

1. The invasion schedule shall be changed as follows:
Western Java:
Day $\mathrm{X}+75^{*}$
(21 February; postponed for five days)
Eastern Java:
Day $X+77$
(23 February; postponed for seven days)
Southern Sumatra:
Day $X+64$
(10 February; postponed for four days)
Makassar:
Day $X+63$
(9 February; postponed for ten days)

2. The seaborne [operation] to seize Banjarmasin shall be called off; instead, Bali shall be captured around day $\mathrm{X}+75^{*}$ (two days prior to the landing on eastern Java) in order to make use of it as a base for the air operations at the time of the invasion of eastern Java.

\section{[The Circumstances] After the Manila Conference Until the Launch of the Operation}

\section{The Situation of the Units to Be Involved [in the Operation]}

The situation of the units to be involved in the Java invasion [operation] as of 28 January was roughly as follows: $(53,62,68,71,78,118,119)$

\section{The Dutch East Indies Unit}

The main unit (directly led by the Ashigara): at Davao, directing the whole operation

The 4th Destroyer Squadron (minus 4th Destroyer Division and the Yamagumo): in the course of the Balikpapan operation

The $2 \mathrm{~d}$ Base Force: in the course of the Balikpapan operation (one element in Tarakan)

The 5th Destroyer Squadron: assembling in Gaoxiong to escort the 48th Division

The $2 \mathrm{~d}$ Destroyer Squadron (minus the 18th Destroyer Division): in the course of the Ambon operation along with the 21st Minesweeper Division and the 1st Subchaser Division

The 5th Cruiser Division (minus the Myōkō): in the course of supporting the Ambon operation along with the $2 \mathrm{~d}$ Section of the 6th Destroyer Division

\footnotetext{
* The text mistakenly has 57 .
} 
The 1st Base Force (minus the 21st Minesweeper Division and the 1st Subchaser Division): two patrol boats were in the course of the Kendari operation (one element at the Bangka anchorage)

The 11th Seaplane Tender Division and two patrol boats: in the course of supporting the Kendari and the Ambon operations

\section{The Air Unit}

The Eleventh Air Fleet headquarters: at Davao; directing the whole operation

The 21st Air Flotilla (minus the main body of the Kanoya Air Group) and the 3d Air Group: in charge of the air operations in Celebes, the Banda Sea as well as in the central and southern Philippines, with its main force in Kendari and one element in Menado and Davao

The 23d Air Flotilla (minus the 3d Air Group): in the course of air operations in the Makassar area with its main force in Tarakan (and all land-based attack planes in Jolo)

The $2 \mathrm{~d}$ Carrier Division, the Maya, the 7th Destroyer division, and the 2d Section of the 27th

Destroyer Division: after completing the Ambon operation, arrived at Palau on the 28th

3. The Malaya Unit

The main unit (directly led by the Chōkai): in Cam Ranh Bay; directing the whole operation

The 7th Cruiser Division, and a few destroyers of the 3d Destroyer Squadron: in the course of supporting the Endau and the Anambas operations

The 3d Destroyer Squadron (minus one element): in the course of the Endau operation

The main force of the 9th Base Force: in the course of the Anambas operation

The 22d Air Flotilla: conducting air campaigns in the Malaya area, with its main force in southern French Indochina

The 4th Submarine Squadron: in Cam Ranh Bay; in preparation for the subsequent operations

4. The Submarine Unit

The 5th Submarine Squadron: in the course of the Indian Ocean operation (with its headquarters in Penang)

The 6th Submarine Squadron: returning to Davao from the Port Darwin operation

5. The main body of the Southern Task Force

The 1st Section of the 4th Cruiser Division, the $2 \mathrm{~d}$ Section of the $3 \mathrm{~d}$ Battleship Division, the 4th Destroyer Division: in Palau, directing the whole operation

6. The Army Units

The Sixteenth Army headquarters and the 2d Division: assembling in Gaoxiong and Tainan

The 48th Division: in the course of assembling at Lingayen Gulf in the Philippines (the delay in the capture of the Bataan Peninsula prevented them from departing from Manila Bay).

The 38th Division (the Shōji Detachment): in Hong Kong (due to leave 29 January and assemble at Gaoxiong on the 31st)

\section{The Outline of the Arrangements Between the Commanders of the Army and the Navy}

The arrangements between the Army and the Navy commanders were made on 24 January in accordance with the Manila Agreement, and following the formal implementation of the Manila Agreement on the 28th, they came into effect on the 30th. The outline of the parts relevant to the Java invasion was as follows (details will be described later):

1. The landing areas and dates

Area No. 1: Bantam Bay and Merak Bay (the main force of the Sixteenth Army), on Day H (21 February)

Area No. 2: Patrol (Shōji Detachment)

Area No. 3: Kragan (48th division) on Day I (23 February)

2. Assembly points and departure dates 
The units for Areas No. 1 and No. 2: Gaoxiong and then Cam Ranh Bay on Day H - 8

The units for Area No. 3: Lingayen Gulf and then Jolo on Day I - 7

3. The responsibility for the air operations

(1) The air operations against Java: the Army shall take charge of western [Java] and the Navy of central and eastern [Java]

(2) Guard against [enemy] submarines (of the transport ships under sail and the anchorages): entirely assigned to the Navy

(3) Antiaircraft guard in the air (ditto): the Army [shall take charge of the units for] Area No. 1 and the Navy of those for Area No. 2 (the Army [shall take charge of the guard] after [the Shōji Detachment] has separated [from the main convoy]); the Navy [shall take charge of] those for Area No. 3.

(4) Support for the ground operations: the Army [is responsible for] western [Java] and the Navy [for] eastern [Java]

(5) Attacks on enemy naval vessels: mainly [the task of] the Navy

\section{The Operational Policy of the Southern Task Force Commander}

As mentioned previously [p. 331], on 9 February, the Southern Task Force Commander V. Adm. Kondō Nobutake announced his plan for the entire southern operation by means of Southern Task Force Telegraphic Order No. 92, which was in outline as follows: ${ }^{(53)}$

1. The Malaya Unit is currently carrying out an attack on the port of Singapore and intends to capture Bangka and Palembang in mid-February.

2. Following the capture of Makassar, the Dutch East Indies Unit and the Air Unit are going to capture Bali and Timor around 20 February, and launch [the operation to] capture Java from 25 February onwards.

3. The Carrier Task Force shall try to completely destroy the enemy air power in the Port Darwin area as well as catch and destroy enemy fleets and transport convoys, while attacking the enemy forces in the Java area from their rear by carrying out carrier operations in the eastern part of the Indian Ocean in order to accelerate the clearing [of the enemy] from the Dutch East Indies in general.

4. The Submarine Unit shall watch and patrol the area to the north of Australia, Ceylon, the coastal areas of India, the Malacca Strait and the area south of Java.

5. The main body of the Southern Task Force shall advance into the Indian Ocean in tandem with the Carrier Task Force to support the whole operation.

\section{The Operational Policy of the Dutch East Indies Unit Commander}

As mentioned previously, on 28 January, the day when the Manila Agreement came into effect, the [Navy] Dutch East Indies Unit Commander V. Adm. Takahashi Ibō announced his plan for the operations of the Dutch East Indies Unit after the Makassar operation and until the Java invasion operation by means of Operation Order No. 9, which was (as previously told) in outline as follows: ${ }^{(54,56,90)}$

1. After the capture of Ambon, the Eastern Support Unit, the 2d Escort Unit, the 1st Base Unit and the $2 \mathrm{~d}$ Air Unit shall capture Makassar, Bali, and Kupang.

2. The 3d Escort Unit and the 1st Air Unit shall escort and disembark the Sixteenth Army in western Java, while the 1st Escort Unit, the 2d Base Unit and the 2d Air Unit [shall do the same] in eastern Java. 
3. The date of the landing on western Java is set for 21 February (Day H), and that on eastern Java for 23 February (Day I).

\section{The Problems in the Java Invasion [Operation] in Terms of Strength}

The Dutch East Indies Unit's plan to capture Java contained considerable problems in terms of strength.

1. The shortage of escort strength

(1) Because [now] four operational lines toward eastern and western Java, Bali and Kupang are supposed to be simultaneously pursued in parallel, extreme lack of strength, particular that of escort forces is anticipated.

(2) Concerning [the operational line towards] western Java in particular, merely two light cruisers, thirteen or fourteen destroyers and several minesweepers are allotted as the core strength to escort a large convoy made up of as many as fifty-five transport ships. A reinforcement of escort forces as well as minesweepers and naval defense vessels is required.

(3) Since the $2 d$ Destroyer Squadron and the 1st Base Force are executing operations almost concurrently in Celebes and the Banda Sea, destroyer forces are particularly lacking.

(4) Summing up, a reinforcement of a total of about three destroyer divisions, [namely] at least another destroyer division for western Java and two more for the area to the north of Australia and eastern Java all together, is required.

2. The shortage of support forces

Because [the units] in all areas are tied up with escorting the invasion units, leaving no strength to spare, it is anticipated that in case of a full-scale counterattack by powerful enemy surface vessels, the lack of support strength will lead to serious consequences.

Against these problems, Southern Task Force Commander Vice Admiral Kondō took the following measures:

\section{A reinforcement of destroyers}

(1) [He] transferred the 21st Destroyer Division ([consisting of] four destroyers), which had advanced to Davao on 21 January escorting the 101st Fuel Depot, to the Dutch East Indies Unit.

(2) On 28 January, [he] transferred as of 30 January the 7th Destroyer Division ([consisting of] three destroyers) and the 1st Section ([consisting of] two destroyers) of the 6th Destroyer Division to the Dutch East Indies Unit respectively from the carrier-based air unit and from the Air Unit. (The former was supposed to return to its original unit after completing the Timor operation on the 24th [of February].)

With these [measures], three destroyer divisions (nine destroyers) were added.

2.The support strength

(1) [The forces in] the eastern Java area shall be provided with support by the main body of the Southern Task Force and the carrier-based air unit in concert with the Air Unit and the Submarine Unit. For this purpose, [an] appropriate advance base for the fleet and submarines shall be set up in the Banda Sea area.

(2) For [the forces in] the western Java area, support by the forces of the Malaya Unit shall be considered, depending on the war situation in the southern Sumatra and Malaya areas. 


\section{The Preparations of Each Unit}

In response to the reinforcement of destroyers, Dutch East Indies Commander Vice Admiral Takahashi incorporated the 21st and the 7th Destroyer Divisions into the Eastern Attack Unit, intending to assign them for the time being to the operations in the area of the 5th Cruiser Division, the 2d Destroyer Squadron and the 1st Base Force, while planning to add the 1st Section of the 6th Destroyer Division to [the forces in] the western Java area. Also, at 1600 on 29 January, in consequence of the Manila Agreement, the Dutch East Indies Unit commander ordered 4th Destroyer Squadron Commander R. Adm. Nishimura Shōji to sail to Lingayen, leading one destroyer division as the core on 30 and 31 January to escort and bring the 48 th Division to Jolo by around 12 February, while

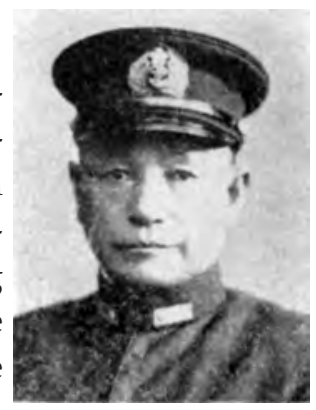

5th Destroyer Squadron Commander R. Adm. Hara Kenzaburō having the other forces of the 4th Destroyer Squadron remain in Balikpapan and be put under the command of $2 \mathrm{~d}$ Base Force Commander R. Adm. Hirose Suéto.

From 20 January onwards, the 5th Destroyer Squadron (commander: R. Adm. Hara Kenzaburō) in charge of the western Java [operation] had in Taiwan steadily made preparations for the operation. On 27 January, it had already at Gaoxiong concluded the Army-Navy arrangements concerning the invasion operation with the Sixteenth Army, the $2 \mathrm{~d}$ Division and the Shōji Detachment (of the 38th Division). [The preparations of] the other units [can be gathered] from the following order issued by the Dutch East Indies Unit commander on 29 January: ${ }^{(63)}$

1. The forces to be incorporated to the 3d Escort Unit from the 1st Base Force for the Batavia operation shall be the Shirataka, two minesweepers and one half of the 1st Defense Unit.

2. The San'yo-maru shall join the Shirataka en route and sail to Cam Ranh Bay by 7 February; the two minesweepers as well as the one half of the 1st Defense Unit in the above item [shall sail there] by 10 February.

3. The 1st Section of the 6th Destroyer Division shall sail to Cam Ranh Bay by 10 February by way of Davao.

4. The 1st Base Force shall be relieved of the task to guard Ambon, which was ordered by means of Third Fleet Classified Telegram No. 907.

Notes by the author:

1. The 1st Section of the 6th Destroyer Division was at that time under the command of the Air Unit and in charge of escorting the ship[s] transporting air base matériel to Kendari from Davao.

2. The Shirataka and the 1st Base Force were stationed at the Bangka anchorage and engaged in the defense of the area.

3. The minesweeper unit of the 1st Base Force was participating in the Ambon operation following the Kendari operation.

4. Although it had been planned to also send the Sanuki-maru to Cam Ranh Bay along with the San'yo-maru, the former sustained damage in the [enemy] air raid at Balikpapan on 27 January, which led to the cancellation of her sailing [to Cam Ranh Bay].

In the meantime, the Malaya Unit had by 30 January designated the 11th Destroyer Division (three destroyers), the 12th Destroyer Division (two destroyers) and the 1st Minesweeper Division (five minesweepers) as [respectively] the two destroyer divisions of the $3 \mathrm{~d}$ Destroyer Squadron and one of the minesweeper divisions of the 9th Base Force that were to participate 
in the western Java operation, and communicated this to the Dutch East Indies Unit commander and 5th Destroyer Squadron Commander R. Adm. Hara Kenzaburō.

Meanwhile on 9 February, Southern Task Force Commander Vice Admiral Kondō issued, by means of Telegraphic Order No. 93, the order to organize the 2d Submarine Squadron into Submarine Unit $C$ and the 4th and the 6th Submarine Squadrons into Submarine Unit A (as of 18 February). He also ordered, by means of Telegraphic Order No. 94, the 2d Carrier Division and the 1st Section of the 7th [4th] Destroyer Division to respectively return to the Carrier Task Force and to the main body [of the Southern Task Force] as of 10 February. ${ }^{(53)}$

\section{Partial Changes in the Disposition of Forces of the Dutch East Indies Unit}

1. The measures taken after the 21st Minesweeper Division had sustained damage Since (as previously told) the 21st Minesweeper Division had sustained the loss of having Minesweeper No. 9 sunk and Minesweepers No. 11 and No. 12 damaged in the Ambon Bay minesweeping operation, Dutch East Indies Unit Commander Vice Admiral Takahashi called off the division's participation in the western Java operation. Instead, he changed the disposition of forces having the 1st Section (two torpedo boats) of the 21st Torpedo Boat Division of the $2 \mathrm{~d}$ Base Force, which was engaged in protecting the shipping lanes in the rear in the Makassar Strait and the Celebes Sea, join the western Java operation. The Dutch East Indies Unit, which was already suffering from a lack of strength to protect the shipping lanes in the rear, requested reinforcements and, as a result, the minelayers Tsubame and Kamome, attached to the Sasebo naval station, were put by means of IGHQ Navy Department Instruction No. 50 under the operational command of the commander in chief of the Combined Fleet as of 5 February and transferred to the Dutch East Indies Unit of the Southern Task Force. These two boats were put under the command of the $2 \mathrm{~d}$ Base Force commander, replacing the 1st Section of the 21st Torpedo Boat Division, to take charge of protecting the shipping lanes.

2. The measures taken following the damage to the Sanuki-maru

Since the Sanuki-maru had been crippled due to the damage inflicted by the [enemy] bombings at Balikpapan on 27 January, Dutch East Indies Unit Commander Vice Admiral Takahashi decided on the same day to keep her in Balikpapan and issued an order to put her (with Patrol Boat No. 36 and two fishing boats attached to her) under the command of $2 \mathrm{~d}$ Base Force Commander Rear Admiral Hirose, with instructions to assign her the task of neutralizing enemy submarines in the Makassar Strait and later from 7 February onwards to incorporate her in the 1st Base Force.

3. The problem of the continuous employment of the 11th Seaplane Tender Division In the initial plan, the 11th Seaplane Tender division was supposed to break off [its operations] after the capture of Ambon and Makassar until its deployment for the invasion operation against eastern Java. However, the division was engaged in both the Kendari and Ambon operations for a longer period than anticipated, which put it in a situation that it barely had time to service its aircraft. Therefore, on 2 February, Dutch East Indies Unit Commander Vice Admiral Takahashi gave informal instructions that the Chitose should sail to Jolo to prepare for the eastern Java operation when the Ambon operation was largely completed, while the Mizuho should continue to carry out the Ambon and the Makassar operations, after which she should enter Staring Bay for service, and that it would be all right if she were not ready in time for the eastern Java operation. 


\section{The Postponement of the Landing Date [on Java] Until 26 February}

[The landing dates] arranged in the Manila Agreement were the 10th of February for Bangka and Palembang, and the 21st and 23d for western and eastern Java respectively. However (as previously told), due to the delay in the Bangka and Palembang operations, the landing on Java had necessarily been postponed as well. After conferring with the Southern Army headquarters on 9 February, [the new landing dates] were set on Day X + 81 (27 February) for western Java and no later than Day $X+81$ for eastern Java. However, on the 9th, when this order was issued, Malaya Unit Commander V. Adm. Ozawa Jisaburō launched Operation $\mathrm{L}$ one day earlier, because the outlook for the construction of bases and the deployment of the air unit had become clear. Following the advance of [Operation] L by one day, Dutch East Indies Unit Commander Vice Admiral Takahashi (at Davao) conferred with the Sixteenth Army (at Cam Ranh Bay) by telegram and on the next day, 11 February, he issued the following order to change the invasion schedule: ${ }^{(54)}$

1. Batavia and Surabaya: [on] 26 February (Day X +80$)$

2. Kupang and Dili: [on] 20 February

3. Bali: [on] 18 February

With this [change], the landings on both eastern and western Java came to be carried out on 26 February.

\section{The Assembling of the Invasion Convoys Completed}

1. The units for the western Java invasion [operation] assemble in Cam Ranh Bay (10 February)

On 29 January, all fifty-five ships of the convoy of the main force of the Sixteenth Army had assembled in Gaoxiong. The convoy [then] advanced to Cam Ranh Bay in the following four groups. Fifth Destroyer Squadron Commander Rear Admiral Hara (the 3d Escort Unit commander) sailed ahead, leading the Natori, and arrived in Cam Ranh Bay on 3 February prior [to the convoy's arrival].

1st Group: twelve ships; escorted by the $2 \mathrm{~d}$ Section (the Nagatsuki and the Minazuki) of the 22d Destroyer Division

Departed at 1200 on 1 February; arrived at 0900 on 6 February

2d Group: seventeen ships; escorted by the 1st Section (the Harukaze and the Hatakaze) of the 5th Destroyer Division

Departed at 1200 on 3 February; arrived at 0900 on 8 February

3d Group: eighteen ships; escorted by the 1st Section (the Fumizuki and the Satsuki) of the 22d Destroyer Division

Departed at 1000 on 5 February; arrived at 0900 on 10 February

4th Group: eight ships; escorted by the 2d Section (the Asakaze and the Matsukaze) of the 5th Destroyer Division

Departed at 1200 on 6 February; arrived at 0900 on 10 February

In the meantime, from the eastern part of the Dutch East Indies, the Shirataka, the Myōkōmaru (a transport ship of about 5,000 tons), the 1st Section (the Hatsukari and the Chidori) of the 21st Torpedo Boat Division arrived at 1200 on 9 February, and again, at 1200 on the 
10th, the 1st Section (the Akatsuki and the Hibiki) of the 6th Destroyer Division, the San'yomaru and Patrol Boat No. 35 arrived in Cam Ranh Bay. Thus, all the units for the western Java invasion [operation], except for the forces from the Malaya Unit that were to join en route, had assembled in Cam Ranh Bay.

2. The units for the eastern Java invasion [operation] assemble in Jolo (13 February)

Fourth Destroyer Squadron Commander Rear Admiral Nishimura (the 1st Escort Unit commander), who had left Balikpapan leading the Naka and the 2d Destroyer Division (minus the Harusame) on 30 January, arrived in Lingayen Gulf on 2 February. The Harusame, which was to join from Davao en route, [first] called at Tarakan for replenishment and arrived in Lingayen Gulf on 3 February. The remaining force of the 4 th Destroyer Squadron in Balikpapan had been instructed to arrive in Jolo on the 13th or the 14th, after cooperating in the Makassar invasion operation of the $2 \mathrm{~d}$ Base Force under the command of 2d Base Force Commander Rear Admiral Hirose.

At 0800 on 8 February, 1st Escort Unit Commander Rear Admiral Nishimura, leading the Naka and the 2d Destroyer Division and having put the 53d Subchaser Division (three auxiliary submarine chasers) of the Third Southern Expeditionary Fleet under his command and supported by the Kuma also of the Third Southern Expeditionary Fleet, left Lingayen, escorting the thirty-nine transport ships of the 48th Division. The commander had requested 2d Base Force Commander Rear Admiral Hirose to provide him with a reinforcement of escort strength and had gotten a reinforcement of three submarine chasers. By 1400 on 13 February, all of the convoy put in at Jolo.

In the meantime, the $2 \mathrm{~d}$ Base Force and the remaining force of the 4th Destroyer Squadron had left Balikpapan on the 8th. After having participated in the Makassar operation on the 9th, they called off the support for the operation on the evening of the 10th, sailed north and reached Jolo on the 13th. Also, calling off the Makassar operation at 1930 on 10 February, the Chitose, Patrol boats Nos. 34 and 38 of the 11th Seaplane Tender Division sailed north and arrived in Jolo at 1830 on the 13th, which completed the assembly of almost the whole strength of the unit for the eastern Java invasion [operation] at Jolo.

3. The advance of the main unit of the Dutch East Indies Unit to Jolo (14 February)

At 1700 on 13 February, Dutch East Indies Unit Commander Vice Admiral Takahashi left Davao leading the Ashigara and the Yamakaze. After having been joined by the Murasame and the Samidare, which had sailed from Jolo to meet and guard them on the next day, the 14 th, he put in at Jolo at 1530.

\section{Insufficient Results of the Air Campaign to Destroy the Enemy Air Power}

\section{Eastern Java}

The main force of the land-based air unit, which had advanced to the line Balikpapan Kendari in late January, launched an air campaign to destroy the enemy air power in eastern Java (Operation $\mathrm{Z}$ ) and reported the following military gains (as previously told [pp. 233-244]).

3d [of February]: It had shot down or destroyed about sixty enemy aircraft and inflicted damage to twenty.

4th: It had sunk two [enemy] cruisers and inflicted serious damage to another, and some or minor damage to another two. 
5th: It had shot down or destroyed eleven [enemy] fighter planes.

It was considered that this three-day air operation had destroyed the main force of the enemy naval surface vessels and delivered a serious blow to the enemy air power in eastern Java.

After that, the land-based air unit carried out air strikes on Surabaya, Malang, Bali and other places with more than a dozen aircraft on the 7th, the 8th and the 9th. From the 10th onwards, in order to act in concert with the first carrier operation of the Carrier Task Force, it shifted the focus of its attacks to western New Guinea as well as the Arafura Sea. From mid-[February], with the Bali operation ahead, the land-based air units again planned to conduct attacks on eastern Java [p. 311]. However, due to bad weather, which lasted for several days, it was not able to carry out air operations other than just an attack on Surabaya with twenty-three land-based attack planes and eight fighter planes on 18 February, one day before the raid on Bali. In the attack, the unit engaged with twenty [enemy] $\mathrm{P}-40$ fighter planes above Surabaya and reported military gains of having shot down nine (three of which unconfirmed). ${ }^{(71)}$

\section{Western Java}

As for [the air campaign on] western Java, on 9 February, sixteen fighter planes of the Air Unit of the Malaya Unit carried out strikes on Batavia for the first time from Kuching [p. 281]. Then on 11 February, twenty-seven land-based attack planes made a sortie for the first time from the Malay Peninsula for an attack on western Java. (However, due to bad weather the fighter plane unit was unable to participate, and the target of the attack was changed to [enemy] naval vessels in the Bangka area [pp. 290-291].)

After that, the Navy air units were day after day busily occupied with attacking enemy naval vessels in the Bangka area [pp. 291-292]. Also, the poor condition of the airfield at Kuching did not allow the aircraft [to take off] with a full load of fuel, which made it difficult for them to conduct air strikes on Java. On the other hand, the Army air unit had advanced powerful fighter plane and bomber units to Palembang from the 17th to the 18th of February, and launched a large-scale air campaign to destroy the enemy air power in western Java day in and day out from the 19th onwards. As many as thirty to fifty fighter planes and bombers were employed day after day, directing their attacks towards the airfields in Buitenzorg, Bandung, Kalijati, Batavia, etc. ${ }^{(117)}$

\section{The Malaya Unit's Cooperation in the Western Java Operation}

As described previously, the western Java invasion unit was particularly short of escort and support strength. However, before the Manila Conference the outlook for the war situation in the Singapore area was still dim, which made it impossible to estimate how much support could be expected from the Malaya Unit. In late January, after the Manila Conference, it was decided that, apart from the 5th Destroyer Squadron, two destroyer divisions, one minesweeper division, and the Yura from the Malaya Unit, some minesweeping and defense strength from the 1st Base Force as well as the 1st Section of the 6th Destroyer Division of the main body of the Southern Task Force should be added, which considerably increased the escort strength. However, since considerable counterattacks by [enemy] air as well as surface and submarine forces were expected against the advance of a large convoy of as many 
as fifty-five ships to Batavia, the last bastion of the allied forces, it was feared that even with this [reinforced] strength, the direct escort forces would still be insufficient, and that in case of a counterattack by an enemy fleet, the convoy would be totally bereft of support forces. On advancing to Cam Ranh Bay on 3 February, 5th Destroyer Squadron Commander Rear Admiral Hara had made a request to First Southern Expeditionary Fleet Commander in Chief Vice Admiral Ozawa for [the latter's] support and cooperation at the time of the western Java invasion [operation]. In response to the request of the 5th Destroyer Squadron commander, Commander in Chief [Ozawa] had advised that the First Southern Expeditionary Fleet would cooperate as much as possible if the war situation in the Malaya area would permit it, and that [Rear Admiral

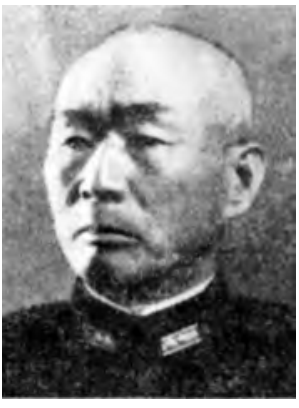

7th Cruiser Division Commander R. Adm. Kurita Takeo Hara] should offer his opinion to the Second Fleet since [such a matter] should be dealt with through the fleet, while indicating that he would dispatch the 7 th Cruiser Division for support if it should prove necessary.

On the evening of 16 February, when the outlook for the Bangka and Palembang operations had become clear, Malaya Unit Commander Vice Admiral Ozawa informed the Southern Task Force of his cooperation in the Java operation: "Regarding the Java operation, we won't mind if from 21 February onwards the Yura, the 11th and the 12th Destroyer Divisions, the 1st Minesweeper Division, the Kamikawa-maru, two auxiliary submarine chasers, two fishing boats and the supply ship Tsurumi should be transferred to the Dutch East Indies Unit."(63) Also on the 17th, without waiting for orders from the Southern Task Force, he issued on his own initiative an order to 7th Cruiser Division Commander R. Adm. Kurita Takeo about the support for the 5th Destroyer Squadron: "The 7th Cruiser Division commander shall lead both the 7th Cruiser Division as well as 19th Destroyer Division (minus the Isonami) and take charge of the support for the 3d Escort Unit of the Dutch East Indies Unit at the time of the Java operation." (63)

Having been notified by the Malaya Unit, the Southern Task Force issued on the 17th a preliminary order to transfer one element of the surface forces of the Malaya Unit to the Dutch East Indies Unit; at the same time it announced its plan to put the main force of the 22d Air Flotilla of the Air Unit of the Malaya Unit back under the command of Eleventh Air Fleet Commander in Chief Vice Admiral Tsukahara in order to conduct the air campaign on Java under a unified command. ${ }^{(63)}$ The order read:

\section{Second Fleet Classified Telegram No. 978}

Southern Task Force Telegraphic Order No. 103 [idem p. 298]

1. As of 21 February, the disposition of forces shall be changed as follows:

(a) [To be transferred] from the Malaya Unit to the Dutch east Indies Unit: The Yura, the 11th and the 12th Destroyer Divisions, the 1st Minesweeper Division, the Kamikawa-maru, two auxiliary submarine chasers, two fishing boats, and the Tsurumi.

(b) [To be transferred] from the Malaya Unit to the Air Unit: The 22d Air Flotilla (minus the Mihoro Air Group), a detachment from the 21st Air Flotilla and a detachment (minus Type-96 carrier-based fighter planes) from the 23d Air Flotilla.

2. The Malaya Unit shall cooperate in the western Java invasion operation, while staying engaged in its own mission. 
On the early morning of the 18th, 5th Destroyer Squadron Commander Rear Admiral Hara sent a request to the chief of staff of the First Southern Expeditionary Fleet concerning the cooperation by the Malaya Unit. ${ }^{(63)}$

1. Besides carrying out a preliminary air campaign to destroy the enemy air power, I request that in the western Java operation there will be conducted at the same time an operation to destroy enemy naval vessels in the western part of the Java Sea as well as in the Sunda Strait.

2. Concerning the cooperation by the 7th Cruiser Division, I request that, in the light of the recent increase in enemy naval vessels in the western part of the Java Sea, the 7th Cruiser Division will [first] operate near the Karimata Strait, and thereafter sail by and large along with the transport ships while staying in close contact so that it can immediately destroy enemy vessels. Also, if possible, I would like the Ryujjo to take appropriate actions and provide support as well, so that it will be able to attack enemy naval vessels.

3. Our unit will leave Cam Ranh Bay on 18 February.

Having received this telegram of request, Malaya Unit Commander Vice Admiral Ozawa gave on the 18th an order to 22d Air Flotilla Commander Rear Admiral Matsunaga concerning the air operations against western Java: "The 1st Air Unit shall contact the Eleventh Air Fleet and assume the responsibility for conducting a timely search and attack mission on enemy naval vessels in the western part of the Java Sea and the Sunda Strait, in addition to its mission of destroying the enemy air power in western Java." ${ }^{(63)}$ By this order, the units for the western Java invasion [operation] were able to depart from Cam Ranh Bay with the prospect of being able to obtain from the Malaya Unit by and large the support and cover they had hoped for.

\section{The Participation of the Sakaguchi Detachment in the Eastern Java Invasion Operation}

After having captured Davao, Jolo, Tarakan and Balikpapan one after another and dispatched one element to capture Banjarmasin, the Sakaguchi Detachment was in charge of clearing Balikpapan [of the enemy] and maintaining public order with its main force. However, since it was decided that the Navy should take charge of the military administration and the guarding of Dutch Borneo, the detachment was successively handing over the tasks to the Navy side. Then, the successive delays in the schedule of the Java operation gave the Sakaguchi Detachment some leeway in its schedule to reorganize the unit after the seizure of Balikpapan. On 10 February, when the seizure of Banjarmasin was accomplished, the detachment offered to the Sixteenth Army a proposal to participate in the eastern Java operation. The Sixteenth Army then assigned the Sakaguchi Detachment to land in eastern Java and charge to Cilacap to seize the place. Thus, leaving about one battalion to maintain public order in Samarinda and Balikpapan, most of the rest of the Sakaguchi Detachment came to participate in the Java operation.

On the 17th, 4th Destroyer Squadron Commander Rear Admiral Nishimura held talks on the escort for the Sakaguchi Detachment with 48th Division Commander Lt. Gen. Tsuchihashi Yūitsu in Jolo, where the following was decided: ${ }^{(56)}$ (Summary)

1. The Sakaguchi Detachment shall embark on the Ehime-maru and the Havana-maru, and join the convoy of the 48th Division in the Makassar Strait. The Navy shall assign the Kawakaze and Submarine Chaser No. 4 of the 1st Escort Unit for its escort. 
2. As for the rear units of the detachment, since the Sasako-maru and the Sagami-maru, [currently] engaged in the [operation to] capture Bali, will return to Makassar on 20 February or later, they shall be sent to Banjarmasin to embark the [rear units of the] detachment, and disembark them roughly by about 27 February. The Navy shall escort these ships with forces of the $2 \mathrm{~d}$ Base Force.

\section{The Situation Right Before the Invasion [Operation]}

The western and the eastern Java invasion units of the Dutch East Indies Unit had respectively assembled in Cam Ranh Bay and Jolo on 12 and 13 February, and were hurriedly preparing for the operation, aiming to land on 26 February. The developments until 21 February right before the invasion of Java were in summary as follows:

14 February: The positions of the units involved as of that day were as follows:

Cam Ranh Bay: The 5th Destroyer Sqdn (the Natori, the 5th and the 22d Destroyer Divs), the 1st Section of the 6th Destroyer Div, the Shirataka, the Myōkō-maru, the 1st Section of the 21st Torpedo Boat Div, the San'yo-maru, Patrol Boat No. 35 and fifty-five transport ships of the Army (the main force of the Sixteenth Army)

Jolo: The Ashigara (the flagship of the Third Fleet), the 4th Destroyer Sqdn (the Naka, the $2 \mathrm{~d}$ Destroyer Div, the 9th Destroyer Div (minus the Yamagumo), the 24th Destroyer Div (minus the Suzukaze)), the Itsukushima (the flagship of the 2d Base Force), the Wakataka, the 11th, the 30th and the 20th Minesweeper Divs, ${ }^{*}$ the 21st Subchaser Div (six submarine chasers), the Chitose, Patrol Boats No. 34 and No. 38, the 54th Subchaser Div and thirtynine transport ships of the Army (the 48th Div)

Balikpapan: The $2 \mathrm{~d}$ Section of the 21st Torpedo Boat Div (the Tomozuru), the Sanuki-maru (minus the aircraft unit) and two transport ships of the Army (the Sakaguchi Det)

Makassar: The aircraft unit of the Sanuki-maru and Patrol Boat No. 36

Palau: The 4th Cruiser Div (minus the Chōkai, the flagship of the Second Fleet [Malaya Unit]), the 3d Battleship Div, the 8th Cruiser Div, the 1st Destroyer Sqdn (the Abukuma, the 17th Destroyer Div, the 2d Section of the 27th Destroyer Div), the 1st Carrier Div (the flagship of the First Air Fleet), the 2d Carrier Div, the 4th Destroyer Div, the 18th Destroyer Div (minus two destroyers) and the Akigumo

\section{February}

1. The Carrier Task Force (the 1st and the $2 \mathrm{~d}$ Carrier Divs, the Takao, the Maya, the 8th Cruiser Div, the 1st Destroyer Sqdn (minus the 6th Destroyer Div, the 1st Section of the 27th Destroyer Div and the 21st Destroyer Div), the 18th Destroyer Div (minus two destroyers) and the Akigumo) left Palau for Port Darwin for the first carrier operation. ${ }^{(68)}$

2. The Dutch East Indies Unit commander postponed for one day the departure of the main unit (the Ashigara and the Yamakaze) from Jolo, scheduled for the 16th, to the 17th, so as to arrive in Staring Bay on the 19th. ${ }^{(53)}$ It was because the schedule of the Dutch East Indies operation was postponed and also because the meetings in Jolo took too much time.

3. The Malaya Unit launched [the operation to] capture Bangka and Palembang (as previously told [p. 295]).

4. Singapore, Britain's largest base in East Asia, surrendered.

\section{February}

1. Since it was not possible to conduct the expected search and attack missions in the Surabaya area due to bad weather in the Makassar Strait area day after day, Dutch East Indies Unit Commander Vice Admiral Takahashi decided to postpone the operation to capture Bali for one day, to be executed on the 19th, (as previously told [p. 311]). ${ }^{(78)}$

\footnotetext{
* Actually: the 11th and 30th Minesweeper Divs, and Minesweeper No. 20. See p. 126.
} 
2. Since considerably powerful [enemy] naval surface vessels including cruisers were spotted by an air reconnaissance over the Surabaya area, the Dutch East Indies Unit commander called off the main unit's sailing to Staring Bay and changed [its destination] so as to advance to Balikpapan to be ready for the Bali operation. ${ }^{(62)}$

3. Malaya Unit Commander Vice Admiral Ozawa reported to the Southern Task Force that he would not mind if the forces [in his unit] that were supposed to participate in the western Java invasion operation would be transferred to the Dutch East Indies Unit from 21 February onwards (as previously told [p. 369]).

4. At midnight, the Sixteenth Army communicated that it would request arrangements to be made with the 48th Div concerning the participation of the Sakaguchi Det and the escort to be provided (as previously told [p. 370]).

5. At 1840 on that day, the Dutch East Indies Unit commander incorporated the aircraft unit of the Sanuki-maru, Patrol Boat No. 36 and two fishing boats (at Makassar) into the 2d Air Unit.

\section{February}

1. At 0615, the Dutch East Indies Unit commander left Jolo for Balikpapan, leading the main unit (the Ashigara, the Kawakaze and the Yamakaze).

2. Fourth Destroyer Sqdn Commander Rear Admiral Nishimura held talks in Jolo concerning the outline of the escort of the Sakaguchi Det.

3. The Malaya Unit commander issued an order to the 7th Cruiser Div and the 19th Destroyer Div to support the 5th Destroyer Sqdn at the time of the western Java invasion [operation] (as previously told [p. 369]).

4. Southern Task Force Commander Vice Admiral Kondō issued preliminarily orders to the forces of the Malaya Unit that were to be transferred to the Dutch East Indies Unit and the Air Unit as of 21 February [for the Java operation], while issuing an order to the Malaya Unit to support the western Java invasion operation (as previously told [pp. 298, 369-370]).

\section{February}

1. At 1000, the unit for the western Java invasion [operation] left Cam Ranh Bay.

2. The unit to capture Bali left Makassar before dawn (as previously told [p. 311]).

3. The main body of the Southern Task Force and the remaining force of the Carrier Task Force (the Atago, the 3d Battleship Div and the 4th Destroyer Sqdn*) left Palau for Staring Bay.

4. At 1400, the main unit of the Dutch East Indies Unit advanced to Balikpapan.

\section{February}

1. In the early morning, the unit for the first [phase of the] Bali raiding operation successfully made a surprise landing on Bali (as previously told [p. 312]).

2. The Carrier Task Force carried out a surprise attack on Port Darwin, and the land-based attack planes of the Air Unit also attacked the place in concert with the former; they reported having sunk twenty or more enemy ships in the port, shot down or destroyed twenty or more enemy aircraft while having inflicted serious damage to the airfield, port facilities and others (as previously told [p. 341]).

3. The unit for the western Java invasion [operation] was sailing southward on the waters east of Puolo Condore.

4. At 0800, the unit for the eastern Java invasion [operation] left Jolo.

5. In the evening, the Chitose left Jolo.

6. The 22d Air Flotilla was transferred to the $3 \mathrm{~d}$ Air Raid Unit (as previously told).

\section{February}

1. In the early morning, the 2d Escort Unit disembarked the Army Itō Detachment at Kupang and Dili (as previously told [pp. 351, 355-356]).

2. The $3 \mathrm{~d}$ Yokosuka Special Landing Force parachuted down near Kupang (as previously told [p. 351]). 
3. Before dawn, the 8th Destroyer Division in the course of the Bali operation had engagements with a powerful enemy surface unit and reported military gains of having sunk three destroyers and seriously damaging one cruiser (as previously told*); [also] before dawn, the Dutch East Indies Unit commander left Balikpapan for Bali, leading the Ashigara, the Kawakaze (dispatched from the 4th Destroyer Squadron for the direct escort of the main unit) and the Yamakaze, to support the 7th Destroyer Division** (as previously told).

4. In the evening, the unit for the western Java invasion [operation] reached the waters between Puolo Condore and the Anambas Islands and sent the destroyers and the lesser escort naval vessels ahead to the Anambas Islands one after another for replenishment.

5. The unit for the eastern Java invasion [operation] was sailing southward in the Celebes Sea and approached the north entrance of the Makassar Strait in the evening. [Meanwhile] at 0800, the Chitose reached Dondon Bay ${ }^{* * *}$ in the northwestern part of Celebes, to [start] her mission to guard the invasion unit against [enemy] submarines.

6. Due to the appearance of an enemy task force on the waters northeast of Rabaul, the Combined Fleet ordered the 1st Air Group to advance to the area of the [equatorial] Pacific Islands by means of Telegraphic Order No. 76.

7. The Army 38th Division marched overland southward from Palembang and captured Tanjungkarang on the shore of the Sunda Strait opposite from Java.

8. The fighter plane unit of the Air Unit advanced to Bali (as previously told [p.321]).

\section{February}

1. At 0800 , the forces transferred from the Malaya Unit joined the unit for the western Java invasion [operation] about 100 nautical miles north of the Anambas Islands.

2. The Southern Task Force commander officially announced the date of Java invasion (day Z) as 26 February (as previously told. ${ }^{* * *}$ ).

3. In the morning, the main body of the Southern Task Force and the Carrier Task force, both having departed from Palau, the latter of which had finished the air strike on Port Darwin, arrived in Staring Bay (as previously told [p. 341]).

4. Because the sea engagement off Bali was over and no [immediate] counterattacks by the enemy fleet were expected anymore, the main unit of the Dutch East Indies Unit, which had been heading for the Bali area to support the 8th Destroyer Division, changed course en route and headed for Staring Bay (as previously told [p. 322]).

5. The Dutch East Indies Unit commander issued the following change of the disposition of his forces:

(1) He ordered the Mizuho and Patrol Boat No. 39, engaged in the Kupang operation, to return to their original unit (which had taken up positions for the eastern Java invasion operation, as previously told [p. 365]).

(2) He incorporated the 8th Destroyer Division into the main unit and had it stay on standby in Makassar (as previously told ${ }^{* * * * *}$ ).

6. In the early morning, the unit for the eastern Java invasion [operation] reached the north entrance of the Makassar Strait. In the evening, it reached a point about 80 nautical miles off Samarinda and heading for a point off Balikpapan, it sailed along the western side of the strait.

* Probably p. 320 is meant, but there different figures are cited.

** Probably the 8 th Destroyer Division is meant. See also below: item 4 under 21 February

*** Dondo Bay?

**** Probably p. 366, but there the announcement is made by the Dutch East Indies Unit commander. See also Vol. 3, pp. 440-41.

***** Probably p. 319, but there the date is mistakenly given as 22 February. See also Vol. 3, pp. 440-41. 


\section{The Army-Navy Arrangement and the Plan of Operations of Each Unit}

\section{The Army-Navy Arrangement for the Java Invasion Operation ([at] Manila)}

On 23 and 24 January, after having come to terms at the Manila Conference, the units to be involved in the Java invasion operation made the following Army-Navy arrangements (the outline of which has already been given [pp. 361-362]). The arrangement had the following contents $^{(148)}$ and came into effect along with the Manila Agreement of 28 January.*

\section{Memorandum of the Arrangements for Operation $\mathrm{H}$ between the Sixteenth Army, the \\ Third Air Force, the Third Fleet and the Eleventh Air Fleet [See also Vol. 3, pp. 226-233]}

I. Distribution of the landing forces, landing points, names for landing sectors and their reconnaissance

1. Landing points and names for landing sectors

(1) Units in the first transport

\{1\} Area No. 1 ([assigned to] the 2d Division and the main force of the units under the direct control of the army)

Sector A Landing Unit ([consisting of] 2 infantry battalions and a reconnaissance regiment as its core): on the south side of Merak

Sector B Landing Unit ([consisting of] 2 infantry battalions as its core): on the north side of Merak

Sector C Landing Unit ([consisting of] the main force of the [2d] Division and the main force of the units under the direct control of the army): along Bantam Bay

\{2\} Area No. 2 ([assigned to] the Shōji Detachment, [consisting of] 2 infantry battalions as its core): [on the coast near] Patrol

\{3\} Area No. 3 ([assigned to] the 48th Division as its core)

Sector D: Right Wing Unit ([consisting of] 3 infantry battalions as its core): on the north side of Kragan

Sector E: Left Wing Unit ([consisting of] the main force of the division): on the south side of Kragan

(2) Units in the second transport

Area No. 1: Batavia (or Bantam) about 100,000 tons

Area No. 3 Surabaya (or Kragan) about 50,000 tons

(3) Units in the third transport

Area No. 1: Batavia (or Bantam) about 100,000 tons

2. Reconnaissance of the landing points

(1) Reconnaissance by aircraft

Army: Thirty copies of the photomaps roughly on a scale of 1 to 25,000 of the landing coasts of Areas No. 1 and No. 2 shall be delivered to the [Sixteenth] Army headquarters in Saigon by around 10 February (three copies of which shall be delivered to the 12th Seaplane Tender Division (the Kamikawa-maru) in Cam Ranh).

Navy: Thirty copies of the photomaps roughly on a scale of 1 to 25,000 of the landing coast of Area No. 3 shall be delivered to the 48th Division in Jolo (the Pata anchorage) by around 10 February.

\footnotetext{
* The document referred to in note 148 could not be located. We have generally followed here the version given in Vol. 3.
} 
(2) Other prior reconnaissance, if necessary, shall be conducted by arrangement between the commanders of the landing corps, escort units and air units.

II. Assembly points, arrival and departure dates of the transport ships (as shown in the following table)

\begin{tabular}{|c|l|l|l|l|}
\hline Transport & \multicolumn{1}{|c|}{ Areas } & \multicolumn{1}{|c|}{ Assembly Points } & \multicolumn{1}{c|}{$\begin{array}{c}\text { Dates of } \\
\text { Departure }\end{array}$} \\
\hline \multirow{2}{*}{ First } & $\begin{array}{l}\text { Areas No. 1 } \\
\text { and No. 2 }\end{array}$ & $\begin{array}{l}\text { Gaoxiong then } \\
\text { Cam Ranh }\end{array}$ & $\begin{array}{l}\text { Leave Gaoxiong during the period between } \\
\text { the beginning till the 6th of February one } \\
\text { after another and assemble in Cam Ranh }\end{array}$ & Day H - 8 \\
\cline { 2 - 5 } & Area No. 3 & $\begin{array}{l}\text { Lingayen then the } \\
\text { Jolo/ Pata anchorage }\end{array}$ & $\begin{array}{l}\text { Complete embarkation by 7 February, leave } \\
\text { on 8 February and assemble at the Pata an- } \\
\text { chorage on 12 February }\end{array}$ & Day I - 7 \\
\hline \multirow{2}{*}{ Second } & Area No. 1 & $\begin{array}{l}\text { Advance from the mainland [Japan] to Cam Ranh first, and then go ashore in } \\
\text { Batavia (or Bantam) }\end{array}$ \\
\cline { 2 - 6 } & Area No. 3 & $\begin{array}{l}\text { Advance from Lingayen to Jolo or Davao and then go ashore in Surabaya (or Kra- } \\
\text { gan) }\end{array}$ \\
\hline \multirow{2}{*}{ Remarks } & $\begin{array}{l}\text { The Sixteenth Army commander shall determine the second and later transports after due con- } \\
\text { sultation with the commanders of the 4th and the 5th Destroyer Sqdns. }\end{array}$
\end{tabular}

III. Starting date and time of the landings and the schedule

1. Starting date and time of the landings and the schedule

The first day of the landings are set as follows:

Eastern Java: on Day I

Western Java: on Day $\mathrm{H}$

Although Days H and I are scheduled for "XX" (note by the author: pending), the Sixteenth Army commander shall fix [them] after due consultation with the commander in chief of the Third Fleet by 1200 on Day H - 9. However, if further changes to these [dates] become necessary after the departure [of the units], [new dates] shall be decided upon through consultations each time.

2. Start of the landings

Entry into the anchorage shall be made around 0000 for both Day H and Day I. Although the start of the landings is set at 0200 for both Day H and Day I, [the landings] in each area shall be started as soon as [the units] in the area are ready.

3. Landing schedule

(1) Units in the first transport

Area No. 1: [shall be completed] roughly in seven days.

Area No. 2: [shall be completed] roughly in five days. Depending on the circumstances, on Day $\mathrm{H}+2$ and onwards, units yet to be disembarked may be [again] transported and put ashore at Area No. 1. The decision of whether to implement [this] shall be made by the Sixteenth Army commander after due consultation with the 4th Destroyer Squadron* commander.

Area No. 3: [shall be completed] roughly in five days.

(2) Units in the second transport

Area No. 1: [shall be completed] roughly in five days.

Area No. 3: [shall be completed] roughly in five days.

* Actually: 5th Destroyer Squadron. 
IV. Distribution of the convoy of transport ships, the commander's whereabouts, and the escort forces:

\begin{tabular}{|c|c|c|c|c|c|c|c|}
\hline \multirow[t]{2}{*}{ Transport } & \multirow{2}{*}{\multicolumn{2}{|c|}{ Areas and Groups }} & \multirow[t]{2}{*}{ Units } & \multirow{2}{*}{$\begin{array}{c}\text { Number of } \\
\text { Ships }\end{array}$} & \multicolumn{2}{|c|}{$\begin{array}{l}\text { Commander's } \\
\text { Whereabouts }\end{array}$} & \multirow[t]{2}{*}{ Escort Forces } \\
\hline & & & & & Army & Navy & \\
\hline \multirow{6}{*}{ First } & & 1st Group & $\begin{array}{c}\text { Sector A } \\
\text { landing unit }\end{array}$ & 8 & $\begin{array}{c}\text { Inf Gp Cdr: } \\
\text { Kōyō-maru }\end{array}$ & & \multirow{4}{*}{$\begin{array}{l}\text { 5th Destroyer } \\
\text { Sqdn and } 6 \text { de- } \\
\text { stroyers, } 1 \\
\text { light cruiser, } \\
\text { and } 5 \\
\text { minesweepers } \\
\text { of the South- } \\
\text { ern Expedi- } \\
\text { tionary Fleet } \\
\text { as the core }\end{array}$} \\
\hline & & 2d Group & $\begin{array}{c}\text { Sector B } \\
\text { landing unit }\end{array}$ & 6 & $\begin{array}{l}\text { Rgt Cdr: } \\
\text { Reiyō-maru }\end{array}$ & & \\
\hline & Area No. 1 & 3d Group & $\begin{array}{l}\text { Sector C } \\
\text { landing Unit } \\
\text { (main force of } \\
\text { the [2d] Div } \\
\text { and main } \\
\text { force of the } \\
\text { units under } \\
\text { the direct con- } \\
\text { trol [of the } \\
\text { 16th Army]) }\end{array}$ & $\begin{array}{c}27 \\
2 \text { munition } \\
\text { ships, } \\
1 \text { No. } 333, \\
1 \text { water sup- } \\
\text { ply ship, } \\
1 \text { coaling ship, } \\
1 \text { repair ship }\end{array}$ & $\begin{array}{c}\text { Army Cdr: } \\
\text { Sakura-maru } \\
\text { Div Cdr: } \\
\text { Ayatosan- } \\
\text { maru }\end{array}$ & Natori & \\
\hline & Area No. 2 & 4th Group & Shōji Det & 7 & $\begin{array}{l}\text { Rgt Cdr: } \\
\text { Suwa-maru }\end{array}$ & $\begin{array}{l}\text { Yura or } \\
\text { Sendai } \\
\text { (depend- } \\
\text { ing on } \\
\text { the situa- } \\
\text { tion) }\end{array}$ & \\
\hline & & 5th Group & $\begin{array}{c}\text { Right Wing } \\
\text { Unit }\end{array}$ & 6 & $\begin{array}{l}\text { Rgt Cdr: } \\
\text { Aden-maru }\end{array}$ & & \\
\hline & Area No. 3 & 6th Group & $\begin{array}{l}\text { Left Wing } \\
\text { Unit } \\
\text { (main force of } \\
\text { the [48th] } \\
\text { Div) }\end{array}$ & $\begin{array}{l}19 \\
2 \text { munition } \\
\text { ships } \\
1 \text { water sup- } \\
\text { ply ship } \\
1 \text { coaling ship } \\
1 \text { hospital ship } \\
1 \text { repair ship }\end{array}$ & $\begin{array}{c}\text { Div Cdr: } \\
\text { Teiyō-maru } \\
\text { Inf Gp Cdr: } \\
\text { Tonegawa- } \\
\text { maru }\end{array}$ & Naka & $\begin{array}{l}\text { 4th Destroyer } \\
\text { Sqdn (minus } 1 \\
\text { destroyer div) } \\
\text { and one ele- } \\
\text { ment of the 2d } \\
\text { Base Force }\end{array}$ \\
\hline Second & $\begin{array}{l}\text { Area No. } 1 \\
\text { Area No. } 3\end{array}$ & \multicolumn{6}{|c|}{ To be determined depending on the situation at the time } \\
\hline
\end{tabular}


V. Route of the convoys

As shown in Supplement No. 1 (omitted by the author)

VI. Reconnaissance and diversions

The Navy air units shall conduct feint bombings of enemy naval bases and others in the

Probolinggo area (note by the author: southeast of Surabaya).

VII. Anchorage and the formation at the anchorage

Anchorages and the transport ships' formation at the anchorage shall be determined by the commander of the landing corps after due consultation with the commander in charge of the escort.

VIII. Outline of landing attack

Although [the landing shall be made as] a surprise landing in principle, it shall be carried out by assault if the situation should require it.

IX. Use of air units

1. Forces to be employed

(1) The Eleventh Air Fleet

About 80 Type-1 land-based attack planes, about 35 Type-96 land-based attack planes, about 70 Type- 0 fighter planes, and about 5 land-based reconnaissance planes

(2) The Third Fleet

About 50 reconnaissance seaplanes

(3) The [Army] Third Air Force

About 15 command reconnaissance planes, about 4 army reconnaissance planes, about 40 Type- 1 fighter planes, about 50 Type- 97 fighter planes, about 20 assault planes, about

20 twin-engine light bombers, and about 30 heavy bombers

The above forces may slightly be increased or decreased depending on the situation.

2. Bases to be used

(1) [Bases] in Sumatra, Borneo and others

\{1\} The Palembang [airfield] shall be made ready and used by the Army. The Navy may use this [base] by advancing some land-based attack planes, or as a staging base for about thirty-six land-based attack planes when attacks on enemy surface forces in the Indian Ocean are necessary.

\{2\} The Mentok [airfield] shall be made ready for use mainly by the Army, but with the cooperation of the Navy. The Army and the Navy shall share the airfield with about thirty fighter planes each. However, when the Army starts using the Tanjungkarang airfield, the Navy shall exclusively use the Mentok airfield.

\{3\} The Ledo [airfield] shall be used by the Navy. However, the Army may advance several command reconnaissance planes there.

\{4\} As for the airfields other than the above, those in Sumatra shall be used by the Army, and those in Borneo by the Navy.

(2) [Bases] in Java

\{1\} [The airfields in] Batavia and Cililitan (note by the author: east of Batavia*) shall be made ready for use by the Army and shared by the Army and the Navy in the following way:

The Navy: about 36 land-based attack planes and about 27 fighter planes

The Army: about 20 twin-engine light bombers and about 15 command reconnaissance planes

\{2\} The Buitenzorg [Bogor] and Kalijati [airfields] shall be made ready and used by the Army. However, if the Batavia or Cililitan airfields cannot be used or if it takes more time than expected to make them ready, the Navy shall advance about 27 fighter planes to the Kalijati [airfield].

* Actually: South of Batavia; the civil airfield, Kemayoran, was east of the city 
3. Outline of operations

(1) [We shall] promptly destroy the enemy air power in Java. The areas assigned [to the Army or the Navy] in particular are as follows:

$\{1\}$ The areas assigned [to the Army and the Navy] after the advance of the Army air units to Palembang are roughly decided as follows:

The Navy: [the area] east of $108^{\circ} \mathrm{E}$

The Army: [the area] west of $108^{\circ} \mathrm{E}$

$\{2\}$ In general the Navy shall mainly take charge of destroying the remnants of the enemy air power after the Army has gone ashore.

(2) The attack on enemy naval vessels shall be mainly assigned to the Navy.

(3) Cover of the convoy under sail and at anchorage

$\{1\}$ The main force of the Sixteenth Army

(a) The Navy shall be charged with the cover before and on Day $\mathrm{H}-2$.

Note: [The cover] in the area north of $5^{\circ} \mathrm{N}$ shall be provided by the First Southern Expeditionary Fleet.

(b) The cover of the transport convoy up to the point of separation of the Shōji Detachment from the main force of the army ([indicated as] point "J" in Supplement No. 1) on Day H - 1 shall be charged to the Navy. After that, the Navy shall take charge of the cover of the Shōji Detachment, and the Army of the cover of the rest of the main force of the [Sixteenth] Army. However, guarding against [enemy] submarines shall be wholly assigned to the Navy.

\{2\} The 48th Division

Along with guarding against [enemy] submarines, the Third Fleet shall take charge of guarding in the air [against enemy aircraft over the anchorage] as well, from the time when the transport convoy enters the anchorage until the advance of the fighter plane unit of the Eleventh Air Fleet there. After that, the Eleventh Air Fleet shall take over [the task of] guarding.

$\{3\}$ The antiaircraft guarding in the air over the anchorage

The guarding in the air against [enemy] aircraft shall be provided by the Army all the time until sunset on Day $\mathrm{H}+2$ over the anchorage for the units landing in Bantam, and on Day $\mathrm{H}+1$ over that for the units landing in Merak. After that, it shall provide cover in the air [against enemy aircraft] as needed depending on the situation.

(4) Support of the ground operations

$\{1\}$ The area of the main force of the Sixteenth Army

(a) The Army shall be in charge of the direct support of the ground operations.

(b) The Navy shall be in charge of cutting off the transport routes of the enemy in the Cilacap area. It shall [also] be in charge of attacking enemy reinforcements or forces in retreat when requested by the Army.

\{2\} The area of the 48th Division

The Third Fleet shall be in charge of direct support of the ground operations and the Eleventh Air Fleet shall appropriately provide support at the request of the Army. The Army shall join in [the direct support] if possible.

4. Information

(1) Military gains of [the campaign] to destroy the [enemy] air power, the results of reconnaissance of enemy airfields, weather information and others shall promptly be shared between the Army and the Navy air units.

(2) Other information concerning enemy movements and others shall be exchanged every time [it is obtained].

5. Allotment [of facilities] and rules about the use of the shared airfields 
The allotment [of facilities] and rules about the use of the airfields shared by the Army and the Navy shall be arranged between senior commanding officers of the Army and the Navy [units] which [actually] use the airfield.

6. Identification of friends

Conforms to the agreement between the Southern Army and the Combined Fleet.

$X$. Defense facilities of landing bases

1. The landing bases shall be set up as follows:

For Areas No. 1 and No. 2: Batavia (Bantam shall be used at the beginning.)

For Area No. 3: Surabaya (Kragan shall be used at the beginning).

2. The Navy shall take charge of the sea defense, the Army of the defense on land, and both shall jointly take charge of the air defense.

XI. Move of the transport ships after the completion of disembarkation After completing disembarkation, [the transport ships] shall separately return under the direct or indirect cover of the escort unit in the area to the required areas.

XII. Signal Communications

As specified in the signal communication arrangement in the separate volume (omitted by the author)

XIII. Others

1. The 48th Division shall have an element seize the Bali airfield in conjunction with the Navy no later than Day I - 2 to make it ready for use, with the aim of advancing a naval air base.

2. The Navy, in concert with the ground operations, shall neutralize [the enemy on] the waters south of Java, and block the enemy's retreat.

3. Details other than the above shall be discussed and decided between the commanders of the landing corps, escort forces and air units concerned.

As mentioned before, along with the Manila Agreement, which had officially become effective on 28 January, this draft of the arrangements for Operation $\mathrm{H}$ (of 23 January) [officially] came into effect on 30 January. Although the dates of Day H and Day I had been respectively set for Day X + 75 (21 February) and Day X + 77 (23 February), later on 10 February, due to the delay in the southern Sumatra operation, the dates of Day H and Day I were revised to 26 February [for both].

\section{The Plan of Operations of the Dutch East Indies Unit}

As previously told, on 28 January, Dutch East Indies Unit Commander Vice Admiral Takahashi announced the plan of operations of the Dutch East Indies Unit from the Makassar operation until the Java invasion operation ([by means of] Operation Order No. 9), the outline of which was as follows: ${ }^{(54,55,56)}$

\section{Mission}

After the capture of Ambon, the Dutch East Indies Unit shall capture Makassar, Bali and Kupang with the Eastern Support Unit, the 2d Escort Unit, the 1st Base Unit and the 2d Air Unit. At the same time, it shall escort and put ashore the Sixteenth Army on western Java with the 3d Escort Unit and the 1st Air Unit, and on eastern Java with the 1st Escort Unit, the 2d Base Unit and the $2 \mathrm{~d}$ Air Unit. The date of landing in western Java is scheduled for 21 February (Day H) and that in eastern Java for 23 February (Day I).

II. Disposition of forces

The disposition of forces shall be planned as in the following table and set in motion by special orders after occupying Ambon. 


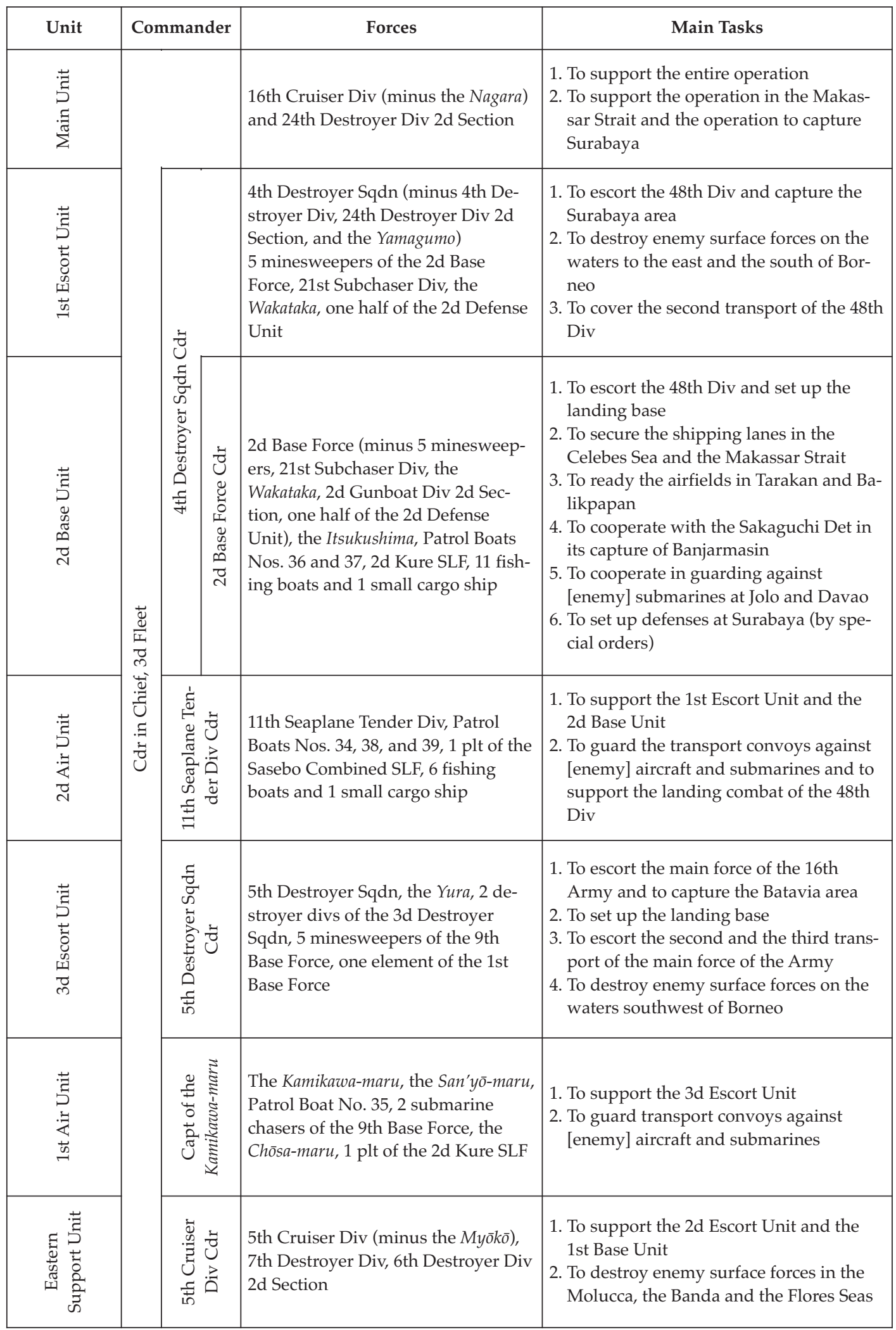




\begin{tabular}{|c|c|c|c|c|c|}
\hline 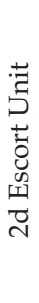 & \multirow{4}{*}{ 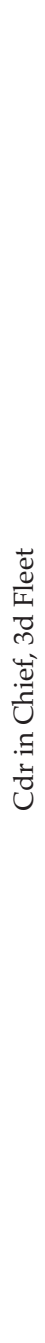 } & \multirow[b]{2}{*}{ 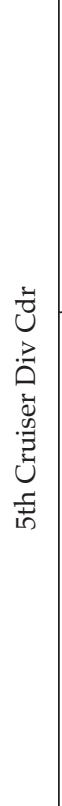 } & 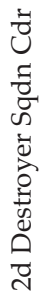 & $\begin{array}{l}\text { 2d Destroyer Sqdn (minus 18th De- } \\
\text { stroyer Div), 9th Construction } \\
\text { Squad, } 2 \text { plts of the Sasebo Com- } \\
\text { bined SLF, one element of the 3d } \\
\text { Military Supplies Dept, } \\
3 \text { minesweepers of the 1st Base Force } \\
\text { (at the time of [the operation to] cap- } \\
\text { ture Kupang) }\end{array}$ & $\begin{array}{l}\text { 1. To escort the Army Itō Det and capture } \\
\text { Kupang } \\
\text { 2. To rapidly prepare and secure the air- } \\
\text { field there } \\
\text { 3. To destroy enemy surface forces in the } \\
\text { Molucca, the Banda and the Flores Seas } \\
\text { 4. To guard the sea near Menado and } \\
\text { Ambon after the capture of Kupang }\end{array}$ \\
\hline 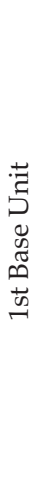 & & & 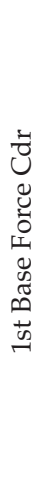 & $\begin{array}{l}\text { 1st Base Force (minus one element), } \\
\text { the Nagara, 21st Destroyer Div } \\
\text { (minus the Hatsuharu), 1st Patrol } \\
\text { Boat Div (minus } 6 \text { patrol boats), 5th } \\
\text { and 6th Construction Squads, bulk } \\
\text { of the Sasebo Combined SLF (until } \\
\text { [the operation to] capture Makas- } \\
\text { sar), one element of the 3d Military } \\
\text { Supplies Dept, } 5 \text { fishing boats, 8th } \\
\text { Destroyer Div (until [the operation } \\
\text { to capture] Bali), 15th Destroyer Div } \\
\text { (until [the operation to capture] } \\
\text { Makassar) }\end{array}$ & $\begin{array}{l}\text { 1. To seize Makassar and rapidly prepare } \\
\text { the airfield there, while destroying } \\
\text { enemy surface forces on the waters in } \\
\text { the area } \\
\text { 2. To escort the army units, carry out a } \\
\text { sudden attack on Bali and rapidly pre- } \\
\text { pare the airfield there } \\
\text { 3. To set up defenses at Batavia (by special } \\
\text { orders) }\end{array}$ \\
\hline 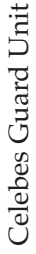 & & 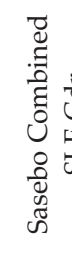 & & $\begin{array}{l}\text { Bulk of the Sasebo Combined SLF } \\
\text { (after the capture of Makassar), 2d } \\
\text { Gunboat Div 2d Section }\end{array}$ & To guard Menado, Kendari and Makassar \\
\hline 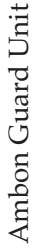 & & 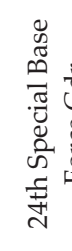 & & $\begin{array}{l}\text { 24th Special Base Force (from } 5 \text { Feb- } \\
\text { ruary onwards) } \\
\text { 1st Kure SLF (except for the units } \\
\text { kept in Legaspi and Jolo) }\end{array}$ & To guard Ambon \\
\hline
\end{tabular}

III. The main points of the execution of the Java operation and the outline of operations of each unit 1. Western Java

(1) After making arrangements with the Sixteenth Army commander at Gaoxiong, the $3 d$ Escort Unit commander shall advance to Cam Ranh Bay roughly by around 4 February to make the necessary preparations for the operation.

(2) The convoy of the Sixteenth Army shall advance from Gaoxiong to Cam Ranh Bay by around 10 February under the direct escort of the 5th Destroyer Squadron.

(3) The 3d Escort Unit (other than the forces to be transferred from the Malaya Unit) shall leave Cam Ranh Bay around 13 February, escorting the convoy of the main force of the Sixteenth Army. It shall take command of the forces transferred from the Malaya Unit en route around 17 February and, with the support and under the cover of the Air Unit of the Malaya Unit and the Army air units, it shall put ashore the army units at Bantam Bay, Merak and Patrol before dawn on 21 February. While taking charge of cover and support of the landing operations, it shall [also] take charge of clearing the areas surrounding the anchorage of enemy submarines and destroying enemy surface forces there. It shall also set up a landing base along Bantam Bay with one element. 
(4) The San'yō-maru and Patrol Boat No. 35 shall, by separate orders, arrive in Cam Ranh Bay by around 11 February, leave the bay around 13 February and join the Kamikawamaru around 16 February, while taking charge of the guarding of the transport convoy against [enemy] aircraft and submarines. After that, the 1st Air Unit shall continue the guarding of the transport convoy against [enemy] aircraft and submarines and support the $3 \mathrm{~d}$ Escort Unit.

(5) By special orders, the 1st Base Force shall set up defenses at the port of Batavia.

2. Eastern Java

(1) After making arrangements with the 48th Division commander at Gaoxiong, * the 1st Escort Unit commander shall escort the convoy of the division, which is at Lingayen, with the 4th Destroyer Squadron and advance to Jolo by around 12 or 13 February.

(2) The $2 d$ Base Unit commander shall have the forces, which are to be incorporated into the 1st Escort Unit, advance to Jolo by 12 February, cooperate in sweeping the anchorage [of mines] and clearing enemy submarines in the neighboring areas, and join the 1st Escort Unit after the 4th Destroyer Squadron arrives in Jolo.

(3) The 1st Escort Unit shall leave Jolo around 16 February, escorting the convoy of the 48th Division, and with the support and under the cover of the $2 \mathrm{~d}$ Air Unit and the Air Unit of the Southern Task Force, it shall put ashore the army units at Kragan before dawn on 23 February. While in charge of the cover and support of the landing operation, it shall also take charge of clearing the areas surrounding the anchorage of enemy submarines as well as destroying enemy surface forces there.

(4) The 2d Air Unit shall sail to Jolo after the Makassar operation, after which it shall cooperate with the 1st Escort Unit by guarding the transport convoy against [enemy] aircraft and submarines while roughly sailing along the 1st Escort Unit, and support the landing combat and ground combat of the army units.

(5) The 2d Base Unit shall deploy its forces at key places along the Makassar Strait and take charge of clearing enemy submarines from the sailing routes of the 1st Escort Unit. It shall also by and large follow in the wake of the unit to the Kragan anchorage and set up a landing base there. [Then] when required, it shall take back its forces that have been [temporarily] incorporated in the 1st Escort Unit, after which it shall clear the waterway leading to the Surabaya port, clear the area within the port and set up defenses there.

Due to changes in the circumstances, the disposition of forces in Operation Order No. 9 was later changed to some extent in the following way:

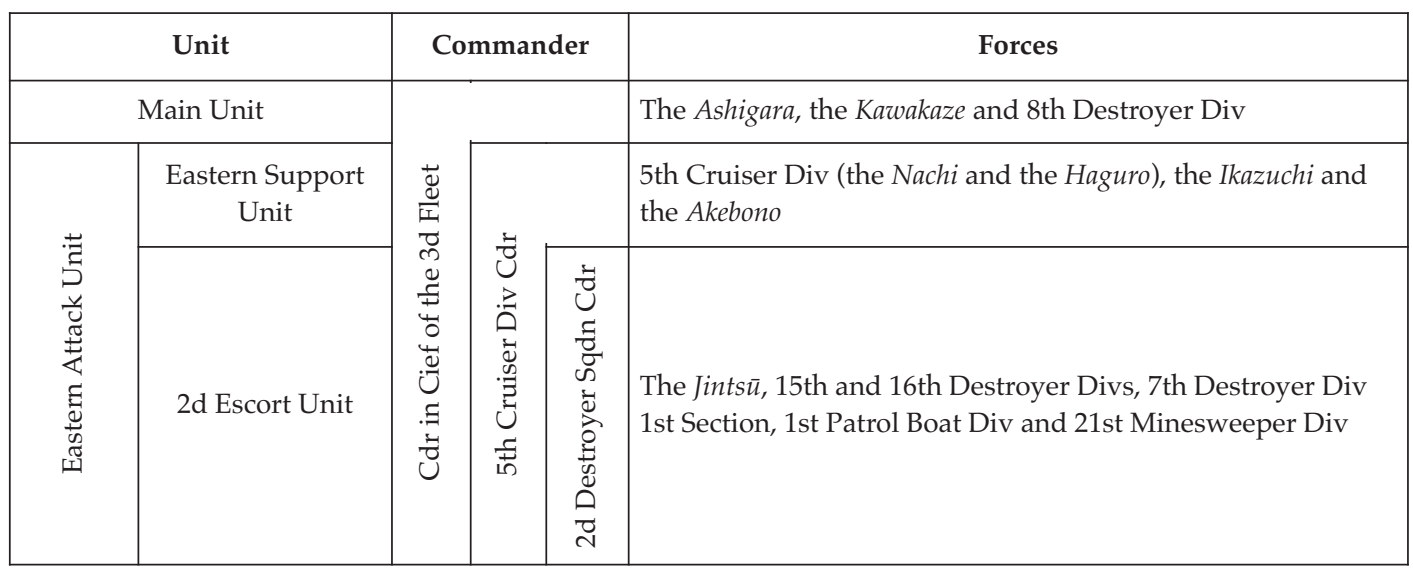

* Actually at Manila, see p. 391 


\begin{tabular}{|c|c|c|c|c|}
\hline 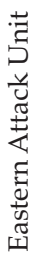 & 1st Base Unit & \multirow{6}{*}{ 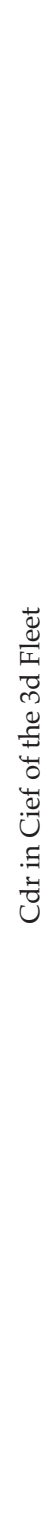 } & 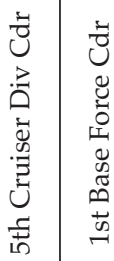 & $\begin{array}{l}\text { The Nagara, 21st Destroyer Div (minus the Hatsuharu), the } \\
\text { Tsukushi, 1st, 2d, 5th [52d?], and 12th Subchaser Divs, the } \\
\text { Kimishima-maru, the Ikushima-maru, the Aotaka, the Hakusan- } \\
\text { maru, one half of the 1st Defense Unit, 1st Signal Unit and the } \\
\text { Sanuki-maru [According to the order of the 3d Fleet, the latter } \\
\text { was under the command of the } 2 \mathrm{~d} \text { Base Force until } 6 \text { Febru- } \\
\text { ary, and the 1st Base Force after } 7 \text { February. See p. 365]. }\end{array}$ \\
\hline \multirow{2}{*}{ 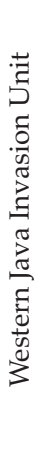 } & 3d Escort Unit & & 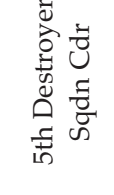 & $\begin{array}{l}\text { 5th Destroyer Sqdn (the Natori, 5th and 22d Destroyer Divs), } \\
\text { the Yura, 11th and 12th Destroyer Divs, 1st Minesweeper Div, } \\
\text { 6th Destroyer Div 1st Section, the Shirataka, the Myōko-maru } \\
\text { and 21st Torpedo Boat Div 1st Section }\end{array}$ \\
\hline & 1st Air Unit & & 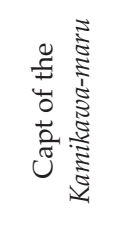 & $\begin{array}{l}\text { The Kamikawa-maru, the San'yo-maru, Patrol Boat No. 35, 91st } \\
\text { Subchaser Div and } 2 \text { fishing boats }\end{array}$ \\
\hline \multirow{3}{*}{ 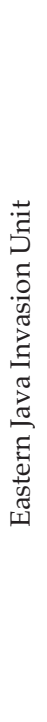 } & 1st Escort Unit & & 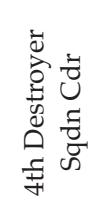 & $\begin{array}{l}\text { The Naka, 2d Destroyer Div, 9th Destroyer Div (minus the Ya- } \\
\text { magumo), 24th Destroyer Div (minus three destroyers), 11th } \\
\text { and 21st [30th?] Minesweeper Divs, Patrol Boat } \\
\text { [Minesweeper?] No. 20, 21st Subchaser Div, the Wakataka and } \\
\text { one half of the 2d Defense Unit }\end{array}$ \\
\hline & 2d Base Unit & & 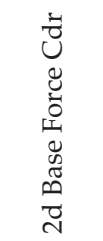 & $\begin{array}{l}\text { The Itsukushima, 21st Torpedo Boat Div 2d Section, } 2 \mathrm{~d} \text { Gun- } \\
\text { boat Div 1st Section, 31st Subchaser Div, one half of the } 2 \mathrm{~d} \\
\text { Defense Unit, 2d Signal Unit, the Sanuki-maru (minus the air- } \\
\text { craft unit), Patrol Boat No. } 37,8 \text { auxiliary naval vessels, } 9 \text { fish- } \\
\text { ing boats and the 2d Kure SLF }\end{array}$ \\
\hline & 2d Air Unit & & 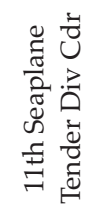 & $\begin{array}{l}\text { 11th Seaplane Tender Div (the Chitose and the Mizuho), Patrol } \\
\text { Boats Nos. 34, 38, } 39 \text { and 36, the aircraft unit of the Sanuki- } \\
\text { maru, and } 2 \text { fishing boats }\end{array}$ \\
\hline
\end{tabular}

Remark: The terms Eastern Attack Unit, and Eastern and Western Java Invasion Units have been employed by the author for convenience' sake.

\section{The Units Involved in the Western Java Invasion [Operation]}

\section{The Army-Navy Arrangements Between the Sixteenth Army and the 5th Destroyer Squadron}

The outline of the arrangement made at Gaoxiong on 27 January was as follows: ${ }^{(63)}$ 
1. The signatories

The Sixteenth Army commander, the 2d Division commander, the Shōji Detachment commander and the 5 th Destroyer Division commander

2. The assembly points and the program at the assembly points

(a) The transport ships shall successively arrive at Gaoxiong by 5 February, and then assemble at Cam Ranh Bay by 10 February.

(b) The program at Cam Ranh Bay

11 February: Meetings between the landing units of each sector and the escort units of each area, meetings between the captains of the ships and meetings concerning communications 12 February: Training by the army as such

3. The distribution of the transport ships (omitted)

4. The landing points and the distribution of forces (as in the following table)

\begin{tabular}{|c|c|l|l|l|}
\hline \multicolumn{2}{|c|}{ Name of the Areas } & Landing Points & \multicolumn{1}{c|}{$\begin{array}{c}\text { Core Forces } \\
\text { (Commander) }\end{array}$} & Transport Ships \\
\hline Sector A & South of Merak & $\begin{array}{l}\text { 2 Inf bns and a reconnaissance unit } \\
\text { (Major General Nasu) }\end{array}$ & 1st Group; 8 ships \\
\cline { 2 - 6 } & Sector B & North of Merak & $\begin{array}{l}\text { 2 Inf bns } \\
\text { (Colonel Fukushima) }\end{array}$ & 2d Group; 7 ships \\
\cline { 2 - 6 } & Sector C & $\begin{array}{l}\text { Western part of } \\
\text { Bantam Bay }\end{array}$ & $\begin{array}{l}\text { The main force of the [2d] Div and } \\
\text { the main force of the units under } \\
\text { the direct control of the [16th] } \\
\text { Army } \\
\text { (Colonel Satō) }\end{array}$ & 3d Group; 32 ships \\
\hline \multirow{2}{*}{ Area No. 2 } & Coast of Patrol & $\begin{array}{l}\text { 2 Inf bns } \\
\text { (Colonel Shōji) }\end{array}$ & 4th Group; 7 ships \\
\hline
\end{tabular}

5. The times and dates of the landings and the schedules (omitted)

6. The outline of the escort

(1) Scheduled sailing route: As shown in Separate Illustration No. 77 (omitted by the author)

(2) The sailing speed: 8 knots at normal speed

(3) Direct escort shall be provided.

The forces: the Natori, the Yura, sixteen destroyers, five minesweepers, and another vessel, of which the Yura, six destroyers and five minesweepers shall join en route.

(4) The protective sailing formation (omitted)

7. The entry into the anchorages, the landing combat and the cover (omitted)

8. The movements of the transport ships after the landing and the later-arriving transport ships (omitted)

9. Others (omitted)

\section{The Plan of Operations of the 3d Escort Unit}

In accordance with Dutch East Indies Unit Operation Order No. 9, the aforementioned ArmyNavy arrangement and the subsequent orders and instructions, 3d Escort Unit Commander Rear Admiral Hara announced on 1 February en route from Gaoxiong to Cam Ranh Bay his plan of operations for the capture of western Java by means of 3d Escort Unit Order No. 2, which was in outline as follows: ${ }^{(63)}$ 
1. The distribution of forces

(1) The 1st distribution of forces

\begin{tabular}{|c|c|c|c|c|}
\hline Unit & & Commander & Forces & Main Tasks \\
\hline Main Unit & \multirow{4}{*}{ 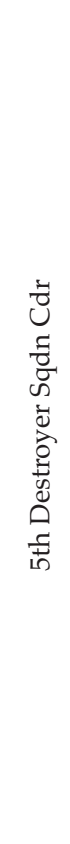 } & & $\begin{array}{l}\text { The Natori, 11th Destroyer Div, } \\
\text { 1st Minesweeper Div (minus } 1 \\
\text { minesweeper), the Shirataka, the } \\
\text { Myōko-maru and one half of 1st } \\
\text { Defense Unit }\end{array}$ & $\begin{array}{l}\text { To support the entire es- } \\
\text { cort as well as the opera- } \\
\text { tion }\end{array}$ \\
\hline 1st Guide Unit & & 5th Destroyer Div Cdr & 5th Destroyer Div & $\begin{array}{l}\text { To guide and escort the } 3 \mathrm{~d} \\
\text { Group (Sections } 1 \text { to } 4 \\
\text { until the the point where } \\
\text { the } 2 \mathrm{~d} \text { Guide Unit sepa- } \\
\text { rates [from the main con- } \\
\text { voy]) }\end{array}$ \\
\hline 2d Guide Unit & & 22d Destroyer Div Cdr & $\begin{array}{l}\text { 22d Destroyer Div, }{ }^{*} 12 \text { th De- } \\
\text { stroyer Div and 21st Torpedo } \\
\text { Boat Div 1st Section }\end{array}$ & $\begin{array}{l}\text { To guide and escort the } \\
\text { 1st and } 2 \mathrm{~d} \text { Groups (and } \\
\text { also Sections } 5 \text { and } 6 \text { of } \\
\text { the } 3 \mathrm{~d} \text { Group until the } \\
\text { separation point) }\end{array}$ \\
\hline 3d Guide Unit & & Capt of the Yura & $\begin{array}{l}\text { The Yura, 6th Destroyer Div 1st } \\
\text { Section, 22d Destroyer Div 2d } \\
\text { Section, and } 1 \text { Minesweeper of } \\
\text { the 1st Minesweeper Div }\end{array}$ & $\begin{array}{l}\text { To guide and escort the } \\
\text { 4th Group }\end{array}$ \\
\hline Remarks & \multicolumn{4}{|c|}{$\begin{array}{l}\text { 1. The Yura, the } 11 \text { th and the } 12 \text { th Destroyer Divs and the } 1 \text { st Minesweeper Div shall be trans- } \\
\text { ferred to the } 3 \mathrm{~d} \text { Escort Unit around } 16 \text { February. } \\
\text { 2. Until being joined by the Yura, the 6th Destroyer Division commander shall take command } \\
\text { of the 3d Guide Unit. }\end{array}$} \\
\hline
\end{tabular}

(2) The $2 d$ distribution of forces (from the entry into the anchorages onwards)

\begin{tabular}{|c|c|c|c|c|}
\hline Unit & & Commander & Forces & Main Tasks \\
\hline Main Unit & \multirow{3}{*}{ 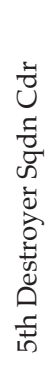 } & & The Natori & $\begin{array}{l}\text { To support and direct the } \\
\text { entire operation, and pro- } \\
\text { vide guard to the whole } \\
\text { [convoy] }\end{array}$ \\
\hline 1st Guard Unit & & 22d Destroyer Div Cdr & $\begin{array}{l}\text { 22d Destroyer Div 1st Section, } \\
\text { 12th Destroyer Div, 21st Torpedo } \\
\text { Boat Div 1st Section }\end{array}$ & To guard Sectors A and B \\
\hline 2d Guard Unit & & 5th Destroyer Div Cdr & 5th Destroyer Div & To guard Sector C \\
\hline
\end{tabular}

* According to the original archival document: minus the $2 d$ Section. See also the item directly below it. 


\begin{tabular}{|c|c|c|c|c|}
\hline 3d Guard Unit & \multirow{4}{*}{ 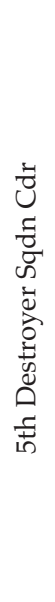 } & 11th Destroyer Div Cdr & 11th Destroyer Div & To guard Sector C \\
\hline 4th Guard Unit & & Capt of the Yura & $\begin{array}{l}\text { The Yura, 6th Destroyer Div 1st } \\
\text { Section, 22d Destroyer Div 2d } \\
\text { Section and } 1 \text { minesweeper of } \\
\text { the 1st Minesweeper Div }\end{array}$ & To guard Area No. 2 \\
\hline $\begin{array}{l}\text { Minesweeper } \\
\text { Unit }\end{array}$ & & $\begin{array}{l}\text { 1st Minesweeper Div } \\
\text { Cdr }\end{array}$ & $\begin{array}{l}\text { 1st Minesweeper Div } \\
\text { (minus } 1 \text { minesweeper) }\end{array}$ & $\begin{array}{l}\text { To sweep for mines in } \\
\text { the outer areas of Area C } \\
\text { and the anchorage of } \\
\text { Batavia }\end{array}$ \\
\hline Defense Unit & & Capt of the Shirataka & $\begin{array}{l}\text { The Shirataka, one half of the } 1 \text { st } \\
\text { Defense Unit and the Myōkō- } \\
\text { maru }\end{array}$ & Defense of Bantam Bay \\
\hline
\end{tabular}

2. The outline of the escort at sea (omitted by the author)

3. The outline of the entry into the anchorages (omitted by the author)

4. The outline of the guarding of the anchorages (omitted by the author)

5. The outline of the operations of the minesweeper unit (omitted by the author)

6. The outline of the operations of the defense unit (omitted by the author)

7. Communications (omitted by the author)

8. Supply (omitted by the author)

Concerning the outline of operations of the five fishing boats deployed as rescue ships for the army transport ships, 3d Escort Unit Commander Rear Admiral Hara gave the outline by Order No. 3 below on 10 February: ${ }^{(63)}$

1. The names of the fishing boats

The Kōyo-maru No. 6 (73 tons), the Taiei-maru No. 2 (61 tons), the Nanshin-maru No. 48 (50 tons), The Rokko-maru No. 12 (56 tons), and the Tenjin-maru (40 tons)

2. The Natori shall dispatch about ten armed communications personnel led by a sub-lieutenant or ensign.

3. The fishing boats shall sail ahead to the Anambas Islands, leaving Cam Ranh Bay on Day H 10. Then, they shall leave the islands on the afternoon of Day H -6 and, by way of Point $\mathrm{D}$, join the $3 \mathrm{~d}$ Escort Unit near Point I, after which they shall sail in the wake of the escort unit and enter into the anchorage of Area C.

4. After their arrival at the landing sector, the fishing boats shall be attached to the 1st Defense Unit until separately ordered otherwise, and stand by for rescue [operations] of the army transport ships.

In addition, the $3 \mathrm{~d}$ Escort Unit commander issued orders on the outline of setting up of a land [base] at Batavia (by the means of Order No. 6 on 15 February), the supply plan at the landing points (by means of Order No. 6 on 15 February), and the outline of the second transport of the main force of the Sixteenth Army (by means of Order No. 6 on 15 February). ${ }^{(63)}$

After having been assigned to support the 3d Escort Unit by Malaya Unit Telegraphic Operation Order No. 39 on 17 February [p. 369], 7th Cruiser Division Commander Rear Admiral 
Kurita announced the outline of the support for the 3d Escort Unit on 21 February as follows: ${ }^{(63)}$

The 7th Cruiser Division and the 19th Destroyer Division (minus the Ayamami) shall leave Anambas at 1800 on 22 February (Day $\mathrm{H}-4$ ), and reach an area close to the transport convoy at 1200 on 24 February, after which they shall appropriately operate on the western part of the Java Sea to support the 3d Escort Unit.

\section{The Plan of Operations of the 1st Air Unit}

On 12 February at Cam Ranh Bay, 1st Air Unit Commander R. Adm. Fujita Ruitarō* announced the operations of the 1st Air Unit in the Java invasion operation by means of Operation Order No. $1{ }^{(55)}$ which was in outline as follows:

1. The outline of tasks and operations of the naval vessels (as shown in the following table)

\begin{tabular}{|c|c|c|}
\hline Name of Ships & Main Tasks & Operations \\
\hline Kamikawa-maru & $\begin{array}{l}\text { Support for and guard of base } \\
\text { operations at the Anambas Is- } \\
\text { lands and the Batavia area }\end{array}$ & $\begin{array}{l}\text { 1. She shall stay at anchor while on guard near the Anam- } \\
\text { bas Base. } \\
\text { 2. Subsequent operations shall be ordered later. }\end{array}$ \\
\hline San'yo-maru & $\begin{array}{l}\text { Support for and guard of base } \\
\text { operations at the Anambas Is- } \\
\text { lands and the Batavia area }\end{array}$ & $\begin{array}{l}\text { 1. She shall advance to the Anambas [area] by Day H - } 7 \text {. } \\
\text { 2. Subsequent operations shall be ordered later. }\end{array}$ \\
\hline Patrol Boat No. 35 & $\begin{array}{l}\text { Transport of base personnel } \\
\text { and matériel }\end{array}$ & $\begin{array}{l}\text { 1. She shall advance to Mentok on the morning of Day } \mathrm{H} \\
-7 \text {. } \\
\text { 2. She shall sail to Lepar Island from Mentok on Day } \mathrm{H}- \\
6 \text {. } \\
\text { 3. She shall leave Lepar Island on Day } \mathrm{H}-1 \text {, arrive in } \\
\text { Bantam Bay on the morning of Day } \mathrm{H} \text {, refuel from the } \\
\text { Tsurumi on Day H, leave the bay on the morning of } \\
\text { Day } \mathrm{H}+1 \text { and arrive at Patrol on the afternoon of Day } \\
\mathrm{H}+1 \text {. } \\
\text { 4. Subsequent operations shall be ordered later. }\end{array}$ \\
\hline $\begin{array}{l}\text { Shōnan-maru } \\
\text { No. } 7 \text { and No. } 12\end{array}$ & $\begin{array}{l}\text { Guard of the base and the } \\
\text { mother ships under sail }\end{array}$ & $\begin{array}{l}\text { 1. They shall guard the Anambas base. } \\
\text { 2. Subsequent operations shall be ordered later. }\end{array}$ \\
\hline Two fishing boats & $\begin{array}{l}\text { Transport of base personnel } \\
\text { and matériel and guard of the } \\
\text { base }\end{array}$ & $\begin{array}{l}\text { 1. They shall sail to Lepar Island from Mentok on Day H - } \\
6 \text {. } \\
\text { 2. On Day H, after the takeoff of the aircraft unit, they } \\
\text { shall dismantle the Lepar base, and sail to Bantam Bay. } \\
\text { 3. Subsequent operations shall be ordered later. }\end{array}$ \\
\hline
\end{tabular}

* According to the tables on pp. 380, 383, the captain of the Kamikawa-maru (Capt. Shinoda Tarohachi) was the commander of the 1st Air Unit. According to pp. 163, 218, R. Adm. Fujita Ruitarō was the commander of the 2d Air Unit, which was to support the eastern Java operation. 
2. The distribution [of forces] for the air campaign*

\begin{tabular}{|c|c|c|c|c|c|c|c|}
\hline Date & No. & Tasks & $\begin{array}{c}\text { Departure } \\
\text { ([and] Arrival) } \\
\text { Points }\end{array}$ & $\begin{array}{c}\text { Times of } \\
\text { Takeoff } \\
\text { (and Return) }\end{array}$ & $\begin{array}{c}\text { Numbers and } \\
\text { Types of Air- } \\
\text { craft Em- } \\
\text { ployed }\end{array}$ & $\begin{array}{l}\text { Launching } \\
\text { Vessels }\end{array}$ & Comments \\
\hline \multirow{7}{*}{\begin{tabular}{l}
10 \\
1 \\
$I$ \\
\multirow{2}{*}{} \\
0
\end{tabular}} & \multirow{7}{*}{1} & \multirow{7}{*}{ 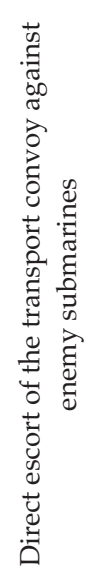 } & \multirow{7}{*}{$\begin{array}{l}\text { Anambas } \\
\text { (Ditto) }\end{array}$} & 0800 (1215) & $\begin{array}{l}1 \text { Three-seater } \\
\text { recon. sea- } \\
\text { plane }\end{array}$ & San'yō-maru & \\
\hline & & & & $1015(1430)$ & Ditto & Ditto & \\
\hline & & & & $1230(1545)$ & $\begin{array}{l}\text { 1 Observation } \\
\text { seaplane }\end{array}$ & Ditto & \\
\hline & & & & 1345 (1645) & Ditto & Ditto & \\
\hline & & & & 1445 (1745) & Ditto & Ditto & \\
\hline & & & & 1545 (1845) & Ditto & Ditto & \\
\hline & & & & 1645 (1950) & Ditto & Ditto & \\
\hline \multirow{7}{*}{ 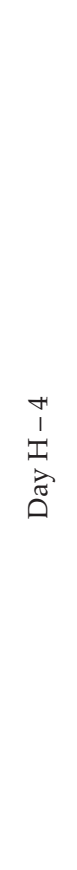 } & \multirow{6}{*}{2} & \multirow{6}{*}{ 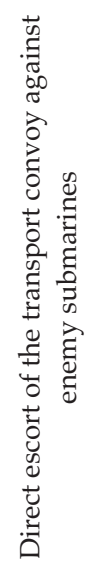 } & \multirow{6}{*}{$\begin{array}{l}\text { Anambas } \\
\text { (Ditto) }\end{array}$} & $0800(1200)$ & $\begin{array}{l}1 \text { Observation } \\
\text { seaplane }\end{array}$ & $\begin{array}{l}\text { Kamikawa- } \\
\text { maru }\end{array}$ & \\
\hline & & & & 1015 (1415) & Ditto & San'yō-maru & \\
\hline & & & & 1130 (1530) & Ditto & $\begin{array}{l}\text { Kamikawa- } \\
\text { maru }\end{array}$ & \\
\hline & & & & 1245 (1745) & $\begin{array}{l}1 \text { Three-seater } \\
\text { recon. sea- } \\
\text { plane }\end{array}$ & San'yō-maru & \\
\hline & & & & 1445 (1845) & Ditto & $\begin{array}{l}\text { Kamikawa- } \\
\text { maru }\end{array}$ & \\
\hline & & & & 1545 (1950) & Ditto & San'yō-maru & \\
\hline & 3 & 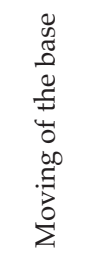 & $\begin{array}{c}\text { Anambas } \\
\text { (Lepar Island) }\end{array}$ & 0900 & $\begin{array}{l}4 \text { Observation } \\
\text { seaplanes } \\
4 \text { Observation } \\
\text { seaplanes }\end{array}$ & $\begin{array}{l}\text { Kamikawa- } \\
\text { maru } \\
\text { San'yo-maru }\end{array}$ & \\
\hline
\end{tabular}

* The following table is based on the "Action Report of the San'yō-maru." See: JACAR (https:/ / www.jacar.go.jp/) Ref: C08030661900 昭和16年11月7日～昭和17年5月23日 山陽丸戦闘詳報(4). There are, however, a number of differences. The major ones are: (1) The departure and arrival points on Day H - 2: Lepar Island (Ditto); (2) The tasks of the San'yo-maru on Day H - 1: Direct escort of the transport convoy ([of] the detachment unit) against enemy submarines; and (3) On Day H, two observation seaplanes of the Kamikawa-maru and the San'yō-maru shall depart from Lepar Island and advance to Patrol. 


\begin{tabular}{|c|c|c|c|c|c|c|}
\hline \multirow{8}{*}{$\begin{array}{l}0 \\
1 \\
1 \\
1 \\
\text { तే } \\
0\end{array}$} & \multirow{7}{*}{4} & \multirow{7}{*}{ 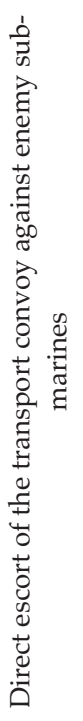 } & \multirow{7}{*}{$\begin{array}{l}\text { Lepar Island } \\
\text { (Ditto) }\end{array}$} & 0900 (1300) & $\begin{array}{l}1 \text { Observation } \\
\text { seaplane }\end{array}$ & $\begin{array}{l}\text { Kamikawa- } \\
\text { maru }\end{array}$ \\
\hline & & & & $1000(1400)$ & Ditto & San'yō-maru \\
\hline & & & & 1100 (1500) & Ditto & $\begin{array}{l}\text { Kamikawa- } \\
\text { maru }\end{array}$ \\
\hline & & & & 1215 (1615) & Ditto & San'yō-maru \\
\hline & & & & $1330(1730)$ & Ditto & $\begin{array}{l}\text { Kamikawa- } \\
\text { maru }\end{array}$ \\
\hline & & & & 1445 (1845) & Ditto & San'yō-maru \\
\hline & & & & 1545 (1950) & Ditto & $\begin{array}{l}\text { Kamikawa- } \\
\text { maru }\end{array}$ \\
\hline & 5 & 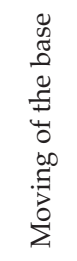 & $\begin{array}{c}\text { Anambas } \\
\text { (Lepar Island) }\end{array}$ & 0900 & $\begin{array}{l}1 \text { Observation } \\
\text { seaplane } \\
2 \text { Three-seater } \\
\text { recon. sea- } \\
\text { planes }\end{array}$ & $\begin{array}{l}\text { Kamikawa- } \\
\text { maru } \\
\text { San'yō-maru }\end{array}$ \\
\hline \multirow{8}{*}{ 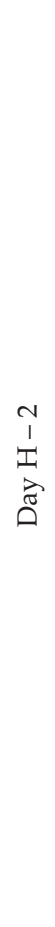 } & \multirow{8}{*}{6} & \multirow{8}{*}{ 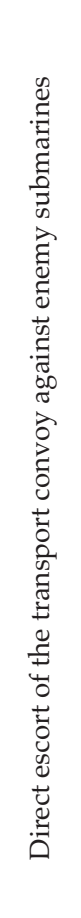 } & & $0800(1200)$ & $\begin{array}{l}2 \text { Observation } \\
\text { seaplanes }\end{array}$ & $\begin{array}{l}\text { Kamikawa- } \\
\text { maru }\end{array}$ \\
\hline & & & & $0900(1300)$ & Ditto & San'yō-maru \\
\hline & & & & $1000(1400)$ & Ditto & $\begin{array}{l}\text { Kamikawa- } \\
\text { maru }\end{array}$ \\
\hline & & & & $1100(1500)$ & Ditto & San'yō-maru \\
\hline & & & & 1215 (1615) & $\begin{array}{l}2 \text { Three-seater } \\
\text { recon. sea- } \\
\text { planes }\end{array}$ & $\begin{array}{l}\text { Kamikawa- } \\
\text { maru }\end{array}$ \\
\hline & & & & 1330 (1730) & Ditto & San'yō-maru \\
\hline & & & & 1445 (1845) & $\begin{array}{l}2 \text { Observation } \\
\text { seaplanes }\end{array}$ & $\begin{array}{l}\text { Kamikawa- } \\
\text { maru }\end{array}$ \\
\hline & & & & 1645 (1950) & Ditto & San'yō-maru \\
\hline
\end{tabular}




\begin{tabular}{|c|c|c|c|c|c|c|c|}
\hline \multirow{14}{*}{$\begin{array}{l}\vec{I} \\
\text { I } \\
\text { I } \\
\text { त् }\end{array}$} & \multirow{14}{*}{7} & \multirow{14}{*}{ 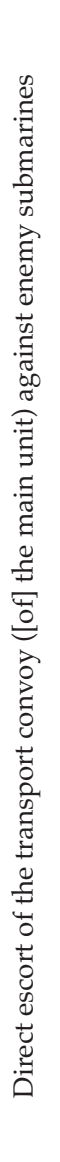 } & \multirow{14}{*}{$\begin{array}{l}\text { Lepar Island } \\
\text { (Ditto) }\end{array}$} & 0800 (1100) & $\begin{array}{l}1 \text { Observation } \\
\text { seaplane }\end{array}$ & \multirow{7}{*}{$\begin{array}{l}\text { Kamikawa- } \\
\text { maru }\end{array}$} & \\
\hline & & & & 0900 (1200) & Ditto & & \\
\hline & & & & $1000(1300)$ & Ditto & & \\
\hline & & & & 1100 (1400) & Ditto & & \\
\hline & & & & 1215 (1515) & Ditto & & \\
\hline & & & & $1330(1730)$ & $\begin{array}{l}1 \text { Three-seater } \\
\text { recon. seaplane }\end{array}$ & & \\
\hline & & & & 1545 (1950) & Ditto & & \\
\hline & & & & 0800 (1100) & $\begin{array}{l}1 \text { Observation } \\
\text { seaplane }\end{array}$ & \multirow{7}{*}{ San'yō-maru } & \\
\hline & & & & 0900 (1200) & Ditto & & \\
\hline & & & & $1000(1300)$ & Ditto & & \\
\hline & & & & $1100(1400)$ & Ditto & & \\
\hline & & & & 1215 (1515) & Ditto & & \\
\hline & & & & $1330(1730)$ & $\begin{array}{l}1 \text { Three-seater } \\
\text { recon. seaplane }\end{array}$ & & \\
\hline & & & & 1545 (1950) & Ditto & & \\
\hline \multirow{4}{*}{ 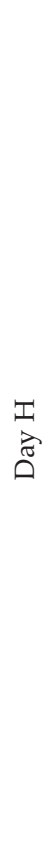 } & \multirow{4}{*}{8} & \multirow{4}{*}{ 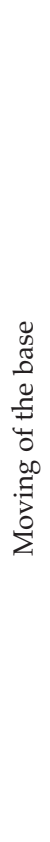 } & \multirow{4}{*}{$\begin{array}{l}\text { Lepar Island } \\
\text { (Bantam Bay) }\end{array}$} & \multirow{4}{*}{$\begin{array}{l}\text { Immediately } \\
\text { after the avail- } \\
\text { ability of } \\
\text { base[s] be- } \\
\text { comes clear }\end{array}$} & $\begin{array}{l}3 \text { Observation } \\
\text { seaplanes } \\
2 \text { Three-seater } \\
\text { recon. sea- } \\
\text { planes }\end{array}$ & $\begin{array}{l}\text { Kamikawa- } \\
\text { maru }\end{array}$ & \multirow{4}{*}{$\begin{array}{l}\text { The planes shall take } \\
\text { off in the order of the } \\
\text { observation seaplanes } \\
\text { and the reconnais- } \\
\text { sance seaplanes. After } \\
\text { the landing at the } \\
\text { base, three observa- } \\
\text { tion seaplanes of the } \\
\text { Kamikawa-maru shall } \\
\text { continue the guard } \\
\text { over the anchorage. } \\
\text { After the landing on } \\
\text { the base [at Patrol], } \\
\text { two observation sea- } \\
\text { planes of the San'yō- } \\
\text { maru shall continue } \\
\text { the guard of the an- } \\
\text { chorage. } \\
\text { The others shall im- } \\
\text { mediately refuel. The } \\
\text { actions thereafter } \\
\text { shall be ordered later. }\end{array}$} \\
\hline & & & & & $\begin{array}{l}3 \text { Observation } \\
\text { seaplanes } \\
2 \text { Three-seater } \\
\text { recon. sea- } \\
\text { planes }\end{array}$ & San'yō-maru & \\
\hline & & & & & $\begin{array}{l}2 \text { observation } \\
\text { seaplanes }\end{array}$ & $\begin{array}{l}\text { Kamikawa- } \\
\text { maru }\end{array}$ & \\
\hline & & & & & Ditto & San'yō-maru & \\
\hline
\end{tabular}


3. The setup of bases (omitted by the author)

4. Communications (omitted by the author)

5. Communications with the fishing boats (omitted by the author)

\section{The Units Involved in the Eastern Java Invasion (Operation)}

\section{The Arrangements Between the 4th Destroyer Squadron and the [Army] 48th Division}

Having reached Manila from Lingayen Gulf overland, 4th Destroyer Squadron Commander Rear Admiral Nishimura concluded on 4 February with the [Army] 48th Division commander the Army-Navy arrangements on the eastern Java invasion operation. The outline of the arrangements was as follows: ${ }^{(56)}$

1. The outline of the operation

[The units shall] leave Lingayen Gulf on 8 February, arrive in Jolo on 12 or 13 February, and after making necessary preparations there, leave Jolo on Day I - 7 (note: 16 February) and enter into the anchorage for the landing points at night on Day I - 1.

2. The program at the assembly points:

7 February at Lingayen at 1330 Meetings between the captains of the ships and those concerning communications

14 February at Jolo

at 0930 Meetings on details between the escort unit and the [transport] ships

at Jolo

at 1330 Meetings between the captains of the ships

3. The main points concerning the sail from Lingayen Gulf to Jolo (omitted)

4. The distribution of the transport ships (omitted by the author)

5. The landing points and the distribution of forces to the landing points (as in the following table)

\begin{tabular}{|c|c|c|c|}
\hline Unit & $\begin{array}{l}\text { Core Forces } \\
\text { (Commander) }\end{array}$ & Landing Point & $\begin{array}{l}\text { Places to Advance to } \\
\text { After Landing }\end{array}$ \\
\hline Imai Unit & $\begin{array}{l}2 \text { Inf bns and } 1 \text { mountain artillery bn } \\
\text { (Colonel Imai) }\end{array}$ & \multirow{2}{*}{$\begin{array}{l}\text { Kragan, } \\
\text { Sector B }\end{array}$} & Sedan, Meduran* \\
\hline Kitamura Unit & $\begin{array}{c}\text { Reconnaissance Regt } \\
\text { (Lieutenant Colonel Kitamura) }\end{array}$ & & Bojonegoro \\
\hline Abe Unit & $\begin{array}{c}3 \text { Inf bns, } 2 \text { tank sqdns, } 2 \text { mountain artillery bns } \\
\text { (Major General Abe) }\end{array}$ & \multirow{2}{*}{$\begin{array}{l}\text { Kragan, } \\
\text { Sector A }\end{array}$} & $\begin{array}{l}\text { "Bonjoru" ("Burujaku")** } \\
\text { [Bancar (Bulujawa)] }\end{array}$ \\
\hline Tanaka Unit & $\begin{array}{l}2 \text { Inf bns and } 1 \text { mountain artillery bn } \\
\text { (Colonel Tanaka) }\end{array}$ & & Cepu \\
\hline
\end{tabular}

6. The time and date of the landing and the landing schedule

(1) The date of the start of the landing, Day I, is set on Day X + 77 (23 February). [The units shall] leave Jolo on Day I - 7, drop anchor at 0100 on Day I, and start landing at 0200 on that day. However, if there are mines at the anchorage and their clearing is expected to require time, [the units] may enter the anchorage when the clearing is completed.

* The text says Mazuran. In Vol. 3, p. 238, it is Mazeran. The "Action Report of the 4th Destroyer Squadron" (第 4水雷戦隊戦闘詳報42/2/8-3/10(5); JACAR Ref: C08030111000, pdf 31/51) says that it is a place about $3 \mathrm{~km}$ southeast of Cape Bendo. This would be Meduran. The supposition in Vol. 3, p. 238 that it might be a corruption of Semarang is wrong.

** The reference cited above proves the identification of Bonjōru/Ponjōru and Bulüjaku with Bancar and Bulujowo or Bulujawa in Vol. 3 to be correct. 
(2) The landing schedule

[The landing shall be completed] roughly in five days, and in terms of the disembarkation of the military supplies, [the transport ships] shall change anchorage to an area to the east of Cape Bendo from Day I +2 onwards.

7. The outline of the escort

(1) The scheduled sailing route: As shown in Separate Illustration No. 84 (omitted by the author)

(2) The sailing speed: 8 knots at normal speed

(3) Direct escort shall be provided. The strength [of the escort] is:

Between Lingayen and Jolo: One cruiser and four destroyers (to which three submarine chasers and one minelayer shall be added up until the Apo [Reef] Channel.)

Between Jolo and Kragan: One cruiser, nine destroyers, two minesweepers, six submarine chasers and one minelayer

(4) The protective sailing formation (omitted by the author)

8. The entry into the anchorage, the landing combat and the cover (omitted by the author)

9. The movements of the transport ships after the landing (omitted by the author)

10. Others (omitted by the author)

\section{The Plan of Operations of the 1st Escort Unit}

1. The plan of escort for the sailing from Lingayen to Jolo ([as in] Operation Order No. 4; [issued on] 6 February; contents omitted)

2. The general plan of landing operation ([as in] Operation Order No. 6; [issued on] 12 February)

On 12 February, 1st Escort Unit Commander Rear Admiral Nishimura advanced to Jolo where, after discussions with 2d Base Force Commander Rear Admiral Hirose and 11th Seaplane Tender Division Commander Rear Admiral Fujita, he announced his plan for the landing operation, which in summary was as follows: ${ }^{(56)}$

(1) The distribution of forces

$\{1\}$ First distribution of forces (from the departure from Jolo until the issue of the order to change into the formation to enter into the anchorage)

(Note by the author: as in the following table)

\begin{tabular}{|c|c|c|c|c|}
\hline Unit & & Commander & Forces & Main Tasks \\
\hline Main Unit & \multirow{4}{*}{ 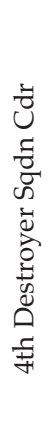 } & & The Naka & To support the entire operation \\
\hline $\begin{array}{l}\text { Clearing } \\
\text { Unit }\end{array}$ & & $\begin{array}{l}\text { 2d Destroyer } \\
\text { Div Cdr }\end{array}$ & $\begin{array}{l}\text { 2d Destroyer Div, 21st Subchaser Div } \\
\text { and the Kawakaze }\end{array}$ & $\begin{array}{l}\text { To clear the sailing route ahead } \\
\text { of the transport ship unit }\end{array}$ \\
\hline $\begin{array}{l}\text { Transport } \\
\text { Ship Unit }\end{array}$ & & $\begin{array}{l}\text { 24th Destroyer } \\
\text { Div Cdr }\end{array}$ & $\begin{array}{l}\text { 24th Destroyer Div (the Umikaze), the } \\
\text { Wakataka, 11th, 30th, the 20th } \\
\text { Minesweeper Divs, }{ }^{*} \text { the Myōkō-maru, one } \\
\text { half of the 1st Defense Unit** }\end{array}$ & $\begin{array}{l}\text { To guide the transport ships, } \\
\text { providing direct escort }\end{array}$ \\
\hline $\begin{array}{c}\text { Rear Guard } \\
\text { Unit }\end{array}$ & & $\begin{array}{l}\text { 9th Destroyer } \\
\text { Div Cdr }\end{array}$ & $\begin{array}{l}\text { 9th Destroyer Div (minus the } \\
\text { Yamagumo) }\end{array}$ & $\begin{array}{l}\text { To guard the rear of the trans- } \\
\text { port ship unit }\end{array}$ \\
\hline
\end{tabular}

* Actually: 11th and 30th Minesweeper Divs, and Minesweeper No. 20

** Actually: 2d Defense Unit. See pp. 380, 383. 
\{2\} Second distribution of forces (after the issue of the order to change to the formation to enter into the anchorage)

\begin{tabular}{|c|c|c|c|c|}
\hline Unit & \multicolumn{2}{|r|}{ Commander } & Forces & Main Tasks \\
\hline Main Unit & \multirow{6}{*}{ 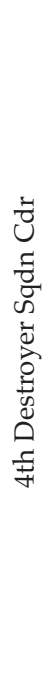 } & & The Naka & To support the entire operation \\
\hline $\begin{array}{l}\text { Clearing } \\
\text { Unit }\end{array}$ & & $\begin{array}{l}\text { 21st Subchaser } \\
\text { Div Cdr }\end{array}$ & 21st Subchaser Div & $\begin{array}{l}\text { To clear the route ahead of } \\
\text { enemy submarines }\end{array}$ \\
\hline $\begin{array}{l}\text { Minesweep- } \\
\text { ing Unit }\end{array}$ & & $\begin{array}{l}\text { Capt of the } \\
\text { Harusame }\end{array}$ & $\begin{array}{l}\text { 2d Destroyer Div 2d Section and 11th } \\
\text { Minesweeper Div }\end{array}$ & $\begin{array}{l}\text { To sweep the route ahead of } \\
\text { the transport ship unit for } \\
\text { mines }\end{array}$ \\
\hline $\begin{array}{l}\text { Transport } \\
\text { Ship Unit }\end{array}$ & & $\begin{array}{l}\text { 24th Destroyer } \\
\text { Div Cdr }\end{array}$ & $\begin{array}{l}\text { 24th Destroyer Div 1st Section and the } \\
\text { Wakataka }\end{array}$ & $\begin{array}{l}\text { To guide the transport ships, } \\
\text { providing direct escort }\end{array}$ \\
\hline $\begin{array}{c}\text { Front Guard } \\
\text { Unit }\end{array}$ & & $\begin{array}{l}\text { 2d Destroyer } \\
\text { Div Cdr }\end{array}$ & $\begin{array}{l}\text { 2d Destroyer Div 1st Section, 30th and } \\
\text { 20th Minesweeper Divs* }\end{array}$ & $\begin{array}{l}\text { To guard the front of the trans- } \\
\text { port ship unit, sail ahead to the } \\
\text { anchorage to sweep the place } \\
\text { for mines }\end{array}$ \\
\hline $\begin{array}{l}\text { Rear Guard } \\
\text { Unit }\end{array}$ & & $\begin{array}{l}\text { 9th Destroyer } \\
\text { Div Cdr }\end{array}$ & $\begin{array}{l}\text { 9th Destroyer Div (minus the } \\
\text { Yamagumo) }\end{array}$ & $\begin{array}{l}\text { To guard the rear of the trans- } \\
\text { port ship unit }\end{array}$ \\
\hline
\end{tabular}

(2) The outline of the escort at sea (omitted)

(3) The outline of the entry into the anchorage (omitted)

(4) The outline of the guard of the anchorage (omitted)

(5) Communications (omitted)

(6) Others (omitted)

Since it was decided that the Sakaguchi Detachment should participate in the eastern Java operation, 1st Escort Unit Commander Rear Admiral Nishimura issued an order that the Kawakaze and the Submarine Chaser No. 4 should be dispatched to Balikpapan to escort the Havana-maru and the Ehime-maru with the Sakaguchi Detachment on board to join [the main convoy].

\section{The Plan of Operations of the 2d Base Unit ${ }^{(53,55,142)}$}

1. The disposition of forces (as in the following table)

\begin{tabular}{|c|c|c|c|c|}
\hline Unit & \multicolumn{2}{|c|}{ Commander } & Forces & Main Tasks \\
\hline Main Unit & \multirow{3}{*}{ 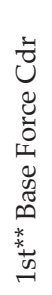 } & & The Itsukushima & To support the entire operation \\
\hline $\begin{array}{l}\text { 1st Guard } \\
\text { Unit }\end{array}$ & & $\begin{array}{l}\text { 31st Subchaser } \\
\text { Div Cdr }\end{array}$ & $\begin{array}{l}\text { 31st Subchaser Div ( } 3 \text { submarine } \\
\text { chasers) }\end{array}$ & $\begin{array}{l}\text { To clear the waters south of the } \\
\text { Makassar Strait of enemy sub- } \\
\text { marines }\end{array}$ \\
\hline $\begin{array}{l}\text { 2d Guard } \\
\text { Unit }\end{array}$ & & $\begin{array}{l}\text { Senior capt [of } \\
\text { the boats] }\end{array}$ & 21st Torpedo Boat Div 2d Section & $\begin{array}{l}\text { To escort the second landing } \\
\text { unit of the Sakaguchi Det }\end{array}$ \\
\hline
\end{tabular}

* Actually: 30th Minesweeper Div and Minesweeper No. 20.

** Actually: 2d. See p. 383. 


\begin{tabular}{|c|c|c|c|c|}
\hline $\begin{array}{l}\text { 3d Guard } \\
\text { Unit }\end{array}$ & \multirow{4}{*}{ 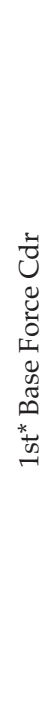 } & $\begin{array}{l}\text { 2d Gunboat } \\
\text { Div Cdr }\end{array}$ & $\begin{array}{l}\text { 2d Gunboat Div 1st Section and 54th } \\
\text { Subchaser Div }\end{array}$ & $\begin{array}{l}\text { To guard the rear bases and } \\
\text { protect the sea lines of commu- } \\
\text { nication }\end{array}$ \\
\hline $\begin{array}{l}\text { Surabaya } \\
\text { Invasion } \\
\text { Unit }\end{array}$ & & $\begin{array}{l}\text { 30th } \\
\text { Minesweeper } \\
\text { Div Cdr }\end{array}$ & $\begin{array}{l}\text { 30th, } 11 \text { th and } 20 \text { th Minesweeper } \\
\text { Divs, }{ }^{* *} \text { and } 21 \text { st Subchaser Div ( } 6 \text { subma- } \\
\text { rine chasers) }\end{array}$ & $\begin{array}{l}\text { To come back under the [origi- } \\
\text { nal] command roughly on Day } \\
\text { I }+1 \text { and clear the waterways } \\
\text { to Surabaya }\end{array}$ \\
\hline Land Unit & & $\begin{array}{l}\text { 2d Kure SLF } \\
\text { Cdr }\end{array}$ & 2d Kure SLF (minus one element) & $\begin{array}{l}\text { To guard the Tarakan and the } \\
\text { Balikpapan airfields }\end{array}$ \\
\hline $\begin{array}{l}\text { Attached } \\
\text { Unit }\end{array}$ & & & $\begin{array}{l}\text { The Sanuki-maru (minus the aircraft } \\
\text { unit), Patrol Boat No. } 37,8 \text { auxiliary } \\
\text { naval vessels, one half of the } 2 \text { d Defense } \\
\text { Unit and } 9 \text { fishing boats }\end{array}$ & $\begin{array}{l}\text { 1. Replenishment } \\
\text { 2. To protect the sea lines of } \\
\text { communication and guard } \\
\text { anchorages } \\
\text { 3. To transport the base } \\
\text { matériel for the Banjarmasin } \\
\text { base }\end{array}$ \\
\hline
\end{tabular}

2. The outline of the operations of each unit

(1) The main unit (The Itsukushima)

[The unit shall] leave Jolo principally ahead of the convoy of the 1st Escort Unit, and while supporting [the unit], [sailing] by way of Tarakan, Balikpapan and Banjarmasin, enter Kragan around Day $\mathrm{H}+1,{ }^{* * *}$ and support the operation to occupy Surabaya.

(2) The 1st Guard Unit (The 31st Subchaser Division)

[The unit] shall operate principally in the Balikpapan area and take charge of clearing enemy submarines on the scheduled sailing route of the 1st Escort Unit in the area south of the Makassar Strait.

(3) The 2d Guard Unit (The 2d Section of the 21st Torpedo Boat Division)

[The unit shall] sail to Makassar and escort the Army transport ships Sasako-maru and Sagamimaru from there to Banjarmasin to embark the Sakaguchi Detachment, after which the unit shall escort them to Kragan.

(4) The 3d Guard Unit (The 1st Section of the 2d Gunboat Division and the 54th Subchaser Division)

[The unit shall] principally be responsible for clearing the areas of Davao, Jolo and Tarakan of enemy submarines, while protecting the sea lines of communication.

(5) The Surabaya invasion unit (The 30th, the 11th and the 20th Minesweeper Divisions ${ }^{* *}$ and the 21st Subchaser Division)

After entering into the Kragan anchorage and sweeping the anchorage for mines and providing guard there under the command of the 1st Escort Unit commander, [the unit shall] come back under the command of the $2 \mathrm{~d}$ Base Force commander from the time when they would be required to take charge of occupying the port of Surabaya and clearing the waterways.

(6) The unit attached (omitted)

Note by the author: The names of units were given by the author for convenience's sake.

* Actually: 2 d. See p. 383.

** Actually: 30th and 11th Minesweeper Divs and Minesweeper No. 20.

*** Or Day I + 1. Day I was the code name for the eastern Java operation; Day $\mathrm{H}$ the code name for the western Java operation. 


\section{The Plan of Operations of the 2d Air Unit and Its Circumstances}

The 2d Air Unit, which consisted of the 11th Seaplane Tender Division, Patrol Boats Nos. 34, 38 and 39, one platoon of the Sasebo Combined Special Landing Force, six fishing boats and one small cargo ship, was supposed to support the 1st Escort Unit and the $2 \mathrm{~d}$ Base Unit by guarding the transport convoy against [enemy] aircraft and submarines as well as to support the [Army] 48th Division in its landing combat (as previously told).

On 18 February, the 11th Seaplane Tender Division staff (at the Pata anchorage of Jolo) communicated the following operation schedule of the division to the staff of the 4th Destroyer Squadron: ${ }^{(62)}$

1. The operation schedule of our unit (minus the Mizuho, Patrol Boat No. 39 and the Ebisu-maru) until the morning of the 20th is as follows:

(a) The Chitose: shall leave this anchorage at 1915 on the 19th; [sailing] at a speed of 24 knots, she shall pass by the waters east of your unit around 0000 on the 20th and arrive in Dondo Bay (note by the author: located to the north of the Gulf of Tomini [on the northwest coast] of Celebes) around 0830 on the 20th.

(b) Patrol Boat No. 34: shall leave Tarakan around 1300 on the 19th and arrive in Dondo Bay around 0600 on the 20th.

(c) Patrol Boat No. 38: shall leave this anchorage around 0900 on the 19th, and [by sailing] at a speed of 14 knots, arrive in Dondo Bay at 0800 on the 20th.

2. The Ebisu-maru shall follow in the wake of the transport convoy up to the Wota* (note by the author: unknown) anchorage.

3. The Mizuho and Patrol Boat No 39 are expected to join our unit around 24th or the 25th.

4. The aircraft unit of the Sanuki-maru is studying [the possibility] to move to somewhere near Baha** (note by the author: to the west of Gulf of Tomini [on the west coast] of Celebes) from around the 21st.

The Mizuho, which had been incorporated in the 2d Escort Unit to engage in the Kupang operation, returned to her original unit at 1000 on the 21 st and headed for Celebes. ${ }^{(54)}$

\section{The Plan of Operations of the Land-Based Air Unit}

The arrangements for the Java operation between the Sixteenth Army, the [Army] Third Air Force, the Third Fleet and the Eleventh Air Fleet came into effect on 28 January; their contents have been previously related [p. 374-97]. Moreover, the outline of [the land-based air unit's] support for the first and the second carrier operations of the Carrier Task Force has also been described [p. 331]. On 19 February (two days earlier than the scheduled day, the 21st) the 22d Air Flotilla headquarters, the Genzan Air Group, the main body of the Kanoya Air Group and the Type- 0 fighter plane unit of the $22 \mathrm{~d}$ Air Flotilla of the Air Unit of the Malaya Unit were transferred to the $3 \mathrm{~d}$ Air Raid Unit, so as to participate in the Java operation under the unified command of the Eleventh Air Fleet commander in chief in accordance with the phasethree disposition of forces. The phase-three disposition of forces of the Air Unit of the Southern Task Force was as follows:(135)

\footnotetext{
* Most likely Oti is meant.

** Most likely Baya is meant.
} 


\begin{tabular}{|c|c|c|c|c|c|c|}
\hline \multicolumn{2}{|c|}{ Unit } & \multicolumn{2}{|c|}{ Commander } & \multirow[b]{2}{*}{\begin{tabular}{l}
\multicolumn{1}{c}{ Forces } \\
21st Air Flotilla \\
(minus the main \\
body of the Kanoya \\
Air Gp, 1st Air Gp \\
and the Katsuragi- \\
maru), and the 3d \\
Air Gp
\end{tabular}} & \multirow{2}{*}{\begin{tabular}{|c} 
Deployment \\
\\
Kendari, Kupang \\
and Ambon areas
\end{tabular}} & \multirow[b]{2}{*}{$\begin{array}{l}\text { Main Tasks } \\
\text { 1. To destroy the enemy air power in } \\
\text { the Sunda Islands, the northwestern } \\
\text { part of Australia and the northwest- } \\
\text { ern part of New Guinea } \\
\text { 2. To search for and attack enemy } \\
\text { naval vessels on the waters to the } \\
\text { south of the Sunda Islands }\end{array}$} \\
\hline \multirow{7}{*}{ 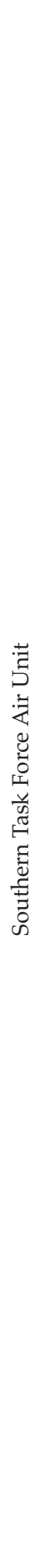 } & 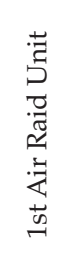 & \multirow{7}{*}{ 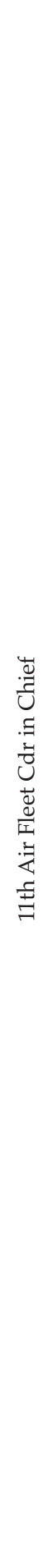 } & 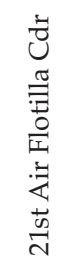 & & & \\
\hline & 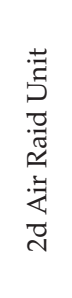 & & 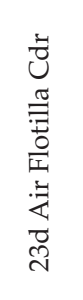 & $\begin{array}{l}\text { 23d Air Flotilla } \\
\text { (minus 3d Air Gp } \\
\text { and the Komaki- } \\
\text { maru) }\end{array}$ & Bali area & $\begin{array}{l}\text { 1. To destroy the enemy air power in } \\
\text { eastern Java } \\
\text { 2. To search for and attack enemy } \\
\text { naval vessels in the Java and the } \\
\text { Sunda Seas as well as on the waters } \\
\text { to the south of Java } \\
\text { 3. To support the eastern Java invasion } \\
\text { operation }\end{array}$ \\
\hline & 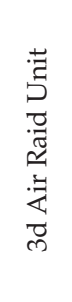 & & 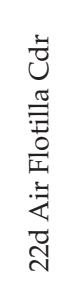 & $\begin{array}{l}\text { 22d Air Flotilla } \\
\text { (minus the Fujikawa- } \\
\text { maru) and the main } \\
\text { body of the Kanoya } \\
\text { Air Gp }\end{array}$ & $\begin{array}{l}\text { Mentok, Kuching } \\
\text { and Gelumbang } \\
\text { areas }\end{array}$ & $\begin{array}{l}\text { 1. To destroy the enemy air power in } \\
\text { western Java } \\
\text { 2. To search for and attack enemy } \\
\text { naval vessels in the Java Sea and on } \\
\text { the waters to the south of Java and } \\
\text { Sumatra } \\
\text { 3. To support the western Java inva- } \\
\text { sion operation }\end{array}$ \\
\hline & 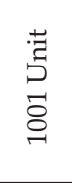 & & 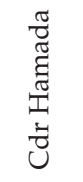 & $\begin{array}{l}\text { 1st Air Gp transport } \\
\text { plane unit, 1st and } \\
\text { 3d Yokosuka SLFs }\end{array}$ & $\begin{array}{l}\text { Kendari, Menado } \\
\text { and Kupang areas }\end{array}$ & $\begin{array}{l}\text { 1. Transportation } \\
\text { 2. Patrolling } \\
\text { 3. Guarding of the bases }\end{array}$ \\
\hline & 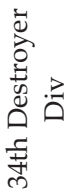 & & 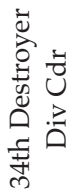 & $\begin{array}{l}\text { Tachikaze, Akikaze, } \\
\text { and Hakaze }\end{array}$ & $\begin{array}{l}\text { Dutch East Indies } \\
\text { and South China } \\
\text { Sea areas }\end{array}$ & $\begin{array}{l}\text { 1. Escort at sea } \\
\text { 2. Support for the move of bases } \\
\text { 3. Guarding of the bases }\end{array}$ \\
\hline & 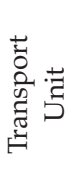 & & & $\begin{array}{l}\text { Katsuragi-maru, } \\
\text { Keiyō-maru, Lyons- } \\
\text { maru, Komaki-maru, } \\
\text { Kamogawa-maru and } \\
\text { Fujikawa-maru }\end{array}$ & & $\begin{array}{l}\text { 1. Transportation } \\
\text { 2. Replenishment }\end{array}$ \\
\hline & $\begin{array}{l}\text { 节 } \\
5 \\
\text { ते } \\
\frac{2}{3} \\
\text { की }\end{array}$ & & 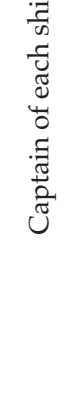 & $\begin{array}{l}\text { Amagisan-maru, } \\
\text { Hino-maru No. 5, } \\
\text { Nisshun-maru, Ku- } \\
\text { nikawa-maru, Okitsu- } \\
\text { maru, Nagisan-maru, } \\
\text { Yūbari-maru, Rakutō- } \\
\text { maru, Asama-maru, } \\
\text { Tenzan-maru, Hitachi- } \\
\text { maru, Shinkoku-maru } \\
\text { [A], and Shinsei- } \\
\text { maru No. } 18\end{array}$ & & $\begin{array}{l}\text { 1. Transportation } \\
\text { 2. Replenishment }\end{array}$ \\
\hline
\end{tabular}

Note: The Kamogawa-maru was sunk at the north entrance of the Lombok Strait on 2 March. 
That is, the Air Unit planned to accelerate the air campaign over Java with the 23d Air Flotilla from the east and the $22 \mathrm{~d}$ Air Flotilla from the west, while carrying out consecutive attacks on key places in northwestern Australia with the 21st Air Flotilla and the $3 \mathrm{~d}$ Air Group to contain the operations of the enemy. Also, in concert with the operations of the Carrier Task Force, the unit was supposed to carry out search and attack missions in the eastern part of the Indian Ocean to catch and destroy enemy surface forces.

\section{The Plan of Operations of the Army Units}

On 20 January, the Southern Army commander issued the following order to capture Java by way of Southern Army Operation Order Classified No. 43.

\section{Southern Army Order [See also Vol. 3, p. 155.]}

1. The overall operations of the Southern Army are progressing as scheduled.

2. In conjunction with the Navy, I intend to swiftly capture Java.

The cooperation with the Navy shall be based on General Agreements No. 2 and No. 4 .

3. The commander of the Sixteenth Army shall swiftly capture Java in the following manner:

(a) Exploiting the results of the neutralization of [the enemy] air power on Java, he shall almost simultaneously land his main force in western Java and an element in eastern Java. When conducting the landing operations, interference from enemy naval and air forces is expected.

(b) After the landing, he shall defeat the enemy and promptly seize Batavia, Surabaya and Bandung.

(c) He shall swiftly make air bases in Java ready for use.

4. The commander of the Third Air Force shall support the Sixteenth Army's operation in the following manner:

(a) As soon as the airfields on Bangka Island and southern Sumatra have been made ready for use, he shall advance there, without missing an opportunity, as much strength as possible, swiftly destroy the enemy air power in western Java, and directly and closely support the landing operations of the main force of the Sixteenth Army.

(b) As soon as the air bases in Java are ready for use, he shall swiftly advance an element of his force.

5. The captain general of the Shipping Transport Command shall closely support the operations conducted by the commanders of the Sixteenth Army and the Third Air Force.

6. I shall [command from] Saigon.

The plan of operations of the Southern Army at that time was as follows:

Western Java: [The units] under the direct command of the Sixteenth Army, 2d Division, and two battalions of the 38th Division

Eastern Java: 48th Division ([consisting of] nine infantry battalions as the core)

Sumatra: the main force of the 38th Division ([consisting of] four infantry battalions as the core)

Eastern Borneo: The Sakaguchi Detachment

The areas north of Australia: The Itō Detachment ([consisting of] three battalions of the 38th Division)

Note: The operation to capture Bali was not yet on the table around that time.

The Sixteenth Army's plan for the Java invasion operation ([as of] 27 January) was in outline as follows: 
1. Mission

(1) The main force of the Sixteenth Army shall, in conjunction with the Navy, land with the units of first transport in western Java ([at] Merak, Bantam Bay and Patrol) before dawn on Day $\mathrm{H}$, defeat the enemy and swiftly capture first Batavia and then Bandung without a break.

(2) The 48th Division shall land in eastern Java ([at] Kragan) before dawn on Day I, capture Surabaya and then Malang, and swiftly subjugate eastern Java.

(3) In order to advance a naval air base to be used at the time of [the operation to] capture eastern Java, the 48th Division shall on Day I - 5 in conjunction with the Navy carry out a sudden attack on Bali with one element, swiftly seize the airfield there and make it ready for use.

2. Disposition of forces for the capture of western Java

(1) The 2d Division ([consisting of] seven infantry battalions, three field artillery battalions, one heavy field artillery battalion and one tank regiment as the core)

$\{1\}$ Before dawn on Day H, one element shall land near Merak and the main force along Bantam Bay, to swiftly advance to the line of Ciujung River first.

$\{2\}$ One powerful element shall be swiftly dispatched toward Buitenzorg to divide the enemy in the Batavia and the Bandung areas and secure as forward as possible a footing for the seizure of Bandung.

\{3\} The main force of the division shall advance through the areas along the road connecting Serang, Tangerang and Batavia toward Batavia and the sector to its south, and swiftly capture the place.

(2) The Shōji Detachment ([consisting of] two infantry battalions and one mountain artillery battalion of the 38th Division as the core)

$\{1\}$ [The detachment] shall land in Patrol before dawn on Day H and swiftly secure the Kalijati airfield.

\{2\} [The detachment] shall take control of the crossing point of the Citarum River to divide the enemy in the Bandung and the Batavia areas, and depending on the situation, shall capture Batavia with one element.

(3) The disposition of forces for the capture of eastern Java

The 48th Division ([consisting of] eight infantry battalions and four mountain artillery battalions as the core)

$\{1\}$ [The division shall] land in Kragan before dawn on Day I, defeat the enemy and swiftly seize Surabaya.

$\{2\}$ [The division] shall have one powerful element charge toward Cilacap to cut off the escape routes of the enemy.

\{3\} [The division shall] land in Surabaya swiftly after capturing the place and set up a base, while clearing eastern Java [of the enemy].

(4) The disposition of forces for the capture of Bali

The 48th Division shall have one element ([consisting of] one infantry battalion as the core) conduct a sudden attack on Bali on Day I - 5 to seize the airfield there.

Since it was decided, as previously told, that the Sakaguchi Detachment should participate in the eastern Java invasion operation, [a new] disposition of forces was decided upon as follows by around 17 February:

1. The bulk of the Sakaguchi Detachment ([consisting of] two and a half infantry battalions as the core) shall participate in the operation in eastern Java.

2. The Sakaguchi Detachment shall first of all embark in Balikpapan its detachment headquarters and one infantry battalion in the transport ships and sail south under the escort of the Navy. 
After joining the 48th Division en route, it shall sail together and land near Kragan along with the 48 th Division before dawn on Day I.

3. Then, the detachment shall have the transport ships sail back to Banjarmasin to embark its remaining force of about one and a half battalion and bring them to Kragan.

4. After having completed preparations and assembling its force near Kragan, the detachment shall charge toward Cilacap at a dash, seize the place, and cut off the escape routes of the enemy from Batavia and Bandung.

5. The 48th Division shall be relieved of the task to charge toward and seize Cilacap.

6. The 48th Division commander shall make the necessary revisions in the arrangements with the 4th Destroyer Squadron commander concerning the participation of the Sakaguchi Detachment and arrange for the detachment the escort during the sailing and the outline of the landings, etc. 


\section{Chapter VII The Implementation of the Java Invasion Operation}

\section{Outline of the Progress of the Operation}

lthough, as previously told, the scheduled dates of the Java invasion operation were
at [the conference for] the Cam Ranh Agreement on $19^{*}$ December moved up to Day
$X+70$, they were again postponed to Day X +75 and Day X +77 (21 and 23 February) at the Manila Conference on 23 January.

The main force of the Sixteenth Army ([consisting of] the 2d Division as the core), which was supposed to land in western Java, had advanced to Taiwan from mainland Japan in late January, and in early February further advanced under the escort of the 5th Destroyer Squadron to stand by at Cam Ranh Bay.

The 48th Division, which was supposed to land in eastern Java, came under the command of the Sixteenth Army after completing the operation to capture Manila. The division assembled in Lingayen, departed on 8 February under the escort of the 4th Destroyer Squadron and sailed south. Then, as previously told [p. 379], due to the delay in the preparations for the western Java invasion [operation], the date of the landings on Java was eventually set on Day X +80 (26 February).

Following the decision on the schedule, the units involved in the western Java invasion [operation] left Cam Ranh Bay on 18 February and sailed south, escorted by the 5th Destroyer Squadron and the reinforcement from the Malaya Unit (the 7th Cruiser Division that was to join from the Anambas Islands, leaving there on the 22d). In the meantime, the units involved in the eastern Java invasion [operation], which were temporarily standing by at Jolo, departed on 19 February and sailed south toward Java.

However, due to the unsatisfactory results of the air campaign to destroy the enemy air power, the prospect that considerable strength of the enemy had survived became very likely. Consequently, following a proposal offered by Dutch East Indies Unit Commander V. Adm. Takahashi Ibō on 23 February, it was decided that the landing on Java should be further postponed for two days until 28 February. This postponement made the western and eastern Java invasion units bide their time, the former by reversing course on the waters east of the Anambas Islands and the latter by temporarily staying off Balikpapan.

The land-based air unit launched air attacks on eastern Java from 18 February onwards from Kendari and then from Bali, while the units stationed at Kuching and those which had advanced from French Indochina by temporarily using the Gelumbang base (located by army units on 16 February about forty kilometers southwest of Palembang) launched attacks on 
western Java from 25 February onwards. In the meantime, the Army Third Air Force advanced to Palembang on 18 February and launched attacks on western Java from the 19th onwards.

Both the eastern and western [Java invasion] units entered the Java Sea on the morning of 26th February. However, first of all in the western [Java Sea] area, several enemy naval vessels including cruiser[s] were spotted near Batavia on the morning of 27 th, which was followed by the spotting in the eastern [Java Sea] area of a powerful enemy fleet consisting of more than a dozen naval vessels off Surabaya. While postponing the landing on Java for another day and letting the convoys temporarily evacuate to the north, Dutch East Indies Unit Commander Vice Admiral Takahashi issued an order to assemble the escort vessels to destroy the enemy.

Whereas the enemy naval vessels in the western [Java Sea] area sought shelter in [the port of] Batavia by evening, the powerful unit in the eastern part [of the Java Sea] sailed northward in search of the Japanese Navy, which led to a major sea engagement with the 5th Cruiser Division and the 4th and $2 d$ Destroyer Squadrons. The sea engagement lasted from the evening till the early morning of the next day, in which the Japanese Navy sunk two enemy cruisers and two destroyers, and routed the others (the sea engagement off Surabaya). On 1 March, the invasion unit successfully landed in Kragan. On that day, in a daytime sea engagement, the surface unit destroyed the remnants of the enemy fleet.

No enemy movements were spotted in the western part after that, and before dawn on 1 March, the convoy reached Bantam Bay and started landing. Right after [the convoy's] entry into the anchorage, two enemy cruisers raided the anchorage under the cloak of darkness. However, the 5th and 3d Destroyer Squadrons and the 7th Cruiser Division on site immediately encircled the enemy and sank both ships by a concentrated fire of shells and torpedoes (the sea engagement off Batavia). During this engagement, some [Japanese] transport ships were sunk or seriously damaged by torpedoes that seemed to have been launched by friendly naval vessels, but it caused no major hindrance in the landing operation.

The army units that had landed in western Java occupied Batavia on 5 March and closed in on the Bandung stronghold with one element. Meanwhile, those that had landed in eastern Java seized Cilacap on 8 March, while closing in on Surabaya.

In the meantime, the main body of the Southern Task Force, which had advanced from Palau, the Carrier Task Force, which had carried out the attack on Port Darwin, and the 2d Submarine Squadron and others, which had advanced from mainland Japan, were [all gathering] at Staring Bay. On 25 February, they left the bay to advance to the waters south of Java and to the Indian Ocean in an operation to cut off the escape routes of the enemy. From 28 February until around $8 \mathrm{March}$, starting with air strikes on Cilacap, the units shelled Christmas Island, while catching and attacking the escaping enemy units. Meanwhile, one element of the submarine unit operated as far as in the vicinity of Freemantle on the southwestern coast of Australia. After having sunk some enemy naval vessels and about forty transport ships, in early March [all units] returned to Staring Bay (the submarine units to Penang).

On 9 March, the enemy ground forces surrendered, and the operation to capture Java was completed. 


\section{From the Launch of the Operation Until the Landings}

\section{Further Postponement of the Landing Dates}

The Java invasion operation was planned in such a way that the air campaign to destroy the enemy air power should be carried out over western Java from western Borneo and southern Sumatra and over eastern Java from southern Borneo and Celebes; by exploiting the results, large invasion forces should be advanced almost simultaneously into eastern and western [Java]. However, with the air campaign to destroy the enemy air power in Java launched from mid-February in the state as roughly [summarized] in the following table, the results fell short of expectations. ${ }^{(71)}$

$\checkmark$ : attacks implemented; $\mathbf{x}$ : attacks called-off; ( ): the bases from which the units took off; the military gains as reported $^{*}$

\begin{tabular}{|c|c|c|}
\hline Date & Western Java & Eastern Java \\
\hline 9 February & $\begin{array}{l}\checkmark 16 \text { Type-0 fighter planes and } 2 \text { land-based } \\
\text { recon. planes of the } 22 \mathrm{~d} \text { Air Flotilla conducted } \\
\text { ([from] Kuching) an attack on Batavia; shot } \\
\text { down } 12 \text { [enemy aircraft] and destroyed } 8 \text {, } \\
\text { which caught flames; } 1 \text { Type- } 0 \text { fighter plane } \\
\text { was seriously damaged in landing. }\end{array}$ & $\begin{array}{l}17 \text { Land-based attack planes and } 9 \text { Type- } 0 \\
\text { fighter planes of the } 23 \mathrm{~d} \text { Air Flotilla conducted } \\
\text { ([from] Balikpapan) an attack on Malang; shot } \\
\text { down } 1 \text { P-40. }\end{array}$ \\
\hline 11 February & $\begin{array}{l}\text { x } 27 \text { Land-based attack planes of the } 22 \mathrm{~d} \text { Air } \\
\text { flotilla intended to attack Batavia; since the } \\
\text { fighter planes were unable to attend [the unit], } \\
\text { it changed the plan and attacked [enemy] naval } \\
\text { vessels in the Bangka [Strait] (taking off from } \\
\text { Kahang and returning to Kuantan); destroyed } 1 \\
\text { [enemy] cruiser and } 2 \text { merchantmen. }\end{array}$ & \\
\hline 15 February & $\begin{array}{l}\text { The full force of the 22d Air Flotilla carried out } \\
\text { an attack on the enemy fleet to the north of the } \\
\text { Gaspar Strait ([from] Kuching, Kuantan and } \\
\text { Thủ Dâu Một); no direct hits. }\end{array}$ & $\begin{array}{l}\text { 23d Air Flotilla ([from] Balikpapan) conducted } \\
\text { weather reconnaissance and returned due to } \\
\text { bad weather. }\end{array}$ \\
\hline 16 February & & $\begin{array}{l}\text { 23d Air Flotilla conducted weather reconnais- } \\
\text { sance ([from] Balikpapan). }\end{array}$ \\
\hline 17 February & $\begin{array}{l}15 \text { Land-based attack planes of the 22d Air } \\
\text { Flotilla conducted an attack on [enemy] naval } \\
\text { vessels to the south of Bangka Island ([from] } \\
\text { Kuching); sank } 1 \text { [enemy] merchantman. }\end{array}$ & $\begin{array}{l}\text { x } 25 \text { Land-based attack planes of the } 23 \mathrm{~d} \text { Air } \\
\text { Flotilla ([from] Balikpapan) intended to attack } \\
\text { Surabaya, but returned due to bad weather. }\end{array}$ \\
\hline
\end{tabular}

* See also pp. 281, 290, 292-94, 311, 321-22. The numbers differ slightly. 


\begin{tabular}{|c|c|c|}
\hline 18 February & & $\begin{array}{l}\checkmark 23 \text { Land-based attack planes and } 15 \text { fighter } \\
\text { planes of the 23d Air Flotilla attacked Surabaya } \\
\text { ([from] Balikpapan); destroyed } 2 \text { [enemy] cruis- } \\
\text { ers and } 3 \text { destroyers and shot down } 4 \text { fighter } \\
\text { planes; } 3 \text { [friendly aircraft] crashed themselves, } \\
4 \text { crews killed and } 2 \text { wounded on board, and } 7 \\
\text { aircraft were marked by bullets. }\end{array}$ \\
\hline 19 February & $\begin{array}{l}\text { Land-based recon. planes of the 22d Air Flotilla } \\
\text { reconnoitered Batavia ([from] Kuching) and } \\
\text { spotted } 1 \text { [enemy] ship which looked like an } \\
\text { aircraft carrier, } 3 \text { cruisers and } 40 \text { merchantmen. } \\
\checkmark 60 \text { Army fighter planes and bombers ([from] } \\
\text { Palembang) attacked Bandung and Buitenzorg; } \\
\text { engaged with } 30 \text { enemy aircraft or more; shot } \\
\text { down or destroyed } 28 \text { [enemy] aircraft. }\end{array}$ & $\begin{array}{l}\text { x } 18 \text { Land-based attack planes and } 24 \text { fighter } \\
\text { planes of the 23d Air Flotilla intended to attack } \\
\text { Surabaya ([from] Balikpapan), but unable to } \\
\text { enter [the sky over Surabaya] due to bad } \\
\text { weather, attacked Bawean Island and other tar- } \\
\text { gets instead. }\end{array}$ \\
\hline 20 February & $\begin{array}{l}\text { Land-based attack planes of the } 22 \mathrm{~d} \text { Air Flotilla } \\
\text { reconnoitered Batavia and spotted } 5 \text { [enemy] } \\
\text { cruisers, } 8 \text { destroyers } 50 \text { or more merchantmen, } \\
10 \text { flying boats, and } 3 \text { recon. seaplanes. } \\
\checkmark \text { About } 50 \text { Army fighter planes and bombers } \\
\text { attacked Kalijati ([from] Palembang); destroyed } \\
5 \text { planes. }\end{array}$ & $\begin{array}{l}27 \text { Fighter planes and } 3 \text { land-based recon. } \\
\text { planes of the 23d Air Flotilla advanced to Bali. } \\
\sqrt{ } 22 \text { Fighter planes of the } 23 \mathrm{~d} \text { Air Flotilla at- } \\
\text { tacked Surabaya and Malang ([from] Balikpa- } \\
\text { pan and Bali); set fire to } 4 \text { B-17s and destroyed } \\
1 \text { B-17 and } 1 \text { twin-engine plane. }\end{array}$ \\
\hline 21 February & $\begin{array}{l}\checkmark \text { About } 30 \text { Army fighter planes and bombers } \\
\text { attacked Kalijati and Bandung ([from] Palem- } \\
\text { bang); shot down or destroyed } 8 \text { [enemy] air- } \\
\text { craft. }\end{array}$ & $\begin{array}{l}\checkmark 13 \text { Type-0 fighter planes of the } 23 \mathrm{~d} \text { Air } \\
\text { Flotilla attacked the vicinity of Surabaya ([from] } \\
\text { Bali and Balikpapan); shot down } 3 \text { P-40s and } \\
\text { destroyed } 3 \text { small planes. } \\
\checkmark 21 \text { Land-based attack planes of the flotilla at- } \\
\text { tacked the naval vessels at anchor in Surabaya } \\
\text { port ([from] Balikpapan); destroyed } 1 \text { [enemy] } \\
\text { cruiser and } 1 \text { merchantman and shot down } 1 \text { P- } \\
40 \text {. }\end{array}$ \\
\hline
\end{tabular}

On the early morning of 22 February, Dutch East Indies Unit Commander Vice Admiral Takahashi put in at Staring Bay, met with Southern Task Force Commander Vice Admiral Kondō, examined the results of the above-described air campaigns and made the following judgment: ${ }^{(53)}$

1. Although the Army air units have finally launched their attack on the 19th in western Java, the Navy air units are still stationed in Kuching and Kuantan, far away [from the targets], and have not yet launched the air campaign to destroy the enemy air power in Java. [Enemy] naval surface vessels including cruiser[s] have been spotted in Batavia, and it seems that considerable [enemy] air strength has survived.

2. Although the air campaign to destroy the enemy air power in eastern Java has been launched in earnest on the 18th, a considerable number [of enemy aircraft] including B-17s and P-40s remain on the bases in the area. As for the [enemy] naval surface vessels, units including cruisers are also still stationed in the Surabaya area.

3. To summarize the above, the results of the air campaign both in eastern and western Java are [still] unsatisfactory, and it is necessary to wait for [better] results by postponing the landing dates for about two days. 
In accordance with this judgment, Dutch East Indies Commander Vice Admiral Takahashi sent on the morning of 22 February the following advisory telegram to Sixteenth Army Commander Imamura (also notifying the Southern Army):*(30)

In view of the activities of enemy aircraft and naval vessels in the Java area as well as the results of our air campaigns, I would like to postpone the date of the start of landing for two days until 28 February and discuss this with you.

On the same day, he issued the following order to his subordinate units by means of Third Fleet Classified Telegram No. 445:**(53)

The dates of the start of landing of Operation Su (note by the author: eastern Java operation) and Operation YA (note by the author: western Java operation) shall be postponed until 28 February.

The units for Operation Su shall stay on standby near Balikpapan; the units for Operation YA shall appropriately act as designated by their commander.

[Issued at] 1200, on the 22d

In the meantime, the chief of staff of the Southern Task Force also wired the chief of staff of the Southern Army a telegram to the same effect, while at the same time requesting the Army's cooperation in the Navy Air Unit's advance to the Gelumbang base (which had been located by Army units on 19 February about forty kilometers southwest of Palembang) and the preparation of the base. Having received the advisory telegram, the Southern Army headquarters expressed disapproval lest an unnecessary postponement of the invasion schedule would lead to squandering an opportune moment to attack. However, since their units were already at sea under the escort of the Navy and it was no use opposing [the Navy] at that moment, [the headquarters] consented to the postponement of the invasion schedule on the condition that the invasion schedule would not be further postponed. The Army also promised that it would provide adequate support for the Navy concerning the latter's [use of] the Gelumbang airfield. ${ }^{(30)}$

\section{The Conduct of the Operation by the Commanders of the Southern Task Force and the Dutch East Indies Unit}

In parallel with the consultation with the Army, Southern Task Force Commander Vice Admiral Kondō and Dutch East Indies Unit Commander Vice Admiral Takahashi discussed the outline of the subsequent operations and on the $22 \mathrm{~d}$ made the following decisions: ${ }^{(53)}$

1. In view of the presence of enemy surface vessels in the Surabaya area, the operation of the core force of the 5th Cruiser Division to act in concert with the second carrier operation shall be called off. The force shall quickly be sent to the Makassar Strait area to support the units for the eastern Java invasion [operation].

2. At the same time, since the Timor operation is on the whole making smooth progress, the destroyer forces, such as the $2 \mathrm{~d}$ Destroyer Squadron, the 7th Destroyer Division and others, shall

* See also Vol. 3, p. 443.

** See also Vol. 3, p. 443. 
be withdrawn from the area as of 24 February in order to be advanced to the Makassar Strait [as well] to support the invasion unit.

3. One destroyer division of the $2 \mathrm{~d}$ Destroyer Squadron shall be made to participate in the carrier operation from the area near Timor. This is a measure taken to supplement the insufficient destroyer strength of the carrier operation unit.

4. The main unit of the Dutch East Indies Unit shall advance to the waters north of the Lombok Strait to support the entire operation as well as to catch escaping enemy units.

5. The core force of the 1st Base Force shall carry out the second phase of the Bali [operation, i.e.] the transport operation on 25 February, while being prepared for [enemy] units escaping from the Java area.

Based on these discussions, Southern Task Force Commander Vice Admiral Kondō issued on the $22 \mathrm{~d}$ the following order by means of Southern Task Force Telegraphic Order No. 106:(53)

1. As of 26 February, one destroyer division designated by the Dutch East Indies Unit commander shall be removed from the unit and transferred to the main body of the Southern Task Force.

2. The above-mentioned destroyer division shall join the Southern Task Force near the Ombai Strait on 26 February.

Further on the 23d, by means of Telegraphic Order No. 107, [the Southern Task Force commander] revised one part of the order issued by means of Telegraphic Order No. 92 (note: the outline of the operation of the Carrier Task Force issued on 9 February) in the following way:

[Part of] the order issued by means of Southern Task Force Telegraphic Order No. 92 shall be revised in the following way:

1. The task assigned to the core force of the 5th Cruiser Division in the second carrier operation shall be deleted; the Dutch East Indies Unit commander shall determine the operations of the division.

2. [The time and place of] the return of the Submarine Unit $C$ after the second carrier operation shall be changed; it shall return to Ambon around 10 March.

On the same day, Dutch East Indies Unit Commander Vice Admiral Takahashi also issued the order concerning the operations of the 5th Cruiser Division, the 2d Destroyer Squadron, the 1st Base Force and other units involved in the Java invasion operation by means of Third Fleet Classified Telegram No. 459, which is in outline as follows (as previously told [pp. 322$23,354]):(53)$

1. It seems that there are five to seven enemy cruisers and about ten destroyers in Batavia, and one De Ruyter- and one Java-class [cruiser] and about five destroyers in Surabaya.

2. The Dutch East Indies Unit shall, with the support of the Air Unit ([of] the Southern Task Force) and the Malaya Unit, cover the Sixteenth Army's landings on Java, while catching and destroying enemy naval vessels.

3. Other than the following, all units shall operate in accordance with the outline stipulated in the Dutch East Indies Unit Order Classified No. 9.

(1-3) Omitted

(4) From the evening of the 26th onwards, the 5th Cruiser Division (minus the Myōkō), the 1st Section of the 7th Destroyer Division, the Yamakaze and the Kawakaze shall appropriately operate in the rear of the 1st Escort Unit, taking charge of its support as well as catching and 


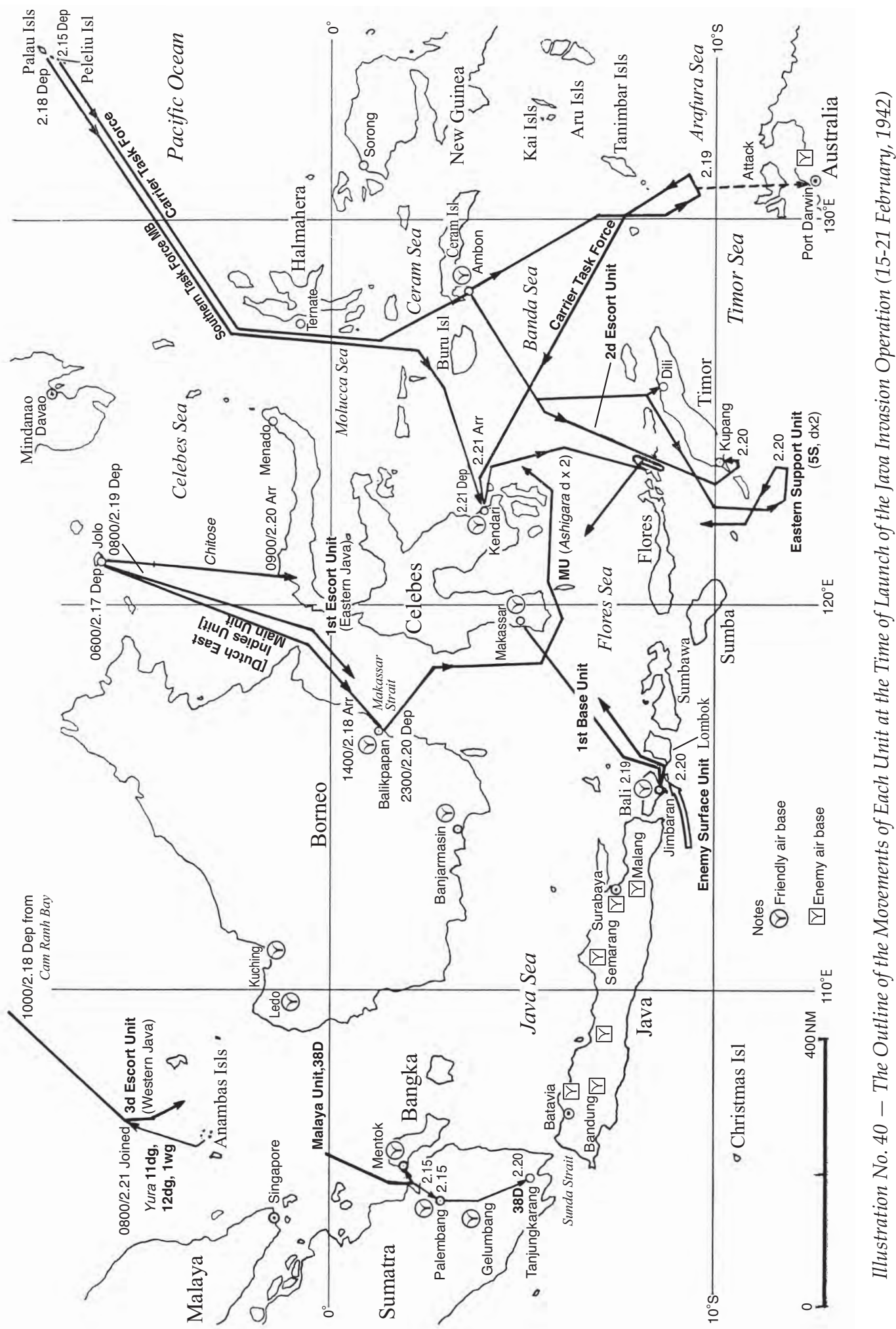




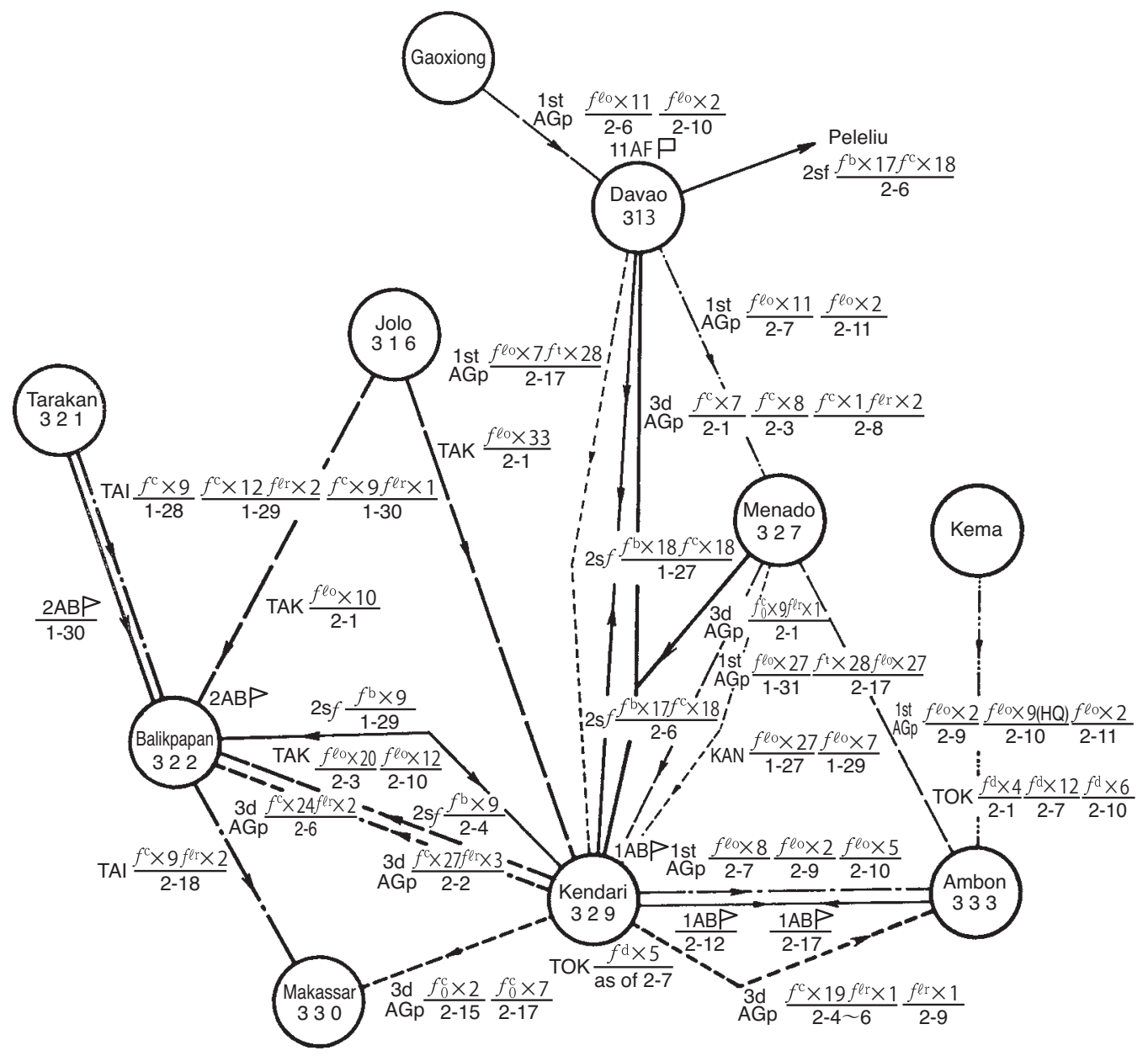

Illustration No. 41 - The Movements of the Bases of the Air Units (27 January-18 February, 1942)

destroying enemy naval vessels. The 5th Cruiser Division commander may at his discretion arrange the tasks of the 4 th and the $2 \mathrm{~d}$ Destroyer Squadron commanders.

(5) The operations of the main unit (the Ashigara, the Ikazuchi and the Akebono) (omitted)

On the morning of 23 February, Southern Task Force Commander Vice Admiral Kondō received a reply telegram from the Southern Army that the latter consented to setting the landing date on 28 February, and issued the following order: ${ }^{(53)}$

\section{Southern Task Force Telegraphic Order No. 108 [at] 1300, the 23d}

The Southern Task Force shall in close conjunction with the Southern Army determinedly carry out the landing operations in eastern and western Java roughly on Day Z +2 (note by the author: Day $\mathrm{Z}$ denotes 26 February) and destroy the base and center of the Dutch East Indies, while at the same time catching and destroying the enemy forces in the east Asian seas at a stroke. Each 
unit shall operate as planned, and particularly through close cooperation and by making thoroughgoing and careful preparations and conducting dauntless attacks, thoroughly envelop and destroy the enemy forces around the island of Java, thereby enhancing and accomplishing the military gains of the southern operation in general.

\section{The Unsatisfactory Prior Neutralization of the Enemy Air Power Both in Eastern and Western [Java]}

On 20 February, a search plane of the 22d Air Flotilla (the 3d Air Raid Unit) had spotted a powerful unit including five cruisers and eight destroyers in the Batavia area. However, since the unit used the Kuching [airfield] as its front base, from which the aircraft could not take off with a full load of fuel, it was fairly difficult for the unit to implement an attack in the Batavia area. Because of this [issue], the unit planned to advance its land-based attack planes to Gelumbang in southern Sumatra and started transporting its base matériel. However, due to the distance of the airfield from the coast, the transport made little progress, which hindered the advance of the land-based attack planes. Whereas Army air units had launched their air campaign to destroy the enemy air power in the Batavia area from Palembang, attacks by the Navy air unit had not yet been launched, a situation that was particularly serious in regard to attacking the [enemy] surface vessels. ${ }^{(135)}$

On 24 February, the Southern Task Force wired the following telegram to the chief of staff of the First Southern Expeditionary Fleet and the 22d Air Flotilla commander under the name of its chief of staff: ${ }^{(150)}$

\section{Second Fleet Classified Telegram No. 41}

The date of the landings on Java is now approaching, but the fact that we have not yet been able to get an opportunity to destroy the enemy surface forces in the Java Sea area will greatly affect the implementation of the landing operations. Therefore, success in the air operations in the [coming] several days is desperately hoped for. Since the Army has offered its cooperation (cf. 81st Signal Unit Classified Telegram No. 769) and also in view of the condition of the Gelumbang base ([see] Classified telegram, No. 822 from the Shimushu), I want you to be ready to promptly destroy enemy aircraft as well as naval vessels in the area before the implementation of the landing by accelerating as much as possible the preparation of this base conjointly with putting it to use. The transport convoy is already under sail, and since the date of landing has already been postponed for two days in view of the intensification of the air campaign, no further postponements of the date will be allowed. At this juncture, I want you to arrange that the attack on enemy naval vessels in western Java area shall be carried out with the full force of the Mihoro Air Group. The above is pursuant to the orders [received].

[Then] it became likely that the Gelumbang base would be available from 25 February, and first of all thirty-three land-based attack planes and one transport plane of the Genzan Air Group and six land-based attack planes of the Kanoya Air Group advanced to the base on the 24th. On the 25th, the Genzan Air Group carried out an attack on Batavia with twentyseven land-based attack planes, along with thirteen Type-0 fighter planes and one land-based reconnaissance plane that had advanced to Mentok, and reported having shot down four Spitfires and set ablaze two small planes. ${ }^{(71)}$ However, according to a reconnaissance by the search plane, one Class-A cruiser, two Class-B cruisers and five destroyers were spotted in the Batavia port, and also one Class-B cruiser and one gunboat were spotted in the Sunda 
Strait, sailing north. ${ }^{(119)}$ On the 26th, twenty-five land-based attack planes of the Kanoya Air Group advanced to Gelumbang from Thủ Dâu Một (French Indochina), while twenty-nine land-based attack planes of the Genzan Air Group returned to the Kuching [airfield] instead, after which the Kanoya Air Group mainly took charge of the air attacks in western Java. ${ }^{(71)}$ (Because the transportation of fuel and ammunition was inadequate at Gelumbang, it was difficult for two air groups to simultaneously use the airfield.) In the meantime, the Mihoro Air Group of the Malaya Unit dispatched five Type-96 carrier-based fighter planes to directly guard the base from the air against enemy aircraft, while advancing ten land-based attack planes to Kahang on the 26th, to be ready for search and attack missions in the Batavia area.

The Air Unit also pushed forward bases toward eastern Java and gradually intensified the air attacks. However, despite almost daily attacks, enemy surface naval vessels were still operating in the area. The outline of the attack was as follows: ${ }^{(71)}$ (The bases used for the attack are put within parentheses.)

22d [February] Six Type-0 fighter planes attacked Malang, etc. ([from] Bali)

$23 \mathrm{~d}$

Fourteen Type-0 fighter planes attacked Malang, etc. ([from] Bali)

24th

Fifty-one land-based attack planes attacked Surabaya ([from] Kendari, Bali, and

Balikpapan); Nine Type-0 fighter planes attacked Surabaya ([from] Bali)

25th Twenty-two land-based attack planes attacked Surabaya ([from] Balikpapan); Nine Type-0 fighter planes attacked Surabaya ([from] Bali)

26th Twenty-six land-based attack planes attacked Surabaya ([from] Makassar); Eight Type-0 fighter planes attacked Surabaya ([from] Bali)

On 26 February, Air Unit Commander V. Adm. Tsukahara Nishizō informed the Southern Task Force and the Dutch East Indies Unit of the following general enemy movements [obtained] by air reconnaissance: ${ }^{(53)}$

1. According to a reconnaissance by land-based reconnaissance planes on the morning of the 25th, one large enemy cruiser, three light cruisers, five destroyers, some small naval vessels and thirty or more merchantmen were spotted in the port of Surabaya, and one cruiser and more than a dozen merchantmen in the port of Batavia.

Although the Air Unit has been attacking enemy naval vessels every day, it is difficult to destroy enemy naval vessels in quick order. In view of the fact that powerful naval vessels of the Southern Task Force have already advanced to the Sunda and the Java Seas, taking up positions so that they could prevent the escape of the enemy and destroy them, it may be better if they take action to further advance to neutralize enemy ports and completely contain and capture the enemy naval vessels.

2. The military gains of the air campaigns in eastern Java since 18 February are forty-three aircraft shot down (of which eleven were unconfirmed), and forty-eight aircraft set ablaze. Although the Army has also attained considerable military gains in western Java, about fifty fighter planes, about forty bombers and about twenty flying boats of the enemy still survive, and they are starting to wage guerrilla warfare. Since the 26th, Bali has been reinforced with the main body of the 3d Air Group (about twenty Type-0 fighter planes and about ten aircraft, which had earlier been incorporated in the $2 \mathrm{~d}$ Air Raid Unit), and with these we intend to rapidly clear and destroy the [remaining] enemy aircraft.

Having earlier discussed the matter with Southern Task Force Commander Vice Admiral Kondō, Dutch East Indies Unit Commander Vice Admiral Takahashi had called off the 5th 
Cruiser Division force's support for the carrier operation and ordered it to advance to the Java Sea [instead]; he had also called off the forces of the $2 \mathrm{~d}$ Destroyer Squadron's [participation in] the Timor operation earlier than planned and hastened them to advance to the Java Sea. In view of the movements of the enemy heavy cruiser[s] in the Surabaya area on the evening of the 24th, he [further] had instructed them to advance as soon as possible. ${ }^{(53)}$ Meanwhile, the Myōkō, who had been damaged by an [enemy] air strike in Malalag Bay (south of Davao) on 4 January, had completed its repairs and left Sasebo on 20 February. The Dutch East Indies Unit commander had [also] ordered this ship to swiftly advance to Makassar, having decided to incorporate her into the main unit upon her arrival, which was due on 26 February. ${ }^{(72)}$

In the meantime, Dutch East Indies Unit Commander Vice Admiral Takahashi had left Staring Bay on the early morning of 23 February, leading the main unit (the Ashigara, the Ikazuchi, the Akebono and the Yamakaze (who had replaced the Kawakaze)* and arrived in Makassar on the 25th. [Then] considering the enemy movements in the Surabaya area, he advanced to the waters north of the Kangean Islands, leaving Makassar on the morning of the 26th. He also ordered the Myōkō to join the main unit near the Kangean Islands, after quickly replenishing at Makassar. ${ }^{(72)}$

Despite all possible measures taken to accelerate the air campaign also in western Java, a reconnaissance report of the $3 \mathrm{~d}$ Air Raid Unit on the 25th reported the continuing presence of a powerful [enemy] unit in the Batavia area. Therefore, Southern Task Force Commander Vice Admiral Kondo decided to add to this operational unit the 4th Carrier Division, which was then on standby at Cap Saint Jacques (south of Saigon) after completing Operation L, and ordered it on the morning of 27 February to advance. ${ }^{(134)}$

\section{The Operations of the Surface Unit in the Western Java Area}

The Sailing of the Convoy (See Illustrations No. 42 and No. 43)

At 1000 on 18 February, the 3d Escort Unit left Cam Ranh Bay, escorting fifty-six Army transport ships (one ship had been added). It was a large unit, [consisting of] one light cruiser, ten destroyers, three naval vessels of other types, and fifty-six transport ships, totaling as many as seventy ships. ${ }^{(150)}$ Since the Ayanami of the 19th Destroyer Division had hit an uncharted reef at the Anambas Islands on the previous day, it was decided that the Isonami of the main unit of the Malaya Unit should take over her tasks. The change caused the 19th Destroyer Division commander to change ships to the Uranami, and the Isonami to separate from the Chōkai and head for the Anambas, while the Ayanami joined the Chōkai and headed for Cap Saint Jacques. ${ }^{(150)}$

On the evening of the 20th, the convoy reached a point about 250 nautical miles northeast of the Anambas Islands, where one element of the $3 \mathrm{~d}$ Escort Unit sailed ahead for the islands for replenishment, and the unit, which had been on standby at the Anambas Islands, replaced it and escorted the convoy. As of the 21st, the Yura, the 11th and the 12th Destroyer Divisions, the 1st Minesweeper Division, the Kamikawa-maru, the Tsurumi and others were transferred from the Malaya Unit to the Dutch East Indies Unit. ${ }^{(150)}$ The convoy passed through the waters between the Anambas Islands and Great Natuna Island towards midnight on that day. [Also] on that day, 7th Cruiser Division Commander R. Adm. Kurita Takeo, who had been on

\footnotetext{
* Actually, the Yamakaze and Kawakaze had both joined the 5th Cruiser Division.
} 
standby at the Anambas Islands, communicated to the units involved that he would leave the islands at 1800 on the $22 \mathrm{~d}$, leading the 7th Cruiser Division, along with the 19th Destroyer Division and approach the convoy at 1200 on the 24th, and that from that time on [his unit] would appropriately operate in the western part of the Java Sea to support the $3 \mathrm{~d}$ Escort Unit. ${ }^{(119)}$

Around noon on the $22 \mathrm{~d}$, the $3 \mathrm{~d}$ Escort Unit reached a point about eighty nautical miles northwest of Singkawang. The [total] strength including the forces transferred from the Malaya Unit had become a total of eighty-three ships, consisting of two light cruisers, fifteen destroyers, two torpedo boats, five minesweepers, three naval vessels of other types and fifty-six transport ships. There the convoy received the [above-mentioned] order from the Dutch East Indies commander: "The landing on Java shall be postponed until 28 February. The units for the Batavia operation shall appropriately operate as designated by their commander." (150) Because of this order, the convoy reversed course at 1400 and [started] sailing north on a $320^{\circ}[\mathrm{NW}]$ course. Due to this change in schedule, the 7th Cruiser Division postponed its departure from the Anambas Islands for two days until the 24th. ${ }^{(119)}$ At $2040^{*}$ on that day [the 22d], one enemy PBY flying boat came flying over the Anambas anchorage.

At 1400 on the $23 \mathrm{~d}$, after having sailed on a reverse course for one day, the convoy reversed again and set a $140^{\circ}$ [SE] course. Due to the two-day postponement, all vessels were scheduled to refuel while under sail between that afternoon and the 24th. The refueling started with the Natori and the Yura, and was finished on the morning of the 24th. ${ }^{(150)}$ At $1650^{* *}$ on the 24th, the aircraft of the Kamikawa-maru patrolling against enemy submarines about forty nautical miles off Singkawang spotted [an] enemy submarine and attacked her. The $3 \mathrm{~d}$ Escort Unit also dispatched the Harukaze and the Fubuki to neutralize the area while carrying out an attack with antisubmarine depth charges, but the results were unknown. The reconnaissance seaplanes of the Yura also supported the operation. ${ }^{(150)}$ At 1800 on that day, the 7th Cruiser Division and the 19th Destroyer Division left the Anambas Islands and sailed south. At 0930 on the 25th, the Harukaze and the Fubuki returned to the escort unit. At 1600 on the 25th, the convoy passed the Karimata Strait without incident and entered into the Java Sea. At 1100 while en route off Cape Jang, [the 7th Cruiser Division] was approached by an enemy flying boat, which came probing. An observation seaplane[s] of the Kamikawa-maru attacked [the enemy], but let it slip away due to a squall. ${ }^{(119)}$ At 1800 on that day, the 7th Cruiser Division and the 19th Destroyer Division approached the rear of the $3 \mathrm{~d}$ Escort Unit at a distance of about 140 nautical miles. In the meantime, air reconnaissance reported that one Class-A cruiser, two Class-B cruisers and five destroyers were in the port of Batavia as of 1005 , and that one Class-B cruiser and one gunboat were sailing north in the Sunda Strait as of 1130 . $^{(119)}$

On the morning of the 26th, the convoy reached the waters about 215 nautical miles northeast of Batavia. ${ }^{(150)}$ At that time, the 7 th Cruiser Division unit was reaching a point about fiftyfive nautical miles north of the convoy. ${ }^{(119)}$ No search planes spotted the enemy except for the aircraft of the Kumano, which spotted two merchantmen and one destroyer-like ship to the northeast of Batavia. However, one enemy flying boat came probing at 1000, as well as at 1300. In the meantime, the 7th Cruiser Division unit [further] gradually approached the con-

* On p. 420: 2015.

** On p. 420: 1635 . 
voy, and around 1400, the unit and the convoy spotted each other at the $4^{\circ} \mathrm{N}^{*}$ parallel, after which the unit shifted to the support operation, while keeping on sailing to the south of and in parallel with the 3d Escort Unit. ${ }^{(119)}$ R. Adm. Hara Kenzaburō, commander of the 5th Destroyer Squadron, requested 7th Cruiser Division Commander Rear Admiral Kurita to provide the following support operations. ${ }^{(150)}$

1. The actions of our unit shall be changed as follows:

From 1200 on the 26th onwards, [our unit] shall [continue] sailing westward along the $4^{\circ} \mathrm{S}$ parallel to reach a point $4^{\circ} 00^{\prime}[\mathrm{S}] 107^{\circ} 05^{\prime} \mathrm{E}$ at 0400 on the $27 \mathrm{th}$, from where the main force and the detachment shall separate and head for their landing points as scheduled, the main force setting a $210^{\circ}[\mathrm{SSW}]$ course and the detachment a $155^{\circ}$ [SSE] course.

2. In view of the enemy movements in the Batavia and Sunda Strait areas, I would like you to see to it that [your unit] generally operates along with our unit until the morning of the 27th, and thereafter with one element support and assist the main force, but with the bulk [of your unit] support and assist the detachment for Patrol.

3. Communication signals (omitted by the author)

\section{The Appearance of a Powerful Enemy Surface Unit}

At 0530 on 27 February, the 3d Escort Unit reached the separation point about 140 nautical miles north of Batavia and separated as planned. While appropriately sailing westward about forty nautical miles south of the $3 \mathrm{~d}$ Escort Unit, the 7th Cruiser Division unit launched four search planes at 0800 at one hundred nautical miles north of Batavia toward the Sunda Strait, the port of Batavia and Patrol. At 0935**, the aircraft of the Kumano spotted one large [enemy] cruiser, two light cruisers and two destroyers at thirty-five nautical miles $310^{\circ}$ [NW] of Batavia. The enemy fleet was sailing on a steady $160^{\circ}$ [SSE] course at a speed of twenty knots; its position was eighty-five nautical miles $220^{\circ}$ [SW] of the current position of the 7 th Cruiser Division.

Having received the report, 7th Cruiser Division Commander Rear Admiral Kurita made the following initial judgment:(119)

1. In order to block our invasion unit, the enemy will operate on the waters north of the Sunda Strait and thereafter head for Batavia.

2. Since it is very likely that mines have been laid and [enemy] submarines etc. are in hiding in the areas north of the Sunda Strait, the best way to proceed is not to advance to catch the enemy outside the port of Batavia.

3. We shall keep on operating near the convoy and if the enemy should sail northward [toward us], then we shall destroy them.

Then at 0948, the aircraft of the Kumano reported: "The large cruiser in front is huge and we suspect that she is a battleship. Although we checked up on her at a distance of four thousand meters, we are not sure." "0935: The enemy has reversed course. His new course is set at $345^{\circ}$ $[\mathrm{N}] .{ }^{\prime \prime(150) * * *}$ Even after receiving these reports, 7th Cruiser Division Commander Rear Admiral Kurita continued sailing northward on a $0^{\circ}[\mathrm{N}]$ course. On the other hand, the $3 \mathrm{~d}$ Escort Unit

* Actually: the $4^{\circ} S$ parallel. See also Illustration No. 42.

** The original sources state: 0900.

*** Not mentioned in the source cited in note 150. Most of the following pages seem to be based on a mixture of sources: the reports of the 5th Destroyer Division, the 7th Destroyer Division, and the Captain of the Mogami. 


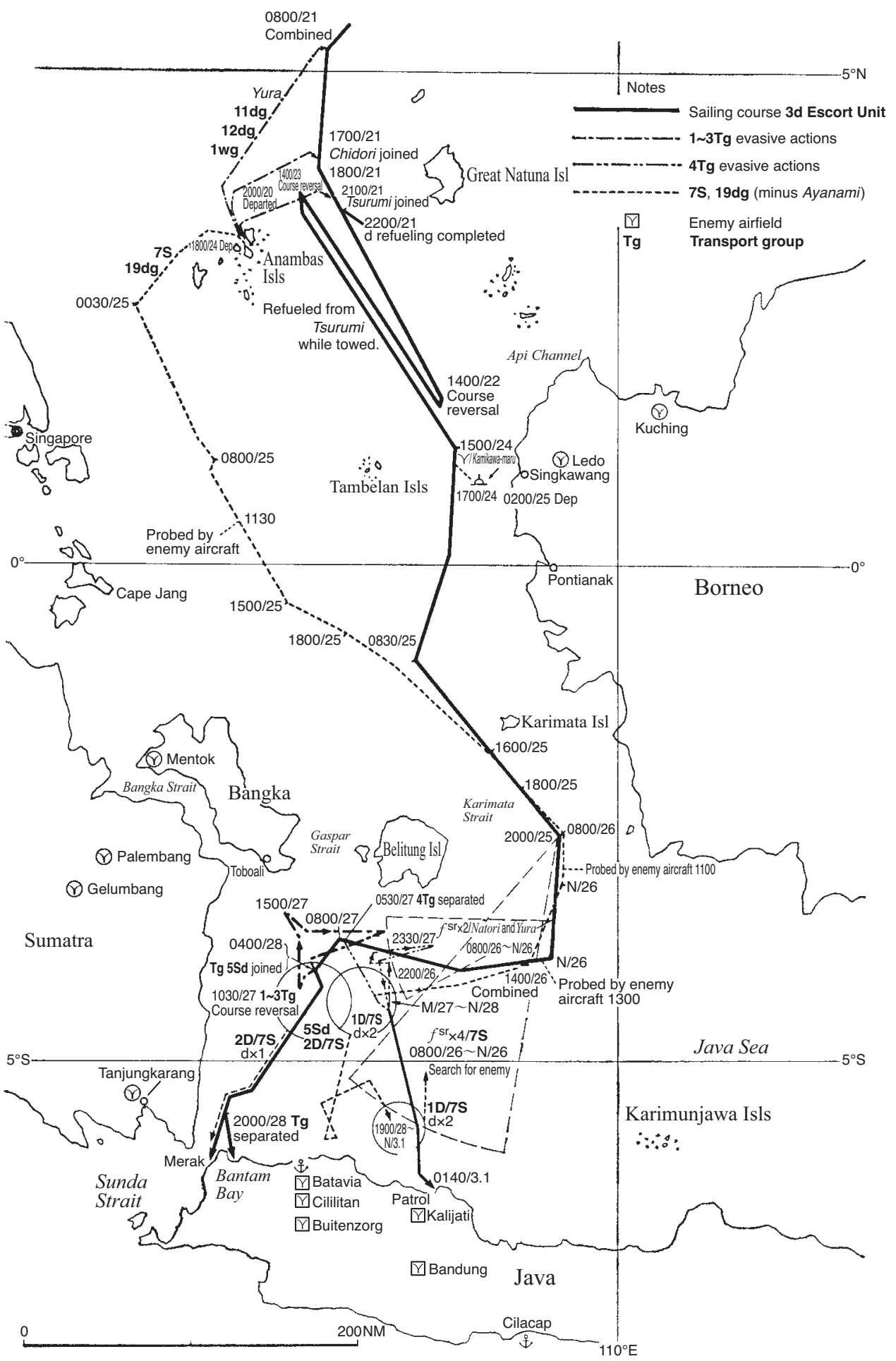

Illustration No. 42 - The Movements of the Units for the Western Java Invasion [Operation], Map No. 1 (21 February - 1 March, 1942) 
commander (5th Destroyer Squadron Commander Rear Admiral Hara) who [also] had received these reports judged as follows and made up his mind [to attack]:(150)

1. The enemy has made a sortie in order to attack our invasion unit.

2. I will immediately have the transport convoy evacuate northward and, together with the 7th Cruiser Division unit, swiftly confront this enemy with the Natori, the Yura and the bulk of the destroyers, determined to destroy them.

In line with this decision, 3d Escort Unit Commander Hara immediately ordered the transport convoy, which was heading for Area No. 1 under his direct command, to reverse course under the command of the 5th Destroyer Division commander, while ordering the unit for Area No. 2 to reverse course, too. Along with this, the commander also requested the Air Unit to attack [the enemy].

At 1030, 5th Destroyer Squadron Commander Hara contacted 7th Cruiser Division Commander Kurita in the following way: ${ }^{(150)}$

1. Our unit shall temporarily reverse course at 1030 at $4^{\circ} 25^{\prime} \mathrm{S} 106^{\circ} 40^{\prime} \mathrm{E}$.

2. I have ordered the detachment for Patrol to reverse course, too.

3. I would like you to have your unit repulse the enemy reported by the aircraft of the Kumano.

4. I would like you to inform us about your position.

Note by the author: At that time, there was a distance of about thirty nautical miles between the 7th Cruiser Division and the 5th Destroyer Squadron.

[Then] 5th Destroyer Squadron Commander Hara started sailing southward on a $200^{\circ}$ [SSW] course toward the enemy, leading the Natori, the 11th and the 12th Destroyer Divisions.

\section{The 7th Cruiser Division's Avoidance of a Decisive Battle}

Whereas 5th Destroyer Squadron Commander Hara took such measures [as described above], 7th Cruiser Division Commander Kurita, without responding [to the former], continued sailing northward, while taking the following measures. ${ }^{(119)}$

1. At 0930, he ordered the aircraft of the Kumano to conduct the scheduled search missions.

2. At 1000, he ordered the aircraft of the Mikuma and the Mogami to probe the enemy spotted by the aircraft of the Kumano.

3. At 1024, two Type- 0 reconnaissance seaplanes of the $2 \mathrm{~d}$ Section of the 7 th Cruiser Division were launched for probing.

The 7th Cruiser Division and the 5th Destroyer Squadron on site continued cooperating with each other in this fashion. R. Adm. Kurita Takeo, commander of the 7th Cruiser Division was a graduate of the 38th class of the Naval Academy, whereas R. Adm. Hara Kenzaburō, commander of the 5th Destroyer Squadron, was a graduate of the 37th class, but the 7th Cruiser Division commander had been promoted earlier [and was therefore actually the senior commander on site].

At 1040, 5th Destroyer Squadron Commander Hara ordered the Yura to join him. By this order, the Yura separated from the unit for Area No. 2 at 1115 and rushed westward to join the Natori. The unit for Area No. 2 [then] evacuated northward under the command of the 
6th Destroyer Division commander. While sailing southward, 5th Destroyer Squadron Commander Hara ordered the 5th Destroyer Division to join him, while ordering the convoy to evacuate to the Bangka Strait. Commander Hara continued sailing south, leading the Natori, the 11th and the 12th Destroyer Divisions. However, with no response from the 7th Cruiser Division about its position, he changed course to $120^{\circ}$ at 1120 in order to locate it. Meanwhile, after retrieving the search planes at 1040, 7th Cruiser Division Commander Kurita finally started sailing south and after conveying at 1130 his current position, he communicated [his decision] to 5th Destroyer Squadron Commander Hara: "The 2d Section of the 7th Cruiser Division and the Shikinami shall provide support on the waters where the Natori operates, while the rest of the unit shall do so on the waters where the Yura operates." (150) Then at 1140, while sending off the $2 \mathrm{~d}$ Section (the Mikuma and the Mogami) of the 7th Cruiser Division southeastward, he changed course to $125^{\circ}$ [ESE], away from the enemy (which was supposed to be on the waters southwest [of the division]), leading the 1st Section (the Uranami and the Shikinami*) of the 19th Destroyer Division. The enemy movements reported by the probing aircraft of the 7th Cruiser Division during these hours were as follows: ${ }^{(119)}$

The aircraft of the Mogami at 1115:

The aircraft of the Mogami at 1127: The aircraft of the Mikuma at 1140: The aircraft of the Mikuma at 1300:

The aircraft of the Mikuma at 1300: The aircraft of the Mogami at 1305:
The enemy force consist of one Glasgow-class and two Danae-class [cruisers] and two destroyers.

No battleships or aircraft carriers accompany the enemy. The enemy changed course to $90^{\circ}[\mathrm{E}]$.

The enemy position as of 1220 is fourteen nautical miles $356^{\circ}$ [N] of Cape Kait, [sailing] on a $95^{\circ}[\mathrm{E}]$ course at twelve knots.

The enemy changed course to $0^{\circ}[\mathrm{N}]$ at eighteen knots. The enemy reversed course; he is at nineteen nautical miles $290^{\circ}$ [WNW] of Cape Krawang and set on a $0^{\circ}[\mathrm{N}]$ course.

The report at 1300 of the enemy sailing northward clearly indicated that the enemy was prepared to attack the Japanese forces. Based on this, 7th Cruiser Division Commander Kurita finally made contact at 1330: "I will head for the enemy, sailing on a $230^{\circ}$ [SW] course at sixteen knots," while ordering [his unit] to be ready from 1430 onwards to immediately increase the speed to twenty-eight knots. In the course of joining the 7th Cruiser Division, 5th Destroyer Division Commander Hara communicated to the 7th Cruiser Division commander: "In the light of the current movements of the enemy, I would like to defeat the enemy in front [of us] on the waters northwest of Batavia, with the 7th Cruiser Division, the Yura, the Natori, the 11th, the 12th and the 19th Destroyer Divisions, while postponing the date of landing for another day." (159) Further, he communicated to the Dutch East Indies Unit commander: “The enemy is prepared to take the offensive against our transport convoy with one large cruiser, two light cruisers and two destroyers. Presently, while having the transport ships temporarily reverse course, we are gathering surface forces to defeat [the enemy] first. [Thus,] we have no choice but to postpone the date of landing for another day. I would like your approval for a one-day postponement." He also communicated the matter to Sixteenth Army Commander Lieutenant General Imamura, who was on one of the ships of the transport convoy. $^{(150)}$

\footnotetext{
* Probably the Isonami is meant. The Shikinami was part of the $2 \mathrm{~d}$ Section.
} 
At 1340, the 5th Destroyer Division unit and the 1st section of the 7th Cruiser Division came within sight [of each other]. The $2 \mathrm{~d}$ section of the 7th Cruiser Division, which at one point had [operated] separately, also joined them. Since he had had no response whatsoever from 7th Cruiser Division Commander Kurita to his "I would like to defeat the enemy in front [of us with my unit] joined by yours" inquiry communicated at 1345, he resent at 1400 the telegram by signal (i.e. the telegram that he would like to postpone the date of landing for another day to defeat the enemy in front).

Without responding to it either (and remaining on a $230^{\circ}$ [SW] course), 7 th Cruiser Division Commander Kurita only signaled the outline of the subsequent search mission of the 7th Cruiser Division. Also, without gaining speed, he maintained his speed at sixteen knots. Meanwhile, 5th Destroyer Squadron Commander Hara issued the following order concerning the outline of the subsequent operations to the $3 \mathrm{~d}$ Escort Unit:(150)

1. It seems that the enemy will try to block our transport ships with [a force consisting of] one large cruiser, two light cruisers and two destroyers as the core.

2. The Natori, the Yura the 11th and the 12th Destroyer Divisions shall, along with the 7th Cruiser Division and the 19th Destroyer Division, defeat the enemy in front on the waters northwest of Batavia.

3. The date of landing shall be postponed for another day.

4. The transport ships shall appropriately operate as designated by the commanders of the $22 \mathrm{~d}$ and the 6th Destroyer Divisions, while being strictly on guard against enemy aircraft and submarines, so as to enter the scheduled route at $3^{\circ} 53^{\prime} \mathrm{S} 107^{\circ} 10^{\prime} \mathrm{E}$ at 0500 on the 28 th.

Meanwhile, after having received a report from the aircraft of the Mikuma [saying], "1443: The enemy changed course to $215^{\circ}$ [SW]," 7th Cruiser Division Commander Kurita swiftly wired 5th Destroyer Squadron Commander Hara at 1445: "The enemy is very likely to flee into Batavia or other [ports]. If [the enemy] should flee into Batavia, I would like to have the $2 \mathrm{~d}$ Section of the 7th Cruiser Division directly support [the landing units in] Area No. 1 and the 1st Section to operate appropriately blocking the waters east of Batavia." ${ }^{(119)}$ To this message, 5th Destroyer Squadron Commander Hara replied at 1450: "Regarding the current situation that the enemy vessels have escaped into Batavia, our unit shall appropriately operate on the waters northeast of Northwatcher* tonight, while on guard against the enemy. Tomorrow morning, as in your plan, I would like the support of the 7th Cruiser Division split into its sections in the landings of the main force as well as of the detachment." (119)

At 1450, the aircraft of the Mogami reported: "The enemy is about to flee into Batavia, [sailing] at ten nautical miles $20^{\circ}$ [NNE] of Batavia." Also, a land-based attack plane unit of the Kanoya Air Group reported: "1450: We finished bombing at 1437. Scored two direct hits at the first ship, which we are sure caught fire. They are at ten nautical miles $28^{\circ}$ [NNE] of Batavia, basically sailing on a $206^{\circ}$ [SSW] course. We are flying in a formation of eight aircraft." (119) At 1455, 7th Cruiser Division Commander Kurita urged 5th Destroyer Squadron Commander Hara: "I suggest you proceed with the operation at this opportunity. A one-day postponement is not convenient for us in terms of the fuel [situation] of our destroyers."(119) However, 5th Destroyer Squadron commander replied: "Due to the landing times, it is too late [to resume] the landing operation today. We have arranged to postpone the landing by

\footnotetext{
* Actually: Noordwachter, the northernmost island of the Pulau Seribu Islands. It had a lighthouse erected in 1869; nowadays known as Pulau Sabira or Pulau Jaga Utara.
} 
one day." After communicating at 1500 that "[he would] stop the pursuit," 7th Cruiser Division Commander Kurita suspended the operation to approach [the enemy], again detached the $2 \mathrm{~d}$ Section of the 7 th Cruiser Division and the Shikinami to separately operate [in the area of the Natori], while he himself reversed course and took a northeastward course. His position at that time was sixty-five nautical miles north of Batavia. ${ }^{(150)}$

The 5th Destroyer Squadron also suspended the pursuit and started sailing northward to support the transport convoy. At 1500, a telegram came from the chief of staff of the Combined Fleet: "In consideration of the enemy movements in the Batavia area, it is appropriate that the 7th Cruiser Division commander shall take a unified command of the units in the said area." (150) It was sent by the Combined Fleet headquarters, and showed that the headquarters was no longer able to put up with the exchange of telegrams between the 7th Cruiser Division and the 5th Destroyer Squadron. At 1500, 7th Cruiser Division Commander Rear Admiral Kurita wirelessed to the Dutch East Indies Unit as well as the Air Unit: "The enemy consists of one large cruiser, two light cruisers and two destroyers. Although the support unit and the bulk of the 3d Escort Unit were heading to attack the enemy en masse, he will very likely flee back into [the port of] Batavia. Unless [the enemy] would be destroyed by a full-scale air attack, it will be difficult to conduct the disembarkation for several days in succession. In terms of fuel, the 7th Cruiser Division cannot stay in this area for long. I would like you to see to the matter of the air attack."(119) Furthermore, the 7th Cruiser Division commander [announced] his plan of operations for that night: "Tonight, the 1st Section of the 7th Cruiser Division and the 1st Section of the 19th Destroyer Division shall appropriately operate [in the area] one hundred nautical miles northeast of Batavia, while the $2 \mathrm{~d}$ Section of the 7th Cruiser Division and the Shikinami shall be on the waters northeast of Northwatcher [Noordwachter] along with the Natori, to be ready against the appearance of the enemy."(119)

On the evening of the 27th, the Southern Task Force and the Dutch East Indies Unit commanders sent the following telegraphic orders concerning the disposition of forces. ${ }^{(150)}$

1. The 7th Cruiser Division and the 4th Carrier Division (minus the $2 \mathrm{~d}$ Section) shall be transferred to the unit for the Batavia invasion [operation] (including the destroyers accompanying each division).

2. The 7th Cruiser Division commander shall take operational command of the unit for the Batavia invasion [operation].

Rear Admiral Kurita, commander of the 7th Cruiser Division, who had newly assumed the unified command of the units on site by these orders, requested Southern Task Force Commander Vice Admiral Kondō to increase the allotment of supply ships. Also, concerning the operations on the next day the 28th, he ordered the 5th Destroyer Squadron to sweep for mines on the waterway south of Northwatcher [Noordwachter] (where [an enemy] auxiliary transport ship had been spotted by the aircraft of the Kumano on the 27th), and at the same time issued an order to dispatch one of its destroyers to escort the 4th Carrier Division, which was expected to reach the Karimata Strait on the 28th. He further ordered the Kamikawa-maru to attack an enemy submarine, which had also been spotted on that day [the 27th] to the south of Northwatcher [Noordwachter]. ${ }^{(119)}$ Furthermore, at night a reply came from the Sixteenth Army commander, which read that he had no objection to the postponement of Day $\mathrm{H}$ for another day but that he would like to execute [the operation for] Day I without postponing the date, unless it caused problems. ${ }^{(150)}$ 


\section{Heading for the Landing Points}

On 28 February, 5th Destroyer Squadron Commander Rear Admiral Hara ordered the Yura to return to its original unit (the $3 \mathrm{~d}$ Destroyer Squadron), while ordering the 1st Minesweeper Division (minus Minesweeper No. 5) to sweep for mines and the Matsukaze to return to the Karimata Strait to escort the 4th Carrier Division. ${ }^{(150)}$ The units for Areas No. 1 and No. 2 [changed course and] started sailing toward the landing points on the planned sailing routes respectively at 0415 and 0500 . In the morning, search planes of the 7th Cruiser Division sporadically reported having spotted a small number of destroyers, patrol boats, submarines, merchantmen, etc. on the waters north of Batavia. ${ }^{(119)}$ The aircraft of the $22 \mathrm{~d}$ Air Flotilla reported the results of a reconnaissance of the port of Batavia conducted in the morning: "1050: Spotted fifteen large merchantmen and one large flying boat in the port of Batavia," which raised suspicion that the cruisers spotted on the day before might have escaped somewhere. Around noon, the 1st Section of the 7th Cruiser Division approached about ten nautical miles west of the unit for Patrol so that it could provide direct support for it, when at 1215, it received a report from the Yura: "1200: Spotted one enemy cruiser and one destroyer at fortyfive nautical miles $280^{\circ}$ [W] of Boompjes Island [Pulau Biawak], sailing on a $250^{\circ}$ [WSW] course at twenty knots." (119) Since the location was about forty-eight nautical miles south of the current position of the 1st Section of the 7th Cruiser Division, it judged that it could catch up with the enemy outside the port of Batavia if it closed in on him now, and at 1230 headed for the enemy, setting its course on $200^{\circ}$ [SSW]. However, after having received at 1417 a report from the aircraft of the Kumano that "one Glasgow-class and one light cruiser had stopped at about ten nautical miles $20^{\circ}$ [NNE] of Batavia," the section judged that the enemy had already put in at Batavia port. It called off its southward sailing, reversed course at 1450 and sailed northward to reach in the evening the waters about forty nautical miles north of Patrol, the position where it was supposed to support the Patrol unit. ${ }^{(119)}$

At 1900, the units for Area No. 1 turned toward the landing points on a $210^{\circ}$ [SW] course, reached a point eighteen nautical miles north of St. Nicholas Point [Tanjung Pujut] at 2020, and split into the units for Sectors A and B and those for Sector C. At 2210, 5th Destroyer Squadron Commander Rear Admiral Hara wirelessed the 22d Air Flotilla and the [Army] Third Air Force and requested them to pay particular concern to the guarding of the anchorages at dawn on the next day. At 2245, the captain of the Mikuma sent the following report of the reconnaissance results over Batavia conducted by the aircraft of the Mogami. ${ }^{(150)}$

The results of the reconnaissance of the Batavia area conducted at 8 p.m. on the 28 th by the aircraft of the Mogami (reconnaissance altitude: 1,500 meters)

1. One large cruiser moored at the pier, one light cruiser at anchor inside the wing dam, and further three flying boats.

2. One gunboat and two patrol boats patrolling the mouth of the bay.

3. One destroyer and one large transport ship sailing westward on the waterway north of Cape Kait.

4. One submarine sailing eastward on the said waterway.

At 2300, the Harukaze, which was guiding the invasion unit for Bantam Bay, spotted one enemy cutter, and in cooperation with the Fubuki, shelled the cutter and caused her to run aground. ${ }^{(150)}$ In the meantime at 2120, the unit for the Patrol area had come under probing 


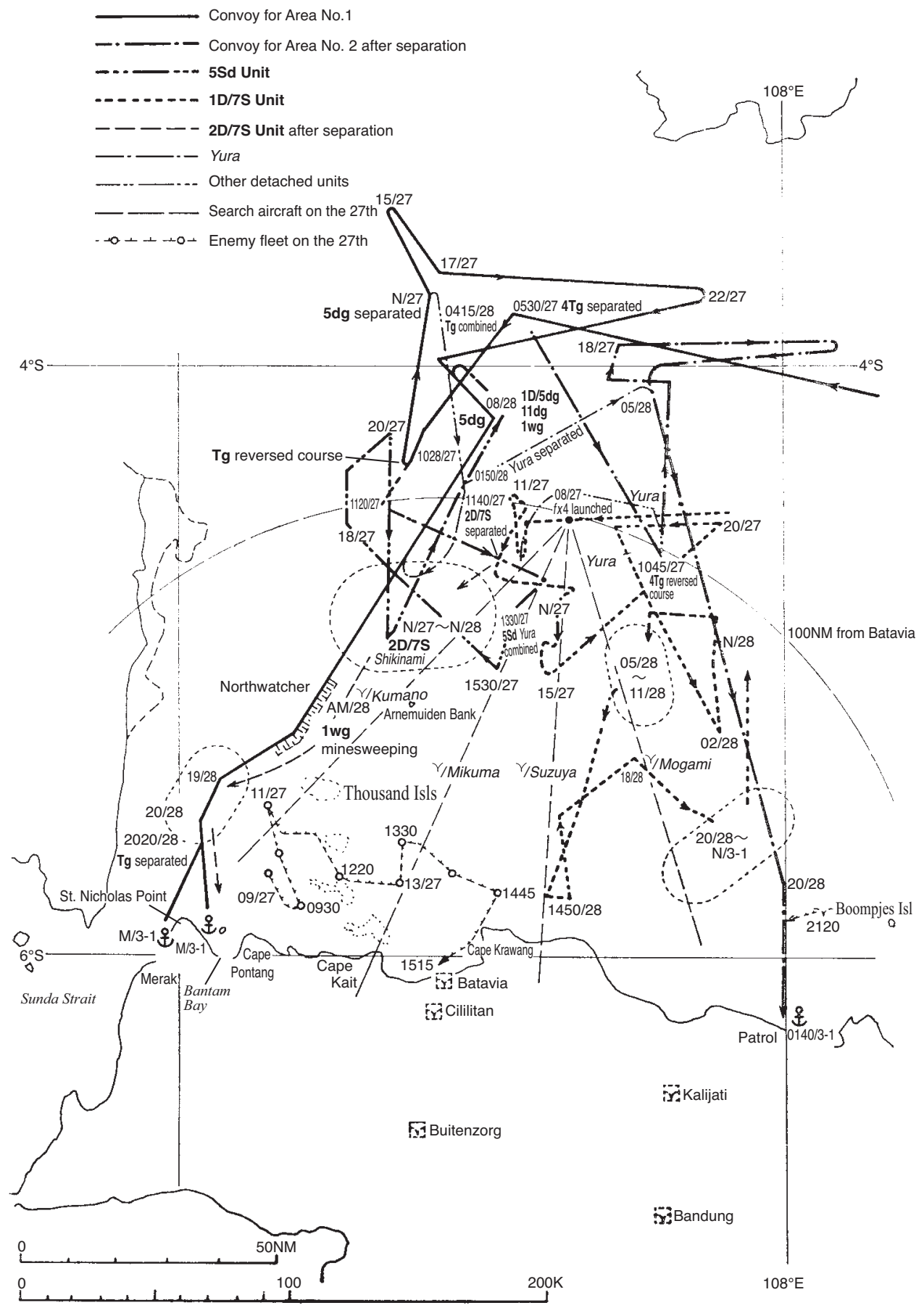

Illustration No. 43 - The Movements of the Units for the Western Java Invasion [Operation], Map No. 2 (27 February - 1 March, 1942) 
and an attack by two enemy aircraft at a point about thirty nautical miles north of Patrol, but sustaining no damage, it continued sailing south.

\section{The Engagements of the 1st Air Unit}

On 31 January, the San'yo-maru left Balikpapan along with Patrol Boat No. 35 (with one platoon of the 2d Kure Special Landing Force on board) and put in at Cam Ranh Bay on 8 February. [Then] at 1700 on the 17th, the San'yo-maru left Cam Ranh Bay and arrived at the Anambas Islands at 1700 on the 19th, where she joined the Kamikawa-maru to carry out the direct escort of the transport convoy against enemy submarines from 21 February onwards.

There was nothing unusual on that day. On the $22 \mathrm{~d}$, a base was set up in Toboali (on the southern coast of Bangka Island; [the advance to] Lepar Island was called off), to where one Type- 0 [three-seater] reconnaissance seaplane and four Type- 0 observation seaplanes advanced. Although nothing unusual [was spotted] while guarding against [enemy] submarines, at 2015* one enemy flying boat flew over the Anambas anchorage, but slipped away without conducting a bomb attack. Nothing unusual was spotted on the $23 \mathrm{~d}$. On the 24 th, at 1635, one Type-0 reconnaissance seaplane of the Kamikawa-maru spotted a surfaced submarine at fifteen nautical miles southeast of the convoy and dropped a bomb. It scored a near miss but the results were unknown, because the submarine had submerged. It further guided two of the [convoy-]guarding destroyers to the spot to attack it with antisubmarine depth charges [See p. 411]. In the meantime, three Type-0 observation seaplanes and two Type-0 reconnaissance seaplanes of the Kamikawa-maru had advanced to the Toboali base. That evening, land-based attack planes of the Genzan Air Group spotted four or more enemy submarines at the north point of the Karimata Strait and neutralized them. On the 25th, one Type- -0 reconnaissance seaplane and two Type- 0 observation seaplanes of the Kamikawa-maru moved [their base] from the Anambas Islands to Toboali. During the operation, one Type-0 observation seaplane spotted one enemy flying boat probing the 7th Cruiser Division at eighty-three nautical miles $91^{\circ}$ [E] of Cape Jang ([on] Lingga Island) and attacked it, but had to let it slip away due to a squall (as previously told [p. 411]). Meanwhile, one Type-0 reconnaissance seaplane of the Kamikawa-maru flew to an uninhabited island one hundred kilometers northwest of Batavia, escorted by one army fighter plane, to rescue the flight crew of an army aircraft, which had made an emergency landing there, successfully rescued them and brought them to their army unit in Palembang. On that day, while moving to the Toboali base, two Type- 0 reconnaissance seaplanes and one Type- 0 observation seaplane of the San'yo-maru spotted a surfaced submarine sailing south at twenty-five nautical miles $290^{\circ}$ [WNW] of Pejantan Island. They scored near misses, but the results were unknown.

On the 26th, nothing unusual was spotted other than four enemy flying boats, which a Type- 0 reconnaissance seaplane of the Kamikawa-maru spotted at thirty nautical miles $240^{\circ}$ [SW] of the convoy. On the 27th, with the discovery of an enemy fleet by the aircraft of the Kumano, it was decided that [the unit] should support [the neutralizing of the fleet] as much as possible, besides its original tasks. Accordingly, one Type-0 reconnaissance seaplane searched the whole area of the Sunda Strait and the waters surrounding the Thousand Islands [Pulau Seribu], but spotted no enemy other than two enemy minesweepers at 1525, which

* On p. 411: 2040. 
were sweeping for mines [in an area] eight nautical miles $20^{\circ}$ [NNE] of Cape Pontang while sailing on a $270^{\circ}[\mathrm{W}$ ] course. On the 28th, in addition to the scheduled direct escort [of the convoy] against enemy submarines, one Type-0 reconnaissance seaplane carried out a search and attack mission against enemy submarines on the waters south of Northwatcher [Noordwachter] Island, only to spot one destroyer and one gunboat at about twenty nautical miles northwest of Batavia. Meanwhile, the advance base personnel for the bases for the next operations ([at] Bantam Bay and the coast of Patrol) and Patrol Boat No. 35 left Toboali.

\section{The Operations of the 3d Air Raid Unit Fell Short of Expectations}

It was decided that the bulk of the Air Unit of the Malaya Unit ([consisting of] the 22d Air Flotilla as the core) should come under the command of the Air Unit of the Southern Task Force to take part in the Java operation as the 3d Air Raid Unit on 19 February ([the transfer was] advanced by two days from the 21st in view of the enemy movements).

On 19 February, the Genzan Air Group conducted a search mission over the Java Sea from Kuching with four land-based attack planes, but spotted no enemy. ${ }^{(71)}$ One land-based reconnaissance plane of the Yamada Unit conducted a reconnaissance over Batavia and spotted one Class-A cruiser, three light cruisers and forty merchantmen [p. 403]. ${ }^{(29)}$ On that day, a survey of the Mentok base was conducted, and it was reported that [a runway with] a length of 1,000 meters and a width of 200 meters was completed and that the felling of the rubber tree forest on the extension of the runway would be completed on the 21st. ${ }^{(122)}$ On the 20th, no campaign was conducted due to the preparations for the advance of the bases. On the 21st, the Genzan Air Group conducted a search mission over the western part of the Java Sea from Kuching with four land-based attack planes, but only encountered one PBY flying boat (which fled). ${ }^{(71)}$ [On that day,] one land-based attack plane of the Kanoya Air Group headed for Palembang from Thủ Dâu Một to conduct a survey of the base, ${ }^{(135)}$ while the Yamada Unit engaged in preparations for the advance to Mentok. On the 22d, four land-based attack planes of the Genzan Air Group [again] conducted a search mission over the Java Sea from Kuching only to spot no enemy, while one transport plane of the air group headed for Palembang from Kuching to conduct a survey of the Gelumbang base. On that day, due to bad weather, the Type-0 fighter planes' advance to Mentok was called off. ${ }^{(71)}$

On the 23d, four land-based attack planes of the Genzan Air Group [again] searched for the enemy on the western part of the Java Sea, but only spotted several merchantmen, which had either sunk or run aground. On that day, fifteen Type-0 fighter planes and three landbased reconnaissance planes of the Yamada Unit advanced from Kuching to Mentok with the support of eight land-based attack planes and one transport plane of the Genzan Air Group. ${ }^{(29)}$ [En route,] the land-based attack planes of the group spotted enemy submarine[s] at twenty-five nautical miles $180^{\circ}$ [S] of Pejantan Island, which led to a dispatch of two other land-based attack planes to attack them, but the latter were unable to spot them. [That day,] the land-based attack plane of the Kanoya Air Group that had been dispatched to conduct a survey on the base, returned to Thủ Dâu Một, and it was decided that first of all six landbased attack planes of the group should be advanced to Gelumbang on the 24th and then twenty-five planes on the 26th. ${ }^{(135)}$

On the 24th, thirty land-based attack planes of the Genzan Air Group advanced to Gelumbang from Kuching to be ready for an attack on Batavia on the 25th. On that day, the Type- 
0 fighter plane units [that had moved to] Mentok spotted two Dornier-type flying boats and reported having shot down one of them. [In the meantime,] while advancing to Gelumbang, the Genzan Air Group spotted four enemy submarines on the waters to the south of Pejantan Island and neutralized them [p. 420]. [On that day] a land-based reconnaissance plane of the Yamada Unit reported on the enemy movements around Batavia as of 1200 as follows: ${ }^{(135)}$

1. Inside the port: one large cruiser, ten merchantmen and eight large flying boats

2. Cililitan: eight large and seven small aircraft

3. Kemayoran: three large and two small aircraft

On the 25th, at 1000, twenty-seven land-based attack planes of the Genzan Air Group took off from the Gelumbang base, and in cooperation with thirteen Type-0 fighter planes and one land-based reconnaissance plane of the Yamada Unit, headed for an attack on enemy vessels at anchor at Batavia. Between 1200 and 1230, they bombed a British heavy cruiser (with fifty-two 250-kg [bombs]), scored a direct hit at her stern and reported having destroyed the cruiser. ${ }^{(71)}$ Although the unit was supposed to return to the Kuching base, it [had to] return to the Gelumbang base due to bad weather. The enemy antiaircraft fire was extremely fierce, and inflicted damage to eleven aircraft, which were marked by bullets, and left two crew members slightly injured. The thirteen Type- 0 fighter planes that accompanied the unit engaged in the air over Batavia with eight Spitfires coming to intercept them and reported having shot down four (one of which unconfirmed). After that, they reported having strafed the Cililitan airfield, destroyed two small planes, which were set ablaze, while one element reported having strafed the oil tanks at the port and set ablaze three of them. After this engagement, one land-based reconnaissance plane and one Type- 0 fighter plane did not return. ${ }^{(135)}$

On the 26th, the land-based attack planes of the Genzan Air Group returned to Kuching, and replacing them, twenty-five land-based attack planes of the Kanoya Air Group advanced to the Gelumbang base. ${ }^{(135)}$ Since the Gelumbang [base] was situated far from the coast, it was difficult to transport fuel and ammunition. On top of that, with no facilities for sleeping, etc., the crew had to go so far as to sleep under mosquito nets hung over the wings. Although large, the airfield was not in a condition to accommodate two air groups for continuous operations.

At 0900 on the 27th, on learning that the reconnaissance seaplane of the Kumano had spotted an enemy fleet, [the unit] tried to conduct an attack on the enemy. However, the Genzan Air Group in Kuching was not able to take off due to bad weather in the area of the base, ${ }^{(71)}$ while the Kanoya Air Group in Gelumbang launched only eight of its land-based attack planes with $60-\mathrm{kg}$ land bombs due to the delay in [the transport of] fuel and ammunition. At 1430 , they spotted the enemy fleet at fifteen nautical miles $28^{\circ}$ [NNE] of Batavia, carried out an attack, scored two or more direct hits on the vessel in front (a heavy cruiser) causing two fires to erupt amidships. Another land-based attack plane completed preparations for an attack and headed for the enemy fleet alone. However, unable to spot it, it bombed a 2,000tclass merchantman it had spotted (at anchor) at twenty nautical miles north of Batavia, and inflicted considerable damage by near misses. Meanwhile, the Type- 0 fighter planes of the Yamada Unit patrolled the air above the convoy but did not spot the enemy. ${ }^{(135)}$ 
The Summary Report of the Actions of the 3d Air Raid Unit on the 28th read as follows:(135)

1. The Yamada Unit

(1) One land-based reconnaissance plane reconnoitered Batavia, spotted two flying boats and fourteen mid-sized merchantmen in port; no other [ships including] naval vessels were spotted.

(2) Nine Type-0 fighter planes in total patrolled the air over the transport convoy but spotted no enemy.

2. The main body of the Kanoya Air Group

Two land-based attack planes carried out a search mission in the southern part of the Java Sea west of $110^{\circ} \mathrm{E}$ [longitude]. Although one returned due to bad weather, the other [spotted] at 1225 an 8,000t-class merchantman at sixty nautical miles $20^{\circ}$ [NNE] of Cape of Indramayu, sailing on a $110^{\circ}[\mathrm{E}]$ course at twelve knots.

3. The Genzan Air Group

Due to bad weather at Kuching and the soft ground of the airfield, it did not take off.

Note: The Genzan air Group was supposed to advance to and operate from Gelumbang.

\section{The Mihoro Air Group of the Malaya Unit Failed to Provide Effective Support}

As previously told, the bulk of the Air Unit of the Malaya Unit was incorporated into the Air Unit of the Southern Task Force and supposed to participate in the Java operation as the 3d Air Raid Unit under the unified command of Eleventh Air Fleet Commander in Chief Vice Admiral Tsukahara. However, the Mihoro Air Group was kept in the Malaya Unit to remain engaged in the northern Sumatra operations. Then, by the (previously-mentioned) instructions given to the Malaya Unit on the 24th [p.408], the group was assigned to carry out an attack on enemy vessels in the western Java area with its full force.

On the 26th, ten land-based attack planes took off from the Kuantan base at 1500, landed in the Kahang base at 1600, where they completed refueling, and took off from the Kahang base at 0855 on the 27 th for a search and attack mission in the Batavia area. Having learned at 1100 about the telegram from an aircraft of the Kumano that it had spotted an enemy fleet, they headed for an attack on the enemy but unable to spot the enemy fleet due to low visibility, all returned to the Kahang base at $1800 .{ }^{(71)}$ On the 28th, the air unit left Kahang to return to Kuantan, which meant that they failed to provide effective support for the air operation to destroy the enemy air power in Java.

\section{The Belated Advance of the 4th Carrier Division}

The 4th Carrier Division, which had returned to Cap Saint Jacques ([in] French Indochina) on 19 February, was on standby for the subsequent operations. However, since the landbased attack plane unit did not produce significant results in the air campaign in the western Java area, Southern Task Force Commander Vice Admiral Kondō issued at 0850 on the 27th the following order by means of the Second Fleet Classified Telegram No. 50. ${ }^{(150)}$ Southern Task Force Telegraphic Order No. 114: "The Malaya Unit commander shall have the 4th Carrier Division (minus the $2 \mathrm{~d}$ Section) promptly advance to the Java Sea area to have it support the operations of the Dutch East Indies Unit." In line [with the above], Malaya Unit Commander Vice Admiral Ozawa issued Malaya Unit Telegraphic Order No. 156, which read: “1150, 27 February: The 4th Carrier Division (minus the 2d Section) shall operate as [in- 
structed] in Southern Task Force Telegraphic Order No. 114."(134) Then at 1600 on the 27th, Southern Task Force Commander Vice Admiral Kondō incorporated the 7th Cruiser Division as well as the 4th Carrier Division (minus the $2 \mathrm{~d}$ Section) into the Dutch East Indies Unit (including the destroyers accompanying the divisions). ${ }^{(150)}$ In accordance with this, Dutch East Indies Unit Commander Vice Admiral Takahashi issued the following order by means of Third Fleet Classified Telegram No. 519.(119)*

1. The 7th Cruiser Division and the 4 th Carrier Division (minus the $2 \mathrm{~d}$ Section) shall be transferred to the unit for the Batavia invasion [operation].

2. The 7th Cruiser Division commander shall take operational command of the unit for the Batavia invasion [operation].

Based on this order, the 4th Carrier Division hurriedly left Cap Saint Jacques on the afternoon of the 27 th to rush to the Java Sea but it was not in time for the engagements before the 28th.

\section{The Engagements of the Army Air Units}

The main force of the [Army] Third Air Force had advanced to the Palembang airfield on both 17 and 18 February, carried out attacks on the airfields in Batavia, Kalijati, Bandung and Buitenzorg from the 19th until the 25th, and reported having shot down or destroyed 211 enemy aircraft. The numbers of the army aircraft advanced at that time was as follows. ${ }^{(17)}$

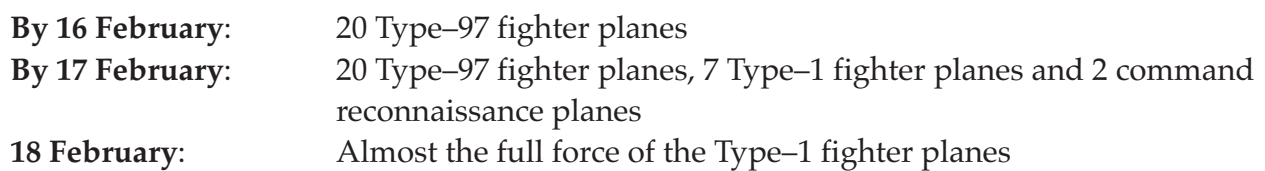

On 17 February, the [Army] 12th Air Division advanced the 11th Air Group to Palembang to assign the latter to [guard] the oil refineries against enemy aircraft and cover the anchorage of the Sixteenth Army. [Then] on the 22d, after the capture of the Tanjungkarang airfield, [the division] advanced one element to the airfield as the advance unit, which was followed by the advance of the main force on the 24 th. The group reported military gains of having shot down or destroyed 132 [enemy] aircraft by the 25th, and from the 27th onwards, took charge of the cover of the convoy under sail and the guarding of the anchorage against enemy aircraft.

\section{The Sailing of the Convoy for the Eastern Java Invasion [Operation]}

(See Illustrations No. 44 and No. 45)

At 0800 on 19 February, the 1st Escort Unit left Jolo, escorting thirty-eight Army transport ships. The [escort] strength at that time consisted of the Naka, the 24th Destroyer Division (one destroyer), the 2d Destroyer Division (four destroyers), the 9th Destroyer Division (three destroyers), the 30th Minesweeper Division (two minesweepers), the 11th Minesweeper Division (two minesweepers), Minesweeper No. 20, the 21st Subchaser Division (five submarine chasers), the Wakataka, the Hayatomo, and the Ebisu-maru, that is, one light cruiser, eight de-

\footnotetext{
* See also p. 417.
} 


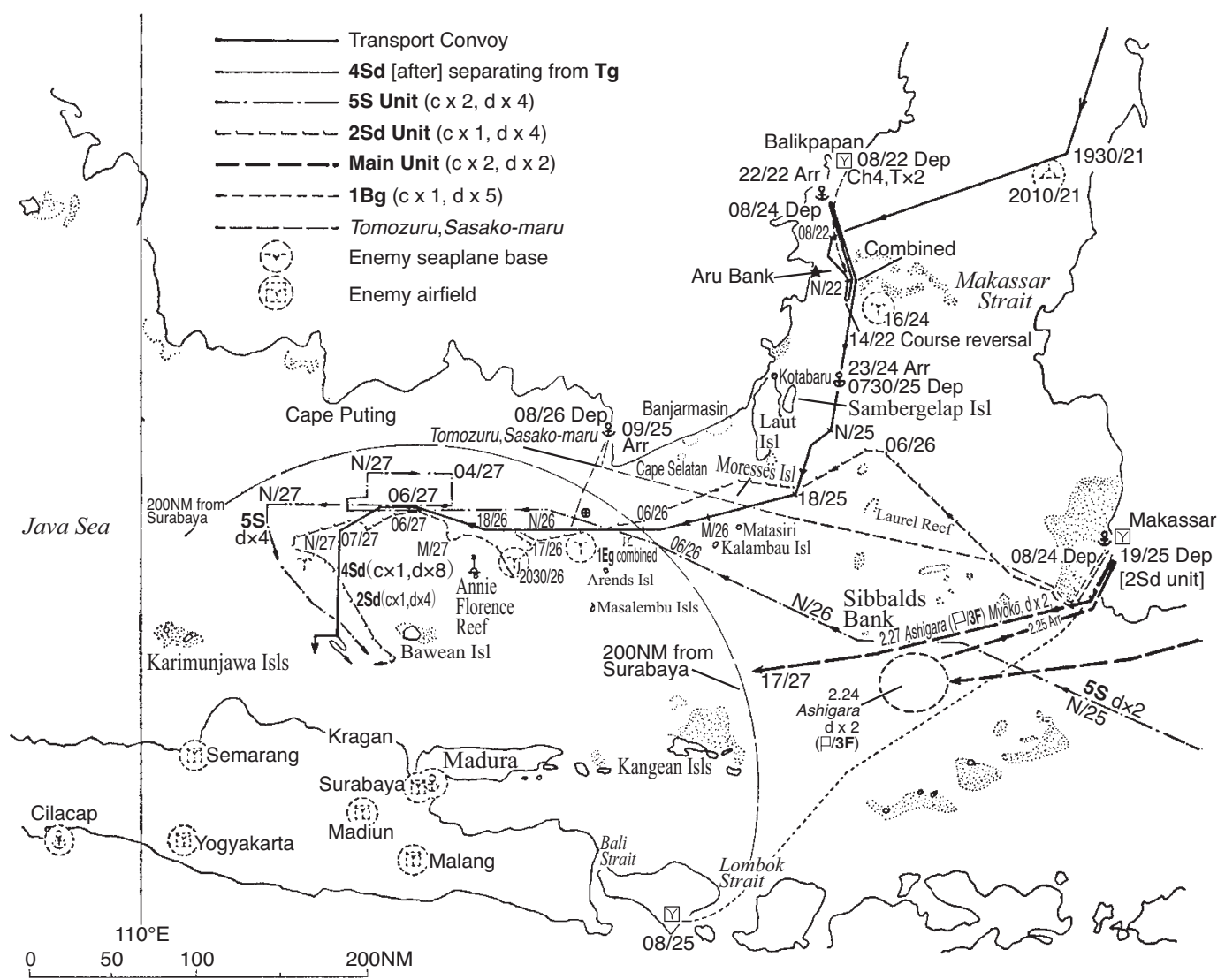

Illustration No. 44 - The Operations of the Eastern Java Invasion Unit and the Units Involved Before the Sea Engagement off Surabaya (21-27 February, 1942)

stroyers, five minesweepers, five submarine chasers, and three vessels of other types, totaling twenty-two naval vessels, which, including the thirty-eight transport ships, made up a large unit of a total of sixty ships. At 1930, Submarine Chaser No. 16 in the front line detected enemy submarine[s], attacked [them] with depth charges and searched for the enemy until 2100. However, nothing in particular was detected, so the results remained unknown. ${ }^{(56)}$ On that day, the Carrier Task Force and the Air Unit carried out an air strike on Port Darwin, while the unit to capture Bali left Makassar (as previously told [p. 337; pp. 311-12]).

On 20 February, the 1st Escort Unit sailed southward on the Celebes Sea roughly on a $200^{\circ}$ [S] course and in the evening approached a point about seventy nautical miles from the north entrance of the Makassar Strait. On that day, while the sea engagement off Bali occurred before dawn, [the operations] to capture Kupang and Dili were launched. The main unit [of the Dutch East Indies Unit] (the Ashigara, the Kawakaze and the Yamakaze) rushed toward Bali to support the unit to capture Bali, leaving Balikpapan around 0300 (as previously told [p. 
373]). Meanwhile, the Myōkō, who had sustained damage by the enemy air strike in Malalag Bay, completed a speedy repair at Sasebo, left the port at 1400 and sailed toward Makassar. ${ }^{(72)}$

At 1100 on 21 February, the 1st Escort Unit crossed the equator and at 1930 turned to head for an area off Balikpapan on a $250^{\circ}$ [WSW] course. From that day onwards, a direct escort by the fighter planes of the $2 \mathrm{~d}$ Air Raid Unit was provided. In the meantime at 1000, the Mizuho, who had been in the middle of the Kupang operation, was ordered to return from the $2 \mathrm{~d}$ Escort Unit to her original unit and without a break participate in the eastern Java operation (as previously told [p. 373]). ${ }^{(54)}$

On the morning of the 22 February, the 1st Escort Unit arrived off Balikpapan. At 0800, the Ehime-maru and the Liverpool-maru with the Sakaguchi Detachment on board, left Balikpapan, escorted by Submarine Chaser No. 4, the Aotaka of the 1st Base Force, and the 2d Gunboat Division, and joined the 1st Escort Unit at a point north of Aru Bank at 1200. Around 1345, when [the unit] had passed through the narrow waterways of Aru Bank, an order of Dutch East Indies Commander Vice Admiral Takahashi came in: "The landing dates shall be postponed until 28 February. [The unit] shall stay on standby near Balikpapan." [The unit] reversed course at 1400, and around 2200 dropped anchor off the mouth of the river at Sapunang about thirteen nautical miles southwest of Balikpapan to temporarily ride at anchor [there]. ${ }^{(54)}$ On that day at 1600, the eastern support unit (the 5th Cruiser division, the Ikazuchi and the Akebono) returned from the Timor operation to Staring Bay, where the 5th Cruiser Division's task of supporting the second carrier operation was changed to supporting the 1st Escort Unit by advancing into the Java Sea (as previously told [pp. 354-55]). Meanwhile, Dutch East Indies Unit Commander Vice Admiral Takahashi issued an order that the 2d Escort Unit, then engaged in the Timor Operation, should be disbanded as of 24 February, and that the main force of the $2 \mathrm{~d}$ Destroyer Squadron and the 1st Section of the 7th Destroyer Division, too, should swiftly advance to the Java Sea after replenishing at Makassar (as previously told [pp. 354-55]).

On 24 February, the 1st Escort Unit left its temporary anchorage south of Balikpapan. At 1600 , one enemy flying boat approached [the unit] to probe from the south from a long distance, but friendly fighter planes and observation plane[s] shot it down. ${ }^{(56)}$ On that day, at 0830, the 1st Section of the 7th Destroyer Division left Dili for Makassar and the 2d Destroyer Squadron (the Jintsū and the 16th Destroyer Division) left Kupang at 1200 also for Makassar, ${ }^{(54)}$ while the 5th Cruiser Division (the Nachi and the Haguro) and the Yamakaze and the Kawakaze left Staring Bay at 1200 to advance to the Java Sea. ${ }^{(75)}$ At 2300, the 1st Escort Unit temporarily rode at anchor at thirty nautical miles off Kotabaru on Laut Island to adjust the sailing schedule. In the meantime, the main unit of the Dutch East Indies Unit appropriately operated in the area northeast of the Kangean Islands to support the second Bali [transport] operation.

On 25 February, the Sasako-maru (which had left Makassar on the 24th) under the escort of the Tomozuru arrived in Banjarmasin at 0900, where the embarkation of the Yamamoto Regiment of the Sakaguchi Detachment was started. In the meantime, at 0730 the 1st Escort Unit left the temporary anchorage off Kotabaru, began to sail southward and entered the Java Sea in the middle of the night. ${ }^{(56)}$ The 5th Cruiser Division (minus the Myōko), the Yamakaze and the Kawakaze sailed westward on the waters south of Makassar, rushing around noon towards the waters south of Banjarmasin, where they were supposed to join the 1st Escort Unit. ${ }^{(78)}$ Also, at 1900, the 2d Destroyer Squadron (the Jintsu and the 16th Destroyer Di- 
vision) left Makassar to follow in the wake of the 1st Escort Unit. ${ }^{(54)}$ On that day, 1st Base Force Commander R. Adm. Kubo Kyūji arrived in Bali at 0800 and started the disembarkation of the unit of the second phase of the transport [operation], while the Dutch East Indies Unit commander called off the support for the Bali operation and returned to Makassar in the evening.

At sunrise on 26th February, the 1st Escort Unit reached a point forty nautical miles south of Cape Selatan (south of Banjarmasin) and continued sailing westward. Around noon, the Sasako-maru and the Tomozuru, who had sailed from Banjarmasin, joined them and by sunset they reached a point 150 nautical miles north of Surabaya. ${ }^{(56)}$ Around 0630, the 5th Cruiser Division unit caught up with the 1st Escort Unit and shifted to the support operation by sailing westward ahead of the 1st Escort Unit on its starboard bow. ${ }^{(78)}$ By the evening, the $2 \mathrm{~d}$ Destroyer Squadron unit also joined the 1st Escort Unit and shifted to the support operation by taking a position on its port side quarter. ${ }^{(54)}$ In the meantime between 1245 and 1330, the 1st Escort Unit and the 2d Destroyer Squadron unit were probed by one enemy flying boat and later at 2005 bombed by two enemy four-engine heavy bombers, but they sustained no damage. ${ }^{(56)}$ At 1500, 1st Escort Unit Commander R. Adm. Nishimura Shōji contacted 5th Cruiser Division Commander R. Adm. Takagi Takeo: "I suspect that the transport ships were spotted by the enemy. To be prepared against an appearance of enemy naval vessels tonight, I would like [you] to search for the enemy on the waters north of Surabaya before sunset with the aircraft of the 5th Cruiser Division. If [enemy] naval vessels should appear, I plan to have the aircraft of the Naka probe them at night and destroy the enemy with the full force of our unit." ${ }^{(56)}$ Accepting this proposal, 5th Cruiser Division Commander Rear Admiral Takagi searched for the enemy in the area between Bawean Island and Surabaya, but only spotted three [enemy] patrol boats to the north of Surabaya. ${ }^{(78)}$ On the other hand, the reconnaissance over Surabaya by aircraft of the $2 \mathrm{~d}$ Air Raid Unit still reported that several powerful enemy naval vessels including cruisers were at anchor [there]. At 2150, 2d Air Raid Unit Commander R. Adm. Takenaka Ryōzō sent the following assessment about the enemy movements:

1. Outside the port: one heavy cruiser, two light cruisers, several destroyers and torpedo boats at anchor.

2. North entrance of Surabaya port: two destroyer-like vessels sailing eastward.

At 2330, the 1st Escort Unit commander requested the 5th Cruiser Division commander: "It is required to guard in particular against the enemy, who might come for an attack from the Surabaya area when the transport ships enter into the anchorage. We have figured out our countermeasures, however, if possible, I would like you to look out for [the enemy] by positioning appropriate naval vessels near the north entrance of Surabaya."

\section{The Operations of the $2 \mathrm{~d}$ Air Unit}

On 19 February, the convoy left Jolo. The Chitose, which had been guarding the sailing route ahead of the convoy while providing guard in the air against [enemy] aircraft, spotted nothing unusual. ${ }^{(68,79)}$ At 1915 on that day, the Chitose left Jolo for Dondo Bay (on the north coast of Celebes). Patrol Boat No. 34 left Tarakan for Dondo Bay around 1300, while Patrol Boat No. 38 left Jolo around 0900 [also] for Dondo Bay. At 0830 on the 20th, the Chitose put in at Dondo Bay and provided the whole day [the convoy] with a guard on the sailing route ahead 


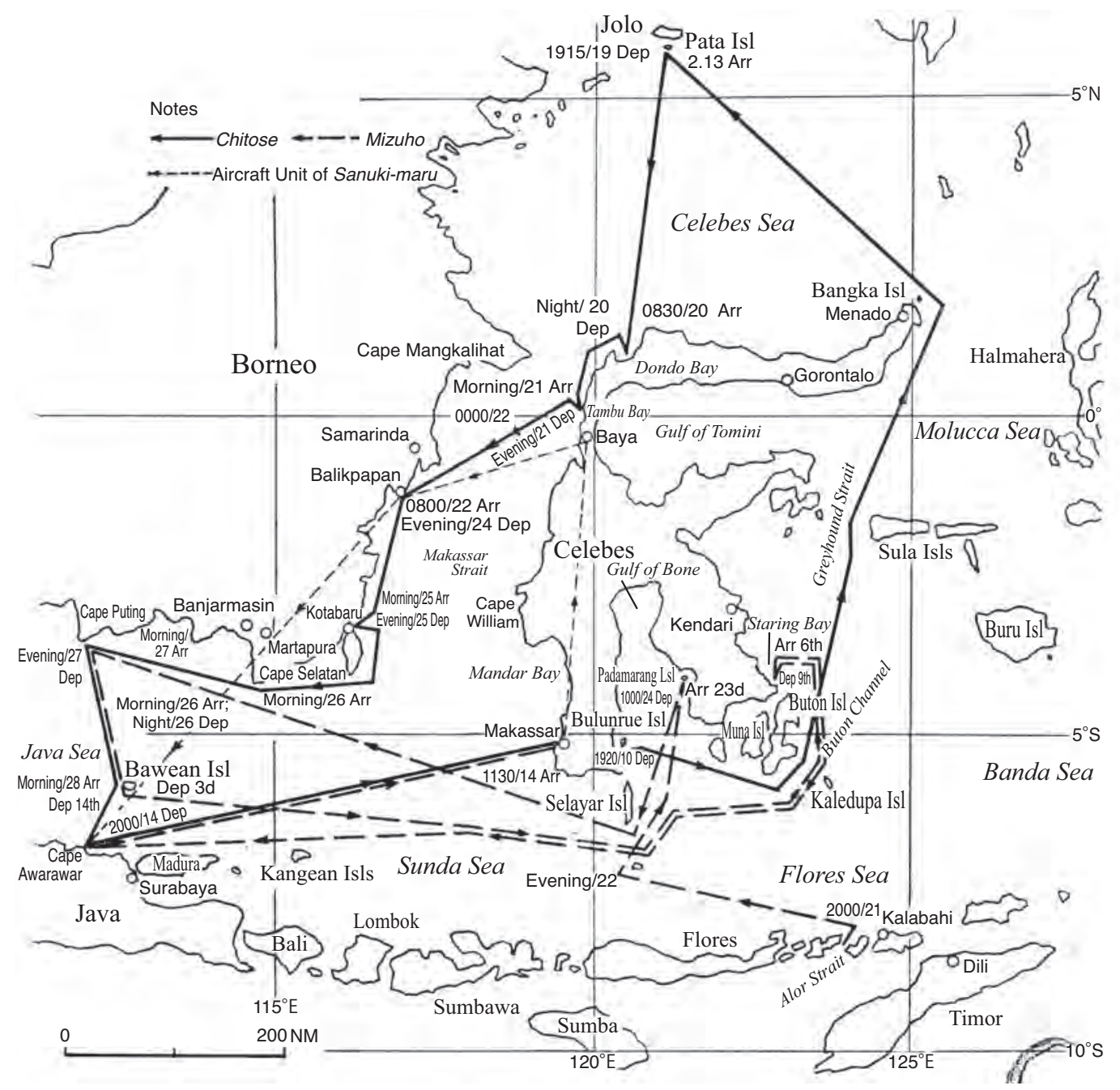

Illustration No. 45 - The Outline of the Movements of the $2 d$ Air Unit

as well as a guard in the air [against enemy aircraft], but nothing unusual was spotted. Patrol Boats No. 34 and No. 38 had respectively put in at Dondo Bay around 0600 and around 0800. On the 21st, the Chitose and Patrol Boat No. 38 put in at Tambu Bay (on the west coast of Celebes) after having left Dondo Bay and provided a guard in the air against enemy aircraft and submarines in the same way as the previous day. On the morning of the $22 \mathrm{~d}$, the Chitose, coming from the Gulf of Tambu, entered the port of Balikpapan and stayed at anchor there. On that day, a guard against [enemy] aircraft and submarines was again provided in the same way as the previous day. On the $23 \mathrm{~d}$, while remaining at anchor in Balikpapan, the Chitose continued providing the convoy with a guard against [enemy] aircraft and submarines from the air. On the 24th, while providing the convoy with a guard in the air against [enemy] aircraft and submarines in the same way as the previous day, the Chitose left Balikpapan for Laut Island. On that day, one enemy flying boat came probing [the convoy], but the fighter planes of the Tainan Air Group shot it down [p. 426]. ${ }^{(68)}$ On the 25th, the Chitose dropped anchor near Kotabaru on Laut Island, and on the 26th near Cape Selatan to provide the convoy 
with a guard in the air against [enemy] aircraft and submarines. The Mizuho joined her [off] Cape Selatan, and provided a guard in the air against [enemy] aircraft and submarines along with her. In the meantime, the aircraft unit of the Sanuki-maru provided the convoy with a guard in the air against [enemy] aircraft and submarines from Baya ([in] central Celebes). The Sanuki-maru's aircraft unit is presumed to have operated along with the Chitose after that, but its operations are not clear.

\section{The 2d Air Raid Unit Largely Neutralized Eastern Java}

The major operations of the 2d Air Raid Unit from 19 until 26 February were as follows: ${ }^{(71)}$

\begin{tabular}{|c|c|c|c|c|}
\hline Date & Unit & Forces & Outline of Operations & $\begin{array}{l}\text { Reported Military Gains } \\
\text { and Losses }\end{array}$ \\
\hline \multirow{3}{*}{$\begin{array}{l}\text { 19th } \\
{[\mathrm{Feb}]}\end{array}$} & Takao Air Gp & $\begin{array}{l}18 \text { land-based attack } \\
\text { planes }\end{array}$ & $\begin{array}{l}\text { Attacked the urban area of } \\
\text { Bawean Island }\end{array}$ & \\
\hline & \multirow{2}{*}{ Tainan Air Gp } & 6 Type- -0 fighter planes & $\begin{array}{l}\text { Patrolled in the air over the } \\
\text { Bali anchorage }\end{array}$ & $\begin{array}{l}\text { Raided by a total of } 7 \text { B- } \\
17 \text { s and } 3 \text { B-24s; could not } \\
\text { shoot them down }\end{array}$ \\
\hline & & 23 Type- 0 fighter planes & $\begin{array}{l}\text { Attacked Surabaya; engaged } \\
\text { with } 30 \mathrm{P}-40 \text { s in the air }\end{array}$ & $\begin{array}{l}\text { Shot down } 17 \text { P-40s; } 1 \\
\text { Type-0 fighter plane } \\
\text { crashed itself }\end{array}$ \\
\hline \multirow{5}{*}{ 20th } & \multirow{2}{*}{ Takao Air Gp } & $\begin{array}{l}16 \text { land-based attack } \\
\text { planes }\end{array}$ & $\begin{array}{l}\text { Attacked enemy naval ves- } \\
\text { sels in Madura Bay }\end{array}$ & Scored no hits \\
\hline & & $\begin{array}{l}13 \text { land-based attack } \\
\text { planes }\end{array}$ & $\begin{array}{l}\text { Attacked enemy naval ves- } \\
\text { sels in the Lombok Strait }\end{array}$ & $\begin{array}{l}\text { No enemy naval vessels } \\
\text { spotted; bombed the city } \\
\text { of Banyuwangi [instead] }\end{array}$ \\
\hline & \multirow[b]{2}{*}{ Tainan Air Gp } & 13 Type- 0 fighter planes & Attacked Surabaya & No enemy spotted \\
\hline & & 9 Type- 0 fighter planes & $\begin{array}{l}\text { Attacked the airfield[s] near } \\
\text { Malang }\end{array}$ & $\begin{array}{l}\text { Set fire to } 4 \text { B-17s and de- } \\
\text { stroyed } 1 \text { B-17 and } 1 \text { twin- } \\
\text { engine plane }\end{array}$ \\
\hline & 3d Air Gp & 4 Type- 0 fighter planes & $\begin{array}{l}\text { Patrolled over the Bali an- } \\
\text { chorage }\end{array}$ & $\begin{array}{l}\text { Raided by } 3 \text { light bombers } \\
\text { and } 20 \text { fighter planes; shot } \\
\text { down } 6 \text { fighter planes }\end{array}$ \\
\hline \multirow{3}{*}{$21 \mathrm{st}$} & Takao Air Gp & $\begin{array}{l}21 \text { land-based attack } \\
\text { planes }\end{array}$ & $\begin{array}{l}\text { Attacked naval vessels at an- } \\
\text { chor in Surabaya port }\end{array}$ & $\begin{array}{l}\text { Destroyed } 1 \text { cruiser and } 1 \\
\text { merchantman }\end{array}$ \\
\hline & Tainan Air Gp & 7 Type-0 fighter planes & $\begin{array}{l}\text { Attacked the airfields in } \\
\text { Maospati and Malang }\end{array}$ & $\begin{array}{l}\text { Shot down } 1 \text { P-40; } 1 \text { land- } \\
\text { based attack plane badly } \\
\text { damaged during an emer- } \\
\text { gency landing; destroyed } 3 \\
\text { small planes }\end{array}$ \\
\hline & 3d Air Gp & 6 Type- 0 fighter planes & $\begin{array}{l}\text { Provided cover for the land- } \\
\text { based attack plane unit at- } \\
\text { tacking Surabaya; engaged } \\
\text { with } 10 \mathrm{P}-40 \text { s }\end{array}$ & $\begin{array}{l}\text { Shot down } 3 \text { P-40s, set fire } \\
\text { to } 1 \text { B-17 and destroyed } 2 \\
\text { mid-sized planes and } 1 \\
\text { small plane }\end{array}$ \\
\hline
\end{tabular}




\begin{tabular}{|c|c|c|c|c|}
\hline \multirow{5}{*}{$22 d$} & \multirow{4}{*}{ Tainan Air Gp } & 12 Type- 0 fighter planes & $\begin{array}{l}\text { Provided direct escort in the } \\
\text { air over the convoy }\end{array}$ & Spotted no enemy \\
\hline & & 6 Type- 0 fighter planes & $\begin{array}{l}\text { Attacked Yogyakarta and Se- } \\
\text { marang }\end{array}$ & $\begin{array}{l}\text { Set fire to } 1 \text { B- } 24 \text { and } 2 \\
\text { twin-engine planes and } \\
\text { destroyed } 9 \text { planes of other } \\
\text { types }\end{array}$ \\
\hline & & 4 Type- 0 fighter planes & Attacked the Pasirian airfield & $\begin{array}{l}\text { Set fire to } 1 \text { B-17 and de- } \\
\text { stroyed } 5 \text { B-17s and } 2 \\
\text { twin-engine planes }\end{array}$ \\
\hline & & 6 Type- 0 fighter planes & $\begin{array}{l}\text { Attacked [the airfields in] } \\
\text { Pasirian and Malang }\end{array}$ & $\begin{array}{l}\text { Set fire to } 4 \text { B-17s and } 1 \mathrm{P}- \\
40 \text {, and destroyed } 2 \text { twin- } \\
\text { engine planes }\end{array}$ \\
\hline & 3d Air Gp & 3 Type- 0 fighter planes & $\begin{array}{l}\text { Carried out a reconnaissance } \\
\text { attack on Yogyakarta }\end{array}$ & $\begin{array}{l}\text { Set fire to } 2 \text { large and } 1 \\
\text { mid-sized planes and de- } \\
\text { stroyed } 1 \text { large, } 3 \text { mid- } \\
\text { sized and } 5 \text { small planes }\end{array}$ \\
\hline \multirow[t]{2}{*}{$23 d$} & \multirow[t]{2}{*}{ Tainan Air Gp } & 9 Type- 0 fighter planes & $\begin{array}{l}\text { Provided cover for the land- } \\
\text { based attack planes attacking } \\
\text { Malang; engaged with } 6 \mathrm{P}- \\
40 \text { s }\end{array}$ & Shot down $3 \mathrm{P}-40 \mathrm{~s}$ \\
\hline & & 8 Type- 0 fighter planes & $\begin{array}{l}\text { Provided direct escort in the } \\
\text { air over the convoy }\end{array}$ & Spotted no enemy \\
\hline \multirow{4}{*}{ 24th } & \multirow{3}{*}{ Takao Air Gp } & 9 land-based attack planes & Attacked Malang & $\begin{array}{l}\text { Destroyed } 2 \text { twin-engine } \\
\text { planes }\end{array}$ \\
\hline & & 9 land-based attack planes & $\begin{array}{l}\text { Attacked naval vessels in } \\
\text { Surabaya }\end{array}$ & Sank 1 merchantman \\
\hline & & $\begin{array}{l}15 \text { land-based attack } \\
\text { planes }\end{array}$ & Ditto & $\begin{array}{l}\text { Destroyed } 2 \text { cruisers and } 1 \\
\text { merchantman }\end{array}$ \\
\hline & Tainan Air Gp & 10 Type-0 fighter planes & $\begin{array}{l}\text { Provided direct escort in the } \\
\text { air over the convoy }\end{array}$ & Shot down 1 flying boat \\
\hline \multirow{3}{*}{ 25th } & Takao Air Gp & $\begin{array}{l}22 \text { land-based attack } \\
\text { planes }\end{array}$ & $\begin{array}{l}\text { Attacked naval vessels at an- } \\
\text { chor in Surabaya [port] }\end{array}$ & $\begin{array}{l}\text { Bombed cruiser[s]; scored } \\
\text { no hits; } 4 \text { [Japanese planes] } \\
\text { marked by bullets }\end{array}$ \\
\hline & \multirow[t]{2}{*}{ Tainan Air Gp } & 9 Type- 0 fighter planes & $\begin{array}{l}\text { Provided cover for the land- } \\
\text { based attack plane unit at- } \\
\text { tacking Surabaya; engaged } \\
\text { with } 13 \text { P-40s }\end{array}$ & $\begin{array}{l}\text { Shot down } 8 \text { P-40s (4 of } \\
\text { which unconfirmed) }\end{array}$ \\
\hline & & 10 Type-0 fighter planes & $\begin{array}{l}\text { Provided direct escort in the } \\
\text { air over the convoy }\end{array}$ & Spotted no enemy \\
\hline
\end{tabular}




\begin{tabular}{|l|l|l|l|l|}
\hline 26th & Tainan Air Gp & 12 Type-0 fighter planes & $\begin{array}{l}\text { Provided direct escort in the } \\
\text { air over the convoy }\end{array}$ & Spotted no enemy \\
\hline \multirow{2}{*}{ Takao Air Gp } & 5 land-based attack planes & $\begin{array}{l}\text { Searched for the enemy in the } \\
\text { Indian Ocean }\end{array}$ & $\begin{array}{l}\text { Spotted 1 aircraft carrier } \\
\text { and 1 submarine }\end{array}$ \\
\cline { 3 - 5 } & 4 land-based attack planes & $\begin{array}{l}\text { Searched for the enemy in the } \\
\text { Sunda and Java Seas }\end{array}$ & $\begin{array}{l}\text { Spotted 3 light cruisers, 3 } \\
\text { destroyers and 2 torpedo } \\
\text { boats (which later put in at } \\
\text { Surabaya port) }\end{array}$ \\
\hline
\end{tabular}

During this period, the 1st Air Raid Unit supported the Timor operation, while at the same time carrying out the attack on Port Darwin as well as the attack on the neighborhood of Surabaya.

\section{The Sea Engagement off Surabaya}

(See Attached Illustrations No. 5 and No. 6)

\section{The Appearance of a Powerful Enemy Surface Unit (27 February)}

Around sunrise on 27 February, the 1st Escort Unit reached [a point] about fifty nautical miles northwest of Bawean Island and at 0700 turned to head for Kragan on a $190^{\circ}$ [S] course. Both the 5th Cruiser Division unit (the 5th Cruiser Division, the 1st Section of the 7th Destroyer Division and two destroyers of the 24th Destroyer Division) and the 2d Destroyer Squadron (the Jintsu $\bar{u}$ and the 16th Destroyer Division) were sailing westward, supporting the 1st Escort Unit from a position about fifty nautical miles to the northeast of the latter. At 0900, 5th Cruiser Division Commander Rear Admiral Takagi issued the following order concerning the deployment of the units on site around the time of the [convoy's] entering into the anchorage. ${ }^{(56)}$

Unless enemy movements significantly change, [the units on site] shall be deployed to the following [areas] around the time of the [convoy's] entry into the anchorage tonight:

1. The area north of Surabaya: $2 \mathrm{~d}$ Destroyer Squadron (minus the 15th, the 8th and the 18th Destroyer Divisions)

2. The area between the Karimunjawa Islands and Jati Point: the 1st Section of the 7th Destroyer Division

3. The 5th Cruiser Division, the Yamakaze, and the Kawakaze shall, depending on the situation at Kragan, appropriately operate within a range of ninety nautical miles [from Kragan] between the Karimunjawa Islands and Bawean Island.

From around 1100, the $2 \mathrm{~d}$ Destroyer Squadron changed course southeastward to take a position to cover the northwest of the 1st Escort Unit, while at 1200 the 5th Cruiser division steered southward and followed the 1st Escort Unit. Although the 2d Destroyer Squadron was bombed around 1150 by two enemy heavy bombers, no damage was sustained. About then, a telegram came in from [an] aircraft of the 2d Air Raid Unit, which read: "1150: Five 
enemy cruisers and six destroyers [are spotted] at sixty-three nautical miles $310^{\circ}[\mathrm{NW}]$ of Surabaya, steering $80^{\circ}$ [E] at twelve knots." ${ }^{(56)}$ The location was about sixty nautical miles to the south of the convoy and 120 nautical miles from the 5th Cruiser Division. Having received this report, 5th Cruiser Division Commander Rear Admiral Takagi headed for the enemy from 1230 onwards, steering a $150^{\circ}$ [SE] course and increasing his speed. While launching [an] aircraft of the Nachi at 1307 to probe the enemy, he issued at 1320 the following order to the 4th Destroyer Squadron (the 1st Escort Unit) and the 2d Destroyer Squadron. ${ }^{(56)}$

1. Five enemy cruisers and six destroyers were reportedly spotted at sixty-three nautical miles $310^{\circ}[\mathrm{NW}]$ of Surabaya steering $80^{\circ}[\mathrm{E}]$ at a speed of eighteen knots.

2. The 5th Cruiser Division shall immediately head for the enemy. The location [of the division] as of 1300 is 165 nautical miles $328^{\circ}$ [NW] of Surabaya, sailing at a speed of twenty-four knots.

3. The $2 \mathrm{~d}$ Destroyer Squadron shall join [the division] on the spot. At 1315, one aircraft has been launched for probing.

In the meantime, at 1245, 1st Escort Unit Commander Rear Admiral Nishimura had ordered the 4th Destroyer Squadron to "Complete preparations for torpedo warfare," while launching at 1255 an aircraft of the Naka for probing. While ordering at 1300 the captain of the Wakataka to let the convoy change course westward and evacuate under his command, Commander [Rear Admiral Nishimura] assembled the 4th Destroyer Squadron (the Naka, the 2d Destroyer Division, the 1st Section of the 9th Destroyer Division - one light cruiser and six destroyers), changed course southeastward from around 1310 onwards and headed for the enemy. ${ }^{(56)}$ From 1315 onwards, the 2d Destroyer Squadron (one cruiser and four destroyers) [also] headed for the enemy, sailing on a $150^{\circ}$ [SE] course at twenty-one knots, while expecting to be joined by the 5 th Cruiser Division. ${ }^{(54)}$

The reports delivered thereafter from the aircraft of the $2 \mathrm{~d}$ Air Raid Unit were as follows: ${ }^{(54)}$

1225: [The enemy consisting of] three destroyers, three cruisers, two cruisers and three destroyers, are [sailing] in three columns. Two torpedo boat-like vessels are sailing along at both sides [of the fleet]. [They are] sailing on a $120^{\circ}$ [ESE] course at eighteen knots.

1245: The enemy sails on a zigzag course, all turning their bows at certain intervals, but he currently advances roughly on a $90^{\circ}[\mathrm{E}]$ course.

The aircraft of the Nachi also spotted the enemy and reported as follows: ${ }^{(54)}$

1405: The enemy consists of two Class-A cruisers, three light cruisers and nine destroyers and is at forty-five nautical miles $194^{\circ}$ [SSW] from the reference point, steering $180^{\circ}$ [S] at twentyfour knots.

1425: The enemy seems to be heading for Surabaya.

1455: The enemy is putting in at Surabaya.

At that moment, Rear Admiral Takagi, commander of the 5th Cruiser Division formed the following judgment:

It is not possible to firmly judge whether the enemy movements are an offensive against our transport convoy or an action to avoid our daytime air raid over the port of Surabaya. 
1. If the enemy flees into [the port of] Surabaya, it is possible to execute the landing tonight as scheduled by watching and staying on guard at the north entrance of Surabaya.

2. If the enemy sails northward, it is likely that we can catch up with him by the evening and we will need to destroy him in a night engagement.

According to this judgment, 5th Cruiser Division Commander Takagi issued the following order: ${ }^{(54)}$

1. The enemy cruiser unit seems to head for Surabaya.

2. The 5th Cruiser Division shall take a position to the east of the transport ships and appropriately slow down.

3. The 2d Destroyer Squadron shall operate so as to take its assigned position for tonight.

When he received this order issued at 1510, the 1st Escort Unit commander had [at 1425*] already given an order to the transport convoy, "Change course at 1500 to head for the planned landing point," (56) while he himself reversed course at 1430, and returned to his position [of escorting] the transport convoy. [Meanwhile] the 2d Destroyer Squadron continued sailing southeastward to head for the waters north of Surabaya, its scheduled deployment point that night. From 1500 onwards, the transport convoy one by one changed course southward and headed again for Kragan. However, reports came in one after another that the enemy fleet, which at one point had shown signs of putting in at Surabaya, had again started sailing northward.

[From]

The aircraft of the Nachi: 1523: The enemy shows no signs of putting in [at Surabaya]. The enemy steers a $60^{\circ}$ [ENE] course at eighteen knots.

The aircraft of the Nachi: 1615 : The enemy reversed course, steering $20^{\circ}$ [NNE] at eighteen knots.

The aircraft of the Nachi: 1620: The enemy sails on a $0^{\circ}[\mathrm{N}]$ course at eighteen knots.

The aircraft of the Nachi: 1648: The enemy sails on a $315^{\circ}$ [NW] course at twenty-two knots.

On receiving these reports, 5th Cruiser Division Commander Takagi immediately increased his speed, and issued an order to the $2 \mathrm{~d}$ and the 4th Destroyer Squadrons: "1635: I will steer $220^{\circ}$ [SW] at twenty-one knots. We shall combine, while enticing the enemy." ${ }^{\prime(56)} \mathrm{R}$. Adm. Tanaka, commander of the $2 \mathrm{~d}$ Destroyer Squadron had already accelerated his speed to twenty-eight knots at the first report of the Nachi.

Receiving the reports of the enemy's course reversal a little late, 4th Destroyer Squadron Commander Nishimura had at 1600 according to schedule already shifted to the operation of having the convoy enter into the Kragan roadstead. However, learning before long that the enemy had reversed course, he headed for the enemy, leading the 4th Destroyer Squadron unit (the Naka, the 1st Section of the 9th Destroyer Division and the 2d Destroyer Division), while assigning the 24 th Destroyer Division commander to command the convoy. Thus, by around 1650, all [escort] units (the 5th Cruiser Division and the $2 \mathrm{~d}$ and the 4th Destroyer Squadrons) were heading for the enemy more or less in parallel. The $2 \mathrm{~d}$ Destroyer Squadron, which sailed ahead, reported: "1659: We see masts that appear to be the enemy's. The direc-

* See Action Reports of the 2d and 4th Destroyer Divisions (JACAR Ref: 4th DS: C08030111200 7/59; 2d DS: C08030093600 37/59). 
tion from us is $150^{\circ}$ [SE] and the distance is twenty-nine kilometers." (62) (At that time, the weather was fine with the time of sunset at 1950 and a [gibbous] moon of about the twelfth lunar day that had [already] risen at 1653.)

The lineup and strength of the Japanese forces at that time was as follows: ${ }^{(78)}$

The 5th Cruiser Division unit (support unit)

The 5th Cruiser Division (the Nachi and the Haguro), the 1st Section of the 7th Destroyer Division (the Ushio and the Sazanami), the Yamakaze and the Kawakaze

The $2 \mathrm{~d}$ Destroyer Squadron

The Jintsu and the 16th Destroyer Division (the Yukikaze, the Tokitsukaze, the Hatsukaze and the Amatsukaze)

The 4th Destroyer Squadron unit

The Naka, the 2d Destroyer Division (the Murasame, the Samidare, the Harukaze* and the $Y \bar{u}$ -

dachi), and the 9th Destroyer Division (the Asagumo and the Minegumo)

In total: two heavy cruisers, two light cruisers and fourteen destroyers

(151)

\begin{tabular}{|c|c|c|c|c|c|}
\hline \multirow[b]{2}{*}{ Ship Class } & \multirow[b]{2}{*}{ Tonnage } & \multirow[b]{2}{*}{ Speed } & \multicolumn{2}{|c|}{ Guns } & \multirow{2}{*}{$\begin{array}{c}\text { Number of Torpedo } \\
\text { Tubes }\end{array}$} \\
\hline & & & Main Guns & $\begin{array}{l}\text { Antiaircraft } \\
\text { Guns }\end{array}$ & \\
\hline Myōkō-class [the Nachi] & 10,000 & 35.5 & $20-\mathrm{cm} \times 10$ & $12-\mathrm{cm} \times 6$ & $61-\mathrm{cm} \times 16^{* *}$ \\
\hline Jintsu-class (the Naka) & 5,195 & 35.25 & $14-\mathrm{cm} \times 7$ & $8-\mathrm{cm} \times 2$ & $61-\mathrm{cm} \times 8$ \\
\hline Ushio-class (the Sazanami) & 1,680 & 38.0 & $12.7-\mathrm{cm} \times 6$ & & $61-\mathrm{cm} \times 9$ \\
\hline $\begin{array}{l}\text { Yamakaze-class (the Kawakaze, } \\
\text { the } 2 \mathrm{~d} \text { Destroyer Div) }\end{array}$ & 1,685 & 34.0 & $12.7-\mathrm{cm} \times 5$ & & $61-\mathrm{cm} \times 8$ \\
\hline $\begin{array}{l}\text { Yukikaze-class (the 16th De- } \\
\text { stroyer Div) }\end{array}$ & 2,000 & 35.0 & $12.7-\mathrm{cm} \times 6$ & & $61-\mathrm{cm} \times 8$ \\
\hline Asagumo-class (the Minegumo) & 1,961 & 35.0 & $12.7-\mathrm{cm} \times 6$ & & $61-\mathrm{cm} \times 8$ \\
\hline
\end{tabular}

For reference:

The total numbers of guns and torpedoes [of the vessels that participated in the engagement]:

20-cm guns: 20 (the Myō $\bar{o}^{* * *}$ and the Haguro)

14-cm guns: 14 (the Jints $\bar{u}$ and the Naka)

12.7-cm guns: 78 (the Ushio, the Sazanami, the Yamakaze, the Kawakaze, and the 16th, the 2d and the 9th Destroyer Divisions)

12-cm guns: 12 (the Myōko $\bar{c}^{\star * *}$ and the Haguro)

8-cm guns: 4 (the Jintsu and the Naka)

61-cm torpedo tubes: 168

* Probably a mistake for the Harusame; the Harukaze belonged to the 5th Destroyer Division.

** The number differs from that in the list on p. 735.

*** Probably the Nachi is meant. The Myōkō did not appear on the scene until after the battle, together with the main unit of the Dutch East Indies Unit. 


\section{The First Phase of the Daytime Engagement (from 1725 until 1850) ${ }^{(54,56,78,62)}$}

While steering $270^{\circ}$ [W] to join the 5th Cruiser Division, 2d Destroyer Squadron Commander Tanaka spotted masts at $150^{\circ}$ [SSE], which appeared to be the enemy's. At the same time, he recognized the masts of the 5 th Cruiser Division at $320^{\circ}[\mathrm{NW}]$ and approached them steering $300^{\circ}$ [WNW]. At 1720, he took a position eight kilometers ahead of the 5 th Cruiser Division and headed for the enemy steering $180^{\circ}$ [S], while launching the aircraft of the Jints $\bar{u}$ at 1731 . Since the 2d Destroyer Squadron had joined him, 5th Cruiser Division Commander Takagi incorporated the 1st Section of the 7th Destroyer Division as well as the Yamakaze and the Kawakaze, which were [all] under his direct command, into the 2d Destroyer Squadron. These units then moved into position as the second unit of the $2 \mathrm{~d}$ Destroyer Squadron. At 1738, 5th Cruiser Division Commander Takagi issued the order, "I plan to deploy southward to attack. The enemy is at forty nautical miles $157^{\circ}$ [SSE] of us." He [also] launched two artillery observation planes from each ship, totaling four planes.

At 1739, on changing course southward, the 2d Destroyer Squadron spotted the masts of enemy cruisers at a distance of twenty-eight kilometers $150^{\circ}$ [SSE]. Gradually changing course southwestward, the squadron began to sail on a parallel course with the enemy, while the 5th Cruiser Division also changed course westward to sail in parallel astern of the 2d Destroyer Squadron. At 1745, the 2d Destroyer Squadron increased its speed to thirty knots steering $230^{\circ}$ [SW] and opened fire, first of all from the Jints $\bar{u}$, at the leading enemy destroyer, which was closing in from $150^{\circ}$ [SSE] as close as 16,800 meters. At 1747, the enemy destroyers also started returning fire, which was followed at 1748 by the enemy cruisers, who also opened fire, and their shells began to drop near the $2 d$ Destroyer Squadron. At 1747, the 5th Cruiser Division also opened fire at the enemy cruisers at a distance of 22,000 to 25,000 meters. Since the enemy shells kept dropping all around, the $2 \mathrm{~d}$ Destroyer Squadron, steering $280^{\circ}[\mathrm{W}]$, moved away from the enemy at 1750, and stopped firing. Spreading smoke screens, the squadron evacuated on a $300^{\circ}[\mathrm{WNW}]$ course.

Just then, the 4th Destroyer Squadron appeared from the north, sailing southward straight at the enemy at a speed of thirty knots. Crossing in front of the $2 \mathrm{~d}$ Destroyer Squadron and closing with the enemy, it launched from 1804 till 1815 twenty-seven Type93 Torpedoes against the enemy cruiser unit roughly at a distance of 15,000 to 12,500 meters before evacuating while spreading smoke screens. At 1805, the Jints $\bar{u}$ also launched four torpedoes from the farther side of the 4 th Destroyer Squadron. However, some torpedoes exploded before running far, throwing up large columns of water, which led to quite confused interpretations at the different (command) staffs; some guessed that the explosions were those of enemy mines and others misjudged that the torpedoes had hit enemy vessels.

During this period, the 5th Cruiser Division continued firing at the enemy, sailing on a parallel course, while maintaining a distance of roughly over 20,000 meters, but due to the frequent evasive actions of the enemy vessels, the division was unable to get effective results and only wasted its shells. Nevertheless, at least several shells seemed to have scored direct hits, for some disorder became noticeable in the columns of the enemy. Although from 1800 until around 1820 the enemy shells fell short, their fire gradually became more accurate after that. Quite frequently dye-capped shells* (note by the author: shells which would color the water columns red, blue, etc., depending on the vessel in order to facilitate the observation

\footnotetext{
* According to Morison, The Rising Sun in the Pacific, p. 345, the Houston used crimson dye in her shells.
} 


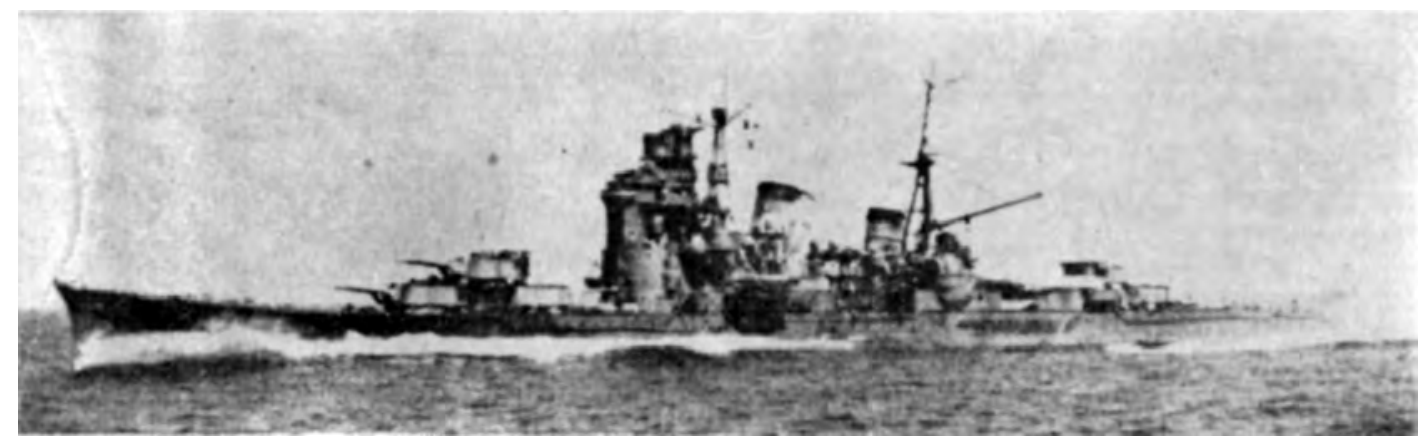

The Cruiser Myōkō

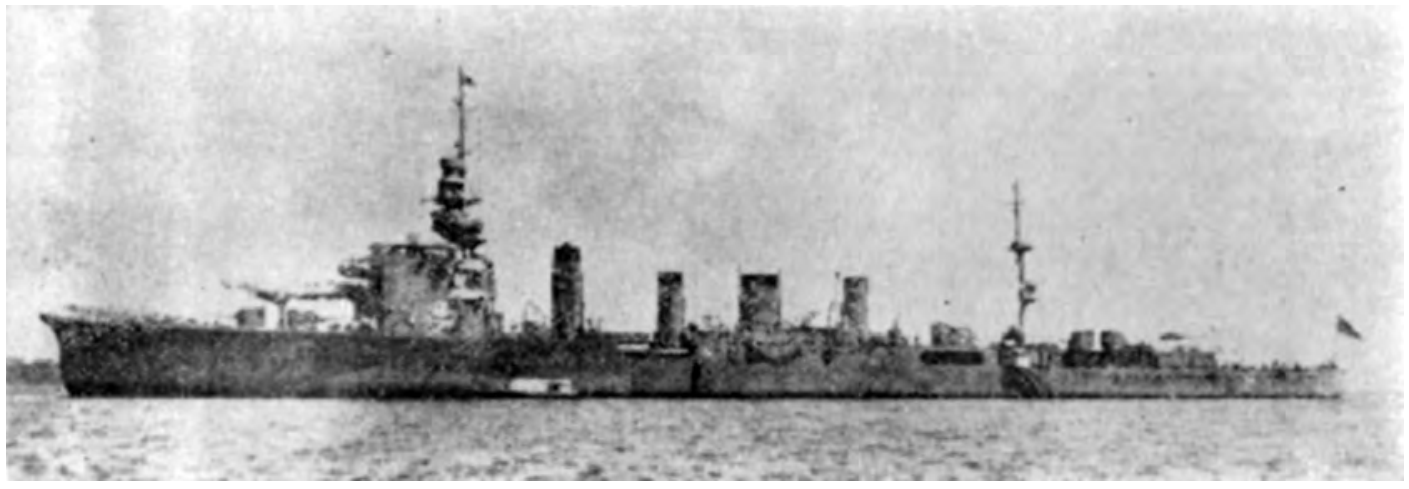

The Cruiser Jintsū

of the impact results) straddled [the division]. At 1822, the 5th Cruiser Division started torpedo warfare. However, only the Haguro launched eight torpedoes, whereas the Nachi was unable to launch hers because of launcher trouble.

Around that time, while sailing on parallel courses and with the shell and torpedo warfare continuing, the engagement moved westward. At 1834, the 24th Destroyer Division commander reported: "We are coming under a bombing attack of a dozen or more enemy bombers." Noticing that the distance to the convoy had already been reduced to about twenty nautical miles, 4 th Destroyer Squadron Commander Nishimura immediately gave the order: "The convoy must evacuate to the west."

Since the enemy was superior in cruisers, 5th Cruiser Division Commander Takagi's initial battle plan was to appropriately entice the enemy into a daytime engagement, and [then] destroy him at a stroke in a night engagement, making the most of the superior [Japanese] torpedo power. However, the enemy had already come close enough to the convoy and any closer approach could not be allowed. At 1833, although there was still one and a half hour before sunset, [Commander Takagi] gave the order: "All ready to charge!" Around that time, a vessel in the enemy fleet seemed to have sustained damage; spreading thick smoke screens, [the enemy] started to cover the damaged vessel, and his formation became seriously disordered. [Considering] that he must not miss this war opportunity, Commander Takagi gave at 1837 the order: "All charge!" The [first phase of the daytime] engagement, which had started at 1745 with the opening fire of the Jintsū, lasted about fifty minutes. Although the damage inflicted on the enemy was not clear, at least two or three enemy vessels had presumably sustained damage. At the charge of the Japanese Navy, the enemy started to evac- 
uate southeastward in a disorderly formation. No loss was sustained on the Japanese side, but the consumption of shells (torpedoes) was as follows:

20-cm guns (the Nachi and the Haguro): 1,271 shells

14-cm guns (the Jintsu and the Naka): 171 shells

Type93 Torpedoes (the Haguro, the 4th Destroyer Squadron and the Jintsü): 39 torpedoes

\section{The Second Phase of the Daytime Engagement (from 1850 until 1950) $)^{(54,56,62,78)}$}

At 1839, all [Japanese] units turned left at once and proceeded to charge. Counting from the right, the line of battle consisted of the 4th Destroyer Squadron, the 2d Destroyer Squadron and the 5th Cruiser Division. At that moment, the formation of the enemy was in total disorder and started to retreat southeastward, spreading thick smoke screens. Around 1920, the $N a k a$, the flagship in the lead of the 4th Destroyer Squadron opened fire at the enemy cruiser unit at a distance between 15,000 and 12,000 meters and then launched four torpedoes, while its subunits, the $2 \mathrm{~d}$ and the 9th Destroyer Divisions, pushed even closer to the enemy. Then, the $2 \mathrm{~d}$ Destroyer Squadron, which was sailing in parallel on the north side of the 4th Destroyer Squadron, broke into the smoke screen belt spread by the enemy, where they encountered the enemy who had reversed course to cover the damaged vessel. At 1924, the flagship Jints $\bar{u}$ first of all launched torpedoes at a distance of 18,000 meters, after which the 16th Destroyer Division and the 1st Section of the 7th Destroyer Division, the Yamakaze and the Kawakaze, rushed in even further and, closing to 9,000 or 8,500 meters, launched torpedoes. However, since the enemy again made a wide turn spreading smoke screens, the results of the torpedoes were unknown. The 5th Cruiser Division sailing on the north side of the $2 \mathrm{~d}$ Destroyer Squadron, while firing at the enemy from a great distance of 25,000 meters, [also] launched sixteen torpedoes from a long distance against the enemy vessels, who were reversing course from 1918 until 1924. After that, the division [also] reversed course. The results of this torpedo attack were, as a matter of course, unknown.

At 1934, The 2d Destroyer Division of the 4th Destroyer Squadron, which had taken the southernmost course, drew near the enemy cruisers as close as 10,000 to 7,500 meters to launch torpedoes. The Asagumo and the Minegumo of the 9th Destroyer Division closed in even closer and launched torpedoes at a range of 6,000 meters, when all of a sudden two enemy destroyers jumped out of the smoke screen belt, which instantly led to a two-againsttwo artillery duel between fellow destroyers at a close distance of 3,000 meters. The first vessel quickly reversed course and fled back into the smoke screen. The Asagumo and the Minegumo concentrated their fire on a British destroyer with the sign $\mathrm{H}-27$ on her side, which had come out next, and crippled her. However, one enemy shell hit the engine room of the Asagumo, stopped her engine and also caused an electric power failure. Nevertheless, she dauntlessly continued firing in cooperation with the Minegumo, and finally sank the British vessel at 1954 .

Around that time the sun set, and also because of the artillery smoke and the smoke screens, visibility on the battle site rapidly decreased. The battle site had gradually moved southward, and the positions of the 4 th and the $2 \mathrm{~d}$ Destroyer Squadrons drew very near to the coast, presumably within twenty nautical miles north of Cape Awarawar, where many huge explosions of what seemed to be controlled mines were spotted (note: they later turned out to have been the self-destruction of Type93 Torpedoes [going off in the middle of their 
run]). Judging that it was not appropriate to come closer to waters fortified by the enemy, 5th Cruiser Division Commander Takagi decided to stop the pursuit, swiftly assemble his forces, rearrange them, and by taking a position roughly between the convoy and the enemy, conduct a search and patrol mission to search for the enemy and destroy him. Accordingly, at 2005 Commander Takagi issued the order to the $2 \mathrm{~d}$ and the 4th Destroyer Squadrons: "All units swiftly assemble and prepare for a night engagement."

Meanwhile, Dutch East Indies Unit Commander Vice Admiral Takahashi had communicated that the main unit was hurrying to the battle site, leaving the waters north of the Kangean Islands on that evening after having been joined by the Myōko, who had arrived from Sasebo. At 2025, Commander Takagi replied: "We have inflicted serious damage to one enemy cruiser and some damage to a few destroyers, but [the status of] the other [ships] is unknown. We would like you to swiftly join us." Then from 2027, the 5th Cruiser Division began to retrieve all of its aircraft (three aircraft of the Nachi and two aircraft of the Haguro), which had been employed in the daytime engagement.

[Earlier,] at 1940, after all his units had completed launching their torpedoes, 2d Destroyer Squadron Commander Tanaka had given the order: "Assemble." The flagship Jintsū slowed down to wait for the units to assemble. At 2015, the 1st Section of the 7th Destroyer Division, and the Yamakaze and the Kawakaze joined her. However, while witnessing the artillery duel between the 1st Section of the 9th Destroyer Division and the [two] enemy destroyers, the 16th Destroyer Division had reversed course after launching its torpedoes to support the section, thereby delaying its action to join. The division finally joined at 2037. Having assembled, the $2 \mathrm{~d}$ destroyer Squadron headed northwestward to join the 5th Cruiser Division.

[As for the engagement of] the 4th Destroyer Squadron, Commander Nishimura had rushed into the attack after issuing at 1906 to the convoy the order: "We have sunk three enemy cruisers and are pursuing [the others]. The convoy shall head for the landing points as scheduled." At 1920, his flagship Naka had come under fire of the 20-cm guns of the USS Houston, one of whose salvos straddled her so perfectly that water columns totally surrounded and covered the entire ship. The 1st Section of the 9th Destroyer Division had pushed closest to the enemy. However, when about to launch her torpedoes, the Minegumo had to haul out of her line in order to evade the torpedoes launched by friendly vessel[s]; she lost sight of the enemy in his smoke screen and lost the opportunity to launch. Then the artillery duel [of the section] with the [two] enemy destroyers had followed. At 2000, the Naka had been joined by the $2 \mathrm{~d}$ Destroyer Division, but since he was caught in a situation where the status the 9th Destroyer Division was unclear and also the movements of the enemy were unknown because of the smoke screens they had spread, Commander Nishimura considered the risks to the transport convoy and at 2015 issued the order, "The transport convoy shall reverse course. The battle site has not been cleared yet," after which he offered at 2030 his opinion to the 5th Cruiser Division commander: "Under such circumstances, it is difficult for the transport convoy to enter into the anchorage. So, I had them reverse course at 2015. I think we will need to clear the enemy in a night engagement."

In the meantime, the aircraft of the Jints $\bar{u}$ was probing the enemy and had begun reporting the movements of the enemy vessels one after another. At 2020, 5th Cruiser Division Commander Takagi issued an order concerning the outline of the subsequent operations: "We shall conduct patrols around this area, [keeping] the enemy to the east [of us] with the 5th Cruiser Division, the 2d Destroyer Squadron and the 4th Destroyer Squadron in that order 
from the north, and destroy him in a night engagement tonight." [Meanwhile] at 2016, the aircraft of the Jintsu reported that the enemy was sailing on a $310^{\circ}$ [NW] course. Since the enemy had reversed course and again set about to attack the Japanese forces, 4 th Destroyer Squadron Commander Nishimura [once again] ordered: "2034: The transport convoy shall swiftly reverse course." "2035: The enemy is heading for the transport convoy." At 2045, the aircraft of the Jintsu again reported: "The main force of the enemy is [sailing] on a $310^{\circ}$ course at twenty knots." While dropping flares, the aircraft of the Jints $\bar{u}$ kept on probing the enemy.

The ammunition consumed during this period [the second phase of the daytime engagement] was as follows:

20-cm gun shells (the Nachi and the Haguro): 302 shells

14-cm gun shells: 50 shells

12.7-cm gun shells: 515 shells

25-mm gun: 256 bullets

Type93 torpedoes: 98 torpedoes

\section{The First Phase of the Night Engagement (from 2050 until 2110) $)^{(54,56,62,78)}$}

At 2027, the 5th Cruiser Division stopped on the sea to start retrieving the five aircraft that had been employed for the daytime engagement. At 2052, when just about to complete retrieving the last aircraft, it spotted silhouettes of presumably enemy naval vessels approaching from $150^{\circ}$ [SE]. Since the enemy started firing star shells at 2055, the 5th Cruiser Division evaded the enemy by all at once accelerating to twenty-eight knots and spreading smoke screens. (The last aircraft was nearly left out [on the sea], but fortunately raised before the vessels gained speed.) At 2107, after completing preparations for shelling, the division was about to reverse course, when the $2 \mathrm{~d}$ Destroyer Squadron came sailing in between the division and the enemy. On top of this, due to the smoke screens of the enemy and his change of course, the division lost sight of the enemy in the direction of $120^{\circ}$ [ESE]. Having spotted the firing of star shells at the 5th Cruiser Division, the 2d Destroyer Squadron hurried toward the enemy, and at 2106 the Jintsu launched torpedoes from a distance of 19,000 meters while sailing on a parallel course. However, since the enemy swung to the right and kept going, the squadron let him escape to the east.

In the meantime, around that time, the following reports [finally] came in concerning the situation of [the Asagumo of] the 9th Destroyer Division of the 4th Destroyer Squadron: “2020: [the Asagumo is] sailing on one engine under the escort of the Minegumo, steered by manpower, on a $280^{\circ}[\mathrm{W}]$ course at twelve knots. Now checking the damage on the body and the crew. No leaks. Since the Asagumo is unable to sail for long, she will sail to a point near the convoy, drop anchor and make emergency repairs. Our location is sixty-three nautical miles $215^{\circ}$ [SSW] from the base point." "2040: Restored the engine in working order and are able to sail on one engine at a maximum speed of twenty-four knots. We engaged with one enemy cruiser together with the Minegumo and sank her." "2150: The Asagumo has dropped anchor at $6^{\circ} 38^{\prime} \mathrm{S} 111^{\circ} 43^{\prime} \mathrm{E}$. Now conducting emergency repairs on the damaged parts." 


\section{The Second Phase of the Night Engagement (from 0030 until 0100)}

After the first night engagement, the aircraft of the Jints $\bar{u}$ kept on probing the enemy, while frequently dropping flares over him. From 2250 onwards, relieving the aircraft of the Jints $\bar{u}$, the aircraft of the Naka started to probe the enemy. However, from around 2330 onwards, communications with the aircraft of the Naka were disrupted, and the enemy's whereabouts were lost after he had sailed southward closer inshore. After ordering the $2 \mathrm{~d}$ Destroyer Squadron, "0000: Since the enemy movements are unclear, the 2d Destroyer Squadron shall sail close to the 4th Destroyer Squadron," 5th Cruiser Division Commander Takagi started sailing south. However at 0033, when the 5th Cruiser Division was sailing south on an $180^{\circ}$ [S] course, it sighted at a distance of 15,000 meters, $152^{\circ}$ [SE], the silhouettes of four vessels sailing northward. At 0040 after reversing course, the division set on a $0^{\circ}[\mathrm{N}]$ course, increased its speed to thirty-three knots to sail north on a parallel course with the enemy. Just before the 5th Cruiser Division reversed course, the enemy had started firing star shells.

While sailing on a parallel course with the enemy and keeping him at a distance of 12,000 13,500 meters, the division fought back with slow salvos (salvos from alternate guns at longer intervals, because the division had consumed much of its ammunition during the daytime engagement and only a little was left) and without using searchlights, measuring the distance by eye under the moonlight. At 0053, sailing on a parallel course [with the enemy], the division launched torpedoes (the Nachi eight and the Haguro four). Since the division was falling away from the enemy after launching the torpedoes, it [also] stopped shelling and reduced its speed to twenty-eight knots, when around 0106, suddenly a huge explosion with flames soaring up to the sky occurred. Around 0110, it was followed by [another] explosion and another flame shot up to the sky. It was confirmed that the torpedoes had instantly sunk one [enemy] vessel, and set another ablaze. While immediately reporting this to the $2 \mathrm{~d}$ and the 4th Destroyer Squadrons, 5th Cruiser Division Commander Takagi kept sailing north at a reduced speed, waiting for both units [to join]. However, around 0125, he rapidly lost sight of the enemy. He changed to a $90^{\circ}$ [E] course, launched at 0145 an aircraft of the Nachi to probe [the enemy] and [kept on] searching for him setting on a $150^{\circ}$ [SE] course at 0200 , but could not find him. Meanwhile, the $2 \mathrm{~d}$ Destroyer Squadron, which was positioned to the southwest of the 5th Cruiser Division, had immediately increased its speed to sail north when it had spotted the enemy's firing of star shells. After seeing the large columns of flames at 0108, the squadron pursued the enemy on a $45^{\circ}$ [NE] course from 0120 onwards, and further pursued the enemy fleet, setting on a $90^{\circ}[\mathrm{E}]$ course at 0130 .

The 4th Destroyer Squadron, positioned further southwest of the 2d Destroyer Squadron, was not in time for this engagement. [Then] expecting the arrival of the main unit of the Dutch East Indies Unit on the battle site in a short while, 5th Cruiser Division Commander Takagi wired: "0210: The Ashigara and the Myōkō will soon join us. Be careful in identifying friendly forces." Although the aircraft of the Nachi searched for the enemy until around 0245 in the neighborhood of the battle site, no enemy was spotted within a radius of twenty nautical miles with the burning enemy vessel at the center. It further searched for the enemy as far as to the vicinity of the port of Surabaya, but did not spot him. Since the whereabouts of the enemy remained unknown even at 0135 , Commander Takagi had the $2 \mathrm{~d}$ and the 4 th Destroyer Squadrons take up their respective guard positions, with the order, "Guard the southeastern side of the convoy." The numbers of shells ([and] torpedoes) consumed in the first and second phases of the night engagement were as follows: 
The first phase:

Type93 Torpedoes (the Jints $\bar{u}$ ): 4 torpedoes

The second phase:

20-cm guns (the Nachi and the Haguro): 46 shells

Type93 Torpedoes: 12 torpedoes

Cdr. Suékuni Masao, then gunnery staff officer of the 5th Cruiser Division, recalled the engagements as follows:

When we encountered the enemy at 1730, I thought that the sun would set soon. So, I figured out that we could destroy the enemy if we carried out a night engagement after the engagement at dusk. At that time, the staff officers shared the unspoken thought that our convoy could possibly be destroyed if the 5th Cruiser Division should sustain damage in the engagement, and that [the division] should [only] conduct an "outranging" artillery duel at a distance of 23,000 to 20,000 meters (note by the author: a situation where the enemy shells would not reach the Japanese vessels but the Japanese shells could reach the enemy) and at an appropriate moment launch Type93 torpedoes to finish it off.

We launched torpedoes at 1826, [ordered] "all ready for charge" at 1833, and then ordered to charge at 1837. After supporting the charge of the destroyer squadrons for a while by sailing on a parallel course with the enemy, the 5th Cruiser Division shifted to the pursuit of the enemy on a south-southeast course from around 1840. Around 1850, when the torpedoes of the first launch were supposed to have reached the enemy vessels, no explosions, which should have been caused by hits, occurred. Commander Takagi asked his staff what to do next. In response, Senior Staff Officer Nagasawa Kō answered that we should conduct a night engagement. When someone of the staff asked the signal officer about the time of sunset, it was reported as 1950, which reminded [the staff] for the first time that sunset was quite some time off. We still had about a good hour before sunset, but with no particular course to be taken, we [just] continued the engagement. However, from around that time, both the enemy and us [had to] sail in or out of the smoke screens that the destroyers on both sides had spread, which naturally slowed down the artillery duel. In this engagement, every time our vessels appeared from the smoke screens, enemy shells came instantly flying at them. We, on the other hand, needed some measuring time to calculate our firing data. (Later, when we reviewed the engagement at Makassar, we suspected that the enemy must have used radar for its gunnery that time.*)

After the charge, around 1918, we carried out the second launch of torpedoes. Then from around 1924, the destroyer squadrons launched torpedoes. From around that time onwards, a number of large water columns were spotted particularly on the waters near the $2 \mathrm{~d}$ Destroyer Squadron, which made us fear that the squadron was heading into an enemy minefield. The fear of enemy minefields made us reverse course and sail away from the shore, and consequently away from the enemy.

When the daytime engagements were mostly over, we ordered [the units] to report the remaining amounts of ammunition. In an hour and a half, overall reports came in all together, which revealed that the remaining amounts of ammunition had gotten unexpectedly low, and we became suddenly concerned about the remaining amounts.

In the night engagements, we conducted shelling [at the enemy] from a distance of 17,000 to 18,000 meters without using searchlights. The chief gunner had requested to turn off the lights, because he could not see the targets when they were on.

* Although most sources maintain that none of the Allied ships had radar, HMS Exeter had actually just been refitted with Type278 early-warning radar and Type284 fire-control radar, https://en.wikipedia.org/ wiki/HMS_Exeter_(68). 
In the daytime engagement, the launching tubes of the Nachi had malfunctioned and she could not launch her torpedoes. [The truth was that] the launching crew had forgotten that the valve to supply compressed air to the launching tubes had already been turned fully open; by the torpedo chief's order to open the valve, they tried to open [it] but were unable to turn it any further, because it had already been fully opened; consequently, it was reported that the launching tubes had malfunctioned. In actual engagements, unexpected and absurd things do happen. However, the torpedoes that could not be launched [in the daytime engagement] because of this [mistake] were launched in the night engagement and achieved a great success by sinking two enemy (main force) cruisers. This instantly retrieved the honor of the torpedo chief and his men, which had been lost in the daytime engagement. In this world you never know what may turn out to your advantage.

After the night engagement, we [again] checked the remaining amounts of shells and torpedoes; the amounts were low enough to make us extremely concerned about how to handle this in future engagements.

Reflecting on the engagements, I realized that drills would usually come to a close after a series of attack actions triggered by the "all charge" order were finished, and that we rarely conducted post-attack training. I keenly felt that, without adequate training for the actions to be taken after attacks, it is difficult to destroy the enemy, because people do not perform better in actual engagements than in normal training.

\section{The Main Unit of the Dutch East Indies Unit Came to Assist But Too Late to Participate in the Engagement}

On 27 February, around the time when the 5th Cruiser Division, the $2 \mathrm{~d}$ and the 4 th Destroyer Squadrons encountered the enemy fleet on the waters southwest of Bawean Island, the Dutch East Indies Unit commander had [already] advanced to the waters north of the Kangean Islands, leading the Ashigara, the Myōkō, the Ikazuchi and the Akebono (having left Makassar on 26 February*). In view of the enemy movements in the Surabaya area, Dutch East Indies Unit Commander Vice Admiral Takahashi had at 1420 an instruction sent under the name of his chief of staff to the 1st Base Unit engaged in the Bali operation to advance the Kinu and [some] destroyers to the area where the 5th Cruiser Division and the 2d Destroyer Squadron were operating. In response, 1st Base Force Commander Rear Admiral Kubo replied at 1700 that he would dispatch the Kinu and the 8th Destroyer Division (minus two destroyers). ${ }^{(54)}$

On receiving the report from 5th Cruiser Division Commander Takagi that he had encountered the enemy, Dutch East Indies Unit Commander Vice Admiral Takahashi decided to immediately rush to the site and sent a telegram: "1830: Our position as of 1830 is 'HoWA-RE-19' and we expect to reach [a position] about forty nautical miles southeast of Bawean Island at 0230." While communicating its own position to the 5th Cruiser Division, the main unit rushed to the battle site roughly on a $270^{\circ}$ [W] course, and at 2330 radioed its plan of operations as follows: "The main unit shall basically combine with the 5th Cruiser Division. The other units shall take up appropriate positions. We shall do our utmost to destroy the enemy in a night engagement tonight, and completely destroy the remnants of the enemy in a subsequent daytime engagement."

Around 0230, the main unit reached the waters south of Bawean Island. However, unable to sail west any farther due to the situation on the battle site, the unit operated in the sur-

* The Myōkō actually joined later. See p. 410. 
rounding waters at high speed for a while, while sending a telegram to the 5th Cruiser Division: "Report your next attack plan." In the meantime, 4th Destroyer Squadron Commander Nishimura offered his proposal: “0420: In terms of the remaining enemy surface strength, I think it better to postpone the start of the landings for one day. The convoy seems to be [still] evacuating to the north," to which Dutch East Indies Unit Commander Takahashi responded that he had no objections; [accordingly, the start of] the landing in eastern Java was postponed for one day. During these hours, a reconnaissance by the aircraft of the Nachi and a search mission conducted by the surface units made it clear that no enemy other than the blazing damaged vessels were seen at the battle site. The main unit advanced from the area south of Bawean Island to the area to its west, and at 0600 specified the designated meeting point for the 5th Cruiser Division in the following [telegram]: “0600: Join [the main unit] at sixty-three nautical miles $292^{\circ}[\mathrm{WNW}]$ of the reference point at 0700 . The main unit is bearing $0^{\circ}[\mathrm{N}]$ at sixteen knots."

\section{The Transport Convoy's Entry into [the Anchorage off] Kragan}

The sun rose, while the 5th Cruiser Division and the 2d Destroyer Squadron were [still] unable to get further information about the enemy movements. At 0730 on the 28th, [they] joined the main unit at the designated meeting point. Fourth Destroyer Squadron Commander Nishimura ordered the transport convoy "to operate so as to reach, at 1200 today on the 28th, the point that you were designated to reach at 1200 on the 27 th ([in accordance with] Escort Unit Order Separate Illustration, No. 2), (54)"' and again shifted to the formation to escort the convoy. At 0815, the Asagumo, which had sustained damage the previous night, [also] joined, escorted by the Minegumo. It was decided that the Asagumo should sail to Balikpapan to repair the damage, while the 9th Destroyer Division commander changed ships to the Natsugumo.

Dutch East Indies Unit Commander Takahashi assigned the guarding of the areas east of the convoy to the $2 \mathrm{~d}$ Destroyer Squadron, the 5th Cruiser Division and the main unit in that order from the south, and each unit broke up its columns to take up their respective positions. Tanaka, commander of the 2d Destroyer Squadron, sent the 1st Section (the Ushio and the Sazanami) of the 7th Destroyer Division, which had a short cruising range, to Banjarmasin for replenishment, while returning the Yamakaze and the Kawakaze to the 5th Cruiser Division unit at the latter's request, ${ }^{(54)}$ which changed the [distribution of] forces in the following way:

The 2d Destroyer Squadron unit: The Jints $\bar{u}$ and the 16th Destroyer Division

The 5th Cruiser Division unit: The Nachi, the Haguro, the Yamakaze and the Kawakaze

The main unit: The Ashigara, the Myōkō, the Ikazuchi and the Akebono

The transport convoy: The Naka, the 2d Destroyer Division, the 9th Destroyer Division (minus the Asagumo and the Yamagumo), the Shirataka, ${ }^{*}$ the 21st Torpedo Boat Division 1st Section, the 11th and the 30th Minesweeper Divisions, Patrol Boat ${ }^{* *}$ No. 20, the 21st Subchaser Division, the Myōko-maru, ${ }^{* * *}$ and the forty-three army transport ships

\footnotetext{
* A mistake for the Wakataka. The Shirataka was part of the western Java escort (p. 366).

** Actually Minesweeper.

*** The Myōkō-maru was part of the western Java convoy (p. 366).
} 
The Kinu (the flagship of the 4th Submarine Squadron) and the 8th Destroyer Division (minus the Asashio and the Arashio), which had been dispatched by the 1st Base Force, also joined the transport convoy around 1330. At the request of the 4th Destroyer Squadron commander, they guarded the rear of the convoy on its eastern port quarter, while sailing south [along with it]. ${ }^{(62)}$

Right before entering into the anchorage, the minesweeping unit and the convoy came under a persistent attack by about ten enemy dive-bombers, their near misses caused the Tokushima-maru some leaks and made her run aground on the coast, while direct hits inflicted a loss of about 150 casualties on the Johor-maru. She also sustained minor damage, but since her hull and engine were still intact, she continued sailing and entered into the anchorage for Kragan at 0235 on 1 March [along with the other ships], as scheduled. Even after their entry into the anchorage, the enemy repeated its persistent attacks while dropping flares. Meanwhile, three [enemy] torpedo boats raided the anchorage, of which the Harusame sank one and destroyed the other [two]. Also after sunrise, [enemy] fighter planes strafed [the Japanese forces], however, at 0400 the army units successfully landed the first landing unit.

\section{Destroying the Remnants of the Enemy Fleet}

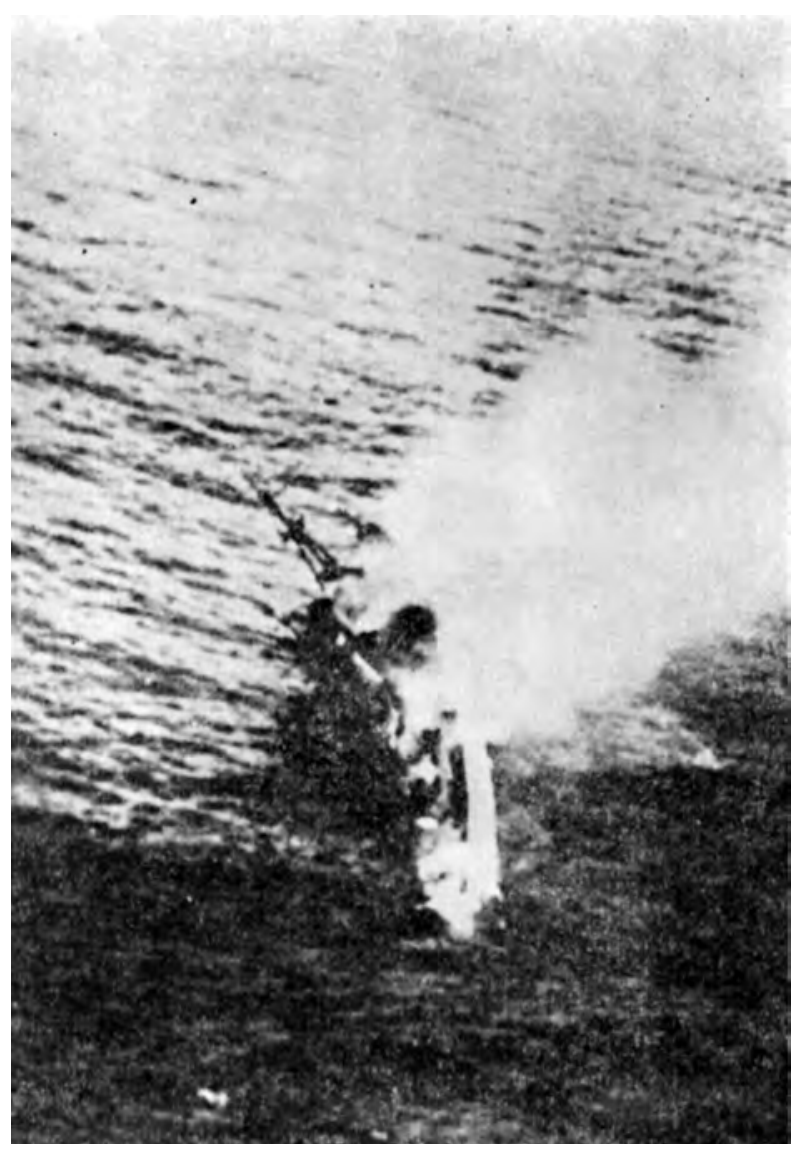

The British Heavy Cruiser HMS Exeter About to Sink
At 1103 on the morning of 1 March, while patrolling in an area about ninety nautical miles west of Bawean Island, the 5th Cruiser Division unit spotted at $64^{\circ}$ [ENE] one enemy cruiser and one destroyer (which later turned out to be two), sailing westward. Since the 5 th Cruiser Division had used up much of its ammunition in the engagements since the 27th, it decided to enlist the Ashigara and the Myōko to attack the enemy. The division informed all units of its decision, while launching two observation seaplanes between 1117 and 1128. Around that time, the enemy started to escape by changing course to [first] northward and then eastward, while spreading smoke screens. The 5 th Cruiser Division also changed course eastward and began to pursue him, and along with the main unit, which was sailing around from the west to the north, they took up positions to launch a pincer attack on him from the north and the south. 


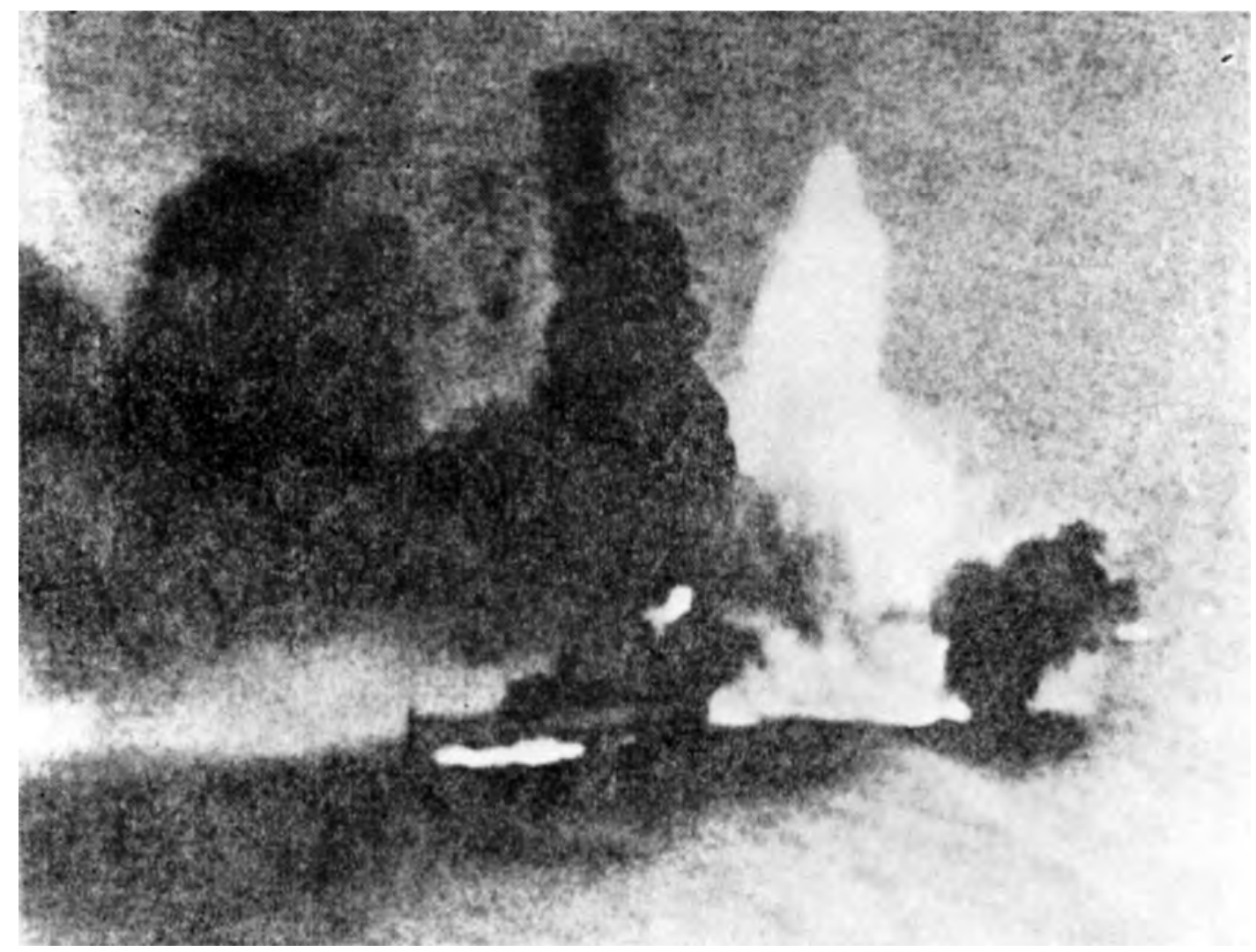

The HMS Exeter at the Moment of Being Hit by Torpedoes

Both units pursued the enemy from the south and the north; at 1150, the main unit first of all opened fire from a distance of about 23,500 meters, and then the 5th Cruiser Division followed, opening fire from around 1225 from about 16,000 to 18,000 meters away. Although the enemy tried to escape eastward spreading smoke screens, the cruiser took a number of direct hits from around 1240 onwards, which caused fires and reduced her speed. Around 1250 , the units simultaneously conducted a concentrated torpedo attack and delivered a decisive blow to the cruiser. It was the British heavy cruiser HMS Exeter. Then, the units concentrated their fire on the remaining two destroyers; the British destroyer sank at 1330, while the other destroyer escaped eastward, taking advantage of a squall. Ordering the 5th Cruiser Division unit to leave for Banjarmasin for replenishment, Dutch East Indies Unit Commander Takahashi hotly pursued the fleeing destroyer, leading the main unit. The [enemy] destroyer escaped as far as the southern coast of Borneo where she was bombed by aircraft of the 4th Carrier Division and the Eleventh Air Fleet. The main unit spotted her crippled from the [bombing] damage, and sank her at 1540. The former British destroyer was the HMS Encounter, whereas the destroyer sunk later was the USS Pope.

The number of shells ([and] torpedoes) expended in the daytime engagement on 1 March was as follows: 
12.7-cm guns (the Ashigara):

ditto (the Ikazuchi):

Type93 torpedoes (the Nachi, the Haguro, the Ashigara and the Myōkō):

Type93 torpedoes (the Ikazuchi, the Yamakaze and the Kawakaze):
14 shells

279 shells

24 torpedoes

11 torpedoes

The remaining number of shells and torpedoes of the 5th Cruiser Division after this engagement was as in the following table: ${ }^{(78)}$

\begin{tabular}{|c|c|c|}
\hline Name of Ship & Main Guns & Remaining Torpedoes \\
\hline Nachi & 7 shells per gun & 4 \\
\hline Haguro & 19 shells per gun & 4 \\
\hline
\end{tabular}

Note: The number of shells loadable to each $20-\mathrm{cm}$ gun: 200 shells ${ }^{(69)}$

The number of torpedoes loadable to each ship: 24 torpedoes $^{(151)}$

\section{Lessons Learned and Reviews After the Sea Engagements}

1. The Action Report of the 5th Cruiser Division ${ }^{(78)}$ (submitted on 20 March)

(1) Concerning the large blackish gray water columns

We guessed, [judging from] the location of the battle site at that time (about fifty nautical miles northwest of the north entrance of [the port of] Surabaya and about twenty nautical miles north of the closest coast) that the supersized blackish gray water columns that appeared in large numbers in the daytime engagement off Surabaya on 27 February must have been controlled mines of the enemy and reported as such in our summary report of the actions sent by telegram. However, some later reports of other units took them for [Japanese] torpedoes that had self-destructed.

However, in the engagement with the British vessel HMS Exeter on 1 March, we confirmed three times that about the same time and in the same areas where enemy shells had landed, the aforementioned supersized blackish gray water columns (guessed from memory, not measured by instruments, about five or six meters wide and about seventy or eighty meters high, and taking about thirty seconds to disperse and disappear) had appeared mixed [with the enemy shell splashes].

Whether these were a means employed by the enemy, particularly at the time of test-firing their guns in order to facilitate the measuring of the impact points of their shells, or whether they were used as a threat or for cover, we still entertained many doubts on a technical level, for if we saw that in the engagements of 27 February, when we were all charging toward the enemy, the enemy, apart from wrapping himself in chemical smoke screens spread by the main ships and also in sooty and chemical smoke screens emitted by the destroyers of their direct escort, had moreover created walls of large black water columns with presumably a special type of shells on the route ahead of our destroyer units, the fact remains that those water columns were too supersized to have been created just by $20-\mathrm{cm}$ gun shells.

Then, when the recollections of observations by the flight crews were put together and added, it turned out that no circular ripples, which must have been caused by dropping shells, had been spotted at all right before the appearances of the large water columns. [Apparently,] the large water columns were not created by explosions caused by something dropped, but were consistent with columns that had arisen directly from the water. Moreover, after comprehensively judging the accounts of several persons of other units, who had 


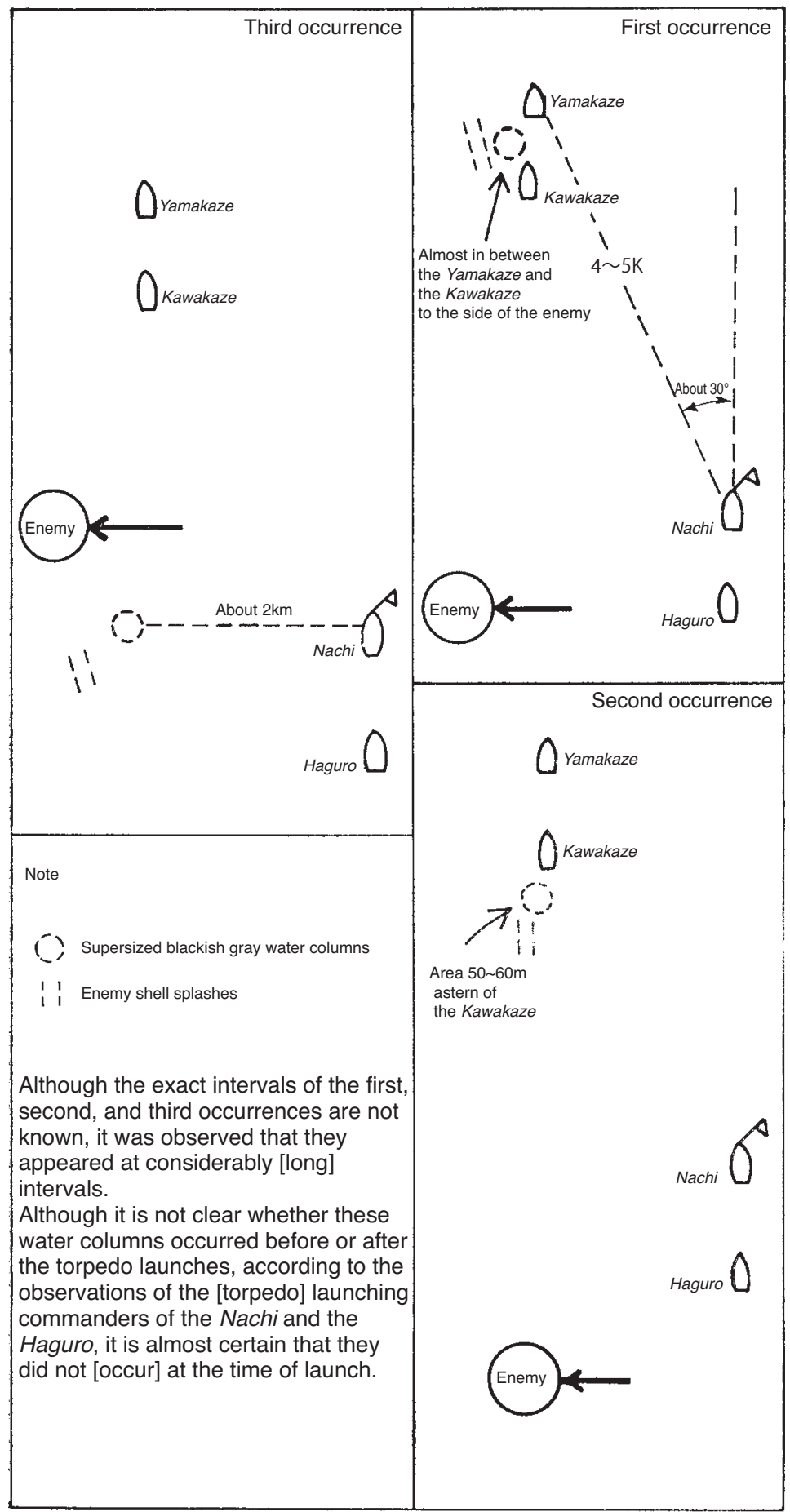

Illustration No. 46 - The Circumstances at the Time of the Appearance of the Large Water Columns 
participated in the daytime engagement on 27 February (but who had not yet had an opportunity to satisfactorily review [the engagement]), as well as the accounts of [other] persons concerned of friendly units who had participated in the engagement, suspicions hardened that [the water columns] might have been caused by the self-destruction of friendly torpedoes.

If [the water columns] were [indeed] caused by the self-destruction of [our] torpedoes, it would be a grave situation, which would require a prompt and thorough examination in order to take countermeasures.

However, this is not certain either, because among the torpedoes launched four times [in total] on 27, 28 February and 1 March by our unit (minus the Myōkō), only one torpedo, which had been launched at night, was suspected of having self-destructed.

(2) Ideas about [using special] 20 -cm gun shells for finding the range in test-firings. Even if explosive shells are fired at [actual] target ships by $20-\mathrm{cm}$ guns in long-range artillery duels, ranging the fire from aboard a ship remains difficult, as has always been said.

If we would apply the idea of throwing up large columns of water, as suggested by this engagement, to smoke shells for the 20-cm guns, conduct research and create special smoke shells that can throw up smoke/ water columns similar to those caused by shells but by far larger than those thrown up by regular shells, and launch such smoke shells along with the [other] shells at the time of ranging the fire (or when we intend to make more reliable observations of shelling distances), they would certainly enable us to easily observe the distance [between the enemy and us] even without observations by aircraft, and obviously give us an advantage when carrying out artillery duels.

I think it is essential to speedily research and create special smoke shells for observation.

(3) It is imperative to conduct thorough drills and gain the skills [required] for sudden artillery duels.

As seen in the engagements on 27 February and the engagement on 1 March, the enemy spread smoke screens on an extensive scale and fired [at us] skillfully making use of them by sailing in and out of them, which in many cases made it difficult for us to visually confirm him from our side. Therefore, it is imperative to conduct thorough drills to improve the skills [required] for sudden artillery duels against targets, which would come in and go out of sight, making use of smoke screens. The traditional trainings for combat skills are far from sufficient. Even more "severe" drills are required.

(4) When attacking the enemy by encircling him, it is absolutely necessary to take adequate measures on a technical level as well as on a tactical level to prevent friendly torpedoes launched from the opposite side of the enemy from doing harm to [other] friendly vessels.

There are indications that in the engagement [of 1 March], the passing torpedoes, which the Yamakaze reported around 1315 to the 5th Cruiser Division and which the 5th Cruiser Division evaded with a sudden wide swerve, must not have been enemy torpedoes but friendly torpedoes launched from the north of the enemy (launched at $130^{\circ}$ [by] the Ashigara at 1300), which had run [past the enemy] and were coming [toward the division].

We became painfully aware of the absolute necessity in terms of combat duties that the launching times, the position in relation to the enemy at the time of launch, and direction of the line of fire are promptly reported to friendly forces on the opposite side of the enemy, while making sure that the [friendly] forces receive it.

(5) Apart from the need to use ammunition efficiently by quickly evaluating the damage inflicted on the enemy, appropriately shifting firing targets, and avoiding the unnecessary shelling of disabled enemy vessels, one should also not stick to one target more than necessary while letting other enemy vessels slip away.

It is extremely difficult in combat to judge whether the enemy has been totally disabled or not. In the engagement [of 1 March], considerable time presumably passed since the exact 
moment that HMS Exeter had really been disabled until it was confirmed that she had lost her fighting capacity, [that is] when the traverse and the elevation of her gun turrets became odd and [she] stopped firing. Also, by continuously attacking the enemy cruiser, [we let] one of the enemy destroyers slip away, which put us in a situation that later we had to pursue her over a long distance to catch her.

(6) A damaged vessel loses speed sooner than expected; nevertheless, it is difficult to detect the speed reduction of a damaged enemy vessel from aboard one's ship.

In the engagement [of $1 \mathrm{March}$ ], the shells we fired around 1250 continuously deflected to the right. It was because the enemy vessel had suddenly reduced her speed (which became known later). According to observations from our aircraft, by around 1256, the enemy [vessel] already seemed to have almost completely stopped.

I think this should be particularly kept in mind when making observations either from aircraft or vessels ([on the latter], the observations need to be made by personnel other than those in charge of range taking, and the results should be advised to the fire-control officer or the range-taking officer, since those right in the heat of artillery duels will not easily detect [the reduction in speed].)

\section{The Action Report of the 4th Destroyer Squadron (23 March)}

(1) In such exceptional circumstances as accompanying a large convoy that could not make more than eight knots and with a distance of merely about one hundred nautical miles between the enemy and the convoy, we nevertheless completed the operation successfully. We owe that of course to the tremendous spirit and technical skill [of our forces], but, among others, it also depended greatly on the following factors.

$\{1\}$ The Japanese side mostly had the upper hand in the air. Although enemy [aircraft] came for an attack on the convoy, none participated in the engagements; on the other hand, we made the most of our land-based attack planes and aircraft carried on board the vessels. While [having our aircraft] keep on reporting on the enemy movements and block his surprise attack maneuvers, we concentrated our forces for seizing the offensive, and throughout made one-sidedly better use of all aircraft for observing the situation and the results of shelling as well as for probing at night.

Moreover, in our further review of [the engagement], we noticed that the enemy [still] had flying boats and land-based aircraft among its remaining forces, all of which had their own bases at close distance, and that though there might have been some obstacles, he was still in a position where he could have used them in a much better way. If he had made use of them in reconnaissance, observation of the situation (or observation of the artillery duel) or probing at night, we think that [our fight against the enemy] would have involved considerable difficulties. Among the various reasons that prevented the enemy from conducting the war in such a way were weak points attributable to the allied forces, [poor] daily trainings (no great amount of training seems to have been given [to the crews] of the flying boats, not to mention the training [of the crews] of land-based aircraft, who presumably had been given no training at all), and poor tactics, etc. Nevertheless, our appropriate use of ship-based aircraft was to a high degree [responsible for our success]. However, when considering sea engagements against America, which will certainly involve considerable obstacles, we cannot expect the same perfect use of ship-based aircraft as this time, therefore I think that further research and improvement will be required concerning the performance of ship-based aircraft in air engagements, their cruising time and speed, or the number of aircraft to be carried on board, the measures against blast [damage produced by the main guns], or the continuous use of shipbased aircraft. 
$\{2\}$ On the afternoon of the 26th, several enemy naval vessels consisting of two light cruisers as the core were cruising outside the port of Surabaya and then put into port, [which gave an opportunity to] the 1st Escort Unit to make an outline of precautions to take in case [it had to] separate the 4th Destroyer Squadron for an attack on the enemy and [thus] already getting ready for an attack at any time. I think it not only helped the 4th Destroyer Squadron to quickly assemble immediately after the first report of the spotting of a powerful enemy fleet on the 27th, swiftly join the 5th Cruiser Division and the $2 \mathrm{~d}$ Destroyer Squadron to concentrate forces for seizing the offensive and to get the upper hand in the engagement, but it also enabled the transport convoy to appropriately operate in perfect order.

\{3\} The enemy fully revealed the weaknesses of the allied forces by:

1) Its confused rout after [the Japanese attack in] the first phase of the daytime engagement (when the Japanese torpedoes reached him)

2) The escape of the USS Houston and the HMAS Perth when the enemy lost the HNLMS De Ruyter and the HNLMS Java in the night engagement

3) The fact that the signal staff of the USS Houston had been dispatched to work on the HNLMS De Ruyter for communications (this was brought to light in the interrogation of the prisoners)

\{4\} The enemy was very passive in his use of destroyers, whereas we were totally aggressive as is our tradition. On top of that, our performance from our torpedoes down to our guns was far superior; such ships as the enemy destroyers are not even worth considering. Also in the light of the hard fighting of the 8th Destroyer Division in the Lombok Strait, it is regrettable that in this fight the superior power of our destroyers could not be fully demonstrated in their torpedo power. Nevertheless, I think that we gave the enemy a massive lesson in combat leadership and combat spirit.

(2) Although the first launch [of our torpedoes] in the daytime engagement was carried out under totally favorable circumstances, [including] a perfect launching point and precise reports by our aircraft about the speed of the enemy, we were not able to fully demonstrate our torpedo power because many torpedoes self-destructed [halfway], which was very regrettable. Since the employment of Type93 torpedoes [in attacks] is one of the [main] tactics of the Imperial Navy for certain victory, these self-destructions are a crucial problem in a decisive battle. Therefore, it is necessary to immediately improve the detonators and remove these worries. According to the torpedo chief of the HMS Exeter, who later became prisoner, he saw some exploding in reaction to her wake while [she was] taking evasive actions (at twenty-five knots) after spotting the wake of our torpedoes.

(3) In the daytime engagement, the enemy consisted of five cruisers (of which two were equipped with 20-cm guns), and ten destroyers, ${ }^{*}$ whereas Japanese forces consisted of two heavy cruisers, two light cruisers and fourteen destroyers, [which meant] that in power both sides were almost equivalent. In reality, we fought against the five [cruisers] of the enemy cruiser unit with two [cruisers] of our cruiser division and two destroyer squadrons. The circumstances at the time of the charge of the destroyer squadrons were somewhat like a decisive battle. Under such circumstances, the 5th Cruiser Division fired at the enemy cruiser unit at a distance of about 26,000 to 21,000 meters. [However,] before having inflicted considerable damage to the [enemy] ships other than the HMS Exeter (the second ship), whose damage was serious enough to let her drop out of line, [the division] used up more than half of the ammunition loaded on the ships. Also, even when the [Japanese] destroyer squadrons shifted to a pursuit battle, taking advantage of the enemy, whose formation had become totally disorderly at their charge, no perfect results were attained, either. These may

* Actually nine: four American, three British and two Dutch destroyers. 
be considered partly due to the enemy's skillful evasive actions, but I [rather] think that it was because the shelling was carried out at too great a range.

It was observed from afar that there might be some scope for reconsideration of the decisions concerning effective shelling ranges. And, the various issues of artillery duel tactics, including the "outranging" tactics to be used at the beginning of an engagement, [might be reviewed] with a mind to decisive battles when encountering the main force of the enemy taking the present battle into consideration. I think we need to further re-examine the amounts of ammunition etc. loaded [onto our vessels] based on the changes in various battle situations.

(4) I think that the following matters require prompt research and measures for improvement:

$\{1\}$ Fire control when the enemy takes skillful and bold evasive actions

\{2\} Comparison and examination of evasive actions and methods to make the most of our firepower, and studying appropriate evasive actions

$\{3\}$ To re-examine the outline of our current night engagement tactics in such night engagements where the enemy uses star shells on a large scale, as well as to study the use of them.

3. The Action Report of the 2d Destroyer Squadron (dated 12 March, submitted 23 March)

(1) It is extremely difficult to carry out a charge from one direction against an [enemy] cruiser unit in daytime because the enemy can freely take evasive actions, and also because there is little difference between his speed and ours. I keenly felt the necessity for torpedoes that can instantly be launched at a favorable opportunity and with an oblique second-stage run (and running in a circular pattern at their final stage).

It is necessary to immediately distribute such torpedoes also to the destroyer squadrons.

(2) When a superior enemy rapidly advances toward us at the beginning of an engagement, the S-launch (note by the author: a long-distance launch) ${ }^{(152)}$ is also effective against [such] cruiser units.

Since our squadron had taken a favorable position against the enemy also at the initial stage of this sea engagement, I am certain that if we had carried out [the S-launch], with the Jintsu and one element of our destroyers combined, we could have achieved a huge effect.

Traditionally there is a preconceived idea that destroyer squadrons should avoid Slaunches, particularly against cruiser units. However, it is more sensible that we should determinedly conduct such launches at favorable opportunities.

That is to say, since the critical turning point between win or lose as was shown in this sea engagement will be decided in the blink of an eye, I was made fully aware that we should determinedly carry out torpedo warfare at any favorable opportunity. For this purpose, I consider it necessary also for destroyer squadrons to study and drill S-launches.

(3) It is extremely difficult to fight a night engagement (particularly when visibility is high) against enemy cruiser units, whose vessels can sail at a same speed and can freely take evasive actions. This is the reason why we failed to satisfactorily pursue [him] in this night engagement. Accordingly, I keenly felt that it is also essential [in engagements] against an [enemy] cruiser unit to approach the enemy up to the visibility limit and as soon as his direction becomes clear conduct O-launches (note by the author: covert launches from a [long] range, which are carried out in such a [stealthy] way that even a launching action would not be detected by the enemy).

If S- and O-launches were to be carried out by the destroyer squadrons, the number of torpedoes on hand on the destroyers may not be sufficient, but even if the number of torpedo launches is reduced or if the launches would be carried out by only part of the destroyers, I still think that implementing these [S- and O-] launches at favorable opportunities will bring advantages to the overall situation. 
Particularly, the O-launch carried out this time by 5th Cruiser Division in its simultaneous artillery and torpedo duel, was extremely effective.

(4) In relation to the previous three items, I think that a thorough study and tactical drills against cruiser units are most urgently required.

(5) When launching torpedoes during daytime against enemy cruiser units, which take a zigzag evasive action, it is better to launch them at a maximum spread angle with no deflection angle set.

(6) The self-destruction of Type93 torpedoes in this sea engagement was confirmed by later investigations.

[This meant that] at least dozens of torpedoes self-destructed in the daytime engagement, and that the large water columns that the Jintsu spotted right after having launched her [torpedoes] in the first phase of the night engagement were probably caused by the self-detonation of our torpedoes as well.

Since these self-detonations of our torpedoes, which [our men] "had launched after daring to jump into the midst of the enemy," will affect their morale, it is urgently required to take steps [to prevent it].

(7) The guarding in this engagement after sunset could better have been assigned to the $2 \mathrm{~d}$ Destroyer Squadron, the 5th Cruiser Division and the 4th Destroyer Squadron in that order from the north.

Even if the enemy could possibly have come for an attack on the convoy from either way [north or south], it would have been easier for either of the destroyer squadrons to advance into his sailing route and have an opportunity to charge toward him while the 5th Cruiser Division was [engaging him] in an artillery duel. In order to destroy a superior enemy cruiser unit, I think it a standard move to swiftly advance destroyer squadrons (destroyer divisions) into the sailing route of the enemy while friendly cruisers [engage him] in an artillery duel, and at a favorable opportunity have [the destroyers] shift and charge toward him.

Neither in the first nor the second phase of the night engagement did the destroyer squadrons have time to advance to positions to charge [against the enemy].

$(8,9)$ (Omitted by the author - these items concern submarines; will be described later.)

(10) The artillery ability of the enemy cruisers was excellent; the dispersion area of their shells fired in salvos by four to six guns from about twenty kilometers afar was [only] about 150 to 200 [meters].

It is necessary [for our forces] to study and take steps to narrow down the dispersion area of our guns.

(11) It seems that the enemy destroyers accompanied [the cruisers] only to directly escort the main unit and to spread smoke screens. They seem to have had no intention to carry out aggressive torpedo attacks ([or] charges) either in the daytime and the night engagements, which gave us an impression that their power to conduct torpedo warfare is inferior.

(12) The enemy used dye-capped shells in daytime and star shells (British and U.S. forces) at night. However, the range of the star shells must have been almost the same as our shells; in the artillery duel against the 5th Cruiser Division (at a range of about eighteen kilometers), the star shells exploded so close that I thought that they must rather have hampered [than helped] the enemy's visual confirmation. We visually confirmed that all his shells fell short.

(13) It is better to conduct artillery warfare without using searchlights when visibility is high. I keenly felt it when firing at [enemy] submarines.

Also, as seen and clearly shown in the battle example of the 8th Destroyer Division in the Lombok Strait, in some cases, the use of searchlights is rather disadvantageous even on a dark night.

Particularly, it is true when charging with a small number of vessels into a large number [of enemies] to fiercely attack from a close range. 
I think that from now on artillery drills without using searchlights need to be greatly encouraged for destroyer squadrons.

Capt. (then Cdr.) Takedai Takashi of the Navy Technical Department, who was in charge of torpedoes at that time, wrote the following recollection of the self-destruction of the Type93 torpedoes: ${ }^{(153)}$

In February 1942, on the sea [off] Surabaya, a Japanese elite division of the latest cruisers and a destroyer group consisting of the $2 \mathrm{~d}$ and 4 th Destroyer Squadrons, also made up of destroyers of the latest type in the world, caught up in a skillful operation with an enemy fleet ([of] five cruisers and six destroyers) and were poised to destroy the latter at a stroke. The enemy fleet was just like a small bird stalked by a predatory eagle, and its destruction was just a matter of time.

The Japanese cruiser division operated in perfect order, just as in the yearly Pacific Ocean exercises. At a range of about 30,000 meters, it carried out the first long-distance concentrated [torpedo] launch; in concert with this, the destroyer squadrons carried out the second launch, and over a hundred torpedoes simultaneously ran toward the enemy vessels.

The torpedoes were the pure oxygen Type93 torpedoes, which were [at that time] the best performing torpedoes in the world. Sixty-one centimeters in diameter, four meters long and carrying 1.5 tons of explosive in their warhead, they resembled a baby whale when they rushed like lightning several meters below the surface of the sea off Surabaya towards the enemy fleet, rolling their massive bodies. The total amount of explosive added up to about two hundred tons; no matter how [skillfully] the enemy vessels would try to evade them, they would have no way to escape from the gigantic swarm of torpedoes, ready to catch them as if in a net. The biggest show of the century was just about to begin. The officers and men shuddered imagining the impending gruesome scene of the enemy vessels being annihilated at a stroke.

However, after plunging into the water and running for about five hundred to one thousand meters, the launched torpedoes exploded with a terrific bang, tossing up huge splashes. One after another the torpedoes exploded, and they were followed by those from other vessels.

The torpedoes exploded too early. The moment they passed through the safety distance, the fuze automatically actuated and set off the explosive. They literally self-destructed.

The number of the torpedoes that self-destructed in this sea engagement reached as many as about one third of the launched torpedoes. It was a true disaster. What had the Navy Technical Department been doing? What about the personnel in charge of torpedoes? The operational units were so angry that they just wanted the personnel responsible to take their own lives. You can imagine our panic when we were told the news. Having no idea at all about the cause, we had no excuse to offer. We had no words to apologize to the officers and men of the operational units, who risked their lives in battle. As the competent person in charge of the torpedoes, I felt more dead than alive. However, since taking my life would not solve this problem, I promptly set up an investigation panel in the Navy Technical Department to investigate the cause. Upon the return of the fleet to the Inland Sea [of Japan], all persons involved, from the director down to the personnel in charge of torpedoes, immediately presented themselves to investigate the situation. I felt completely miserable at that time; scolded and yelled at everywhere, I felt more dead than alive.

[Then] the results became clear; the main cause was a manifestation of the fighting spirit of the Imperial Japanese Navy personnel.

The fuze worked in such a way that, after running through the safety distance, the inertia mechanism in it would be set free; when [the torpedo] hit something with a force above a fixed level, the inertia mechanism would tip forward and release the firing pin, which would strike into the detonator by force of a spring and detonate the explosive. The force, at which the inertia 
mechanism would move, was adjusted with [special] measuring instruments. It would not move at a small force; it was supposed to actuate only when a force above a fixed level operated on it. However, in the sea engagement [off] Surabaya, the fuze was actuated at a very low level. How could that happen?

[When] the fuzes of the remaining torpedoes of the sea engagement were put on the testing instrument in the presence of the persons concerned, about half of the fuzes actuated on a small force that deviated from the standard setting. No wonder that they had exploded on the impact of waves at the moment they ran out of the safety distance. We investigated in detail the causes why the fuzes were adjusted to such a substandard level. In the end, it turned out that, displaying the Japanese spirit of loyalty and patriotism, those in charge of adjusting the fuzes had set them to a somewhat lower level for fear that it would be a serious problem if the fuzes should not actuate when the torpedoes hit enemy vessels. That is why, after running five hundred or a thousand meters and getting out of the safety distance, the torpedoes self-destructed under the impact of the waves. At that time, torpedoes were also adjusted both at the naval arsenals and military supplies departments. However, none [of those adjusted there] self-destructed.

The main cause for the self-destruction turned out to be the devotional zeal of the Imperial Japanese Navy personnel. I am not sure even now whether I should deplore or be impressed [by their devotion].

Also R. Adm. of Engineering Ōyagi Shizuo, an authority on Type93 torpedoes remarked in his recollections: "It was a matter of eternal regret that we had provided each vessel with a sensitivity adjuster for the fuzes."

The "Excerpts of lessons learned in the Greater East Asia War and observations by the Yokosuka Gunnery School," prepared on 24 August 1944, has the following to say on shelling distances and the firing on targets taking evasive actions:

\section{Shelling distances}

1. Example engagement

In the engagement off Surabaya (27 February - 1 March, 1942), our large cruisers, although at one moment having closed to about fifteen kilometers on the enemy, on the whole continued the artillery duel from a considerable distance of twenty to twenty-five kilometers, during which, due to the evasive actions of the enemy, they used up most of their ordnance, and that without achieving satisfactory military gains.

2. Observations by the Yokosuka Gunnery School

(1) To open fire from as long a range as possible, at which results may [still] be expected, promptly deliver a preemptive strike on the enemy, and at a favorable opportunity close in on him to within decisive-battle range and destroy him at a stroke is what gunnery textbooks teach. However, once an artillery duel has begun, it is difficult [to continue] the artillery duel at close range. This tendency is all the stronger when the enemy guns are powerful. [Therefore,] you need to "go one step closer" and open fire at a closer range, where it is possible to demonstrate considerably bigger firing results. (The weakness commonly seen in combat psychology is to overestimate the power of the enemy and to take your own damage too seriously, which may be regarded as one of the factors that makes closing in on the enemy difficult.)

(2) You need to see to it that that you do not continue a long-range artillery duel for [too] long without confirming the results or unconsciously let it go on while admitting that the results are unsatisfactory, as if you have forgotten your real ability for a fierce attack at short range. 
(3) There are indications that make us think that maybe [the participating units] overindulged in long-range shelling from a force of habit acquired in normal drills, where skills are honed through firing drills for the initial stages of an engagement, the most difficult stage of all engagement stages. However, the main point of engagements lies in the destruction of the enemy, and the essential and most important condition for this is to fiercely attack him by closing in on him at short range for a decisive battle, while longrange shelling is [nothing more than] a means of preemptive attacks. It would be the best if both [methods] are combined, however, when implementing them, you rather need to attach more importance to the former.

In other words, since short-range shelling is extremely difficult [to implement] in actual battle, you need to have enough grit to endure some sacrifices to win the battle, while courageously deciding and determinedly implementing [short-range shelling].

(4) [The following] needs to be avoided: to continue distant shelling while being distracted by enemy shellfire; to totally forget your effective shelling range, due to being too cautious about enemy shellfire made more effective by radar; or to miss an opportunity to fiercely attack him from close range by not fully understanding your own skills.

(5) Since a fierce attack from close range is the main characteristic of decisive battles, you need to clearly grasp the distances at which to conduct a decisive battle.

(6) Although the main points of conducting a fierce attack from close range may differ depending on the circumstances, they are generally considered to be the following:

$\{1\}$ When confronting an enemy with great fire power, make your silhouette as small as possible, so as to reduce the accuracy of his shelling, and conduct a fierce attack by rapidly approaching him at close range, bringing rapid fire into play and reducing the difference in fire power between him and us (particularly the difference in power per shell).

\{2\} When our fire power is superior [to that of the enemy], we shall destroy him while keeping him at a distance, so as not to allow him access into the midst of our units.

(7) The firing distance shall be decided by keeping in mind the mission, the purpose of the shelling, the power and the skills of the enemy and us, the power of the guns, the armor, the meteorological and terrestrial circumstances, the length of time available for the engagement, the current amount of ammunition, etc. However, assuming [our] present skills, the power of our guns and our armor, etc., the following is usually considered an appropriate standard under the present conditions.

Note by the author: Since the tables included cases of shelling using radar, ${ }^{*}$ [only] the tables of the cases where radar was not used or the accuracy of the radar was bad were selected, with the following results:

\footnotetext{
* Although we use the term "radar," it should be kept in mind that the Japanese naval equivalent den[pa] tan[shingi] (electronic wave search device) was a far more primitive system than the American radar systems. In fact, during the war the Japanese never developed a fully functional and effective air-search, surface-search, or fire-control radar. See David C. Evans and Mark R. Peattie, Kaigun; Strategy, Tactics, and Technology in the Imperial Japanese Navy 1887-1941. Annapolis, Naval Institute Press 1997, pp. 411-15.
} 
The (desirable close) range at the time of decisive battles

(1) Daytime

\begin{tabular}{|c|c|c|c|}
\hline Type of Vessel & Target & Range & Remarks \\
\hline Battleship & Battleship & 20,000 & Vessels with 36-cm guns were also taken into account. \\
\hline Cruiser & Cruiser & 12,000 & \\
\hline Destroyer & Destroyer & 5,000 & \\
\hline
\end{tabular}

(2) Nighttime ([or] at times of low visibility)

\begin{tabular}{|c|c|c|c|}
\hline Type of Vessel & Target & Range & Remarks \\
\hline Battleship & Battleship & 15,000 & \\
\hline Cruiser & Cruiser & 10,000 & \\
\hline Destroyer & Destroyer & 4,000 & \\
\hline
\end{tabular}

II. Firing at targets taking evasive actions

1. Example engagement

In the engagement off Surabaya, our cruiser division carried out shelling from about twenty kilometers, which allowed the enemy to take evasive actions (while also using smoke screens). Although the division fired a large number of shells (using up most of the ordnance on board), it did not attain remarkable military gains.

In other past engagements, the enemy with few exceptions [always] seemed to take evasive actions, in which, even if he consisted of a single vessel or vessels in formation, he drastically changed course in various ways, and sometimes even abruptly changed speed. Also, in general, he often used smoke screens while taking evasive actions.

When he thought that we might use torpedoes, he sometimes took large evasive actions and even reversed course in order to evade our torpedoes as well.

The delay in noticing the enemy's evasive actions or the failure to communicate [the enemy movements] to the [fire control] command station sometimes led to a lack of appropriate measures.

2. Observations by the Yokosuka Gunnery School

(1) The first principle in firing at a target taking evasive actions is to shorten the firing distance. Although the closing-in distance should differ according to the type and movements of the enemy vessels, visibility, etc.,

$\{1\}$ the distance needs in general to satisfy the following conditions:

a. It should enable us to notice the enemy's course changes without delay and make it relatively easy to determine the enemy's [future] course.

b. It should enable our adjusted fire to score hits before the enemy's change of course takes effect.

$\{2\}$ In view of the above, the desirable close-in ranges in the following table shall generally be considered appropriate: 


\begin{tabular}{|c|c|c|}
\hline Firing Vessel & Target Vessel & Firing Range \\
\hline \multirow{2}{*}{ Large cruiser } & Large cruiser & Within $12 \mathrm{~km}$ \\
\cline { 2 - 3 } & Destroyer & Within $7 \mathrm{~km}$ \\
\hline Destroyer & Destroyer & Within $7 \mathrm{~km}$ \\
\hline
\end{tabular}

(2) In order to reduce the effects of the enemy's evasive actions or contain his evasive actions, it is advantageous to concentrate fire or simultaneously fire from different directions and, if possible, to conduct a pincer attack.

(3) Whereas there are no particularly [difficult] points when firing at short range, when it comes to shelling from farther distances, the firing method to be taken can be variously thought of in the following ways making the lateral control of the fire very difficult:

\{1\} Shortening the intervals of salvos. In order to implement this, alternate firing [the firing of the guns of a multiple gun turret in turn] is generally considered advantageous. However, in the case of vessels equipped with a [small] number of guns, where the number of shells to be fired in an alternate-firing salvo very much decreases, salvos of all guns together are rather more advantageous. (In general, salvos using all guns together are more advantageous for vessels, which carry six or less guns).

\{2\} Applying the measurement-based fire control method, where the data of plotted ranges on the fire control table* are used [to decide the line of fire].

\{3\} Applying the dispersion fire method.

\{4\} Applying the [farthest/ closest] limit fire method when the enemy is expected to take large evasive actions.

\{5\} Applying the range-rate-based fire control method using the firing calculator against slow evasive actions of the enemy.

Based upon this method, you should try to shorten the time between noticing the course changes of the enemy and measuring his position and control your fire in such a way so as to obstruct the enemy's evasive actions, when his plan of evasive actions (particularly such plans as changing course to a farther side at the sight of our overshot shells, expecting our fire control correction [to a nearer side]) is detected (or anticipated). (Study and drills are necessary regarding the decision on the enemy's [new] course, the estimation of the angle of change of his course, which do depend on the delay in detecting the enemy's course change and the time spent [for the detection], as well as regarding the share of responsibility for the adjustments and adjustment methods between the ship's commander and the chief of the fire control command station.)

In short, it is not easy to apply each item of the above; there is no better way at present than to conduct intense drills on each vessel according to her armaments and facilities.

(4) Since long-range gunfire not only produces poor results but also raises concerns about wasting ammunition, you need to pay particular attention to confirming the fire results and keeping your gunfire under control.

\footnotetext{
* For a discussion of Japanese fire control systems and their problems, see David C. Evans and Mark R. Peattie, Kaigun; Strategy, Tactics, and Technology in the Imperial Japanese Navy 1887-1941. Annapolis, Naval Institute Press 1997, pp. 250-53.
} 


\section{The Engagements of the $2 \mathrm{~d}$ Air Unit}

\section{The Engagements of the $2 d$ Air Unit}

On the early morning of 27 February, the 2d Air Unit dropped anchor off Cape [Tanjung] Puting, and carried out operations. ${ }^{(79)}$ On that day, an enemy fleet was spotted off Surabaya, which made the convoy evacuate westward along with one element of the escort unit. Although part of the aircraft unit of the Chitose and the Mizuho seemed to have participated in the engagements, the details are unclear. According to a journal kept by Yamada Shigeru, the weather was so bad that day that they only flew a very few flights. ${ }^{[106]}$ At night, the $2 \mathrm{~d}$ Air Unit left the area off Cape [Tanjung] Puting for Bawean Island.

On the 28th, the $2 \mathrm{~d}$ Air Unit dropped anchor [off] the west coast of Bawean Island and provided guard [for] the transport convoy [against] the remnant [enemy] vessels [which had survived] the engagement off Surabaya. However, other than having spotted three 2,000tclass auxiliary gunboats and eight torpedo boat-like ships (sailing southward in the Surabaya Strait), and a few submarine chasers at several nautical miles offshore at the north entrance of the strait, they did not see any enemy vessels. ${ }^{(53)}$

On 1 March, the $2 \mathrm{~d}$ Air Unit operated in the same way as the previous day near the west coast of Bawean Island. Since at 0945 the staff of the 1st Escort Unit reported the following movements of enemy aircraft, 2d Air Unit Commander R. Adm. Fujita Ruitarō decided to directly guard for the time being the echelon in the air [against enemy aircraft] with aircraft that was supposed to be employed for supporting the land combat. ${ }^{(56)}$

1. Last night, there were persistent attacks by enemy light bombers throughout the night. After the moon set, they continued their attacks, dropping large flares. Although the exact number of aircraft was unclear, ten or more aircraft [were spotted].

2. This morning, at 0736 , ten four-engine bombers came for a raid, along with more than a dozen fighter planes (P-40s), which had come at 1735 . The fighter planes repeatedly strafed the convoy and the landing craft from a low altitude for twenty minutes. Both the bombers and the fighter planes evacuated bearing $240^{\circ}$ [SW].

3. Yesterday at dusk, just before entering into the anchorage, we were persistently probed by threeengine enemy flying boat[s].

4. Nine observation seaplanes as well as two Type-0 fighter planes arrived in the air [over the convoy] at 0815 (right after the enemy fighter planes evacuated).

The Type-0 observation seaplanes on guard in the air above the convoy reported having shot down three Northrop light bombers, while those in support of the land combat reported having blown up six enemy tanks on the road near Kragan, and [also] supported [the ground units] by a bombing attack on an enemy position. ${ }^{(71)}$ On that day, eleven Type-0 observation seaplanes took off at 1240 for an attack on the enemy cruiser and destroyer, but could not spot them due to a squall. It was [well] after the enemy vessels had been sunk when they spotted the friendly unit. ${ }^{(56)}$ Since it turned out that the coast near Kragan was shallow for a good distance from the shore and not fit for a [seaplane] base, it was decided that [the air unit] should continue the air campaign [with its base] near Bawean Island until a better base was found. ${ }^{(56)}$ 


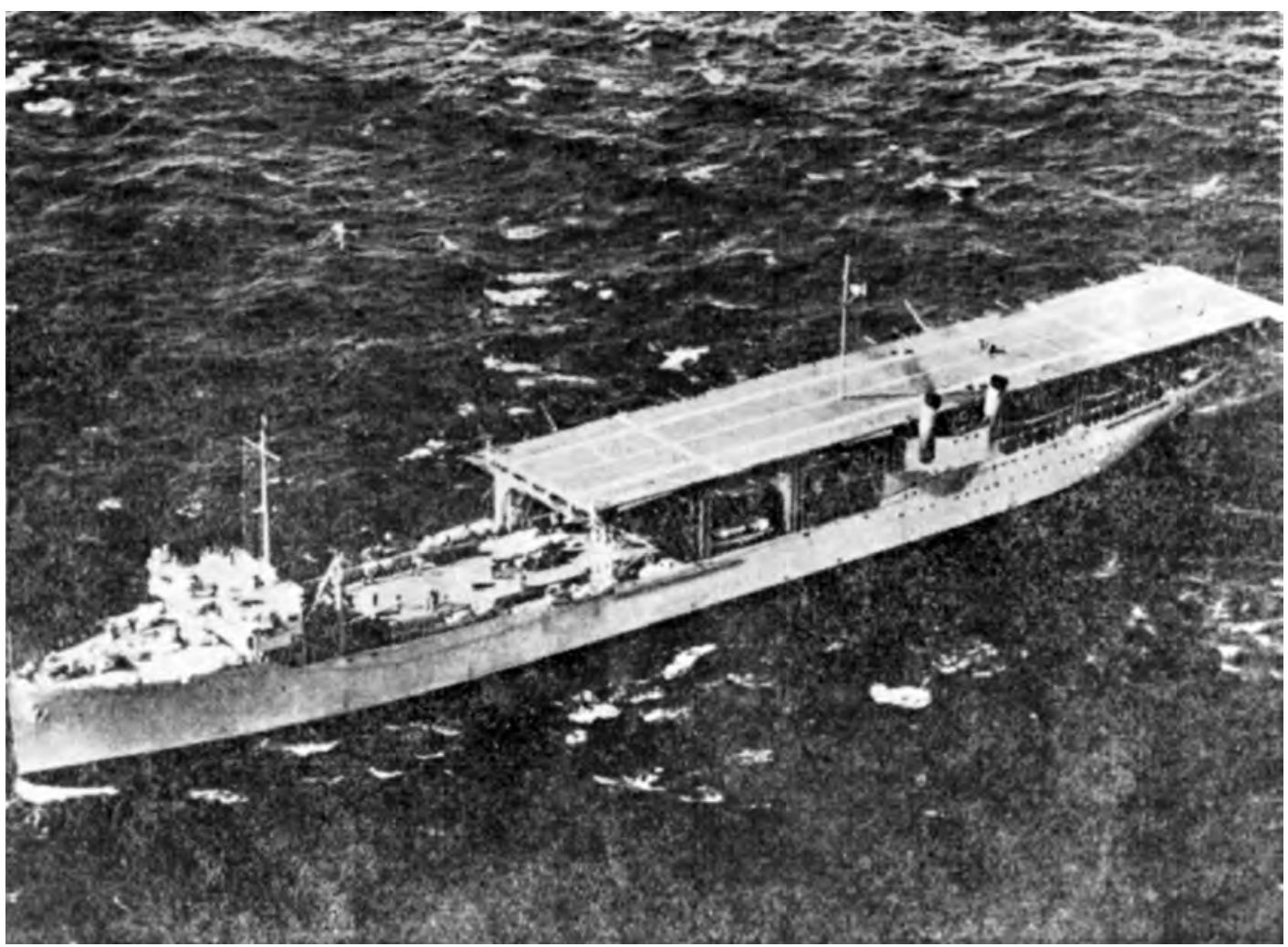

The U.S. Tender USS Langley

\section{The Land-Based Air Unit Sinks the Tender USS Langley}

On the 27th, the 1st Air Raid Unit was not able to conduct an attack on the enemy fleet due to bad weather, and on the 28th, no attack was conducted either, other than a search mission by flying boat[s]. On 1 March, twenty-seven land-based attack planes of the Kanoya Air Group Detachment carried out a bombing attack on naval vessels in the port of Surabaya and reported having inflicted damage to two destroyers, two submarines, two special service vessels and one merchantman. However, due to the accurate and fierce antiaircraft fire, fourteen were marked by bullets (of which two made an emergency landing on Bali). ${ }^{\left({ }^{(1)}\right.}$

Meanwhile, at 0950 on the 27 th, the $2 \mathrm{~d}$ Air Raid Unit spotted the U.S. Tender USS Langley (at 368 nautical miles $265^{\circ}$ [W] of the Bali base sailing on a $230^{\circ}$ [SW] course at ten knots), and at 1340 sank her with sixteen land-based attack planes of the Takao Air Group stationed at Bali. ${ }^{(71)}$ According to a U.S. book They Fought with What They Had by Walter D. Edmonds [pp. 315-16], the tender carried thirty-two P-40s on her deck. Lt. Adachi Jirō, who led the attack unit, recalled the attack as follows:

The fighter plane unit took off first guided by a land-based reconnaissance plane and advanced without directly covering the attack unit. I made the sortie as the commander of the attack unit and spotted the enemy fleet sailing northward. The enemy sailed with two destroyers in a line abreast with the tender USS Langley in the rear, following the former. When our attack unit ap- 
peared above the enemy fleet, it split and started an evasive action. The bombs delivered by the 1st Kusuhata Squadron (led by Lt. Kusuhata Yoshinobu) did not score a hit; I aborted my bombing run twice, carried out the bombing on the third try, and scored a hit at the fore part of the flight deck. Our bombs straddled the tender, and three $250-\mathrm{kg}$ bombs and three $60-\mathrm{kg}$ bombs hit her. Since they were land bombs with instantaneous fuses, they caused large fires upon hitting her, setting the aircraft and the fuel bunker ablaze. When we entered the bombing run for the third time, we came under defensive fire from the destroyers, but it was nothing serious. The [enemy] escort destroyers transmitted in plain that the USS Langley was coming under a bomb attack by enemy aircraft.

We circled the scene once, but considering that enemy fighter planes might come for support from the Cilacap area, we left at a proper moment to return [to base].

Although [our] fighter plane unit had left the base earlier, they had not spotted the enemy [tender], but while returning to base, they [finally] spotted the tender in flames and strafed her. After returning to base, I reported that we believed that we had sunk the USS Langley. However, staff officers Yasunobu Takeo and Nomura Ryōsuke judged that we had only inflicted damage on her, but had not sunk her. That time, I wished we could have carried our regular bombs with us but I remember that we only had land bombs.

Note by the author: According to The Rising Sun in the Pacific by [Samuel] Morison [p. 363], the ship had been crippled by too many fires and leaks, so the destroyer escort "scuttled the old tender with torpedo and shellfire."

The land-based attack planes, which left the Banjarmasin base on 27 February, also spotted the enemy fleet off Surabaya [p. 432], but they were not able to attack it; the Takao Air Group because of [its assignment to] attack the tender [USS Langley], and the Kanoya Air Group Detachment because of bad weather. ${ }^{(71)}$ On that day, a total of fourteen Type-0 fighter planes of the Tainan Air Group from Banjarmasin provided the transport ships with direct escort in the air [against enemy aircraft]. Two aircraft of the third shift reported having driven away two B-17s and shot down one flying boat. [However,] all three Type-0 fighter planes of the sixth shift, which took off at 1430, went missing due to bad weather. [Meanwhile], the Type0 fighter planes of the Tainan Air Group stationed in Bali were engaged in patrolling in the air over the Bali base while providing cover for the land-based attack planes conducting the attack on the USS Langley, and reported having strafed the tender with machineguns, set five or more mid-sized aircraft ablaze, inflicted damage to five or more aircraft and shot down one four-engine flying boat and one two-engine flying boat. One of the Japanese aircraft got hit and went missing. ${ }^{(71)}$ The Type-0 fighter planes of the $3 \mathrm{~d}$ Air Group also stationed in Bali were [also] assigned to the cover of the land-based attack planes conducting the attack on the tender as well as to cover the land-based attack planes conducting an attack on Surabaya (the latter was called off due to bad weather). While the Type-0 fighter planes in charge of [covering] the Surabaya attack [unit] did not spot the enemy, those in charge of covering the attack on the tender reported having strafed three aircraft on the deck of the tender and set them ablaze, and shot down two flying boats (one of which was unconfirmed).

On 28 February, the 2d Air Raid Unit carried out an attack on the airfield[s] near Surabaya as well as an attack on Christmas Island, while providing the convoy with direct escort in the air [against enemy aircraft] and reported having shot down one four-engine flying boat and two Buffalo fighter planes. ${ }^{(71)}$

On 1 March, the 2d Air Raid Unit [again] directly guarded the convoy and [the base on] Bali in the air [against enemy aircraft], while carrying out a search mission in the Indian 
Ocean, as well as attacking the airfield[s] near Surabaya. Reporting military gains of having set two large aircraft ablaze and inflicting damage on two large aircraft, fourteen $\mathrm{P}-40 \mathrm{~s}$ and eight Buffalo fighter planes, they all returned [to base]. ${ }^{(71)}$

\section{The Engagements of the 4th Carrier Division}

On the morning of 1 March, the 4th Carrier Division reached a point north of the Karimata Strait. On receiving the previously-mentioned report [pp. 444-45] that one enemy cruiser and one destroyer had been spotted near Bawean Island, the division launched six carrier-based attack planes at 1300. The attack [plane] unit reached the site at 1505; since the [enemy] cruiser had already been sunk by the 5th Cruiser Division, the unit carried out a bombing attack ([with] six 250-kg bombs and twenty-four 60-kg bombs) on the destroyer [USS Pope], which was trying to escape, and crippled her. (As has already been told [p. 445], the destroyer was sunk by the main unit of the Dutch East Indies Unit that pursued her.)

Meanwhile, [another] six carrier-based attack planes bombed a 10,000t-class cargo ship in the port of Semarang at 1640; the ship ran aground and caught fire, after which all planes returned to the carrier. ${ }^{(71)}$

\section{The Situation of the Allied Forces}

According to The Rising Sun in the Pacific by [Samuel] Morison, the following unit had made a sortie to attack the Japanese invasion unit: ${ }^{(92)}$

Commander: Rear Admiral Doorman of the Dutch Navy (flagship HNLMS De Ruyter)

Forces: The Dutch light cruiser HNLMS De Ruyter, the British heavy cruiser HMS Exeter, the U.S. heavy cruiser USS Houston, the Australian light cruiser HMAS Perth, the Dutch light cruiser HNLMS Java, the U.S. destroyers USS John D. Ford, USS Paul Jones, USS [John D.] Edwards, USS Alden, the British destroyers HMS Electra, HMS Encounter, HMS Jupiter, the Dutch destroyers HNLMS Witte de With, and HNLMS Kortenaer, totaling two heavy cruisers, three light cruisers, and nine destroyers

From the Japanese record and The Rising Sun in the Pacific by Morison we may infer the following state of affairs on the allied side:

1. [The allied unit which] in the beginning engaged with the $2 \mathrm{~d}$ Destroyer Squadron was the British destroyer unit.

2. In the initial artillery duel, HNLMS De Ruyter was hit by a dud shell.

3. None of the torpedoes in the first torpedo attack by the 4th Destroyer Squadron hit the enemy.

4. At 1838, a shell hit the engine room of HMS Exeter, which caused confusion in the formation [of the allies]. (The shell is presumed to have been fired by the Haguro.)

5. At 1845, in the middle of the confusion, the Dutch destroyer HNLMS Kortenaer was hit by a torpedo and instantly sank. (The torpedo is presumed to have been fired by the Haguro.)

6. The speed of HMS Exeter dropped to fifteen knots, and she pulled back into the smoke screen spread by the Australian cruiser HMAS Perth, covered by the British destroyers.

7. It were the British destroyers HMS Encounter and HMS Electra who exchanged fire at short range with the Asagumo and the Minegumo. Both vessels had reversed course and carried out the attack in order to cover HMS Exeter, however, HMS Electra was sunk by the 9th Destroyer Division. It was HMS Electra who delivered a direct hit on the Asagumo. 
8. After the daytime engagement, HMS Exeter* and HNLMS Witte de With retreated to Surabaya.

9. It were the four cruisers, HNLMS De Ruyter, USS Houston, HMAS Perth and HNLMS Java, and the British destroyers HMS Jupiter and HMS Encounter, who had reversed course and around 2100 attacked the 5th Cruiser Division, which was retrieving its aircraft.

10. After the first phase of the night engagement, the four U.S. destroyers headed for Surabaya for replenishment.

11. While the remaining forces were sailing eastward ${ }^{* *}$ near the coast, the British destroyer HMS Jupiter hit at 2255 a mine laid by the Dutch and sank.

12. The remaining forces started sailing northward from 2300. At 2347, they passed the spot where HNLMS Kortenaer had sunk and took her crew onto HMS Encounter, who [then] headed for Surabaya.

13. Only four ships, [i.e.] HNLMS De Ruyter, HMAS Perth, USS Houston and HNLMS Java participated in the second phase of the night engagement against the 5th Cruiser Division.

14. HNLMS De Ruyter and HNLMS Java were hit by torpedoes of the 5th Cruiser Division and sank. Right after that, USS Houston and HMAS Perth changed course southwestward and escaped to Batavia. They successfully avoided being spotted [by the Japanese forces] since the latter searched for them in an area east [of the battle site]. (Both vessels went down after having exchanged fire with a Japanese fleet off Batavia on the early morning of the 1st, as will be described later.)

15. Around 0000 of 1 March, the British cruiser HMS Exeter left Surabaya accompanied by the British destroyer HMS Encounter and the U.S. destroyer USS Pope. They tried to head for Cilacap by sailing east of Bawean Island, then turning westward to sail by way of Batavia and [through] the Sunda Strait. However, they were caught by the main unit of the Dutch East Indies Unit and sunk.

16. In the end, among the allied forces that had participated in the sea engagement off Surabaya, only four U.S. destroyers managed to escape. They passed through the Bali Strait on the early morning of 1 March and successfully escaped after breaking through the guard of the 21st Destroyer Division and the Tsukushi, who were on guard off Bali Island.

The characteristics of the enemy naval vessels were as shown in the following table. ${ }^{(154)}$

\begin{tabular}{|c|c|c|c|c|c|}
\hline \multirow[b]{2}{*}{ Name of Vessel } & \multirow[b]{2}{*}{ Tonnage } & \multirow[b]{2}{*}{ Speed } & \multicolumn{2}{|c|}{ Installed Guns } & \multirow[b]{2}{*}{$\begin{array}{l}\text { Number of Torpedo } \\
\text { [Launchers] }\end{array}$} \\
\hline & & & Main Guns & $\begin{array}{l}\text { Antiaircraft } \\
\text { Guns }\end{array}$ & \\
\hline $\begin{array}{l}\text { HNLMS De Ruyter } \\
\text { (Dutch light cruiser) }\end{array}$ & 6,450 & 32.0 & $7 \times 15-\mathrm{cm}$ & & $\mathrm{N} / \mathrm{A}$ \\
\hline $\begin{array}{l}\text { HMS Exeter } \\
\text { (British heavy cruiser) }\end{array}$ & 8,390 & 32.0 & $6 \times 20-\mathrm{cm}$ & $3 \times 10-\mathrm{cm}$ & $6 \times 53-\mathrm{cm}$ \\
\hline $\begin{array}{l}\text { USS Houston } \\
\text { (U.S. heavy cruiser) }\end{array}$ & 9,050 & 32.7 & $9 \times 20-\mathrm{cm}$ & $8 \times 12.7-\mathrm{cm}$ & $\mathrm{N} / \mathrm{A}$ \\
\hline $\begin{array}{l}\text { HMAS Perth } \\
\text { (Australian light cruiser) }\end{array}$ & 6,980 & 32.5 & $8 \times 15-\mathrm{cm}$ & $8 \times 7-\mathrm{cm}$ & $4 \times 53-\mathrm{cm}$ \\
\hline $\begin{array}{l}\text { HNLMS Java } \\
\text { (Dutch light cruiser) }\end{array}$ & 6,670 & 31.0 & $7 \times 15-\mathrm{cm}$ & & $\mathrm{N} / \mathrm{A}$ \\
\hline
\end{tabular}

* The text mistakenly includes HMS Encounter.

** Actually westward, see also Morison p. 350, 355. 


\begin{tabular}{|c|c|c|c|c|c|}
\hline $\begin{array}{l}\text { USS John D. Ford } \\
\text { USS Paul Jones } \\
\text { USS [John D.] Edwards } \\
\text { USS Alden } \\
\text { USS Pope } \\
\text { (U.S.) }\end{array}$ & 1,190 & 35.0 & $4 \times 10-\mathrm{cm}$ & $\begin{array}{l}\text { A few 20-mm } \\
\text { machineguns }\end{array}$ & $6 \times 53-\mathrm{cm}$ \\
\hline $\begin{array}{l}\text { HMS Electra } \\
\text { (British) }\end{array}$ & 1,375 & 36.0 & $4 \times 12-\mathrm{cm}$ & $1 \times 10-\mathrm{cm}$ & $4 \times 53-\mathrm{cm}$ \\
\hline $\begin{array}{l}\text { HMS Encounter } \\
\text { (British) }\end{array}$ & 1,375 & 36.0 & $4 \times 12-\mathrm{cm}$ & $1 \times 10-\mathrm{cm}$ & $4 \times 53-\mathrm{cm}$ \\
\hline $\begin{array}{l}\text { HMS Jupiter } \\
\text { (British) }\end{array}$ & 1,690 & 36.0 & $6 \times 12-\mathrm{cm}$ & $1 \times 10-\mathrm{cm}$ & $5 \times 53-\mathrm{cm}$ \\
\hline $\begin{array}{l}\text { HNLMS Witte de With } \\
\text { (Dutch) }\end{array}$ & 1,650 & 36.0 & $4 \times 12-\mathrm{cm}$ & $1 \times 8-\mathrm{cm}$ & $6 \times 53-\mathrm{cm}$ \\
\hline $\begin{array}{l}\text { HNLMS Kortenaer } \\
\text { (Dutch) }\end{array}$ & 1,640 & 36.0 & $4 \times 12-\mathrm{cm}$ & $2 \times 8-\mathrm{cm}$ & $6 \times 53-\mathrm{cm}$ \\
\hline
\end{tabular}

Note: Due to engine trouble, the U.S. destroyer USS Pope did not participate in the sea engagement off Surabaya. ${ }^{(176)}$

Reference: A comparison of the guns and torpedo [launchers] employed by both sides in the sea engagement off Surabaya

\begin{tabular}{|c|c|c|c|c|}
\hline \multirow{2}{*}{ Size of Guns (or Torpedoes) } & \multicolumn{4}{|c|}{ Total Numbers } \\
\hline & \multicolumn{2}{|c|}{ Japanese Side } & \multicolumn{2}{|c|}{ Allied Side } \\
\hline 20-cm Guns & \multicolumn{2}{|c|}{20} & \multicolumn{2}{|c|}{12} \\
\hline 14-15-cm Guns & \multicolumn{2}{|c|}{$14 \times 14-\mathrm{cm}$} & \multicolumn{2}{|c|}{$22 \times 15-\mathrm{cm}$} \\
\hline 12.7-cm Guns & 78 & \multirow{3}{*}{90} & 8 & \multirow{3}{*}{61} \\
\hline 12-cm Guns & 12 & & 22 & \\
\hline 10-cm Guns & 0 & & $31^{*}$ & \\
\hline 8-cm Guns & \multicolumn{2}{|c|}{4} & \multicolumn{2}{|c|}{4} \\
\hline Torpedo launchers & \multicolumn{2}{|c|}{$160 \times 61-\mathrm{cm}$} & \multicolumn{2}{|c|}{$79 \times 53-\mathrm{cm}$} \\
\hline
\end{tabular}

Note: Since the USS Houston had sustained damage at her after turret by a Japanese air attack some time ago [4 February], the number of her $20-\mathrm{cm}$ guns was calculated as six. As seen in this table, the offensive power of the Japanese side was overwhelmingly superior [to that of the allies].

\footnotetext{
* If based on the table on pp. 462-63, the number of allied 10-cm guns (excluding the USS Pope) would be 22, not 31 . The author probably misread the Japanese numbers in the original manuscript.
} 


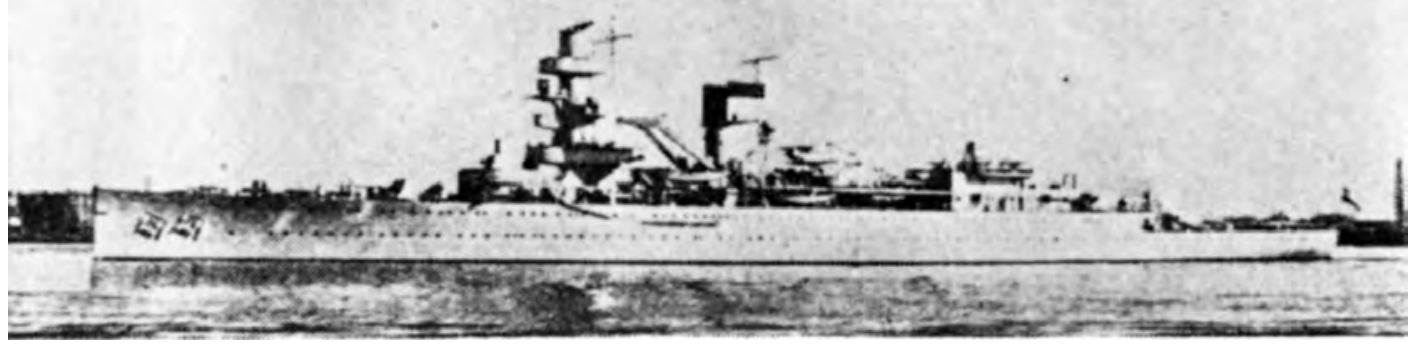

The Dutch Light Cruiser HNLMS De Ruyter

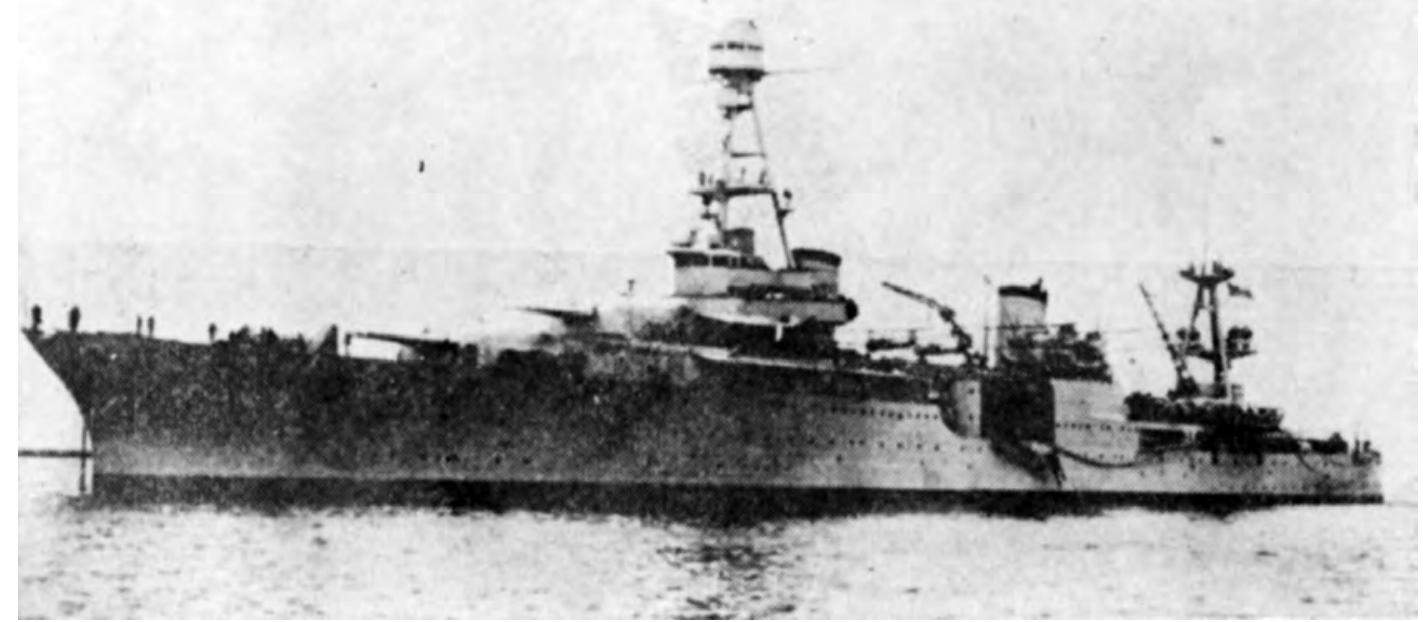

The U.S. Heavy Cruiser USS Houston

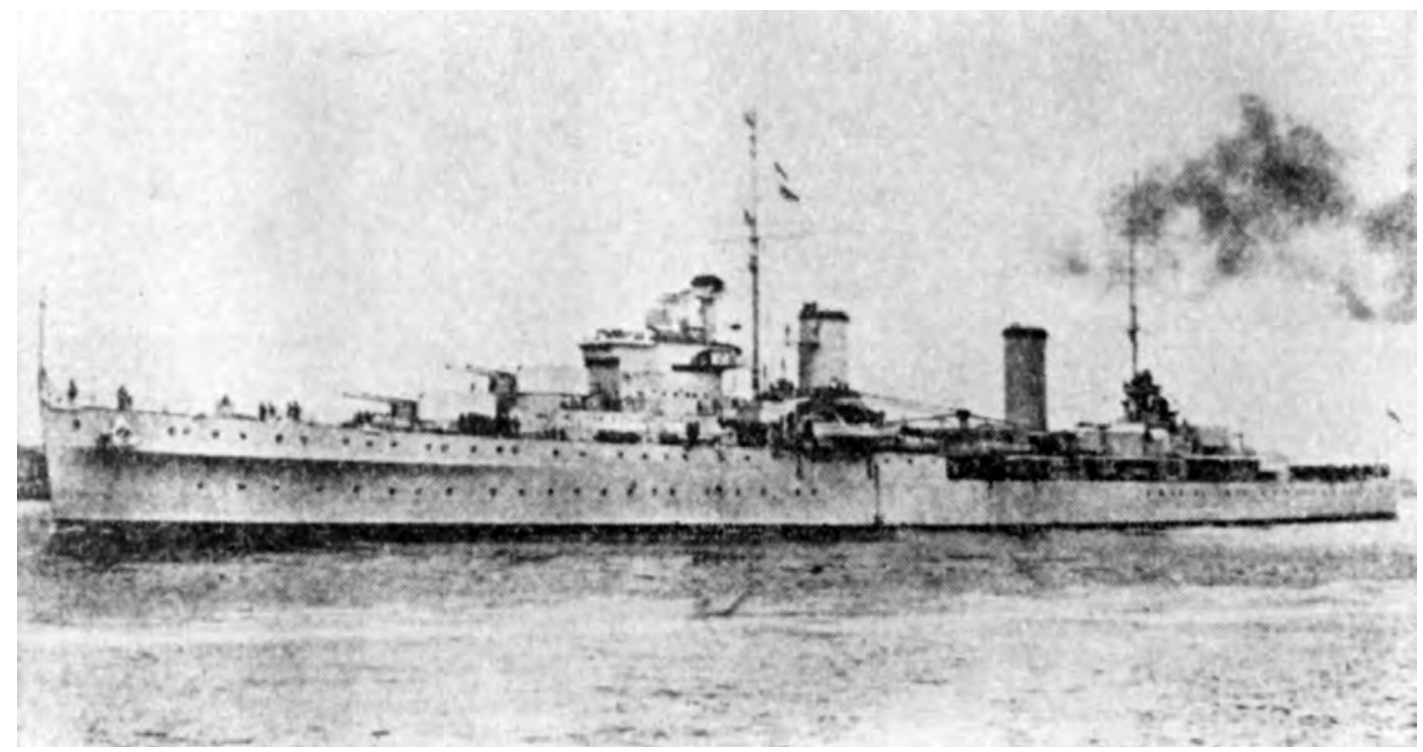

The Australian Light Cruiser HMAS Perth 


\section{The Sea Engagement off Batavia (28 February - 1 March)}

\section{(See Attached Illustration No. 7)}

At 2350 on 28 February, 3d Escort Unit commander (5th Destroyer Squadron Commander Rear Admiral Hara) gave the order [to shift to] the second disposition of forces (the disposition after the transport ships' entry into the anchorage). On this order, each unit started for its patrol area, keeping a strict guard. The $2 \mathrm{~d}$ Section of the 7 th Cruiser Division headed for an area about twenty nautical miles $10^{\circ}[\mathrm{N}]$ of St. Nicholas Point [Tanjung Pujut]. Both the Merak and Bantam Bay [sections of] the transport convoy completed entering into their anchorages at 0000 on 1 March without problems. The main forces ${ }^{(150)}$ of the Japanese Navy near the convoy's anchorages at that time as well as their characteristics ${ }^{(151)}$ were as follows:

1. Bantam Bay

7th Cruiser Division 2d Section (support unit)

The Mikuma, the Mogami and the Shikinami

5th Destroyer Squadron

The Natori

5th Destroyer Division (the Asakaze, the Harukaze and the Hatakaze)

11th Destroyer Division (the Hatsuyuki, the Shirayuki and the Fubuki)

Two heavy cruisers, one light cruiser and seven destroyers in total

2. The Merak area

22d Destroyer Division (the Satsuki, the Minazuki, the Nagatsuki and the Fumizuki)

12th Destroyer Division (the Shirakumo and the Murakumo)

Six destroyers in total

3. Characteristics (as shown in the following table)

\begin{tabular}{|l|c|c|c|c|c|}
\hline \multirow{2}{*}{ Ship Class } & Tonnage & Speed & Main Guns & $\begin{array}{c}\text { Antiaircraft } \\
\text { Guns }\end{array}$ & $\begin{array}{c}\text { Installed Guns } \\
\text { [Launchers] }\end{array}$ \\
\cline { 4 - 6 } Mogami-class & 8,500 & 37.0 & $10 \times 20-\mathrm{cm}$ & $8 \times 12.7-\mathrm{cm}$ & $12 \times 61-\mathrm{cm}$ \\
\hline Natori-class & 5,170 & 36.0 & $7 \times 14-\mathrm{cm}$ & $2 \times 8-\mathrm{cm}$ & $61-\mathrm{cm}$ (Type8) \\
\hline Asakaze-class & 1,270 & 37.25 & $4 \times 12-\mathrm{cm}$ & & $6 \times 53-\mathrm{cm}$ \\
\hline $\begin{array}{l}\text { Fubuki-class } \\
\text { (Shirakumo-class) }\end{array}$ & 1,680 & 38.0 & $6 \times 12.7-\mathrm{cm}$ & & $9 \times 61-\mathrm{cm}$ \\
\hline
\end{tabular}

The First Phase of the Engagement ${ }^{(150)}$ (from 0009 until 0100)

At 0009, the 11th Destroyer Division's Fubuki, who was patrolling in the easternmost part of Bantam Bay, spotted black silhouettes at a distance of 10,000 meters, $85^{\circ}$ [E], and immediately reported to the 3d Escort Unit: "Spotted two silhouettes of naval vessels, which look like enemy vessels, to the northeast of Babi Island." Then after confirming that the black silhou- 


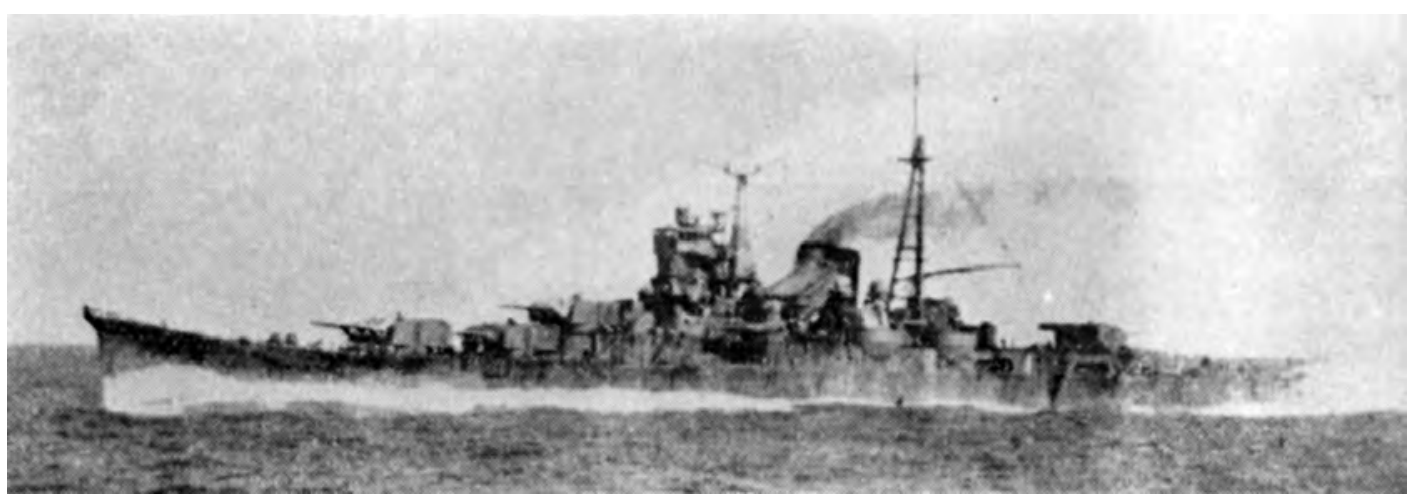

The Cruiser Mogami

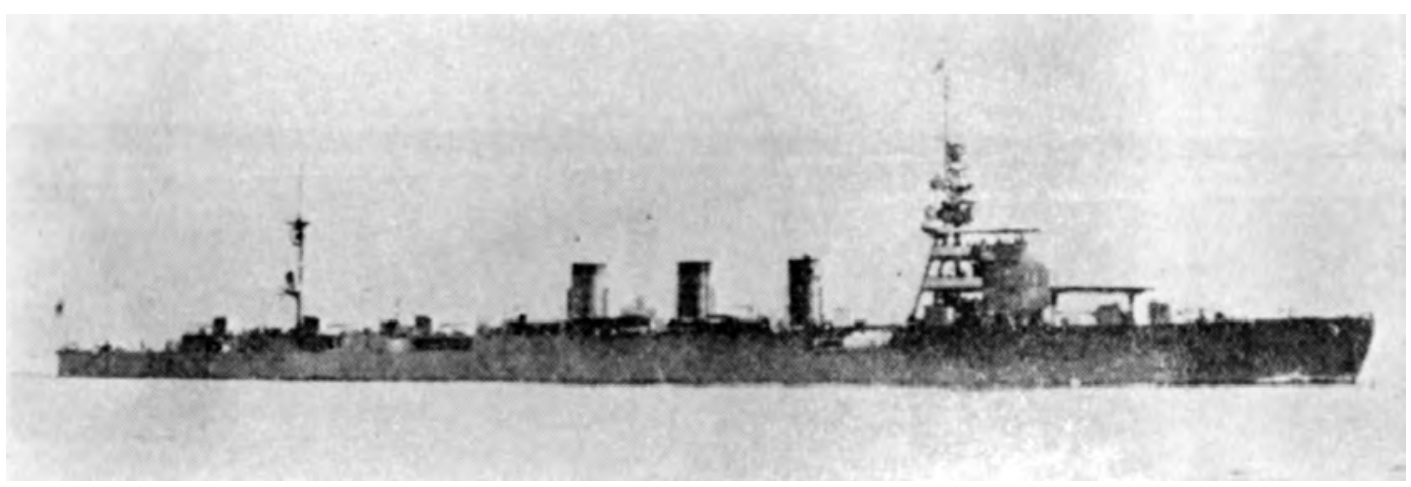

The Cruiser Natori

ettes were those of two [enemy] cruisers, she continued at 0013: "Spotted enemy cruisers. Our position is two nautical miles west of Cape Babi. The enemy is sailing on a $240^{\circ}$ [WSW] course." In the meantime, at 0018, the Natori and the 11th Destroyer Division (minus the Fubuki), which were patrolling in an area about eight nautical miles north of St. Nicholas Point [Tanjung Pujut], also spotted enemy-like silhouettes at a distance of about 20,000 meters, $115^{\circ}$ [ESE]. Then around 0030, the Fubuki, who had sailed around Babi Island hugging its coast to hide herself in the silhouette of the island, took up a position about 8,000 meters behind the enemy and kept reporting on the enemy movements. [Meanwhile] at 0029, the Harukaze of the 5th Destroyer Division, who was patrolling the area between Babi Island and Panjang Island around that time, also spotted the two enemy cruisers at a distance of 8,000 meters, $60^{\circ}$ [ENE] and reported it. [By] around that time, the Natori also reached the conclusion that the silhouettes presumed to be enemy [vessels] were [indeed] two enemy cruisers.

Based on the above enemy movements, 3d Escort Unit Commander Hara made up his mind that in order to secure the safety of the transport convoy, he needed to quickly gather the support forces, [i.e.] the $2 \mathrm{~d}$ Section (the Mikuma and the Mogami) of the 7th Cruiser Division, and the Shikinami to promptly defeat the enemy. At 0029, he ordered the Natori and the 11th Destroyer Division: "Prepare for torpedo warfare. The 11th Destroyer Division shall follow in the wake [of the Natori.]" [Then] at 0030, he ordered the 2d Section of the 7th Cruiser Division and the 5th Destroyer Division (the Harukaze, the Hatakaze and the Asakaze) to "assemble!" 
At that time, 3d Escort Unit Commander Hara had the following plan of action: "It is possible that the enemy will try to escape seeing our powerful [cruisers of the] 7th Cruiser Division, $2 \mathrm{~d}$ Section, appear. Then we may lose the opportunity to catch and destroy him. So, first of all, we will entice him into broader waters with the Natori and the destroyer divisions; in that way, we shall avoid waters where there is a risk of mines and also keep away from the anchorage. Once the enemy has got deeply involved in the engagement, we shall bring in the $2 \mathrm{~d}$ Section of the 7 th Cruiser Division and destroy him at a stroke. I consider this the best way. The Natori and the destroyer divisions shall operate as a destroyer squadron, while the $2 \mathrm{~d}$ Section of the 7th Cruiser Division shall act as the main unit; [both] shall close in on the enemy and carry out a joint attack, closely cooperating with each other. Tonight, under the [bright] moonlight of the almost full moon ([of] fourteenth lunar day) with a high visibility, we will be able to operate in the same way as we do in daytime."

At 0035, the Harukaze reported: "Spotted two enemy cruisers at $70^{\circ}$ [ENE], to the southeast of Babi Island." Since at 0037 the enemy opened fire on the Japanese transport convoy, the Harukaze immediately threw up a very effective smoke screen between the enemy and the transport convoy. Meanwhile, the Fubuki, who was reporting on the enemy movements by probing him from behind, took advantage of the enemy's right turn at 0043. At 0044, she launched (nine torpedoes) at the second enemy vessel sailing on a parallel course on her port beam from a short range of about 2,500 meters and [also] fired (sixteen shells) for about two minutes using her searchlights, after which she saw that her torpedo[es] had hit the enemy vessel and made the latter slow down. The first enemy vessel returned fire at the Fubuki using her searchlights, but inflicted no damage.

Having seen that the enemy had opened fire on the Japanese convoy, 3d Escort Unit Commander Hara at 0045, in order to immediately relieve the crisis, ordered the 11th and the 5th Destroyer Divisions: “Destroyer units, charge!" Along with this, at 0047, he [also] ordered the 12th Destroyer Division (the Shirakumo and the Murakumo), who were in an area near Thwartway Island [Dwars-in-den-Weg, Pulau Sangiang], to "Join!" In the meantime, the 2d Section of the 7th Cruiser Division and the Shikinami, which were preparing for the engagement on the 0010 radio-telephoned report that the enemy had been spotted, started sailing southward toward the enemy, following the 0030 order to assemble. Furthermore, after the Harukaze had thrown up her smoke screens, the 5th Destroyer Division was assembling at a point to the north of the convoy's anchorage. North of Panjang Island at 0052, in order to cover the convoy, the Hatakaze fired on the first vessel of the enemy at a range of 3,500 meters using her searchlights. Although she [also] came under fierce enemy fire, she sustained no damage. At 0056, 3d Escort Unit Commander Hara ordered the 5th Destroyer Division to charge. After having completed her shelling, the Hatakaze joined the Harukaze. They were then joined by the Asakaze as well, and at 0102 the 5th Destroyer Division completed assembling at about ten kilometers north of St. Nicholas Point [Tanjung Pujut].

\section{The Second Phase of the Engagement ${ }^{(150)}$ (from 0100 until 0116)}

The 11th Destroyer Division (minus the Fubuki), which on the order to charge was approaching the enemy, started its charge at 0056, bearing $135^{\circ}$ [SE]. At 0110, despite fierce enemy fire, it carried out a torpedo launch (nine per vessel) from a range of 3,500-3,800 meters while sailing on a parallel course at the second enemy vessel on starboard beam, after which [the 
destroyers] evacuated northward, throwing up smoke screens. After having assembled, the 5th Destroyer Division, too, promptly changed to the charge; it reached around 0110 a launching point while sailing on a parallel course with the enemy on starboard beam. However, fierce enemy fire hit the flagship Harukaze, causing trouble with her steering and forcing her to turn to port, thereby missing her opportunity to launch. The Hatakaze was also unable to launch due to the water columns caused by enemy near misses. Only the third vessel, the Asakaze, launched her torpedoes (six of them) at 0113 at the first enemy vessel on starboard beam from a range of 3,700 meters while sailing on a parallel course with the latter, after which the division was forced to evacuate northward.

In the meantime, the Natori had from 0100 onwards changed to the charge bearing $135^{\circ}$ [SE]; at 0113 she opened fire at the first enemy vessel using her searchlights and at 0114 launched four torpedoes at the latter on starboard beam while sailing on a parallel course. After that, she ordered the 3d Escort Unit, "Those who have finished their [torpedo] launch shall join the Natori," and evacuated northward, throwing up smoke screens. Meanwhile, at 0106, the 12th Destroyer Division, which was [also] rushing toward the site, visually confirmed the enemy at a range of about 13,000 meters, at $15^{\circ}$ on her right. The $2 \mathrm{~d}$ Section of the 7 th Cruiser Division and the Shikinami also spotted the enemy ahead at 0106. After marking time until the destroyers had completed their attacks, from 0113 onwards, they gradually shortened the distance to the enemy while sailing on a parallel course, bearing $110^{\circ}$ [ESE]. During that time, at 0116, the Mikuma launched her first aircraft for probing. From around 0056, the Shirataka, which had been on the waters to the north of the convoy and [temporarily] evacuated to the west so as not to encumber the charge of the Natori and the destroyers, [also] started advancing toward the enemy; she opened fire from 0114 onwards and scored hit[s]. During this period, the enemy returned fire on the Natori and the destroyer divisions using all his guns including main guns, auxiliary guns and machineguns. Due to the [Japanese] attacks until that time, the enemy had sustained serious damage, lost speed as well as control over his movements, and his formation became very much disorderly. On the Japanese side, the Shirayuki and the Harukaze sustained damage, including eight casualties each.

\section{The Third Phase of the Engagement ${ }^{(150)}$ (from 0116 until 0132)}

At 0119 , the $2 \mathrm{~d}$ Section of the 7th Cruiser Division, sailing on a parallel course with the enemy bearing $110^{\circ}$ [ESE], launched six torpedoes each against the first enemy vessel from a range of 11,200 meters, and reversed course to port because they came too close to Babi Island. Around that time, the enemy, who had been pouring fire on the 11th Destroyer Division (the Hatsuyuki and the Shirayuki), also started firing at the 5th Destroyer Division (the Harukaze and the Hatakaze) around 0118. At 0118, the Harukaze again got a fix on the enemy, and at 0119, while ordering to prepare for a torpedo launch at the enemy on starboard beam on a parallel course, turned to port. However, due to the water columns thrown up by the enemy shells, she again lost an opportunity to launch. Around that time, the enemy was beginning to turn to starboard to reverse course. Maintaining her readiness, the Harukaze swiftly approached the enemy; at 0126 she launched six torpedoes at the first enemy vessel and reversed course to starboard to evacuate northward; after two minutes, she spotted large water columns presumably caused by hits of her torpedoes. Meanwhile, the Hatakaze launched six torpedoes at a range of 3,800 meters, and evacuated westward, splitting from the Harukaze. 
Earlier at 0122 , the $2 \mathrm{~d}$ Section of the 7 th Cruiser Division had opened fire on the second enemy vessel from a range of 11,200 meters using searchlights. A number of direct hits caused fires and explosions of the turrets on the enemy vessel, providing a quite spectacular view, and her speed got slower all the time. Although the enemy had also started returning fire on the $2 \mathrm{~d}$ Section of the 7th Cruiser Division from 0122 onwards, the power of his searchlight[s] was too weak to enable him to carry out effective shelling. At 0125, due to trouble with her main [power] switch, the Mikuma became unable to use her searchlights and main guns, after which only the Mogami continued her shelling, using searchlights. At 0127 the Mogami launched six torpedoes against the second enemy vessel.

At 0130 the main [power] circuit of the Mikuma was restored, and after sending a telegram to the entire fleet, "We will finish off the enemy from now," she opened fire at the second enemy vessel at a range of the 9,000 meters using her searchlights and scored a large number of direct hits. The fierce attacks by all [Japanese] vessels caused huge fires on the first enemy vessel, while the concentrated fire at her portside bow caused the second enemy vessel to list to port. Meanwhile, the Natori, who had evacuated northward after having completed the first launch earlier, again got a fix on the enemy movements. At 0130 she opened fire using searchlights at the second enemy vessel, who had come within a range [as close as] 8,000 meters, but since she entered a smoke screen at 0132, she halted firing. Meanwhile, the 12th Destroyer Division had been rapidly advancing toward the enemy; [of this division] the Murakumo was the first [to open fire]; at 0130, using her searchlights, she started firing at the first enemy vessel (who was [already] crippled by now). [Then] both vessels [of the division] launched nine torpedoes each at both the first and second enemy vessels, and confirmed that their torpedoes hit both of them. This [attack] seemed to have aggravated the second enemy vessel's difficulty in sailing. On the Japanese side, only the Shikinami had sustained minor damage to a part of her propeller due to near misses during this period.

\section{The Fourth Phase of the Engagement ${ }^{(150)}$ (from 0138 until 0206)}

At 0135, 3d Escort Unit Commander Hara ordered the units, which had finished their first launch, to report on their preparations for the next launch. (Note by the author: it [usually] took five to twenty minutes [to load the launchers] on smooth waters.) At that time, the first enemy vessel was already on the verge of sinking. While setting a $90^{\circ}$ [E] course at 0133 and pursuing the enemy, the $2 \mathrm{~d}$ Section of the 7 th Cruiser Division spotted at 0135 the first enemy vessel practically coming to a halt, and opened fire at her from a range of 7,300 meters. At 0142 the section confirmed that the first enemy vessel had sunk, and stopped firing. But then getting a fix on the second enemy vessel at 0146, they immediately approached the latter and at 0150 opened fire at her using searchlights. By that time, the enemy vessel had lost most of her means to fight, including her main guns, which had fallen completely silent. At 0156, the section stopped firing and detached the Shikinami to finish off the enemy. She launched a torpedo to deliver the final blow, which brought the enemy vessel to a complete halt, and she finally sank at 0206 .

Prior to this, the destroyer divisions had been ordered by $3 \mathrm{~d}$ Escort Unit Commander Hara at 0140 to "form a single column behind [the Natori] in the order of their number," and they had completed assembling by 0200 [at a point] about five nautical miles north of St. Nicholas Point [Tanjung Pujut], where they were about to reverse course right away to head 
for the enemy. However, since the first enemy vessel had already sunk and the second vessel had lost most of her means to fight by that time, the commander ordered the 5th and the 12th Destroyer Divisions at 0200 to: "Go and guard the transport convoy." Following this order, both the 5th and the 12th Destroyer Divisions returned to their patrol areas. At first, the 3d Escort Unit staff had judged the two [enemy] vessels to be one Glasgow-class [cruiser] and one light cruiser. However, as a result of later [interrogations] of prisoners, it was learned that they were the Australian light cruiser HMAS Perth (the first vessel) and the U.S. heavy cruiser USS Houston (the second vessel) who had been attempting to reach Cilicap after fleeing from [the battle off] Surabaya.

Capt. Sakiyama Shakao, captain of the Mikuma of the 7th Cruiser Division, described the engagement [off Batavia] in his "Report on the battle circumstances" to the 5th Destroyer Squadron commander in the following way:

1. At 0010, the Natori called that two vessels, which looked like large enemy cruisers had been spotted two nautical miles southeast of Babi Island. We immediately formed a single column, increased speed, reported it, and completed preparations for an engagement.

2. By measuring the flash of the enemy's firing of star shells we assessed [the distance of the enemy from us] as $26,000-27,000$ meters.

3. At 0104 , we increased our speed to thirty knots, when we spotted the enemy at $30^{\circ}$ to the left. Artillery duels [had already opened]; especially when the enemy fired red tracer shells, the red [tracers] of their Pom-Pom guns streaming toward our friendly units together with the star shells and smoke screens produced quite a magnificent sight. Since we noticed that the enemy was taking evasive actions and sailing [now] on a reverse course on starboard bow of the Natori and the destroyers, we decided to conduct the fight with the enemy on our port hand. However, the enemy movements were still not clear. We wanted to launch an aircraft, but we could not because of the wind direction.

4. In a while, we received a report that the enemy was bearing $45^{\circ}$ [NE]. After [taking a good look] through the rifts in the smoke screens, we changed to a $60^{\circ}$ [ENE] course, and prepared for an engagement with the enemy on starboard. Although we realized that sailing at high speed in a night engagement might be excessive, we set our speed at the second war speed [twenty-one knots], hoping to arrive at the decisive battle site sooner. However, considering that [the course and speed] not only would not let us take up a position [as close as] 9,000 meters where we expected to start illuminating the enemy, but would [actually] carry us away from the enemy, I ordered to set a $110^{\circ}$ [ESE] course [and increase speed to] the third war speed [twenty-four knots].

In the meantime, to my great joy, the wind direction became favorable. At 0116, the first aircraft was launched. Feeling relieved that finally we would be able to begin the engagement with the enemy on the starboard, I ordered all aircraft to take off. However, the third aircraft slid from its platform onto the port catapult, where the second aircraft had already been set on; [both aircraft] with their flight crews on board got stuck and were unable to take off.

5. Through our launch of an aircraft, the enemy became aware of us and [fired] shells which straddled us ahead and astern, which was a bit unpleasant. At 0118, we attacked the HMAS Perth who sailed on our starboard on a reverse parallel course, launching six torpedoes each at a $40^{\circ}$ angle to the right from a range of 10,000 meters, while she was sailing at twenty knots (twentyfour knots at most). After a few moments, I ordered to [fire at the enemy] using searchlights. The enemy sailed remarkably fast.

6. The sound of enemy shells landing nearby felt as if they were directly hitting us.

As Babi Island was approaching ahead, the navigation officer, the communications officer and others lost patience and requested to change course. Since there was a risk of getting [too] close to the enemy by changing course to starboard, we boldly put the helm hard aport and sus- 
pended firing so as to get ready to fire at the enemy from our port hand sooner. We [hurriedly] prepared for firing from our port hand, while keeping our searchlights on for the sake of the Mogami. Interestingly, most of enemy shells dropped in front of us, as if he had set the wrong deflections by judging from the waves produced by our paravane chains that we were sailing at a very high speed. And while we were changing course, all his shells dropped on starboard and then astern, as if he had aimed at our searchlights or had no idea about our course change. Around that time, our torpedo attacks sounded like the sudden [explosions of] antisubmarine depth charges. As the enemy shells roared under water, [the sound] made me worry whether we might have sustained damage. I truly experienced a baptism of fire. Although the enemy turned his searchlights toward us, they were weak, whereas ours were very strong.

7. We resumed the engagement bearing $285^{\circ}$ [WNW] and at 0124 we again opened fire while sailing on a $260^{\circ}[\mathrm{W}]$ course. [Scored] direct hits, which presented a spectacular sight. The enemy's speed was dropping a little.

In the same way as before, the enemy shells dropped in front of our bow. The navigation officer was shouted at by the captain, having tried to change course possibly [to avoid] friendly destroyers, or something else, or enemy shells; the officer later seemed to feel ashamed. [Then] the [main power] switch broke down, which made us unable to use searchlights or our main guns. The captain considered it damage inflicted by enemy shells, and ordered the fourth ship [the Mogami] to turn on her searchlights. He was greatly relieved at the report that the problem had been fixed, and he ordered the unit to launch [torpedoes]. However, the torpedo chief insisted that the enemy was dropping speed and that no gunfire [had been observed], and we finally [decided] not to launch ours, while the fourth ship [the Mogami] launched hers.

After that, reports came in: [Our shells and torpedoes are] torturing [her], they have hit her and caused fire, her turret[s] have been blown off, she is about to sink, etc. Very good! The captain also watched from nearby the 12[.7]-cm [antiaircraft] guns.

Due to our high speed, we were sailing past the enemy; we turned to port to reverse course, and bearing $90^{\circ}$ [E], fired at her [at a range of] 7,000 [meters]; scored direct hits; splendid!

At 0143, HMAS Perth suddenly went down and sank.

8. Since it was reported that the other vessel was presumably heading for the Babi Island waterway, we moved ahead, increasing our speed to the third war speed [twenty-four knots], and to the fourth war speed [twenty-seven knots]. While sailing on a $165^{\circ}$ [SSE] course, we spotted the silhouette of the enemy vessel. She still seemed to be firing her Pom-Pom guns, but her main guns did not seem to work.

On the way, we spotted a cutter, which made me worry that a friendly destroyer might have been hit, but with no time to check those on board, we [kept on] sailing. Since the Shikinami sailing ahead of us prevented us from turning our searchlights [on the enemy and firing at him], I ordered her to move to the left. At 0150, we [again] opened fire at a range of about 6,500 [meters]. The second salvo scored a hit, after which we kept scoring hits. After three minutes, we spotted waves ahead, reversed course at a point close to shore, and resumed firing. Our shells hit, caused fires, blew off her foretop, and flames burst out. [The staff on] our bridge observed the battle situation with great excitement; even without conveying orders to the engine room things went well.

9. [The enemy vessel] did not sink despite such [enormous] damage. I thought for a moment that she had run aground. She came to a halt, whereas we continued sailing at a high speed. In night engagements, sailing at high speed is problematic, so I gave orders [to slow down to] strong speed [fifteen knots] and to normal speed [twelve knots], etc., just for my own peace of mind.

The enemy [vessel] had sustained concentrated fire at her port bow, which had blown off her turret[s] and caused fire; she listed to port and began to sink, losing [all] means to fight and we stopped firing. 
10. The torpedo chief offered a proposal that since the Shikinami did not seem to have launched her torpedoes yet, perhaps you could let her launch hers. Accordingly, I ordered her to launch one torpedo and charge.

Although the torpedo chief said that I should let her decide the number of torpedoes to be launched, I thought we should not waste them. While I was wavering about letting her decide [the number], the transmission [of the order] was finished. The Shikinami launched [only] one torpedo, but I could not tell whether it was because she faithfully executed the order, or because she herself made the decision.

This torpedo attack sped up the enemy vessel's sinking, and she went down with her bow first. It was 0205.

11. Although the enemy had consisted of [only] two vessels, it was not clear when they had disbanded the formation or when they had reversed course.

12. I was deeply grateful to my men that they supported and guided their captain with such a battle spirit.

I was also relieved that the vessels behind me instantly reacted [at unanticipated orders to increase their speed] to high speed, and followed me in good order. (The rest omitted by the author.)

\section{The Damage Sustained by the Army Transport Ships and Minesweeper No. 2}

At 0135 on 1 March, Minesweeper No. 2, who was guarding the transport convoy [on the waters] south of Panjang Island, was hit by a torpedo on starboard in her boiler room; she broke up at that section and capsized. Around that time, the transport ships were also hit by torpedoes, which caused the loss of the Sakura-maru, who sank, while the Ryujjo-maru, the Hōrai-maru and the Tatsuno-maru sustained serious damage. Among them, the Ryūjō-maru was carrying [Sixteenth] Army Commander Imamura on board, and was in the middle of the second landing operation. [The accident caused] Army Commander Imamura to swim around just in his life vest in a sea covered with heavy oil for about three hours until he was finally picked up and rescued around 0430. In view of the launching points, the lines of fire, and the performance of the torpedoes, it was certain that these torpedoes were among those which the 7th Cruiser Division had launched in its second launch. ${ }^{(150)}$ (The tails of Type93 torpedoes were recovered near the landing area of the army. $)^{(199)}$ However, concerning this incident, it was generally believed that enemy torpedo boats had intruded into the anchorage following the attack by the enemy cruisers and had inflicted the damage [to the vessels]. It was because Commander Imamura had graciously accepted the apology of the Navy side that this fact was kept from becoming publicly known.

\section{Lessons of War and Observations After this Sea Engagement}

The lessons of war drawn by 5th Destroyer Squadron Commander Rear Admiral Hara and the observations he made were according to the "Action Report of the 5th Destroyer Squadron" the following:

1. When implementing plans of operations, we need to take appropriate measures at appropriate moments as the movements of the enemy which we are facing change. More often than not, you should not stick to plans that have been drawn up long before. When the defeat of the enemy air power, which should be a necessary condition when implementing landing operations, has 
not yet been completed, you also need to accordingly change at an appropriate moment [the schedule of] the advance of the transport ships and the execution of the landing operation, just like this time in the Java landing operation. Particularly, in the operations of the land-based air units, the conditions of the advance bases are often unknown, which at times hinders them from carrying out air campaigns to destroy the enemy air power as planned. Therefore, the commander on site's judgment of the enemy movements needs to be respected and without sticking to the basic plans, instructions need to be given in such a way that the operations at the front can be implemented appropriately and with ease.

2. Although it is essential to reinforce the support forces so as to match the movements of the enemy, it will be useless unless the specially-dispatched reinforcements arrive in time for the engagement. The dispatch of the Ryūjo this time is a good example of such [a case]. Thus, I think careful consideration is required so that appropriate reinforcements will be dispatched to an appropriate place at an appropriate time.

3. The sea engagement off Batavia, which occurred on waters very close to the anchorage of the transport convoy, was extremely disadvantageous for us as escort unit to fight. The conceivable reasons for this were that in the first place the landing was forced in an area close to waters where powerful enemy surface forces existed, and that in the second place, we did not have forces enough to conduct the landing operation while carrying out attacks on the enemy. At that time, our escort forces were not enough [in strength] to defeat the enemy surface forces beforehand and grasp the command of the sea in the surrounding areas, and we did not have sufficient time, either. [Therefore,] it became necessary for us to have the indirect escort forces further advance and enhance their operations in concert with the air campaign to destroy the enemy air power, by which we would locally gain the upper hand [over the enemy] and hence locally gain command of the sea before the landing operation. If the enemy had intended to aggressively carry out an offensive in the engagement off Batavia, he could have conducted a far more effective attack by taking advantage of the home ground. [Therefore], I think this will make a good example when conducting landing operations in the future.

4. When a concentrated attack of all units (and vessels) becomes excessively dense in night engagements, it is common that consecutive direct hits by the units (or vessels), water columns created by their torpedo hits as well as the flashes of enemy gunfire make it extremely difficult to judge the general situation on both sides, observe the landing of shells, or to assess the effect of torpedoes etc. It is crucial to report the damage to the enemy, such as a dropping of his speed, or fires. However, at the sight of water columns or black smoke caused by friendly shells landing near the enemy, all units (and vessels) too quickly jumped to report them as the results of their own shelling or torpedo hits. Although it may boost morale, there is some fear that it may instead not only crowd communications but also mislead the judgment of the commanders.

5. Although such issues as the depth of torpedo [trajectories] or excessive running range in torpedo attacks against [enemy] cruisers have traditionally been studied, in the engagement off Batavia, again many trails of torpedoes, presumably launched by our cruisers, ran through waters very close to [our] destroyer divisions then in the middle of charging toward the enemy, which made us feel in danger of getting hit.

6. Shelling conducted only with medium-caliber guns on cruisers or lesser vessels can degrade the enemy's fighting ability, but it is not [strong] enough to sink them. In many cases, torpedo attacks are required to completely sink them. [However,] when conducting torpedo warfare such as in the recent engagement where the engagement occurred on waters very close to the anchorage of the transport convoy and where many units engaged in the night engagement took up positions to make a pincer attack on the enemy, we need to pay special attention to the direction of the lines of fire.

7. The fighting ability of our special-type destroyers was superior and their reputation as the [Navy's] principal weapon particularly in night engagements was confirmed in the successive 
engagements in the Java area. In the future, we need to attach greater importance to drills for night engagements, so as to make the most of their strong points; at the same time the performance of the special-type destroyers should be further improved; [on top of that,] the crew [of these vessels], from the captain and staff officers down to those in important positions, should be specially selected as has been done before, and appropriately assigned, so that [these destroyers] will form the elite of our navy and a national treasure both in name and reality. Also, I keenly felt that the [performance of the] torpedoes of the Natori-class cruisers was very poor, and that they must be quickly upgraded to Type90 or Type93 [torpedoes].

Note by the author: The torpedoes of the vessels that participated in the engagement ${ }^{(155)}$

Mikuma-class: Type93 (with an [effective] range of 20,000 meters [when running at] 48 knots, a range of 30,000 meters [when running at] 41 knots, with a range of 38,000 meters, [when running at] 36 knots)

Natori-class: Type8 (with an [effective] range of 10,000 meters [when running at] 39 knots)

Harukaze-class: Type6 (with an [effective] range of 6,000 meters [when running at] 37 knots)

Hatsuyuki-class: Type90 (with an [effective] range of 7,000 meters [when running at] 45 knots)

Shirakumo-class: Type90

Shikinami-class: Type90

8. We need to see to it that friend-or-foe identification signals shall be given swiftly.

Needless to say, this is without fail necessary when the enemy and us are mixed up in a night [engagement]. However, when deployed for patrolling and [sailing] on guard, sometimes there is a lack in swiftness [in giving signals and responding], possibly due to a hasty conclusion that vessels approaching the patrol area border must be friends. A little delay in response nearly led sometimes to a situation that was only seconds away from an unfortunate friendly fire [incident].

Not only the signal staff but also the crew on the bridge during a patrolling deployment need all to be fully aware of this.

9. General observations on providing escort for landing operations

(1) Although attaching Class-A cruisers to an escort unit as its support unit and have the former support the latter may increase confidence, they [usually] support [the escort unit] in a roundabout way, which, more often than not, does not fit the actual situation. We need to put the support unit and one element of the air unit under the unified command of the escort unit commander and have them operate at a short distance of the escort unit depending on the enemy movements so as to make the most of them.

(2) Since in sea areas such as where we carried out the recent Java operation, the days when seaplanes are not able to operate in terms of weather and sea conditions are rare, I think it would be best to have seaplane tenders like the San'yō-maru or the Kamikawa-maru sail together within the columns of the transport convoy and assign [these tenders] to guard against enemy aircraft and submarines under the direct command of the escort unit commander ([because such tenders] are able to retrieve their aircraft at sea, it becomes possible for the escort unit to neutralize enemy submarines by itself).

10. Needless to say, the escort forces should not leave the landing point too early. A review of the course of invasion operations until now indicates that it is one or two days after the convoy's entry into the anchorage that the enemy flocks to the [landing point], which makes me think that we need to have the escort forces remain [at the landing point] until at least the disembarkation is completed. Nevertheless, in such local invasion operations as the seizure of a [nearby] air base, I think it stands to reason to first of all only disembark the things required for the immediate engagements, and have the transport convoy leave the anchorage for the time being and at the appropriate moment [return and] carry out the second and third transports. 


\section{The Main Body of the Southern Task Force Advances to the South of Java (See Illustration No. 47)}

On 22 February, Southern Task Force Commander Vice Admiral Kondō had made various arrangements with Dutch East Indies Commander Vice Admiral Takahashi, who had put in at Staring Bay on that day, concerning the outline of the Java invasion operation. Those directly relevant here concern the second carrier operation, which were the following (as previously told [p. 404]): (53)

1. In view of the presence of enemy surface vessels in the Surabaya area, the operation of the core force of the 5th Cruiser Division to act in concert with the second carrier operation shall be called off. The force shall quickly be sent to the Makassar Strait area to support the units for the eastern Java invasion [operation].

2. As a measure to supplement the insufficient destroyer strength of the carrier task force, one destroyer division shall be extracted from the $2 \mathrm{~d}$ Destroyer Squadron currently engaged in the Kupang operation to participate in the carrier operation from the area near Timor.

Meanwhile on the same day, Southern Task Force Commander Vice Admiral Kondō sent a proposal to the Southern Army to postpone the starting date of the landing [operation] for two days. At 1830, he informed the carrier task force that the departure of the main body of the Southern Task Force from Staring Bay had been set for 0800 on 25 February.

At 0830 on 25 February, following the departure of the Carrier Task Force from Staring Bay, Southern Task Force Commander Vice Admiral Kondō left the bay for the Indian Ocean, leading the main body of the Southern Task Force ([consisting of] the 4th Cruiser division (the Atago, the Takao and the Maya), and the 4th Destroyer Division 1st Section (the Arashi and the Nowaki). Having followed in the wake of the Carrier Task Force until 1530, the main body separated from the former and headed for the Ombai Strait. [Then] joined around noon on 26 February at Ombai Strait by the Hayashio of the 2d Section of the 15th Destroyer Division, who had cut short the Kupang operation, the main body headed for the waters south of Sumba Island and reached the waters south of Sumbawa Island on the 27th. On that day, the sea engagement off Surabaya took place in the eastern part of the Java Sea while in the western part an enemy fleet [was spotted] making a sortie (it was later [judged to] have escaped into the port of Batavia), which led to the afore-mentioned delay of the landing operations both in eastern and western Java for one day (the postponement of the eastern Java [operation] was decided in the early morning of the 28th).

Also on the 28th, the main body continued to sail westward, and on the early morning of that day it reached the waters south of Bali. At 1000, Southern Task Force Commander Kondō sent the following telegram to commanders in chief as well as commanders of all units of the Southern Task Force by way of Second Fleet Classified Telegram No. 56: "From now on, the main body of the Southern Task Force shall sail to the waters about seventy nautical miles south of Cilacap, after which it shall meet, catch and destroy the evacuating enemy while cruising from east to west on the waters south of Java." (141)

On the early morning of 1 March, the main body of the Southern Task Force reached the waters about seventy nautical miles south of the Cilacap, after which, it gradually pushed southward while cruising from east to west on the waters south of Java. Between 0142 and 0529, the 1st Section (the Arashi and the Nowaki) of the 4th Destroyer Division sank four 
enemy merchant ships. ${ }^{(58)}$ On top of that, at 0740, the Arashi captured a Dutch merchantman (1,000t-class), while between 1330 and 1620, the aircraft of the Takao carried out a bombing attack on an armed Dutch ship (7,000 tons) and caused a large fire on her.

\section{The Operations of the Carrier Task Force (Until 1 March)}

The distribution of forces for the second carrier operation by the Carrier Task Force was as follows. ${ }^{(141,143,156)}$ (Although the 2d Section of the 3d Battleship Division had been incorporated in the main body of the Southern Task Force, it was returned to the $3 \mathrm{~d}$ Battleship Division as of 16 February to participate in the second carrier operation.)

\begin{tabular}{|c|c|c|c|c|c|}
\hline & Unit & & ommander & Forces & Tasks \\
\hline & Air Raid Unit & & & $\begin{array}{l}\text { 1st Carrier Div (Akagi and } \\
\text { Kaga as the core; minus the } \\
\text { 7th Destroyer Div) } \\
\text { 2d Carrier Div (Sōryū and } \\
\text { Hiryu as the core, minus } \\
\text { the } 23 \mathrm{~d} \text { Destroyer Div) }\end{array}$ & $\begin{array}{l}\text { Attacks on enemy fleets } \\
\text { and transport convoys }\end{array}$ \\
\hline $\begin{array}{l}\mathscr{U} \\
\stackrel{0}{0} \\
\text { İ } \\
\underline{y}\end{array}$ & Support Unit & 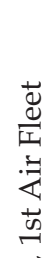 & $\begin{array}{l}\text { 3d Battleship } \\
\text { Div Cdr }\end{array}$ & $\begin{array}{l}\text { 3d Battleship Div (Hiei, } \\
\text { Kirishima, Haruna, and } \\
\text { Kongō) } \\
\text { 8th Cruiser Div (Toné, } \\
\text { Chikuma) }\end{array}$ & $\begin{array}{l}\text { Cover for air raid units } \\
\text { Attacks on enemy fleets }\end{array}$ \\
\hline$\overbrace{\tilde{U}}^{\tilde{U}}$ & Guard Unit & 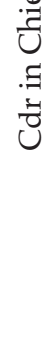 & $\begin{array}{l}\text { 1st Destroyer } \\
\text { Sqdn Cdr }\end{array}$ & $\begin{array}{l}\text { Abukuma, 17th Destroyer } \\
\text { Div, 18th Destroyer Div } \\
\text { 1st Section, 4th Destroyer } \\
\text { Div 2d Section, 27th De- } \\
\text { stroyer Div 2d Section, } \\
\text { Akigumo, 15th Destroyer } \\
\text { Div 1st Section ([during] } \\
\text { 6-10 March) }\end{array}$ & $\begin{array}{l}\text { Guarding } \\
\text { Attacks on enemy fleets } \\
\text { and transport convoys }\end{array}$ \\
\hline & Supply Unit & & $\begin{array}{l}\text { Capt of the } \\
\text { Kyokutō-maru }\end{array}$ & $\begin{array}{l}\text { 1st Supply Unit (Kyokutō- } \\
\text { maru, Ken'yō-maru, Nip- } \\
\text { pon-maru, Tōei-maru [A], } \\
\text { and Teiyō-maru) }\end{array}$ & Replenishment \\
\hline
\end{tabular}

The outline of the planned operations of the units was as follows:(156)

1. The air raid unit, the support unit and the guard unit shall leave Staring Bay at 0700 on the 25 th, conduct the first refueling at Point $\mathrm{A}\left(11^{\circ} 50^{\prime} \mathrm{S}, 117^{\circ} 40^{\prime} \mathrm{E}\right)$ at 1800 on the $27 \mathrm{th}$, and the second refueling at Point B $\left(16^{\circ} 20^{\prime} \mathrm{S}, 107^{\circ} 20^{\prime} \mathrm{E}\right)$ at 1800 on 1 March. Thereafter, while searching for enemy 
fleets, they shall advance to the waters south of Java by way of Point $C$ $\left(17^{\circ} 30^{\prime} \mathrm{S}, 104^{\circ} 30^{\prime} \mathrm{E}\right)$, and Point $\mathrm{D}\left(10^{\circ} 0^{\prime} \mathrm{S}, 101^{\circ} 10^{\prime} \mathrm{E}\right)$. If [the units] spot enemy fleets or transport convoys, [they] shall operate generally westward so as to cut off the enemy's escape routes while carrying out air attacks, and quickly and completely destroy him by repeatedly conducting fierce attacks. After having destroyed enemy carriers, the support unit and the bulk of the guard unit shall be advanced with the intention to completely destroy the enemy in concert with the air campaign. Depending on the circumstances, [enemy] transport convoys shall be captured. If the units should spot no enemy fleets or transport convoys even as far as Point $\mathrm{D}$, the units shall advance to Point $\mathrm{E}\left(9^{\circ} 20^{\prime} \mathrm{S}, 106^{\circ} 10^{\prime} \mathrm{E}\right)$ around 0600 on the 4 th, where they shall conduct an air raid on [enemy] transport convoys in the Cilacap area, and head for Point $\mathrm{F}$ $\left(15^{\circ} 0^{\prime} \mathrm{S}, 110^{\circ} 0^{\prime} \mathrm{E}\right)$, where they shall have the third refueling before returning to Staring Bay.

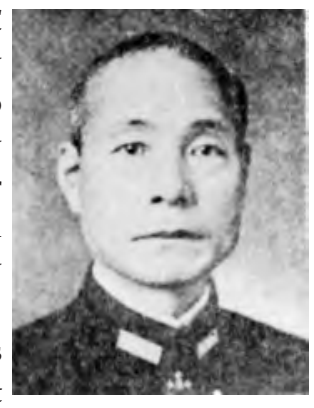

Third Battleship Division Commander V. Adm. Mikawa Gun'ichi

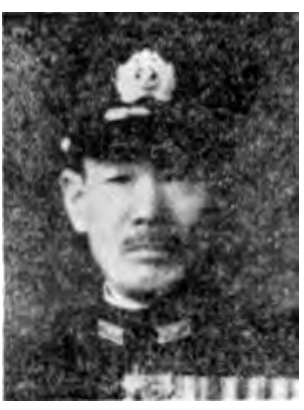

Eighth Cruiser Division Commander R. Adm. Abe Hiroaki 27 , having received reports from the land-based air unit of spotting enemy carrier (at 368 nautical miles $265^{\circ}[\mathrm{W}]$ of Bali), Carrier Task Force Commander V. Adm. Nagumo Chūichi signaled: "After finishing refueling, the Carrier Task Force shall swiftly advance to take up a position to the south of the enemy carrier and completely destroy her tomorrow early in the morning. The supply unit and the 1st Section of the 15th Destroyer Division shall directly head for the area of Point B and stay on standby." ${ }^{(141)}$ However, the [enemy] carrier (the converted U.S. seaplane tender USS Langley) was severely damaged by a land-based attack plane unit of the Takao Air Group and sank on the same day.

On the 28th, an aircraft patrolling the route ahead of the Carrier Task Force spotted an armed merchantman and carried out an attack ([with] one 60-kg bomb, which missed). However, other than her, the Carrier Task Force spotted no enemy. At 0700 on 1 March, the Carrier Task Force

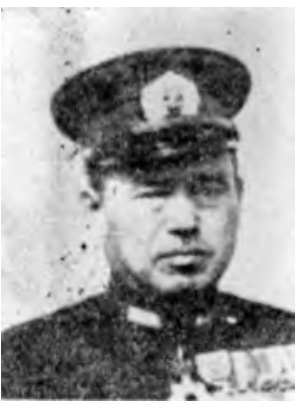

First Destroyer Squadron Commander R. Adm. Ōmori Sentarō reached the waters about 140 nautical miles $150^{\circ}$ [SE] of Christmas Island. On that day, the force sank one Dutch merchantman (the Modjokerto, 8,082t, [equipped with] one 3-inch antiaircraft gun and two machineguns), one U.S. oiler (the Pecos, [equipped with] two antiaircraft guns and a number of small machineguns) and one U.S. destroyer (the USS Edsall).

The circumstances at the time of the sinking of the U.S. Destroyer USS Edsall were as follows:(156) (See Illustration No. 48) 
At 1722, Carrier Task Force Commander Vice Admiral Nagumo ordered V. Adm. Mikawa Gun'ichi, commander of the support unit: "The support unit (minus the 3d Battleship Division $2 \mathrm{~d}$ Section) shall sink the enemy light cruiser that is following us astern." Almost simultaneously with this order, the support unit (the Hiei, the Kirishima, the Toné and the Chikuma), too, spotted the [enemy] masts at a distance of about thirty kilometers $335^{\circ}$ [NNW], reversed course and headed for the attack. At that time, three aircraft of the Sōry u were directly escorting the force in the air. Although the weather was fine, a rather dense mist covered the surface of the sea while at sea level the wind was blowing from $130^{\circ}$ [SE] at ten meters per second; visibility was thirty-five kilometers. From around 1732, the Chikuma opened fire at a range of 21,000 meters. At 1745, the 3d Battleship Division launched three Type-95 reconnaissance seaplanes to observe the artillery engagement, and at 1747 started firing with its main guns at a range of 27,000 meters. The Toné opened fire at a range of 23,500 meters around 1815 . However, because the enemy made large right-about turns almost every minute and often skillfully threw up smoke screens, the Japanese forces were hardly able to score hits.

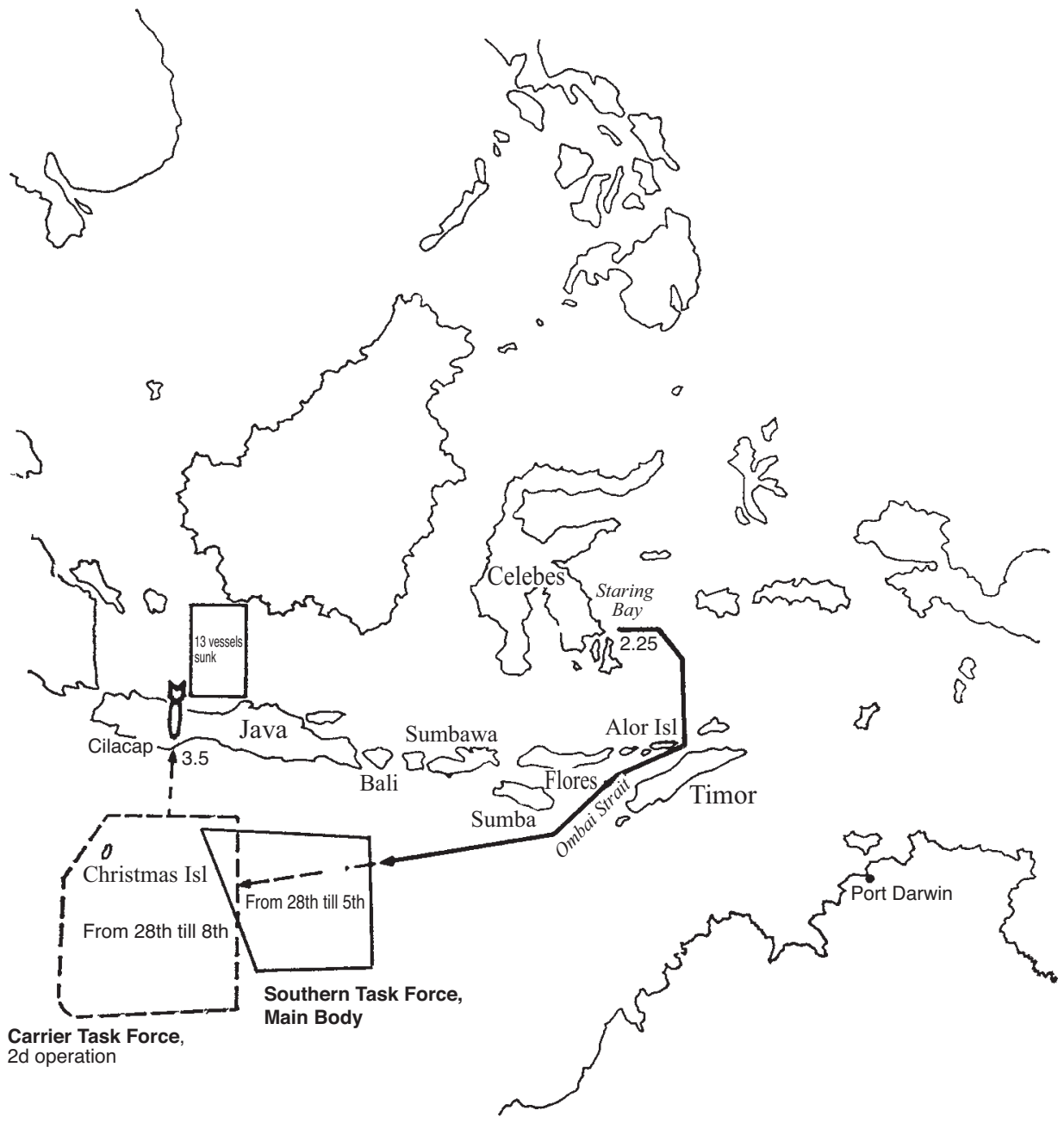

Illustration No. 47 - The Sea Area of the Second [Carrier] Operation of the Main Body of the Southern Task Force and the Carrier Task Force 
Since the attacks by the surface units were not producing the intended results, eight carrierbased bombers of the Akagi and nine of the Sōryu respectively took off at 1800 and 1805, carried out dive bombings from 1827 until 1857 ([and dropped] nine 500-kg and eight 250-kg bombs). With many direct hits and near misses, the enemy destroyer lost her speed and finally came to a halt. During this period and holding their fire, the surface units gradually reduced the distance. From around 1850, they resumed firing, and making use of [all guns including] secondary guns and antiaircraft guns, they finally sank the enemy destroyer at 1901. The shelling of the surface units lasted as long as one hour and fourteen minutes; the amount of ordnance consumed was enormous as seen below:

The 3d Battleship Division: 297 36-cm shells and $13215-\mathrm{cm}$ shells

The 8th Cruiser Division: $\quad 84420-\mathrm{cm}$ shells and $6212.7-\mathrm{cm}$ shells

Concerning this engagement, the 3d Battleship Division and the 8th Cruiser Division made the following observations. ${ }^{(158,159)}$

\section{The 3d Battleship Division}

1. Since the enemy was a destroyer sailing alone and did not need to take into consideration how to bring her gun power into play due to the distance between us, she was able to freely move without restriction, which enabled her to take skillful evasive actions and throw up smoke screens. (It looked as if she made a right-about turn almost every minute or changed course after observing our discharges.)

2. Because we fired roughly at a range between 28,000 meters and 24,000 meters, which made the flight time of our shells fairly long (about forty-five seconds or more), and because the intervals between our salvos were also long, it became even easier for the enemy to take evasive actions.

3. From the beginning [of the engagement], the Hiei and the Chikuma had figured out that the enemy was not a light cruiser but a destroyer, and hence carried out the shelling using the target-gauging calculator.*

Although entertaining some doubts, the Kirishima and the Toné dealt with her as a light cruiser ([of the] Marblehead-class).

\section{The 8th Cruiser Division}

1. Long-range firing at a fast vessel that freely takes evasive actions lowers the hit rate and ends up consuming an unexpectedly large amount of ordnance.

In order to [avoid] this [situation] in these kinds of artillery duels, it is absolutely essential to heed the following [points]:

(1) To carry out shelling from a range as close [to the enemy] as possible.

The appropriate firing range for the main guns on our vessel to fire on [enemy] destroyers should be deemed to be within 10,000 meters.

(2) If it is impossible to wait for [an opportunity to] close in on the enemy due to circumstances, you should closely watch the enemy movements while conducting slow fire; rapid fire shall be conducted only when the fire is seen to produce results.

2. You need to try to confirm the type of enemy vessel before opening fire.

* For fire control the Japanese Navy used the British-derived "fire control director [hōiban]" and "fire control table/calculator [shagekiban]," to which they had added a uniquely Japanese instrument to measure the speed and course of the target, the so-called "sokutekiban [gauging-the target-calculator]." See David C. Evans and Mark R. Peattie, Kaigun; Strategy, Tactics, and Technology in the Imperial Japanese Navy 1887-1941. Annapolis, Naval Institute Press 1997, pp. 250-53. 


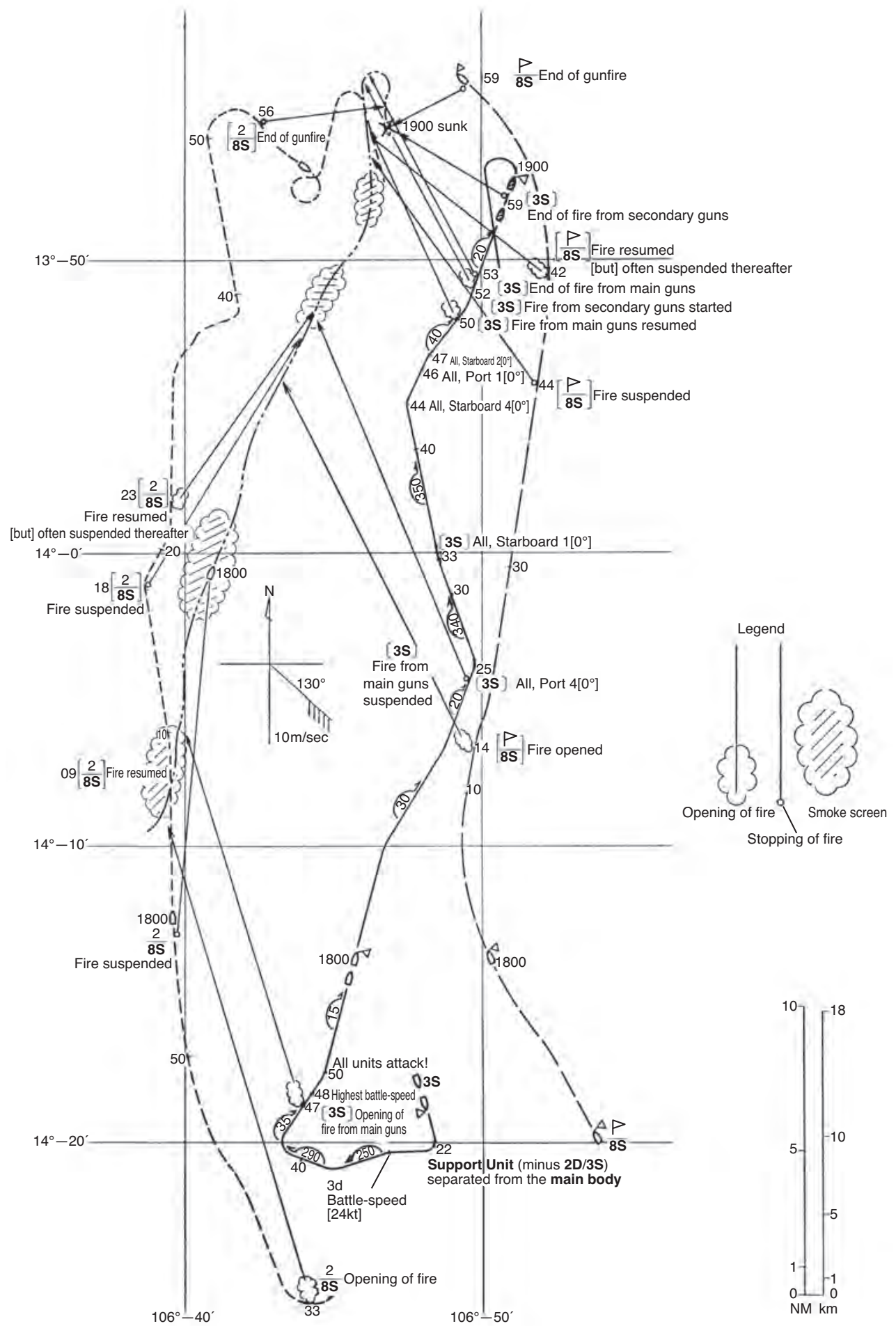

Illustration No. 48 - The Engagement of the Support Unit of the Carrier Task Force with the USS Edsall (U.S. Destroyer)

1 March 1942, on the waters to the south of Christmas Island 


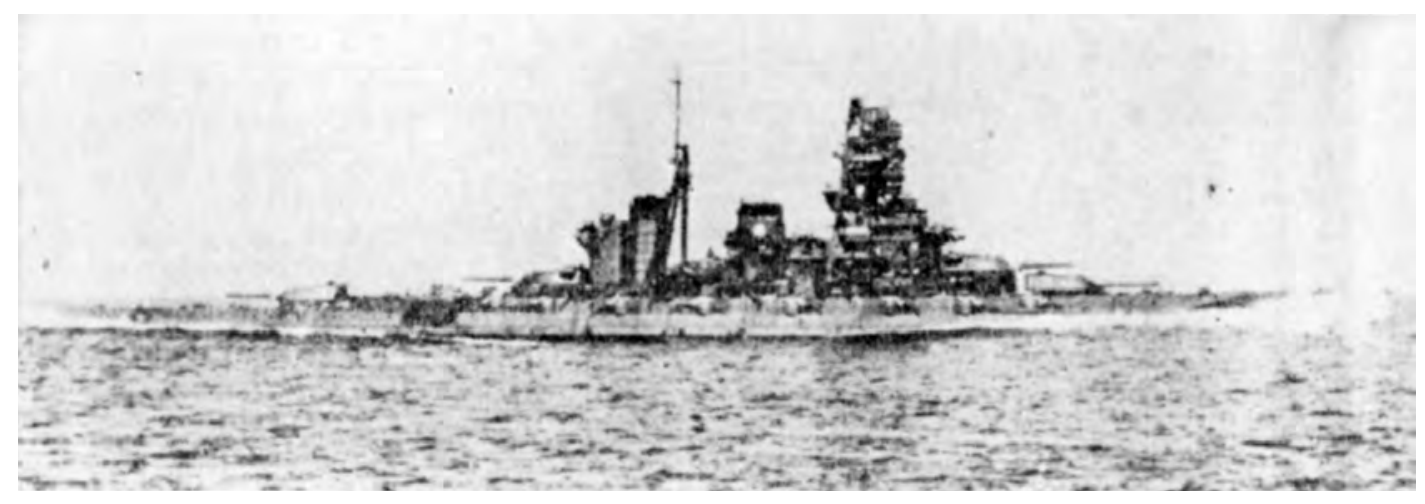

The Battleship Hiei

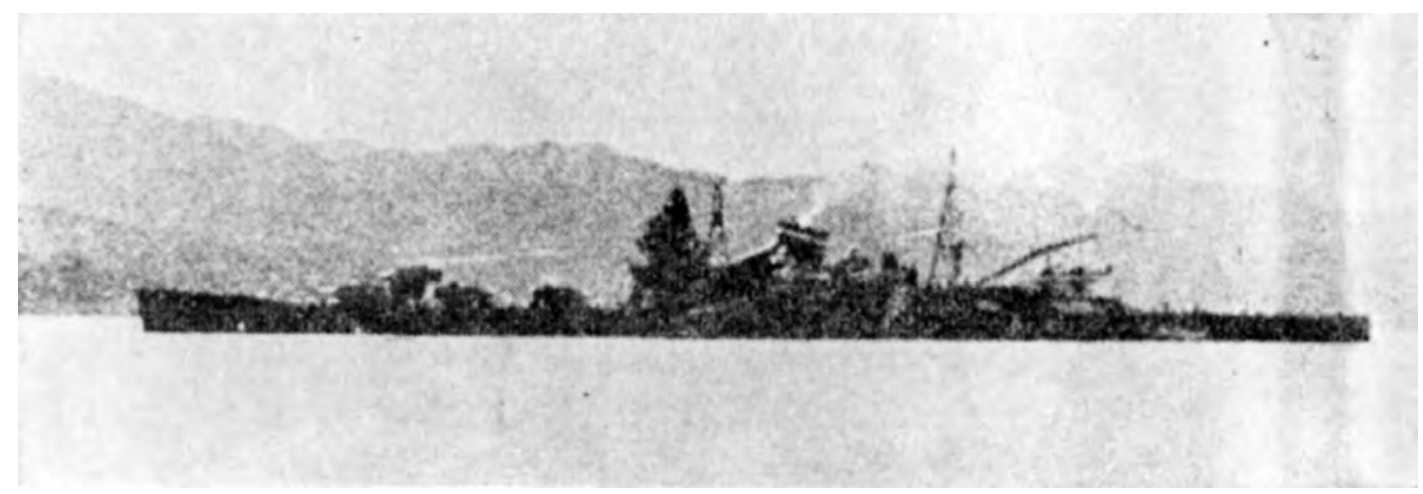

The Cruiser Toné

The Toné mistakenly took the enemy vessel in the engagement for a Marblehead-class [cruiser], which considerably disadvantaged her in terms of the artillery duel as well as in terms of gauging the speed and course of the target.

\section{The Operations of the Submarine Units (See Illustration No. 49)}

Southern Task Force Commander Vice Admiral Kondō had informally announced to the units concerned that he would combine the 6th Submarine Squadron (Commander: R. Adm. Kawano Chimaki), then under his direct command, with the 4th Submarine Squadron, currently incorporated in the Malaya Unit, to form Submarine Unit A (under the command of 4th Submarine Squadron Commander R. Adm. Yoshitomi Setsuzō) and put it under his [Kondō's] unified command. On 1 February, by means of Second Fleet Classified Telegram No. 820, the Southern Task Force commander announced the outline of operations for Submarine Unit A at the time of the Timor, Bali and Java invasion operations, the main points of which were as follows: ${ }^{(60)}$

\section{Mission}

(1) To catch and destroy reinforcements and/or escaping forces of the enemy.

(2) To watch and attack key enemy areas.

2. Deployment 
(1) Five submarines in the area [off] the southern coast of Java and the Sunda Islands (roughly within sixty nautical miles offshore). However, before the landing on Java, two submarines each shall be deployed at the southern entrances of [both] the Sunda and the Lombok Straits. After the landings two or more submarines shall be deployed off Cilacap.

(2) Two submarines in the Torres Strait

(3) One submarine [off] Port Darwin

In accordance with this outline, Rear Admiral Yoshitomi, Submarine Unit A commander, issued on 5 February the following order by means of Submarine Unit A Telegraphic Operation Order No. 1:

1. The deployment of the 4 th Submarine Squadron

[At] the southern entrance of the Sunda Strait, [the area] off Cilacap, and the southern entrance of the Lombok Strait

2. The deployment of the 6th Submarine Squadron

[At] Port Darwin and the Torres Strait

Since the 2d Submarine Squadron was [also] transferred to the Southern Task Force later on 8 February, Southern Task Force Commander Vice Admiral Kondō formed with this squadron Submarine Unit C, and on 9 February, by means of Telegraphic Order No. 92 (as previously told [pp. 331-32]) he outlined his plans for all units [of the Southern Task Force] including the submarine units. The items concerning the submarine units will be cited again. ${ }^{*}$ It was a very grand plan: ${ }^{(141)}$

7. Submarine Unit A (the 4th and the 6th Submarine Squadrons) shall operate as scheduled; it shall be assigned to watch and patrol the southern coast of the Dutch East Indies east of (and including) Java as well as the Torres Strait and the Port Darwin area.

8. Submarine Unit B (the 5th Submarine Squadron) shall be assigned to watch and patrol the coastal areas of Ceylon and India as well as the north entrance of the Malacca Strait and the southern coast of Sumatra.

9. Submarine Unit C (the $2 d$ Submarine Squadron) shall leave Staring Bay around 23 February and advance into the Indian Ocean. The bulk of the unit shall advance while searching for the enemy more or less 400 nautical miles south of Java, and swiftly reach the area south of the Cocos Islands. After that and until about 1 March, it shall conduct patrols from a position on the waters between about $97^{\circ} \mathrm{E}$ and $100^{\circ} \mathrm{E}$ beyond the 600 nautical miles range from Palembang. One element shall be assigned to covertly patrol the regular sailing routes on the western coast of Australia off Freemantle, after which it shall return to Staring Bay around 6 March. Also, one designated submarine shall promptly be assigned to reconnoiter and watch the Cocos Islands.

\section{Submarine Unit A, Guarding Java and [the Area] to the East}

On 6 February, Submarine Unit A Commander Rear Admiral Yoshitomi issued the details on the deployment of the submarines of the 4th Submarine Squadron in the Java operation by means of Submarine Unit A Operation Order No. 2. In accordance with this order, Sub-

\footnotetext{
* The quote on pp. 331-32 is from the Action Report of the 2d Destroyer Squadron. The quote here is from the Action Report of the 1st Destroyer Squadron. The main difference is that the first report says that the search for the enemy should be conducted southeast of Java, while all other reports say south.
} 
marines I-53, I-54 and I-58 left Cam Ranh Bay on 7 February, and Submarine Ro-33 on 8 February, for their respective stations. However, since on the 9th the [landing] date of the Java operation became likely to be postponed, Submarine Unit A Commander Rear Admiral Yoshitomi ordered the submarines, which were under sail southward toward their stations, to stand by in the Anambas Islands [instead].

On 11 February, after having been notified that the invasion schedule for Batavia and Surabaya had been postponed until 26 February and the schedule for Bali and Kupang until 20 February, the Submarine Unit A commander gave orders regarding the operations of each submarine by means of Telegraphic Operation Order No. 42. [Accordingly], submarines I53, I-54, and I-58, as well as submarine Ro-33, left the Anambas Islands on 13 February, while submarine Ro-34 left Cam Ranh Bay on 17 February, heading for their respective stations for the Java operation. The operations of each submarine will be outlined below.

Submarine I-54 (with the 18th Submarine Division commander on board): Having left the Anambas Islands on 13 February, she reached via the Lombok Strait her patrol area in the western part of the waters south of the Sunda Strait roughly around the 20th, pulled out [from the area] on 4 March, and returned to Staring Bay on the 9th. During this period, she attacked three merchant ships and sank one 10,000t-class passenger ship. She [also] heard a sound presumably caused by a [torpedo] hit on a $15,000 t$-class tanker, but the result was unclear.

Submarine I-53: Having left the Anambas Islands on 13 February, she took up position along with her fellow submarines ( $I-55$ and Ro-33) on 15 February on a skirmish line in order to obstruct the escape routes of the enemy fleet [then] sailing northward through the Gaspar Strait [p. 300]. However, having spotted no enemy [there], the line was called off on the evening of the 16th and she advanced to [the area] off Cilacap through the Lombok Strait, after which she pulled out of the area on 4 March and returned to Staring Bay on the 8th. During this operation, she sank one 10,000t-class and one 15,000t-class merchantman.

Submarine I-58: Having left the Anambas Islands on 13 February, she arrived at her patrol area in the eastern part of the waters south of the Sunda Strait around the 20th via the Lombok Strait, pulled out [from the area] on 4 March and returned to Staring Bay on the 8th. During this period, she sank one 15,000t-class tanker as well as one 4,000t-class and one 3,000t-class merchantman.

Submarine Ro-33: Having left the Anambas Islands on 13 February, she operated in the Sunda Strait for an attack on the enemy fleet on the 15th, after which she arrived in her patrol area in the western part of the waters south of the Lombok Strait. Then from the 21st to the 24th, she was deployed for watching [enemy movements] near Bali until returning to her original patrol area. On 1 March, she advanced to [the area] off Cilacap due to a change in her deployment on the 28th, after which she pulled out from the area on 4 March and returned to Staring Bay on the 8 th. During this period, she spotted a considerable number of enemy merchant ships, destroyers and submarines and attacked them, but every time she failed to produce results due to evasive actions of the enemy.

Submarine Ro-34: Because Submarine I-57 had become unable to conduct operations for the rest of the February due to an outbreak of dysentery, it was decided that the Ro-34 would replace her and take up position in the patrol area in the eastern part of the waters south of the Lombok Strait. She left Cam Ranh Bay on 17 February, and after having been deployed for watching [enemy movements] near Bali from the 21st to the 24th along with Submarine Ro-33, she returned to her original patrol area on the 24th. She [again] changed her position to [an area] off 


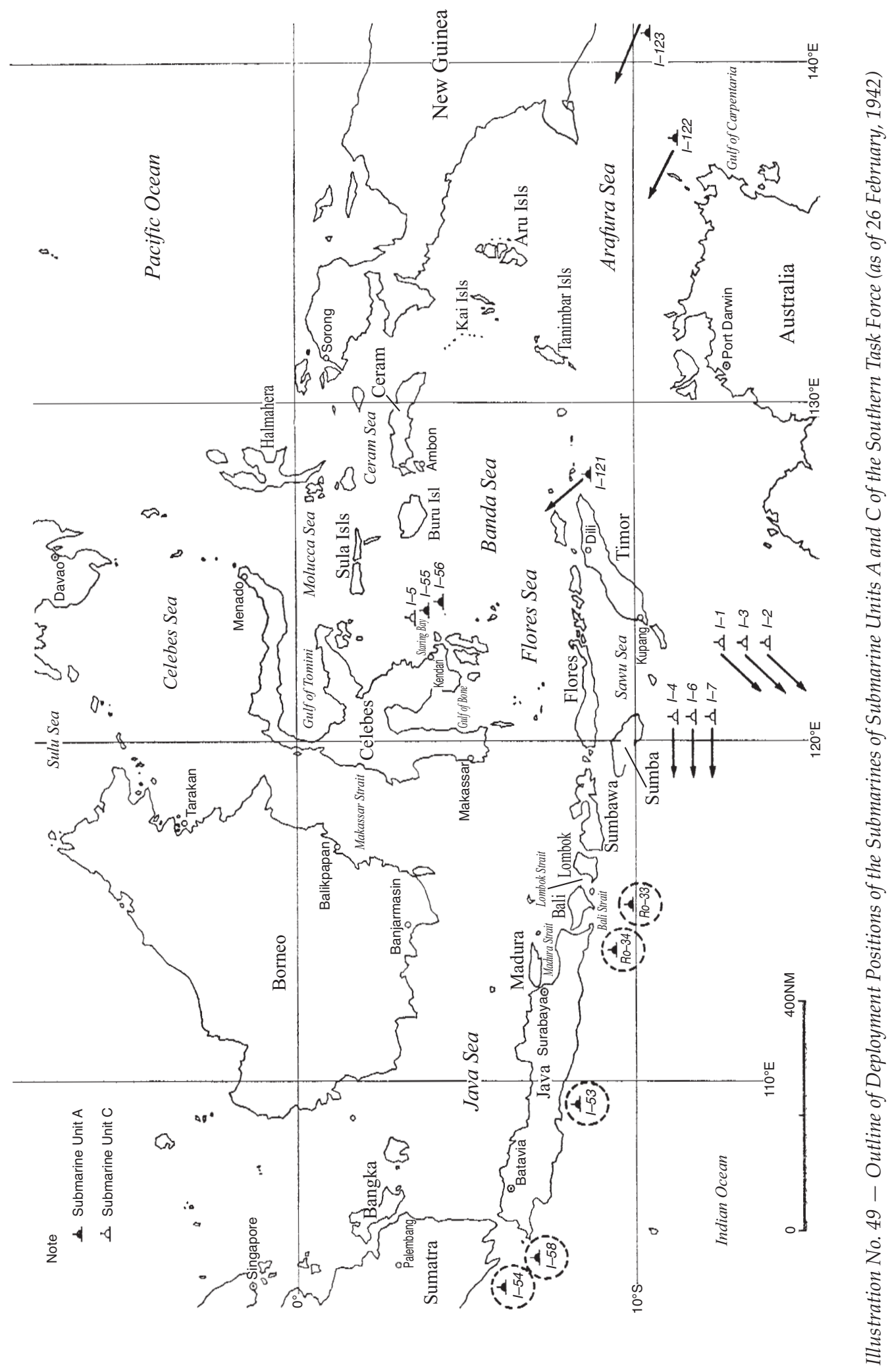


Cilacap from the 28th onwards. However, she did not spot any enemy vessels other than once spotting [an] enemy destroyer; she pulled out of the area on 4 March and returned to Staring Bay on 7 March.

In the meantime, after having watched [enemy movements] in her patrol area at the southern entrance of the Sunda Strait during Operation L [the southern Sumatra operation], Submarine I-56 returned to Staring Bay on the 21st, where she stayed on standby. [Then] on 4 March she was ordered by the Southern Task Force commander to hurriedly deploy to [the area] off Cilacap to watch [enemy movements] in this area; she left port on the morning of the 5th for [the area] off Cilacap and took charge of patrolling from the 8th onwards. However, on the afternoon of the next day, the 9 th, she was ordered to return to Staring Bay. She left the patrol area on the same day and put in at Staring Bay on 12 March. During this period, she was not able to sink a single ship.

[Meanwhile,] the 6th Submarine Squadron operated in outline as follows:

Submarine I-121: She left Davao on 9 February, [arrived] in the Arafura Sea on the 14th, [reached] the waters west of Port Darwin on the 16th (where she supported the air campaign by communicating weather information) and returned to Staring Bay on the 28th; other than several times spotting enemy aircraft, she spotted no enemy.

Submarine I-122: She left Davao on 9 February, and [reached] the Torres Strait on the 15th, where she engaged in watching [enemy movements] until the 26th, and returned to Staring Bay on the 28th. Other than encountering one enemy patrol boat, she spotted no enemy.

Submarine I-123: She left Davao on 19 February, and reached the Torres Strait on the 24th, where she laid mines at night on the 25th and returned to Staring Bay on 9 March. She spotted no enemy during this deployment.

Chōgei: She left Davao on 20 February, put in at Staring Bay on the 23d, and directed the operations.

The operations of Submarine Unit B (in the areas along the coast of Ceylon and India as well as the north entrance of the Malacca Strait) are omitted here, because they were not directly related to the Java invasion operation.

\section{Submarine Unit C, Guarding [the Area] South of Java}

On 21 January, ${ }^{*}$ Combined Fleet Commander in Chief Admiral Yamamoto Isoroku announced his plans for the carrier operations of the Southern Task Force by means of Telegraphic Operation Order No. 54 (as previously told), in which he disclosed that one element of the Sixth Fleet would be transferred to the Southern Task Force (the name of the vessels and the timing would be given later). ${ }^{(141)}$ On 3 February, the Navy General Staff informally notified the $2 \mathrm{~d}$ Submarine Squadron that it should participate in the carrier operations in the southern [theater]. The $2 \mathrm{~d}$ Submarine Squadron returned to Yokosuka in early February after having participated in the Hawaii operation right at the opening of hostilities, and was doing maintenance in preparation for the operation in the Indian Ocean. On 8 February, the 2d Sub-

* Probably a misprint for 31 January, see pp. 211-12. 
marine Squadron was officially transferred to the Southern Task Force by means of Combined Fleet Telegraphic Operation Order No. 64. ${ }^{(141)}$ Conform to this order, Southern Task Force Commander Vice Admiral Kondō gave orders to form Submarine Unit C with the 2d Submarine Squadron, while ordering the squadron to advance to Palau as soon as possible. The forces of the unit consisted of the following:

Submarine I-7 (flagship)

7th Submarine Division (Submarines $I-1, I-2$, and $I-3$ )

8th Submarine Division (Submarines $I-4, I-5$, and $I-6$ )

The Santos-maru

On 16 and 17 February, the 2d Submarine Squadron advanced to Palau

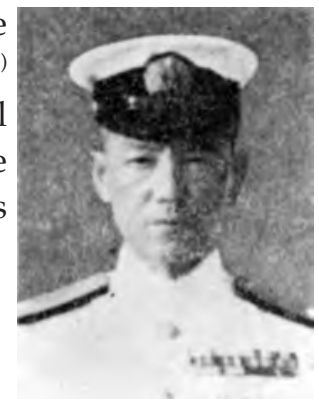

2d Submarine Squadron Commander R. Adm. Ichioka Hisashi (Submarines I-1 and I-6 directly headed for Staring Bay and put in there on 22 February due to their delayed departure from Yokosuka). On 16 February, Southern Task Force commander ordered 2d Submarine Squadron Commander R. Adm. Ichioka Hisashi to sail to Staring Bay, and thus the [whole] squadron put in at the bay on the 21st and the $22 \mathrm{~d}$.

Although the main points of the operations of Submarine Unit C are not very clear in detail, they are presumed to have been as follows [See also pp. 331-32, 482]:

1. [The squadron] should leave Staring Bay on 23 February.

2. The 7th Submarine Division shall sail and search for [the enemy] along the regular sailing routes on the western coast of Australia and, after patrolling the area off Freemantle, return to Staring Bay around 6 March.

3. Submarine $I-7$ and the 8 th Submarine Division should sail while searching for the enemy on the waters about four hundred nautical miles from the southern coast of Java and reach the area south of the Cocos Islands. After that and until about 1 March, they should reach a point between about $97^{\circ} \mathrm{E}$ and $100^{\circ} \mathrm{E}$ beyond the six hundred nautical miles range from Palembang, conduct patrols [there] and then return to Staring Bay around 10 March.

4. Submarine I-4 should reconnoiter and watch [enemy movements near] the Cocos Islands.

The operations of the submarines of Submarine Unit C were as follows:

Submarine I-1: She left Staring bay at 1700 on 23 February, using only one of her engines. At that time, her starboard engine was out of order and needed repair at a naval arsenal. On the 25th, the submarine passed through the Ombai Strait. She searched for the enemy while sailing on the waters northwest of Australia; on 3 March she sank one 8,000t-class armed merchantman (the Dutch ship Sianter, 8,667 tons) at a point four hundred nautical miles northwest of Sharks Bay. ${ }^{(160)}$ She returned to Staring Bay on the 11th, and was ordered to leave the bay for Yokosuka on the 15th.

Submarine I-3 (with the 7th Submarine Division commander on board): At 1630 on 22 February, she left Staring Bay along with Submarine I-2. At 0135 on the 23d, she spotted [an] enemy submarine, but did not have an opportunity to attack her. On 2 March, she passed the skirmish line $\mathrm{X}-4$, and headed for a point six nautical miles $270^{\circ}$ of Cape Leeuwin. On 3 March, she spotted and attacked one 7,000t-class cargo ship sailing westward but let her slip away. Then on 6 March, she reconnoitered Sharks Bay as ordered, spotted one surfaced [enemy] submarine, fired at the 
latter but let her slip away, without being able to score a hit. After reporting on the reconnaissance results of Sharks Bay, she put in at Penang on 14 March by way of Skirmish Line Q-2.

Submarine I-2: On 22 February, along with Submarine I-3, she left Staring Bay to advance to the Indian Ocean. At 2103 on 1 March, she spotted two mid-sized cargo ships at 31 $50^{\prime} \mathrm{S} 113^{\circ} 30 \mathrm{E}^{\prime}$ and sank one of them (the Dutch ship Parigi, 1,172 tons) ${ }^{(160)}$ with two torpedoes. [Then,] at 0358 on the $2 \mathrm{~d}$, she also spotted one mid-sized merchantman off Freemantle, attacked her but gained no results. She [further] spotted one large cargo ship at 2000 and attacked her but let her slip away when counterattacked. After that, she was persistently pursued by two enemy patrol boats, which did not allow her to surface from 0700 on the $3 \mathrm{~d}$ until 2000 on the 4th. On 5 March, she left her patrol area to head northward for Skirmish Line Q-2. On the 11th, she again sank one merchantman (the British ship Chilka, 4,360tons) ${ }^{(160)}$, crossed Skirmish Line Q-2 on the 12th, and put in at Penang on the 14th.

Submarine I-4 (with the 8th Submarine Division commander on board): She left Staring Bay on 23 February and advanced into the Indian Ocean. On the 28th, she sank one mid-sized cargo ship (the Dutch ship Ban Ho Guan, 1,693 tons) ${ }^{(160)}$ on the waters southwest of Bali, after which she headed for the Cocos Islands as ordered to conduct shelling but the results were unclear. Thereafter, by way of Skirmish Line Q-2, she put in at Penang at 1250 on 8 March.

Submarine I-5: Although she left Staring Bay on 23 February, she came under friendly fire from two aircraft on the waters west of Timor on the 25th. This caused serious injury to the captain and two non-commissioned officers and caused her to put in at Kupang, where she underwent emergency repairs; she left there on the 27th back for Staring Bay. However, at 0908 on the 28th, she ran aground on the south side of the North Channel at the entrance of Kendari. After that, a rescue operation was conducted under the command of the 6th Submarine Squadron commander, the senior commander on site. Although she was finally successfully refloated at 1640 on 20 March, she was unable to join the [designated] operations.

Submarine I-6: At 0800 on 23 February, she left Staring Bay and advanced to the Indian Ocean. [On her way to her designated position] at 1230 on the 25th, she was also mistakenly fired on by friendly aircraft on the waters west of Timor (a little after the friendly fire [incident] on Submarine I-5) but sustained no damage. On 8 March, she put in at Penang by way of Skirmish Line Q-2. During [her deployment], she spotted no enemy.

Submarine I-7 (the flagship of the 2d Submarine Squadron): She left Staring Bay on 23 February and advanced to the Indian Ocean. Having sunk a passenger cargo ship (the Dutch ship Le Maire, 3,271 tons) ${ }^{(160)}$ at a point 250 nautical miles $330^{\circ}$ [NW] of the Cocos Islands at 1300 on the 4th, she put in at Penang at 1030 on 9 March by way of Skirmish Line Q-2.

Santos-maru: She left Yokosuka on 21 February and arrived in Palau on the 27th. Then she left there on 1 March and put in at Staring Bay on the 5th, where she stayed until 25 March, engaging in the rescue operation of Submarine I-5. 


\section{The Army Units Sweep Across Java}

Before dawn on 1 March, escorted by the [Navy] 3d Escort Unit, the main force of the Sixteenth Army put the Satō Detachment ashore near Cape Awuran at the mouth of Bantam Bay, the Nasu and the Fukushima Detachments near Merak and the Shōji Detachment near Eretan to the east of Batavia. Meanwhile before dawn on the same day, escorted by the [Navy] 1st Escort Unit, the [Army] 48th Division and the Sakaguchi Detachment also successfully landed in front of the enemy near Kragan to the west of Surabaya. As early as by the end of the day, the main force of the army had advanced one element to the line of the Ciujung River, while the Shōji Detachment had advanced to the whole area of the Kalijati airfield, and the Sakaguchi Detachment to the area near Blora. The 48th Division had also driven the enemy back to fifty kilometers or more from its landing point and secured the latter.

In western Java, the Nasu Detachment of the $2 \mathrm{~d}$ Division reached the area near Leuwiliang on the evening of the $3 \mathrm{~d}$, seized the town after a fierce fight with an Australian garrison near the town at the night on the 4th and reached the front of Buitenzorg [Bogor] on the next day, the 5th. [Meanwhile] on the $3 \mathrm{~d}$, the Fukushima and the Sato Detachments respectively reached the areas near Maja and Balaraja, where their advance was temporarily hindered by destroyed bridges. On the afternoon of the $3 \mathrm{~d}$, the $2 \mathrm{~d}$ Division commander decided to transfer the main force of the division to the Buitenzorg area where the war situation was making steady progress, and transferred one element of the Fukushima and the Satō Detachments to the Nasu Detachment. On the night of the 5th, the Nasu Detachment determinedly carried out a night attack on Buitenzorg, drove back 2,000 to 3,000 Australian troops to the south and seized the place at 0600 on the 6th. Meanwhile at 2130 on the 5th, the Satō Detachment seized Batavia. The 2d Division continued its advance toward Bandung* when on the early morning of the 8th, it received a report from the Army that the enemy in Bandung had offered to surrender, which was followed by an Army order concerning the occupation of Bandung received on the afternoon of the 9th. In accordance with the order, the division occupied the city with about two battalions.

In the meantime, at 1200 on the 1st, the raiding unit of the Shōji Detachment, assigned to charge toward the Kalijati airfield, had rushed into the airfield and completely seized it at 1230. Although the airfield was in [good] condition and available for immediate use, it was impossible to report it to the Army headquarters or the 3d Air Division because no communications could be established. Before dawn on the $2 \mathrm{~d}$, the main force of the detachment arrived in Subang, where around 1100 it came under attack of a powerful mechanized enemy unit from the Bandung area, and narrowly defeated it after an engagement of an hour and a half. On that afternoon, the 3d Air Division forced its advance to the Kalijati airfield, and intensified its support for the Shōji Detachment. On the 3d, despite several attacks by powerful enemy tank units, [the detachment] successfully frustrated the enemy's intentions with the effective support of the air division. Having learned the situation of the bitter fight of the Shōji Detachment, the Army headquarters was deeply concerned about the war situation in that area. On the 4th, the headquarters requested the Southern Army to airlift one element of the 38th Division [to the area], but this was not approved.

Judging that uselessly making a defensive stand when enveloped by the enemy would only lead to self-destruction, the detachment commander decided that the best way was to

\footnotetext{
* It was slightly more complicated than the impression given here. See Vol. 3, pp. 500-501.
} 
carry out a sudden assault [on Bandung] and seize the city before the stronghold got well prepared and requested the 3d Air Division commander to support him. From the 5th onwards, with close cooperation of the air division, the detachment shifted to the attack on Bandung and seized Lembang on the night of the 7th. That night, an enemy messenger bearing a flag of truce arrived at the detachment headquarters and offered a cease-fire by Major General Pesman, the garrison commander of the Bandung sector.

Moreover, the Sakaguchi Detachment, which had been assigned to cut off the enemy escape routes by seizing Cilacap on the southern coast of central Java, had seized Blora on the night of the 1st. Thereafter having captured key places such as Surakarta, Yogyakarta, Magelang, Semarang, Purwokerto in succession, it finally seized Cilacap on the 8th.

The 48th Division with the task of capturing Surabaya in eastern Java commenced its operation on 4 March when the [temporary] bridge over the Solo river was completed near Cepu.* The main force of the division charged around the clock along the road connecting Cepu, Kertosono, Jombang, and Mojokerto while fighting off resistance by the enemy and reached Mojokerto on the 6th, whereas a raiding unit, which had charged toward Bojonegoro seized the city on the morning of the $3 \mathrm{~d}$, continued its advance eastward, and captured Lamongan on the 7 th, and Gresik on the 8 th. ${ }^{* *}$

Army Commander Imamura, who had learned in the middle of the night of the 7th of the enemy's offer to surrender to the Shōji Detachment, considered that the offer of surrender of the commander of the garrison in the Bandung sector should be expanded to a surrender of the entire allied army stationed in the Dutch East Indies. He demanded the presence of not only Major General Pesman but also of Governor-General [Tjarda van] Starkenborgh [Stachouwer] of the Dutch East Indies and Lieutenant General Ter Poorten, the commander of the Dutch East Indies Forces (and chief of the Dutch East Indies Army Department). At 1800 on the 8th, he opened at Kalijati the meeting concerning the cease-fire. ${ }^{* *}$ Although the Dutch East Indies side was reluctant to accept an overall surrender at the meeting, the army commander demanded: “The Japanese army demands your overall and unconditional surrender. If you cannot accept it, we shall promptly reopen hostilities and resort to force until the Dutch East Indies Army is destroyed. If you should have the intention to surrender totally and unconditionally, you must give an order that [your forces] shall stop all resistance after 1200 tomorrow, the 9th, and that each regional unit shall surrender to the Japanese Army in its area." ${ }^{* * * *}$

At 1200 on the 9th, the Dutch East Indies side put in outline the following broadcast on the air:*****

The Japanese Army succeeded in breaking through into the intermountain area of Bandung. It has taken complete command of the air, which made it impossible for us to put up resistance in the intermountain area of Bandung. Therefore, we had no choice but to hold cease-fire negotiations.

The Japanese Army demanded prompt talks with our governor-general and me. In these talks, the Japanese Army commander made the following demands on 8 March:

* A fuller version may be found in Vol. 3, p. 555.

** According to Vol. 3, p. 567, on the 9th.

*** See Vol. 3, p. 531.

**** See Vol. 3, pp. 532-33. The text in the present volume has been somewhat abridged.

***** See Vol. 3, p. 534 
1. Our overall surrender.

2. A prompt discontinuance of all hostilities.

3. The raising of white flags as a proof of our overall surrender.

4. All forces shall be disarmed and handed over. For this purpose, after disarmament, units in positions shall assemble at clearly visible places, and other units in barracks. Collected weapons and ammunition shall be gathered and put under supervision.

5. The demands stated in Items 1 to 4 shall be completed by 1200 on 9 March.

6. Bodies identified as Japanese military, [Japanese] prisoners of war, and deceased and living Japanese residents shall be promptly handed over.

7. Any kind of destruction is prohibited. For example, the destruction of war materials, weapons, ammunition, roads or traffic structures is forbidden.

8. Communications with foreign countries are prohibited.

9. The operations of the Japanese Army shall be continued.

10. If the above demands are not met, attacks will be immediately resumed. In order to ensure [compliance with] the demands, armed patrol units necessary to maintain public order shall be formed and provided with a certain number of weapons and ammunition. These patrol units need to be supervised by officers as much as possible. The patrol units shall be made distinguishable by a white armband and a white flag.

After due consideration, I finally had no option but to meet these stipulated demands. I order you to suspend the current hostilities and obey the above-mentioned demands.

When you have received this order, or when you have been contacted by the Japanese Army commander, I ask you to communicate or broadcast [this] through the available radio communication facilities and broadcasting stations, on every whole hour and every thirty minutes starting at 0900 until 1200.

This order applies also to the Navy and all directors of customs.

Major General Pesman, on behalf of the Chief of the Dutch East Indies Army Department

At that time, the positions of [Japanese] units were as follows:

Shōji Detachment: in Lembang (since the evening of the 7th)

Nasu Detachment: in Cimahi (since 0200 on the 9th)

The 2d Division commander: in Kalijati (since before the noon on the 9th)

Satō Detachment: in Krawang (since the night of the 7th)

Fukushima Detachment: near Cibarusa, about thirty kilometers southwest of Krawang, marching toward Krawang

Sakaguchi Detachment: Cilacap

48th Division: near Surabaya and Malang

Following the surrender of the main force of the Dutch East Indies Army, the enemy units in all areas, including about 11,000 British and U.S. troops [stationed] in areas southeast of Bandung, surrendered one after another, and the invasion of the whole of Java was completed by around 12 March. 


\section{The [Naval] Operations Around Java After the Landing of the Army Units}

\section{The Devastation of Cilacap by the Carrier Task Force}

The Carrier Task Force, which had sunk the armed Dutch merchantman Modjokerto, the U.S. special service vessel Pecos, and the U.S. destroyer USS Edsall on 1 March, was joined by the 1st Supply Unit and the 1st Section of the 15th Destroyer Division at 0047 on 2 March at $16^{\circ} 15^{\prime} \mathrm{S} 107^{\circ} 16^{\prime} \mathrm{E}$, then by the 8th Cruiser Division at 0144 at $16^{\circ} 16^{\prime} \mathrm{S} 107^{\circ} 7^{\prime} \mathrm{E}$, and further by the 1st Section of the $3 \mathrm{~d}$ Battleship Division at 0450 at $16^{\circ} 16^{\prime} \mathrm{S} 106^{\circ} 29^{\prime} \mathrm{E}$, and was sailing westward bearing $270^{\circ}$ [W]. On that day, no enemy was spotted. At 2150, the 1st Supply Unit and the 15 th Destroyer Division separated from the main unit at $16^{\circ} 6^{\prime} \mathrm{S} 103^{\circ} 42^{\prime} \mathrm{E} .^{(141)}$

On 3 March, the force spotted no enemy either; Carrier Task Force Commander Vice Admiral Nagumo issued the following order concerning the attack on Cilacap on the next day, the 4 th: ${ }^{(141)}$

\section{Carrier Task Force Signal Order No. 49}

1. At 1100 tomorrow on the 4 th, the Carrier Task Force shall reach a point about 230 nautical miles $215^{\circ}[\mathrm{SW}]$ of the lighthouse of 'JG' (note by the author: Cilacap), and launch the first attack unit. Then, the second attack unit shall be launched as soon as it is ready, and they shall destroy enemy naval vessels at anchor in the port of Cilacap.

2. The formation of the aircraft unit:

The first attack unit: the 4 th formation

The second attack unit: the 5th formation (minus the 11th and the 12th attack units)

The carrier-based attack plane units shall form formations of six aircraft each as long as guiding planes are available. Each carrier shall assign nine of its aircraft for securing air supremacy, while assigning one element of its fighter planes to cover the carrier-based attack plane units in the air.

3- 7. (Omitted by the author: [items concerning] guarding against [enemy] aircraft and submarines, etc.)

8. Target assignments

(a) Carrier-based attack planes and bombers: primarily [enemy] naval vessels and secondly [enemy] merchantmen

(b) Carrier-based fighter planes: enemy aircraft in the air and aircraft at seaplane bases

9- 10. (Omitted by the author: [items concerning] assembling after the attacks; ordnance, etc.)

On 4 March, due to bad weather, the Carrier Task Force postponed the attack on Cilacap until the next day, the 5th. ${ }^{(141)}$ On that day [the 4th], aircraft guarding the route ahead of the force spotted one [enemy] destroyer and one merchantman. One of them attacked the destroyer but did not score a hit. An attack unit (consisting of ten carrier-based bombers) took off, too, but did not spot the enemy due to low visibility. Also, aircraft of the Hiryū spotted an enemy cargo ship ablaze (the Dutch armed merchantman Enggano 5,000* tons at $12^{\circ} 4^{\prime} \mathrm{S} 108^{\circ} 1.5^{\prime} \mathrm{E}^{* *}$ The Chikuma and the Urakaze were sent to deal with her, and at 2043 they sank her with their torpedoes. ${ }^{(141)}$ In executing this task, the Chikuma had at first shelled her. However, since the

* The text mistakenly has 15,000 tons.

** The exact spot is differently cited in the original documents. 
Chikuma used armored shells, whose penetrating power was too strong, the shells did not explode inside the [cargo] ship, and she just uselessly punched holes through [the Enggano's] topsides (the sides above the water), but could not sink her despite the many shells she wasted; in the end, she used her torpedoes. Concerning the attacks on merchantmen, the Malaya Unit had already suffered the same bitter experience in the Bangka Sea (i.e. since merchantmen do not sink instantly even if hit by many shells, [naval vessels] tend to use more shells than necessary). However, this lesson of war was not immediately conveyed to the Carrier Task Force, which led to the useless expenditure of a large number of shells. ${ }^{(124)}$

Meanwhile, Carrier Task Force Commander Vice Admiral Nagumo issued his outline for the attack on the next day by means of Signal Order No. 50.

On 5 March, the Carrier Task Force carried out its attack on Cilacap and reported having sunk or inflicted damage on almost all ships at anchor in the port (the attack was led by Cdr. Fuchida Mitsuo). According to the summary report of the actions, the military gains were as follows: ${ }^{(141)}$

1. Sunk four large and fifteen mid-sized merchantmen, nineteen in total.

2. Bombed and destroyed a few barracks, warehouses, freight cars and antiaircraft batteries.

3. Inflicted serious damage on one small naval vessel.

The Japanese side only sustained damage to a few of its aircraft, which were marked by bullets.

At 1030 on 6 March, at a point about $13^{\circ} \mathrm{S} 109^{\circ} \mathrm{E}$, the Carrier Task Force separated into the main unit ([consisting of] the 1st Carrier Division, the $3 \mathrm{~d}$ Battleship Division 1st Section, the 8th Cruiser Division, the Abukuma and six destroyers) and the detached unit ([consisting of] the $2 \mathrm{~d}$ Carrier Division, the 3d Battleship Division 2d Section and four destroyers), sailed eastward intending to clear the remnants of the enemy, but spotted none. ${ }^{(141)}$

On the early morning of 7 March, the detached unit bombed and destroyed [enemy] ground facilities (the telegraph station, pier[s] and oil tank[s]) on Christmas Island for about twenty minutes. The enemy raised a white flag, which led the force to think that the island could easily be captured with a small force. On that day, the aircraft unit of the Sōryū sank two armed merchantmen at a point about ninety nautical miles $300^{\circ}$ [WNW] of Christmas Island. ${ }^{(71)}$ After that, neither the main unit nor the detached unit spotted any enemy; at 1030 on the 11th, the Carrier Task Force returned to Staring Bay without incident. ${ }^{(141)}$

Earlier, when changing anchorages at Palau, the Kaga had hit an uncharted reef in the east waterway and sustained minor damage to her hull, which caused some leaks. The vessel had participated in the first and the second carrier operations after emergency repairs conducted by her crew. However, as a result of an examination of her bottom on her return to Staring Bay on 11 March after the second carrier operation, it was decided that, since the damage was serious enough to raise concern about her participation in the attack on Ceylon, she should return to mainland Japan for a while for repairs. As of 13 March, she was removed from the Carrier Task Force and transferred to the guard unit. 


\section{The Main Body of the Southern Task Force Destroys Enemy Vessels [on the Waters] South of Java (See Illustrations No. 50 and No. 51)}

On the early morning of 1 March, the main body of the Southern Task Force reached the waters about seventy nautical miles south of Cilacap, after which, it gradually pushed southward while cruising from east to west on the waters south of Java (as previously told [pp.475-76]). The military gains reported on that day were four merchantmen, who were sunk, ${ }^{(58)}$ one ship, who was set ablaze, and another, who was captured. On the morning of 2 March, the Hayashio captured a Dutch ship (1,100 ton). As of the noon that day, the location of [the main body of] the Southern Task Force was about three hundred nautical miles south of Cilacap. At 1340, the chief of staff of the force sent the following telegram concerning the subsequent operation schedule: ${ }^{(141)}$

From: Chief of Staff of the Second Fleet

To: The Dutch East Indies Unit (minus the Supply Unit), the Air Unit, and the Carrier Task Force Second Fleet Classified Telegram No. 63 ([at] 1340, [on] 2 March 1942)

1. The main body of the Southern Task Force ([consisting of] the 4th Cruiser Division (minus the Chōkai), the 4th Destroyer Division 1st Section) shall operate on the waters south of Java, and after passing a point about 160 nautical miles $196^{\circ}$ [S] of Bali at 1000 on the $3 \mathrm{~d}$, it shall reach a point about one hundred nautical miles $150^{\circ}$ [SE] of Cilacap at 0800 on the 4 th, to act in concert with the attack to be conducted by the Carrier Task Force.

2. The oiler Tōei-maru [A] and the [destroyer] Hayashio shall join the main unit at a point around 160 nautical miles $204^{\circ}$ [SSW] of Bali at noon on the $3 \mathrm{~d}$, and follow in the wake of the unit.

3. Since the ships captured in our area (most of which will be provided with a crew, sail our naval flag and hoist antiaircraft identification marks (the national flag)) will be sent to Bali or Makassar, see to it that they will not be attacked.

After having sent this telegram, [the Southern Task Force] received a report from the landbased air unit that two enemy destroyers had been spotted at a point about three hundred nautical miles southwest of Bali and one [enemy] light cruiser about one hundred nautical miles to their south. On receiving this report, Southern Task Force Commander Vice Admiral Kondō gave orders to the Atago and the Takao to go in hot pursuit of the enemy light cruiser, and to the Maya and the 1st Section of the 4 th Destroyer Division to go in pursuit of the enemy destroyers, and destroy them. ${ }^{(68)}$

In accordance with the order, the Atago and the Takao sailed south at twenty-six knots bearing $130^{\circ}$ [SE], searching for the enemy. At 2200 , at $15^{\circ} 38^{\prime} \mathrm{S} 113^{\circ} 13^{\prime} \mathrm{E}$, they spotted at about 18,000 meters at $73^{\circ}$ [ENE] the silhouette of a vessel, which looked like an enemy [vessel] that gradually approached them. After taking a good look, she was identified as a U.S. Marblehead-class* cruiser; at 2225, with their searchlights on, they opened fire at the enemy at a range of 5,200 meters, and sank her at 2232. Although the enemy was seen to have fired from her aft turrets during the artillery duel, it was unclear where her shells had landed. ${ }^{(162)}$ In the meantime, the Maya and the 1st Section of the 4th Destroyer Division hotly pursued the enemy destroyer (the British destroyer HMS Stronghold). At 1912, first of all the Maya opened

\footnotetext{
* She actually was the destroyer USS Pillsbury. The mistake is understandable as both the USS Marblehead and the USS Pillsbury were four-stackers.
} 


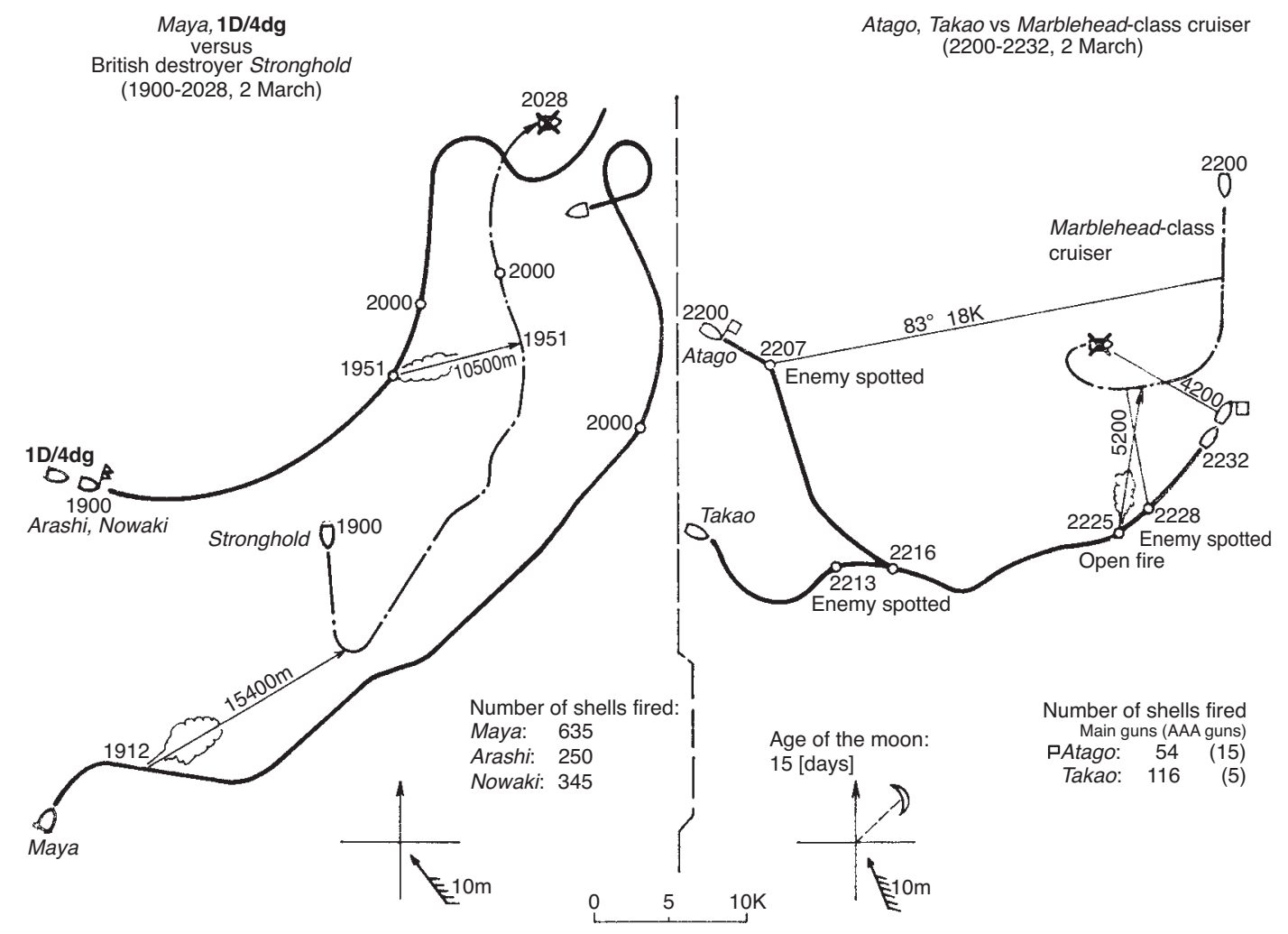

Illustration No. 50 - The Engagements with a British Destroyer and a U.S. Cruiser

fire at a range of 15,400 meters, and then the 1st Section of the 4 th Destroyer Division at a range of 10,500 meters at 1951. They sank her at 2028. ${ }^{(162)}$

At 1000 on 3 March, the main body of the Southern Task Force reached a point about 160 nautical miles $196^{\circ}$ [S] of Bali, and changed course westward. At 1036, the 1st Section of the 4th Destroyer Division caught up with the U.S. Gunboat USS Asheville, opened fire at a range of 8,500 meters, and sank her at 1108. Around noon that day, the main body joined the Tōeimaru and the Hayashio, who had operated separately, and carried out a refueling at sea. ${ }^{(68)}$

At 0800 on 4 March, the main body of the Southern Task Force was cruising around 280 nautical miles $170^{\circ}$ [S] of Cilacap, and from 0740 until around 0900, it sank one Australian sloop, one British oiler, one British merchantman and one British minesweeper. ${ }^{(68)}$ Meanwhile at 1620, the Arashi seized an armed Dutch merchantman (7,089 tons, carrying about 250 marines and about 250 sailors called "cadets"), wich the land-based air unit had spotted and reported. ${ }^{(163)}$ Further at 2030, the Atago seized another Dutch ship (1,030 tons). ${ }^{(68)}$ As of that day, the main body of the Southern Task Force completed the carrier [operation] on the sea to the south of Java, and returned to Staring Bay at 1305 on 7 March without incident. ${ }^{(61)}$ 


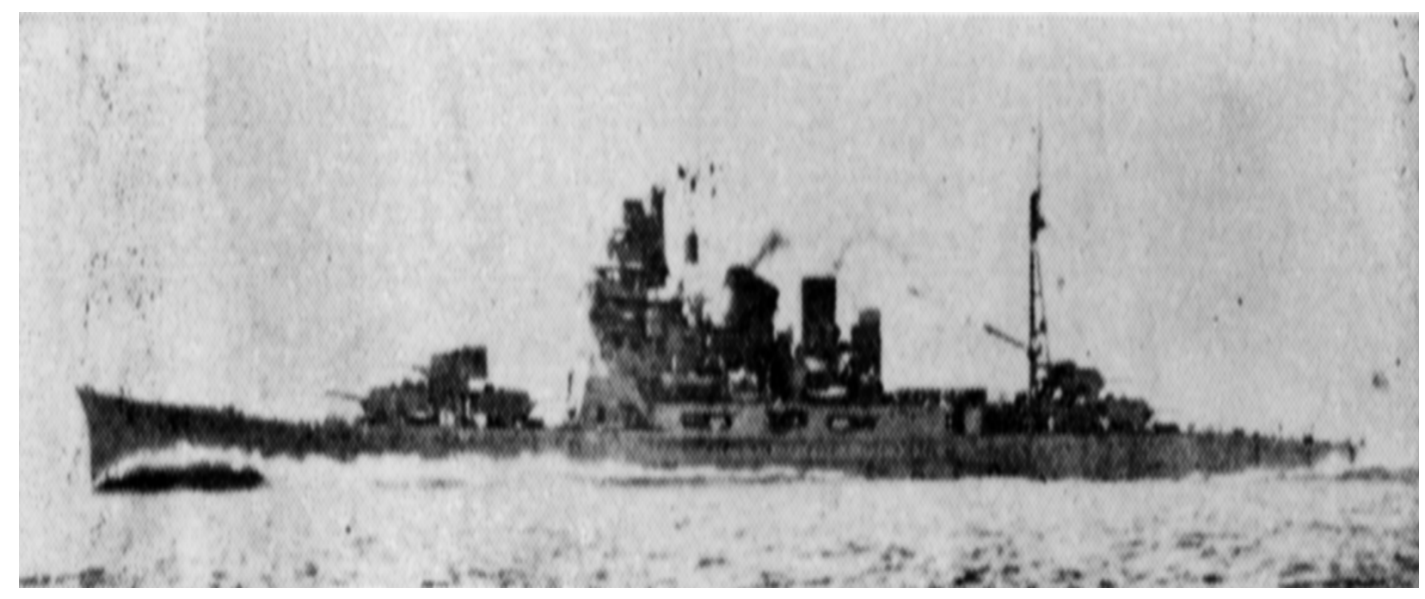

The Cruiser Atago

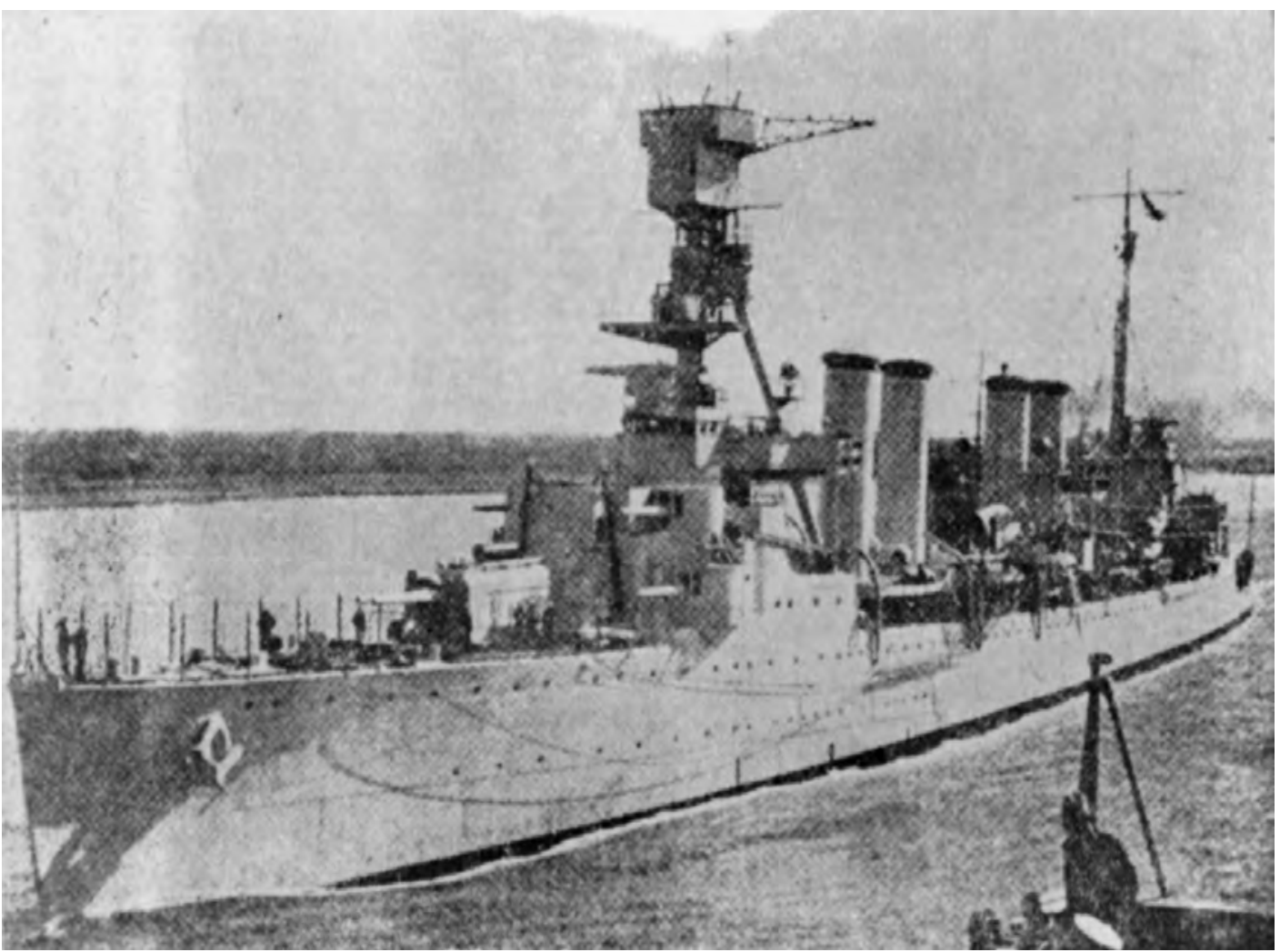

The U.S. Cruiser USS Marblehead

The Actions of the [Land-Based] Air Unit

The major operations carried out by the 1st Air Raid Unit were as follows: ${ }^{(71,81)}$ (The military gains [cited below] are those that were reported.) 

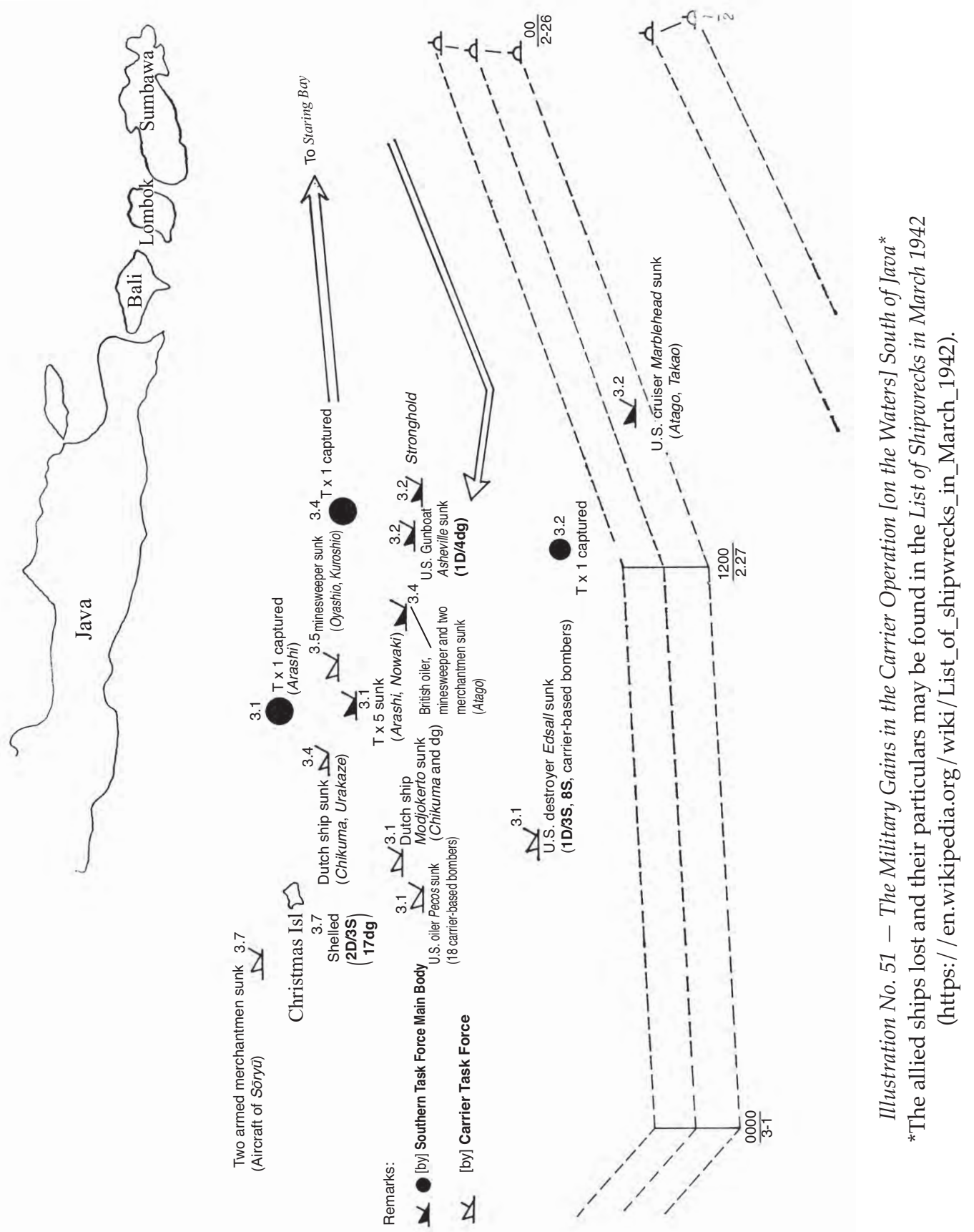
1 March: Twenty-seven land-based attack planes of the Kanoya Air Group conducted an attack on [enemy] cruisers in the Surabaya area. [Having spotted no cruisers], they inflicted damage on two destroyers, two submarines, two special service vessels and one merchantman.

3 March: One land-based reconnaissance plane and nine Type- 0 fighter planes of the $3 \mathrm{~d}$ Air Group Detachment raided Broome ([on] the northern coast of Australia), brought down four [enemy] aircraft and set twenty-four aircraft [on the ground] ablaze; two Type-0 fighter planes did not return (of which one crew was rescued on the 21st). [Another] land-based reconnaissance plane and eight Type- 0 fighter planes of the $3 \mathrm{~d}$ Air Group Detachment carried out an attack on Wyndham ([on] the northern coast of Australia), set ablaze one [enemy] transport plane, one hangar, and six hundred drums.

4 March: One land-based reconnaissance plane and nine Type-0 fighter planes conducted a reconnaissance attack on Port Darwin, and set five bombers ablaze; four of Japanese aircraft were marked by bullets.

During these days, the Tōkō Air Group conducted a search mission over the waters up to six hundred nautical miles southwest of Kupang as well as patrolling the surrounding areas, while the 3d Air Group Detachment patrolled in the air above Kupang, but spotted almost no enemy. On 5 March, the 21st Air Flotilla headquarters and the Kanoya Air Group were transferred to the Northern Task Force; they left Kendari at 0830 for Kasumigaura.

[Meanwhile,] the major operations carried out by the $2 \mathrm{~d}$ Air Raid Unit were as follows:(71) (The military gains [cited below] are those that were reported.)

1 March: Seven land-based attack planes of the Takao Air Group carried out an attack on the Blimbing airfield ([in] eastern Java) and inflicted damage on fourteen P-40s and five Buffalo fighter planes [on the ground]. [Another team of] seven land-based attack planes [of the group] carried out an attack on the Yogyakarta airfield and set two large aircraft ablaze and blew up one large aircraft. [One element of] twenty-five Type-0 fighter planes (in five shifts) of the Tainan Air Group on patrol in the air over the convoy [against enemy aircraft] also spotted enemy aircraft on the Blimbing airfield and inflicted damage on one twin-engine aircraft and more than a dozen fighter planes. Also, six Type-0 fighter planes of the $3 \mathrm{~d}$ Air Group [went for] an attack on Blimbing, while providing cover to the land-based attack plane unit, carried out an attack and inflicted serious damage on seven $\mathrm{P}-40$ fighter planes and three Buffalo fighter planes.

2 March: Fourteen land-based attack planes of the Takao Air Group carried out a bombing attack on the Yogyakarta airfield, set two large aircraft ablaze and blew up two other large aircraft. Nine Type-0 fighter planes of the Tainan Air Group carried out an attack on a reconnaissance seaplane base to the north of Malang, blew up one four-engine flying boat, two twin-engine flying boats, and one [single-engine] flying boat, while six [other] Type-0 fighter planes of the group conducted an attack on Yogyakarta and Malang and blew up two twin-engine aircraft.

3 March: Twenty-four land-based attack planes of the Takao Air Group carried out an attack on the Bandung airfield and set two aircraft ablaze. Six Type-0 fighter planes of the Tainan Air Group attacked Cilacap and set one PBY flying boat ablaze, while twelve [other] Type- 0 fighter planes of the group carried out an attack on Bandung and brought down one P-40 fighter plane and blew up eight aircraft [on the ground]. Twelve Type- 0 fighter planes of the $3 \mathrm{~d}$ Air Group provided cover for the units carrying out a bombing on the Bandung [airfield], and also blew up seven large and two smaller aircraft. 
4 March: Twenty-three land-based attack planes of the Takao Air Group carried out an attack on the naval vessels at anchor in the port of Cilacap, sank four merchantmen and one cruiser, while destroying five merchantmen.

From 5 March onwards, [the Air Unit] spotted almost no enemy, except for a few merchantmen and submarines [on the waters] near Java, and by 9 March, no enemy was in sight. During this period, the Takao Air Group carried out search missions in the Indian Ocean day after day, whereas the Tainan Air Group and the 3d Air Group busily patrolled in the air over the convoy anchorage as well as over the Bali base while providing cover for the land-based attack plane units to attack [enemy] airfields.

The 3d Air Raid Unit from 1 March onwards also day after day carried out search missions in the eastern parts of the Indian Ocean as well as on the waters south of the Sunda Strait, reconnaissance attacks in western Java, a reconnaissance over the Cocos Islands, and attacks on Christmas Island, while conducting patrols in the air over Patrol as well as over the convoy. In the attack on Bandung on 4 March, twenty-five land-based attack planes of the Kanoya Air Group made a sortie and reported having inflicted damage on eight large, four mid-sized and four small aircraft as well as setting ablaze one hangar. Meanwhile, the main body of the Kanoya Air Group was transferred to the Northern Task Force as of 5 March and took off from the Gelumbang base [first] for the Thủ Dâu Một base to head back for Tokyo Bay. Also, the Genzan Air Group moved to Saigon from the 7th to the 10th of March, in order to participate in the operations in the Burma area. ${ }^{(71)}$

As for the Mihoro Air Group of the Malaya Unit, it put five of its Type-96 carrier-based fighter planes under the command of 22d Air Flotilla (3d Air Raid Unit) Commander R. Adm. Matsunaga Sadaichi on 4 March and advanced them to Kalijati, leaving Gelumbang at 0915. Although one of them was seriously damaged at the time of the advance, the fighter plane unit actively conducted patrols in the air over the convoy from Kalijati, and then headed for the Penang base on the 6th by way of Mentok. ${ }^{(135)}$ Four land-based attack planes, which had been dispatched [from the air group] to Sungai Petani as well as the land-based attack plane unit of the Mihoro Air Group, which had been stationed at the Kuantan base, also presumably moved to the Penang base on the 6th.

[In the meantime,] the major operations of the 1st Air Group (the 12th Seaplane Tender Division) were as follows.

At 0400 on 1 March, 3d Escort Unit Commander Rear Admiral Hara reported the successful landing in the Patrol area. On receiving this report, 1st Air Unit Commander R. Adm. Imamura Osamu sent an order to the Toboali Base Commander: "[They] successfully landed. Promptly advance [the aircraft]." (122) Accordingly, all aircraft stationed at the Toboali base left by 1115 . Three Type- 0 observation seaplanes and one Type- 0 reconnaissance seaplane each of the Kamikawa-maru and the San'yō-maru arrived in Bantam Bay one after another a little after noontime and provided guard against enemy submarines at the anchorages in Bantam Bay as well as for Merak. ${ }^{(55)}$ At 1905, [a] Type-0 reconnaissance seaplane of the Kamikawamaru spotted a periscope on the waters southwest of St. Nicholas Point [Tanjung Pujut], carried out a bombing and scored a direct hit. Following that, [a] Type-0 observation seaplane of the San'yo-maru also attacked the submarine and scored a direct hit. Then they dropped a smoke marker to guide two friendly destroyers and have them attack the submarine, judging that fatal damage had been inflicted. Since no location along the coast of Bantam Bay was 
found suitable for a base, [the unit] narrowly managed to set up a base by the evening on an uninhabited island in the western part of the bay.

However, because the base did not have adequate space to set up a camp, [the personnel] slept in an enemy gunboat which had run aground on the island. Since the sea was calm and had an appropriate depth, the place was about fit for use.

In the meantime, two Type-0 observation seaplanes each of the Kamikawa-maru and the San'yo-maru advanced to the Patrol area as well to provide guard over the convoy anchorage against enemy submarines. During that time, they fought off frequent raids by enemy fighter planes. However, enemy strafing set ablaze one Type-0 observation seaplane that was in the middle of refueling and inflicted damage on another which made it unable to fly. Since also the waves were high at Patrol, which made it difficult to set up a base there, the remaining two Type-0 observation seaplanes called off the use of the Patrol base and shifted to the Bantam base. ${ }^{(122)}$

Thereafter, the 1st Air Unit provided every day direct guard over the anchorage against enemy aircraft as well as submarines. On the $2 \mathrm{~d}$, the unit reported having sunk three enemy submarines and driven back enemy bombers, which had come for a raid. On the 4th, at the request of the Army, the unit provided support for the ground combat, in which it bombed enemy strongholds and attacked [enemy] tanks. Meanwhile, the Kamikawa-maru and the San'yo-maru had left Anambas at 1900 on the 2d and put in at Bantam Bay at 1130 on the 5th. Although the Kamikawa-maru had been removed from the Dutch East Indies Unit and transferred to the Malaya Unit on the 4 th, she continued her operations. ${ }^{(122)}$ On that day [the 4th], at 1420 , the oiler Erimo (14,050 tons) was sunk by enemy torpedo attacks at $4^{\circ} \mathrm{S} 108^{\circ} \mathrm{E}$; reconnaissance seaplanes of the Kamikawa-maru and the San'yō-maru were dispatched to reconnoiter the situation and neutralize the enemy submarines, but they spotted no enemy. From that time on, neither enemy aircraft nor submarines were spotted either in Bantam Bay or [near] Patrol. ${ }^{(55)}$

On the 8th, Southern Task Force Commander Vice Admiral Kondō removed the Kamikawamaru, which he had earlier transferred to the Malaya Unit, from the Malaya Unit, and transferred the San'yo-maru to the unit instead. ${ }^{(55)}$ On that day, the Kamikawa-maru left Bantam Bay for Singapore (and put in at Seletar on 11 March). The San'yo-maru, who was at anchor in Bantam Bay until the 10th, participated in the Andaman operation from the 22d. [Meanwhile] it was decided that the Kamikawa-maru should operate as designated by the Fourth Fleet commander in chief; she headed for the southeastern theater. ${ }^{(63)}$

The $2 \mathrm{~d}$ Air Unit (the 11th Seaplane Tender Division), which was operating on the waters near the west coast of Bawean Island on 1 March (as previously told [p. 458]), set up a base at Karangdawa about three nautical miles west of Cape Awarawar on the $2 \mathrm{~d} .{ }^{(71)}$ Thereafter, the Chitose, the Mizuho and the aircraft of the Sanuki-maru day after day provided guard in the air above the convoy, and conducted patrols against enemy submarines as well as search missions over the Java Sea, while [also] supporting the ground combat. The military gains the unit reported in the Surabaya invasion operation were as shown in the following table. ${ }^{(79)}$ 


\begin{tabular}{|c|c|c|c|c|c|}
\hline $\begin{array}{c}\text { Participating } \\
\text { Forces }\end{array}$ & $\begin{array}{c}\text { Number of } \\
\text { Sorties in } \\
\text { Total }\end{array}$ & $\begin{array}{c}\text { Number of } \\
\text { [Enemy] Air- } \\
\text { craft Shot } \\
\text { Down }\end{array}$ & $\begin{array}{c}\text { Number of } \\
\text { [Enemy] Air- } \\
\text { craft De- } \\
\text { stroyed }\end{array}$ & $\begin{array}{c}\text { Number of } \\
\text { [Enemy] Ve- } \\
\text { hicles De- } \\
\text { stroyed }\end{array}$ & [Enemy] Naval Vessels \\
\hline $\begin{array}{c}\text { 11th Seaplane } \\
\text { Tender Div }\end{array}$ & 643 & 3 & 19 & About 21 & $\begin{array}{c}\text { Rendered 1 Destroyer } \\
\text { abandoned; sank 1 mer- } \\
\text { chantman and destroyed } \\
\text { another; destroyed 2 sub- } \\
\text { marines, the latter was un- } \\
\text { confirmed }\end{array}$ \\
\hline Sanuki-maru & 77 & 1 & 0 & 0 & 0 \\
\hline
\end{tabular}

In this period, on the 4th, the Mizuho sailed to Kendari to repair her hull and engine; after she underwent maintenance until the 9th, she headed back for the Surabaya area. After the overall surrender of the Dutch East Indies on the 9th, the $2 \mathrm{~d}$ Air Unit put in at Kragan on the 12th, dismantled the Karangdawa seaplane base and left Awarawar at 2000 for Makassar, where the unit put in at 1130 on the 14th. ${ }^{(169)}$ The aircraft unit of the Sanuki-maru presumably returned to the Sanuki-maru at anchor in Balikpapan on 12 March.

As for the 4th Carrier Division, it had reached a point to the north of the Karimata Strait on the morning of $1 \mathrm{March}^{(72)}$ and supported the 5th Cruiser Division's attack on the enemy cruiser unit [HMS Exeter, p. 445, 461]. Then on the 2d and the 3d, it carried out search missions in the western parts of the Java Sea, in the Karimata Strait as well as in the coastal areas of northern Java, while searching for remnant [enemy] vessels [in] Cilacap, and reported military gains of having sunk one 6,000t-class merchantman, and having two 500-ton class merchantmen run aground. ${ }^{(71)}$ Then in accordance with the telegraphic order of the Southern Task Force issued at 2040 on the $3 \mathrm{~d}$ that [the 4 th Carrier Division] should be removed from the Dutch East Indies Unit and transferred to the Malaya Unit as of 5 March, ${ }^{(53)}$ the division left the western part of the Java Sea that night for Singapore, and put in at the port on 5 March. ${ }^{(72)}$

\section{The Engagements of the Army Air Units ${ }^{(117)}$}

At 2000 on 28 February, [Army] Third Air Force Commander Lt. Gen. Sugawara Michiō had given orders to the 12th Air Division and the $3 \mathrm{~d}$ Air Division that the former should cover the sailing of the convoy and provide guard over the anchorages against enemy aircraft, while the latter should from 1 March onwards mainly provide direct support to the operations of the main force of the $2 \mathrm{~d}$ Division and the Shōji Detachment. In accordance with these orders, the 12th Air Division took charge of providing antiaircraft guard over the anchorages with a total of fifty-five aircraft on 28 February, a total of ninety aircraft on 1 March and a total of seventy-four aircraft on the $2 \mathrm{~d}$. From the $3 \mathrm{~d}$ onwards, the division provided antiaircraft guard over the Merak and Bantam Bay anchorages with its main force, while guarding the Palembang refineries from the air.

Meanwhile on 1 March, the 3d Air Division directly supported the engagements of the $2 d$ Division and the Shōji Detachment with its full force. Upon the seizure and conditioning of the Kalijati airfield by the Shōji Detachment on 2 March, the 3d Air Division commander 
advanced one element of the 59th Air Group and the main force of the 27th Air Group, which was followed by the advance of the main force of the $3 \mathrm{~d}$ Air Division to the airfield as early as on the $3 \mathrm{~d}$. On that day, [the air division] carried out attacks on mechanized enemy units coming for a counterattack toward the airfield, destroyed and set ablaze the major part of it, and completely crushed the intentions of the enemy [Vol. 3, p. 513, 521]. From the 4th onwards, the air division supported the engagements of the Shōji Detachment with its main force and those of the $2 \mathrm{~d}$ Division with one element, while carrying out attacks on the airfields near Bandung, thereby facilitating the Shōji Detachment's charge toward Bandung.

\section{The Eastern Java Units Clear [the Sea of] the Enemy}

At 0235 on 1 March, the 1st Escort Unit led the convoy carrying the main force of the 48th Division into the Kragan anchorage with the direct support of the 5 th Cruiser Division unit and the $2 \mathrm{~d}$ Destroyer Squadron unit, and the army unit successfully made its first landing at 0400. After that, the surface unit mainly engaged in guarding near the anchorage of the convoy as well as watching the area at the north entrance of the port of Surabaya, ready against escaping enemy vessels. At that time, no chain of command existed between the 1st Escort Unit Commander (4th Destroyer Squadron Commander Rear Admiral Nishimura) and 2d Destroyer Squadron Commander Rear Admiral Tanaka; the 2d Destroyer Squadron unit [simply] supported the 1st Escort Unit.

At 0405 on 1 March, the Natsugumo of the 9th Destroyer Division spotted an enemy torpedo boat and fired at the latter using her searchlights, but she was not able to sink the boat. At 0605, again an enemy torpedo boat intruded into the anchorage; the Murasame of the $2 \mathrm{~d}$ Destroyer Division immediately responded by firing at the boat but the enemy escaped, spreading a smoke screen. ${ }^{(62)}$ Following the persistent [air] raids of the previous night, on this day again from around 0735 onwards ten four-engine bombers and more than a dozen enemy fighter planes raided the anchorage of the convoy. Although the fighter planes repeatedly strafed the convoy and the landing craft from a low altitude for about twenty minutes, fortunately no damage was sustained. At 0815, right after the enemy fighter planes had left the scene, nine friendly observation seaplanes and two Type-0 fighter planes finally appeared in the sky over the convoy. ${ }^{(62)}$

At 1120, the 4th Destroyer Squadron commander received orders from Dutch East Indies Unit Commander Takahashi that he should take the 2d Destroyer Squadron commander under his command regarding the guarding [of the waters] surrounding the anchorage of the transport ships off Kragan. ${ }^{(62)}$ In line with this order, 4th Destroyer Squadron Commander ([and] 1st Escort Unit Commander) Nishimura gave orders to assign the guarding of the waters to the west of $112^{\circ} \mathrm{E}$ to the 4 th Destroyer Squadron and the $2 \mathrm{~d}$ Base Force, while that of the waters to the east of $112^{\circ} \mathrm{E}$ to the $2 \mathrm{~d}$ Destroyer Squadron. ${ }^{(53)}$ It was around that time that the 5th Cruiser Division spotted the enemy cruiser and two destroyers to the west of Bawean Island. (The daylight engagement on 1 March.)

On that day, the following enemy raids occurred: ${ }^{(53,62)}$

0935: The Jintsū spotted two wakes of enemy torpedoes at $100^{\circ}$ starboard* and evaded them; the 1st Section of the 8th Destroyer Division guarding the patrol area conducted an attack

* In the Action Report of the 2d Destroyer Squadron: port. 
with depth charges at the point where the torpedo wakes had started. However, in the subsequent search no clues were detected, and the section reported having almost certainly sunk [the enemy] ([at] forty-eight nautical miles $230^{\circ}$ [SE] of Bawean Island).

1343: Enemy aircraft raided and bombed the convoy anchorage but inflicted no damage.

2223: The Jintsu spotted a surfaced enemy submarine; the Amatsukaze and the Hatsukaze immediately pursued and attacked her with depth charges, but the results were unclear ([at] fortyeight nautical miles $230^{\circ}$ [SE] of Bawean Island).

2332: The Natsugumo and the Minegumo detected an enemy submarine and attacked her; having spotted oil and air bubbles welling up, they reported the results as certain ([at] the outer area of the convoy anchorage).

The small-scale minesweeping, which had been conducted on that day from early morning onwards, made smooth progress; it was roughly completed in the morning with no mines snagged. By sunset, the convoy completed shifting its anchorage to the second anchorage (an anchorage closer to the shore). Meanwhile at 2305, the Tomozuru of the 21st Torpedo Boat Division put in at Kragan from Banjarmasin without incident, escorting the Sasako-maru carrying the Sakaguchi Detachment on board. ${ }^{(62)}$

The situation on 2 March was as follows: ${ }^{(53,62)}$

0438: The Jintsū spotted a surfaced enemy submarine; the Yukikaze and the Tokitsukaze headed for an attack but since she submerged at a point 1,000 meters* from them, the result of their depth charge attack was unclear ([at] fifty nautical miles $235^{\circ}$ [SW] of Bawean Island).

0532: The Tokitsukaze spotted a surfaced enemy submarine. As she was approaching, the enemy submerged at a point 5,500 meters from her. She conducted a depth charge attack, but with unknown results.

0655: The Yukikaze spotted an enemy submarine which was about to submerge and conducted a depth charge attack, but with unknown results ([at] thirty-four nautical miles $200^{\circ}$ [SSW] of Bawean Island).

2040 The Yukikaze spotted a surfaced enemy submarine, but the enemy submerged shortly. She conducted a depth charge attack but with unknown results ([at] thirty-one nautical miles $233^{\circ}[\mathrm{SW}]$ of Bawean Island).

On that day, the aircraft of the Naka took off at 1250 for a search mission over the outer sea areas of the anchorage ranging from the north entrance of the port of Surabaya to Bawean Island to the Karimunjawa Islands, but spotted no enemy. At 1540, 1st Escort Unit Commander Nishimura reported the progress of the disembarkation of the transport ships to the chief of staff of the Third Fleet: "The disembarkation of the Army transport ships in our area has been making very smooth progress. It is expected that [the disembarkation of] about fifteen ships will be completed by tomorrow evening, the $3 \mathrm{~d}$, and that of the remaining ships by around the 6th."

The situation on 3 March was as follows:

2002 The Jintsū spotted a surfaced enemy submarine. The Amatsukaze headed for an attack; at 2026, at a range of 2,000 meters, she started firing at [the submarine] using her searchlights and scored a number of hits. Then she carried out a depth charge attack at the center of the spot where oil and bubbles were welling up and spreading all over the area, and reported

\footnotetext{
* In the Action Report of the 2d Destroyer Squadron: $10 \mathrm{~km}$.
} 
having sunk [the enemy submarine] with certainty. While engaging with this enemy, she spotted the wake of a torpedo and evaded it. ([at] forty-one nautical miles $234^{\circ}$ [SW] of Bawean Island)

2105 Having detected a submerged [enemy] submarine, the $Y \bar{u}$ dachi carried out a depth charge attack, spotted flames and black smoke arising, and reported the result as certain ([at] 700 meters $333^{\circ}[\mathrm{NW}]$ of Cape Petokol).

On that day, the aircraft of the Naka took off to guard the outer sea area of the convoy anchorage and the north entrance of the port of Surabaya but spotted no enemy other than [one] patrol boat of about 200-ton [along] the west coast of the north entrance channel. Meanwhile, the destroyers took turns heading for Banjarmasin for replenishment. ${ }^{(53)}$

At 1100 on 4 March, 1st Escort Unit Commander Nishimura sent the following telegram to the chief of staff of the Third Fleet after having discussed with the Army side the escort of the transport ships after their disembarkation had been completed:(62) "Since the disembarkation of the Army transport ships in our area has made such smooth progress that it is likely that everything will be completed by the end of the 6th, it was decided in principle that the ships should [be sent back] to mainland Japan by way of Saigon, and that one element should directly sail to Gaoxiong after sailing part of the route along with the others. Therefore, we would like you to know that we have agreed that our unit shall directly escort the above convoy until it passes through the Karimata Strait and that indirect escort shall be provided thereafter." On that day, aircraft of the Jintsu searched for the enemy on the waters nearby, but spotted no enemy other than one patrol boat at the north entrance of [the port of] Surabaya, and it was judged that most of the enemy surface vessels had been destroyed. However, enemy submarines were still considered to be around. Concerning [the mission of] destroying [enemy] submarines, the 1st Escort Unit received the following telegram. ${ }^{(62)}$ (Third Fleet Classified Telegram No. 638)

\begin{abstract}
Putting together the statements of a captured U.S. submarine captain, we may conclude that British, Dutch and U.S. submarines are crowding near our landing points in an unorganized way, and that, moreover, due to their prolonged operations ([for example,] the submarine USS "Baachi,"* which was sunk on 21 January, had replenished only once at Balikpapan, after having left Manila on 11 December), their fighting power has remarkably deteriorated. Although we are more than aware that the crew of our destroyers and lesser vessels are exhausted from prolonged engagements for days and nights on end, taking this opportunity, I would like you to more aggressively hunt enemy submarines, thoroughly carry out attacks until their sinking is confirmed, and thereby produce adequate military gains. Moreover, it seems that U.S. submarines [usually] surface some (illegible) hours after sunset and their battery charging would finish in four or five hours. In such a case, conducting clearing operations at night will be a particularly effective method.
\end{abstract}

Also, 2d Destroyer Squadron Commander Tanaka expressed his views as to [the mission of] destroying [enemy] submarines in his action report of 12 March in the following way:

\footnotetext{
* Probably USS Perch is meant. However, she was not sunk on 21 January, but scuttled by her crew on 3 March near Bawean Island after having been badly damaged by Japanese depth charges on 1 March. Her entire crew was captured by the Japanese. See: https: / / en.wikipedia.org/wiki/USS_Perch_(SS-176)
} 
1. In the mission to completely destroy enemy submarines in this operation, we were able to achieve phenomenal results because the dispositions of the clearing units were appropriate, the [bright] moonlight made it easy to spot enemy submarines at an early stage, the enemy was totally exhausted from our clearing [operations] carried out for days and nights on end, and because the power of the depth charges was enhanced due to shallowness of the waters. It was very efficient to relentlessly conduct day and night attacks on "enemy submarines that would gather to get their prey in sight," and, above all, to carry out rapid clearing operations around one hour after sunset, when they would surface.

2. It seemed that the enemy submarines swarmed around without any direction, simply taking aim at our convoy. It did not look like an organized deployment. On top of that, their skills in launching torpedoes were poor; the torpedo wakes were obvious (like those running on compressed air) and their speed was thought to be about thirty-five knots at best.

This is also evident from the fact that since the opening of hostilities no enemy torpedoes have hit [Japanese] naval vessels sailing at high speed (sixteen knots or more).

If we sail at an appropriate speed, appropriately use a [destroyer] screen and take appropriate evasive actions, I consider it easy to force our way through waters where so far enemy submarines have appeared and are likely to be hiding underwater.

At 0415 on 5 March, the Tokitsukaze of the 16th Destroyer Division, who was on her way back to her patrol area after refueling at Banjarmasin, came under a torpedo attack by an enemy submarine at a point eighteen nautical miles $300^{\circ}$ [WNW] of Bawean Island. She promptly evaded the attack and carried out a depth charge attack. When she spotted a large amount of heavy oil and many bubbles welling up, she reported having confirmedly sunk the submarine. ${ }^{(53)}$ At 0630 1st Escort Unit Commander Nishimura received the following telegram from Dutch East Indies Commander Takahashi. ${ }^{(56)(63)}$

\section{Third Fleet Classified Telegram No. 643}

1. After putting together various kinds of information, it seems that as a result of the recent engagements, the enemy fleets in the Dutch East Indies area have all been destroyed except for some of the smaller vessels.

2. All units shall continue their previous tasks other than [those specified] below and particularly strive to completely destroy enemy submarines and capture enemy vessels:

(a) The main unit (the Ashigara and the 1st Section of the 7th Destroyer Division) shall leave the site on the night of 4 March and put in at Makassar on 5 March.

(b) The 5th Cruiser Division shall sail to Makassar after replenishment.

(c) The 1st Base Force commander shall sail to the Batavia area leading the Nagara, the Tsukushi, the $2 \mathrm{~d}$ Subchaser Division, the 21st Minesweeper Division (minus Minesweepers No. 11 and No. 12) and the 21st Subchaser Division and put himself under the command of the $3 \mathrm{~d}$ Escort Unit commander.

(d) Submarine Chaser No. 1 shall sail to Makassar to take charge of guarding the place.

(e) The 8th Destroyer Division (minus the Ōshio and the Michishio) and the 21st Destroyer Division (minus the Hatsuharu) shall continue their previous tasks under the command of the 8th Destroyer Division commander.

(f) The 4th Destroyer Squadron commander shall continue his previous tasks leading the $2 \mathrm{~d}$ Destroyer Squadron and the forces of the $2 \mathrm{~d}$ Base Force operating near Kragan, while watching the northern channel of Surabaya.

(g) The 11th Seaplane Tender Division commander shall support the 4th Destroyer Squadron commander with one element of his force in watching enemy vessels evacuating from Surabaya. 


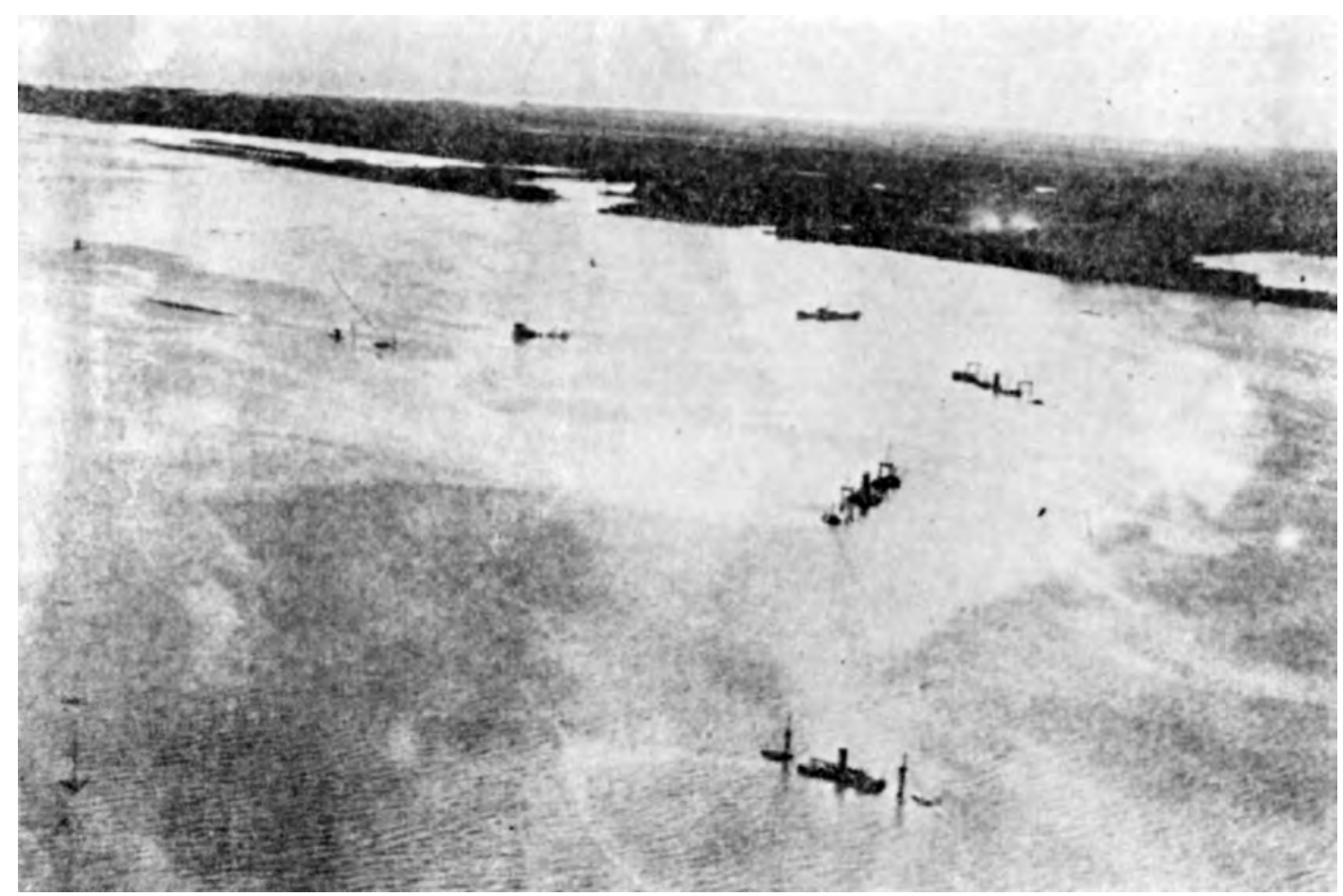

The Miserable State of the Port of Surabaya at the Time of the Invasion

On that day, aircraft of the Naka searched the vicinity for the enemy, but spotted none, other than one patrol boat near the mouth of the bay. ${ }^{(62)}$

On 6 March, no enemy was spotted in either the patrol areas or the convoy anchorage. On that day, 1st Escort Unit Commander Nishimura sent [the following] telegram about the schedule of the return of the transport ships: "It was decided in the talks with the Army that the Army transport ships in our area should leave Kragan on the morning of the 8th and pass through the Karimata Strait, and that the major part of them should return to mainland Japan by way of Saigon, while one element should sail to Gaoxiong or Singapore." Along [with this telegram], he issued the 1st Escort Unit Order concerning the escort of the convoy. ${ }^{(62)}$

At 1430 on 7 March, 1st Escort Unit Commander Nishimura sent the following telegram to $2 \mathrm{~d}$ Destroyer Squadron Commander Tanaka and 2d Base Force Commander Hirose Suéto: ${ }^{(62)}$

1. I shall leave the anchorage at 0900 on the 8th leading the 1st Escort Unit (4th Destroyer Squadron (minus the 4th Destroyer Division, the 24th Destroyer Division, the Asagumo and the Yamagumo), the 11th Minesweeper Division, Minesweeper No. 20, the 31st Subchaser Division (minus Submarine Chaser No. 11)) to escort the transport convoy of thirty-nine ships up to the north entrance of the Karimata Strait, except for the Tokushima-maru, who was beached due to leaks and will be left behind under a guard. I shall return to Kragan on the morning of the 13th. During my absence, the $2 \mathrm{~d}$ Base Force commander and the $2 \mathrm{~d}$ Destroyer Squadron commander shall cooperate with each other and continue the tasks given in Dutch East Indies Unit Classified Telegram No. 643.

2. The three Army transport ships to be sent to Balikpapan shall be escorted by naval vessels designated by the $2 \mathrm{~d}$ Base Force commander. 
On that evening, a report came from 11th Seaplane Tender Division Commander Rear Admiral Fujita, "One element of the main force of our Army charged into Surabaya at 1550 and seized one half of the city (reconnoitered by aircraft)."(62) The guard against escaping [enemy] naval vessels was tightened, but nothing unusual was spotted.

At 0900 on 8 March, the 1st Escort Unit left the Kragan anchorage for the Karimata Strait escorting thirty-nine transport ships returning to mainland Japan. On that day, no enemy was spotted either in the Kragan anchorage or in the patrol areas to the north of Surabaya.

At 0230 on 9 March, the 8th Destroyer Division commander guarding the waters near Bali reported having sunk one enemy minesweeper (attacked by the Arashio), and requested 2d Destroyer Squadron Commander Tanaka to dispatch one destroyer for guarding the Bali channel. At 0400, the [2d Destroyer Squadron] commander hurriedly dispatched the Hatsukaze, who was patrolling her [assigned] patrol area, to the north entrance of the Bali channel, while he had the Tokitsukaze at the Kragan anchorage leave the anchorage area to be deployed at Patrol Area A. ${ }^{(53)}$ In the meantime, considering the enemy movements in the Bali area, the commander of the 1st Escort Unit, who had almost reached midpoint between Cape Puting and the Karimunjawa Islands escorting the returning transport convoy, promptly had the 9th Destroyer Division (minus the Asagumo and the Yamagumo) return to be put under the command of $2 \mathrm{~d}$ Destroyer Squadron Commander Tanaka in order to tighten the guarding of the area. However, no enemy was spotted since then. ${ }^{(62)}$ On that day, the Dutch East Indies forces on Java came to accept a general unconditional surrender, and the Combined Fleet announced the completion of the stage-one, phase-three operations.

On 10 March, judging from the unconditional surrender of the Dutch East Indies forces and other intelligence that almost no operational enemy vessels remained in the Surabaya area, 2d Destroyer Squadron Commander Tanaka offered his opinion to 1st Escort Unit Commander Nishimura that the deployment to watch the north entrance of [the port of] Surabaya and the east entrance of Madura Bay should gradually be withdrawn. ${ }^{(53)}$ Meanwhile on the early morning of the 10th, 1st Escort Unit Commander Nishimura received Third Fleet Classified Telegram No. 779 (sent at 1520 on 9 March), concerning the [change of] operations of all units and vessels in consequence of the forming of the Second Southern Expeditionary Fleet, which read as follows: ${ }^{(63)}$

In consequence of the reorganization of the Second Southern Expeditionary Fleet on 10 March, all units (vessels) shall operate as follows:

1. The 5th Destroyer Division and the San'yō-maru [shall operate] as designated by the commander in chief of the First Southern Expeditionary Fleet.

2. The Nichiyu-maru, the Seian-maru, the Sanuki-maru, the 30th Minesweeper Division, the 32d Minesweeper Division, and the 31st Subchaser Division [shall operate] as designated by the commander in chief of the Third Southern Expeditionary Fleet.

3. The Kamikawa-maru [shall operate] as designated by the commander in chief of the Fourth Fleet.

4. Other units (vessels) shall continue current tasks until a new disposition of forces is announced.

5. The following units shall be added to the disposition of forces of the Dutch East Indies Unit: Submarine Unit ([under the command of] the 6th Submarine Squadron commander): 6th Submarine Squadron

(a) The 13th Submarine Division and Submarine I-23 [correctly: I-123] shall return to mainland Japan for maintenance as designated by the commander [of the Dutch East Indies Unit].

(b) Other units (vessels) shall operate as designated by the [squadron] commander. 
In accordance with this telegram, 1st Escort Unit Commander Nishimura removed the 31st Subchaser Division at 0810 and also removed the 11th Minesweeper Division and Minesweeper No. 20 at 0825 from the line to return to their original units.

At 1400, at the north end of the Karimata Strait, the 1st Escort Unit commander ordered the $2 \mathrm{~d}$ Destroyer Division to escort the convoy, which was returning to mainland Japan, up to Singapore, while he himself reversed course for the Kragan anchorage, leading the Naka. As of that day, the stage-one, phase-four disposition of forces [of the Combined Fleet] was put into effect as follows: ${ }^{(63)}$

Southern Task Force Telegraphic Order No. 127 (issued at 1010 on 10 March)

The disposition of forces of the Southern Task Force in the Combined Fleet stage-one, phasefour disposition of forces shall remain as they are except for those mentioned below, until ordered otherwise by special order:

1. The Third Fleet shall become the Second Southern Expeditionary Fleet, and the Third Fleet commander in chief shall become the Second Southern Expeditionary Fleet commander in chief.

2. As of 12 March, the 5th Destroyer Division shall be removed from the Dutch East Indies Unit and transferred to the Malaya Unit, while the 24th Destroyer Division shall be removed from the Malaya Unit and transferred to the Philippines Unit.

Accordingly, Dutch East Indies Unit Commander Vice Admiral Takahashi issued the following order: ${ }^{(63)^{*}}$

Dutch East Indies Unit Classified Telegram No. 21 (issued [at] 2000 [on] 10 March)

1. Each base force [incorporated] in the 1st and the $3 \mathrm{~d}$ Escort Units shall respectively return to the $2 \mathrm{~d}$ and the 1 st Base Units.

2. The 1st and the $3 \mathrm{~d}$ Escort Unit commanders shall respectively be relieved of the command of the $2 \mathrm{~d}$ and 1 st Base Units.

3. The 1st and the $3 \mathrm{~d}$ Escort Unit commanders shall have the forces, other than those required for the escort of Army transport ships, sail to Makassar in such a way as designated by the commander [of each force].

4. The 2d Destroyer Squadron (minus the 8th, the 15th and the 18th Destroyer Divisions) shall gradually withdraw from its deployment in watching the north entrance of [the port of] Surabaya and the east entrance of Madura Bay, and send the [deployed vessels] to Makassar.

5 The 1st Base Unit commander shall continue his previous tasks, leading his own forces as well as the forces of the $2 \mathrm{~d}$ Base Unit in the Java Sea area (minus the $22 \mathrm{~d}$ Special Base Force headquarters and the Itsukushima).

6. After handing over his current tasks, the 22d Special Base Force commander shall sail to Balikpapan via Makassar, leading the Itsukushima.

7. The $2 \mathrm{~d}$ Air Unit shall dismantle its provisional base and sail to Makassar.

On 11 March, having received this order, 1st Escort Unit Commander Nishimura called off his plan to return to Kragan, changed it in such a way as to sail to Makassar after refueling at Banjarmasin on his way. He withdrew the 9th Destroyer Division from the command of 2d Destroyer Squadron Commander Tanaka and ordered the division to join the Naka at Ban-

\footnotetext{
* Note 63 refers to the journal of the 5th Destroyer Squadron. However, the same order is also quoted in the journal of the $2 \mathrm{~d}$ Destroyer Squadron. Both texts differ slightly. We have followed the most likely redaction.
} 
jarmasin. ${ }^{(62)}$ All units left their patrol areas one after another for Makassar. On that day, the 2d Destroyer Squadron was removed from the Dutch East Indies Unit and transferred to the main body of the Southern Task Force, and [its divisions and vessels were told] to sail to their home ports as soon as possible for maintenance as designated by the [2d Destroyer Squadron] commander. ${ }^{(53)}$

\section{The Western Java Units Clear [the Sea of] the Enemy}

With the direct support of the 7th Cruiser Division, the 3d Escort Unit had put the convoy carrying the main force of the Sixteenth Army into the Merak and the Bantam Bay anchorages at 0000, and into the Patrol anchorage at 0140 on 1 March. After having sunk two enemy cruisers who had come raiding Bantam Bay, the unit mainly guarded the waters surrounding the anchorages of the convoy. The major engagements on that day were as follows: ${ }^{(63)}$

\section{Area No. 1}

1. At 0330, the 12th Destroyer Division ([consisting of] the Shirakumo and the Murakumo), patrolling Area G, spotted an enemy destroyer (HNLMS Evertsen) at a point about five nautical miles west of Thwartway Island [Pulau Sangiang], engaged her and scored more than a dozen hits. Sinking from the stern, the enemy threw up smoke screens and escaped into Lampung Bay. Later investigations revealed that HNLMS Evertsen had run aground on Sebuku Island and sunk around 1700 after huge explosions.

2. Simultaneously at 0330, the 11th Destroyer Division (the Fubuki and the Hatsuyuki) patrolling near Babi Island spotted one 5,000t-class oiler sailing south of the island, shelled and sank her.

3. At 0400 the 1st Defense Unit and the Myōkō-maru put a landing force on Panjang Island and seized the whole area along the coast. Also, minesweeping of Bantam Bay using large-sized motorized landing craft was carried out, but no mines were snagged as of around 0600 .

4. At 1023 , the Hatsuyuki detected an enemy submarine at a point thirty-five nautical miles $170^{\circ}$ [SSE] of the lighthouse on Babi Island and promptly attacked her with depth charges, but the results were unclear.

5. Although the Tsurumi sustained some damage from a torpedo attack by [an] enemy submarine at 1355 at the mouth of Bantam Bay, she was still able to sail at slow speed and supply oil [to the other ships]. The Natori as well as the Harukaze and the Hatakaze of the 5th Destroyer Division attacked the submarine with depth charges, guided by aircraft of the Natori, and reported having sunk her with certainty.

6. At 1922, the 22d Destroyer Division (the Fumizuki and the Satsuki) attacked [an] enemy submarine with depth charges at a point three nautical miles $325^{\circ}[\mathrm{NW}]$ of the lighthouse on Toppers Island [Pulau Tampurung], guided by a Type-0 reconnaissance seaplane of the Kamikawa-maru and a Type-0 observation seaplane of the San'yō-maru, but the results were unclear.

7. At 2000, the 1st Minesweeper Division detected [an] enemy submarine at a point five nautical miles $78^{\circ}$ [ENE] of St. Nicholas Point [Tanjung Pujut] and attacked her with depth charges; after spotting many bubbles and a large amount of oil welling up, they reported that the results were certain.

8. At 2125, the Hatsuyuki and the Fubuki spotted one British destroyer and one minesweeper* accompanied by two torpedo boats, promptly attacked them, and at 2200 sank the destroyer and had the minesweeper run aground. **

\footnotetext{
* According to the War Journal of the 5th Destroyer Squadron: gunboat.

** Idem: set the destroyer ablaze and made her run aground, while sinking the gunboat.
} 


\section{Area No. 2}

1. At 1605 , the Yura came under attack from [an] enemy submarine at $6^{\circ} 4^{\prime} \mathrm{S} 108^{\circ} 0^{\prime} \mathrm{E}$; she evaded the attack and sustained no damage. Promptly, she carried out a depth charge attack on the point where the [enemy] torpedoes had been launched, while having the Nagatsuki sweep the waters but both obtained no clue [about the movements of the enemy submarine].

2. From the previous night onwards, a total of fifty enemy bombers in groups of three to seven aircraft at a time came raiding more than a dozen times during the night and the day, and attacked the convoy (mainly with torpedoes). However, every time the 1st Section (the Akatsuki and the Hibiki) of the 6th Destroyer Division, the Nagatsuki and Minesweeper No. 5 shelled them and drove them back. Minor damages and casualties were sustained by a few transport ships, but they caused no hindrance to the disembarkation operation.

3. The search for and clearing of mines at the Patrol anchorage on that day resulted in no mines snagged.

The major actions taken on 2 March were as follows:

\section{Area No. 1}

1. At 1145 , the Hatakaze of the 5th Destroyer Division conducted a depth charge attack against [an] enemy submarine at a point 8.5 nautical miles $339^{\circ}$ [NNW] of St. Nicholas Point [Tanjung Pujut] guided by a Type-0 reconnaissance seaplane of the Kamikawa-maru, but the result was unclear.

2. At 1300, the Hatsuyuki of the 11th Destroyer Division detected [an] enemy submarine at a point 7.2 nautical miles $178^{\circ}[\mathrm{S}]$ of Pebelokan Island. She carried out a depth charge attack, spotted a small amount of oil welling up, and concluded that [the attack] had to some extent been effective.

3. At 1515 the Fumizuki of the 22d Destroyer Division conducted a depth charge attack on [an] enemy submarine at a point fifty-five ${ }^{*}$ nautical miles $325^{\circ}[\mathrm{NW}]$ of the light house on Toppers Island [Pulau Tampurung] led by [a] Type-0 reconnaissance seaplane of the Kamikawa-maru. She felt sound of explosions below her bottom and considered that [the attack] had to some extent been effective.

4. At 1810, the Hatsuyuki detected an oil trail and the propeller sound of a submarine at seven nautical miles $135^{\circ}$ [SE] of Babi Island, and conducted a depth charge attack in cooperation with [a] Type-0 reconnaissance seaplane of the Kamikawa-maru. Having spotted a large amount of oil welling up and the surfacing of a part of the upper structure [of a submarine], she reported the result as certain.

In Area No. 2, neither enemy submarines nor surface units were spotted; only a total of twelve aircraft came for a raid.

From the $3 \mathrm{~d}$ onwards, attacks by enemy submarines and air raids drastically decreased. However, at 1325 on the 4th, the oiler Erimo came under a torpedo attack by [an] enemy submarine in the Java Sea (at $4^{\circ} 22^{\prime} S 108^{\circ} 23^{\prime} \mathrm{E}$ ) and eventually sank at 1505 (as previously told [p. 499]). Although 162 members of the crew including the captain were rescued by the Yura, eighteen shared the fate of the ship. The ship was heading for Singapore alone after finishing refueling the 7 th Cruiser Division unit. ${ }^{(63)}$ Other than this, the Japanese side sustained no loss. On the 6th, the aircraft of the Natori spotted sixty or more mines at an area four nautical miles $10^{\circ}[\mathrm{N}]$ of the lighthouse on the jetty of Tanjung Priok, which were disposed of with the forces of the 1st Defense Unit.

\footnotetext{
* According to the Action Report of the 5th Destroyer Squadron: 5.5 nautical miles.
} 
From the 4th onwards, all units shifted one after another [to their designated locations] to prepare for the subsequent operations in the following way: ${ }^{(63)}$

[March]

4th: The 11th Destroyer Division and the Yura left for Singapore.

The 1st Section of the 22d Destroyer Division escorted fourteen returning [transport] ships [up to] the north end of the Karimata Strait, after which the section sailed for Cam Ranh Bay.

The Nagara, the Tsukushi, the 2d Subchaser Division, the 21st Minesweeper Division (minus Minesweepers No. 11 and No. 12), and the 21st Subchaser Division, which had been operating in the eastern Java area, sailed to Batavia, led by the 1st Base Force commander, where they were put under the command of the $3 \mathrm{~d}$ Escort Unit commander.

5th: The Kamikawa-maru and the San'yō-maru put in at Bantam Bay.

The Nagatsuki of the 22d Destroyer Division escorted eight [transport] ships returning to Singapore [up to] the north entrance of the Karimata Strait, from where she headed for Cam Ranh Bay.

6th: The 6th Destroyer Division was removed from the Dutch East Indies Unit and transferred to the Philippines Unit.

7th: The Minazuki of the 22d Destroyer Division escorted ten [transport] ships returning to Singapore [up to] the north entrance of the Karimata Strait, from where she headed for Cam Ranh Bay.

8th: The Hatakaze of the 5th Destroyer Division headed for Singapore escorting the Tsurumi.

10th: The Asakaze of the 5th Destroyer Division headed for Singapore escorting eleven [trans port] ships returning to Singapore.

The Harukaze and the Matsukaze of the 5th Destroyer Division sailed toward Singapore.

The 3d Escort Unit commander was relieved of his command over the 1st Base Force and the forces of the latter returned to their original units. Meanwhile, it was decided that the 3d Escort Unit should head for Makassar, leaving behind the forces required to escort the Army transport ships.

11th: The Nagara sailed for Makassar.

12th: The 3d Escort Unit commander headed for Makassar, leading the Natori.

In the meantime, when the sea engagements off Batavia took place, the 1st Section of the 7th Cruiser Division and the 19th Destroyer Division (minus the Ayanami and the Shikinami) had taken up position in an area about thirty nautical miles north of Bobos Point to support the Area No. 2 Unit. Then, joined by the $2 \mathrm{~d}$ Section [of the 7th Cruiser Division] and the 4th Carrier Division at 0100 on the 4 th at a point of $4^{\circ} 48^{\prime} S 107^{\circ} 34^{\prime} \mathrm{E}$, they pulled out of their deployment and headed for Singapore to get ready for subsequent operations. At 1900 on the 5th, they put in at Singapore without incident and completed their support operations in the Java [invasion] operation. ${ }^{(126)}$

\section{The Formation of Special Base Forces}

On 9 March, stage-one, phase-three operations ended with the fall of Java, the last stronghold of the Dutch East Indies, and the focus in the tide of the war for the Southern Task Force shifted to the area west of Java, i.e. the Burma Sea [Andaman Sea], and the eastern part of the eastern Indian Ocean. That is to say, among the plans drawn up were the northern Sumatra invasion operation (Operation T), which before the opening of hostilities had [already] been planned for execution after the fall of Singapore, the Burma operation, which after the 
smooth progress of the Southern operation was decided to be launched ahead of schedule, the Andaman Islands operation (Operation O), which was to be dealt with along with the Burma operation, and the surprise attack operations in the Ceylon Area (Operation C), to be conducted mainly by the Carrier Task Force in early April.

From 10 March onwards, the Combined Fleet put the stage-one, phase-four operations in motion (by means of Combined Fleet Telegraphic Operation Order No. 87), in which the Dutch East Indies Unit was assigned to guarding the areas in its charge, clearing away remnants of the enemy, protecting the shipping lanes, developing natural resources, implementing a military administration and conducting the second or later transports of army units. In the Army-Navy Central Agreement Concerning the Implementation of a Military Administration in the Occupied Areas ${ }^{(146)}$ of 26 November 1941, it was stipulated that the military administration in Borneo, Celebes, the [Lesser] Sunda Islands, and the Moluccas was mainly assigned to the Navy. In the subsequent Army-Navy Central Agreement Concerning the Guarding of British Malaya and the Dutch East Indies Areas as of 20 January 1942, ${ }^{(43)}$ it was laid down that [all areas] in Java and Sumatra, except for naval zones and premises as well as air bases assigned to the Navy, should be assigned to the Army, whereas [all areas] in the Dutch East Indies other than Java and Sumatra should be assigned to the Navy, except for posts and stations of Army units.

In early January 1942, in line with these agreements, the following plan for the organization of base forces had been taking shape in the Naval General Staff:

\section{Surabaya}

A base force consisting of the current 1st Base Force as the core shall be stationed [there] to take charge of Java and the Lesser Sunda Islands area (The guarding of Java itself is assigned to the Army).

\section{Balikpapan}

A base force consisting of the current $2 \mathrm{~d}$ Base Force with the $2 \mathrm{~d}$ Kure Special Landing Force added as the core shall be stationed [there] to take charge of Dutch Borneo.

Makassar (including the guard on the land)

A base force consisting of the current Sasebo Combined Special Landing Force with some surface defense forces added as the core shall be stationed [there] to take charge of the area of Celebes (including the guard on land).

\section{Ambon}

A base force consisting of the current 1st Kure Special Landing Force with some surface defense forces added as the core shall be stationed [there] to take charge of the areas to the north of Australia (including the guard on land).

Among them, first of all the 24th Special Base Force was formed on Ambon as of 5 February. Then, following a partial revision of the Wartime Formation of the Imperial Japanese Navy of the fiscal year 1941, made as of 10 March [1942], the Third Fleet was disbanded and the Second Southern Expeditionary Fleet was newly established. Simultaneously, the 21st, the 22d, and the 23d Special Base Forces were formed respectively at Surabaya, Balikpapan and Makassar, and together with the 24th Special Base Force incorporated into the Second Southern Expeditionary Fleet.

The forces at the time of their formation were as follows: ${ }^{(164)^{*}}$

\footnotetext{
* The text contains a number of mistakes. We have revised the text based on the original sources.
} 
21st Special Base Force (Surabaya; Commander: R. Adm. Kubo Kyūji) The Shirataka, Minesweepers Nos. 8, 11, and 12, the 1st Subchaser Division (Submarine Chasers Nos. 1, 2 and 3,) the 2d Subchaser Division (Submarine Chasers Nos. 13, 14 and 15,) the Ikushima-maru, the 1st Port Administration Department (the above [from] the 1st Base Force)

The Tatsumiya-maru, the 33d Air Group ([formerly] attached to the Third Fleet)

The 21st Signal Unit, and the 21st Submarine Base Unit (the above newly formed)

22d Special Base Force (Balikpapan; Commander: R. Adm. Hirose Suéto)

The Wakataka, Minesweepers Nos. 15 and 16, and the 21st Subchaser Division (Submarine Chasers Nos. 4, 5, 6, 16, 17, and 18), the Tatsuharu-maru, the Imizu-maru, the 2d Port Administration Department (the above [from] the $2 \mathrm{~d}$ Base Force)

The 2d Guard Unit (newly formed with the 2d Kure Special Landing Force)

23d Special Base Force (Makassar; Commander: Capt. Mori Kunizō)

The Aotaka and the 12th Subchaser Division ([from] the 1st Base Force)

The Chidori, the Manazuru, the Shinko-maru [A] and the 54th Subchaser Division ([from] the 2d Base Force)

The 3d Guard Unit (newly formed with the 2d Sasebo Special Landing Force)

The 35th Air Group ([formerly] attached to the Third Fleet)

24th Special Base Force (Ambon; Commander: R. Adm. Hatakeyama Kōichirō)

The Hatsukari, the Tomozuru, and the Seian-maru ([from] the 2d Base Force)

The 52d Subchaser Division ([from] the 1st Base Force)

The 24th Navy Signal Unit

The 4th Guard Unit

\section{Revision of the Disposition of Forces of the Dutch East Indies Unit}

After the revision of the Wartime Formation on 10 March, the Dutch East Indies Unit greatly changed in character from being up to that time an invasion operation unit with the Third Fleet as its basis into a unit with defense forces as its core (the Second Southern Expeditionary Fleet). ${ }^{(164)}$ That is, since the Java invasion operation was mostly completed, the forces of other units, which had been incorporated into the Dutch East Indies Unit to participate until that time in the operation according to the Southern Task Force phase-three disposition of forces, left the command of the Dutch East Indies Unit commander one after another from the beginning of March. Some returned to their original units, while other units were transferred to different units or made to operate as designated by the commander in chief of the Combined Fleet, and other units again were put in the main body of the Southern Task Force to return to mainland Japan for repairs and the maintenance of hulls, engines and ordnance. Meanwhile on 7 March, the Dutch East Indies Unit had been given orders to carry out operations to clear enemy remnants from and seize important places in Dutch New Guinea after the fall of Java. ${ }^{(100)}$

The phase-four disposition of forces of the Dutch East Indies Unit announced on 15 March was as follows: ${ }^{(165)}$

\section{Dutch East Indies Unit Classified Telegram No. 132}

The disposition of forces of the Dutch East Indies Unit shall be changed as follows:

1. [The units] under the direct command of the main unit: The Ashigara and the 16th Destroyer

Division $2 \mathrm{~d}$ Section shall support all operations. 
2. The Java Guard Unit: [led by] the 21st Special Base Force commander; the 21st Special Base Force, the Tsubame, the Kamome, the Tsukushi, the 1st Survey Unit, and the Myōkō-maru.

3. The Borneo Guard Unit: [led by] the 22d Special Base Force commander; the 22d Special Base Force, the Itsukushima and the Kenryu-maru.

4. The Celebes Guard Unit: [led by] the 23d Special Base Force commander; the 23d Special Base Force.

5. The Ambon Guard Unit: [led by] the 24th Special Base Force commander; the 24th Special Base Force (except for those transferred to the $\mathrm{N}$ invasion unit).

The tasks of 2, 3, 4 and 5: Guarding the assigned areas, the clearing of enemy remnants, as well as protecting shipping lanes and implementing the military administration (except for 2) in their assigned areas.

6. The N Invasion Unit: [led by] the 11th Seaplane Tender Division commander; the 11th Seaplane Tender Division (minus Mizuho), the Nagara, the 2d Gunboat Division (minus Kamitsu-maru), the 16th Destroyer Division 1st Section, the Tomozuru, the Hatsukari, Patrol Boats Nos. 1, 2, 38, and 39, the Seian-maru, the Hokuriku-maru, and the 4th Guard Unit shall capture strategic places on Ceram Island, Halmahera Island as well as the former Dutch New Guinea. The N invasion unit shall assemble in Ambon by 27 March. The Tomozuru shall escort the Hayatomo from a point off Davao $\left(5^{\circ} 40^{\prime} \mathrm{N} 127^{\circ} 40^{\prime} \mathrm{E}\right.$, where she will be sailing southwards at noon on the $21 \mathrm{st}$ ) to Ambon.

7. The 1st Escort Unit

[Led by] the 4th Destroyer Squadron commander; the 4th Destroyer Squadron (minus the 2d, the 4th, the 24th Destroyer Divisions and [minus] the 9th Destroyer Division 2d Section) shall escort the transport of reinforcements of the 48th Division.

8. The $3 \mathrm{~d}$ Escort Unit

[Led by] the 16th Cruiser Division commander; the 16th Cruiser Division (minus the Nagara) and the $22 \mathrm{~d}$ Destroyer Division shall escort the transport of reinforcements of the main force of the Sixteenth Army.

Note by the author: Along with the revision of the Wartime Formation as of 10 March, the 5th

Destroyer Squadron was disbanded, and with the Natori the flagship of the squadron, the

Nagara (formerly [in] the 16th Cruiser Division) and the Kinu (the former flagship of the 4th

Submarine Squadron), the 16th Cruiser Division was [re]organized and transferred to the

Second Southern Expeditionary Fleet.

9. Attached Units: Other than those specified otherwise, [attached units] shall continue their presently assigned tasks.

Remarks:

(1) Those currently operating in the Java area, except for those to be transferred to the N invasion unit, shall, after completion of their current tasks, shift to the disposition of forces given above as designated by the 21st Special Base Force commander.

(2) The Taikō-maru shall take on board two large-sized motorized landing craft as well as special service personnel for four landing craft.

(3) When the invasion of Christmas Island [is decided], [the operation shall be carried out by] the 1st and 3d Escort Units as the core. Details of the operation shall be given later.

\section{The Lessons of War in the Air Campaign in the Dutch East Indies [Operation]}

\section{Lessons of War; General [Issues]}

From “The Greater East Asia War's Lessons of War ([section] Air Operations)” prepared in October 1942 by the Naval Investigation Committee on Engagements and Lessons of War 
(Subcommittee on Air Operations), the following passages may be extracted concerning the Dutch East Indies [campaign]:[75]

\section{The Operations of the Enemy}

\section{Air Forces}

Although not as unenterprising as the U.S. air forces in the Philippines, the enemy was very slow in implementing his air operations.

(1) He may not have had a [clear] idea of [how to conduct] air campaigns to destroy the air power [of the opponent], or [maybe] his implementation of such campaigns was very inconsistent. It was plain to see that we pushed our forces forward while capturing [certain areas] in order to seize the bases [there] and advance our air forces. Also, it was evident that [the enemy could have attained] very effective results if he had attacked [us] at the small bases we had seized, where we had concentrated as many aircraft as could be accommodated. Nevertheless, the enemy only sporadically came to make attacks with just a small number of aircraft. At first, the air forces of the Dutch East Indies and Australia often raided our convoys as well as our bases. However, interception by our fighter planes inflicted on them immense losses, ending in all or most of their aircraft being shot down. No sooner had our fighter planes advanced to the bases we had captured than they disappeared. After our invasions of Balikpapan and Menado, [enemy aircraft] seldom came to make raids.

On learning through several air engagements that the American four-engine bombers were seldom brought down by our fighter planes owing to their heavy armor, [the enemy] tenaciously continued attacks with a small number of these aircraft. Nevertheless, [these attacks] never constituted a [true] air campaign to destroy the opponent's air power.

(2) [The enemy] did not conduct powerful air operations when there was a major opportunity to attack. Even at such critical moments to attack as when our invasion convoys had started sailing, and the enemy faced an emergency, he did not attack them while they were under sail. Even after [our convoys] reached the invasion points, the enemy did nothing more than conducting raids with a small number of aircraft only at dawn and dusk, taking advantage of the absence of patrols in the air [over the landing points] by our fighter plane units (which had to take off from the bases in the rear). Only our invasion of Bali created a situation where the enemy seemed to feel as if a dagger had been pointed at his throat, which [finally] made him to repeatedly conduct attacks on us. But even then, he stopped his attacks after a number of our fighter planes had advanced there.

(3) [The enemy] used his forces [only] in small-scale [units] (the largest number of aircraft in his formations was twelve; usually his aircraft flew in groups of four or five, or in groups of even smaller numbers). He did not seem to have an idea of how to make the most of collective power. Consequently, his attacks [only] produced small and indecisive results.

(4) [The enemy] was not seen to strongly keep up his attacks.

Although repeated attacks were conducted on our convoy carrying the forces to capture Menado as well as [on our forces] at the Bali base, both attacks lasted only for a few days and stopped once our fighter plane units had advanced. In the other cases, his attacks were even less tenacious.

Attacks by such large land-based attack planes as B-17s and B-24s were also sporadic.

(5) When [enemy] aircraft in small numbers raided the bases where our fighter planes had been advanced, they conducted relatively brave attacks.

Many of them bravely and determinedly carried out bombings from a low altitude, though presumably one of the reasons was that there was almost no antiaircraft [artillery] fire at all at these bases. 


\section{Surface forces}

(1) Although the major part of the U.S. Asiatic Fleet as well as the Dutch surface vessels generally used Surabaya as their base, they conducted almost no operations, other than one or two small-scale actions, that should be considered aggressive. It seems that after the operational range of our air force had reached as far as Surabaya, [the enemy vessels] ordered into action sustained considerable damage from attacks by our [air] units, and that the major part of them evacuated to Australia or to the western parts of the Dutch East Indies, while some damaged vessels remained in Surabaya to undergo repairs.

Then, prior to [our] launch of the Java invasion operation, the major part of them again assembled on the waters near Surabaya. [However,] in the course of the operation, our forces gained command of the eastern and western ends of the Java Sea, which cut off the escape routes of the enemy and [then] the sea engagement off Surabaya took place.

(2) As our Malaya invasion operation made progress, the major part of the British naval surface vessels [first of all] took charge of escorting escaping vessels. Then, other than some which escaped to the Indian Ocean, [most of] the vessels remained in the areas of Batavia and Surabaya, and operated almost in the same way as the U.S. and Dutch naval vessels.

(3) Although enemy submarines appeared in all operational areas, their power was not great, and they inflicted [only] insignificant damage on us.

\section{Replenishment}

1. Replenishment of aviation fuel, bombs, and machinegun ammunition

(1) [The replenishment in] the eastern Borneo and Java areas

Since the Tarakan airfield was too small and had no space for expansion and Balikpapan had been swiftly seized, the fighter plane units shifted [to Balikpapan] in just ten-odd days. Because of that, the supply of fuel, bombs, etc. could more or less be covered by the amounts that had been carried as the first reserve supply (note by the author: the amounts transported on the ships carrying the construction squad at the time of the invasion [operation]). However, at Balikpapan, due to the loss of the Nan'a-maru on 23 January, who had been bombed by enemy aircraft right before putting in at the port, caught fire and sunk in the end, and the Tatsugami-maru, who had also sunk on the next day the 24th at the anchorage due to enemy torpedo[es], large amounts of aviation fuel, bombs, machinegun ammunition, etc. that should have been disembarked there were totally lost. On top of that, because the ship that advanced to Balikpapan carrying the construction squad was not loaded with the first reserve [supplies], the advance of the aircraft units was temporarily impeded. However, they took stopgap measures by landing the aviation fuel carried on the Kamogawa-maru and the Okitsu-maru, who had advanced there next, and [also] by hurriedly sending there the Rakutō-maru (attached to the Navy Ministry) who was in the port of Tarakan after loading her with the aviation fuel kept at the island.

After that, the Nagisan-maru (attached to the Combined Fleet), who was on her way to Davao with a full load of aviation fuel, and the Yübari-maru (attached to the Navy Ministry) with a full load of bombs and machinegun ammunition were [also] added to the Air Unit of the Southern Task Force and hurriedly diverted to Balikpapan, which helped the operation to be conducted without hindrance.

As for the Banjarmasin [airfield], it was decided that, due to changes in the plan for the subsequent operation [to seize it], the amount of fuel, machinegun ammunition, etc. required for the advance of the aircraft units for [just] a short period of time should be forwarded [from Balikpapan]. And since it was considered that it would be fine to do this by small vessels [because the operation was to be conducted] by maneuvering small craft along the coast, the transport was carried out using a dozen or more fishing boats requisitioned by the 
Eleventh Air Fleet and the Third Fleet. Concerning the Makassar [airfield], it was decided to transport the amount of fuel required for the advance of about twenty fighter planes for about one week. [Eventually,] the fuel was transported on the ships carrying the construction squad and the military supplies department at the time of the advance.

As for Bali, since the decision to capture the place was made in late January based on the progress of the [other] operations, the first reserve of fuel [to be sent] there was loaded at Jolo on the transport ships Sagami-maru and Sasako-maru, both carrying the army unit that was to capture the island, and transported to the island. However, due to the conditions at the Bali anchorage, it was difficult to quickly disembark the fuel from the ships, and it was not possible to disembark the entire load. Then, due to a coal supply problem, the Rakutōmaru and the Okitsu-maru, who [were supposed to] advance to Bali next [were delayed, which caused] a delay in the transport of fuel and bombs. On top of that, the Kamogawamaru was sunk on 2 March by a torpedo attack of an enemy submarine in the Lombok Strait and all the fuel, bombs, etc. that she carried were lost. [These circumstances] led to a temporary suspension of the advance of land-based attack plane units [to the Bali airfield] and the airlift of machinegun ammunition together with the maintenance personnel from Makassar.

(2) The Ambon area

As soon as the Ambon [base] was captured on 31 January and readied, one element of the $3 \mathrm{~d}$ Air Group as well as the 1st Air Group advanced there. Since the amount of the first reserve loaded along with the construction squad on the ship was too small, it was supplemented by hurriedly disembarking what was loaded on the Hino-maru No. 5 and the Lyons-maru, who had advanced there first, and what was loaded on the Komaki-maru, who had advanced there next.

(3) The eastern Celebes and Timor areas

The first reserve loaded along with the construction squad on the ship carrying the squad for Menado did not include bombs, and the ship with the construction squad for Kendari had not loaded bombs, fuel, etc. at all. Therefore, the amount [of fuel and ammunition] required for the Menado base was disembarked mainly from the Amagisan-maru and the Katsuragi-maru, which accompanied the Menado invasion units, whereas in Kendari, the preparations for the operation were made by disembarking all [remaining fuel and ammunition] from the Amagisan-maru, who had advanced there first, and part [of the supply] loaded on the Nisshun-maru, who had advanced there next.

As for the Kendari [base], where all land-based attack planes [operating in this theater] were to be concentrated in early February to launch Operation Z, large amounts of fuel, bombs, etc. had become necessary. Therefore, in addition to the above two ships, the Tenzan-maru, who had been added on 15 January, was fully loaded with aviation fuel and bombs at Sasebo and sent to Kendari.

As soon as the major part of the 1st Air Raid Unit had advanced to Kupang after the capture of the place on 20 February, the Nisshun-maru and the Tenzan-maru were advanced from Kendari, and the Hino-maru No. 5 from Ambon to take charge of providing supplies.

In late February, the 1st Air Group was shifted to Rabaul, which was followed by the shift of the 21st Air Flotilla headquarters and the Kanoya Air Group Detachment to Kisarazu. Replacing them, the $2 \mathrm{~d}$ Air Raid Unit advanced to Kupang from Bali; the Yūbari-maru, the Nagisan-maru, the Okitsu-maru, and the Rakuto-maru, who were deployed in the Bali area, followed, and thereafter the supplies in this area were provided from the load on these ships.

2. The supply of provisions (omitted by the author)

3. The replacement of aircraft

From around the time of shifting to the Dutch East Indies area, all units suffered from a gradual attrition of aircraft, which was caused not only by the damage or loss sustained but also caused by their intensive use as well as wear and tear. On top of that, a shortage of spare parts delayed 
the complete repair of aircraft. Under these circumstances, upon the completion of replacement aircraft, air crews from the front [were dispatched] to fly the replacement aircraft from Taiwan or mainland Japan.

However, after the [air units'] advance to Kendari and Balikpapan, the distance became markedly long while operations gradually increased, which made the air transport of replacement aircraft more and more difficult. Due to such circumstances, eighteen replacement Type0 fighter planes [had to be] transported by sea up to Davao on the Zuihō to supplement [the air units].

As for spare parts, those for the Type-0 fighter planes and tires for the Type-96 land-based attack planes in particular were not smoothly supplemented. Therefore, [the maintenance of] aircraft was [sometimes] completed by cannibalizing other aircraft, whose repair lagged behind time, by using [parts] of different types of aircraft, or by reusing nondurable parts. In such ways, every measure was taken to prepare for the day-to-day engagements.

4. The supply of fuel and clear water for the naval vessels (omitted by the author)

\section{Matters That Affected Operations}

1. Weather

The plan was that after the capture of Balikpapan, Bali should be captured by [first] destroying the enemy air power in eastern Java or neutralizing the major part of it. However, as previously told, bad weather in the eastern part of the Java Sea seriously impeded the execution of the operation, and the capture of Bali was inevitably postponed for one day.

2. The condition of the seized bases

(1) Davao and Jolo

Both airfields had large inclinations (a part of the Davao [airfield]: $1 / 25$ and the Jolo [airfield]: $1 / 25-1 / 50$ ) and were narrow. On top of that, the Davao airfield had a soft ground, which was frequently swept by sudden showers in the earlier period [after our capture]. [Consequently,] it took respectively sixteen and fifteen days before our land-based attack plane units were advanced to Davao and Jolo.

Even after their advance, due to the steep gradients, our land-based attack planes were unable to take off [from the airfields] with a full load, and they were never able to display the full capabilities of the aircraft. However, the enemy's inactivity during this period helped them to complete the operations without major frustrations.

(2) Tarakan

Use of this airfield by land-based attack planes had not been part of the plan. However, due to the soft ground and frequent torrential rains, even its use by fighter planes was seriously impeded. It not only led to a miscalculation about [the plan of] dispatching aircraft to cover the air over the units to capture Balikpapan, but also caused damage to not a few aircraft at the time of their take-off or landing.

3. The use of the airfields on Sumatra

In connection with the condition of the airfields in western Borneo, the First Southern Expeditionary Fleet and the Air Unit of the Southern Task Force repeatedly negotiated with the Army side on the 22d Air Flotilla's use of the Palembang airfield, but they did not reach an agreement and it was decided that [the Navy] was to use the Gelumbang airfield. However, due to the difficulty of [transporting] supplies to the airfield, it became practically impossible to execute the air campaign to destroy the enemy air power in western Java as scheduled.

4. Replenishments

The plan was that after the capture of Davao on 20 December, the necessary facilities should swiftly be set up there so as to make it a supply base for the units advancing toward the southern theater. However, it was not easy to realize it. In early January, the major part of the 1st Air Raid Unit had advanced to the place and conducted air campaigns day after day, which was followed 
by the advance of the supply ships of the Air Unit to Menado and Tarakan after their capture in mid-January. Even then, the mid-sized land-based attack plane units and seaplane units still used [Davao] as their base from where to conduct operations.

Due to these circumstances, the amounts of fuel and bombs kept in Davao had gradually decreased and it became impossible to cover the attrition only with the capacity of the supply ships that occasionally put in at the port. Therefore, [the Navy] used the Matsumoto-maru of the Third Fleet to hurriedly transport the aviation fuel kept on Palau. They [also] disembarked part of the first reserve of the auxiliary aircraft transport vessels that happened to be at anchor, and even put into drums the aviation fuel loaded in bulk on the oiler Hishi-maru, who had put in at the port on her way back to mainland Japan, and transported them to the airfield. [As seen from the above,] it was felt quite difficult to provide supplies there.

That is, after one month or more had passed since the capture of Davao, the city had not yet substantially assumed its role as a supply base. Since it turned out impossible to have the place provide supplies for the [air] units advancing [to Davao] and further south, the air units became entirely dependent on mainland Japan or Taiwan for supplies.

\section{The Lessons of War [Drawn] by the Commander of the Genzan Air Group}

The lessons of war below represent the personal view of Cdr. Maéda Kōsei, commander of the Genzan Air Group based on his experiences from the opening of hostilities until July 1942. The passages relating to the Dutch East Indies operation may be excerpted as follows:

\section{Air operations}

1. Patrol and Search [Missions]

(1) Weather

$\{1\}$ The weather in the South China Sea and the Java Sea

We learned from experience in December, January, February and March that over the southern oceanic areas cumulonimbi clouds develop and rise very quickly with the top of the clouds often reaching 10,000 meters, while bringing on fierce squalls [to the area] below them. [Even if] we saw just a few clouds on our way to a patrol [mission] in the morning, on our return in the afternoon, we were often forced to make a long detour due to the development of cumulonimbi clouds.

The clouds sometimes linger over the sea at night. When flying aircraft, caution is required.

$\{2\}$ The weather in the northern part of the Indian Ocean

From our experience in March, fair weather generally continued in the northern part of the Indian Ocean during this period, which made it easy to conduct patrols.

However, [dense] mist often caused poor visibility. When drawing search mission patterns, caution is required.

(2) Prohibition of using radio communications

Despite strict controls, [some] crews had the bad habit of secretly using it. It is necessary to see to it [that it will not be used].

2. Reconnaissance

(1) Many mistakes occurred when identifying types of vessels. It needs to be done carefully. In general, large cruisers were often mistaken for battleships and destroyers for light cruisers. An extreme case was that [an] Army aircraft reported a number of fishing boats it had spotted in the Malacca Strait as a large transport convoy. There was even a case of having mistaken lighters in the naval port of Singapore for aircraft carriers. There may possibly be a case in the future that the enemy uses decoy carriers. [Identification of types] requires attention. 
(2) When conducting reconnaissance, not only visual reconnaissance but also photo reconnaissance is absolutely necessary.

(Examples omitted by the author)

3. Probing

It is necessary to have a skilled officer crew with excellent tactical insight conduct probing. In general, the usual exercises tend to make [crews] think light of probing. [However,] probing an enemy who deploys fighter planes is by far the most difficult [mission] of all.

4. Attacks

(1) When conducting an attack with a large number of aircraft, it is better to assign the targets of the attack to them beforehand.

In actual engagements, [attacks] generally tend to concentrate on easy targets, which creates a risk that attacks are over-concentrated on some [targets], while leaving others intact. When the enemy situation is known, I think we need to roughly assign targets [to the attack units] before takeoff according to the number of aircraft [available].

(2) Since it is very unlikely that bombing attacks on [enemy] naval vessels under sail by single aircraft produce results, [bombing attacks] should be carried out by a team of nine to twenty-seven aircraft in formation that drop bombs all at once.

The bombing results of our group in the seven months from the opening of hostilities are as follows:

\begin{tabular}{|c|c|c|c|}
\hline $\begin{array}{c}\text { Type of Bombing } \\
\text { Attack }\end{array}$ & $\begin{array}{c}\text { Number of Attacks on } \\
\text { Naval Vessels }\end{array}$ & $\begin{array}{c}\text { Number of Ships } \\
\text { Sunk or Destroyed }\end{array}$ & Success Ratio \\
\hline $\begin{array}{c}\text { Bombing by a single } \\
\text { aircraft }\end{array}$ & 22 & 2 & $2 / 22$ \\
\hline $\begin{array}{c}\text { Bombing by a team of } \\
\text { three aircraft in } \\
\text { formation }\end{array}$ & 4 & 2 & $2 / 4$ \\
\hline $\begin{array}{c}\text { Bombing by a team of } \\
\text { six aircraft in formation }\end{array}$ & 4 & 1 & $1 / 4$ \\
\hline $\begin{array}{c}\text { Bombing by a team of } \\
\text { eight or nine aircraft in } \\
\text { formation }\end{array}$ & 16 & 7 & $7 / 16$ \\
\hline $\begin{array}{c}\text { Bombing by a team of } \\
\text { eighteen or nineteen } \\
\text { aircraft in formation }\end{array}$ & 4 & 3 & $3 / 4$ \\
\hline
\end{tabular}

5. Operations to Destroy [Enemy] Sea Lines of Communication

It is difficult to thoroughly destroy [enemy] sea lines of communication with land-based aircraft, unless considerably large forces are employed. When the air strength is insufficient, it is essential to also deploy surface forces, particularly submarines. On top of that, it is better to have air unit commanders take a unified command of both [the air and naval forces]. 
As the fate of Singapore was about to be sealed, the enemy was desperately conducting last-minute rescue [operations] or trying to escape, which made the traffic between Singapore and Java as well as Sumatra very busy.

That is, the total number of enemy naval vessels that the patrol aircraft of our group spotted in the Bangka and the Karimata Straits between 1 and 17 February reached seventy-six or more (including destroyers). Although we were able to attack thirty of them, the number of vessels we [actually] sank or destroyed were only nine in total. The reason for this was that due to its cramped conditions and the poor quality of its ground at that time, the Kuching airfield allowed in the beginning only about a section of the group to advance. Since it was anticipated that bombing attacks had to be conducted mainly by single patrol aircraft, we requested the cooperation of friendly surface vessels, only to find out that eventually no vessels were dispatched at all. If the condition of the Kuching airfield had been good and fit for use by a large number of aircraft, we could have destroyed most of those enemy vessels.

II. The air units' shift of bases

1. The air units' method of shifting bases needs to be studied for drastic improvements.

Needless to say, winning or losing air operations solely depends on appropriate preemptive strikes and a concentration [of forces]. In order to make the most of the advantage of inner lines in a [vast] operational area that stretches for close on five thousand nautical miles [only] with a small number of air units, nothing is more important indeed than the swift shift of bases.

Whereas the shifts of our aircraft units [in this operation] were easily and swiftly carried out without accidents, the embarkations and disembarkations for the transfer of our base personnel and matériel took considerable days and much effort at some places. [Partly due to] the speed of the transport ships, [shifts] took many days and were not easily [accomplished].

In view of the [current] situation in the transportation of base matériel, [we need to do the following] for a swift shift of bases:

(1) The [current] shifting system where all units transport their own stuff every time they shift, should be changed in such a way that, like bombs and fuel, military supplies departments and the Yokosuka Naval Air Technical Arsenal shall prepare [equipment and matériel] at the bases concerned, and that the shifting unit shall borrow and use it at the site and return it when they are shifting [somewhere else].

(2) Whereas warrant and higher-ranking officers can in general bring [a minimum amount of] personal items necessary for the shift and leave other belongings in their houses, noncommissioned officers and men bring [not only] their duffle bags [but also] all their other belongings, taking transfers to [other] sites into consideration. Moreover, unmarried men bring all their stuff including even the stuff they use at their lodgings, which adds up to a considerable amount. We need to keep these unnecessary things at military supplies departments in mainland Japan and they should [only] be sent on to another place on request at the time of a transfer [of personnel].

(3) At least five transport aircraft should be assigned to each unit so that base personnel needed for ongoing operations right after the shift can be airlifted.

(4) Since others have to be transported by transport ships, we need to assign fast transport ships specified for the purpose with the right set of equipment for embarkation/disembarkation.

2. Sometimes [air units] need to rapidly advance only their aircraft unit to a base with no facilities in order to execute operations for several days.

Our unit had to advance twice to the Gelumbang airfield which had no base facilities at all, the first time for the attacks on Java from 24 to 26 February and the second time for the support of the Carrier Task Force's [operation in] the Indian Ocean from 3 to 6 March. In 
view of these experiences, we keenly felt that the following points need to be studied and prepared from early on:

(1) If in addition to the regular crews, base personnel, signal personnel, nurses as well as portable radio equipment parts, spare tires, beddings and provisions were to be put on vacant seats of the aircraft, operations with only the aircraft units may be implemented for a couple of days at best; it is difficult to implement them any longer due to fatigue of the crews.

(2) One blanket per person will do for bedding in the tropics; even if it is impossible to carry blankets due to the loading capacity, it is absolutely necessary to carry mosquito nets.

(3) Although we camped under the wings of the aircraft hanging mosquito nets from them, sometimes we could not sleep due to squalls at night. Simple portable tents fit to be carried on aircraft are required.

(4) If machine gunners take up positions at the machineguns [on the aircraft on the ground] at the time of enemy air raids, it is likely that they will also be killed or injured along with [the damage to] the aircraft. It is better to bring simple ground mountings for 20$\mathrm{mm}$ machineguns which will enable them to be used as antiaircraft artillery, appropriately set them up around the airfield to be ready against enemy aircraft.

(5) Although rifles are necessary for guarding on the ground, it is difficult to load and carry them on aircraft. Therefore, it is better to supply portable ground stands for the 7.7-mm machineguns that are fitted on the aircraft so that they can be used for the guarding on the ground.

(6) Since bomb carts for 250-kg [bombs] cannot be loaded on aircraft, it is necessary for the Yokosuka Naval Air Technical Arsenal to always provide carts together with the bombs. Since the bombs were ready but the carts were not provided this time, we managed to mount the $250-\mathrm{kg}$ bombs on the aircraft using carrying pole[s]. In a case like this, it would be convenient if simple portable carrying pole[s] for $250-\mathrm{kg}$ bombs would be manufactured and supplied. Also, I think that we need to research [and work on] a simple knockdown cart for $50-\mathrm{kg}$ bombs.

(7) When military supplies departments prepare [aviation] fuel, they also need to provide fuel trucks as well. This time, fuel was provided but the trucks were not, and we had to manually fuel [each aircraft]. Although it [usually] takes much time to manually refuel, we managed to do it relatively swiftly since we had brought along gasoline filters, which we had specially built by cutting drums in halves. In order to deal with such situations, [air units] need to be supplied with large light-weight gasoline filters suitable to be carried on aircraft.

(8) It is not easy to implement operations in circumstances where air crews [have to] cook their own meals without adequate cooking utensils. Moreover, it is difficult to bring their own eating utensils. I think it would be easy and convenient if such mess gear as used in the Army is provided.

Some of the canned sweet red bean rice among the canned food we had brought along this time as part of our provisions had gone bad and turned black.

(9) Air crews need to be supplied with a regulation light-weight case of a fixed size like the wicker trunk provided to Army officers [to facilitate] the shift of aircraft units.

III. Replacement of aircraft

It should be made a principle that personnel from mainland Japan should fly replacement aircraft to battlefronts.

At the outset of the war, [replacement aircraft] were flown to battlefronts by personnel of units from the mainland. However, it was changed afterwards in such a way that front personnel were dispatched to the mainland to fly them back [to the battlefronts]. But even when we dispatch personnel to fly back replacement aircraft that have reportedly completed their test flights 
at the Yokosuka Naval Air Technical Arsenal in mainland Japan, the fact remains that none of these planes have been tuned perfectly enough to meet the demands in actual fights (particularly, their performance was unsatisfactory when they were flown at a high altitude), and the dispatched personnel need to spend another several days performing maintenance work on the aircraft they flew [to the front].

During these periods [of transport and maintenance], unexpected enemy movements really worry us. It is of course not absolutely impossible to dispatch personnel from operational units to fly [replacement aircraft], considering the number of crews in reserve at the [less] busy moments of an operation. There might be some advantage anyways in having part of crews return to mainland Japan in turns and let them have an opportunity for some mental rest. However, from another point of view, not a few [personnel] are feeling uncomfortable at returning to mainland Japan alone, leaving many brothers in arms at the front, which means [returning to mainland Japan to fly replacement aircraft] does not necessarily give mental rest to those assigned. When considering that the operations are the top priority, we need to make it a principle that replacement aircraft should be flown [to the fronts] by personnel of the units in the mainland.

IV. Drills

1. I think that we need to set up a training base suitable for every theater of operations, deploy a suitable target ship, at suitable moments pull back elements of an aircraft unit depending on the progress of the operations and have them conduct drills.

In my opinion, the bombing drills against the Settsu, conducted from 10 October until the end of November before the opening of hostilities, were very effective in that the drills gave [the participants] the confidence to face the enemy and destroy him. Bombing and torpedoing always require tireless trainings. Although [my men] have been making efforts to maintain and improve their skills by faithfully conducting as many drills as possible in their spare moments between missions [even] after the opening of hostilities, they were not able to produce the results they had hoped for, since it was often impossible to obtain suitable targets regardless. The need for such [drills] is keenly felt, [particularly] under current circumstances where a large number of new crews are being allocated to operational units and where trainings to upgrade copilots to [full-fledged] pilots are constantly required as in midsized land-based attack plane units.

2. I [also] keenly felt that the regular studies and drills for reconnaissance and probing are remarkably deficient. From now on, we need conduct drills that are more useful in actual engagements.

(1) In regular exercises, enemy movements can easily be gathered from the so-called exercise situations, while this is not the case at all in actual engagements. Also, whereas in regular exercises not much attention needs to be paid to obstruction by enemy aircraft, in actual engagements we do. Since both reconnaissance and probing are inevitably conducted from afar at a high altitude, they consequently take place under conditions that are very different from everyday conditions, for which reason we experienced failure so often.

(2) As a result of [reconnaissance and probing] conducted from a long distance at high altitudes, it is extremely difficult to identify types of ships, etc. We need to regularly practice solid basic trainings in identifying types of enemy naval vessels.

(3) Photo reconnaissance is absolutely necessary. [However,] photographing skills are generally not sufficient. Trainings in photo reconnaissance [skills] from a high altitude are required.

(4) We need to thoroughly conduct drills in how to probe with probing aircraft.

3. I [also] keenly felt our lack of study and drills in [improving] our capacity to operate at night and execute night attacks. I think we need to stage from now on more exercises [on night operations]. 


\section{Aircraft and ordnance}

1. I keenly felt that not only the performance of our Type-96 land-based attack planes but also even that of our Type-1 land-based attack planes do not meet the requirements of modern warfare. I think we need to swiftly work on a mid-sized land-based attack plane that will meet the following conditions.

(1) In order to deliver effective attacks on the enemy while eliminating interceptions by enemy fighter planes with a single land-based attack plane, fast speed is absolutely necessary; its cruising speed needs to be 250 knots or more and its maximum speed needs to be 300 knots or more when flying at an altitude of 4,000 meters.

Also, [the fuselage of] the plane needs to be strong enough to enable [us] to dive at an angle of 30 degrees or more when engaging enemy aircraft.

(2) [The plane] needs to be able to carry at least two No. 50 bombs or one 1-ton torpedo as offensive weapons.

(3) Considering the geographical features of the Greater East Asia Co-Prosperity Sphere which stretches over a vast area close on 5,000 nautical miles, [the plane] needs to have a practical action radius of 1,500 nautical miles at minimum in offensive conditions in order to adequately display our offensive power.

(4) In order to break through bad weather and fully demonstrate its cruising range, [the plane] needs to be able to fly at an altitude of 10,000 meters or more.

(5) Defensively, [the plane] needs to be [as flame-proof] as U.S. B-17s so as not to easily catch fire by attacks of enemy fighter planes. It needs no saying that the more machineguns are fitted for its defense, the better. Nevertheless, in my opinion it is adequate to equip it with 13-mm machineguns (with a high rapidity of fire) at its nose and tail as long as they do not harm its previously-mentioned performance [requirements].

2. The currently used Type-98 land-based reconnaissance planes are [already] wanting in performance. In my opinion, we need to promptly work on a [new] reconnaissance aircraft with a cruising range of at least 1,500 nautical miles, putting top priority on its speed.

3. We need to work on a telescope that is easily usable for reconnaissance on aircraft.

After coming through several sea engagements in this [operation], I keenly felt that the drills for crews to identify types of naval vessels were insufficient. Moreover, unlike in regular exercises, in actual engagements we were often compelled to conduct reconnaissance from a [long] distance at high altitudes; for such cases, we need telescopes that are usable on aircraft. They should be swiftly worked on.

4. When taken from a high altitude, the currently used air photos are unclear, and in most cases, they are so unclear that it is difficult to identify types of naval vessels on them. We need to work on an on-board camera suitable for [photographing from] high altitudes.

5. My group has installed in the aircraft fuselages a simple space for processing photo films where during the flight we can process the reconnaissance results or the impact of shells, and present them upon landing, which has enabled us to promptly obtain very precise knowledge. In my opinion, large land-based reconnaissance aircraft as well as mid-sized land-based attack planes need to be outfitted with such equipment.

6. In some cases, [even] two direct hits from $60-\mathrm{kg}$ regular bombs at the bow only listed a midsized merchantman, without easily sinking her. Also, $60-\mathrm{kg}$ bombs are too small for light cruisers or submarines. In my opinion, we need to newly manufacture and provide $150-\mathrm{kg}$ regular bombs.

I think that the appropriate standard [sizes of] bombs to be used are the following:

a battleship:

a large cruiser: $500-\mathrm{kg}$ to $800-\mathrm{kg}$ regular bombs

$250-\mathrm{kg}$ to $500-\mathrm{kg}$ regular bombs 


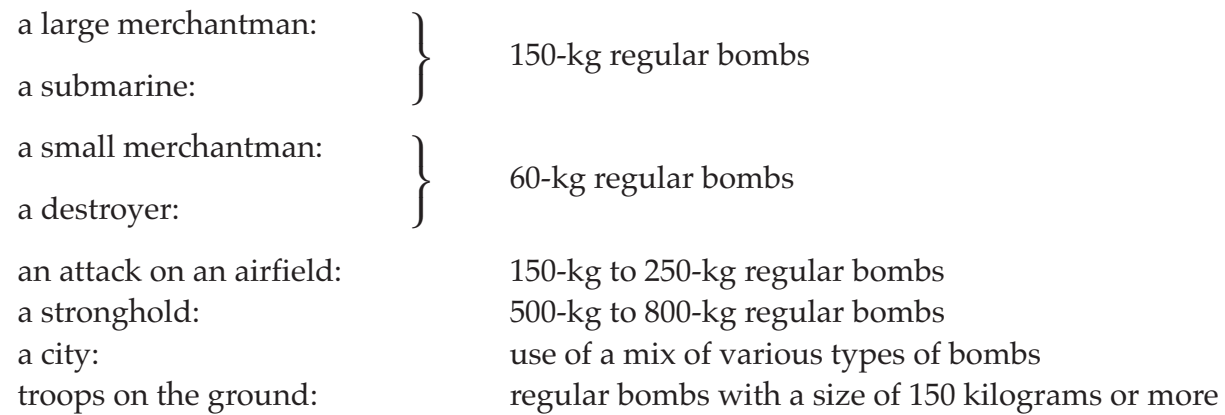

[In my opinion], it is in general more expedient to drop a small number of large bombs with a wider damage radius than dropping a large number of small bombs with a smaller damage radius in attacking airfields or [enemy] troops on land.

When in the future large land-based attack planes are to be put into service, we need to work on 1.5-ton bombs.

7. We need to work on a light torpedo with a total weight of 500 kilograms for attacks on merchantmen.

During the period from 1 until 17 February mainly at the Bangka and Karimata Straits, our unit bombed as many as thirty merchantmen, who were conducting rescue [operations] or were trying to escape from Singapore, but those we scored hits on and sank were just nine ships. In view of the fact that the strike accuracy was very poor in bombings by a single aircraft, I think we need to work on such a torpedo. In regard to merchantmen, I think that we can produce certain results even if such a torpedo runs on the surface of the waters. Therefore, a simple one with a running range of [as short as] 500 meters needs to be worked on.

8. We need to work on a large antisubmarine machinegun to be fitted on mid-sized land-based attack planes.

Although mid-sized land-based attack planes were often employed for guarding against or attacking enemy submarines, antisubmarine bombing attacks by mid-sized land-based attack planes produced very few results. I think we need to work on a large machinegun [effective enough to] make it impossible for enemy submarines to submerge.

\section{The Conclusion of the Java Invasion Operation}

\section{Military Gains and Losses}

Although it is impossible to show the military gains and losses of each unit during an identical period of time due to a lack of data, the gains and losses thought at that time to have been gained or sustained mostly during the period of the Dutch East Indies operation were as follows (some numbers only cover the period of the Java operation while others include periods after the Java operation):*

\footnotetext{
* The following lists and tables contain a number of problems when compared to data given earlier in the present volume or to data found in the archival records, Japanese or Allied. For the sake of consistency, we have silently corrected some of the data, but left most of them as they are in the Japanese text. These lists should be handled with caution. It is beyond the scope of the present translation project to try to solve the problems which these lists present.
} 
1. The military gains and losses of the Dutch East Indies Unit, Part I

The military gains and losses in the operations to capture Tarakan, Balikpapan, Menado and Kendari from 16 December 1941 until 24 January 1942 as reported at that time were as follows: ${ }^{(68)}$

(1) The military gains

Sank:

1 Minelayer

4 Submarines

[Aircraft] brought down:

6 aircraft

[Ships] captured:

3 (1 merchantman, 1 light ship, and 1 steam launch)

Abandoned bodies:

about 520 men

Captured ordnance:

Armored cars:

4

Field guns:

a few

Bombs, machineguns and rifles: large numbers

Disposed mines:

325

(2) The losses

Sunk: The Tatsugami-maru (auxiliary personnel transport ship), the Sumanoura-maru (oiler), the Nan'a-maru (transport ship), the Myōken-maru, the Kankō-maru (auxiliary gunboat), and Minesweepers No. 13 and No. 14

Shot down:

2 Aircraft

Seriously damaged:

Patrol Boat No. 37 and 2 aircraft

Killed in action:

258 men

Wounded in action:

361 men

2. The military gains of the Dutch East Indies Unit, Part II

The military gains of the Dutch East Indies Unit during the period from the capture of Ambon until the completion of the Java operation, i.e. from 24 January until 10 March 1942 were as shown in the following table:(68)

\begin{tabular}{|c|c|c|c|c|c|c|c|c|}
\hline $\begin{array}{l}\text { Unit } \\
\text { Name }\end{array}$ & $\begin{array}{c}\text { Attacking } \\
\text { Vessel }\end{array}$ & Dates & $\begin{array}{l}\text { [Enemy] } \\
\text { Cruisers }\end{array}$ & $\begin{array}{c}\text { [Enemy] } \\
\text { Destroyers }\end{array}$ & $\begin{array}{c}\text { [Enemy] } \\
\text { Submarines }\end{array}$ & $\begin{array}{c}\text { [Enemy] } \\
\text { Transport } \\
\text { Ships or } \\
\text { Merchant- } \\
\text { men }\end{array}$ & $\begin{array}{c}\text { [Enemy] } \\
\text { Aircraft } \\
\text { etc. }\end{array}$ & Location \\
\hline \multirow{3}{*}{ 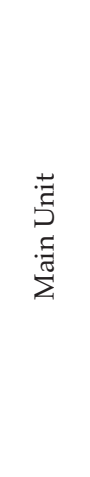 } & Ikazuchi & $18 \mathrm{Feb}$ & & & Sank 1 & & & $\begin{array}{l}72 \mathrm{NM} \text { north- } \\
\text { east of Manui } \\
\text { Island }\end{array}$ \\
\hline & \multirow{2}{*}{ Ushio } & 2 Mar & & & Sank 1 & & & $\begin{array}{l}75 \mathrm{NM} \text { west } \\
\text { of Bawean } \\
\text { Island }\end{array}$ \\
\hline & & 3 Mar & & & Sank 1 & & & $\begin{array}{l}85 \text { NM north- } \\
\text { west of } \\
\text { Bawean } \\
\text { Island }\end{array}$ \\
\hline
\end{tabular}




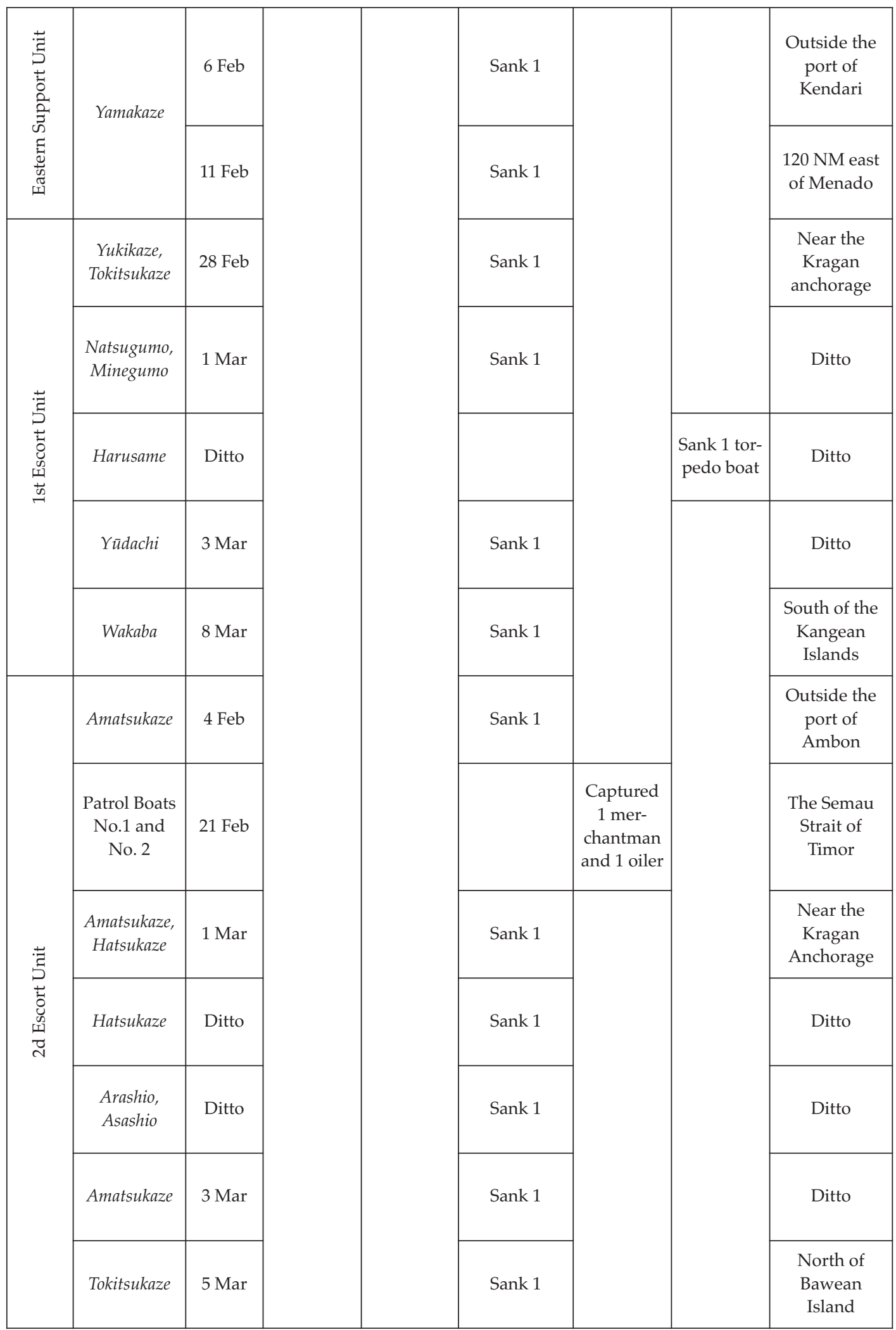




\begin{tabular}{|c|c|c|c|c|c|c|c|}
\hline \multirow{5}{*}{ 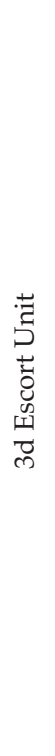 } & Harukaze & $1 \mathrm{Mar}$ & & & $\begin{array}{l}\text { Sank } 1 \\
\text { transport } \\
\text { ship }\end{array}$ & & Off Bantam \\
\hline & $\begin{array}{c}\text { Natori, } \\
\text { Harukaze, } \\
\text { Hatakaze }\end{array}$ & Ditto & & Sank 1 & & & Ditto \\
\hline & $\begin{array}{l}\text { Minesweep- } \\
\text { ers No. } 3 \\
\text { and No. } 4\end{array}$ & Ditto & & Sank 1 & & & Ditto \\
\hline & $\begin{array}{c}\text { Matsukaze, } \\
\text { Shiokaze }\end{array}$ & 2 Mar & & & & $\begin{array}{l}\text { Sank } 1 \\
\text { gunboat }\end{array}$ & $\begin{array}{l}80 \text { NM south } \\
\text { of Cape } \\
\text { Belitung }\end{array}$ \\
\hline & $\begin{array}{l}\text { 11th De- } \\
\text { stroyer Div } \\
\text { (minus } \\
\text { Hatsuyuki) }\end{array}$ & $1 \mathrm{Mar}$ & Sank 1 & & & $\begin{array}{l}\text { Sank } 1 \\
\text { gunboat }\end{array}$ & Bantam Bay \\
\hline \multirow{5}{*}{ 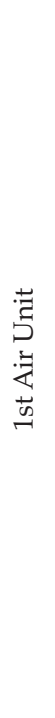 } & $\begin{array}{l}\text { Aircraft of } \\
\text { the } \\
\text { Kamikawa- } \\
\text { maru }\end{array}$ & $1 \mathrm{Mar}$ & & Sank 1 & & & Off Merak \\
\hline & Ditto & & & & $\begin{array}{l}\text { Sank } 1 \\
\text { transport } \\
\text { ship }\end{array}$ & & $\begin{array}{c}\text { Off Cape } \\
\text { Batang }\end{array}$ \\
\hline & & & & & & $\begin{array}{c}\text { Destroyed } \\
1 \text { aircraft } \\
\text { on the } \\
\text { ground }\end{array}$ & Makassar \\
\hline & & & & & & 19 aircraft & Surabaya \\
\hline & & & & & & $\begin{array}{c}\text { Shot } \\
\text { down } 3 \\
\text { aircraft }\end{array}$ & Ditto \\
\hline \multirow{4}{*}{ 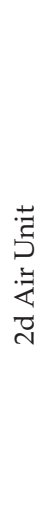 } & & $1 \mathrm{Mar}$ & $\begin{array}{c}\text { Destroyed } \\
1 \text { U.S } \\
\text { destroyer }\end{array}$ & & & & Off Surabaya \\
\hline & & $8 \mathrm{Mar}$ & & & $\begin{array}{c}\text { Sank 1 } \\
\text { merchant- } \\
\text { man }\end{array}$ & & Cilacap \\
\hline & & & & & & $\begin{array}{c}\text { Shot } \\
\text { down } 9 \\
\text { aircraft }\end{array}$ & \\
\hline & & & & & & $\begin{array}{c}\text { Destroyed } \\
3 \text { aircraft }\end{array}$ & \\
\hline
\end{tabular}




\begin{tabular}{|c|c|c|c|c|c|c|c|c|}
\hline & $\begin{array}{c}\text { Antisubma- } \\
\text { rine net }\end{array}$ & $1 \mathrm{Feb}$ & & & Sank 1 & & & $\begin{array}{l}\text { The Bangka } \\
\text { anchorage } \\
\text { (contacted } \\
\text { mines) }\end{array}$ \\
\hline & $\begin{array}{c}\text { Submarine } \\
\text { Chaser } \\
\text { No. } 3\end{array}$ & 2 Feb & & & Sank 1 & & & $\begin{array}{l}\text { Northeast of } \\
\text { the Bangka } \\
\text { anchorage }\end{array}$ \\
\hline & Michishio & 7 Feb & & & Sank 1 & & & $\begin{array}{c}\text { East of } \\
\text { Butung } \\
\text { Island }\end{array}$ \\
\hline & $\begin{array}{c}\text { 8th } \\
\text { Destroyer } \\
\text { Div }\end{array}$ & $20 \mathrm{Feb}$ & $\begin{array}{c}\text { Caused } \\
\text { minor } \\
\text { damage to } \\
1\end{array}$ & $\begin{array}{c}\text { Sank } 4 \\
\text { and } \\
\text { seriously } \\
\text { damaged } \\
1\end{array}$ & & & & $\begin{array}{c}\text { Sea } \\
\text { engagement } \\
\text { off Bali }\end{array}$ \\
\hline & $\begin{array}{l}\text { Fukuei-maru } \\
\text { No. } 15\end{array}$ & $21 \mathrm{Feb}$ & & & Sank 1 & & & $\begin{array}{l}7 \text { NM north- } \\
\text { east of } \\
\text { Batang Island }\end{array}$ \\
\hline 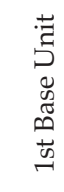 & Asashio & $2 \mathrm{Mar}$ & & & Sank 1 & & & $\begin{array}{c}50 \mathrm{NM} \text { north } \\
\text { of the east } \\
\text { point of } \\
\text { Madura } \\
\text { Island }\end{array}$ \\
\hline & $\begin{array}{c}\text { Submarine } \\
\text { Chaser } \\
\text { No. } 2\end{array}$ & 3 Mar & & & Sank 1 & & & $\begin{array}{l}\text { North en- } \\
\text { trance of the } \\
\text { Lombok } \\
\text { Strait }\end{array}$ \\
\hline & $\begin{array}{c}21 \text { st } \\
\text { Destroyer } \\
\text { Div }\end{array}$ & $28 \mathrm{Feb}$ & & & & $\begin{array}{l}\text { Sank } 1 \\
\text { transport } \\
\text { ship }\end{array}$ & & $\begin{array}{l}\text { South en- } \\
\text { trance of the } \\
\text { Lombok } \\
\text { Strait }\end{array}$ \\
\hline & $\begin{array}{c}\text { Submarine } \\
\text { Chaser } \\
\text { No. } 14\end{array}$ & $5 \mathrm{Mar}$ & & & Sank 1 & & & $\begin{array}{l}\text { North en- } \\
\text { trance of the } \\
\text { Lombok } \\
\text { Strait }\end{array}$ \\
\hline & Arashio & 9 Mar & & & & & $\begin{array}{c}\text { Sank } 1 \\
\text { mine- } \\
\text { sweeper }\end{array}$ & $\begin{array}{c}\text { East of the } \\
\text { Madura } \\
\text { Strait }\end{array}$ \\
\hline & Michishio & $21 \mathrm{Feb}$ & & & & & $\begin{array}{c}\text { Shot } \\
\text { down } 1 \\
\text { bomber }\end{array}$ & $\begin{array}{c}\text { North of the } \\
\text { Lombok } \\
\text { Strait }\end{array}$ \\
\hline
\end{tabular}




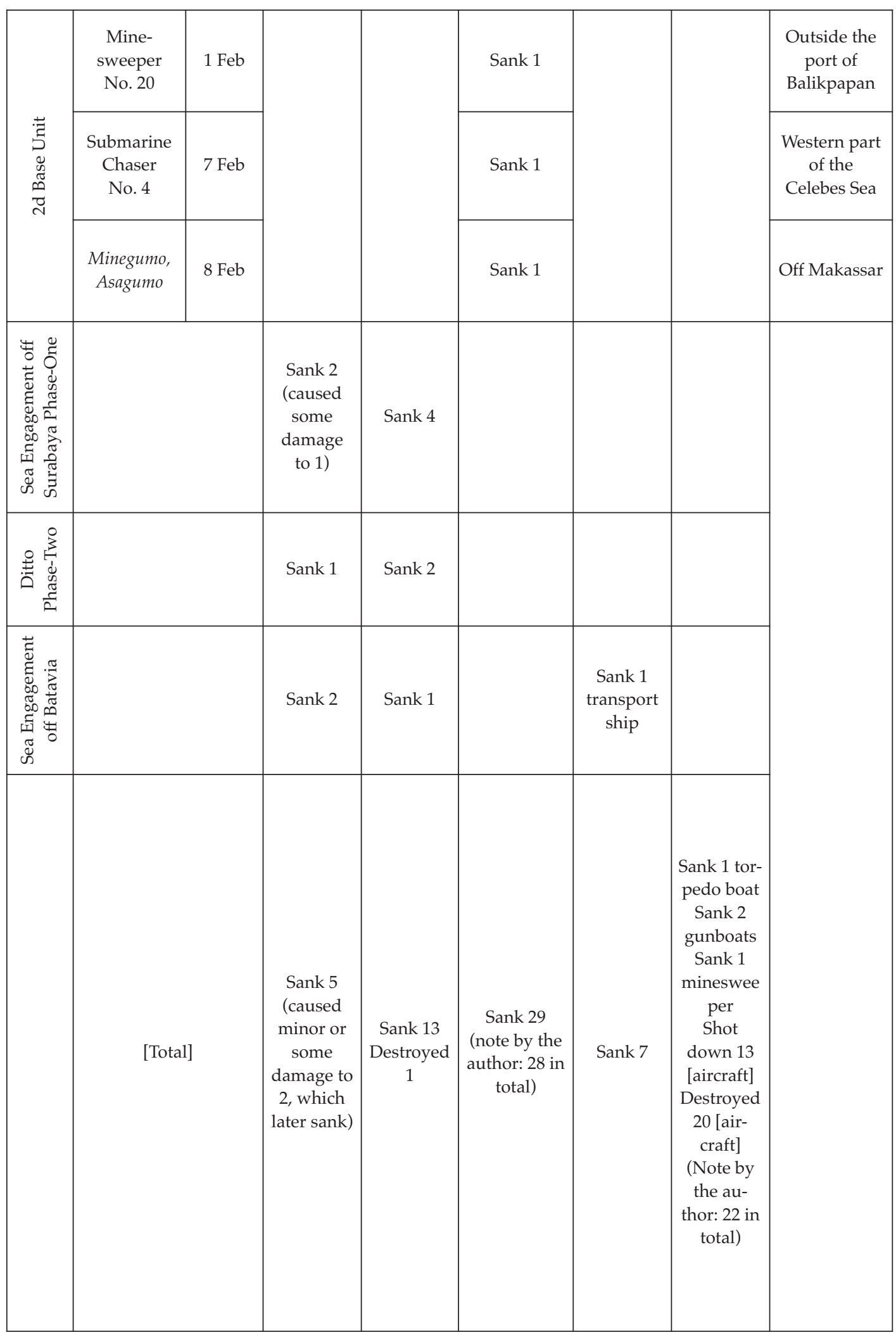


That is, [the Dutch East Indies Unit]

Sank:

7 cruisers, 13 destroyers, 29 submarines, 7 merchantmen/

transport ships and 4 other types of ships

Destroyed: $\quad 1$ destroyer

Brought down: 13 aircraft

Inflicted damage to: 20 aircraft

However, despite the [reported] number of sunken submarines (twenty-nine submarines), according to the documents made available to the public by the United States after the war, ${ }^{(176)}$ the submarines sunk during the Dutch East Indies operation were just the following four submarines:

1. U.S. submarines

SS-174 USS Shark: sunk on 11 February off Menado

SS-176 USS Perch: sunk on 3 March north of Surabaya

2. Dutch submarines

K-XIX: Sunk on 26 January in the Makassar Strait

K-XIII: Sunk in the eastern part of the Indian Ocean in early 1942

3. The losses sustained by the Dutch East Indies Unit, Part II ${ }^{(68)}$

(between 24 January and 10 March)

\begin{tabular}{|c|c|c|c|c|}
\hline $\begin{array}{c}\text { Vessel (Ship) } \\
\text { Type }\end{array}$ & $\begin{array}{l}\text { Vessel/Ship } \\
\text { Name }\end{array}$ & Date & Degree of Damage & Cause \\
\hline Cruiser & Nagara & 25 Jan & $\begin{array}{l}\text { Minor damages (will with- } \\
\text { stand military operations } \\
\text { after emergency repairs at } \\
\text { Davao) }\end{array}$ & $\begin{array}{l}\text { Minor collision with the Hat- } \\
\text { suharu near the mouth of the } \\
\text { Bay of Kendari }\end{array}$ \\
\hline Destroyer & Hatsuharu & 25 Jan & Ditto (ditto) & $\begin{array}{l}\text { Minor collision with the Nagara } \\
\text { near the mouth of the Bay of } \\
\text { Kendari }\end{array}$ \\
\hline Ditto & Suzukaze & $4 \mathrm{Feb}$ & $\begin{array}{l}\text { Ditto (emergency repairs pro- } \\
\text { vided by the } A k a s h i \text { ) }\end{array}$ & $\begin{array}{l}\text { Leaks caused by a torpedo at- } \\
\text { tack from an enemy submarine, } \\
\text { while patrolling the mouth of } \\
\text { the Bay of Kendari }\end{array}$ \\
\hline Ditto & Natsushio & $8 \mathrm{Feb}$ & Sunk & $\begin{array}{l}\text { Sunk by a torpedo attack from } \\
\text { an enemy submarine at } 50 \mathrm{NM} \\
\text { southwest of Makassar }\end{array}$ \\
\hline Ditto & Michishio & 20-21 Feb & $\begin{array}{l}\text { Minor damages (engines in- } \\
\text { operable) }\end{array}$ & $\begin{array}{l}\text { Hit in the sea engagement off } \\
\text { Bali }\end{array}$ \\
\hline Ditto & Ōshio & 20-21 Feb & $\begin{array}{l}\text { Ditto (will withstand engage- } \\
\text { ments and cruising, though } \\
\text { hit at the searchlights and the } \\
\text { powder handling room) }\end{array}$ & $\begin{array}{l}\text { Hit in the sea engagement off } \\
\text { Bali and in an air raid the next } \\
\text { morning }\end{array}$ \\
\hline Ditto & Asagumo & $27 \mathrm{Feb}$ & $\begin{array}{l}\text { Ditto (able to cruise on her } \\
\text { own) }\end{array}$ & $\begin{array}{l}\text { Hit in the first phase of the sea } \\
\text { engagement off Surabaya }\end{array}$ \\
\hline
\end{tabular}




\begin{tabular}{|c|l|l|l|l|}
\hline Ditto & Harukaze & 1 Mar & $\begin{array}{l}\text { Ditto (will withstand engage- } \\
\text { ments) }\end{array}$ & $\begin{array}{l}\text { Hit in the sea engagement off } \\
\text { Batavia }\end{array}$ \\
\hline Ditto & Shikinami & Ditto & Ditto & Ditto \\
\hline Minesweeper & No. 9 & 2 Feb & Sunk & $\begin{array}{l}\text { Sank after contacting mine[s] } \\
\text { while sweeping the port of } \\
\text { Ambon }\end{array}$ \\
\hline Ditto & No. 11 & Ditto & $\begin{array}{l}\text { Some damage (unable to } \\
\text { cruise on her own) }\end{array}$ & $\begin{array}{l}\text { Sustained some damage by } \\
\text { mine[s] while sweeping the port } \\
\text { of Ambon }\end{array}$ \\
\hline $\begin{array}{c}\text { Ditto } \\
\text { Ditto }\end{array}$ & No. 12 & Ditto & Ditto & Ditto \\
\hline $\begin{array}{c}\text { Auxiliary } \\
\text { Teaplane }\end{array}$ & Sanuki-maru & 27 Jan & $\begin{array}{l}\text { Some damage (emergency re- } \\
\text { pairs provided) }\end{array}$ & $\begin{array}{l}\text { Leaks and ran aground in an } \\
\text { [enemy] air raid at Balikpapan }\end{array}$ \\
\hline
\end{tabular}

That is, [The Dutch East Indies Unit sustained the following losses:]

Sunk:

1 Destroyer and 2 minesweepers

Sustained minor or some damage: 1 Cruiser, 7 destroyers, 2 minesweepers and 1 auxiliary seaplane tender

4. The military gains and losses reported by the Carrier Task Force ${ }^{(68)}$

(1) The first carrier operation (attack on Port Darwin)

Brought down 8 enemy aircraft, set 10 aircraft ablaze and inflicted serious damage on 5

Sank 2 destroyers and 8 auxiliary naval vessels

Inflicted serious damage on 7 naval vessels

Set 3 hangars ablaze

(2) The second carrier operation (carrier operation [on the waters] south of Java)

Sank 1 destroyer, 5 merchantmen, 1 minesweeper, 13 special service vessels and others

(3) Losses sustained (aircraft): 1 carrier-based bomber and 1 carrier-based fighter plane, which crashed themselves

5. The military gains reported by the main body of the Southern Task Force ${ }^{(68)}$

Sank [enemy] vessels [of] 1 cruiser, 1 destroyer, 1 gunboat, 1 sloop, 1 oiler, 1 minesweeper and 6 merchantmen

Inflicted damage on 1 armed merchantman

Captured 4 merchantmen

6. The military gains and losses reported by the Air Unit of the Southern Task Force ${ }^{(75)}$ (4 January - 6 April)

(1) Losses inflicted on the enemy air force (as shown in the following table): 


\begin{tabular}{|c|c|c|c|c|c|c|c|}
\hline \multicolumn{4}{|c|}{$\begin{array}{l}\text { Shot down } \\
\text { (unconfirmed within parentheses) }\end{array}$} & \multicolumn{4}{|c|}{$\begin{array}{l}\text { Set ablaze on the ground } \\
\text { (destroyed within parentheses) }\end{array}$} \\
\hline $\begin{array}{l}\text { Large } \\
\text { Aircraft }\end{array}$ & $\begin{array}{l}\text { Small } \\
\text { Aircraft }\end{array}$ & $\begin{array}{l}\text { Flying } \\
\text { Boats }\end{array}$ & Others & $\begin{array}{l}\text { Large } \\
\text { Aircraft }\end{array}$ & $\begin{array}{c}\text { Small } \\
\text { Aircraft }\end{array}$ & $\begin{array}{c}\text { Flying } \\
\text { Boats }\end{array}$ & Others \\
\hline $24(12)$ & 111 (37) & $19(0)$ & $3(0)$ & $77(31)$ & $34(33)$ & $38(18)$ & $28(4)$ \\
\hline \multicolumn{4}{|c|}{157 (49) } & \multicolumn{4}{|c|}{$177(86)$} \\
\hline \multicolumn{8}{|c|}{334 (135) } \\
\hline
\end{tabular}

469 aircraft in total

(2) Enemy naval vessels sunk or destroyed (as shown in the following table):

\begin{tabular}{|c|c|c|c|c|c|c|c|}
\hline \multicolumn{4}{|c|}{ Sunk, Set Ablaze, Listed or Seriously Damaged } & \multicolumn{4}{|c|}{ Considerable Damage Inflicted by Direct Hits } \\
\hline $\begin{array}{c}\text { Naval } \\
\text { Vessels }\end{array}$ & Destroyers & Submarines & $\begin{array}{l}\text { Merchant- } \\
\text { men } \\
\text { of } 10,000 t \\
\text { or more }\end{array}$ & $\begin{array}{c}\text { Naval } \\
\text { Vessels }\end{array}$ & Destroyers & Submarines & $\begin{array}{c}\text { Merchant- } \\
\text { men } \\
\text { of } 10,000 t \\
\text { or more }\end{array}$ \\
\hline $\begin{array}{l}2 \text { Heavy } \\
\text { cruisers } \\
2 \text { Light } \\
\text { cruisers } \\
1 \text { Auxiliary } \\
\text { carrier } \\
1 \text { Minelayer } \\
1 \text { Gunboat }\end{array}$ & 0 & 3 & 18 & $\begin{array}{l}2 \text { Heavy } \\
\text { cruisers } \\
4 \text { Light } \\
\text { cruisers } \\
1 \text { Minelayer }\end{array}$ & $\begin{array}{l}8 \text { Destroy- } \\
\text { ers } \\
1 \text { Torpedo } \\
\text { boat }\end{array}$ & 2 & 17 \\
\hline
\end{tabular}

(3) The Losses [of the unit itself]

\{1\} Aircraft

\begin{tabular}{|l|c|c|c|c|c|}
\hline \multicolumn{1}{|c|}{ Type of Loss } & $\begin{array}{c}\text { Land-based } \\
\text { Attack Planes }\end{array}$ & $\begin{array}{c}\text { Land-based } \\
\text { Reconnaissance } \\
\text { Planes }\end{array}$ & Fighter Planes & Flying Boats & Total \\
\hline Crashed themselves & 12 & 6 & 14 & 2 & 34 \\
\hline Hit or marked by bullets & 2 & 0 & 2 & 0 & 4 \\
\hline Total & 14 & 6 & 16 & 2 & 38 \\
\hline
\end{tabular}

\{2\} Naval vessels

4 Transport ships were sunk 
7. The military gains and losses reported by the Submarine Unit of the Southern Task Force $^{(60)}$

(1) The military gains of Submarine Unit A Sank 6 merchantmen Inflicted damage on 1 oiler

(2) The military gains of Submarine Unit C Sank 3 merchantmen

(3) The losses

Submarine I-5 (Submarine Unit C) sustained damage by friendly fire from our aircraft

8. The military gains and losses reported by the army units ${ }^{(166)}$

(1) The military gains obtained on Java (until 25 March)

Prisoners of war: 82,618 men in total

Captured goods:

177 Aircraft

A total of 940 [large] guns

4,228 Heavy and light machineguns

80,778 Rifles and pistols

5,153 Searchlights

$1,728,585$ Shells and ammunition

$89,071,820$ Cartridges for machineguns and rifles

36,000 Bombs

Vehicles, tanks, armored cars and special service vehicles, 1,059 in total

9,500 Automobiles

7,108 Train carriages

About one-year [supply] of medicines for 100,000 men

(2) The losses sustained in the Java operation

\begin{tabular}{|c|c|c|c|c|}
\hline \multirow{2}{*}{ Unit } & \multicolumn{2}{|c|}{ Up to 1 March } & \multicolumn{2}{c|}{ 2-5 March } \\
\cline { 2 - 5 } & Killed & Wounded & Killed & 26 \\
\hline Shōji Detachment & 63 & 165 & 2 & 28 \\
\hline Sakaguchi Detachment & 1 & 18 & 64 & 180 \\
\hline 2d Division & 15 & 10 & 0 & 21 \\
\hline 48th Division & 91 & 254 & 85 & 255 \\
\hline Total & 170 & 447 & & 2 \\
\hline
\end{tabular}

Meanwhile on 10 March, the Emperor granted the following Imperial Rescript to the commanders in chief of the Combined Fleet and the Southern Army. ${ }^{(62)}$

The Army and Navy units operating in the Dutch East Indies theater have in close and effective cooperation and covering enormous distances overcome numerous difficulties, fought bravely, and destroyed the enemy's air power and fleets, while at the same time determinedly carrying out the most difficult landing operations in various areas, crushing strong enemy [forces] every- 
where, and by completely and boldly demolishing every major base of the enemy with great speed, they swept away the military forces of the enemy. We highly approve of them.

\section{An Assessment of the Enemy Movements in the Southwestern Theater}

According to the "Greater East Asia War's Lessons of War ([section] Air Operation)," the assessment of the enemy movements after the Dutch East Indies operation was virtually completed was as follows:

\section{Australia}

\section{Air forces}

(1) U.S. Air Forces

It seems that reinforcements from the mainland of the United States had finally gotten on track and that they were trying to bring aircraft [to the front], when the swift invasion of Java by the Japanese forces took them by surprise. (The USS Langley, which was sunk at a point south of Cilacap on 27 February, had been transporting a full load of reinforcement aircraft. It is also presumed that about thirty large aircraft destroyed on the ground at Broome on 3 March had been on their way to Java as reinforcements, too.) Accordingly, we expect that in Australia, not only a remarkable number of reinforcements for Australia and the Dutch East Indies have been assembled but that also a considerable number of U.S. air forces will be transported and assembled there in the future.

(2) The forces that escaped from Java to Australia Since both [the routes between Java and] the Lesser Sunda Islands and [between Java and] Sumatra were cut off and Java was swiftly captured, it is presumed that the enemy air forces on Java that had [successfully] escaped to Australia were limited to a very small number of large aircraft.

(3) The Australian Air Force

Although it is clear that [some of the] Australian Air Force had been dispatched to the Dutch East Indies, details are not known. Accordingly, it is difficult to assess its current power.

According to an estimate by the Navy General Staff, the Australian Air Force is being reinforced with about 150 aircraft per month on average, including those which returned from overseas deployment, reinforcements provided by the United States and Britain and those which are domestically manufactured (2 February).

2. Surface Forces

Apart from the naval vessels proper to the Australian Navy, we may assume that roughly the following vessels are present in the area:

(1) U.S. Naval vessels

$\{1\}$ Reinforcements

Although it is difficult to confirm the [number of U.S.] naval vessels [mentioned] in the intelligence reports of early January, in view of the intelligence report communicated right before the sea engagement off Surabaya (27 February) that a considerable number of U.S. naval vessels had been [seen at anchor] in Sharks Bay on the west coast of Australia, it is thought that a certain level of reinforcements has been provided on top of the remaining forces of the Asiatic Fleet.

\{2\} Task Force

Although the force seems to have returned to Hawaii after its operations in the Rabaul area, in view of the [past] case of having returned to Sydney after the first surprise attack [operation] (in the Marshall Islands on 1 February), we cannot exclude the possibility that the force is operating in Australian waters. 
\{3\} The forces that escaped from Java

About four destroyers, [which escaped] after the sea engagement off Surabaya, and a few destroyers and submarines that had escaped prior to the engagement seem to be staying in the Australia area.

(2) British and Dutch naval vessels

$\{1\}$ It is thought that part of the British vessels (the bulk of them [were operating] in the India area) as well as some of the Dutch destroyers, who were in the Java area before the [Japanese] invasion operation against Java, have escaped to Australia.

\{2\} The British battleship HMS Warspite is likely to have left the west coast of the United States and be operating in the Australia area or in the Indian Ocean.

II. India and Burma

1. Air forces in the India area

(1) Currently deployed forces: about 230 aircraft

(2) Reinforcements

About 150 aircraft from North Africa as well as from the Middle and the Near East (anticipated to be completed in early April)

About 100 aircraft reinforced by Britain and the United States

About 80 aircraft in preparation to be sent as reinforcements from Britain and the United States

2. Air forces in the Burma area (Intelligence provided by the Army 5th Air Force)

(1) Forces

Large aircraft: About 20 aircraft, mostly Blenheims.

Small aircraft: 50-60 aircraft, of which Hurricanes were largest in number; about 20 of them were $\mathrm{P}-40 \mathrm{~s}$.

(2) Replacement air forces

So far, it seems that replacements other than those required to keep up the strength [in the area] as shown in the previous item will not be brought in.

(3) Deployment of the forces

\{1\} Magwe (60 nautical miles about $210^{\circ}[\mathrm{SW}]$ of Mandalay)

It seems to be a core base of enemy forces retreating from Rangoon; 12-13 large aircraft, a few mid-sized aircraft and forty-odd small aircraft.

\{2\} Akyab: about 20 [aircraft], mostly small.

\{3\} The Taunggyi area (85 nautical miles about $140^{\circ}$ [SE] of Mandalay) Sometimes two or three aircraft appear. There are five airfields in the area.

\{4\} Lashio: Two or three aircraft sometimes appear.

(4) The operational movements of enemy air forces

\{1\} Bombing of cities

[The enemy] has executed bombing attacks on the border areas with Thailand. The bombing attacks on Bangkok are only conducted on moonlit nights with two or three aircraft.

No air raids have been conducted since early February.

\{2\} Bombing of bases

No particular bombing attacks have been conducted other than those by $\mathrm{P}-40$ s on the Chiang Mai [base] (330 nautical miles north north-west of Bangkok).

\section{Surface forces}

(1) Forces

2 to 3 Battleships (both [or either one of] HMS Royal Sovereign and HMS Ramillies, and HMS Revenge)

2 Carriers (HMS Hermes, HMS Indomitable)

4 Class-A cruisers (HMS Cornwall, HMS London, HMS Sussex and HMAS Canberra) 
About 10 Class-B cruisers

About 13 destroyers

Several submarines

Other than the above, it seems that the enemy has a few auxiliary aircraft carriers.

The Battleship HMS Warspite is likely to operate in this area. Another battleship and two aircraft carriers are anticipated to be sent in as reinforcements in the near future.

(2) Bases

Colombo, Bombay, Mombasa (the east coast of Africa) and Durban (the southeast coast of Africa)

(3) Submarines

Having lost all their bases in the Dutch East Indies and Malaya areas, it is thought that enemy submarines will use bases in Ceylon and Perth (western Australia) in the future.

Since the enemy may turn places in the Dutch East Indies that we have not yet seized into supply bases for submarines, it is necessary to be on guard against this [possibility].

\section{Evaluation of the World Situation and the Fundamental Principles in Conducting the War}

On 7 March 1942, the following evaluation of the world situation was agreed upon at the liaison conference between IGHQ and the Government: ${ }^{(144)}$

\section{Evaluation of the World Situation (excerpt)}

I. Measures the United States and Britain are likely to take

From now on, the United States and Britain will cooperate all the more closely in military, economic, financial and other fields. While unitedly striving to degrade the military power of the Axis [Powers] on the one hand, they will on the other hand strive for a rapid buildup of their own military power. By making the conduct of the war against the Axis Powers in Europe their top priority, they will try in conjunction with the Soviet Union to turn the war situation in that theater to their advantage, while striving to secure and strengthen the bases that will enable them to strike back at and attack Japan. And when their power becomes superior, they will plan a counterattack against Japan at a stroke. That is,

1. For the time being, along with the United States and the Soviet Union, Britain will first of all try to rapidly destroy the military capabilities of Germany and Italy, while securing the Mediterranean Sea and western Asia, so as to block Japan, Germany and Italy from cooperating [with each other].

In the east, Britain will strive as much as possible to maintain her naval supremacy in the Indian Ocean as well as to secure India and Australia in order to make counterattacks against Japan and to keep the British Empire united.

2. For the time being, along with Britain and the Soviet Union, the United States will first of all try to rapidly destroy the military capabilities of Germany and Italy, while in Australia and the Indian Ocean areas, striving to secure and strengthen the bases from where to launch counterattacks against Japan. It also will strive to concentrate powerful naval and air forces in the Pacific and with one element try to conduct guerrilla-type actions, such as sabotaging Japanese shipping lanes, or conducting surprise attacks on pivotal areas of Japan.

3. While supporting the Soviet Union and the Chiang [Jiang] regime [on the one hand], the United States and Britain are on the other hand pinning their hopes on a move by the Soviet Union to check Japan or its participation in the war against Japan and they are doing their 
utmost to realize this. For the time being, they may also plan to obtain bases in the eastern part of the Soviet Union from where to attack Japan.

4. At an appropriate moment when their military strength has become strong enough, the United States and Britain will shift to large-scale offensives against the Axis [Powers]. It is highly likely that against Japan they will in conjunction with the Soviet Union and China, try to directly attack pivotal areas in Japan from the continent, while with their main force launching counterattacks to recapture one strategic point after another [in the southern areas] from the direction of Australia and the Indian Ocean.

[However,] it will be by and large in 1943 or later before they will be able to execute such large-scale offensives.

Reference: Situation in Australia and India (Omitted by the author)

II. The measures the Soviet Union is likely to take (Omitted by the author)

III. The measures Germany and Italy are likely to take (Omitted by the author)

IV. The movements of the Chongqing regime (Omitted by the author)

$\mathrm{V}$. The movements of neutral countries (Omitted by the author)

VI. The changes in the national strength of the countries

1. The United States and Britain's war potential

(1) The United States

The United States is likely to devote all its energies to improving bottlenecks in its production sectors and getting ready for a total war. Generally speaking, until the end of 1944 its military readiness and production capacity [to supply] military demand will have made dramatic progress.

However, after that, due to shortages of resources that are dependent on the outside world, of labor and transport capacity, the rise in production capacity may gradually come to a standstill.

(2) Britain

If current conditions continue, a slight increase in its military capacity will still be likely in the future.

However, in terms of human resources, the British mainland has almost reached its limit. Since in terms of physical resources, it further has to depend on overseas countries particularly the United States, and with the loss of its naval supremacy as well as its [overseas] territories and colonies, its war potential will inevitably show a tendency to decline.

(3) An overall observation about the United States and Britain's war potential The United States and Britain's total war potential when combined is very strong; they have the capacity to rapidly create a war capability superior to that of Japan and prosecute the war for a longer period of time.

Although they are on the whole also very strong in their fighting spirit, they have the following weak spots.

$\{1\}$ Their human military potential is not as [excellent] as their physical military potential.

\{2\} Although [they] have a massive military potential, the political and economic systems of the United States and Britain, those of the United States in particular, have not yet been put on a footing essential for prosecuting a total war. From now on, numerous conflicts and complications will arise before such a footing is established.

\{3\} Although they have superior armaments, the loss of operational bases has markedly reduced their value.

\{4\} Britain's war potential very much depends on its maritime transport capacity.

$\{5\}$ The maritime transport capacity of the United States is poor compared to its national power, which makes it impossible for the country to give Britain all-out support. 
\{6\} The impact of isolating and separating the United States and Britain from each other on their ability to prosecute the war is incomparably greater than that of isolating and separating Japan and Germany from each other.

$\{7\}$ It is possible that isolating and separating Britain from its self-governing dominions and colonies may lead to the fall of the country in the end.

$\{8\}$ Since the living standards of the people of the United States and Britain are high and a fall in these standards may cause much pain, a continuation of the war with no hope for [immediate] victory will foment social instability and bring about a decline in morale in general. Particularly, the defeat of Britain will have a huge impact on [the morale of] the United States.

\{9\} While the ties between the United States and Britain are natural, the alliance between the United States, Britain and the Soviet Union is unnatural, and contains many contradictions.

$\{10\}$ Since the policies adopted by Roosevelt and Churchill tend to be speculative and adventurous, not all people necessarily are willing to follow their leadership.

2. The Soviet Union's war potential (Omitted by the author)

3. Germany and Italy's war potential (Omitted by the author)

Following this evaluation of the situation, Japan decided on the following fundamental principles in conducting the war to be adopted from now on (excerpts). ${ }^{(144)}$

The Fundamental Principles in Conducting the War to Be Adopted from Now on (7 March 1942)

1. In order to make Britain surrender and the United States lose its will to fight, [Japan] shall continue expanding the military gains it has already achieved, and at appropriate opportunities take aggressive measures, while preparing a political and military system that will be invincible for a long time.

2. By securing the occupied areas and the main lines of communication, [Japan] shall expedite the development and use of [natural] resources essential for its national defense, establish a condition of self-sufficiency and strive to strengthen the military power of the nation.

3. A concrete plan for a more aggressive conduct of war shall be decided upon after having taken into consideration such circumstances as the Japan's national power, the progress of the operations, the war situation between Germany and the Soviet Union, the relations between the United States and the Soviet Union, and the movements of the Chongqing [regime].

4. The measures to be taken against [movements of] the Soviet Union (Omitted by the author)

5. The measures to be taken against [movements of] the Chongqing [regime]. (Omitted by the author)

6. The cooperation with Germany and Italy (Omitted by the author)

\section{Evaluation of the Achievements of the Initial Operations}

On 11 March 1942, IGHQ and the [Japanese] government made the following evaluation of the achievements of the initial operations: ${ }^{(144)}$

What are the differences in the achievements of the initial operations, compared to the plans in terms of [Japan's] military, economic, and political [goals]?

I. Military

1. [Achievements] against the United States, Britain and the Netherlands

As a result of the fact that the [Japanese] Army and Navy have achieved far greater initial military gains than expected, both the United States and Britain have been put on the de- 
fensive for the time being, which has created a situation that is advantageous [to Japan] in terms of the defense of its territory and securing its vital shipping lanes. Moreover, it has brought an opportunity to be now able to shift to an offensive strategy by making use of the current tide of the war, contrary to the expectations that [Japan] would be forced to adopt a defensive strategy in order to carry on a drawn-out war to a successful finish.

Explanation:

(1) Except for some delay in the Philippines (note by the author: the capture of Bataan Peninsula), the army operations have progressed on the whole by about one month faster [than planned]. Also, the losses of our forces were unexpectedly light.

Above all, this made it possible to already launch the Burma operation, which was expected to be conducted after the rough completion of the southern operation, with the reserve strength that had been spared early on in the southern theater.

(2) Whereas our naval operations have not just dealt a great blow to the main forces of the U.S. and British fleets in the Pacific area at the beginning of the hostilities but [actually] destroyed most of the enemy surface forces in the East, our own losses were unexpectedly small. For the time being, this has led to a reversal of offensive and defensive positions in the military power balance between the enemy and us in the Pacific and Indian Oceans.

(3) Also, the air operations of the [Japanese] Army and Navy have destroyed the huge enemy air power at a relatively low cost and produced more military gains than expected. Therefore, [the Japanese forces] will be ready to deal with a rapid reinforcement of enemy air forces and prevent a massive enemy air power from being deployed in the Pacific and Indian Oceans in the future.

(4) It is likely that when the United States and Britain regain their military power in the future, they will plan large-scale offensives, making use of their remaining bases for counterattacks.

(5) Particularly the psychological blow dealt [by Japan] to the enemy military at the beginning of the hostilities must have been immense.

2. [Achievements] against the Chongqing [regime]

Concerning [the achievements against] the Chongqing [regime], the enormous military gains in the initial operations, particularly the quicker-than-expected cutting of the Burma route [to supply the Chongqing regime] (note by the author: the capture of Rangoon, the starting point of the Burma route on 8 March) have led us to expect that they will have a considerable impact on the [regime's] power of resistance.

3. [Achievements] against the Soviet Union (Omitted by the author)

4. [Effects] on Germany and Italy (Omitted by the author)

II. Politics

If, with a focus on the [Japanese] Empire, we compare the current world situation with what had been expected before the opening of the hostilities, there is on the whole not much difference with what had been expected at the beginning, though most developments have been more favorable to the Empire than expected.

Explanation (Omitted by the author)

III. Economics

Owing to the huge military gains at the beginning of the hostilities,

1. Securing the [natural] resources in the areas specified in the plans and cutting off the supply of essential materials to the United States and Britain were for the most part achieved earlier [than planned].

2. The maritime transport capacity was on the whole maintained as planned.

3. The prospect is certain that compared to the plans, the acquisition of materials, oil in particular, is likely to achieve excellent results. 
Although it may be expected, as shown in the above, that our war capacity in terms of materials will on the whole be strengthened more than planned, our food security still needs consideration.

Explanation

1. Maritime transport capacity

Although there are some differences in the factors by which the [total] tonnage is calculated, the shipping capacity on the whole has mostly stayed [on the level] specified in the plans.

Namely, the decrease in the use of captured ships and the larger-[than-expected] number of requisitioned ships and ships which need repair are offset by the increase in the number of charters from foreign countries and the smaller number of lost or destroyed ships (C ships). Moreover, the ships returning to mainland Japan from now on will be counted as an increase in shipping capacity.

2. Steel

(1) The planned [production amount]

\{1\} The [planned] amount of steel produced in the fiscal year 1941 shall be [changed] to $4,500,000$ tons, which was set at the time of opening of the hostilities, from 4,760,000 tons, which was specified in the materials mobilization plan.

\{2\} As for the amount for the fiscal year 1942, the amount produced during the southern operation shall be reduced to $3,800,000$ tons when calculated on an annual basis.

(2) An estimation based on the current [production amount]

\{1\} The [actual] amount of steel produced in the fiscal year 1941 reached 4,650,000 tons, which was 150,000 tons more than planned.

$\{2\}$ For the fiscal year 1942, given that the shipping capacity remains as specified in the plan, the prospect is that a production level of 5,000,000 tons can be secured by intensifying the collection of scrap iron and using [the materials] in store.

3. Rice (Omitted by the author)

4. Materials to be obtained in the southern areas (except for oil)

The [amounts] specified in the plans will more or less be attained.

5. Oil

(1) Expected amounts to be obtained from the southern areas

([The numbers] in the explanation as given by the president of the [Cabinet] Planning

Board at the Imperial Conference on 5 November [1941])

$\begin{array}{llrrr} & & 1 \text { 1st year } & 2 \text { d year } & 3 \text { d year } \\ \text { Borneo: } & 300,000 \mathrm{kl} & 1,000,000 \mathrm{kl} & 2,500,000 \mathrm{kl} \\ \text { Sumatra: } & \text { southern area } & - & 750,000 \mathrm{kl} & 1,400,000 \mathrm{kl} \\ & \text { northern area } & - & 250,000 \mathrm{kl} & 600,000 \mathrm{kl} \\ \text { total } & & 300,000 \mathrm{kl} & 2,000,000 \mathrm{kl} & 4,500,000 \mathrm{kl}\end{array}$

(2) The expected amount to be obtained in the fiscal year 1942

$\begin{array}{lr}\text { British Borneo } & 700,000 \mathrm{kl} \\ \text { Tarakan } & 250,000 \mathrm{kl} \\ \text { Sanga Sanga } & 300,000 \mathrm{kl} \\ \text { Sumatra } & 500,000 \mathrm{kl} \\ \text { Total } & 1,750,000 \mathrm{kl}\end{array}$

Thus, with the completion of Java invasion operation and taking the first stage of the invasion operations as completed, the prospects for the shift to the subsequent operations were very bright. 


\section{A Critical Review [of the Operation]}

Although the Dutch East Indies operation looked as if it had progressed smoothly, the symptoms of the causes that would become the source of many troubles in the future were already visible, namely:

1. Offense-related [matters]

(1) The antisubmarine attacks were often ineffective.

(2) The accuracy of horizontal bombing deteriorated (due to a lack of training).

(3) It was very difficult to bring down large enemy aircraft.

2. Defense-related [matters]

(1) While the hit rate of the enemy antiaircraft fire was good, ours was poor.

(2) [Our forces] lacked the notion of protecting their bases, due to which no adequate countermeasures were taken and [our bases] were susceptible to enemy surprise attacks.

(3) [Our forces] had a poor notion of emergency repairs (such as measures to fix damage caused by shots or bombs) and their skills were poor. (For instance, the case of the destroyer Natsushio off Makassar.)

(4) The defensive capacity of our land-based attack planes was remarkably poor. (Note: It was impossible to increase their defensive capacity with the technology on hand at that time since longer cruising ranges to enable them to conduct operations over the open seas were given priority.)

\section{Others}

(1) A serious lack of capabilities to set up bases

(2) Insufficient communication capabilities, particularly the insufficient capability of signal communications of the rapidly constructed land bases.

Among these problems, the fact that the antisubmarine attacks were not effective became the source of enormous problems in later periods.

Reference: The actual performance of antisubmarine attacks by the Japanese Navy at that time

1. The performance of the sonar equipment (Type93 Mark I and Mark III) on the destroyers of the fleet [in a test mission to] clear [hostile] submarines (according to 'A study on the improvement of the underwater detection skills of the fleet')

\begin{tabular}{|c|c|c|}
\hline \multicolumn{2}{|c|}{ The [successful] detection rate of totally submerged submarines } & $50 \%$ \\
\hline \multicolumn{2}{|c|}{ The percentage of false detections in the total number of detections } & $50 \%$ \\
\hline \multicolumn{2}{|c|}{ The detectable distance } & 1700 [meters] \\
\hline \multirow{2}{*}{ Accuracy } & Margin of error in terms of direction & $+-6.5^{\circ}$ \\
\hline & Margin of error in terms of distances & $4 \%$ \\
\hline \multicolumn{2}{|c|}{ The maximum speed at which detection [is possible] } & $\begin{array}{l}14 \text { knots (though noise from the direction } \\
\text { of the bow was large) }\end{array}$ \\
\hline \multicolumn{2}{|c|}{ The capability to receive sounds emitted by hostile submarines } & $\begin{array}{l}\text { Able to detect their direction when sailing } \\
\text { at } 18 \text { knots }\end{array}$ \\
\hline \multicolumn{2}{|c|}{ The interference of sounds emitted by other [friendly] vessels } & $\begin{array}{l}\text { Sometimes it is difficult to detect [the } \\
\text { enemy] due to mutual [friendly] interfer- } \\
\text { ence }\end{array}$ \\
\hline
\end{tabular}


The distance at which totally submerged submarines are acoustically locatable

500 [meters] or less to locate them with certainty

(Findings)

Their [main] weakness is their poor reliability with too many [reports of] false detections. [Also] their performance varies very much according to the season and sea areas.

2. Findings on the maintenance of the underwater detection equipment ${ }^{(167)}$ (according to 'A study on the improvement of the underwater detection skills of the fleet')

(1) Having served in the fleet and actually having handled underwater detection equipment and personally having made efforts to service the equipment, we keenly feel that the underwater detection equipment still possesses a great many mechanical defects, that it is too intricate [for the personnel in charge] to handle, and that the personnel are so unskilled that it is currently impossible to expect them to perfectly tune up the equipment.

When we look at the circumstances of the troubles, we found that about 130 cases of the about 330 problems [reported] in about six months were caused by poor maintenance and service.

This large number proves how important it is in the current [situation] of the fleet to service the equipment in order to fully bring into play our underwater detection skills. Although there may be various measures to counter this [situation], the following will generally be needed:

$\{1\}$ To quickly improve the current underwater detection equipment so that all mechanical defects will be eliminated.

$\{2\}$ To study and improve its installation.

\{3\} To simplify the equipment.

\{4\} To prepare manuals with illustrations and send them quickly to the vessels on which the equipment is installed.

$\{5\}$ To rapidly prepare textbooks for the handling of the underwater detection equipment and distribute them.

\{6\} In the courses on underwater detection equipment at schools, the main emphasis needs to be put on handling the actual equipment firsthand, and it is necessary to particularly emphasize the lessons on servicing as well as on how to locate and fix problems.

\{7\} All naval arsenals should swiftly train a number of skilled workers and set up acceptance test sites [for when the equipment is received from the factory], so that it will be impossible that imperfect installations, deficient equipment or incompletely tuned-up equipment will pass through [inspection].

$\{8\}$ The number of personnel attached to the staff of the fleet and in charge of underwater detection [operations] should be increased; at least one special duty officer or warrant officer should be assigned to each division, and on top of that, warrant officers with a knowledge of underwater detection [operations] should be put on board of (vessels or a vessel of) each unit as personnel attached to the unit or as a crewman.

\{9\} Skilled workers should be sent on the Akashi to be assigned to each division.

$\{10\}$ Lectures for the torpedo chiefs in charge should be given at [antisubmarine warfare] school or other places at the beginning of [every] fiscal year.

\{11\} Appropriate instruments necessary in testing and checking the equipment, such as testers, should be developed, manufactured and quickly provided to the units using the equipment.

$\{12\}$ Items concerning the periodic inspections of the underwater detection equipment should be studied, specified [and included] in the inspection regulations at the time of building or repairing vessels. 
\{13\} As for the hydrophones, the types and the number of spare parts as well as the tools for service and maintenance should be increased in view of the troubles reported this time.

(2) As stated in the above, [the fact] that no detailed [wiring] diagrams nor manuals were distributed to each vessel seriously hindered maintenance. This was particularly the case with the sonar equipment.

We hope that such documents will swiftly be distributed. From my experiences this time, we suspect that [the Navy] may have left the work concerning the sonars entirely to the manufacturing companies.

In one example, the circuit of the receiver of the Type93 Mark4 sonar had been unknowingly changed. Because of this, the personnel dispatched from the Yokosuka Naval Arsenal ([an] assistant-engineer and several men), who should have been working most closely [with the manufacturing companies] and who should have had the best knowledge of handling the latest weapons, were not aware that the schematic sheet[s] they had brought along were different [from the actual wiring] until they were told by engineer[s] of the Navy Technical Department. It was a good example; it made us keenly feel that the [manufacturing] companies, the Navy Technical Department, the naval arsenals and the operational units did not even [properly] communicate, and in particular that the school, which is supposed to train the personnel handling the equipment, is least of all informed.

We decided to mention [here] the change in the circuit of the receiver of the Type93 Mark4 [sonar] (Receiver No. 14 and later [numbers]) just for reference, because it does show that not only operational units but even the school is not informed. (Separate illustrations omitted by the author.)

(3) The number of troubles considered to be careless mistakes by [either] naval arsenals or [manufacturing] companies is significantly large. [The fact that] a large number of troubles derives from faulty equipment is most troublesome to operational units, the fleets in particular. It is quite a challenge for operational units to locate mistakes in wiring or misplaced parts. A few examples [of faults] found in the Type93 Mark3 sonars installed on [the destroyers of] the 2d Destroyer Squadron are the following:

$\{1\}$ In the sonars installed on six destroyers (the Kuroshio, the Yukikaze, the Ōshio, the Arashio, the Shiranui and the Kagerō), $500 \mathrm{k} \Omega$ instead of $100 \mathrm{k} \Omega$ resistor[s] were set at R6 in the grid of the resistors of the receiver.

$\{2\}[A] 10 \mathrm{k} \Omega$ resistor was placed instead of a $100 \mathrm{k} \Omega$ [resistor] for R8 of Receiver T5 of [the sonar on] a destroyer (the Hatsukaze).

\{3\} [The electric current] did not pass through the resistor[s] of the projection-reception relay when the the switch circuit worked (the Shiranui).

(4) Faulty installations are so-called irrecoverable mistakes. In view of the difficulty in changing equipment on already-built vessels, we hope that the installation of such equipment will be done with particularly great care and meticulousness. (The rest omitted by the author; items on faulty installations.)

(5) It is surprising that the basic tune-up of the Type93 sonars is very much defective, which makes us suspicious about the skills of the naval arsenal workers. When Mark3 sonars installed on [the destroyers of] the $2 \mathrm{~d}$ Destroyer Squadron were looked at, only one of [the destroyers], the Yukikaze, had the basic tune-up of its equipment mostly completed, while the basic tune-up of the equipment on all other vessels had to be done all over again from the beginning by [personnel] attached to the staff. Also, all the submarines of the 4th Submarine Squadron, who were equipped with Mark4 sonars, [had to] have the basic tune-up of the equipment done all over again.

The situation of the 4th Submarine Squadron (Omitted by the author)

(6) The tune-up of the sonars (Omitted by the author)

(7) Maintenance and [other important] points of attention 
Although many troubles derive from poor maintenance and service as mentioned in the above, the maintenance methods and [other important] points of attention do not go beyond what is [provided in] the lectures at the beginning of [each] fiscal year and the items mentioned in the reference documents handed out there.

The reason why [maintenance] is not thoroughly done is because the sonar personnel are not willing to do it. We felt that even when they notice malfunctions or the unsatisfactory operation [of the equipment], the personnel tend to leave the troubles as they are due to a lack of confidence in testing and tuning up the equipment. Since acoustic equipment is special in the sense that insignificant malfunctions will greatly affect [its operation], particularly in such intricate weapons as sonars, where [multiple] functions operate in correlated ways, just a trivial malfunction in one part will quite often disable [the entire] detection [process].

In view of this [aspect], maintenance training needs to be stressed also in the education of the trainees at schools. Just for reference and in order to grasp the general tendencies, let us give you a few examples below: (Examples omitted by the author).

(8) Findings on the maintenance of sonars on each vessel in [some] destroyer squadrons

\{1\} 1st Destroyer Squadron

1) [The personnel of] this squadron are generally able to tune up the transducers but have not yet acquired the proper tune-up methods.

2) Many use the latch on the headphones in an opposite way.

3) Not a few are inadequately installed. (Inadequate points omitted by the author.)

4) [They tend to] drag the wires of the resistors to control the output of the receivers or the oscillation strength, but such acts will easily disfigure the parts, which then becomes the main cause of noise while having little effect [on improving the output].

\{2\} 2d Destroyer Squadron

1) The maintenance of the equipment

[Personnel] of all vessels make efforts to maintain the equipment but their efforts are off the point and lack efficiency.

We recorded, as seen in the [list] of problems, inadequate checking of the circuits, inadequate checking and maintenance of the parts in immediate contact [with the personnel], and the defective tune-ups of parts. Although they carry spare parts, relatively few troubles have occurred involving those parts. They need to get a thorough training in how to handle and service sonars.

The points to be considered when servicing [sonars] (Omitted by the author)

2) The sonar personnel

The sonar personnel do not have much knowledge of or experience with oscillating currents and this kind of equipment, and their ability of locating troubles or making inferences about the condition [of the equipment] is poor. Therefore, it is necessary to give them a training as realistic as possible by training them at any available opportunity and having them do acoustic training at least one hour every day.

Concerning [the skills to] detect and locate [the enemy], their [skills to] shift from a search and detect mission to a continuous detection mission, as well as their skills to avoid false detections are still very poor. [Therefore], attaching [more] importance to such [skills] rather than to searching skills, they need to conduct exercises in soundrecognition as much as possible.

(End [of quotation])

3. Comments on the 'Findings on the maintenance of the underwater detection equipment' Concerning the findings [quoted] in the previous item, Cdr. Tsukuda Sadao, member of the Navy Technical Department at the time of the opening of hostilities, had after the war the following recollections: 
(1) Comments on the poor quality of the underwater detection equipment

$\{1\}$ Unlike other weapons, such as big guns and torpedoes, where it is common knowledge that after handling them for years or even decades, defects have been eliminated, the underwater detection equipment had clearly not yet moved beyond the stage of being a prototype weapon. The point that should absolutely be brought up as a fundamental problem is that the performance of the underwater detection equipment was affected by so many various and complicated conditions that it was impossible to show the true capability of the equipment itself without stating the environment in which it was used.

For example, if we look at the hydrophones, the transducers were theoretically to be placed on a flat surface, in reality however they were arranged three-dimensionally on the outside of a complexly curved surface, which differed according to the class of the vessel [on which they were placed]. One cannot ignore the possible effects of the threedimensional arrangement, nor the effects of the shape of the hull of the ships on the sound waves.

As for where to install the equipment [on the vessels], it was almost impossible at that time to install it on the most desirable place to make the most of its performance; particularly in the early times, very little attention was paid to the equipment, and quite often the installation conditions were obviously very unfavorable.

On top of that, it was impossible to eliminate such external influences as the effects of the waves, underwater noises, bathymetric features and the refraction of soundwaves caused by anomalies in the underwater temperature distribution, let alone the effects of the water current [which would change] according to the speed [of the vessel] and interference by the vibration of the hull coming from the engines.

It needs no saying that [the detection results] are greatly and directly affected by the features of the target, such as the strength, frequency, and rhythm of the sound of the target in case of acoustic detection, and shape, structure and reflective power of the target in case of sound pulse detection.

Taking such conditions into consideration, upgrading and improving the performance of the equipment would only make them mechanically [more] complicated, which is an unavoidable problem with underwater detection equipment.

$\{2\}$ It was in the early years of the Showa period [late 1920s] that underwater acoustics finally attracted general attention, but just like the general attention paid to it, its history as a weapon was quite shallow and low. Consequently, piles of even fundamental problems were left unsolved.

A considerable long period is needed to improve a weapon and make it ready to such a degree that after a crash course even unskilled soldiers can handle it, and [in that sense] the [underwater detection] equipment was still quite far from the final stage [of development].

$\{3\}$ The number of troubles was astonishing; the admittedly major cause seems to me to have been the poor quality and low reliability of the numerous electrical parts that constituted the complex equipment. Compared to the present-day standards of the electronics industry, the standards at that time were quite low. Since even such words as quality control or reliable technology, which are common these days, did not exist, there must have been problems in the manufacturing processes as well as with the test techniques.

As a result, besides [poor] parts of very dubious uniformity, we have to add the variations in performance caused by temperature and humidity, or the instability caused by mechanical vibrations, etc., and that is why it was not only very difficult to tune up the equipment but also why minor causes would get the equipment out of order, or in extreme cases even the weather would affect its condition.

(2) Comments on unskilled personnel 
$\{1\}$ It was true that the quality of the personnel in charge of underwater detection was so low that they did not even have a beginner's knowledge of electrical [engineering] or acoustics. However, prior to that, and taking into account the [equipment's] essential nature as a weapon, I think that we need to change our way of thinking that the weapon depends on the individual personnel's advanced training or their having a good ear for distinguishing subtle differences in sound.

However, it takes a long time for a weapon to reach a level where it can be handled [without advanced training or special skills]. The situation was that it was quite impossible to expect that the underwater detection equipment would actually reach a standard worthy of being called a weapon in only a short period of two or three years.

\{2\} Simplification of weapons should be considered only after they have reached a satisfactory level of performance. As for the underwater detection equipment, it was out of the question because making it simple and handy would only worsen its already inadequate performance.

$\{3\}$ It is a big mistake to think that one could compensate for the deficiencies and faults of weapons with trainings and drills by the personnel in charge.

A U.S. technical officer in charge of radar, whom I interrogated at Corregidor, was originally a medical engineer, and electric [engineering] or wireless [technology] were out of his field.

He stated that he had been given a special training for [operating] radar for only three months. [According to him,] although he did not understand the intricate system of radar at all, he had mastered how to handle it. There was a list [for how to] deal with troubles; several causes were stated according to the types of troubles, and the measures to fix them were [also] shown in quite a simple way. It went like, "change this part," "if it does not work, then change that," "if both do not work, replace the entire sliding block with a spare;" there were no theories or textbook explanations at all. With that system, he stated, he had never felt handicapped in servicing his weapon.

This is what a real weapon is supposed to be. I keenly felt an immense difference compared to the Japanese underwater detection equipment.

You cannot call it weapons [manufacturing] technology if it cannot produce a weapon that a layman after a mere three months of training can fully handle. It is a stupid effort to give lessons on the theories of electric [engineering] or acoustics, or to explain about circuits to personnel with no basic knowledge of the subjects, and it is nonsense to expect any results from that.

(3) Comments on the measures to prepare the equipment

$\{1\}$ It is an ideal to eliminate all mechanical defects, and it is a condition for making it into a weapon. However, at that time, it was almost impossible to achieve that at the [technology] level of not only the Navy but also of the whole of Japan.

$\{2\}$ Although there were problems with the installation itself, more basically, the [level of] understanding and recognition of underwater detection equipment on the part of [naval] tacticians and ship-building engineers was also problematic.

$\{3\}$ It is true that the diagrams and manuals were incomplete and that they were not appropriately distributed. The system of those days of having engineers in charge throughout [the whole process] from conducting fundamental research, experimenting, planning, supervising manufacturing and writing manuals was quite primitive. Manuals to be read by personnel should not be written by engineers.

\{4\} It is only proper that trainings should be focused on firsthand practice at the real system. However, if the equipment is intricate and its reliability low, the trainings will produce little effect despite the enormous burdens laid on the training program. The training methods may have had problems, but I think the equipment bore a heavier onus. 
$\{5\}$ Even naval arsenals had only a few skilled workers; the reality was that technicians were dispatched from the Naval Technical Research Institute when any troubles occurred. Since [the number of workers was] increased so rapidly, training could not keep up [with the increase]. Although acceptance tests were conducted as a matter of course, I do not think the installation work was perfectly carried out.

\{6\} Although I agree with the necessity to attach special duty officers and warrant officers specifically in charge of underwater detection to the staff, I very much doubt their level of competence, [in the sense whether] special duty officers and warrant officers, who are transferred in the middle [of their careers] to take charge of underwater detection, can really be called experts.

\{7\} Although the idea of placing a large number of professional workers on repair vessels and assign workers to all units was preferable, [the Japanese forces] did not have enough reserves to permanently assign such skilled workers.

$\{8\}$ It is true that sonar was mostly left to [the private manufacturing] companies. Although it may seem that the personnel and financial costs to the Navy were smaller if from the beginning one relied upon the private [sector] with no leadership taken by the Navy, one cannot expect that private companies would take on business that was not commercially profitable. And it is no wonder that [the Navy] ended up being pulled about by the nose at the convenience of the private companies. In all ages, there is no easy way to obtain results without making efforts and sacrifices yourself.

(4) General comments

$\{1\}$ I wonder to what extent the [naval] tacticians understood and recognized the characteristics of the underwater detection equipment, which was based on underwater acoustics, [a technology] highly susceptible to unstable external conditions. Perhaps their lack of understanding and recognition gave rise to excessive hope and expectations, which [then] resulted in large miscalculations.

\{2\} Even graduates of the advanced general and advanced professional courses, the so-called marked-out set, were guys that fundamentally speaking had no close affinity with science or technology, and from the point of view of advanced technology, they were just amateurs.

The equipment to be handled by such men should be very simple and sturdy; prototype-kind machinery that may get out of order anytime or take much effort to locate problems, should be rejected right from the start.

(End [of quotation])

4. Findings on the drills for underwater detection ${ }^{(167)}$ (according to 'A study on the improvement of the underwater detection skills of the fleet')

The underwater detection drills conducted by the fleet did not seem to be thorough at all, and records, rules and handling methods were also ill-prepared and incomplete. In order to enhance the effects of the drills, we need in view of the results of this fiscal year to study and improve them.

It is considered necessary for the fleet to conduct and execute drills on the following items and take the results into account.

(1) In order to improve underwater detection skills, it is necessary to attach importance to drills at anchor, as previously told (omitted by the author). [In such drills,] relatively effective drills may be conducted if for the divisions or fleets the anchorages at the point of operations or the formations at the anchorages are given [careful] consideration.

(2) Mutual drills between submarine and destroyer squadrons need to be studied and conducted.

That is, destroyer squadrons have few training opportunities where submerged submarines are set as their targets, while submarine squadrons do not get much training op- 
portunities for assaulting directly escorted targets. However, from the beginning of [this] fiscal year, both have actually admitted the need for such basic drills in the first half of the year. If [such drills] that would allow both squadrons to train together are studied and worked out, it would immediately make [more] effective drills possible.

(3) It is necessary to increase the frequency of [depth charge] projector drills so that they will be conducted twice, both in the first and the latter halves of the fiscal year.

The frequency of [depth charge] projector drills at the fleet was [only] at a rate of once a year. Even at present, when sonars are [already] installed and when the necessity of drills using sonar is recognized, the drills have not changed for a long time. In the current circumstances where sonars are going to be increasingly used, there is no doubt that an improvement of skills cannot be expected with a drill rate of only once [a year], and that, moreover, in the latter half [of the fiscal year]. On top of that, inadequate study and review will lead to the wrong handling of sonars and, along with unskilled instructions, give us no hope for satisfactory results.

Currently the least improved, studied, trained and also the least developed subject in the [operations of the] fleet must be the frequency [depth charge] projector drills. It is most regrettable that in that respect the [attack] fleets are particularly inferior even to the defense units.

It is said that the fleets have conducted drills as much as possible when under sail on alert, [particularly when operating] as clearing units to detect [the enemy]. However, such [underwater detection] drills without projecting [depth charges] will not allow an adequate review of the results, and moreover, they are not drills that include everybody from the commander down.

(4) There is a need to study [and improve] the reviewing methods of underwater detection drills.

Although [underwater detection drills] have been conducted using explosives as a sound source and smoke-emitting shells, respectively for [the drills of] destroyers and submarines, there still seems to be a reluctance to use such [items in drills].

It is necessary to further increase the number of these [items for drills], adequately use them in all drills and see to it that the results shall be reviewed without fail. It is no exaggeration to say that drills without reviews are worth little.

In the current circumstances, I think further progress can be achieved by using sonars for mutual underwater communications between destroyers and submarines.

If this research produces considerable results, some sonars should be modified so that they can also be used as underwater telephones. By measuring the results through underwater telephones, not only [the issues concerning] the reviews of the results but also security issues can be solved, which, I believe, will have a major impact on the practice of drills.

(5) It is necessary that rules about underwater detection drills be established at the fleet in the same way as communication rules, and that the drills be conducted under control.

(End [of quotation])

5. [Building] an imitation of a British antisubmarine weapon ${ }^{(168)}$

In the early period after the opening of hostilities, following the seizure of allied naval bases such as Hong Kong, Singapore and Surabaya, investigations into [enemy] ordnance were made, and a British antisubmarine acoustic equipment device called 'ASDIC' (AntiSubmarine Detection Indicating [Investigation] Committer [Committee]) was gotten hold of. [The Japanese Navy] began research into the strong points of the equipment, the flow-straightening cover for the transducer[s] to be installed at the bottom of a ship and the distance recording indicator, and started working on a prototype. The former is expected to help to improve the detection performance under sail, and the latter to facilitate the evaluation of situations in antisubmarine attacks. However, it was not until 1944 that these devices were put into practical use. 
6. Antisubmarine depth charges

(1) On 10 December 1941, Minesweeper No. 10 of the Philippines invasion unit was strafed off Vigan by enemy fighter planes. The strafe directly hit the antisubmarine depth charges (containing Carlit explosive powder) loaded on the upper deck, inducing explosions and sinking the minesweeper. In the next two months, the sensitive Carlit explosive powder was all changed to Type1 explosive powder, which was safer. Due to this change, the explosive power was reduced somewhat compared to those which contained the Carlit explosive powder. ${ }^{(169)}$

(2) The antisubmarine depth charges in the early years had a slow descending speed (Type95: 1.9 meters [per second]). Since it was slower than the submerging speed of [enemy] submarines, they exploded [far] above them and did not display their full power. ${ }^{(170)}$

(3) The number of antisubmarine depth charges that could be loaded on a vessel was small; the charges would run out after several drops, which made it impossible to carry out adequate antisubmarine attacks. An example of the numbers of antisubmarine depth charges carried on a vessel at the time of the opening of hostilities is shown in the following table (Later the numbers were gradually increased; by the end of 1942, the number of antisubmarine depth charges carried by a coastal defense ship reached 120.)

\begin{tabular}{|c|c|c|c|c|c|}
\hline Vessel Type & Name & $\begin{array}{c}\text { Standard } \\
\text { Displacement }\end{array}$ & Speed & Mounted Guns & $\begin{array}{c}\text { Number of } \\
\text { Antisubmarine } \\
\text { Depth Charges }\end{array}$ \\
\hline $\begin{array}{c}\text { Coastal Defense } \\
\text { Ship }\end{array}$ & Shimushu & 860 & 19.7 & $3 \times 12-\mathrm{cm}$ & 18 \\
\hline $\begin{array}{c}\text { Submarine } \\
\text { Chaser }\end{array}$ & No. 1 & 266 & 24.0 & $\begin{array}{l}2 \times 40-\mathrm{mm} \\
\text { machinegun }\end{array}$ & 36 \\
\hline Ditto & No. 51 & 110 & 23.0 & $\begin{array}{l}1 \times 40-\mathrm{mm} \\
\text { machinegun }\end{array}$ & 18 \\
\hline $\begin{array}{l}\text { Auxiliary Sub- } \\
\text { marine Chaser }\end{array}$ & No. 1 & 130 & 11.0 & $\begin{array}{l}1 \times 7.7-\mathrm{mm} \text { or } \\
1 \times 13-\mathrm{mm} \\
\text { machinegun }\end{array}$ & 18 \\
\hline $\begin{array}{c}\text { Auxiliary } \\
\text { Minesweeper }\end{array}$ & No. 1 & 215 & 9.5 & $1 \times 8-\mathrm{cm}$ & 15 \\
\hline $\begin{array}{l}\text { Auxiliary } \\
\text { Patrol Boat }\end{array}$ & No. 1 & 238 & 9.0 & $\begin{array}{l}2 \times 25-\mathrm{mm} \\
\text { machinegun }\end{array}$ & 8 \\
\hline Patrol Boats & $\begin{array}{l}\text { No. } 37 \\
\text { (converted from } \\
\text { the 2d class de- } \\
\text { stroyer Hishi) }\end{array}$ & 770 & 18 & $3 \times 12-\mathrm{cm}$ & $16 ?$ \\
\hline
\end{tabular}

Remarks: Although antisubmarine depth charges were also loaded on destroyers, minesweepers and other vessels right before the opening of hostilities, the number of charges [per vessel] was [only] 18-20.(172)

7. Submarine attacking methods

Sublieutenant (Later Lt. Cdr.) Mizoguchi (originally Kuzuhara) Satoshi, then torpedo chief of the destroyer Kawakaze recalled [the attacks on enemy submarines] as follows: 
When attacking [submarines], the center method and the half-circle method were generally adopted. In the center method, we headed with increasing speed toward the point where [the submarine] was spotted or detected and, by calculating the seconds [for us] to reach the spot using charts and counting the time with a stopwatch, covered the point with antisubmarine depth charges released in a zonate way. The half-circle method was used when the direction and the speed of the target was deducible; we would describe a half-circle based on the direction in which the target would advance and calculated on the basis of its speed the distance it would advance and the time when we would encounter it, and cover the central part of the [half-]circle with antisubmarine depth charges released in a zonate way. For this purpose, every vessel measured its inertia at the time of its increase in speed or course change and prepared its own chart, which would enable you to instantly know the angle to turn your vessel and the seconds to reach the point [of encounter] by using it with such data as the distance of the target [from your vessel] when spotted or detected, your speed, the direction of the target from your vessel and the direction in which the target was moving and its speed. The chart was placed on the bridge along with a stopwatch so that the officers on duty could immediately conduct antisubmarine depth charge attacks. Since in this method the distance [to the target], the direction, and the speed of the target was measured only by eyesight, and evasive actions by the [target] submarine after its submersion were not considered at all, it was only with great luck that one could catch the enemy submarine in the zone where the charges were released. On top of that, since there was a risk that the crystals used as oscillators in the transducers at that time might break by the impact [of the blasts], it became practice to retract the transducers into the vessels when antisubmarine depth charges were dropped, which made it impossible to continue the detection up to a close distance. [The order to] "retract the transducer[s]" would be given at 1,000-1,500 meters [from the target] before the vessel gained speed and turned her bow [toward it]. Also, no particular methods based on mathematics were provided concerning [how to] resume detection after attacks. When oil circles came up after the first attack, attacks might be continued with the help of them; otherwise, in most cases they were simply called off. ${ }^{(173)}$

Sublieutenant (later Lt.) Yoshimatsu Yoshihiko, then torpedo chief of the destroyer Ushio, recalled [the antisubmarine attacks] as follows:

[We] mainly located [enemy] submarines by visually spotting their periscopes or the wakes of their torpedoes. When an [enemy] submarine was spotted, we rushed toward her at the order of "full speed ahead," and dropped antisubmarine depth charges at the point where she had presumably submerged. There were four or five patterns in a zonate way to release the charges. Although these thunderous attacks were an inspiring sight, their effect was doubtful. Unlike today, few thought that by making use of underwater detection equipment enemy submarines could be caught and destroyed for certain. Thorough neutralization of [enemy submarines] was impossible also because of the shortage in escort vessels; it was customary to call off attacks at some point to follow the convoy. Although we carried antisubmarine depth charges enough to conduct a couple of [zonate] attacks, I don't recall a time when we attacked the enemy persistently until we used up the entire load of charges.

8. Comments on antisubmarine warfare in general

(1) Comments by Cdr. Tsukuda Sadao (member of the Navy Technical Department at the time of the opening of the hostilities)

On the morning of the day of the opening of hostilities on 8 December 1941, I was privately not at all ready or prepared for it. Though dismayed, I had no choice but to brace myself for the worst. In the previous years, the general use and development of underwater detection equipment had progressed beyond my expectations and to all appearances it looked as if it was ready. In reality, it was too unreliable as a weapon and it was not in a condition to be used to its full extent. As the main person in charge, I knew very well that we 
could not expect effective results from it, which made me all the more anxious and kept me awake [at night].

For example, the hydrophones sometimes located a submarine [as far as] 6,000 meters away, but at other times could not locate one [as close as] 2,000 meters away. Also, the sonars sometimes detected one 3,000 meters away for certain, but at other times their performance became unreliable even if [the target was] only 1,500 meters away.

The reasons for the unstable performance were very complex; the conditions of the vessel greatly affected the performance, and so did the conditions of the target. The geographical features, the depth and the wave conditions of the sea [area], the underwater noises and even the distribution of the underwater temperatures had an impact, and in combination, they created an immense variety [of conditions]. Each of these problems could not be solved without spending a considerable amount of time conducting a series of fundamental studies and experiments while gathering and sorting out data. The nature of these problems was not such that you could master them with just skill or intuition. That the Acoustic Research Department (established in 1940) had selected the waters [off] Numazu was also because it hoped to proceed with its theoretical research in tandem with experiments. In terms of the massiveness of the research subject, our research had only just begun.

(2) The recollections of Capt. Asahiro Hiroji ([became] member of the Navy Technical Department in April 1942)

I [started] working at the Navy Technical Department in April 1942 as a member mainly in charge of the underwater detection equipment. For half a year from February 1943 onwards, I was attached to the Combined Fleet headquarters, and with the Yamato as my base, I conducted research on the practical use of the underwater detection equipment at the front, while supporting and guiding the teaching and training [for the equipment].

My conclusion was that the underwater detection equipment, which had been installed with great trouble, was not fully used due to the deficiencies in the equipment and the mental attitude of the [naval] tacticians, and that it was too dangerous to be solely dependent on the underwater detection equipment.

I believe that the Naval Antisubmarine [Warfare] School had done its utmost [in training personnel], but I realized that with a few special exceptions, crash-course-trained underwater detection personnel would hardly be able to handle the equipment. On top of that, the captains of naval vessels seemed to lack an eagerness to actively use it, which, in not a few cases, made the equipment a useless possession. Particularly, it seemed that destroyers, which usually sailed fast, had not had much opportunity to use it. (Detection was possible only at fourteen knots or less.)

(3) The recollections of R. Adm. Aruga Takeo (then head of the 6th Department of the Navy Technical Department)

The reasons why the improvement of antisubmarine weapons had fallen behind may be viewed as follows:

$\{1\}$ Misunderstanding and misjudgment of the importance of antisubmarine weapons

From the start, the Japanese Navy had a great interest in gunnery and torpedoes, and with thorough research and an abundance of talented people had reached a level that compared generally favorably to that of Britain or the United States except for some firecontrol devices. It was natural since these were the main weapons in battle. However, defensive aspects, along with damage control on vessels, were considered of lesser importance, and being understaffed, research [in these fields] could not produce effective results. Although recognition of these fields finally improved around the time right before the opening of hostilities and [the Navy] started to put some effort into these fields, the reality was that everything was thrown into great confusion by the opening of hostilities. 
Because in the Japanese Navy, such fields as mines, minesweeping, or damage control were essentially viewed as jobs for losers who were not marked out for navigation, gunnery, or torpedoes, those assigned [to antisubmarine warfare] seem to have had a sense of inferiority, and even if they did not, they certainly did not have a sense of superiority.

I believe that such a mindset had a great impact on the morale of the persons concerned. When looking nowadays at European and U.S. antisubmarine weapons, I realize that our point of view was childish and our research effort insufficient, but at the same time I feel a kind of bitterness that the Navy's treatment and leadership in this field at that time caused a loss of opportunities.

Those in charge of administering military affairs or directing military forces in the future must take good note of this point, follow the truth, and draw up careful and appropriate plans, without being deluded by superficial opinions or dazzled by superficial splendor.

\{2\} The organizational improvement required for technological integration was too late. Although considerable attention was paid to the research of acoustic weapons, researchers in the fields of navigation or mines [separately] conducted research from their own standpoints without sharing technologies; [both fields] uselessly quarreled with each other over [research] territories, adopting the wrong course for a successful cooperation in this serious matter. It was only after the new establishment of the 6th Department of the Navy Technical Department three years before the opening of hostilities that they finally came together in one coherent team.

\{3\} Lessons

1) Everyone focuses on showy subjects and neglects the dull ones. But it is the dull ones that [often] contain matters of importance.

2) The adoption of weapons or improvements of the system need to be approached in a far-sighted, intelligent and cautious way and never miss the right time [to implement them]. It should be done calmly and appropriately and not be disturbed by the actual situation.

3) Technological [research] should be brought together and concentrated, and not be studied at different places [in a fragmentary way].

(4) The recollections of Cdr. Koyama Tadashi (staff of a destroyer squadron and [later] member of Navy Technical Department)

$\{1\}$ It is said that a leading member of the U.S. Navy, who was stationed in Sasebo after the war, commented on the defensive weapons of the Japanese Navy wondering that they were no different from what they had been after WWI, and that he had thought that the Japanese should have made more progress. Although his comments may have been somewhat exaggerated, it seems impossible to say that his evaluation was far off the mark in the case of mines, antisubmarine depth charges, or minesweeping devices, not to mention the underwater detection equipment, which had just marked a step toward practical use only a few years before the opening of hostilities.

$\{2\}$ No epoch-making development or innovation can be discovered in the Japanese Navy's ideas on the defensive employment of forces from the time of the stipulation of the Sea Defense Order in 1904 until WWI. [But] this the Navy had in common with the navies of all other countries.

However, after the turning point of WWI, along with the progress in the development of naval vessels, weapons, and aircraft in the navies of every country, also in defensive warfare epoch-making changes had occurred in the field of antisubmarine warfare. However, in the Japanese Navy, which after the Russo-Japanese War had been focusing on war preparations against the United States, strategic and tactical thinking was [still] based on the concepts of interceptions and decisive battles between fleets. Especially 
after the conclusion of the Washington Naval Treaty [1922], when it came to upgrading naval armaments in line with the defense restrictions included in the treaty as well as with the [Imperial] Defense Policy of 1923 and the revision of the main points of the employment of forces, defensive fields such as defensive warfare were necessarily limited to a bare minimum. These circumstances affected organization, personnel and budgets, and presumably became the main cause of the lack of thorough policies concerning defense.

\{3\} Since the Japanese Navy gave priority to decisive battles between fleets, it had kept for years to a policy that matters of defense and the protection of shipping lanes should be limited to the defense of the main ports of mainland Japan and specified advance bases, as well as the protection of the commerce between the Asian continent and the mainland on the waters to the north of the Taiwan Strait.

It is fair to recognize that the armaments required for such a [minimal] degree of defense had been [properly] provided throughout the years. The painstaking efforts, with which the naval authorities had striven for years to improve [naval] armaments on a limited military budget, must have been huge.

However, in the Greater East Asia War, the face and scale [of the defense] had completely changed and become quite different from what the Japanese Navy had envisioned for years. As a result of the expansion and elongation of the sea lines of communication, and also in view of the [available] weapons for antisubmarine warfare, we may say that all the peacetime research, development and preparations were totally insufficient compared to the reality of this war.

(End [of quotation])

As [seen] in the above, the Japanese Navy's actual capability to attack [enemy] submarines was quite inadequate. However, it is impossible to deny that there also existed in the background an atmosphere of thinking lightly of the military power of U.S. submarines. On top of that, for good or for evil, due to the less aggressive operations of the enemy submarines at the beginning of the hostilities, their poor attacking methods, the poor [quality of] their torpedoes (many were duds and others passed under the bottoms of [Japanese] vessels), and their shortage of torpedoes (233 torpedoes in store were lost in the [Japanese] bombing of the torpedo warehouses in the naval port of Cavite, ${ }^{(113)}$ while mass production of torpedoes was still lacking), the Japanese side had only sustained light losses, which made the Japanese Navy further underestimate the ability of the enemy submarines (see the Action Report of the 2d Destroyer Squadron [p. 504]), and it got too late for fundamental countermeasures against enemy submarines. 


\section{Chapter VIII The State of the Allied Forces Before the Java Operation}

\section{The State of the Allied Forces Before the Outbreak of the Second European War*}

\section{The United States}

\section{The New War Plan Orange}

S ince 1922, the U.S. Navy had kept the major part of the U.S. Fleet in the Pacific Ocean. ${ }^{(92)}$ This was because the Japanese advance toward the Caroline, Marshall and Mariana Islands as well as the decline in Russian power after World War I had made the U.S. Army and Navy very much concerned about the movements of Japan in the Pacific Ocean.

The plan of operations against Japan was called War Plan Orange, and the gist of the plan drawn up in 1928 was as follows:(174)

1. In case hostilities are opened between the United States and Japan, Japan's first hostile act will probably be an invasion of the Philippines. In such a case, the forces stationed in the Philippines shall hold out against the Japanese attack as much as possible and try to secure Manila Bay.

2. Leaving some forces such as submarines, small naval vessels and patrol aircraft behind in the Philippines, the U.S. Asiatic Fleet shall withdraw its main force to the Indian Ocean to avoid the brunt of the attack of the Japanese fleet.

3. During the holding operations in the Far East, an expeditionary force shall be prepared as soon as possible on the United States mainland to win the final victory.

However, the plan only indicated the strategic course to be followed against Japan; without concrete arrangements to implement it, it was no better than a paper plan.

From 1935 onwards, with the international situation becoming tense mainly due to the actions of Japan, Germany and Italy, both the U.S. Army and Navy secretaries recognized that the current Plan Orange was too obsolete and drew up a new Plan Orange. Compared to the old plan, it was remarkably specific and practical, and it also included [items on] the cooperation between the U.S. and British Navies. The cooperation was in outline as follows: ${ }^{(92,174)}$

\footnotetext{
* The author refers only in a general way to his sources without giving chapter and verse. In a few cases, we could trace his source and restore the original text; however, in most cases, this turned out to be a hopeless task.
} 


\section{Operation}

1. The basic policy is that in case of war against Japan in the Pacific Ocean, Britain shall dispatch a battle fleet to Singapore and operate based on Singapore, while the U.S. Fleet shall concentrate in Hawaii.

2. In a war against Japan, both the United States and Britain shall make their waters available for each other's vessels.

\section{The Rainbow Plans}

Subsequently, along with Germany's expansion in Europe, Italy's acting in concert, and Japan's employment of armed force in wider areas of mainland China, it was considered impossible to cope with this state of affairs with the present Plan Orange. In February 1939, the Rainbow Plans were newly drawn up on the assumption that Britain and France would act in concert with the United States. Their outline was as follows. ${ }^{(175)}$

\section{Assumptions}

Assuming that the United States will wage war against either Japan, Germany or Italy individually, or against their combined forces. In that case, we assume that Britain and France will support the United States or act in concert with her.

2. The plans

(1) [Rainbow] 1

A plan to defend the area to the north of $10^{\circ} \mathrm{N}^{*}$ in the western hemisphere.

(2) [Rainbow] 2

Along with the defense of the western hemisphere stated in Rainbow 1, the United States, jointly with Britain and France, shall assume her share of the operations to protect the interests of the allied countries mainly in the Pacific. No forces will be sent to Europe.

(3) $[$ Rainbow] 3

Along with the defense of the western hemisphere stated in Rainbow 1, [the United States] will rapidly conduct an operation to secure control of the western Pacific.

(4) [Rainbow] 4

A plan to provide for the defense of the entire western hemisphere as well as the eastern Pacific.

(5) $[$ Rainbow 5

A plan where, in order to attain the aims of Rainbow 1 and Rainbow 4, and assuming that combined operations with Britain and France will be conducted, the United States will dispatch military forces to Europe to deliver a decisive blow to Germany and Italy.

However, the deployment of the U.S. Army and Navy in the Far East around September 1939 at the time of the breakout of World War II was not so much different from that in 1931.(175) The forces in 1931 were the following: ${ }^{(154)}$

The U.S. Asiatic Fleet

Southern China Patrol Unit: 19 Destroyers (based in Chefoo)

Yangtze [Patrol] Unit: 6 River-Gunboats (based in Shanghai)

Others: 12 Submarines and some auxiliary vessels

The U.S. garrison army on the Philippines

About 10,000 men ([with] officers mainly consisting of Americans, and noncommissioned officers and men of Filipinos, half of the army were Philippine Scouts)

* Actually $10^{\circ}$ S. See Corps of Engineers: The War Against Japan (https:/ / history.army.mil/html/books/010/10-

6/CMH_Pub_10-6.pdf), p. 10: north of 10 degrees south latitude. 


\section{Operation}

As of 1939, only two cruisers were added to the [Asiatic] Fleet, while as for the Army, after the Philippines Independence Act was passed in 1934, the Commonwealth Government of the Philippines, with the support of its American Military Advisor MacArthur, was making strenuous efforts to have a regular force of 10,000 men and a reserve force of 400,000 men by 1946 (the year of full independence). ${ }^{(177)}$

\section{Britain}

After World War I, the U.S. and Japanese navies rapidly grew larger, replacing the German Fleet, which had [practically] disappeared. Japanese naval power provided a potential threat to the security of the sea communications between Great Britain, India, Australia and New Zealand, and Britain considered it neither necessary nor possible to maintain fleets of adequate strength in both the western and eastern hemispheres; it was accordingly decided that the British Fleet should be held in a central position in European waters, from which it could reinforce the Far East as and when required. ${ }^{(85)}$

In order to implement this strategy, a naval base with adequate strength and facilities at a strategically advantageous position in the Far East came to be considered necessary. As a result of discussions between the top leaders concerned of the Army and Navy, they came to the conclusion that their only existing base in Hong Kong was not strategically worthy in terms of its geographical location and facilities, and that it was necessary to construct a base in Singapore since it was strategically the best situated for the control of sea communications in the Indian Ocean and the southwestern Pacific. This was in 1921. ${ }^{\left({ }^{85}\right)}$

Because of the Anglo-Japanese Alliance, Britain maintained cooperative relations with Japan during the Russo-Japanese War and in World War I. However, having perceived Japan's expansionist designs since Japan's Twenty-One Demands on China in 1915, Britain changed course to contain Japan's intentions. In 1921, Britain abrogated the Anglo-Japanese Alliance and simultaneously drew up a strategy with Japan as a potential enemy, and proceeded to try to implement it. ${ }^{(85)}$

The plan to construct a naval base in Singapore was approved by cabinet and parliament in 1923 and was supposed to be carried out, but due to the subsequent political situation in Britain and conflicting opinions over the defense of the base between the Army, Navy and Air Force, it was not easily realized. After various twists and turns, the construction of the base was finally started from May 1932 onward, based on the following policies. ${ }^{(85)}$

1. The main deterrent against naval attacks on Singapore shall be guns.

2. As auxiliary forces, fighter planes for the defense and attack planes for attacks on enemy ships shall be added.

3. The first stage of the construction of the base shall be the full installation of guns for coastal defense and the preparation of the required air units and airfields, which shall be completed by 1936 or 1937 at the latest.

After Hitler took political control in Germany in January 1933, the country in quick succession took steps to break up the [post] Versailles [political] order, withdrew from the League of Nations in October that year, and proclaimed rearmament in March 1935, thereby becoming a major threat to Britain. Furthermore, as Italy was also stirring, the situation had changed in such a way that [Britain] could no longer afford to dispatch massive military forces to the 


\section{Operation}

Far East, while emptying Europe as specified in the current Far East strategy plan, and that it should be anticipated that the strength of the fleet which could be sent to the Far East would have to be governed by home requirements. ${ }^{(85)}$

In July 1935, the British Government authorized the start of part of the second stage of the construction work on the Singapore base (the construction of additional heavy artillery emplacements and two airfields). It was considered that the completion of this second stage work would enable Singapore to hold out for about seventy days against the expected scale of attacks before the arrival of a British fleet in the Far Eastern waters. However, improvements in aircraft performance [made it possible] to use aircraft for offensive purposes, which brought about a [new] phase where such a plan as to solely fortifying Singapore should fundamentally be reconsidered. After having reexamined the defense plans on site from a new angle, Major General [W.G.S.] Dobbie, who had become the commander in [British] Malaya in 1937, sent the following reports to the War Office from October to November that year. ${ }^{(85)}$

1. It is possible for the enemy to land on the east coast of Malaya during the northeastern monsoon (from October to March), because poor visibility on the waters during that period will limit the capability of our air reconnaissance.

2. It is very likely that when Japanese forces should come for an attack on Singapore, instead of a direct attack from the sea front, as [we] have considered earlier, they will [first] seize Singora, Pattani, or Kota Bharu, push forward their advanced airfields there, and carry out attacks from the north. Therefore, the security of [the base in] Singapore would largely be dependent on the defense of northern Malaya and Johore.

3. From the above point of view, the defense of Singapore should in fact be considered inclusive of the defense of the whole of the Malay Peninsula.

The major general further warned in July of the next year (1938) that the jungle in Johore was in most places not impassable for infantry. Despite such warnings, the construction work on [the naval port of] Singapore was continued following the plan of 1932. ${ }^{(85)}$ It was finally around August 1940 when the proposals of Major General Dobbie were actually adopted, but then it was too late.

In July 1937, the China Incident broke out in the Far East, which frequently caused conflicts between Japan's military operations and Britain's [attempts to] preserve its interests in China, and added to the tensions between both countries. Also, from the latter half of 1938 onwards, the situation in Europe became more critical, and with Germany's advance into Sudetenland in October that year as the turning point, a [new] plan of operations which would meet the new state of affairs needed to be drawn up. The plan sent by the Chiefs of Staff to the Committee of Imperial Defence in February 1939 focused on naval strategies and was in outline as follows: ${ }^{(178)}$

1. This plan is a strategic plan for Britain in case Britain and France should jointly go to war against Germany and Italy. It also anticipates the case that Britain may fight Japan in the Far East, too.

2. The theaters regarded to be most important to Britain are the home country, the Mediterranean, and the Far East, in that order.

3. The Home Fleet and the Mediterranean Fleet shall be deployed respectively on the waters near Britain and in the Mediterranean mentioned in the previous item, and be assigned the task to enforce naval blockades against Germany and Italy as well as to destroy [their] fleets. 


\section{Operation}

4. In the operation in the Mediterranean, its western basin shall be a French responsibility and the responsibility for its eastern basin falls on Britain.

5. The protection of shipping lanes spanning the rest of the world shall be the responsibility of the area fleets abroad (in the East, the China [Station] Fleet and the East Indies Fleet) or the navies of the dominions.

6. In order to respond to Japanese aggression in the Far East, the need to dispatch a fleet from Europe is recognized. But we are not strong enough to maintain a third fleet equivalent to the Home Fleet or the Mediterranean Fleet. Since part of the forces in the European theater will have to be spared for dispatching such a fleet, [the scale of] the dispatched forces shall depend on the war situation in Europe.

While the Committee of Imperial Defence was examining the plan, the situation in Europe rapidly changed; in March 1939, Germany invaded Czechoslovakia, which was followed by the Italian invasion of Albania. Consequently, on 2 May of the same year, the committee drew the following conclusions: ${ }^{(85)}$

1. The order of priority regarding our potential enemies shall be Germany, Italy and Japan, in that order.

2. It is not possible to definitely state how soon a fleet can be dispatched to the Far East after Japan has initiated an offensive there or how large a fleet can be sent.

Also, the Admiralty, while making clear its view that even if war broke out in the Far East, it would be impossible to send more than two capital ships, ${ }^{(92)}$ informed the United States in the same month (May 1939) that owing to the necessity of watching the Mediterranean, it would be impossible to send a battle force to Singapore and suggested that the U.S. Navy defend the Malay Barrier (the British and Dutch colonies from Timor to Malaya). It was obvious that the contents of this announcement fundamentally changed the basic principles of the Anglo-American agreement for joint operations formed one and a half years before. By that time, the United States had already begun to work on the Rainbow Plans on the assumption that it could not count on the British Fleet in the Far East. ${ }^{(92)}$

In March 1939, an Anglo-French staff meeting on their joint operations was held in London, where France accepted the following items. ${ }^{(178)}$

1. The French Navy shall assume control of the western basin of the Mediterranean.

2. If Japan takes the offensive in the Far East, the need to dispatch one fleet to the Far East is recognized. However, the dispatch shall be dealt with in due consideration of the balance of peril between Europe and the Far East.

Based on this meeting, a conference was held in June of that year in Singapore between the commanders of the British and French forces on site. In this conference, the following conclusions were drawn and sent as recommendations to both governments: ${ }^{(85)}$

1. Since it seems impossible to station adequate naval forces in the Far East in peacetime, the only practical solution seems to have considerably large air units on hand [there] instead.

2. The strength of the combined British and French air and ground units [stationed in the Far East] is inadequate.

3. Reinforcements of two brigades should be sent to the Far East as soon as possible. 


\section{Operation}

4. In order to avert Thailand from plotting with Japan, diplomatic steps should be taken so that British and French forces can freely pass Thai territory in time of war.

In July of the same year, in view of the uncertainty about dispatching a British fleet to the Far East, the [British] Committee of Imperial Defence decided to increase the period for Singapore to hold out on its own from seventy to ninety days, and ordered an investigation into the possibility of storing enough supplies to support civilians and the garrison for six months in Malaya. ${ }^{(85)}$

In August, the committee decided to reinforce Singapore, and sent reinforcements of one infantry brigade, one field [actually: mountain] artillery regiment and two bomber squadrons, and was further planning to send in September two bomber squadrons from mainland Britain, when World War II broke out. The British forces in the Far East at that time were roughly the following:(178)

1. Navy

(1) China Station (Commander in Chief: Admiral [P.] Noble)

$\{1\}$ Area covered: the whole western Pacific excluding the waters around Australia and New Zealand

\{2\} Bases: Singapore and Hong Kong

\{3\} Forces: 4 cruisers, 1 aircraft carrier, 10 destroyers, 5 escort vessels, 15 submarines, 5 coastal defense vessels, 20 river-gunboats, and 6 torpedo boats as the core

(2) East Indies Station (commander in chief: Rear Admiral [R.] Leatham)

$\{1\}$ Area covered: the entire Indian Ocean

\{2\} Base: Trincomalee (Ceylon)

\{3\} Forces: 3 cruisers, 7 escort vessels (of which 5 vessels belonged to the Indian Navy)

(3) The Australian Navy

Forces: 5 cruisers, 3 destroyers and 2 escort vessels

(4) The New Zealand Navy

Forces: 2 cruisers and 2 escort vessels

2. Air Force (forces in Malaya)

24 Bombers (in 2 squadrons), 24 torpedo bombers (in 2 squadrons), 10 flying boats (in 2 squadrons), a total of 58 aircraft (in 6 squadrons)

3. Army

(1) Malaya

\{1\} Singapore: 5 Infantry battalions, heavy artillery units and antiaircraft artillery units as the core, [comprising] 23 guns for the stronghold, [a total of] about 12,000 men

\{2\} Penang: 1 Infantry battalion as the core, [consisting of] about 3,000 men

$\{3\}$ Northern Malaya and Johore: Voluntary units of about 1,000 men as the core

\{4\} Reserve: 1 Infantry Brigade and 1 mountain artillery regiment [consisting of] about 7,000 men 23,000 men in total

(2) Hong Kong: 4 Infantry battalions and artillery units as the core, [consisting of] about 19,000 men

(3) Burma: About 20 infantry battalions as the core, [consisting of] about 20,000 men

\section{The Netherlands}

[Even] after [seeing] Japan's growing tendency toward expansion in the Far East after the Russo-Japanese War, the purpose of the Dutch Navy had remained the preservation of the 


\section{Operation}

sea lines of communication between the home country and its East Indies colony as well as the shipping lanes between the islands within the colony, and it assumed that in anticipated future conflicts with Japan, the British and U.S. navies would play the major role. Accordingly, the Dutch Navy [had chosen] not to have capital ships; its forces consisted of cruisers and destroyers as their core, which were suitable for the protection of shipping lanes. ${ }^{(179)}$

Therefore, it was not at all possible for the Netherlands to defend its colony in the Far East solely with its own navy, and it had to depend on Britain with its large interests and forces in the Far East. In the spring of 1936, the Dutch Government examined the defense situation of Dutch East Indies, and came to the conclusion that its defensive capability was very weak. Because it considered that the security of the Dutch East Indies was of interest [also] to Britain, the Dutch Government proposed to the British Government informal talks between both countries concerning defense policies in the Far East. ${ }^{(85)}$

The British Government agreed that cooperation between the British and Dutch units in the Far East was desirable, but did not make a commitment that it would cooperate in the defense of the Dutch East Indies. Asked about the matter, the Committee of Imperial Defence also advised the Government in July that "the Dutch should be encouraged to improve their defences but that it would be unwise to consent to any proposals for a joint Anglo-Dutch Defense Scheme." ${ }^{(85)}$ However, considering it desirable that the Dutch air forces in the Dutch East Indies would be appropriately equipped to play their part in a combined air defense of the Far East, the British Air Ministry held talks on technical matters with their Dutch counterparts. ${ }^{(85)}$

The Netherlands had the following forces [in the East Indies] at the breakout of World War II (September 1939): ${ }^{(34,87)}$

1. Navy: 2 Cruisers, 5-6 destroyers, 12 submarines and some other vessels

2. Air Force: About 100 Army aircraft and about 50 Navy aircraft, a total of about 150 [aircraft]

3. Army: About 19,000 men on Java, and about 12,000 men on the islands other than Java, a total of 31,000 men

\section{The Situation of the Allied Forces Right Before the Opening of Hostilities}

Although the allied forces had thereafter made efforts to reinforce their forces in the Far East, the war situation in Europe did not allow them to send adequate reinforcements. The situation of the allied forces [in the Far East] right before the opening of hostilities was as follows:

\section{Britain}

\section{Air Force}

In late January 1941, the Chiefs of Staff gave approval only to [the deployment of] army troops out of the request made by the local forces (in Malaya), which had been 582 aircraft of the Air Force and twenty-six battalions [of the Army]. As for [the deployment of] the air force, [the Chiefs of Staff] insisted on setting the [total deployment at only] 336 aircraft as they had estimated earlier, and decided to attain this goal as much as possible by the end of 1941. ${ }^{(85)}$ However, the war situation in Europe made it impossible to fulfill this plan at all. The following forces were [stationed in the Far East] at the time of the opening of hostilities: $(85,139)$ 


\title{
Operation
}

(1) Malaya: 158 Aircraft, [consisting of] 13 squadrons and 88 reserve aircraft, (about 60 of which were operable)

(2) Burma: 16 (Buffalo) fighter planes

21 (P-40) fighter planes

\section{Army}

In the summer of 1940, when the Chiefs of Staff estimated the defense forces required for the Far East at eighteen battalions (six brigades) as the core on condition that 336 aircraft [should be fully made available] by the Air Force, there was in Malaya [already] a force of nine battalions, or about 30,000 men including volunteers. ${ }^{(85)}$ By the end of 1940 , this force was increased to seventeen battalions as the core, totaling about 40,000 men, with which the deployment of the targeted number of troops was more or less attained. After that, the request [for an increase to] twenty-six battalions was almost fulfilled by April of next year, which rapidly increased the total [size of the ground] forces to close to twenty-six battalions, totaling 60,000 men. However, this was based on the condition that an air force of 582 aircraft were made available. In view of very slow progress in the reinforcement of the air force, the local garrison further made a request for [an increase in] ground forces to forty-eight infantry battalions as the core, with attached tank, artillery, antiaircraft [artillery] and engineer units. ${ }^{(85)}$ Concerning this request, reinforcements were made from the summer to the autumn of 1941, which increased the infantry to thirty-one battalions as the core. However, the tank units which the local garrison had most [strongly] requested were not reinforced. ${ }^{(85)}$ The army strength [in Malaya] at the time of the opening of hostilities was as follows: ${ }^{(85,95)}$

\author{
Malaya area (including northern Borneo) \\ 31 Infantry battalions (about 3-5 divisions) \\ 8 Field and mountain artillery regiments (about 175 guns) \\ 2 Antitank gun regiments and some smaller units (about 95 guns) \\ 8 Volunteer infantry battalions and 10 other units
}

A total of 88,600 men (consisting of 19,600 British, 15,200 Australians, 37,000 Indians, and some 16,800 Malays)

\section{Navy}

Having her hands full with the war against Germany in Europe, Britain was too busy to pay attention to the situation in the Far East. However, the outbreak of war between Germany and the Soviet Union in June 1941 and the reinforcement of forces in the Atlantic by the U.S. Fleet from June to August allowed the Navy some scope to organize an Eastern Fleet to contain Japan's southern advance, and dispatch it to the Far East in December of that year. The strength of this fleet was as follows: ${ }^{(178)}$

Battleships: HMS Prince of Wales, HMS Repulse (to Malaya), and HMS Revenge (to Ceylon) Aircraft Carriers: HMS Indomitable (who ran aground near Jamaica on 3 November; with no alternatives, the dispatch [of carriers] was cancelled.)

4 Destroyers 


\section{Operation}

\section{The United States}

Around the spring of 1941, with their attention still taken up by the situation in the Atlantic, the U.S. Chiefs of Staff were too busy to consider the situation in the Far East at all. ${ }^{(174)}$ However, such factors as the possibility of a military buildup in the Far East after the outbreak of war between Germany and the Soviet Union in June that year and the possibility of gaining air supremacy at last by the completion of the state-of-the-art heavy bomber B-17 allowed the country to send large reinforcements around November of that year with as goal a perfect defense of the Philippines. ${ }^{(174)}$ [As a result,] the strength available at the time of the opening of hostilities became as follows: ${ }^{(177)}$

1. Army

(1) Ground forces:

U.S. Army: The Philippine Division and 7 regiments of [other] various forces, ground units of air units, and harbor defense units, a total of 31,095 men

Philippine Army: 10 Divisions (though poorly equipped and trained), about 80,000 men

(2) Air forces: 1 Regiment each of bombers, fighter planes and combined forces, a total of 277

2. $\mathrm{Navy}^{(92)}$ aircraft (of which about 150 aircraft were operable)

1 Heavy cruiser, 2 light cruisers, 13 destroyers, 29 submarines, 4 seaplane tenders, 4 submarine tenders, 5 minesweepers, 6 torpedo boats, 6 gunboats and 6 other types of vessels; 32 flying boats, about 20 reconnaissance seaplanes, 1 marine regiment (1,600 men) and ground personnel of the 16th Naval District (20,000 men)

\section{The Netherlands}

The Dutch strength in the Far East around August and September of 1940 was by and large as follows: ${ }^{(86)}$

Navy: 2 Cruisers, 6 destroyers and 16 submarines as its core

Air force: About 150 aircraft (most of them were outdated U.S. aircraft)

Army: About 30,000 men

The Dutch Navy had successively shifted its forces to the Dutch East Indies after the collapse of its home country, and by December 1941, the following forces were added [to the forces in the Dutch East Indies]:(179)

2 Cruisers, 1-2 destroyers, and 3 submarines

\section{The Situation of the Allied Forces at the Time of [Japan's] Launch of the Dutch East Indies Operation}

The following is the deployment of the allied forces in the Dutch East Indies as of early January 1942, when the Japanese forces were about to launch the Dutch East Indies operation:

Surface Forces ${ }^{(87,92,178,179)}$

Dutch East Indies Fleet

Waters near Java 


\section{Operation}

2 Light cruisers: HNLMS De Ruyter and HNLMS Tromp [probably HNLMS Java is meant] 5 Destroyers: HNLMS Piet Hein, HNLMS Van Ghent, HNLMS Kortenaer, HNLMS Banckert, and HNLMS Witte de With

3-4 Minelayers and minesweepers

1 Gunboat: HNLMS Sumatra [Actually a Java-class cruiser]

3 (Old-type) submarines: K-VII, K-VIII, K-IX

Sea to the north of Australia

1 Gunboat: HNLMS Soerabaja [former coastal defense ship HNLMS De Zeven Provinciën]

1-2 Minelayers

Waters near Makassar

1-2 Minelayers

2 Submarines: $K-X$ and $K-X V I I I$

Waters near Singapore

1 Light cruiser: HNLMS Tromp

2 Light cruisers: HNLMS Evertsen and HNLMS Van Nes [Actually destroyers]

6 Submarines: K-XI, K-XII, K-XIII, K-XIV, K-XVI, and O-XIX

U.S. Asiatic Fleet

Sea to the north of Australia

1 Heavy cruiser: USS Houston

2 Light cruisers: USS Boise and USS Marblehead

11 Destroyers

Waters near Makassar

5-9 Submarines

Waters surrounding Celebes

3 Seaplane Tenders: USS Heron, USS Childs and USS [William B.] Preston

3 Submarines: USS Pickerel, USS Permit and USS Swordfish

Air forces $(85,86,95,139)$

\begin{tabular}{|c|c|c|c|c|c|}
\hline \multirow[b]{2}{*}{ Areas } & \multicolumn{2}{|c|}{ Dutch East Indies } & \multirow{2}{*}{$\begin{array}{l}\text { Australia } \\
\text { Air Force }\end{array}$} & \multicolumn{2}{|c|}{ United States } \\
\hline & Army & Navy & & $\begin{array}{c}\text { Army Forces } \\
\text { Far East }\end{array}$ & Asiatic Fleet \\
\hline Java & 60 Fighter planes & $\begin{array}{l}15 \text { Reconnais- } \\
\text { sance seaplanes }\end{array}$ & & $\begin{array}{l}10 \text { Heavy } \\
\text { bombers }\end{array}$ & \\
\hline $\begin{array}{l}\text { Southern } \\
\text { Sumatra }\end{array}$ & $\begin{array}{l}15 \text { Fighter planes } \\
35 \text { Bombers }\end{array}$ & 10 Flying boats & & & \\
\hline Tarakan & & 2-3 Flying boats & & & \\
\hline Balikpapan & 15 Bombers & & & & \\
\hline Menado & & & & & \\
\hline Kendari & & 5-6 Flying boats & & & 2-3 Flying boats \\
\hline Ambon & $\begin{array}{l}5 \text { Fighter planes } \\
15 \text { Bombers }\end{array}$ & 10 Flying boats & 12 Bombers & & 5 Flying boats \\
\hline Kupang & & & 12 Bombers & & \\
\hline Port Darwin & & & & $\begin{array}{l}100 \text { Fighter planes } \\
10 \text { Bombers }\end{array}$ & \\
\hline Total & 145 & $42-44$ & 24 & 120 & $7-8$ \\
\hline
\end{tabular}




\section{Operation}

\section{Ground units ${ }^{(85)}$}

\begin{tabular}{|c|c|c|l|}
\hline Areas & Dutch East Indies Army & Australian Army & Notes \\
\hline Tarakan & 1,300 & - & \\
\hline Menado & 1,500 & - & \\
\hline Balikpapan & $800 ?$ & - & \\
\hline Kendari & $?$ & - & \\
\hline Makassar & $500 ?$ & - & \\
\hline Ambon & 2,600 & 1,000 & Australian Army advanced in late December \\
\hline Kupang & 400 & $250 ?$ & Occupied by both armies on 17 December \\
\hline Dili & 250 & & \\
\hline Total & & 1,500 & Australian Army advanced in mid-December \\
\hline
\end{tabular}

Remarks: Excluding Java and Sumatra 


\title{
Chapter IX The Neutralization of the Indian Ocean
}

(See Attached Illustrations Nos. 1, 8, 9 and 10) [Omitted]

\section{Outline of the Course of the Operation}

\author{
The Circumstances Leading to the Capture of Burma and Neighboring \\ Strategic Areas
}

\section{Burma}

$\mathrm{F}$ or the sake of prosecuting a drawn-out war, Burma was not only a vital strategic point which Japan needed for securing the important southern resource areas, but also a vital base [for operations] to cut off the route of support for Chiang [Kai-shek] in China as well as to encourage India to break away from Britain. However, for reasons of [available] army forces before the opening of hostilities, the Burma operation was supposed to be implemented in such a way that first of all air bases in southern Burma were to be captured, and that then the invasion of the whole of Burma should be conducted if the circumstances permitted it after the first stage of the operation was roughly completed. ${ }^{(34)}$ On 11 December, the order to seize the air bases in southern Burma was given by Southern Army Commander in Chief General Terauchi Hisaichi to Fifteenth Army Commander Lt. Gen. Iida Shōjirō, who had completed the invasion operation of Thailand. ${ }^{(34)}$ On 31 January, the army seized the air base in Moulmein.

Prior to this, on 21 December, Col. Hattori Takushirō, chief of the operations section of the Army General Staff, had visited Southern Army headquarters in Saigon and disclosed a plan to take advantage of the very smooth progress of the war since the opening of hostilities by implementing at this juncture the Burma invasion operation with the Fifteenth Army at a stroke. ${ }^{(180)}$ Against this plan, the Southern Army headquarters had argued that the Army would not be able to execute an invasion operation against the whole of Burma in terms of strength, matériel, etc., and the headquarters and Section Chief Hattori had agreed that the [invasion] operation should for the time being be limited to the capture of the Rangoon area.

On 22 January, IGHQ issued [the order to] capture key areas in Burma by means of IGHQ Army Department Order No. 590, ${ }^{(145)}$ and announced the main points of the Burma operation and the Army-Navy Central Agreement on the Burma Operation by means of IGHQ Army Department Instruction No. 1008. ${ }^{(146)}$ The Navy, too, announced the Army-Navy Central Agreement on the Burma Operation by means of a supplementary volume to IGHQ Navy Department Instruction No. 45. ${ }^{(43)}$ 
The Army-Navy Central Agreement on the Burma Operation (22 January 1942)

I. Mission

1. The mission of the operation against Burma is to destroy the enemy in Burma, occupy and secure key areas there, as well as to intensify the pressure on China.

II. Forces to be employed

2. The forces to be employed in the operation are as follows:

Army: The Fifteenth Army ([consisting of] two divisions as the core; depending on the situation, further reinforcements of about two divisions are expected).

Navy: Part of the First Southern Expeditionary Fleet

Part of the Combined Fleet

III. Outline of the operation

3. The Fifteenth Army shall advance to the line of the Salween River near Moulmein, prepare for the operations [there], and then capture Rangoon with its main force from the sector along the road connecting Moulmein and Pegu. In order to facilitate the above operation, the army shall endeavor to have one element head for the area near Rangoon by sea from the west coast of southern Burma.

4. After Rangoon and its surrounding areas have been captured, depending on the enemy movements, the necessary forces (by and large two divisions as a norm) shall be diverted to capture key areas near Mandalay and the oilfields near Yenangyaung.

On that occasion, at a time before or after the capture of the above areas, [the Army] shall endeavor to destroy the enemy forces, the Chinese army in particular.

(Directions for the execution of this operation shall be given separately.)

Circumstances permitting, the Army may, after the capture of Rangoon and vicinity, without break conduct the operation against Mandalay and Yenangyaung with the currently employed forces.

5. While continuing their air campaign to destroy the enemy air power in Burma and [the operation to] cut off enemy reinforcements, the Army air units shall closely support the [ground] operations of the Army.

6. The Navy shall cover ([and] escort) the [Army's] maritime deployment and transport operations mentioned in Items 3 and 4, while securing the Army units' maritime lines of communication with their rear.

For this mission, the Navy shall appropriately use the air bases in Thailand and Burma.

IV [Code] name of the operation, etc.

7. The Burma operation shall be called Operation U.

8. For items other than those stipulated in this agreement, one shall refer to the Army-Navy Central Agreement for the Southern Operation.

In accordance with the Imperial Command of 22 January, Southern Army Commander in Chief General Terauchi issued on 9 February the order to the Fifteenth Army to capture key areas in Burma. ${ }^{(34)}$

\section{Northern Sumatra}

The [operation to] capture northern Sumatra was specified in the Army-Navy Central Agreement on the Southern Operation concluded before the opening of hostilities in such a way that when the Malacca Strait was about to be neutralized after the capture of Singapore, one element of the Twenty-fifth Army should land near Medan from the west coast of the Malay Peninsula at an appropriate moment, seize strategic areas in Aceh, and then taking an opportunity, seize Sabang Island. Also, in Combined Fleet Operation Order Classified No. 1 is- 
sued in conformity with this agreement, it was specified that strategic areas in northern Sumatra should be captured after the capture of Singapore. Then, following the smooth progress of the operations, in the Cam Ranh Agreement of 29 December, it was stipulated that capture of northern Sumatra should be scheduled on Day X +80 (26 February), that the assembly point should be Penang, and that details should be discussed between First Southern Expeditionary Fleet Commander in Chief V. Adm. Ozawa Jisaburō and Twenty-fifth Army Commander Lt. Gen. Yamashita Tomoyuki.

\section{The Andaman Islands}

The capture of the Andaman Islands was not included in the plans of IGHQ at the time of the opening of hostilities. This speaks for itself because the Andaman Islands were also not mentioned at all in the Imperial Japanese Navy Operations Policy decided on 5 November 1941, or the Army-Navy Central Agreement on the Southern Operation concluded on the same day. However, in view of the fact that the Andaman Islands were included along with Midway and others as 'areas to be occupied or destroyed as swiftly as the operational situation permits' in the 'areas planned to be occupied or destroyed in stage-two operations' in Combined Fleet Operation Order Classified No. 1 (of 5 November 1941), ${ }^{(45)}$ the Combined Fleet seems to have recognized the necessity of their capture or destruction at an early stage considering the strategic importance of the islands. Then, along with the progress in the Malaya operation, the defense of Malaya had increased the necessity to advance operational bases onto the line of the archipelagos connecting Sumatra, the Nicobar Islands, the Andaman Islands, and the southwestern point of Burma. Then [the decision] to implement the Burma operation also increased the necessity to secure this line of archipelagos prior to the operation for the sake of the maritime transport operation of reinforcements. Consequently, IGHQ came to consider an operation to capture the Andaman Islands. On 4 February, the head of the 1st Bureau of the Navy General Staff informally informed Admiral Yamamoto Isoroku, commander in chief of the Combined Fleet, of the plan to capture the islands. ${ }^{(46)}$ On 7 February, [the order to] capture the Andaman Islands was issued by means of IGHQ Navy Department Order No. 15. ${ }^{(42)}$

\section{Christmas Island}

At the time of the opening of hostilities, neither IGHQ nor the Combined Fleet headquarters had plans to capture Christmas Island during the stage-one operations. Being a small island about 220 nautical miles south of Java in the Indian Ocean, it was a British possession, known for its production of rock phosphate. It was [just] a volcanic island of only twenty-three kilometers at its longest part, but it was equipped with wireless communication facilities and located at a key point on the shipping lanes between India and Australia. Since it was disadvantageous to leave this island uncaptured not only in terms of the subsequent operations to be conducted in the Indian Ocean but also in terms of the defense of the already seized island chain from Sumatra and Java to the Lesser Sunda Islands, the swift capture of the island to set up a lookout base in the Indian Ocean was [considered] necessary. IGHQ [Navy Department] decided to put in motion [an operation to] capture the island immediately after the conquest of Java, and on 14 March gave directions for capturing it to the commander in chief of the Combined Fleet. ${ }^{(43)}$ On 15 March, Admiral Yamamoto issued an order 
to Southern Task Force Commander V. Adm. Kondō Nobutake to capture the island, ${ }^{(182)}$ who then ordered Dutch East Indies Unit Commander V. Adm. Takahashi Ibō to execute it. On 18 March, the Dutch East Indies Unit commander announced the outline of the operation by means of Dutch East Indies Order Classified No. 203. ${ }^{(62)}$

\section{The Arrangements Between the Army and the Navy, etc.}

With the capture of Singapore almost achieved, the staff of the Southern Army [started] from 14 February onwards (Singapore fell on 15 February) preliminary discussions with the staff of the Second Fleet about the [means of] transportation for the northern Sumatra invasion operation (Operation T), the operation to capture the Andaman Islands (Operation D) and the Burma operation (Operation U). ${ }^{(30)}$ On 21 February, Southern Army Commander in chief General Terauchi and First Southern Expeditionary Fleet Commander in Chief Vice Admiral Ozawa finally reached an agreement, the contents of which were roughly as follows: ${ }^{(34)}$

1. The standard date [to calculate] the implementation date of the operation

(1) The operation schedule shall be calculated from the day when the clearing of mines in the Malacca Strait is roughly completed (Day W), which is expected to be by and large at the end of February or the beginning of March.

(2) The standard landing date of each operation shall be set as in the following table:

\begin{tabular}{|c|c|c|c|}
\hline Operation & Operation Code & Standard Landing Date & Notes \\
\hline Sumatra Operation & Operation T & About early March & \\
\cline { 1 - 2 } Andaman Operation & Operation D & \multirow{2}{*}{ Around Day W +20} & $\begin{array}{l}\text { The availability of naval air } \\
\text { units after their advance to } \\
\text { Bangkok is a requirement. }\end{array}$ \\
\cline { 1 - 2 } Burma Operation & Operation U & $\begin{array}{l}\text { The assembly points for Operation U shall be the ports of Singapore and Penang, and } \\
\text { the landing point shall be Rangoon. }\end{array}$ \\
\hline
\end{tabular}

2. The transportation [mission] in Operation U (Omitted by the author)

3. The detailed arrangements to be made between the Army and Navy units concerned (Omitted by the author)

4. Security (Omitted by the author)

During this period, the [Army] 38th Division had carried out the Bangka and Palembang operations with the support of naval units; it successfully landed on Bangka on the early morning of 15 February, and in Palembang from 15 to 16 February, and without a break went on to the operation to capture strategic places in southern Sumatra, as previously told. On 17 February, after the Bangka and Palembang operations were for the most part completed, Malaya Unit Commander Vice Admiral Ozawa ordered 9th Base Force Commander R. Adm. Hiraoka Kumeichi to clear the waterways of Singapore and the Malacca Strait. ${ }^{(118)}$ The waterways-clearing unit started its operation from 21 February, and completed clearing the waterways of Singapore on 24 February, and the Malacca Strait on 5 March. ${ }^{(68)}$ 


\section{The Course Leading to the Implementation of a Carrier Operation in the Indian Ocean}

\section{The Surprise Attack Operation on Ceylon}

On 14 February, after having studied a surprise attack operation on Ceylon and anticipating that the British fleet would be operating in the said area against [Japan's] operations to capture the Andaman Islands and Burma, the Navy Department of IGHQ and the Combined Fleet headquarters decided to let the Carrier Task Force, which had been incorporated in the Southern Task Force, operate in the Indian Ocean to the east of Ceylon and conduct a surprise attack operation on the island at an appropriate moment (in late March). ${ }^{(46)}$

On 1 March, the Sixteenth Army landed on both eastern and western Java, and the operations made smooth progress. On 5 March, the chief of staff of the Combined Fleet disclosed the outline of operations for the stage-one, phase-four operations ([to be conducted] from the rough completion of the Java operation until early April), in which he announced the implementation of a carrier operation in the Ceylon area by the Southern Task Force. ${ }^{(54)}$ Then, following the unconditional surrender of the Dutch East Indies on 9 March, Combined Fleet Commander in Chief Admiral Yamamoto issued an order to Southern Task Force Commander Vice Admiral Kondō to implement the surprise attack operation on Ceylon, the content of which was as follows: ${ }^{(53)}$

\section{Combined Fleet Telegraphic Operation Order Classified No. 86}

The Southern Task Force commander shall execute the carrier operation in the Ceylon area specified in the following:

1. Mission

To conduct a surprise attack on the enemy fleet in the Ceylon area and destroy it.

2. Date of the operation

From mid-March until early April

3. Participating forces

The force with the Carrier Task Force as the core

The stage-one, phase-four disposition of forces was put in motion as of 10 March. ${ }^{(141)}$

\section{The Striking Operation in the Bay of Bengal}

Since considerable time to spare was expected between the scheduled completion date of the Andaman Islands capture and the rough date of completion of the capture of [other] southern strategic areas including the Burma operation, Malaya Unit Commander Vice Admiral Ozawa had been planning to seize this opportunity and conduct an operation that would be the crowning operation of the surface unit of the Malaya Unit, by employing as his main force the temporarily incorporated vessels (the Chōkai, the 7th Cruiser Division, the 3d Destroyer Squadron and the 4th Carrier Division, which were to be returned to their original units after the rough completion of stage-one operations). Since early February, he had been drawing up a full-scale plan to independently conduct a striking operation by the Malaya Unit in the northern part of the Bay of Bengal, so as to check the British-Indian Army in the Burma theater by threatening the allied supply route from the Indian Ocean to Calcutta through the Bay of Bengal, and on the other hand to crush [any] enemy intentions to make 
counterattacks against the Andaman Islands after their capture. ${ }^{(38)}$ On having formally been informed of the implementation of the carrier operation in the Ceylon area by the Combined Fleet Order of 9 March, Malaya Unit Commander Vice Admiral Ozawa made a proposal to Southern Task Force Commander Vice Admiral Kondō that a striking operation in the northern part of the Bay of Bengal, which his unit had already been studying, should be implemented in concert with the operation of the Carrier Task Force of the Southern Task Force as long as the situation should permit it. ${ }^{(181)}$ Having obtained the approval of Combined Fleet Commander in Chief Admiral Yamamoto for the proposal by the Malaya Unit commander, the Southern Task Force commander announced, on the night of 14 March by means of telegraphic order No. 139, the outline [of actions to be taken] in concert by [the relevant] units. It specified that while continuing its current tasks, the Malaya Unit should conduct a striking operation in the Bay of Bengal to the north of the line connecting Madras (inclusive) [in India] and Babi Island [off Sumatra] ${ }^{*}$, but that it should not advance to the waters to the west of $85^{\circ} \mathrm{E}$ longitude until the first air raid by the Carrier Task Force. ${ }^{(181)}$

\section{[The Operation to] Capture Burma and Key Areas Nearby Is Put in Motion}

After the clearing of the waterways of Singapore on 24 February, the Malaya Unit commander entered the naval port of Seletar in Singapore on the evening of 27 February, leading the Chōkai and the Ayanami. Following that, the transport convoys that were to participate in the Indian Ocean theater operations began to assemble in Singapore one after another. ${ }^{(68)}$

The units for the northern Sumatra invasion assembled in Singapore between 27 February and 6 March, left the port of Singapore on 8 March, and mopped up [the enemy in] northern Sumatra by 31 March. ${ }^{(68)}$ Meanwhile, [the operation] to capture the Andaman Islands was launched on 20 March and completed by the 30th. ${ }^{(118)}$ During these operations, they hardly met any major resistance from the enemy.

On 8 March, the Fifteenth Army seized Rangoon. On the previous day, the 7th, Southern Army Commander in Chief General Terauchi had ordered Fifteenth Army Commander Lieutenant General lida to destroy the enemy in the Mandalay area, while at the same time issuing an order to newly add to the Fifteenth Army the 56th Division (which was no longer needed in the Malaya operation due to the smooth progress in the operation) as well as the 18th Division, which had completed its operations in Malaya. ${ }^{(145)}$ The Navy was supposed to escort the transport convoys of these units. On 19 March, the Burma transport operation was launched with the first transport. [The Navy] escorted a total of 134 transport ships by 28 April and made a huge contribution to the Burma operation. The loss sustained by the Japanese forces in this transport operation was only two (empty) Army transport ships, which were sunk by enemy submarines while returning from Rangoon to Singapore. ${ }^{(68)}$

On 31 March, the Christmas Island invasion units captured the island as scheduled. In this operation, there were no enemy counterattacks on the ground, but there was an incident with the Naka, the flagship of the 4th Destroyer Squadron, which was torpedoed by an enemy submarine while on guard in the surrounding waters of the island, but somehow she managed to return to Bantam Bay. ${ }^{(56)}$

\footnotetext{
* The text has Babié Island. Since the Action Report of the 5th Carrier Division and that of the Hiryu mention Babi Island in one breath with Simeulue Island (off the northwest coast of Sumatra), we assume that Babié Island refers to the small Babi Island between Simeulue and Nias.
} 


\section{The Carrier Operation in the Indian Ocean Is Put in Motion}

The Carrier Task Force of the Southern Task Force was originally scheduled to leave Staring Bay on 21 March and conduct attacks on Ceylon on 1 April. ${ }^{(100)}$ However, since the return to the Carrier Task Force of the 5th Carrier Division, which had been kept in mainland Japan to be ready against air raids by an enemy striking force, was delayed due to the reports on the air raid on Minami-Torishima [Marcus Island] by an enemy striking force on 4 March and on the appearance of an enemy striking force [on the waters] to the north of Wake Island on 10 March, the schedule [of the carrier operation] was changed on 17 March in such a way that [the Carrier Task Force] should [now] leave Staring Bay on 26 March and attack Ceylon on 4 April. In the meantime, since the Kaga of the 1st Carrier Division had earlier touched an uncharted rock at Palau and sustained minor damage to her hull, she was removed from the Carrier Task Force as of 13 March and left Staring Bay on 15 March for Sasebo for repairs (as previously told). ${ }^{(141)}$ For about three weeks until their departure on 26 March, the carrierbased aircraft of the 1st and the $2 \mathrm{~d}$ Carrier Divisions had conducted hard drills at the Kendari base, which had remarkably improved their skills. ${ }^{(75)}$ On 24 March, the 5th Carrier Division entered Staring Bay, which finished the assembly of the units for the Ceylon attack. ${ }^{(100)}$

On 26 March, the Carrier Task Force of the Southern Task Force left Staring Bay and raided Colombo on 5 April; while delivering a heavy blow to the enemy air power and his ground facilities, it also sank two British heavy cruisers HMS Cornwall and HMS Dorsetshire. Further on 9 April, it dealt a massive blow to the enemy by an attack on Trincomalee and also sinking the small British aircraft carrier HMS Hermes. ${ }^{(141)}$

In the meantime, on 1 April, the Malaya Unit Striking Force had left Mergui. On 6 April, after splitting into three units, the force sank a number of [enemy] merchantmen by closing in to the coast of India in the northern part of the Bay of Bengal.(119)

After achieving the major aims of the Southern Operation, the Combined Fleet shifted to stage-two operations from 10 April onwards, ${ }^{(53)}$ and the focus of the operations of the Navy shifted from the previous areas southwest [of Japan, i.e. Southeast Asia] to the east of Honshū.

On 13 April, the Minister of the Navy and the Chief of Naval General Staff sent the following congratulatory telegram to the commanders in chief of the Combined Fleet and the Second Fleet: ${ }^{(141)}$

\section{Office of the Navy Minister Telegram Classified No. 183}

You have attained great military results in the recent operations in the Indian Ocean by destroying almost all enemy naval vessels, his air power and merchantmen and blowing up his military facilities around the Bay of Bengal and on Ceylon, on which we offer you our congratulations.

\section{Clearing the Waterways in the Malacca Strait}

(See Illustration No. 52)

\section{Plan of Operations and Preparations}

The disposition of forces for this operation was in outline as follows. ${ }^{(68)}$

1. The operation to clear the waterways of Singapore (as shown in the following table) 


\begin{tabular}{|c|c|c|c|c|}
\hline Unit & & Commander & Forces & Main Tasks \\
\hline Main Unit & \multirow{4}{*}{ 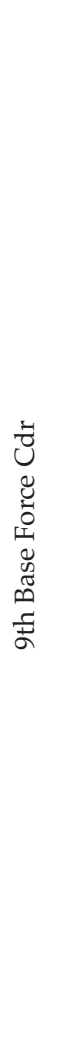 } & & 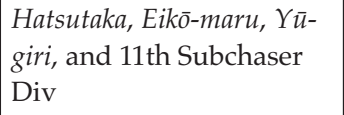 & $\begin{array}{l}\text { Support of the } \\
\text { minesweeping units }\end{array}$ \\
\hline $\begin{array}{c}\text { 1st Minesweeping } \\
\text { Unit }\end{array}$ & & $\begin{array}{l}\text { 41st Minesweeper Div } \\
\text { Cdr }\end{array}$ & $\begin{array}{l}\text { 41st Minesweeper Div, } \\
\text { 11th Subchaser Div, } \\
\text { Otowa-maru, Rumoi-maru, } \\
5 \text { [4?] cutters, } 2 \text { large- } \\
\text { sized motorized [landing] } \\
\text { craft, } 9 \text { [4?] or more motor } \\
\text { launches }\end{array}$ & $\begin{array}{l}\text { 1. Clearing the waterways } \\
\text { of Singapore } \\
\text { 2. Sweeping the anchor- } \\
\text { ages of Keppel Har- } \\
\text { bour and the } \\
\text { commercial port for } \\
\text { mines } \\
\text { 3. Clearing the waterways } \\
\text { from Keppel Harbour } \\
\text { to the main waterway }\end{array}$ \\
\hline $\begin{array}{l}\text { 2d Minesweeping } \\
\text { Unit }\end{array}$ & & $\begin{array}{l}\text { 44th Minesweeper Div } \\
\text { Cdr }\end{array}$ & $\begin{array}{l}\text { 44th Minesweeper Div, } \\
\text { 11th Subchaser Div, } 2 \\
\text { motor launches and } 1 \\
\text { large-sized motorized } \\
\text { [landing] craft }\end{array}$ & $\begin{array}{l}\text { 1. Clearing the waterways } \\
\text { of Johor } \\
\text { 2. Sweeping the anchor- } \\
\text { age for the naval port } \\
\text { for mines } \\
\text { 3. Clearing the waterways } \\
\text { from the commercial } \\
\text { port to the main water- } \\
\text { way }\end{array}$ \\
\hline Supply Unit & & 91st Guard Unit Cdr & $\begin{array}{l}\text { 91st Guard Unit, Nojima- } \\
\text { maru, Kōryū-maru, and } \\
\text { Kisogawa-maru }\end{array}$ & $\begin{array}{l}\text { Providing supply and } \\
\text { guard }\end{array}$ \\
\hline Notes & \multicolumn{4}{|c|}{$\begin{array}{l}\text { 1. The } 3 \mathrm{~d} \text { Destroyer Squadron commander shall, when specifically ordered, support the } \\
\text { above [mission to] clear the waterways, leading the Sendai, the Amagiri, and the Asa- } \\
\text { giri. } \\
\text { 2. One reconnaissance seaplane of the Chōkai (including } 9 \text { service personnel at the Men- } \\
\text { tok and the Anambas [bases]) shall engage in the clearing of the waterways of Singa- } \\
\text { pore. }\end{array}$} \\
\hline
\end{tabular}

2. The operation to clear the waterways in the Malacca Strait

\begin{tabular}{|c|c|c|c|c|}
\hline Unit & & Commander & Forces & Main Tasks \\
\hline Main Unit & \multirow{3}{*}{ 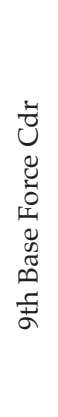 } & & Hatsutaka & $\begin{array}{l}\text { Support of the } \\
\text { Minesweeping Unit }\end{array}$ \\
\hline Minesweeping Unit & & $\begin{array}{l}\text { 44th Minesweeper Div } \\
\text { Cdr }\end{array}$ & $\begin{array}{l}\text { 44th Minesweeper Div, } \\
\text { 11th Subchaser Div, and } 2 \\
\text { cutters }\end{array}$ & $\begin{array}{l}\text { Clearing the waterways } \\
\text { in the Malacca Strait } \\
\text { and sweeping anchor- } \\
\text { ages for mines }\end{array}$ \\
\hline Supply Unit & & 91st Guard Unit Cdr & $\begin{array}{l}\text { 91st Guard Unit, Eikō- } \\
\text { maru and Nojima-maru }\end{array}$ & $\begin{array}{l}\text { Providing supply and } \\
\text { guard }\end{array}$ \\
\hline
\end{tabular}


At 0800 on 18 February, 9th Base Force Commander Rear Admiral Hiraoka left Palembang leading the Hatsutaka, sailed downstream and arrived at the mouth of the [Musi] river at 1500. After having been joined by the Eikō-maru and the Kōryū-maru off Mentok, he headed for Mapur Island. The Otowa-maru, the Rumoi-maru, and six auxiliary cutters, too, called off their minesweeping operations by the end of the 18th and headed for Mapur. Following them, the 11th Subchaser Division, the 41st and the 44th Minesweeper Divisions, the Yügiri and the Nojima-maru also left Anambas or their own patrol areas on the 19th and headed for Mapur; the main force for the operation to clear the waterways of Singapore assembled at the anchorage to the south of Mapur by 0915 on 20 February. ${ }^{(68)}$

\section{Clearing of the Waterways Completed}

The operation to clear the waterways of Singapore took the following course. ${ }^{(68)}$

\section{[February]}

20th: At 2030, the minesweeping units left Mapur.

21st: Having started sweeping at 1000, the units swept the central waterway, the main waterway to Keppel [Harbour] and the Johor waterway for mines but snagged no mines. At 2030, the minesweeping operation was suspended. In the minesweeping operation, other than making use of the buoys set by the British, [the unit] conducted the operation with a British navy commander (former commander of a minesweeping unit at Singapore) taken prisoner off Mentok, on board of [one of] minesweepers.

22d: At 0800, the minesweeping operation was resumed. The 1st Minesweeping Unit cleared the main waterway to Keppel Harbour, while the $2 \mathrm{~d}$ Minesweeping Unit the main waterway to the naval port of Seletar. With no mines snagged, [the units] suspended the operation at 2030.

23d: At 0800, the minesweeping operation was resumed. The 41st Minesweeper Division swept the anchorage of the naval port of Seletar for mines, while the 44th Minesweeper Division, the Otowa-maru, the Rumoi-maru and others swept the anchorages of Keppel Harbour and the commercial port. At 1300, the minesweeping operation at the anchorage of the Seletar naval port was completed with no mines snagged.

24th: At 0800, the minesweeping operation at the anchorages of Keppel Harbour and the commercial port was completed.

25th: Preparations for the minesweeping operation of the waterways in the Malacca Strait. On that day, the $3 \mathrm{~d}$ Destroyer Squadron swept the areas about sixty nautical miles $120^{\circ}$ of the east entrance of the central waterway of Singapore for mines. ${ }^{(118)}$ However, no mines were snagged.

The operation to clear the waterways in the Malacca Strait took the following course. ${ }^{(68)}$

26th: At 0800, the Hatsutaka, the 44th Minesweeper Division, Submarine Chaser No. 7 and two cutters left Singapore and at 2040 started the minesweeping of the waterways in the Malacca Strait ([with] the effective width and depth of 1,000 meters and 15 meters respectively). [The unit] disposed of one floating mine.

27th: [The unit] resumed the minesweeping operation at 0730 and suspended it at 2100. At 2200, a reconnaissance seaplane of the Chōkai, which had been supporting the minesweeping operation, returned [to the vessel]. It was decided that the aircraft of the Sagara-maru should support the minesweeping [operation, replacing the seaplane]. [On that day, the unit] disposed of eight floating mines. 
574 Chapter IX / The Neutralization of the Indian Ocean

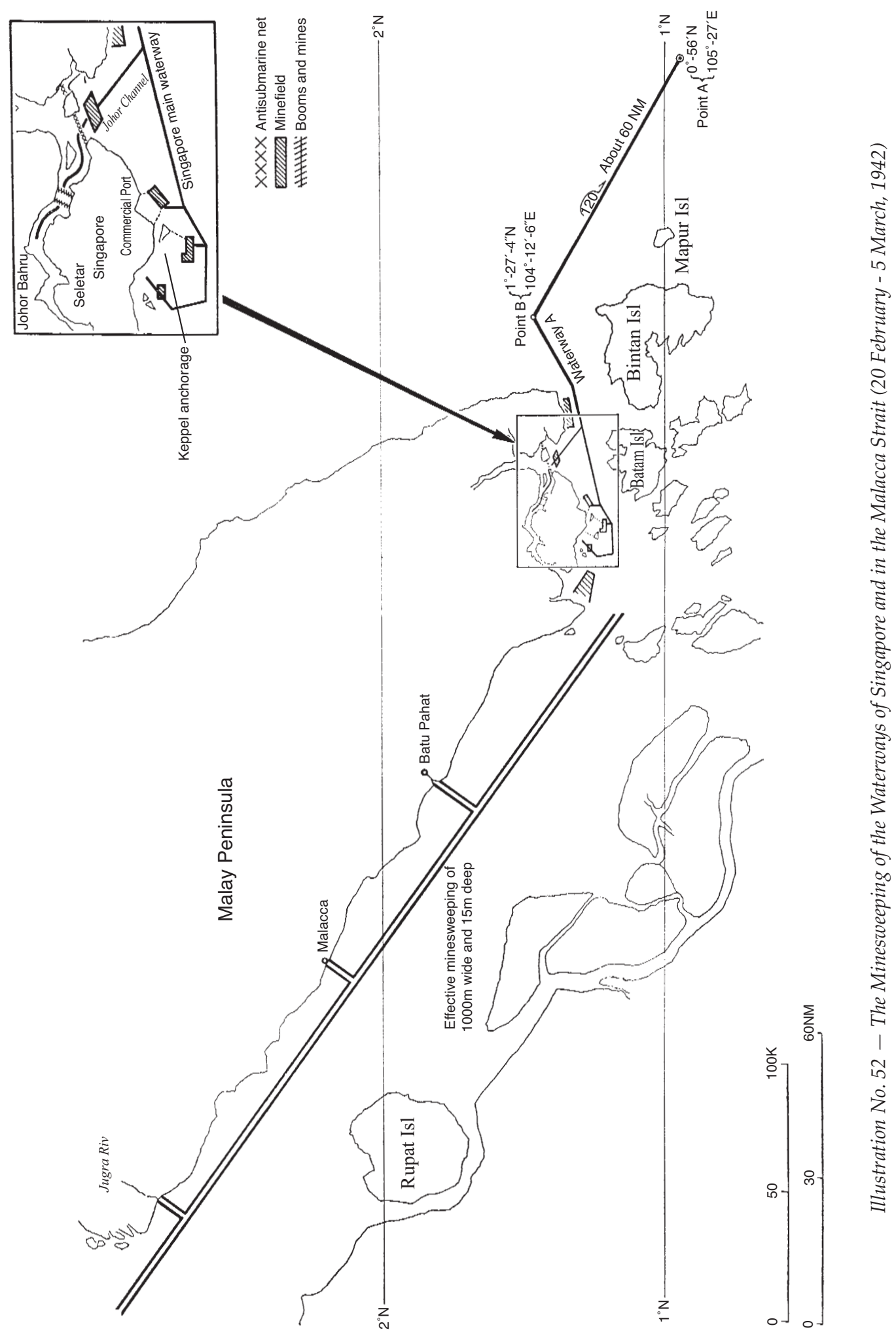


28th: [The unit] resumed the minesweeping operation at 0730 and suspended it at 2000, disposing of one floating mine.

March

1st: The minesweeping operation of the waterways in the Malacca Strait was completed.

2d: [The unit also] completed the minesweeping of the anchorage at the mouth of the Jugra River and disposed of one floating mine.

3d: [The unit] completed the minesweeping of the anchorage at Malacca.

4th: [The unit] completed the minesweeping of the anchorage at Batu Pahat and disposed of five floating mines.

5th: At 1500 the minesweeping units returned to the naval port of Seletar.

Malaya Unit Commander Vice Admiral Ozawa, who had entered the port of Cap Saint Jacques ([in] French Indochina) leading the Chōkai and the Ayanami on 19 February after the completion of Operation L, stayed there and directed the overall operation from there. Since the clearing of the waterways of Singapore was completed, he left Cap Saint Jacques at 0800 on 25 February, leading the Chōkai and the Ayanami, and entered the naval port at Seletar on the evening of the 27th. ${ }^{(118)}$ Thereafter, the surface units of the Malaya Unit began to advance one after another to the naval port at Seletar, while the transport convoy [carrying units to] participate in the coming operations in the Indian Ocean also began to assemble one after another at Singapore from 2 March onwards. ${ }^{(68)}$

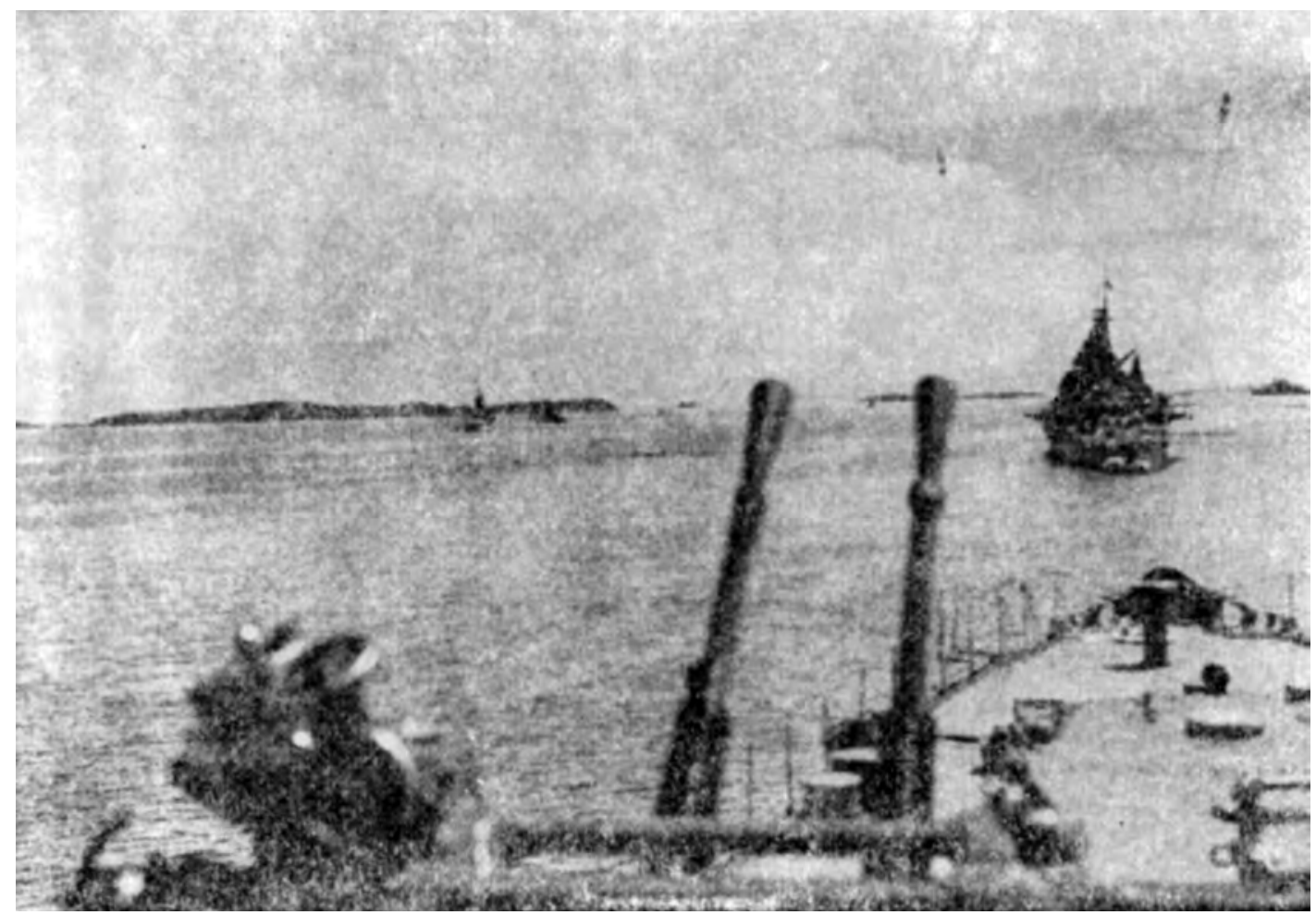

Our Fleet Dominating the Naval Port of Singapore 


\section{The Northern Sumatra Invasion Operation}

(See illustration No. 53)

In accordance with the arrangements for Operations T, D and U concluded on 21 February between the [Navy] First Southern Expeditionary fleet and the Southern Army at Saigon, the Twenty-fifth Army commander, the [Army] Third Air Force commander and the commander in chief of the First Southern Expeditionary Fleet made arrangements concerning the operation to capture strategic areas in northern Sumatra at Singapore on 28 February, ${ }^{(34)}$ in which they reached an agreement on the following: the mission (to capture key areas in northern Sumatra and swiftly seize naval bases and airfields there, while securing important resource areas), the operation schedule, the landing points and their reconnaissance, the disposition of forces, the embarkation of forces [on the transport ships], the assembly, departure and things to be done [before the departure] of the transport ships, the time and date of the start of the landing and the landing schedule, the distribution of the transport ships and their escort at sea, the air operations, feint operations and diversions, the landing battles, the cover of the landings and support of the disembarkation, the defense facilities at the landing points and landing bases, joint operations between the Army and the Navy after the landing, intelligence, detailed arrangements to be made between the Army and Navy commanders concerned, etc. ${ }^{(120)}$ In this arrangement, Day $W$ and the date of the landing were set respectively on 2 March and on Day W +10 . Following the arrangement, in the beginning of March, the arrangements for communications in Operation $\mathrm{T}$ between the commander in chief of the First Southern Expeditionary Fleet, the Twenty-fifth Army commander and the army Third Air Force commander as well as detailed arrangements between the 3d Destroyer Squadron commander and the commander of the Imperial Guard Infantry Group were concluded. ${ }^{(120)}$

\section{The Plan of Operations}

\section{The Malaya Unit}

In accordance with the aforementioned agreement and arrangements between the Army and the Navy, Malaya Unit Commander Vice Admiral Ozawa announced the Malaya Unit's plan of operations for Operations T, D, and U in Singapore on 5 March. Although the whole plan is not extant, part of the plan was as follows. ${ }^{[119](125)}$

\section{Mission}

In conjunction with the Army, [the unit shall] swiftly capture key places in northern Sumatra and the Andaman Islands, while escorting the Army units for the Burma invasion [operation] from Singapore to Rangoon and facilitate [the operation to] capture Burma.

2. Outline of the operation

(1) First of all, [the unit] shall capture key places in northern Sumatra to set up a naval air base on Sabang Island.

(2) Then, [the unit] shall capture key places on the Andaman Islands to set up a naval air base and a base for naval vessels there.

(3) Almost simultaneously with the operation to capture the Andaman Islands, [the unit] shall escort army transport ships from Singapore (part of them from Penang) to Rangoon and facilitate the Burma invasion operation.

3. The disposition of forces in Operation $\mathrm{T}$ (as shown in the following table) 


\begin{tabular}{|c|c|c|c|c|}
\hline Unit & & Commander & Forces & Main Tasks \\
\hline Main Unit & \multirow{5}{*}{ 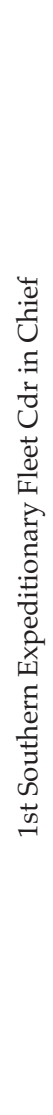 } & & $\begin{array}{l}\text { Chōkai, 7th Cruiser Div, } 6 \text { destroyers } \\
\text { of 3d Destroyer Sqdn, Mihoro Air } \\
\text { Group (Type-96 carrier-based fighter } \\
\text { plane unit attached), 40th Air Group, } \\
\text { 4th Carrier Div (minus 2d Section), } \\
\text { Sagara-maru, Kamikawa-maru and 91st } \\
\text { Subchaser Div }\end{array}$ & $\begin{array}{l}\text { 1. To support the whole op- } \\
\text { eration } \\
\text { 2. [To conduct] air opera- } \\
\text { tions }\end{array}$ \\
\hline $\begin{array}{l}\text { 1st Escort } \\
\text { Unit }\end{array}$ & & $\begin{array}{l}\text { 3d Destroyer Sqdn } \\
\text { Cdr }\end{array}$ & $\begin{array}{l}\text { 3d Destroyer Sqdn (minus } 6 \text { destroy- } \\
\text { ers), Kashii, 1st Minesweeper Div } \\
\text { (incl. Minesweeper No. 5), } 2 \text { subma- } \\
\text { rine chasers of 11th Subchaser Div, } \\
\text { (and Yura) }\end{array}$ & $\begin{array}{l}\text { 1. To escort the units land- } \\
\text { ing along Sabang Bay and } \\
\text { at Kutaraja } \\
\text { 2. To sweep inside the port } \\
\text { of Sabang for mines }\end{array}$ \\
\hline $\begin{array}{l}\text { 2d Escort } \\
\text { Unit }\end{array}$ & & $\begin{array}{l}\text { 9th Special Base } \\
\text { Force Cdr }\end{array}$ & $\begin{array}{l}\text { Hatsutaka, Shimushu, Chōsa-maru, } \\
\text { Eikō-maru, } 1 \text { submarine chaser of 11th } \\
\text { Subchaser Div, 41st Minesweeper Div } \\
\text { 2d Section and 44th Minesweeper } \\
\text { Div 1st Section }\end{array}$ & $\begin{array}{l}\text { To escort the Labuhanruku } \\
\text { and Idi landing units }\end{array}$ \\
\hline $\begin{array}{l}\text { Penang Base } \\
\text { Unit }\end{array}$ & & $\begin{array}{l}\text { 9th Special Base } \\
\text { Force Cdr }\end{array}$ & $\begin{array}{l}\text { 11th Submarine Base Unit, the } \\
\text { ground patrol and surface patrol sec- } \\
\text { tions of 9th Special Base Force and } 4 \\
\text { large-sized motorized [landing] craft }\end{array}$ & $\begin{array}{l}\text { 1. To provide supplies } \\
\text { 2. To defend and guard } \\
\text { Penang } \\
\text { 3. To protect the [sea] lines } \\
\text { of communication }\end{array}$ \\
\hline $\begin{array}{c}\text { Sabang } \\
\text { Base } \\
\text { Unit }\end{array}$ & & $\begin{array}{l}\text { Sabang Base } \\
\text { Unit Cdr }\end{array}$ & $\begin{array}{l}\text { About 1plt of the ground patrol sec- } \\
\text { tion of the 9th Special Base Force, } 3 \\
\text { large-sized motorized [landing] craft, } \\
2 \text { auxiliary cutters }\end{array}$ & $\begin{array}{l}\text { To defend and guard Sa- } \\
\text { bang }\end{array}$ \\
\hline
\end{tabular}

Remarks:

1. From 25 February, 1942 onwards, the 9th Base Force became the 9th Special Base Force.

2. The 40th Air Group was formed in Tateyama on 1 February, 1942 and incorporated into the First Southern Expeditionary Fleet as of that day. Its forces consisted of eight carrier-based attack planes and eight carrier-based bombers; the former advanced to Singapore in mid-February and the latter in early April. ${ }^{(183)}$

3. The Kamikawa-maru was removed from the Malaya Unit as of 10 March by means of Southern Task Force Telegraphic Order No. 120; she headed for the areas to the southeast [of Japan, i.e. the western Pacific], as previously told [pp. 499, 506].

\section{The 1st Escort Unit}

The outline of operations of the 1st Escort Unit of the Malaya Unit in Operation T was as follows: ${ }^{(118)}$

\section{Outline of the mission}

[The unit] shall escort the transport ships carrying the [Army] Kobayashi Detachment of the Imperial Guard Division ([consisting of] one infantry battalion as the core for [the capture of] Sabang, and two infantry battalions and one field artillery battalion as the core for [the capture 
of] the Kutaraja area) as well as the navy unit for the Sabang base from the port of Singapore to northern Sumatra, and disembark them on Sabang Island and in the vicinity of Kutaraja.

2. Disposition of forces

[The unit] shall be divided into the direct escort unit and the minesweeping unit; the former shall be assigned to directly escort the transport ships and support the landing [of forces] under the command of the 1st Escort Unit commander, while the latter shall be assigned to dispose of floating mines in the Malacca Strait and sweep the sailing routes ahead of the transport ships and their anchorages for mines under the command of the 1st Minesweeper Division commander.

3. Outline of actions of both units

(1) On Day W +6, the direct escort unit shall leave the west Keppel Harbour escorting the eight transport ships carrying the Kobayashi Detachment of the Imperial Guard Division and enter the anchorages of Kutaraja and Sabang around Day W +10 . When the disembarkation is completed, the unit shall return to Penang.

(2) The minesweeping unit shall depart at an appropriate moment on the morning of Day W + 6. After disposing of floating mines in the Malacca Strait, it shall join the transport ships on the evening of Day $\mathrm{W}+7$. When entering the anchorages, the unit shall [start] sweeping for mines on the sailing routes ahead of the ships as well as in their anchorages from Point $Y$ without [specific] order.

\section{The 2d Escort Unit}

\section{Outline of the mission}

[The unit] shall escort the main force of the Imperial Guard Division ([consisting of] five infantry battalions, one tank squadron, two field batteries, two trench mortar batteries as the core with two engineer companies and one air unit element) and the Yoshida Detachment ([consisting of] one infantry battalion as the core) from the port of Singapore respectively to Labuhanruku and Idi, and put them ashore.

\section{Disposition of forces}

[The unit] shall be divided into Escort Units A, B and the Penang Base Unit. Escort Unit A shall escort the Labuhanruku landing unit under the command of the 9th Special Base Force commander, and Escort Unit B shall escort the Idi landing unit under the command of the captain of the Shimushu, while the Sabang Base Unit of the Penang Base Unit shall be assigned to the defense and guarding of Sabang Island after it has been captured by the army unit.

\section{Outline of the actions of the units}

1. On Day $W+8$, Escort Unit A shall leave the west Keppel Harbour, escorting eight transport ships carrying the main force of the Imperial Guard Division and enter the anchorage of Labuhanruku around 0300 on Day $\mathrm{W}+10$. When disembarkation is completed, the unit shall return to Penang.

2. On Day W +7 , Escort Unit B shall leave the west Keppel Harbour, escorting two transport ships carrying the [Army] Yoshida Detachment, and enter the anchorage of Idi around 0100 on Day $\mathrm{W}+10$. When disembarkation is completed, the Shimushu shall return to Singapore, escorting the empty ships by way of Labuhanruku, while the $2 \mathrm{~d}$ Section of the 41st Minesweeper Division shall return to Penang.

3. The Sabang Base Unit shall embark on navy transport ships escorted by the 1st Escort Unit; after the army Kobayashi Detachment has captured Sabang Island, it shall take charge of the defense and guard of the island. 


\section{Preparation for the Operations}

The units for Operation T assembled in Singapore between 27 February and 6 March. ${ }^{(114,150)}$ Meanwhile, since the Yura, which had operated in the western Java area, returned to Singapore on the afternoon of the 6th, Malaya Unit Commander Vice Admiral Ozawa incorporated her in the 1st Escort Unit. Also, since it was decided to additionally send a construction unit to Sabang Island, he added another transport ship. ${ }^{(63)}$

In the meantime, the Mihoro Air Group and the Type-96 carrier-based fighter plane unit (put under the commander of the Mihoro Air Group) were [still] based in Kuantan, and even after the main force of the 1st Air Unit of the Malaya Unit (the 22d Air Flotilla headquarters, the Genzan Air Group, the main body of the Kanoya Air Group and the Type-0 fighter plane unit of the 22d Air Flotilla) was transferred to the Air Unit of the Southern Task Force to participate in the Java operation, they were kept in the Malaya Unit, and mainly engaged in attacking enemy vessels on the sea near Bangka Island as well as in the Gaspar Strait. On 19 February, the Mihoro Air Group commander was ordered by the Malaya Unit commander to advance about four of its land-based attack planes to Sungai Petani, so as to reconnoiter [enemy] seaplane bases, air bases on the ground as well as port facilities (and [take reconnaissance] photos of key places) on the Andaman and Nicobar Islands, and of Sabang and Kutaraja. He was also given a preparatory order that all aircraft units [under his command] should be advanced to the west coast of Malaya (Sungai Petani or Ayer Tawar) after the [Army's] landing on Java. ${ }^{(135)}$ Accordingly, four land-based attack planes were advanced to Sungai Petani on the 20th and conducted reconnaissance over the Andaman Islands and northern Sumatra on the 21st, the 22d, the 24th, the 26th and the 28th, but they spotted no enemy. ${ }^{(71)}$ On 5 March, the orders concerning Operations T, D and U were issued by means of Malaya Unit Operation Order Classified No. 18 and the Mihoro Air Group was incorporated in the main unit of the Malaya Unit along with the Type-96 carrier-based fighter plane unit. The units advanced to Penang by the 9th and completed preparations for Operation T. ${ }^{(135)}$ Meanwhile, the carrier-based attack plane unit of the 40th Air Group arrived in Singapore on 16 February and completed its preparations for Operations T, D and U on $5 \mathrm{March}^{(184)}$ (its carrier-based bomber unit arrived in Singapore in early April). Following them, the Sagara-maru entered the port of Penang on 9 March and completed her preparations for Operation $\mathrm{T}$, having her aircraft advance to the seaplane base of Penang. ${ }^{(125)}$

\section{Landings Made Without Bloodshed}

The 1st Escort Unit, the main unit of the Malaya Unit and the 2d Escort Unit left the port of Singapore respectively on 8, 9 and $10 \mathrm{March}$, and headed toward the landing points, sailing northward in the Malacca Strait. ${ }^{(114,118)}$ In the meantime, the air campaign against northern Sumatra was launched on the 9th with an air raid on Sabang Island by the Mihoro Air Group. ${ }^{(68)}$ From 10 March onwards, the Sagara-maru, too, provided the 1st Escort Unit and the convoy with direct escort against [enemy] submarines as well as patrols on the sailing routes ahead of them, employing the aircraft unit at the Penang seaplane base, while the 40th Air Group provided the escort units and the main unit sailing in the southern part of the Malacca Strait with patrols on the sailing routes ahead of them as well as patrols against [enemy] submarines. ${ }^{(71)}$ Before dawn on the 12th, the landing units landed without bloodshed on Sabang Island, in Kutaraja, Labuhanruku and Idi. On the 14th, the 1st and the 2d Escort 


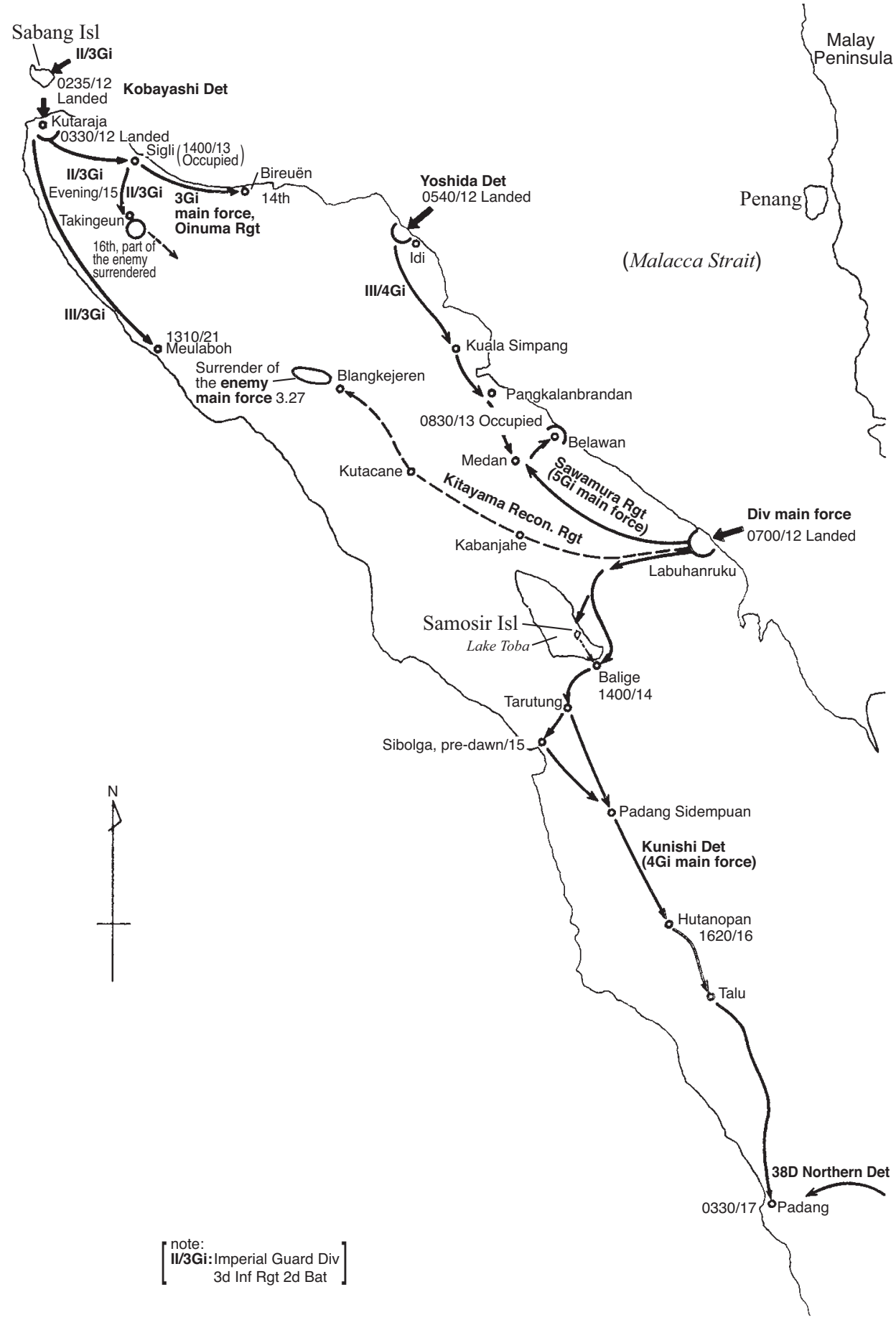

Illustration No. 53 - Rough Sketch of the Course of the Imperial Guard Division's Invasion Operation in Central and Northern Sumatra 
Units departed respectively for Penang and Singapore, completed this operation and started preparing for the coming Andaman Islands operation. ${ }^{(118)}$ During this period, the Mihoro Air Group conducted bombing attacks on Sabang Island and search missions in the Indian Ocean, while the Sagara-maru and the 40th Air Group conducted patrols on the sailing routes ahead of the convoys as well as patrols against [enemy] submarines and neutralized the landing points but spotted no enemy. The surface units encountered no enemy either and [thus] no loss was sustained by our forces. ${ }^{(71,118,125)}$

The army units operated as shown in Illustration No. 53; they mostly completed the clearing of northern Sumatra by around the 21st. ${ }^{(185)}$

\section{The Capture of the Andaman Islands}

(See Illustration No. 54)

In accordance with the arrangement between the Southern Army commander in chief and the commander in chief of the First Southern Expeditionary Fleet, Twenty-fifth Army Commander Lt. Gen. Yamashita Tomoyuki and First Southern Expeditionary Fleet Commander in Chief Vice Admiral Ozawa concluded in Singapore an arrangement for [the operation to] capture the Andaman Islands. The main points of the arrangement were as follows: ${ }^{(34)}$

\section{Mission}

[The units] shall capture key places in the Andaman Islands and swiftly secure naval bases and airfields there.

2. Forces to be employed

(1) Army

Commander: the 56th Infantry Regiment 2d Battalion commander

The 56th Infantry Regiment 2d Battalion

The regimental artillery battery (minus one half) of the 56th Infantry Regiment

One half of the antitank guns of the 56th Infantry Regiment

Other than the above, some medical units, signal units and engineer units

(2) Navy

Detached Unit of the 12th Special Base Force

3. Landing points

The west coast of Ross Island, the sandy beach two kilometers west of Ross Island and others; after that, Havelock, Stewart Sound, Port Cornwallis, etc. shall be seized in succession on request of the Navy.

4. Embarkation, assembly, departure and landing

(1) Embarkation point: the port of Singapore

(2) Assembly point and date of assembly

Assembly point: Penang

Date of assembly: Day W +18 , by when [each vessel] shall sail on their own [to the assembly point]

5. Chain of command

From the assembly at Penang until ordered [otherwise] by specific orders, the army landing units shall come under the command of the navy landing unit commander concerning the operation.

6. Escort at sea

(1) The bulk of the Malaya Unit

(2) One element of the Eleventh Air Fleet ([consisting of] the 22d Air Flotilla as the core) 
In accordance with the above arrangement, the 3d Destroyer Squadron commander, the 12th Special Base Force Detached Unit commander and the [army] 56th Infantry Regiment 2d Battalion commander made detailed arrangements on 1 March. ${ }^{(118)}$

\section{The Plan of Operations}

\section{The Malaya Unit}

On 5 March, the Malaya Unit commander gave instructions for the plan of operations of the Malaya Unit concerning Operations T, D and U in Singapore by means of Malaya Unit Operation Order Classified No. 18, in which the disposition of forces of Operations D and U was as shown in the following table: $(68,118,119)$

\begin{tabular}{|c|c|c|c|c|c|}
\hline \multicolumn{2}{|r|}{ Unit } & \multicolumn{2}{|r|}{ Commander } & Forces & Main Tasks \\
\hline \multirow{5}{*}{ 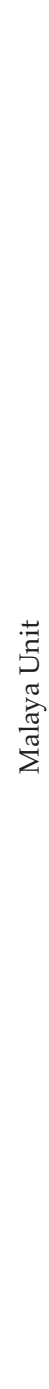 } & Main Unit & \multirow{5}{*}{ 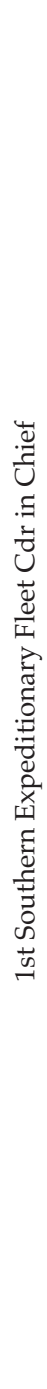 } & & $\begin{array}{l}\text { Chōkai, 7th Cruiser Div, } 1 \text { de- } \\
\text { stroyer div of the 4th [3d?] } \\
\text { Destroyer Sqdn, 4th Carrier } \\
\text { Div (minus 2d Section), 40th } \\
\text { Air Group, Sagara-maru, and } \\
\text { San'yō-maru }\end{array}$ & To support all operations \\
\hline & $\begin{array}{l}\text { 1st Escort } \\
\text { Unit }\end{array}$ & & $\begin{array}{l}\text { 3d Destroyer } \\
\text { Sqdn Cdr }\end{array}$ & $\begin{array}{l}\text { 3d Destroyer Sqdn (minus } 4 \\
\text { [6?] destroyers), (Yura), 1st } \\
\text { Minesweeper Div (with } \\
\text { Minesweeper No. } 5 \text { in- } \\
\text { cluded), 11th Subchaser Div }\end{array}$ & $\begin{array}{l}\text { To escort the units to capture the } \\
\text { Andaman Islands }\end{array}$ \\
\hline & 2d Escort Unit & & $\begin{array}{l}\text { 9th Special Base } \\
\text { Force Cdr }\end{array}$ & $\begin{array}{l}\text { Kashii, Hatsutaka, Shimushu, } 4 \\
\text { [1?] destroyers of the 3d De- } \\
\text { stroyer Sqdn, 5th Destroyer } \\
\text { Sqdn [Div?] }\end{array}$ & $\begin{array}{l}\text { To escort the transport ships car- } \\
\text { rying the [army] 56th Div, 18th } \\
\text { Div, and the units under the di- } \\
\text { rect control of the army from } \\
\text { Singapore (one element from } \\
\text { Penang) to Rangoon }\end{array}$ \\
\hline & $\begin{array}{l}\text { Singapore } \\
\text { Base Unit }\end{array}$ & & $\begin{array}{c}\text { 10th Special } \\
\text { Base Force Cdr }\end{array}$ & $\begin{array}{l}\text { Bulk of 10th Special Base } \\
\text { Force, Asahi, Chōsa-maru, } \\
\text { Rumoi-maru, Otowa-maru, } \\
\text { 44th Minesweeper Div, } 2 \\
\text { large-sized motorized [land- } \\
\text { ing] craft, } 6 \text { fishing boats and } \\
\text { [some] captured ships }\end{array}$ & $\begin{array}{l}\text { 1. To continue the previous tasks } \\
\text { 2. To escort the second landing } \\
\text { units of Imperial Guard Div } \\
\text { from Singapore to Belawan } \\
\text { 3. To clear the waterway[s] of } \\
\text { Belawan }\end{array}$ \\
\hline & $\begin{array}{l}\text { Rangoon Base } \\
\text { Unit }\end{array}$ & & $\begin{array}{c}\text { 12th Special } \\
\text { Base Force Cdr }\end{array}$ & $\begin{array}{l}\text { Main body of 12th Special } \\
\text { Base Force (minus Detached } \\
\text { Unit), Kari, Nojima-maru, } \\
\text { Kōshō-maru, 41st } \\
\text { Minesweeper Div, 12th Gun- } \\
\text { boat Div, } 4 \text { large-sized mo- } \\
\text { torized [landing] craft, 12th } \\
\text { Subchaser Div [Signal } \\
\text { Unit?], and [some] captured } \\
\text { ships }\end{array}$ & $\begin{array}{l}\text { To clear waterways from the } \\
\text { mouth of the Irrawaddy River to } \\
\text { Rangoon and guide and escort } \\
\text { the army transport ships }\end{array}$ \\
\hline
\end{tabular}




\begin{tabular}{|c|c|c|c|}
\hline $\begin{array}{l}\text { Unit to } \\
\text { Capture the } \\
\text { Andaman } \\
\text { Islands }\end{array}$ & $\begin{array}{c}\text { Capt Kawasaki } \\
\text { Harumi }\end{array}$ & $\begin{array}{l}\text { Detached Unit of the 12th } \\
\text { Special Base Force, one ele- } \\
\text { ment of the 9th Special Base } \\
\text { Force, about } 1 \text { bn of the } \\
\text { [army] 18th Div, led by Capt } \\
\text { Hayashi, Kinugasa-maru } \\
\text { (Navy), Hirokawa-maru } \\
\text { (Army), } 4 \text { large-sized motor- } \\
\text { ized [landing] craft and } 2 \\
\text { auxiliary cutters }\end{array}$ & $\begin{array}{l}\text { To seize key areas of the An- } \\
\text { daman Islands } \\
\text { To set up [an] air base. } \\
\text { (Although being an army- navy } \\
\text { joint operation, the navy com- } \\
\text { mander shall [also] lead the } \\
\text { [army] Hayashi Detachment } \\
\text { along with the navy unit.) }\end{array}$ \\
\hline
\end{tabular}

Remark: The San'yō-maru was removed from the Dutch East Indies Unit and transferred to the Malaya Unit as of 10 March.

\section{The Air Unit of the Southern Task Force}

The disposition of forces of the Air Unit of the Southern Task Force in these areas from 5 March onwards was in outline as shown in the following table:(186)

\begin{tabular}{|c|c|c|c|c|c|}
\hline Unit & & Commander & Forces & Deployment & Main Tasks \\
\hline $\begin{array}{c}\text { Tōkō Air } \\
\text { Group Det }\end{array}$ & \multirow{4}{*}{ 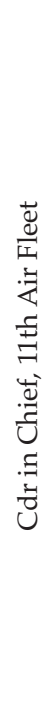 } & $\begin{array}{l}\text { Aviation officer, } \\
\text { Tōkō Air Group }\end{array}$ & $\begin{array}{l}9 \text { Flying } \\
\text { boats }\end{array}$ & $\begin{array}{l}\text { From Ambon } \\
\text { to Penang to } \\
\text { Port Blair }\end{array}$ & $\begin{array}{l}\text { 1. Dutch East Indies Operation (omitted by } \\
\text { the author) } \\
\text { 2. Burma Operation } \\
\text { a) To search and patrol } \\
\text { b) To destroy enemy naval vessels }\end{array}$ \\
\hline $\begin{array}{c}\text { 2d Air Raid } \\
\text { Unit }\end{array}$ & & $\begin{array}{l}\text { 23d Air Flotilla } \\
\text { Cdr }\end{array}$ & & & Omitted by the author \\
\hline \multirow[t]{2}{*}{$\begin{array}{c}\text { 3d Air Raid } \\
\text { Unit }\end{array}$} & & $\begin{array}{l}\text { 22d Air Flotilla } \\
\text { Cdr }\end{array}$ & $\begin{array}{l}\text { 22d Air } \\
\text { Fotilla }\end{array}$ & $\begin{array}{l}\text { From Kuch- } \\
\text { ing, Mentok } \\
\text { and Gelum- } \\
\text { bang to } \\
\text { Bangkok and } \\
\text { Penang }\end{array}$ & $\begin{array}{l}\text { 1. Until the rough completion of the Java } \\
\text { operation (omitted by the author) } \\
\text { 2. Operations against the Andaman Islands } \\
\text { and Burma } \\
\text { a) To patrol over the Bay of Bengal and } \\
\text { the waters southwest of Sumatra } \\
\text { b) To destroy the enemy surface power } \\
\text { c) Depending on the situation, to destroy } \\
\text { the enemy air power }\end{array}$ \\
\hline & & \multicolumn{4}{|c|}{ The rest omitted by the author } \\
\hline
\end{tabular}

With the surrender of the Dutch East Indies on 9 March, the Air Unit of the Southern Task Force called off most operations in its initial plan of operations in the southwest [of Japan, i.e. southeast Asia]. However, the subsequent operations of the unit still included the following extensive and complex missions. ${ }^{(186)}$

1. To act in concert with the Burma and Andaman operations

2. To support and act in concert with the third carrier operations (the Ceylon operation)

3. To support the operation to capture Christmas Island

4. To support the western New Guinea invasion operation

5. To support the operations against Bataan and Corregidor 
Among them, the mission in Burma and the Andamans was as follows. ${ }^{(75)}$

1. [The Air Unit] shall conduct extensive search missions in the Bay of Bengal with the $3 \mathrm{~d}$ Air Raid Unit, to be prepared against maneuvers of the enemy surface forces. If they should come for an attack, the unit shall destroy them in cooperation with friendly surface vessels.

2. The army shall take the responsibility for [the air campaign to] destroy enemy air power in Burma; our unit shall not conduct operations other than necessary for self-defense.

3. The guarding of the convoy from the air shall be shared [between the units].

It was also announced that in order to direct Operations $U$ and D, the Eleventh Air Fleet headquarters would shift to Bangkok, and that operations in the Dutch East Indies area should mainly be directed by 23d Air Flotilla Commander R. Adm. Takenaka Ryōzō (commander of the $2 \mathrm{~d}$ Air Raid Unit). ${ }^{(186)}$ In the meantime, after the raid of a U.S. Striking Force in the Marshall Islands at the end of January, the war situation in the central [south] Pacific and the areas southeast [of Japan, i.e. the west Pacific] had gradually started showing signs of intensification, due to which the 1st Air Group ([of] the 1st Air Raid Unit) under the command of the Air Unit of the Southern Task Force had already been transferred to the South Seas Unit (it had left Ambon on 22 February). At the beginning of March, the land-based air units were reorganized, and further extractions and transfers of forces were ordered one after another. ${ }^{(186)}$ Namely:

As of 5 March: The 21st Air Flotilla headquarters and the Kanoya Air Group were transferred to the Northern Task Force and sent back to mainland [Japan].

As of 10 March: One half of the $3 \mathrm{~d}$ Air Group ([of] the 23d Air Flotilla) was [also] transferred to the Northern Task Force and sent back to mainland [Japan].

As of 15 March: The Mihoro Air Group and the Type-96 carrier-based fighter plane unit was returned to the 22d Air Flotilla from the Malaya Unit.

On top [of the above], in [the plan of] the reorganization of the Navy air units scheduled to be implemented as of 1 April in preparation for stage-two operations, ${ }^{(187)}$ the fighter plane unit formerly attached to the $22 \mathrm{~d}$ Air Flotilla headquarters (two squadrons of Type-0 fighter planes dispatched from the 23d Air Flotilla) were supposed to be incorporated into the Kanoya Air Group. Since the Kanoya Air Group was to be transferred to the Northern Task Force, [the incorporation meant that] no fighter plane units would remain deployed in the Indian Ocean area [supposed to be covered] by the Air Unit of the Southern Task Force. Against this decision, on 1 March, Air Unit Commander V. Adm. Tsukahara Nishizō requested that the fighter plane units of the 22d Air Flotilla remain [in the theater], which was narrowly approved, and he barely managed to keep a fighter plane unit (about twenty aircraft in two squadrons) in the Indian Ocean area. ${ }^{(188)}$

\section{The Shift of the Air Units}

R. Adm. Matsunaga Sadaichi, commander of the 3d Air Raid Unit (and the 22d Air Flotilla), who had been directing operations in Kuching since 8 February, advanced to Bangkok on 13 March. On 17 March, Air Unit Commander Vice Admiral Tsukahara (commander in chief of the Eleventh Air Fleet) shifted to Bangkok, too. ${ }^{(186)}$ The shift of the air units [in preparation for Operations D and U] was as follows: 


\section{The Genzan Air Group}

The air group had carried out operations while shifting between the Kuching and Gelumbang [airfields] during the Java invasion operation and [then] conducted search missions in the eastern part of the Indian Ocean from Gelumbang from 3 March onwards. On 7 March, its aircraft unit ([consisting of] twenty-seven Type-96 land-based attack planes) left Gelumbang under the direct command of the commander [of the group] and, by way of Saigon, advanced to Bangkok on the 13th. The remaining six aircraft also completed their advance in Bangkok on the 17th, while [supporting] the shift of the Yamada Unit (a fighter plane unit). ${ }^{(21)}$

The Yamada Unit (fighter plane unit attached to the 22d Air Flotilla headquarters)

On 24 February, the Yamada Unit, the Type-0 fighter plane unit, had advanced from Kuching to the Mentok base, where it had participated in the western Java invasion operation and chiefly conducted patrols in the air over the convoys with its main [force] while carrying out with one element [air] reconnaissance over Batavia as well as patrols in the air over the anchorage at Patrol. On 15 March, the unit began its shift from the Mentok base and on the 16th, twenty Type-0 fighter planes including the commander's [plane] and three land-based reconnaissance planes completed their advance to Bangkok. ${ }^{(129)}$

\section{The Mihoro Air Group and Type-96 carrier-based fighter plane unit}

Having been put in the main unit of the Malaya Unit, they had stayed on at the Penang base after the northern Sumatra invasion operation and maintained their aircraft ready for use, waiting for the runway extension work on their next advance base at the Sabang airfield to be completed. As of 15 March, they were removed from the Malaya Unit and transferred to the Air Unit, where they returned to [their original unit,] the 22d Air Flotilla, and prepared for Operations D and U. ${ }^{(186)}$

\section{The Tōkō Air Group Detachment}

During the Java invasion operation, the Tōkō Air Group had operated with Ambon as its service base and Semau (an island five nautical miles west of Kupang) in Timor as its advance base (to where twelve large flying boats had advanced on 25 February). On 10 March, when the Java invasion operation was mostly completed, in accordance with the (aforementioned [p. 604]) phase-four disposition of forces of the Air Unit of the Southern Task Force, seven Type-97 large flying boats left the Semau base from the 10th onwards and advanced to Penang by the 13th by way of Kendari and Singapore, led by Aviation Officer Cdr. Itō Sukemitsu. After its arrival in Penang, the detachment prepared the base while servicing its aircraft to be ready for the [coming] shift to its next base, Port Blair. ${ }^{(189)}$

\section{The Enemy Garrison Unconditionally Surrenders}

At 0800 on 10 March, the Andaman Islands Operation was launched with the departure of the 1st Escort Unit and the 1st Minesweeping Unit from Penang. ${ }^{(118)}$

Prior to this, the 22d Air Flotilla (the 3d Air Raid Unit) and the Tōkō Air Group Detachment, which were supposed to act in concert in this operation, had advanced their bases to the bases in Thailand, Malaya and northern Sumatra. The Genzan Air Group and the Mihoro 


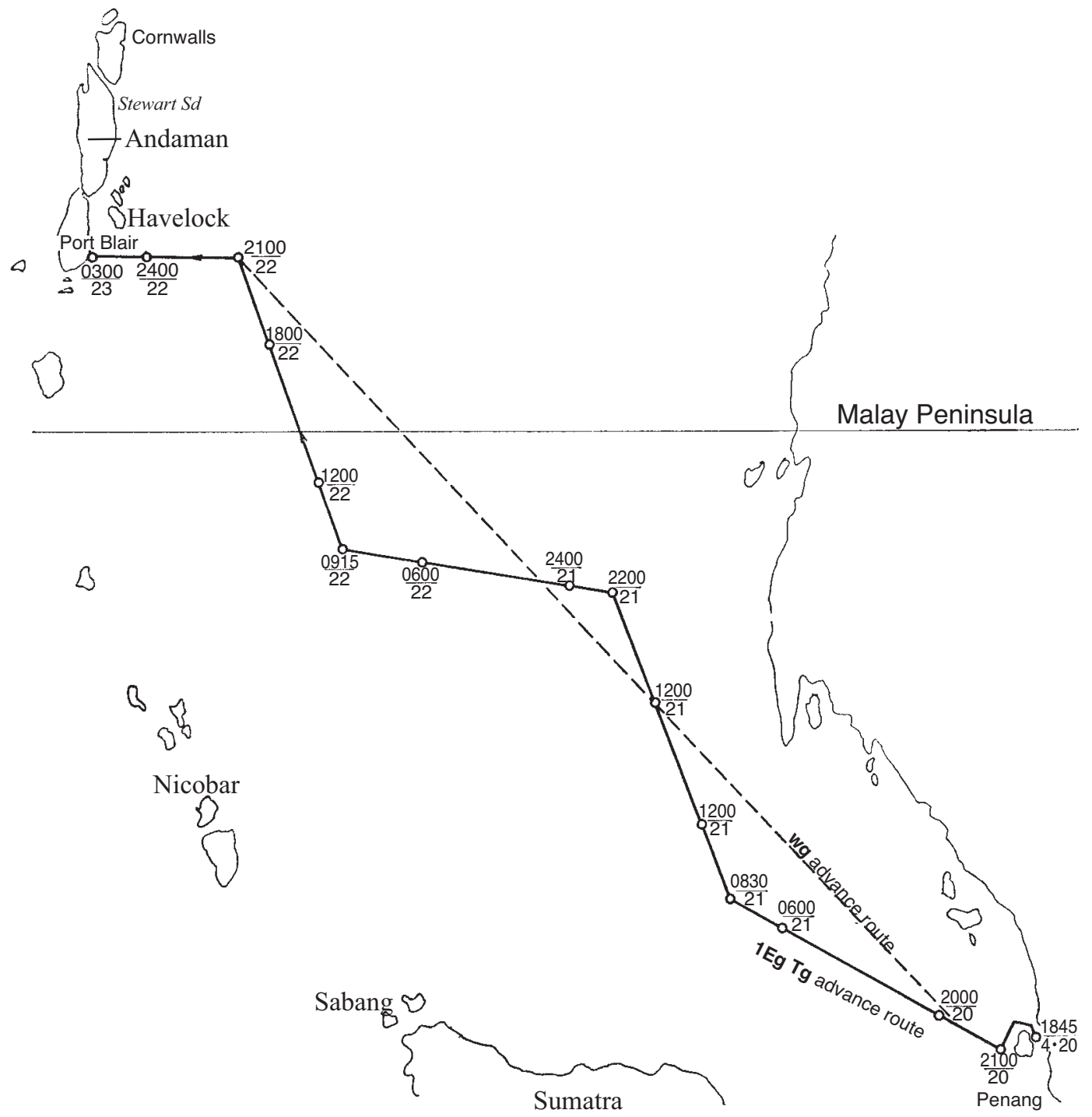

Illustration No. 54 - The Operations of the 1st Escort Unit in Operation D (from 1845 on 20 March until 0300 on 23 March)

Air Group conducted search missions over the waters about 100 to 150 nautical miles west of the Andaman Islands, [each] employing eight to ten land-based attack planes day after day, the former from Bangkok from 17 March onwards, and the latter [first] from Penang from 18 March onwards and then from Sabang from the 24th onwards. However, they spotted no enemy. ${ }^{(71)}$

At 0400 on the $23 d$, the transport ships entered the planned anchorage without having encountered the enemy during their sail. At 0630, the invasion unit under the command of Capt. Kawasaki Harumi successfully made a surprise landing on Ross Island, the coast to the south of Atalanta Point and the coast to the west of Snake Island. [The unit] seized the whole area of the southern part of Port Blair on Ross Island as well as the airfield without 
meeting resistance from the enemy. Twenty-three British officers and three hundred Indian garrison troops surrendered unconditionally. On that day, based on the information obtained from the inhabitants, a minesweeping operation was carried out in the northern and the southern waterways, in which twenty-three mines were disposed of in the northern waterway, while no mines were snagged in the southern waterway. At 1330, one large [enemy] aircraft flew over Havelock Island, to which the Isonami responded and drove it off. At 1900, the disembarkation of the Hirokawa-maru was completed. (118) $^{(18}$

At 0100 on the 24th, the Hirokawa-maru who had completed disembarkation left for Singapore. On that day, the army units that were to seize strategic places embarked on three large-sized motorized [landing] craft and headed for Havelock Island, escorted by the Yura and the 1st Section of the 19th Destroyer Division. However, since there were no airfield or houses, the invasion unit cancelled the landing, and after conducting a reconnaissance in the areas near the eastern entrance of the Andaman Strait, returned to port at 2000. [Meanwhile,] minesweeping was continued and forty-four mines were disposed of. Although one Lockheed aircraft came for a raid at 1420, the Sendai drove it off with her guns. ${ }^{(118)}$ On that afternoon, seven flying boats of the Tōkō Air Group advanced to Port Blair. ${ }^{(189)}$

From the 25th onwards, the invasion units of Army and Navy [conducted an operation to] clear the Elphinstone and Stewart Sound Islands, and the port of Cornwallis and completed it by the 27th. Meanwhile, having completed disembarkation by the 30th, the transport ships headed back for Penang or Singapore, and completed their operation. In the meantime, since the 3d Destroyer Squadron (minus six destroyers) was assigned as the Guard Unit in the disposition of forces for the Malaya Unit striking operation in the northern part of Bay of Bengal and supposed to advance to the waters to the west of the Andaman Islands, the unit stayed on standby while continuously guarding the area off Port Blair.

During this period, the Sagara-maru carried out search missions on the waters in the Port Blair area while supporting the ground operations; after having set up a seaplane base in the port of Port Blair on the 24th and letting the Tōkō Air Group [Detachment] advance its seven large flying boats there, she [also] stayed in Port Blair until the 30th, when she left for Penang in order to participate in Operation U. The 4th Carrier Division carried out search missions in the Port Blair

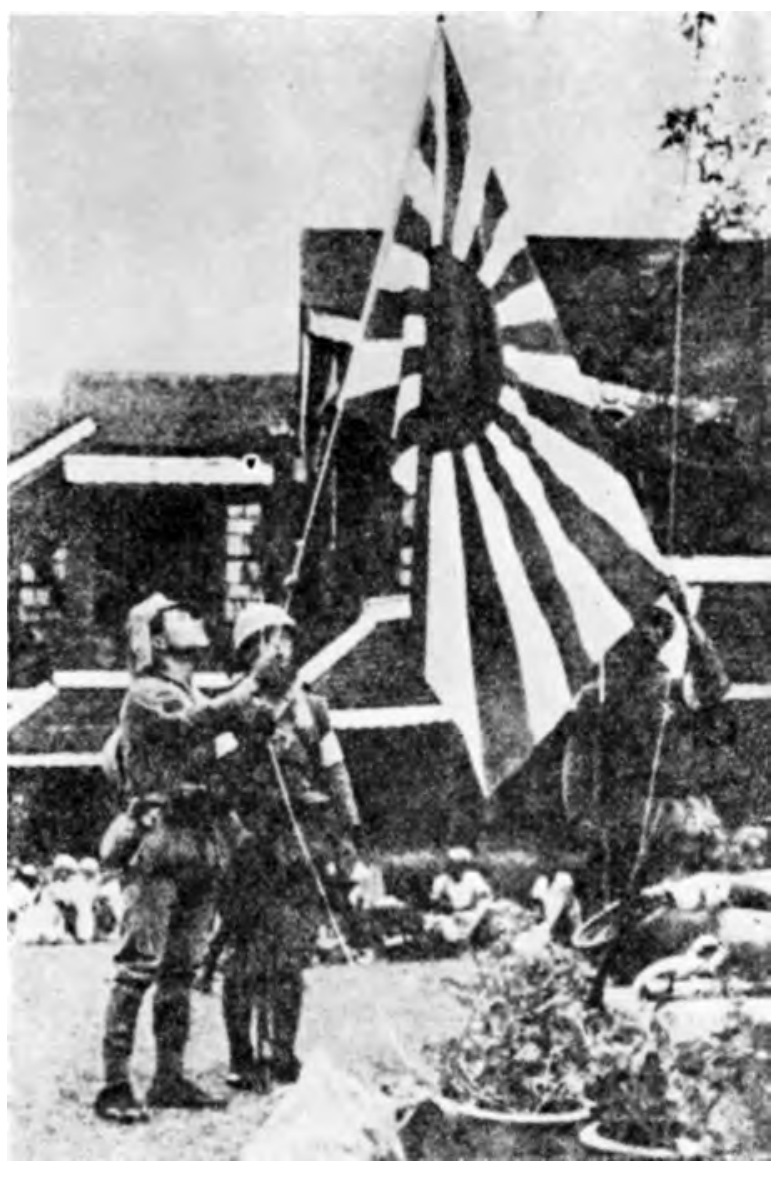

The Glorious Ceremony of Raising the Naval Flag in Front of the Government House on Ross Island 
area and the Bay of Bengal, after which it left the waters of Andaman Islands on the 25th and headed for Mergui to prepare for the Indian Ocean operation. ${ }^{(72)}$

After its advance to the [seaplane] base in Port Blair, the Tōkō Air Group Detachment joined the search missions. From the 25th onwards, it carried out search missions day after day on the sea about six hundred nautical miles to the west [of the Andaman Islands] (up to [as far as] about 150 nautical miles from the east coast of India) with three large flying boats, to be ready against counter attacks by enemy naval vessels coming from the west. ${ }^{(71)}$ In order to catch the Lockheed aircraft which had flown over Ross Island for reconnaissance day after day from the landing of the invasion unit on the $23 \mathrm{~d}$ until the 26 th, the Type-0 fighter plane unit attached to the 22d Air Flotilla headquarters, which had been advanced to Bangkok, further advanced to Tavoy on the 29th and carried out patrols in the air over the Andaman Islands for about four consecutive days with a total of ten aircraft, but no enemy raids were spotted thereafter. $^{(141)}$

\section{The Burma Transport Operation (See Illustrations No. 55 and No. 56)}

When the minesweeping in the Malacca Strait was for the most part completed, Malaya Unit Commander Vice Admiral Ozawa had announced on 2 March the plan of operations of the Malaya Unit for Operations T, D and U, as previously told [p. 576, 582; there the date is 5 March]. He specified that almost simultaneously with the capture of the Andaman Islands, the mission was to escort the army transport ships from Singapore (one element of them from Penang) to Rangoon and facilitate the Burma invasion operation. At 0000 on 15 March, the disposition of forces for Operations D and $U$ was put in motion, and on 19 March, the operation to transport [the units for the invasion of] Burma was launched with the first transport (a convoy [consisting of] thirty-two transport ships carrying the [Army] 56th Division). ${ }^{(68)}$

\section{The Position of the Units Right Before the Launch of the Operation}

The position of the [relevant] units right before the launch of the operation was as follows:

\section{Main Unit}

The Chōkai, the Murakumo and the Ayanami: Had entered the port of Penang on 14 March after [having participated in] Operation T.

The 7th Cruiser Division, the Hatsuyuki and the Fubuki: Had entered the port of Singapore on 15 March after [having participated in] Operation T.

The Shirayuki: Had entered the port of Singapore on 14 March, after having engaged in the escort of the transport ships carrying the 56th Division from Cap Saint Jacques ([in] French Indochina) to Singapore [ordered] by means of Malaya Unit Telegraphic Operation Order No. 52.

The 4th Carrier Division: Had stayed in Singapore from 5 March onwards, servicing, replenishing and conducting drills.

The 40th Air Group: Was in Singapore, servicing and conducting drills after the completion of Operation T.

The Sagara-maru: Arrived in Penang on 15 March after the completion of Operation T; was preparing for Operation D.

The San'yo-maru: Had been on standby in Penang since 19 March. 


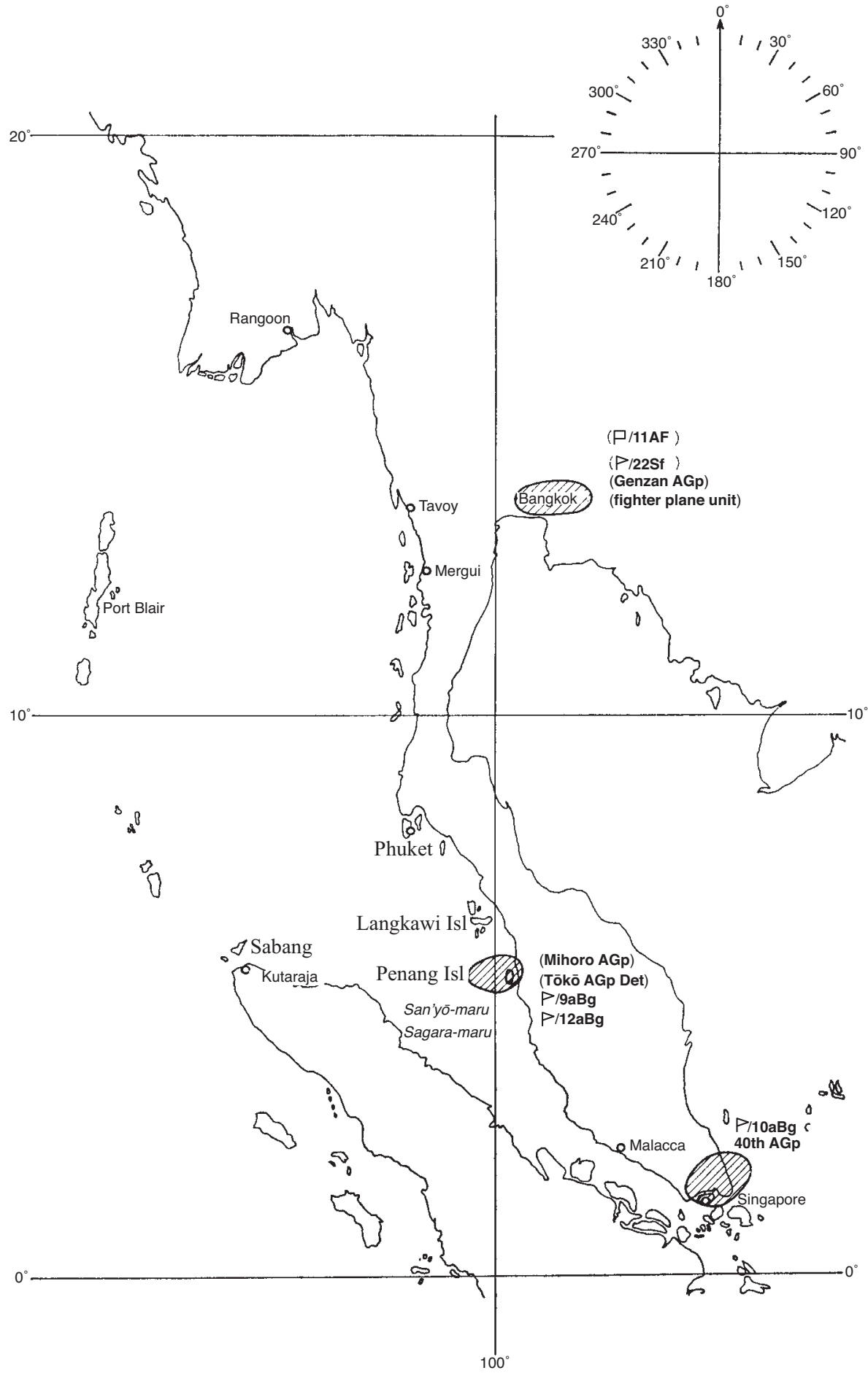

Illustration No. 55 - The Deployment of the Air Forces for Operation U on 19 March The Air Unit of the Southern Task Force put in parentheses 


\section{Second Escort Unit}

The Kashii: Entered the port of Singapore on 16 March after [having participated in] Operation $\mathrm{T}$ and was on standby.

The Hatsutaka: Entered the port of Penang on 15 March after [having participated in] Operation $\mathrm{T}$ and was on standby.

The Shimushu: Entered the port of Singapore on 15 March after [having participated in] Operation $\mathrm{T}$ and was on standby.

The 11th Subchaser Division: Entered the port of Penang on 15 March after [having participated in] Operation T and was incorporated in the Penang Base Unit as of 17 March.

The 5th Destroyer Division: After operating in the Bantam Bay area, [its destroyers] entered the port of Singapore one by one between 12 and 14 March, and were on standby.

The Shikinami: Entered the port of Singapore on 15 March, after having escorted the transport convoy carrying the 56th Division from Cap Saint Jacques to Singapore, and was on standby.

\section{The Singapore Base Unit (The 10th Special Base Force as the core)}

The 10th Special Base Force was formed in Saigon as of 15 January 1942 (with R. Adm. Oku Nobukazu as commander). Having been incorporated in the First Southern Expeditionary Fleet, it advanced to the Seletar naval port on 14 February, and from the beginning of March onward, was in charge of the defense and guarding of assigned sectors in the Singapore area, the protection of [sea] lines of communication, and reconstruction work in the sectors of Singapore assigned to the Navy.

\section{The Rangoon Base Unit (The 12th Special Base Force as the core)}

The 12th Special Base Force was formed in Sasebo as of 15 February 1942 (with R. Adm. Ishikawa Shigeru as commander). Having been incorporated in the First Southern Expeditionary Fleet, it advanced first to Singapore from 4 to 5 March, then to Penang on 17 March, and was preparing for advance to Rangoon.

\section{The Air Unit of the Southern Task Force (land-based air unit)}

The Genzan Air Group and the Mihoro Air Group had started search missions over the waters to the west of the Andaman Islands respectively from Bangkok from the 17th onwards and from the Penang base from the 18th onwards.

\section{The Transport of More Than Two [Army] Divisions}

The Burma Transport Operation was started with the first transport, which was put in motion on 19 March, and was continued until the fourth transport (which was completed on 28 April). During this period of about forty days, the Malaya Unit escorted as many as a total of 134 ships, in which, in addition to the two divisions (the 56th and the 18th Divisions), [the unit also] transported many [army] units under the direct command of the [Twenty-fifth] Army. And by also transporting large quantities of ammunition and matériel as well as equipment, [the Malaya Unit] very much contributed to the Burma operation. During this transport operation, no particular loss was caused by enemy aircraft or submarines and the operation did progress very smoothly. ${ }^{(68)}$ The only regret was that two army transport ships, the Yaeyama-maru [Yae-maru] and the Shunsei-maru (both empty), returning from Rangoon to Sin- 


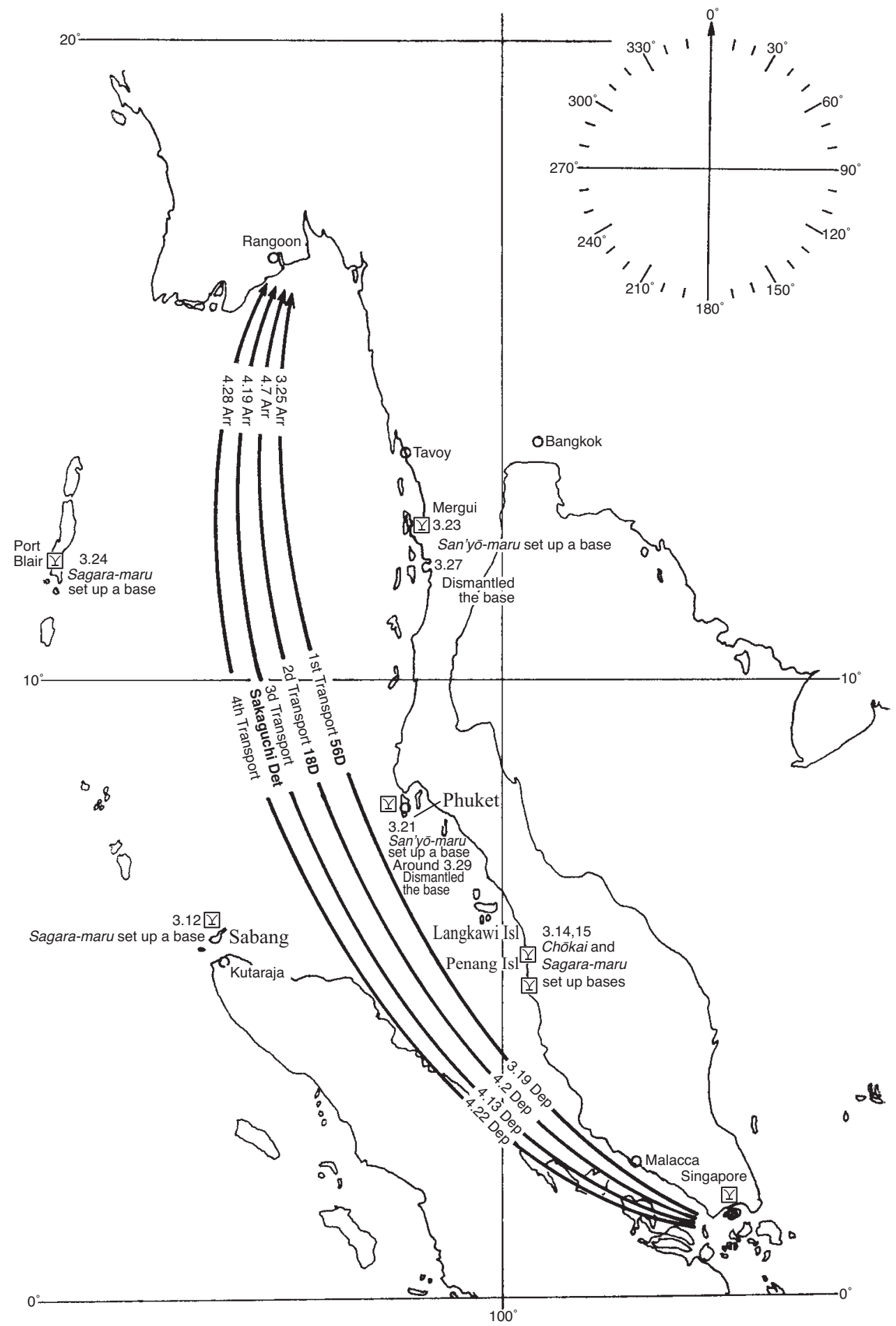

Illustration No. 56 - The Seaplane Bases at the time of Operation U (Malaya Unit) 
gapore, were sunk by an enemy submarine attack at about seventy nautical miles northwest of Penang. ${ }^{(190)}$

During this period, the main unit of the Malaya Unit left Penang on 20 March and advanced to the waters to the south of Burma on the 24th to support Operations D and U, after which it left the waters on the 25th for Mergui, where it arrived at 1500 on the 26th. ${ }^{(19)}$ Then, in concert with the Ceylon operation of the Carrier Task Force of the Southern Task Force, the Malaya Unit formed a Striking Force of its own, advanced to the northern part of the Bay of Bengal on 6 April and sank a number of enemy merchantmen. ${ }^{(119)}$ When the Ceylon operation was completed on 10 April, the disposition of forces for stage-two, phase-one operations was put into effect; the 2d Escort Unit was disbanded, and the Penang Base Unit (the 9th Special Base Force as the core) was formed instead, which turned the escort of the transport convoys [to Burma] into a relay-type of operation between the Singapore Base Unit and the Penang Base Unit, and between the Penang Base Unit and the Rangoon Base Unit. ${ }^{(53)}$ In the meantime, the Air Unit of the Southern Task Force carried out search missions in the Bay of Bengal and the Indian Ocean with the land-based attack planes of the Genzan and Mihoro Air Groups as well as the large flying boats of the Tōkō Air Group, while conducting patrols in the air over the Port Blair area (from 30 March until 2 April) with the fighter plane unit, which had been advanced to Tavoy. Moreover, the aircraft of the 40th Air Group, the Sagaramaru and the San'yo-maru, which had been incorporated into the main unit, were [also] engaged in patrols against enemy submarines as well as on the sailing routes ahead of the convoys, while providing direct escort against enemy submarines and conducting search missions near their sailing routes, but spotted no enemy submarines or naval vessels. It so happened that patrols by aircraft against enemy submarines were not provided in the area about seventy nautical miles northwest of Penang, where at 2315 on 1 April and at 0015 on 2 April two army transport ships were sunk.

\section{The Capture of Christmas Island (See Illustration No. 57)}

As previously told [p. 568], on 18 March, Dutch East Indies Unit Commander Vice Admiral Takahashi announced the outline of the operation to capture Christmas Island by means of Dutch East Indies Unit Classified Telegram No. 203, which meant that the unit started on preparing for the operation with a landing scheduled for 31 March. The contents of the outline were as follows: ${ }^{(62)}$

1. Our unit shall implement the Christmas Island operation in the following way:

(1) Mission: To capture Christmas Island and secure the rock phosphate resources

(2) Commander: the 16th Cruiser Division commander

(3) Forces: the 16th Cruiser Division (minus the Kinu and the Nagara - note by the author: [consisting] only of the Natori), the 4th Destroyer Squadron (minus the 2d, the 24th, the 4 th Destroyer Divisions, and minus the 2d Section of the 9th Destroyer Division - note by the author: [consisting] only of the Naka and the 1st Section of the 9th Destroyer Division), the detached unit of the 24th Special Base Force, one element of the 21st Special Base Force (including four 12-cm guns, four 8-cm antiaircraft guns and their personnel), the Kimishimamaru, the Kumagawa-maru, Patrol Boats No. 34 and No. 36 (the time of incorporation shall be given by special order), the Akebono-maru and one element of the 102 Construction Unit (about 200 men from Makassar) 
(4) Implementation schedule: [The participating units] shall assemble on the waters northwest of the Bantam anchorage (Batavia) by 28 March and complete replenishment and preparations for the operation. The landing shall be conducted on 31 March.

(5) The course of action after the invasion: Leaving the ground defense unit and the construction unit behind, the other units shall swiftly withdraw from the site after the disembarkation is completed.

2. When [the operation to] capture Christmas Island is under way, the main unit shall in general advance to the north of the island and support [the capture operation].

3. [All] other units shall continue their current tasks.

On that day and [again] on the 19th, Dutch East Indies Unit Commander Vice Admiral Takahashi took steps to remove the Nagara from the Dutch New Guinea invasion unit and incorporate the Kinu into that unit instead, while incorporating the Nagara into the unit to capture Christmas Island. ${ }^{(62)}$ This was done because he had been informally notified that with the revision of the Imperial Navy Wartime Formation as of 10 April, the Nagara was to be put into the 10th Destroyer Squadron (the unit [formed to] guard the aircraft carriers). By avoiding her inclusion in the Dutch New Guinea invasion unit, [an operation] that was expected to take a considerably long period from now on, he could include her in the unit to capture Christmas Island, an operation that was to be more or less completed in a short period. He also incorporated the 22d Destroyer Division into the main unit and ordered it to join the main unit as soon as it completed its task of [escorting] the second transport of the Sixteenth Army to Java. ${ }^{(182)}$

\section{The Plan of Operations}

On 25 March at Makassar, Christmas Island Invasion Unit Commander (R. Adm. Hara Kenzaburō, [who had become] 16th Cruiser Division commander since 10 March from being commander of the 5th Destroyer Squadron) announced the plan of operations to capture Christmas Island by means of Dutch East Indies Unit Christmas Island Invasion Unit Order Classified No. 1, the outline of which was as follows: ${ }^{(62)}$

1. The Christmas Island invasion unit shall capture Christmas Island, secure the resources of rock phosphate there and as much as possible conduct surveys as to where to set up a ground air base (to be used by fighter planes) as well as to arrange for a quick construction of it.

2. The disposition of forces (as shown in the following table)

\begin{tabular}{|c|c|c|c|c|c|}
\hline \multicolumn{2}{|r|}{ Unit } & \multicolumn{2}{|c|}{ Commander } & Forces & Main Tasks \\
\hline \multirow{3}{*}{ 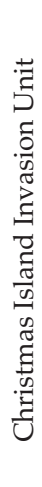 } & Main Unit & \multirow{3}{*}{ 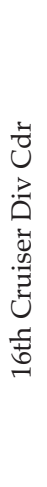 } & & 16th Cruiser Div (minus Kinu) & $\begin{array}{l}\text { To direct the operation and } \\
\text { support the guarding }\end{array}$ \\
\hline & Guard Unit & & $\begin{array}{l}\text { 4th Destroyer } \\
\text { Sqdn Cdr }\end{array}$ & $\begin{array}{l}\text { Naka, 9th Destroyer Div 1st Section, Pa- } \\
\text { trol Boats Nos. } 34 \text { and 36, Kumagawa- } \\
\text { maru and Kimishima-maru }\end{array}$ & $\begin{array}{l}\text { To escort the transport } \\
\text { To guard the anchorages }\end{array}$ \\
\hline & $\begin{array}{l}\text { Landing } \\
\text { Force Unit }\end{array}$ & & $\begin{array}{l}\text { Cdr of 24th } \\
\text { Special Base } \\
\text { Force De- } \\
\text { tached Unit }\end{array}$ & $\begin{array}{l}\text { 24th Specal Base Force Detached Unit (a } \\
\text { landing force of about } 450 \text { men), one ele- } \\
\text { ment of } 21 \text { st Special Base Force (about } \\
200 \text { artillery personnel, } 4 \times 12 \text {-cm guns } \\
\text { and } 4 \times 8 \text {-cm antiaircraft guns) and one } \\
\text { element of } 102 \mathrm{~d} \text { Construction Unit } \\
\text { (about } 200 \text { personnel) }\end{array}$ & $\begin{array}{l}\text { Ground combat of the opera- } \\
\text { tion to capture Christmas Is- } \\
\text { land; to set up defense; to } \\
\text { conduct a survey of ground } \\
\text { air bases and quickly prepare } \\
\text { for [their construction] }\end{array}$ \\
\hline
\end{tabular}




\begin{tabular}{|l|l|l|l|l|}
\hline $\begin{array}{c}\text { Supply } \\
\text { Unit }\end{array}$ & $\begin{array}{c}\text { Akebono-maru } \\
\text { Superintend- } \\
\text { ent }\end{array}$ & Akebono-maru & To provide supplies \\
\hline $\begin{array}{c}\text { ¿ } \\
\text { Z }\end{array}$ & $\begin{array}{l}\text { Amatsukaze shall be put into the Christmas Island invasion unit until 28 March to attend to the escort be- } \\
\text { tween Makassar and Bantam Bay. }\end{array}$ \\
\hline
\end{tabular}

3. Time of Departure: At 1900 on 29 March

4. Landing points:

First landing point: Flying Fish Cove Pier No. 3 and the coast nearby (mainly to its southwest)

5. Time of entering [into the anchorage]: At 0700 on 31 March

\section{The Naka Torpedoed}

At 1700 on 29 March, the 1st Section of the 9th Destroyer Division left Bantam Bay ahead [of the other units] in order to clear enemy submarines off the outer area of Bantam Bay and along the planned sailing route of the invasion unit. Then, at 1900 as scheduled, the main unit ([consisting of] the Natori and the Nagara), the Guard Unit ([consisting of] the Naka, the Kumagawa-maru and Patrol Boat No. 34) left the anchorage of Bantam Bay in that order. Without encountering any enemy at all during the sail, the invasion unit reached a point about fifteen nautical miles north of the anchorage [at Flying Fish Cove on Christmas Island] at 0700 on 31 March, and changed its formation to enter into the anchorage. ${ }^{(122)}$

At 0708 , the Naka of the Guard Unit spotted a surfaced enemy submarine at about 12,000 meters $48^{\circ}$ on port hand. While immediately ordering the 1st Section of the 9th Destroyer Division to attack her, [the Naka] herself closed in, firing [at the submarine] using searchlights, but the enemy rapidly submerged in about one minute. The Naka kept rushing towards the enemy. After launching her aircraft at 0718 in order to support the attack on the enemy submarine, reconnoiter the landing point as well as to attack the enemy battery, she carried out an antisubmarine attack (with four depth charges) at 0726 around the point where the enemy submarine had submerged. Meanwhile around 0720, the 16th Cruiser Division also launched the aircraft of the Natori and the Nagara for the same purpose. While having the transport ships temporarily evacuate to the west of the anchorage, Guard Unit Commander R. Adm. Nishimura Shōji tried hard to detect and intercept the enemy submarine. ${ }^{(56)}$

The reconnaissance seaplanes, which had been launched from the Natori, the Nagara and the Naka, made some intimidating flyovers over Christmas Island and conducted reconnaissance. At 0747, they first of all made a bombing attack near the houses at the eastern end of Flying Fish Cove and then bombed the enemy battery at Smith Point. In the meantime, at 0754, the Naka had reached a point about 9,000 meters from the Smith Point battery, and opened fire (three shells). Since the enemy put up white flags everywhere around 0800 , the shelling and bombing was suspended. The transport ships immediately moved on to enter into the anchorage, and at 0910 they completed entering. At 0945, without meeting resistance from the enemy, the landing force successfully made the first landing. ${ }^{(56)}$

At 0949, while supporting the landing of the landing force, the Naka came under attack from an enemy submarine (three torpedoes) at a close range of 1,000 meters. She successfully evaded the attack and immediately counterattacked (with six antisubmarine depth charges). Having spotted bubbles and the welling-up of a large amount of oil, and detecting no echoing 


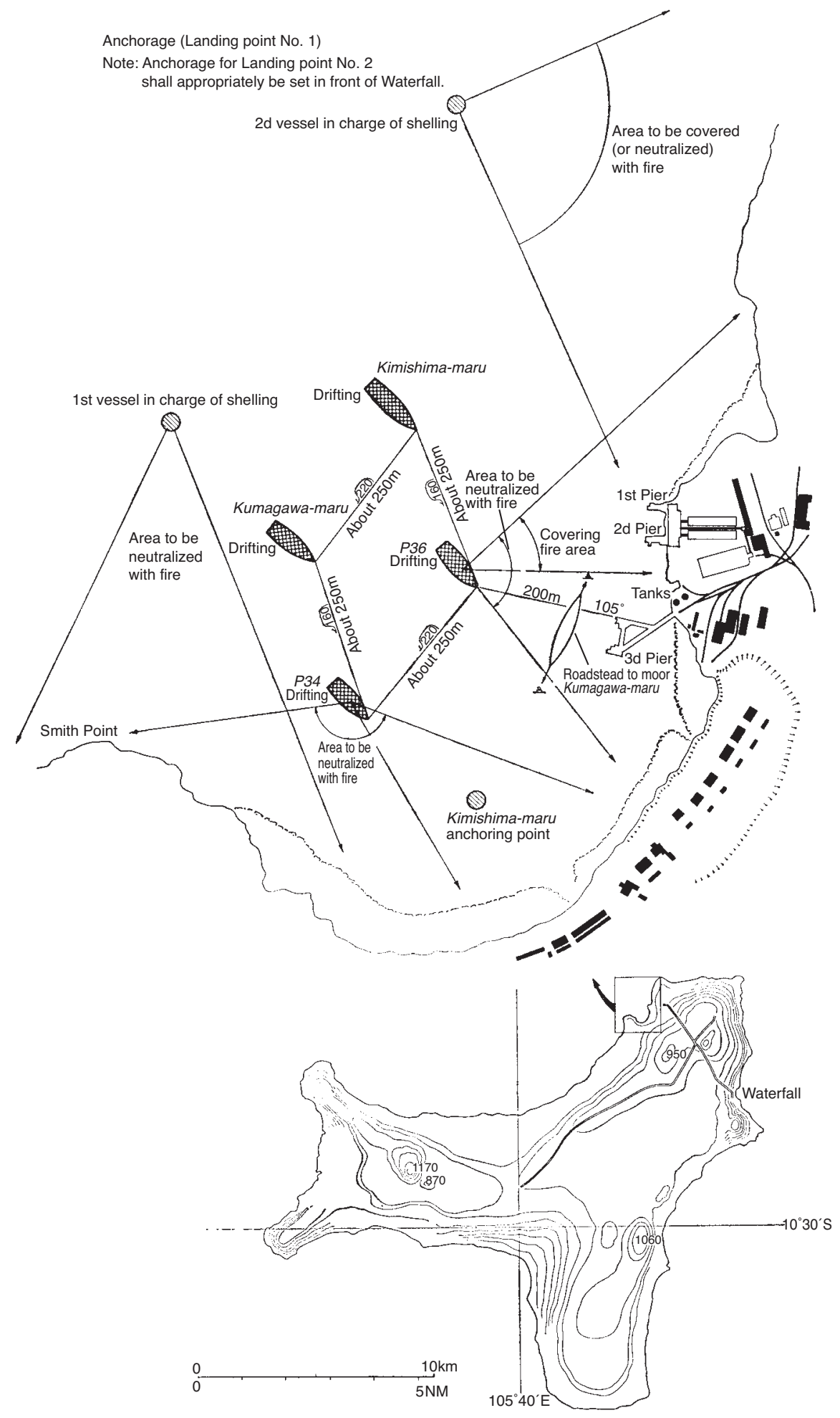

Illustration No. 57 - The Outline of the Capture of Christmas Island 


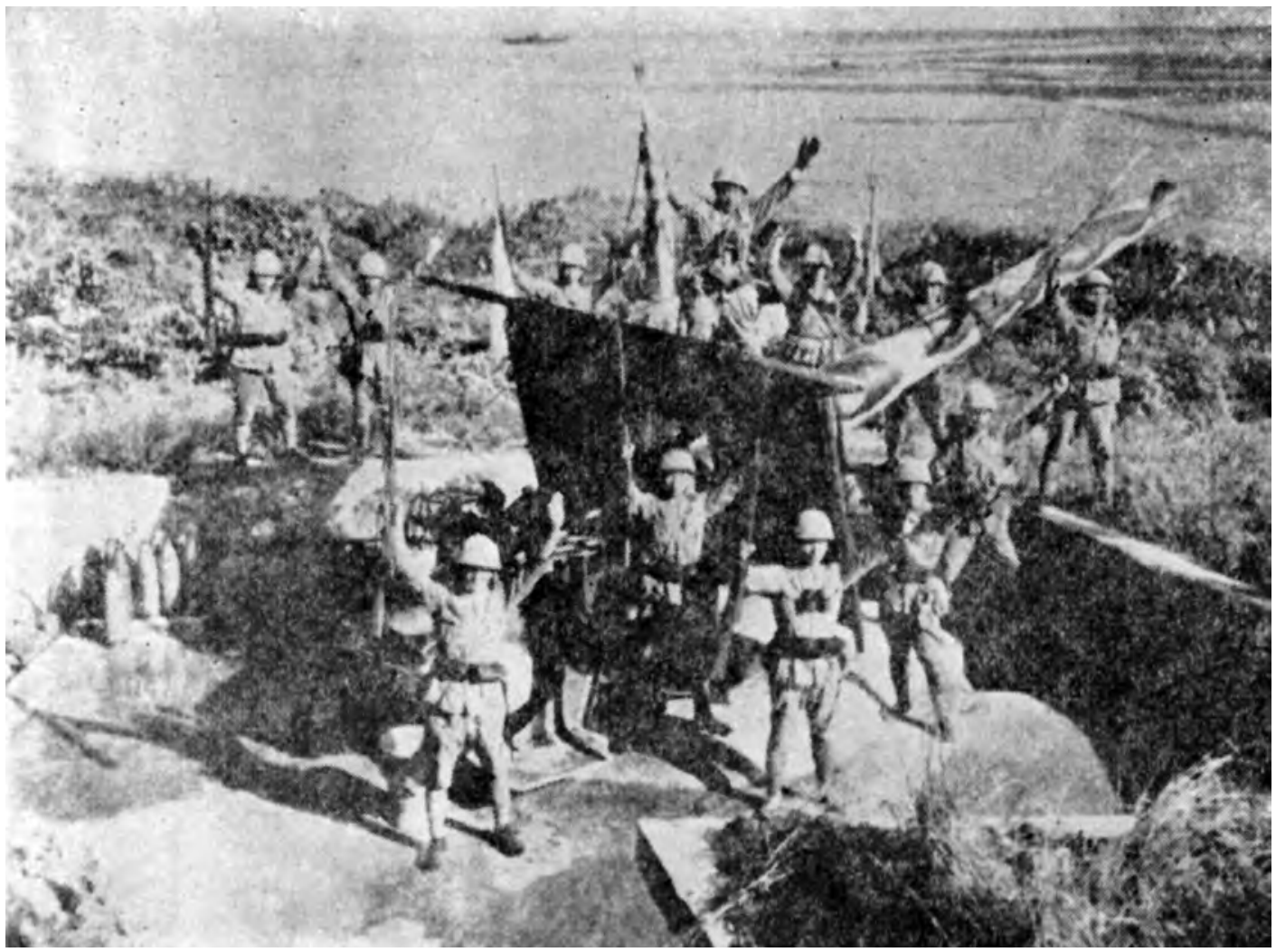

Occupying the Enemy Battery on Christmas Island

sound, she believed that she had sunk the enemy submarine for certain. In the meantime, at 1425, the Landing Force Unit commander reported the results of the clearing of the town as follows:

We have completed the clearing of the town at 1230 as scheduled. It is very calm on the island; all hostile foreigners have been confined. The rest, twenty-seven Indians, have all surrendered. The enemy battery is usable. Although 20,000 tons of rock phosphate is kept in the warehouse, it is impossible to [carry it out of the warehouse] and ship it due to trouble with the generators. Although other things are still under investigation, it seems that there is quite some damage.

The threat of enemy submarines around the anchorage was not gone. While keeping a strict guard against them, Guard Unit Commander Rear Admiral Nishimura accelerated as much as possible the disembarkation of the transport ships. At 2030 on the same day, the Amatsukaze, who had been dispatched from the main unit of the Dutch East Indies Unit, arrived [at the site] and immediately engaged in clearing the area of enemy submarines. At 0650 on 1 April, the Natori of the main unit spotted a torpedo wake in an area twenty nautical miles north of the anchorage, fired warning shots, but with unknown results. At 1804 on that day, when conducting a patrol by sailing a zigzag course on the waters to the north of the anchorage with the 1st Section of the 9th Destroyer Division as her direct escort, the Naka was hit by a torpedo launched by an enemy submarine about 700 meters $70^{\circ}$ on her starboard (from 


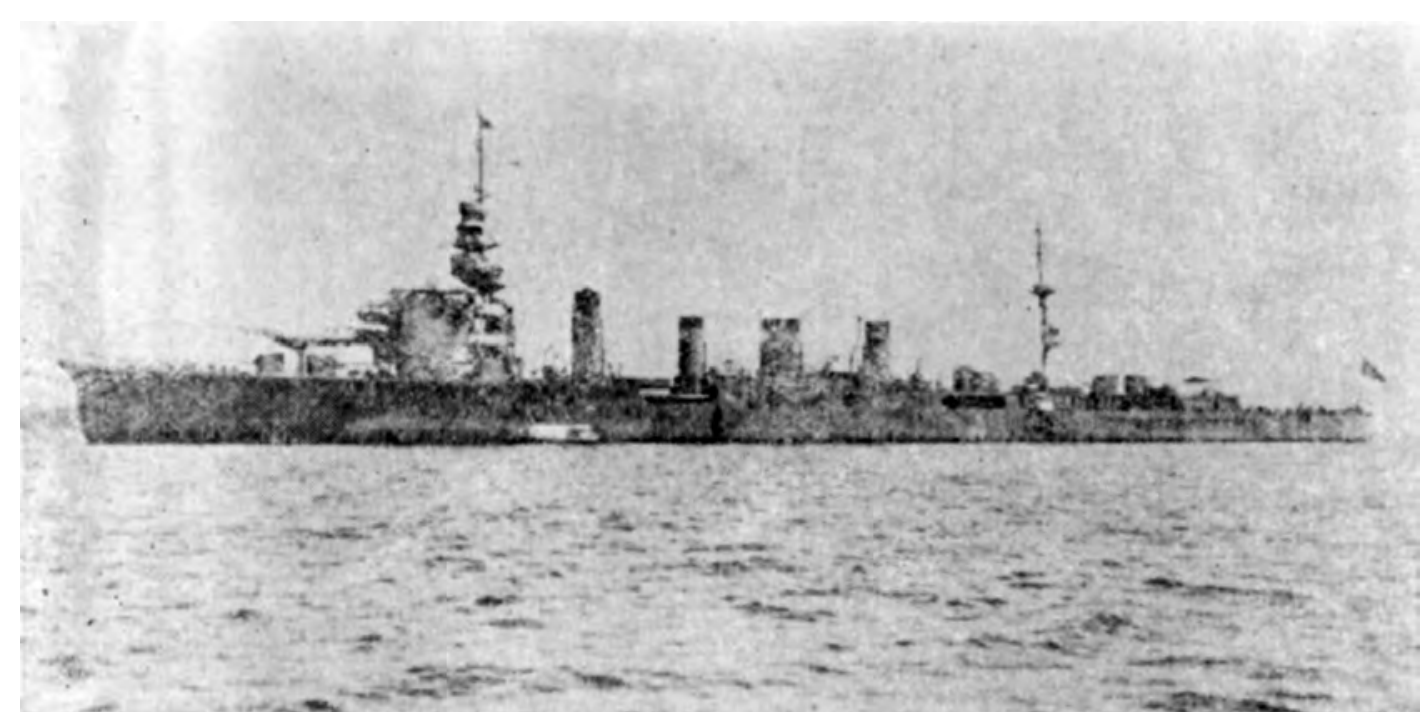

The Cruiser Naka

the center between her and the destroyer escorting her on starboard). Although she had quickly changed course, it was too late; the torpedo hit her amidships on starboard beam in one of her boiler rooms. Her position at that time was 6.3 nautical miles $28^{\circ}$ off Smith Point. After quickly projecting one antisubmarine depth charge, the Naka tried to come closer to Christmas Island while stemming the flooding and making emergency repairs to the engine. However, she temporarily became unable to operate or communicate. While immediately striving to neutralize the enemy submarine, catch, and destroy her, the 1st Section of the 9th Destroyer Division called the Amatsukaze and Patrol Boat No. 34 to the site to provide the Naka with an all-around guard. ${ }^{(56)}$

While drifting and trying to control the damage, the Naka spotted a surfaced submarine at 1920 about 6,000 meters on starboard quarter and immediately fired her guns to warn the vessels nearby. Although the [enemy] submarine quickly submerged, all vessels tried hard to detect her, and at 2030, Patrol Boat No. 36 detected her as close as five hundred meters and dropped antisubmarine depth charges. Having spotted the welling-up of a large amount of oil, the patrol boat believed that she had sunk the submarine for certain. In view of the rampant presence of enemy submarines, ${ }^{*} 4$ th Destroyer Squadron Commander Rear Admiral Nishimura decided to leave these dangerous waters by being towed away, and at 2031 he requested the Natori (the flagship of the 16th Cruiser Division) patrolling in a neighboring area to tow her. At 2230, escorted by the 1st Section of the 9th Destroyer Division and the Amatsukaze, the Natori started towing the Naka and headed for Bantam Bay. Earlier at 1945, Invasion Unit Commander Rear Admiral Hara had notified the Landing Force Unit commander that in view of the rampant presence of enemy submarines, the unloading should be terminated and that the transport ships should leave [the anchorage] as soon as they were ready. At 2230, without completely unloading part of the matériel, Patrol Boats No. 34 and No. 36 left the anchorage for Bantam Bay, respectively escorting the Kimishima-maru and the 
Kumagawa-maru. Forty-two tons of rock phosphate packed in bags had been loaded onto the Kimishima-maru. ${ }^{(56)}$

On receiving the report that the Naka had been torpedoed, Dutch East Indies Unit Commander Vice Admiral Takahashi ordered on 2 April the rescue ship Seiha-maru, who happened to be in Bantam Bay, to make ready to be dispatched, while giving an order to the $2 \mathrm{~d}$ Section of the 22d Destroyer Division to hurry to the site to escort the Naka. In the meantime, since the Naka became able to sail on her own at slow speed [6 knots] or half speed [9 knots], [the dispatch of] the Seiha-maru to accompany her was called off; the Naka managed to arrive in Bantam Bay at 1245 on 3 April. ${ }^{(56)}$ With her return, all units for the capture of Christmas Island returned to Bantam Bay, except for the [ground] Guard Unit that was left on site, and the capture operation was completed.

For reference: The operational state of the Naka after having been torpedoed

I. Condition of the engines when the torpedo hit

1. State of the engines: The engines were on standby so that speed could be increased to 21 knots in an instant, to 26 knots in ten minutes, and to full speed in one hour.

2. Speed: 12 knots

3. Situation of the engines

(1) The four main [propeller] shafts were in operation

(2) The boilers in use

Boilers Nos. 7, 10, and 11: Type A Boilers

Boiler No. 6: Type B Boiler (a low combustion boiler with a fixed rate of evaporation)

Boilers Nos. 5, 8, 9, and 12: Supplementary boilers

Boilers Nos. 1, 2, 3, and 4 (small boilers): All ready for a quick start (Boiler Rooms Nos. 1 and 2)

(3) Auxiliary equipment

Evaporators Nos. 1 and 2: (At that time, we were in the course of supplying boiler water to the reserve water tanks in Boiler Rooms Nos. 2 and 4 as well as to the main water supply tanks.)

Generator No. 2

Refrigerators Nos. 1 and 2: (In the course of cooling the powder magazine[s] at the fore) Icemaker[s]

(4) State of the piping

Steam pipes and exhaust pipes: [Set to] battle-ready mode

However, the intermediate valve between Auxiliary Steam [Pipes] Nos. 1 and 2 (in Boiler Room No. 2) was open. The interconnection valves between the main steam [pipes which ran] on both sides of the ship were slightly open.

(5) Electric Circuit: Power distribution on alert

II. Situation when the damage was sustained and outline of the course of the damage control

1. After a massive violent shock, the lights in the vessel went out (shut down by the automatic circuit breaker), but the lights were turned on again in about two minutes.

2. After the violent shock, the steam pressure in the main and auxiliary steam pipes rapidly dropped respectively to 16.5 tons (the pressure in [normal] operation: 18 tons) and 13.5 [tons], and the rotation speed [of the shafts] temporarily decreased to the rotation speed for half speed [9 knots].

3. Instantly after the violent shock, the vacuum in the condensers of the front and rear turbines rapidly dropped to about $60-\mathrm{cm}[\mathrm{Hg}]$. Even though both vacuum pumps on [each of] the front and the rear [turbine condensers] were started and the rotation of the circulating pumps 
was increased to almost the maximum, the vacuum in the condenser[s] on starboard did not recover. Since the temperature of the condensate and the temperature of the seawater at the outlet [of the condenser[s]] showed a tendency to rise all the time, we judged that [one of] the condensers on starboard was out of order; we stopped the outer [propeller] shaft on starboard ([operated by] the front turbine), while letting the other three shafts remain in operation. (A later examination revealed that the cause of the vacuum decrease was because heavy oil, which had flowed out by large amounts due to the damage caused on the heavy oil tanks on starboard side, was sucked in [together with the seawater].)

4. When we checked the salinity of the condensate and the main water supply tanks in the engine room[s]about seven minutes after the hit, the increase in salinity was so acute that we cut out the main water supply tanks in the front engine rooms, stopped the [remaining] front turbine, and operated only the two [inner] propeller shafts on the rear turbines.

5. At that time, the main valves of the feedwater pipes in Boiler Rooms Nos. 1 and 2 were open. Although we immediately closed the main valve of the feedwater pipe in Boiler Room No. 2 when we were hit, we were late in closing the valve in Boiler Room No. 1. Moreover, we were supplying distilled water to the main water supply tanks as well as the reserve water tanks in Boiler Rooms Nos. 2 and 4, and due to the water pressure of [the reserve water tank in] Boiler Room No. 2, which had become full, only the reserve water tank in Boiler Room No. 4 [was left to store the distilled water.] However, due to [the design of] the piping, it was impossible to directly supply water from the reserve water tank in Boiler Room No. 4 to the main water supply tank [s] in the rear engine rooms. [Therefore], we decided to directly conduct the collected distilled water to the main water supply tank[s] in the rear engine rooms. However, by that time, the quantity of the water to be collected had markedly decreased because the evaporators had already drawn in a large amount of heavy oil, which was flowing past the bottom of the ship.

6. Since [the $\mathrm{Naka}$ ] needed to escape from the waters as soon as possible partly because of the risk that enemy submarines might come [back] for a raid again, we tried hard to keep on operating [the engines] as much as possible, leaving the steam gushing out of Boiler Room No. 1 (due to leaking valves, it was impossible to control the damage unless the main engines were stopped and the boilers were turned off). However, because of the large consumption of boiler water and the marked decrease in the amount of the distilled water collected, the quantity of the water in the main water supply tank[s] in the rear engine rooms decreased minute by minute. At that rate, even if the damage had been [successfully] controlled, the reserve quantity of boiler water necessary to make steam was expected to become insufficient. So, we stopped the engines, turned off all the boilers generating steam ([at] 1845), and started to seal off the damaged auxiliary steam pipes at 1900 .

7. At that time, since the flooding of Boiler Room No. 2 was so rapid and also because of the steam gushing out [of the pipes], it was impossible to close the intermediate valve in Boiler Room No. 2 between Auxiliary Steam [Pipes] Nos.1 and 2, which ran on both sides of the ship. Therefore, we decided to install blind patches between the [piping] joints in Boiler Room No. 3 to seal off both auxiliary steam pipes on both sides of the ship.

8. We made makeshift blind patches and tried to install them [between the joints] but the bolts and nuts on the flanges of the auxiliary steam pipes were stuck because of the heat. Moreover, because [the joints] were situated in difficult places to work on, it took a considerably long time [to install them]. We completed [that part of] the damage control work around 2220.

9. At 2220, as soon as we finished the work to seal off the auxiliary steam [pipes], we conducted a test operation (at 50 [rpm]) with four boilers in Boiler Room No. 4, two rear turbines and both inner propeller shafts. At 2230, [the Naka] began to be towed by the Natori. After that, while being towed, we kept operating [the rear turbines] so that [the Naka] would still sail 
by herself at a slow speed [of 6 knots] on her own engines. However, the salinity of the boiler water was so high (unmeasurably so) that it caused boiler priming, which [needed to be blown down and] caused a considerable amount of drain every several minutes. On top of that, since we were not able to get the evaporators working properly (though we had tried to get rid of the heavy oil sucked into the evaporators, it was not easily removed), it became difficult to collect [sufficient] water. Since the quantity of water to be collected [dropped to] one ton per hour, [the water in] the main water supply tanks in the rear engine rooms decreased minute by minute, and at 0355 we could not afford to keep [the turbines] in operation any longer.

10. After that, we decided to [also] install blind patches in the auxiliary [steam] exhaust pipes of Boiler Room No. 1 passing through Boiler Room No. 3 so as to seal them off, and in order to implement it, we turned off Boilers Nos. 10 and 12 at 0408 . Earlier, when we tried to start the draft fan in Boiler Room No. 3 to turn on Boilers Nos. 5 and 7, it was impossible to start it up due to the huge [amount of] drain, due to which, for a while Boilers Nos. 9 and 11 became the only operating boilers.

11. At 0440 the towing cable was cut and the work to seal off the auxiliary [steam] exhaust [pipes of Boiler Room No. 1] was also finished. At 0530, the steam evaporation by all boilers in Boiler Room No. 4 [was started]; the draft fan of Boiler Room No. 3 was successfully started up as well; at 0645 Boilers Nos. 5, 7, and 8 were turned on, and by operating them all together [the Naka finally] started sailing on her own at about half speed on both inner propeller shafts (with an oil pressure of 6 tons in the burners of each boiler).

12. Although a considerably large quantity of drain came out even after starting the above operation, the salinity gradually decreased by rigorously blowing down [the boilers], while the amount of collected water by the evaporators increased. From around 2000 on the $2 \mathrm{~d}$ onwards, the water level in the boilers became more or less stable, which enabled us to increase the rotation of the shafts so that [the Naka] would be able to sail at a speed of about eleven knots. At 1330 on the 3d, we were finally able to reach the Bantam anchorage.

At 0930 on 3 April, the Christmas Island invasion unit was disbanded when the Natori, who had gone ahead, entered into the Bantam anchorage; the units, [which had participated in the operation,] were thereafter [assigned] the following tasks and operations:

1. The 16th Cruiser Division (minus the Nagara and the Kinu) and the 22d Destroyer Division shall form an escort unit and, staying in the Java area, take charge of guarding the sea as well as the protecting of the [sea] lines of communication in the area along with the 21st Special Base Force.

2. Patrol Boats Nos. 34 and 36 shall be incorporated in the attached unit, and after respectively escorting the Kimishima-maru to Surabaya and the Akebono-maru to Makassar, [both shall] stay on standby in Makassar.

3. The Kimishima-maru and the Kumagawa-maru shall act as specified by the commanders of the 21st Special Base Force and the 22d Special Base Force respectively, after which both shall return to mainland [Japan] as soon as possible.

4. The Christmas Island landing unit shall be incorporated into the Java Guard Unit, and assigned to guard the island and secure the resources.

On the morning of 3 April, the Christmas Island Guard Unit completed its preparations for antiaircraft engagements by completing [the set-up of] antiaircraft batteries. (The island was unsuitable for setting up an air base.) Meanwhile on the 6th, the Naka left Bantam Bay for Singapore, where she went into dock on 3 May, came out of dock on 2 June, and left Singapore on the $3 \mathrm{~d}$ to return to Yokosuka on the 12 th by way of Magong. ${ }^{(56)}$ 


\section{The Carrier Operations in the Indian Ocean}

\section{Return of the 5th Carrier Division Delayed}

As previously told [p. 212], the main force of the Carrier Task Force (minus the 5th Carrier Division, the Arare and the Kagerō) was transferred to the Southern Task Force on 8 February to implement the 1 st and $2 \mathrm{~d}$ carrier operations (respectively to Port Darwin and to the south of Java). Meanwhile, to be prepared against a [possible] attack by an enemy striking force on the Tokyo area, the 5th Carrier Division was kept on standby in Mikawa Bay as the Combined Fleet's Air Unit, while at the same time engaging in drills. ${ }^{(100)}$

On 3 March, following the decision (of 14 February, as previously told [p. 569]) to conduct a carrier operation in the Indian Ocean, Combined Fleet Commander in Chief Admiral Yamamoto decided to return the 5th Carrier Division to the Carrier Task Force as of the 5th, and in order to be prepared against [possible] enemy air raids on Tokyo, he issued an order to transfer the 21st Air Flotilla (minus the Tōkō and the 1st Air Groups) to the Northern Task Force [instead]. ${ }^{(100)}$

However, at 0425 on 4 March, about forty enemy carrier aircraft raided Minami-Torishima [Marcus Island], which caused the Combined Fleet commander in chief to temporarily postpone the 5th Carrier Division's return to the Carrier Task Force. On 5 March, he temporarily put the division into the Guard Unit and ordered it to attack the enemy striking force. However, since there was no information on the enemy movements after that, the 5th Carrier Division's temporary transfer to the Guard Unit and its attack on the enemy striking force was called off; it was decided that the division should stay on standby while remaining at its present station. ${ }^{(100)}$

The 5th Carrier Division was relieved from standby duty on 7 March; on 8 March, the division left mainland Japan for Staring Bay to return to the Carrier Task Force. However, [again] at 1830 on 10 March, information came in that radio waves, which presumably belonged to an enemy striking force, had been detected in an area six hundred nautical miles $350^{\circ}[\mathrm{N}]$ of Otorishima (Wake Island), and the Combined Fleet commander in chief judged that the enemy striking force was likely to conduct an air raid on Tokyo. Based on this judgment, Operation Tactics 3 against the U.S. Fleet [p. 49] were put in motion on 11 March, which meant that the 5th Carrier Division was again incorporated into the Guard Unit and assigned to attack the enemy striking force. ${ }^{(100)}$

The 5th Carrier Division on a southward course toward Staring Bay quickly reversed course and headed for an attack on this enemy. On the evening of the 11th, the division commander R. Adm. Hara Chūichi reported his scheduled course of action as follows: "[the division] will advance to an area 120 nautical miles $190^{\circ}$ [S] of Minami-Iwo-Jima [South Iwo Jima] at 0600 on the 13 th and 300 nautical miles $50^{\circ}$ [NE] of Hahajima at 1200 on the 14th."(100) However, as no enemy movements were reported after that, the likelihood grew that the radiolocation [of the enemy] had been faulty. On 12 March, the chief of staff of the Combined Fleet notified the chief of staff of the First Air Fleet that the 5th Carrier Division should be returned to the Carrier Task Force after completing the operation against the [supposed] enemy striking force and that the Kaga was scheduled to be returned to mainland Japan for repairs as soon as she was ready. In reply, the chief of staff of the First Air Fleet sent a telegram to the chief of staff of the Combined Fleet on 13 March, saying that the Carrier Task Force was scheduled to leave Staring Bay around 21 March to attack Ceylon around 1 April and 


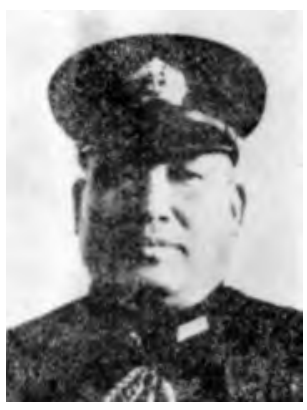

5th Carrier Division Commander R. Adm. Hara Chūichi

that since it was difficult to anticipate when the 5th Carrier Division could join the force, the Kaga should participate in the Ceylon operation, although her present condition gave concerns about her readiness for action, and if one aircraft carrier needed to be kept on standby in mainland Japan, he wanted it to be one of the carriers of the 5th Carrier Division. ${ }^{(100)}$

Since no enemy movements were reported thereafter, Combined Fleet Commander in Chief Admiral Yamamoto issued an order on 15 March that the 5th Carrier Division should return to the Carrier Task Force. At 1400 on that day, 5th Carrier Division Commander Rear Admiral Hara reported to the chief of staff of the First Air Fleet that the division would leave its area of operations on the 15th, arrive in Yokosuka on the 16th for replenishment, leave there on the 17th and arrive in Staring Bay on the 24th. ${ }^{(100)}$

On 16 March, the chief of staff of the Combined Fleet informally suggested to the chiefs of staff of the First Air Fleet and the Second Fleet that in connection with the delay in the operations of the 5th Carrier Division, one element of the Carrier Task Force should now, if possible, attack and destroy the enemy naval vessels in Port Darwin. In reply, at 2300 on 17 March, the chief of staff of the Second Fleet opposed the suggestion for an attack on Port Darwin on the following grounds: for an attack on Port Darwin one would need to arrange for oil supply ships; since the bulk of the aircraft units of the Carrier Task Force were [currently] dispatched to Kendari for planned maintenance and were [also] earnestly conducting drills according to the [new] directions for attack units that met the revised engagement tactics based on the [latest] lessons of war, it would be difficult to make a sortie before 21 March; if the force were to conduct an attack on Port Darwin, the sortie of the Carrier Task Force from Staring Bay for the 3d carrier operation should be [delayed until] the 28th or later and the attack on Ceylon until 7 April or later; in view of the current condition of the enemy strength, an attack by the $2 \mathrm{~d}$ Air Raid Unit [on Port Darwin] would be sufficient. ${ }^{(141)}$

Meanwhile at 1840 on the 17th, Southern Task Force Commander Vice Admiral Kondō had issued the following orders by means of the Southern Task Force Telegraphic Order No. 145:(141)

1. The 3d carrier operation of the Southern Task Force shall be called Operation C, the scheduled date of attack shall be called Day C, and Day C shall be scheduled for 5 April.

2. The above name shall be abandoned simultaneously with the completion of the attack.

Combined Fleet Commander in Chief Admiral Yamamoto approved the order, and the attack on Ceylon was set to be carried out on 5 April. According to The Second World War by W. Churchill, the allies had information (by breaking codes?) that the [Japanese] attack on Ceylon would be conducted around 1 April. However, they had no chance to know that the attack had been postponed until the 5 th, and the British Fleet acted on the premise that the Japanese Fleet would attack Ceylon on 1 April. ${ }^{(178)}$

Meanwhile the Kaga was removed from the Carrier Task Force as of 13 March, transferred to the Guard Unit, and left Staring Bay on 15 March for Sasebo. ${ }^{(141)}$ 


\section{The Enemy Movements in the Indian Ocean}

I. The outline of the principal telegrams concerning the enemy movements ${ }^{(141)}$

\section{IGHQ Navy Staff Classified Telegram No. 974}

\section{Air Strength}

(1) Current numbers (10 March)

The Indian area (including Ceylon): 230 [aircraft]

Burma: 80 [aircraft] (of which 30-40\% fighter planes)

(2) Reinforcements (expected to be completed in the beginning of April)

Reinforcements dispatched from North Africa and Middle and Near East: 150 [aircraft]

Reinforcements dispatched from mainland Britain: 100 [aircraft]

Reinforcement in preparation for departure from mainland Britain: 80 [aircraft]

2. Movements of naval vessels (as of early March)

(1) The naval vessels stationed in the Indian Ocean are operating with Colombo, Bombay, Mombasa (South Africa), Durban (South Africa), etc., as their bases; the main vessels are: Battleships: HMS Revenge (Britain), HMS Royal Sovereign (Britain), HMS Ramillies (Britain) Aircraft carriers: HMS Hermes (Britain), HMS Indomitable (Britain)

Heavy cruisers: HMS Cornwall (Britain), HMS London (Britain), HMS Susan [Sussex?] (Britain), HMAS Canberra (Australia)

(2) Major forces expected to be dispatched as reinforcements in the near future

Two battleships

Two aircraft carriers

Intelligence indicates that HMS King George V (British battleship) and HMS Warspite (British battleship) have been brought to the Indian Ocean and the Australian waters from late February onwards.

II. Prior reconnaissance results of the island of Ceylon ${ }^{(191)}$

1. When the reports of the covert reconnaissance by the Submarine Unit and the Air Unit of the Southern Task Force were put together, it turned out that the patrols near the mouth of the ports of Colombo and Trincomalee were very strict, which made it difficult for submarines to approach these places. Moreover, it seems that [the enemy] conducts patrols within a radius of two hundred nautical miles [from Ceylon] with destroyers and gunboats and within a radius of five hundred nautical miles from Ceylon with aircraft.

2. The land-based air units have not yet spotted large enemy vessels in [the port of] Trincomalee or the Bay of Bengal during their reconnaissance.

III. The state of the defense of Colombo

\section{Defense}

Four 24-cm guns, four or five 14-cm guns; an antisubmarine net has been put up at the mouth of the port and a night-time dummy city has been set up in the northern part [of the town]. [The town] holds a garrison of about 3,000 troops.

2. Major military facilities The airfield, barracks, batteries, rice storehouses, oil tanks, radio station, arsenals and powder magazines.

IV. The enemy's anticipation of the Japanese operations

1. Britain's anticipation of our Indian invasion operation

(1) A surprise attack on Ceylon by the [Japanese] Navy is anticipated.

(2) Invasions of Colombo, Calcutta, Madras and Bombay may be started within six or seven weeks (before the monsoon season). 
2. Foreign telegrams (on 3 April) reported that Ceylon was exposed to the danger of an attack by Japanese forces, but there are no indications that [the enemy] has gotten wind of our plans.

For reference:

According to the "The Greater East Asia War's Lessons of War ([section] Air Operations: The Operations on Ceylon)," the domestic and foreign state of affairs relevant to the Ceylon operation was on page 36 viewed as follows:

India is a treasure house for Britain both in terms of matériel and human [resources], and its attitude affects the fate of Britain.

The Indian people, who have started to harbor doubts about the armed strength of Britain because of our quick and bold southern operation, are showing signs of unrest about [Britain's] perennial oppression and exploitation. Britain has immediately dispatched [Sir Richard Stafford] Cripps, who is leaving no stone unturned to placate people; at the moment, he is negotiating with the Indian National Congress.

It is thought that a carrier operation against Ceylon at this juncture will, combined with the operation in the Bay of Bengal, affect the Anglo-Indian relations in a subtle way and have quite some impact, indeed.

On the other hand, it is expected that our attack on the Indian area will absorb the military strength of the allied forces, and ought to facilitate the operations of the Axis countries on other fronts very much; furthermore, it will facilitate the communication [between the Axis countries] via India when Germany and Italy's operations in the Near East or in North Africa make progress.

\section{The Plan of Operations}

\section{The Southern Task Force}

On 14 March, Southern Task Force Commander in Chief Vice Admiral Kondō announced the outline of the third carrier operation by means of Telegraphic Order No. 139, the contents of which were as follows: ${ }^{(141)}$

The Southern Task Force shall conduct the third carrier operation in the following way: it shall destroy the enemy power in the Ceylon area in a surprise attack, while striving to ensure a perfect escort at sea for [the forces of] the Burma operation.

1. The Carrier Task Force shall at an appropriate moment leave Staring Bay, and advance to Ceylon by way of the waters to the south of Java and to the southwest of Sumatra. In the beginning of April, it shall carry out surprise attacks on enemy vessels ([enemy] air power, naval bases, facilities and so forth) in the area and return to the South China Sea by way of the Malacca Strait.

2. Submarine Unit $C$ shall be assigned to watch and patrol of the waters to the west of Ceylon (a line connecting the Laccadive and Maldive Islands as well as the Chagos Archipelago) and the Bombay area with its main force, while with one element conducting a covert reconnaissance (two days prior to [the day of the] air raids as a standard) and weather reconnaissance (on the day of the air raids) of Colombo, Trincomalee and other places.

3. While continuing its current tasks, the Air Unit shall act in concert with the actions of the Carrier Task Force; it shall conduct reconnaissance over the Cocos and Christmas Islands as well as search missions and neutralization attacks over the waters to the southwest of Sumatra and in the Bay of Bengal. 
4. While continuing its current tasks, depending the movements of the enemy, the Malaya Unit shall at an appropriate time start operating in the Bay of Bengal more or less to the north of the line connecting Madras (inclusive) and Babi Island [p. 570, note] at both ends, and act in concert with the Carrier Task Force. However, it shall not advance to the waters to the west of $85^{\circ} \mathrm{E}$ longitude until the first air raid by the Carrier Task Force.

5. All units other than the above shall continue their current tasks.

6. The main unit ([consisting of] the Atago and the 4th Destroyer Division (minus the $2 \mathrm{~d}$ Section) shall operate appropriately in the Malacca Strait and [near] the Andaman Islands.

\section{The Carrier Task Force of the Southern Task Force}

On 19 March, Carrier Task Force Commander V. Adm. Nagumo Chūichi announced the plan of the carrier operations in the Indian Ocean by means of Carrier Task Force Operation Order Classified No. 31, the contents of which were as follows: ${ }^{(192)}$

\section{Enemy movements}

When various sources of information are combined, it seems that a British fleet consisting of three battleships, two aircraft carriers, four Class-A cruisers and about eleven Class-B cruisers as its core is operating in the Indian Ocean, and an air power of a total of about five hundred aircraft is deployed in the India area (including Ceylon). It is judged likely that a considerable part of the above [forces] is deployed in the Ceylon area and one part is operating in the Bay of Bengal. Although it seems that an element of the British, Australian, Dutch, and U.S. forces remains in the Australia area, the details are unknown.

2. The movements of our forces

As shown in Southern Task Force Telegraphic Order No. 139 in the separate sheet (Note by the author: as already told)

3. In accordance with Southern Task Force Telegraphic Order No. 139, the Carrier Task Force shall advance to the waters to the south of India, and try to catch and destroy the enemy fleet as well as his air power

4. The disposition of forces (as shown in the following table)

\begin{tabular}{|c|c|c|c|c|c|}
\hline & Unit & & Commander & Forces & Main Tasks \\
\hline & Air Raid Unit & & & $\begin{array}{l}\text { 1st Air Fleet (minus the Kaga and } \\
\text { destroyer division(s)) }\end{array}$ & $\begin{array}{l}\text { To destroy enemy fleets and } \\
\text { air power }\end{array}$ \\
\hline & Support Unit & & $\begin{array}{l}\text { 3d Battleship Div } \\
\text { Cdr }\end{array}$ & $\begin{array}{l}\text { 3d Battleship Div and 8th Cruiser } \\
\text { Div }\end{array}$ & $\begin{array}{l}\text { To cover the Air Raid Unit } \\
\text { To attack enemy fleets }\end{array}$ \\
\hline & Guard Unit & 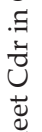 & $\begin{array}{l}\text { 1st Destroyer } \\
\text { Sqdn Cdr }\end{array}$ & $\begin{array}{l}\text { 1st Destroyer Sqdn, 17th and 18th } \\
\text { Destroyer Divs, Akigumo and 4th } \\
\text { Destoyer Div 2d Section }\end{array}$ & $\begin{array}{l}\text { To guard [the units] } \\
\text { To attack enemy fleets }\end{array}$ \\
\hline 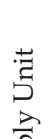 & 1st Supply Unit & 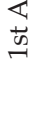 & $\begin{array}{l}\text { Shinkoku-maru }[B] \\
\text { Superintendent }\end{array}$ & $\begin{array}{l}\text { Shinkoku-maru [B], Ken'yō-maru, } \\
\text { Nippon-maru, Tōei-maru [A], } \\
\text { Kokuyō-maru and Kyokutō-maru }\end{array}$ & Supply and refueling \\
\hline के & 2d Supply Unit & & $\begin{array}{l}\text { Under direct } \\
\text { command }\end{array}$ & $\begin{array}{l}\text { Nichirō-maru, Kyōei-maru No. } 2 \text { and } \\
\text { Hōkō-maru }\end{array}$ & \\
\hline
\end{tabular}


5. The outline of the operations of the units

(1) The Air Raid Unit, the Support Unit, the Guard Unit and the Shinkoku-maru [B] shall leave Staring Bay at 0800 on 26 March and operate as designated in Separate Illustration No. 1 (omitted by the author). At 1000 on 31 March, after having been joined by the Ken'yō-maru and the Nippon-maru at Point A $\left(9^{\circ} 0^{\prime} \mathrm{S}, 106^{\circ} 0^{\prime} \mathrm{E}\right)$, they shall complete the replenishment while sailing up to Point $\mathrm{B}\left(1^{\circ} 0^{\prime} \mathrm{N}, 90^{\circ} 0^{\prime} \mathrm{E}\right)$. Thereafter, depending on the whereabouts of the enemy fleet, they shall advance to either Points $\mathrm{C}\left(8^{\circ} 0^{\prime} \mathrm{N}, 84^{\circ} 0^{\prime} \mathrm{E}\right), \mathrm{D}\left(6^{\circ} 20^{\prime} \mathrm{N}, 82^{\circ} 40^{\prime} \mathrm{E}\right)$ or E $\left(4^{\circ} 40^{\prime} \mathrm{N}\right.$, $\left.81^{\circ} 40^{\prime} \mathrm{E}\right)$, to resolutely carry out the attack on Ceylon. If no information about the enemy movements is obtained [by the time they reach] Point B, they shall postpone the air raid for one day and have the 8th Cruiser Division advance to conduct a covert reconnaissance of Trincomalee and Colombo with the reconnaissance seaplanes of the division from outside a radius of four hundred nautical miles from enemy territory.

Depending on the movements of the enemy, further air raids shall be repeatedly conducted on the next day. When the attack on the Ceylon area is completed, they shall head for Point $\mathrm{F}\left(10^{\circ} 0^{\prime} \mathrm{N}, 95^{\circ} 0^{\prime} \mathrm{E}\right)$, while searching for the enemy in the vicinity of the Bay of Bengal. The time to reach Point F shall be set at 1800 on Day C +3 .

(2) After completing the replenishment around Point B, the 1st Supply Unit (minus the Tōeimaru and the Kokuyō-maru) shall sail to the area near Point F, and stay [there] on standby.

The Tōei-maru [A] shall join at Point F while the Kokuyō-maru shall sail to Singapore by Day C +6 .

(3) The 2d Supply Unit

The Nichirō-maru shall stay on standby at Palau. The Kyōei-maru No. 2 and the Hōkō-maru shall stay on standby at Kure and Yokosuka after servicing the ship [including] the engines.

6. The Air Raid Plans

(1) When the major part of the enemy fleet is in Trincomalee

\{1\} The formation of the air units for air combat

The first formation (with nine aircraft per carrier for the unit that is to take control of the air)

$\{2\}$ The [priority of] targets

1st Group: Enemy aircraft carriers, battleships and cruisers in that order.

2d Group: Enemy aircraft carriers, cruisers, battleships and small vessels in that order.

However, the 14th Attack Unit shall [attack] enemy hangar[s] on the airfield.

3d Group: Enemy aircraft in the air as well as on the ground; however, the 6th Air Control

Unit shall directly cover the 1st Group.

If the number of enemy target vessels is markedly less than expected, the groups shall appropriately direct their attacks to transport ships or military facilities on the ground.

$\{3\}$ The armament

1st Armament: Carrier-based attack planes: No. 80 Mark 5 bombs ([with] Fuse C)

Carrier-based bombers: Type99 No. 25 regular bombs ([with] Fuse C)

2d Armament: Carrier-based attack planes: No.80 regular bombs ([with] Fuse C)

Carrier-based bombers: Type99 No. 25 regular bombs ([with] Fuse C)

3d Armament: Carrier-based attack planes: No. 80 land bombs ([with] Fuse C)

Carrier-based bombers: No. 25 land bombs ([with] Fuse B)

In any case, the airfield attack unit shall carry No. 25 land bombs ([with] Fuse A). The orders for the types of armament shall be given the day before the air raid.

For the period up to the day before the air raid and after it, carrier-based attack planes and bombers shall be prepared respectively with torpedoes and No. 25 land bombs ([with] Fuse A). 
Note by the author:

1) Fuse $A, B$ and $C$ indicate the delay before detonation.

Fuse A: 0.03 sec.; B: 0.01 sec.; C: 0.02 sec.

2) No. $80: 800 \mathrm{~kg}$ bombs; No. $25: 250 \mathrm{~kg}$ bombs

\{4\} Takeoff times

The first units, [i.e.] the carrier-based attack plane and fighter plane units, are scheduled to take off at 0900, and the second unit, [i.e.] the carrier-based bomber unit, shall take off thirty minutes after the takeoff of the first units.

Note by the author: the local time is four hours behind Japan time.

$\{5\}$ The time of assembly and the assembly point after the attacks

The time of assembly: Forty-five minutes after the start of the attack.

The assembly point: Ten nautical miles $90^{\circ}$ of Foul Point, at an altitude of 2,000 meters

[Radio] communications: the 1st Attack Unit

(2) When the bulk of the enemy fleet is in Colombo

The same as under (1) other than the following:

The assembly point after the attack: Ten nautical miles $270^{\circ}$ of Galbokka Point

(3) When the enemy fleet is berthed both in Trincomalee and Colombo

$\{1\}$ The formation of the air units for air combat

The Trincomalee attack unit: The second formation ([with] nine aircraft each of the 1st, the $3 \mathrm{~d}$ and the 4 th Air Control Units)

The Colombo attack unit: The third formation ([with] twelve aircraft each of the 5th and the 6th Air Control Units)

\{2\} The [priority of] targets and the armament

The same as under (1) and (2) other than the following:

Both in the second and the third formations, one element of the carrier-based bombers shall attack enemy airfields there; no direct cover units shall be dispatched from the air control units.

\{3\} Takeoff times

The second formation: 0900

The third formation: 0945

\{4\} The assembly shall be made in the same ways as under (1) and (2), other than the following:

[Radio] communications

The Trincomalee unit: 1st Attack Unit

The Colombo unit: 6th Attack Unit

7. The guard against aircraft as well as submarines of the enemy (note by the author: as shown in the following table) 


\begin{tabular}{|c|c|c|c|c|c|c|c|c|c|}
\hline \multirow[b]{2}{*}{$\begin{array}{l}\bar{d} \\
0 \\
0 \\
0\end{array}$} & \multicolumn{4}{|c|}{ Antisubmarine Guard } & \multicolumn{4}{|c|}{ Antiaircraft Guard } & \multirow[b]{2}{*}{ Remarks } \\
\hline & 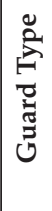 & 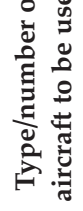 & 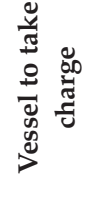 & 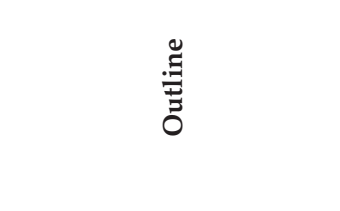 & 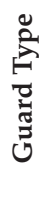 & 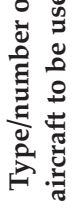 & 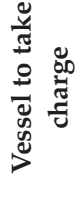 & 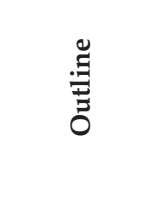 & \\
\hline \multirow{3}{*}{ 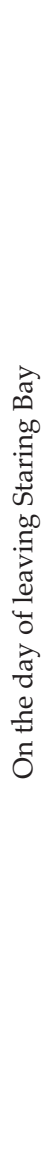 } & 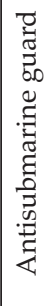 & 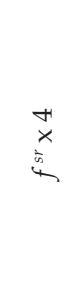 & 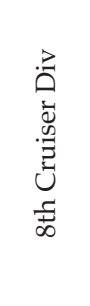 & 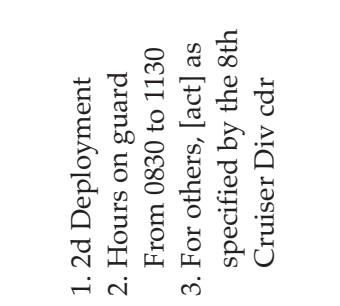 & & \multirow{3}{*}{$\begin{array}{l}\infty \\
x \\
\dot{x} \\
\dot{x}\end{array}$} & \multirow{3}{*}{ 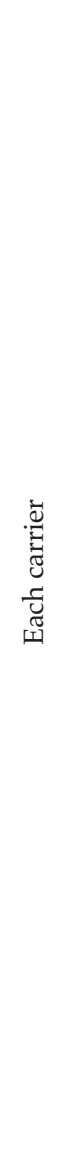 } & \multirow[b]{3}{*}{ 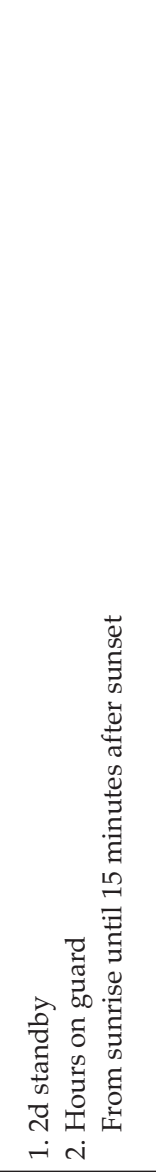 } & \multirow{3}{*}{ 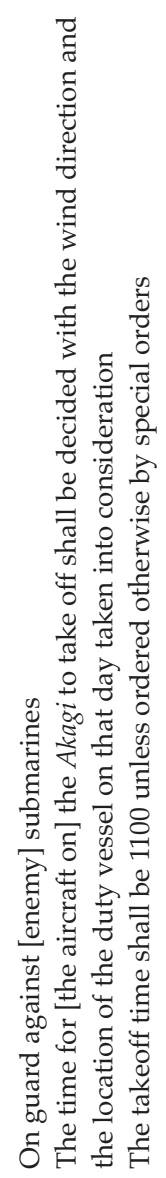 } \\
\hline & $\stackrel{P}{\stackrel{*}{0}}$ & $\begin{array}{l}x \\
x \\
\dot{x}\end{array}$ & $\begin{array}{l}\overrightarrow{50} \\
\frac{8}{\pi}\end{array}$ & 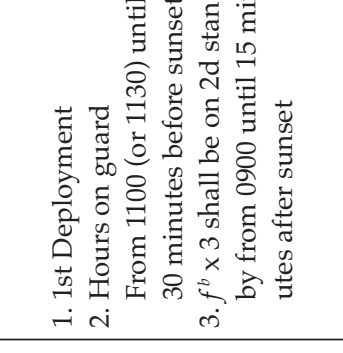 & & & & & \\
\hline & 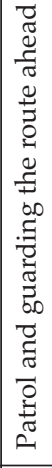 & $\begin{array}{l}\overrightarrow{\vec{x}} \\
\frac{0}{\vec{n}} \\
\vec{x}\end{array}$ & 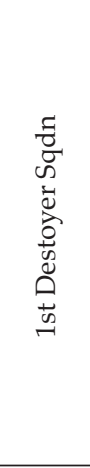 & 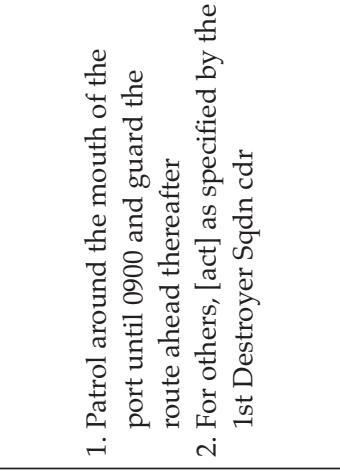 & & & & & \\
\hline 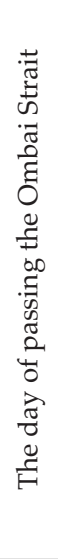 & 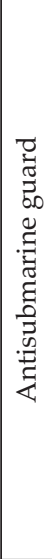 & $\begin{array}{l}+ \\
\times \\
\dot{x}\end{array}$ & $\begin{array}{l}\text { ? } \\
\text { ? } \\
\text { के }\end{array}$ & 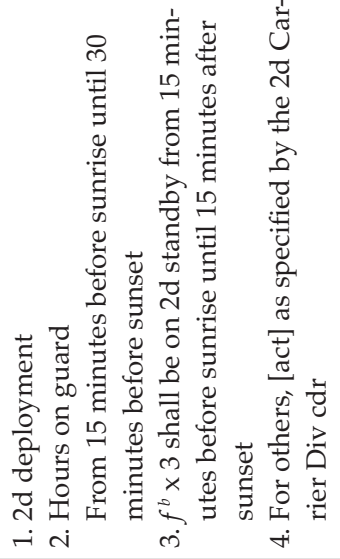 & & 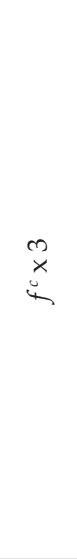 & 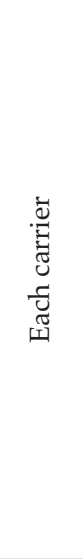 & 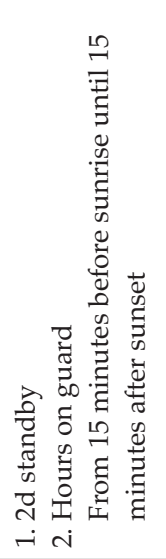 & \\
\hline
\end{tabular}




\begin{tabular}{|c|c|c|c|c|c|c|c|c|c|}
\hline 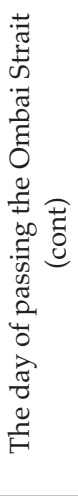 & 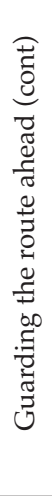 & 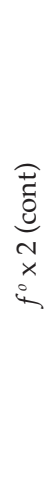 & 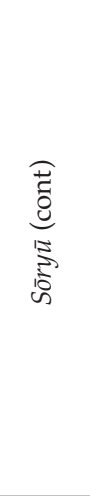 & 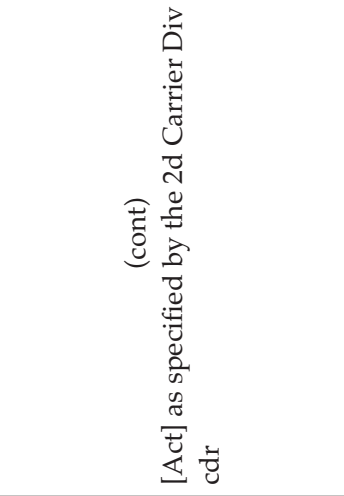 & & 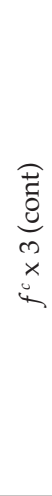 & 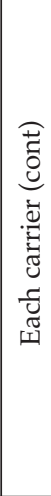 & 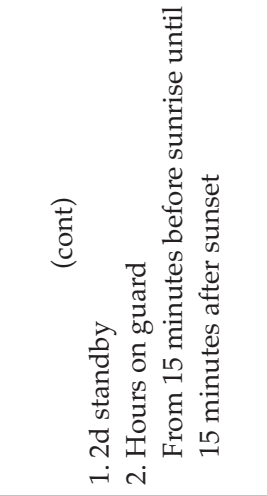 & \\
\hline \multirow{2}{*}{ 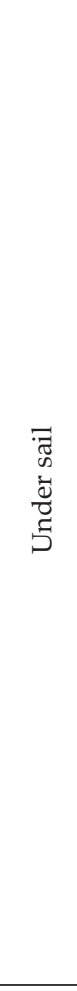 } & 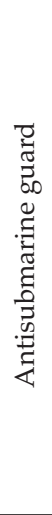 & 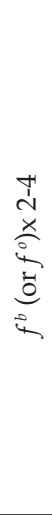 & 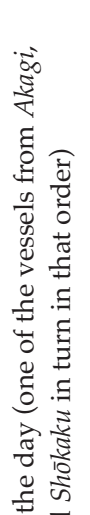 & 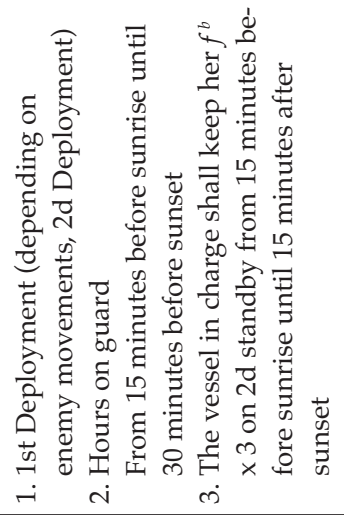 & & \multirow{2}{*}{$\begin{array}{l}\infty \\
x \\
\dot{4}\end{array}$} & \multirow{2}{*}{ 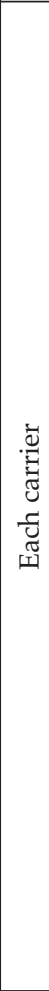 } & \multirow{2}{*}{ 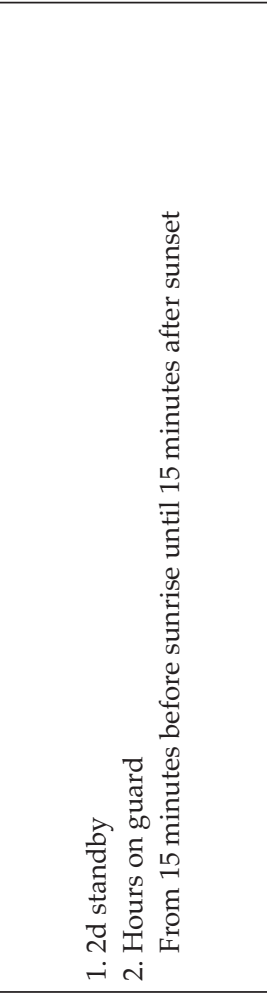 } & \multirow{2}{*}{ 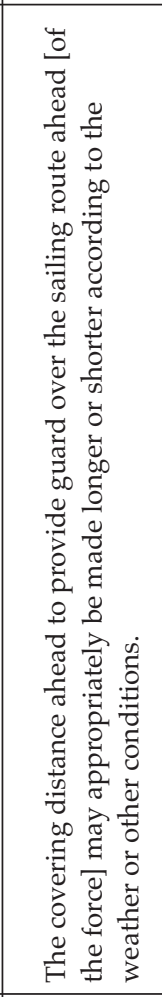 } \\
\hline & 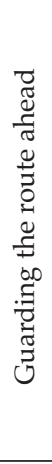 & 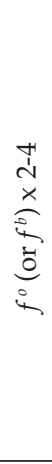 & 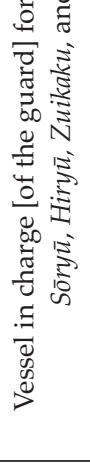 & 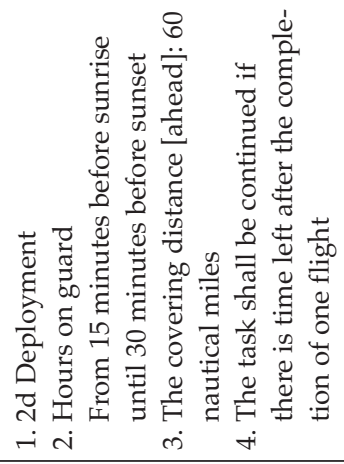 & & & & & \\
\hline 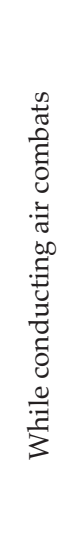 & 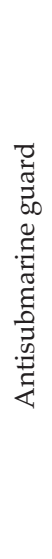 & $\frac{\underset{x}{+}}{\stackrel{+}{v}}$ & 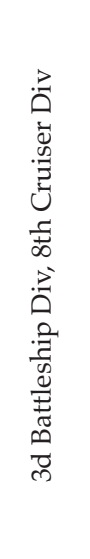 & 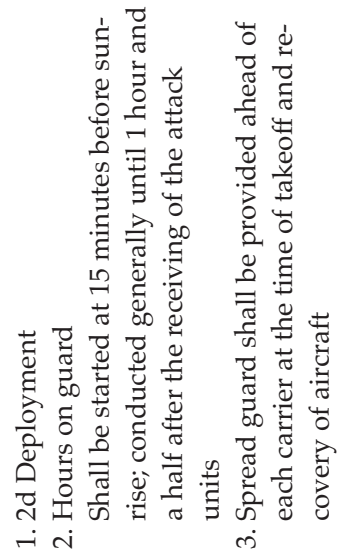 & 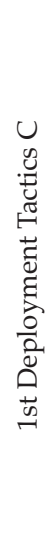 & $\begin{array}{l}a \\
x \\
x \\
x\end{array}$ & 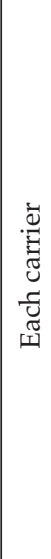 & 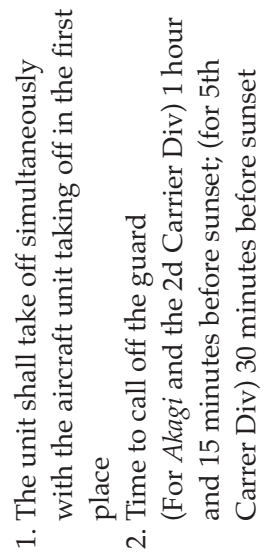 & 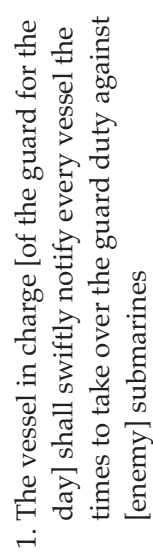 \\
\hline
\end{tabular}




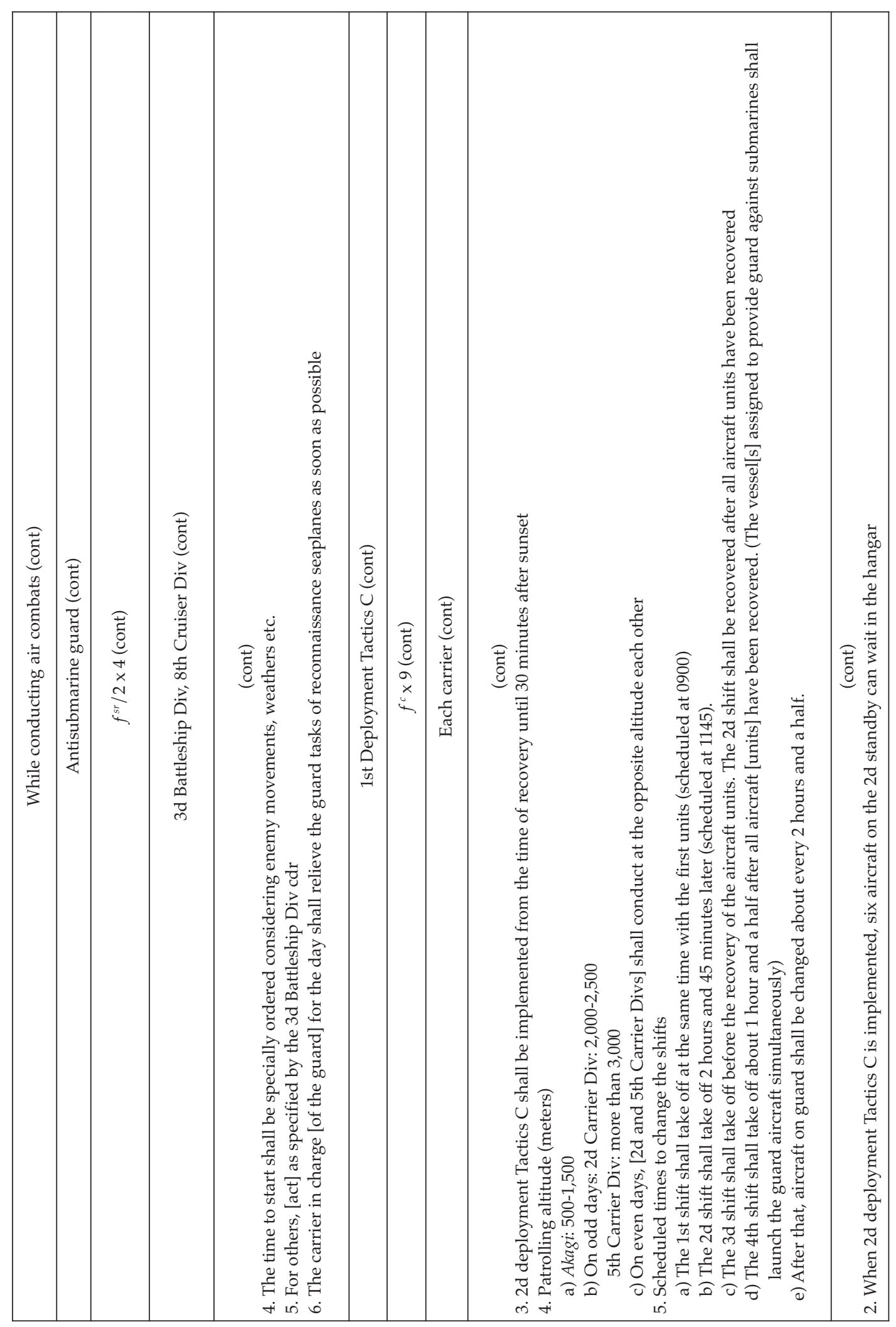


(Note by the author)
$f^{s r}$ : Reconnaissance seaplane
$f^{s r} / 2$ : $\quad$ Two-seater reconnaissance seaplane
$f^{s r} / 3$ : $\quad$ Three-seater reconnaissance seaplane
$f^{\circ}$ : $\quad$ Carrier-based attack plane
$f^{b}: \quad$ Carrier based bomber
$f^{c}$ : $\quad$ Carrier-based fighter plane
(Remarks)

1. One duty vessel from among the Akagi, the Sōry $\bar{u}$, the Hiryū, the Zuikaku and the Shōkaku, in that order, shall be made the vessel in charge for the day, and the vessels will take turns regardless of whether an aircraft guard is employed or not.

2. The vacant spaces [in the line] caused by carriers' change of location due to the takeoff and recovery of their aircraft shall be left as they are.

3. In order to covertly conduct the operations, radio transmissions shall be refrained from.

8. The standby [positions] for guarding against unexpected encounters with the enemy (note by the author: as shown in the following table)

\begin{tabular}{|c|c|c|c|c|}
\hline $\begin{array}{c}\text { Vessel[s] in } \\
\text { Charge }\end{array}$ & $\begin{array}{c}\text { Type and } \\
\text { Number of } \\
\text { Aircraft }\end{array}$ & $\begin{array}{c}\text { Tasks and } \\
\text { Armaments }\end{array}$ & $\begin{array}{c}\text { Standby } \\
\text { Preparation }\end{array}$ & Notes \\
\hline $\begin{array}{c}\text { 8th Cruiser } \\
\text { Div }\end{array}$ & $\begin{array}{c}2 \text { Type-0 re- } \\
\text { connaissance } \\
\text { seaplanes }\end{array}$ & $\begin{array}{c}\text { Search, reconnaissance } \\
\text { and probing }\end{array}$ & 3d Standby & $\begin{array}{c}\text { Upon spotting enemy carrier-based } \\
\text { aircraft, [the aircraft shall] follow } \\
\text { them without special orders. }\end{array}$ \\
\hline $\begin{array}{c}\text { 3d Battle- } \\
\text { ship Div }\end{array}$ & $\begin{array}{c}\text { 4 Reconnais- } \\
\text { sance sea- } \\
\text { planes }\end{array}$ & $\begin{array}{c}\text { Guard against [enemy] } \\
\text { submarines }\end{array}$ & 3d Standby & 3d Standby \\
$\begin{array}{c}\text { 1st Air Fleet } \\
\text { (except for } \\
\text { the vessel in } \\
\text { charge [of } \\
\text { guard duty } \\
\text { for the day]) }\end{array}$ & $\begin{array}{c}\text { 9 Carrier- } \\
\text { based } \\
\text { carrier (except } \\
\text { for the vessel } \\
\text { in charge [of } \\
\text { guard duty] }\end{array}$ & $\begin{array}{c}\text { Type99 No. 25 regular } \\
\text { bombs ([with] Fuse C) }\end{array}$ & $\begin{array}{c}\text { 2. [Units shall] conduct attacks } \\
\text { under the unified command of the } \\
\text { senior commanders in the above, } \\
\text { unless otherwise specially or- } \\
\text { dered. }\end{array}$ \\
\hline
\end{tabular}

\section{Remarks}

1. The starting time will be ordered later.

2. Solo attacks [without support] are allowed to be carried out only when the commander or the captain of the vessel specifically recognizes their necessity.

3. Takeoff of three aircraft for each carrier (except for the one on guard duty for the day) may be ordered when air control units become necessary.

4. Attacks by the carrier-based attack planes [shall be conducted] as specified in Carrier Task Force Signal Order No. 51.

5. If an urgent takeoff of aircraft units should be ordered, the units shall report [back] the time they are able to take off; they shall [also] report it to the vessel carrying the senior commander on board. (End) 


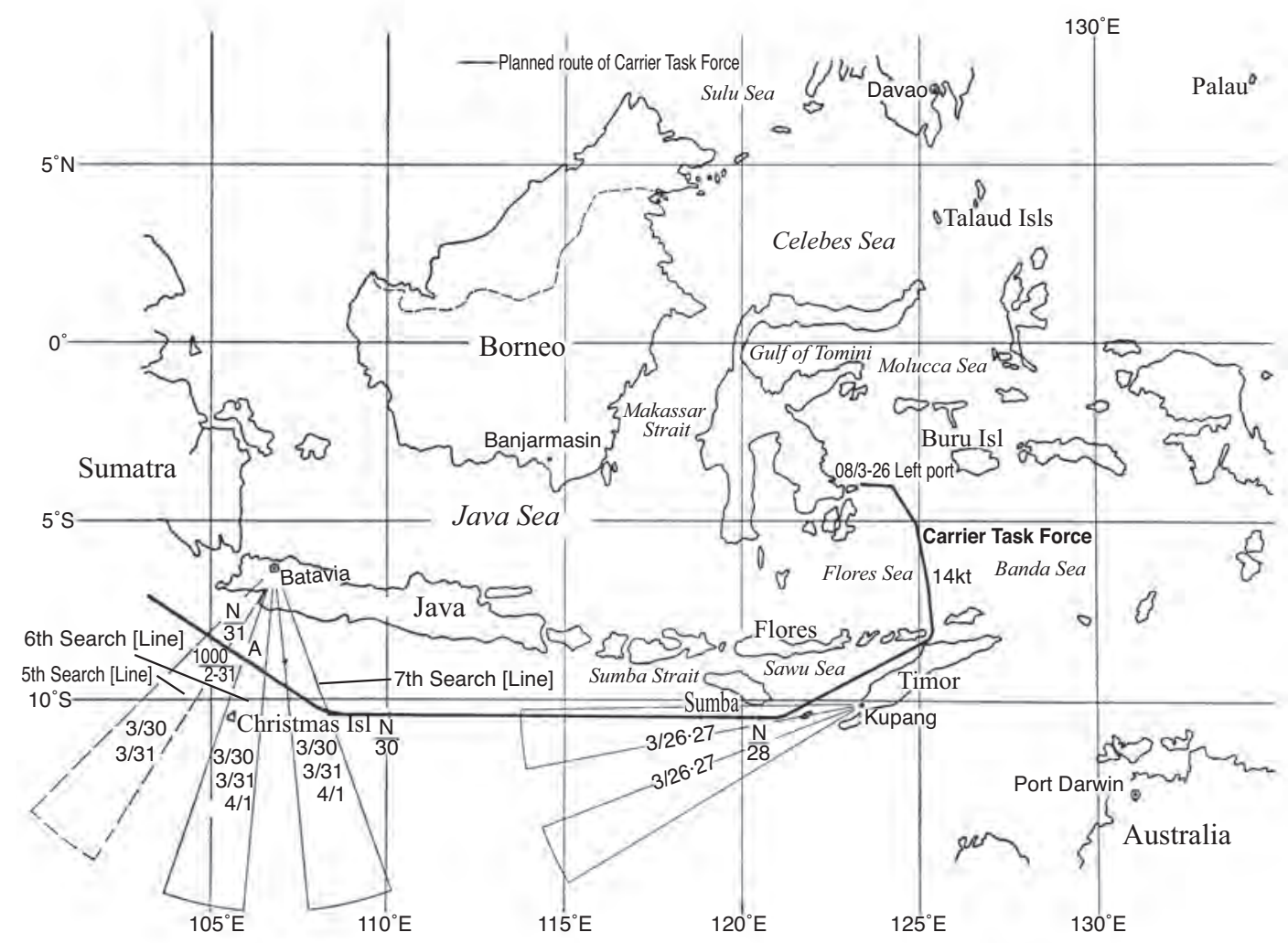

Illustration No. 58 - The Plan for the Search Missions of the Air Unit of the Southern Task Force in Operation C (Part 1)

The Air Unit of the Southern Task Force (See Illustrations Nos. 58, 59, 60 and 61)

By means of Operation Order No. 50, Air Unit Commander Vice Admiral Tsukahara had issued his plan of operations in the Indian Ocean and the Bay of Bengal, which were to be conducted mainly by the $3 \mathrm{~d}$ Air Raid Unit during the Andaman Islands, Burma and Ceylon operations. However, its main text is no longer extant and the details are unclear. Nevertheless, according to Separate Illustration No. 1 of the order, the search mission was planned as follows ${ }^{(192)}$ (See Illustrations Nos. 58 and 59). In view of the fact that the search areas [shown in the separate illustration] were relevant to Operations D and $U$, the order seems to have been issued around 17 March. Then on 21 March, the Air Unit commander issued the following plan of operations for his unit when acting in concert with Operation C of the Carrier Task Force. ${ }^{(141)}$ (Southern Task Force Air Unit Classified Telegram No. 918.)

\section{Telegraphic Operation Order No. 77}

1. The Southern Task Force shall implement Operation C in accordance with Southern Task Force Telegraphic Order No. 139.

2. The Dutch East Indies Unit shall capture Christmas Island on 31 March in accordance with

Dutch East Indies Unit Classified Telegram No. 203. 
3. The schedule of operations of the Carrier Task Force is as shown in First Air Fleet Classified Telegram No. 118.

4. While continuing current tasks, all air raid units shall support the above operations in the following way:

(a) The 2d Air Raid Unit

(1) Shall conduct search missions on the routes ahead of the Carrier Task Force within a radius of six hundred nautical miles from Kupang before its departure.

(2) One element of the main body of the Tōkō Air Group shall be dispatched to Batavia (the number of the aircraft [to be dispatched] shall be decided by the $2 \mathrm{~d}$ Air Raid Unit commander), so as to conduct search missions in the Christmas Island area on 29 and 30 March and in the Cocos Islands area on 31 March and 1 April.

(b) The 3d Air Raid Unit

(1) On 1 and 2 April, the search area of Sector A shall be [shifted] to an area within six hundred nautical miles between $170^{\circ}$ and $280^{\circ}$ from Sabang. From 3 April onwards, the search missions in the heretofore areas shall be resumed.

(2) Depending on the enemy movements until Day C - 1, the land-based attack plane unit of the Genzan Air Group shall, by a special order, attack enemy naval vessels near Calcutta from base[s] in Rangoon.

(c) The Tōkō Air Group Detachment

(1) On 1 and 4 April, one element of [the detachment] shall extend [the search distance of] Sector $\mathrm{C}$ up to seven hundred nautical miles and, with one element, reconnoiter Trincomalee and, if possible, Palk Bay and Strait.

(2) On 2 April, [the detachment] shall conduct a search mission in Sector D, with an [extended] distance of seven hundred nautical miles. ([However,] it shall not approach the area within twenty nautical miles from the shore).

(3) On 3 April, [the detachment] shall conduct a search mission in Sector E. However, it shall not advance within twenty nautical miles from the shore.

\section{The Malaya Unit}

On having been officially informed that Day C should be set on 5 April by Southern Task Force Telegraphic Order No. 145 on 17 March, Malaya Unit Commander Vice Admiral Ozawa started to work on a detailed plan for his unit's striking operation in the northern part of the Bay of Bengal, which should be conducted in concert with Operation C. We may assume the outline to have been as follows. ${ }^{(118)}$ (Malaya Unit Operation Order Classified No. 20.)

\section{Mission}

While continuing its current tasks, the Malaya Unit shall act in concert with the Carrier Task Force's surprise attack in the Ceylon area (scheduled for 5 April), in accordance with Southern Task Force Telegraphic Order No. 139, timely operate in the Bay of Bengal by and large to the north of a line connecting Madras and the western point of Babi Island [p. 570, note], disrupt enemy sea lines of communication in the Madras and Calcutta areas as well as search for enemy naval vessels, and catch and destroy them.

2. The disposition of forces (as shown in the following table) 


\begin{tabular}{|c|c|c|c|c|c|}
\hline & Unit & & Commander & Forces & Main Tasks \\
\hline & Center Unit & $\stackrel{\breve{\Xi}}{\rightleftharpoons}$ & & $\begin{array}{l}\text { Chōkai, Yura, } \\
\text { 4th Carrier Div } \\
\text { (minus 2d Section and } \\
\text { Shiokaze) } \\
2 \text { destroyers of 20th } \\
\text { Destroyer Div }\end{array}$ & $\begin{array}{l}\text { 1. To support the entire operation } \\
\text { 2. To disrupt [enemy] sea lines of communi- } \\
\text { cation and attack enemy naval vessels } \\
\text { around the midpoint between Madras } \\
\text { and Calcutta }\end{array}$ \\
\hline 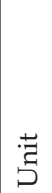 & North Unit & 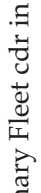 & $\begin{array}{l}\text { 7th Cruiser Div } \\
\text { cdr }\end{array}$ & $\begin{array}{l}\text { 7th Cruiser Div 1st } \\
\text { Section (Kumano and } \\
\text { Suzuya) } \\
1 \text { destroyer of 20th } \\
\text { Destroyer Div }\end{array}$ & $\begin{array}{l}\text { To disrupt enemy sea lines of communica- } \\
\text { tion and attack enemy naval vessels on the } \\
\text { waters off Calcutta and southwards }\end{array}$ \\
\hline$\frac{\pi}{\sum^{\pi}}$ & South Unit & 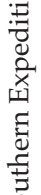 & Capt of Mikuma & $\begin{array}{l}\text { 7th Cruiser Div 2d } \\
\text { Section (Mikuma and } \\
\text { Mogami) } \\
1 \text { destroyer of 20th } \\
\text { Destroyer Div }\end{array}$ & $\begin{array}{l}\text { To disrupt enemy sea lines of communica- } \\
\text { tion and attack enemy naval vessels on the } \\
\text { waters to the north of Madras }\end{array}$ \\
\hline & Supply Unit & 苟 & $\begin{array}{l}\text { Cdr of De- } \\
\text { stroyer Ayanami }\end{array}$ & $\begin{array}{l}\text { Ayanami, Shiokaze and } \\
\text { Nichiei-maru }\end{array}$ & $\begin{array}{l}\text { To provide guard for supply ships and con- } \\
\text { duct replenishment }\end{array}$ \\
\hline & Guard Unit & & $\begin{array}{l}\text { 3d Destroyer } \\
\text { Sqdn Cdr }\end{array}$ & $\begin{array}{l}\text { 3d Destroyer Sqdn } \\
\text { (minus } 6 \text { destroyers) }\end{array}$ & To be on standby near the Andaman Islands \\
\hline
\end{tabular}

3. The outline of the operation

(1) The Chōkai, the 7th Cruiser Division, the 4th Carrier Division (minus the 2d Section and the Shiokaze), the Yura and the 11th Destroyer Division shall leave Mergui on Day C - 3 under the direct command of the Malaya Unit commander and advance into the Bay of Bengal, passing to the north of the Andaman Islands (the 1st route). On the morning of Day $C-2$, the 11th Destroyer Division shall separate from the main unit to sail to Port Blair, where it shall come under the command of the 3d Destroyer Squadron commander. The 20th Destroyer Division shall appropriately withdraw from its patrol area near the Andaman Islands from Day C -2 onwards, and join the main unit on the waters to the west of the islands on the early morning of Day $C-1$. The main unit shall reach Point $C\left(16^{\circ} 0^{\prime} \mathrm{N}, 86^{\circ} 40^{\prime} \mathrm{E}\right)$ at 2100 on Day C - 1, from where the 1st Section of the 7th Cruiser Division and one destroyer of the 20th Destroyer Division shall form the North Unit, and under the command of the 7th Cruiser Division commander advance to the area of Point D $\left(19^{\circ} 20^{\prime} \mathrm{N}, 87^{\circ} 30^{\prime} \mathrm{E}\right)$ around 0900 on Day C, to take charge of disrupting the enemy sea lines of communication as well as catching and destroying enemy naval vessels mainly in the area to the south of Calcutta up to Point E ( $\left.18^{\circ} 20^{\prime} \mathrm{N}, 8^{\circ} 50^{\prime} \mathrm{E}\right)$. Meanwhile, the $2 \mathrm{~d}$ Section and another destroyer of the 20th Destroyer Division shall form the South Unit, and under the command of the captain of the Mikuma, reach Point $\mathrm{F}\left(15^{\circ} 30^{\prime} \mathrm{N}, 83^{\circ} 20^{\prime} \mathrm{N}\right)$ around 0900 on Day C, to take charge of disrupting the enemy sea lines of communication as well as catching and destroying enemy naval vessels in the area to the north of Madras. The remaining main unit shall become the Center Unit, and under the direct command of the Malaya Unit commander, sail westward almost in the middle between the sailing routes of the North and the South Units, reach the waters southeast of Visakhapatnam, after which it shall appropriately operate on the waters be- 


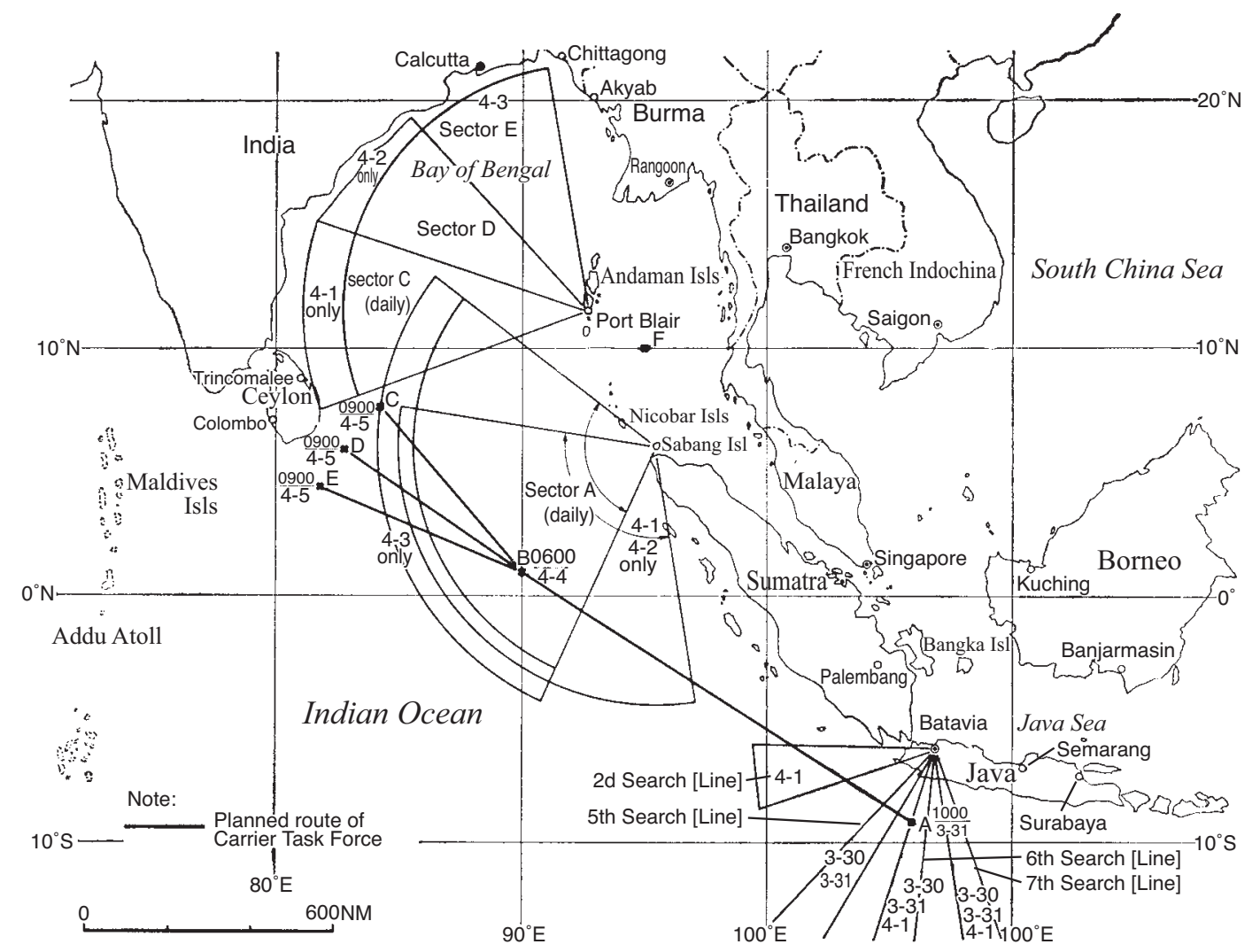

Illustration No. 59 - The Plan for the Search Missions of the Air Unit of the Southern Task Force in Operation C (Part 2)

tween [there] and near Point $\mathrm{E}$ to disrupt the enemy sea lines of communication and attack enemy naval vessels.

At 1000 on Day C + 1, the Center, North and South Units shall assemble near Point G $\left(16^{\circ} 30^{\prime} \mathrm{N}, 85^{\circ} 40^{\prime} \mathrm{E}\right)$, and return to Penang and Singapore, passing to the south of the Andaman Islands.

(2) The Guard Unit shall stay on standby near the Andaman Islands. On day C + 2 or later when the 11th Destroyer Division joins the unit, it shall appropriately leave the area and advance to the waters to the west of the Andaman Islands on Day C, to take charge of guarding the rear of the main unit. The operations thereafter shall be ordered by special orders.

(3) The Supply Unit shall stay on standby on the waters near Port Blair.

(4) In case the attack of the Carrier Task Force of the Southern Task Force should be postponed to Day C +1 , the Striking Force of the Malaya Unit shall appropriately operate on the waters to the west of the Andaman Islands, and postpone the operations specified in the previous items by one day.

Then, on the 21st, the 20th Destroyer Division commander assigned the following destroyers to be incorporated into the Center, North and South units:

The Center Unit: Y Yügiri and Asagiri

The North Unit: Shirakumo

The South Unit: Amagiri 


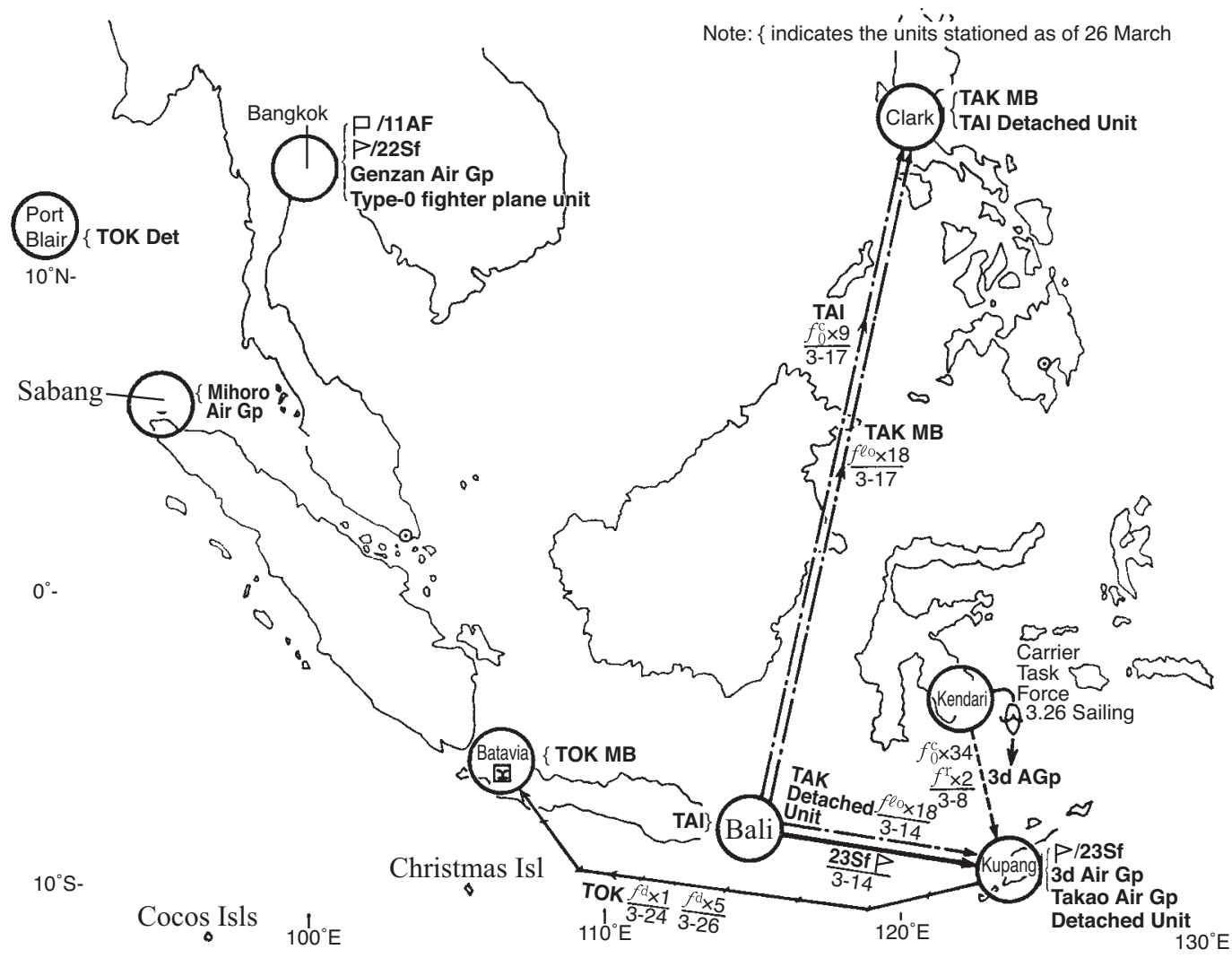

Illustration No. 60 - The Deployment of the Forces of the Air Unit of the Southern Task Force and the Shift of the Bases of the Second Air Raid Unit ([as of] 26 March)

\section{The Submarine Unit}

On 20 March, in accordance with the Southern Task Force Telegraphic Order No. 139, Submarine Unit C Commander R. Adm. Ichioka Hisashi (commander of the 2d Submarine Squadron) issued orders for Submarine Unit C. Although their contents are unclear, we may assume the deployment of the submarines to have been as follows: ${ }^{(193)}$

1. Submarine $I-7$ shall conduct air reconnaissance [with her aircraft] over Colombo and Trincomalee two days prior to the air raids.

2. Submarines $I-3$ and $I-2$ shall respectively reconnoiter Colombo and Trincomalee and report on the weather there. (The above concerns the 7th Submarine Division.)

3. The 8th Submarine Division (Submarines $I-4$ and $I-6$ ) shall reconnoiter and watch the line [connecting] the Laccadive and the Maldive Islands and the Chagos Archipelago as well as the area off Bombay, and after the success of the air raids, it shall shift to operations to disrupt the enemy sea lines of communication. 


\section{The Launch of the Operation}

\section{The Movements of the Air Unit of the Southern Task Force}

On 26 March, when Operation C was launched with the Carrier Task Force's departure from Staring Bay, the Air Unit was positioned as follows:

1. Air Unit Commander Vice Admiral Tsukahara was in Bangkok from 17 March onwards, giving directions to the Air Unit concerning the air operations connected to Operations D and U.

2. Rear Admiral Matsunaga, commander of the 3d Air Raid Unit was [also] in Bangkok from 13 March, directing the air operations of the Genzan and Mihoro Air Groups as well as the Type0 fighter plane unit attached [to the $22 \mathrm{~d}$ Air Flotilla headquarters] in relation to Operations D and $U$.

(1) The Genzan Air Group, which had been stationed in Bangkok conducting search missions over the Burma Sea and the Andaman Islands with eight land-based attack planes, shifted to search missions in the Bay of Bengal to the north of $270^{\circ}[\mathrm{W}]$ of Bangkok with four landbased attack planes from 26 March onwards.

(2) The Mihoro Air Group, which had been stationed in Sabang conducting search missions within a radius of about six hundred nautical miles from the northwest of Sabang toward the southwestern waters, shifted to search missions over the waters to the west of [Sabang] with five land-based attack planes from 26 March onwards.

3. The Tōko Air Group Detachment had advanced to the Andaman Islands on the 25th under the direct command of the Air Unit commander, where it carried out search missions over the waters of Sector A up to six hundred nautical miles from Port Blair.

4. The 2d Air Raid Unit (the 23d Air Flotilla and the main body of the Tōkō Air Group) had started its shift from 8 March onwards, took new positions by 17 March and started on its missions. ${ }^{(71)}$

(1) The 23d Air Flotilla headquarters advanced to Kupang, and directed the air campaigns mainly in the area to the north of Australia.

(2) The main body of the Takao Air Group advanced to Clark Base in mid-March, and engaged in the air operations in the Bataan and Corregidor areas.

(3) The unit dispatched from the Takao Air Group ([of] eighteen land-based attack planes) advanced to Kupang on 14 March, and started its attack on the airfield[s] of Port Darwin on 16 March.

(4) The 3d Air Group advanced to Kupang from Kendari ([with] thirty-four fighter planes and two land-based reconnaissance planes) on $8 \mathrm{March}$, whereupon it continued reconnaissance of strategic places to the north of Australia with land-based reconnaissance planes and attacks on these places with Type- 0 fighter planes. From the 16th onwards, the group covered the attacks on the area to the north of Australia conducted by the land-based attack planes of the Takao Air Group.

(5) On 5 March, with [the start of] the fourth disposition of forces of the Air Unit of the Southern Task Force, the Tōkō Air Group was put under the command of the 2d Air Raid Unit. The group was still kept at the Semau Seaplane Base in Kupang after the completion of the Java operation and conducted search missions and patrols over the Arafura Sea and the waters to the south of Java. By the 25th, eight large flying boats [of the group] had advanced to Port Blair on the Andaman Islands, while its main body advanced to Batavia by the 26th, to be ready for the operations in the Bay of Bengal as well as the Christmas Island invasion operation and the carrier operation in the Indian Ocean.

(6) The Tainan Air Group was kept at Denpasar on Bali after the completion of the Java operation, doing maintenance, conducting drills and taking some rest. In late March, nine of its Type-0 fighter planes were transferred to the Philippines with as their main task providing cover for the Takao Air Group's attacks on Corregidor from the 22d onwards. However, with 


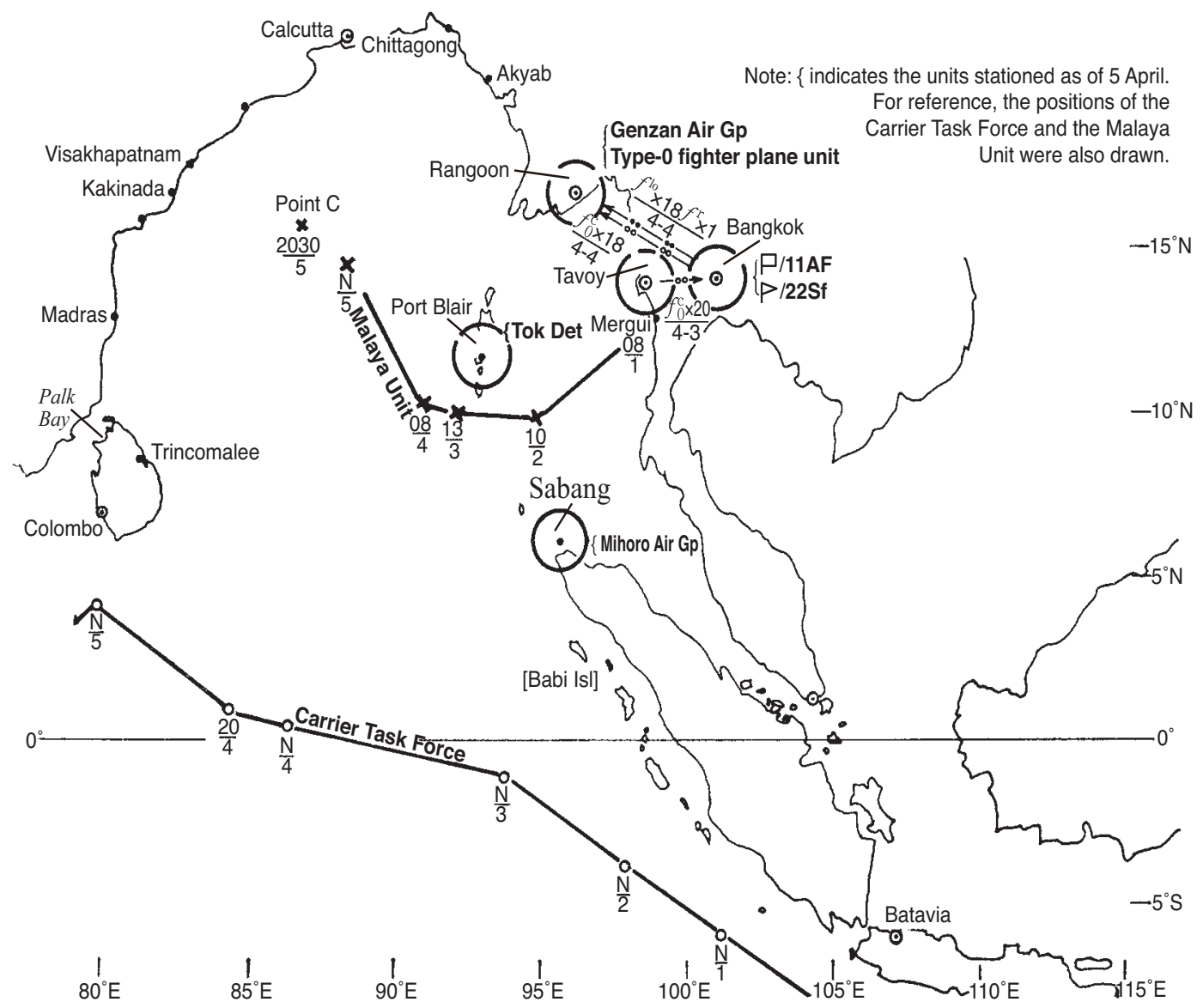

Illustration No. 61 - The Deployment of the Forces of the Air Unit of the Southern Task Force as of 5 April and the Shift of the Bases of the 3d Air Raid Unit

the reorganization of 1 April, the group was incorporated into the 25th Air Flotilla to operate in the theater southeast [of Japan; i.e. southwestern Pacific] under the command of the South Seas Unit commander (Commander in Chief of the Fourth Fleet V. Adm. Inoue Shigeyoshi), due to which the unit was no longer involved in Operation C.

\section{The Movements of Units Other Than the Carrier Task Force as of 31 March}

Eleventh Air Fleet headquarters and the 22d Air Flotilla headquarters:

Having completed their advance to Bangkok in mid-March, the Mihoro Air Group, the Genzan Air Group and one element of the Tōkō Air Group were respectively deployed to Sabang, Bangkok (part of the group to Rangoon and Tavoy) and Port Blair, and conducted search and attack missions toward Ceylon and the northern part of the Bay of Bengal.

\section{Submarine Unit (2d Submarine Squadron):}

Deployed Submarines $I-2, I-3$ and $I-7$ respectively off Trincomalee and off Colombo, and on the waters to the southeast of Ceylon, while deploying Submarines I-4 and I- 6 off the west coast of India to watch and guard. 


\section{The Main Body of the Southern Task Force:}

Was at anchor in the port of Seletar [Singapore], due to depart from the port on the early morning of 2 April.

\section{The Striking Force of the Malaya Unit:}

Was at anchor in Mergui (southern part of Burma), due to depart from the port on 1 April.

\section{The Advance of the Carrier Task Force of the Southern Task Force}

Under the [overall] cover provided by the Air Unit of the Southern Task Force, the Carrier Task Force left Staring Bay at 0800 on 26 March and sailed toward Ceylon, heavily guarding its sailing route ahead with carrier-based attack planes and guarding itself against enemy submarines with carrier-based attack planes or bombers.

In the meantime, the Christmas Island invasion unit had left Bantam Bay on the 29th and occupied the island on the 31st, the same day that the Carrier Task Force passed the waters one hundred nautical miles to the north of the Island.

On 1 April, an aircraft of the Eleventh Air Fleet reported:(119, 194) "1005; three enemy merchantmen (10,000-ton class each), and one minesweeper are sailing northward [along] the northwestern coast of Ceylon at eight knots." "1030: In Palk Bay, no enemy naval vessels or aircraft were spotted other than two [enemy] merchantmen (4,000-ton class) at anchor." "No enemy aircraft were spotted at the airfield or the seaplane base near Trincomalee, no patrolling aircraft or antiaircraft fire, either." [Later] at 2330 on the same day, the flagship of the $2 \mathrm{~d}$ Submarine Squadron (Submarine $I-7$ ) reported that the enemy antisubmarine guard was very strict in the Colombo area. On 2 April, Submarine I-7 again reported that the guard outside the port of Colombo was so strict that it was impossible to reconnoiter the inside of the port; on the situation of incoming and outgoing vessels it reported (one ship on the $2 \mathrm{~d}$ and another on the $3 \mathrm{~d}$ ) etc. Then at 0000 on the $3 \mathrm{~d}$, Submarine $I-7$ reported that it had called off the air reconnaissance [with her aircraft]. ${ }^{(141)}$

On 3 April, after having completed its last refueling, the Carrier Task Force dropped the Ken'yo-maru and the Nippon-maru from the line, and sailed closer toward Ceylon, while tightening its guard. On that day, Carrier Task Force Commander Vice Admiral Nagumo issued an order that the aircraft formation for the attack on Colombo should be the 1st [type] formation (formation details unclear) and the armament the $2 \mathrm{~d}$ [type] armament, while announcing that if enemy battleships should be spotted at anchor at the time of attack, the force should carry out the second attack with 1st [type] armament on that afternoon or before dawn of the next day. Meanwhile on that day, the commander of the Air Unit of the Southern Task Force ordered the land-based attack planes of the Genzan Air Group as well as one element of the fighter plane unit detached from the Kanoya Air Group and its land-based reconnaissance unit to conduct reconnaissance attacks in the Calcutta and the Akyab areas (from 4 until 7 April). ${ }^{(141)}$

At 0840 on 4 April, the Carrier Task Force commander ordered by signal: "Keep a strict guard. Keep the standby fighter planes on 1st standby, but the crews do not need to wait on board their planes." At 1205, a report from Submarine I-2 was received that the enemy's guard outside the bay of Trincomalee was very tight. At 1855, the Hiei spotted an enemy flying boat to her north and immediately opened fire, also to alert friendly units. Responding 
to the alert, Type-0 fighter planes on standby (three from each carrier, except for the Hiryu, who launched six, totaling eighteen aircraft) took off from the carriers all at once, and at 1920, they forced the enemy flying boat to make an emergency landing. However, during that time, the enemy aircraft had been monitored sending out messages in the clear that [the Japanese force consisted of] three battleships and one carrier on a $305^{\circ}$ [NW] course. Since the enemy aircraft had landed on the water at 1922 due to fire, the Isokaze of the Guard Unit immediately approached and took the crew prisoner. The enemy aircraft had probed our fleet for twentyseven minutes, during which it radioed our movements, which wireless stations at Colombo, Bombay and Aden relayed. At 1945, all Type-0 fighter planes returned. Although the enemy patrol aircraft had been brought down, it became certain through intercepted messages that it had [already] reported our movements. ${ }^{(158)}$ Now that [the enemy] knew [our intentions] because of our reconnaissance, considerably strong counterattacks might be expected, but it was nevertheless decided that the air raid on Colombo should be carried out as scheduled. The formation of the attack units was as shown in the following table:*(75,191,192)

\begin{tabular}{|c|c|c|c|c|c|c|}
\hline & & Unit & & Commander & Forces & Mission \\
\hline \multirow{9}{*}{ 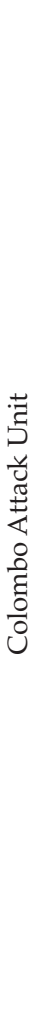 } & 1st Group & 1st Attack Unit & \multirow{9}{*}{ 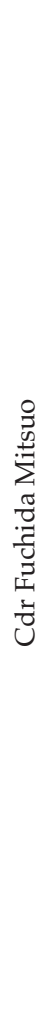 } & & $\begin{array}{l}17 \text { Carrier-based at- } \\
\text { tack planes of } A k a g i\end{array}$ & \multirow{3}{*}{$\begin{array}{l}\text { Bombing ground facilities } \\
\text { and [enemy] naval vessels }\end{array}$} \\
\hline & \multirow{2}{*}{ 2d Group } & 4th Attack Unit & & $\begin{array}{l}\text { Lt Cdr Kusumi } \\
\text { Masashi }\end{array}$ & $\begin{array}{l}18 \text { Carrier-based at- } \\
\text { tack planes of Hiry } \bar{u}\end{array}$ & \\
\hline & & 3d Attack Unit & & Lt Abe Heijirō & $\begin{array}{l}18 \text { Carrier-based at- } \\
\text { tack planes of } S \bar{o} r y \bar{u}\end{array}$ & \\
\hline & \multirow{2}{*}{ 7th Group } & $\begin{array}{l}\text { 16th Attack } \\
\text { Unit }\end{array}$ & & Lt Sakamoto Akira & $\begin{array}{l}19 \text { Carrier-based } \\
\text { bombers of Zuikaku }\end{array}$ & \multirow{2}{*}{$\begin{array}{l}\text { Bombing and strafing } \\
\text { enemy naval vessels at an- } \\
\text { chor and facilities on the } \\
\text { onshore airfield }\end{array}$} \\
\hline & & $\begin{array}{l}\text { 15th Attack } \\
\text { Unit }\end{array}$ & & $\begin{array}{l}\text { Lt Cdr Takahashi } \\
\text { Kakuichi }\end{array}$ & $\begin{array}{l}19 \text { Carrier-based } \\
\text { bombers of Shōkaku }\end{array}$ & \\
\hline & \multirow{3}{*}{ 9th Group } & $\begin{array}{l}\text { 1st Air Control } \\
\text { Unit }\end{array}$ & & $\begin{array}{l}\text { Lt Cdr Itaya } \\
\text { Shigeru }\end{array}$ & $\begin{array}{l}9 \text { Carrier-based } \\
\text { Type- } 0 \text { fighter planes } \\
\text { of } A k a g i\end{array}$ & \multirow{3}{*}{$\begin{array}{l}\text { Direct cover of the 1st and } \\
\text { the } 2 \mathrm{~d} \text { Parties } \\
\text { Destroying enemy aircraft } \\
\text { Strafing ground [facilities } \\
\text { etc.] }\end{array}$} \\
\hline & & $\begin{array}{l}\text { 3d Air Control } \\
\text { Unit }\end{array}$ & & Sublt Fujita Iyozō & $\begin{array}{l}9 \text { Carrier-based } \\
\text { Type- } 0 \text { fighter planes } \\
\text { of } S \bar{o} r y \bar{u}\end{array}$ & \\
\hline & & $\begin{array}{l}\text { 4th Air Control } \\
\text { Unit }\end{array}$ & & Lt Nōno Sumio & $\begin{array}{l}9 \text { Carrier-based } \\
\text { Type- } 0 \text { fighter planes } \\
\text { of Hiry } \bar{u}\end{array}$ & \\
\hline & $\begin{array}{l}\text { 10th } \\
\text { Group }\end{array}$ & $\begin{array}{l}\text { 6th Air Control } \\
\text { Unit }\end{array}$ & & $\begin{array}{l}\text { Lt Makino } \\
\text { Masatoshi }\end{array}$ & $\begin{array}{l}9 \text { Carrier-based } \\
\text { Type-0 fighter planes } \\
\text { of Zuikaku }\end{array}$ & $\begin{array}{l}\text { Direct cover of the 1st } \\
\text { Party and strafing ground } \\
\text { [facilities] }\end{array}$ \\
\hline
\end{tabular}

* The author bases his account of the attacks on Colombo and Trincomalee mainly on the "Greater East Asia War's Lessons of War," and the "Action Reports" of the 5th Carrier Division and the carrier Hiryū. Since we found a number of discrepancies and inconsistencies in the tables and the text that mainly concern the number of planes and the names or ranks of officers involved, we consulted the action reports of the other carriers, which may not have been available to the author at that time, and corrected the text and tables where necessary. 
To be ready against the appearance of enemy vessels, carrier-based attack planes and bombers were kept on standby on the decks, of which the formation of the carrier-based bombers was as shown in the next table.

\begin{tabular}{|c|c|c|c|c|}
\hline 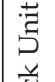 & $\begin{array}{c}\text { 11th Attack } \\
\text { Unit }\end{array}$ & Lt Abe Zenji & $\begin{array}{l}17 \text { Carrier-based } \\
\text { bombers of } A \text { kagi }\end{array}$ & \multirow{3}{*}{$\begin{array}{l}\text { Destroying enemy naval } \\
\text { vessels }\end{array}$} \\
\hline $\begin{array}{l}\varangle \\
\infty \\
\mathbb{D} \\
w \\
0 \\
d\end{array}$ & $\begin{array}{c}\text { 13th Attack } \\
\text { Unit }\end{array}$ & $\begin{array}{c}\text { Lt Cdr Egusa } \\
\text { Takashige }\end{array}$ & $\begin{array}{l}18 \text { Carrier-based } \\
\text { bombers of Sōryū }\end{array}$ & \\
\hline 䒕 & $\begin{array}{c}\text { 14th Attack } \\
\text { Unit }\end{array}$ & $\begin{array}{l}\text { Lt Kobayashi } \\
\text { Michio }\end{array}$ & $\begin{array}{l}18 \text { Carrier-based } \\
\text { bombers of Hiry } \bar{u}\end{array}$ & \\
\hline
\end{tabular}

For reference: The regular number of the aircraft on each carrier of the 1st, $2 \mathrm{~d}$ and 5 th Carrier Divisions were as shown in the following table (the first number before "/" is the regular number and the latter number is the number of spare aircraft. $)^{(187)}$

\begin{tabular}{|c|c|c|c|c|c|c|}
\hline Carrier Div & Mothership & Fighter Planes & Bombers & Attack Planes & Total & Grand Total \\
\hline 1st Carrier Div & Akagi & $18 / 3$ & $18 / 3$ & $27 / 3$ & $63 / 9$ & \\
\hline \multirow{2}{*}{ 2d Carrier Div } & Sōryū & $18 / 3$ & $18 / 3$ & $18 / 3$ & $54 / 9$ & \\
\cline { 2 - 7 } & Hiryū & $18 / 3$ & $18 / 3$ & $18 / 3$ & $54 / 9$ & \multirow{2}{*}{$315 / 45$} \\
\hline \multirow{2}{*}{ 5th Carrier Div } & Shōkaku & $18 / 3$ & $27 / 3$ & $27 / 3$ & $72 / 9$ & \\
\cline { 2 - 7 } & Zuikaku & $18 / 3$ & $27 / 3$ & $27 / 3$ & $72 / 9$ & \\
\hline \multirow{2}{*}{ Total } & & $90 / 15$ & $108 / 15$ & $117 / 15$ & & \\
\hline
\end{tabular}

\section{The Air Raid on Colombo; the Sinking of Two [Enemy] Heavy Cruisers (75, 100, 141, 158, 191, 192)}

The 5th of April; it was fair with a southwestern wind at a velocity of seven meters per second; there was good visibility and sunrise was at 0931. At 0900, the 1st Section of the 3d Battleship Division, the 8th Cruiser Division and the Abukuma each launched one of their reconnaissance seaplanes, which headed for search missions over the waters to the west of the Carrier Task Force. Simultaneously, the first units for the attack on Colombo and the aircraft of the direct air escort [of the carriers] began to take off. At 0945, an aircraft of the Hiry $\bar{u}$ in the Attack Unit signaled: "0938: Enemy aircraft spotted. One [enemy] flying boat at fortythree nautical miles $346^{\circ}$ of the starting point, on a $180^{\circ}$ course." The enemy flying boat, which had been probing the Carrier Task Force by skillfully making use of the dense clouds, was brought down at 1046 by aircraft of the Hiryū's direct air escort.

Fifty-three Type-97 carrier-based attack planes and thirty-eight Type-99 carrier-based bombers of the units for the attack on Colombo entered the air over Colombo escorted by 
thirty-six Type-0 fighter planes, and at 1045, Commander Fuchida, the general commander, gave the "all go." Since the enemy was waiting for them in the air with dozens of Spitfire and Hurricane fighter planes, a fierce air battle broke out right away between [the enemy] and the Japanese fighter planes. In a thirty minutes' engagement, the Japanese Type- 0 fighter planes reported having brought down nineteen Spitfires, twenty-one Hurricanes, ten Swordfish (carrying torpedoes) and one Defiant, a total of fifty-one aircraft (of which nine were unconfirmed). The loss sustained by the Japanese fighter planes was one plane that had crashed itself.

During this period, first of all the carrier-based bomber unit started bombing the Colombo airfield, tankers, merchantmen and other targets. However, the weather at that time was very bad, and it was rather difficult to carry out the bombing. After the attack, the unit came under a sudden attack of more than a dozen enemy fighter planes; while it reported having brought down six Hurricanes, five carrier-based bombers of the Zuikaku and one carrier-based bomber of the Shōkaku crashed themselves. The military gains reported by this bombing attack were four large merchantmen, one small cargo ship and one hangar, which were set ablaze, and one tanker, two hangars and one repair shop, which were blown up. Next, the carrier-based attack plane unit entered the air over Colombo and carried out bombing attacks on ships in the port, piers, naval office[s], barracks and other targets between 1056 and 1113. [The unit] sank or caused damage to several large merchantmen and one small merchantman, while blowing up piers and railways. At 1128, the general commander's aircraft reported: “1118: Would like you to prepare the second sortie. Twenty transport ships spotted in the port. Also, antiaircraft fire on the ground. [Spotted] some enemy aircraft. Dense clouds at an altitude of 1,000 [meters]." Having received this report, Carrier Task Force Commander Vice Admiral Nagumo gave at 1152 the order: "[Ready] the 3d Formation [unit] ([and] six aircraft for each carrier to control the air) with the $3 \mathrm{~d}$ Armament. [Aircraft] shall be launched after recovering the $2 \mathrm{~d}$ Formation [unit]." Due to this order, the carrier-based attack plane unit, which had been on standby armed with torpedoes, were made to hastily change them to bombs. After assembling in the air over Point de Galle one after another, the units for the attack on Colombo headed back to the force. At 1233, the Carrier Task Force commander ordered 5th Carrier Division Commander Rear Admiral Hara to launch (an appropriate number of) carrier-based attack planes to form an east-west [guiding] line for returning aircraft at fifty nautical miles to the north of the Carrier Task Force. In accordance with this order, the 5th Carrier Division commander had both carriers launch three carrier-based attack planes each (a total of six aircraft) at 1236, and had them form an east-west [guiding] line for the returning [aircraft], positioning them at a distance of 10 kilometers from each other at fifty nautical miles to the north of the main unit. The attack units returned one after another between 1248 and 1325 (six carrier-based bombers and one carrier-based fighter plane did not return), and the aircraft which had formed the [guiding] line for the returning [aircraft] returned at 1550. In the meantime, at 1300, a Type-94 reconnaissance seaplane of the Toné, which was searching for the enemy over the waters to the west of the Carrier Task Force, had spotted vessels that looked like enemy cruisers at $3^{\circ} 1^{\prime} \mathrm{N}, 77^{\circ} 58^{\prime} \mathrm{E}$. “Two enemy cruiser-like vessels spotted at 150 nautical miles $268^{\circ}$ of the starting point, on a $160^{\circ}$ course at twenty knots." On reception of this report, Carrier Task Force Commander Vice Admiral Nagumo immediately had one Type- 0 reconnaissance seaplane each of the Toné and the Chikuma launched for probing and issued the following preparatory order of attack at 1323: "The 3d Formation [unit] shall attack the enemy cruisers. Carrier-based attack planes shall conduct the attack with torpedoes as 


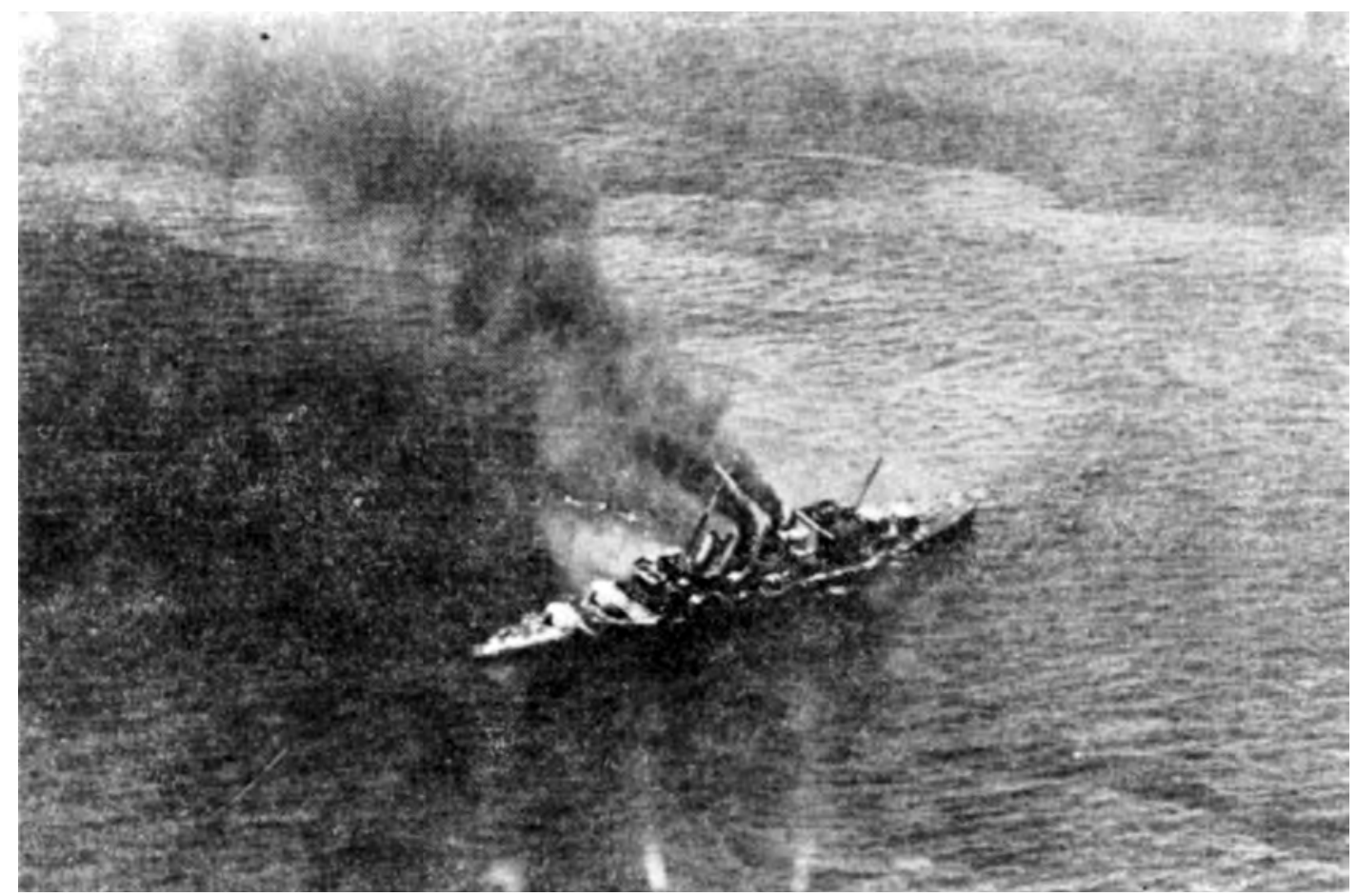

HMS Cornwall About to Sink

far as possible." Accordingly, the carrier-based attack planes, which had been in the middle of changing their armament to bombs, were supposed to again replace them with torpedoes. Following that, the commander [successively] issued orders: "1330: Report the available launching time of the 3d Formation [unit] (minus the Air Control Unit);" then, "1350: The 2d Formation [unit] (minus the Air Control Unit) shall stay on standby in the hangar after the takeoff of the $3 \mathrm{~d}$ Formation [unit] (minus the Air Control Unit). The carrier-based attack planes shall conduct a torpedo attack. Adjust the running depth to three meters." Replying to the Carrier Task Force commander's request to report the available launching time, 5th Carrier Division Commander Rear Admiral Hara reported: (1357:) "Ready to launch at 1600."

At 1350, the aircraft of the Abukuma reported: "Two [enemy] destroyers sailing at 200 nautical miles $250^{\circ}$ of the starting point." At 1418, Carrier Task Force Commander Vice Admiral Nagumo gave the following order for the sortie of the Attack Unit: "The 3d Formation [unit] (minus the Air Control Unit) shall take off at 1500 and attack the enemy cruisers at $235^{\circ}$. They are sailing on a $200^{\circ}$ course at twenty-four knots. Any plane that cannot get ready in time follows [when ready]." However, at that time, the aircraft of the Abukuma reported that no enemy was spotted [other than the above], and doubt arose that the aircraft of the Toné had mistook [enemy] destroyers for cruisers. The captain of the Abukuma ordered [his aircraft] to continue the search mission near the enemy just to be sure. At 1427, the Carrier Task Force commander [changed] his order: "The earlier [report of] 'cruisers' was a mistake for 'destroyers.' Only the carrier-based bombers of the 3d Formation [unit] shall take off." Accordingly, seventeen carrier-based bombers of the Akagi took off at 1449, which was followed by eighteen carrier-based bombers of the Hiry $\bar{u}$ and eighteen of the Sōry $\bar{u}$ respectively at 1459 and at 1503. 


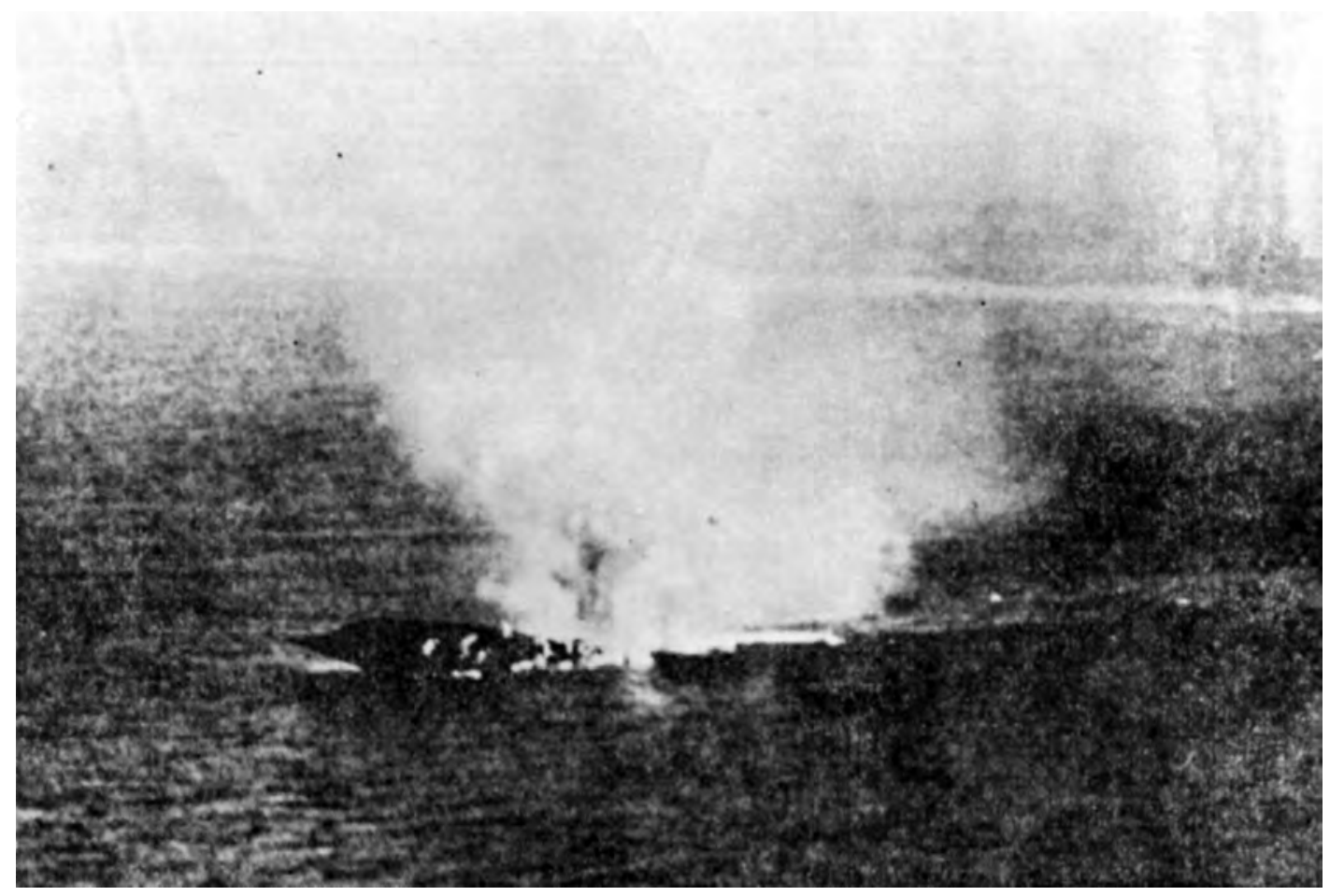

HMS Dorsetshire Capsized and Sinking

At 1455, a Type-0 reconnaissance seaplane of the Toné, which had gone probing, spotted the enemy and reported: "1455: Spotted two enemy cruisers at 158 nautical miles $235^{\circ}$ of the starting point. Sailing on a $200^{\circ}$ course at twenty-six knots." Receiving this, the captain of the Toné wirelessed her aircraft: "Confirm the type of the enemy [vessels]. They can be destroyers, can't they?" At 1556, the reply of the aircraft of the Toné came in: "1545: Enemy cruisers are HMS Kent-class. No other enemy [vessels] are spotted in their vicinity. Visibility 30 nautical miles." Having received this telegram, Carrier Task Force Commander Vice Admiral Nagumo ordered at 1610: "The enemy cruisers are of the HMS Kent-class. The 5th Carrier Division shall attack them with about one half of its carrier-based attack planes and bombers," while ordering the aircraft of the Toné to guide them. At 1625, 5th Carrier Division Commander Rear Admiral Hara ordered: "The Attack Unit shall take off at 1700. Target: the Kent-class cruisers. Attack course 200' [SSW], distance to target 150 nautical miles."

Earlier at 1554, the commander plane of the carrier-based bomber unit (Lt. Cdr. Egusa Takashige) had wirelessed: "Enemy spotted." Then at 1629, he ordered [his unit]: "Go! Assault Tactics No. 2. Bombing direction: $50^{\circ}$. Wind from $230^{\circ}$, velocity six meters [per second]." The carrier-bomber unit skillfully approached the enemy from the direction of the sun, carried out a surprise bombing on the enemy heavy cruisers from 1638 until 1655. Having scored hits with most of the bombs, the unit sank them at 1658. It was a truly superbly executed attack.

Concerning these [attacks], the then British Prime Minister [Sir Winston] Churchill wrote the following in his book The Second World War:*

* W. S. Churchill, The Second World War, Volume IV, The Hinge of Fate, Book I, The Onslaught of Japan, Chapter X, Ceylon and the Bay of Bengal, p. 160. 
Japanese success and power in naval air warfare were formidable. In the Gulf of Siam two of our first-class capital ships had been sunk in a few minutes by torpedo aircraft. Now two important cruisers had also perished by a totally different method of air attack — the dive-bomber. Nothing like this had been seen in the Mediterranean in all our conflicts with the German and Italian Air Forces.

Having received the report of the sinking of the large enemy cruisers, the second sortie unit, which was supposed to take off at 1700, was made to stay on 1 st standby at 1702 . Then after receiving the report from the aircraft of the Toné at 1705, "Advanced fifty nautical miles to the southwest of the enemy cruisers, but no enemy spotted," the sortie of the unit was called off. All aircraft of the first sortie unit safely returned by 1745 , and the attack on that day was wrapped up. Then at 1909, a friendly surface vessel signaled that she had spotted enemy aircraft, which the aircraft directly escorting the carriers in the air had not been able to spot. At 1929, six Type-0 fighter planes of the Hiryu $\bar{u}$ took off, spotted two Swordfish, brought down one of them but let the other slip away out of sight in the direction of the sun. No enemy was spotted thereafter, and the engagements for that day were over. At 2158, the staff of the Carrier Task Force signaled the total military gains on the 4th and the 5th to the vessels of the force as follows:

1. Brought down two probing PBYs and one Fairey Albacore

2. At Colombo

(1) Brought down a total of 57 aircraft, of which 9 were not confirmed.

Aircraft 19 Spitfires

27 Hurricanes

10 Swordfish (carrying torpedoes)

1 Defiant

(2) Set one hangar ablaze and caused damage to two, also caused serious damage to one repair shop.

(3) Inflicted serious damage on five large merchantmen, which caught fire, and blew up more than a dozen small merchantmen.

(4) Blew up part of the governmental area and pier[s].

3. By the probing and under the guidance of the reconnaissance seaplanes, carrier-based bombers instantly sank two HMS Cumberland-class large cruisers.

4. At Colombo

One carrier-based fighter plane of the Sōryū, five carrier-based bombers of the Zuikaku and one carrier-based bomber of the Shōkaku met a heroic end by crashing themselves.

The following table illustrates the on-target rate and the situation of the hits in the attack on [enemy] large cruisers on that day:

\begin{tabular}{|c|c|c|c|c|c|}
\hline $\begin{array}{c}\text { Number of } \\
\text { Attack Planes }\end{array}$ & $\begin{array}{c}\text { Number of } \\
\text { bombs dropped }\end{array}$ & $\begin{array}{c}\text { Number of } \\
\text { bombs on target }\end{array}$ & On-t & & Notes \\
\hline Akagi: 17 & 16 & 15 & 94 & \multirow{3}{*}{88} & \multirow{3}{*}{$\begin{array}{l}\text { One of the carrier-based } \\
\text { bombers of the Akagi dic } \\
\text { not release its bomb. }\end{array}$} \\
\hline Sōryū:18 & 18 & 14 & 78 & & \\
\hline Hiryū: 18 & 18 & 17 & 94 & & \\
\hline
\end{tabular}




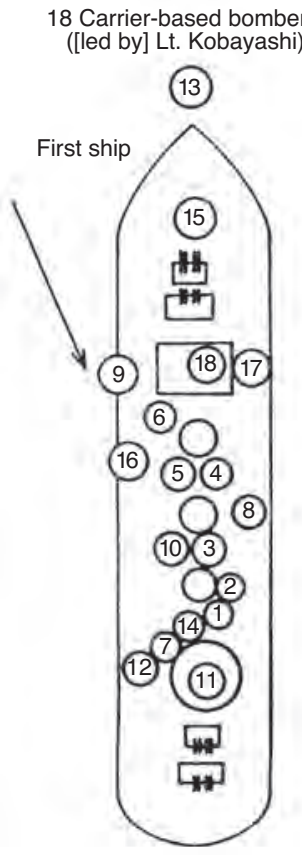

Illustration No. 62 - The Bombing of the [Enemy]

Cruisers by the Carrier-based Bombers of the Hiry $\bar{u}$
The bewildering changes of armament for the carrier-based attack unit, from the initially-planned bombs to torpedoes, and then to bombs and back again to torpedoes, left behind a serious problem. However, only in the 5th Carrier Division's Action Report No. 5, it was mentioned under item three, "The standby situation of the carrier-based attack planes," of the matters that had affected operations. Hidden behind the successful attack on the [enemy] heavy cruisers, it does not seem to have been dealt with as a big problem at that time. However, the same situation occurred later in the Battle of Midway, in which the changes of armament delayed the takeoff of the aircraft and the Japanese carrier group was hit by a surprise attack of enemy dive-bomber units. The attack induced successive explosions of torpedoes loaded on the carrier-based attack planes on deck, leading to the tragedy of losing at one stroke four aircraft carriers (the Akagi, the Kaga, the Sōry $\bar{u}$ and the Hiry $\bar{u})$, who had won consecutive victories. The excerpt of "The standby situation of the carrier-based attack planes" in the Action Report of the 5th Carrier Division reads as follows:

In accordance with Carrier Task Force Signal Order No. 75 [sent] at 2303 on the 4th, the carrier-based attack plane units changed their armament from bombs to torpedoes (note by the author: since it had been spotted by a patrolling enemy flying boat on the 4th, the task force had changed its air raid plan), and [the units on] both vessels completed their change of armament by 0630 . To be prepared against

an enemy surface vessel attack, the [attack plane] unit was kept on standby in the hangar after the takeoff of the carrier-based bomber unit.

1010: A report came from the Colombo Attack Unit: "A number of enemy merchantmen were spotted in the port. A second sortie is required."

1210: According to the order from the Carrier Task Force commander to "immediately change the armament to bombs (No. 80 land bombs)," [the unit] started changing the armament.

1305: A report came that two large enemy cruisers were spotted. Then,

1323: [Another] order [was issued] "The 3d Formation [unit] shall attack the enemy cruisers.

The carrier-based attack plane unit shall change its armament to torpedoes as far as possi-

ble," according to which the units in the midst of [fitting bombs] again started putting torpedoes back on. This was followed by:

1415: "The 3d Formation [unit] (minus the Air Control Unit) shall take off at 1500 to attack the enemy cruisers. Any plane that cannot get ready in time, follows [when ready]."

1427: "The cruisers in the earlier [report] were a mistake for destroyers. Only the carrier-based bomber unit of the 3d Formation [unit] shall take off."

1610: On receiving the order that "The enemy cruisers were HMS Kent-class. The 5th Carrier

Division shall attack them with about one half each of its carrier-based attack planes and bombers."

1625: The order was given: "The Attack Unit shall take off at 1700. The target: the HMS Kentclass cruisers. Attack course $200^{\circ}$, distance to target 150 nautical miles."

1656: On receiving the report that the two large cruisers had sunk:

1657: [We ordered,] "Hold the launch for a moment!" after which [we] issued the order to remain on 1st standby. 
1720: According to the order of the Carrier Task Force commander, [we] kept the unit on standby in the hangar.

The time required to switch the armament between torpedoes and bombs of the eighteen Type-97 carrier-based attack planes studied by the Hiry $\bar{u}$ was as shown in the following table:[(75)]

\begin{tabular}{|c|c|c|c|}
\hline No. & Changes & $\begin{array}{l}\text { Time Required } \\
\text { (Hour-Min.) }\end{array}$ & Notes \\
\hline 1 & Torpedo $\rightarrow 2 \times$ No. 25 bombs & $2: 30$ & \multirow{3}{*}{$\begin{array}{l}\text { Bombs were [already] } \\
\text { brought to the hangar, } \\
\text { ready to be loaded }\end{array}$} \\
\hline 2 & Torpedo $\rightarrow 1 x$ No. 80 regular bomb & $1: 30$ & \\
\hline 3 & Torpedo $\rightarrow 1 x$ No. 80 Mark 5 bomb & $2: 30$ & \\
\hline 4 & Bombs $(2 x$ No. 25$) \rightarrow$ Torpedo (or 1 x No. 80 regular bomb) & 2:00 & \multirow{3}{*}{$\begin{array}{l}\text { Torpedoes were brought } \\
\text { to the hangar, ready to be } \\
\text { loaded }\end{array}$} \\
\hline 5 & Bomb $(1 \times$ No. 80 regular bomb $) \rightarrow$ Torpedo & 2:00 & \\
\hline 6 & Bomb $(1 \times$ No. 80 Mark 5 bomb $) \rightarrow$ Torpedo & $1: 30$ & \\
\hline
\end{tabular}

According to the Action Report of the 5th Carrier Division, the situation of the enemy in the attack on the 5 th was as follows.

1. The enemy anticipated our attack and deployed several dozens of fighter planes for the defense in the air.

2. The antiaircraft fire from the ground was very fierce.

3. More than ten twin-engine large bombers and about twenty fighter planes were on the airfield.

4. About thirty large and small merchantmen as well as three destroyers were spotted in and outside the port of Colombo; the merchantmen were all armed.

5. At the time of our attack and pullback, [our unit] came under a considerably fierce attack by more than ten enemy Hurricane fighter planes.

6. In order to attack the Carrier Task Force, the enemy had launched ten aircraft of their torpedo attack [plane] unit (Swordfish).

7. Since two aircraft, which looked like enemy carrier-based biplanes, came to probe us on the evening of the 5 th, we suspected the presence of enemy carrier[s] near us.

Thus, the Carrier Task Force successfully completed the attacks on Colombo, pulled back in a southeastern direction, and then sailed north on the waters outside a radius of 450 nautical miles from Ceylon for an attack on Trincomalee. The [enemy] heavy cruisers it had sunk were later identified as the HMS Dorsetshire and the HMS Cornwall.

The Air Strike on Trincomalee; the Sinking of One Small Aircraft Carrier ${ }^{(75,100,158,191,192,194)}$

In view of the movements of the heavy enemy cruisers on 5 April, Carrier Task Force Commander Vice Admiral Nagumo judged it very likely that enemy aircraft carrier[s] were deployed in the area; he took a detour around the waters outside a radius of 450 nautical miles from Ceylon and headed for Trincomalee, while particularly tightening his guard. However, except for an enemy flying boat spotted on the 6th at seventy nautical miles $350^{\circ}[\mathrm{N}]$ of the 
Akagi by an aircraft of the Hiryu which was on a search mission, no enemy was spotted on [the 6th and] also on the 7th. At 1820 on the 8th, the Abukuma spotted at 35,000 meters $260^{\circ}$ $[W]$ of her a probing enemy flying boat and opened fire, but she lost sight of it at 1835, and the fighter planes that headed to attack it also let it slip away due to a squall. At 2000 on that day, through intelligence sent by the Takao Signal Unit, the Carrier Task Force learned that the enemy [flying boat] had sent a telegram: "1900: Spotted three battleships and one aircraft carrier on a $350^{\circ}$ course at 260 nautical miles $90^{\circ}$ [E of us]."

Although the Carrier Task Force learned that it had been spotted by the enemy, it continued to sail toward Trincomalee to attack the place as scheduled. The formation of the units for the Trincomalee attack was as follows:

1. Trincomalee Attack Unit (as shown in the following table)

\begin{tabular}{|c|c|c|c|c|c|c|}
\hline \multicolumn{3}{|c|}{ Unit } & & Commander & Forces & Tasks (Targets) \\
\hline \multirow{5}{*}{ 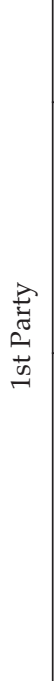 } & $\vec{\omega}$ & $\begin{array}{l}\text { 1st Attack } \\
\text { Unit }\end{array}$ & \multirow{10}{*}{ 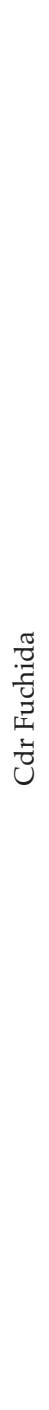 } & & $\begin{array}{l}18 \text { Carrier-based at- } \\
\text { tack planes of } A k a g i\end{array}$ & Naval arsenal and vicinity \\
\hline & $\begin{array}{l}\text { Oे } \\
0\end{array}$ & $\begin{array}{l}\text { 4th Attack } \\
\text { Unit }\end{array}$ & & Lt Cdr Kusumi & $\begin{array}{l}18 \text { Carrier-based at- } \\
\text { tack planes of Hiry } \bar{u}\end{array}$ & $\begin{array}{l}\text { Official residence of the commander } \\
\text { in chief of Ceylon, barracks to its } \\
\text { south, antiaircraft battery }\end{array}$ \\
\hline & స్త & $\begin{array}{l}\text { 3d Attack } \\
\text { Unit }\end{array}$ & & Lt Abe & $\begin{array}{l}18 \text { Carrier-based at- } \\
\text { tack planes of Sōry } \bar{u}\end{array}$ & Naval arsenal and vicinity \\
\hline & 2 & $\begin{array}{l}\text { 5th Attack } \\
\text { Unit }\end{array}$ & & $\begin{array}{l}\text { Lt Ichihara } \\
\text { Tatsuo }\end{array}$ & $\begin{array}{l}19 \text { Carrier-based at- } \\
\text { tack planes of } \\
\text { Shōkaku }\end{array}$ & $\begin{array}{l}\text { Onshore airfield and the vicinity of } \\
\text { the seaplane base }\end{array}$ \\
\hline & $\frac{\tilde{n}}{\tilde{n}}$ & $\begin{array}{l}\text { 6th Attack } \\
\text { Unit }\end{array}$ & & $\begin{array}{l}\text { Lt Cdr Shimazaki } \\
\text { Shigekazu }\end{array}$ & $\begin{array}{l}18 \text { Carrier-based at- } \\
\text { tack planes of } \\
\text { Zuikaku }\end{array}$ & $\begin{array}{l}\text { Battery and barracks at Flagstaff } \\
\text { Point and the area of the naval com- } \\
\text { mander's official residence and the } \\
\text { governor's residence to its south }\end{array}$ \\
\hline \multirow{5}{*}{ 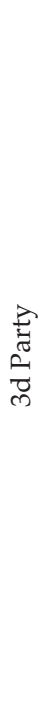 } & 1st Ai & Control Unit & & Lt Cdr Itaya & $\begin{array}{l}6 \text { Carrier-based } \\
\text { Type- } 0 \text { fighter } \\
\text { planes of } A k a g i\end{array}$ & Direct escort of the 1st Party \\
\hline & $3 \mathrm{~d} \mathrm{Ai}$ & Control Unit & & $\begin{array}{l}\text { Lt Suganami } \\
\text { Masaji }\end{array}$ & $\begin{array}{l}6 \text { Carrier-based } \\
\text { Type- } 0 \text { fighter } \\
\text { planes of Sōryū }\end{array}$ & \multirow{2}{*}{$\begin{array}{l}\text { Control of the air } \\
\text { Attack on the seaplane base }\end{array}$} \\
\hline & \multicolumn{2}{|c|}{$\begin{array}{l}\text { 4th Air Control } \\
\text { Unit }\end{array}$} & & $\begin{array}{l}\text { Sublt Shigematsu } \\
\text { Yasuhiro }\end{array}$ & $\begin{array}{l}6 \text { Carrier-based } \\
\text { Type- } 0 \text { fighter } \\
\text { planes of Hiry } \bar{u}\end{array}$ & \\
\hline & \multicolumn{2}{|c|}{$\begin{array}{l}\text { 6th Air Control } \\
\text { Unit }\end{array}$} & & Lt Makino & $\begin{array}{l}10 \text { Carrier-based } \\
\text { Type-0 fighter } \\
\text { planes of Zuikaku }\end{array}$ & \multirow{2}{*}{$\begin{array}{l}\text { Control of the air } \\
\text { Attack on the onshore airfield }\end{array}$} \\
\hline & \multicolumn{2}{|c|}{$\begin{array}{l}\text { 5th Air Control } \\
\text { Unit }\end{array}$} & & $\begin{array}{l}\text { Lt Kaneko } \\
\text { Tadashi }\end{array}$ & $\begin{array}{l}10 \text { Carrier-based } \\
\text { Type-0 fighter } \\
\text { planes of Shōkaku }\end{array}$ & \\
\hline
\end{tabular}


2. Unit for Attacking Enemy Vessels

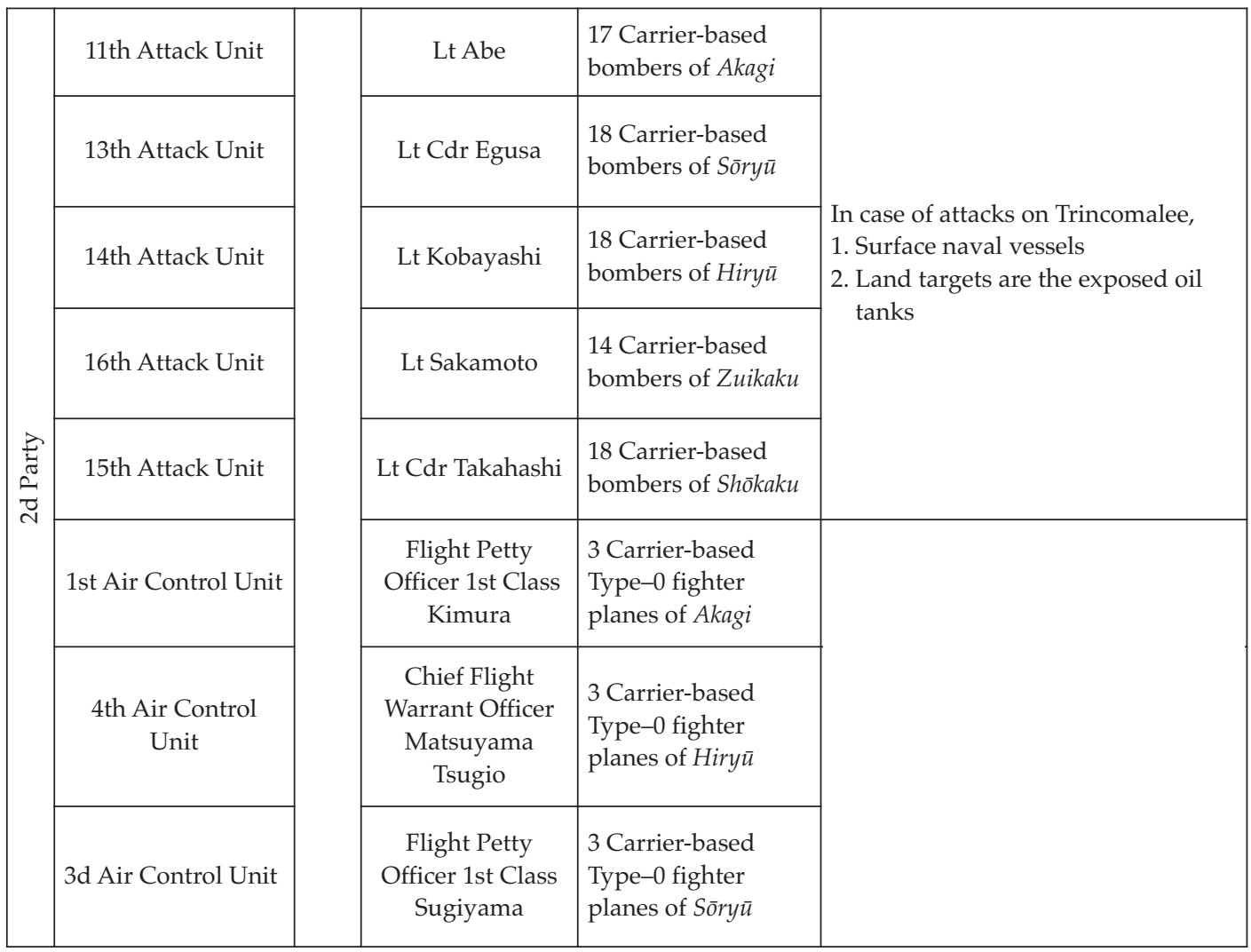

At 0645 on 9 April, one Type- 0 reconnaissance seaplane of the Toné was launched for a covert weather reconnaissance over Trincomalee. Then at 0900, the first sortie unit (the 1st Formation [unit], minus the 2d Party) for Trincomalee took off. The force consisted of ninety-one carrier-based attack planes and thirty-eight Type-0 fighter planes. The aircraft of each carrier for the direct escort in the air as well as the search aircraft of the 3d Battleship Division, the 8th Cruiser Division and the 1st Destroyer Squadron also took off. At 1008, one enemy flying boat probing at a distance of 30,000 meters $80^{\circ}$ [E] of the Carrier Task Force was spotted; the aircraft of the Hiry $\bar{u}$ providing direct escort in the air brought it down. At 1020, Commander Fuchida, commander of the units for the Trincomalee attack ordered all units to charge. The carrier-based attack plane units carried out the attacks as designated from 1030 until 1045 and returned at 1230, after inflicting enormous damage to the light cruisers and merchantmen in the port, as well as land facilities, antiaircraft guns and other targets.

The loss sustained by the carrier-based attack plane units in this attack was one carrierbased attack plane, which had crashed itself, two crew members killed on board, one heavily injured and two with minor injuries. Meanwhile, the thirty-eight fighter planes in charge of the direct escort of the units engaged with several dozens of enemy fighter planes; they reported having brought down thirty-nine enemy fighter planes and one reconnaissance seaplane, while setting ablaze to two Hurricanes and one mid-sized plane and one small biplane. In this engagement, the Japanese force lost three Type-0 fighter planes. 


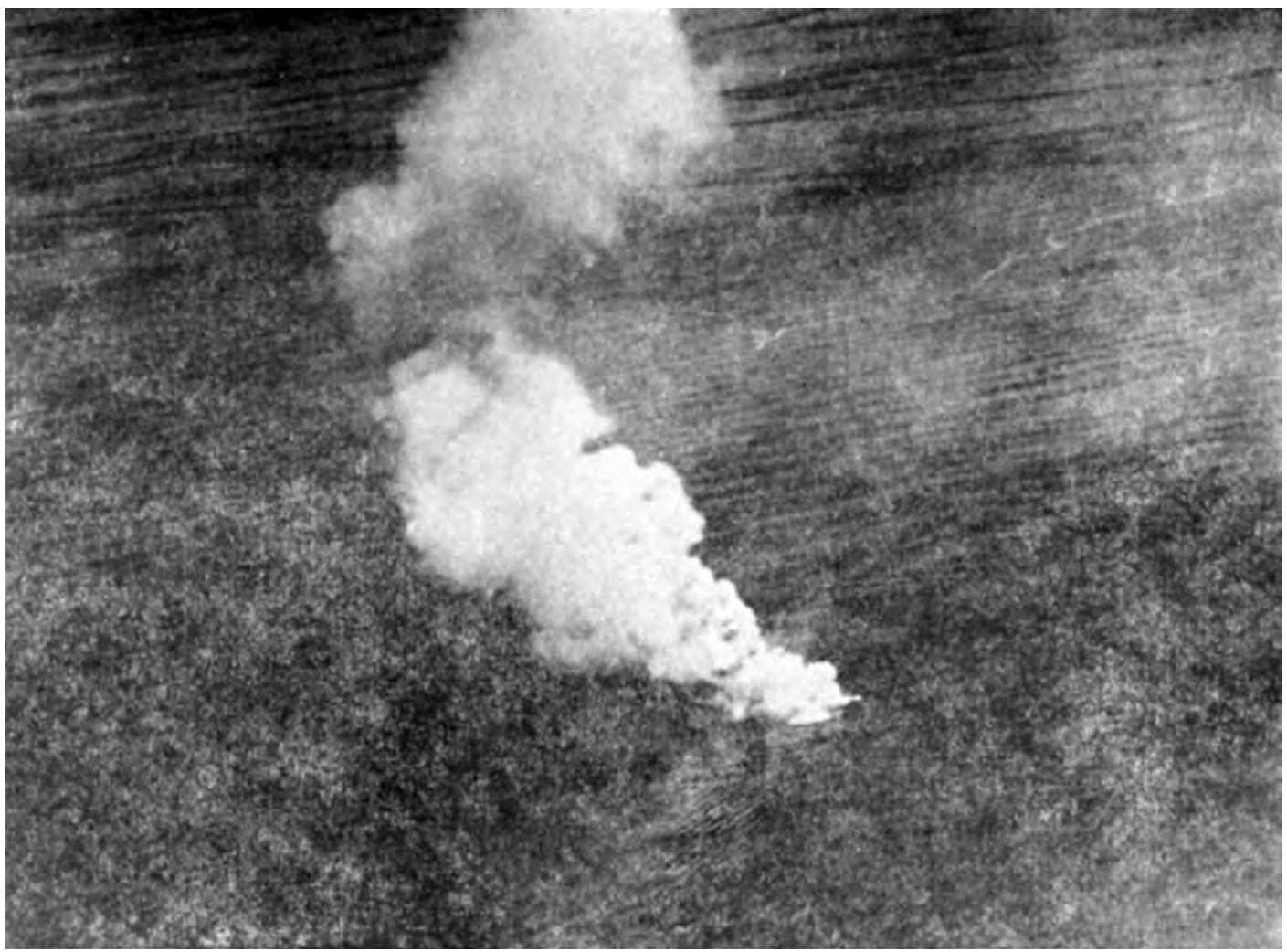

The Sinking of the British Aircraft Carrier HMS Hermes

At 1055, right after the units of the Trincomalee attack finished their attack, the third aircraft of the Haruna reported: "Spotted the enemy carrier Hermes and destroyers, [a total of] three [vessels]. Our position is 155 nautical miles $250^{\circ}$ [WSW] of the starting point." At 1100, the Carrier Task Force commander ordered: "Carrier-based bomber units and designated carrier-based fighter planes, get ready for a sortie to attack the carrier." At 1120, the third aircraft of the Haruna continued its report: "The enemy, [consisting of] one cruiser and two destroyers, are at 155 nautical miles $270^{\circ}$ [W] of the starting point, sailing on a $180^{\circ}$ [S] course at twelve knots." At 1143, the Naval Vessel Attack Unit of eighty-five carrier-based bombers and nine Type- 0 fighter planes took off. The attack unit (led by Lt. Cdr. Takahashi Kakuichi) spotted an HMS Hermes-class carrier at 1330, carried out dive bombings from 1335 until 1350, and sank her at 1355. Without a break, the attack unit went on to attack the destroyers, merchantmen, patrol boats, etc. that were sailing nearby and reported having sunk one destroyer, one patrol boat and two merchantmen. Further, between 1435 and 1447 on its return to the carriers, the unit spotted four Blenheims (the aircraft which had bombed the Akagi and Toné) and reported having brought down two of them. And again from 1515 and 1540, the unit engaged with nine enemy fighter planes, and reported having brought down seven (two of which unconfirmed) and returned around 1545. In the air engagements with the enemy fighter planes, four carrier-based attack planes and one Type-0 fighter plane crashed themselves.

Almost at the same time with our carrier-based bomber units' attack on the HMS Hermes, nine enemy heavy bombers came to attack the Carrier Task Force, and dropped bombs near 
the Akagi and the Toné. Fortunately, no damage was sustained, but the truth was that the Japanese force had not noticed the attack until water columns caused by the bombing shot up, and the Akagi had not been able to fire even a single shot. After that, the fighter planes in the air [over the Carrier Task Force] pursued the bombers and reported having brought down five of them. Nevertheless, the unexpected attack of the enemy aircraft [despite the escort aircraft on guard] posed a serious problem for the Carrier Task Force.

Although a total of eighty-five aircraft of the direct escort had guarded the air over the Carrier Task Force, they had not spotted the enemy besides the above-mentioned heavy bombers attacking the force. The loss sustained by the aircraft of the direct escort was one Type- 0 fighter plane, which had crashed itself in the air engagement with the enemy heavy bombers.

On 10 April, the Carrier Task Force commander reported the military gains and losses in the attack on Trincomalee as follows (Summary Report of the Actions of the Carrier Task Force No. 9):

1. At 1800 on the 8 th, an enemy flying boat was spotted probing us at 450 nautical miles $105^{\circ}$ [E] of Trincomalee. We pursued it but let it slip away due to a squall.

2. At 1030 on the 9 th, the full force of the carrier-based attack planes and thirty-seven fighter planes attacked Trincomalee, sank two large and one small merchantmen, caused serious damage to one HMS Leander-class light cruiser (which probably sank), blew up, set ablaze and mostly destroyed the naval arsenal and its facilities near the piers, antiaircraft batteries, the residence of the commander in chief of Ceylon, three barracks and a group of oil tanks. They also blew up and set ablaze two large hangars on the onshore airfield, which led to huge explosions of the powder magazines, and totally destroyed the facilities of the airfield. In the air engagement, [our force] brought down thirty-eight Hurricanes, two Blenheims, one Supermarine Walrus (the end of three of which not confirmed), strafed one mid-sized and three small-sized aircraft on the ground, which caught fire. The loss sustained was one carrier-based attack plane of the Hiry $\bar{u}$, which had crashed itself, two crew members killed on the aircraft, one heavily injured and two carrier-based fighter planes of the Zuikaku and one of the Shōkaku that had crashed themselves.

3. At 1055 on the 9 th, a reconnaissance seaplane searching for the enemy on the waters to the east of Ceylon spotted the enemy aircraft carrier HMS Hermes and a destroyer sailing southward at a point seventy nautical miles $147^{\circ}$ of Trincomalee (within ten nautical miles from the east coast of Ceylon), and probed them. At 1400, the full force of the carrier-based bombers and nine fighter planes attacked them, and sank both of them and [also] sank three large merchantmen sailing on the waters nearby with the remaining forces. Apart from them, the reconnaissance seaplane inflicted damage on another small merchantman. On their return, the carrier-based bomber units engaged with nine Spitfires, and brought down seven of them (two of which unconfirmed). The loss sustained were four carrier-based bombers of the Sōry $\bar{u}$, which had crashed themselves in the engagement with the Spitfires.

4. At 1016 on the 9th, [our force] brought down one probing enemy flying boat. At 1350, nine enemy Blenheims came for a raid. We brought down seven of them (five of which by the aircraft of the direct escort in the air and the other two by [the aircraft of] the unit, which were on their return from the attack on the HMS Hermes). Although the Akagi and the Toné came under attack, they sustained no damage.

5. Comments

The enemy has been concentrating a considerable air strength for the defense of Ceylon. It is required to take countermeasures.

6. (Omitted by the author) 
The following table illustrates the on-target ratio and the hit scores in the attack on the HMS Hermes and other targets on that day:

\begin{tabular}{|c|c|c|c|c|c|c|}
\hline Target & $\begin{array}{l}\text { Number of Aircraft } \\
\text { in the Attack }\end{array}$ & $\begin{array}{c}\text { Number of } \\
\text { Bombs Dropped }\end{array}$ & $\begin{array}{c}\text { Bombs on } \\
\text { Target }\end{array}$ & \multicolumn{2}{|c|}{ On-Target Rate } & Notes \\
\hline \multirow{4}{*}{$\begin{array}{l}\text { Aircraft carrier } \\
\text { (HMS Hermes) }\end{array}$} & Akagi: 2 & 2 & 2 & 100 & \multirow{4}{*}{82} & \\
\hline & Hiryū: 11 & 11 & 9 & 82 & & \\
\hline & Zuikaku: 14 & 14 & 13 & 93 & & \\
\hline & Shōkaku: 18 & 18 & 13 & 72 & & \\
\hline \multirow{2}{*}{ Destroyer } & Akagi: 12 & 12 & 12 & 100 & \multirow{2}{*}{81} & \\
\hline & Hiryū: 4 & 4 & 1 & 25 & & \\
\hline Patrol Boat & Sōryū: 6 & 6 & 1 & \multicolumn{2}{|l|}{17} & \\
\hline \multirow{3}{*}{$\begin{array}{l}\text { Large } \\
\text { merchantmen }\end{array}$} & Akagi: 3 & 3 & 3 & 100 & \multirow{3}{*}{92} & \\
\hline & Sōryū: 6 & 6 & 5 & 83 & & \\
\hline & Hiryū: 3 & 3 & 3 & 100 & & \\
\hline $\begin{array}{c}\text { Small } \\
\text { merchantmen }\end{array}$ & Sōryūu: 6 & 6 & 5 & 83 & & \\
\hline
\end{tabular}

“The Greater East Asia War's Lessons of War ([section] Air Operations: The Operations on Ceylon)" analyzed the reasons for the almost miraculous gains as follows:

1. With fair weather, a slight breeze and a good air stream, the meteorological conditions were favorable for the bombing attack.

2. The commanders gave very appropriate directions and the actions at the time of approaching and attacking the enemy were very skillful.

3. The crews were elite members of intact original units with a strong mental bond. Moreover, their skills had been very much improved by the drills before the sortie (note by the author: the drills conducted at Kendari).

4. The attack units' raid was a sudden attack by rushing in all at once, which limited the enemy's evasive actions.

Furthermore, the "Lessons of War" mentioned the power of the No. 25 regular bombs: 


\begin{tabular}{|c|c|c|l|}
\hline Target & $\begin{array}{c}\text { Number of } \\
\text { Direct Hits }\end{array}$ & Effects & Notes \\
\hline HMS Dorsetshire (1st vessel) & 31 & Sank in 13 min. & $\begin{array}{l}\text { Number of aircraft in the at- } \\
\text { tack: } 53 \\
\text { No. 25 Regular bombs: } 37 \\
\text { No. 25 Land bombs: } 16\end{array}$ \\
\hline HMS Cornwall (2d vessel) & 15 & Sank in 18 min. \\
[Employed] Fuses: C
\end{tabular}

After completing the attacks on Trincomalee on the 9th, the Carrier Task Force pulled back to the east, conducted a refueling on the 10th and passed through the Malacca Strait on the morning of the 13th. [Then,] having separated the 5th Carrier Division in the South China Sea on the 14th, the force returned to its original port[s] for docking, servicing, and replenishment. The 5th Carrier Division, after separating [from the Carrier Task Force], headed for Magong to prepare for the subsequent Port Moresby operation. Although the Kaga was intended to be employed for the Port Moresby operation, due to the delay in her repairs and the strong demand for reinforcements from the South Seas Unit commander (Fourth Fleet Commander in Chief Vice Admiral Inoue), it was decided to employ the 5th Carrier Division. [The dispatch] seems partly to have been intended to further train the division, because the 5th Carrier Division was the least skilled among the Carrier Task Force. It was arranged that the 5th Carrier Division would be supplemented with as many aircraft as possible from the 1st and the $2 \mathrm{~d}$ Carrier Divisions.

\section{The Lessons of War Drawn from the [Operations of the] Carrier Task Force in Operation C}

According to the Action Report of the Hiryū, the lessons of war drawn from the Ceylon operation were as follows:

1. The power of the Type99 No. 25 regular bombs, which we had not been able to examine [after] the air strikes at Hawaii, was fully displayed this time in the attacks on the large British cruisers and HMS Hermes.

2. We found that Type98 No. 25 land bombs were effective in neutralizing antiaircraft guns and machineguns on enemy vessels. In the attack on the large [enemy] cruisers and the carrier, the first three aircraft of each squadron were equipped with land bombs. On impact, the bombs in- 
stantly silenced the enemy's antiaircraft fire and facilitated the bombings thereafter. Having the carrier-based bomber unit use the land bombs in simultaneous attacks with both torpedoes and bombs was found effective, too.

3. Concerning the new installation of training rooms with radiosets to maintain communication skills.

In the current situation where crucial operations are usually conducted after having operated for a long period under combat-controlled [conditions for] short wave [communications], it is quite difficult to maintain the communication skills [of the crews]. Therefore, it is very much necessary to newly install handset training rooms in the crew rooms (or a room for that purpose).

4. The need for new aerial cameras

The currently used F-8 cameras are heavy and large, and are very inconvenient to handle within the narrow confines of the reconnaissance seat on small aircraft. [Moreover,] when photos are taken under increased gravity (note by the author: under the influence of centrifugal force) on carrier-based bombers, their shutters are often damaged. Therefore, we want smaller cameras of about $\mathrm{f} 2.0 \sim \mathrm{f} 2.8$ equipped with a telephoto lens. We feel that there is an urgent need to use infrared photos in reconnaissance and for the confirmation of military results [particularly] when there is smoke and fog.

5. Although we did not really evaluate the effectiveness of the antiaircraft artillery this time because the firing was, among others, instantaneous and at a great range, the following lessons of war were drawn:

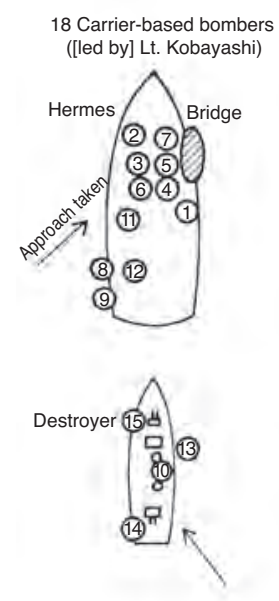

(1) With the current Hiry $\bar{u}$-type lookout facilities, it is quite difficult to spot targets at an altitude of 5,000 meters or more. At that time, the Carrier Task Force was sailing ahead in an antiaircraft guard formation, spread out across a large area. Although all vessels were on alert, maintaining based bomber unit of the 1st patrol stations on each vessel, it turned out that they were not able to spot the enemy bomber unit intruding into the middle of the sailing formation from astern on a parallel course, before the water columns of the bombing against the Akagi finally alerted [most of the vessels]. Moreover, the circumstances that the Akagi did not start taking evasive actions until several bombs had been dropped and did not fire a single shot, may be said to show that she was too late in spotting the targets and not ready for a prompt artillery exchange. As countermeasures, we need to swiftly equip [the vessels] with radar or sound detection equipment for the antiaircraft watch.

(2) In antiaircraft artillery engagements, the vessel who spots the targets first shall open fire in order to give warnings to all [friendly] vessels and air control units as well as to promptly show the broad bearings of the target, and do so in the following way regardless of the firing range: Even if [the enemy] is out of range, she shall open fire with one or two of her antiaircraft guns. Depending on the circumstances, if she notices that friendly forces are in danger of being bombed, she shall open fire with all antiaircraft guns and machineguns.

6. In the matter of abbreviated signals, more study and exercise is needed.

Although signals using the abbreviations decided on by the Carrier Task Force were tested in this operation, due to the lack of a proper structure of the abbreviated words as well as a lack of training, they were not fully used. Since signals using abbreviations are quite essential in view of a speedy transmission and a shortening of [the period of] exposing lights at night, it is necessary to take the following measures:

(Measures) 
(1) The number of abbreviated words for signals should be increased so that the words and phrases used by the Carrier Task Force shall be covered as much as possible.

(2) The abbreviated words for signals should be further edited in a more simplified way so that coding and decoding will be easier.

(3) The drills for signaling with abbreviated words shall be promoted so that officers as well as the signal personnel shall be well acquainted with them.

7. In order to ensure a speedier reporting of spotted enemy aircraft, we think that it is quite effective to take the following [steps], in combination with the currently used [system of] signals to report the spotting [of the enemy].

(1) When all units and vessels operate by spreading out across a wide area of ten to twenty kilometers: gunfire to give warnings

(2) When all units and vessels operate by spreading out across an area of twenty kilometers or more: sooty smoke screens (one [screen] for probing aircraft and two or more for aircraft groups of more than several aircraft; these should be spread only by the vessel who spotted the aircraft first) and gunfire to give warnings.

8. The time zone must be added when times are mentioned in the communicated information.

An actual example: "At 1045, the station at Ceylon broadcasted an air-raid warning," raises doubts whether the time is local time or [Japan] Standard Time. It will become much clearer if this is communicated as "At 1045 ([Japan] Standard Time), the station at Ceylon ...".

9. It is deemed a must to plan any astern refueling, when sailing on alert, on the leeward side of the carriers. Since the carriers [need to] sail toward the wind at high speed for the takeoff or landing of aircraft, the takeoff and landing operations of aircraft may be obstructed if there are vessels that cannot freely move on the windward side of the carriers.

10. An aircraft carrier needs to keep at least two or more spare sets of anemoscopes and anemometers. Since troubles with electric circuits are expected to occur often when [a carrier] operates for a long period in humid areas, spare sets of anemoscopes and anemometers, which are indispensable for the takeoff and landing operations of aircraft, are required as a precaution against troubles.

11. It is necessary that the facilities of all oilers for astern refueling are made to match, so that smooth refueling can be conducted in whatever combination [of vessels] or with whatever methods. For example, the "slip" [hook, or pelican hook] for the towing cable [jackstay] on the Nipponmaru did not match the cable of our vessel; since the cable had to be fastened with strops, its release took time. Moreover, the Tōei-maru [A] did not have her onboard [dead] weight [to buffer the tension in the jackstay] with her.

The Action Report of the 5th Carrier Division drew the following lessons of war [from this series of operations]. ${ }^{(191)}$

The recent attacks on the enemy carrier HMS Hermes and the attack on the British cruisers on 5 April have shown that we need to attach greater importance to and conduct more joint exercises between search aircraft and attack plane units. In particular, we need a better coordination between different types of aircraft in cases where reconnaissance seaplanes are employed as search aircraft.

Since better and accurate navigation and reconnaissance by our search aircraft are key elements that will decide the outcome of air operations at sea, we think that it is necessary to conduct drills as often as possible.

The following excerpts from "The Greater East Asia War's Lessons of War ([section] Air Operations: The Operations on Ceylon)" are [also] relevant: 
1. In view of the fact that an attack on key enemy places with carriers is very likely to be carried out by assault, we need to take all possible measures to guard the aircraft carriers, keeping in mind their characteristics.

As seen in the example of the present engagements, it is highly likely that attacks against strategic enemy places with carriers, where [the enemy] widely conducts aerial patrols with its land-based air power, come to be carried out by assault.

Therefore, when conducting these kinds of operations, you should obtain as much as possible information on the enemy movements before striving to carry out surprise and destroy attacks, because air operations with carriers against [well-]prepared [enemy] bases are generally disadvantageous unless you are absolutely sure of [being able to successfully conduct] a surprise and destroy attack by hitting the enemy quite unexpectedly. Nevertheless, you need to expect that such an attack may inevitably become an assault, and take all possible measures to guard [the carriers] by concealing yourself by means of your mobility, moreover by limiting simultaneous damage by spreading out, as well as by carefully searching for the enemy.

The present operation was an exceptional example of an operation where [after] a proper evaluation of the movements of the enemy and us, an assault was conducted at a stroke, and the enemy counterattack being blocked, enormous military gains were produced. Nevertheless, when we examine the course of events, we think that more adequate search power needs to be allocated for guarding.

Although there were no critical problems that might have frustrated the operation in the present course of events, we think that the search unit's poor reconnaissance performance, which will be mentioned under a later heading, reduced the enlargement of military gains. ([Subheading] General [Matters] on the Employment of Forces)

2. Since the quality of reconnaissance is a crucial element that decides the outcome of air engagements at sea, more training is needed in view of the actual situation presented by this engagement.

In the attack on the large cruisers on 5 April and the attack on the carrier on 9 April in this operation, it occurred again and again that search aircraft, which had spotted the enemy and probed him, wrongly identified the type of the vessels. As a result, it delayed the operations and reduced the expansion of military gains, as mentioned separately in the account of the course of events. (Note by the author: the separate account of the course of events is omitted [Subheading] Military Tasks)

3. Each flagship of [the units forming] the Carrier Task Force must at least carry about six to nine high-performance reconnaissance aircraft (experimental 13-shi carrier-based bombers).

It may be said that the tragic end of the British probing aircraft in the present carrier operation clearly showed that probing a fleet accompanied by aircraft carriers is most difficult unless [conducted] by high-performance aircraft. That is, in order to ensure [a successful] probing of the enemy and even conduct a forced reconnaissance if necessary to identify the type of vessels, as well as in order to swiftly search designated areas so as to [enable] the conduct of quick and brisk air operations, we deem it most urgent to equip the Carrier Task Force with high-performance reconnaissance aircraft. ([Subheading] Reconnaissance)

4. The ability to look out for and spot [enemy] aircraft coming for a raid at high altitudes must rapidly be improved.

In the raid by the twin-engine heavy enemy bombers on 9 April, the actual situation was that none of the vessels spotted the enemy until just before being bombed from right above their own unit or until just after having been bombed.

We deem it necessary that as well as drills, the following measures are to be taken concerning the [lookout] facilities:

(1) Enhancing and improving the lookout capacity 
$\{1\}$ It is necessary to increase the special duty lookout personnel; they should operate at least in two shifts even during engagements.

$\{2\}$ Concerning the improvement of the general capability to spot targets at a vertical angle of more than $30^{\circ}$, wide-angle binoculars rather than those with a high magnification are required for antiaircraft surveillance. (The currently used 20-power binoculars with a view of 3 degrees should preferably be changed to 10 to 15 -power binoculars with a view of 15 degrees.)

\{3\} It is necessary that the [information on] targets spotted by the lookouts shall be systematically communicated to the positions who need it.

$\{4\}$ It is necessary to conduct lookout drills when large evasive actions are taken.

$\{5\}$ It is necessary to improve the lookout commanders' knowledge of air engagements in general so that they can make tactical judgments.

(2) Radar

It is of immediate necessity to urgently equip every vessel of the Carrier Task Force and part of the aircraft [with radar] and put it to use, even though it is [still] somewhat unsatisfactory in precision.

(3) Deployment of aerial patrol aircraft

It is necessary to think about deploying aerial patrol aircraft at times of poor high altitude visibility due to too many clouds, etc. ([Subheading] Air Defense)

5. The power of antiaircraft fire needs to be drastically improved. For this, I deem it necessary to swiftly take measures concerning the following items.

(1) Armament

$\{1\}$ Cruisers and larger vessels

It is necessary that they be equipped with four groups of machineguns (nine to twelve guns per group) and two groups of antiaircraft guns (six to twelve guns per group) and that two machinegun groups and one or more antiaircraft gun groups can cover [any place] around the vessel.

$\{2\}$ Destroyers

It is necessary that they be equipped with two or more groups of machineguns (six to nine guns per group) and two groups of antiaircraft guns (four guns per group) and that one or more groups of machineguns and antiaircraft guns can cover [any place] around the vessel.

(2) Fire control

In view of the present situation in which the accuracy of our [antiaircraft] fire is poor, it is deemed urgently necessary to train competent fire-control officers and improve the necessary fire control instruments. However, for the time being we need to conduct studies and drills on throwing up dense artillery barrages around the targets of [enemy] torpedoes or bombs.

(3) Facilities

$\{1\}$ It is necessary to improve the [antiaircraft] artillery equipment so as to be able to follow enemy [aircraft] speeds of 500 knots.

$\{2\}$ It is necessary to increase the traverse and elevation speeds and also to increase the angles of the antiaircraft fire control equipment as well as of the antiaircraft guns and machineguns.

\{3\} It is better to mix in smoke tracer or light tracer shells so as to show the whereabouts of the enemy to friendly aircraft and facilitate the fire control.

(4) Antiaircraft formations

Since the present antiaircraft artillery armament of each vessel is poor, it is necessary to study formations and evasive actions in order to put up effective antiaircraft walls of fire by concentrating the fire of the vessels of a formation. ([Subheading] Air Defense) 
6. Establishing a new institution to research air defense

Since air combat and antiaircraft artillery, which are the core of air defense, are closely and inseparably related, and it is impossible to conduct research and drills without aircraft, we deem it necessary, in order to make rapid improvements, to newly establish an air defense research institution that has a close connection with aviation and attach to it an air defense technical arsenal to start a new field in air defense research. ([Subheading] Air Defense)

The Cooperation of the Air Unit of the Southern Task Force (From 26 March to 8 April)

[See also the maps on pp. 612, 615, 616, and 618]

On 26 March, the Carrier Task Force left Staring Bay, and passing through the Ombai Strait advanced to the Indian Ocean on the 27th. On both days, the Air Unit conducted search missions over the northern part of the Bay of Bengal with four land-based attack planes, over Sector $\mathrm{C}$ with three large flying boats, and over Sector A with four to five land-based attack planes, but no enemy was spotted. ${ }^{(71)}$ On the 28th, the Carrier Task Force passed the waters to the south of Sumba Island. On that day, the Air Unit conducted search missions over the northern part of the Bay of Bengal with four land-based attack planes, over Sector A with five [of them], and Sector E with three large flying boats. Two of the large flying boats spotted two merchantmen in Sector E, carried out a bombing, and stopped one 3,000-ton-class cargo ship with a near miss. Apart from them, one land-based attack plane carried out a search mission on the sailing route ahead of the Carrier Task Force, but spotted no enemy. ${ }^{(71)}$

On the 29th, the Carrier Task Force sailed westward on the waters to the south of Bali. The Air Unit carried out search missions over the northern part of the Bay of Bengal with four land-based attack planes, over Sector A with five [of them], and over Sector C with three large flying boats. One of the latter scored a hit on a cargo ship. On that day, one land-based reconnaissance aircraft reconnoitered Calcutta and reported fifty merchantmen at anchor. ${ }^{(71)}$ On the 30th, the Carrier Task Force [continued to] sail westward on the waters to the south of Java and passed the midpoint between Java and Christmas Island on the 31st. On both days, the Air Unit carried out search missions over the northern part of the Bay of Bengal with four land-based attack planes, over Sector A with five [of them] and over Sector C with three large flying boats, but spotted no enemy. The [other] three large flying boats also carried out search mission on the waters to the south of Java in concert with the Christmas Island invasion operation. On top of that, in view of an enemy aircraft's reconnaissance over Port Blair, an air patrol by Type- 0 fighter planes was also started from the 30th onwards [p. 588]..$^{(71)}$

On 1 April, the Carrier Task Force reached the waters to the north of the Cocos Islands, while also the Malaya Unit Striking Force left Mergui. The Air Unit carried out search missions over Sector A with thirteen land-based attack planes and over Sector $C$ with three large flying boats (pressing on to a distance of seven hundred nautical miles). The large flying boat[s] reported the enemy movements as follows: ${ }^{(119)}$

1. At 1030 a.m., no enemy vessels or aircraft were spotted other than two merchantmen of 4,000ton class at anchor in Palk Bay.

2. At 1005 a.m., three 10,000-ton-class merchantmen and one minesweeper escorting them [were spotted] sailing northward off the northeastern end of Ceylon at eight knots.

3. No enemy aircraft was spotted on the airfield or at the seaplane base near Trincomalee. No patrol aircraft was spotted, [either]. No antiaircraft fire. Eight destroyers or larger vessels [were 
spotted] inside the port and one destroyer was [spotted] escorting [a] large merchantman outside the bay.

In continuation of the previous day, Type- 0 fighter planes patrolled in the air above Port Blair and three large flying boats searched for the enemy in the direction of Christmas Island, but no enemy was spotted.

At noon on the $2 \mathrm{~d}$, the Carrier Task Force reached the $3^{\circ} 45^{\prime} \mathrm{S} 97^{\circ} 42^{\prime} \mathrm{E}$ point. The Air Unit carried out search missions over Sector D (pressing on to a distance of seven hundred nautical miles, but twenty nautical miles short of the shore of India) with three large flying boats, spotted one 10,000t-class and one 8,000t-class merchantmen, and caused damage to both of them with near misses. As on the previous days, the unit conducted search missions over Sector A with thirteen land-based attack planes and a patrol in the air over Port Blair with Type -0 fighter planes. At noon on the $3 \mathrm{~d}$, the Carrier Task Force reached the point of $1^{\circ} 17^{\prime} \mathrm{S}$ $93^{\circ} 34^{\prime} \mathrm{E}$. The Air Unit carried out search missions over Sector E (twenty nautical miles short of the shore) with three large flying boats, and reported having spotted thirteen merchantmen, of which they sank one 20,000t-class cargo ship, scored two hits (with 250-kg bombs) on a 7,000t-class cargo ship and caused damage to one 8,000t-class cargo ship with near misses. ${ }^{(71)}$

Also on the same day, search missions over Sector A were conducted with nine land-based attack planes but no enemy was spotted. The twenty Type- 0 fighter planes, which had been dispatched to Tavoy for the patrol over Port Blair, returned to Bangkok, and came under the command of the Genzan Air Group commander. On the early morning on that day, there was a small enemy raid over the Andaman Islands by three to four Boeings and one Lockheed [bomber]. Although the raid inflicted minor damage on the Japanese side to the Yügiri by near misses, we brought down one large aircraft with concentrated fire (which will be mentioned later). On the 3d, Air Unit Commander Vice Admiral Tsukahara issued the following order concerning the reconnaissance attack over the Calcuttta and[/or] the Akyab areas by means of classified telegram No. 184. ${ }^{(141)}$

(Telegraphic Operation Order No. 84)

The 3d Air Raid Unit commander shall conduct reconnaissance attacks over the Calcutta and Akyab areas as designated by him, on top of the following:

1. Forces: The land-based attack plane unit of the Genzan Air Group, one element of the fighter plane unit and land-based reconnaissance aircraft unit dispatched from the Kanoya Air Group

2. Dates: During the period from 4 until 7 April

3. Bases to be used: Rangoon (depending on the situation, Bassein shall also be used)

4. Targets: Enemy naval vessels and aircraft (the Southern Army commander in chief, the Fifteenth Army commander, and the [Army] 5th Air Force commander shall be informed)

At noon on 4 April, the Carrier Task Force reached the $0^{\circ} 13^{\prime} \mathrm{N} 86^{\circ} 16.5^{\prime} \mathrm{E}$ point. The Air Unit carried out a covert reconnaissance over Trincomalee with one large flying boat, and reported having spotted eight mid-sized or larger merchantmen (one of which was a hospital ship), one large destroyer inside the port and patrol boat[s] outside. The unit also conducted search missions over Sector $C$ up to a distance of seven hundred nautical miles with three large flying boats, and over Sector A with nine land-based attack planes, but no enemy was spotted. ${ }^{(194)}$ In the meantime, twenty-eight land-based attack planes, eighteen Type-0 fighter planes and one land-based reconnaissance aircraft advanced to the Mingaladon airfield of 
Rangoon under the command of the Genzan Air Group commander for the attack on Calcutta. $^{(71)}$

On 5 April, the Carrier Task Force attacked Colombo. The Air Unit carried out search missions over Sector C with two large flying boats, over Sector A with nine land-based attack planes, and over the northern part of the Bay of Bengal with three land-based attack planes, while patrolling in the air over Rangoon with Type-0 fighter planes, but no enemy was spotted. ${ }^{(71)}$ On that day, the Malaya Unit Striking Force advanced to the northern part of the Bay of Bengal. On the 6th, the Carrier Task Force of the Southern Task Force pulled back to the east of Ceylon to make preparations for the Trincomalee attack, while on the same day, the Malaya Unit Striking Force cleared the northern part of the Bay of Bengal of enemy naval vessels and merchantmen and attained large military gains. The Air Unit [also] carried out search missions over Sector $C$ with three large flying boats, Sector A with nine land-based attack planes only to spot no enemy. In the meantime, the attack unit against Calcutta* carried out bombing attacks on Calcutta* for about one hour from 1155, and reported the following military gains: ${ }^{(71)}$

1. Bombed the Akyab airfield; all bombs hit the runway and the [airfield] facilities and blew up one large and one small aircraft.

2. Bombed naval vessels in the port and sunk one 2,000t-class minelayer.

3. Strafing by the fighter plane unit set fire to one Hurricane and one DC-3.

In this attack, the enemy antiaircraft artillery was sparse and caused no damage to the Japanese forces.

At noon on 7 April, the Carrier Task Force of the Southern Task Force reached the $0^{\circ} 25^{\prime} \mathrm{N}$ $88^{\circ} 1^{\prime}$ E point, while the Malaya Unit had completed its operation and was heading back to the Nicobar Islands. On that day, the land-based Air Unit did not conduct operations (the reason is unknown; maybe just to avoid being mistaken by the Carrier Task Force for enemy aircraft). The Genzan Air Group and the fighter plane unit of the Kanoya Air group returned from Rangoon to Bangkok. ${ }^{(75)}$ After reaching the point of $9^{\circ} 49^{\prime} \mathrm{N} 89^{\circ} 53^{\prime} \mathrm{E}$ at noon on the 8th, the Carrier Task Force changed course to west-northwest and headed for Ceylon to attack Trincomalee. The land-based air unit did not conduct operations on that day, either.

On 9 April, the Carrier Task Force of the Southern Task Force carried out the attack on Trincomalee; it inflicted devastating damage on the naval port facilities and the airfield, and sank HMS Hermes. Without conducting operations again on that day, the land-based air unit resumed its search missions over the Indian Ocean from the 10th onwards. On that day, the Combined Fleet shifted to stage-two operations, by which the main theater against the enemy was meant to shift from the area southwest [of Japan] to that to the east [of Japan]. Accordingly, the Eleventh Air Fleet headquarters also moved to Tinian in the Mariana Islands on 18 April. ${ }^{(75)}$

\section{The Malaya Unit Striking Force Neutralizes the Bay of Bengal (From 1 to 11 April)}

At 1400 on 1 April, the Striking Force of the Malaya Unit left Mergui and headed for the waters west of Tavoy. On that day thirteen land-based attack planes of the Mihoro Air Group

\footnotetext{
* Probably Akyab is meant. Both the reports of the units involved and the following report on military gains only mention Akyab.
} 
carried out search missions in the areas between $170^{\circ}$ and $280^{\circ}$ of Sabang up to a distance of six hundred nautical miles but spotted no enemy. ${ }^{(119)}$

On 2 April, in order to support Operation C, Southern Task Force Commander Vice Admiral Kondō left the naval port of Seletar for the northern entrance of the Malacca Strait, leading the main body of the Southern Task Force (the Atago and the 4th Destroyer Division (minus the $2 \mathrm{~d}$ Section)). In the evening, the Malaya Unit Striking Force changed course to $270^{\circ}[\mathrm{W}]$, and headed for the waters between the Andaman and the Nicobar Islands. ${ }^{(114)}$ On that day, thirteen land-based attack planes of the Mihoro Air Group again carried out search missions as they had done on the previous day, but spotted no enemy.

On 3 April, the I-7, who on the two days prior to the air raid on Ceylon had been assigned to covert air reconnaissance in the Colombo area with her onboard aircraft, reported that it was impossible to conduct the air reconnaissance due to the strict guard of the enemy. From the report, Malaya Unit Striking Force Commander Vice Admiral Ozawa judged it inevitable that the attack by the Carrier Task Force of the Southern Task Force would be postponed for one day, and changed the actions of his striking force in the following way: ${ }^{(181)}$

1. The date of attack to be carried out by the Malaya Unit Striking Force shall be postponed for one day.

2. [The unit shall] reverse course at 0413 , setting on a $90^{\circ}$ [E] course, and then appropriately operate on the waters east of the Nicobar Islands.

3. The search missions by the aircraft of the Ryujjō shall be postponed until tomorrow, the 4th.

4. The 11th Destroyer Division's separation from the main unit to sail for Port Blair shall be postponed for one day until tomorrow, the 4 th.

Meanwhile at 0645 on that day, three to four Boeings and one Lockheed aircraft came for a raid over the anchorage of the Guard Unit at Port Blair, and bombed it making use of flares. In this attack, due to near misses, the Yügiri sustained minor damage, which, however, did not impair her fighting or sailing [capability]. Fighting back, the Guard Unit brought down by concentrated fire at 0720 one large enemy aircraft which landed in the back part of Mangrove Bay. ${ }^{(118)}$

From 0900 onwards, the Malaya Unit Striking Force appropriately operated on the waters to the north of the Nicobar Islands. At 1430, [one of] the flying boats of the Tōkō Air Group, which had carried out search missions in the northern part of the Bay of Bengal on that day, reported: "[Spotted] seven enemy transport ships 120 nautical miles $19^{\circ}$ [NNE] of Calcutta, sailing on a $180^{\circ}$ [S] course at twelve knots." At 1810 on the 4 th, in view of enemy movements, Southern Task Force Air Unit Commander Vice Admiral Tsukahara ordered reconnaissance attacks against the Calcutta and Akyab areas between 4 and 7 April with the land-based attack plane unit of the Genzan Air Group and one element of the fighter plane unit and the land-based reconnaissance plane unit dispatched from the Kanoya Air Group (as previously told). ${ }^{(141)}$

On 4 April, after reaching an area about sixty nautical miles southeast of Little Andaman Island, the Malaya Unit Striking Force headed for the Ten Degree Channel, setting on a $270^{\circ}$ [W] course. At 0725, the Yura, who had sailed to Port Blair for refueling on the previous day, joined the main unit, just passing at 0800 the 11th Destroyer Division which had been separated from the main unit to sail for Port Blair, after incorporation in the Guard Unit. After passing through the Ten Degree Channel, the Malaya Unit Striking Force took a $330^{\circ}$ [NW] 
course at 0858 and headed for Point C, where the Central Unit, the South Unit and the North Unit would split up [p. 614]. ${ }^{(181)}$

At 1000, a flying boat of the Tōkō Air Group reported the results of its reconnaissance of Trincomalee: "Eight mid-sized or larger merchantmen (including a hospital ship) and one large destroyer inside the port."(181) The Ryujjo conducted search missions with four of her carrier-based attack planes in the morning and with three in the afternoon over the designated waters but spotted no enemy. At 2030, the Guard Unit commander left [the waters] off Port Blair, leading the Sendai, the 11th Destroyer Division (which had arrived off Port Blair at 1730 and immediately refueled), and the 1st Section of the 19th Destroyer Division, and headed for the waters to the northwest of Port Blair to guard the rear of the main unit. ${ }^{(118)}$

At 0300 on 5 April, the main unit took a $320^{\circ}$ [NW] course. At 0420, the 20th Destroyer Division (which had left Port Blair on the $3 \mathrm{~d}$ ) joined the unit and started its direct escort. At 0855, three carrier-based attack planes of the Ryūjo took off and conducted search missions in the area 120 nautical miles northwest [of the unit] but did not spot any enemy. ${ }^{(181)}$ Around that time, the Carrier Task Force of the Southern Task Force had reached a point 180 nautical miles to the south of Colombo, where the first sortie unit against Colombo and the direct air escort unit [of the carriers] were launched. At 1046, the [enemy] Ceylon station issued airraid warnings to all naval vessels. ${ }^{(141)}$ Since the air raid on Colombo was carried out as scheduled, the Malaya Unit Striking Force Commander Vice Admiral Ozawa decided to launch his attack operations also in the Bay of Bengal, and first of all at 1340, ordered the Ryūjo to advance ahead of the main unit and conduct search and attack missions. ${ }^{(181)}$ She launched ten carrier-based attack planes between 1433 and 1510, which carried out search missions in the area 260 to 280 nautical miles to her northwest. The enemy movements reported by the aircraft of the Ryujjō were as shown in the following table:(119)

\begin{tabular}{|c|c|c|c|c|}
\hline Spotted Time & [Spotted] Point & $\begin{array}{c}\text { Types and Numbers } \\
\text { of Vessels }\end{array}$ & Course (Speed) & Remarks \\
\hline 1640 & $18^{\circ} 50^{\prime} \mathrm{N} 86^{\circ} 20^{\prime} \mathrm{E}$ & $\begin{array}{c}\text { Special service vessel } \\
(9,000 \text {-ton class) }\end{array}$ & $\begin{array}{c}\text { Bombed; } \\
1 \times 60-\mathrm{kg} \text { bomb } \\
\text { scored a direct hit }\end{array}$ \\
\hline 1705 & $19^{\circ} 30^{\prime} \mathrm{N} 86^{\circ} 5^{\prime} \mathrm{E}$ & 5 Large merchantmen & $240(8)$ & \\
\hline 1725 & $17^{\circ} 50^{\prime} \mathrm{N} 84^{\circ} 14^{\prime} \mathrm{E}$ & 1 Merchantman & $220(10)$ & \\
\hline 1740 & $18^{\circ} 10^{\prime} \mathrm{N} 84^{\circ} 30^{\prime} \mathrm{E}$ & 1 Merchantman & $40(8)$ & $260(16)$ \\
\hline 1742 & $16^{\circ} 52^{\prime} \mathrm{N} 82^{\circ} 45^{\prime} \mathrm{E}$ & 2 Merchantmen & $\begin{array}{c}\text { Bombed; } \\
\text { caught fire }\end{array}$ \\
\hline
\end{tabular}

Judging from these reports on the movements of the enemy that the enemy lines of communication were by and large within thirty nautical miles from the shore, Malaya Unit Striking Force Commander Vice Admiral Ozawa recognized the necessity to change the launching 
points for the attacks even closer to the shore; he changed Point E to $17^{\circ} 20^{\prime} \mathrm{N} 83^{\circ} 40^{\prime} \mathrm{E}$, along with which, the South Unit and the North Unit also shifted Point F and D closer to the shore. The new Point F was $16^{\circ} 0^{\prime} \mathrm{N} 82^{\circ} 50^{\prime} \mathrm{E}$ and the new Point D $19^{\circ} 40^{\prime} \mathrm{N} 87^{\circ} 0^{\prime} \mathrm{E} .^{(181)}$ At 2030 on that day the Malaya Unit Striking Force reached the splitting-up point, from where [each unit] respectively started to advance to Points D, E and F from the north. On that day, only one enemy submarine was spotted at 140 nautical miles $255^{\circ}$ [WSW] of Sabang in the search missions conducted by nine land-based attack planes of the Mihoro Air Group. ${ }^{(114)}$

On 6 April, each unit operated as follows:

The Center Unit reached around Point F at 0856; at 0900, the Ryūjo launched four of its carrier-based attack planes to conduct search and attack missions over the area to the south [off the coast of India] and near Visakhapatnam, while the Chōkai launched her search aircraft at 0902. After that, the unit acted as shown in Attached Illustration No. 10 [omitted] and reported the following military gains off Kakinada and Visakhapatnam. ${ }^{(190)}$

1. The Chōkai

0944 Sank one British merchantman ([of] 5,000 tons)

1119 Sank one U.S. oiler ([of] 9,000 tons)

1140 Sank one British oiler ([of] 3,000 tons)

Her aircraft conducted bombing and inflicted serious damage to one cargo ship ([of] 6,000 tons) and serious damage to one armed marchantman ([of] 4,000 tons)

2. The Yura (including the Ryūjō and Yügiri)

0955 Sank one Dutch merchantman ([of] 3,000 tons)

1045 Sank one British armed merchantman ([of] 6,000 tons)

1145 Sank one Dutch armed merchantman ([of] 3,000 tons)

3. The aircraft unit of the Ryūjo

Sank one large merchantman ([of] 8,000 tons)

Sank one mid-sized merchantman ([of] 5,000 tons)

Inflicted serious damage to large merchantmen ([of] 10,000 tons)
([of] 9,000 tons)

$$
\left.\begin{array}{l}
\text { ([of] 9,000 tons) } \\
\text { ([of] 7,500 tons) } \\
\text { ([of] 6,500 tons) }
\end{array}\right\} \text { setting them to fire or making them unable to sail }
$$

Inflicted serious damage to two small merchantmen ([of] 2,000 tons)

Blew up two oil tanks ([at] Coringa)

Blew up two warehouses ([at] Coringa and Visakhapatnam)

[In the meantime,] the South Unit ([consisting of] the 2d Section of the 7th Cruiser Division and the Amagiri) neared Point F at 0900 and launched search aircraft. Having first of all spotted two enemy transport ships at 1030, the unit reported the following military gains by that afternoon.

Sank one passenger-cargo ship ([of] 7,000 tons)

Sank two passenger-cargo ships ([of] 6,000 tons)

Sank two passenger-cargo ships ([of] 5,000 tons)

The amount of ammunition used in the [South Unit's] engagements was as follows:(114) 
Mikuma: 120 main gun shells, 22 antiaircraft gun shells, and 5 No. 6 regular bombs Mogami: 137 main gun shells, 47 antiaircraft gun shells and 4 No. 6 regular bombs Amagiri: 78 main gun shells and 3 torpedoes

Cap. Soné Akira, then captain of the Mogami recalled the engagements of that day as follows: ${ }^{(195)}$

1. No raid or reconnaissance by enemy aircraft was spotted whole day.

2. Even though warnings had been issued [by the enemy] since the previous day due to our successive air raids, a number of merchantmen still operated.

3. Even when fired on at close range, merchantmen do not easily sink when armor-piercing ammunition is used. [However,] once they catch fire, they meet their end fast.

4. Most of the merchantmen were empty and sailing southward.

5. The crew fled on boats one after another, raising sails and heading for the shore; they mostly consisted of Indians, with a sprinkling of white men.

6. In the actual situation, it was difficult to seize [such] ships; particularly the crews fled very fast.

7. In these circumstances, it was impossible to catch them unless we drew very much nearer to the shore.

The North Unit (the 1st Section of the 7th Cruiser Division and the Shirakumo) reached the $19^{\circ} 33^{\prime} \mathrm{N} 87^{\circ} 8.5^{\prime} \mathrm{E}$ point at 0855 and launched [more than] two search aircraft. [They] first of all spotted one transport ship at 0915 and were probing it, when they spotted six transport ships at 0940 . Between 0952 and 1150, the unit sank all of them. The amount of ammunition used in these engagements was as follows:

Kumano: 333 main gun shells and 186 antiaircraft gun shells

Suzuya: 190 main gun shells and 64 antiaircraft gun shells

Shirakumo: 200 main gun shells

That is, the average amount of ammunition used to sink one merchantman was about seventy-five $20-\mathrm{cm}$ armor-piercing shells and about sixty-five $12.7-\mathrm{cm}$ regular shells, with an average firing range of 5,000-6,000 meters. When probing the transport convoy during this engagement, the 1st aircraft of the Kumano (Lt. Itō Motoé) facilitated our warships' attack by strafing the bridges [of the enemy vessels] from the west so as not to let them draw near to the shore. When returning from the search mission, the aircraft came under a persistent attack from three enemy Hurricanes, which were driven away around 1300 by a brave air fight of the $2 \mathrm{~d}$ aircraft of the Suzuya (a Type-95 reconnaissance seaplane) and the antiaircraft fire from [friendly] vessels. At 1326, the North Unit recovered all its aircraft. Although having sustained as many as nineteen hits, the crew of the 1st aircraft of the Kumano was unscathed. Due to the attack by the three [enemy] fighter planes, the North Unit (led by R. Adm. Kurita Takeo) hurriedly withdrew southeastwards, forced to temporarily suspend the operation to destroy the [enemy] sea lines of communication. Since the unit had spotted sooty smoke to its west after having recovered its aircraft, it headed there; sighting one 10,000-ton-class merchantman drifting with fires at her stern, it sank her. With no information coming in on enemy movements after that, the North Unit set a $180^{\circ}$ [S] course from 1516 and headed for the rendezvous point [scheduled] for the 7th. ${ }^{(119)}$ Meanwhile, the Guard Unit had been operating on 
the waters about 250 nautical miles to the northwest of the Andaman Islands to guard the rear of the Malaya Unit Striking Force, but spotted nothing unusual. ${ }^{(118)}$

On 7 April, all units first of all headed for the rendezvous point; at 0630 the South Unit joined the Center Unit, which was followed by the North Unit, which joined the Center Unit at 0830 , and at 0900 the force took a $140^{\circ}$ [SE] course at fifteen knots, heading straight for the Nicobar Islands. ${ }^{(181)}$ At 0905, the 20th Destroyer Division left the main unit for the Andaman Islands for refueling. In the meantime, the Guard Unit was about two hundred nautical miles northwest of Port Blair and on its way to join the main unit on the morning of the 8th. ${ }^{(190)}$

At 0800 on 8 April, the main unit reached a point about 150 nautical miles to the west of Port Blair, and having been joined by the Guard Unit, it headed for the Ten Degree Channel. ${ }^{(181)}$ The unit searched the channel with four carrier-based attack planes of the Ryūjo, but no enemy was spotted. The unit reached the western entrance of the channel at 1600, uneventfully passed through the channel, and at 2115 took a course toward the north entrance of the Malacca Strait at a point about thirty nautical miles north of Car Nicobar Island. Meanwhile, the Yura left the main unit at 2300 to head for Penang for refueling. ${ }^{(181)}$

At 1200 on 9 April, the Malaya Unit Striking Force reached a point about one hundred nautical miles to the north of Sabang. Joined by the 20th Destroyer Division at 1440, which had completed refueling at Port Blair, the force entered the Malacca Strait in the evening and reached the port of Singapore between 1030 and 1100 on 11 April without problems. Meanwhile at 0915 on the 10th, the Yura had entered the port of Penang without problems. ${ }^{(114)}$ During this period, the disposition of forces for the stage-two, phase-one operations of the Combined Fleet was put in motion as of 10 April. Accordingly, the Chōkai and the 7th Cruiser Division were transferred to the Forward Unit, while the Ryūjo and the $3 \mathrm{~d}$ Destroyer Squadron were put into the main unit. Prior to this, on 7 April, Southern Task Force Commander Vice Admiral Kondo had issued by means of telegraphic order No. 159 the following orders concerning the operations of the units ([and] vessels) of the Southern Task Force at the time of shifting to the new disposition of forces (as of 10 April): ${ }^{(53)}$

1. The 7th Cruiser Division, the 3d Destroyer Squadron, the 4th Carrier Division (minus the 2d Section) and the Chōkai shall be removed from the Malaya Unit. As soon as having completed their [current] tasks, the above-mentioned units ([and] vessels) shall return to their home ports for maintenance work.

Concerning the sail to mainland Japan, the 7th Cruiser Division commander shall group and control the above-mentioned units ([and] vessels), giving consideration to the guarding and sweeping [operations] against enemy submarines.

2. Having completed their mission in the Carrier Task Force, the $3 \mathrm{~d}$ Battleship Division (minus the $2 \mathrm{~d}$ Section) and the $2 \mathrm{~d}$ Section of the 4 th Destroyer Division shall sail to their naval [home] ports for maintenance work. As to the sail to mainland Japan, they shall obey the directions of the Carrier Task Force commander.

3. The Yura shall be removed from the Malaya Unit and returned to the 5th Submarine Squadron.

4. The $2 \mathrm{~d}$ and the 5th Submarine Squadrons shall be removed from the Southern Task Force. Each squadron shall operate as designated by its own commander.

5. The 16th, the 18th and the 2d Destroyer Divisions, the 24th Destroyer Division (minus the Suzukaze) and the 11th Seaplane Tender Division (minus the Mizuho) shall remain in their current positions until specified otherwise by special orders.

6. The remaining units ([and] vessels) shall be mobilized in accordance with the disposition of forces for the stage-two, phase-one operations. 
The Chōkai, the 7th Cruiser Division, the 4th Carrier Division (minus the $2 \mathrm{~d}$ Section), the $3 \mathrm{~d}$ Destroyer Squadron and the Yura, which were removed from the Malaya Unit by these orders, operated as follows:

The Chōkai: After the flag of the First Southern Expeditionary Fleet had been transferred to the Kashii on the 12th, the Chōkai left the port of Singapore together with the 4th Carrier division (minus the $2 \mathrm{~d}$ Section) on the 13th, and entered the port of Yokosuka on the $22 \mathrm{~d}$ by way of Cam Ranh Bay.

The 4th Carrier Division (minus the 2d Section): On the 13th, the division left Singapore along with the Chōkai [for Japan] by way of Cam Ranh Bay. On its way, it separated from the Chōkai, arrived at Hashirajima on the 22d, and entered the port of Kure on the 23d.

The Sendai: She left the port of Singapore on the 13th; arriving at Sanya on the 17th and leaving the port on the same day, she entered the port of Sasebo on the 22d.

The 7th Cruiser Division: The division left Singapore on the 13th; arriving in Cam Ranh Bay on the 16th and leaving the port on the same day, it entered the port of Kure on the 22d.

The Yura: She left Penang on the 11th and arrived in the temporary anchorage at Malacca on the 12th; she left there on the 13th and entered the port of Sasebo on the 20th.

The aggregate military gains reported by the Malaya Unit in the striking operation in the northern part of the Bay of Bengal were as shown in the following table. ${ }^{(181)}$

\begin{tabular}{|c|c|c|c|c|c|c|}
\hline & \multicolumn{4}{|c|}{ [Enemy] Naval Vessels } & \multirow{2}{*}{ [Enemy] Facilities } & \multirow{2}{*}{ Notes } \\
\hline & \multicolumn{2}{|r|}{ Sank } & \multicolumn{2}{|c|}{ Inflicted Serious Damage } & & \\
\hline Center Unit & 8 & Approx. 42,000 tons & 8 & Approx. 47,000 tons & $\begin{array}{l}\text { Blew up } 2 \text { oil tanks } \\
\text { Blew up } 2 \text { warehouses }\end{array}$ & \multirow{4}{*}{$\begin{array}{l}\text { All serious dam- } \\
\text { age inflicted to } \\
\text { [enemy] naval } \\
\text { vessels and the } \\
\text { blowing up of } \\
\text { facilities were } \\
\text { [military] gains } \\
\text { attained by air- } \\
\text { craft. }\end{array}$} \\
\hline North Unit & 8 & Approx. 66,000 tons & & & & \\
\hline South Unit & 5 & Approx. 29,000 tons & & & & \\
\hline Total & 21 & Approx. 137,000 tons & 8 & Approx. 47,000 tons & $\begin{array}{l}\text { Blew up } 2 \text { oil tanks } \\
\text { Blew up } 2 \text { warehouses }\end{array}$ & \\
\hline
\end{tabular}

On the other hand, the damage sustained by the Japanese forces was very slight, [namely] the 1st aircraft of the Kumano, which was marked by nineteen bullets, ([but] repairable on the ship), and some damage to the $3 \mathrm{~d}$ aircraft of the Kumano, which was caused by the gun blast of its own vessel. ${ }^{(119)}$

\section{The Reconnaissance of Key [Enemy] Places by the Submarines Proved Difficult}

At that time [at the start of the carrier operation in the Indian Ocean], out of Submarine Unit $\mathrm{C}$ (consisting of seven submarines of the $2 \mathrm{~d}$ Submarine Squadron), Submarine $I-1$ was returning to Yokosuka, having left Staring Bay on 15 March due to trouble with her starboard engine, which required repair at a naval arsenal, while Submarine $I-5$, who had run aground 
at the entrance to Kendari on 28 February, was in the middle of an operation to refloat her. Consequently, [the number of] the submarines, which participated in the third carrier operation in the Indian Ocean was five in the beginning, namely, I-7, I-2, I-3, I-4 and I-6; after having been joined by the $I-5$, who had completed repairs after being refloated, they totaled six submarines. The operations of each of them were as follows: ${ }^{(60)}$

\section{Submarine $I-7$ (with the Submarine Unit $\mathrm{C}$ commander on board)}

I-7 was supposed to conduct air reconnaissance [with her onboard aircraft] over Colombo and Trincomalee two days before the air raids. At 2330 on the 1st, she sent the following telegram to the $2 \mathrm{~d}$ Submarine Squadron:(191) At 0817 on the 1st, I-7 came under a bombing attack by an enemy seaplane at a point 180 nautical miles $147^{\circ}$ [SE] of Ceylon. Although nearly missed, no damage was caused, because it was dud. Four hours after the bombing, an [enemy] patrol aircraft came to our position. When the communication [signals] from the [enemy] aircraft at night and the reports from the 5th Submarine Squadron are taken into consideration together, we presume that the enemy is trying to clear the sea of submarines at night with his aircraft, taking advantage of current [bright] moonlight. It is necessary to keep a strict watch."

Then at 0000 on 3 April by means of Submarine Unit C Classified Telegram No. 96, she reported the cancellation of the air reconnaissance over Colombo: "The guard within a radius of seventy to eighty nautical miles from the shore southwest of Ceylon is very strict around the clock. Since there will be almost no chance for a launch of the flight operations, $I-7$ shall cancel the air reconnaissance over Colombo and take up her designated position." Later at 0740, I-7 attacked a cargo ship (the British ship Glenshiel, 9,415 tons) (100) $^{(12} 1^{\circ} 0^{\prime} \mathrm{S} 78^{\circ} 11^{\prime} \mathrm{E}$, and sank her with two torpedoes and twenty shells.

On 7 April, Submarine Unit C Commander Rear Admiral Ichioka ordered Submarines I-3 and $I-2$ to conduct a weather reconnaissance around their stations in the Trincomalee area. On the 9th, after the completion of the attack on Trincomalee by the Carrier Task Force, the commander issued an order to the unit to withdraw from their stations and return to Singapore by means of Submarine Unit C Telegraphic Operation Order No. 6, and he returned to Singapore at 1600 on the 15 th.

\section{Submarine I-3 (with 7th Submarine Division commander on board)}

Submarine I-3 had left Penang on 28 March and took up her position to reconnoiter and watch Colombo. She made the following reports on enemy movements and the weather: ${ }^{(194)}$

Sent at 2200 on 3 April: "A number of enemy patrol vessels were outside the port of Colombo. Since his guard was very strict, we were not yet able to reconnoiter the inside of the port. [Enemy] ships considered to have departed [from Colombo] were one merchantman, who was sailing south alone at a point seventy nautical miles $220^{\circ}$ [SW] of Colombo at 0725 on the $2 \mathrm{~d}$, and another, who was sailing westward alone at a point seventy nautical miles $235^{\circ}$ [SW] of Colombo at 0130 on the $3 \mathrm{~d}$. However, other than them, we have not encountered any naval vessels entering or leaving the port. As for [enemy] aircraft, although one land-based aircraft was spotted at a point 195 nautical miles $135^{\circ}$ [SE] of Colombo at 1600 on the 31st, the situation of the [enemy] air patrols is unclear because we remained submerged during the day since then." Then at 0200 on 5 April, the following was sent: "The weather is fine around [here]; the cloud cover is five and its height 1,000 [meters]. A southern wind with a velocity of five meters [per second]. Visibility is good. More clouds are seen near the horizon and lightening is seen sometimes. Almost no changes in the weather in the past two days other than some increase in wind velocity. Our position is fifty nautical miles $240^{\circ}$ [WSW] of Colombo." Then at 0400 on 5 April: "Weather and atmospheric conditions were as sent in our Classified Telegram No. 30 (note by the author: the previous telegram). The sea is calm. Our position is thirty-six nautical miles $240^{\circ}$ [WSW] of Colombo." 
Later at 0540 on the 7th, I-3 spotted five cargo ships sailing east, one cargo ship sailing westward and one oiler on the waters 100 to 150 nautical miles to the west of Colombo. Although she attacked three of them, she was not able to produce any results, other than scoring fourteen hits on one of them (the British ship Elmdale, 4,872 tons) (Consumed ammunition: four torpedoes and thirty-nine shells). Then at 0450 on the 8 th, she attacked a cargo ship sailing westward (the British ship Fultala, 5,051 tons) ${ }^{(160)}$ about 180 nautical miles west of Colombo and sank her with one torpedo. Having reported the results of her weather reconnaissance at a point one hundred nautical miles west-southwest of Colombo at 0200 and 0400 on the 9th, she withdrew from her patrol area by the order of the Submarine Unit C commander of the 10th, and returned to Singapore on 15 April.

\section{Submarine $I-2$}

In order to take up her position to watch [the waters] off Trincomalee, Submarine $I-2$ had left Penang at 1200 on 28 March for Trincomalee. At 2130 on 3 April, she sent the following report: ${ }^{(141)}$ "Reconnaissance report of Trincomalee: 1 . Although we reached a point ten nautical miles outside the port of Trincomalee at 1100 on 3 April, we were not able to approach [the port], being blocked by patrolling enemy vessels. No enemy was spotted around the mouth of the port other than the patrolling vessels. 2. During the period we have watched this area from 31 March onwards, we have spotted no enemy aircraft around sunrise [or sunset] or at night (we remained submerged during daytime). 3. General weather conditions in this area: fair until 1 April; overcast with thin clouds on 2 and 3 April and there was a light rain on the evening of the $3 \mathrm{~d}$. However, the weather is generally fine in the morning, and the sea is very calm every day." [Then] at 0400 on 5 April, she [also] sent: "Overcast in the vicinity with a cloud cover of 8 and a height of 1500 [meters]. Southeast wind with a velocity of seven meters [per second]; visibility is good. Generally, in these days, the amount of clouds is small in the morning; it increases in the evening and causes light rains at times. The wind velocity tends to increase a little. Our position is fifty nautical miles $40^{\circ}$ [NE] of Trincomalee." [Later,] she reported having sunk a mid-sized cargo ship with two torpedoes at 1020 on the 7 th at $6^{\circ} 48^{\prime} \mathrm{N} 82^{\circ} 18^{\prime} \mathrm{E}$. Then sending a weather reconnaissance report at 0400 on the 9 th at a point sixty nautical miles $100^{\circ}$ [E] of Trincomalee, she [also] reported on the enemy movements [at the time of] the air raid on Trincomalee at 2200 [on that day] as follows: ${ }^{(193)}$ "The enemy movements we witnessed during submerged operations around a point eighty nautical miles (seventeen nautical miles off the shore) $143^{\circ}$ [SE] of Trincomalee on the 9th were as follows: 1 . The two steamers sailing southward around 1430 were both sunk by the bombing of [our] aircraft. 2. At 1515 to our west, a huge explosion was caused by the bombing of [our] aircraft; a flame shot up to the sky, but disappeared in an instant, which made us presume that the naval vessel had instantly sunk. After withdrawing from her station on 10 April, Submarine $I-2$ returned to Singapore on the 15th.

\section{Submarine I-4 (with the 8th Submarine Division commander on board)}

Submarine $I-4$ had left Penang at 1200 on 28 March and headed toward her designated position ([in] the vicinity of Eight Degree Channel?). At 1900 on the 6th, she sank a cargo ship (the U.S. ship Washingtonian, 6,617 tons) with two torpedoes at the western entrance of the channel. She then reported having inflicted serious damage on a motorized sailing boat (200-ton class) off Colombo at 0400 on the 10 th by shelling (fourteen shells); she returned to Singapore at 1800 on the 16th.

\section{Submarine $I-6$}

Submarine I-6 had left Penang at 1600 on 26 March for the Bombay area. At 1835 on the 31st, she reported having sunk one mid-sized cargo ship with two torpedoes to the east of Eight Degree Channel. [Then] at 1714 on 2 April, she sank a cargo ship (the British ship Clan Ross, 5,897 tons) off Bombay with three torpedoes, while at 2200 on the 7 th, she sank another mid-sized cargo ship (the British ship Bahadur, 5,424 tons) ${ }^{(160)}$ with seven torpedoes and eight shells in the same area. Next, in the same area at 1115 on the 10th, she also shelled two 150t-class motorized 
sailing boats ([with] sixteen shells). After reporting having sunk them, she withdrew and returned to Singapore at 1600 on 17 April.

\section{Submarine $I-5$}

Having been refloated on 20 March and undergone emergency repairs at Kendari, she hurried to the Ceylon area, leaving there on 25 March. On 8 April, she was ordered to advance to the south of Cape of Comorin [Kanyakumari]. After having carried out patrols in the area, she returned to Singapore at 1800 on 16 April.

The military gains Submarine Unit $C$ had reported between 3 and 10 April were six cargo ships and four motorized sailing boats, who had been sunk, and one cargo ship, on whom serious damage had been inflicted, while no damage was sustained on the Japanese side. In accordance with the stage-two, phase-one disposition of forces, which was put in motion on 10 April, the $2 \mathrm{~d}$ Submarine Squadron was removed from the Southern Task Force and returned to the Advance Unit; [accordingly, ] it left Singapore at 1000 on 21 April for mainland Japan, and entered the port of Yokosuka on 1 May.

Concerning the use of submarines, “The Greater East Asia War's Lessons of War ([section] Air Operations: The Operations on Ceylon)" says the following:

In reconnoitering enemy movements, one must employ submarines within the limits of their capabilities, without overestimating them.

When launching new operations, the use of submarines is a very effective means in case you decide to try every means available to thoroughly spy on the movements of the enemy. Therefore, as stated in the previous item, it is necessary to deploy submarines at key enemy points (note by the author: Aden, Durban, Cape Town, Bombay and Ceylon), have them directly watch these places along with conducting a timely reconnaissance inside these ports with their aircraft, conduct a sweep of the waters where engagements are anticipated so as to have them try as much as possible to spy on the enemy forces at their locations and in their movements. However, viewed in the light of their performance in this operation, the dispersal of the six submarines of the $2 \mathrm{~d}$ Submarine Squadron to the various areas of Trincomalee, Colombo, Bombay, the Chagos Archipelago and the Maldive Islands, etc., meant that not only almost nothing was achieved in their reconnaissance let alone their attacks, but that [ironically] their stationing actually deprived [the task force] of the reconnaissance that was supposed to be done and on which it so much depended. In such a situation where no reinforcements of submarines are expected as in this operation, we think that it would have been better if they had rather all been concentrated off Colombo.

Thus, conceptually and fundamentally we cannot expect too much from the current practice of reconnaissance with aircraft carried by submarines. Therefore, we deem it necessary to study as a new concept a method of how to carry along land-based reconnaissance planes or carrierbased reconnaissance aircraft, which are fast and able to return to considerably remote bases or carriers, whose main purpose is to be employed for a single forced photo reconnaissance in ongoing operations.

\section{The Distress of Britain (See Illustration No. 64)}

The situation of Britain, as described by [Captain S.W.] Roskill in his book The War at Sea 1939-1945, may be summarized as follows:*

\footnotetext{
* Vol. II, Chapter I “The Pacific and Indian Oceans," pp. 22-32.
} 
On 8 March, the First Sea Lord Admiral Pound reported to the prime minister that Ceylon was threatened and that a situation similar to what had happened to Malaya might occur. According to his view, the loss of Ceylon would result in undermining the whole strategic position [of Britain] in the Middle and the Far East. Upon this, the British government newly appointed Admiral [Sir James] Somerville to commander-in-chief of the Eastern Fleet and ordered him to protect Ceylon, employing HMS Ramillies, HMS Royal Sovereign and as many other naval vessels as possible. Somerville retorted to the First Sea Lord that [the deployment of] only two R-class battleships with fighter planes to directly escort them in the air would just repeat [the tragedy of] the HMS Prince of Wales and the HMS Repulse.

On his way to his new assignment, the new commander-in-chief [Admiral] Somerville sent a letter to the First Sea Lord in which he described his prospects. "Ceylon is obviously exposed to the danger of being lost. If the Japanese are intending to invade the island with their entire fleet, he could do little against them. If, on the other hand, an attack were made on a smaller scale, the best counter would be to preserve the military strength of the Eastern Fleet."

On 26 March, Admiral Somerville arrived in Colombo, where he assumed command of the Eastern Fleet, replacing former commander-in-chief Admiral [Sir Geoffrey] Layton. His fleet consisted of two large aircraft carriers (HMS Indomitable and HMS Formidable), one small aircraft carrier (HMS Hermes), five battleships (HMS Warspite, HMS Resolution, HMS Ramillies, HMS Royal Sovereign, and HMS Revenge), two heavy cruisers, five light cruisers (including the Dutch HNLMS Jacob van Heemskerck), sixteen destroyers and seven submarines, which on paper were superior forces. ${ }^{*}$ However, the number of attack planes carried by the three carriers was only fifty-seven, and the number of fighter planes was merely thirty-six. Furthermore, there were insufficient shore-based long-range reconnaissance aircraft, and almost no land-based attack plane units. His fleet was outdated, and was not adequately trained. On top of that, the defenses of his main bases, [i.e.] Colombo, Trincomalee and Addu Atoll (the latter of which will be explained later) were very weak.

The former commander-in-chief of the Eastern Fleet Admiral Layton was a renowned admiral and a person of action with a strong will, and one of the officers who had escaped from the successive defeats in Malaya and the Dutch East Indies. Having arrived in mid-January at Ceylon from Batavia, he was newly appointed commander-in-chief of Ceylon with wide powers to command the three forces on the island as well as the civil officers including the governor. Admiral Layton anticipated that Ceylon would come under attack before long, which quickly became a fact.

In the middle of March, [Vice] Admiral Kondō (note: commander of the Southern Task Force) ordered two attacks against India. One was the attack on Ceylon carried out by the Carrier Task Force (consisting of five aircraft carriers, four battleships, three cruisers and eight destroyers) led by Vice Admiral Nagumo, while the other was a sweeping operation in the northern part of the Bay of Bengal conducted by a fleet consisting of one light aircraft carrier, six cruisers and eight destroyers led by Vice Admiral Ozawa (note: commander of the Malaya Unit). It was soon after his arrival at his new post that Admiral Somerville got this information.

Both Admirals Somerville and Layton knew that under such circumstances, it was [too] dangerous to use Colombo and Trincomalee as anchorages for the fleet. Therefore, it was decided to use a secret base at Addu Atoll, the southern end of the Maldive Islands, six hundred nautical miles southwest of Ceylon. Although the island was relatively safe against a surprise attack by an enemy fleet, it totally lacked antiaircraft and antisubmarine defenses. But, fortunately, the Japanese forces did not learn of the base on Addu Atoll.

Intelligence indicated that the attack against Colombo and Trincomalee was to be expected on or around 1 April. [Admiral] Somerville judged that the Japanese attacks would be conducted from the southeast at dawn; planning to destroy the Japanese forces by torpedo** attacks at night by carrier aircraft, he concentrated [his fleet] to the south of Ceylon on the last day of March. However, he tried to avoid being attacked by enemy carrier aircraft; he had been ordered to preserve his fleet. In accordance

* The remark "which on paper were superior forces" is not in Roskill.

** "Torpedo" is not in Roskill. 
with his operational plan, six twin-engine reconnaissance seaplanes (Catalinas) of the 205th Squadron of the Royal Air Force (which were all the [search] aircraft available on Ceylon) carried out search missions as far as 420 nautical miles to the south of Ceylon.

The intelligence which reached [him] on 31 March was that the enemy attack would soon be made. On 1 April, the cruiser HMS Dorsetshire stopped her refit in Colombo and joined the fleet. On 1 and 2 April, the British fleet conducted search missions and patrolling while sailing eastward by night and westward by day. However, no information on the enemy came in. Late at night on the $2 \mathrm{~d}$, Admiral Somerville concluded that either the information of the attack on Ceylon was wrong, or the attack plan had been postponed. Since part of the British fleet required replenishment of fuel and/or fresh water, Admiral Somerville returned to Addu Atoll for replenishment, while dispatching HMS Dorsetshire to Colombo [to resume] her refit and HMS Cornwall was sent to provide escort for the transport convoy of Australian army troops due to arrive on the 8th. Furthermore, he also dispatched the aircraft carrier HMS Hermes and one destroyer to Trincomalee to prepare for the invasion of Madagascar.

On the afternoon of 4 April, the fleet entered the port of Addu Atoll. However, right after that, a report came in from a search aircraft that a superior enemy force had been spotted 360 nautical miles southeast of Ceylon. At that time, the fast division (HMS Indomitable, HMS Formidable, HMS Warspite, HMS Cornwall, * HMS Emerald and HMS Enterprise) was in the middle of refueling, while the slow division (the R-class battleships and the remaining cruisers) could not be ready until the next day. Admiral Somerville decided to let the fast division sail as soon as possible and let the slow division follow in an attempt to conduct a torpedo attack at night to block the enemy's course of retreat.

Since it was impossible to expect support from Somerville's fleet, Admiral Layton, commander-inchief of Ceylon, sent away the naval vessels at anchor, while strengthening his defenses on his own. The main vessels who escaped were the heavy cruisers HMS Cornwall and HMS Dorsetshire in Colombo and the carrier HMS Hermes in Trincomalee. The attack on Colombo was conducted from 0800 on 5 April (Sunday) with ninety-one bombers and thirty-six fighter planes. Two squadrons of Hurricanes (another squadron was deployed in Trincomalee) as well as two squadrons of Navy Fulmar fighter planes, totaling forty-two aircraft intercepted them, and after a fierce air engagement, brought down many** [enemy] aircraft, although the British forces also lost nineteen fighter planes. Furthermore, six Navy torpedo bombers (Swordfish) had been sent from Trincomalee to conduct torpedo attacks. However, they arrived at the scene in the middle of the air engagement and were all brought down. Fortunately, the damage to the ships at anchor in the port as well as that to the port facilities was relatively slight.

The heavy cruisers HMS Dorsetshire and HMS Cornwall had left the port late on 4 April to join Somerville's fleet. However, both vessels were spotted by enemy search aircraft on the morning of the 5 th, attacked by more than fifty [enemy] bombers on the late ${ }^{* * *}$ afternoon of that day and sank in a few minutes. The deadly power of Japanese carrier aircraft was again demonstrated. On the late afternoon of the next day, the 6th, 1,112 survivors of both vessels were rescued by vessels sent by Admiral Somerville. However, 424 officers and men were lost.

Somerville's fleet advanced halfway between Ceylon and Addu Atoll. However, with no information on the enemy reported, he gave up the idea of attacking the enemy and entered the port of Addu Atoll at 1100 on the 8th. Nagumo's Unit also made efforts to spot Somerville's fleet, only to fail. [It was because] the Japanese fleet conducted search missions in the area southeast of Ceylon, whereas Somerville's Fleet was operating [on the waters] far to the west.

After [attacking Colombo], Nagumo's fleet was heading for an attack on Trincomalee. On the afternoon of the 8th, a British search aircraft spotted a large force at four hundred nautical miles to the east of Ceylon. That night, the naval vessels at anchor in Trincomalee were made to evacuate the port. Through this action the carrier HMS Hermes, the destroyer HMAS Vampire, some merchantmen and naval vessels attached to the fleet retired to the south.

\footnotetext{
* HMS Cornwall had already been sent away.

** The original text only says seven.

*** Roskill: early.
} 


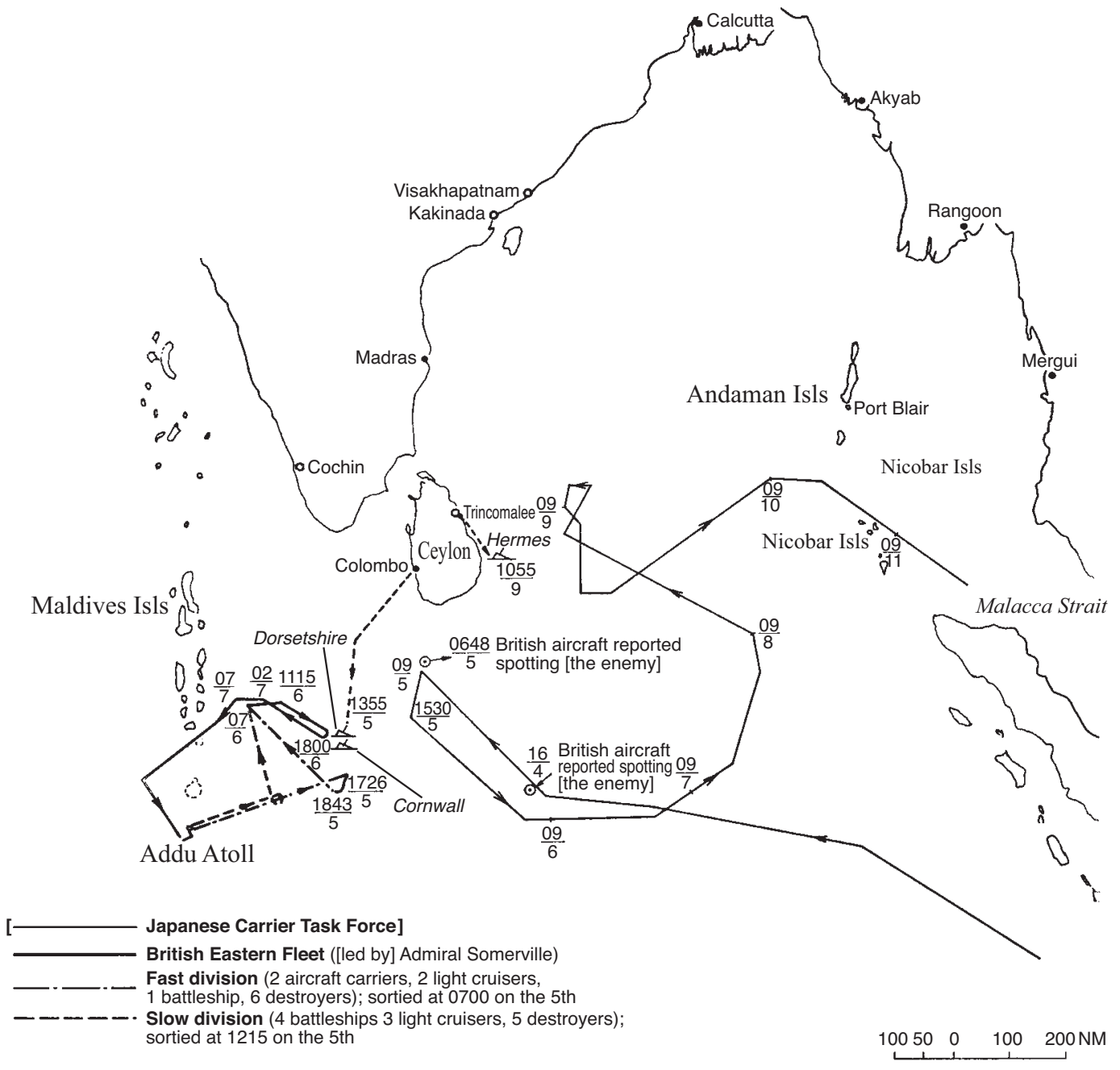

Illustration No. 64 - The Outline of the Actions of the British Eastern Fleet (from 5 till 8 April, 1942)

On the early morning of the 9th, the attack by enemy carrier aircraft took place. The [enemy] strength was almost the same as that employed in the attack on Colombo. However, only twenty-two fighter planes rose to meet them. The enemy attack did huge damage to shore facilities. Nine Blenheims of the 11th Squadron (the entire forces available to fight back) headed for an attack on the enemy carriers, but five of them were lost before scoring any hits.

Having heard that the attack was over, the vessels which had escaped from Trincomalee reversed course at 0900 on the 9 th to return to the port. Their position was about sixty-five nautical miles from the base. Unfortunately, this unit was spotted by Japanese search aircraft, came under attack around 1030; the HMS Hermes sank [after] having been hit by forty bombs in ten minutes, and the destroyer HMAS Vampire, the corvette HMS Hollyhock and two transport ships were also sunk. It was fortunate that more than six hundred survivors were rescued by a nearby hospital ship.

Meanwhile, Ozawa's striking force had been running riot in the northern part of the Bay of Bengal, due to which twenty-three merchantmen of a total of 112,312 tons were sunk between $5^{*}$ and 9 April.

* Roskill: 4 . 
Japanese submarine units also operated in the waters off the west coast of India, and sank five merchantmen of a total of 32,404 tons in the first ten days of April. The command of the sea as well as the air over the Indian Ocean was completely taken over by the enemy.

On the morning of 7 April, the [British] Admiralty sent an instruction telegram to Admiral Somerville that in such circumstances, the R-class battleships were a liability instead of an asset, and that it would let the commander-in-chief use his own discretion to withdraw the battleships to Africa. On the 8th, Admiral Somerville replied that he agreed to the instruction and had decided to send the slow division to Kilindini in east Africa to have it engage in guarding the sailing routes of convoys in the area, and that he had further decided to keep the fast division in the Indian Ocean to be ready against rapid enemy forces, but would keep it far away from Ceylon.

Fortunately, Japan had not planned to implement large-scale invasion operations in the Indian Ocean. Without pressing home the advantage they had gained in the Indian Ocean, the Japanese forces shifted their main strength to the east; two months later, they entered the decisive battle of Midway, where Nagumo's unit was totally destroyed.

\section{The Shift to Stage-Two Operations}

As previously mentioned, the Combined Fleet, which had entered stage-one, phase-four operations from 10 March onwards, the day after the fall of Java, decided to shift to stage-two, phase-one operations from 10 April onwards, following the completion of the major part of the Burma operation in early April. ${ }^{(141)}$

From the opening of hostilities, the Japanese forces had won victory after victory and their power was reaching its peak, sweeping everything before them. With their morale soaring to high heaven, they felt as if the United States and Britain did not amount to anything. The following gives an outline of the concept of the stage-two operations.

\section{The Grand Plan of Operations of IGHQ [Navy Department]}

The Plan of Operations of the Imperial Japanese Navy for Stage-Two Operations ${ }^{(196)}$ ([as of] 15 April 1942) by IGHQ [Navy Department] may be excerpted as follows:

I. General Policies (Omitted by the author)

II. Purpose of the Operations

4. The purpose of the operations of the Imperial [Japanese] Navy is to destroy the enemy fleets and air power in the Pacific and Indian Oceans, secure the necessary strategic places so as to strengthen and establish an undefeatable strategic position of the [Japanese] empire, by which [the Navy] shall bring Britain to submission and crush the morale of the United States.

III. Missions

5. [The Navy shall] destroy the British fleet in the Indian Ocean, and in tandem with the progress of the German and Italian operations in west Asia, capture Ceylon as far as the circumstances permit it in conjunction with the Army, so as to cut the communications between Britain and India and secure the cooperation with Germany and Italy.

6. [The Navy shall] intensify the operations against Australia, particularly those to cut off [the communications between] the United States and Australia, to expedite their submission.

7. [The Navy shall] keep a strict watch against surprise attacks, particularly air strikes by enemy task forces on mainland Japan, and catch and destroy them.

8. Against the United States, [the Navy shall] conduct surprise attacks on, destroy or capture their operational bases in the Pacific Ocean as required, by which it shall try to diminish U.S. surface and air power. After the operations in the Indian Ocean and against Australia 
are mostly completed, [the Navy shall] search for the U.S. main fleets (including those combined with British forces), coercively draw them into decisive battles and destroy them.

9. At an appropriate moment, the operations against China shall be intensified, and along with the results of the Burma operation, the submission of the Chiang regime shall be expedited.

10. Operational bases in the captured areas shall quickly be prepared and their defenses be strengthened.

IV. Outline of the Operations

11. The disposition of forces in the initial period of stage-two operations shall be as follows:

(1) The occupied areas in [the area to] the south [of Japan]

The forces consisting of the First, Second, and Third Southern Expeditionary Fleets as the core and one element of the Combined Fleet

(2) The [equatorial] Pacific Islands and the South Pacific Islands

The forces consisting of the Fourth Fleet and the Eleventh Air Fleet as the core and one element of the Combined Fleet

(3) The Sea to the east of Japan

The forces consisting of the Fifth Fleet as the core

(4) The Pacific and the Indian Oceans

A force consisting of the Sixth Fleet as the core and one element of the Combined Fleet

(5) The Japanese waters

The main force of the Combined Fleet

(6) The China area

The China Area Fleet

12. The Operations shall be carried out in outline as follows:

(1) [The forces shall] swiftly search for the British fleet in the Indian Ocean, destroy it and in tandem with the progress of German and Italian operations in west Asia, capture Ceylon as far as the circumstances permit it, so as to cut the communications between Britain and India and secure the cooperation with Germany and Italy.

(2) Against Australia, [the forces shall] intensify the operations to cut off [its communications] with the United States and Britain, while destroying enemy fleets in the Australian [waters], to expedite its submission.

For that purpose, the following operations shall be conducted.

$\{1\}$ The land-based air units and the Carrier Task Force shall smash the enemy power and military facilities in strategic points on the eastern and northern coasts of Australia to contain enemy counter offensives.

$\{2\}$ The Carrier Task Force and the submarines shall destroy enemy fleets in the Australian waters, while destroying enemy sea lines of communication.

$\{3\}$ In conjunction with the Army, [the forces] shall capture Fiji, Samoa and New Caledonia, prepare air and submarine bases at these points so as to cut off the sea lines of communication as well as air traffic routes between Australia and the United States. However, concerning Samoa, it is possible that the forces shall be withdrawn when after its capture the base facilities have been completely destroyed.

After the China Incident has been settled or the relations with the Soviet [Union] have become less tense, an invasion of Australia may be planned if circumstances should permit it.

(3) Against the eastern front, the following operations shall be conducted:

$\{1\}$ Midway Island shall be captured with as main intention to make it difficult [for the enemy] to conduct surprise attacks.

$\{2\}$ [To be ready] against enemy surprise attacks, necessary forces shall appropriately be deployed, and patrols shall be conducted. Particularly, [the forces] shall maintain a strict watch against air raids over mainland Japan, strive to find out the intentions of 
the enemy beforehand, and catch and destroy him by concentrating our strength at appropriate moments.

\{3\} By surprise attacks with submarines and air units [the forces shall] strive to degrade the power of the enemy and destroy his operational bases in the Pacific Ocean, mainly on Hawaii and other places.

$\{4\}$ Operational bases on the Aleutian Islands shall be destroyed or captured as soon as possible to contain U.S. intentions of conducting operations from the north Pacific.

(4) After the operations in the Indian Ocean and the Australia area are roughly completed, [the Navy shall] direct its whole strength toward the eastern front, coercively draw the U.S. main fleets (including those combined with British forces) into decisive battles and destroy them.

For this purpose, when preparations have been completed, the following operations shall be implemented.

$\{1\}$ The bases on the periphery of Hawaii (Johnston and Palmyra Atolls, etc.) shall be captured.

$\{2\}$ At an opportune moment, large-scale surprise attacks shall be implemented against Hawaii to destroy the enemy air power there.

\{3\} While carrying out the above two operations, the bulk of the Combined Fleet shall catch and destroy the surface forces of the enemy to coercively draw the enemy main force into decisive battles as much as possible.

$\{4\}$ In connection with the operations in the above items, and if circumstances permit it, [the forces may] capture Hawaii in conjunction with the Army with the intention to destroy the enemy's advance bases, disrupt his commerce, as well as to intensify surprise attacks on strategic places on the west coast of the United States.

(5) Throughout this period of operations, [the Navy] shall conduct effective commerce disruption warfare in the Indian and Pacific Oceans, while securing the sea lines of communication required for the [Japanese] empire.

(6) [The Navy] shall rapidly strengthen the defenses of the [equatorial] Pacific Islands as well as the captured areas so as to be prepared against counterattack and recapture operations of the enemy.

(7) As for China, by enforcing strict naval blockades in the India and Burma areas, conjointly with the Army operations, the submission of the Chiang regime shall be expedited.

\section{The Revision of the Wartime Formation}

Since the opening of hostilities, several times partial revisions had been made of the Wartime Formation of the Imperial Japanese Navy; on 1 April [1942], a change in the formation of the Eleventh Air Fleet was implemented in order to enormously strengthen the land-based air unit. Namely, the 24th Air Flotilla, made up by extracting [forces] from the Fourth Fleet, and the newly-organized 25th and the 26th Air Flotillas were added to the [current] 21st, the 22d and the 23d Air Flotillas, which increased [the number of air flotillas] to six. Following that, along with the Combined Fleet's shift to stage-two operations on 10 April, the Wartime Formation was substantially revised. The major changes were the following:(187)

1. The (newly-built) Yamato was incorporated into the 1st Battleship Division.

2. The First Air Fleet, which until now was made up of four carrier divisions, ([i.e.] the 1st, the $2 \mathrm{~d}$, the 4th, and the 5th Carrier Divisions) with destroyer divisions or destroyers attached to each of them, was changed in such a way that each carrier division only contained carriers and that the newly-formed 10th [Destroyer] Squadron (consisting of one light cruiser and three destroyer 
divisions) was incorporated into the fleet instead to take unified [control over the] destroyer divisions (or destroyers) assigned to guard and escort the carriers.

3. The 8th Destroyer Division was removed from the 2d Destroyer Squadron and incorporated into the 4th Destroyer Squadron, while the 24th Destroyer Division was removed from the 4th Destroyer Squadron and incorporated into the 1st Destroyer Squadron. The 17th Destroyer Division was removed from the 1st Destroyer Squadron and incorporated into the 10th [Destroyer] Squadron.

4. The Southwest Area Fleet was newly formed to take command of the current First, Second, and Third Southern Expeditionary Fleets. The commander of the Southwest Area Fleet was concurrently assigned to be the commander in chief of the Second Southern Expeditionary Fleet.

5. In order to strengthen the protection of the sea lines of communication, the 1st and the $2 \mathrm{~d}$ Surface Escort Units were newly formed, and respectively incorporated into the Southwest Area Fleet and the Fourth Fleet.

6. The 6th Submarine Squadron, which had been attached to the Combined Fleet, was disbanded.

\section{The Main Points of the Outline of the Stage-Two Operations of the Combined Fleet}

Based on the plan for stage-two operations of IGHQ, the main points of the operational plan of the Combined Fleet for stage-two was to go ahead with the preparations for the invasions of Port Moresby and Tulagi with one element, and continue to make preparations for the Midway and Aleutians operations with the main force, while keeping an eye on the eastern [front]. The outline of phase-one operations (to be conducted from 10 April till late May) was by and large as follows: ${ }^{(157)}$

1. The main force unit shall primarily stay at anchor on alert in the western part of the Inland Sea, conducting drills and doing maintenance work, while keeping a strict watch on the east front to be prepared against attacks by U.S. striking forces.

2. The Forward Unit and the Carrier Task Force shall stay at anchor on alert in the western part of the Inland Sea (in the southern part of Kyūshū for the carrier aircraft), engaging in drills and maintenance work.

3. The Advance Unit shall operate in the areas near Hawaii, the west coast of the United States, the Aleutians, New Zealand, Australia, South Africa as well as in the Indian Ocean from its main base in the Marshall Islands; watching [enemy] strategic points, it shall conduct attacks on enemy naval vessels, carry out Operation K (note: an operation to reconnoiter (and attack) Hawaii with Type-2 flying boat[s]) and disrupt enemy sea lines of communication, while patrolling the waters to the east of the Honshū with one element. [The unit shall also] support with the major part of the 8th Submarine Squadron the Moresby invasion operation to be conducted by the South Seas Unit.

4. In order to conduct air operations at the east and southeast fronts, the land-based air unit shall deploy by and large four air flotillas (the 21st, the 24th, the 25th and the 26th Air Flotillas) to Honshū, Saipan, Wake Island, the Bismarck Archipelago, the Marshall, Gilbert, and Solomon Islands, and New Guinea, while at the same time engage in Operation K with one element in cooperation with the Advance Unit.

5. The South Seas Unit shall, in conjunction with the Army, capture Port Moresby in early May. After that, the unit shall continue stage-one, phase-four operations, while patrolling and defending the assigned areas and protecting the [friendly sea] lines of communication, in addition to the clearing of the enemy from British New Guinea and the Solomon Islands. 
6. The Northern Task Force shall continue stage-one, phase-four operations, while patrolling and defending assigned areas as well as keeping a watch on the Soviets.

7. The former Southern Task Force shall be divided into the East Indies Unit, Malaya Unit, the Philippines Unit and the Surface Escort Unit. They shall continue stage-one, phase-four operations, while strengthening the defense of the occupied strategic areas, clearing enemy remnants, protecting the [friendly sea] lines of communication in their assigned areas as well as conducting air campaigns over the Indian Ocean and against Australia (with the 22d and the 23d Air Flotillas).

The disposition of forces of the Combined Fleet in the stage-two, phase-one operations was in outline as follows: ${ }^{(157)}$

\section{The Main Force Unit}

(1) The Main Unit: the 1st Battleship Division, the 3d Destroyer Squadron (minus one destroyer division) and the 4 th Carrier Division (minus the $S h \bar{o} \bar{o}$ )

(2) The Guard Unit: the First Fleet (minus the 3d Battleship Division, the 6th Cruiser Division, the 27th Destroyer Division, and minus the 3d Destroyer Squadron (minus one destroyer division)), the 4th Cruiser Division 2d Section, one element of the First Air Fleet

2. The Forward Unit

The Second Fleet (minus the 4th Cruiser Division 2d Section, the 5th Cruiser Division, the 8th Cruiser Division, and one destroyer division of the 4th Destroyer Squadron), the 3d Battleship Division (minus the 2d Section), the 11th Seaplane Tender Division (minus the Mizuho)

3. The Carrier Task Force

The First Air Fleet (minus one element), the 3d Battleship Division 2d Section, the 8th Cruiser Division, one destroyer division of the 4 th Destroyer Squadron

4. The Advance Unit

The Sixth Fleet, the 5th Submarine Squadron, the Chiyoda and the Nisshin

5. The Land-based Air Unit

The Eleventh Air Fleet (minus the 22d Air Flotilla (minus one element) and minus the 23d Air Flotilla and the Tōkō Air Group)

6. The South Sea Unit

The Fourth Fleet, the 6th Cruiser Division, the 5th Cruiser Division (minus the Nachi), the 18th Cruiser Division, the Kaga, the Shōo, the Mizuho, the 7th Destroyer Division, the 27th Destroyer Division, the 3d Kure Special Landing Force

7. The Northern Task Force

The Fifth Fleet and the Nachi

8. The Southern Task Force

The Southwest Area Fleet, the 22d Air Flotilla (minus the land-based attack plane unit of the Genzan Air Group), the 23d Air Flotilla, the Tōkō Air Group, the 1st and the 3d Yokosuka Special Landing Forces and some patrol boats

That is to say, the Second Fleet Commander in Chief Vice Admiral Kondō, who had been in command of overall operations in the area south [of Japan], was relieved of his command and assigned to become commander of the Forward Unit in the stage-two phase-one disposition of forces. Replacing him, Vice Admiral Takahashi, commander in chief of the Southwest Area Fleet assumed command of the operations in the area southwest [of Japan]. Thus, the focus of the operations of the Japanese Navy shifted to the east of Honshū and the areas southeast [of Japan] away from the southwestern areas as had been the case until then. 
On 10 April, Combined Fleet Commander in Chief Admiral Yamamoto issued the following order to put in motion the stage-two, phase-one disposition of forces: ${ }^{(157)}$

\section{Combined Fleet Classified Telegram No. 724}

\section{Combined Fleet Telegraphic Order No. 109}

The stage-two, phase-one disposition of forces shall be put in motion.

The outline of the disposition is as sent by means of Combined Fleet Classified Telegram No. 694, except that the 5th Carrier Division and the Kaga shall switch stations and that the assignment of the 16th Destroyer Division shall remain as it is until late April.

In accordance with this order, the 5th Carrier Division was made to participate in the Port Moresby operation in place of the Kaga, as previously told.

The Combined Fleet scheduled stage-two, phase-two operations from late May until about 20 June, in which the capture of strategic places in the Midway and Aleutian Islands areas were planned.

\section{Plan for the Stage-Two, Phase-One Operations of the Southwest Area Fleet}

The plan for stage-two, phase-one operations of the Southwest Are Fleet may be presumed to have been as follows: ${ }^{(182,190,197)}$

1. While keeping a strict watch over the Indian Ocean with the $22 \mathrm{~d}$ Air Flotilla (minus the landbased attack plane unit of the Genzan Air Group) and with the Tōkō Air group, the Malaya Unit shall continue its operation to transport reinforcements for the Fifteenth Army to Burma, and also take charge of guarding the waters around the seized strategic points, setting up defenses at the main ports and bases, and protecting the sea lines of communication of the assigned areas.

2. While conducting operations to neutralize the [enemy] air power in the northern part of Australia with the 23d Air Flotilla, the East Indies Unit shall continue its operation to clear western New Guinea of the enemy, which was launched at the end of the last month. Along with the above, the unit shall take charge of escorting the transport of rear units of the Sixteenth Army, the defense of the captured strategic areas, as well as the protection of the sea lines of communication in its assigned area, etc. It shall also launch a clearing operation of the Lesser Sunda Islands with one element of its forces at the beginning of May.

3. The Philippines Unit shall, in conjunction with the Army, swiftly seize the enemy stronghold at the mouth of Manila Bay. For this purpose, it shall strive to catch and destroy escaping vessels of the enemy by intensifying the blockade at the mouth of Manila Bay, and in conjunction with the Army, clear the southern islands of the Philippines of the enemy as quickly as possible. The unit shall also take charge of protecting the sea lines of communication in its assigned area, and push forward the preparation of various facilities for the naval bases.

4. The Surface Escort Unit (minus the 22d Destroyer Division) shall, while maintaining close cooperation and communication with other units, take charge of protecting the sea lines of communication in the following sea areas: (Sea areas — omitted by the author).

The outline of the disposition of forces of stage-two, phase-one operations of the Southwest Area Fleet was as follows: ${ }^{(182)}$ 
1. The main unit

The Ashigara and the 16th Cruiser Division 2d Section

2. The Malaya Unit

The First Southern Expeditionary Fleet, the 22d Air Flotilla (minus one element), and the Tōkō Air Group

3. The East Indies Unit

The Second Southern Expeditionary Fleet, the 23d Air Flotilla, the 11th Seaplane Tender Division (minus the Mizuho), the 1st Patrol Boat Division (minus four patrol boats), the 22d Destroyer Division, the 16th Destroyer Division 1st Section, the 1st and the 3d Yokosuka Special Landing Forces

4. The Philippines Unit

The Third Southern Expeditionary Fleet

5. The Surface Escort Unit

The 1st Surface Escort Unit

Of the above, the forces of the 1st Surface Escort Unit were quite meager, as shown in the following:

The 13th Destroyer Division: three Wakatake-class (old 2d-class destroyers)

The 22d Destroyer Division: four Minazuki-class (1st-class destroyers)

The 32d Destroyer Division: three Asagao-class (old 2d-class destroyers)

The (torpedo boats) Sagi and Hayabusa

Six auxiliary gunboats (merchantmen with some guns fitted)

It was almost impossible to protect the sailing routes of more than 2,500 nautical miles between Moji and Singapore with such a small force. However, at that time, the losses caused by enemy submarines were unexpectedly small, and since the power of the enemy submarines was rated [also] very low, matters of escort at sea were taken too lightly. The majority [in the Navy] did not recognize that this would become one of the major causes that would prove fatal to Japan in the future.

At 0910 on 10 April, along with the launch of the stage-two, phase-one disposition of forces, Southwest Area Fleet Commander in Chief Vice Admiral Takahashi gave the following instructions to the units under his command by means of Southwest Area Fleet Classified Telegram No. 660:(182)

At this juncture, when stage-one operations are mostly completed, the Southern Task Force has been disbanded and the new Southwest Area Fleet has been formed, I have been assigned the heavy responsibility of commander in chief of this fleet. It is my earnest hope to fulfill my grave responsibility by implementing the right tactics and conducting the right fights at all constituent fleets. In my view, invasion operations are easy whereas long-term holdout operations are difficult. Not to mention that all forces must cooperate and unite, further enhance their strong fighting spirit and preemptively and perfectly block enemy counteroffensives, I hope [all shall] aggressively strive to defeat the enemy by always catching every opportunity, and in view of the characteristics of these operations, further closely cooperate with the Army, giving adequate thought to the real significance of Army-Navy joint operations, and thus without reserve accomplish their missions. 


\section{Conclusion}

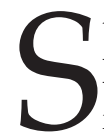

tage-one operations were concluded earlier than scheduled and with a huge success. In the southwestern theater, the Japanese Navy had advanced as far as Ceylon and defeated British fleets, while in Burma the Japanese Army continued its advance after having occupied Rangoon on 8 March. The air attacks on the Australian key point of Port Darwin were [also] continued, and India seemed to show tendencies to gradually break away from Britain.

In the southeastern theater, Rabaul on the island of New Britain had been occupied on 23 January, and land-based air units had immediately advanced there. Then, the capture of key places in British New Guinea (Lae, Salamaua, and Port Moresby) and strategic places in the Solomon Islands (Tulagi, etc.) had been ordered at the end of that month. The aim was to secure defensive positions in the area to the north of eastern Australia by taking control of the waters (the Coral Sea), while cutting off the area's communications with mainland Australia. Lae and Salamaua were captured on $8 \mathrm{March}$, and the preparations for the capture of Port Moresby was in steady progress.

Meanwhile, the enemy on the Bataan Peninsula in the Philippines surrendered on 9 April after the attacks by the Fourteenth Army from 3 April onwards, while the days of the Corregidor stronghold were numbered.

Through the stage-one operations, [Japan] acquired the resources areas of the South, which, as to the oil it craved, allowed the country to expect that 1.7 million tons could be acquired in the first year of the war, which was about six times as large as [the prewar estimation of] 300,000 tons.

The shipping losses since the beginning of the hostilities were as shown in the following table. Compared to an estimated loss of 800,000 to 1,000,000 tons for the first year of the war, only about 260,000 tons were [actually] lost in these four months. Particularly, the loss caused by enemy submarines, which had been the chief concern, was [only] about 150,000 tons, and moreover, the loss sustained by regular transports, which was supposed to give a rough idea of [the loss in] the transport of resources in the future, was just 30,000 tons.

For Reference: Shipping Losses Classified by Cause ${ }^{(198)}$

\begin{tabular}{|c|c|c|c|c|c|c|c|c|c|c|}
\hline \multirow{2}{*}{ Caused by } & \multicolumn{2}{|c|}{ Submarine } & \multicolumn{2}{|c|}{ Aircraft } & \multicolumn{2}{c|}{ Shells/Mines } & \multicolumn{2}{c|}{$\begin{array}{c}\text { Ordinary } \\
\text { Shipwrecks }\end{array}$} & \multicolumn{2}{c|}{ Total } \\
\cline { 2 - 11 } & Ships & $\begin{array}{c}\text { Total } \\
\text { Tonnage }\end{array}$ & Ships & $\begin{array}{c}\text { Total } \\
\text { Tonnage }\end{array}$ & Ships & $\begin{array}{c}\text { Total } \\
\text { Tonnage }\end{array}$ & Ships & $\begin{array}{c}\text { Total } \\
\text { Tonnage }\end{array}$ & Ships & $\begin{array}{c}\text { Total } \\
\text { Tonnage }\end{array}$ \\
\hline 1941-Dec & 6 & 31,673 & 3 & 16,901 & 0 & 0 & 2 & 6,585 & 11 & 55,159 \\
\hline 1942-Jan & 9 & 41,104 & 2 & 9,686 & 3 & 2,133 & 5 & 19,455 & 19 & 72,378 \\
\hline
\end{tabular}




\begin{tabular}{|c|c|c|c|c|c|c|c|c|c|c|}
\hline 1942-Feb & 6 & 29,000 & 4 & 4,619 & 1 & 6,566 & 2 & 8,085 & 13 & 48,270 \\
\hline 1942-Mar & 11 & 47,017 & 3 & 10,516 & 4 & 25,331 & 0 & 0 & 18 & 82,864 \\
\hline Total & 32 & 148,794 & 12 & 41,722 & 8 & 34,030 & 9 & 34,125 & 61 & 258,671 \\
\hline
\end{tabular}

Shipping Losses Classified by Tasks ${ }^{(198)}$ (excluding shipwrecks)

\begin{tabular}{|c|c|c|c|c|c|c|c|}
\hline \multirow{2}{*}{$\begin{array}{c}\text { Loss } \\
\text { sustained } \\
\text { Year/month }\end{array}$} & \multicolumn{2}{|c|}{$\begin{array}{c}\text { In Engagements or } \\
\text { Transport for Op- } \\
\text { erations }\end{array}$} & \multicolumn{2}{|c|}{$\begin{array}{l}\text { In Regular } \\
\text { Transport }\end{array}$} & \multicolumn{2}{|c|}{ Total } & \multirow{2}{*}{ Remarks } \\
\hline & Ships & $\begin{array}{c}\text { Total } \\
\text { Tonnage }\end{array}$ & Ships & $\begin{array}{c}\text { Total } \\
\text { Tonnage }\end{array}$ & Ships & $\begin{array}{c}\text { Total } \\
\text { Tonnage }\end{array}$ & \\
\hline 1941-Dec & 9 & 48,574 & 0 & 0 & 9 & 48,574 & \multirow{5}{*}{$\begin{array}{l}\text { The ships operated by the } \\
\text { Ship Management Association } \\
\text { and shipwrecks on the Japan- } \\
\text { ese sea were calculated as } \\
\text { [losses sustained] in regular } \\
\text { transport. }\end{array}$} \\
\hline 1942-Jan & 10 & 36,064 & 4 & 16,859 & 14 & 52,923 & \\
\hline 1942-Feb & 10 & 39,196 & 1 & 989 & 11 & 40,185 & \\
\hline 1942-Mar & 15 & 70,909 & 3 & 11,955 & 18 & 82,864 & \\
\hline Total & 44 & 194,743 & 8 & 29,803 & 52 & 224,546 & \\
\hline
\end{tabular}

The attacks by enemy submarines, particularly U.S. submarines, lacked aggressiveness, and the performance of their torpedoes was bad, too. On top of that, just during the phase-three operations of the Dutch East Indies operation, twenty-nine enemy submarines were reported to have been sunk. (The number [of enemy submarines] actually sunk was four.)

Thus, the prospect of acquiring the southern resources was bright and the consolidation of a long-term absolutely unbeatable position seemed certain, which led the Government and Imperial General Headquarters to even start mulling over steps to facilitate the conclusion of the war.

It can be said that the major reason for this success was owed to the remarkable service of the air units. That is to say, the Carrier Task Force completely destroyed the U.S. Fleet in Hawaii, while the land-based air unit sank two significant battleships of Britain off Malaya, and easily defeated the U.S. Far East Air Force in the Philippines, which had been considered very strong. Also after that, the air units were busily engaged in all directions; between 4 January and 6 April, the Air Unit of the Southern Task Force reported having brought down 334 enemy aircraft with certainty, along with 135 aircraft unconfirmed, having sunk seven naval vessels and warships, three submarines, eighteen merchantmen of 10,000 tons or more, as well as having inflicted damage on seven naval vessels and battleships, nine destroyers, two submarines and seventeen merchantmen of 10,000 tons or more. Japanese losses on the contrary were very small, as shown in the following table. ${ }^{(75)}$ 


\begin{tabular}{|c|c|c|c|c|c|}
\hline Causes & $\begin{array}{c}\text { Land-based } \\
\text { Attack Planes }\end{array}$ & $\begin{array}{c}\text { Land-based } \\
\text { Reconnaissance } \\
\text { Planes }\end{array}$ & Fighter Planes & Flying Boats & Total \\
\hline $\begin{array}{c}\text { Crashed } \\
\text { themselves }\end{array}$ & 12 & 6 & 14 & 2 & 34 \\
\hline $\begin{array}{c}\text { Hit by bombs or } \\
\text { marked by } \\
\text { bullets }\end{array}$ & 2 & 0 & 2 & 0 & 4 \\
\hline Total & 14 & 6 & 16 & 2 & 38 \\
\hline
\end{tabular}

The losses sustained in the Philippines and Malaya in the beginning of the hostilities were also very small as shown in the following table. Although in the map exercise at the Naval College, a loss of $160 \%$ of the Type- 0 fighter planes and $40 \%$ of the land-based attack planes had been anticipated before the advance to Java, this turned out to be just a groundless fear.

The Losses Sustained in the Air Campaigns over the Philippines (From 8 December till 3 January) (75)

\begin{tabular}{|c|c|c|c|c|c|}
\hline Causes & $\begin{array}{c}\text { Land-based } \\
\text { Attack Planes }\end{array}$ & $\begin{array}{c}\text { Land-based } \\
\text { Reconnaissance } \\
\text { Planes }\end{array}$ & Fighter Planes & Flying Boats & Total \\
\hline $\begin{array}{c}\text { Crashed } \\
\text { themselves }\end{array}$ & 1 & 0 & 13 & 1 & 15 \\
\hline $\begin{array}{c}\text { Hit by bombs or } \\
\text { marked by } \\
\text { bullets }\end{array}$ & 0 & 0 & 2 & 0 & 2 \\
\hline Total & 1 & 0 & 15 & 1 & 17 \\
\hline
\end{tabular}

The Losses Sustained in the Air Campaigns over Malaya (From 8 December till 15 February) $)^{(75)}$

\begin{tabular}{|c|c|c|c|c|c|}
\hline Causes & $\begin{array}{c}\text { Land-based } \\
\text { Attack Planes }\end{array}$ & $\begin{array}{c}\text { Land-based } \\
\text { Reconnaissance } \\
\text { Planes }\end{array}$ & Fighter Planes & Flying Boats & Total \\
\hline $\begin{array}{c}\text { Crashed } \\
\text { themselves }\end{array}$ & 5 & 1 & 3 & 0 & 9 \\
\hline
\end{tabular}

Furthermore, the power of the Carrier Task Force was tremendous; the on-target rates in the attacks on the heavy cruisers and the carrier in the Ceylon attack were respectively $88 \%$ and 
$82 \%$. An example of the comparison of its aircraft's performance in air combats was as follows, which gave the impression as if they were matchless.

The Air Strikes on Colombo (as reported)(75)

\begin{tabular}{|c|c|c|c|c|c|c|}
\hline \multirow{2}{*}{$\begin{array}{c}\text { Type of } \\
\text { Aircraft }\end{array}$} & \multicolumn{2}{|c|}{$\begin{array}{c}\text { IReported by] } \\
\text { Fighter Planes }\end{array}$} & \multicolumn{2}{c|}{$\begin{array}{c}\text { [Reported by] } \\
\text { Carrier-based bombers }\end{array}$} & \multicolumn{2}{c|}{ Total } \\
\cline { 2 - 7 } & Confirmed & Unconfirmed & Confirmed & Unconfirmed & Confirmed & Unconfirmed \\
\hline Spitfires & 12 & 5 & 0 & 0 & 12 & 3 \\
\hline Hurricanes & 18 & 3 & 6 & 0 & 24 & 2 \\
\hline $\begin{array}{c}\text { Swordfishes } \\
\text { Swefiants }\end{array}$ & 1 & 2 & 0 & 0 & 0 & 1 \\
\hline $\begin{array}{c}\text { Total } \\
\text { The Loss } \\
\text { Sustained } \\
\text { by }\end{array}$
\end{tabular}

While these results show how powerful the Japanese air forces were, they also suggested that the war from then on would be fought over the command of the air. However, there were many in the top echelons of the Japanese Navy who still stuck to the view that large vessels and giant guns were also required, due to which, despite the recognition of aircraft power, drastic measures to provide [adequate aircraft] were not carried out. [The Navy] further failed to take adequate measures against [enemy] submarines, partly due to its overoptimistic judgment on the enemy submarines. And along with quite a number of other problems that were kept within [the Navy], such as the leakage of information concerning operations (for example the Colombo operation) and the fact that the lessons of war were not immediately put into practice, the Navy shifted to stage-two operations. 


\section{List of Abbreviations and Symbols Used in the Imperial Japanese Navy}

Addendum

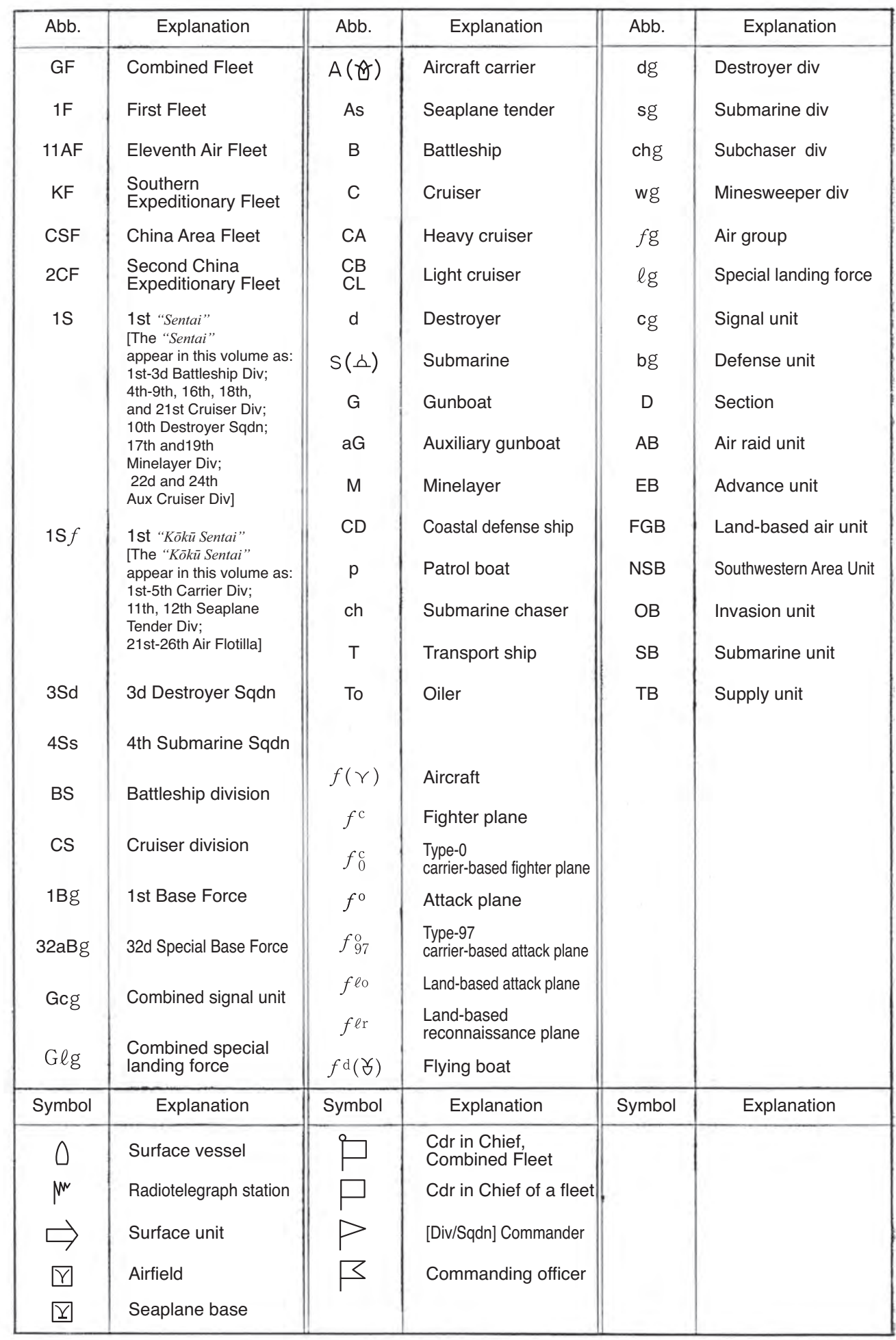




\section{Notes}

1. Kihon Kokuryoku Dōtai Sōran, Kokumin Keizai Kenkyūkyōkai（『基本国力動態総覧』国民 経済研究協会編昭和29年9月 [Compendium of a dynamic survey on fundamental national wealth, ed. by the Association for Research on the National Economy, Sept. 1954]).

2. Gozen Kaigi Gijiroku (「御前会議議事録」[The minutes of the Imperial Conferences]).

3. Daihon'ei - Seifu Renraku Kaigi Kettei-tsuzuri (「大本営政府連絡会議決定綴」[The files of [documents on] the decisions at the Liaison Conferences between IGHQ and the Government]).

4. Daihon'ei Kimitsu Sensō Nisshi (「大本営機密戦争日誌」[Classified war journal kept by IGHQ]).

5. Taiheiyō-sensō Gen'in-ron, Nihon Gaikō Gakkai hen（『太平洋戦争原因論』日本外交学会編, 昭和28年6月, 660ページ [A Re-examination of the Causes of the Pacific War, ed. by The [Provisional] Study Group on Japanese Diplomacy], June 1953, p. 660]).

6. 'Nakazawa Tasuku Chūsa Memo' (「中沢佑中佐メモ」 ['Notes of Cdr. Nakazawa Tasuku']). [Then] chief of operations of the Navy General Staff; later [promoted to] Vice Admiral.

7. Kaigun Nenryō Enkaku（「海軍燃料沿革」昭和10年9月30日 [A history of the fuel [used by] the Navy, 30 Sept 1935]). A report presented to Ōsumi Kaigun Daijin (大角海軍大臣 [Navy Minister Ōsumi]) by Maki Shunkai(真木俊魁), commissioned by the Navy Ministry.

8. Jinzō Sekiyu Seisaku to Sono Jigyō [by] Enomoto Takaichirō published by Kaikei Bunseki Kenkyūjo (『人造石油政策とその事業』榎本 隆一郎著 昭和17年7月 会計分析研究所発行 [The policy for artificial oil and its projects by Enomoto Takaichirō, published by the Research Institute of Accounting Analysis, July 1942]).

9. Iino Rokujūnen no Ayumi, Iino Kaiun Kabushiki Gaisha Shashi Hensan-shitsu hen (『飯野 六○年の歩み』飯野海運株式会社社史編纂室編 昭和34年6月 [Sixty years of Iino, ed. by the Company History Compiling Office, Iino Kaiun Kaisha Ltd., June 1959]).

10. Sekiyu Shiryō Geppō, Sekiyu Renmei hen（『石油資料月報』石油連盟編 [Monthly newsletter of data [related to the] oil [industry], ed. by the Petroleum Association of Japan]).

11. Yamaki Akira Taisa Sengo no Kaisō (矢牧章大佐戦後の回想 [Postwar recollections of Capt. Yamaki Akira]). [Then] senior staff of the Third Fleet; later [promoted to] rear admiral.

12. 'Shibata Bunzō Chūsa Memo' (「柴田文三中佐メモ」['Notes of Cdr. Shibata Bunzō']). [Then] senior staff of the 21st Air Flotilla.

13. 'Matsumoto Makoto Shōsa Memo' (「松本真実少佐メモ」[‘Notes of Lt. Cdr. Matsumoto Makoto']). [Then] aviation officer of the [Navy] 1st Air Group.

14. Hitō Jijō by Hiratsuka Takeshi and Madarame Fumio (『比島事情』平塚武・斑目文雄著昭 和17年10月 非凡閣発行 [The Circumstances in the Philippines, by Hiratsuka Takeshi and Madarame Fumio, published by Hibonkaku, Oct 1942]).

15. Indoshina by Muroga Nobuo (『印度支那』室賀信夫著 昭和16年11月 白楊社発行 [Indochina by Muroga Nobuo, published by Hakuyōsha, Nov. 1941]).

16. Nampo-kyō'ei-ken no Zembō, Satō Hiroshi hen(『南方共栄圈の全貌』佐藤弘編 昭和17年12月 旺文社発行 [The whole picture of the co-prosperity sphere in the south, ed. by Satō Hiroshi, published by Ōbunsha, Dec. 1942 ]). 
17. Ranryō Indo Nōgyō Seisaku-shi, Taiheiyō Kyōkai Chōsa-bu hen(『蘭領印度農業政策史』太 平洋協会調査部編 昭和16年9月 中央公論社発行 [History of agricultural policies in the Dutch East Indies, ed. by the Research Department of the Pacific Society, published by Chūō Kōronsha, Sept 1941]).

18. Ran'in Seikatsu Nijūnen by Wada Tamiji (『蘭印生活二十年』和田民治著 昭和17年5月 講談 社発行 [Twenty years in the Dutch East Indies, by Wada Tamiji, published by Kōdansha, May $1942]$ ).

19. Nampō-ken no Kikō by Fukui Eiichirō (『南方圏の気候』福井英一郎著 昭和17年9月 東京堂 発行 [Climate in the Southern sphere, [by] Fukui Eiichirō, published by Tōkyōdō, Sept. 1942]).

20. Yasunobu Takeo Chūsa Sengo no Kaisō (安延多計夫中佐戦後の回想 [The Postwar recollections of Cdr. Yasunobu Takeo]). [Then] senior staff of the 23d Air Flotilla; later [promoted to] captain.

21. 'Maéda Kōsei Chūsa Nisshi' (「前田孝成中佐日誌」['Journal kept by Cdr. Maeda Kōsei']). [Then] commander of the Genzan Air Group; later [promoted to] captain.

22. Hitō Suiroshi, Suiro-bu hakkō (『比島水路誌』水路部発行 [Sailing directions for the Philippines, published by the Hydrographic Department]).

23. Minami-Shinakai Suiroshi, Suiro-bu hakkō (『南支那海水路誌』水路部発行 [Sailing directions for the South China Sea, published by the Hydrographic Department]).

24. Malacca Kaikyō Suiroshi, Suiro-bu hakkō (『マラッカ海峡水路誌』水路部発行 [Sailing directions for the Malacca Strait, published by the Hydrographic Department]).

25. Sumatra Tōbu Suiroshi, Suiro-bu hakkō (『スマトラ東部水路誌』水路部発行 [Sailing directions for the [waters] east of Sumatra, published by the Hydrographic Department]).

26. Java-kai Suiroshi, Suiro-bu hakkō (『ジャバ海水路誌』水路部発行 [Sailing directions for the Java Sea, published by the Hydrographic Department]).

27. Yonehara Tsunaki Shōsa Shiryō (米原綱明少佐資料 [Documents kept by Lt. Cdr. Yonehara Tsunaki]). [Then] air unit commander of the Tōkō Air Group.

28. Tomioka Sadatoshi Taisa Sengo no Kaisō (富岡定俊大佐戦後の回想 [Postwar recollections of Capt. Tomioka Sadatoshi]). Chief of the 1st Section of the Navy General Staff between 1941 and 1943 and then director of its 1st Department; later [promoted to] rear admiral.

29. ‘Nakahara Yoshimasa Shōshō Nisshi' (「中原義正少将日誌」[’Journal kept by R. Adm. Nakahara Yoshimasa']). [Then] chief of Personnel Bureau, the Navy Ministry; later [promoted to] vice admiral.

30. 'Arao Okikatsu Rikugun Chūsa Sakusen Nisshi' (「荒尾興功陸軍中佐作戦日誌」[‘Operational Journal kept by Lt. Col. Arao Okikatsu']). [Then] chief of staff of the Southern Army; later [promoted to] colonel.

31. Watanabe Yasuji Chūsa Sengo no Kaisō (渡辺安次中佐戦後の回想 [Postwar recollections of Cdr. Watanabe Yasuji]). [Then] staff of the Combined Fleet; later [promoted to] captain.

32. Takahashi Chihaya Taisa Sengo no Kaisō (高橋千隼大佐戦後の回想 [Postwar recollections of Capt. Takahashi Chihaya]). [Then] staff of the Eleventh Air Fleet.

33. 'Sanagi Sadamu Chūsa Memo' (「佐薙毅中佐メモ」['Notes of Cdr. Sanagi Sadamu']). [Then] staff of Section 1 of the Navy General Staff; later [promoted to] captain.

34. Ishii Masayoshi Rikugun Taisa Hokan Shiryō nado (石井正美陸軍大佐保管資料等 [Documents etc. kept by Col. Ishii Masayoshi]). [Then] senior staff of Section 1 of the Southern Army; later [promoted to] major general.

35. Miyo Tatsukichi Chūsa Sengo no Kaisō (三代辰吉中佐戦後の回想 [Postwar recollections of Cdr. Miyo Tatsukichi]). [Then] staff of the operations section of the Navy General Staff in charge of aviation; later [promoted to] captain. He changed his [first] name to Kazunari.

36. Fujita Masamichi Chūsa Sengo no Kaisō (藤田正路中佐戦後の回想 [Postwar recollections of Cdr. Fujita Masamichi]). [Then] staff of the Second Fleet; later [promoted to] captain. 
37. Odagiri Masanori Chūsa Sengo no Kaisō (小田切政徳中佐戦後の回想 [Postwar recollections of Cdr. Odagiri Masanori]). [Then] senior staff of the 4th Carrier Division; later [promoted to] captain.

38. ‘Ozawa Jisaburō Chūjō Shuki' oyobi Sengo no Kaisō (「小沢治三郎中将手記」及び戦後の 回想 ['Memoirs of V. Adm. Ozawa Jisaburō' and his postwar recollections]). [Then] commander in chief of the Southern Expeditionary Fleet ([and] the commander of the Malaya Unit).

39. Kuroshima Kameto Taisa Sengo no Kaisō (黒島亀人大佐戦後の回想 [Postwar recollections of Capt. Kuroshima Kameto]). [Then] senior staff of the Combined Fleet; later [promoted to] rear admiral.

40. 'Imoto Kumao Rikugun Chūsa Gyōmu Nisshi' (「井本熊男陸軍中佐業務日誌」[‘Operation journal kept by Lt. Col. Imoto Kumao']). [Then] staff of the Operations Section of the Army General Staff.

41. 'Sugiyama Gen Rikugun Taishō Memo' (「杉山元陸軍大将メモ」[’Notes of General Sugiyama Gen']). The records were [compiled] by the Sensō Shidōhan (戦争指導班 (課) [War Direction Group (Section)]) [by] sorting out the deliberations at the liaison meetings and conferences and the notes taken by Chief of Army General Staff Sugiyama from January to May 1942 and making them into a clean copy.

42. 'Daikairei-tsuzuri' (「大海令綴」['The files of IGHQ Navy Department Orders']). Daikairei was the reference code for the Imperial orders, which, among the Imperial orders of command, were received and passed down by the chief of the Navy General Staff. However, they were usually recognized as Imperial Commands issued toward the Navy.

43. 'Daikaishi-tsuzuri' (「大海指綴」['The files of IGHQ Navy Department Instructions']). Daikaishi was the reference code for the instructions issued by the chief of the Navy General Staff, which were issued in accordance with the clause in the Daikairei that 'details shall be instructed by the chief of the Navy General Staff.' However, they were usually recognized as instructions given by the chief of the Navy General Staff.

44. Sentō Joretsu (戦闘序列 [Order of battle]). An army term denoting the organization of an operational army ordered by the Emperor on the occasion of hostilities or incidents.

45. 'Kimitsu Rengō Kantai Meirei Saku Dai-ichi-gō' (「機密聯合艦隊命令作第一号」['Combined Fleet Operational Order Classified No. 1']). A copy seized by the U.S. forces from the Nachi sunk in Manila Bay, which was returned to Japan after the war.

46. 'Sen-sō-roku' by Ugaki Matome Shōshō ( 「戦藻録」宇垣縓少将 ['Sen-sō-roku, ' journal kept by R. Adm. Ugaki Matome]). [Then] chief of staff of the Combined Fleet; later [promoted to] vice admiral.

47. Matsudaira Nagayoshi Kikan Taii Shiryō (松平永芳機関大尉資料 [Documents kept by Lieutenant of Engineering Matsudaira Nagayoshi]). [Then] chief engineer of the Destroyer Inazuma; later [promoted to] lieutenant commander.

48. ‘Nairei Teiyō’ [by] Kaigun Daijin Kambō (「内令提要」海軍大臣官房 [‘Classified rules and regulations,' [by] the Office of the Navy Minister]).

49. Yamamoto Chikao Taisa Sengo no Kaisō (山本親雄大佐戦後の回想 [Postwar recollections of Capt. Yamamoto Chikao]). [Then] chief of Section 1, General Affairs Department, [Navy] Aeronautical Department; later [promoted to] rear admiral.

50. ‘Kaigun Kōkū Hombuchō Mōshitsugisho' (「海軍航空本部長申継書」昭和16年7月 [’Communication notes of the director of the Navy Aeronautical Department,' July 1941]).

51. 'Kaigun Kōkū Hombu Senji Nisshi' ( 「海軍航空本部戦時日誌」[’War journal kept by the Navy Aeronautical Department']).

52. ‘Nagaishi Masataka Chūsa Memo' (「永石正孝中佐メモ」 [’Notes of Cdr. Nagaishi Masataka']). Aviation officer of the Hiryū between 1939 and 1940; later [promoted to] captain. 
53. ‘Dai-ni Suirai Sentai Senji Nisshi'（「第二水雷戦隊戦時日誌」 [‘War journal kept by the 2d Destroyer Squadron']).

54. ‘Dai-ni Suirai Sentai Sentō Shōhō' (「第二水雷戦隊戦闘詳報」[‘Action report of the 2d Destroyer Squadron']).

55. 'San'yō-maru Sentō Shōhō' (「山陽丸戦闘詳報」['Action report of the San'yō-maru']).

56. 'Dai-yon Suirai Sentai Sentō Shōhō' (「第四水雷戦隊戦闘詳報」['Action report of the 4th Destroyer Squadron']).

57. 'Dai-go Sentai Senji Nisshi' (「第五戦隊戦時日誌」[‘War journal kept by the 5th Cruiser Division']).

58. 'Daitōa-sensō Senkun' [prepared by] Kaigun Senkun Chōsa Iinkai（「大東亜戦争戦訓」海 軍戦訓調査委員会 ['Greater East Asia War's Lessons of War,' prepared by the Naval Investigation Committee on Engagements and Lessons of War]).

59. ‘Dai-ichi Konkyochi-tai Senji Nisshi'（「第一根拠地隊戦時日誌」[’War journal kept by the 1st Base Force']).

60. Shibuya Tatsuwaka Taisa Shiryō (涉谷龍䅏大佐資料 [Documents kept by Capt. Shibuya Tatsuwaka]). A record of submarine operations, sorted out right after the war by the captain mainly in charge of submarines. [In Attached Table No. 1, his rank is Cdr.]

61. ‘Nampō Butai Sentō Gaihō’ (「南方部隊戦闘概報」[‘Summary report of the actions of the Southern Task Force']).

62. 'Dai-yon Suirai Sentai Senji Nisshi'（「第四水雷戦隊戦時日誌」[’War journal kept by the 4th Destroyer Squadron']).

63. 'Dai-go Suirai Sentai Senji Nisshi'（「第五水雷戦隊戦時日誌」[‘War journal kept by the 5th Destroyer Squadron']).

64. Nomura Ryōsuke Shōsa Sengo no Kaisō (野村了介少佐戦後の回想 [Postwar recollections of Lt. Cdr. Nomura Ryōsuke]). [Then] staff of the 23d Air Flotilla; later [promoted to] commander.

65. ‘Nampō Butai Sentō Shōhō' (「南方部隊戦闘詳報」['Action report of of the Southern Task Force']).

66. Okazaki Seizaburō Rikugun Shōshō Sengo no Kaisō (岡崎清三郎陸軍少将戦後の回想 [Postwar recollections of Maj. Gen. Okazaki Seizaburō]). [Then] chief of staff of the Sixteenth Army; later [promoted to] lieutenant general.

67. 'Rikusentai Kōdō Chōsho' [summarized at] Kaigun Kōseki Chōsa-bu (「陸戦隊行動調書」 海軍功績調査部 ['Action records of the special landing forces,' [summarized at] the Navy Department of Investigation of Achievements]).

68. 'Sakusen Kenkyū Shiryō' (「作戦研究資料」[Operation reviews]), compiled by the the Navy Department of Investigation of Achievements to examine the achievements [in each operation].

69. Suékuni Masao Chūsa Sengo no Kaisō (末国正雄中佐戦後の回想 [Postwar recollections of Cdr. Suékuni Masao]). [Then] staff of the 5th Cruiser Division; later [promoted to] captain.

70. 'Tōyama Yasumi Chūsa Nisshi' (「遠山安巳中佐日誌」[’Journal kept by Cdr. Tōyama Yasumi']). [Then] senior staff of the $2 \mathrm{~d}$ Destroyer Squadron.

71. 'Hikōki-tai Kōdō Chōsho' [compiled by] Kaigun Kōseki Chōsa-bu (「飛行機隊行動調書」 海軍功績調査部作成 [Action records of the air units, compiled by the Navy Department of Investigation of Achievements]).

72. 'Kansen Kōdō Chōsho' compiled by the Kaigun Kōseki Chōsa-bu（「艦船行動調書」海軍 功績調査部作成 [’Operation records of vessels' compiled by the Navy Department of Investigation of Achievements]). 
73. ‘Okazaki Seizaburō Rikugun Shōshō Nisshi’ (「岡崎清三郎陸軍少将日誌」[’Journal kept by Maj. Gen. Okazaki Seizaburō']). [Then] chief of staff of the Sixteenth Army; later [promoted to] lieutenant general.

74. Takashima Tatsuhiko Rikugun Taisa Sengo no Kaisō (高嶋辰彦陸軍大佐戦後の回想 [Postwar recollections of Col. Takashima Tatsuhiko]). [Then] senior staff of Section 1, Staff Department of the Sixteenth Army; later [promoted to] major general.

75. 'Daitōa-sensō Senkun (Kōkū)' [prepared by] Kaigun Senkun Chōsa Iinkai (「大東亜戦争戦 訓（航空）」海軍戦訓調査委員会 ['The Greater East Asia War's Lessons of War ([section] Air Operations),' prepared by the Naval Investigation Committee on Engagements and Lessons of War]).

76. 'Sanuki-maru Sentō Shōhō' (「讃岐丸戦闘詳報」[Action report of the Sanuki-maru]).

77. Nihon Sekiyu-shi, Nihon Sekiyu Kabushiki Gaisha hen(『日本石油史』日本石油株式会社編 昭和33年5月 [The History of Nippon Oil Co. Ltd. ed. by the Nippon Oil Co. Ltd., May 1958]).

78. 'Dai-go Sentai Sentō Shōhō' ( 「第五戦隊戦闘詳報」 ['Action report of the 5th Cruiser Division']).

79. ‘Watanabe Tasuke Shōsa Nisshi' ( 「渡部太助少佐日誌」[’Journal kept by Lt. Cdr. Watanabe Tasuke']). [Then] staff of the 11th Seaplane Tender Division; later [promoted to] commander.

80. 'Yokosuka Chinjufu Dai-ichi Tokubetsu Rikusentai Sentō Shōhō' (「横須賀鎮守府第一特別 陸戦隊戦闘詳報」['Action report of the 1st Special Landing Force of the Yokosuka Naval Station']).

81. 'Dai-ichi Kūshū Butai Sentō Gaihō Tsuzuri'（「第一空襲部隊戦闘概報綴」[‘File of summary reports of the actions of the [Navy] 1st Air Raid Unit']).

82. Itō Atsuo Taii Sengo no Kaisō (伊藤敦夫大尉戦後の回想 [Postwar recollections of Lt. Itō Atsuo]). [Then] group commander of the air unit of the Mizuho; later [promoted to] lieutenant commander.

83. Takagi Hisamori Shōsa Sengo no Kaisō (高木長護少佐戦後の回想 [Postwar recollections of Lt. Cdr. Takagi Hisamori]). [Then] staff of the 11th Seaplane Tender Division; later [promoted to] commander.

84. Hamada Takeo Chūsa Sengo no Kaisō (浜田武夫中佐戦後の回想 [Postwar recollections of Cdr. Hamada Takeo]). [Then] executive officer of the 1st Air Group; later [promoted to] captain.

85. S. Woodburn Kirby, The War against Japan, Vol. I: The Loss of Singapore.

86. W. F. Craven and J. L. Cate eds., The Army Air Forces in World War II, Vol. I: Plans \& Early Operations, January 1939 to August 1942.

87. G. Hermon Gill, Australia in the War of 1939-1945, Series 2: Navy, Volume I: Royal Australian Navy, 1939-1942.

88. 'Yasen Kōshahō Dai-yonjūyon Daitai Sentō Shōhō' (「野戦高射砲第四十四大隊戦闘詳報」 ['Action report of the 44th Field Antiaircraft Artillery Battalion']).

89. Yano Tsuneo Rikugun Chūsa Sengo no Kaisō (矢野常雄陸軍中佐戦後の回想 [Postwar recollections of Lt. Col. Yano Tsuneo]). [Then] staff of the Sakaguchi Detachment.

90. 'San'yō-maru Sentō Shōhō' (「山陽丸戦闘詳報」['Action report of the San'yō-maru']).

91. ‘Kabashima Senzō Taii Nikki’ (「椛島千蔵大尉日記」[‘Diary of Lt. Kabashima Senzō’]). [Then] navigation officer [correctly, chief gunner] of the destroyer Yüdachi; later [promoted to] lieutenant commander.

92. S. E. Morison, The Rising Sun in the Pacific, 1931-April 1942 (History of United States Naval Operations in WWII, Vol. 3).

93. 'Yabushita Toshiharu Chūi (Kuchikukan Natsushio Kōkaichō) Nisshi' (「藪下利治中尉（駆逐 艦夏潮航海長）日誌」[‘Journal kept by Sublieutenant Yabushita Toshiharu, navigation officer of the destroyer Natsushio']). 
94. 'Hara Tameichi Chūsa (Kuchikukan Amatsukaze Kanchō) Nisshi' (「原為一中佐（駆逐艦天 津風艦長) 日誌」[’Journal kept by Cdr. Hara Tameichi, ([then] captain of the destroyer Amatsukaze']).

95. L.G. Wigmore, Australia in the War of 1939-1945, Series 1: Army, Volume IV: The Japanese Thrust.

96. 'Gen'eki Kaigun Shikan Meibo' (「現役海軍士官名簿」[’A list of naval officers in active service']).

97. 'Inoguchi Kaneo Shōsa Nisshi' oyobi Sengo no Kaisō（「井口兼夫少佐日誌」及び戦後の回 想 [’Journal of Lt. Cdr. Inoguchi Kaneo' and his postwar recollections]). [Then] staff of the First Southern Expeditionary Fleet attached to the [Army] Third Air Force; later [promoted to] commander.

98. Terasaki Takaji Chūsa Sengo no Kaisō (寺崎隆治中佐戦後の回想 [Postwar recollections of Cdr. Terasaki Takaji]). [Then] staff of the First Southern Expeditionary Fleet; later [promoted to] captain.

99. ‘Nampō-gun (Reika Butai) Kankei Dempō Tsuzuri’ (「南方軍（赨下部隊）関係電報綴」 ['File of telegrams related (to the units under the command of) the Southern Army']).

100. ‘Dai-go Kōkū Sentai Senji Nisshi'（「第五航空戦隊戦時日誌」[‘War journal kept by the 5th Carrier Division']).

101. Suzuki Eijirō Chūsa Sengo no Kaisō (鈴木栄二郎中佐戦後の回想 [Postwar recollections of Cdr. Suzuki Eijirō]). [Then] staff of the 2d Carrier Division; later [promoted to] captain.

102. Tosaka Susumu Rikugun Shōsa Sengo no Kaisō (登坂進陸軍少佐戦後の回想 [Postwar recollections of Maj. Tosaka Susumu]). [Then] staff of the 38th Division; later [promoted to] lieutenant colonel.

103. ‘Kure Chinjufu Dai-ichi Tokubetsu Rikusen-tai Sentō Shōhō' (「呉鎮守府第一特別陸戦隊戦 闘詳報」 ['Action report of the 1st Special Landing Force of the Kure Naval Station']).

104. ‘Tōhō Shitai Senji Geppō'（「東方支隊戦時月報」['Monthly war report of the [Army] Eastern Detachment']).

105. ‘Kirai Jikkembu Chōsei Sōkaigu Ichiranhyō' (「機雷実験部調整掃海具一覧表」 [A list of minesweeping devices prepared by the Mine Experimentation Department']).

106. 'Yamada Shigeru Ittō Hikōheisō Nisshi' (「山田茂一等飛行兵曹日誌」[’Journal kept by Flight Petty Officer 1st Class Yamada Shigeru']). A [flight] crew member of the Mizuho.

107. 'Dai-nijūyon Tokubetsu Konkyochi-tai Senji Nisshi' (「第二十四特別根拠地隊戦時日誌」 ['War journal kept by the 24th Special Base Force']).

108. 'Sanagi Sadamu Chūsa Nisshi' (「佐薙毅中佐日誌」[’Journal kept by Cdr. Sanagi Sadamu']). [Then] staff of Section 1 of the Navy General Staff; later [promoted to] captain.

109. Daihon'ei Happyō: Kaigun-hen [by] Tominaga Kengo（『大本営発表海軍篇』富永謙吾著 昭和27年6月 青潮社発行 [Imperial General Headquarters Communiqués: Volume of the Navy, [by] Tominaga Kengo, published by Seichō-sha, June 1952]).

110. ‘Dai-ichi-gō Shōkaitei Senji Nisshi'（「第一号哨戒艇戦時日誌」[‘War journal kept by Patrol Boat No. 1']).

111. Nagai Sumitaka Chūsa Sengo no Kaisō (長井純隆中佐戦後の回想 [Postwar recollections of Cdr. Nagai Sumitaka]). [Then] captain of the destroyer Natsushio; later [promoted to] captain.

112. 'Hayashi Toshifusa Taii (Kuchikukan Umikaze Kōkaichō) Nisshi'（「林利房大尉（駆逐艦海 風航海長）日誌」['Journal kept by Lt. Hayashi Toshifusa, [then] navigation officer of the destroyer Umikaze']).

113. T. Roscoe, et al., United States Submarine Operations in World War II, United States Naval Institute. 
114. ‘Dai-nana Sentai Senji Nisshi'（「第七戦隊戦時日誌」[‘War journal kept by the 7th Cruiser Division']).

115. 'Imazato Yoshimitsu Chūsa Shuki' (「今里義光中佐手記」 [’A personal account of Cdr. Imazato Yoshimitsu']). [Then] senior staff of the $2 \mathrm{~d}$ Base Force; later [promoted to] captain.

116. 'Saiki Ikuzō Chūsa Nisshi' (「齋木郁三中佐日誌」[’Journal kept by Lt. Col. Saiki Ikuzō’]). [Then] staff of Section 2 (Chief Signal Communication Staff) of the staff department of the Sixteenth Army.

117. 'Ran'in Kōkū Sakusen Kiroku' ( 「蘭印航空作戦記録」[’Records of the air operations in the Dutch East Indies operation']), compiled by Lt. Col. Miyashi Minoru, chief of operations staff of the [Army] Third Air Force based on contemporary materials.

118. 'Dai-san Suirai Sentai Sentō Shōhō' (「第三水雷戦隊戦闘詳報」['Action report of the 3d Destroyer Squadron']).

119. ‘Dai-nana Sentai Sentō Shōhō’ (「第七戦隊戦闘詳報」[‘Action report of the 7th Cruiser Division']).

120. ‘Dai-san Suirai Sentai Senji Nisshi' (「第三水雷戦隊戦時日誌」[‘War journal kept by the 3d Destroyer Squadron']).

121. Abe Yoshimitsu Rikugun Taisa Kaisō (阿部芳光陸軍大佐回想 [Recollections of Col. Abe Yoshimitsu]). [Then] chief of staff of the 38th Division. They include “Bangka, Palembang Sakusen Kiroku” prepared by Fukuinkyoku（「バンカ、パレンバン作戦記録」復員局調製 ["Records of the Bangka and Palembang operation," prepared by the Demobilization Bureau]), which he wrote after the war based on materials in his possession and those kept at demobilization offices.

122. 'Kamikawa-maru Sentō Shōhō' (「神川丸戦闘詳報」['Action report of the Kamikawa-maru']).

123. 'Dai-yon Sensui Sentai Sentō Shōhō' (「第四潜水戦隊戦闘詳報」['Action report of the 4th Submarine Squadron']).

124. Tsunoda Hitoshi Shōsa Sengo no Kaisō (角田求士少佐戦後の回想 [Postwar recollections of Lt. Cdr. Tsunoda Hitoshi]). [Then] instructor of the Yokosuka Air Group, temporarily attached to the Eleventh Air Fleet headquarters; later [promoted to] commander.

125. ‘Sagara-maru Sentō Shōhō' (「相良丸戦闘詳報」['Action report of the Sagara-maru']).

126. 'Dai-nana Sentai Senji Nisshi'（「第七戦隊戦時日誌」['War journal kept by the 7th Cruiser Division']).

127. 'Nampō-sōgun no Tōsui' (「南方総軍の統帥」[‘The high command of the Southern Army']), the journal in which Lt. Col. Arao Okikatsu (荒尾興功中佐), chief of operations staff of the Southern Army, recorded in detail the classified matters on the high command of the Southern Army from the time of the preparation of the operations by the army to the completion of most of the southern invasion operation.

128. 'Yamada Takeo Hikō-heisōchō Nisshi' (「山田猛夫飛行兵曹長日誌」[’Journal kept by Chief Flight Warrant Officer Yamada Takeo']). [Then] attached to the Mihoro Air Group.

129. 'Yamada Yutaka Chūsa Nisshi' (「山田豊中佐日誌」[‘Journal kept by Cdr. Yamada Yutaka']). [Then] commander of the fighter plane unit attached to the 22d Air Flotilla headquarters.

130. ‘Unagi Tsuyoshi Taii Nisshi' (「宇那木勁大尉日誌」['Journal kept by Lt. Unagi Tsuyoshi']). [Then] torpedo chief of the destroyer Isonami.

131. Yamaguchi Shirō Shōsa Sengo no Kaisō (山口史郎少佐戦後の回想 [Postwar recollections of Lt. Cdr. Yamaguchi Shirō]). [Then] staff of the 3d Destroyer Squadron; later [promoted to] commander.

132. 'Dokuritsu Kōhei Dai-nijūroku Rentai Dai-ni Chūtai Dai-ichi Shōtai Sentō Shōhō’ ( 「独立工 兵第二十六聯隊第二中隊第一小隊戦闘詳報」['Action report of the 1st Platoon of the $2 \mathrm{~d}$ Company of the 26th Independent Engineer Regiment']). 
133. Tanaka Ryōsaburō Rikugun Taisa Sengo no Kaisō (田中良三郎陸軍大佐戦後の回想 [Postwar recollections of Col. Tanaka Ryōsaburō]). [Then] commander of the 229th Infantry Regiment.

134. Tanaka Kikumatsu Taisa Shiryō (田中菊松大佐資料 [Documents kept by Capt. Tanaka Kikumatsu]). [Then] captain of the Kumano of the 7th Cruiser Division

135. 'Dai-san Haken Tsūshin-tai Sentō Kiroku'（「第三派遣通信隊戦闘記録」['Action records of the [Navy] 3d Detached Signal Unit']).

136. C. van den Hoogenband and L. Schotborgh, eds., Nederlands-Indië contra Japan. Deel VII.

137. ‘Oyadomari Chōsei Chūsa Shuki' (「親泊朝省中佐手記」 ['A personal account of Lt. Col. Oyadomari Chōsei']). [Then] chief of operations staff of the 38th Division. [And] his contribution “Sumatra Sakusen Obo'egaki”（「スマトラ作戦覚書」[‘Memorandum on the Sumatra operation'], a part of the article “Hong Kong, Sumatra, Ga-tō Sakusen Dampen” ( 「香港、ス マトラ、ガ島作戦断片」[“Snippets of Hong Kong, Sumatra, and Guadalcanal operations”]), which was written for the December 1943 [issue of] the Kaikōsha-kiji (『偕行社記事』[Bulletin of the Kaikōsha]).

138. Itoda Isamu Chūsa Sengo no Kaisō (井戸田勇中佐戦後の回想 [Postwar recollections of Lt. Col. Itoda Isamu]). [Then] staff of Section 1 (Aviation) of the staff department of the Sixteenth Army.

139. D. Richards and H. St. George Saunders, The Royal Air Force 1939-1945, Volume II: The Fight Avails.

140. Kanemura Matabē Shōsa Sengo no Kaisō (金村亦兵衛少佐戦後の回想 [Postwar recollections of Maj. Kanemura Matabē]). [Then] commander of the 3d Battalion of the 1st Taiwan Infantry Regiment.

141. 'Dai-ichi Suirai Sentai Senji Nisshi' (「第一水雷戦隊戦時日誌」[‘War journal kept by the 1st Destroyer Squadron']).

142. Sasabe Risaburō Chūsa Sengo no Kaisō (雀部利三郎中佐戦後の回想 [Postwar recollections of Cdr. Sasabe Risanburō]). [Then] navigation staff of the First Air Fleet; later [promoted to] captain.

143. ‘Dai-hachi Sentai Senji Nisshi' (「第八戦隊戦時日誌」[‘War journal kept by the 8th Cruiser Division']).

144. 'Daihon'ei-Seifu Renraku Kaigi Gijiroku'（「大本営政府連絡会議議事録」[‘The minutes of the Liaison Conferences between IGHQ and the Government']).

145. 'Tairikumei-tsuzuri' (「大陸命経」[‘The files of IGHQ Army Department Orders']). File[s] of the Imperial Orders passed down by the Army Department of IGHQ.

146. 'Tairikushi-tsuzuri' (「大陸指綴」['The files of IGHQ Army Department Instructions']). File[s] of the instructions given by the chief of Army General Staff in accordance with the Imperial Orders.

147. Itō Hiroshi Taii Sengo no Kaisō (伊藤博大尉戦後の回想 [Postwar recollections of Lt. Itō Hiroshi]). [Then] adjutant of $3 \mathrm{~d}$ Yokosuka Special Landing Force; later [promoted to] lieutenant commander.

148. 'Shōji Shitai Meirei Tsuzuri'（「東海林支隊命令綴」[‘The file of the orders of the Shōji Detachment']).

149. Imazato Yoshimitsu Chūsa Sengo no Kaisō (今里義光中佐戦後の回想 [Postwar recollections of Cdr. Imazato Yoshimitsu]). [Then] senior staff of the 2d Base Force; later [promoted to] captain.

150. 'Dai-go Suirai Sentai Sentō Shōhō' (「第五水雷戦隊戦闘詳報」['Action report of the 5th Destroyer Squadron']).

151. 'Kaigun Zōsen Gijutsu Gaiyō’ ( 「海軍造船技術概要」[’An overview of naval engineering in the [Japanese] Navy']). 
152. Tōyama Yasumi Chūsa Sengo no Kaisō (遠山安巳中佐戦後の回想 [Postwar recollections of Cdr. Tōyama Yasumi]). [Then] senior staff of the 2d Destroyer Squadron; later [promoted to] captain.

153. Kaihei Gojukki Kyūkai Kaisō-roku (「海兵五○期級会回想録」昭和35年11月発行 [Memoirs of the graduates of the 50th class of the Naval Academy, published in Nov. 1960]).

154. Jane's Fighting Ships, 1941 ed.

155. Showa Jügo-nendo Suiraijutsu Nempō (『昭和十五年度水雷術年報』[Annual report on the engineering of torpedoes, mines and depth charges of the fiscal year of 1940]).

156. 'Dai-san Sentai Senji Nisshi' (「第三戦隊戦時日誌」[‘War journal kept by the 3d Battleship Division']).

157. ‘Rengō Kantai Senji Nisshi' (「聯合艦隊戦時日誌」[‘War journal kept by the Combined Fleet']).

158. ‘Dai-san Sentai Sentō Shōhō' (「第三戦隊戦闘詳報」['Action report of the 3d Battleship Division']).

159. ‘Dai-hachi Sentai Sentō Shōhō'（「第八戦隊戦闘詳報」['Action report of the 8th Cruiser Division']).

160. 'Nihon Sensuikan no Senka' (「日本潜水艦の戦果」[Military gains by the submarines of the Japanese Navy]). Data provided by Jürgen Rohwer, director of the Library of Contemporary History.

161. 'Ran'in Sakusen Kiroku' ( 「蘭印作戦記録」['Records of the Dutch East Indies operations']), compiled by Lt. Col. Oda Akimitsu (於田秋光), [then] chief of operations staff of the Sixteenth Army, based on the materials at that time.

162. ‘Gunkan Atago Sentō Shōhō' (「軍艦愛宕戦闘詳報」[‘Action report of the warship Atago']).

163. ‘Gunkan Kumano Setsuju Dempō Tsuzuri' (「軍艦熊野接受電報綴」[‘The file of telegrams received by the warship Kumano']).

164. 'Senji Hensei Kaitei Tsuzuri' (「戦時編制改定綴」[‘The file of [the records of] revisions of the wartime organization']).

165. ‘Dai-ni Hōkan-tai Senji Nisshi' (「第二砲艦隊戦時日誌」[‘War journal kept by the 2d Gunboat Division']).

166. Kaikōsha-kiji, Kaikōsha hen(『偕行社記事』偕行社編 [Bulletin of the Kaikōsha, ed. by the the Association of Army Officers]).

167. 'Kyōiku Sankō Shiryō (Sui[rai-jutsu]) Dai-nijūhachi-gō: Kantai Suichū Sokuteki-jutsu-ryoku Kōjō ni kansuru Kenkyū,' by Kaigun-shō Kyōiku-kyoku（「教育参考資料（水）第二十八 号 艦隊水中測的術力向上二関スル研究」海軍省教育局作成 昭和16年8月 [Educational Reference Materials ([concerning] torpedoes, mines and depth charges) No. 28: A Study on the improvement of underwater aiming skills in the fleet,' by the Education Bureau of the Navy Ministry, Aug. 1941]).

168. Nawa Takeshi Gijutsu Chūjō Shiryō (名和武技術中将資料 [Materials kept by Vice Admiral of Engineering Nawa Takeshi]). [Then] director of the 3d Department, Naval Technical Department.

169. Sukigara Kengo Chūsa Sengo no Kaisō (鋤柄健吾中佐戦後の回想 [Postwar recollections of Cdr. Sukigara Kengo]). [Then] member of Navy Technical Department.

170. Tsukuda Sadao Chūsa Sengo no Kaisō (佃定雄中佐戦後の回想 [Postwar recollections of Cdr. Tsukuda Sadao]). [Then] member of Navy Technical Department.

171. Zōkan Gijutsu no Zembō, Sendō Michizō (daihyō)（『造艦技術の全貌』千藤三千造（代表）著 興洋社発行 昭和27年7月 [The Overall Aspects of Ship-building Technology, by Sendō Michizō, et al., published by Kōyōsha, July 1952]). 
172. Koyama Tadashi Chūsa Sengo no Kaisō (小山貞中佐戦後の回想 [Postwar recollections of Cdr. Koyama Tadashi]). [Then] senior staff of the 6th Destroyer Squadron; later [promoted to] captain.

173. Kaikankō Hyōron Dai-go-kan Dai-ichi-gō, Kaijō Jiei-tai Kambu Gakkō hakkō (『海幹校評 論』第五巻第一号（通巻二三号） 海上自衛隊幹部学校発行 昭和42年1月 [Maritime SelfDefense Force Officer Candidate School Review, Vol. 5 No. 1 (Serial No. 23), published by Maritime Self-Defense Force Officer Candidate School, Jan 1967]).

174. [M.S. Watson], Chief of Staff: Prewar Plans and Operations, in: United States Army in World War II; The War Department series.

175. [R.S. Cline], Washington Command Post: The Operations Division in United States Army in World War II: The War Department series.

176. R. Kafka [et al.], Warships of the World, Cornell Maritime Press.

177. [L. Molton,] The Fall of Philippines, in: United States Army in World War II; The War in the Pacific series.

178. S.W. Roskill, The War at Sea 1939-1945, vol. I.

179. G.W. Stove, “Queen's Navy at War" in U.S. Naval Institute Proceedings, Mar. 1950.

180. Hattori Takushirō Rikugun Taisa Sengo no Kaisō (服部卓四郎陸軍大佐戦後の回想 [Postwar recollections of Col. Hattori Takushirō]). [Then] chief of Operations Section of the Army General Staff.

181. ‘Marē Butai Sentō Shōhō' (「馬來部隊戦闘詳報」['Action report of the Malaya Unit']).

182. 'Dai-jūroku Sentai Senji Nisshi'（「第十六戦隊戦時日誌」[‘War journal kept by the 16th Cruiser Division']).

183. 'Kōkūtai Hensei Suii Ichiran-hyō,' Dai-ni Fukuin-kyoku Zammu-shori-bu chōsei (「航空隊 編制推移一覧表」第二復員局残務処理部調製 昭和24年7月 [’Table[s] of the organizational changes of the air groups,' prepared by the Backlog Clearing Department of the $2 \mathrm{~d}$ Demobilization Bureau, July 1949]).

184. Furuta Yoshio Chūsa Sengo no Kaisō (古田良夫中佐戦後の回想 [Postwar recollections of Cdr. Furuta Yoshio]). [Then] commander of the 40th Air Group; later [promoted to] captain.

185. Compiled by the author from the Ishii documents and other Army documents.

186. ‘Dai-jūichi Kōkū Kantai Senji Nisshi'（「第十一航空艦隊戦時日誌」[‘War journal kept by the Eleventh Air Fleet']).

187. 'Kaigun Senji Hensei Tsuzuri’ (「海軍戦時編制綴」[‘The file of [the records of] the Navy Wartime Formation']).

188. Uchida Shigeshi Chūsa Shiryō (内田成志中佐資料 [Documents kept by Cdr. Uchida Shigeshi]). [Then] member of the Navy General Staff; later [promoted to] captain.

189. Itō Sukemitsu Chūsa Sengo no Kaisō (伊東祐満中佐戦後の回想 [Postwar recollections of Cdr. Itō Sukemitsu]). [Then] aviation officer of the Tōkō Air Group; later [promoted to] captain.

190. ‘Dai-ichi Nanken Kantai Senji Nisshi’（「第一南遣艦隊戦時日誌」[‘War journal kept by the First Southern Expeditionary Fleet']).

191. ‘Dai-go Kōkū Sentai Sentō Shōhō' (「第五航空戦隊戦闘詳報」['Action report of the 5th Carrier Division']).

192. ‘Gunkan Hiryū Sentō Shōhō' (「軍艦飛龍戦闘詳報」['Action report of the Warship Hiryū']).

193. ‘Dai-nana Sensui-tai Senji Nisshi'（「第七潜水隊戦時日誌」[’War journal kept by the 7th Submarine Division']).

194. 'Dai-ichi Suirai Sentai Sentō Shōhō' (「第一水雷戦隊戦闘詳報」['Action report of the 1st Destroyer Squadron']).

195. 'Soné Akira Taisa Nisshi' (「曾爾章大佐日誌」 ['Journal kept by Capt. Soné Akira']). [Then] captain of the cruiser Mogami; later [promoted to] rear admiral. 
196. ‘Daitōa Sensō Dai-nidan Sakusen Teikoku Kaigun Sakusen Keikaku’ [by] Gunrei-bu ( 「大 東亜戦争第二段作戦帝国海軍作戦計画」軍令部昭和17年4月15日 [’The Plan of Stage-Two Operations of the Imperial Japanese Navy in the Greater East Asia War,' [announced by] the Navy General Staff on 15 April 1942]).

197. ‘Dai-san Nanken Kantai Senji Nisshi' (「第三南遣艦隊戦時日誌」[‘War journal kept by the Third Southern Expeditionary Fleet']).

198. Sempaku Un'eikai oyobi Dai-ni Fukuin-kyoku Chōsa Shiryō (船舶運営会及び第二復員局調 査資料 [Information researched by the Ship Management Association and the 2d Demobilization Bureau]).

199. Yoshikawa Shūkichi Chūsa Sengo no Kaisō (由川周吉中佐戦後の回想 [Postwar recollections of Cdr. Yoshikawa Shūkichi]). [Then] senior staff of the 5th Destroyer Squadron; later [promoted to] captain. 



\section{Glossary}

\section{Army}

15-cm Howitzer Battery

1st Bureau (Operations Bureau),

[Army Department of IGHQ]

1st Disembarkation Group

2d Bureau (Intelligence Bureau),

[Army Department of IGHQ]

air division

[Numbered] Air Force

air ground support unit

air ground support headquarters

[Army] air group

air signal regiment

air signal unit

air transport company

airfield battalion/ company

airfield duty unit

anchorage headquarters

antiaircraft artillery regiment/battalion

antiaircraft searchlight company

[Numbered] Army

Army Aviation Headquarters

Army Department of IGHQ

Army Flying School,

Baichengzi/Hamamatsu

army railway unit

battalion artillery section

bridge building material company

cavalry regiment

Central District Army

Central Shipping Transport,

[Ministry of War]

China Expeditionary Army

construction duty company

detachment

disembarkation working unit

division

division headquarters

divisional district

\begin{tabular}{|c|c|}
\hline tūtai & 十五榴中隊 \\
\hline Dai-ichi-bu (Sakusen-bu) & 第一部 (作戦部) \\
\hline ai-ichi Yōriku Dan & 第一揚陸団 \\
\hline ai-ni-bu (Jōhō-bu) & 第二部 (情報部) \\
\hline ikō dan & 飛行団 \\
\hline Iikō Shūdan & 飛行集団 \\
\hline kōkū chiku butai & 航空地区部隊 \\
\hline kōkū chiku shirei-bu & 航空地区司令部 \\
\hline hikō sentai & 飛行戦隊 \\
\hline kōkū tsūshin rentai & 航空通信聯隊 \\
\hline kōkū tsūshin tai & 航空通信隊 \\
\hline yusō hikō chūtai & 輸送飛行中隊 \\
\hline hikō-jō daitai/ chūtai & 飛行場大隊/中隊 \\
\hline hikō-jō kimmu butai & 飛行場勤務部隊 \\
\hline teihaku-jō shirei-bu & 碇泊場司令部 \\
\hline kōshahō rentai/daitai & 高射砲聯隊/ 大院 \\
\hline shōkū chūtai & 照空中隊 \\
\hline Gun & 軍 \\
\hline Rikugun Kōkū Hombu & 陸軍航空本部 \\
\hline Daihon'ei Rikugun-bu & 大本営陸軍部 \\
\hline Hakujōshi / Hamamatsu & 白城子/浜松 \\
\hline Rikugun Hikō-gakkō & 陸軍飛行学校 \\
\hline gun tetsudō butai & (第16)軍鉄道部隊 \\
\hline daitaihō shōtai & 大隊砲小隊 \\
\hline kakyō zairyō chūtai & 架橋材料中隊 \\
\hline kihei rentai & 騎兵聯隊 \\
\hline Chūbu Gun & 中部軍 \\
\hline Un'yu-bu & 運輸部 \\
\hline
\end{tabular}

Shina-haken Gun

支那派遣軍

kenchiku kimmu chūtai

shitai

建築勤務中隊

支隊

yōriku sagyō tai

揚陸作業隊

師団

師団司令部

shidan shirei-bu

shikan
師管 
Eastern District Army

Economic Mobilization Bureau,

[Ministry of War]

engineer regiment

equipment platoon

field aircraft repair depot

field airfield construction unit

field antiaircraft defense unit headquarters

field artillery regiment

field duty unit headquarters

field freight depot

field gas company

field heavy artillery regiment

field hospital

(field) meteorological company

field military police unit

field motor transport depot

field ordnance depot

field postal unit

field road unit

field transport headquarters

field well-drilling company

fixed radio unit

ground duty company [Army aviation]

Imperial Guard Division

Imperial Japanese Military Academy

independent air unit

independent antitank gun

battalion/company

independent engineer company

(electricity)/ ([to facilitate] river-crossing

of heavy equipment)

independent field antiaircraft artillery

battery (horse-carried)

independent motor transport

battalion/company

independent radio platoon

independent squadron

[of Army Air Forces]

infantry artillery unit

infantry group

infantry regiment/battalion/

company/platoon

Information Department,

[Ministry of War]

Inspectorate General of [Army] Aviation

Inspectorate General of

Line of Communication
Tōbu Gun

東部軍

Seibi-kyoku

整備局

kōhei rentai

kizai shōtai

yasen kōkū shūri-shō

yasen hikō-jō settei tai

yasen bōkū tai shirei-bu

yahōhei rentai

yasen kimmu tai hombu

yasen kamotsu-shō

yasen gasu chūtai

yasen jūhōhei rentai

yasen byōin

(yasen) kishō chūtai

yasen kempei tai

yasen jidōsha-shō

yasen heiki-shō

yasen yūbin tai

yasen dōro tai

yasen yusō shirei-bu

yasen sakusei chūtai

kotei musen tai

rikujō kimmu chūtai

Kono'e Shidan

Rikugun Shikan-gakkō

dokuritsu hikō tai

dokuritsu sokushahō daitai/chūtai

dokuritsu kōhei chūtai

(denki)/ (jūtoga)

dokuritsu yasen kōshahō chūtai (daba)

dokuritsu jidōsha

daitai/chūtai

dokuritsu musen shōtai

dokuritsu hikō chūtai

hoheihō tai

hohei dan

hohei rentai/daitai/

chūtai/shōtai

Hōdō-bu

Kōkū Sōkan-bu

Heitan Sōkan-bu

\section{工兵聯隊}

器材小隊

野戦航空修理廠

野戦飛行場設定隊

野戦防空隊司令部

野砲兵聯隊

野戦勤務隊本部

野戦貨物廠

野戦瓦斯中隊

野戦重砲兵聯隊

野戦病院

(野戦)気象中隊

野戦憲兵隊

野戦自動車廠

野戦兵器廠

野戦郵便隊

野戦道路隊

野戦輸送司令部

野戦作井中隊

固定無線隊

陸上勤務中隊

近衛師団

陸軍士官学校

独立飛行隊

独立速射砲

大隊/中隊

独立工兵中隊

(電気)/(重渡河)

独立野戦高射砲

中隊 (駄)

独立自動車

大隊/ 中隊

独立無線小隊

独立飛行中隊

歩兵砲隊

歩兵団

歩兵聯隊/大隊/

中隊/小隊

報道部

航空総監部

兵站総監部 
Inspectorate General of Military Training intendance department director

Kwantung Army

legal department director

light-armored car unit

line-of-communication sick horse depot

line-of-communication area unit

line-of-communication

hospital/medical unit

machine gun company

Mark-3 radio squad

material depot

medical department director

medical unit

meteorological observation detail

military administration department

Military Affairs Bureau,

[Ministry of War]

Ministry of War

mixed brigade

motor transport squad

motorcycle unit

mountain artillery regiment

Northern China Area Army

Northern District Army

Office of Army General Staff

on-board antiaircraft artillery regiment

ordnance department director

ordnance service unit

patient transport unit HQ/

platoon

press corps

Propaganda Group

radio telegraph platoon

raiding air group, [paratroop]

Raiding Group, [1st Paratroop]

raiding regiment, [paratroop]

railway depot headquarters

railway regiment

reconnaissance regiment

regimental artillery section

Resource section, [Ministry of War]

river-crossing material company

sea duty company

sea transport supervisory unit

Section 2 (Operations Section),

[Army Department of IGHQ]

Section 3 (Organization and
Kyōiku Sōkan-bu

keiri-buchō

Kantō Gun

hōmu-buchō

kei-sōkōsha tai

heitan byōba-shō

heitan chiku tai

heitan

byōin/ eisei tai

kikanjū chūtai

San-gō-musen buntai

zairyō-shō

gun'i-buchō

eisei tai

sokkō han

gunsei-bu

Gummu-kyoku

Rikugun-shō

konsei ryodan

jidōsha han

jidō-nirinsha tai

sampōhei rentai

Kita-shina-hōmen Gun

Hokubu Gun

Sambō Hombu

sempaku kōshahō rentai

heiki-buchō

heiki kimmu tai

kan'ja yusō tai hombu/

shōtai

hōdō han

Senden Han

musen denshin shōtai

teishin hikō-rentai

[Dai-ichi] Teishin Dan

teishin rentai

teishajō shirei-bu

tetsudō rentai

sōsaku rentai

rentaihō shōtai

Shigen-ka

toga zairyō chūtai

suijō kimmu chūtai

kaijō yusō kanshi tai

Dai-ni-ka (Sakusen-ka)
教育総監部

経理部長

関東軍

法務部長

軽装甲車隊

兵站病馬廠

兵站地区隊

兵站

病院/衛生隊

機関銃中隊

3号無線 分隊

材料廠

軍医部長

衛生隊

測候班

軍政部

軍務局

陸軍省

混成旅団

自動車班

自動二輪車隊

山砲兵聯隊

北支那方面軍

北部軍

参謀本部

船舶高射砲聯隊

兵器部長

兵器勤務隊

患者輸送隊本部/

小隊

報道班

宣伝班

無線電信小隊

挺進飛行戦隊

[第一]挺進団

挺進聯隊

停車場司令部

鉄道聯隊

捜索聯隊

聯隊砲小隊

資源課

渡河材料中隊

水上勤務中隊

海上輸送監視隊

第二課 (作戦課)

Dai-san-ka

第三課 
Mobilization Section),

[Army Department of IGHQ]

ship repair depot

shipping engineer

shipping signal regiment

Shipping Transport Command

shore duty company

signal unit

sick horse depot

Soutern Army

Southern China Area Army

Southern Group,

[Army Department of IGHQ]

Special Broadcasting Detail

squad

squad for collecting cast-off articles

squadron, [Army air group]

supply platoon of the train [of regiment]

Taiwan Army

tank regiment

telegraph regiment

transport regiment

Transport section, [Ministry of War]

unit

unit under direct control of

the [Sixteenth] Army

vessel launching unit

veterinary department director

veterinary quarantine depot

War College

War Preparation Section, [Ministry of War]

water supply and purification department weather observation detail

wire company
(Hensei, Dōin-ka)

(編成・動員課)

sempaku kōsaku-shō

sempaku kōhei

sempaku tsūshin rentai

Sempaku Yusō Shirei-bu

rikujō kimmu chūtai

tsūshin tai

byōba-shō

Nampō Gun

Minami-shina-hōmen Gun

Nampō Han

船舶工作廠

船舶工兵

船舶通信聯隊

船舶輸送司令部

陸上勤務中隊

通信隊

病馬廠

南方軍

南支那方面軍

南方班

Tokushu Hōsō Han

特殊放送班

buntai

分隊

遺棄物収集班

飛行中隊

hikō chūtai

聯隊段列補給小隊

rentai danretsu hokyū shōtai

Taiwan Gun

sensha rentai

台湾軍

戦車聯隊

denshin rentai

電信聯隊

shichō rentai

輜重聯隊

Kōtsū-ka

交通課

tai/butai

隊/部隊

(Jūroku-)gun-chokuzoku butai

hensui sagyō tai

jūi-buchō

gumba bōeki-shō

Rikugun Daigakkō

Sembi-ka

bōeki kyūsui-bu

kansoku han

yūsen chūtai
(第16)軍直属部隊

泛水作業隊

獣医部長

軍馬防疫廠

陸軍大学校

戦備課

防疫給水部

観測班

有線中隊 


\section{Navy}

1001 [paratroop] Unit

Acoustic Research Department

Advance Unit

Air Fleet [Eleventh] [or Air Unit]

Air Fleet [First]

Air Flotilla [21st, 22d, 23d, 24th, 25th, 26th]

Air Group [1st, 3d, 4th, 18th, 33d, 35th, 40th, Iwakuni, Kanoya, Kisarazu, Genzan, Tainan, Takao, Chitose, Tōkō, Mihoro, Yokohama]

air group detachment

Air Raid Unit [1st, 2d, 3d; A, B, C, D]

air training units

air unit

Air Unit [1st, 2d, 3d] [of the Malaya Unit,

Dutch East Indies Unit, etc.]

[airborne] raiding unit

antitank gun unit [of the SLF]

artillery unit [of the SLF]

attached unit [of the SLF]

Auxiliary Cruiser Division [22d, 24th]

Auxiliary Minesweeper Division [32d]

Auxiliary Subchaser Division [51st, 52d,

53d, 54th, 55th, 91st]

aviation officer

Aviation System Study Committee

1001 Butai

Onkyō Kenkyū-bu

Senken Butai

Kōkū Kantai

[Dai-jū-ichi]

[or Kōkū Butai]

Kōkū Kantai [Dai-ichi]

Kōkū Sentai

[Dai-nijū-ichi,

Dai-nijū-ni, Dai-nijū-san,

Dai-nijū-yon, Dai-nijū-go,

Dai-nijū-roku]

Kōkū-tai [Dai-ichi, Dai-san，航空隊 [第1，3，4，18，33， Dai-yon, Dai-jū-hachi,

Dai-sanjū-san,

Dai-sanjū-go, Dai-yonjū,

Iwakuni, Kanoya,

Kisarazu, Genzan,

Tainan, Takao, Chitose,

Tōkō, Mihoro,

Yokohama]

kōkū-tai shitai

Kūshū Butai

[Dai-ichi, Dai-ni,

Dai-san; Kō,

Otsu, Hei, Tei]

renshū kōkū-tai

kōkū butai

Kōkū Butai [Dai-ichi,

Dai-ni, Dai-san]

Teishin Butai

sokushahō-tai [rikusen-tai] 速射砲隊 [陸戦隊]

hō-tai [rikusen-tai]

fuzoku-tai [rikusen-tai]

Sentai [Dai-nijū-ni,

Dai-nijū-yon]

Sōkai-tai [Dai-sanjū-ni] 掃海隊 [第32]

Kusen-tai [Dai-gojū-ichi,

Dai-gojū-ni,

Dai-gojū-san,

Dai-gojū-yon,

Dai-gojū-go,

Dai-kyūjū-ichi]

hikō-chō

Kōkū Seido Kenkyū linkai
1001部隊

音響研究部

先遣部隊

航空艦隊

[第11]

[航空部隊]

第1航空艦隊

航空戦隊 [第21，22，23，24，

$25,26]$

35,40 , 岩國, 鹿屋, 木更津, 元山, 臺南,

高雄, 千歳、東港,

美幌, 横濱]

航空隊支隊

空襲部隊 [第1，2，3；甲，乙，

丙, 丁]

練習航空隊

航空部隊

航空部隊 [第1，2，3]

挺進部隊

砲隊 [陸戦隊]

付属隊 [陸戦隊]

戦隊 [第22, 24]

駆潜隊 [第51, 52, 53, 54，

$55,91]$

飛行長

航空制度研究委員会 
Base Force [1st, 2d, 3d, 5th, 9th]

Base Unit [1st, 2d, 9th, Penang, Singapore, Rangoon]

Base Unit [Anambas, Penang, Sabang, Singora]

battalion headquarters [of the SLF]

Battleship Division [1st, 2d, 3d]

captain (of a ship)

Carrier Division [1st, 2d, 3d, 4th, 5th]

Carrier Operation unit

Carrier Task Force

carrier-based air unit

chief gunner

China Area Fleet

China Expeditionary Fleet [2d]

Combined Fleet [or Main Unit]

Combined Signal Unit [1st]

commander/ commanding officer

commander

commander in chief

Commercial [Maritime] Transport

Disruption Unit

communication officer

company [of the SLF]

Construction Squad [1st, 2d, 3d,

4 th, 5th, 6th, 8th, 9th]

Construction Unit [102d]

Cruiser Division [4th, 5th, 6th, 7th, 8th, 9th, 16th, 18th, 21st]

Defense Detail [1st, 2d]

Defense Unit [1st, 2d]
Konkyochi-tai [Dai-ichi，根拠地隊 [第1, 2, 3, 5, 9]

Dai-ni, Dai-san, Dai-go,

Dai-kyū]

Konkyochi Butai

[Dai-ichi, Dai-ni, Dai-kyū, Penang, Shōnan,

Rangoon]

Kichi Butai [Anambas,

Penang, Sabang,

Singora]

daitai hombu [rikusen-tai]

Sentai [Dai-ichi, Dai-ni,

Dai-san]

kanchō

根拠地部隊 [第1, 2, 9， 彼南, 昭南, 蘭貢]

基地部隊 [アナンバス、 ペナン、サバン、 シンゴラ]

大隊本部 [陸戦隊]

戦隊 $[$ 第 $1,2,3]$

艦長

Kōkū Sentai [Dai-ichi，航空戦隊 [第1, 2, 3, 4, 5]

Dai-ni, Dai-san,

Dai-yon, Dai-go]

Kidō-sakusen butai

Kidō Butai

bokan kōkū butai

hōjutsu-chō

Shina Hōmen Kantai

Kenshi Kantai [Dai-ni]

Rengō Kantai

[Shuryoku Butai]

Rengō Tsūshin-tai

[Dai-ichi]

shirei

shirei-kan

shirei-chōkan

Tsūshō hakai tai

tsūshin-chō

機動作戦部隊

機動部隊

母艦航空部隊

砲術長

支那方面艦隊

遣支艦隊 [第2]

聯合艦隊, [主力部隊]

聯合通信隊 [第1]

司令

司令官

司令長官

通商破壊隊

通信長

chūtai [rikusen-tai]

Setsuei-han [Dai-ichi,

Dai-ni, Dai-san,

Dai-yon, Dai-go,

Dai-roku, Dai-hachi,

Dai-kyū]

Kensetsu-bu

[Dai hyaku-ni]

Sentai [Dai-yon, Dai-go,

Dai-roku, Dai-nana,

中隊 [陸戦隊]

設営班 [第1，2，3，4，5，6，

$8,9]$

建設部 [第102]

戦隊 $[$ 第4, 5, 6, 7, 8, 9, 16,

$18,21]$

Dai-hachi, Dai-kyū,

Dai-jū-roku, Dai-jū-hachi,

Dai-nijū-ichi]

Bōei-han [Dai-ichi, Dai-ni] 防衛班 [第1, 2]

Bōbi-tai [Dai-ichi, Dai-ni] 防備隊 [第1, 2] 
Destroyer Division [2d, 3d, 4th, 5th, 6th, 7th, 8th, 9th, 11th, 12th, 13th, 15th, 16th, 17th, 18th, 19th, 20th, 21st, 22d, 23d, 24th, 27th, 29th, 30th, 32d, 34th]

Destroyer Squadron [1st, 2d, 3d, 4th, 5th, 6th]

“Destroyer Squadron

[10th [Destroyer] Squadron]"

detached unit [of a base force]

detached unit [of an air flotilla]

Dutch East Indies Unit

East Indies Unit

East Philippines Unit

Eastern Attack Unit

Eastern Support Unit

engineer unit [of the SLF]

Escort Unit [1st, 2d, 3d]

[of Malaya Unit,

Dutch East Indies Unit, etc.]

fighter plane unit

dispatched from an air group

fire-control officer

Fleet [First, Second, Third, Fourth, Fifth, Sixth]

Forward Unit

Fuel Depot [101st]

ground patrol section [of base force]

Greater East Asia War's Lessons of War ([section] Air Operations)

Guard Unit [2d, 3d, 4th, 91st, Celebes, Ambon]
Kuchikutai [Dai-ni,

Dai-san, Dai-yon,

Dai-go, Dai-roku,

Dai-nana, Dai-hachi,

Dai-kyū, Dai-jū-ichi,

Dai-jū-ni, Dai-jū-san,

Dai-jū-go, Dai-jū-roku,

Dai-jū-nana, Dai-jū-hachi,

Dai-jū-ku, Dai-nijū,

Dai-nijū-ichi, Dai-nijū-ni,

Dai-nijū-san, Dai-nijū-yon,

Dai-nijū-nana, Dai-nijū-ku,

Dai-sanjū, Dai-sanjū-ni,

Dai-sanjū-yon]

Suirai Sentai [Dai-ichi,

水雷戦隊 [第1, 2, 3, 4, 5, 6]

Dai-ni, Dai-san, Dai-yon,

Dai-go, Dai-roku]

Sentai [Dai-jū]

bunken-tai

kōkū sentai haken-tai

Ran'in Butai

Tōin Butai

Hitō Higashi Butai

Tōhō Kōryaku Butai

Tōhō Shién-tai

kōsaku-tai [rikusen-tai]

Goéi-tai [Dai-ichi,

Dai-ni, Dai-san]

[Malaya Unit,

Dutch East Indies

Unit, etc.]

kōkū-tai haken sentōki-tai 航空隊派遣戦闘機隊

shageki-shiki-kan

Kantai [Dai-ichi, Dai-ni,

Dai-san, Dai-yon,

Dai-go, Dai-roku]

Zenshin Butai

Nenryō-shō

[Dai-hyaku-ichi]

rikukei-ka [of base force]

Daitōa-sensō Senkun

(Kōkū)

Keibi-tai [Dai-ni,

Dai-san, Dai-yon,

Dai-kyūjū-ichi, Celebes,

Ambon]
戦隊 [第10]

射撃指揮官

駆逐隊 [ 第2，3，4，5，6，

$7,8,9,11,12,13,15$,

$16,17,18,19,20,21$,

22, 23, 24, 27, 29, 30,

$32,34]$

分遣隊

航空戦隊派遣隊

蘭印部隊

東印部隊

比島東部隊

東方攻略部隊

東方支援隊

工作隊 [陸戦隊]

護衛隊 [第1，2，3]

[馬來部隊、蘭印部隊

ほか]

艦隊 [第1, 2, 3, 4, 5, 6]

前進部隊

燃料廠 [第101]

陸警科 (根拠地隊)

大東亞戦争戦訓 (航空)

警備隊 [第2，3，4，91， セレベス,アンボン] 
Gunboat Division [1st, 2d, 3d, 12th]

gunnery staff
headquarters
headquarters [of the SLF]
homeland units
Hydrographic Department
Kure [Naval Station] Special Landing Force
$\quad$ [1st, 2d, 3d]

land-based air unit

lookout commander

main body [of task force, group, unit]

main force

main unit [of task force, group, unit]

Malaya Unit

Malaya Unit Striking Force

medical unit [of the SLF]

military supplies department

Minelayer Division [17th, 19th]

Minesweeper Division [1st, 11th, 21st, 30th, 41st, 44th]

Naval Affairs Bureau [of Navy Ministry]

Naval Antisubmarine [Warfare] School

Naval Arsenal [101st, Toyokawa, Yokosuka]

Naval College

Naval Investigation Committee on

Engagements and Lessons of War

(Subcommittee on Air Operations)

Naval Technical Research Institute

navigation officer

Navy Aeronautical Department

Navy Department of IGHQ

Navy Facility Department

Navy General Staff

Navy Ministry

Navy Technical Department

Northern Task Force

occupying units
Hōkan-tai [Dai-ichi, Dai-ni，第1砲艦隊 [第1，2，3，12]

Dai-san, Dai-jū-ni]

hōjutsu sambō

砲術参謀

shirei-bu

司令部

hombu [rikusen-tai]

naisen butai

本部 [陸戦隊]

内戦部隊

Suiro-bu

水路部

Kure [Chin'ju-fu]

呉特別陸戦隊 [第1,2,3]

Tokubetsu Rikusen-tai

[呉一特、吳二特、

[Dai-ichi, Dai-ni, Dai-san] 呉三特]

[or Kure-ittoku,

Kure-nitoku,

Kure-santoku]

kichi kōkū butai

mihari-chō

基地航空部隊

hontai

見張長

本隊

shuryoku 主力

shutai 主隊

Marē Butai

マレー部隊, 馬來部隊

Marē Butai Kidō Butai

馬來部隊機動部隊

医務隊 [陸戦隊]

軍需部

gun'ju-bu

戦隊, [第17, 19]

Sentai [Dai-jū-nana,

Dai-jū-kyū]

Sōkai-tai [Dai-ichi,

Dai-jū-ichi,

掃海隊 [第1，11，21，30，41，

Dai-nijū-ichi, Dai-sanjū,

Dai-yonjū-ichi,

Dai-yonjū-yon]

Gummu-kyoku

Kaigun Taisen Gakkō

Kaigun Kōshō

[Dai-hyaku-ichi,

Toyokawa, Yokosuka]

Kaigun Daigakkō

Kaigun Sentō Senkun

Chōsa Iinkai

(Kōkū Bunka-kai)

Kaigun Gijutsu

Kenkyū-sho

kōkai-chō

Kōkū-Hombu

Daihon'ei-Kaigun-bu

Shisetsu-bu

Gunrei-bu

Kaigun-shō

Kansei Hombu

Hoppō Butai

shinchū butai
軍務局

44]

海軍対潜学校

海軍工廠

[第101，豐川，横須賀]

海軍大学校

海軍戦闘戦訓調查委員会

(航空分科会)

海軍技術研究所

航海長

航空本部

大本営海軍部

施設部

軍令部

海軍省

艦政本部

北方部隊

進駐部隊 
paratroop unit

Patrol Boat Division [1st]

patrol stations [1st ] [on board]

paymaster [of the SLF]

Philippines Unit

Port Administration Department [1st, 2d]

Preparatory Fleet Mobilization Order

[first/second stage of $~$ ]

protective sailing formation

protective sailing order

Raid Unit [1st, 2d, 3d, 4th, 5th]

range-taking officer

rapid unit

River-ascending unit for Palembang

Sasebo [Naval Station]

Combined Special Landing Force

[1st, 2d]

seaplane base

Seaplane Tender Division [11th, 12th]

section [of the 1st Combined Signal Unit]

section [of a ship division]

senior staff officer

Ship Management Association

Signal Unit [1st, 2d, 3d, 4th, 5th, 6th,

12th, 21st, 24th, 91st, Chichijima,

Okinawa, Takao, Tokyo]

South Seas Unit

Southern Expeditionary Fleet

[First, Second, Third]

Southern Task Force

Southwest Area Fleet

Special Base Force [9th, 10th, 11th, 12th,

21st, 22d, 23d, 24th, 31st, 32d]

special landing force [SLF]

special meteorological detail kūtei butai

空挺部隊

Shōkai-tai or Shōkaitei-tai 哨戒隊, 哨戒艇隊 [第1]

[Dai-ichi]

Kannai shōkai

dai-ichi haibi

shukei-tai [rikusen-tai]

Hitō Butai

艦内哨戒第一配備

主計隊 [陸戦隊]

比島部隊, 菲島部隊

Kōmu-bu [Dai-ichi, Dai-ni] 港務部 [第1, 2]

Suishi Jumbi

[Dai-itchaku sagyō,

出師準備

Dai-ni-chaku sagyō]

Keikai kōkō taikei

(第一着作業,

第二着作業)

Keikai kōkō joretsu

警戒航行隊形

警戒航行序列

Kyūshū-tai [Dai-ichi,

急襲隊 [第1，2，3，4，5]

Dai-ni, Dai-san, Dai-yon,

Dai-go]

sokuteki shiki-kan

keikai butai

測的指揮官

Palembang sokō-butai

軽快部隊

Sasebo [Chin'ju-fu] Rengō

Tokubetsu rikusen-tai

[Dai-ichi, Dai-ni]

Suijō kichi

パレンバン遡江部隊

佐世保[鎮守府]

第1,2 聯合特別陸戦隊

Kōkū Sentai [Dai-jū-ichi， 航空戦隊 [第11，12]

Dai-jū-ni]

rentai [of 1st Comb. S. U.]

shōtai

聯隊 $[$ 第1, 2] [聯合通信隊]

小隊

shuseki sambō

首席参謀

Sempaku Un'ei-kai

船舶運営会

Tsūshin-tai [Dai-ichi,

Dai-ni, Dai-san,

Dai-yon, Dai-go,

通信隊 [第1，2，3，4，5，6，

12, 21，24，91，父島，

沖縄, 高雄, 東京]

Dai-roku, Dai-jū-ni,

Dai-nijū-ichi, Dai-nijū-yon,

Dai-kyūjū-ichi, Chichijima,

Okinawa, Takao, Tokyo]

Nan'yō Butai

南洋部隊

Nanken Kantai [Dai-ichi，南遣艦隊 [第1, 2, 3]

Dai-ni, Dai-san]

Nampō Butai

Nansei Hōmen Kantai

Tokubetsu Konkyochi-tai

[Dai-kyū, Dai-jū,

Dai-jū-ichi, Dai-jū-ni,

南方部隊

南西方面艦隊

特別根拠地隊 [第9, 10, 11，

12, 21, 22, 23, 24, 31,

32]

Dai-nijū-ichi, Dai-nijū-ni,

Dai-nijū-san, Dai-nijū-yon,

Dai-sanjū-ichi, Dai-sanjū-ni]

tokubetsu rikusen-tai 特別陸戦隊

tokubetsu kishō-han 特別気象班 
special minesweeping service unit squadron [of air units]

Subchaser Division [1st, 2d, 5th, 11th, 12th, 21st, 31st]

Submarine Base Unit [11th, 21st]

Submarine Division [1st, 2d, 3d, 4th, 7th, 8 th, 9th, 11th, 12th, 13th, 18th, 19th, 20th, 21st, 26th, 27th, 28th, 29th, 30th, 33d]

Submarine Squadron [1st, 2d, 3d, 4th, 5th, 6th, 7th, 8th]

Submarine Unit

supply unit

support unit

Surface Escort Division [1st, 2d]

surface patrol section [of base force]

Survey Unit [1st, 2d]

Torpedo Boat Division [21st]

torpedo chief

torpedo launching commander

transport aircraft unit

transport unit [of the SLF]

units engaged in operations outside [Japan]

Wartime Formation

West Philippines Unit

Western Attack Unit

Yokosuka [Naval Station]

Special Landing Force [1st, 2d, 3d]

Yokosuka Gunnery School

Yokosuka Naval Air Technical Arsenal

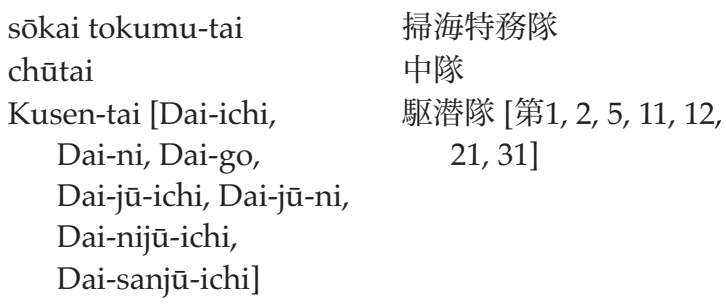

sōkai tokumu-tai

掃海特務隊

chūtai 中隊

Kusen-tai [Dai-ichi，＼cjkstart駆潜隊 [第1, 2, 5, 11, 12, Dai-ni, Dai-go, 21, 31]

Dai-jū-ichi, Dai-jū-ni,

Dai-nijū-ichi,

Dai-sanjū-ichi]

Sensuikan Kichi-tai

[Dai-jū-ichi, Dai-nijū-ichi]

Sensui-tai [Dai-ichi,

Dai-ni, Dai-san,

潜水隊 [ 第1, 2, 3, 4, 7, 8, 9,

Dai-yon, Dai-nana,

Dai-hachi, Dai-kyū,

$11,12,13,18,19,20$,

$21,26,27,28,29,30$,

33]

Dai-jū-ichi, Dai-jū-ni,

Dai-jū-san, Dai-jū-hachi,

Dai-jū-ku, Dai-nijū,

Dai-nijū-ichi, Dai-nijū-roku,

Dai-nijū-nana, Dai-nijū-hachi,

Dai-nijū-ku, Dai-sanjū,

Dai-sanjū-san]

Sensui Sentai [Dai-ichi，潜水戦隊 [第1, 2, 3, 4, 5, 6,

Dai-ni, Dai-san, Dai-yon, 7,8]

Dai-go, Dai-roku, Dai-nana,

Dai-hachi]

Sensui Butai 潜水部隊

hokyū-tai 補給隊

shién-tai 支援隊

Kaijō Goéi-tai [Dai-ichi，海上護衛隊 [第1, 2]

Dai-ni]

Suikei-ka [of base force] 水警科 [根拠地隊]

Sokuryō-tai [Dai-ichi，＼cjkstart測量隊 [第1,2]

Dai-ni]

Suirai-tai [Dai-nijū-ichi]＼cjkstart水雷隊 [第21]

suirai-chō

水雷長

hassha-shiki-kan

yusōki-tai

発射指揮官

輸送機隊

un'yu-tai [rikusen-tai] 運輸隊 [陸戦隊]

gaisen butai

外戦部隊

Senji Hensei 戦時編制

Hitō Nishi Butai 比島西部隊

Seihō Kōryaku Butai 西方攻略部隊

Yokosuka [Chin'ju-fu] 横須賀[鎮守府]第1,2,3

Tokubetsu rikusen-tai 特別陸戦隊

[Dai-ichi, Dai-ni, Dai-san] （横一特）（横二特）

[or Yoko-ittoku, Yoko-nitoku，（横三特）

Yoko-santoku]

Yokosuka Hōjutsu Gakkō 横須賀砲術学校

Kōkū-shō 航空廠 


\section{Index of Personal Names}

The characters used in Japanese names can often be read in more than one way. We have tried to ascertain the correct readings based on several outside sources (see Editor's Note). Here we have added a question mark behind the family and/or personal name whenever the reading remains open to interpretation. This index only covers personal names that appear in the main text.

Abe Heijirō (阿部平次郎), Lt, Sōryū Carrier-based Attack [Plane] Unit cdr, IJN, 338, 620, 628

Abe Hiroaki (阿部弘毅), R Adm, 8th Cruiser Div cdr, IJN, 477

Abe Kōichi (安部孝一) Maj Gen, 48th Inf Gp cdr， IJA, 391

Abe Toshio (阿部俊雄) Capt, 8th Destroyer Div cdr, IJN, 320

Abe Zenji (阿部善次), Lt, Akagi Carrier-based Bomber Unit [gp] cdr, IJN, 621, 629

Adachi Jirō (足立次郎) Lt, Takao Air Gp Landbased Attack Plane Unit cdr, IJN, 241, 459

Aizawa Tatsuo (相沢達雄) Cdr, Tōkō Air Group cdr, IJN, 115

Aoki Shigemasa (青木重誠) Lt Gen, Southern Army V Ch of staff, IJA, 64-65

Aruga Takeo (有賀武夫) R Adm, Navy Technical Dept 6th Dept director, IJN, 551

Asahiro Hiroji (朝広裕二) Capt, Navy Technical Dept member, IJN, 551

Asai Masao (浅井正雄) Lt, Tainan Air Group senior unit cdr, IJN, 237

Chiang Kai-shek, [Jiang Jieshi] (蒋介石), 4, 14, 16， 535-36, 565, 654-55

Chihaya Takehiko (千早猛彦) Lt, Akagi Carrierbased Bomber Unit cdr, IJN, 337

Churchill, [Sir Winston] (チャーチル), 538, 602， 624

Colijn, [Anton Hendrikus] (コーレン) Capt, BPM manager, Tarakan garrison army adjutant, KNIL, 179

Cripps, [Sir Richard Stafford] (クリップス), 604
Daigo Tadashige (醍醐忠重) R Adm, 5th Submarine Sqdn cdr, IJN, 67

Dobbie [W.G. S.] (ドビー陸軍少将) Maj Gen, Gen Ofcr Commanding, Malaya Command, 557

Doorman [Karel W. F. M.] (ドルーマン) R Adm, Royal Netherlands Navy cdr, 243, 305, 323, 328, 461

Egusa Takashige (江草隆繁) Lt Cdr, Sōryū Carrier-based Bomber Unit cdr, IJN, 338, 621, 624, 629

Fuchida Mitsuo (淵田美津雄) Cdr, Akagi Carrierbased Attack [Plane] Unit cdr, IJN, 336-37, $492,620,622,628-29$

Fujimura Masasuke (藤村正亮) Cdr, 1st Kure Special Landing Force cdr, IJN, 217

Fujita Iyozō (藤田怡與蔵) Sublieutenant, Sōryū Carrrier-based Fighter Plane Unit [gp] cdr, IJN, 620

Fujita Ruitarō (藤田類太郎) R Adm, 11th Seaplane Tender Div cdr, IJN, 161, 163, 218, 387, 392, 458, 506

Fukushima Kyūsaku (福島久作) Col, 4th Inf Rgt cdr, IJA, 384, 488, 490

Glassford [William A. Jr.] (グラスフォード) R Adm, U.S. naval forces cdr, 192

Hamada Takeo (浜田武夫) Cdr, 1001 Unit cdr, IJN, 153, 396

Hamanaka Shūichi (浜中修一[脩一]) Cdr, Capt of the Yamakaze, IJN, 143

Hara Chūichi (原忠一) R Adm, 5th Carrier Div cdr, IJN, 601-02, 622-24

Hara Kenzaburō (原顕三 郎) R Adm, 5th Destroyer Sqdn cdr; [later] 16th Cruiser Div cdr, 
IJN, 364-66, 369-70, 384, 386, 412, 414-16, 418, $465-67,469,472,498,593,597$

Hart, [Thomas C.] (ハート) Adm, U.S. Asiatic Fleet $\mathrm{C}$ in $\mathrm{C}, 174,328$

Hashiguchi Takashi (橋口喬) Lt Cdr, Kaga Carrier-based Attack [Plane] Unit cdr, IJN, 337

Hashimoto Shintarō (橋本信太郎) R Adm 3d Destroyer Sqdn cdr, IJN, 266-67, 284-85, 298

Hashimoto Uroku (橋本卯六) Cdr, 2d Sasebo Combined Special Landing Force cdr, IJN, 160

Hasuo Ryūichi [Takaichi?] (蓮尾隆市) Lt, 3d Air Gp unit cdr, IJN, 241

Hatakeyama Kōichirō (畠山耕一郎) R Adm, 24th Special Base Force cdr, IJN, 217, 225-26, 232, 512

Hatakeyama Kunito (畠山国登) Lt, 1st Kure Special Landing Force senior ofcr, acting cdr, IJN, $217,225-26$

Hattori Takushirō (服部卓四郎) Col, IGHQ Army Dept Ch of opns; Army Gen Staff Ch of opns, IJA, 90, 565

Hayakawa Kikuo (早川菊夫) Maj, 228th Inf Rgt 1st Bn cdr, IJA, 228, 353

Hayashi Reizō [?] (林礪三) Capt, 18th Div 56th Inf Rgt 2d Bn cdr, IJA, 583

Hayashi Shōjirō (林鉦次郎) Cdr, 1st Kure Special Landing Force cdr, IJN, 217

Helfrich, [C. E. L.] (ヘルフリッツ) V Adm, Royal Netherlands Navy cdr, 328

Hiraoka Kumeichi (平岡夈一) R Adm 9th Base Force cdr, IJN, 270, 295-96, 568, 573

Hirose Suéto (広瀬末人) R Adm, 2d Base Force cdr; [later] 22d Special Base Force cdr, IJN, 130, 198, 252, 364-65, 367, 392, 505, 512

Hitler [A.] (ヒトラー), 556

Homma Masaharu (本間雅晴) Lt Gen, 14th Army cdr, IJA, 64

Horiuchi Toyoaki (堀内豊秋) Cdr, 1st Yokosuka Special Landing Force Paratroop Unit cdr, IJN, 160
Ichihara Tatsuo (市原辰雄) Lt, Shōkaku Carrierbased Attack [Plane] Unit cdr, IJN, 628

Ichioka Hisashi (市岡寿) R Adm, 2d Submarine Sqdn cdr, IJN, 486, 616, 647

Ieki Kōnosuke (家木幸之輔) Cdr, 1st Kure Special Landing Force [staff?], IJN, 217, 225, 227

Iida Shōjirōo (飯田祥二郎) Lt Gen, 15th Army cdr, IJA, 65, 565, 570

Imai Kazufumi (今井一二三) Col, 1st Taiwan Inf Rgt cdr, IJA, 391

Imamura Hitoshi (今村均) Lt Gen, 16th Army cdr, IJA, 65, 116, 256, 258, 265, 343-44, 404, $415,472,489$

Imamura Osamu (今村脩) R Adm 12th Seaplane Tender Div cdr, IJN, 131, 271, 498

Inoue Shigeyoshi (井上成美) V Adm, 4th Fleet C in C, IJN, 618, 633

Irisa Toshiié (入佐俊家) Lt Cdr, Kanoya Air Gp avn ofcr, IJN, 115, 153, 235, 238-39, 242-43

Isayama Haruki (諌山春樹) Maj Gen, 15A Ch of staff, IJA, 65

Ishii Masayoshi [Masami ?] (石井正美) Col, Southern Army Section 1 (opns section) senior staff, IJA, 277

Ishikawa Shigeru (石川茂) R Adm, Rangoon Base Unit cdr, IJN, 590

Itaya Shigeru (板谷茂) Lt Cdr, Akagi Carrierbased Fighter Plane Unit cdr, IJN, 337, 620, 628

Itō Motoé (伊藤素衛) Lt, Kumano avn ofcr, IJN, 290,644

Itō Sukemitsu (伊東祐満) Cdr, Tōkō Air Gp avn ofcr, IJN, 585

Itō Takeo (伊東武夫) Maj Gen, 38th Inf Gp cdr, Eastern Det cdr, IJA, 111-12, 116, 171, 213-16, 226-28, 232, 265, 342-47, 349, 352-54, 373, 381, 397

Itoda Isamu (井戸田勇) Lt Col, 16th Army, Section 1 (Ch avn staff), IJA, 303

Iwabuchi [Iwafuchi ?] Tsuneo (岩淵經夫) Lt. Col., 38th Engr Rgt cdf, IJA, 266, 303-04 
Kakuta Kakuji (角田覚治) R Adm, 4th Carrier Div cdr, IJN, 272-73, 290, 294-95

Kanauji [Kaneuji ?] Ken'ichi (金氏堅一) Maj, 146th Inf Rgt 2d Bn cdr, IJA, 130

Kaneko Tadashi (兼子正) Lt Shōkaku Type-0 Fighter Plane Unit [gp] cdr, IJN, 628

Kanemura [Kanamura?] Matabē (金村亦兵衛) Maj, 1st Taiwan Inf Rgt 3d Bn cdr, IJA, 310, 312,322

Kanki Takekichi (神吉武吉), Col., 38th Mountain Arty Rgt cdr, IJA, 303

Kawaguchi Kiyotake (川口清健) Maj Gen, 18th Div 35th Inf Bde cdr; Kawaguchi Det cdr, IJA, 65, 69-70, 75, 81, 91, 120, 209, 274-75

Kawano Chimaki (河野千万城) R Adm, 6th Submarine Sqdn cdr, IJN, 481-82

Kawasaki Harumi (川崎晴実) Capt, 91st Guard Unit cdr, IJN, 583, 586

Kitayama [Yūzō] (北山 [雄三]) Col, Imperial Guard Div Reconnaissance Rgt cdr, IJA, 580

Kikkawa Kiyoshi (吉川潔) Cdr, Capt of the Ōshio, IJN, 320

Kimura Eijirō (木村栄次郎) Maj, 228th Inf Rgt 2d Bn cdr, IJA, 228

Kimura Tadao [Nobuo, Yoshio?] (木 村信 雄) Flight Petty Ofcr 1st Class, IJN, Akagi fighter plane unit [grp] cdr, 629

Kitamura Kurō (北村九郎) Lt Col, 48th Recon Rgt cdr, IJA, 391

Kobayashi Ichizō (小林一三) Japanese Minister of Commerce and Industry; special envoy [to the Dutch East Indies], 4

Kobayashi Michio (小林道雄) Lt, Hiryū Carrierbased Bomber Unit cdr, IJN, 338, 621, 626, 629, 634

Kobayashi [Takashi] (小林隆)Maj Gen, Imperial Guard Inf Gp cdr; Kobayashi Det cdr, IJA, $577-78,580$

Kobayashi Tetsuri (小林徹理 ) R Adm, 17th Minelayer Div cdr, IJN, 99
Kōmura Takeo (甲村武雄) Maj, 2d [Paratroop] Raiding Rgt cdr, IJN, 302

Kondō Nobutake (近藤信竹) V Adm, 2d Fleet C in C; Navy Southern Task Force cdr; [later] Forward Unit cdr, IJN, 62, 66-67, 70, 87, 94, 101-02, 125, 205, 210, 212, 276, 330-32, 343, 362-63, 365, 372, 403-05, 407, 409-10, 417, 423-24, 475, 481-82, 486, 493, 499, 568-70, 602, 604, 641, 645, 650, 657

Konoé Fumimaro (近衛文麿) Prime Minister of Japan, 13

Koseki [Akira] (小関晟) Cdr, 3d Fleet staff, IJN， 344

Koyama Tadashi (小山貞) Capt, staff of destroyer sqdn [then] Naval Technical Dept member, IJN, 552

Kōzai Fusaichi (香西房市) Lt Cdr, Sanuki-maru avn ofcr, IJN, 310

Kubo Kyūji (久保九次) R Adm, 1st Base Force cdr; [later] 21st Special Base Force cdr, IJN, 159, 171-72, 200, 202, 246, 248, 251, 253-54, 311-12, 317, 319, 323-24, 427, 442, 512

Kuboki Hideo (久保木英雄) Cdr, Capt of the Arashio, IJN, 320

Kume Seiichi (久米精一) Col, 1st [Paratroop] Raiding Gp cdr, IJA, 302-03

Kunishi [Kentarō] (国司[憲太郎]) Col, Imperial Guard Div 4th Inf Rgt cdr, IJA, 580

Kurita Takeo (栗田健男) R Adm, 7th Cruiser Div cdr, IJN, 369, 387, 410, 412, 414-17, 644

Kurusu Saburō (來栖三郎) Ambassador [sent to the U.S.-Japanese negotiations], 14

Kusuhata Yoshinobu (楠畑義信) Lt, Takao Landbased Attack Plane Unit sqdn cdr, IJN, 460

Kusumi Masashi (楠美正) Lt. Cdr., Hiryū Carrierbased Attack [Plane] Unit cdr, IJN, 219, 338, 620,628

Layton [Sir Geoffrey] (レイトン) Adm Former C in $\mathrm{C}$ of the Eastern Fleet; $\mathrm{C}$ in $\mathrm{C}$ of Ceylon, $650-51$ 
Leatham [Sir Ralph, KCB] (レーサム) R Adm, East Indies Station C in C, 559

Maéda Kōsei (前田孝成) Cdr, Genzan Air Gp cdr, IJN, 518

Maéda Masami (前田正実) Lt Gen, 14th Army Ch of staff, IJA, 64

Makino Masatoshi (牧野正敏) Lt, Zuikaku Type-0 Fighter Plane Unit [gp] cdr, IJN, 620, 628

Makiuchi Tadao (牧内忠雄) Cdr, 2d Kure Special Landing Force cdr, IJN, 135

Matsumoto Makoto (松本真実) Lt Cdr, 1st Air Gp avn ofcr, IJN, 22

Matsunaga Sadaichi (松永貞市) R Adm, 22d Air Flotilla cdr, IJN, 270, 279, 288, 292, 370, 498, 584,617

Matsuyama Tsugio (松山次男) Ch Flight Warrant Ofcr, Hiryū Type-0 Fighter Plane Unit [gp] cdr, IJN, 629

Mikawa Gun'ichi (三川軍一) V Adm, 3d Battleship Div cdr, IJN, 477-78

Miyazawa Shigezō [Jūzō ?] (宮沢重蔵) Maj, 229th Inf Rgt 2d Bn cdr, IJA, 266, 303-04

Mizoguchi (Kuzuhara) Tomoji (溝口（葛原）智 司) Sublieutenant (later Lt Cdr) Torpedo Ch of the Kawakaze, IJN, 549

Mori Kunizō (森国造) Capt, Sasebo Combined Special Landing Force cdr; [later] 23d Special Base Force cdr, IJN, 160, 201, 512

Morisawa (森澤) 1st Lt, 2d [Paratroop] Raiding Rgt 3d Co cdr, IJA, 302

Morita Rinji (森田林次) Lt, Kanoya Air Gp 2d Sqdn cdr, IJN, 239, 243

Murase Jishichirō (村瀬治七郎) Capt, 3d Machinegun Bat cdr, IJA, 353

Nagai Sumitaka (長井純隆) Cdr, Capt of the Natsushio, IJN, 253

Nagano Osami (永野修身) Adm, Ch of Navy Gen Staff, IJN, 26, 34, 342-43

Nagasawa Kō (長沢浩) Cdr, 5th Cruiser Div senior staff, IJN, 441
Nagumo Chūichi (南雲忠一) V Adm, 1st Air Fleet C in C; Carrier Task Force cdr, IJN, 336-37, $339,477-78,491-92,605,619,622-24,627,650$

Nakamura Toshihisa (中村俊久) R Adm, 3d Fleet Ch of staff, IJN, 66

Namekata Shōichi (行方正一) Lt Col, 56th Field Arty Rgt 1st Bn cdr, IJA, 136-38

Nasu Yumio (那須弓雄) Maj Gen, 2d Inf Gp cdr, IJA, 384, 488, 490

Nikaidō Yasushi (二階堂易) Lt, Kaga Carrierbased Fighter Plane Unit cdr, IJN, 338

Nishimura Shōji (西村祥治) R Adm, 4th Destroyer Sqdn cdr, IJN, 126-27, 136-37, 146, 148-49, 177, 184, 188, 190, 192, 194, 198, 248, $364,367,370,372,391-93,427,432-33,436$, 438-39, 443, 501-07, 594, 596-97

Noble [Sir Percy] (ノーブル) Adm, China Station $\mathrm{C}$ in $\mathrm{C}, 559$

Nomura Kichisaburō (野村吉三郎) Japanese Ambassador to the United States, 6

Nomura Ryōsuke (野村了介) Lt Cdr, 23d Air Flotilla staff, IJN, 460

Nonaka Tarō (野中太郎) Lt Cdr, Takao Air Gp [unit] cdr, IJN, 235

Nōno Sumio (能野澄夫) Lt, Hiryū Carrier-based Fighter Plane Unit cdr, IJN, 338, 620

Ogawa Shōichi [Seiichi? Masakazu?] (小川正一) Lt, Kaga Carrier-based Bomber Unit cdr, IJN, 338

Ogura Masami (小倉正身) Cdr, Capt of the Michishio, IJN, 320

Oinuma Kichirō? [Yoshirō? Yoshio?] (生沼[吉郎]) Col, Imperial Guard Div 4th Inf Rgt cdr, IJA, 580

Okazaki Seizaburō (岡崎清三郎) Maj Gen, 16th Army , Ch of staff, IJA, 65

Oku Nobukazu (奥信一) R Adm, Singapore Base Unit cdr, IJN, 590

Ōmori Sentarō (大森仙太郎) R Adm, 1st Destroyer Sqdn cdr, IJN, 477

Ōmura (大村)（技師） Engr, IJN, 8 
Ōnishi Takijirō (大西瀧治郎) R Adm, 11th Air Fleet Ch of staff, IJN, 67

Orita Masaru (折田優) Cap, 229th Inf Rgt 1st Bn cdr, IJA, 266, 303-04

Ōta Jusō (太田寿双) Lt, Tōkō Air Gp Torpedo Attack Unit cdr, IJN, 115

Ōyagi Shizuo (大八木静雄) R Adm of Engr, IJN， 454

Ozaki Takeo (尾碕武夫) Lt Cdr, 1st Air Gp unit cdr, IJN, 235, 238, 242

Ozawa Jisaburō (小沢治三郎) V Adm, Southern Expeditionary Fleet/1st Southern Expeditionary Fleet C in C; Malaya Unit cdr, IJN, 67, 124-25, 258, 261, 265, 270, 275-77, 279, 282-83, 287-90, 295, 298, 366, 369-70, 372, 423, 567-70, $575-76,579,581,588,613,641-42,650$

Pesman, [Jacob J.] (ベスマン) Maj Gen, Bandung area garrison [army] cdr, KNIL, 489-90

Pibulsonggram, [Luang] (ピブン) Prime Minister of Thailand, 80

Poorten, [Hein] ter (テルポーテン) Lt Gen, Dutch East Indies Army cdr and Ch of the Dutch East Indies Army Dept, KNIL, 489

Pound, [Sir Alfred Dudley Pickman Rogers, GCB, OM, GCVO] (バウンド卿) Adm, First Sea Lord, 650

Reinderhoff [Gerard Leonard] (レンデルボ) Capt, Tarakan garrison staff, KNIL, 179

Roosevelt [Franklin D.] (ルーズベルト) President of the United States, 4, 6, 538

Sakaguchi Shizuo (坂口静夫) Maj Gen, 56th Mixed Inf Gp cdr; Sakaguchi Det cdr, IJA, 37, 70, 87, 92, 97, 103, 111-12, 117, 123, 127-29, 131, 135-38, 145, 149, 177-79, 181, 190, 194-96, $199,210,246,256,307,355,370-72,380$, 393-94, 397-99, 426, 488-90, 502, 533, 591

Sakaguchi Yoshitarō (阪口芳太郎) Lt Gen, Southern Army V Ch of staff, IJA, 64-65

Sakamoto Akira (坂本明) Lt, Zuikaku Carrierbased Bomber Unit cdr, IJN, 620, 629
Sakiyama Shakao (崎山釈夫) Capt, Capt of the Mikuma, IJN, 470

Sanagi Sadamu (佐薙毅) Cdr, Navy Gen Staff Section 1 staff, IJN, 291

Sano Tadayoshi (佐野忠義) Lt Gen, 38th Div cdr, IJA, 266, 303

Satō Hanshichi (佐藤半七) Col, 29th Inf Rgt cdr, IJA, 384, 488, 490

Sawada Torao (沢田虎夫) R Adm, 1st Southern Expeditionary Fleet and Malay Unit $\mathrm{Ch}$ of staff, IJN, 67, 277

Shigematsu Yasuhiro (重松康弘) Sublieutenant, Hiryū Type-0 Fighter Plane Unit [gp] cdr, IJN, 628

Shimazaki Shigekazu (嶋崎重和) Lt Cdr, Zuikaku Carrier-based Attack Plane Unit cdr, IJN, 628 Shingō Hideki (新郷英城) Lt, Tainan Air Gp air unit cdr and [gp] cdr, IJN, 237, 241

Shinoda Tarohachi (篠田太郎八) Capt, Capt of the Kamikawa-maru, IJN, 271, 387, 498

Shiraishi Kazutaka (白石万隆) R Adm, 2d Fleet Ch of staff, IJN, 66-67

Shōji Toshishige (東海林俊成) Col, 230th Inf Rgt cdr; Shōji Det cdr, IJA, 265, 361-62, 364, 374, 376, 378, 384, 398, 488-90, 500-01, 533

Somerville,[ Sir James Fownes, GCB, GBE, DSO, DL] (ソマービル) Adm, Eastern Fleet C in C, $650-53$

Soné [Soji?] Akira (曾爾章) Capt, Capt of the Mogami, IJN, 644

Suékuni Masao (末国正雄) Cdr, 5th Cruiser Div gunnery staff, IJN, 441

Suganami Masaji [Seiji?] (菅波政治) Lt, Sōryū Type-0 Fighter Plane Unit cdr, IJN, 628

Sugawara Michiō (菅原道大) Lt Gen, 3d Air Force cdr, IJA, 65, 258, 273, 500

Sugiyama (杉山) Flight Petty Ofcr 1st Class, Sōryū Type-0 Fighter Plane Unit [gp] cdr, IJN, 629

Sugiyama Gen (杉山元) Gen, Ch of Army Gen Staff, IJA, 26 
Suzuki Sōsaku (鈴木宗作) Lt Gen, 25th Army Ch of staff, IJA, 65

Tada Takeo (多田武雄) R Adm, 21st Air Flotilla cdr, IJN, 168-69, 183, 218-20, 240, 346, 349

Takagi Takeo (高木武雄) R Adm, 5th Cruiser Div cdr, IJN, 106, 110, 150, 172, 200, 218, 247, 307, 333, 344-46, 427, 431-33, 435-36, 438, 440-42

Takahashi Chihaya (高橋千隼) Capt, 11th Air Fleet senior staff, IJN, 205, 207

Takahashi Ibō (高橋伊望) V Adm, 3d Fleet C in C, The Philippines ([and later] the Dutch East Indies) Unit cdr; [then] Southwestern Area Fleet C in C, IJN, 66, 87, 94, 105-07, 118, 131, $174,177,201,217,246-47,307-08,311-12,319$, $322,343-46,354,362,364-67,372,379,400-01$, 403-05, 409-10, 424, 426, 438, 442-43, 445, 475, 501, 504, 507, 568, 592-93, 598, 657, 659

Takahashi Kakuichi (高橋赫一) Lt Cdr, Shōkaku Carrier-based Bomber Unit cdr, IJN, 620, 629-30

Takama Tamotsu (高間完) Capt, Capt of the Haruna, IJN, 66

Takedai Takashi (竹大孝志) Cdr, Navy Technical Dept member, IJN, 453

Takenaka Ryōzōo(竹中龍造) R Adm, 23d Air flotilla cdr, IJN, 130-31, 196, 234, 310, 427, 584

Talbot [Paul H.] (タルボット) Cdr, Destroyer Div cdr, 192

Tanaka Hisakazu (田中久一) Lt Gen, 21st Div cdr, IJA, 65

Tanaka Kikumatsu (田中菊松) Capt, Capt of the Kumano, IJN, 290

Tanaka Raizō (田中頼三) R Adm, 2d Destroyer Sqdn cdr, IJN, 106, 150, 171-72, 200, 213-15, 218, 223-24, 227, 232, 344-45, 347-48, 355, 433, $435,438,443,501,503,505-07$

Tanaka Ryōsaburō [Ryōzaburō?] (田中良三郎) Col, 229th Inf Rgt cdr, IJA, 266, 303-04

Tanaka Takekatsu (田中武克) Lt, Kanoya Air Gp 3d Sqdn cdr, IJN, 239, 243-44
Tanaka Tōru (田中透) Col, 2d Taiwan Inf Rgt cdr， IJA, 391

Terauchi Hisaichi (寺内寿一) Gen, Southern Army C in C, IJA, 62, 64-65, 75, 87, 116, 120, $210,265,565-66,568,570$

Tjarda [van Starkenborgh Stachouwer], Jonkheer Alidius Warmoldus Lambertus] (スタルケン ボルグ) Governor-Gen, Dutch East Indies, 489 Tōjō Hideki (東條英機, 東条英機), War Minister and Prime Minister of Japan, 13, 342-43

Tomari Mitsuyoshi (泊満義) Capt, 1st Southern Expeditionary Fleet/Malaya Unit senior staff, IJN, 277

Tsuchihashi [Tsuchibashi?] Yūitsu [Yūichi?] (土 橋勇逸) Lt Gen, 48th Div cdr, IJA, 370

Tsukada Osamu (塚田攻) Lt Gen, Southern Army Ch of staff, IJA, 64-65

Tsukahara Nishizō (塚原二四三) V Adm, 11th Air Fleet C in C; Air Unit cdr, IJN, 67, 100-01, 113, 126, 130, 233, 237, 310, 330, 335-36, 369, 409, $423,584,612,617,639,641$

Tsukuda Sadao (佃定雄) Cdr, Navy Technical Dept member, IJN, 544, 550

Ugaki Matome (宇垣䌕) R Adm, Combined Fleet Ch of staff, IJN, 330

Wakabayashi Tōichi (若林東一) 1st Lt, 228th Inf Rgt 10th Co cdr, IJA, 214, 217, 224-26, 228

Wakatsuki Ryōzō (若梘龍三) Cdr, 3d Fleet gunnery staff attached to the 16th Army, IJN, 276

Yamada Shigeru (山田茂) Flight Petty Ofcr 1st class, crew of the Mizuho, IJN, 458

Yamada Takeo (山田猛夫) Ch Flight Warrant Ofcr, IJN, 291

Yamada [Yutaka] (山田豊) Cdr, Yamada Unit (fighter plane unit attached to the 22d Air Flotilla HQ) cdr, IJN, 83, 270-71, 276, 280-81, 291-92, 299, 412, 421-23, 585

Yamaguchi Sadao (山口定夫) Sublieutenant, 3d Air Gp unit cdr, IJN, 241

Yamaguchi Tamon (山口多聞) R Adm, 2d Carrier Div cdr, IJN, 212, 330, 339 
Yamaki Akira (矢牧章) Capt, 3d Fleet senior staff, IJN, 205

Yamakuma Wakito (山隈和喜 人 ) Cdr, 11th Minesweeper Div cdr, IJN, 142

Yamamoto Isoroku (山本五十六) Adm, Combined Fleet $\mathrm{C}$ in $\mathrm{C}$, IJN, 13, 32, 34, 62, 77, 83, 118, 122, 204, 212, 485, 567, 569-70, 601-02, 658

Yamamoto Kyōhei (山本恭平) Col, 146th Inf Rgt cdr, IJA, 129, 137, 256-57, 426

Yamashita Tomoyuki (山下奉文) Lt Gen, 25th Army cdr, IJA, 65, 567, 581

Yanagisawa Kuranosuke (柳沢蔵之助) Capt, 2d Fleet senior staff, IJN, 209

Yano Tsuneo (矢野常雄) Lt Col, 56th Inf Gp/Sakaguchi Det staff, IJA, 149

Yasunobu Takeo (安延多計夫) Cdr, 23d Air Flotilla senior staff, IJN, 460

Yokomizo Kōshirō (横溝幸四郎) Lt, Takao Air Gp [unit] cdr, IJN, 238, 242

Yokoyama Tamotsu (横山保) Lt, 3d Air Gp avn ofcr and [unit] cdr, IJN, 235

Yonehara Tsunaki? [Tsunaaki?] (米原綱明) Lt Cdr, Tōkō Air Gp avn ofcr, IJN, 22

Yoshii Gorō (吉井五郎) Cdr, Capt of the Asashio, IJN, 320

Yoshimatsu Yoshihiko [?] (吉松吉彦) Sublieutenant, Destroyer Ushio torpedo Ch, IJN, 320

Yoshitomi Setsuzō (吉富説三) R Adm, 4th Submarine Sqdn cdr, IJN, 272-74, 300, 481-83

Yoshitomi Shigema (吉富茂馬) Lt Cdr, 4th Carrier Div avn staff, IJN, 295

Yoshizawa Kenkichi (芳沢謙吉) Ambassador and special envoy, 5 



\section{Index of Ship Names}

See also Editor's Note. The katakana spellings given here are not official spellings, but the spellings as they are found in the original Japanese text. Since Vol. 26 uses old characters for ship names, we have given these characters together with their modern versions.

Abukuma (阿武隈), 59, 334, 371, 376, 492, 621, 623， 628

Aden-maru (亞丁丸, 亜丁丸), 376

Africa-maru (あふりか丸), 215

Aikoku-maru (愛國丸, 愛国丸), 61

Akagi (赤城), 32, 61, 334, 336-37, 339, 476, 479， $608-11,620-21,623,625-26,628-32,634$

Akashi (明石), 52, 54, 57, 105, 250, 530, 542

Akatsuki (曉, 暁), 367, 509

Akebono (曙), 322, 333, 346-47, 354, 382, 407, 410, $426,442-43$

Akebono-maru (あけぼの丸), 592, 594, 600

Akigumo (秋雲), 49, 54, 61, 371, 476, 605

Akikaze (秋風), 396

Alaska-maru (あらすか丸), 269

Alden (アンデン,アルデン), 174, 305, 461, 463

Amagiri (天霧), 283, 572, 615, 643-44

Amagisan-maru (天城山丸), 151, 159, 166, 396, 516

Amatsukaze (天津風), 150, 205-06, 215，221，223，

$228,434,502,526,594,596-97$

$A n^{\prime} y \bar{o}-$ maru (安洋丸), 269

Aoba (青葉), 59

Aotaka (蒼鷹), 153, 159, 172, 249, 254, 308-09, 383， 426, 512

Arare (霰), 330, 601

Arashi (嵐), 475-76, 494, 496

Arashio (荒潮 ), 221，309，311-12，318-20，323，

$327-28,444,506,526,528,543$

Asagiri (朝霧), 267-68, 282-86, 289, 297, 572, 615

Asagumo (朝雲), 126, 128, 180, 194, 434, 437, 439,

$443,461,505-06,529-30$

Asahi (朝日), 52, 55, 58, 263, 582
Asahi-maru (朝日丸), 52, 54, 189

Asahisan-maru (朝日山丸), 179, 189, 191，193，199

Asaka-maru (淺香丸, 浅香丸), 60

Asakaze (朝風), 366, 465-68, 510

Asama-maru (淺間丸, 浅間丸), 158, 177, 183, 396

Asashio (朝潮), 221-22, 224, 228, 311, 314-20, 323， $325-28,444,526,528$

Asheville (アンビル,アッシュビル), 494, 496

Ashigara (足柄), 60, 105, 110, 158, 174，312，322， 360 , 367, 371-73, 382, 406-07, 410, 425, 440, $442-46,448,504,512,659$

Atago (愛宕), 59, 90, 372, 475, 493-96, 605, 641

Awata-maru (粟田丸), 60

Ayanami (綾波), 282, 298, 410, 413, 510, 570, 575， 588,614

Ayatosan-maru (綾戸山丸), 376

Bahadur (バハダー), 648

Banckert (バンゲルト), 243, 305, 563

Ban Ho Guan (バン・ホ・グァン), 487

Barker (バーカー,パーカー), 174, 243, 305

Boise (ボイス), 174, 192, 204, 563

Bulmer (ブルマ), 174, 243, 305

Canberra (キャンベラ), 341, 535, 603

Canopus (カノパス), 115

Chester (チェスター), 349

Chidori (千鳥), 366, 371, 413, 512

Chikuma (筑摩), 59, 334, 476, 478-79, 491-92, 496, 622

Childs (チャイルズ), 201, 563

Chilka (チルカ), 487 
Chitose (千歳), 60-61, 80, 84-85, 109, 161, 165, 201， 204, 218, 229-31, 247, 249-50, 256, 345, 365, $367,371-73,383,395,406,427-29,458,499$

Chiyoda (千代田), 657

Chōgei (長鯨), 60, 86, 485

Chōkai (鳥海, 鳥海), 59，66-67，72-73，83，260-62， 282-83, 287-88, 292, 294, 361, 371, 410, 493, 569-70, 572-73, 575, 577, 582, 588, 591, 614, 643, 645-46

Chōkō-maru (長江丸), 263

Chōsa-maru (長沙丸), 263, 380, 577, 582

Chōwa-maru (長和丸), 151, 166

Clan Ross (クランロス), 648

Cumberland (カンバーランド), 625

Cornwall (コンウォール), 535, 571, 603, 623, 627, $633,651,652$

Daitō-maru (臺東丸, 台東丸), 322

Danae (ダナエ), 289, 415

De Ruyter (デロイテル), 238, 240, 242-44, 305, 320, 322-25, 328, 405, 450, 461-62, 464, 563

Dorsetshire (ドーセッツシャー), 571, 624, 627, 633， 651-52

Ebisu-maru (蛭子丸), 395, 424

Ebisu-maru (蛭丸; probably the same as the above) Edsall (エドソール), 174, 305, 477, 480, 491, 496

Edwards $\rightarrow$ John D. Edwards

Ehime-maru (愛媛丸), 127, 179, 191, 370, 393, 426

Eifuku-maru (永福丸, 永福丸), 263

Eikō-maru (永興丸), 262, 265, 285, 297, 572-73, 577

Electra (エレクトラ), 461, 463

Elmdale (エルムデール), 648

Emerald (エメラルド), 289, 651

Encounter (エンカウンター), 445, 461-63

Enggano (エンガノ), 491

Enterprise (エンタープライズ), 651

Erimo (襟裳), 264, 499, 509

Evertsen (エベルツェン), 315, 508, 563

Exeter (エクゼター), 294, 305, 441, 444-46, 449-50， $461-62,500$

Ford $\rightarrow$ John D. Ford
Formidable (フォーミダブル), 650-51

Fubuki (吹雪), 282-87, 297，411，418，465-67, 508， 588

Fujikawa-maru (富士川丸), 396

Fukuei-maru No. 15 (第十五福榮丸, 第十五福栄丸), 528

Fultala (フルタラ), 648

Fumizuki (文月), 366，465，508-09

Furutaka (古鷹), 59

Fusō (扶桑), 59

Gen'yō-maru (玄洋丸), 109

Ghent $\rightarrow$ Van Ghent

Gin'yō-maru (銀洋丸), 296

Glasgow (グラスゴー), 415, 418, 470

Glenshiel (グレンシール), 647

Haguro (羽黑，羽黑)，59，109，253，333，382，426， $434,436-41,443,445-47,461$

Hakaze (羽風), 396

Hakusan-maru (白山丸), 109, 308-09

Hankow-maru (漢口丸, 漢口丸), 127, 179-80

Harukaze (春風), 366, 411，418，434，465-68，474， $508,510,527,531$

Haruna (榛名), 59, 66, 72, 83, 476, 630

Harusame (春雨), 126, 128, 196, 367, 393, 434, 444， 526

Hatakaze (旗風), 366, 465, 466-68, 508-10, 527

Hatsuharu (初春), 202, 204, 248, 250, 309, 322-23, $381,383,504,530$

Hatsukari (初雁), 366, 512-13

Hatsukaze (初風), 150, 205-06, 228，434，502，506， 526,543

Hatsushimo (初霜), 202, 251, 319

Hatsutaka (初鷹), 262, 284-85, 295, 572-73, 577， 582,590

Hatsuyuki (初雪)，283-86，297，465，468，474， 508-09, 527, 588

Havana-maru (はばな丸), 128, 179, 180, 370, 393

Hawkins (ホーキンス), 289

Hayabusa (隼), 659 
Hayashio (早潮), 109, 150-51, 166, 203, 205-06, 221， 254, 256, 475, 493-94

Hayatomo (早鞆), 424, 513

Heemskerck $\rightarrow$ Jacob van Heemskerck

Hein $\rightarrow$ Piet Hein

Hermes (ハーメス, ハーミーズ), 535, 571, 603, 630-35, 640, 650-52

Heron (ヘロン), 115, 563

Hibiki (響), 367, 509

Hiei (比塜), 59, 476, 478-79, 481, 619

Hino-maru No. 3 (第三日の丸), 309, 322

Hino-maru No. 5 (第五日の丸), 215, 223, 396, 516

Hirokawa-maru (宏川丸), 583, 587

Hiryu (飛龍), 32, 61, 95, 101，116， 201，219，334，336， $338-39,341,476,491,570,609,611,620-21$, 623, 625-29, 631-34

Hishi-maru (菱丸), 518

Hitachi-maru (日立丸), 396

Hiteru-maru (日照丸), 127，179，191

Hobart (ホバート), 305

Hōkoku-maru (報國丸，報国丸), 61

$H \bar{o} k \bar{o}-m a r u$ (䎧光丸，豊光丸), 605-06

Hokuriku-maru (北陸丸), 151-52, 166, 248, 513

Hollyhock(ホーリー), 652

Hōrai-maru (蓬來丸, 蓬来丸), 472

$H o ̄ s h o ̄$ (鳳翔), 59

Houston (ヒューストン), 122, 174, 204, 219, 239， 243-44, 323, 350, 435, 438, 450, 461-64, 470, 563

Hyūga (日向), 59

I-1 (伊号第一潜水艦), 484, 486, 646

I-2 (伊号第二潜水艦)，484，486-87，616，618-19， 647-48

I-3 (伊号第三潜水艦)，484，486-87，616，618， 647-48

I-4 (伊号第四潜水艦)，484，486-87，616，618， 647-48

I-5 (伊号第五潜水艦)，484，486-87，533，646-47， 649

I-6 (伊号第六潜水艦), 211，484，486-87，616，618， 647-48
I-7 (伊号第七潜水艦), 60, 484, 486-87, 616-19, 641， 647

I-8 (伊号第八潜水艦), 60, 211

I-9 (伊号第九潜水艦), 60

I-10 (伊号第十潜水艦), 60

I-53 (伊号第五十三潜水艦), 300-01, 483-84

I-54 (伊号第五十四潜水艦), 483-84

I-55 (伊号第五十五潜水艦), 273, 299，300-01， 483-84

I-56 (伊号第五十六潜水艦)，273，299，300-01， 483-84

I-57 (伊号第五十七潜水艦), 483

I-58 (伊号第五十八潜水艦), 483-84

I-60 (伊号第六十潜水艦), 121

I-121 (伊号第百二十一潜水艦), 484-85

I-122 (伊号第百二十二潜水艦), 484-85

I-123 (伊号第百二十三潜水艦), 484-85, 506

I-124 (伊号第百二十四潜水艦), 122

Ikazuchi (雷), 150, 223, 322, 333, 346-47, 354, 382, $407,410,426,442-43,446,525$

Ikushima-maru (いくしま丸), 254, 308-09, 383, 512 Imizu-maru (射水丸), 181, 512

Inazuma (電), 150

Indomitable (インドミタブル), 535, 561, 603, 650-51

Ise (伊勢), 59

Isokaze (磯風), 620

Isonami (磯波), 282, 298, 369, 410, 415, 587

Itsukushima (嚴島, 厳島), 60, 96, 98-99, 109, 111， 126, 159, 171, 181, 371, 380, 383, 393-94, 507， 513

Jacob van Heemskerck (ヒームスカーク), 650

Java (ジャバ, ジャワ), 238, 240, 242, 305, 314-17, 320, 322-25, 328, 405, 450, 461-62, 563

Jingei (迅鯨), 60

Jintsu (神通，神通)，60，84，106，109，150，152，159， 171-73, 215, 221-23, 232, 346, 353, 355, 382, 426, 431, 434-41, 443, 451-52, 501-03

John D. Edwards (エドワーズ), 243, 305, 326-28， 461,463 
John D. Ford (ジョン・D・フォード), 192-93, 315，

324-26, 328, 461, 463

Johor-maru (浄宝縷丸), 444

Jones $\rightarrow$ Paul Jones

Jupiter (ジュピター), 461-63

Kaga (加賀)，32，61，334-38，341，476，492，571， 601-02, 605, 626, 633, 657-58

Kagerō (陽炎), 330, 543, 601

Kagu-maru (香久丸), 128

Kako (加古), 59

Kamikawa-maru (神川丸, 神川丸), 60, 260, 262, 271， 274, 298, 345, 369, 374, 380, 383, 387-88, 390, 410-11, 413, 417, 420, 474, 498-99, 506, 508-10, 577

Kamikaze-maru (神風丸, 神風丸), 105

Kamitsu-maru (神津丸, 神津丸), 513

Kamogawa-maru (加茂川丸), 199，200，396, 515

Kamome (鷗, 鴎), 365, 513

Kanayamasan-maru (金耶摩山丸), 191

Kankō-maru (感興丸 [actually: 咸興丸]), 525

Kano-maru (鹿野丸), 127

Kari (雁), 582

Kashii (香椎), 38, 61, 263, 282-83, 298, 577, 582， 590,646

Kashima (鹿島), 60

Kasuga-maru (春日丸), 61

Kasuga-maru No. 2 (第二春日丸), 264

Katsuragi-maru (葛城丸), 151，155，166，215，229， 396

Kawakaze (江風), 126, 128, 184-85，188，354-55, 370, 372-73, 382, 392-93, 405, 410, 425-26, 431, 434-35, 437-38, 443, 446-47, 549

Keiyō-maru (慶洋丸), 398

Ken'yō-maru (健洋丸), 476-77, 605-06, 619

Kenryū-maru (乾隆丸), 513

Kent (ケント), 624, 626

Kiku-maru (菊丸), 96

Kimikawa-maru (君川丸), 60

Kimishima-maru (君島丸), 153，159，308-09，383， $593,595,597-98,600$
Kinai-maru (畿内丸), 151, 166, 248

King George V (キングジョージ5世), 603

Kinu (鬼怒), 61，273-74，283，442，444，513，592-93， 600

Kinugasa (衣笠), 59

Kinugasa-maru (衣笠丸), 583

Kinugawa-maru (鬼怒川丸), 269

Kirishima (霧島), 59, 476, 478-79

Kirishima-maru (霧島丸), 115, 215

Kiso (木曾, 木曽), 60

Kisogawa-maru (木曾川丸, 木曾川丸), 264, 572

Kitakami (北上), 59

Kiyosumi-maru (清澄丸, 清澄丸), 61

Kokuyō-maru (國洋丸，国洋丸), 605-06

Komaki-maru (小牧丸), 396, 516

Kong $\overline{0}$ (金剛), 59, 66, 72, 83, 476

Kortenaer (コルテノール), 305, 461-63, 563

Kōryū-maru (廣隆丸，広隆丸)，264，285，297， $572-73$

Kōshin-maru (興新丸), 151, 166

Kōshō-maru (江祥丸, 江祥丸), 582

Kōyō-maru (香洋丸), 376

Kōyō-maru No. 6 (第六高洋丸), 386

Kuma (球磨), 60, 96, 99, 367

Kumagawa-maru (球磨川丸), 128, 131, 140, 179-81, 189, 191, 193, 199, 592, 594-95, 598, 600

Kumano (熊野), 59, 260, 282, 288-90, 411-12, 414, $417-20,422-23,614,644,646$

Kunikawa-maru (國川丸，国川丸), 127, 396

Kunitsu-maru (國津丸, 国津丸), 128

Kureha-maru No.3 (第三呉羽丸), 96, 126

Kuretake-maru (呉竹丸), 128, 179, 189, 191, 193, 199

Kuroshio (黒潮), 150, 203, 205-06, 252-53, 496, 543

K-VII (潜水艦K-7), 563

K-VIII (潜水艦K-8), 563

K-IX (潜水艦K-9), 563

$K-X$ (潜水艦 $\mathrm{K}-10), 563$

$K-X I$ (潜水艦K-11), 563

K-XII (潜水艦K-12), 563

K-XIII (潜水艦K-13), 530, 563 
$K-X I V$ (潜水艦K-14), 192, 563

$K-X V I$ (潜水艦 $\mathrm{K}-16$ ), 563

K-XVIII (潜水艦K-18), 192, 563

$K-X I X$ (潜水艦K-19), 563

Kyōdō-maru No. 36 (第三十六共同丸), 99

Kyōei-maru No. 2 (第二共栄丸), 605-06

Kyokutō-maru (旭東丸), 476, 605

Langley (ラングレー), 459-60, 477, 534

Leander (レアンダー), 295, 631

Le Maire (レ・マイヤー), 487

Lexington (レキシントン), 211

Liverpool-maru (りばぷーる丸), 127, 179, 191, 426

London (ロンドン), 535, 603

Lyons-maru (りおん丸), 215, 516

Manazuru (眞鶴, 真鶴), 512

Marblehead (マーブルヘッド), 174, 192, 238, 240-44, 479, 481, 493-96, 563

Matsué-maru (松江丸), 249

Matsukaze (松風), 366, 418, 510, 527

Matsumoto-maru (松本丸), 518

Maya (摩耶), 59, 66, 72, 83, 214, 361, 371, 475, 493-94

Michishio (滿潮，満潮 ), 228, 251, 311, 318-20, $322-23,327-28,504,528,530$

Miike-maru (三池丸), 215, 224

Mikazuki (三日月), 59

Mikuma (三隈), 59, 260, 282, 289, 414-16, 418-19, 465-66, 468-70, 474, 614, 644

Minazuki (水無月), 366, 465, 510, 659

Minegumo (峯雲), 126, 128, 252, 434, 437-39, 443, $461,502,526,529$

Minesweeper No. 1 (第一号掃海艇), 297, 549

Minesweeper No. 2 (第二号掃海艇), 472, 531

Minesweeper No. 3 (第三号掃海艇), 297-98, 527

Minesweeper No. 4 (第四号掃海艇), 297, 527

Minesweeper No. 5 (第五号掃海艇), 295, 297, 418, $509,577,582$

Minesweeper No. 7 (第七号掃海艇), 227, 346, 355

Minesweeper No. 8 (第八号掃海艇), 227, 346, 355， 512
Minesweeper No. 9 (第九号掃海艇), 215-16, 223， $227,247,365,512,531$

Minesweeper No. 10 (第十号掃海艇), 549

Minesweeper No. 11 (第十一号掃海艇), 215-16, 223, 227-28, 232, 249, 354, 365, 504, 510, 512, 531

Minesweeper No. 12 (第十二号掃海艇), 227-28, 232, 247, 354, 365, 504, 510, 512, 531

Minesweeper No. 13 (第十三号掃海艇), 140-42, 525

Minesweeper No. 14 (第十四号掃海艇), 141, 525

Minesweeper No. 15 (第十五号掃海艇), 141, 189， 190,512

Minesweeper No. 16 (第十六号掃海艇), 141, 189， 512

Minesweeper No. 17 (第十七号掃海艇), 188

Minesweeper No. 18 (第十八号掃海艇), 188

Minesweeper No. 20 (第二十号掃海艇), 126, 371， $383,392-94,424,505,507,529$

Mizuho (瑞穂), 61, 84-85, 109, 161, 163, 165, 201， 204, 218, 229-31, 247, 249, 250-51, 256, 345-46, $348,351-52,354,365,373,383,395,426$, $428-29,458,499$, 500, 513, 645, 657, 659

Modjokerto (モッドヨカード), 477, 491, 496

Mogami (最上), 59，260，282，289，293，299，412， 414-18, 418-19, 465-66, 469, 471, 614, 644

Montevideo-maru (もんてびでお丸), 249

Murakumo (叢雲), 274, 282, 465, 467, 469, 508, 588 Murasame (村雨), 126, 128-29, 158, 367, 434, 501

Muroto (室戸), 52, 55, 58, 264

Mutsu (陸奥), 59

Myōken-maru (妙見丸), 525

Myōkō (妙高), 59, 109-10, 118, 150, 346, 347, 355， $360,380,405,410,425-26,434,436,438,440$, $442,444,445-46,448$

Myōkō-maru (妙高丸), 247, 371, 383, 385, 392, 443， 508,513

Nachi (那智), 59, 109-10, 253, 333, 382, 426, 432-34， $436-43,445-47,657$ 
Nagara (長 良)，60，96，109，150，153，158-59，

171-72, 201-04, 248-51, 254, 308-09, 313, 317, 319, 322-24, 380-81, 383, 504, 510, 518, 530, $592-94,600$

Nagato (長門), 31-32, 59

Nagatsuki (長月), 366, 465, 509-10

Naka (那珂)，60，84，106，109，126，128-29，137， 140-42, 146, 180-81, 188-92, 194, 248, 367, 371, 376, 383, 392-93, 424, 427, 432-34, 437-38, 440, $443,502-03,505,507,570,592,594,596-99,600$ Nagisan-maru (那岐山丸), 396, 515-16

Nan'a-maru (南阿丸), 128，179，187-88，194，198， $200,515,525$

Nankai-maru (南海丸，南海丸), 109, 151-52, 166, 248

Nanshin-maru No. 48 (第四十八南進丸), 386

Natori (名取 )，60，366，371，376，383-86，411， 413-17, 465-70, 474, 508-10, 513, 527, 592, 594, $596-97,599,600$

Natsugumo (夏雲) , 126, 128-29, 135, 139, 180, 501-02, 526

Natsushio (夏潮), 150, 203, 205-06, 251-54, 256, $346,530,541$

Nenohi (子ノ日), 202, 250, 313, 319

Nes $\rightarrow$ Van Nes

Nichiai-maru (日愛丸), 128

Nichiei-maru (日榮丸，日栄丸), 264, 614

Nichirō-maru (日朗丸), 605-06

Nichiȳu-maru (日祐丸), 506

Nippon-maru (日本丸), 476, 605-06, 619

Nisshin (日進), 657

Nisshun-maru (日春丸), 396, 516

Nittei-maru (日帝丸), 179, 191

Nojima-maru (野島丸), 572-73, 582

Nowaki (野分), 475, 494, 496

O-XIX (潜水艦O-19), 563

Oboro (朧), 51, 54, 61, 330

Oha-maru (おは丸), 151, 159

$\bar{O} i$ (大井), 59

Okinoshima (沖島), 60
Okitsu-maru (興津丸), 199, 322, 515-16

Ōshio (大潮), 311-14, 316-20, 322-23, 325-28, 504， 530,543

Otowa-maru (音羽丸), 285, 295，572-73，582

Oyashio (親潮), 150-51, 166, 205-06, 252-53, 496

Parigi (パリギ), 487

Parrott (バラット,パロット), 174, 192-93, 326-28

Patrol Boat No. 1 (第一哨戒艇), 96，150-51，249， $346,354-55,513,526,549$

Patrol Boat No. 2 (第二哨戒艇)，96，150-51，249， $346,354-55,513,526$

Patrol Boat No. 3 (第三哨戒艇), 298

Patrol Boat No. 15 (第十五哨戒艇), 190

Patrol Boat No. 20 (第二十哨戒艇), 443

Patrol Boat No. 34 (第三十四哨戒艇), 96, 150, 218， $229,231,250,256,367,380,383,395,427-28$, $592-94,597,600$

Patrol Boat No. 35 (第三十五哨戒艇)，96，132，367， $371,380,382-83,387,420-21$

Patrol Boat No. 36 (第三十六哨戒艇), 96, 126, 128-29, 180, 188-89, 190, 252, 310, 346, 365, 371-72, 380, 383, 592-93, 597, 600

Patrol Boat No. 37 (第三十七哨戒艇), 96, 126, 128， 180, 189-91, 380, 383, 394, 525, 549

Patrol Boat No. 38 (第三十八哨戒艇)，96，126， 128-29, 143, 180, 189-90, 231, 250, 256, 367, $371,380,383,395,427-28,513$

Patrol Boat No. 39 (第三十九哨戒艇)，96，126，150， 218, 229, 231, 250-51, 256, 346, 351, 373, 380, $383,395,513$

Paul Jones (ポール・ジョーンズ), 192-93, 243, 461,463

Pecos (ペコス), 243, 477, 491, 496

Perch (バーチ,パーチ), 503, 530

Permit (バーミット,パーミット), 174, 563

Perth (パース), 450, 461-62, 464, 470-71, 530

Peterel (バトレル), 79

Pickerel (ピックレル), 563

Piet Hein (ピート・ハイン), 243, 315, 324-26, 328, 563 
Pike (バイク,パイク), 174

Pillsbury (ピルスベリー), 243, 326-27, 493

Pope (ポープ), 174, 192-93，324-26, 328，445, 461-63

Preston $\rightarrow$ William B. Preston

Prince of Wales (プリンス・オブ・ウェルズ), 81, 561,650

Prins van Oranje (プリンス・ファン・オラーニ エ,プリンス・ファン・オランヂ), 138, 143， 145,149

Rakutō-maru (洛東丸), 128, 322, 515-16

Ramillies (ラミリーズ), 535, 603, 650

Reiyō-maru (麗洋丸), 376

Renown (レナウン), 281

Repulse (レパルス), 81, 414, 561, 650

Resolution (レゾリューション), 650

Revenge (リベンジ), 535, 561, 603, 650

Ro-33 (呂号第三十三潜水艦), 300, 483-84

Ro-34 (呂号第三十四潜水艦)，273，299，300-01， 483-84

Rokkō-maru No. 12 (第十二鹿港丸), 386

Royal Sovereign (ロイアルソベリン,ロイヤルソ ベレーン), 535, 603, 650

Rumoi-maru (留萠丸, 留萌丸), 262, 283, 285, 295， $572-73,582$

Ruyter $\rightarrow$ De Ruyter

Ryōyo-maru (良洋丸), 215-16

Ryūjō (龍驤), 61, 73, 125, 260, 262, 272, 282-83, 285, 292-93, 299, 370, 473, 641-43, 645

Ryūjō-maru (龍城丸), 472

S-37 (潜水艦S-37), 256

Sagami-maru (相模丸), 310-13, 317, 319, 371, 516

Sagara-maru (相良丸)，260，262-63，272，573，577， $579,581-82,587-89,589,591-92$

Sagi (䉆), 659

Sakura-maru (佐倉丸), 376, 472

Samidare (五月雨), 126, 128, 184, 194, 367, 434

San Clemente-maru (さんくれめんて丸), 249, 251

Santos-maru (さんとす丸), 60, 486-87
Sanuki-maru (讃岐丸), 85, 96, 126，131-33，135，144， 181, 195-97, 199, 247, 256, 310-11, 322, 345-46, 364-65. 371-72, 383, 394-95, 428-29, 499, 500, 506,531

San'yō-maru (山陽丸), 60, 83-84, 96, 126, 131-33， 135, 144, 181, 195-96, 198, 345, 364, 371, 380, 382-83, 387-90, 420, 474, 498-99, 506, 508, 510. 582-83, 588-89, 591-92

Sasako-maru (笹子丸)，311-14，355，371，394， $425-27,502,516$

Satsuki (泉月), 366, 465, 508

Sazanami (漣), 229, 434, 443

Seian-maru (西安丸), 506, 512-13

Seiha-maru (靜波丸, 静波丸), 264, 598

Sendai (川内), 59, 260, 267-69, 282-86, 289, 297, $376,572,587,642,646$

Senkō-maru (千光丸 [appears as 千栄丸 in the Japanese text]), 109

Settsu (攝津), 522

Shark (シャーク), 530

Shikinami (敷波)，272，282，293，415，417，419， $465-69,471-72,474,510,531,590$

Shimushu (占守), 38, 61，260，262，264，267，283， 296, 298, 303, 408, 549, 577-78, 582, 590

Shinkoku-maru [A] (新國丸, 新国丸), 396

Shinkoku-maru [B] (神國丸，神国丸), 605-06

Shinkō-maru [A] (新興丸), 512

Shinkō-maru [B] (神功丸, 神功丸), 151

Shinsei-maru No. 18 (第十八眞盛丸, 第十八真盛丸), 396

Shiokaze (汐風), 73, 272, 293, 527, 614

Shirakumo (白雲), 282, 465, 467, 474, 508, 615, 644

Shiranui (不知火), 543

Shirataka (白鷹), 153, 159, 172, 364, 366, 371, 383， $385-86,443,468,512$

Shiratsuyu (白露), 190

Shirayuki (白雪), 268, 282-87, 297, 465, 468, 588

Shōkaku (翔鶴 ), 32，61，609，611，620-22，625， 628-29, 631-32

Shōka-maru (彰化丸), 151, 166 
Shōnan-maru No. 7 (第七昭南丸), 387

Shōnan-maru No.12 (第十二昭南丸), 387

Shōo (祥凰, 祥凰), 657

Shunsei-maru (春生丸 [actually: 春晴丸]), 590

Sianter (シアンター), 486

Sloet van de Beele (スロエト・ヴァン・ベレル), 299, 305

Soerabaja (スラバヤ), 563

Sōryū (蒼龍), 32, 61, 95, 101, 116, 201, 219, 334, 336, 338-39, 476, 478-79, 492, 496, 608-09, 611, 620-21, 623, 625-26, 628-29, 631-32

Stewart (スチュワート), 174, 243, 326-28

Stronghold (ストロングホールド), 493-94, 496

Submarine Chaser No. 1 (第一号駆潜艇), 221， 308, 323, 504, 512, 549

Submarine Chaser No. 2 (第二号駆潜艇), 216, 256, 512, 528

Submarine Chaser No. 3 (第三号駆潜艇), 249, 512,528

Submarine Chaser No. 4 (第四号駆潜艇), 370, $393,426,512,529$

Submarine Chaser No. 5 (第五号駆潜艇), 512

Submarine Chaser No. 6 (第六号駆潜艇), 512

Submarine Chaser No. 7 (第七号駆潜艇)，285， 297,573

Submarine Chaser No. 8 (第八号駆潜艇), 285, 297-98

Submarine Chaser No. 9 (第九号駆潜艇), 267-69， 283

Submarine Chaser No. 10 (第十号駆潜艇), 128， 139

Submarine Chaser No. 11 (第十一号駆潜艇), 128， 505

Submarine Chaser No. 12 (第十二号駆潜艇), 128， 139, 188, 190

Submarine Chaser No. 13 (第十三号駆潜艇), 512

Submarine Chaser No. 14 (第十四号駆潜艇)，249， 251, 512, 528

Submarine Chaser No. 15 (第十五号駆潜艇), 512
Submarine Chaser No. 16 (第十六号駆潜艇)，425， 512

Submarine Chaser No. 17 (第十七号駆潜艇), 512

Submarine Chaser No. 18 (第十八号駆潜艇), 512

Submarine Chaser No. 21 (第二十一号駆潜艇), 323

Submarine Chaser No. 51 (第五十一号駆潜艇), 549

Sumanoura-maru (須磨浦丸), 179, 181, 189-91, 193， 199,525

Sumatra (スマトラ), 563

Sussex (スーザン), 535, 603

Suwa-maru (諏訪丸), 376

Suzukaze (涼風), 126, 128, 251, 371, 530, 645

Suzuya (鈴谷), 59, 260, 282, 285, 289, 419, 614, 644

Swordfish (スオードフィッシュ), 563，622，625， 627,651

Tachikaze (太刀風), 396

Taiei-maru No. 2 (第二大榮丸, 第二大栄丸), 386

Taigei (大鯨), 60

Taikō-maru (大興丸), 513

Tajima-maru (但馬丸), 269, 297

Takao (高雄), 59, 371, 475, 493-94, 496

Tama (多摩), 60

Tatsugami-maru (辰神丸，辰神丸)，128，187-89， 191, 193, 198-99, 200, 515, 525

Tatsuharu-maru (辰春丸), 512

Tatsumiya-maru (辰宮丸), 55, 60，99，264，273-74， 512

Tatsuno-maru (龍野丸), 472

Tatsuta (龍田), 60

Teiryū-maru (帝龍丸), 128, 179, 190-91

Teiyō-maru (帝洋丸), 376, 476

Tenjin-maru (天神丸, 天神丸), 386

Tenryū (天龍), 60

Ten'yō-maru (天洋丸), 60

Tenzan-maru (天山丸), 396, 516

Tōei-maru [A] (東榮丸, 東栄丸), 476, 493，605-06， 635

Tōei-maru [B] (藤影丸), 179, 189, 191, 193 
Tokitsukaze (時津風), 150，166，205-06，434，502， 504, 506, 526

Tokiwa (常盤), 60

Tokushima-maru (徳島丸), 444, 505

Tomozuru (友鶴), 355, 371, 425-27, 502, 512-13

Tonegawa-maru (利根川丸), 376

Toné (利根), 59, 334, 337, 339, 476, 478-79, 481, 622-25, 629-31

Toyosaka-maru (とよさか丸), 309, 322

Tromp (トロンプ), 239-40, 243, 305, 317-18, 320, $326-28,563$

Tsubame (燕), 365, 513

Tsugaru (津輕, 津軽), 60

Tsukushi (筑紫), 249, 254, 308-09, 323, 383, 462, 504, 510, 513

Tsuruga-maru (敦賀丸), 127，179，188，191-93

Tsurumi (鶴見), 264，298，369，387，410，413，508， 510

Umikaze (海風, 海風), 126, 128, 186, 194, 392

Urakaze (浦風), 491, 496

Uranami (浦波), 282, 410, 415

Ushio (潮), 356, 434, 443, 525, 550

Vampire (バンパイヤー), 651-52

Van Ghent (ファンゲント), 243, 305, 563

Van Nes (ヴァンネス), 299, 305, 563

Wakaba (若葉), 202, 250, 319, 526

Wakataka (若鷹), 131, 181, 371, 380, 383, 392-93， $424,432,443,512$

Wake (ウェーク), 79

Warspite (ウォースパイト), 535-36, 603, 650-51

Washingtonian (ワシントニア), 648

Whipple (ホイップル,ホイップル), 174, 243, 305

William B. Preston (プレストン), 80, 563

Witte de With (ヴィテ・デ・ウィット), 461-63, 563

Yae-maru (八重丸), 590

Yaeyama (八重山), 60, 99

Yaeyama-maru [actually: Yae-maru] (八重山丸[八 重丸]), 590

Yamafuku-maru (山福丸, 山福丸), 215

Yamagiri-maru (山霧丸),
Yamagumo (山雲), 126, 128-29, 180, 252-53, 360， $371,380,383,392-93,443,505-06$

Yamakaze (山風), 126, 128，136，138，142-43，145， 312 , 354-55, 367, 371-73, 405, 410, 425-26, 431, 434-35, 437-38, 443, 446-48, 526

Yamashimo-maru (山霜丸), 249

Yamashiro (山城), 59

Yamato (大和), 551, 655

Yamaura-maru (山浦丸), 215

Yasukuni-maru (靖國丸, 靖国丸), 60

Yübari (夕張), 60

Yūbari-maru (夕張丸), 200, 396, 515-16

Yüdachi (夕立), 126, 128, 195, 434, 503, 526

Yūgiri (夕霧), 283, 572-73, 615, 639, 641, 643

Yūkaze (夕風), 59

Yukikaze (雪風), 109, 150, 203, 205-06, 434, 502， 526,543

Yura (由良)，61，86，260，262，267，282-86，289， 297-98, 368-69, 376, 380, 383-86, 406, 410-11, 413-16, 418-19, 509-10, 577, 579, 582, 587, 614, $641,643,645-46$

Zen'yō-maru (善洋丸), 215

Zuihō (瑞鳳), 59, 517

Zuikaku (瑞 鶴 ), 32, 61，609，611，620-22，625， 628-29, 631-32 



\section{Index of Place Names}

See also Editor's Note. The katakana spellings given here are not official spellings, but the spellings as they are found in the original Japanese text.

Aceh (アチエ, アチエ), 17, 40, 566

Adang Bay (アダン湾, アタン湾), 187, 257

Addu Atoll (アッヅ環礁, アッヅ島), 615, 650-52

Aden (アデン), 620, 649

Aeng Batoe Batoe (アエンバトバト), 249, 252

Africa (アフリカ, 阿弗利加), 536, 652

Aikaluin, Cape (レラカ岬), 353

Aipelo (written alphabetically in the Japanese text

$$
\text { [アイペロ]), } 344
$$

Airmadidi (アデルマデデ), 152, 160, 166

Akyab (アキャブ), 535, 615, 618-19, 639, 640-41, 652

Alang, Cape, Battery (アロング岬，砲台), 217, 227

Alas (アラス), 24, 313

Albania (アルバニア), 558

Aleutians, Aleutian Islands (アリューシャン, 群島), 36, 45, 50, 655-56, 658

Alor Island (アロル島), 335, 347, 352

Alor Setar (アロールスター), 18, 273

Alor Strait (アロール水道, 海峡)，347-48，354， 428

Amahusu (アマホウソウ), 227, 228

Amal Shore, River (アマル海岸, 河), 129, 136-38, 146

Amami Ōshima (奄美大島), 63, 66

Ambelau Island (アンベラウ島), 222

Ambon, 〜ssland, Bay (アンボン, 島, 〜湾), 19, 22, 31, 36, 39, 45, 48, 55, 64, 68, 70, 88, 89, 90-93, 96-101, 103-05, 107-09, 111-12, 114-16, 118-19, 122-24, 130, 150, 154, 158, 167, 169, 171-74, 200-02, 204, 208, 212-24, 226-33, 236, 244, 246-51, 253-54, 334-35, 340, 342-43, 345,
347-51, 359-62, 364-65, 379, 381, 396, 405-07, 484, 511-13, 516, 525-26, 531, 563-64, 582, $584-85$

Amurang (アムラン), 165-66, 175

Anambas Islands (アナンバス), 20, 120, 125, 204, 263-65, 268, 270-72, 282-83, 292, 298-99, 301, 361, 373, 386-400, 406, 410-11, 413, 420, 483, $499,572-73$

Andaman Islands, Sea, Strait (アンダマン, 群 島，～海， 海峡)，23，45，71，123，499，510-11， 567-69, 570, 576, 579, 581-88, 590, 605, 612, $614-17,639,641,645,652$

Angaur (アンガウル), 340

Anjungan (マンジョガン), 275

Annie Florence (Le Bouef Reef) (アネスフロレン ㅈ), 425

Apar Besar (アバルベサル湾), 257

Aparri (アパリ), 25, 29, 39, 52, 63, 82

Api Channel (アピ水道), 413

Apo [Reef] Channel (アポ水道), 392

Arafura Sea (アラフラ海), 16, 20, 71, 234, 331, 340-41, 368, 406, 484, 485, 617

Arakan Mountains (アラカン山脈), 16

Arends Island [Pulau Keramian] (アレンゾ, アレ ンズ島), 240, 313, 425

Arnemuiden Bank [Beting Raja] (アルネルイデン ), 419

Aru Bank, (waterway of ) (アルーバンク), 187, 254, 425-26

Aru Islands (アル諸島), 334, 340, 406, 484

Arus, Cape (アラス岬), 166 
Asia (アジア), 2, 4, 6, 14, 16, 32, 79, 371, 454, 513, $523,534,536,553,571,583,604,620,632,635$, $649,653-54$

Atalanta Point (アタランタ岬), 586

Atlantic Ocean (大西洋), 561-62

Australia (豪州, 濠州, オーストラリア), 17, 18, 23, $25,45,47,48,66,71,82,88,90,95,97,100$, 102-03, 105, 119, 121-24, 168, 192, 207, 211, $213,323,330-33,336,340,343,357,362-63$, 396-97, 401, 406, 482, 484, 486-87, 497, 511, 514-15, 534-36, 537, 556, 559, 563, 567, 603, $605,612,617,653,654-58,660$

Awarawar, Cape (アワルアワル角), 428, 437, 499, 500

Awuran, Cape (アウラン), 488

Ayer Tawar (アエルタワル), 579

Babar Island (ババル島), 332

Babau (バパウ), 351-52

Babi Island (off Bantam Bay) (バビ島), 465-68, 470-71, 508-09

Babi Island (near Simuelue Island west of Sumatra) (バビエ島), 570, 605, 613, 618

Babo (バボ), 219

Badung Strait (バダン海峡), 317, 328

Baguala Bay (バゴアラ湾), 220-21, 227-28

Baguio (バギオ), 80

Baha [Baya] (バハ), 395

Balabac Strait (バラバック海峡), 16

Balaraja (パララジャ,バララジャ), 488

Bali Ｉsland, Ｓtrait (バリ，＼cjkstart島， 海峡), 16, 19, 24， 69, 93, 96, 100-01, 103, 122-24, 207, 209-10, 213, 241-42, 246, 253-54, 256-57, 301, 305-14, 316-18, 320-25, 327-29, 331, 333, 344-45, 354, 360, 362-63, 366, 368, 371-73, 379, 381, 396-98, 400, 403, 405-06, 409, 425-29, 442, 459-60, 462, 475, 477-78, 481, 483-84, 487, 493-94, 496, 498, 506, 514, 516-17, 528, 530, 616-17, 638

Balige (バリゲ), 580

Balikpapan (バリクパパン,バリックパパン), 17, $19,21,22,25,30,36,39,45,48,55,64,65,71$, 75, 88, 89, 91-93, 96-97, 101, 103, 107-09,
111-12, 114-15, 118-19, 122-23, 133-34, 146, 149, 174, 177-88, 191-96, 198-99, 200, 204, 207-08, 210, 213, 233-38, 240-41, 244-48, 250, 252-54, 257, 305, 307, 309, 310, 312-13, 317, 321-22, 329-30, 342, 345, 358-60, 364-65, 367, 370-73, 380, 393-94, 398, 400, 402-04, 406-07, 409, 420, 425-26, 428, 443, 484, 500, 503, 505, 507, 511-12, 514, 515, 517, 525, 529, 531, 563-64

Ban Don (バンドン), 39, 63

Bancar (ポンジョール), 391

Banda, 〜Sea, Ｉslands (バンダ, 〜海，諸島), 16, 21, 22, 95, 96, 102, 122, 174, 204, 218-20, 222, 230-31, 234-35, 253, 331, 335, 340, 359, 361, 363, 380-81, 406, 428, 484, 612

Banda Anchorage (バンダ泊地), 243

Bandung (バンドン), 19, 40, 71, 104, 329, 368, 397-99, 401, 403, 406, 413, 419, 424, 488-90, 497-98, 501

Bangka, anchorage (north of Menado) (バンカ, ＼cjkstart島，＼cjkstart泊地), 21，98，111，150-53，158-59，163， 165-66, 171-73, 201-02, 206, 213, 215-18, 220-23, 229, 232, 246-47, 249-51, 254, 264, 361, $364,428,528$

Bangka, Island (near Sumatra) (バンカ, 〜島), 39, 68, 71, 90, 92, 93, 112, 116-17, 124-25, 208, 210, 213, 258, 261-62, 266, 271, 280-83, 286, 291-93, 298-99, 301, 303-05, 329, 331, 359, 360, 362, 366, 368-69, 371, 397, 402, 413, 420, 484, 492, $568,579,615$

Bangka Strait (Sumatra) (バンカ海峡, 水道), 264, 267, 269, 280, 283-86, 289-91, 293-94, 297, 402, $413,415,520,524$

Bangkok (バンコク，磐谷)，16,20，80-81，119，535， 568, 583-86, 588-91, 615-18, 639, 640

Banjarmasin (バンジェルマシン), 17, 25, 30-31, 39, 55, 64-65, 69, 71, 75, 89, 92-93, 96-97, 99, 101, 103, 108, 112-12, 122-23, 149, 177, 179, 182, 184, 187, 196, 198, 205, 207-11, 219, 240, 243, 246, 254, 256-57, 301, 305-07, 310, 313, $329,358-60,370-71,380,394,399,406,425-28$, $443,445,460,484,502-04,507,515,612,615$ 
Bantam, Bay, anchorage [Banten] (バンタム, パンタム, 湾, 〜泊地), 361, 374-75, 378-79, 381, 384, 386-87, 390, 398, 401, 413, 418, 421, $465,488,498-99,500,508,510,527,570,590$, 593-94, 597-98, 600, 619

Banyuwangi (バニュワンギ), 322, 429

Bassein (バセイン), 639

Bataan Peninsula (バタン半島 バタアン半島), 116, 209, 361, 539, 583, 617, 660

Batam Island (バタン島), 574

Batan Island (バタン島), 39, 52, 63, 79, 82

Batang, Cape (バタン岬), 527,

Batang Island (バタン島), 528

Batavia [Jakarta] (バ夕ビア,バタビヤ,バダビア), 16, 17, 19, 21, 36, 40, 45, 48, 71,96-97, 101, 104, 111-12, 247, 260, 279, 281, 287, 290-91, 299, $301,305,322-23,329,335,344,354,359,364$, $366,368-69,374-75,377,379-82,386-87$, 397-99, 401-03, 405-06, 408-13, 415-24, 462, $465,473,475,483-84,488,504,510,515,529$, 531, 585, 593, 612-13, 615-18, 650

Bathurst (バザースト島), 334, 340

Batu Ampar (パトアンバル, パトアンパル), 178, 195

Batu, Cape (バッー岬), 97, 137-38, 184

Batu Dua (パットドア), 138

Batu Pahat (バッパハト,バトパハ), 121, 259, 574-75

Batugong (バッゴング), 228

Batumerah, Cape (バレメラー岬), 228

Bau (ブソウ), 275

Baubau (バパウ), 240

Baun (バウン), 353

Bawean Island (バウエアン島), 240, 313-14, 321, 403, 425, 427-29, 431, 442-44, 458, 461-62, 499, 501-04, 525-26

Belang (ベラン, ベーラン), 166, 175

Belawan (ベラワン), 19, 580, 582

Belgium (白[ベルギー]), 3
Belitung Island (ビリトン島), 280, 299, 329, 413， 527

Bendo, Cape (ペント岬), 391-92

Bengal, Bay of (ベンガル湾), 16, 569-71, 583-84， 587-88, 592, 603-06, 612-15, 617-18, 624, 638, 640-42, 646, 650, 653

Bengkayang (ベンカヤン, ペンカヤン), 19, 120, 274,275

Bengkulu (ベンクレン), 303, 304

Berhara Strait (ベルハラ海峡), 285, 294, 297

Berikat, Cape (ベリカト角), 288

Besar [Penida] Island (ベサル島, ヌサベサル島), 313, 316, 318, 327, 353

Binongko Island (ビノンコ), 348, 351

Bintan (ビンタン島), 574

Bireuën (ビルエン), 580

Bismarck , Archipelago (ビスマルク,ビスマー ク，諸島)，36，62，656

Blangkejeren (ブランゲジュラン), 580

Blimbing (ブリンピン), 497

Blora (プロラ), 488-89

Bobos Point (ボボス角), 510

Bohoi (ボホイ岬), 166

Bojonegoro (between Babad and Cepu) (ポジョ ネゴロ), 391, 489

Bombay (ボンベイ，孟買), 48, 536, 603-04, 616, 620, 648-49

Bone, Gulf of (ボニ, ポニ湾), 254, 428, 484

Boompjes Island [Pulau Biawak] (ブームゼス島, ブームジェス島), 418, 419

Borang Island (ブルン島), 296

Borneo (ボルネオ), 8, 11, 16-22, 24, 28, 30-31, 36， 52, 66-67, 92, 112, 115, 118, 120, 122, 124, 133, $144,182,184,208,213,254,261,263-64,271$, $275,301,329,377,380,397,402,406,413,423$, 445, 484, 511, 513, 515, 517, 540, 561, 612, 615

Botok, Cape (ポトク岬), 230

Britain (英国, 英)，1，4-6，9，13-14，16，26，32-34， $39,42-43,45-46,48,357$, 534-39, 551, 555-61, 565, 603-04, 649-50, 653-54, 660-61 
British Borneo (英領ボルネオ)，2，16，19，23-24， 28 , 30, 33, 35, 38-42, 44, 46, 52, 65, 70, 74, 81, 100,540

British Concession (英租界), 2

British Malaya (英領マレー, 英領馬來), 16, 23, 25, 28, 25-36, 39-40, 42, 44, 52, 54, 70-71, 511, 557

Brooklyn (ブルックリン), 244

Broome (ブルーム), 25, 497, 534

Brunei Bay (ブルネー湾), 20

Buitenzorg [Bogor] (ボイテンゾルグ,バイテンゾ ルグ,ボイデンゾルグ,バイデンゾルグ), 19, 304, 368, 377, 398, 403, 413, 419, 424, 488

Bula (ブル, ブラ), 219

Bulujowo (ブルージャク), 391

Bulunrue Island (ブランルウェ), 256, 428

Bunaken Island(ブナケンレ), 166

Bunyu (ブニュー島), 139, 143

Burma (ビルマ,緬甸)，2，4，15-16，22，24，28，31， 35-37, 41-42, 44, 65, 70-71, 75, 81, 91, 117, 123, 498, 510-11, 535, 539, 559, 561, 565-70, 576, 583-84, 588, 590, 592, 603-04, 612, 615, 617, $619,653-55,658,660$

Buru, Island (ブル島, ブルウ島)，16，215，220， 222-23, 230-32, 340, 406, 428, 484, 612

Buton, Island, Cape , Strait, Channel (ブトン, プトン島, 〜海峡， 水道), 203，222，230，240，249， 254,428

Cagayan (カガヤン), 18

Calcutta (カルカッ夕)，23，569，603，613-15， 618-19, 638-41, 652

Cam Ranh, Bay (カムラン，湾)，20，63-64， 86-87, 90, 92, 94, 97-99, 100, 103-05, 108, 111, 116-22, 125, 177, 198, 205, 208-10, 247, 258, 261-69, 271-76, 281-83, 293, 299, 300-01, 342, 345,359, 360-62, 364, 366-67, 369-72, 374-75, 381-82, 384, 386-87, 400, 406, 410, 420, 483, $510,567,646$

Camp Murphy (キャンプマーシー), 23

Camplong (チャムプロン), 353
Cap Saint Jacques (サンジャック), 298-99, 410, $423-24,575,588,590$

Cape Town (ケープタウン), 649

Car Nicobar Island (カーニコバル島), 645

Caroline(s) (カロリン), 554

Carpentaria, Gulf of (カーペンタリア湾), 484

Cavite (キャビテ), 23, 553

Cebu (セブ), 15, 18

Celebes [Sulawesi] Island, $\sim$ Front, $\sim$ Sea (セレベ ス， 島，（線，＼cjkstart海)，16，17，19，21-22，28，30， 35-36, 44, 66, 71, 74, 88, 91-92, 96-97, 99, 112, $114,118,121,133,144,151,154,158,160$, 163-65, 167, 201, 222, 230-31, 240, 246-47, 251-52, 254, 330, 340, 342, 359, 361, 363, 365, 373, 380-81, 395, 402, 406, 425, 427-29, 478, $484,511,513,516,529,563,612$

Ceningan Island (チェニンガン島), 316, 325

Central Pacific (Marshall, Gilbert, Marianas, Carolines) (中部太平洋), 584

Cepu (チェプー), 391, 489

Ceram [Seram] Island, Sea (セラム, 〜島, 〜海, ラム海)，16，22，112，167，173，201，215，219， 220-22, 229-30, 253, 335, 340, 406, 484, 513

Ceylon (セイロン, セイロン島, セーロン島, 錫蘭), 23, 121, 244, 332, 336, 362, 482, 485, 492, 511, $536,559,561,569-71,583,592,601-06,612$, $615,618-19,624,627,631-33,635,638,640-42$, 647, 649-54, 660, 662

Chagos Archipelago (チャゴス), 604, 616, 649 Chefoo (チーフー [煙台市]), 555

Chiang Mai (チェンマイ), 535

Chichijima [Peel Island] (父島), 51，53，56，58，61

China (支那，支)，1-6，12，14，20，26，34-36，38，40， $42,44,46,48,52,65,74,112,537,555-59$, $565-66,654-55$

Chittagong (チッタゴン), 615, 618

Chongqing (重慶), 6, 14, 537-39

Christmas Island (クリスマス島), 112, 329, 331， 333, 401, 406, 460. 477-78, 480, 492, 496, 498, 
513, 567-68, 570, 583, 592-98, 600, 604, 612-13, 616-17, 619, 638-39

Cilacap, (チラチャップ), 17, 21, 240, 244, 323, 329, 370, 378, 398-99, 401, 413, 425, 460, 462, 475, 477-78, 482-83, 485, 489, 490-94, 497-98, 500, 527,534

Cililitan (チリリタン), 281, 377, 413, 419, 422

Citarum River (チタルム河), 398

Ciujung River (チジュン河, チュジュン河), 398, 488

Clark Field (クラークフィールド), 23，616-17

Cochin (コチン), 652

Cocos Islands [Keeling Islands] (ココス島), 71， 331-33, 336, 482, 486-87, 498, 604, 613, 616, 638

Colombo (コロンボ, 古倫母), 48, 536, 571, 603-04， 606-07, 615-16, 618-22, 625-27, 640-42, 647-52, 663

Comorin, Cape of (コモリン), 649

Coral Sea (珊瑚海), 660

Coringa (コリンガ), 643

Corregidor, Island (コレヒドール，＼cjkstart島)，546， $583,617,660$

Cotabato (コタバト), 18

Czechoslovakia (チェッコスロバキア), 558

Daliao (ダリアオ), 117

Damar, Islands (ダマル島, 諸島), 230, 340

Darwin (ダーウィン), 25, 48, 72, 90, 105, 122-23， 174, 212-13,

Datu, Cape (ダトゥ岬), 275

Davao (ダバオ), 15, 18, 19, 25, 29-31, 36, 39, 45, $52,63,70-71,74-75,80,82,84-88,91-93,95$, 97-98, 100-15, 117-18, 121-23, 128, 130-33, $135,144,151-55,158-60,164-65,171-72,174$, 177, 183-84, 196, 201-02, 205-06, 214-16, 218, 220-22, 232-33, 236, 246, 250, 253, 340, 360-61, 363-64, 366-67, 370, 375, 380, 394, 406-07, 410, 484-85, 513, 515, 517-18, 530, 612

Dayu (ダュ), 187, 254, 329

Delmonte (デルモンテ), 18

Denmark (デンマーク), 3
Denpasar (デンパッサル), 241, 254, 307, 310-11, $313,322,324,329,617$

Dili (デリー), 18, 19, 25, 124, 342-45, 347-49, 351, 355-57, 366, 372, 406, 425-26, 428, 484, 564

Dobo (ドボ), 335

Dondo Bay (ドンドン湾), 373, 395, 427-28

Donggang (東港), 84-86, 102

Dunkirk (ダンケルク), 3, 5

Durban (ダーバン), 536, 603, 649

Dutch Borneo [Kalimantan] (蘭領ボルネオ), 16, $35,44,74,370,511$

Dutch East Indies [Indonesia] (蘭印, 蘭領印度, 東 印度諸島，東印度)，1-17，19-21，23-25，27-31， 33 , 35, 37-42, 44, 47-48, 52, 54-55, 66-71, 75, 79, 82, 87-91, 94-96, 100-06, 109-16, 118, 122-23, 137, 143, 158, 177, 179, 195, 199, 200, 204-05, 207-08, 212-14, 220, 232, 242-43, 248, $298,331-32,335,343-44,359,362,366,371$, $396,407,482,489,490,500,504,506,510-11$, 513-16, 518, 524, 530, 533-34, 536, 541, 560, 562-64, 569, 583-84, 650, 661

Dutch Timor (蘭領チモール), 17, 123

Duyoh (ルジョン), 275

Eight Degree Channel (八度水道), 648

Elphinstone (エルヒンストン), 587

Ema (エマ), 228

Endau (エンダウ，エンドウ), 120-21, 124, 204, 272,361

[Equatorial] Pacific Islands (南洋群島, 南洋, 南洋 諸島), 34-36, 38, 43, 47, 373, 654-55

Eretan (エレタン), 488

Eri (エリ), 227-28

Europe (欧州), 2-4, 536, 555, 557-58, 560-61

Fak Fak (ファクファク), 335

Far East (極東), 1-3, 31, 70, 554-63, 650, 661

Fatucama (パトエカマ岬), 356

Fiji (フィジー,フィージー), 45, 50, 654

Finland (フィンランド), 2

Flagstaff Point (フラッグスタフ岬), 
Flores， Sea (フローレス，フロレス，島， 海), 16, 22, 24, 102, 112, 230, 240, 245, 310, 335, 340, 380-81, 406, 428, 478, 484, 612

Flying Fish Cove (フライング・フィッシュ・カ ーブ), 594

Foul Point (ファウル ポイント), 607

Fourcroy, Cape (ワークロイ岬), 339, 340-41

France, (フランス, 仏国, 佛), 1, 3, 5, 555, 557-58

Freemantle (フリーマントル), 332, 401, 482, 486-87

French Indochina (佛印，佛領印度シナ，佛領印度 支那)，4-6，15，18，20，26，29，35，44，48，52，65， $67-68,79,80,112,117,121,301,361,400,409$, $423,575,588,615$

Fushun (撫順), 11

Galala (ガラン), 228

Galbokka Point (in the Japanese text mistakenly written alphabetically as Gabbekku Point [ガ ベックポイント]), 607

Galela (カレラ), 173

Galle, Pt. de (ガツレ岬), 622

Gangga Island (ガンガ島), 166

Gaoxiong (高雄 ), 84-86, 92, 97, 102, 104，106, 111-12, 114, 116, 134, 169, 182-83, 236, 256, 360-62, 364, 366, 375, 381-84, 407, 503, 505

Gaspar Strait, 〜sland (ガスパル海峡，島)，112， 287-88, 290, 293, 295, 299, 301, 305, 323, 328, $402,413,483,579$

Gelumbang (ゲルンバン), 299, 303-04, 396, 400, 404, 406, 408-09, 413, 421-23, 498, 517, 520, 583,585

Gemas (ゲマス), 120-21

Genting, Cape (ジェンティン岬, ジェンティング 岬), 286, 297

Germany (ドイツ, 独), 2-4, 32, 536-39, 554-58， $562,604,653-54$

Gilbert Archipelago (ギルバート群島), 656

Girian (ギリアン,ギリヤン), 151, 166, 222

Gōhoku (Area to the north of Australia) (豪北), $66,102,119,121,362-63,397,511,563,617$
Gorontalo (ゴロンタロ), 88, 158, 230, 428

Great Natuna Island (グレイトナット島, グレイ トナッツ,グレートナツナ島), 283, 410, 413

Great Paternoster Islands [Kepulauan Tengah] ( パタノスター諸島), 313

Greyhound Strait (グレイハウンド海峡), 249, 254,428

Grissee [Gresik] (グリッセ), 489

Groot-Banda (フロートバンダ島), 219

Guam (Island) (グァム,グアム,ガム), 51, 62, 80, 91

Guangdong (広東, 廣東), 63, 65, 119

Gunung Cangkol (ゴンチャンコール, コンジャ ンコール), 130, 138

Hahajima (母島), 601

Hainan Island (海南島), 52

Halmahera Island, Sea (ハルマヘラ島, 海), 16, $115,167,169,173,219,222,230,333,335,340$, $350,406,428,484,513$

Halong (Seaplane Base) (ハロング, ロハング(水 上基地)), 217，221，226

Hashirajima (柱島), 646

Hatalai (ハ夕ラ(街道)), 217, 228

Hatu (ハトエ), 228

Havelock Island (ヘイブロック), 581, 586-87

Hawaii, (Hawaiian Islands) (ハワイ，布哇, 群島), $3,13,27,32$, 35, 49, 50-51, 62, 79, 80, 88, 116, $208,211,295,359,485,534,555,633,655,656$, 661

Highland 385 (385高地), 351

Hitulama, anchorage (ヒトラマ, 泊地), 214, 216-17, 223-25, 227-28

Holland $\rightarrow$ Netherlands

Hong Kong， Island (香港，島), 28, 36-38, 52， 62, 64，68, 72-75, 87, 91-92, 104, 111-12, $116-17,214,342,358,361,548,556,559$

Honshū (本州), 571, 656, 658

Howland Island (ハウランド), 51

Hukurila (ホウコウリラ), 228

Hunut (ホエノート), 224, 228 
Hutanopan (フタノパン), 580

Hutumuri (ホトモリ), 228

Iba (イバ), 80

Idi (イヂ), 577-80

Iloilo (イロイロ), 15, 18

India (インド, 印度), 16, 23, 71, 331-32, 362, 482, $485,535-37,556,565,567,570-71,588,604-05$, $615,618,639,643,650,653-55,660$

Indian Ocean (印度洋，インド洋)，16-17，20，28， 35-36, 47-48, 71, 91, 102-03, 121, 301, 304, 323, 329-32, 336, 359, 361-62, 377, 379, 401, 451, 475, 477, 482, 484-85, 487, 498, 510, 515, 518, $520,530,535-37,539,554,556,559,565,567$, $569,570-71,575,581,584-85,588,592,601$, $603,605,612,615,617,638,640,646-47,649$, $653-58$

Indochina (印度支那, 印度シナ, 半島), 14-16, 20， $25,39,358$

Indramayu Bay, Cape 〜 (インドラマユ湾, 角), 423

Inland Sea of Japan (瀬戸内海)，49，72，116，278， 453,656

Ipoh (イポー), 81, 121, 259, 273

Irrawaddy River (イラワジ河), 16, 582

Italy (イタリア，伊，伊国)，2，4，32，536-39，554-58， 653-54

Iwakuni (岩國), 69-70, 75, 89, 92-93, 100, 103, 127， 307,359

Jabung, Cape (ヤボン角), 284

[Jagui]babang (パパン), 275

Jamaica (ジャマイカ), 561

Jambi (ジャンビー, ジャムビー, ジャンピー), 19, 22,304

Jang, Cape (ジャン角), 283-85, 289, 411, 413, 420 Jati Point (ジャテ岬), 431

Java [Jawa] (ジャワ，爪哇，島，ジャバ), 4, 5, 15-17, 19-22, 24-25, 28, 30-31, 35-36, 40, 42, $44,47,55,57,64,68,71,76,89,90-93,95-96$, 99, 100, 103-04, 112-13, 115,121-26, 169, 174, 198, 204, 207-13, 219, 233-34, 237, 240, 243, 245-46, 248, 254, 256, 259, 261, 264, 271-73,
279, 281, 298-99, 300-01, 304-08, 310-11, 313, $322,324,329-33,336,345,354-55,357-75$, 377-79, 381-84, 387, 391, 393-98, 400-11, 413, $419,421,423-26,428-29,443,473,475,477-78$, 481-86, 488-91, 493-94, 496-98, 500-01, 506, 508, 510-13, 515, 517-18, 520, 524-25, 531, $533-35,540,560,562-64,567,569,583,585$, $593,600-01,604,612,615,617,638,653,662$ Java Sea (ジャワ海, ジャバ海), 16, 21, 30, 88, 95, $103,112,234,242,248,264,290,301,313,329$, 370, 387, 396, 401, 406, 408, 410-11, 413, 421, 423-26, 428, 475, 484, 499, 500, 507, 509, 515, $517-18,612,615$

[Jene]berang River (ベーラン河), 249, 252, 255 Jesselton (Kota Kinabalu) (ゼッセルトン), 19 Jiayi (嘉義), 85-86, 102

Jimbaran (ジンバラン,ヂンバラン), 240, 242, 333, 406

Johnston Atoll (ジョンストン), 655

Johor(e), Strait (ジョホール， 水道), 557，559， $572-74$

Johor Bahru (ジョホールバル), 121, 258, 574

Jolo (ホロ，島), 18-19, 25, 29, 30-31, 39, 52, 63, 65, 68, 71, 74-75, 82, 84-87, 91-92, 95, 98, 100-02, 107-15, 118, 130-31, 133-34, 140, 158, 177, 182-84, 186, 205-06, 233-34, 236, 248, 253-54, $256,307,310,312,345,361-62,364-65,367$, 370-72, 375, 380-82, 391-92, 394-95, 400, 406-07, 424, 427-28, 516-17

Jombang (ジョンバン), 489

Jugra River (ジュクラ河, ジュグラ河), 574-75

Juwata (ジュワタ), 130, 136, 138, 145, 148

Kabaena Island (カバエナ), 230

Kabanjahe (カバンチャイ), 580

Kadola Island (カドラ), 230

Kahang (カハン), 125, 259, 274, 278-79, 290, 292, $302,402,409,423$

Kai Islands (カイ諸島), 340, 406, 484

Kait, Cape (カイト角, カイトミ角), 415, 418-19

Kaitetu (カイテト), 228 
Kakas (カカス)，19，152，154，160-61，165-66，173， 175-76, 222

Kakinada (コカナダ), 618, 643, 652

Kalabahi (カラバヒ), 428

Kalambau Island (カランバウ島), 425

Kaledupa Island (カレッパ島), 203, 428

Kalijati (カリジャチィ,カリヂャチイ,カリヂャ 千), 368, 377, 398, 403, 413, 419, 424, 488-89, $490,498,500$

Kallang (カラン), 18

Kambang Island (カムバン島), 353

Kambing Island (カンビン島, カムビン島), 347， 356

Kangean, 〜slands (カンゲアン， 島), 234, 239-40, 242-43, 311-13, 319, 324, 329, 410, $425-26,428,438,442,526$

Kapal, Mt. (キャペル山), 228

Karangdawa (カランドヴオ), 499, 500

Karimata Island, S Strait (カリマタ島, 海峡), 112, 279-80, 293, 301, 370, 411, 413, 417-18, 420, $461,500,503,505-07,510,520,524$

Karimunjawa Islands (カリムンジャワ,クリモン ジャワ), 413, 425, 431, 502, 506

Karungan River, Battery (カロンガン川, 砲台), 130, 137-38, 140, 145-46

Kasiruta Island (カシルタ島), 115

Kau (カウ), 173

Kawangkoan (カワンコワン,カワンコアン), 165-66, 176

Kecil (ケシル), 353

Kedah (ケダー地区), 80

Kelang Island, Bay, anchorage (ケラン島, 湾 , 泊地), 229-31, 250

Kelian, Cape, lighthouse of (ケリアン岬テリア ン灯台), 287, 297

Kema (ケマ), 151-55, 158-60, 165-66, 173-75, 206, $236,250,348,407$

Kemayoran (ケマジョラン,カマヨラン), 377, 422

Kendari (ケンダリー), 19, 25, 30-31, 39, 55, 63-64, 71, 88-89, 91-92, 96-99, 101, 107-09, 111-12,
118-19, 122-23, 130, 152, 165, 167-69, 171-72, 174, 200-04, 212-16, 218-22, 229-31, 233-54, $256,308,310-11,336,340,342,345-49,354$, 358-59, 361, 364-65, 367, 381, 396, 400, 406-07, $409,428,484,487,497,500,516-17,525-26$, $530,533-34,571,585,602,616-17,632,647,649$ Keppel Harbour (ケッペル港), 572-74, 578

Kera Island (ケラ島), 353

Kertosono (ケルトソノ), 489

Ketil (ケチル), 259, 273

Kilindini (キリンジニ), 653

Kinabohutan Island (キカバフタン島), 166

Kisarazu (木更津), 53, 56, 58, 516

Klabat, Mt. (カラバット山), 166

Kluang (クルアン), 121, 259, 280, 300, 302

Klumpang Bay (キムパン湾), 257

Kobe (神戸), 86

Kolbano airfield (コルバノ飛行場), 343, 345

Kolonodale (コロノダレ), 254

Kota Bharu (Malay Peninsula) (コタバル), 18, 23, 25, 63, 70, 79-81, 119, 259, 280-81, 301, 557

Kotabaru (Laut Island near Borneo) (コタバル), $187,240,254,257,313,425-26,428$

Kragan (クラガン), 361, 374-75, 379, 382, 391-92, 394, 398-99, 401, 425, 431, 433, 443-44, 458, $488,500-02,504-07,526$

Krawang (クラワン), 415, 419, 490

Krokong (クロコン), 275

Kuala Lumpur (クアラルンプール), 121, 259, 301

Kuala Simpang (クワラシンパン), 580

Kuantan (クワンタン), 119, 124-25, 259, 270, 274-79, 281, 290, 292, 301, 402-03, 423, 498, 579

Kuching (クチン), 16,19, 20, 25, 30-31, 39, 55, 63, $70-71,75,81,86,100,112,120,122,124-25$, 133, 208, 259, 270, 274-81, 290-92, 301, 358, $368,396,400,402-03,406,408-09,413,421-23$, $520,583-85,615$

Kupang (クーパン), 17, 19, 25, 39, 48, 55, 64, 68, 71, 88-93, 95-101, 103-04, 107-12, 116, 123-24, 169, 192, 200, 204, 208, 210, 232, 240, 245, 248, 
253-54, 256, 310, 330, 333, 335-36, 342-44, $346-49,351-57,359,362-63,366,372,379,381$, 395-96, 406, 425-26, 475, 483-84, 487, 497, 516, 563-64, 585, 612-13, 616-17

Kure (只), 34, 85, 116, 606, 646

Kurong, Cape (クロン岬), 353

Kutacane (クタチャネ), 580

Kutaraja (クタラジャ), 577-80, 589, 591

Kutei River (クテイ河), 21

Kyūshū (九州), 18, 656

Labuha (ラブハ), 196, 170, 173

Labuhan Amuk (ラブアン湾), 318, 327

Labuhanruku (ラブハンルク), 577-80

Laccadive (ラカデブ), 604, 616

Lae (ラエ), 660

Laha (ラハ ), 217, 219, 221, 223-27, 229, 231-32, 249

Lahat (ラハト), 304

Lamon Bay (ラモン, レモン湾), 39, 63, 82, 84-86, 206

Lamongan (ラモンガン), 489

Lampung Bay (ランプン湾, ランバング湾), 266, 508

Langkawi Island (ランカウイ島), 589, 591

Langoan (ランゴアン, ラゴワン), 154-55, 160-62, 165-66, 169, 175-76

Laoag (ラオアグ), 25, 39, 52, 63

Lashio (ラシオ), 535

Lata (west of Suakodo) (ラタ), 224

Lata (on the inner port of Ambon) (ラタ), 228

Lateri (ラテリ), 228

Laurel Reef [Batu Buntunga] (ラウレルリーフ, ラ ウエルリーフ), 254, 313, 425

Laurot Islands (ラウロット諸島), 313

Laut Island, Strait (ラウト島, 海峡), 187, 234, 240, 254, 257, 313, 425-26, 428

Leahari (リハリ), 228

Ledo (レド), 91, 101, 112, 120, 122, 124, 208-09, $259,270,273-78,280,282-83,292,301,377$, 406,413
Leeuwin, Cape (リーウイン岬), 486

Legaspi (レガスピー)，15，25，39，52，63，74，82， 84-86, 93, 98, 102, 107-09, 112-14, 206, 217, 381

Lehaga Island (レハカ), 166

Lembang (レンバン), 489-90

Lembeh Island (レンバ島), 166

Lembongan Island (レンボンガン島), 316-18, 325-27

Lepar Island (レパル島), 387-90, 420

Leuwiliang (ルイリアン), 488

Lewolein, Cape (レワリン岬), 351

Liat Island (リアト島), 287, 295

Limau (リマウ), 266

Lingayen, Ｇulf (リンガエン，湾), 39，63，82, 84-87, 98, 112, 116, 198, 209, 248, 307, 310, $361-64,367,375,382,391-92,400$

Lingga Island (リンガ島), 285, 420

Lingkas (リンカス), 127, 129-30, 135-38, 147-49, 177

Little Andaman (リトル・アンダマン), 641

Little Paternoster Islands [Balabalagan Islands] (小パタノスタ諸島), 187

Lokon, Mt. (ロコン山), 166

Lomblen (ロンブレン), 230, 351-52

Lombok, I Island, Strait (ロンボック, 〜島, 〜海 峡), 16, 24, 240,242, 254, 265, 272-73, 299, 312-14, 316-17, 319-20, 322-23, 328-29, 396, 405-06, 425, 428-29, 450, 452, 482-84, 496, 516, 528

Longiram (ロンギラム), 187

Lubuklinggau (ルブクリンガウ), 304

Lucipara Island (ルシパラ島), 222,230

Lunyuk (ルニュク), 240

Luzon (ルソン島), 15, 23-25, 28-29, 66, 69, 82, 84, 87,92

Madiun (マジュン), 234, 235, 237, 240, 321, 425

Madras [Chennai] (マドラス ), 570, 603, 605, 613-14, 618, 652 
Madura, Island, Strait, Sea (マヅラ, 〜島, 海 峡, 海), 234-35, 237, 240, 243, 248, 301, 313, 321, 329, 425, 428-29, 484, 506-07, 528

Magelang (マゲラン), 489

Magnaga Bay (マグナガ湾), 106-07, 150, 158, 206

Magong (馬公), 63, 66, 72, 84, 86-87, 94, 97， 105， 110, 119, 600, 633

Magwe (マグウェー), 535

Mai Island (マイ島), 230

Maikuru [? Nai Kliu? Naibonat?] (マイクル), 348 Maja (マジヤ), 488

Makassar, port of ～(マカッサル市， 港), 17, 19, 21, 25, 30-31, 36, 39, 45, 48, 55, 64, 71, 89, 92-93, 96-99, 100-101, 107-08, 111, 118, 122-23, 149, 168, 182, 187, 201, 204, 207-08, 210, 213, 220, 231-32, 236, 240-41, 243, 245-56, 305-13, 317, 319-24, 328, 331, 342, 345, 354-56, 358-62, 365, 376, 370-73, 379-81, 394, 406-07, 409-10, 425-28, 441-42, 475, 484, 493, 500, 504, 507-08, 510-12, 516, 527, 529-30, 541, 563-64, 592-94, 600, 612

Makassar Strait, ～Front (マカッサル海峡, 〜線), 21, 24, 95-97, 112, 114, 187, 243, 246, 248, 252, 254, 256, 308, 311, 313, 342, 354, 359, 365, 370-71, 373, 380, 382, 393-94, 404-06, 425, 428, 475, 484, 530, 612

Malacca (マラッカ), 20, 121, 574-75, 589, 591, 646 Malacca Strait (マラッカ海峡), 17, 20, 40, 47-48, 57, 71, 91, 264, 296, 332, 362, 482, 485, 518, 566, 568, 571-75, 578-80, 588, 604-05, 633, 641, 645, 652

Malalag, Bay (マララグ, 湾), 19, 97-98, 106-07, 109-10, 115, 127-28, 158-59, 161, 206, 410, 426

Malang (マラン), 115, 174, 204, 234-35, 237, 240, 313, 322, 329, 368, 398, 402-03, 406, 409, 429-30, 490, 497

Malay Peninsula (マレー半島，馬来半島), 10, 17-18, 20, 28-29, 40, 42, 71, 79-81, 91, 113, 117, 120-22, 125, 209, 264, 273, 280, 368, 557, 566, $574,580,586$
Malaya (馬来, マレー, 馬來), 16, 18, 20, 23-31, 33, 35, 38-42, 44, 47-48, 52, 54-55, 63-64, 67, 70-71, 75, 79-82, 91, 94-95, 100, 112-13, 261-62, 271, 276-77, 281, 298, 300-01, 359, 361, 363, $369,406,515,536,557-61,567,570,579,585$, $615,650,661-62$

Maldives Islands (マルデブ, マルディブ諸島, マ ルダイブ諸島), 615, 652

Mali, Cape (マリー岬), 348, 351, 353

Mamua, Cape (アモア岬), 228

Manchu(ria) (満州, 満), 2, 6, 11-12

Mandalay (マンダレー), 535, 566, 570

Mandar, Cape, Bay (マンダル岬, 〜湾), 254, 313， 428

Manggar River (マンガル河), 195

Mangkalihat (マンカリハット岬), 184, 187, 428

Mangoli Strait (マンゴリ海峡), $\rightarrow$ (Sula) Mangoli

Mangrove Bay (マングローブ湾), 641

Manila, Bay (マニラ, 馬尼刺, 湾), 15, 19, 28-29, $36,39,45,64,68,82,86-87,92,95,98-99,104$, 111-12, 116, 122, 207-11, 236, 307, 358, 360-61, 374, 382, 391, 400, 503, 554, 658

Manipa Island, Strait (マニパ島, マニバ海峡), 222, 230, 332

Manui Island (マヌイ島), 203, 222, 525

Maospati (マオスバチ, マオスパチ), 429

Mapur (マポール島), 573, 574

Mariana Islands (マリアナ諸島), 554, 640

Mariso (マリソ灯台), 255

Maromaho Island (マロマホ), 347

Maros (マロス飛行場), 249, 252-53

Marshall Islands (マーシャル諸島)，80，123，212， $534,554,584,656$

Martapura (Borneo) (マルタプラ), 187, 254, 257, 428

Martapura (Sumatra) (マルタプラ), 266, 303-04

Masalembu Islands (マサレンボ島), 313, 425 Masalembu Besar (マサレンボベサル), 240 Masalembu Kecil (マサレンボケチル), 240

Matasiri Island (マタリシ島), 425 
Mayu Island (マユ島), 173

Medan (メダン), 17, 19, 40, 71, 300, 566, 580

Mediterranean (地中海), 536, 557-58, 625

Meduran (マズラン), 391

Melak (メラク), 187, 198

Melville (メルヴィル島), 334, 337, 340

Mempawah (マンバワ), 275

Menado [Manado] (メナド), 19, 21, 30-31, 36, 39, $45,55,63,71,82,88-89,91-99,101,107-112$, 114-15, 118-19, 123, 130-31, 149-55, 158-61, 163-75, 183, 186, 200, 201, 205-06, 208, 216, 218, 222, 230-31, 233, 236, 250, 340, 342, 349, 359-61, 381, 396, 406-07, 428, 484, 514, 516, $518,525-26,530,563-64$

Menado Tua (メナドッア), 166

Mengacu, Battery, Channel (メンガチュ, 砲 台, 水道), 127, 130, 136-38, 140, 144

Menjalin (メンジャリン), 275

Mentok (ムントク), 19, 125, 258-61, 263-72, 280, 284-87, 293, 295, 297-300, 302, 304, 377, 387, $396,406,408,413,421-22,498,572-73,583,585$

Menulun Island (メヌルン,メヌロン島), 138, 140

Merak (メラク), 361, 374, 378, 381, 384, 398, 413， $419,465,488,498,500,508,527$

Meratus Mountains (メラトス山脈), 257

Mergui (メルギー), 571, 588-89, 591-92, 614, 619， $638,640,652$

Mersing (メルシン), 121

Metinaro (メチナロ), 344

Meulaboh (メウラボウ), 580

Middle East (中東), 535, 603

Midway Island (ミッドウェー), 45, 49, 567, 626, 653-54, 656, 658

Mikawa Bay (三河湾), 601

Minahasa (ミナハサ州),175

Minami Iwo Jima ((South) Iwo Jima) (南硫黄島), 601

Minami-Torishima [Marcus Island] (南鳥島), 571， 601
Mindanao (ミンダナオ), 15, 18-19, 94, 144, 161， 222, 340, 406

Mingaladon (ミンガラドン), 640

Miri (ミリ), 16, 19, 20, 22, 25, 30-31, 39, 63, 70-71, $75,81,100,112,114,133,301$

Mojokerto (モジョケルト), 489

Molucca Channel (モルッカ水道), 222

Molucca Sea (モルッカ海), 16, 21, 112, 172-73, 214-15, 220-21, 230, 340, 406, 428, 484, 612

Molucca Strait (モルッカ海峡), 230, 332-33

Moluccas, Islands, Spice Islands (モルッカ諸島, 〜群島), 16, 18, 24, 35, 44, 95, 511

Mombasa (モンバサ), 536, 603

Montrado (モンテラド), 274-75

Moresses Island [Pulau Moresa] (モラセス島), 425

Morotai Island (モロタイ島), 173, 340

Motael, Cape (マウツベキ岬), 356

Moulmein (モールメン), 565-66

Muna Island (ムナ島), 203, 240, 428

Musi River (ムシ河), 125, 261-62, 265-67, 269, 283-86, 288-89, 295-98, 303-04, 573

Naibonak (ゲイボナ,ゲイボ), 353-54

Nakhon (ナコン), 29, 63, 80

Nama, Cape (ナマ岬), 228

Namlea (ナンレア), 220, 229-31

Nangka [Besar] Island (ナンカ島), 297

Natuna Islands (ナッツ[島嶼]), 20, 283, 410, 413

Near and Middle East (中近東), 535, 603

Near East (近東), 23, 535, 603-04

Netherlands (オランダ, 蘭, 和蘭), 3-6, 9, 13-14, 26, 32-34, 42-43, 46, 48, 324, 538, 559, 560, 562

New Britain (ニューブリテン), 45, 357, 660

New Caledonia (ニューカレドニヤ), 654

New Guinea (ニューギニア,ニューギニヤ，ニュ ーギネヤ)，8，16-17，20，45，71，167，219-20， 333 , 335, 340, 349, 368, 396, 406, 484, 512-13, $583,593,656-58,660$

New York (ニューヨーク), 244 
New Zealand (ニュージーランド, 新西蘭), 23， $556,559,656$

Ngabang (ナバング), 275

Nichols Field (ニコラスフィールド), 23

Nicobar Islands (ニコバル諸島)，71，123，567，579， $586,615,640-41,645,652$

Nomonhan (ノモンハン), 2

Nona, Gunung (ノナ山, ノマ山), 227-28

North Africa (北阿), 603-04

North Channel (ノースチャンネル), 487

Northwatcher [Noordwachter, Pulau Jaga Utara, Pulau Sabira] (ノースウォッチャー)，416-17， 419,421

Norway (ノルウェー), 3

Nunggul, Cape (ヌンヨル岬), 286

Nunrima (ヌンレウ), 353

Nusanive, Cape (ヌサンバ岬), 221

Obi (Mayor) Island (オビメイヤー島), 221-22, 230

Obi Strait, Islands (オビ海峡，諸島)，173，222， 230

Oebelo (ロバウ), 353

Oecina, Cape (オイシナ岬), 353

Oekabiti (カピチ), 353

Oesapa Besar (ウサパベサル), 353

Oesau (デサウ), 352-54

Ogasawara Islands [Bonin Islands] (小笠原諸島， 群島), 36

Oilalus (アルス), 348, 353

Olongapo (オロンガポ), 23

Ombai Strait (オンバイ海峡), 332, 356, 405, 475, 477-78, 486, 608-09, 638

Pacific Islands (太平洋諸島), 34-36, 38, 43, 47, 51， $53,76,373,654-55$

Pacific, Pacific Ocean (太平洋), 20, 27, 35-38, 79, 192, 199, 201, 222, 242-43, 324, 340, 406, 435, 453, 460-61, 484, 536, 539, 554-56, 559, 577, $584,618,649,653-55$

Padamarang Island (パダマラン島), 428

Padang (パダン), 20, 580
Padang Sidempuan(パダンシジンパン), 580

Pakiputan Strait (パキプタン水道), 161, 174

Palau (パラオ), 24, 52, 63-68, 72, 84-87, 91, 93-94, 102, 104-09, 117, 119, 123, 205-06, 212, 218, 331-33, 335, 340, 345, 360-61, 371-73, 401, 406, $486-87,492,518,571,606,612$

Palawan Island (パラワン島), 15

Palembang (パレンバン), 8, 16-17, 19, 21-22, 25, 39, 71, 90, 92-93, 101, 103, 112, 116-17, 125, $204,208,210,213,258-62,264-66,269-73,281$, 284-87, 293-96, 299, 300-05, 329, 331-33, $359-60,362,366,368-69,371,373,377-78$, 400-01, 403-04, 406, 408, 413, 420-21, 424, 482, 484, 486, 500, 517, 568, 573, 615

Palk Bay, Ｓtrait (パルク海湾, ＼cjkstart湾，～海峡), 613, 618-19, 638

Palmyra Atoll (パルミラ島), 655

Pamekasan (パメカサン), 240

Pamukan [Bay] (バムカン), 257

Pamusian (ペムシャン, ペンシャム, パモシャン), $129,138,148$

Panay (パネー島), 15

Pangkalanbrandan (パンカランブランタン), 580

Pangkalpinang (バンカルピナン), 304

Panjang Island (パンジャン島), 466-67, 472, 508

Pantai Timur (パンタイチムール), 323

Pantar (バンタル), 230

Paracel Islands (西沙群島), 20

Parepare (パラパラ海岸), 256

Paris (パリ), 3

Pasirian (パリシアン, パリシァン), 430

Paso (near Ambon) (パソ), 217, 226-28

Paso (near Lake Tondano) (パソ), 165-66, 175-76 Pasuruan (パスルアン), 329

Pata anchorage (バ夕 泊地), 375, 395, 428

Patrol (パトロール), 361, 374, 381, 387-88, 390, 398, 412-14, 418-21, 298-99, 506, 508-09, 585

Pattani (パタニ), 39, 63, 79-80, 557

Pearl Harbor (真珠湾, 真珠港), 50, 79, 80

Pebelokan (ペベロカン島), 509 
Pegu (ペグー), 566

Pejantan Island (ペジャンタン, ペシャンタン), 420-22

Pekanbaru (パカンバル), 19, 300

Peleliu (ペリリュー), 85, 102, 406-07

Peleng Island, Channel (ペレン島， 水道), 230， 254

Pemangkat (パマンカット), 274-75

Penang (ペナン，彼南), 18, 20, 23, 36, 45, 91-92, 94, 103-04, 121, 263, 265, 361, 401, 487, 498, 559, $567-68,576-83,585-92,615,645-48$

Penfui (プトン, ブトン), 348, 353, 355

Penghu Islands [Pescadores] (澎湖島), 63

Petokol, Cape (ペトコーア岬), 503

Philippines (フィリピン，比島，菲律賓)，1，15-16， 18-22, 24-31, 33, 35-42, 44, 46-49, 52, 54, 64, 66-71, 75, 79-80, 82-84, 87-88, 93, 95, 98-99, $100,107,110,112-15,117-18,121,143,167$, 205, 214, 217, 307, 358-59, 361, 514, 539, $554-56,562,617,658,660-62$

Phnom Penh (プノンペン), 301

Phú Quốc Island (フコク島), 80

Phuket (プケト), 589, 591

Piapi Reef (ピアピリーフ), 109

Piru Bay (ピル湾), 222, 230-31, 250

Pitt Passage (ビット水道), 230

Pluti (プルチ), 353

Poland (ポーランド), 2, 3

Pontang, Cape (ポンタン角, ボンタン角), 419, 421

Pontianak (ポンチャナック), 19, 120, 275-75, 413

Port Blair (ポートブレア,ボーバリア), 583, 585-89, 591-92, 614-18, 638-39, 641-42, 645, 652

Port Cornwallis, Cornwallis (ポートコンウェル， コンウォーリス), 581, 587

Port Darwin (ポートダーウィン，ポートダービ ン ), 25, 48, 72, 90, 105, 122-23, 174, 212-13, 220, 244, 248, 310, 319, 330-37, 339-41, 347, $349,351,357,361-62,371-73,401,406,425$,
$431,478,482,484-85,497,531,563,601,612$, 617,660

Port Moresby (ポートモレスビー), 633, 656-58, 660

Portugal (ポルトガル, 葡), 17, 123, 343

Portuguese Bay (ボルトギース湾, ポリトギュー ス湾), 228-29

Portuguese Timor (葡領チモール, ポルトガル領 チモール), 18, 20, 123, 342-43, 347-48

Postiljon Islands [Kepulauan Sabalana] (ポステ ルジョン諸島), 313

Prabumulih (プラブムリ), 304

Probolinggo (プロポリンゴ), 377

Puisan, Cape (プイサン岬), 166

Puolo Condore (プロコンドル諸島)，120，268， $283,372-73$

Purwokerto (プルオケルト), 489

Puting, Cape (プチン角), 425, 428, 458, 506

Rabaul (ラバウル, ラボール), 36, 45, 51, 91, 116, 211-12, 357, 373, 516, 534, 660

Rangoon (ラングーン ラングン、蘭貢), 16, 48, 81 , 336, 535, 539, 565-66, 568, 570, 576, 582， $588-92,613,615,618,639-40,652,660$

Ratahan (フタハン), 166

Reo (レオ), 245

Riouw Strait [Selat Riau] (リオ海峡), 294

Roi (ルオット), 80

Romang Island (ロマン, ロマング島), 230, 347

Ross Island (ロス島), 581, 586-88

Roti Island, Strait (ロチ島, 海峡), 353-54

Rumahtiga (ルーマチガ), 228

Rupat Island (ラパト島), 574

Rutung (ローテン), 214, 216-17, 223-24, 226-28

Sabang Island, Bay (サバン島, ＼cjkstart湾), 19-20, 40, 71, 566, 576-81, 585-86, 589, 591, 613, 615-18, $641,643,645$

Sadau Island (サウド島), 138

Saigon (サイゴン，西貢)，20，69-70，90，94，104， 112, 116, 263, 265, 274, 277-81, 301, 374, 397, $410,498,503,505,565,585,590,615$ 
Saipan (サイパン島), 80, 656

Sakala Island (セカラ島), 313

Sakhalin (樺太), 8, 11

Salabangka, Channel (サラバンガ島， 水道)， $218,222,230$

Salamaua (サラモア), 660

Saleh River (サレ河), 261, 266-67, 269, 285-86, 303

Salween River (サルウィン河), 566

Samal Island (サマール島), 106-07

Samarinda (サマリンダ), 21, 103, 115，187，254， 373,428

Sambas (サンパス), 274-75

Sambergelap Island (サンラゲラップ島), 425

Samboja (スンボジャ), 187, 195

Samoa (サモア), 45, 50-51, 654

Samosir Island (サモシリ島), 580

San Agustin, Cape (サンオーガスチン岬), 107

Sanga Sanga (サンガサンガ), 17, 22, 187, 540

Sanggau (サンゴウ), 274-75

Sangihe Islands (サンギ島, サンギへ島), 173, 222

Sangkulirang (サンクリラン), 187

Sanur, anchorage (サヌール, 泊地), 307, 309， 312-14, 316-17, 319, 322, 325-27

Sanya (三亜), 63-65, 67, 72, 74, 102, 112, 646

Sapanjang Island (セバジャン, セバヂャン, セバ ンジャン島), 240, 313

Sape Strait (セープ海, 海峡), 24, 313

Sapunang (サプヌン河), 426

Sarangani Bay, 〜slands (サランガニ湾, ～諸島), 107, 144

Sarawak, principality of , (サラワク, 王国), 16, 20

Sasebo (佐世保), 34, 85, 107, 110, 365, 410, 426, $438,516,552,571,590,602,646$

Savu Island (サブ島), 245, 332-33

Sawu Sea (サウ海), 484, 612

Saya Island (サヤ島), 284-85

Seba (セバ), 245

Sebadu (セバドウ), 275

Sebuku Island (near Thwartway) (セグク島), 508
Sebuku Island (near Laut Island, Borneo) (セブ島), 254

Sedan (セダン), 391

Selatan, Cape (セラタン角, セランタン角), 240, 313, 354-55, 425, 427-29

Selayar, Island, Strait (サレーエル, サレエル, ＼cjkstart島， 海峡), 231, 240, 249-51, 254, 428

Seletar (セレター) ) 18, 449, 570, 573, 575, 590, 619， 641

Semangka Bay (スマンカ湾), 266

Semarang (スマラン, セマラン), 301, 323, 329, 391, 406, 425, 430, 461, 489, 615

Semau, Island, Channel, Strait (セマウ, 〜島, ～海峡， 水道，七モウ海峡)，348，353，355，526， 585,617

Sembawang (センバワン), 18

Serang (セラン), 398

Seri (セリ), 228

Seria (セリヤ), 8, 75

Sermata Islands (セルマタ諸島), 230

Shan Plateau (シャン高原), 16

Shanghai (上海), 79-80, 555

Sharks Bay (シャークス湾), 486-87, 534

Siam, Gulf of, (Thailand, Gulf of) (シャム湾), 625

Sibbalds Bank (ジバルヅバンク), 425

Sibolga (シボルカ), 580

Sibutu Passage (シブツ水道), 132

Sidas (シダス), 275

Sigli (シグリ), 580

Siladen (シラデン), 166

Siluas (シリアス), 275

Singapore, S Strait (シンガポール, 島, 新嘉坡, 昭 南, 昭南島， ～海峡)，4，16，18，20，23，28-30， 35-36, 39, 40-41, 44-45, 47-48, 65, 67, 71, 79, 90-91, 93, 95, 112, 258, 264, 276, 279-80, 282-83, 285, 287, 290-91, 296, 301-02, 330-31, $362,368,371,406,413,484,499,500,505,507$, 509-10, 518, 520, 524, 548, 555-59, 563, 566-68, $570-79,581-82,585,587-92,600,606,615,619$, $645-49,659$ 
Singaraja (シンガラジャ), 311, 313, 329

Singkawang (シンカワン), 274-75, 411, 413

Singkep Island (シンケップ島), 283, 293

Singora (Thailand) (シンゴラ), 20, 29, 39, 63, 79-81, 94, 263, 265, 270, 557

Slim (スリム), 121

Smith Point (スミスポイント), 594-95, 597

Snake Island (スネーク島), 586

Solomon Islands (ソロモン, 群島), 656-57, 660

Sorong (ソロン), 55, 88, 219, 340, 406, 484

South Africa (南阿, 南アフリカ), 331, 603, 656

South China Sea (南シナ海, 南支那海) 10, 16, 18， 20-21, 66, 88, 95, 103, 112, 301, 396, 518, 604, 615,633

South Pacific (南太平洋), 38, 584, 654

Southwest Islands (南西諸島), 52, 64

Soviet Union, Russia (ソ, 蘇, ソ連, 露), 1, 2, 3, 6, $26,48,53,536-39,554,561-62$

Spratly Islands (新南群島), 20, 301

St. Nicholas Point [Tanjung Pujut] (ニコラス岬， セントニコラス角), 418-19, 465-67，469，498， 508-09

Staring Bay [Teluk Wawosungu] (スターリング

湾 ), 222, 230，248-51，253-54，300，322-23， $331-33,340-41,345,347,351,354,365,371-73$, $401,403,410,426,428,475-78,482-87,492$, $494,496,571,601-02,604,606,608,617,619$, 638,646

Stewart Sound (ステワート・サウンド), 581, 587

Suakodo (ソワコード), 224-25, 228

Subang (スバン), 488

Sudetenland (ズデーテン), 557

Sudimara Island (セズマラ島), 286

Sula Islands (スラ島, スラ諸島), 169, 173, 221-22, 229-30, 249, 340, 428, 484

(Sula) Mangoli (スラマンゴリ島, 海峡), 222， 229-30

(Sula) Sanana (スラサナナ), 230

Sulamu, Cape (スラム岬), 353

Sulu Archipelago (スール諸島, 列島), 15, 19
Sulu Sea (スール海), 112, 132, 144，154，158, 484， 612

Sumatra (スマトラ), 8, 16-17, 19-22, 24, 28, 30-31, 35-36, 38, 42, 44, 57, 64, 68, 71, 91-93, 103, 112, 120-25, 258-59, 261, 273, 278, 280, 286, 301-02, $304,307,323,329-30,332-33,358-60,363$, 377, 379, 396-97, 402, 406, 408, 413, 423, 482, 484-85, 510-11, 517, 520, 534, 540, 563-64, $566-68,570,576,578-81,583,585-86,604,612$, 615

Sumba Island, Strait (スンバ島, 海峡), 16, 240, 245, 406, 428, 475, 478, 484, 612, 638

Sumbawa (Island) (スンバワ島), 16, 240, 242, 254， 313, 329, 406, 428, 475, 478, 484, 496

Sumber River (サンバニ河), 195

Sunda Islands ([Lesser] Sunda Islands) (スンダ列 島， 諸島)，16，21-22，308，396，482，511，534， 567,658

[Greater] Sunda Islands (大スンダ諸島)，16，18， 20

Sunda Sea (スンダ海), 234-35, 428

Sunda Strait (スンダ海峡), 48, 265, 272-73, 300, 329 , 331, 370, 373, 406, 411-13, 419-20, 462, 482-83, 485, 498

Sungai Mahakam (マハカム河), 187

Sungai Petani (スンゲイパタニ), 18, 81, 259, 273, 280-81, 302, 498, 579

Sungai Pinyuh (スンゲイペニュ), 275

Sungguminasa (スングミナサ), 249, 255

Surabaya, (スラバヤ), 17, 19, 21, 36, 40, 45, 47-48， 71, 96, 100-01, 104, 111-12, 121, 174, 192, 220, 233-35, 238, 240-43, 245, 248, 301, 306, 308, 310-14, 319, 321-24, 329, 344, 346, 354-55, 359, $366,368,371-72,374-75,377,379-80,382,394$, 397-98, 401-06, 409-10, 425, 427-33, 440, 442, 446, 450, 453-54, 456, 458, 460-63, 470, 475, 483-84, 488-90, 497, 499, 500-07, 511-12, 515, 527, 529-30, 534-35, 548, 600, 615

Surakarta (スラカルタ), 489

Sydney (シドニー), 534

Tabung (タブン), 353 
Tainan (台南), 85, 114, 236, 361

Taiwan, Strait (台湾, 臺灣, 海峡), 11, 15, 20, 24, 28-30, 40-41, 52, 64-68, 80, 82, 106, 112-13, $310,358,364,400,517-18,553$

Taizhong (台中), 85, 102

Takatalu Rock (タカタル礁), 187

Takingeun (タキゴン), 580

Takisung (タキソン), 355

[Talang] Abab (アバブ), 266

Talaud Islands (タラウド島), 222, 340, 612

Taliabu (タリアブ), 230

Talisei Island (タリセイ島), 166

Talomo (夕ロモ), 117

Talu (タロル), 580

Tambelan Islands (タンブレン島, タンベラン諸 島), 283, 413

Tambu Bay (夕ムブ湾), 428

Tamperong Island (夕ムペロン島), 166

Tanahgrogot (タナゴロコッド,タナゴロコット), 254, 257

Tanahjampea Island (タナシャンビー島), 254

Tanahwangko (タナワンコ), 166

Tanakeke (夕ナケケ島), 252, 254, 311, 313

Tangerang (タンゲラン), 398

Tanimbar (タニンバル諸島), 340, 406, 484

Tanjung Priok (タンジョンプリオク), 21, 323, 509

Tanjungkarang (タンジュンカラン, タンヂュン カラン), 266, 303, 304, 329, 373, 377, 406, 413， 424

Tantui (タンツイ), 228

Tapah, Cape (トイード岬), 286

Tarakan Island (タラカン), 11, 17, 19, 21-22, 30, 36 , 39, 45, 48, 55, 63-65, 68-69, 71, 75, 81-82, 88-89, 91-97, 99, 101, 103, 107-08, 110-12, 114-15, 117-19, 126-27, 129-38, 140-41, 143-49, 164, 174, 177-87, 192, 198, 205, 207, 216, 236, 250, 306-07, 310, 342, 359-61, 367, $370,380,394-95,407,427,484,515,517-18$, $525,540,563-64$

Tarus (スルタ), 353
Tarutung (タルトン), 580

Tataaran (タタアラン), 166

Tateyama (館山), 102, 577

Taunggyi (タウンギー), 535

Tavoy (タヴォイ,タボイ), 588-89, 591-92, 618， 639,640

Tawiri (タウリ), 225-26

Tawi-Tawi (Island) (タウイタウイ), 19, 23, 131

Tebakubekun [Telukbetong ?] (テバクベクン), 323

Tebas (トバシ), 275

Telang River (テラ河, テラン河), 261, 266, 285-86, 303

Telo (テロ河), 255

Ten Degree Channel (十度海峡), 641, 645

Tenau (テナウ), 352-53, 355

Tengah (テンガー), 18

Tenggarong (テンガロン), 187

Tennasserim (テナセリウム地方), 24

Terengganu (トレンガヌ), 81

Ternate (テルナテ), 88-89, 169, 173, 219, 230, 406 Thailand, Thai, Gulf of (夕イ, 泰, 泰国, 夕イラ ンド,～湾), 5-6, 15-16, 18, 20, 29, 31-32, 35-36, $39,42,44,52,63-65,67,70,75,80-81,117,121$, $535,559,565-66,585,615$

Thousand Islands [Pulau Seribu] (サウザンド諸 島, ダイゼント諸島), 420

Thủ Dâu Một (ツダウム ), 79, 280-81, 292, 402, 409, 421, 498

Thwartway [Dwars-in-den-Weg, Pulau Sangiang] (ソワートウェイ島) 467, 508

Tianjin (天津), 2

Tifore Island (テイホ島), 73

Timor, Island, Sea (チモール, 島, 〜海), 16-20, 24-25, 35-36, 44, 112, 122-23, 192, 207, 213, 219-20, 234, 240, 244, 319, 331, 333, 335-36, 340-43, 345-49, 351, 354-55, 357, 362-63, 404-06, 410, 426, 428, 431, 475, 478, 481, 484, $487,516,526,558,585,612$

Tinian Island (テニアン), 640 
Toba, Lake (トバ湖), 580

Toboali (トホブリ), 304, 413, 420-21, 498

Tokyo, Bay (東京, 湾), 27, 61, 87, 103-04, 116, 342, 345, 498, 601

Tolo, Gulf of (トロ湾), 230

Tombatu (トンバル), 166

Tomini, Gulf of (トミニ湾, ドミニ湾), 154, 158， 164, 168, 201, 230, 395, 428, 484, 612

Tomohon (トモホン), 152, 160, 165-66, 175

Tompaso (トムパソ), 165-66, 175-76

Tondano, Lake 〜 (トンダノ， 湖), 152, 155, 157， $160,165-66,168,176$

Tonsawang, Lake (トンサワン湖), 166

Toppers Island [Pulau Tampurung] (トッパース 灯台), 508-09

Torres Strait (トーレス海峡, トレス海峡), 122, 204, 213, 332, 482, 485

Tountimomor (トウンテイモモル), 166

Trincomalee (ツリンコマリ), 559, 571, 603-04, 606-07, 613, 615-16, 618-20, 627-31, 633, $638-40,642,647-52$

Truk (Islands) (トラック), 212, 334

Tuguegarao (ツゲガラオ), 80

Tuing, Cape (ツイン角), 288

Tujuh Islands (セブン島), 286

Tulagi (ツラギ), 656, 660

Tumpak, Gunung (ツンパ山), 166

Tunang (ツナン), 275

Tutuila Island (ツツイラ), 50

Ujina (宇品), 116

Ujung Parapa (バラバ海岸), 310

Ular, Cape (ウラル角), 286-87, 297

Uloimi, Cape (ウロイム岬), 353

United States (米, A (アメリカ)), 1-6, 9-11, 13-14, 17, 23, 26-27, 32-34, 42-43, 45-46, 48, 76,105, 192, 201, 204, 211, 243, 323, 357, 530, 534-39, 551-52, 554-55, 558, 562-63, 653-56

Upang River (ウパン河, ウバン河), 286, 296

Victoria Point (ビクトリアポイント), 81

Vigan (ビガン), 25, 29, 39, 52, 63, 82, 85, 549
Visakhapatnam (ビザカパタム,ビザガパタム), $614,618,643,652$

Visayan Islands (ビサヤ諸島), 15

Waiame (ワイアメ), 224, 228

Wain River (ワイン河), 178-79, 195

Waingapu (ワインガップ), 245

Wakal (フカル), 228

Wake, Island, Ōtorishima (ウエーク，〜島，ウェ 一キ, 大鳥島), 51, 80, 116, 571, 601, 656

Wanci Island (Wangiwangi) (ホンジ島), 254

Wangiwangi (オンギオンギ島), 203

Waterfall (Christmas Island) (ウォーターフォー ル), 595

Wetar (ウェタル), 230

Weti River (ウエチ河), 224-25

William, Cape [Tanjung Rangas] (ウィリャム岬, ウイリアム岬), 252, 254, 313, 428

Wori (ウオリー), 166

Wota [Oti] anchorage ( $タ$ 夕泊地), 395

Wowoni Island (ウォウォニ島), 203, 222

Wyndham (ウィンダム), 497

Yamaguchi (pref.) (山口(県)), 69

Yangtze Kiang [Yangzi, Chang Jiang] (揚子江), 555

Yenangyaung (イエナンギャング), 22, 566

Yogyakarta (ジョクジャカルタ), 329, 425, 430, 489,497

Yokosuka (横須賀)，34，485-87，600，602，606，646， 649

Yunnan (雲南), 16

Zamboanga (サンボアンガ), 18 



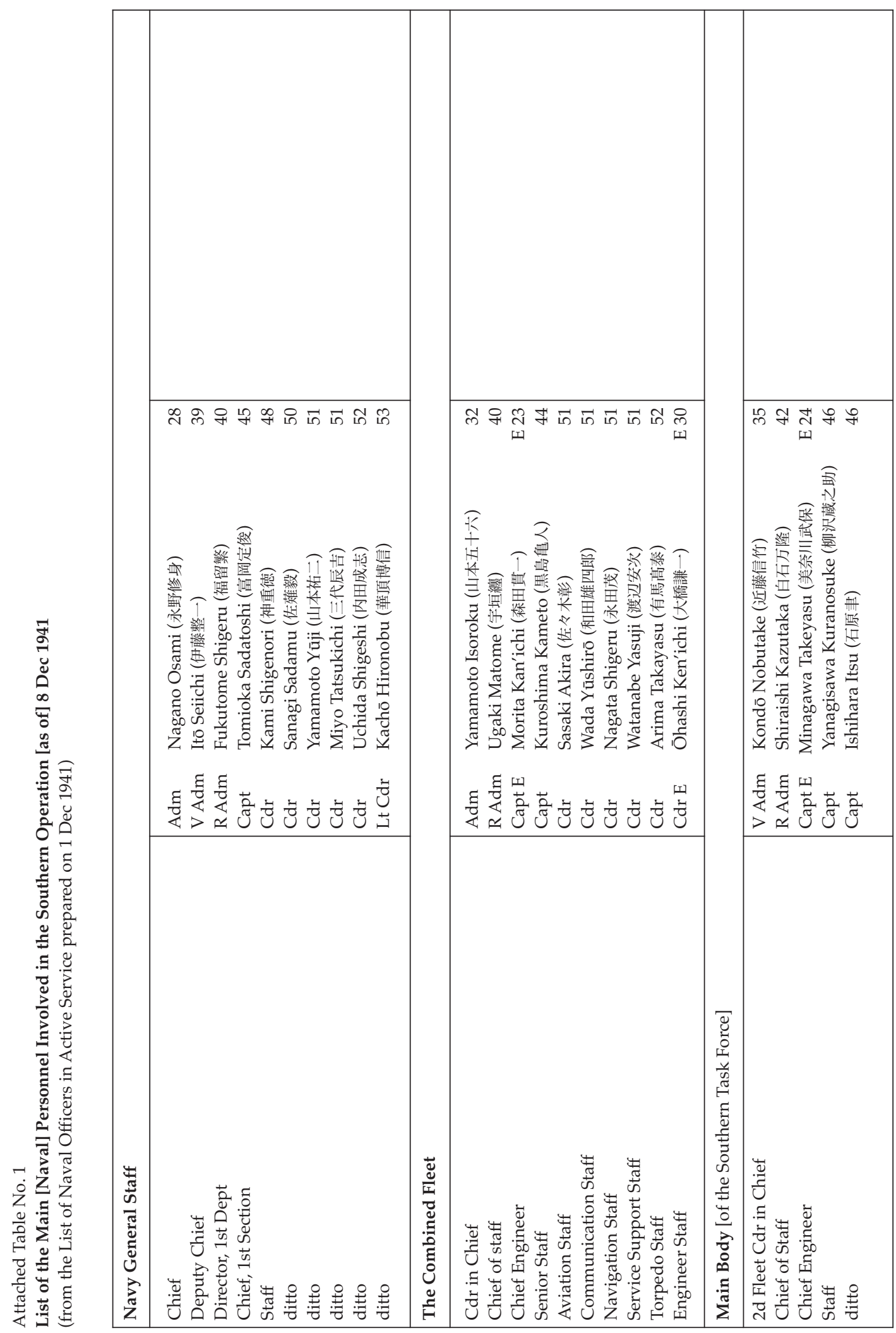




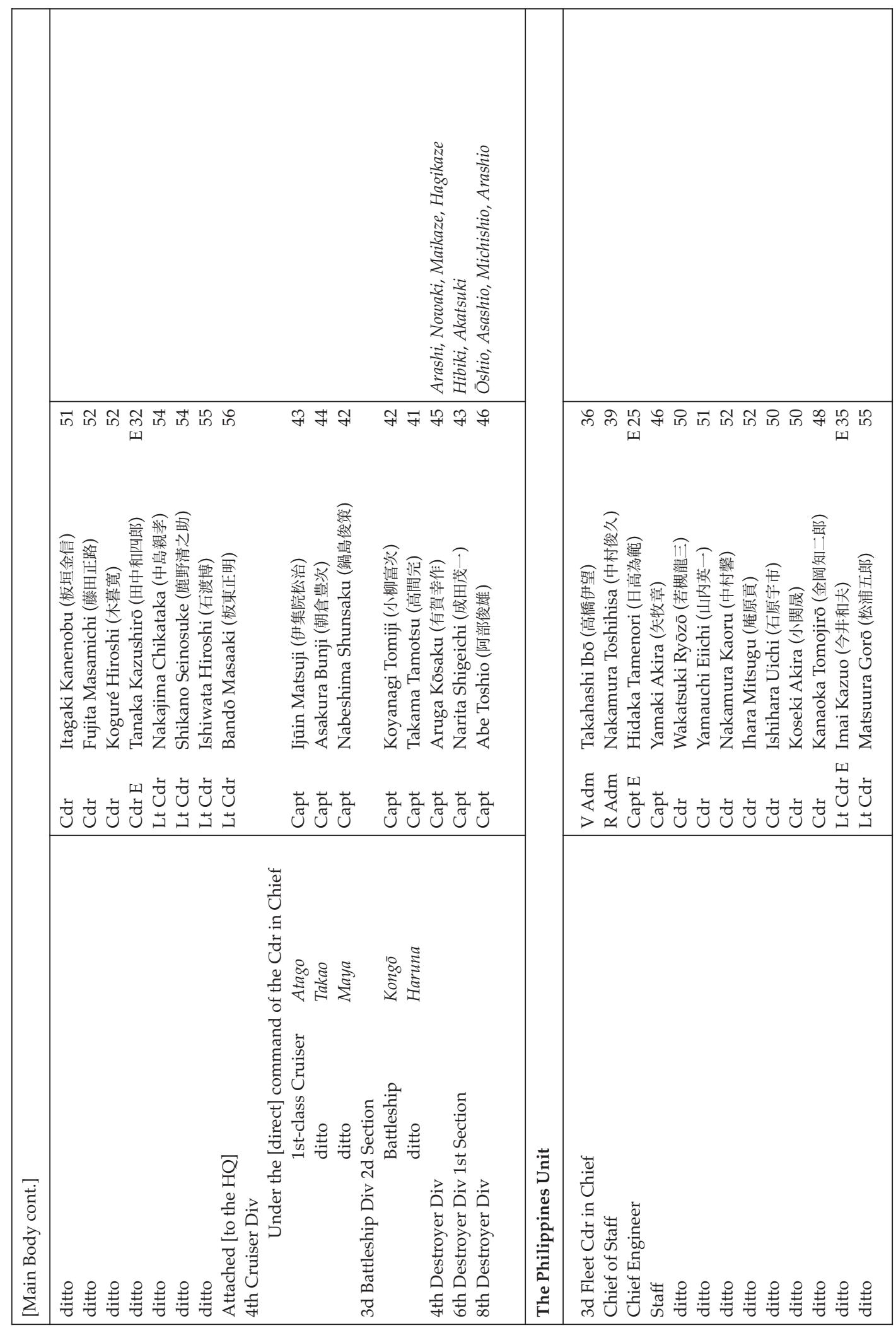




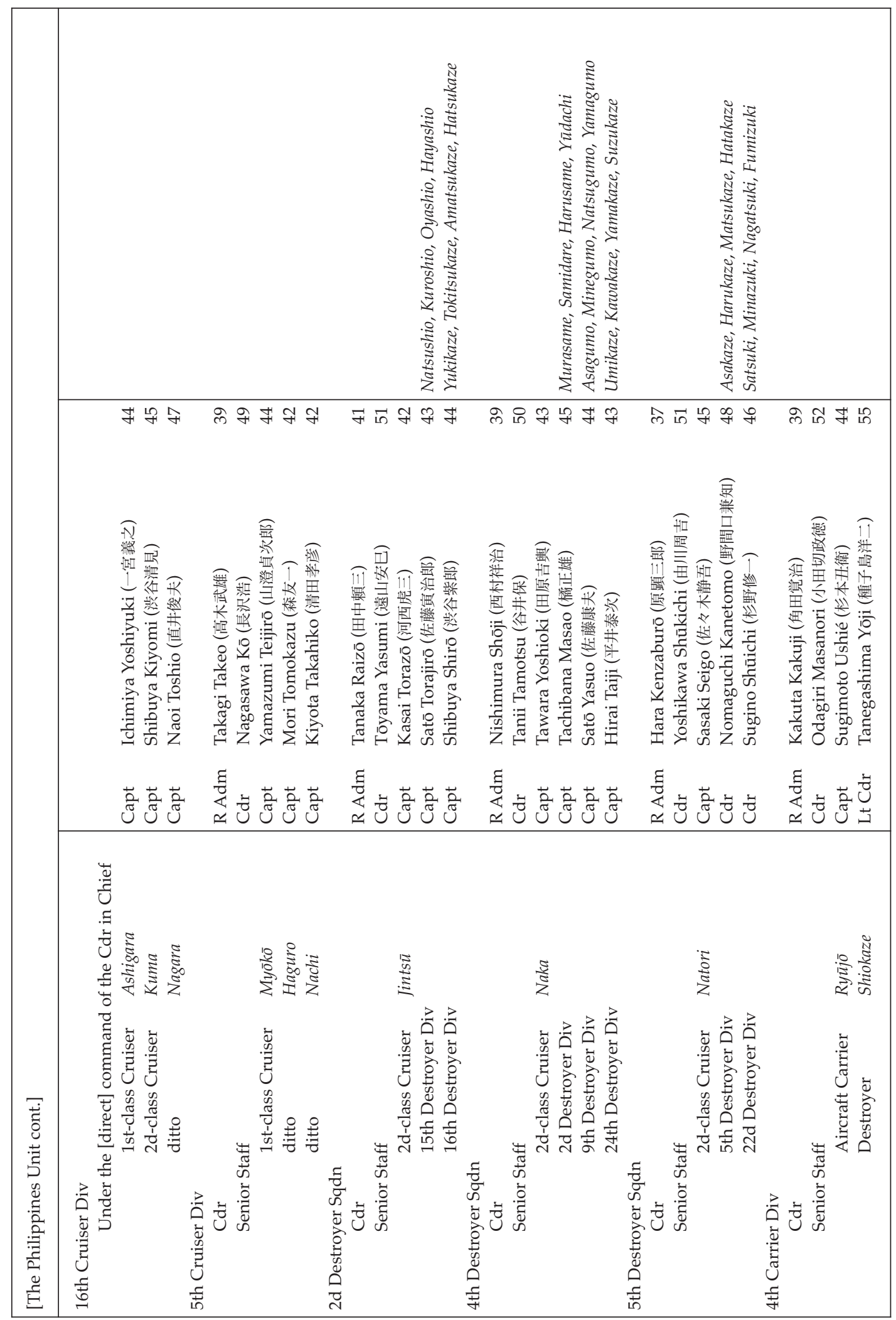




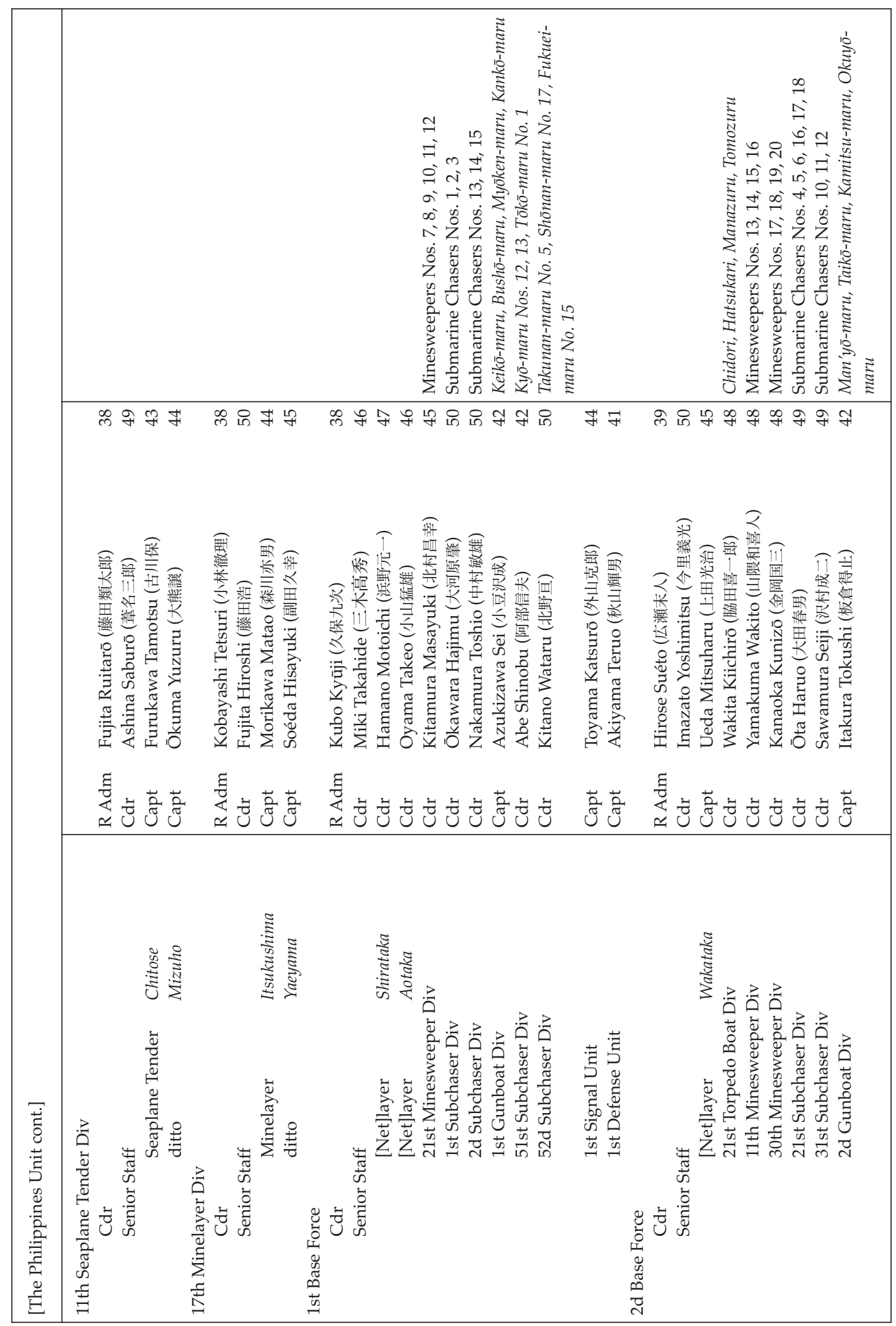




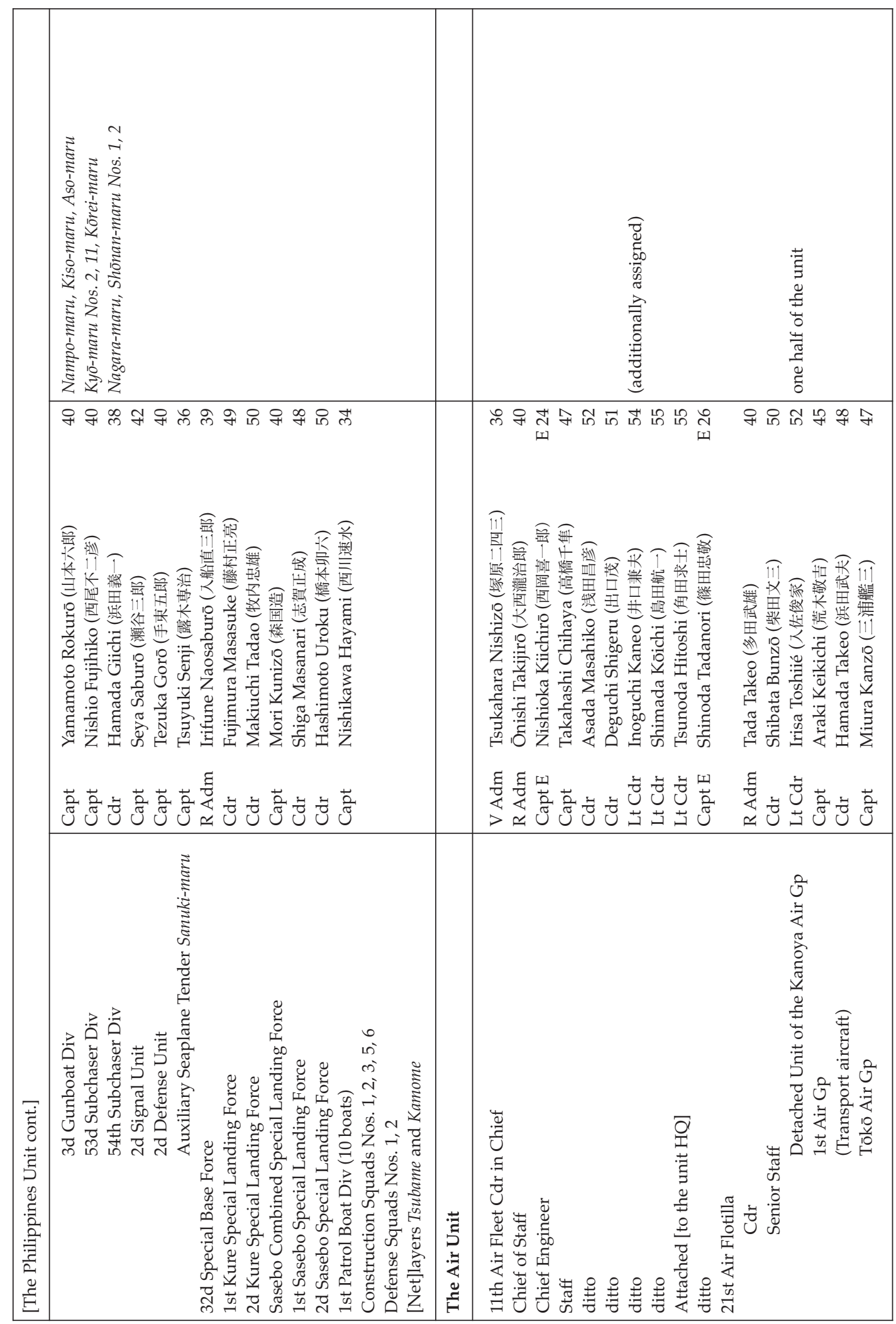




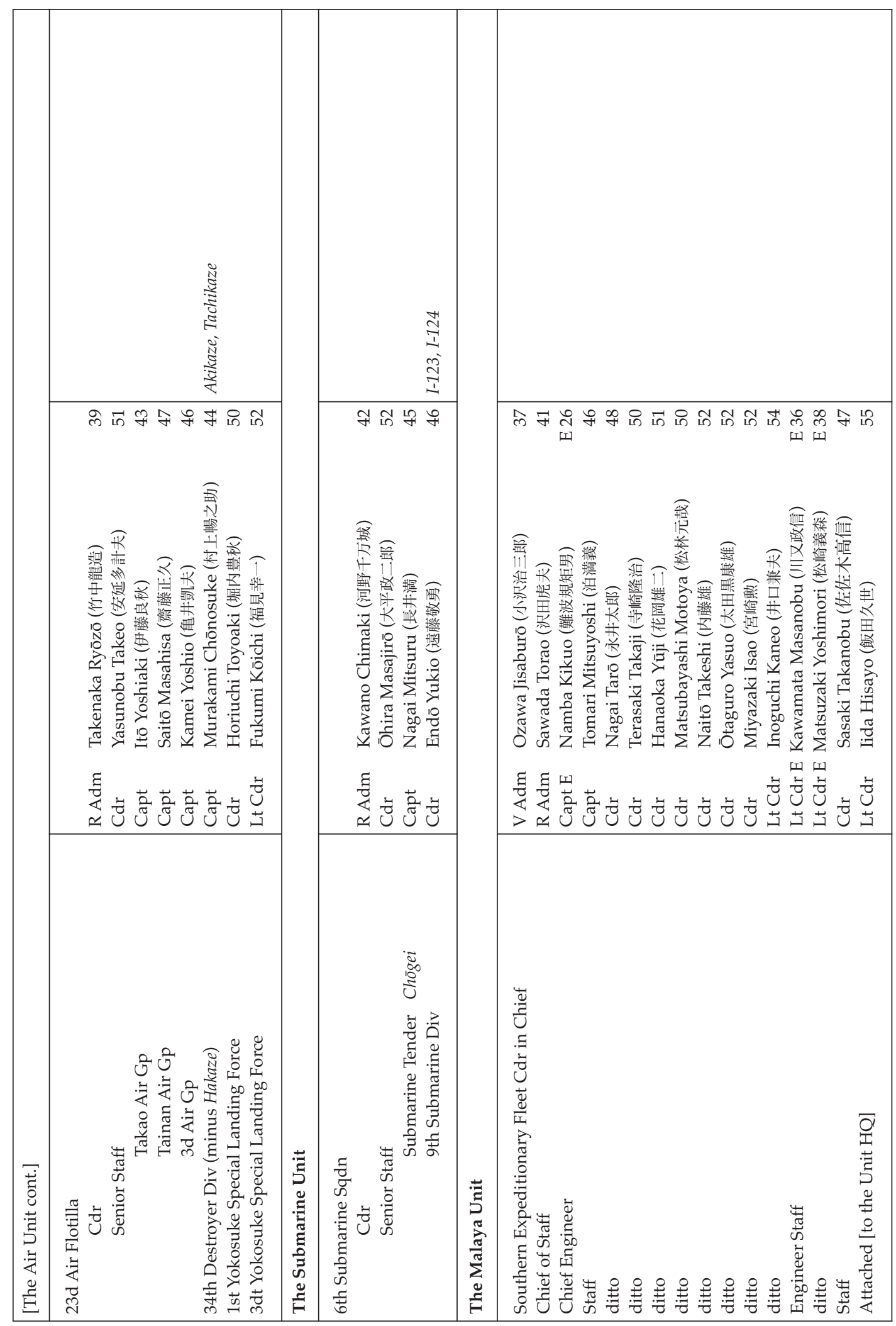




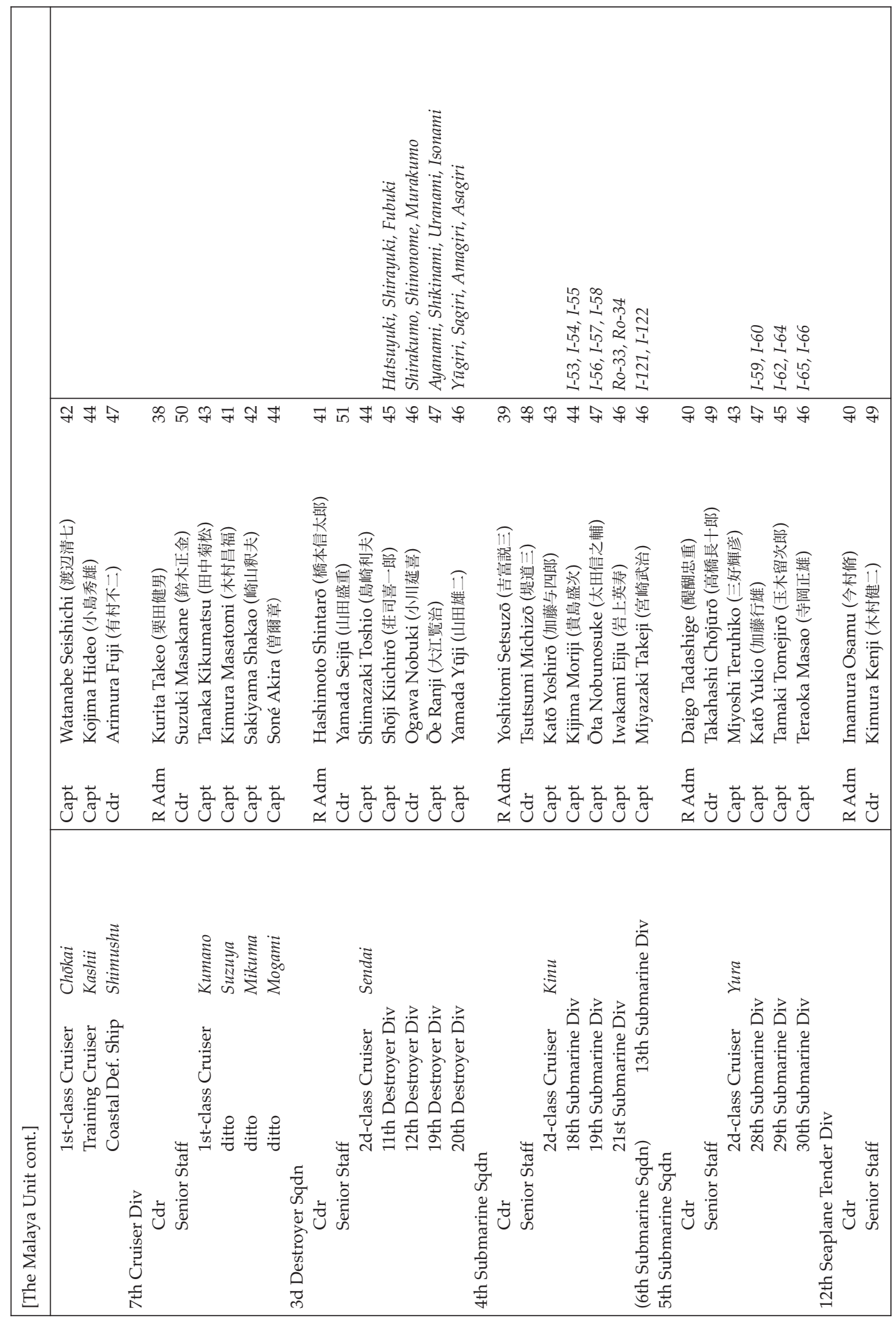




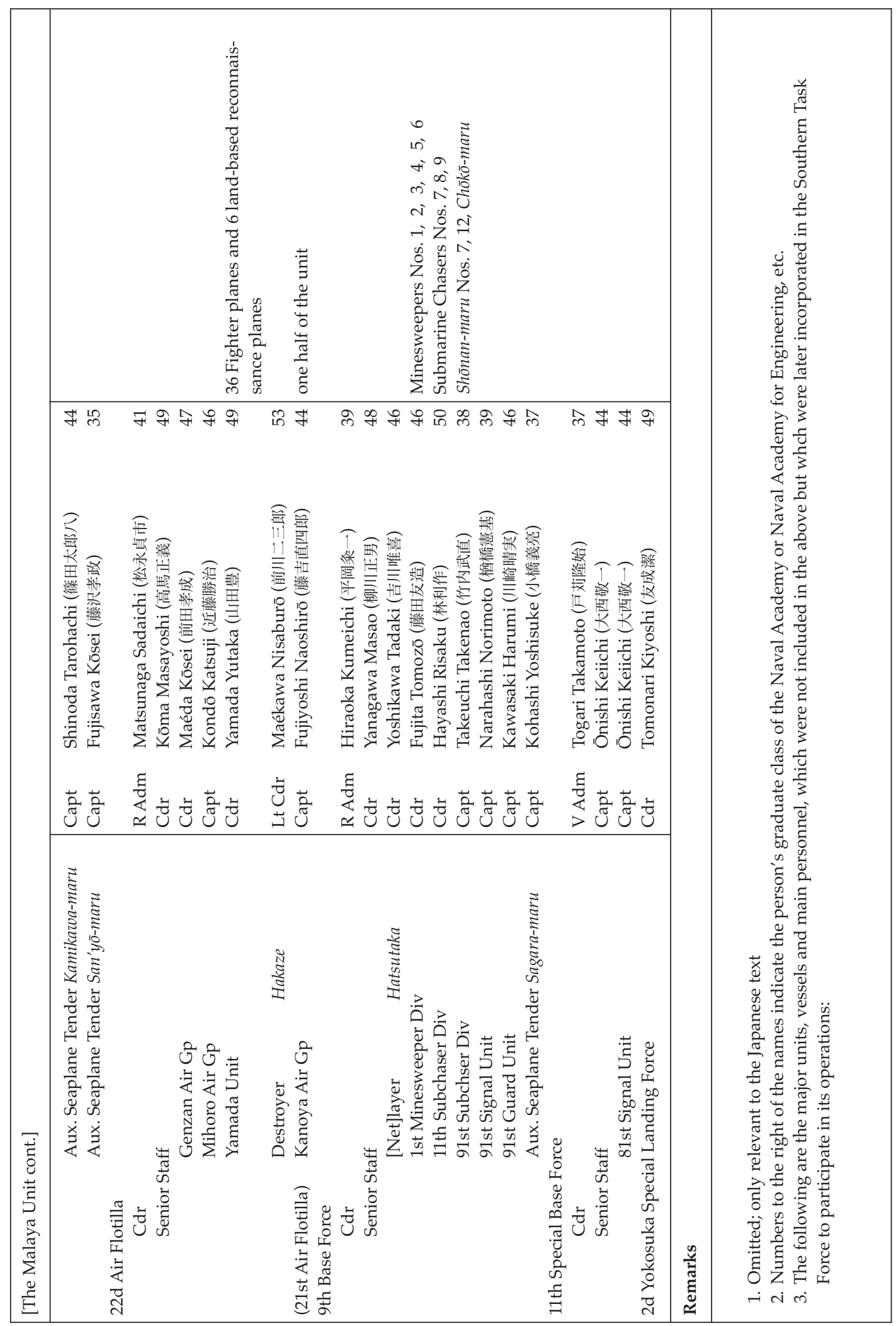




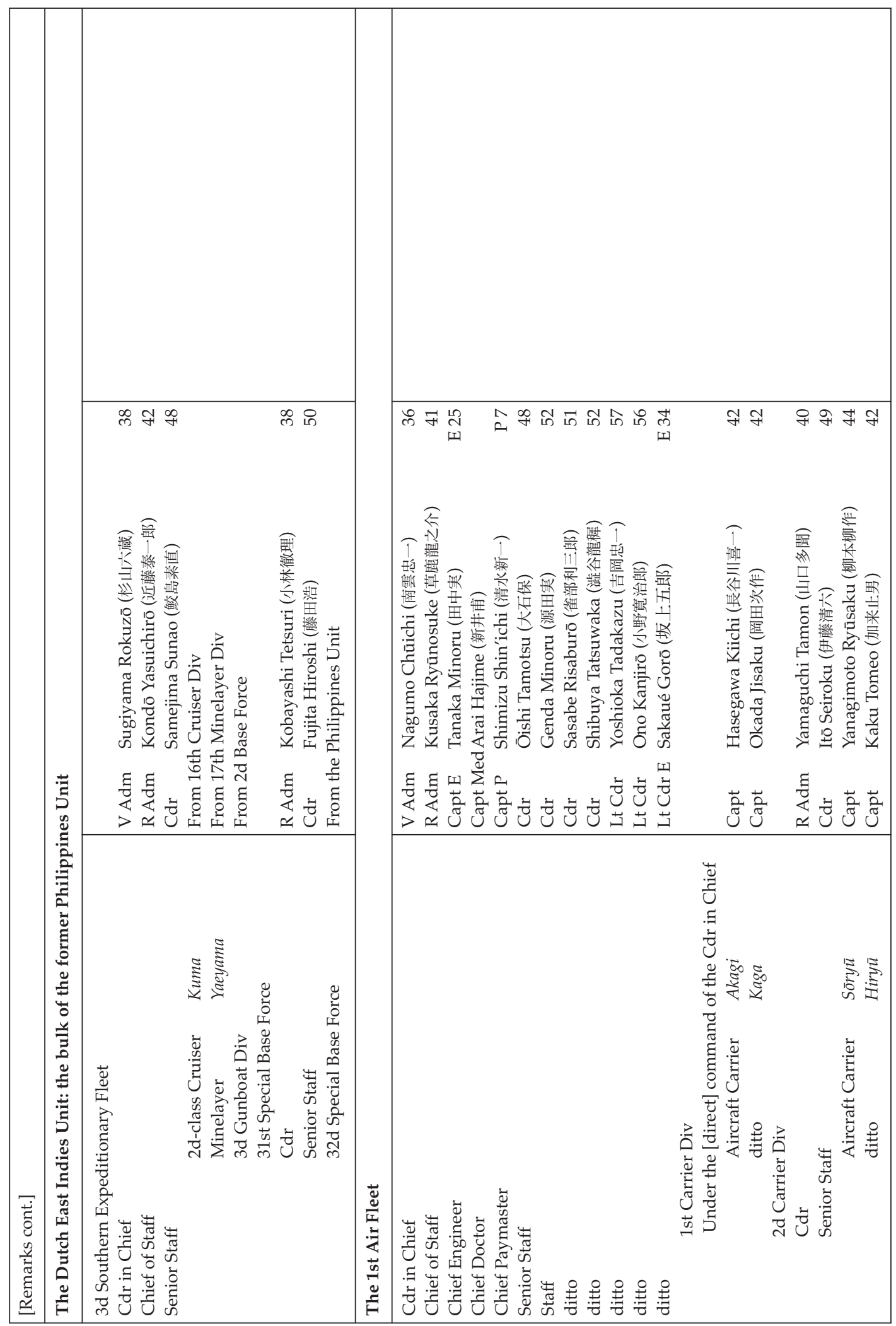




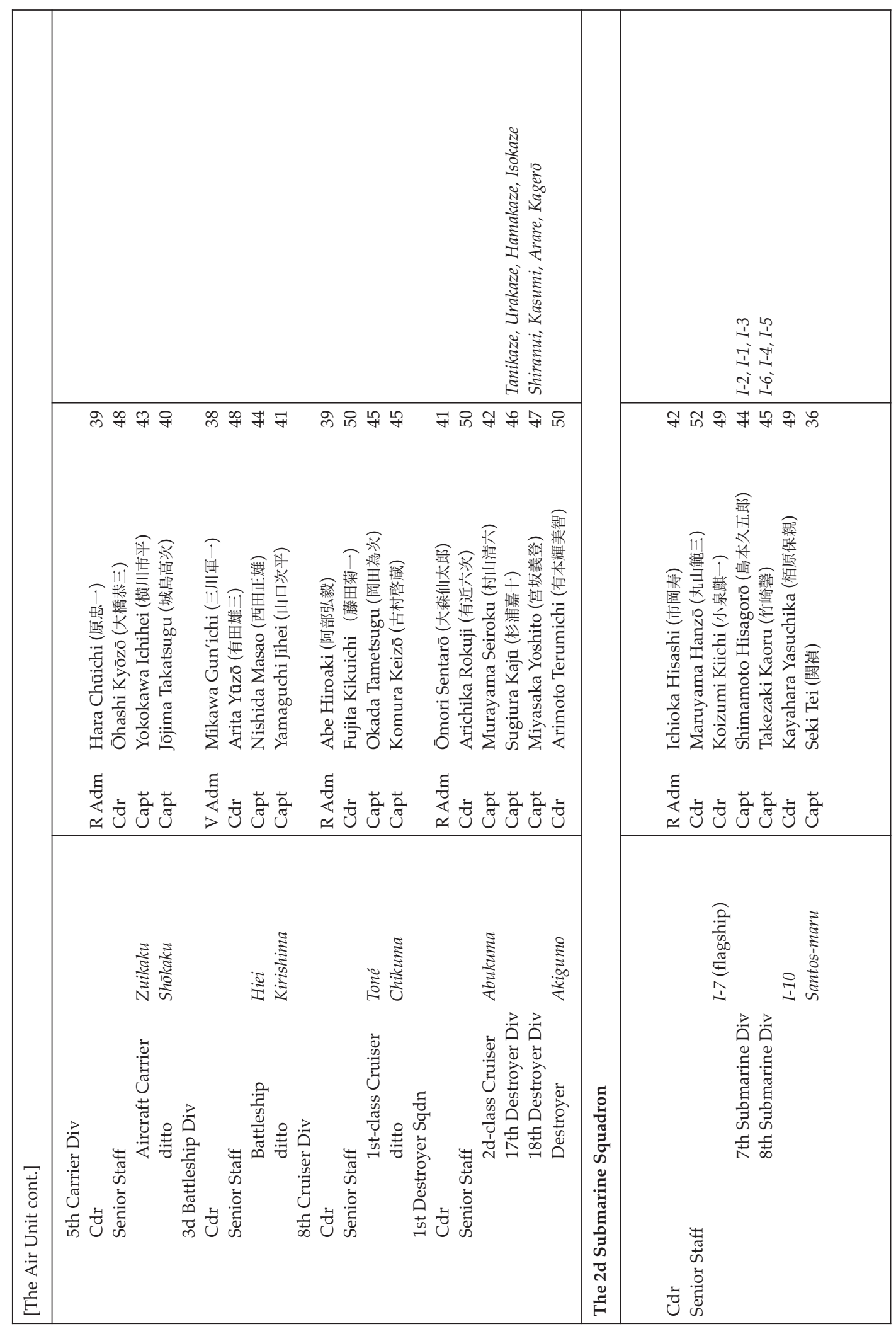




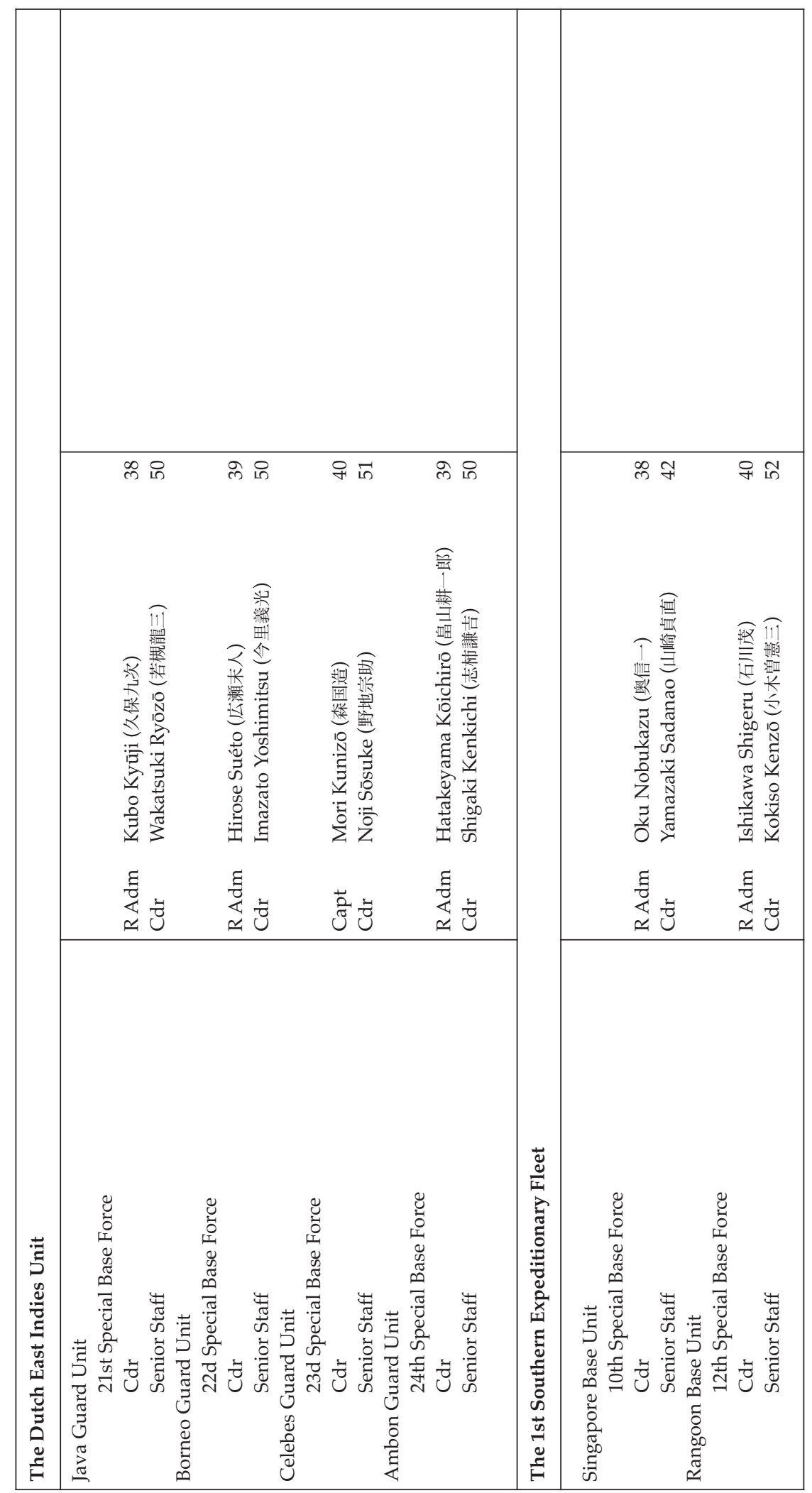




\begin{tabular}{|c|c|c|c|c|c|c|c|c|}
\hline 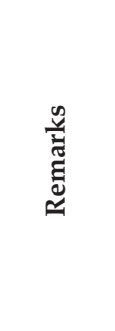 & 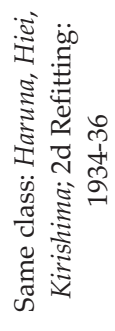 & 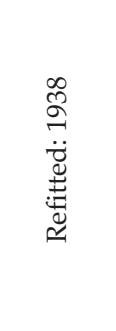 & 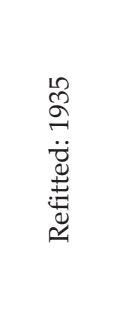 & 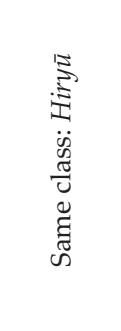 & 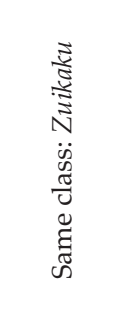 & & & 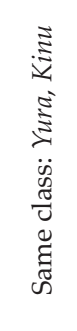 \\
\hline 莺 & & & & & & & & \\
\hline 营 & 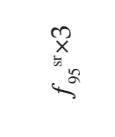 & 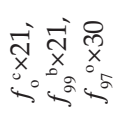 & 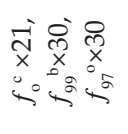 & 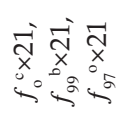 & 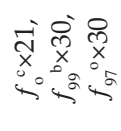 & 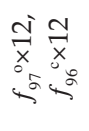 & 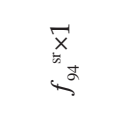 & 袁 \\
\hline 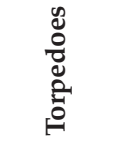 & & & & & & & 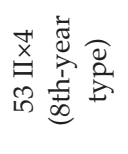 & 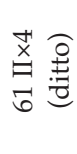 \\
\hline 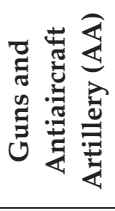 & 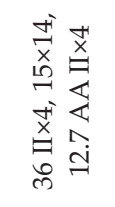 & 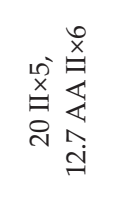 & 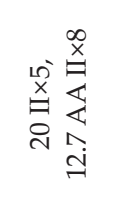 & 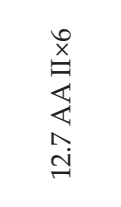 & 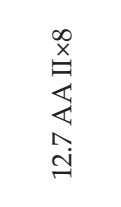 & 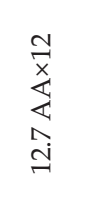 & $\begin{array}{l}\tilde{x} \\
\sum_{4} \\
\infty \\
\hat{x} \\
x \\
\pm\end{array}$ & $\underset{:}{\stackrel{t}{*}}$ \\
\hline $\begin{array}{l}\tilde{\Xi} \\
\frac{0}{0} \\
\frac{0}{0} \\
0\end{array}$ & $\begin{array}{l}\frac{10}{न 1} \\
\frac{0}{\sigma} \\
\frac{\sigma}{\sigma}\end{array}$ & సิ & $\stackrel{\text { ڤ్ }}{\sim}$ & 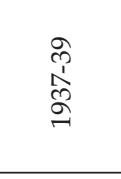 & F & $\underset{\widetilde{\Omega}}{\sigma}$ & 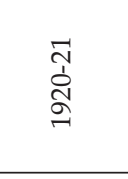 & 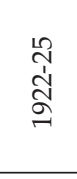 \\
\hline 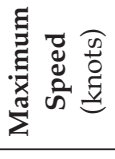 & $\begin{array}{l}\text { Ln } \\
\text { ç }\end{array}$ & $\stackrel{N}{\bar{m}}$ & $\frac{N}{m}$ & مْ & ঙ̊ & ஷें & $\begin{array}{l}\text { Oे. } \\
\text { के }\end{array}$ & 畕 \\
\hline 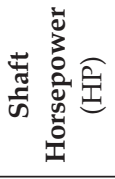 & 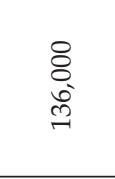 & $\begin{array}{l}8 \\
8 \\
\infty \\
\stackrel{0}{\sigma}\end{array}$ & $\begin{array}{l}\text { \& } \\
\text { İ } \\
\text { ì }\end{array}$ & $\begin{array}{l}8 \\
\text { ¿ } \\
\text { กิ } \\
\text { nิ }\end{array}$ & $\begin{array}{l}8 \\
8 \\
8 \\
0\end{array}$ & $\begin{array}{l}8 \\
8 \\
10\end{array}$ & $\begin{array}{l}8 \\
8 \\
8\end{array}$ & 畕 \\
\hline 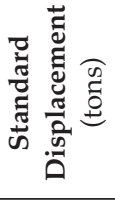 & 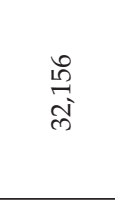 & $\begin{array}{l}8 \\
\text { m } \\
\text { Fi }\end{array}$ & \begin{tabular}{l}
\multirow{H}{*}{} \\
\multirow{y}{*}{}
\end{tabular} & $\begin{array}{l}8 \\
\infty \\
\infty \\
\infty\end{array}$ & $\begin{array}{l}\text { \& } \\
\text { ì }\end{array}$ & $\begin{array}{l}8 \\
8 \\
\infty \\
\infty\end{array}$ & $\begin{array}{l}8 \\
\stackrel{1}{1} \\
\text { ம) }\end{array}$ & 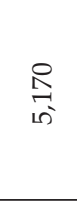 \\
\hline 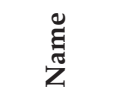 & $\begin{array}{l}180 \\
80 \\
\vdots \\
2\end{array}$ & 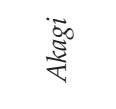 & $\underset{\infty}{\infty}$ & 宽 & $\begin{array}{l}\frac{3}{5} \\
\frac{5}{10} \\
\text { के }\end{array}$ & 隹 & $\stackrel{\Xi}{\Sigma}$ & $\begin{array}{l}\tilde{\Xi} \\
\bar{\Xi} \\
\bar{z}\end{array}$ \\
\hline 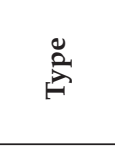 & 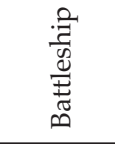 & \multicolumn{5}{|c|}{ 营. } & \multicolumn{2}{|l|}{ 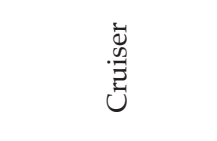 } \\
\hline
\end{tabular}




\begin{tabular}{|c|c|c|c|c|c|c|c|c|c|c|}
\hline 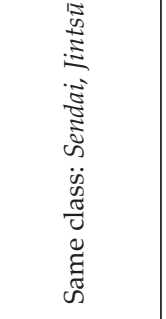 & 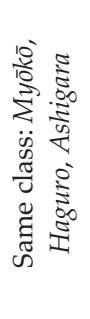 & 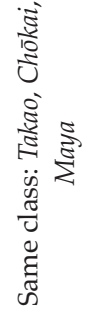 & 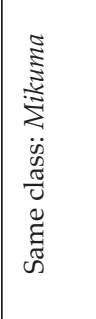 & 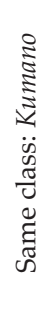 & & 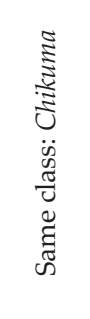 & & & 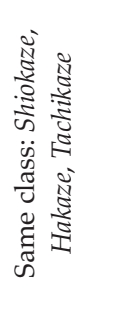 & 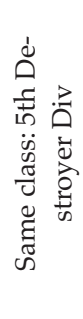 \\
\hline 美 & & 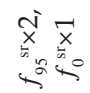 & $\begin{array}{rr}\tilde{y} & \vec{x} \\
x \\
0 \\
0\end{array}$ & 封 & 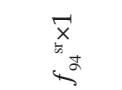 & 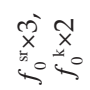 & 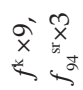 & 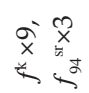 & & \\
\hline 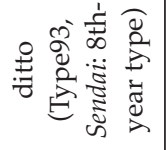 & 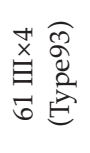 & 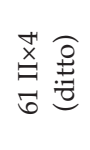 & 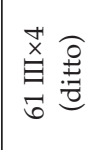 & $\stackrel{P}{:}$ & 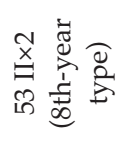 & & & & 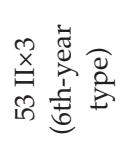 & 堛 \\
\hline 芒 & 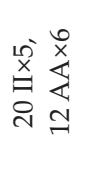 & 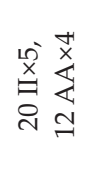 & 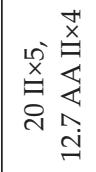 & $\stackrel{P}{\stackrel{7}{*}}$ & 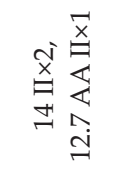 & 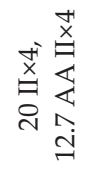 & 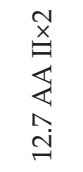 & 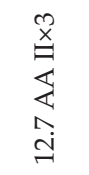 & 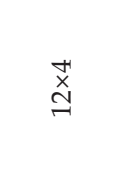 & 莺 \\
\hline 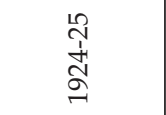 & $\begin{array}{l}\text { సे } \\
\text { ลે } \\
\text { హ}\end{array}$ & $\widetilde{\curvearrowright}$ & 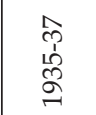 & $\begin{array}{l}\infty \\
\stackrel{\infty}{1} \\
\stackrel{\sigma}{\sigma}\end{array}$ & F & $\begin{array}{l}\text { के } \\
\infty \\
\sigma \\
\sigma\end{array}$ & $\stackrel{\infty}{\sigma}$ & ळे & శ్ & $\begin{array}{l}\text { สิ } \\
\text { ลั } \\
\text { ป }\end{array}$ \\
\hline $\begin{array}{l}\stackrel{\leftrightarrow}{N} \\
\stackrel{\infty}{\infty}\end{array}$ & ํㅜㅇ & 美 & ㅇ. & 요 & $\stackrel{\circ}{\circ}$ & வு. & ல். & $\stackrel{\text { ¿̇ }}{\text { הे }}$ & ஜें & $\stackrel{\stackrel{ }{N}}{\stackrel{m}{m}}$ \\
\hline 苦 & $\begin{array}{l}8 \\
8 \\
0 \\
\end{array}$ & 赽 & $\begin{array}{l}8 \\
8 \\
\text { 1 } \\
\text { ñ }\end{array}$ & 营 & \begin{tabular}{c}
8 \\
\hdashline \\
$\infty$
\end{tabular} & $\begin{array}{l}8 \\
8 \\
\text { i } \\
\text { ñ }\end{array}$ & $\begin{array}{l}8 \\
\infty \\
\infty \\
10\end{array}$ & 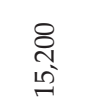 & $\begin{array}{l}8 \\
1 \\
\infty \\
\infty \\
\infty\end{array}$ & 圭 \\
\hline $\begin{array}{l}\frac{2}{\sigma} \\
\frac{1}{5}\end{array}$ & $\begin{array}{l}8 \\
8 \\
0\end{array}$ & $\begin{array}{l}0 \\
\text { bn } \\
\text { an } \\
\text { an }\end{array}$ & $\begin{array}{l}8 \\
\stackrel{1}{ } \\
\infty \\
\infty\end{array}$ & 营 & $\begin{array}{l}8 \\
\infty \\
\infty \\
n^{5}\end{array}$ & $\begin{array}{l}\text { ते } \\
\text { ले } \\
\text { ભે }\end{array}$ & ڤె & $\begin{array}{l}\text { ลे } \\
\text { o }\end{array}$ & $\stackrel{\stackrel{L}{N}}{\rightarrow}$ & 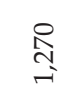 \\
\hline$\frac{\pi}{3}$ & $\begin{array}{l}z \\
\bar{z} \\
z\end{array}$ & $\begin{array}{l}\mathbb{S}_{0} \\
\stackrel{+}{+}\end{array}$ & 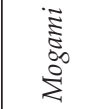 & $\begin{array}{c}\text { S } \\
\text { N } \\
\text { ज }\end{array}$ & :a & : & 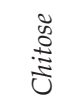 & 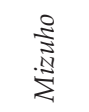 & 咅巡 & 咅 \\
\hline \multicolumn{7}{|c|}{ 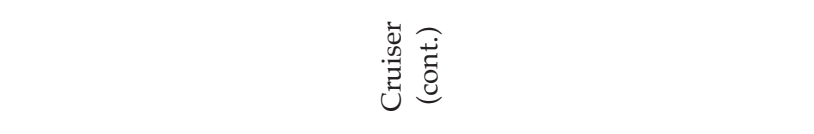 } & \multicolumn{2}{|c|}{ 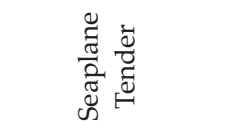 } & \multicolumn{2}{|c|}{ 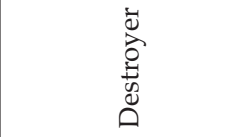 } \\
\hline
\end{tabular}




\begin{tabular}{|c|c|c|c|c|c|c|c|c|c|}
\hline 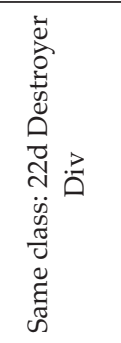 & 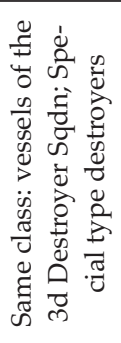 & 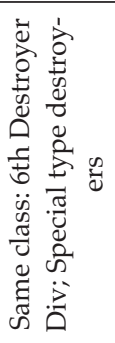 & 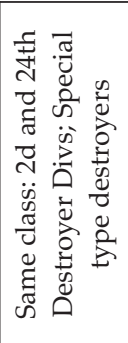 & 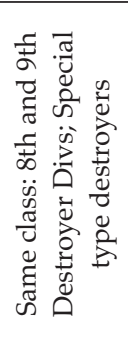 & 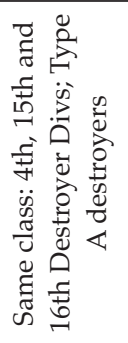 & 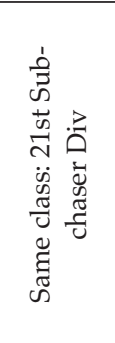 & & & \\
\hline & & & & & & & $\begin{array}{l}\stackrel{8}{\infty} \\
\sum_{\Sigma}^{\infty}\end{array}$ & $\frac{\stackrel{\infty}{\infty}}{\vec{x}}$ & 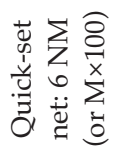 \\
\hline 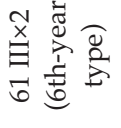 & 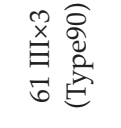 & 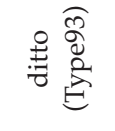 & 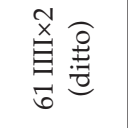 & 营 & 营 & 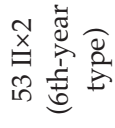 & & & \\
\hline 売 & 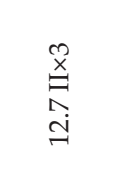 & $\underset{t}{ \pm}$ & 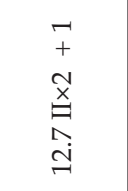 & 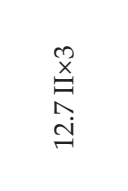 & $\stackrel{0}{ \pm}$ & $\begin{array}{l}\overrightarrow{+} \\
+ \\
\vec{x} \\
\hat{\theta} \\
\text { తi }\end{array}$ & 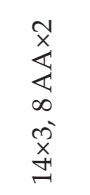 & 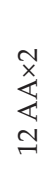 & 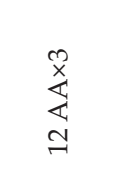 \\
\hline ్ֶ & $\underset{\approx}{\sigma}$ & $\stackrel{\widetilde{\Omega}}{\sigma}$ & $\stackrel{\text { }}{\sigma}$ & $\stackrel{\widehat{\sigma}}{\sigma}$ & ळे & $\stackrel{\infty}{\sigma}$ & సે & $\stackrel{\widetilde{\Omega}}{\sigma}$ & సે \\
\hline$\underset{7}{\stackrel{9}{*}}$ & $\begin{array}{l}0 \\
\infty \\
\infty\end{array}$ & 莺 & 吕 & $\begin{array}{l}\text { ㅁ. } \\
\text { ले }\end{array}$ & 营 & $\begin{array}{l}\circ \\
\dot{\infty}\end{array}$ & $\stackrel{\circ}{\stackrel{0}{0}}$ & 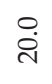 & $\stackrel{0}{0}$ \\
\hline 堛 & $\begin{array}{l}8 \\
8 \\
\circ \\
10\end{array}$ & 売 & 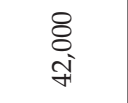 & $\begin{array}{l}8 \\
8 \\
\circ \\
\text { in }\end{array}$ & $\begin{array}{l}8 \\
\text { ¿ } \\
\text { î }\end{array}$ & $\begin{array}{l}8 \\
\stackrel{8}{=}\end{array}$ & $\begin{array}{l}8 \\
\text { ळ) }\end{array}$ & $\begin{array}{l}8 \\
\$ \\
+ \\
+\end{array}$ & 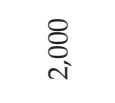 \\
\hline$\stackrel{n}{m}$ & $\begin{array}{l}\stackrel{8}{0} \\
\stackrel{0}{\rightarrow}\end{array}$ & 营 & 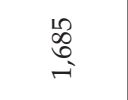 & 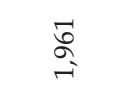 & $\begin{array}{l}8 \\
\vdots \\
i\end{array}$ & $\stackrel{尺}{\wedge}$ & $\stackrel{?}{\stackrel{R}{-}}$ & $\stackrel{\stackrel{M}{⿹}}{=}$ & 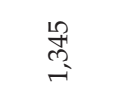 \\
\hline $\begin{array}{l}\frac{\pi}{3} \\
\text { ज. } \\
\vec{\Xi} \\
\omega\end{array}$ & $\begin{array}{l}\frac{1}{3} \\
\frac{3}{3} \\
\frac{7}{3}\end{array}$ & 妾站 & 离泀 & $\begin{array}{l}\stackrel{2}{3} \\
\frac{3}{3} \\
\frac{1}{4}\end{array}$ & 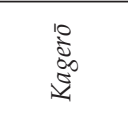 & 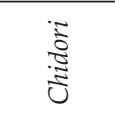 & 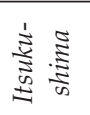 & 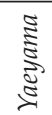 & $\frac{\dot{s}}{\omega} \frac{5}{5}$ \\
\hline \multicolumn{6}{|c|}{ 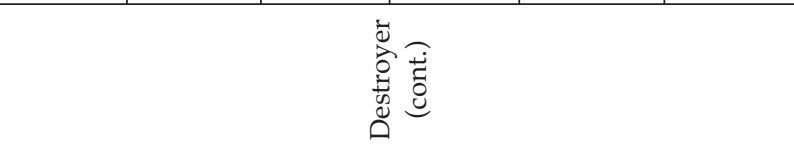 } & 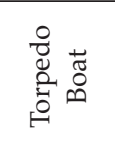 & \multicolumn{2}{|c|}{ 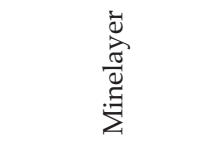 } & 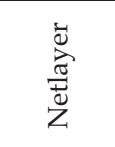 \\
\hline
\end{tabular}




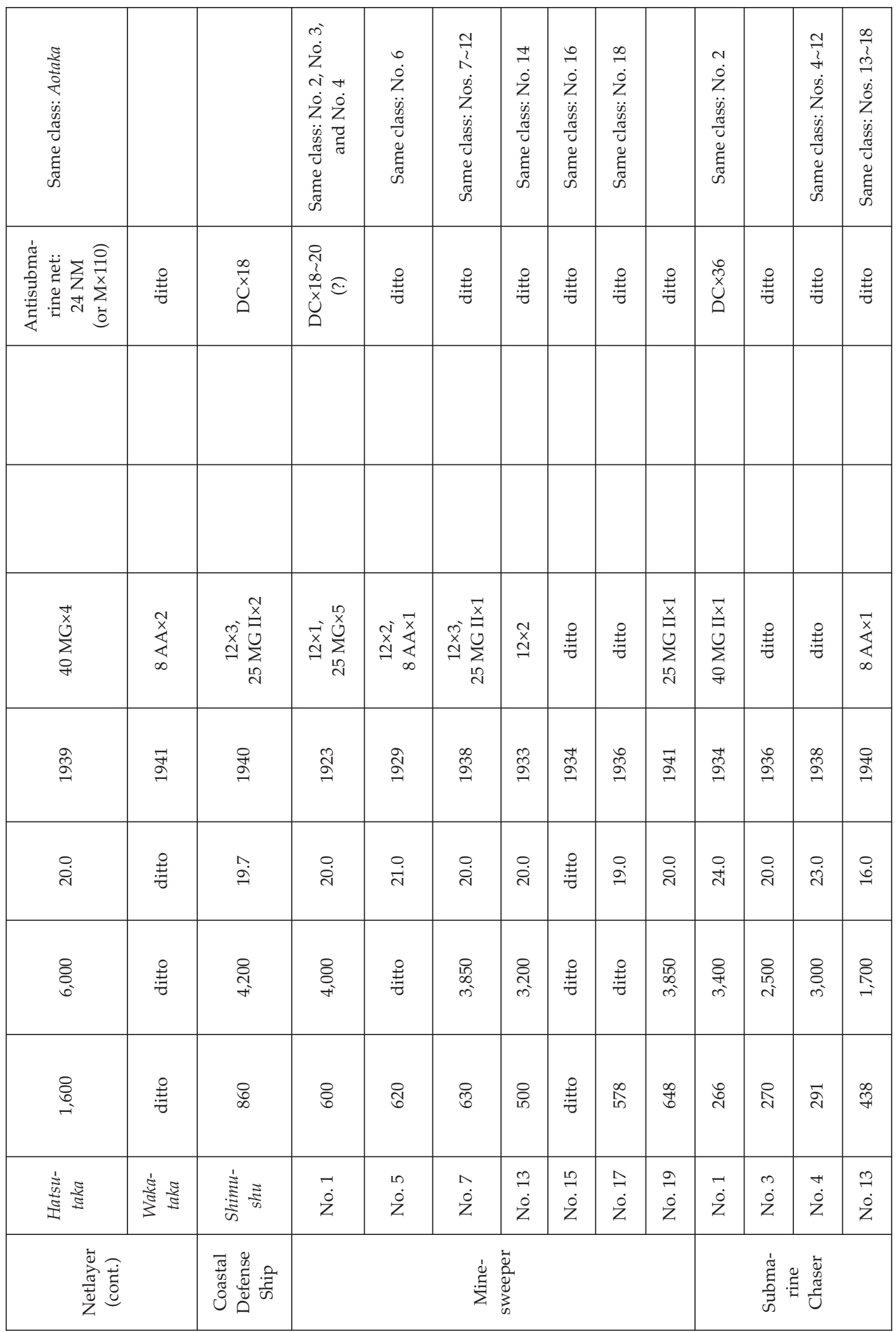




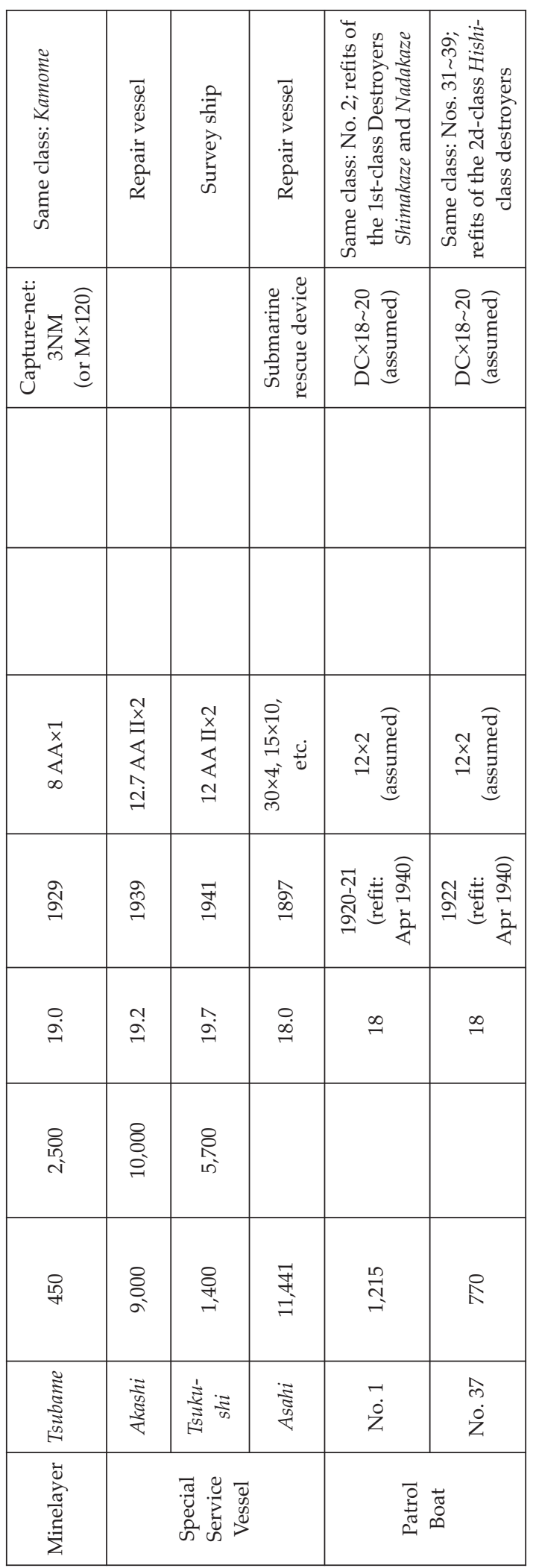

\begin{tabular}{|c|c|c|c|c|c|}
\hline . & & 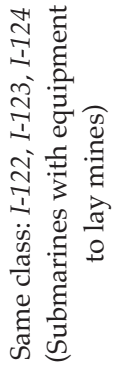 & 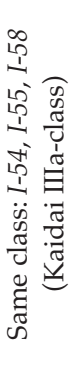 & 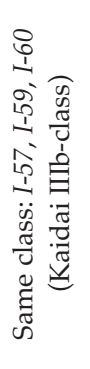 & 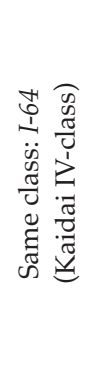 \\
\hline 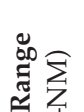 & 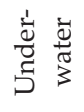 & 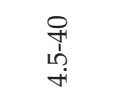 & 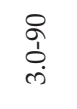 & 焉 & $\begin{array}{l}8 \\
\dot{0} \\
\dot{1} \\
\dot{n}\end{array}$ \\
\hline 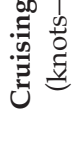 & 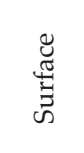 & $\begin{array}{l}8 \\
0 \\
0 \\
0 \\
1 \\
\infty\end{array}$ & $\begin{array}{l}8 \\
8 \\
0 \\
1 \\
1 \\
0\end{array}$ & 壳 & $\begin{array}{l}8 \\
8 \\
0 \\
0 \\
1 \\
0\end{array}$ \\
\hline 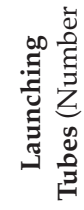 & 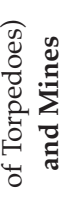 & 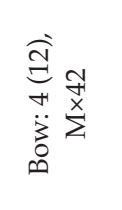 & 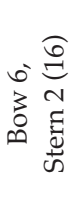 & 壳 & 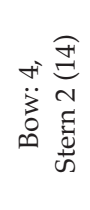 \\
\hline 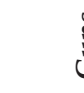 & & $\underset{\vec{x}}{\vec{\forall}}$ & $\begin{array}{l}\vec{x} \\
\text { I }\end{array}$ & 圭 & 营 \\
\hline & & ลે & 䒿 & స్ & $\stackrel{P}{\stackrel{7}{*}}$ \\
\hline 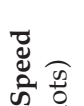 & 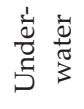 & $\stackrel{\circ}{\circ}$ & $\stackrel{\circ}{\infty}$ & 㽦 & $\mathbb{1}_{\infty}^{\infty}$ \\
\hline 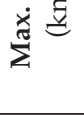 & 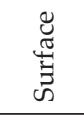 & $\stackrel{\text { In }}{+}$ & ¿ें & 营 & 莺 \\
\hline 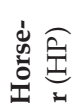 & 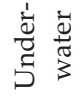 & $\underset{-}{\stackrel{8}{-}}$ & & 堛 & $\begin{array}{l}8 \\
\stackrel{\infty}{-} \\
-\end{array}$ \\
\hline 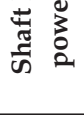 & 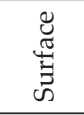 & $\begin{array}{l}\text { \& } \\
\text { i } \\
\text { in }\end{array}$ & $\begin{array}{l}8 \\
\substack{\infty \\
0 \\
0}\end{array}$ & 壳 & \begin{tabular}{l}
8 \\
8 \\
\hdashline
\end{tabular} \\
\hline$\vec{\Xi}_{\tilde{\Xi}}$ & 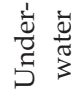 & $\stackrel{\infty}{\stackrel{\infty}{\stackrel{2}{-}}}$ & 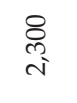 & 圭 & 莺 \\
\hline $\begin{array}{l}\frac{\pi}{2} \\
\frac{0}{2} \\
\text { and } \\
0\end{array}$ & 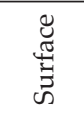 & $\stackrel{\mathcal{F}}{\stackrel{-}{二}}$ & $\begin{array}{l}\text { L } \\
0 \\
- \\
-\end{array}$ & 曾 & 莒 \\
\hline$k$ & & $\underset{I}{I}$ & ? & $\stackrel{L}{1}$ & İ \\
\hline & & sal & uqns & & \\
\hline
\end{tabular}




\begin{tabular}{|c|c|}
\hline 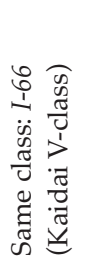 & 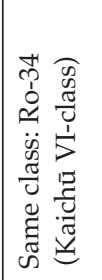 \\
\hline $\begin{array}{l}8 \\
0 \\
1 \\
\dot{m} \\
\dot{0}\end{array}$ & 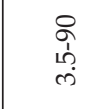 \\
\hline $\begin{array}{l}8 \\
8 \\
0 \\
0 \\
1 \\
0\end{array}$ & 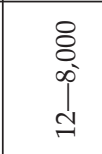 \\
\hline 芒 & $\begin{array}{l}\widehat{O} \\
\stackrel{\vec{V}}{+} \\
3 \\
0 \\
0\end{array}$ \\
\hline 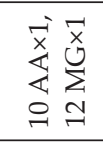 & 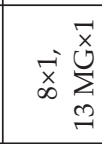 \\
\hline$\stackrel{\widetilde{\Omega}}{\sigma}$ & 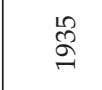 \\
\hline$\underset{\infty}{N}$ & $\underset{\infty}{~ ָ ூ ~}$ \\
\hline ڤ̊ำ & ஜ̊. \\
\hline 畕 & 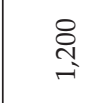 \\
\hline 姜 & 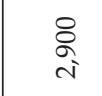 \\
\hline 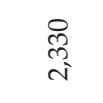 & \\
\hline 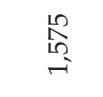 & § \\
\hline ? & 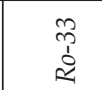 \\
\hline
\end{tabular}

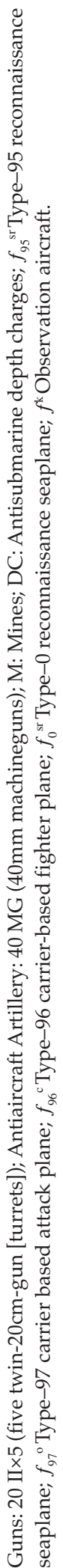

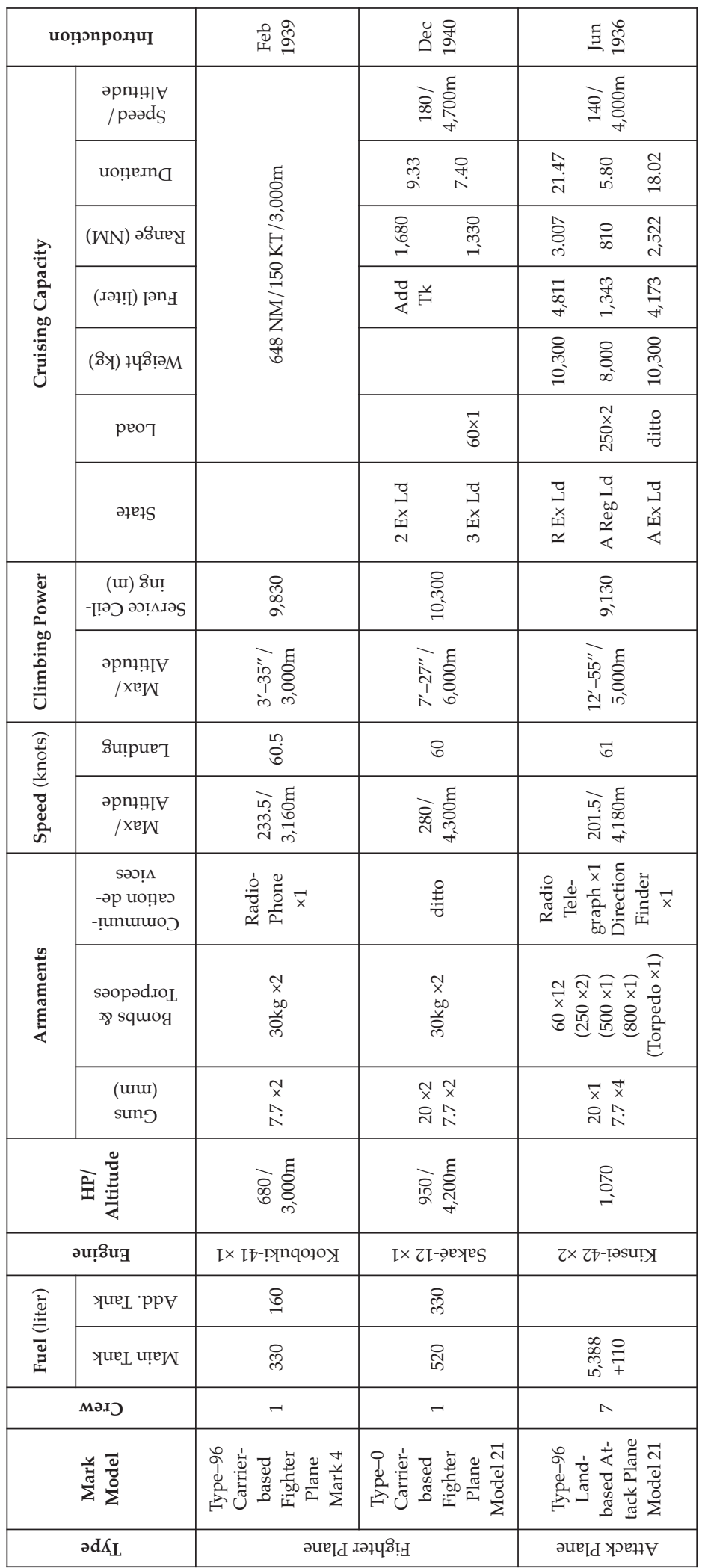




\begin{tabular}{|c|c|c|c|c|}
\hline 晏守 & पूँ & 三孚 & ż & 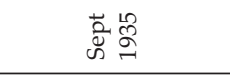 \\
\hline م. & 产 & \multirow{6}{*}{ 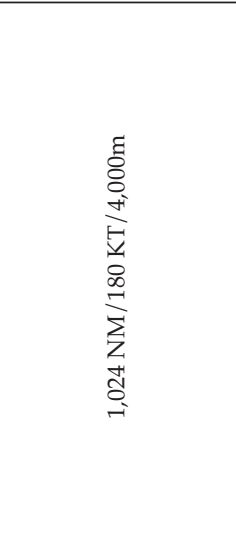 } & 8 & $\stackrel{8}{\circ}$ \\
\hline 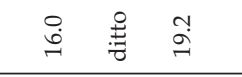 & $\begin{array}{ll}\stackrel{R}{N} & R \\
M & \stackrel{1}{\wedge} \\
\end{array}$ & & & \\
\hline 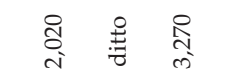 & 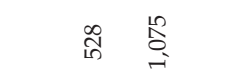 & & 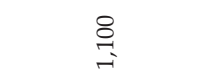 & 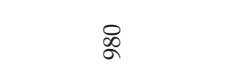 \\
\hline \multirow[t]{2}{*}{ 秊 } & 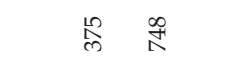 & & & \\
\hline & 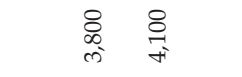 & & & \\
\hline 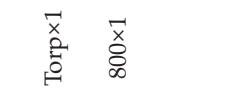 & 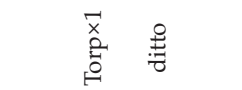 & & & \\
\hline 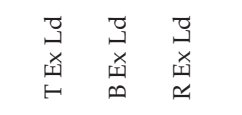 & 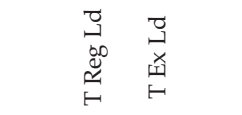 & & 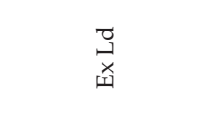 & 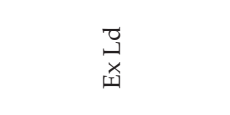 \\
\hline 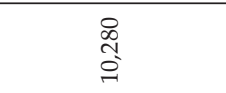 & 导 & 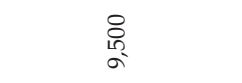 & 离 & 손 \\
\hline 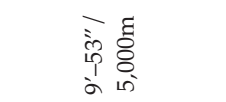 & 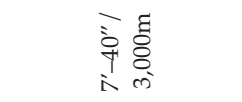 & $\begin{array}{l}\bar{y} \\
\text { iे } \\
\text { ô } \\
\text { के } \\
\text { के ले }\end{array}$ & $\begin{array}{ll} & 0 \\
\text { iे } & 0 \\
1 & 0 \\
\sigma & \text { mे }\end{array}$ & 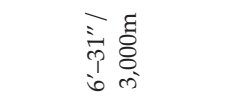 \\
\hline 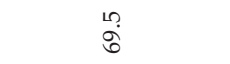 & 5 & & & \\
\hline 啇志 & 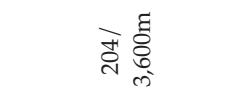 & 产 & 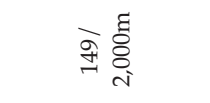 & 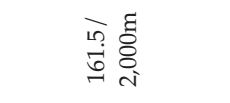 \\
\hline 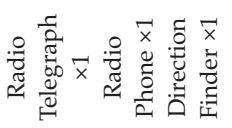 & 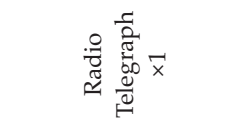 & & 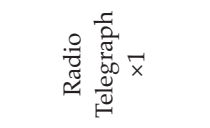 & \\
\hline 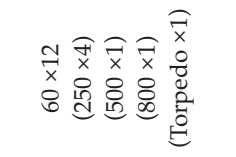 & 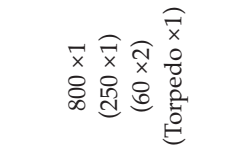 & & $\begin{array}{l}+1 \\
\dot{x} \\
0\end{array}$ & $\begin{array}{l}\tilde{x} \widehat{\tilde{x}} \\
0 \\
0 \\
0\end{array}$ \\
\hline $\begin{array}{l}\vec{x} \\
\vec{x} \\
\stackrel{4}{\Lambda}\end{array}$ & $\begin{array}{l}\bar{x} \\
\hat{n}\end{array}$ & $\begin{array}{l}\vec{x} \\
\hat{n}\end{array}$ & $\begin{array}{l}\tilde{x} \\
\hat{x} \\
\end{array}$ & $\begin{array}{l}\tilde{x} \\
\hat{\Lambda} \\
\end{array}$ \\
\hline 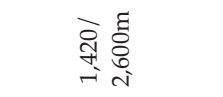 & 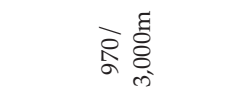 & 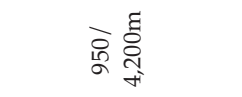 & $\stackrel{\circ}{\infty}$ & 官 \\
\hline$Z \times$ SI-I’Se $>$ & 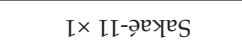 & 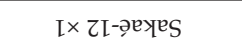 & L× LL-!əs!̣nZ & I× z-poW !’গnqoło> \\
\hline $\begin{array}{l}8 \\
8 \\
0 \\
\text { மn }\end{array}$ & $\stackrel{8}{=}$ & જิ & & \\
\hline$n$ & $m$ & $N$ & $\infty$ & 4 \\
\hline 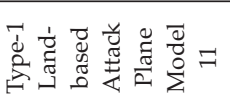 & 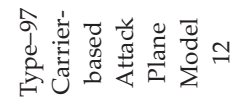 & 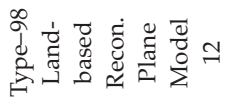 & 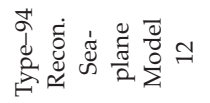 & 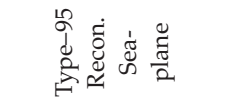 \\
\hline \multicolumn{2}{|c|}{ 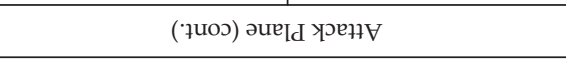 } & \multicolumn{3}{|c|}{ әuе|d әəuеsș̣euuoวəy } \\
\hline
\end{tabular}




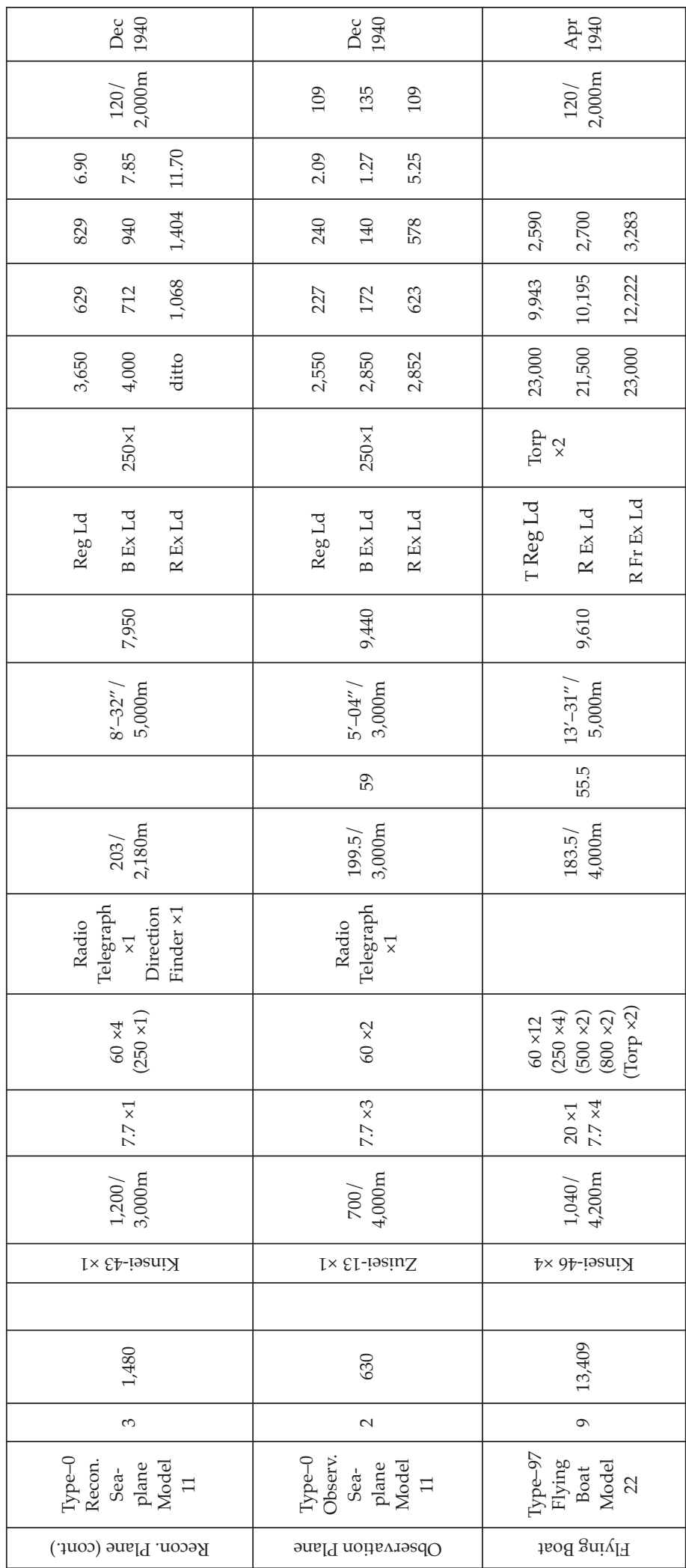

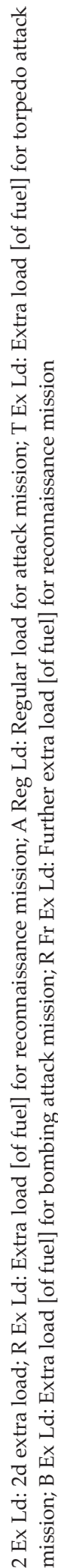




\begin{tabular}{|c|c|c|c|c|}
\hline \multicolumn{2}{|c|}{ uọ̣गnроцичI } & مे & F & F \\
\hline \multicolumn{2}{|r|}{ 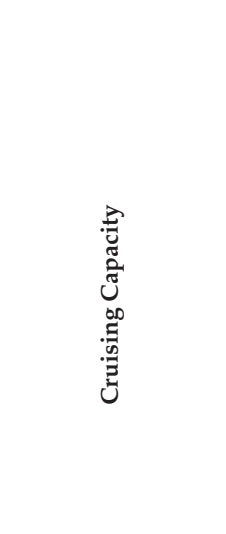 } & 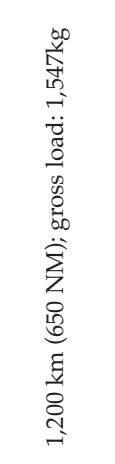 & 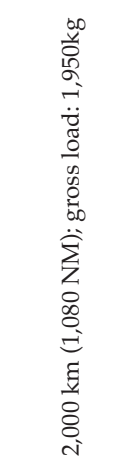 & 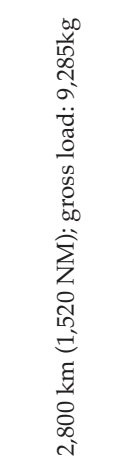 \\
\hline \multirow{2}{*}{ 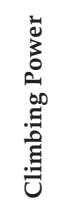 } & 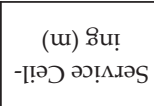 & & $\begin{array}{l}8 \\
8 \\
0 \\
0\end{array}$ & $\begin{array}{l}R \\
\text { Sू } \\
\text { : }\end{array}$ \\
\hline & $\begin{array}{c}\text { әрпч!̣IV } \\
\text { / хемN }\end{array}$ & 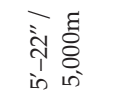 & $\begin{array}{l}\text { रे ह } \\
\text { के } \\
\text { iे } \\
\text { in न }\end{array}$ & \\
\hline \multirow{2}{*}{ 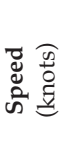 } & 8ụpueт & & & \\
\hline & 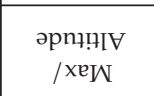 & 点点 & 종 & 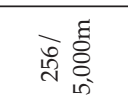 \\
\hline \multirow{3}{*}{ 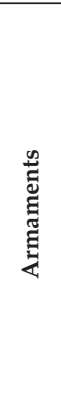 } & $\begin{array}{c}\text { sәว!̣ } \\
\text {-әр uọ̣es } \\
\text {-!̣unumoว }\end{array}$ & & & \\
\hline & $\begin{array}{l}\text { sәорәdıoL } \\
\text { > squog }\end{array}$ & & & 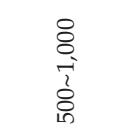 \\
\hline & $\begin{array}{l}\text { (uru) } \\
\text { sung }\end{array}$ & $\begin{array}{l}\tilde{x} \\
\hat{x}\end{array}$ & $\begin{array}{l}\tilde{x} \\
\hat{x} \\
\end{array}$ & 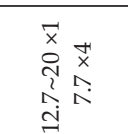 \\
\hline \multicolumn{2}{|r|}{ 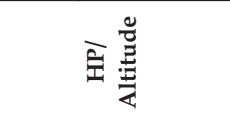 } & 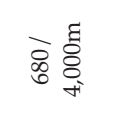 & ̊ू & 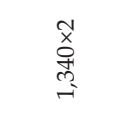 \\
\hline \multicolumn{2}{|r|}{ วu!ด̊uี } & $\angle 6^{-\partial \mathrm{d} \hat{L}_{\mathrm{L}}}$ & $q Z^{-e} \mathrm{H}$ & LOL-e $\mathrm{H}$ \\
\hline \multirow{2}{*}{ 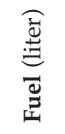 } & yue $_{L} \cdot p p_{V}$ & & & \\
\hline & yue L uाew & & & \\
\hline \multicolumn{2}{|r|}{ мәхכ } & - & - & n $2 \wedge$ \\
\hline \multicolumn{2}{|r|}{ そั } & 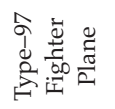 & 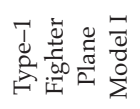 & 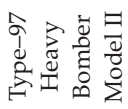 \\
\hline \multicolumn{2}{|r|}{$\operatorname{\partial d} \hat{K}_{\mathrm{L}}$} & \multicolumn{2}{|c|}{ әие [d } & səquiog \\
\hline
\end{tabular}




\author{
Attached Illustrations Nos. 5, 6, 7 \\ The Sea Engagement off Surabaya [Battle of the Java Sea] \\ The Sea Engagement off Batavia [Battle of Sunda Strait]
}

The following illustrations were too large to be scaled down to the confines of the English edition and have been omitted:

Attached Illustration No. 1: General Map of the Southwestern Area with Insets of Java, Sumatra, etc. [Omitted]

Attached Illustration No. 2: An Outline of the Military Strength Deployed in the Southern Countries [Omitted]

Attached Illustration No. 3: The Distances Between the Main Air Bases [Omitted]

Attached Illustration No. 4: The Movements of the Japanese and Enemy Fleets off Bangka on 15 February [Omitted]

Attached Illustration No. 8: The Shift of Forces of the Air Unit of the Southern Task Force [Omitted]

Attached Illustration No. 9: The Operations [of the Japanese Carrier Task Force] in the Attack on Ceylon [Omitted]

Attached Illustration No. 10: The Striking Operation of the Malaya Unit in the Indian Ocean [Omitted] 


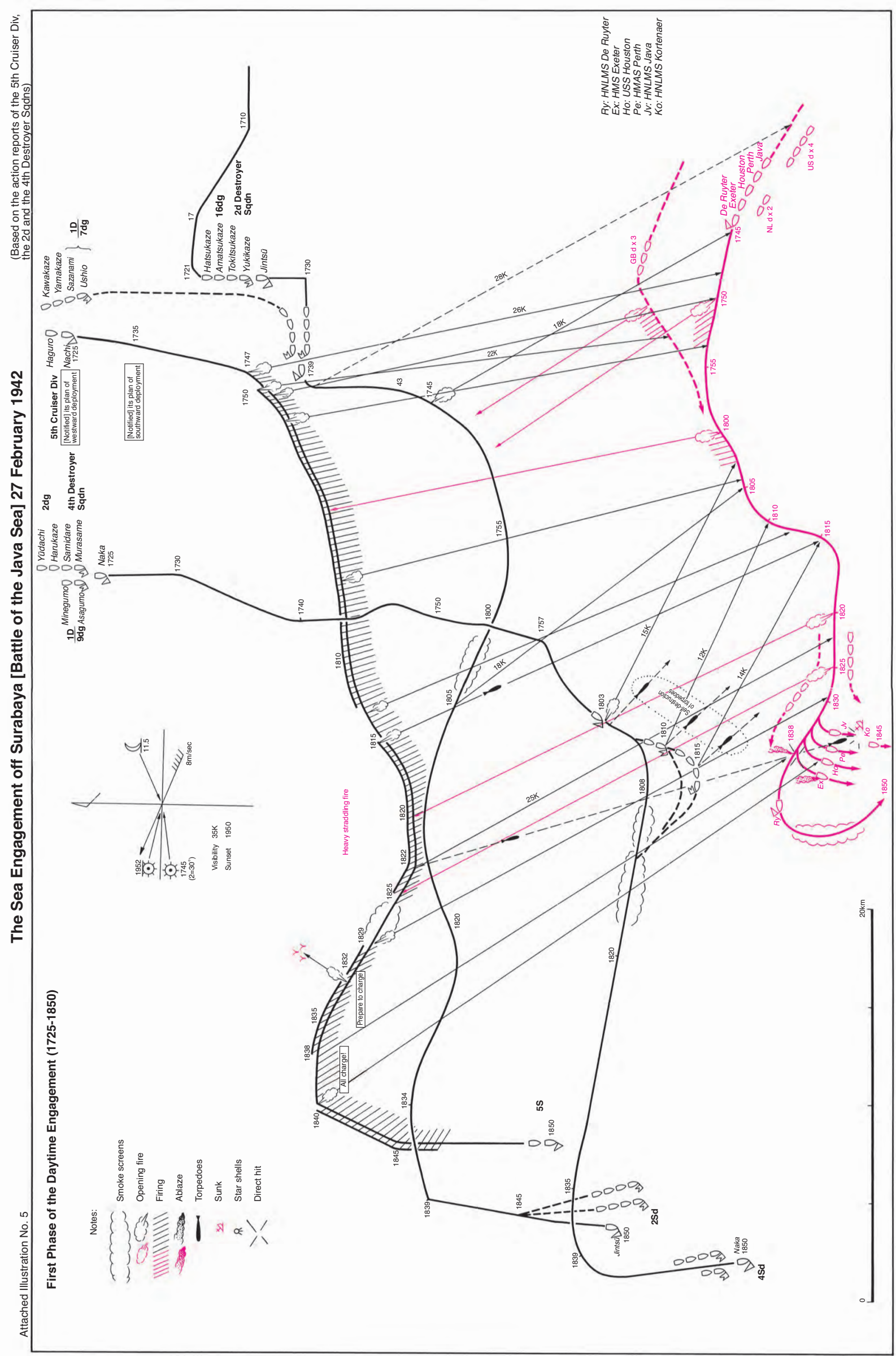




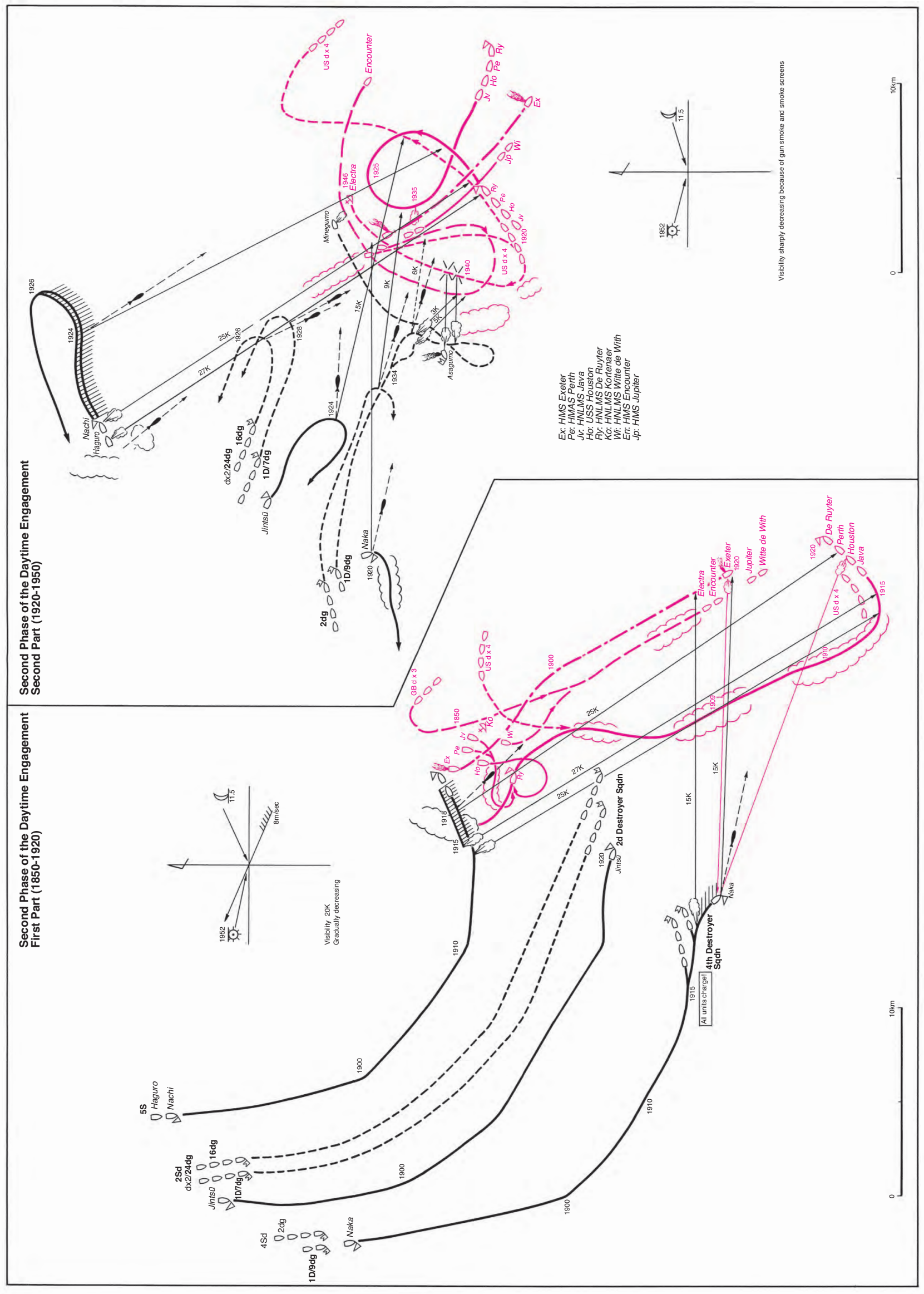




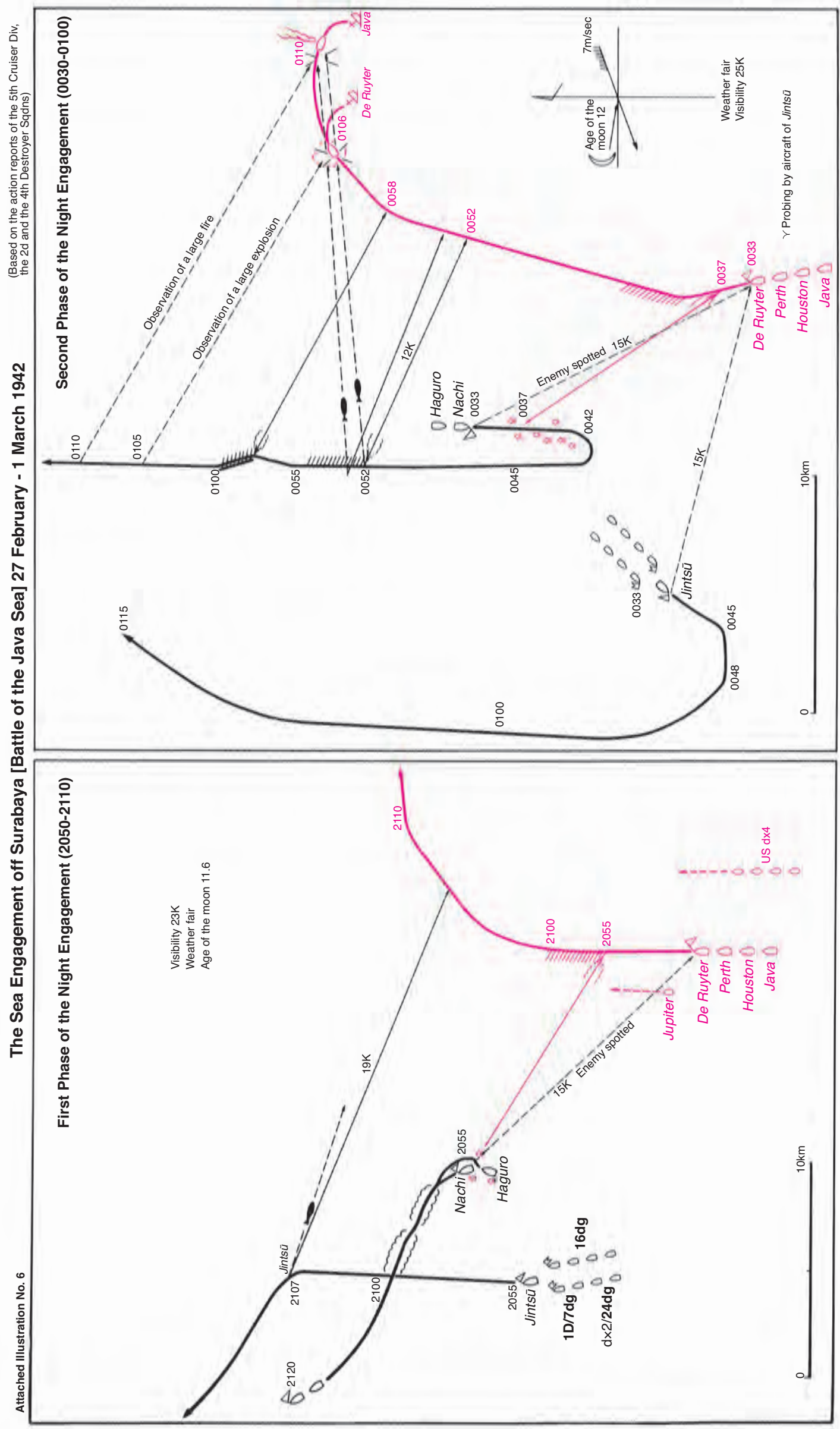




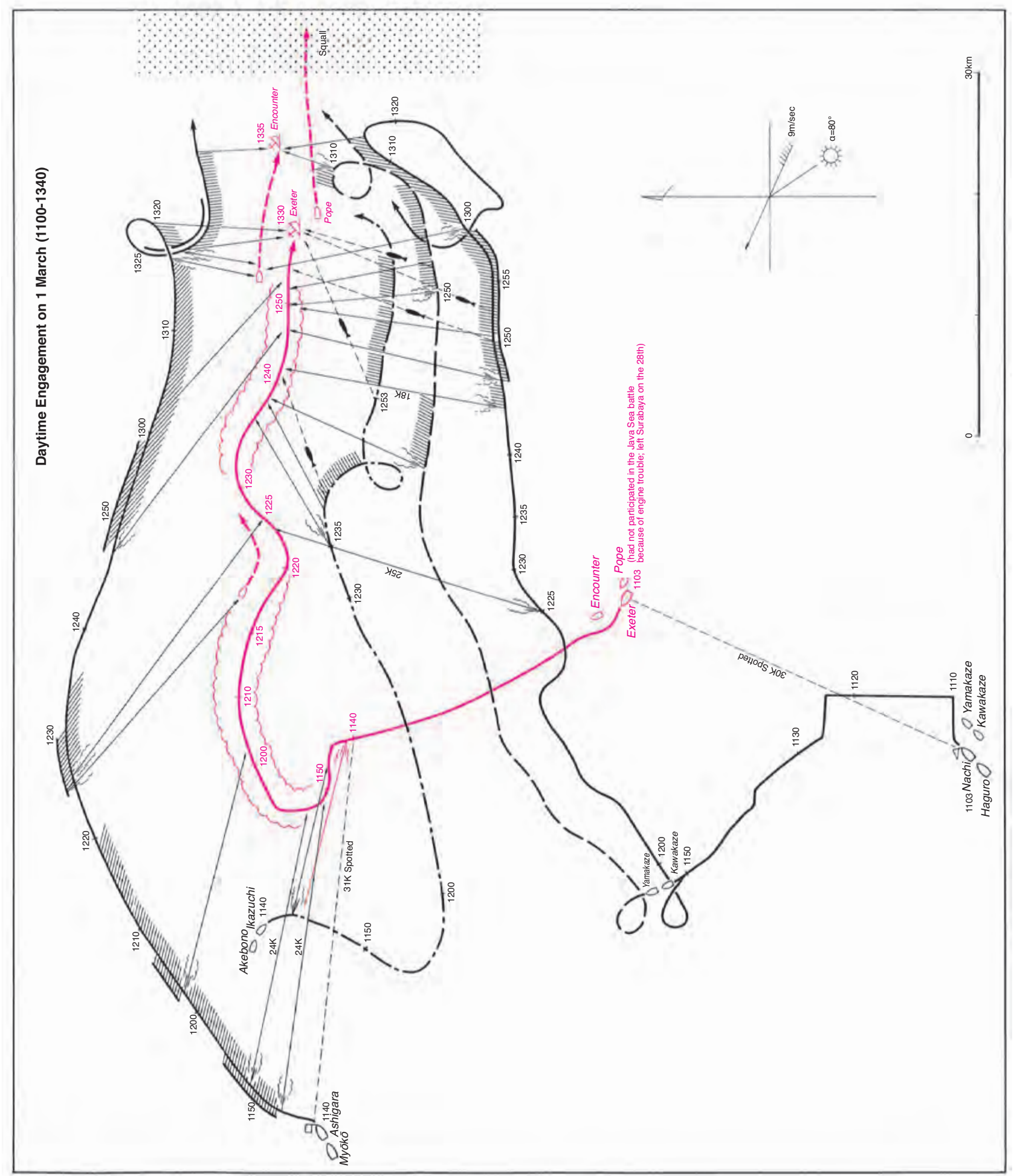




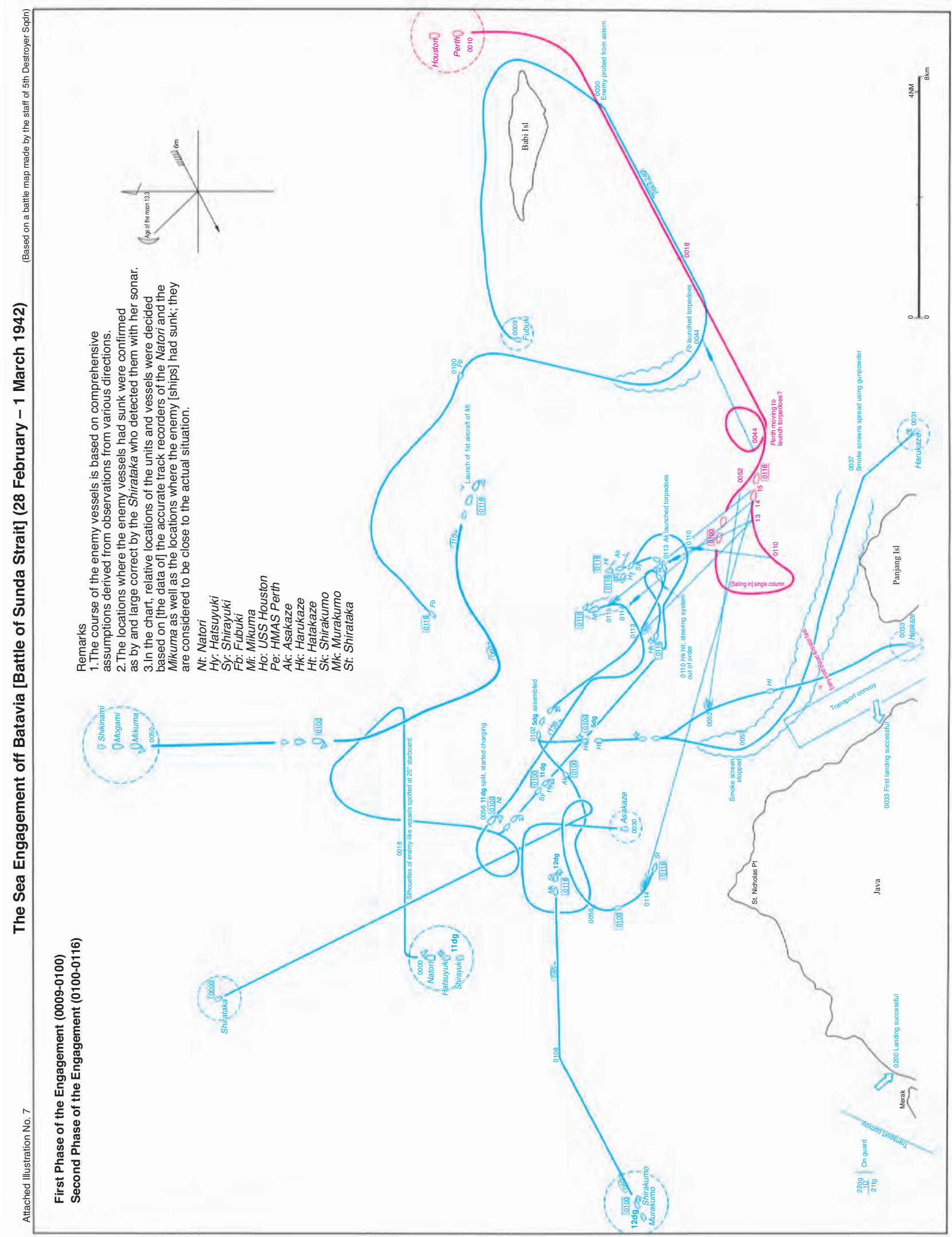




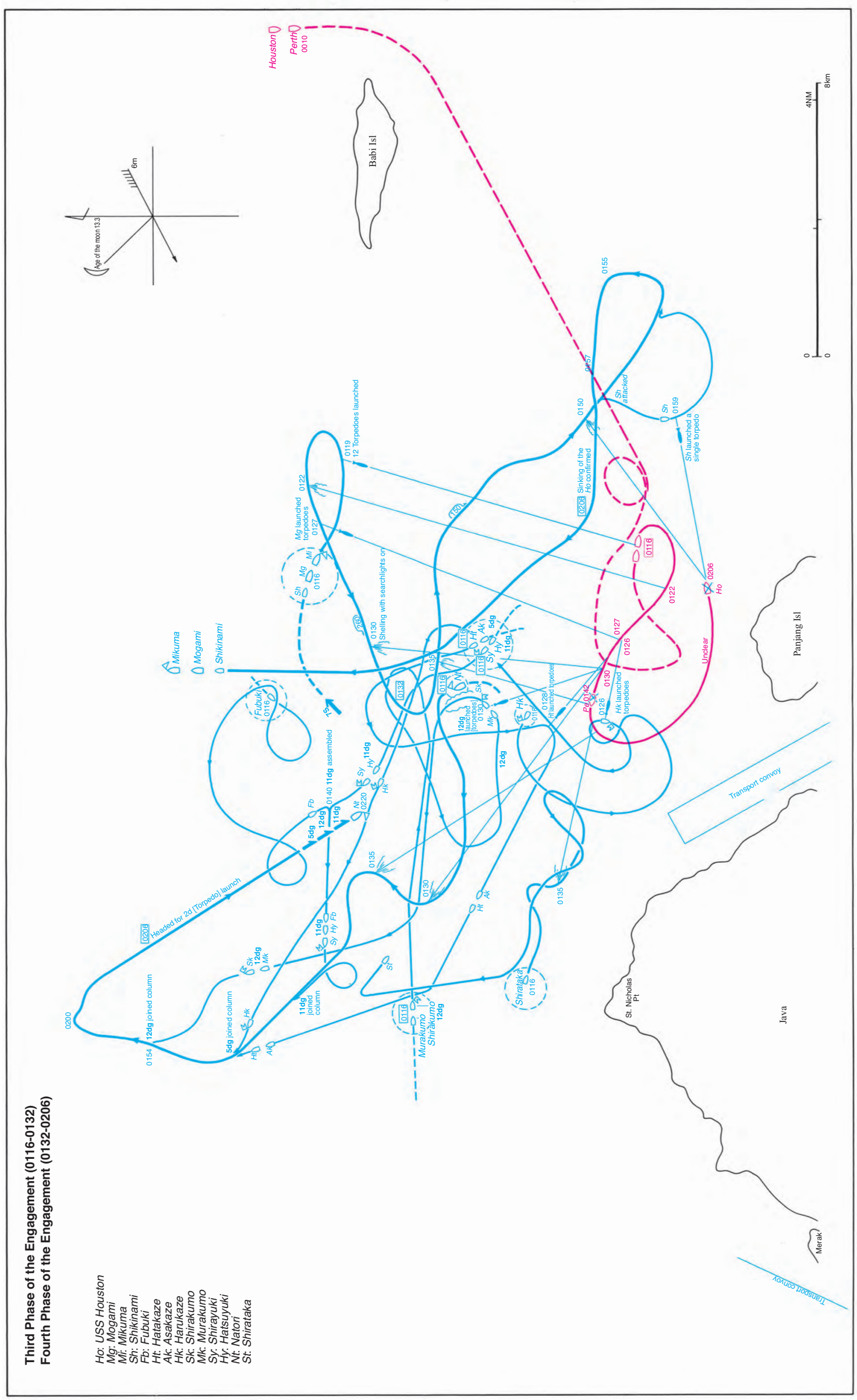


ailion foundation

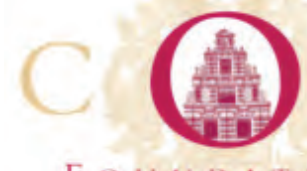

FOUNDATION

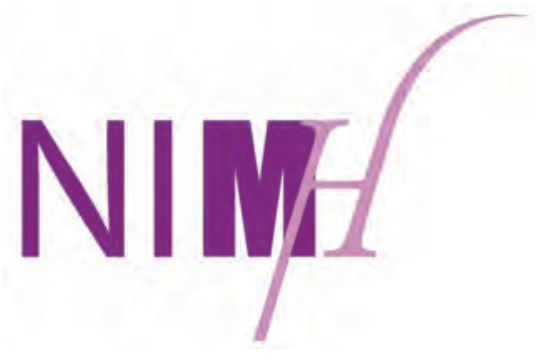

.

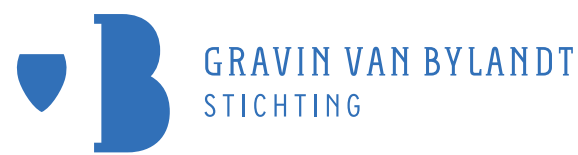

(1) Directie Der OOSTERSCHE HANDEL EN

REEDERIJEN

2 SUNTORY FOUNDATION

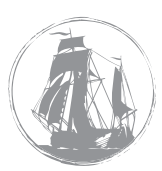

. 